\title{
HABITAR SOCIAL
}

A produção contemporânea na cidade de São Paulo

RENATA FRAGOSO CORADIN

Dissertação apresentada a Faculdade de Arquitetura e Urbanismo da Universidade de São Paulo para obtenção do título de Mestre em Arquitetura e Urbanismo.

Área de concentração:

História e Fundamentos da Arquitetura e do Urbanismo

Orientador: Prof. Dr. Paulo Bruna

SÃO PAULO 2014 
Autorizo a reprodução e divulgação total ou parcial deste trabalho, por qualquer meio convencional ou eletrônico, para fins de estudo e pesquisa, desde que citada a fonte.

e-mail: renata.coradin@terra.com.br

\begin{tabular}{|l|}
\hline Coradin, Renata Fragoso \\
Habitar social: a produção contemporânea na cidade de \\
São Paulo / Renata Fragoso Coradin. -- São Paulo, 2014. \\
542 p. : il. \\
Dissertação (Mestrado - Área de Concentração: História e \\
Fundamentos da Arquitetura e do Urbanismo) - FAUUSP. \\
Orientador: Paulo Júlio Valentino Bruna \\
1.Conjuntos habitacionais - São Paulo (SP) 2.Projeto de \\
Arquitetura - São Paulo (SP) 3. Habitação de interesse social - \\
São Paulo (SP) I.Título \\
CDU 711.582(816.11)
\end{tabular}


Nome: CORADIN, Renata Fragoso

Título: HABITAR SOCIAL: A produção contemporânea na cidade de São Paulo

Dissertação apresentada ao programa de pós-graduação em arquitetura e urbanismo da Universidade de São Paulo para obtenção de título de mestre em arquitetura e urbanismo.

Aprovado em:

Banca Examinadora:

Prof. Dr.

Julgamento:

Prof. Dr.

Julgamento:

Prof. Dr.

Julgamento:
Instituição:

Assinatura:

Instituição:

Assinatura:

Instituição:

Assinatura: 

Ao professor Paulo Bruna pelo exemplo e inspiração

À minhas avós Dorvalina e Yolanda pela força e experiência À meu avô Valdomiro, um arquiteto de coração e não de formação que deve estar olhando por mim lá de cima À meus pais Luiz e Vanda pelo apoio incondicional À Rodrigo pelo incentivo, carinho e companheirismo 



\section{AGRADECIMENTOS}

Ao professor Paulo Bruna por toda a experiência compartilhada.

À professora Ruth Verde Zein que em vários momentos ajudou a nortear minha vida profissional e acadêmica.

À Zaida Muxí e Josep Maria Montaner pelos conhecimentos compartilhados, pela confiança, pelo carinho e pela oportunidade de colaboração.

Aos professores Mônica Junqueira e Hugo Segawa pelo apoio e incentivo.

Às professoras Lizete Rubano, Ana Gabriela Godinho e Gilda Collet pelas conversas inspiradoras.

À Fabricia Zulin, amiga e sócia que pacientemente me escutou e aconselhou durante o desenvolvimento dessa dissertação.

À Alessandra Bedolini, amiga e companheira de trabalho e pós-graduação.

À Roser Casanovas, Daniela Árias e David Falagán, companheiros de trabalho em Barcelona.

À Elisabete França, Maria Teresa Diniz, Maria Tereza Fedeli, Thiago Barbizan, Vanessa Padiá, Marcelo Rebelo, Luiz Fernando Fachini, Stefania Dimitrov, Júlia Araújo Mantovani, aos assistentes sociais e toda equipe da Secretaria Municipal de Habitação (Sehab) que colaboraram para o desenvolvimento da pesquisa.

À Maria Teresa Fedeli pela companhia durante as visitas aos projetos.

À todos os moradores que abriram as portas de suas casas colaborando para o desenvolvimento desse trabalho e um agradecimento especial à Cícera, moradora do Jardim Edite e assistente social do Real Parque que gentilmente me recebeu em sua casa.

À Renata Semin pela agradável conversa e colaboração com a pesquisa.

À Hector Vigliecca e Neli Shimizu por terem compartilhado suas experiências e inquietações.

À Geni Sugai por gentilmente acompanhar a visita ao projeto e pacientemente fornecer todas as informações necessárias ao desenvolvimento desse trabalho. 
À Marta Moreira, Milton Braga, Eduardo Ferroni e Pablo Hereñú pela experiência compartilhada durante palestra na FAUUSP e visita ao conjunto Jardim Edite.

À Christine Van Sluys e Verena Andreatta, arquitetas brasileiras conhecidas em Barcelona, cujos trabalhos representam importantes referências.

À todos os arquitetos autores dos projetos estudados que, direta ou indiretamente, colaboraram para a realização dessa dissertação.

Aos professores Regina Meyer, Marta Dora Grostein, Carlos Lemos, Ricardo Toledo Silva, Rosane Segantin Keppke, Mônica Junqueira e Hugo Segawa pela contribuição a partir das disciplinas cursadas.

Aos companheiros da pós-graduação que proporcionaram discussões interessantes.

À amiga e professora Patrícia Parente que pacientemente contribuiu para a realização do Abstract.

Aos amigos Camila Crisitiani, Fabiana Fraga, Zelcy Dall Acqua Júnior e todos os outros que sempre se interessaram e me apoiaram durante o desenvolvimento dessa dissertação.

À minha família por estar sempre presente me apoiando e incentivando em vários momentos da minha vida profissional e acadêmica.

À minha irmã Roberta pelo apoio e pelos momentos de descontração.

À minha mãe Vanda pela incansável dedicação.

À meu pai Luiz por todo o incentivo, por estar sempre presente e por ter lido, pacientemente, toda essa dissertação, contribuindo com as correções ortográficas.

À minha avó Dorvalina pelo cuidado de toda a vida.

À Rodrigo pelo carinho, paciência e incentivo. Pela colaboração com as fotografias e por ter me acompanhando em algumas visitas aos conjuntos.

Aos funcionários da FAUUSP e a todos que direta e indiretamente colaboraram para a concretização dessa dissertação de mestrado. 


\section{RESUMO}

HABITAR SOCIAL - a produção contemporânea na cidade de São Paulo é uma dissertação de mestrado desenvolvida no âmbito da habitação de interesse social, que tem como objetivo analisar projetos contemporâneos de conjuntos habitacionais promovidos pela Secretaria Municipal de Habitação de São Paulo (Sehab).

A pesquisa abrange o período compreendido entre os anos de 2001 e 2013. Dentro desse período, buscou-se conhecer as atuações da Secretaria de Habitação (Sehab) e identificar a produção realizada. Entre as atuações da Sehab, destacaram-se as intervenções em urbanizações de favelas.

Durante o processo de urbanização, muitas vezes, parte da população precisa ser removida, por estarem vivendo em áreas de risco. A remoção dos moradores leva à necessidade de realocação dessas famílias e, para atender a essa necessidade, são construídos os conjuntos habitacionais em áreas que não sejam de risco, mas que encontrem-se próximas ao local onde esses moradores viviam anteriormente.

Esse trabalho tem como objetivo analisar a produção desses conjuntos, pois essas novas casas é que darão condições à essas pessoas de viverem um uma moradia digna e fazerem parte do bairro e da cidade onde moram.

Quatro projetos foram selecionados para serem observados com maior detalhe: Comandante Taylor, realizado pelo escritório Piratininga Arquitetos Associados; Jardim Edite, desenvolvido pelos escritórios MMBB e $\mathrm{H}_{+} \mathrm{F}$ Arquitetos; Parque Novo Santo Amaro V, de autoria de Vigliecca \& Associados; e Real Parque desenvolvido pelos arquitetos Geni Sugai e Jefferson Diniz, junto ao escritório Paulistano de Arquitetura.

Para desenvolver um estudo legítimo e que permitisse servir de referência para outras análises, fez-se necessário definir uma padronização de critérios, a partir dos quais os projetos foram observados. Outros trabalhos relacionados à habitação coletiva foram utilizados como referência para a definição desses critérios, que foram 
definidos dentro de três escalas principais: conjunto; edifício e unidade, permitindo que os conceitos aplicados, a cada uma delas, fossem identificados com maior detalhe.

O objetivo final desse trabalho não é avaliar positivamente ou negativamente os conjuntos analisados em sua totalidade, mas tornar visíveis os critérios de qualidade existentes para que possam servir de referência para novos projetos.

Além da definição dos critérios, as análises também foram embasadas na experiência de visitar os conjuntos e absorver as sensações transmitidas pelos moradores com relação aos ambientes em que vivem e em que convivem dentro dos conjuntos.

Após a análise dos quatro projetos, foi realizado um capítulo que estabelece relações entre esses projetos, e também, outras referências da produção contemporânea de habitação.

Por fim, espera-se que essa dissertação de mestrado, a partir das análises realizadas, conceitos destacados e relações estabelecidas, seja uma contribuição à "cultura de projeto"1.

Palavras chave: Habitação de interesse social - São Paulo (SP); Conjuntos habitacionais - São Paulo (SP); Projeto de arquitetura contemporânea.

1 Termo utilizado pela arquiteta Lizete Rubano em sua tese de doutorado: Cultura de Projeto: Um estudo das ideias e propostas para habitação coletiva. 2001. 


\section{ABSTRACT}

HABITAR SOCIAL: the contemporary production in the city of São Paulo is a master's degree thesis developed at social housing sphere with the objective of analysing contemporary social housing buildings promoted by the São Paulo City Housing Department.

The research covers the period between the years 2001 and 2013. Over this period, it was intended to know the activities performed by the City Housing Department and identify the production accomplished. Among these activities stand out the interventions in slums urbanizations.

During the process of urbanization, part of the population needed many times to be removed for living in risk areas. The removal of residents led to the necessity of relocating these families and, to meet this need, housing complexes are built in areas which do not offer any risk, but are located near the site where these residents used to live before.

This present study aims at analysing the production of theses complexes, as these new houses will be the ones which will provide these people with decent housing and will allow them to be part of the neighbourhood and the city where they live.

Four projects have been selected to be observed in more details: Comandante Taylor, performed by Piratininga Arquitetos Associados office; Jardim Edite, developed by MMBB and $H+F$ Arquitetos; Parque Novo Santo Amaro $\boldsymbol{V}$, by Vigliecca \& Associados; and Real Parque, developed by the architects Geny Sugei and Jefferson Diniz, together with Paulistano de Arquitetura office.

In order to develop a legitimate study and one that could be used as reference for future analyses, it was necessary to define a standardization of criteria from which such projects were observed. Other studies related to collective 
housing were used as reference to the definition of these criteria, which were defined within three main scales: complex, building and unit, allowing the applied concepts to each one of them to be identified in more detail.

The final objective of this study is not to evaluate positively or negatively the housing complexes analysed in their total, but to make the existing quality criteria visible, so that they can be reference to new projects.

In addiction to the criteria definition, the analyses were also based on the experience of visiting the complexes and absorbing the sensations transmitted by the residents regarding the environments where they live and where they mingle inside the complexes.

After the analyses of the four projects, it was performed a chapter to establish links between these projects, and also other references about the housing contemporary production.

Finally, it is expected that this master's degree thesis, considering the analyses performed, featured concepts and established relations, be a contribution to the "project culture"1.

Key words: Social Interest Housing - São Paulo (SP); Housing complexes - São Paulo (SP); Contemporary architecture project.

1 Term used by the architect Lizete Rubano in her doctorate's thesis: Cultura de Projeto: Um estudo das ideias e propostas para habitação coletiva, 2001. 


\section{SUMÁRIO}

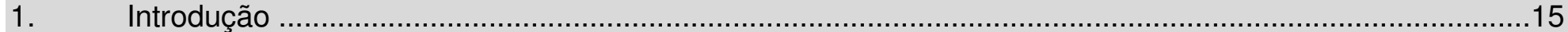

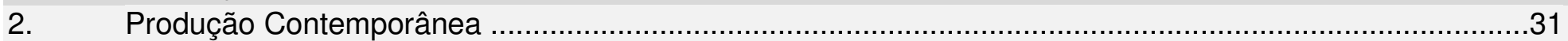

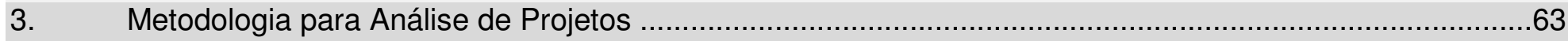

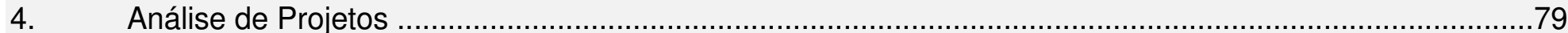

4.1. Comandante Taylor (Piratininga Arquitetos Associados) …...................................................... 81

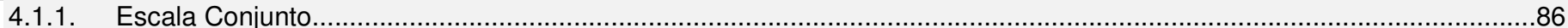

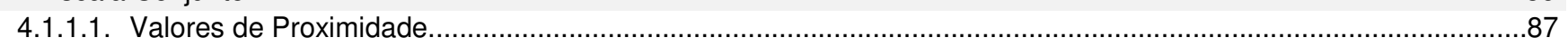

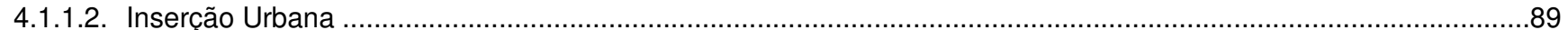

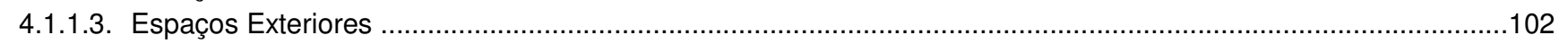

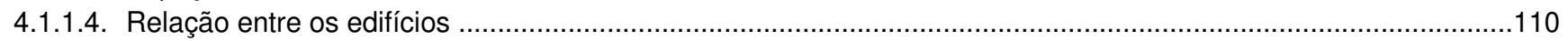

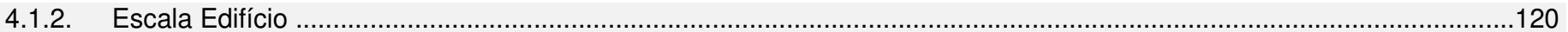

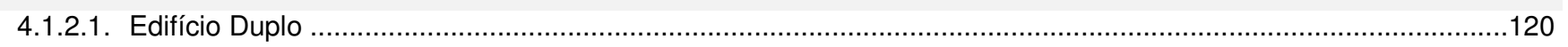

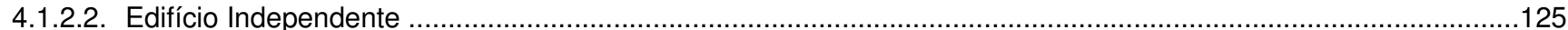

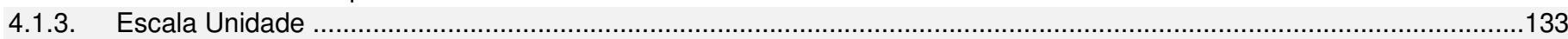

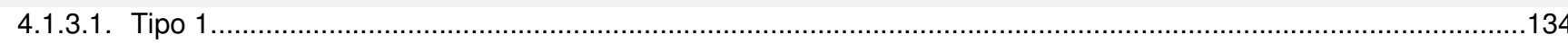

4.1.3.2. Tipo 2 …

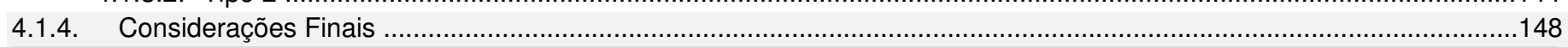

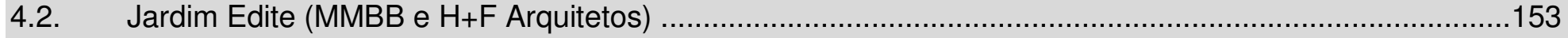

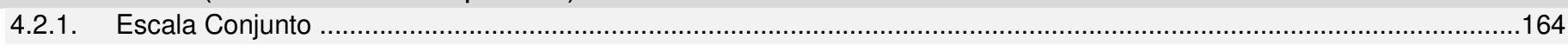

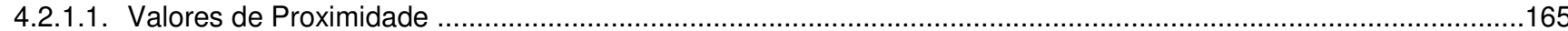

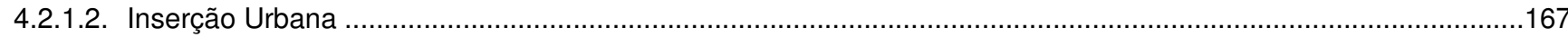

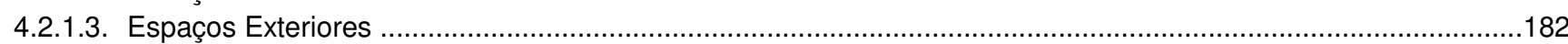

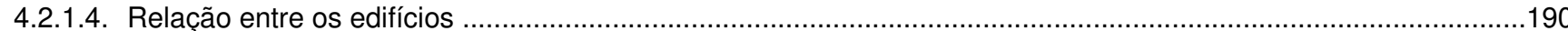

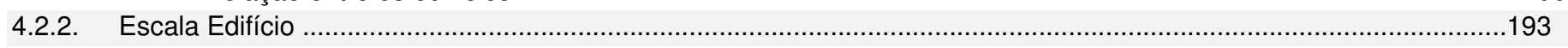

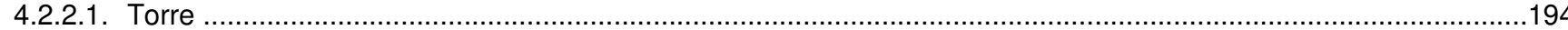

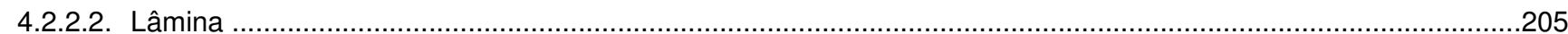

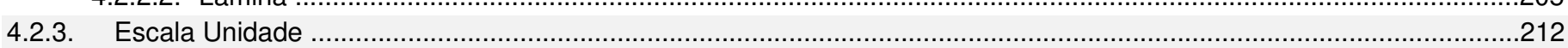

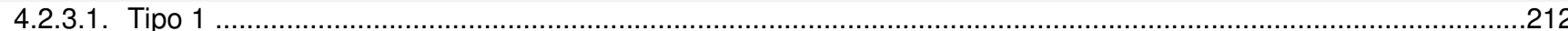

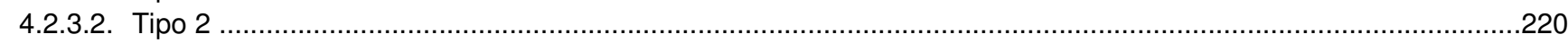

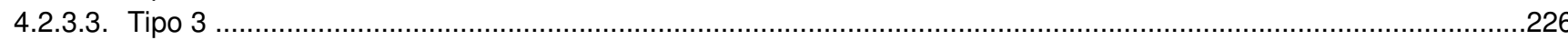

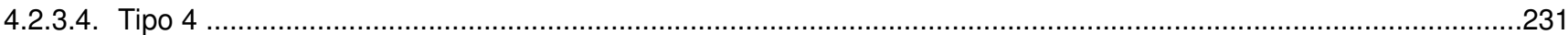

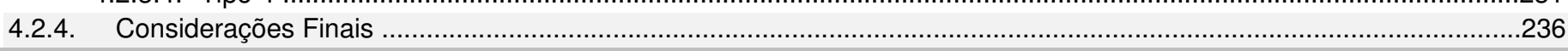

4.3. Parque Novo Santo Amaro V (Vigliecca \& Associados) .........................................................239

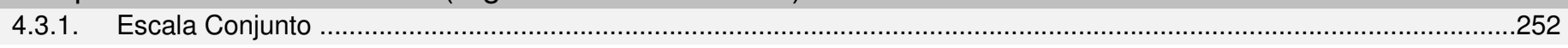

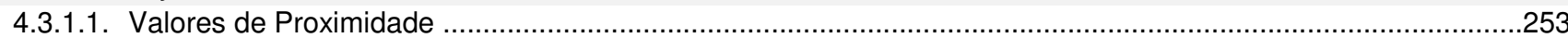


4.3.1.2. Inserção Urbana

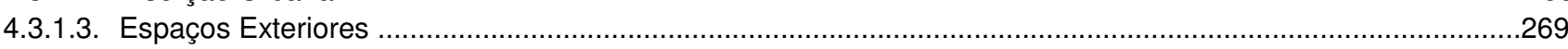

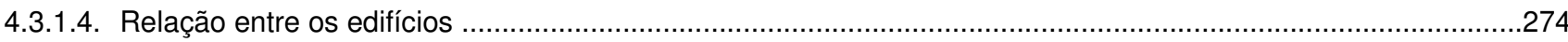

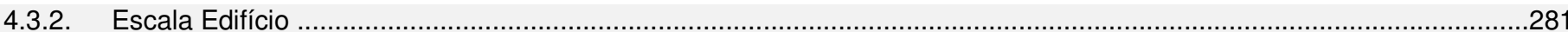

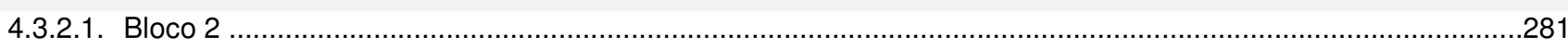

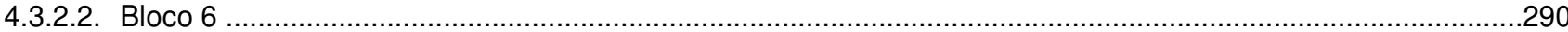

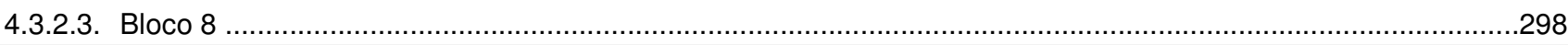

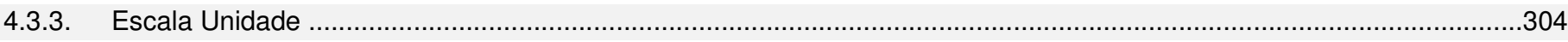

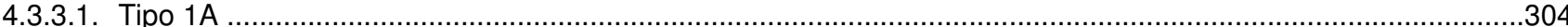

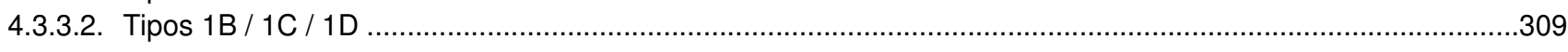

4.3.3.3. Тipo $2 \mathrm{~A}$

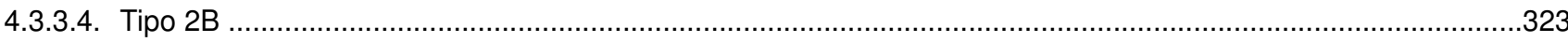

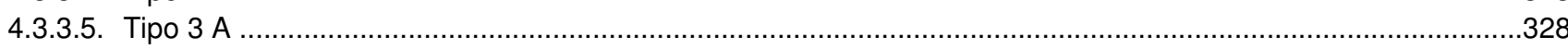

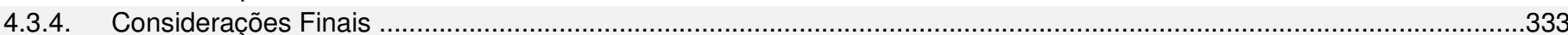

4.4. Real Parque (Escritório Paulistano Arquitetura e arquitetos: Geni Sugai e Jeferson Diniz).....................339

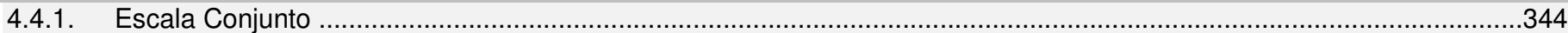

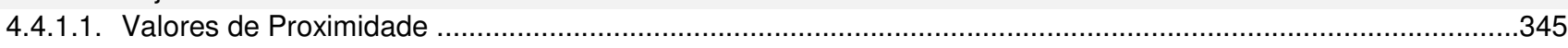

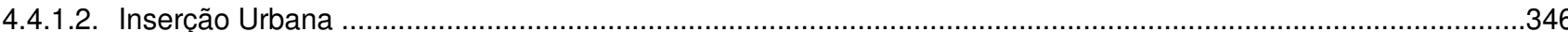

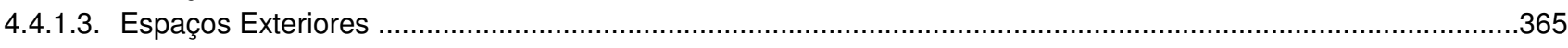

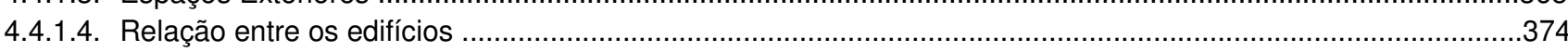

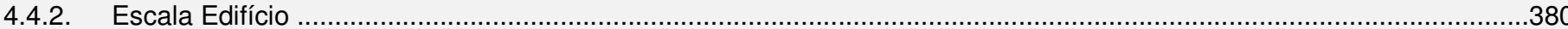

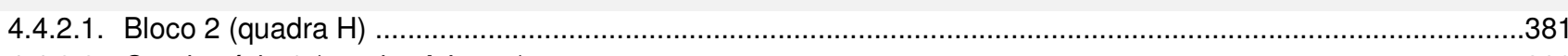

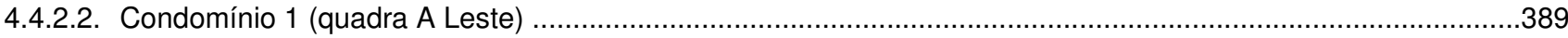

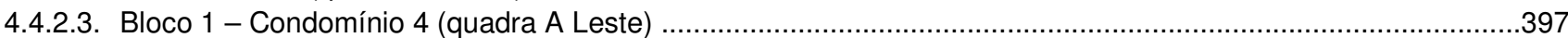

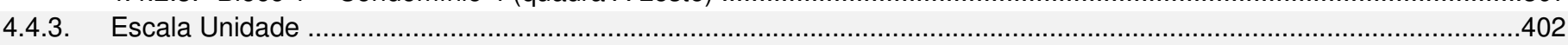

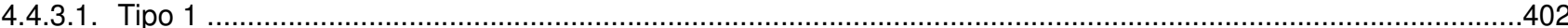

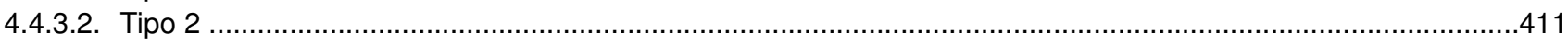

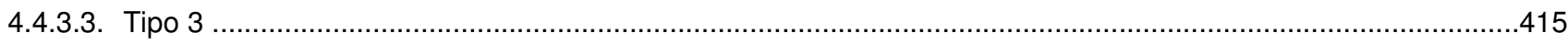

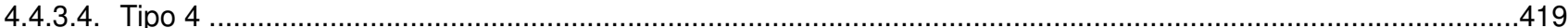

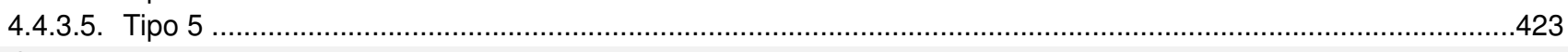

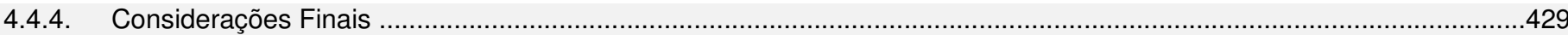

5. Relações - Reflexões - Conclusões. $\quad$.

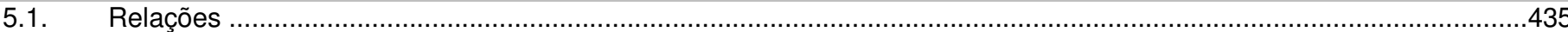

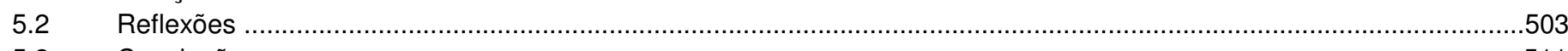

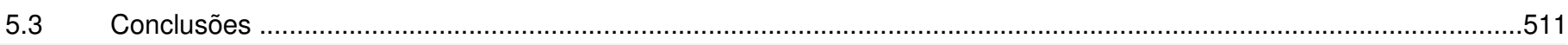

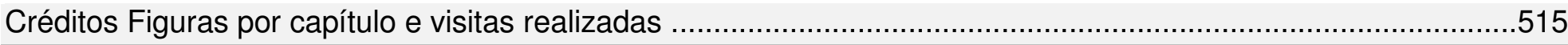

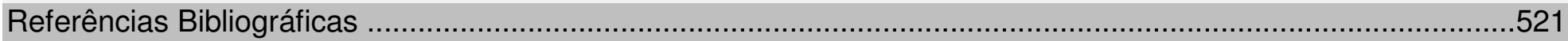




\section{INTRODUÇÃO}

O objetivo dessa dissertação de mestrado é conhecer, estudar e analisar a produção contemporânea de habitação de interesse social na cidade de São Paulo, promovida pela Secretaria Municipal de Habitação (Sehab).

Como produção contemporânea, entende-se o período entre 2001 e 2013. Esse período abrange três mandatos políticos: o primeiro, entre 2001 e 2004, na gestão de Marta Suplicy; o segundo, entre 2005-2008, iniciado por José Serra e finalizado por Gilberto Kassab e o último representa uma continuidade de governo com a reeleição de Gilberto Kassab.

Com base nas publicações de balanço de gestão ${ }^{1}$, foi possível identificar algumas modalidades de intervenção do governo municipal no âmbito da habitação de interesse social: projetos de reabilitação de cortiços; projetos para locação social; reciclagem de edifícios em áreas centrais; programa para melhoria dos conjuntos habitacionais existentes; produção de conjuntos habitacionais realizados a partir da autogestão; programas de urbanização de favelas e produção de conjuntos habitacionais realizados a partir dos programas de urbanização.

O principal foco desta dissertação de mestrado é a análise da produção de conjuntos habitacionais, construídos pela Sehab, para realocar moradores que precisaram ser removidos de suas moradias devido às intervenções realizadas pelas urbanizações em assentamentos precários.

1 Referência bibliográfica referente a essas publicações:

PREFEITURA DE SÃO PAULO. LOPES, Ana Carolina Louback; FERREIRA, João Sette Whitaker (Orgs.). Balanço qualitativo de gestão 2001-2004: Secretaria da Habitacão e Desenvolvimento Urbano do Município de São Paulo - SEHAB, Companhia Metropolitana de Habitação de São Paulo - COHAB. São Paulo, 2004a.

PREFEITURA DE SÃO PAULO. FRANÇA, Elisabete; COSTA, Keila Prado (Orgs.). Plano Municipal de Habitação: A experiência de São Paulo. Volume 1 - 1'a edição - São Paulo: HABI Superintendência de Habitação Popular, 2012a. 
A produção desses conjuntos habitacionais está diretamente relacionada com os programas de urbanização de favelas, uma atitude que, segundo Ermínia Maricato, foi consolidada por parte do governo a partir dos anos 80 . Uma mudança que ocorreu quando "muitos governos municipais perceberam que era mais viável economicamente, e até mais urgente, se levarmos em conta as normas de saúde pública, realizar a urbanização das favelas do que remover seus moradores para novas moradias." O processo de urbanização de favelas consiste em atender às necessidades básicas dos assentamentos através da oferta de iluminação, água tratada, esgoto, drenagem, coleta de lixo, circulação viária e de pedestres e a eliminação dos riscos de vida (MARICATO, em: CASTRIOTA, 2003, p. 78 a 96$)$.

Segundo Maricato, "outro motivo que impulsionou a urbanização de assentamentos ilegais está na vontade dos moradores, que muitas vezes preferem permanecer onde estão por conveniência de localização - oferta de trabalho, rede de amigos e familiares, oferta de equipamentos e serviços urbanos, etc." (MARICATO, em: CASTRIOTA, 2003, p. 78 a 96).

É rara a obra de urbanização que não exija a remoção de uma parte da população da favela. A implantação das redes de água, esgoto e drenagem, além da circulação viária, assim o exige. A remoção de famílias situadas em áreas de risco também exige novas moradias para onde levar essa população. É importante, e as famílias removidas demandam, que a remoção se dê para lugares próximos, de forma a não interromper as rotinas relacionadas à escola, trabalho, amizades, etc. (MARICATO, em: CASTRIOTA, 2003, p. 78 a 96).

Para Elisabete França (2009), ex-superintendente da Secretaria Municipal de Habitação de São Paulo, as políticas de remoção e desfavelização, baseadas na ideia da temporalidade da favela, já tinham se esgotado no final da década de 1970.

A partir daí, as políticas públicas para as favelas passaram a considerá-las com fenômeno urbano, integrante da paisagem da cidade. Tal percepção coincidia com as primeiras mobilizações dos movimentos de representantes 
dos favelados, os quais reivindicavam o acesso ás benfeitorias mínimas, em oposição às ideias do desfavelamento (FRANÇA, 2009, p. 30).

Segundo FRANÇA (2009) até o final da década de 1970, a favela era um fenômeno social e a solução era encontrada na remoção para conjuntos habitacionais periféricos e, a partir da década de 1980, um novo pensamento foi se estabelecendo até os dias atuais.

[...] Essa nova forma de atuação da municipalidade, que reconhece a existência da favela como fenômeno territorial, resultou na implantação de uma série de projetos, que foram sendo aprimorados, e que atualmente apontam para a organização desses territórios de modo a incorporá-los à cidade reconhecida dentro das normas das legislações vigentes (FRANÇA, 2009, p. 146).

De acordo com a ex-superintendente, as atuais intervenções da prefeitura são caracterizadas pela implantação de um plano de urbanização e de projetos desenvolvidos por escritórios de arquitetura que "têm se dedicado a entender o programa de necessidades de seus 'clientes', a buscar novas soluções arquitetônicas, pesquisar materiais construtivos e aprimorar os projetos destinados às áreas públicas” (FRANÇA, 2009, p. 146).

Essa breve passagem pelo processo de urbanização, a partir da qual foi possível identificar mudanças significativas no processo que, inicialmente desejava a eliminação completa das favelas e, ao longo dos anos passou a considerá-las como parte da cidade e desenvolver mecanismos para isso, tem o objetivo de situar o leitor dentro do processo de urbanização para então, esclarecer que o objetivo dessa dissertação é analisar os conjuntos habitacionais construídos, dentro do período estudado, a partir dessa "nova postura" do poder público em considerar as necessidades dos moradores e a importância de mantê-los próximos aos locais onde viviam antes das remoções.

Para isso, se propõe analisar essa produção contemporânea a partir da seleção de alguns exemplos representativos, buscando identificar os partidos adotados na construção desses conjuntos; a forma como se 
inserem na cidade e se relacionam com o entorno; como incorporam as demandas e necessidades dos moradores; enfim, essa análise pretende identificar que qualidades projetuais podem ser ressaltadas nesses conjuntos que representem mudanças significativas para a produção de habitação de interesse social. Por outro lado, as análises também permitirão identificar debilidades que deverão ser registradas como alertas que não deverão ser seguidos em novos projetos.

O interesse pelo tema habitação é uma constante em minha trajetória profissional que se despertou após a conclusão da graduação, quando, graças à professora Ruth Verde Zein, tive a oportunidade de estudar na Universidade Politécnica de Catalunya - UPC - realizando especialização no "Máster Laboratorio de la Vivienda del Siglo XXI", um curso com base histórica e metodológica focado no conhecimento dos principais elementos da evolução da habitação contemporânea, nas interpretações estéticas e antropológicas, nos instrumentos de análise de projetos, na gestão urbana, etc., com o objetivo de desenvolver critérios para a formação de uma cultura crítica. ${ }^{2}$

Durante o desenrolar do curso, foi inevitável desenvolver um olhar mais analítico e crítico com respeito à habitação, principalmente à habitação coletiva que é a tendência no processo de adensamento das grandes cidades. A maneira como as edificações habitacionais e/ou os conjuntos são construídos; como são inseridos nas cidades e que papel possuem no seu crescimento e desenvolvimento; a relação com o entorno; a forma como são implantados no terreno; os espaços comuns e intermediários e a relação entre os espaços interiores das unidades são temas que, aos poucos, foram reforçando meu interesse pela pesquisa no âmbito da habitação.

Como trabalho final dessa especialização foi realizada uma tesina com o título CASA - CIUDAD, una perspectiva de género. Esse trabalho, orientado pela arquiteta doutora Zaida Muxí, teve como objetivo investigar a relação

${ }^{2}$ Máster Laboratorio de la vivienda sostenible del siglo XXI. Disponível em: <http://laboratoriovivienda21.com/blog/>. Acesso em junho de 2013. 
entre a Casa - espaço privado - e a Cidade - espaço público - e, para realizar essa pesquisa, foi definido o ponto de vista a partir da perspectiva de gênero, buscando

[...] adotar um olhar que abrangesse a todos os coletivos e não apenas à dualidade feminino - masculino, apesar de que poder-se-ia ter essa impressão. Nesse caso, falar de gênero é fazer referência a grupos sociais bem diversos que englobam tanto homens como mulheres, crianças, jovens e idosos, assim como pessoas com necessidades especiais de qualquer tipo, respeitando sempre as diversidades culturais (CORADIN, 2010, p.7).

Para o desenvolvimento da tesina, foram analisados, entre outros projetos, três conjuntos de habitação de interesse social construídos na cidade de Viena e promovidos pelo Departamento de Gênero da cidade, os chamados Frauen-Werk-Stadt ${ }^{3} \mathrm{I}$, II e III, que tive a oportunidade de visitar e conhecer as qualidades contidas em cada um.

O estudo desses projetos também me proporcionou a oportunidade de entrar em contato com a tradição de Viena, com relação à produção de habitação de interesse social dos anos 1920. Entre outros exemplos, o Heimhof (19211922), "um conjunto habitacional que tinha como objetivo diminuir a carga de trabalho doméstico a partir da implantação de espaços comuns como cozinha, espaço para as refeições e lavanderia"; e o Karl-Marx-Hof (19261930) "outro exemplo digno de menção, também caracterizado pelas cozinhas coletivas e pela oferta de equipamentos para simplificar a vida cotidiana" ${ }^{4}$ (CORADIN, 2010, p.77).

${ }^{3}$ Frauen-Werk-Stadt (FWS) pode ser traduzido como Mulheres da cidade do trabalho. O projeto FWS I é de 1997 e foi realizado pela arquiteta Franziska Ullmann com a colaboração das arquitetas Gisela Podreka, Else Prochazka e Liselotte Peretti; O FWS II é de 2004 e foi realizado pelas arquitetas Claudia König-Larch e Chistine Zwingl; e o FWS III foi realizado pela arquiteta Sabine Pollak e contou com a participação integral da associação de moradoras.

${ }^{4}$ Quanto ao Karl-Marx-Hof, "a ascensão dos nazistas ao poder no final dos anos 1930, colocou fim ao sonho de uma vida livre de tarefas domésticas: todos os serviços comuns foram suprimidos e foram acrescentadas cozinhas a todos os apartamentos” (BAUER, 1995, p. 03). 
Ainda sobre os anos 1920, não poderia deixar de citar Margarete Shütte-Lihotzky, a primeira arquiteta austríaca que desenvolveu projetos relacionados com questões como a habitação acessível e de qualidade, entre eles, a cozinha de Frankfurt (1927), para a qual realizou uma detalhada análise sobre o trabalho doméstico buscando racionalizá-lo. Segundo Paulo Bruna,

[...] a cozinha, altamente industrializada, era organizada de modo a permitir uma racionalidade e uma eficiência de movimentos condizentes com os estudos de Frederick W. Taylor. [...] Organizada como uma cozinha de navio, media $1,87 \mathrm{~m}$ de largura por $3,44 \mathrm{~m}$ de comprimento com apenas $0,86 \mathrm{~m}$ livre no meio, separando duas filas de tampos de trabalho altamente especializados por funções, como gaveteiros, armários e tomada elétrica. A estandarização de seus componentes permitiu que fosse produzida em série, com um custo realmente baixo para a época (BRUNA, 2010, p. 45).

Margarete Shütte-Lihotzky ao falar sobre as razões pelas quais foi a primeira mulher a estudar arquitetura, em 1916, no Kunstgewerbeschule, comenta que

[...] uma das maiores mudanças na habitação deve refletir o fato de que as mulheres, em geral, começaram a trabalhar. Isso requer focos completamente novos. Como arquitetos, é nosso dever pensar cuidadosamente sobre o que temos que levar em consideração na construção de habitação para tornar a vida mais fácil a homens e mulheres e reduzir o estresse cotidiano, como proporcionar espaços auxiliares para os vizinhos, serviços comunitários, etc. (SHÜTTE-LIHOTZKY, em KAIL; BAUER; ZWINGL, 1996, p. 04).

Essa citação de Shütte-Lihotzky representa um conceito de muita força nas análises de projeto realizadas, pois ressalta uma visão muito atual quanto às necessidades dos moradores com respeito a seus lares e à realização das atividades da vida cotidiana.

Estudar esses conceitos e os conjuntos de Viena, fez com que despertasse em mim um grande interesse pelas análises de projetos, buscando compreender como foram concebidos, quais os partidos adotados, o programa de 
necessidades a que deveriam atender, o grau de participação dos futuros moradores, a forma como se relacionavam com a cidade, etc.

Isso me levou a analisar, também durante o desenvolvimento da tesina, edifícios e conjuntos habitacionais emblemáticos no Brasil, buscando identificar, em cada um, os conceitos aplicados. Entre eles: o conjunto Prefeito Mendes de Moraes (1952) - o Pedregulho - realizado pelo arquiteto Affonso Eduardo Reidy em um momento em que pôde contar com a influente participação de sua companheira, a engenheira Carmen Portinho, diretora do Departamento de Habitação Popular (DPH) do Rio de Janeiro; o Conjunto Residencial Parque Guinle, desenvolvido por Lúcio Costa, também no Rio de Janeiro e nos anos 1950; o edifício Japurá (1947) de Eduardo Kneese de Melo, apenas um entre outros exemplos de conjuntos habitacionais promovidos pelos Institutos de Aposentadorias e Pensões (IAPs) em São Paulo; e, por último, o conjunto habitacional Rio das Pedras, desenvolvido pelos arquitetos Hector Vigliecca e Bruno Padovano entre os anos de 1991 e 1997.

Durante o desenvolvimento do Máster Laboratorio de la Vivienda del Siglo XXI, algumas disciplinas foram bastante significativas para minha formação e colaboraram para o desejo de pesquisar projetos de habitação de interesse social. Entre elas:

- Procesos urbanos y vivienda social en Latinoamérica - ministrada pela arquiteta Verena Andreatta que tratou sobre as habitações espontâneas ou clandestinas autoconstruídas sem normas mínimas de habitabilidade e que, em muitos casos, carecem de infraestrutura básica. "Uma cidade que cresce infinitamente, se converte em fragmentos inconexos, com uma imagem continuamente inconclusa e com graves problemas sociais." (CATÁLOGO MÁSTER LABORATORIO DE LA VIVIENDA DEL SIGLO XXI, 5-1, edição 2008-2009, p. 12).

Entre outros projetos, Verena Andreatta apresentou o programa Favela-Bairro, uma atuação por parte da política habitacional desenvolvida e implementada pela Secretaria Municipal de Habitação do Rio de Janeiro em 1994. 
Segundo Izabel Cristina Reis Mendes, "dentro dessa política, o programa Favela-Bairro apresenta como objetivo construir ou complementar a estrutura urbana principal (saneamento e democratização de acessos) das favelas consolidadas e oferecer condições sociais e ambientais de transformação e integração da favela como bairro da cidade" (MENDES, 2006, p. 128).

Considera-se esse programa um exemplo de intervenção em favelas a partir do momento em que apresenta como objetivo principal assumir a existência dos assentamentos informais na cidade e procura, a partir da implantação de infraestrutura básica, oferecer as condições mínimas para que passem a fazer parte da cidade como bairros. De acordo com um artigo publicado na revista Arquitetura e Urbanismo, em junho de 1998,

"O Programa Favela-Bairro apresenta o mérito de ser o reconhecimento da favela como espaço legítimo da cidade, enterrando de uma vez por todas os fantasmas das remoções tão comuns nas décadas de 60 e 70 . [...] é importante ressaltar o sucesso da intervenção ao permitir a acessibilidade ao interior das favelas e à inserção de equipamentos comunitários, como creches e postos de saúde. [...] Contudo, cabe ressaltar a limitação do programa no que diz respeito às construções - moradias, estabelecimentos comerciais e, até mesmo, industriais - existentes na favela. No contexto da intervenção, a atuação dos escritórios de arquitetura sobre esses espaços só ocorre quando há necessidade de ampliação dos acessos ou diante da situação de risco." (REVISTA AU, edição 78 - junho/1998).

Conforme pôde ser observado no trecho acima, existe uma crítica quando à falta de intervenção nas moradias, porém, é preciso entender que o programa propunha intervenções no espaço público e oferta de infraestrutura, atuando na construção de novas residências, apenas quando fosse necessário. O arquiteto Hector Vigliecca, em uma conferência no Museu da Casa Brasileira em novembro de 2012, comentou que, estabelecer estruturas públicas legíveis deve ser um dos principais pontos de atuação nas urbanizações de favelas, pois os indivíduos se sentem cidadãos e passam a investir na conservação de suas casas uma vez que estão frente a uma estrutura 
pública, ou seja, a uma rua reconhecida oficialmente (informação verbal) 5 . Sendo assim, entende-se que a proposta apresentada pelo Programa Favela-Bairro considerou o primeiro passo para a qualificação desses espaços enquanto parte da cidade.

Cesar Maia, prefeito da cidade do Rio de Janeiro na época em que o Programa Favela-Bairro foi implantado, comenta sobre a importância de incorporar as favelas à cidade:

Com a criação da SMH [Secretaria Municipal de Habitação em 1993] pretendíamos, e estamos caminhando para atingir esse objetivo, que o trabalho da nova Secretaria fosse determinado pela intervenção do Poder Público, como forma de integrar a cidade com as comunidades carentes. Mais do que esgoto, escadarias, pavimentação, essas áreas também precisam ser vinculadas ao resto da cidade, através de projetos de sucesso, como o Favela-Bairro (MAIA, em: DUARTE; SILVA; BRASILEIRO, 1996, p. 7)

- Laboratorio de la vivienda del siglo XXI - ministrada por Jorge Mario Jáuregui que, a partir da experiência do arquiteto em intervenções em favelas, foram expostos os principais conceitos que acompanham seu método de trabalho. O Complexo do Alemão (2009) foi um dos projetos apresentados que, como objetivos principais, buscou: "promover e facilitar uma nova conectividade da região do Complexo, com os bairros do entorno e com a cidade; repor as centralidades existentes introduzindo outras novas junto com serviços e equipamentos de qualidade, criando nova acessibilidade; e incorporar edificações de valor arquitetônico e urbanístico ao tecido da favela" ${ }^{\text {. }}$. Entre outras intervenções, a implantação do teleférico como transporte urbano significou conceber "a acessibilidade, a mobilidade e a conectividade tanto interna, quanto na sua relação com a cidade"7. Essa atitude deve ser ressaltada como exemplo de atuação que extrapola as ações convencionais buscando solucionar os problemas identificados, ainda que isso represente ações diferenciadas.

${ }^{5}$ Conferência de Hector Vigliecca no Museu da Casa Brasileira em 28 de novembro de 2012.

${ }^{6}$ Informações disponíveis no site do arquiteto: http://www.jauregui.arq.br/favelas_alemao.html. Acesso em setembro de 2013.

7 Ibid 4. 
Outro projeto apresentado foi Complexo Manguinhos (2012), em que o arquiteto buscou transformar a linha férrea, que antes funcionava como barreira física e de isolamento do Complexo, em uma "rambla", um espaço público que promove a relação entre as pessoas. Outro exemplo de intervenção em urbanização, acessibilidade, construção de moradias e equipamentos públicos. Ambos os projetos foram realizados na cidade do Rio de Janeiro a partir do programa de financiamento federal, o Programa de Aceleração de Crescimento (PAC).

- Seminario Vivienda y Ciudad - ministrada pela arquiteta Christine Van Sluys. Essa disciplina tratou sobre habitação social no Brasil, em Portugal e Londres além de contar com a experiência de cada aluno solicitando a apresentação de uma obra originária do país de cada um a partir da utilização de fichas de análise como padrão de apresentação que possibilitaram configurar um repertório projetual.

Durante as aulas, Christine comentou sobre habitação social na cidade de São Paulo e, entre outros projetos, apresentou o Concurso Habita Sampa promovido pela Secretaria Municipal de Habitação em 2004.

- Casa sin género - ministrada pelas arquitetas Adriana Cioccoleto e Marta Fonseca colaborou para que despertasse um olhar distinto para o interior das habitações, buscando reconhecer as atividades desenvolvidas pelos moradores em seu cotidiano e, ao mesmo tempo, analisar se os espaços propostos e sua disposição correspondem às necessidades relacionadas à realização dessas atividades. Essa disciplina incentivou uma reflexão sobre como seria uma casa sem hierarquias.

Além das disciplinas, dois trabalhos, desenvolvidos a partir do Máster Laboratorio de la Vivienda del Siglo XXI e coordenados pelos arquitetos Josep Maria Montaner e Zaida Muxí, devem ser citados como referências importantes para a formação da minha metodologia de trabalho: Habitar el Presente. Vivienda en España:

8 Termo utilizado pelo arquiteto: a "Rambla" de Maguinhos. Disponível em: http://www.jauregui.arq.br/miscelaneas_rambla.html. Acesso em setembro de 2013 . 
sociedad, ciudad, tecnología y recursos (2006) e Herramientas para habitar el Presente. La vivienda del Siglo XXI (2011). Essas referências representam exemplos de formas de sistematizar a avaliação de projetos a partir da definição de variáveis comuns, que proporcionam uma leitura rápida sobre essa avaliação permitindo identificar, de modo geral, as qualidades e debilidades de cada projeto dentro dos temas abordados.

Enquanto ainda estava em Barcelona, iniciando o desenvolvimento da tesina, tive a oportunidade de participar, junto às arquitetas Fabricia Zulin e Vivian Cuzziol, do concurso de ideias PREMIO-CAIXA IAB 2008-2009 - 4 edição. Desenvolvemos uma proposta para a modalidade intervenções em áreas urbanas degradadas com o projeto Intervenção Urbana em Zona Especial de Interesse Social Santa Cecília / SP, que foi premiado em primeiro lugar. Esse foi um dos primeiros momentos em que realmente senti a necessidade de compreender que critérios deveriam ser utilizados para a produção de habitação social com qualidade? Como deveriam ser empregados no projeto? Surgiu a necessidade de conhecer e entender melhor os hábitos e costumes da população que seriam os futuros moradores. Essa inquietação foi o motor para o desenvolvimento da tesina que busco explorar esses critérios e analisar os conjuntos de Viena e os projetos emblemáticos no Brasil.

Após a conclusão do Máster, ao voltar para São Paulo, me envolvi mais uma vez na participação de concurso público para o desenvolvimento de projetos para habitação de interesse social. Dessa vez, um concurso promovido pela Companhia de Desenvolvimento Habitacional e Urbano do Estado de São Paulo (CDHU) e organizado pelo IAB/SP, chamado Habitação para Todos, que buscava novas tipologias para habitação de interesse social sustentável. Ao participar desse concurso, junto às arquitetas Fabricia Zulin e Carla Andrade da Silva ${ }^{9}$, mais uma vez me deparei com a necessidade de explorar os critérios para concepção de conjuntos habitacionais de qualidade e, dessa vez, ainda havia a necessidade de atender aos padrões pré-estabelecidos pelos parâmetros da 


\section{CDHU, como o manual Desenho Universal, habitação de interesse social - Diretrizes do desenho universal} na habitação de interesse social no Estado de São Paulo (2010).

Ainda motivada pela pesquisa desenvolvida em Barcelona, me inscrevi para o processo seletivo do curso de pósgraduação para mestrado da Faculdade de Arquitetura e Urbanismo da Universidade de São Paulo (FAUUSP) com o tema de pesquisa: a perspectiva de gênero aplicada à produção arquitetônica. Porém, devido à minha atuação profissional, acabei envolvida em trabalhos relacionados à habitação social na cidade de São Paulo. Esse envolvimento fez com que, pouco a pouco o interesse pelos projetos contemporâneos de habitação de interesse social fosse aumentando ao mesmo tempo em que fui tendo acesso ao material gráfico e a visitas aos projetos e, finalmente, o tema da pesquisa foi alterado para Habitar Social e a produção contemporânea na cidade de São Paulo.

O primeiro trabalho, responsável por esse meu envolvimento, foi o Instrumentos de Avaliação de Projetos (2012b). Esse trabalho, resultado de uma parceria entre a Secretaria Municipal de Habitação (Sehab) e os escritórios Montaner Muxí Arquitectes e Habitar Arquitetas Associadas ${ }^{10}$, consistiu-se no desenvolvimento de um sistema de análise e valoração de projetos.

O trabalho foi desenvolvido a partir da avaliação crítica dos projetos realizados pela Sehab no período compreendido entre 2005 e 2012 e derivou dos trabalhos citados anteriormente - Habitar el Presente e

10 Montaner Muxí Arquitectes: Josep Maria Montaner e Zaida Muxí como coordenadores gerais do trabalho. Equipe: Roser Casanovas, Daniela Arias, David H. Falagán e colaboração de Carla Conill.

Equipe escritório Habitar Arquitetas Associadas: Fabricia Zulin, Renata Coradin e colaboração de Alessandra Bedolini.

Sehab: Coordenação: Elisabete França, Maria Teresa Diniz, Maria Teresa Cardoso Fedeli. Equipe: Thiago Soares Barbizan, Josefina Ocanto, Stefânia Dimitrov, Luis Fernando Arias Fachini e todos os técnicos das regionais que acompanharam as visitas aos projetos. 
Herramientas para habitar el presente - tendo sido adaptado à realidade de São Paulo, uma vez que os anteriores foram desenvolvidos para a realidade espanhola.

Durante o desenvolvimento desse trabalho, tive a oportunidade de visitar aproximadamente vinte e nove projetos entre conjuntos habitacionais e urbanizações, sendo que, em alguns casos, cheguei a visitar o mesmo projeto mais de uma vez. Isso ocorreu quando os projetos ainda estavam em obra na primeira visita e, para poder analisá-los melhor, foi necessário realizar novas visitas após a entrega aos moradores. Essas visitas proporcionaram a oportunidade de conhecer melhor os projetos e observar como os moradores estavam se apropriando desses novos espaços.

As visitas e os desenhos gráficos disponibilizados pela Secretaria de Habitação configuraram um material de excelente qualidade e de enorme contribuição para o desenvolvimento dessa dissertação de mestrado. Além do mais, as visitas proporcionaram percepções que jamais poderiam ter sido compreendidas ou adquiridas apenas com a análise do material gráfico. Nos casos em que foi possível conversar com os moradores e entrar em suas casas, muitas informações empíricas foram adquiridas e poder utilizar essa experiência para a análise dos projetos é um privilégio que deve ser aproveitado.

Além do mais, a execução desse trabalho me colocou em contato com um processo de adequação de critérios de análise, que inicialmente haviam sido desenvolvidos para a realidade espanhola, para a realidade da cidade de São Paulo e, ao mesmo tempo, a incorporação de novos critérios, fruto das Diretrizes de Projetos de Edificação ${ }^{11}$ elaboradas pela equipe de técnicos da Sehab com base na observação e acompanhamento da apropriação dos moradores dos conjuntos habitacionais.

${ }^{11}$ As Diretrizes de Projetos de Edificação foram desenvolvidas pela equipe da Sehab, sob a coordenação da arquiteta Maria Teresa Diniz e estão publicadas no livro "Do Plano ao Projeto: Novos Bairros e Habitação Social em São Paulo" (2012b). 
Ainda, durante o desenvolvimento desse trabalho, ocorreu a participação no terceiro concurso de habitação de interesse social, dessa vez promovido pela Secretaria Municipal de Habitação e pelo IAB/SP, o Renova SP concurso de projetos de arquitetura e urbanismo. Junto aos arquitetos Paulo Bruna e Fabricia Zulin ${ }^{12}$ fomos premiados pela proposta apresentada para o Perímetro de Ação Integrada Água Espraiada 2+5.

Ao desenvolver as propostas para o concurso, mais uma vez me deparei com a necessidade de conhecer, com maior profundidade, critérios para o desenvolvimento de habitação de interesse social com qualidade e, assim, o trabalho em desenvolvimento para a dissertação de mestrado foi sendo norteado para a análise de conjuntos habitacionais de interesse social para, a partir do estudo desses conjuntos, poder refletir sobre os critérios utilizados que tiveram bons resultados e também sobre os mal sucedidos, buscando compreender suas razões para, ao menos, deixar registrado um repertório de atuações que poderão contribuir como referência para o desenvolvimento de novos projetos.

Paulo Bruna, com base no trabalho de Licia do Prado Valladares ${ }^{13}$, comenta que "de modo geral, os trabalhos sobre o problema habitacional no Brasil têm tido um enfoque sociológico, histórico ou econômico, e a grande maioria estuda a criação do BNH e o período posterior a 1964." BRUNA cita ainda que, examinando a produção acadêmica referente à questão habitacional,

[...] verifica-se que há desde temas sobre os quais muito se pesquisou, como por exemplo os estudos pioneiros sobre a favela carioca e depois a paulista, até pesquisas mais recentes que deslocam o interesse central para a ocupação indiscriminada das periferias das áreas metropolitanas, e os processos de autoconstrução de moradias (BRUNA, 2010, p.10).

12 Para a realização desse concurso contamos com a colaboração do arquiteto Jean Felipe Prado.

13 Paulo Bruna em Os primeiros arquitetos modernos: Habitação social no Brasil 1930-1950, 2010, p. 10 se refere à pesquisa de Lícia do Prado Valladares que no trabalho "Estudos Recentes sobre a Habitação no Brasil: Resenha da Literatura", em Repensando a Habitação no Brasil, 1983, organizou toda a produção acadêmica referente à questão habitacional no Brasil. 
A arquiteta Ruth Verde Zein, no livro Brasil: arquiteturas após 1950 inicia o capítulo intitulado Habitação Social: Das Utopias Tecnológicas e Urbanísticas à Repetição dos Modelos ressaltando que "há temas arquitetônicos cuja plena compreensão deve necessariamente passar pelo trato de questões urbanísticas, estando, ademais, indissoluvelmente ligados a debates de ordem política, como é o caso da habitação coletiva de interesse social." A arquiteta também comenta que

[...] frequentemente, a vontade de relacionar a arquitetura habitacional com temas de ordem socioeconômica, política e cultural, acaba deixando a arquitetura propriamente dita em último plano, ou sequer a menciona, sendo comum considerar de menor relevância a análise crítica pormenorizada das soluções arquitetônicas e urbanísticas, propostas ou efetivamente realizadas, para a habitação social; [...] Essa conexão simplista deve necessariamente ser ultrapassada: ninguém mora em políticas habitacionais e sim em casas e edifícios concretos, situados em bairros existentes ou novos, inseridos em cidades reais e não em esquemas urbanos teóricos; e a maneira como são construídas e propostas essas habitações, nesses bairros, nessas cidades é que, afinal de contas, irá garantir ou não a qualidade e pertinência dos resultados - e retroativamente validar, ou não, as políticas que os fomentaram (BASTO; ZEIN. 2010, p. 163).

Sendo assim, se propõe que essa dissertação de mestrado se desenvolva buscando trazer a arquitetura para primeiro plano, a partir do estudo e de análises de uma seleção de obras de conjuntos de habitação de interesse social, construídos na cidade de São Paulo e promovidos pela Secretaria Municipal de Habitação (Sehab), entre os anos de 2001 e 2013.

O trabalho se desenvolverá a partir de quatro partes principais: primeiramente, se propõe conhecer e registrar a produção de habitação de interesse social da Sehab durante o período em questão, selecionando-se, ao final, quatro projetos de conjuntos habitacionais significativos para serem analisados em maior profundidade; em seguida será conhecida a metodologia desenvolvida para realizar as análises propostas. Na terceira parte, os quatro 
projetos selecionados serão analisados a partir de critérios pré-estabelecidos que proporcionarão um maior conhecimento sobre esses projetos; e, por último, se propõe uma reflexão sobre as análises realizadas, estabelecendo-se relações e comparações entre os projetos, incluindo também, outros projetos como referência da produção de habitação social do período estudado. 


\section{PRODUÇÃO \\ CONTEMPORÂNEA}

A cidade de São Paulo tem atualmente um terço de sua população morando em favelas e loteamentos irregulares, a despeito de ser a cidade mais rica e populosa do Brasil. Diante disso, combater a pobreza, gerar emprego e renda, diminuir as desigualdades sociais e contribuir para a sustentabilidade ambiental da cidade são desafios intrínsecos à política habitacional (HERLING em: AMORIN; OTERO, 2010, p. 14 e 15).

A citação de Tereza Herling ressalta a importância e os desafios para a política pública habitacional em São Paulo. A distância entre produção e demanda ainda representa números muito altos, como foi citado acima, um terço da população da cidade vive em assentamentos precários ou irregulares ${ }^{1}$. Segundo HERLING, essa distância pode ser explicada "pelo fato de que a renda das famílias moradoras em assentamentos precários e/ou informais é, em geral, inferior a três salários mínimos mensais, insuficientes para arcar com os custos de financiamento e taxas condominiais - um problema crônico que até hoje representa desafio para as políticas públicas de habitação". (HERLING em: AMORIN; OTERO, 2010, p. 13).

Frente a esse desafio e cientes da necessidade de que se produza habitação social de qualidade, neste capítulo será possível conhecer alguns exemplos sobre a produção contemporânea, para podermos, ao final, avaliar o que tem sido feito para enfrentar o desafio.

1 De acordo com dados da SEHAB (2010) o número total de domicílios em assentamentos precários ou informais no município de São Paulo é de 994.926. Se considerarmos a média de 3,6 habitantes por domicílio - de acordo com dados do IBGE (2010) - chegamos ao total de 3.581.733,60 habitantes vivendo em condições informais. Desse número, 389.112 domicílios precários e irregulares estão nas favelas, o que representa 1.400.803,20 habitantes aproximadamente; e apenas 53.000 são domicílios de conjuntos habitacionais, algo entorno de 190.800 moradores alojados em conjunto habitacionais que ainda não foram regularizados, sendo ainda considerados informais. 
Para isso, foi feito um esforço em representar uma parte significativa da produção de habitação de interesse social, promovida pela Secretaria Municipal de Habitação (Sehab), no período compreendido entre os anos 2001 e 2013.

A relação de projetos resultou de uma seleção feita através de consultas a publicações, tanto de livros como de teses relacionadas ao tema, às publicações de balanço de gestão e às revistas especializadas (Arquitetura e Urbanismo, Projeto Design, Monolito e Revista Suma). Essa seleção também contou com recomendações, sobre os projetos, feitas por técnicos da Sehab². Assim, foi possível chegar à relação de projetos que serão apresentados. A seguir, podem ser observados exemplos de algumas publicações em revistas que tratam do tema da habitação de interesse social.

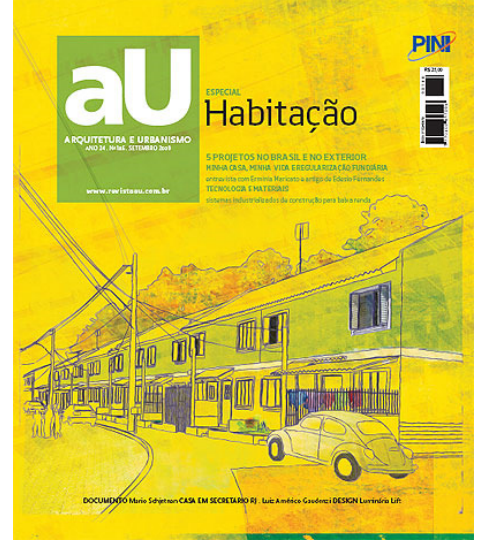

Revista Arquitetura e Urbanismo n.186, setembro de 2009.

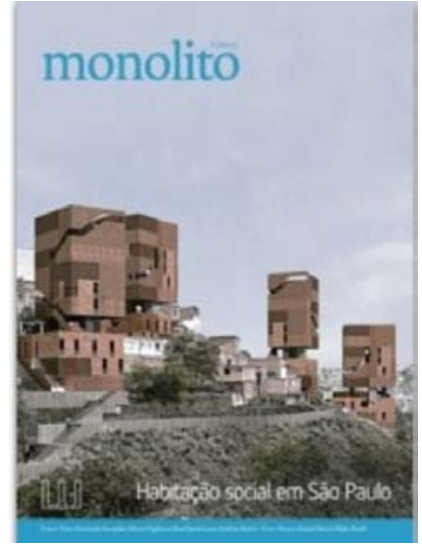

Revista Monolito n.07, março 2012.

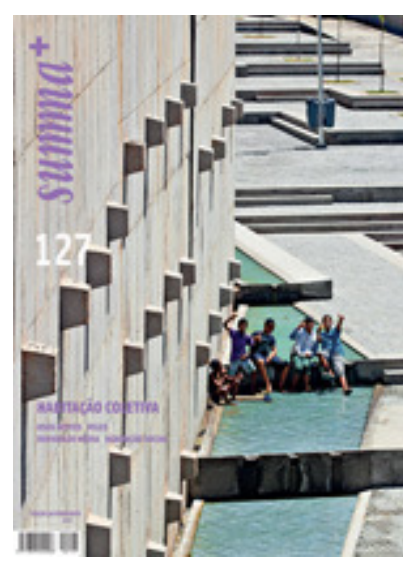

Revista Suma+ n.127, março 2013.

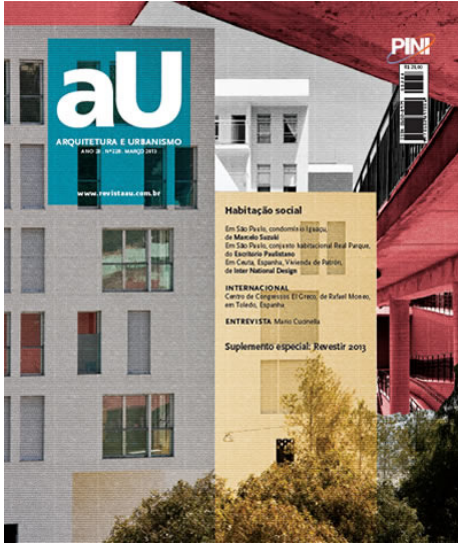

Revista Arquitetura e Urbanismo n.228, março, 2013.

2 O período de pesquisa e visitas aos projetos coincidiu com o período em que estava sendo elaborado o trabalho Instrumentos de Avaliação de Projetos (2012b) e as visitas às obras proporcionaram bastante contato com técnicos da Sehab com os quais sempre foi possível discutir muitos temas relacionados à questão projetual e pós-ocupacional. Essas conversas colaboraram também para a seleção de projetos a serem apresentados nessa dissertação de mestrado. É importante citar a arquiteta Maria Teresa Fedeli, presente na maior parte das visitas, com quem foi possível trocar muitas informações e pontos de vista. 
Segundo a arquiteta Fabricia Zulin que, para o desenvolvimento de sua dissertação de mestrado Habitar Coletivo: obras diferenciadas contemporâneas em São Paulo (2013), consultou todos os números das revistas especializadas nacionais e também da revista Suma a partir de 2000 até 2013, as publicações no âmbito da habitação social ou intervenções em favelas é "algo que começou a ficar mais frequente a partir do ano 2009 aproximadamente" (ZULIN, 2013).

Ao consultar essas publicações, foi possível perceber que as discussões arquitetônicas quanto à produção de habitação de interesse social foram sendo retomadas a partir dos últimos anos, após um longo período de dois mandatos políticos, nas gestões de Paulo Maluf (1993 a 1996) e Celso Pitta (1997 a 2000), durante o qual é possível identificar um declínio na produção de habitação social, marcado pela implantação e repetição do modelo Cingapura, em que parece não ter ocorrido discussões sobre a qualidade ou a relação com a cidade. Segundo Elisabete França,

Como um programa da política habitacional, a verticalização das favelas face à necessidade de desadensamento da área, poderia ter sido considerada como uma das metodologias de intervenção em áreas de baixa renda muito adensadas. Porém, a forma como os debates sobre o Projeto [Cingapura] foram conduzidos terminaram por interromper um processo de construção do conceito de urbanização de favelas, que vinha sendo elaborado, desde 1983, com o esforço de vários profissionais da área da habitação (FRANÇA, 2009, p. 131).

As intervenções urbanas no âmbito dos assentamentos precários e promoção de habitação de interesse social, realizadas pelo Programa Cingapura, pareciam tentar esconder o real problema das favelas através da construção e reprodução de modelos de edifícios habitacionais conformando "novas" fachadas para a cidade e ocultando o problema real vivido pelos assentamentos, sem apresentar, efetivamente, soluções a esses problemas. Elisabete França, ao escrever o capítulo Fatos e Mitos do Projeto Cingapura em sua tese de doutorado ressalta a incompatibilidade do Cingapura como um programa de urbanização de favelas e comenta ainda a contemporaneidade com o Programa Favela-Bairro implantado no Rio de Janeiro. 
O Programa de Melhoramento em Favelas no Município de São Paulo (PROVER), ou Projeto Cingapura, na estrutura organizacional do BID [Banco Interamericano de Desenvolvimento], era considerado como de urbanização de favelas, embora tenha sido adotada, como proposta de intervenção, a construção de edifícios verticais, como a principal solução. Essa forma de conceber este Programa resultou na implantação de projetos de conjuntos isolados, sem integração com a cidade, e que demonstrou não existir propostas de urbanização para as favelas que foram objeto de intervenção.

Cabe lembrar que data dessa mesma época o contrato celebrado entre a Prefeitura da Cidade do Rio de Janeiro e o BID para a implantação do Projeto Favela-Bairro. Sua concepção era bem mais avançada no que diz respeito à compreensão do conceito de urbanização de favelas como elemento de integração dos assentamentos precários à cidade formal, em comparação ao Programa paulistano. O Favela- Bairro priorizou a contratação de projetos de urbanização para as favelas, os quais foram escolhidos a partir de concurso promovido pelo Instituto de Arquitetos do Brasil - Departamento Rio de Janeiro (IAB/RJ), que mobilizou dezenas de escritórios de arquitetura e equipes multidisciplinares para a realização da tarefa (FRANÇA, 2009, p. 135).

De acordo com Tereza Herling, "o paradigma da década de 1990 foi, portanto, o reconhecimento da consolidação dos assentamentos precários como alternativa habitacional e a implantação de políticas públicas de larga escala para enfrentar o problema".

O Programa Guarapiranga é citado por HERLING como a primeira iniciativa de São Paulo, em larga escala, a assumir a importância de manter a população moradora em favelas e loteamentos irregulares em seus locais de moradia, "levando-lhes infraestrutura fundiária e, ao mesmo tempo, integrando as ações habitacionais e ações de saneamento e recuperação ambiental de âmbito estadual". A arquiteta considera esse programa como a "base para o aprimoramento e ampliação dos programas de urbanização e regularização fundiária de assentamentos precários para todo o município" (HERLING em: AMORIN; OTERO, 2010, p. 14). 
Sobre a década de 2000, Tereza Herling comenta que, "iniciados pelos movimentos sociais de moradia, importantes passos foram dados pelo poder público no sentido de implantar programas habitacionais de provisão de moradia na área central do município", citando como exemplos os programas Ação no Centro e Morar no Centro.

Após o ano de 2001, pouco a pouco as discussões arquitetônicas foram sendo retomadas e tornou-se cada vez mais comum o convite e a contratação de escritórios de arquitetura para o desenvolvimento dos projetos de habitação de interesse social em São Paulo. Com isso, esses projetos voltaram a ganhar espaço nas publicações e discussões arquitetônicas, sendo que a variedade de autores (arquitetos) e de propostas é um fator muito positivo que incentiva a busca por melhor qualidade projetual.

No período anterior a esse, citado como de forte declínio (1993 - 2000), no final da década de 1980, durante a gestão de Luiza Erundina (1989 a 1992), podemos identificar alguns exemplos de projetos de habitação de interesse social, bastante significativos para a história recente da habitação.

De acordo com Rosana Rita Folz (2004, p.11), "a prefeitura Municipal de São Paulo, no período de 1989-1992, implantou quase duzentos empreendimentos que iam de conjuntos habitacionais, urbanização de favelas a recuperação de cortiços." Para FOLZ, "uma postura frente ao projeto habitacional e urbano visivelmente contrastante a até então assumida pela 'linha BNH'. Esta diversidade de atuação gerou as mais diferentes implantações de conjuntos". 
Entre essa produção, foram selecionados alguns exemplos representativos:

\begin{tabular}{|c|c|c|c|}
\hline Projeto & Arquitetura & Localização & Data \\
\hline \multirow[t]{2}{*}{ São Francisco } & Invento Espaços e Co-opera-ativa & São Mateus / Z. Leste & $1990-1992$ \\
\hline & Arquiteto Demetre Anastassakis & & \\
\hline Minas Gás & Ubirajara Gillioli & Casa Verde / Z. Norte & $1990-1992$ \\
\hline Madre de Deus & Pedro Sales & Mooca / Z. Leste & $1991-1993$ \\
\hline Rio das Pedras & Héctor Vigliecca e Bruno Padovano & Jardim Helena / Z. Leste & $1991-1997$ \\
\hline $\begin{array}{l}\text { Celso dos Santos e } \\
\text { Pascoal Melantônio }\end{array}$ & $\begin{array}{l}\text { Abrahão Sanovicz, Edson Jorge Elito, João } \\
\text { Honório de Mello Filho e Marcos Carrilho. }\end{array}$ & Cidade Ademar / Z. Sul & $1994-1997$ \\
\hline União da Juta & $\begin{array}{l}\text { Usina - Centro de Trabalho para o Ambiente } \\
\text { Habitado }\end{array}$ & São Mateus / Z. Leste & $1992-$ \\
\hline
\end{tabular}

Entre os projetos destacados, é importante citar que os dois últimos da lista estavam relacionados a programas ou entidades de promoção de habitação social que viabilizaram sua construção nesse período. No caso do Celso dos Santos e Pascoal Melantônio, faziam parte do Plano Geral de Reassentamento do Programa Guarapiranga e o União da Juta, foi um projeto desenvolvido pelo Usina, um coletivo de arquitetos que atua junto aos movimentos sociais viabilizando a construção de conjuntos habitacionais através da autogestão. Esse projeto, teve como referência, o projeto COPROMO desenvolvido pelo Usina na cidade de Guarulhos em 1992 e representa avanços significativos na racionalização das construções a partir da autogestão. "Do ponto de vista construtivo, a utilização de escadas metálicas como elemento referencial e de apoio à edificação do bloco representou um diferencial, agregando à organização do canteiro uma racionalidade e uma forma segura de circulação de pessoas e transporte de materiais." (RUBANO et al. 2006, p. 164). 
São Francisco III é resultado do 1ํ Concurso Nacional de Anteprojetos de Habitação Popular ${ }^{3}$, realizado em 1990. Segundo Ruth Verde Zein, "a ênfase do concurso era na melhoria da qualidade, não apenas da unidade habitacional - ainda limitada a áreas bastante exíguas -, mas também dando ênfase na sua relação com a cidade existente - que se pretendia não fosse de isolamento e diferenciação, mas de integração e continuidade." ZEIN comenta ainda que "naquele momento isso significava, em algumas das respostas, certo alinhamento com as teorias de pensadores como Aldo Rossi, afiliados a uma tendência que recebeu a alcunha de 'pós-moderna' em alguns debates nacionais e internacionais" (BASTOS; ZEIN, 2010, p. 307).

Apesar de o concurso ter contemplado duas áreas na cidade, uma no Brás ${ }^{4}$ e essa na Zona Leste, apenas o projeto São Francisco foi construído, ainda que parcialmente. As tipologias propostas eram de sobrados e unidades térreas sobrepostas.

Quanto à representatividade dos outros projetos, pode-se citar que o Minas Gás foi a primeira experiência de urbanização com verticalização na cidade de São Paulo, segundo RUBANO et al. (2006, p. 210),

[...] no que diz respeito ao partido arquitetônico, a tipologia do bloco $\mathrm{H}$ foi colocada como condição ao projeto, cabendo ao arquiteto uma proposta de implantação e de articulação com o espaço da cidade. [...] As soluções das unidades habitacionais fazem clara alusão ao conhecido e emblemático conjunto Zezinho Magalhães Prado (Cecap - SP), de Vilanova Artigas e equipe, desenvolvido no final da década de 60, quando propõe uma flexibilidade espacial significativa para que os moradores possam adaptar o espaço do apartamento conforme suas necessidades. O elemento fixo e concentrado é a unidade hidráulica (RUBANO et al. 2006, p. 210).

${ }^{3}$ Para mais informações sobre o $1^{\circ}$ Concurso Nacional de Anteprojetos de Habitação Popular, consultar: BASTOS, Maria Alice Junqueira; ZEIN, Ruth Verde. Brasil: Arquiteturas após 1950. São Paulo: Perspectiva, 2010 - capítulo: Um Concurso para Resgatar o Projeto de Habitação Popular, p. 306.

${ }^{4}$ Sobre a área do Brás, o vencedor foi o arquiteto Sylvio de Podestá, porém o projeto nunca foi construído. 
O projeto Madre de Deus representa, junto com o projeto Celso Garcia, "a primeira experiência do Programa de Cortiços da Sehab na gestão 1989 - 1992" (RUBANO et al. 2006, p. 98). Nesse projeto,

[...] as unidades habitacionais com a mesma área mínima de $36 \mathrm{~m}^{2}$ e um dormitório recolocam a revisão programática tão discutida nas décadas de 40 e 50: se as unidades são reduzidas, algumas áreas para as atividades domésticas poderiam ser revistas e reposicionadas no interior dos edifícios, equacionando de modo diverso os espaços condominiais. Entendidas como lugar de serviço a ser prestado profissionalmente, ou como espaço a ser projetado para o uso coletivo, essas áreas aparecem como complemento externo à moradia. No Madre de Deus, as lavanderias comunitárias estão sob a cobertura em arco e além das lavanderias, também foram propostos ambientes de trabalho no térreo, viabilizados pelos pilotis. (RUBANO et al.,2006, p. 98).

O projeto Rio das Pedras foi construído em mutirão e, de acordo com RUBANO, et al. (2006, p. 132), "o projeto reafirma a quadra, ampara a rua e os espaços coletivos e públicos propostos no seu interior. A galeria elevada representa, como anunciado por Hector Vigliecca, o desdobramento do espaço público em altura e permite a conexão das unidades." As unidades térreas têm quintal, o que, para os autores, "coloca uma discussão importante frente ao confronto histórico entre o desejo da população por uma casa isolada no lote e a necessidade de densidade expressiva".

Nabil Bonduki, como superintendente de Habitação Popular da prefeitura de São Paulo na gestão 1989 - 1992 , comenta que

Buscamos [Bonduki falando em nome da Secretaria de Habitação] romper o mito de que bons projetos são incompatíveis com a habitação econômica. Os trabalhadores, organizados de forma coletiva, têm o direito ao serviço dos arquitetos, a discutir e decidir sobre as alternativas de projeto de sua moradia. Isso se viabilizou, sobretudo no programa de produção de habitação em mutirão e autogestão, baseado na parceria entre a administração popular e organizações não governamentais, como ocorreu no Rio das Pedras (BONDUKI, 2000b, p. 125). 
Essa citação representa, acima de tudo, a forte intenção de inserir qualidade arquitetônica e espacial aos projetos de habitação de interesse social que, conforme iremos estudar, parece ter sido retomada pela Secretaria Municipal de Habitação após 2001.

Esse período coincide também com a aprovação do Estatuto da Cidade, lei federal no 10.257 , que introduziu

[...] um conjunto de instrumentos jurídicos capazes de dar ao poder público um controle muito maior sobre as dinâmicas de produção do espaço urbano, no sentido de garantir o exercício da função social da propriedade e combater o mau uso da propriedade urbana, em especial dos terrenos não utilizados dotados de infraestrutura, geralmente objetos da especulação imobiliária. (PREFEITURA DE SÃO PAULO, 2004 a. p.8).

Com base na publicação Balanço qualitativo de gestão 2001-2004 da Secretaria da Habitação e Desenvolvimento Urbano do Município de São Paulo (Sehab), entre os diversos instrumentos do Estatuto, a Sehab estava trabalhando, na época, "na implementação das Zonas Especiais de Interesse Social (ZEIS), que abrem uma nova possibilidade de ação em favelas e que estão, por exemplo, sendo aproveitadas na urbanização, entre outras, das favelas de Heliópolis e Paraisópolis, as maiores da cidade" (PREFEITURA DE SÃO PAULO, 2004a, p.8).

Conforme publicado no balanço qualitativo da gestão, o primeiro objetivo da política habitacional e de desenvolvimento urbano foi promover habitação na região central a partir da criação do Programa Morar no Centro, que foi criado com o objetivo de

[...] articular os agentes públicos, privados e comunitários, envolvidos ou interessados em desenvolver ações ligadas à reabilitação e à inclusão social no centro, promovendo o resgate histórico e arquitetônico da cidade. Ele é direcionado à melhoria das condições de vida de quem já reside na área central e à atração de novos moradores para a região, de todas as classes sociais, priorizando a reciclagem de prédios vazios e de valor arquitetônico e combinando soluções habitacionais com ações qualificadas de geração de renda (PREFEITURA DE SÃO PAULO, 2004a, p. 30). 
Um dos principais instrumentos do Programa Morar no Centro para financiar essas intervenções foi o Programa de Arrendamento Residencial (PAR), a partir de um convênio com a Caixa Econômica Federal (CEF) que permitia financiar a reabilitação de edifícios indicados pela Sehab ou pelos movimentos populares.

Segue alguns exemplos de projetos de reciclagem de edifícios em área central: ${ }^{5}$

\begin{tabular}{|c|c|c|c|}
\hline Projeto & Arquitetura & Localização & Data \\
\hline Edifício Fernão Sales & arquiteta Helena Saia & Sé / Centro & 2001 \\
\hline Edifício Olga Benário Prestes & $\begin{array}{l}\text { Cooperativa de Trabalho Interdisciplinar } \\
\text { Integra }\end{array}$ & Belém / Z.Leste & 2002 \\
\hline Edifício Rizkallah Jorge & arquiteta Helena Saia & Sta. Efigênia / Centro & 2003 \\
\hline Edifício Maria Paula & Fábrica Urbana & Sé / Centro & 2004 \\
\hline $\begin{array}{l}\text { Edifício Labor / } \\
\text { Brigadeiro Tobias }\end{array}$ & $\begin{array}{l}\text { arquiteta Walkíria Maria Pires de Freitas + } \\
\text { Cooperativa de Trabalho Interdisciplinar } \\
\text { Integra }\end{array}$ & Luz / Centro & 2005 \\
\hline Edifício Joaquim Carlos & $\begin{array}{l}\text { Cooperativa de Trabalho Interdisciplinar } \\
\text { Integra }\end{array}$ & Belém / Z.Leste & 2006 \\
\hline Edifício Senador Feijó & Barbosa \& Corbucci Arquitetos Associados & Sé / Centro & 2008 \\
\hline Edifício Riachuelo & Paulo Bruna Arquitetos Associados & Sé / Centro & 2008 \\
\hline $\begin{array}{l}\text { Edifício Astrúbal do } \\
\text { Nascimento }\end{array}$ & $\begin{array}{l}\text { Anastassakis }+ \text { Autografics Arquitetura e } \\
\text { Planejamento }\end{array}$ & República / Centro & 2009 \\
\hline
\end{tabular}

${ }^{5}$ Para mais informações sobre as intervenções e reciclagem de edifícios residenciais no centro de São Paulo, consultar: dissertação de mestrado de Débora Sanches: Gestão condominial de habitação de interesse social: Estudo na Área Central de São Paulo (2008); dissertação de mestrado de Débora Cristina Beraldes Costa: Gestão pós-ocupação em edifícios reabilitados para habitação de interesse social no centro de São Paulo (2009); dissertação de mestrado de Érica Cristina Castilho Diogo: Habitação social no contexto da reabilitação urbana da Área central de São Paulo (2004). 
Além do PAR, outra política implementada pelo Programa Morar no Centro foi o Programa de Locação Social que contemplava a "produção de unidades habitacionais novas ou a compra e reforma de edifícios, para alugar às famílias de baixa renda" (PREFEITURA DE SÃO PAULO, 2004a, p. 32).

São exemplos de projetos construídos para a locação social:

\begin{tabular}{llr} 
Projeto & Arquitetura & Localização \\
\hline Olarias & Fábrica Urbana & Pari / Centro \\
\hline Parque do Gato & Teresa Herling + Peabiru - Trabalhos Comunitários & Bom Retiro / Centro \\
\hline Vila dos Idosos & Vigliecca \& Associados 2004 & $2002-2004$ \\
\hline
\end{tabular}

Motivados pelo Programa Morar no Centro e apostando na locação social como uma das alternativas para atrair maior população residente para o centro da cidade, Sehab e a Companhia Metropolitana de Habitação de São Paulo (COHAB), em conjunto com o Instituto dos Arquitetos do Brasil (IAB), lançaram um concurso público nacional de dois projetos de habitação de interesse social: um para um terreno na Rua Assembleia e outro para um terreno na Rua Cônego Vicente Marino, na Barra Funda.

O concurso Habita Sampa foi apresentado com o propósito de estimular estudos sobre habitação de interesse social buscando "trabalhar com a maior diversidade de programas habitacionais, oferecer um leque de alternativas para a população menos favorecida, além de desenvolver uma grande variedade projetual e arquitetônica e estabelecer um novo marco de qualidade urbana e ambiental na moradia social" (PREFEITURA DE SÃO PAULO, 2004 d, p. 3). 
Os escritórios premiados pela proposta para o terreno da Rua Assembleia foram: Andrade Morettin Arquitetos Associados em 1ำlugar; UNA Arquitetos em $2^{\circ}$ lugar; a equipe do arquiteto Ricardo Bellio ${ }^{6}$ em $3^{\circ}$ lugar ${ }^{7}$.

Quanto ao terreno da Rua Cônego Vicente Marino, os premiados foram: Frentes em $1^{\circ}$ lugar; UNA Arquitetos em $2^{\circ}$ lugar; e Vigliecca Associados em $3^{0}$ lugar ${ }^{8}$.

No mesmo período, além do Habita Sampa, também foi promovido o concurso Bairro Novo com o objetivo de incentivar a construção de um bairro, com área de quase um milhão de metros quadrados, na região da Água Branca. Região bastante próxima ao centro da cidade, caracterizada como uma "antiga área industrial atualmente subutilizada, segregada pela ferrovia e separada do rio Tietê por suas vias expressas marginais" (NETO, 2006).

O novo bairro seria promovido através de uma parceria entre o poder público e a iniciativa privada a partir da Operação Urbana Água Branca. Entretanto, no que diz respeito à habitação de interesse social, segundo NETO (2006), em uma área em que poderiam viver 40 mil pessoas, o edital do concurso previa apenas 600 unidade para habitação de interesse social, o que não pode ser considerado como um avanço quanto à promoção de moradias.

Apesar de apresentarem boas intenções visando qualificar e estimular o crescimento de áreas degradadas na cidade ou incentivar a moradia nas áreas centrais a partir de projetos com qualidade arquitetônica - uma vez que,

${ }^{6}$ Equipe - 3o lugar terreno Assembleia: Ricardo Bellio, Alexandre Mirandez, Carlos Ferrata, Cássia Buitoni, César Shundi, Daniel Pollara, Leonardo Sette, Luciana Yamamura, Marcelo P. Carvalho, Mariana Viegas, Moracy Amaral.

7 Receberam menção honrosa pelo terreno Assembleia os seguintes escritórios: Nitsche Associados; Newton Massafumi Yamato e Tânia Regina Parma; Leandro Medrano e Luiz Recamán; Projeto Paulista; Artur Katchborian, Mario Biselli, Vasco de Mello, Cristiana Rodrigues, Daniel Corsi, Laura Barreto, Thais Silva, Ana Carolina Pudenzi e André Saraiva; Euclides de Oliveira, Carolina M. Carvalho e Dante Furlan.

${ }^{8}$ Receberam menção honrosa pelo terreno da Rua Cônego Vicente Marino os escritórios: Núcleo de Arquitetura; Álvaro Puntoni, Jonathan Davies e João Sodré; Pablo Hereñú, Anna Vilella, Eduardo Ferroni, Fernanda Neiva, Fernanda Palmieri, Maria Julia Herklotz, Paula Cardoso e Silvio Oksma; Ricardo Bellio, Alexandre Mirandez, Carlos Ferrata, Cássia Buitoni, César Shundi, Daniel Pollara, Leonardo Sette, Luciana Yamamura, Marcelo P. Carvalho, Mariana Viegas, Moracy Amaral; Newton Massafumi Yamato e Tânia Regina Parma; Cristina Martins, Aline Valente, Carlos Luz, Giancarlo Gasparotto, Mariana Hugo, Silvio Machado. 
para o desenvolvimento das propostas, foram promovidos concursos públicos - nenhum dos concursos foram adiante. Como não chegaram a ser construídos, apenas podem ser considerados como contribuição para um repertório de propostas em busca da qualidade projetual que, no caso do Habita Sampa, representa uma busca pela qualidade na produção de habitação de interesse social para a cidade.

Outro programa que fez parte da política habitacional do período estudado foi o Programa de Cortiços, que viabilizou a requalificação de cortiços, ou como pôde ser observado nos exemplos estudados, a construção de novos edifícios no terreno anteriormente ocupado por um cortiço.

Como exemplos da produção pelo Programa de Cortiços, foram selecionados os seguintes projetos:

\begin{tabular}{llr} 
Projeto & Arquitetura & Localização \\
$\begin{array}{l}\text { Casarão Celso } \\
\text { Garcia }\end{array}$ & Claudio Manetti & Brás / Centro \\
$\begin{array}{l}\text { Edifício Pedro } \\
\text { Fachini }\end{array}$ & $\begin{array}{l}\text { Barbosa \& Corbucci Arquitetos } \\
\text { Associados }\end{array}$ & Ipiranga / Z. Sudeste \\
\hline Casarão do Carmo & Vigliecca \& Associados & \multicolumn{1}{c}{ Centro } \\
\hline Edifício Imoroti & $\begin{array}{l}\text { Peabiru - Trabalhos } \\
\text { Comunitários }\end{array}$ & Sacomã / Z. Sudeste \\
\hline
\end{tabular}

A implantação desse programa visou a retomada de um programa iniciado na gestão de 1989-1992 para a "produção habitacional para encortiçados, garantindo aos moradores a permanência no mesmo local por meio do sistema de construção em mutirão" (PREFEITURA DE SÃO PAULO, 2004a, p. 40). São exemplos da produção 
desse período os projetos Celso Garcia ${ }^{9}$ e Madre de Deus, já citado anteriormente ao tratar da produção do período anterior.

Como segundo objetivo da política habitacional da gestão 2001-2004, estava o Plano de ação em favelas e loteamentos irregulares e clandestinos a partir da implantação do Programa Bairro Legal. Esse programa considerava também uma ação para a melhoria dos conjuntos habitacionais e foi proposto a partir das seguintes linhas de atuação:

- Obras de Urbanização: que visavam promover a "integração das favelas e loteamentos irregulares à cidade e melhoria das condições de habitabilidade e salubridade, possibilitando o acesso à moradia adequada, infraestrutura, serviços, equipamentos urbanos e comunitários".

- Regularização Urbanística e Fundiária: que visava oferecer aos moradores "acesso à posse segura de seus imóveis em favelas ou loteamentos irregulares" a partir da outorga de títulos de posse.

- Reassentamento: realizado a partir de intervenções em áreas degradadas, "para eliminação de risco e insalubridade ou para viabilizar obras de urbanização. Consiste no reassentamento de famílias em empreendimentos situados em áreas próximas ao local de origem (ou na própria área)".

\section{- Recuperação e Preservação Socioambiental das Áreas de Proteção dos Reservatórios Guarapiranga e}

Billings: "visando respeitar as imposições ambientais e garantir a melhoria da qualidade de vida da população e a sustentabilidade das intervenções por meio de fiscalização integrada" (PREFEITURA DE SÃO PAULO, 2004a, p. 44 e 45$)$. 


\section{Segundo Suzana Pasternak,}

[...] como instrumento de implantação de sua política habitacional, o atual governo municipal [referencia à gestão de Marta Suplicy entre os anos de 2001 e 2004] tem utilizado o Programa Bairro Legal, que pode ser definido como um conjunto de ações integradas em território contínuos e delimitados, ocupados predominantemente por população de baixa renda. Ele compreende a urbanização e regularização de favelas e loteamentos irregulares, e a qualificação de conjuntos habitacionais. (PASTERNAK; BALTRUSIS, em: CARDOSO, 2007, p. 109).

Para PASTERNAK, esse programa "distingue-se dos programas das gestões anteriores pela exigência da atuação integrada entre diferentes organismos municipais, buscando também o envolvimento das demais esferas públicas, de organizações não governamentais e da sociedade civil" (PASTERNAK; BALTRUSIS, em: CARDOSO, 2007, p. 109). A arquiteta comenta ainda o estímulo à participação da população como forma de construção de cidadania $e$ conclui que

Assim, propõe-se uma mudança de paradigma: a substituição de políticas voltadas tanto para a produção de novas moradias quando para o saneamento por intervenções abrangentes, que considerem de forma integrada a qualificação urbana, a regularização fundiária, o acesso a serviços e equipamentos públicos e áreas verdes, justamente com programas sociais. (PASTERNAK; BALTRUSIS, em: CARDOSO, 2007, p. 110).

Com isso, podemos comprovar um grande avanço das políticas habitacionais quanto à intervenção em favelas, colocando em primeiro lugar preocupações quanto à oferta de infraestrutura básica e o envolvimento da população nos processos de intervenção priorizando a fixação da população nos lugares onde vivem.

Nesse momento, vale fazer um parêntese para exemplificar a importância da manutenção das pessoas nos lugares onde já pertencem a uma rede social. Como exemplo dessa necessidade, segue abaixo trecho do livro $\mathbf{O}$ mito da marginalidade, favelas e políticas no Rio de Janeiro de Janice Perlman (1977) onde a autora relata a decepção dos moradores que foram levados para conjuntos habitacionais construídos na periferia da cidade, onde a terra era 
mais barata, durante a década de 1970. PERLMAN documenta a insatisfação quanto a tais transferências, assim como às "devastadoras" repercussões econômicas, sociais, culturais, políticas e físicas.

[...] Além do gasto em tempo e dinheiro, o isolamento dos conjuntos leva a um sentimento de distanciamento do centro da vida e das atividades urbanas. A distância do mercado de trabalho traz sérias consequências para as mulheres que trabalhavam como lavadeiras, costureiras, amas ou empregadas de famílias de posses. Os salários de tais empregos raramente compensam as despesas de transporte, e como elas já não podem ficar em casa, é preciso arranjar onde deixar as crianças (o que se torna mais difícil, diante da desintegração das antigas redes de ajuda mútua). Como os conjuntos em geral se localizam em terrenos da periferia, de baixo valor, longe das famílias ricas, muitas mulheres vêmse forçadas, após a remoção, a simplesmente deixar de trabalhar.

[...] Um grupo severamente afetado pela remoção é o dos comerciantes da favela, que, quase na totalidade, vão à bancarrota devido à perda da freguesia, às despesas com novas licenças, às proibições de utilizarem parte das moradias para instalar seu negócio, ou aos aluguéis exorbitantes de novas lojas.

[...] Os efeitos socioculturais da remoção podem ser melhor compreendidos se pensarmos nas vantagens da favela como uma comunidade funcional. Como as pessoas são espalhadas nos novos conjuntos com base em seu nível de renda, e não de seus relacionamentos sociais e familiares, a estrutura de apoio da favela não sobrevive à erradicação (PERLMAN, 1977, p. 253 a 257).

Felizmente essa mentalidade de construir conjuntos habitacionais na periferia ficou para trás e o grande desafio do período estudado parece, com base nos objetivos dos programas propostos, ter a finalidade de realizar intervenções de qualidade, tanto nas urbanizações, quanto na produção de conjuntos habitacionais. Essa produção representa um fator muito importante dentro dos programas de urbanização de favelas, pois os conjuntos habitacionais são construídos para alojar as pessoas que, em geral, foram removidas de suas casas por estarem sobre áreas de risco; devido à necessidade de ceder lugar para a abertura de viários ou instalação de redes de infraestrutura; ou por questões relacionadas à salubridade e condições mínimas de habitabilidade. Construir 
conjuntos habitacionais, mais além de oferecer uma moradia para as famílias necessitadas, também significa construir cidade.

Como terceiro objetivo da gestão 2001 - 2004, está a política de provisão habitacional de interesse social e, neste sentido, a administração buscou retomar o programa dos mutirões autogeridos que havia sido iniciado na gestão 1989 - 1992 e que havia ficado interrompido durante dois mandatos políticos.

Como exemplo dessa produção, pode-se citar a retomada do Mutirão Apuanã, na Zona Norte e, entre outros projetos que foram viabilizados no final dessa gestão, o Mutirão Paulo Freire coordenado pelo Coletivo Usina ${ }^{10}$.

$\begin{array}{lll}\text { Projeto } & \text { Arquitetura } & \text { Localização } \\ \text { Paulo Freire } & \text { USINA - Centro de Trabalhos para o } & \text { Cidade Tiradentes }\end{array}$
Ambiente Habitado

Como observação sobre a atuação durante esses primeiros quatro anos, pôde-se identificar que a ênfase da gestão foi com relação aos programas de Reabilitação do Centro da Cidade, pelo qual foi viabilizada a reciclagem de edifícios em área central, a reabilitação de cortiços, ou, melhor dizendo, construção de edifícios habitacionais onde antes havia cortiços. Quanto ao Programa Bairro Legal, de acordo com Suzana Pasternak, sua atuação focalizou a "reforma física, por meio da instalação da estrutura viária e de saneamento, e da legalização da terra" (PASTERNAK; BALTRUSIS, em: CARDOSO, 2007, p. 109). Porém, não foi possível identificar uma produção representativa de conjuntos habitacionais.

10 Para saber mais sobre os mutirões realizados pela Sehab, consultar: COHAB SP, Relatório de gestão 2001/2004. (2004b). 
Entretanto, as atuações no âmbito das políticas habitacionais fazem parte de um processo que deve ser considerado ao longo dos anos e não medido a partir de mandatos políticos isoladamente. Sendo assim, Elisabete França comenta que, ao assumir a Superintendência da Secretaria de Habitação em 2005, deparou-se com o grande desafio de dar andamento aos contratos existentes para a urbanização de quatorze favelas ${ }^{11}$. (PREFEITURA DE SÃO PAULO, 2012a, p. 23). Fato que representa certa continuidade com relação ao programa de urbanização de favelas.

A partir da análise da publicação Plano Municipal de Habitação, a experiência de São Paulo - volume 1 (PREFEITURA DE SÃO PAULO, 2012a), realizada no final da gestão 2005 - 2012, foi possível identificar os campos de maior atuação dentro da política habitacional durante esse período.

O desenvolvimento do Plano Municipal de Habitação (PMH) $2009-2024{ }^{12}$, coordenado por Tereza Herling, foi um dos principais trabalhos realizados durante essa gestão. Esse projeto traçou as metas de intervenção dentro do âmbito da habitação visando a atuação ao longo de quatro quadriênios. Para isso, a equipe da Sehab esteve envolvida no levantamento de dados e mapeamento de todas as favelas, cortiços e loteamentos irregulares da cidade. Esse levantamento possibilitou a implantação de um sistema online, alimentado pelas informações adquiridas em campo, de acesso livre a toda a população, o Habisp - atualmente renomeado para Habisp Plus ${ }^{13}$-.

11 As quatorze favelas citadas por Elisabete França são: Vila Nilo; Recanto dos Humildes; City Jaraguá; São Francisco; Vila União Vergueirinho; Dois de Maio; Jardim Olinda; Nova Jaguaré; Heliópolis e Paraisópolis que são consideradas como projetos especiais dentro do Programa de Urbanização de favelas devido a complexidade e dimensão; e Jardim Iporanga, Santa Lúcia e Xavier Magalhães, as três, parte do Programa Mananciais.

12 O PMH 2009 - 2024 foi enviado para aprovação da Câmara dos Vereadores e recebeu a designação de Projeto de Lei no 509/2011, tendo sido aprovado em primeira votação em junho de 2012. (PREFEITURA DE SÃO PAULO, 2012a, p.35).

${ }^{13}$ Disponível em: http://www.habisp.inf.br/. Acesso em outubro de 2013. 
Para a elaboração do Plano foi necessário desenvolver um sistema de priorização a partir de critérios de elegibilidade baseados na oferta de infraestrutura, situação de risco, vulnerabilidade social e salubridade em um primeiro momento e, segundo Elisabete França, a definição de áreas para a implantação de parques lineares. Conforme Plano Estratégico do Município, a implantação de coletores tronco, a recuperação de rios e córregos colaborando para a melhora no sistema de drenagem de toda a cidade, também foram critérios considerados para a priorização das intervenções (PREFEITURA DE SÃO PAULO, 2012a, p.27).

Durante esse processo também houve uma articulação entre a Secretaria de Habitação e a Companhia de Saneamento Básico do Estado de São Paulo (Sabesp) com base no Plano Municipal de Saneamento Ambiental Integrado, o que colaborou para o planejamento da cidade a partir da identificação das sub-bacias hidrográficas.

O desenvolvimento desse plano é um fator muito positivo para a política habitacional, pois proporcionou uma organização a partir da priorização da necessidade de intervenção em todas as áreas de assentamentos precários e irregulares da cidade, traçando um plano de ação que se estende até 2024, com o objetivo de realizar todas as intervenções necessárias até esse horizonte.

Paralelamente ao desenvolvimento do $\mathrm{PMH}$, conforme dados sobre as principais intervenções durante o período de 2005 a $2012^{14}$, a atuação da Sehab também ocorreu a partir dos seguintes programas:

- Programas de intervenções em Cortiços;

- Regularização urbanística e fundiária em loteamentos;

14 Consultar a publicação Plano Municipal de Habitação, a experiência de São Paulo - volume 1 (PREFEITURA DE SÃO PAULO, 2012a, p. 101 a 183). 
- Desativação de alojamentos provisórios - reassentando as famílias desalojadas ou colocando-as no aluguel social à espera de novas unidades habitacionais;

- Recuperação, Revitalização e Regularização de empreendimentos a partir do Programa 3Rs - o equivalente ao programa Viver Melhor implantado pela gestão anterior;

- Programa Mananciais;

- Programa de Urbanização de Favelas;

- Produção de Novas Unidades Habitacionais.

Entretanto, a produção de unidades habitacionais a partir do Programa de Urbanização de Favelas foi a atuação realizada com maior enfoque durante esse período. Pode-se dizer que essa atuação foi o "carro-chefe" dessas duas gestões. Assim como foi possível identificar maior ênfase nas intervenções em áreas centrais durante o período 2001 - 2004, é a produção de novas unidades habitacionais que representa a atuação ao longo dos últimos oito anos.

Essa afirmação pode ser comprovada com base nas revistas especializadas, onde essa produção tem sido altamente publicada ${ }^{15}$ a partir de 2011, aproximadamente e nas premiações dedicadas às intervenções realizadas pela Sehab como o prêmio concedido pela Agência Habitat da Organização das Nações Unidas ao Programa de Urbanização de Favelas, o Scoll of Honour Award, em setembro de 2012.16

15 Revista AU - Arquitetura e Urbanismo no: 186; 217; 225; 228; 231; 234; 236 / Revista Monolito no 07 e 16 / Revista Projeto Design nº: 369 ; 384; 394; 396; 401 / Revista Suma + o 127.

16 Outras premiações podem ser consultadas na publicação Plano Municipal de Habitação, a experiência de São Paulo - volume 1 
Como exemplo da produção desse período, foram selecionados os seguintes projetos de conjuntos habitacionais construídos a partir do Programa de Urbanização de Favelas:

\begin{tabular}{|c|c|c|c|}
\hline Projeto & Arquitetura & Localização & Data \\
\hline $\begin{array}{l}\text { Heliópolis - Gleba A } \\
\text { quadra } 0 \text { + quadra1 }\end{array}$ & Vigliecca \& Associados & Ipiranga / Z. Sudeste & $2004-2007$ \\
\hline Jardim Olinda & GTA - Grupo Técnico de Apoio & Campo Limpo / Z. Sul & $2005-2009$ \\
\hline $\begin{array}{l}\text { Alexandre Mackenzie e } \\
\text { Kenkiti }\end{array}$ & Boldarini Arquitetura e Urbanismo & Jaguaré / Z. Oeste & $2008-2009$ \\
\hline Ceratti & Cubo Arquitetura & Ipiranga / Z. Sudeste & $2008-2010$ \\
\hline Nova Jaguaré & Projeto Paulista & Jaguaré / Z. Oeste & $2003-2011$ \\
\hline Paraisópolis & Elito Arquitetos & Vila Andrade / Z. Sul & $2008-2011$ \\
\hline Sabesp & Ruy Ohtake Arquitetura e Urbanismo & Ipiranga / Z. Sudeste & $2008-2011$ \\
\hline Jardim Celeste & Arquitetos Urbanistas & Jabaquara / Z. Sudeste & $2008-2011$ \\
\hline São Francisco & Arquitetos Urbanistas & São Mateus / Z. Leste & $2008-2011$ \\
\hline $\begin{array}{l}\text { Jardim das Rosas } \\
\text { Jardim Irene I } \\
\text { Parque Fernanda II }\end{array}$ & GTA - Grupo Técnico de Apoio & Campo Limpo / Z. Sul & $2009-2011$ \\
\hline Tiro ao Pombo & Boldarini Arquitetura e Urbanismo & Freguesia do Ó / Z. Norte & $2009-2011$ \\
\hline Jardim Guarani & Boldarini Arquitetura e Urbanismo & Freguesia do Ó / Z. Norte & $2009-2011$ \\
\hline Comandante Taylor & Piratininga Arquitetos Associados & Ipiranga / Z. Sudeste & $2008-2012$ \\
\hline
\end{tabular}




\begin{tabular}{|c|c|c|c|}
\hline Jardim Edite & $\begin{array}{l}\text { MMBB Arquitetura e Urbanismo }+\mathrm{H}+\mathrm{F} \\
\text { Arquitetos }\end{array}$ & Brooklin / Z. Sul & $2008-2012$ \\
\hline Real Parque & $\begin{array}{l}\text { Escritório Paulistano Arquitetura + Geni } \\
\text { Sugai + Jeferson Diniz }\end{array}$ & Real Parque / Z. Sul & $\begin{array}{r}2010-2012 \\
\text { (em obra) }\end{array}$ \\
\hline Ed. Iguaçu & Arquiteto Marcelo Suzuki & Jabaquara / Z. Sudeste & $2010-2012$ \\
\hline Heliópolis Gleba H & Vigliecca \& Associados & Ipiranga / Z. Sudeste & $2010-2013$ \\
\hline $\begin{array}{l}\text { Parque Novo Santo } \\
\text { Amaro V }\end{array}$ & Vigliecca \& Associados & Jd. Angela / Z. Sul & $2009-2013$ \\
\hline Corruíras & Boldarini Arquitetura e Urbanismo & Jabaquara / Z. Sudeste & $2010-2013$ \\
\hline Rocinha & Arquitetos Urbanistas & Ipiranga / Z. Sudeste & 2013 \\
\hline Heliópolis Gleba G & Biselli Katchborian Arquitetos Associados & Ipiranga / Z. Sudeste & 2011 - em obra \\
\hline Diogo Pires & Boldarini Arquitetura e Urbanismo & Jaguaré / Z. Oeste & 2011 - em obra \\
\hline Bamburral & Brasil Arquitetura & Perus / Z. Norte & 2011 - em obra \\
\hline Jardim Lidiane & Andrade Morettin Arquitetos & Casa Verde / Z. Norte & 2011 - em obra \\
\hline Ponte dos Remédios & Marcos Acayaba $+\mathrm{H}+\mathrm{F}$ Arquitetos & Vila Leopoldina / Z. Oeste & 2011 - em obra \\
\hline
\end{tabular}

Além dos conjuntos habitacionais mencionados, as urbanizações realizadas na Vila Nilo, no Jardim Iporanga, em Cidade Júlia e no Cantinho do Céu, entre tantas outras, também são atuações representativas realizadas pela Sehab nesse período. 
Outra atuação significativa foi a promoção de um concurso público nacional, pela Sehab e pelo IAB/SP, para a requalificação de favelas e loteamentos irregulares no município.

O Concurso Renova SP, promovido em 2011, apresentou vinte e dois perímetros de intervenção comportando 209 favelas que demandam de aproximadamente 130 mil moradias. Além da urbanização das favelas, o concurso contemplava, ainda, propostas para construção de conjuntos habitacionais em áreas de provisão, visando o reassentamento de famílias.

Entre os vinte e dois perímetros, apenas dezessete foram premiados e contratados ${ }^{17} \mathrm{e}$, atualmente, os projetos encontram-se em fase de desenvolvimento. É válido comentar que, mesmo com a mudança de gestão - sendo que Fernando Haddad assumiu a prefeitura em 2013 - os projetos contratados pelo Renova SP seguem em andamento, ainda que tenham sofrido uma série de adaptações às novas diretrizes da Secretaria de Habitação ${ }^{18}$.

Considera-se isso um bom sinal frente à constante descontinuidade de planejamento e políticas públicas ao que parecemos estar acostumados. ${ }^{19}$ Lizete Rubano comenta que, "a constituição de uma política habitacional não é

17 Segundo as atas de divulgação do resultado do concurso, alguns perímetros não foram premiados, pois o júri julgou que os projetos apresentados não eram suficientemente consistentes para consolidar uma contratação e, segundo a equipe da Sehab, esses perímetros ficariam disponíveis para serem reapresentados em uma nova realização do Concurso Renova SP que, até o momento, ainda não ocorreu. Os perímetros apresentados pelo concurso e os escritórios de arquitetura premiados em cada um, estão disponíveis na publicação: Renova SP: Concurso de Projetos de Arquitetura e Urbanismo, 2011 e também no website: http://renovasp.habisp.inf.br/concurso/info/apresentacao, acesso em outubro de 2013

18 Entre outras adaptações sofridas pelos contratos do concurso Renova SP, está a necessidade de desenvolver todos os projetos de acordo com os padrões do programa de financiamento habitacional Minha Casa Minha Vida. As considerações e/ou críticas às exigências do programa são um tema que poderia gerar uma nova dissertação de mestrado, porém, cabe aqui, apenas citar que, pelo o que se pôde perceber através da observação dos critérios adotados pelo Programa Minha Casa Minha Vida, ainda há um longo caminho a ser percorrido pelas políticas habitacionais nacionais até que se chegue ao objetivo de produzir com qualidade e não apenas pela quantidade.

${ }^{19}$ Assim como a continuidade dada ao concurso Renova SP, também foi um bom sinal a continuidade dada às urbanizações de favelas, que ocorreu entre a gestão 2001-2004 e a seguinte (2005-2012), que resultou na produção dos conjuntos habitacionais aqui apresentados. 
tarefa fácil, principalmente em um país sem tradição de políticas públicas, que pressupõe uma estrutura, planejamento e continuidade". (Rubano, $2008 \mathrm{em}$ : Vitruvius arquitextos 095.07).

Segundo RUBANO, "as políticas públicas, voltadas à habitação, deveriam refletir a complexidade produzida nas cidades, revendo modelos antigos que são não apenas anacrônicos, como também totalmente inadequados no que se refere à otimização das infraestruturas, às perspectivas de expansão e às densidades urbanas”. (Rubano, 2008 em: Vitruvius arquitextos 095.07).

No momento, tem-se a impressão que, o PMH 2009-2024, se for levado adiante, pode ser um passo em direção à formação de uma política pública mais consistente. Porém, as questões apontadas por RUBANO são essenciais e precisam ser consideradas, pois sem compreender a complexidade produzida nas grandes cidades, nenhuma política pública habitacional poderá ser bem sucedida e, no que se refere à cidade de São Paulo, todos sabemos que a complexidade é enorme.

O que parece ser um objetivo comum a todo o período estudado é a busca por qualidade arquitetônica. Um dos indícios que leva a essa constatação, são os concursos públicos. O primeiro concurso público nacional de projetos dedicado à habitação popular ocorreu em 1990. Um concurso que colocava em pauta intervenções tanto na periferia, com o terreno em São Francisco, como em uma região mais central, com o terreno do Brás. Após esse concurso, apenas em 2004 é que foi promovido outro com o mesmo objetivo: incentivar o desenvolvimento de propostas de qualidade para habitação de interesse social e, dessa vez, os objetos do concurso Habita Sampa, foram dois terrenos no centro da cidade (Rua Assembleia e Rua Cônego Vicente Marino).

De acordo com a arquiteta Lizete Rubano, os concursos são experiências projetuais que apresentam resultados muito significativos 
[...] em que a localização, o desenho urbano, as propostas espaciais e construtivas, a revisão programática e a experimentação plástica têm caracterizado momentos ímpares de discussão do tema da habitação social.

São momentos em que áreas significativas da cidade se apresentam como passíveis de uso para moradia. Densidades importantes são propostas, articulações com a cidade são desejadas e volta-se a investigar modos de vida, contemplando diferenças.

Infelizmente os resultados de concursos raramente são construídos, já que o processo que os caracteriza revela mais claramente, pelo tempo que envolve, a impressionante descontinuidade administrativa do Estado brasileiro (Rubano, 2008 em: Vitruvius arquitextos 095.07).

RUBANO conclui lamentando a não efetivação dos concursos e identificando como responsável a falta de continuidade entre as administrações públicas. Espera-se, entretanto que essa situação possa ser revertida após o concurso Renova SP que, ao menos, nesse momento, permanece em andamento.

Porém, assim como o Habita Sampa (2004), em 2010 foi promovido outro concurso público, dessa vez pela Companhia de Desenvolvimento Habitacional e Urbano (CDHU), o concurso chamado "Habitação para Todos" que tampouco foi construído. Esse concurso buscava novas soluções para as tipologias de casas térreas; casas escalonadas; sobrados; edifícios de três pavimentos; edifícios de quatro pavimentos; e edifícios de seis e sete pavimentos, porém nenhum dos projetos foi construído até o momento.

Além desses três concursos [Habita Sampa (2004); Habitação para Todos (2010) e Renova SP (2011)], também ocorreram, durante o período estudado, concursos de ideias promovidos pela Caixa Econômica Federal. Esses concursos foram realizados a partir de um enfoque nacional, porém também devem ser citados como indícios da busca pela qualidade de projeto arquitetônico para a habitação social. 
O primeiro Premio - CAIXA/IAB ocorreu em 2001/2002; o segundo em 2004; o terceiro em 2006; e o quarto em 2008/2009. Com isso, pode-se concluir que, em nenhum outro momento da história da habitação social em São Paulo houve tantos concursos promovidos em busca de novas propostas para a habitação de interesse social. É obvio que, se compararmos esses dados com outras cidades da Europa como, por exemplo, Madrid, notaremos que a quantidade de concursos públicos realizada aqui é praticamente insignificante perto de uma cidade que chegou a promover vários concursos ao $a^{20}{ }^{20}$. Entretanto, é importante enfatizar que, em São Paulo, foi a primeira vez que se identificou essa preocupação em buscar novas soluções de projetos a partir da promoção de concursos públicos. Espera-se que isso não tenha sido apenas um momento, podendo permitir que a contratação de projetos ocorra, cada vez mais, através de concursos públicos abrindo as possibilidades para incorporação de profissionais e novas ideias na produção pública habitacional.

Outro indício que foi possível identificar quanto à busca por qualidade projetual, é a grande variedade de arquitetos e escritórios de arquitetura envolvidos nessa produção recente. De acordo com Elisabete França, essa foi uma das premissas da Sehab durante esse período. Acredita-se, portanto, que o poder público apostou no envolvimento de arquitetos reconhecidos em busca de uma mudança de paradigma no que diz respeito à produção de habitação de interesse social. Segundo FRANÇA,

Outra decisão importante que caracteriza a atual [refere-se ao período entre 2005 e 2012] política habitacional decorre do caminho adotado em 2005 - apostar na qualidade dos projetos, na boa arquitetura e urbanismo e nas melhores técnicas da nossa engenharia -, o que permitiu que as intervenções da Sehab fossem reconhecidas pelo público beneficiado. A arquitetura pública retomou, na área da habitação, sua importância como elemento essencial na construção da cidade (PREFEITURA DE SÃO PAULO, 2012a, p. 24).

${ }^{20}$ A Relação com Madrid resultou de um Seminário sobre Habitação Contemporânea realizado na FAUUSP em maio de 2013 promovido 
A diversidade de autores (arquitetos) pode sim ser um fator positivo em busca de uma produção de qualidade, porém, é preciso ter cuidado para não rotular a produção como boa ou ruim apenas com base na autoria do projeto. Isso pode levar a conclusões equivocadas como, por exemplo, relacionar a atuação de profissionais envolvidos com a política pública com a falta de qualidade e, por outro lado, acreditar que todo e qualquer escritório de arquitetura reconhecido é capaz de fazer um bom projeto de habitação de interesse social.

Sobre a relação entre arquitetura e política pública, com foco para a produção habitacional, Ruth Verde Zein comenta que

[...] Péssimas arquiteturas podem mostrar-se simplesmente como consequência de projetos de baixa qualidade e não somente de políticas indevidas. E a melhor política do mundo não garante, a priori, uma boa qualidade arquitetônica - embora possa dificultá-la, ou favorecê-la. Tampouco as boas intenções ou afiliações políticas dos autores é garantia suficiente para a realização de uma boa (ou má) arquitetura. Essas afirmações parecem óbvias - mas é tal o costume de justificar a arquitetura unicamente por razões externas a seu campo disciplinar, que parece ser necessário reafirmar que, se bem a interdisciplinaridade seja fundamental, sua base não pode deixar de ser a disciplinaridade - ou seja, o conhecimento aprofundado das características peculiares de cada disciplina (BASTOS; ZEIN, 2010, p. 164).

ZEIN (2010, p. 164) conclui acrescentando que "o debate sobre habitação social não está completo se não for realizada a análise crítica das obras em si mesmas".

Dessa forma, movida por uma forte vontade de identificar qualidades projetuais na produção contemporânea de habitação social, a proposta dessa dissertação de mestrado é, a partir do estudo e da análise de projetos, verificar quando existem e quais são os fatores que atribuem qualidade aos projetos de habitação de interesse social produzidos nos últimos treze anos. Acredita-se que o importante, nesse momento, é tentar identificar os conceitos contidos nessa produção e verificar quando, de fato, estes projetos enfrentam os conflitos urbanos existentes. 
Analisar os projetos significa identificar tanto as qualidades, como os aspectos que precisam ser melhorados. Entende-se que a busca por maior qualidade projetual inicia-se com a observação crítica sobre o que já está construído, para, a partir daí, construir referências e poder rever os conceitos aplicados.

Dentro da produção contemporânea, se propõe realizar as análises a partir dos conjuntos habitacionais construídos para alojar a população de até três salários mínimos, pois são projetos concebidos para realocar uma população que, devido ao processo de urbanização, precisou ser removida de suas casas. Se considerarmos que a urbanização de favelas é uma atuação fundamental para transformar esses territórios informais em parte da cidade, essa produção de unidades habitacionais é um dos principais fatores dentro dessa atuação, pois para essas famílias, é a mudança para esses novos lares a ação que simbolizará o momento em que passarão a fazer parte da cidade e ter direito a uma moradia digna e um endereço reconhecido oficialmente.

Segundo Hector Vigliecca, "construir a cidade significa inserir os empreendimentos na trama ativa e legível, de maneira que o indivíduo que se estabeleça nessa área se integre ao concerto geral da cidade, incentivando os valores de identidade e autoestima". Vigliecca utiliza o termo "infiltração" para definir o processo de restituição da urbanidade através da "inserção ponderada de uma nova estrutura urbana sobre a existente". Para o arquiteto, o território existente deve ser considerado como a base para a intervenção, mesmo que não se equipare à estrutura da cidade formal e a intersecção entre o novo e o existente é chamada por ele de "terceiro território" que, afinal, é o que passará a fazer parte da cidade (VIGLIECCA em: AMORIN; OTERO, 2010, p. 234).

Como foi citado anteriormente, construir os conjuntos habitacionais significa construir cidade, ou de acordo com Vigliecca, construir um terceiro território que não pode deixar de considerar o existente. Essa atuação que já não deve ser realizada sem estabelecer relação com o entorno e simbolizar uma intervenção que qualifique os espaços urbanos é o que se propõe buscar a partir da análise dos projetos. 
O objetivo desse trabalho é, a partir da análise crítica dos projetos selecionados, poder contribuir para a "cultura de projeto" ${ }^{21}$ no âmbito da habitação de interesse social.

Para realizar uma análise com maior profundidade, serão selecionados quatro projetos de conjuntos habitacionais entre toda a produção apresentada. Os critérios definidos para essa escolha foram:

- deveriam ser projetos de conjuntos habitacionais derivados da urbanização de favelas, sendo que o estudo não se estenderá às intervenções de urbanização, não por serem menos importante, mas por definir um foco de análise; ${ }^{22}$

- deveriam ser obras já finalizadas e já entregues aos moradores para a análise poder considerar a apropriação dos espaços;

- a diversidade de localização na cidade para ter uma amostra diversificada de projetos em diferentes pontos da cidade e poder analisar a relação com o entorno;

21 Termo utilizado pela arquiteta Lizete Rubano em sua tese de doutorado "Cultura de Projeto: um estudo das ideias e propostas para habitação coletiva" (2001).

${ }^{22}$ É importante deixar claro nessa colocação que, ao definir que a seleção de projetos não se estenderá aos assentamentos, não significa que o objetivo é analisar conjuntos habitacionais isolados, muito pelo contrário, entende-se que os conjuntos são necessários para alojar as famílias que precisaram ser removidas de suas moradias por risco ou questões de insalubridade e que devem ser construídos em um entorno próximo aos locais de origens das famílias. Acredita-se que a mentalidade de que as favelas e os assentamentos precários devam desaparecer da cidade e ser substituídos por conjuntos habitacionais periféricos, já esteja superada e ultrapassada, considerando a urbanização a atuação mais lógica e ideal para solucionar os problemas das favelas, entendendo, dentro desse contexto, que a construção dos conjuntos habitacionais fazem parte do processo de urbanização e, portanto, devem ser elementos de qualidade arquitetônica tanto para as pessoas que ai irão viver, como para seu entorno e para a cidade. 
- diversidade de arquitetos (autores) que permita conhecer o repertório de cada arquiteto a partir da análise do projeto selecionado;

- decidiu-se que seriam projetos mais recentes dentro do período estudado e com algum reconhecimento através de publicações em livros e revistas especializados.

Com base nesses critérios e considerando também uma porcentagem de subjetividade e intuição pessoal para a escolha dos projetos, foram selecionados para serem analisados com mais detalhe e profundidade os seguintes projetos: Comandante Taylor; Jardim Edite; Parque Novo Santo Amaro V e Real Parque.

O Conjunto Residencial Comandante Taylor encontra-se em Heliópolis, considerada a maior favela da cidade de São Paulo e que vem sofrendo intervenções por parte da Secretaria de Habitação desde os anos 1990. O Comandante Taylor foi construído em uma área de provisão - um terreno adquirido pela prefeitura para a construção de unidades habitacionais - e é marcado pela alta densidade. Diferentemente dos outros exemplos, a relação entre a associação de moradores e os arquitetos já existia antes mesmo da incorporação da Sehab no processo de construção do conjunto, um fator possitivo quanto ao envolvimento dos moradores no desenvolvimento do projeto.

O Conjunto Habitacional Jardim Edite foi construído em um terreno na esquina das Avenidas Engenheiro Luis Carlos Berrini e Jornalista Roberto Marinho, em uma área nobre da cidade onde antes encontrava-se a favela Jardim Edite. Esse conjunto foi escolhido devido a "ousadia" de se construir um conjunto de habitação de interesse social em uma região caracterizada por edicíficos empresariais, permitindo que os moradores da favela tivessem sua permanência no local mantida. A mescla de usos e a incorporação de equipamentos como uma Unidade 
Básica de Saúde (UBS); um Restaurante-Escola e uma Creche ao programa, também representam um fator importante na decisão de selecionar esse conjunto para as análises que serão realizadas.

O projeto Parque Novo Santo Amaro V recebeu menção honrosa na categoria Habitação de Interesse Social do IAB SP 2010 e o terceiro lugar no Concurso Mundial de Habitação de Interesse Social e Desenvolvimento Urbano da Bienal Panamericana de Arquitetura de Quito em 2012. Essa intervenção faz parte do Programa Manaciais e representa um excelente exemplo de inserção urbana e relação com o entorno e a cidade. Os conceitos de circulação e permeabilidade aplicados nesse projeto, fazem dele um exemplo especial para ser estudado que não poderia deixar de compor essa seleção de projetos de habitação de interesse social contemporâneos.

O Conjunto Habitacional Real Parque foi premiado com a segunda menção na categoria Desenho Arquitetônico, Bienal Panamericana de Arquitetura de Quito, em 2012. É o maior entre os seis conjuntos estudados com uma área de intervenção de $36.340 \mathrm{~m}^{2}$ e $79.355 \mathrm{~m}^{2}$ de área construìda. Esse conjunto está sendo construído no terreno ocupado pela favela Real Parque e, a possibilidade de adquirir terrenos no entorno da favela, possibilitou que a construção do conjunto se iniciasse sem a necessidade de remover os moradores. Com isso, os moradores foram realocados apenas após a entrega dos condomínios. Uma parte dos condomínios ainda está em obras, mas alguns deles já foram entregues à população desde o início de 2012 e, portanto, será possível analisar a apropriação dos moradores nesses condomínios já habitados. 



\section{METODOLOGIA}

PARA ANÁLISE DE

PROJETOS

Para um melhor conhecimento sobre a produção contemporânea (2001 a 2013) de habitação de interesse social na cidade de São Paulo, promovida pela Secretaria Municipal de Habitação (Sehab), quatro projetos foram selecionados para serem analisados com maior profundidade. Porém, para fazer uma análise legítima que permita, posteriormente, estabelecer relações entre os projetos além de servir como referência para a análise de outros, foi necessário desenvolver uma metodologia baseada na definição de critérios que possibilitassem explorar temas comuns entre os projetos.

O principal trabalho de referência para a definição dos critérios de análise que, inclusive, contribuiu para a realização da pesquisa para essa dissertação de mestrado foi o Instrumentos de Avaliação de Projetos ${ }^{1}$ (em: PREFEITURA DE SÃO PAULO, 2012b, p. 253). Esse trabalho, do qual tive a oportunidade de participar, foi solicitado pela Secretaria Municipal de Habitação e realizou-se a partir da análise crítica dos projetos produzidos pela Sehab entre os anos de 2005 e 2012.

Nesse trabalho, a avaliação dos projetos é realizada a partir de um check-list elaborado sobre questões de caráter qualitativo complementado por análises gráficas que representam as questões abordadas. Outra característica é a organização da avaliação a partir de quatro escalas: assentamento, conjunto, edifício e unidade habitacional, o que permite a definição de critérios específicos para cada uma.

${ }^{1}$ Trabalho desenvolvido por meio de uma parceria entre a Sehab e os escritórios Montaner Muxí Arquitectes e Habitar Arquitetas Associadas publicado no livro Do Plano ao Projeto: Novos Bairros e Habitação Social em São Paulo (2012b), volume 2 - parte 2. 
As contribuições para o desenvolvimento dos Instrumentos de Avaliação de Projetos ocorreram nos seguintes sentidos:

- Os trabalhos Habitar el Presente. Vivienda en España: sociedad, ciudad, tecnología y recursos (2006) e Herramientas para habitar el presente. La vivienda del Siglo XXI (2011) foram antecedentes importantes para o desenvolvimento da metodologia de análise e avaliação. Entretanto, os critérios apresentados por esses trabalhos, haviam sido desenvolvidos para a realidade espanhola e foi necessário, portanto, adaptá-los à realidade de São Paulo.

O primeiro trabalho, Habitar el Presente (2006) que resultou em uma exposição² e um catálogo, foi solicitado pelo Ministério da Habitação da Espanha com a intenção de expor uma visão panorâmica sobre a questão da habitação contemporânea no país e, para isso, foram selecionados exemplos considerados idôneos para transmitir os valores de qualidade desejados e desenvolvido um sistema de avaliação de projetos dentro de quatro variáveis: Cidade, Sociedade, Tecnologia e Recursos. (MONTANER; MUXí, 2006). O trabalho seguinte, Herramientas para habitar el presente (2011), complementa o primeiro com a incorporação de mais quatro variáveis para a avaliação dos projetos: Gestão, Reabilitação, Tipologia e Percepção.

- As Diretrizes de Projetos de Urbanização e de Edificação (em: PREFEITURA DE SÃO PAULO, 2012b, p. 195), desenvolvidas pela equipe de técnicos da Sehab a partir da experiência de acompanhar a apropriação dos moradores com respeito aos novos conjuntos e às novas formas de morar, representaram

${ }^{2}$ A exposição realizada primeiramente em Madrid, em 2006, tornou-se itinerante e no ano de 2012 passou por várias cidades da América Latina, entre elas, Lima (Peru), Buenos Aires (Argentina), Brasília (Brasil), etc. 
uma importante contribuição quanto à realidade de São Paulo e à percepção da prórpia Secretaria sobre recomendações quanto aos projetos.

Nessas diretrizes, aparecem considerações tanto relacionadas com as redes de abastecimento; com a geometria do sistema viário; com a implantação e orientação dos conjuntos e edifícios; como recomendações quanto ao espaço que deve ser deixado para o fogão no interior das unidade que, segundo as diretrizes, deve ser deixado espaço para fogão de seis bocas. Essa recomendação que, a princípio, pode parecer absurda, passa a fazer sentido quando observa-se que, em geral, os moradores possuem fogões de seis bocas e, ao mudarem para as novas casas, encontram dificuldade para encaixar, adequadamente, seus móveis e eletrodomésticos.

- Por último, o trabalho de campo foi, efetivamente, a principal contribuíção e também a atuação que mais agregou conhecimento e experiência para o desenvolvimento dessa dissertação de mestrado. Durante seis meses, foram realizadas visitas semanais aos projetos de urbanização e conjuntos habitacionais, resultando em aproximadamente vinte e nove projetos visitados. Essas visitas contaram com o acompanhamento e colaboração de técnicos da Sehab que tiveram uma participação muito importante nas discussões desenvolvidas sobre os projetos.

Acredita-se que as visitas de campo proporcionam percepções que, por maior esforço que se dedique, não são possíveis de ser compreendidas apenas com a observação do material gráfico. Muitas vezes, as visitas permitiram identificar apropriações ruins ou indevidas sobre espaços que, no papel, pareciam funcinar bem. Por outro lado, também permitiram identificar boas apropriações e propostas projetuais que tiveram sucesso efetivo, após a ocupação dos espaços pelos moradores. 
A participação no processo de desenvolvimento dos Instrumentos de Avaliação de Projetos foi uma influência muito forte para a pesquisa acadêmica em andamento durante todo o processo de concepção desse trabalho. Realizar as visitas; participar das discussões sobre as soluções projetuais; ter a opotunidade de entrar em contato com as diretrizes de projetos de urbanização e edificação e com a metologia desenvolvida na Espanha, pelos arquitetos Josep Maria Montaner, Zaida Muxí e equipe, para análise e avaliação de projetos e, por fim, participar da junção e adaptação de todas essas informações, foi uma importante experiência.

Outro trabalho utilizado como referência para o desenvolvimento das análises de projetos, foi o Urbanization Primer (1978). Esse trabalho resultou de uma pesquisa solicitada pelo Banco Mundial (World Bank), Washington, D.C. com o objetivo de fornecer informações e diretrizes para o Departamento de Projetos Urbanos. Foi realizado com a intenção de ser um manual para a avaliação de projetos, análise de terrenos, critérios de desenho para implantação de habitação em áreas em desenvolvimento, etc. e foi elaborado a partir da documentação da disciplina de Projeto de Assentamentos Urbanos em Países em Desenvolvimento da Faculdade de Arquitetura e Urbanismo do Instituto de Tecnologia de Massachusetts (MIT), (CAMINOS; GOETHER, 1978).

Segundo os autores (CAMINOS; GOETHER, 1978, p. 7), esse trabalho é direcionado a questões de urbanismo, especificamente, divisão de terrenos e provisão de serviços para o setor mais necessitado da população. É focado nos aspéctos físicos e técnicos e fonece alguns instrumentos de decisão que afetam a política, assim como os desenhos físicos. Esse trabalho apresenta dois caminhos para minimizar os custos: no primeiro, mais relacionado às políticas e à administração, os níveis de serviços são analizados para promover decisões no campo das políticas; no segundo, com maior ênfase nas técnicas e desenho, são propostos indicadores para otimizar a produção, estabelecendo padrões para as decisões projetuais.

A primeira parte do trabalho (Project Assessment) consiste na definição de diretrizes para a avaliação de projetos e 
departamento da faculdade em 1974). O primeiro item abordado na avaliação são as diretrizes para identificação do projeto com a intenção de se obter uma descrição completa sobre o terreno e o projeto; em seguida, são estabelecidos critérios para otimizar os conceitos adotados nos projetos, isso é importante, pois esse critérios serão vistos como alternativas para diferentes tipos terrenos com suas especificidades.

No caso do Mkalles Housing, trata-se de um projeto proposto que é analisado a partir da forma como o terreno foi subdividido; da forma como foram definidas as áreas para os diferentes usos: áreas privadas, semiprivadas, semipúblicas e públicas; uma estimativa de custo é apresentada e por último, são estudadas diferentes tipologias, projetadas para serem facilmente expandidas e permitir flexibilidade de uso para absorver as mudanças relacionadas ao crescimento das necessidades das famílias e minimizar o custo dos investimentos iniciais das tipologias a serem implantadas.

No item Desing Criteria, o trabalho estabelece referências para o projeto de lugares e serviços. As referências envolvem: planejamento e subdivisão de terrenos; provisão de serviços e instalações (água, luz, gás, etc.); e estudo detalhado dos custos. Na última parte são apresentados, como apoio, referencias complementares que permitem a observação de diferentes situações da vida urbana identificadas na época em que o trabalho foi realizado.

É importante deixar claro que a pesquisa no campo da habitação é bastante ampla e as referências são inúmeras. O Instituto de Tecnologia de Massachusetts (MIT) se dedica intensamente à pesquisas nesse âmbito, por exemplo. Em 1955 Burnham Kelly publicou o trabalho Housing and Economic Development reportando uma Conferência realizada no MIT pelo Albert Farwell Bemis Fondation em abril de 1953, que trava da importância do planejamento; das possibilidades de financiamento para a construção de habitação; das políticas públicas, etc. 
Outra publicação do MIT que exemplifica à dedicação à pesquisa é Squatter Settlements and Housing Policy: Experiences with Site-and-Services in Colombia (1980). Essa trabalho, realizado por Edward S. Popko analisa as formas de ocupação e construção nos territórios como favelas e loteamentos irregulares. Como estudo de caso, analisa algumas favelas, ou bairros na Colômbia.

Enfim, o objetivo de Urbanization Primer, entre outros trabalhos, foi realizar estudos, observações e recomendações que sejam úteis a outros projetos e que serão utilizados como referência durante o desenvolvimento das análises de projetos propostas nessa dissertação de mestrado.

O trabalho Cultura de Projeto: um estudo das ideias e propostas para habitação coletiva (2001) é uma tese de doutorado, desenvolvida pela arquiteta Lizete Rubano que "investiga - por meio de projetos de habitação coletiva idealizados no Brasil e na Holanda - a constituição de uma cultura de projeto" (RUBANO, 2001). A hipótese colocada pela autora é a ocorrência de uma fragilidade da cultura de projeto arquitetônico no Brasil e, a partir dessa colocação, passa a pesquisar a produção habitacional através dos diversos momentos, desde o surgimento da habitação social como promoção do Estado até o que a arquiteta chama de produção contemporânea (1986-1992). Porém, além de toda a referência histórica que esse trabalho representa, é importante como referência metodológica a decisão da autora de gerar um material gráfico que complementa as análises textuais e oferece informações relevantes sobre os projetos, como localização da intervenção na cidade de São Paulo, a implantação, as opções de forma urbana, as soluções dadas às tipologias e às unidades habitacionais e a presença de equipamentos coletivos no que se refere à relação entre espaços livres e construídos, públicos e privados. Essa relação entre análise textual e gráfica será aplicada nessa dissertação de mestrado, pois acredita-se que a informação visual é muito importante para a compreensão dos projetos e, ao realizar um trabalho baseado em análises, isso se torna um dado fundamental. 
Habitar Coletivo: obras diferenciadas contemporâneas em São Paulo (2013) é uma dissertação de mestrado, desenvolvida pela arquiteta Fabricia Zulin, que analisa criticamente a produção contemporânea de habitação coletiva a partir de obras singulares que, de alguma maneira, aportam alternativas à "mesmice" (nas palavras da autora) que vemos ser construída ao nosso redor, principalmente pelo mercado imobiliário (ZULIN, 2013). Durante o desenrolar do trabalho, a arquiteta realiza leituras de projetos selecionados e organiza essa análise a partir de critérios pré-estabelecidos como: inserção urbana; partido de implantação; espaços exteriores; perfil dos moradores; agente; sistema estrutural e técnica construtiva; envoltória e unidade habitacional, além de organizar fichas gráficas que, assim como no trabalho da arquiteta Lizete Rubano, auxiliam as leituras. $O$ trabalho também conta com um capítulo no qual, de forma inversa, foram realizadas análises comparativas por temas, estabelecendo relações entre os projetos a partir dos critérios analisados.

A forma como foram organizadas as fichas gráficas, os critérios utilizados e também as análises comparativas por temas são uma importante referência metodológica para o trabalho que está sendo desenvolvido.

Além dos trabalhos citados acima, também foram utilizadas como referência as fichas de análise desenvolvidas pelo Observatório de Arquitetura Latino-americana Contemporânea ${ }^{3}$ e fichas desenvolvidas pela arquiteta Christine Van Sluys utilizadas no curso Seminario Vivienda y Ciudad $^{4}(2008)$.

${ }^{3}$ O Observatório de Arquitetura Latino-americana Contemporânea é um projeto de pesquisa realizado entre universidades na Colômbia, no México e no Brasil que reúne professores e pesquisadores da Universidad Nacional de Colômbia - sede Bogotá, da Unidad Xochimilco e da Universidade de São Paulo que, segundo seus organizadores, se uniram "estimulados pela necessidade de estabelecer uma leitura e compreender o papel da arquitetura latino-americana no cenário arquitetônico mundial”. (SEGAWA; GUERRERO; SILVA, 2013).

${ }^{4}$ Seminario Vivienda y Ciudad: curso sobre habitação social que explorou a produção no Brasil, em Portugal e Londres além de contar com a experiência de cada aluno solicitando a apresentação de uma obra originária do pais de cada um a partir da utilização das fichas como padrão de apresentação e definição de critérios de análise. Aulas ministradas no Máster Laboratorio de la Vivienda del Siglo XX - 5ª edição - 2008/2009. 
Como pôde ser observado, os trabalhos de referência representam diferentes estratégias para analisar projetos de habitação e sua inserção urbana, com exceção do Observatório de Arquitetura, para o qual habitação é apenas um dos temas de pesquisa entre tantos outros. Porém, além do tema, também é comum aos trabalhos a intenção de buscar qualidade arquitetônica nos projetos, seja dando recomendações para o desenvolvimento de novos projetos, como acontece no Urbanization Primer e em Instrumentos de Avaliação de Projetos, seja analisando criticamente os construídos, como é feito pelo Observatório de Arquitetura, por Christine Van Sluys, por Fabricia Zulin e pelos catálogos Habitar el Presente e Herramientas para habitar el presente, cada um à sua maneira. Lizete Rubano desenvolve toda sua tese de doutorado buscando a referência de uma cultura de projeto que, no seu caso, foi encontrada na Holanda, para tentar compreender a fragilidade da produção habitacional aqui no Brasil e mais especificamente em São Paulo.

Dessa forma, o objetivo dessa dissertação de mestrado não é diferente. Assim como os outros trabalhos, este também busca identificar qualidades arquitetônicas na produção habitacional que será estudada e acredita que a análise crítica dos projetos, apoiada nas informações gráficas, poderá contribuir para uma leitura mais profunda que permitirá identificar as qualidades e apontar as debilidades, almejando ser uma contribuição para a "cultura de projeto".

As análises serão realizadas a partir de três escalas principais: Conjunto; Edifício e Unidade Habitacional, dando ênfase aos conceitos relacionados a cada uma. Os critérios definidos para o estudo e análise crítica dos projetos foram: 


\section{FICHA DE INFORMAÇÃO}

\section{ESCALA CONJUNTO}

1.1. Valores de Proximidade

1.2. Inserção Urbana

1.2.1. Programa

1.2.2. Ocupação do terreno

1.2.3. Definição do limite do conjunto

1.2.4. Adaptação ao terreno

1.2.5. Diálogo Volumétrico

\subsection{Espaços Exteriores}

1.4. Relação entre os edifícios

1.4.1. Acessos e circulação no conjunto

1.4.2. Variedade tipológica

1.4.3. Implantação e orientação

\section{ESCALA EDIFÍCIO}

2.1. Acessos e circulação no edifício

2.2. Diversidade de tipologias

2.3. Estrutura e aberturas

\section{ESCALA UNIDADE}

3.1. Ambientes não especializados

3.2. Ambientes especializados

3.3. Relação entre os ambientes

3.4. Espaço exterior próprio

3.5. Variações do tipo 
Como informações relevantes contidas na ficha de informação, foram definidas:

Projeto:

Localização:

Distrito / Subprefeitura / Zona:

Distância até o centro da cidade: em Km

Data conclusão da obra / Data início do projeto:

Arquitetura: autores

Equipe: outros arquitetos e profissionais envolvidos

Promoção / Agentes:

Área do terreno / Área construída:

Coeficiente de Aproveitamento:

no de unidades habitacionais:

Densidade: UHs/Ha e habitantes/Ha

Programa: se há algum outro uso além do residencial, como comércio, equipamentos, etc.

A Ficha de Informação será acompanhada por uma foto do projeto e um mapa em que a localização do conjunto habitacional em análise é destacada. Nesse mapa, também é possível identificar a posição do projeto com relação ao centro da cidade de São Paulo.

O mapa apresenta também a localização de todos os projetos citados no capítulo anterior sobre a produção contemporânea. Como já foi comentado anteriormente, está representada aqui apenas uma parte de toda a produção, exemplares que foram selecionados por terem sido mais divulgados na mídia especializada, projetos com os quais a autora teve maior contato (devido à participação no trabalho Instrumentos de Avaliação de Projetos) e projetos mais citados nas publicações de balanço de gestão. 
PROJETOS INICIO ANOS 1990:

O 1 - São Francisco

2 - Minas Gás

3-Madre de Deus

4 - Rio das Pedras

5 - Celso dos Santos e Pascoal Melantônio

6 - União da Juta

PROJETOS PROGRAMA DE CORTIÇOS

7 - Casarão Celso Garcia

8 - Edifício Pedro Fachin

9 - Casarão do Carmo

10 - Edifício Imoroti

PROJETOS LOCAÇÃo SOCIAL:

11 - Olarias

12 - Parque do Gato

13 - Vila dos Idosos

RECICLAGEM DE EDIFÍCIOS EM ÁREA CENTRAL

14 - Edfício Fernão Sales

15 - Edfício Olga Benário Prestes

16 - Edificio Rizkallah Jorge

17 - Edificio Maria Paula

18 - Edificio Labor / Brigadeiro Tobias

19 - Edificio Joaquim Carlos

20 - Edifício Senador Feijó

21 - Edificio Riachuelo

22 - Edifício Astrúbal do Nascimento

PROJETOS MUTIRÃO AUTOGERIDOS:

23 - Paulo Freire

CONJUNTOS HABITACIONAIS:

24 - Heliópolis - Gleba A quadra 0 + quadra

25 - Jardim Olind

26 - Alexandre Mackenzie

27 - Ceratti

28 - Nova Jaguaré

29 - Paraisópolis

30 - Sabesp

31 - Jardim Celeste

32 - São Francisco

33 - Jardim das Rosas - Jardim Irene I - Parque

Fernanda II

34 - Tiro ao Pombo

35 - Jardim Guarani

36- Comandante Taylor

37 - Jardim Edite

38 - Real Parque

39 - Ed. Iguaçú

40 - Heliópolis Gleba $H$

41 - Parque Novo Santo Amaro V

42 - Curruíras

43 - Rocinha (Heliópolis)

44 - Heliópolis Gleba G

45 - Diogo Pires

46 - Bamburral

47 - Jardim Lidiane

48 - Ponte dos Remédios

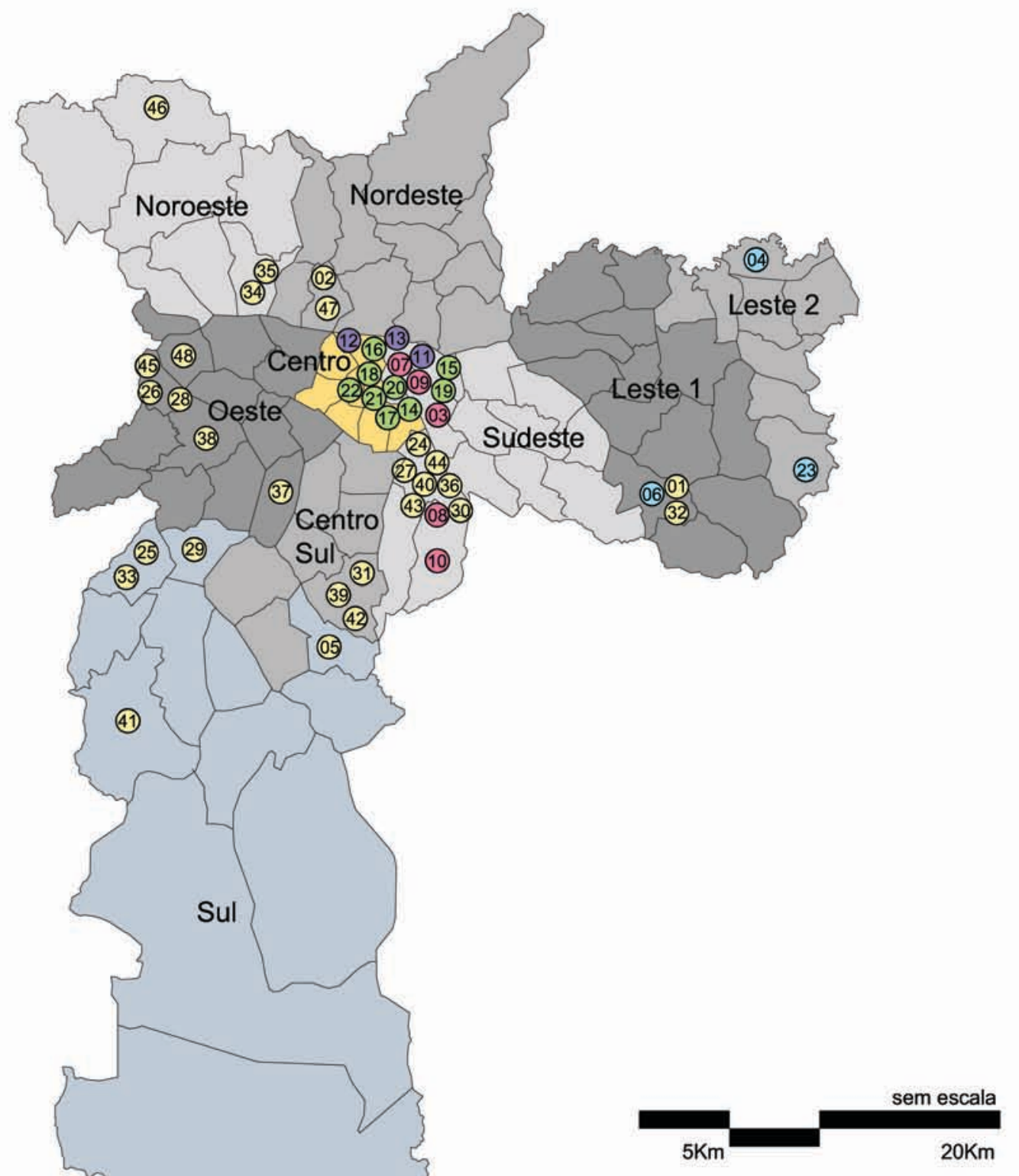

Figura 1 - Mapa da cidade de São Paulo com a localizaçăo dos projetos 
Ao examinar o mapa, algumas conclusões são possíveis, como por exemplo, a concentração dos projetos de intervenção em cortiços e de locação social na região central, além dos projetos de reabilitação de edifícios em áreas centrais. Quanto aos conjuntos habitacionais, é possível identificar um foco mais concentrado no distrito Ipiranga, onde se encontra a favela Heliópolis e certo aglomerado no Jabaquara e na região do Jaguaré.

Para essa pesquisa foi selecionado apenas um exemplar da intervenção em área de mananciais, o Parque Novo Santo Amaro V. Porém, a produção nessa região é bem mais ampla e pode ser consultada em trabalhos específicos como a tese de doutorado da arquiteta e ex-superintendente da Secretaria Municipal de Habitação de São Paulo Elisabete França $(2009)^{5}$ ou até mesmo as próprias publicações da prefeitura de São Paulo como o livro: Plano Municipal de Habitação: a experiência de São Paulo (2012a).

Entre essa seleção de projetos da produção contemporânea, os quatro exemplos selecionados para serem analisados em profundidade são: Comandante Taylor (36); Jardim Edite (37); Real Parque (38) e Parque Novo Santo Amaro V (41).

No item Escala Conjunto será analisada:

- a oferta de equipamentos, comércio, serviços e transporte público ao redor do conjunto a partir dos valores de proximidade. Para essa análise foram definidos dois raios de observação ao redor do projeto: um de 1.000 e outro de 600 metros como referência sobre a proximidade dos equipamentos, pontos de ônibus, etc $^{6}$.

5 Favelas em São Paulo (1980-2008). Das propostas de desfavelamento aos projetos de urbanização: a experiência do Programa Guarapiranga. Elisabete França, tese de doutorado, 2008.

${ }^{6}$ De acordo com as Diretrizes de Projetos de Urbanização, "para poder realizar as atividades cotidianas é necessário contar com as redes de proximidade que permitem o desenvolvimento de todas as fases da vida, especialmente aquelas ligadas ao gênero feminino ou às tarefas de reprodução. Para isso, numa distância de no maximo 1.000 metros da residência, deve se encontrar equipamentos e infraestrutura que 
- a inserção urbana a partir da definição dos limites do conjunto; da relação com a topografia; será observado se existe ou não diálogo volumétrico com o entorno; será analisado o programa proposto e as áreas de projeção da forma como o terreno foi ocupado;

- os espaços exteriores e suas características, as atividades e/ou usos dados a esses espaços, assim como a forma como se relacionam com os edifícios, as circulações e os mobiliários propostos para uso dos moradores;

- a relação entre os edifícios com base na variedade tipológica proposta; na implantação do conjunto com respeito à orientação e às relações de insolação entre as edificações e as circulações.

$\mathrm{Na}$ escala edifício serão analisados os temas relacionados apenas aos espaços propostos pelo próprio edifício, como os acessos às unidades e a forma como foram propostas as circulações verticais e horizontais dentro da edificação. A variedade de tipologias propostas também será observada, verificando se há ou não variação e em que momentos acontecem, buscando compreender as opções tomadas pelo projeto e o que isso representa como resultado final. O sistema estrutural adotado e o impacto causado no edifício e na definição das aberturas também fazem parte dos temas analisados dentro dessa escala.

Quanto à escala da unidade habitacional, se pretende analisar a forma como os ambientes foram dispostos e as possibilidades de relações entre eles. Ao estarmos tratando de unidades de apenas cinquenta metros quadrados, essas relações são muito importantes para a qualidade dos interiores domésticos e temas como os espaços

estratégias urbanísticas, a distância de 1.000 metros equivale a 15 minutos de caminhada em terrenos praticamente planos (máximo de $8 \%$ de inclinação) (PREFEITURA DE SÃO PAULO, 2012b, p.64). Além disso, recomenda-se que a distância máxima entre os pontos de ônibus seja de 600 metros, considerando um raio de 150 metros para terrenos íngremes e 300 metros como regra geral (PREFEITURA DE SÃO PAULO, 2012b, p.100). 
exteriores e as possibilidades de variação das tipologias são contribuições fundamentais para essa qualidade espacial.

Maria Teresa Diniz comenta que, ao projetar para as comunidades, "o arquiteto deve entender que se trata de um 'cliente-difuso'. São diversos os futuros usuários dos apartamentos e dos espaços públicos a serem criados, sendo fundamental a participação da população na definição do programa arquitetônico e urbanístico" (DINIZ em: SILVA; OTERO, 2011, p.151).

Durante as visitas realizadas no período de pesquisa, buscou-se, ao máximo, compreender a forma como os moradores se apropriaram dos espaços para poder transmitir, através das análises, as observações realisadas. Segundo Lizete Rubano, "o tema da gestão dos espaços habitacionais envolve a discussão acerca das possibilidades reais de participação dos futuros usuários no processo de projeto" (Rubano, 2008 em: Vitruvius arquitextos 095.07).

A participação dos moradores na concepção e desenvolvimento dos projetos é outro tema de grande importância. RUBANO questiona sobre o real espaço da participação e argumenta que:

Parece-nos que as possibilidades reais de participação podem estar presentes tanto na escala dos Planos Diretores, quanto na deliberação da necessidade de diferentes tipologias e na discussão dos programas voltados ao espaço coletivo e de convívio.

A gestão que envolve manutenção e uso dos núcleos habitacionais, na escala dos espaços coletivos e públicos, também tem gerado uma discussão muito intensa tanto no que se refere às possibilidades de manutenção física dos edifícios, quanto às formas de uso dos espaços propostos.

Têm-se observado ações dos moradores voltadas à alteração dos projetos originais, quer seja por meio da realização de obras nos edifícios construídos, (anexando-se pequenas construções, criando aberturas não existentes originalmente), quer no uso inadequado dos espaços coletivos e públicos. Aqui, há uma tendência de 
apropriação privada destas áreas, fechando-as e revelando-se uma dificuldade de manutenção e gestão, o que tem colocado ao projeto uma triste perspectiva: a da redução da dimensão do coletivo e público no espaço da habitação social. (Rubano, 2008 em: Vitruvius arquitextos 095.07).

RUBANO conclui observando que a falta de revisão crítica destes projetos e até de possibilidades novas de realização, fragiliza uma avaliação mais densa voltada a essas experiências.

Ao que parece, a participação não é um tema bem resolvido dentro dos processos de urbanização e produção de habitação social. Apesar de ser um fator muito importante, parece que ainda não foi encontrada uma fórmula ideal para que a participação da população aconteça na medida certa. Além do mais, é um campo que extrapola a atuação do arquiteto estando no limite entre arquitetura e os serviços sociais. Como cita Lizete Rubano, qual o real espaço da participação?

Existem muito estudos no campo da Avaliação Pós Ocupação (APO ${ }^{7}$ que analisam a situação dos conjuntos habitacionais após algum tempo já ocupados pelos moradores, buscando identificar como foram apropriados, como os espaços estão sendo utilizados, assim como observar que características apresentadas pelo projeto funcionam ou quando há alteração na utilização dos espaços, tentar compreender os motivos.

Esses estudos são ótimas referências para que novas possibilidades sejam pensadas, porém, parece que ainda faltam estudos com relação à participação durante o processo de concepção dos projetos. Tendo detectado essa fragilidade na concepção dos projetos, se propõe, a partir das análises que serão realizadas, buscar entender como ocorreu e se ocorreu alguma participação por parte dos moradores durante o desenvolvimento dos projetos que serão apresentados.

${ }^{7}$ Como referencia pode-se citar o livro: "Qualidade Ambiental na Habitação: avaliação pós-ocupação", organizado por Simone Barbosa Vila e Sheila Walbe Ornstein (2013). 
As análises dos projetos serão guiadas pela lista de critérios apresentada e embasadas por fotografias e análises gráficas realizadas pela autora que representam, graficamente, os temas abordados.

Também foram realizadas entrevistas com os arquitetos, autores dos projetos. Contudo, como estratégia de trabalho, decidiu-se que as entrevistas só seriam realizadas no final do processo das análises, incorporando as informações adquiridas e os pontos de vista colocados pelos arquitetos sem que isso influenciasse o desenvolvimento das análises.

Ao final, após a realização das quatro análises, mas antes das considerações finais, se propõe desenvolver um capítulo baseado na comparação entre as análises apresentadas, com base nos critérios definidos, estabelecendo também relações entre esses e outros projetos que também fazem parte da produção contemporânea. 



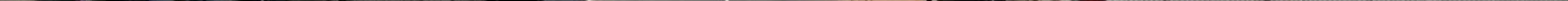




\subsection{COMANDANTE \\ TAYLOR}

O Conjunto Residencial Comandante Taylor, localizado em Heliópolis, foi construído em um terreno onde anteriormente havia uma empresa de terraplenagem instalada ${ }^{1}$ que foi desapropriado e comprado pela Prefeitura de São Paulo para a construção do conjunto.

\section{Conjunto Residencial Comandante Taylor}

Localização: Rua Comandante Taylor, 1.336 - Heliópolis

Distrito: Sacomã - Subprefeitura: Ipiranga - Zona: Sudeste

Distância até o centro da cidade: $8,5 \mathrm{Km}$.

Conclusão da obra: 2011 - início projeto: 2008

Arquitetura: Piratininga Arquitetos Associados

Autores: José Armênio de Brito Cruz e Renata Semin

Equipe: Fabiana Terenzi Stuchi (coordenação de equipe), Ricardo Zemp,

Bruno Valdetaro Salvador, Jéssica Tobaro Modelli (estágio)

Promoção: Programa de urbanização de favelas da Secretaria Municipal de Habitação de São Paulo (Sehab) / Consórcio Habitar São Paulo

Coordenação Sehab: Vanessa Padiá.

Área do terreno: $13.152 \mathrm{~m}^{2}$ / Área Construída: $29.300 \mathrm{~m}^{2}$

Coeficiente de aproveitamento: 2,22

no unidades habitacionais: $421 \mathrm{UHs}$

Densidade: $321 \mathrm{UHs} / \mathrm{ha}-1.092$ habitantes/ha²

Programa: Unidades Habitacionais

Centro Comunitário

Centro para idosos

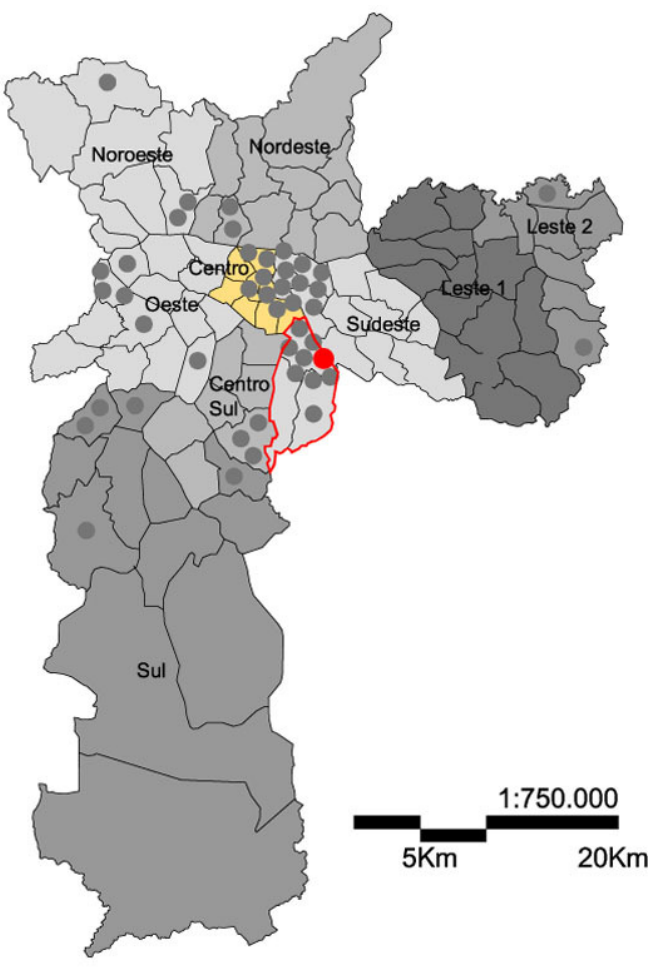

Figura 2 - Localização com relação à cidade.

${ }^{1}$ Informação fornecida pela arquiteta Renata Semin em entrevista realizada em setembro de 2013, em São Paulo.

${ }^{2}$ Foi adotada a média de 3,4 habitantes por unidade habitacional em aglomerados subnormais, em Heliópolis - fonte: IBGE, Censo Demográfico 2010, p. 167. 
Esse projeto é resultado da soma de esforços de três entidades principais: o Movimento social de famílias Sem Teto de Heliópolis e Ipiranga (MSTI), mobilizados por meio do Centro de Defesa dos Direitos da Criança e do Adolescente do Ipiranga (CEDECA CASA DEZ); a Superintendência de Habitação Popular (HABI) e o escritório de arquitetura que, segundo a arquiteta Renata Semin, a articulação entre eles e o movimento já existia há aproximadamente dez anos anteriormente, inclusive à intervenção de HABI (informação verbal) ${ }^{3}$. A arquiteta comenta que antes de encontrarem esse terreno, já haviam estudado outras propostas para outro terreno, também em Heliópolis e que já estavam há algum tempo buscando solucionar o problema e as ilusões de duzentas famílias quando encontraram o terreno da rua Comandante Taylor e puderam apresentar a proposta à Superintendência, que passou a intervir junto a eles para a construção do conjunto.

Ao observar a foto aérea (Figura 1), a primeira impressão que se tem é realmente a alta densidade e isso se confirma quando comparamos a densidade do conjunto com a da própria comunidade de Heliópolis, que já é considerada uma densidade alta se comparada ainda com a do distrito do Sacomã e da Subprefeitura, como pode ser verificado na tabela abaixo:

\begin{tabular}{lr} 
Conjunto Residencial Comandante Taylor & 1.092 habitantes /ha \\
\hline Comunidade Heliópolis ${ }^{4}$ & 544 habitantes/ha \\
\hline Distrito Sacomã ${ }^{5}$ & 174,54 habitantes/ha \\
\hline Subprefeitura Ipiranga ${ }^{6}$ & 123,68 habitantes/ha
\end{tabular}

${ }^{3}$ Informação fornecida pela arquiteta Renata Semin em entrevista realizada em setembro de 2013, em São Paulo.

${ }^{4}$ Dado sobre a densidade da comunidade Heliópolis de 544 habitantes/ha foi fornecido pela equipe de técnicos da Secretaria Municipal de Habitação de São Paulo.

5 Fonte: Dados Demográficos dos Distritos pertencentes às Subprefeituras, site da prefeitura de São Paulo, disponível em: http://www.prefeitura.sp.gov.br/cidade/secretarias/subprefeituras/subprefeituras/dados demograficos/. Acesso em setembro de 2013.

6 Ibid 3. 
De acordo com a arquiteta, essa alta densidade vai de encontro com o objetivo de oferecer o maior número de unidades habitacionais aos moradores. Anteriormente à incorporação de HABI ao projeto, apenas o movimento de moradias já possuía uma demanda de duzentas famílias e, para atender também à demanda da Secretaria, decidiu-se desenvolver o projeto considerando o coeficiente máximo de aproveitamento do terreno. Além disso, atingir esse coeficiente também faz parte das recomendações da Sehab e, de acordo com as Diretrizes de Projetos de Edificação, "devido à escassez de terrenos para a promoção de empreendimentos de Habitação de Interesse Social (EHIS) na cidade de São Paulo, o projeto deverá buscar atingir o coeficiente de aproveitamento máximo definido pela legislação vigente, viabilizando a implantação do maior número de unidades habitacionais permitido" (PREFEITURA DE SÃO PAULO, 2012 b, p. 232).

Entretanto, para qualquer tipo de empreendimento, deve haver um equilíbrio entre o aproveitamento máximo dos coeficientes e a qualidade espacial oferecida pelo projeto. Veremos posteriormente, ao analisar o conjunto e as relações espaciais existentes, como isso ocorre no caso do Comandante Taylor que, como foi citado anteriormente, é caracterizado pela alta densidade. A própria arquiteta reconhece que o conjunto poderia ser menos denso se tivesse cem unidades a menos ou alguns blocos de edifício, porém entende que essa era a demanda a ser atendida e isso foi considerado como condição para o desenvolvimento do projeto (informação verbal) ${ }^{7}$.

Quanto à relação com o entorno, o Conjunto Comandante Taylor é apenas mais uma intervenção dentro de Heliópolis e, como pode ser observado na Figura 3, faz parte de uma sobreposição de intervenções que vêm sendo realizadas desde os anos 1990 e que, de certa forma, marcam a paisagem dessa favela pela diversidade com que foram implantadas.

7 Informação fornecida pela arquiteta Renata Semin em entrevista realizada em setembro de 2013. 
É possível identificar o conjunto Comandante Taylor, com a data de 2011, próximo a uma grande área verde que, segundo informação dos técnicos da Sehab, pertence à Petrobrás e a secretaria está em negociação para a construção de mais 5.000 unidades habitacionais nesse terreno.

Além disso, também é possível identificar nessa foto as vias principais que cortam Heliópolis, identificadas no mapa de valores de proximidade (Figura 4), como a Avenida Almirante Delamare e a Avenida Comandante Taylor.

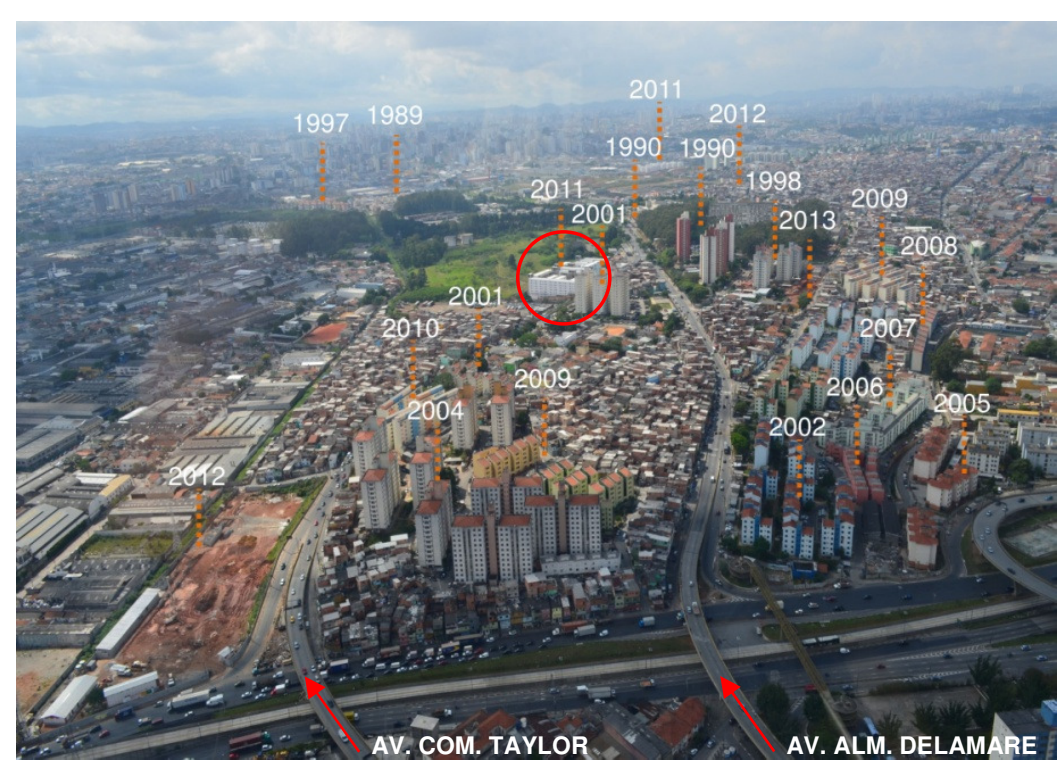

Figura 3 - Vista aérea Heliópolis - sobreposição de intervenções.

\subsubsection{ESCALA CONJUNTO}

A partir da escala do conjunto, o primeiro tema que será analisado são os valores de proximidade identificando a oferta de equipamentos, comércio e serviços no entorno do projeto, assim como as principais vias existentes, a oferta de transporte público e até mesmo a relação com os outros empreendimentos da comunidade Heliópolis, como foi possível observar na foto acima e que poderemos analisar também a partir do mapa gerado pela identificação e localização desses valores.

A partir de uma pesquisa mais detalhada utilizando a ferramenta de localização do Google Maps e com base em visitas ao local, foi possível gerar um mapa destacando os principais elementos encontrados no entorno do conjunto adotando um raio de referência de 600 e 1.000 metros. 


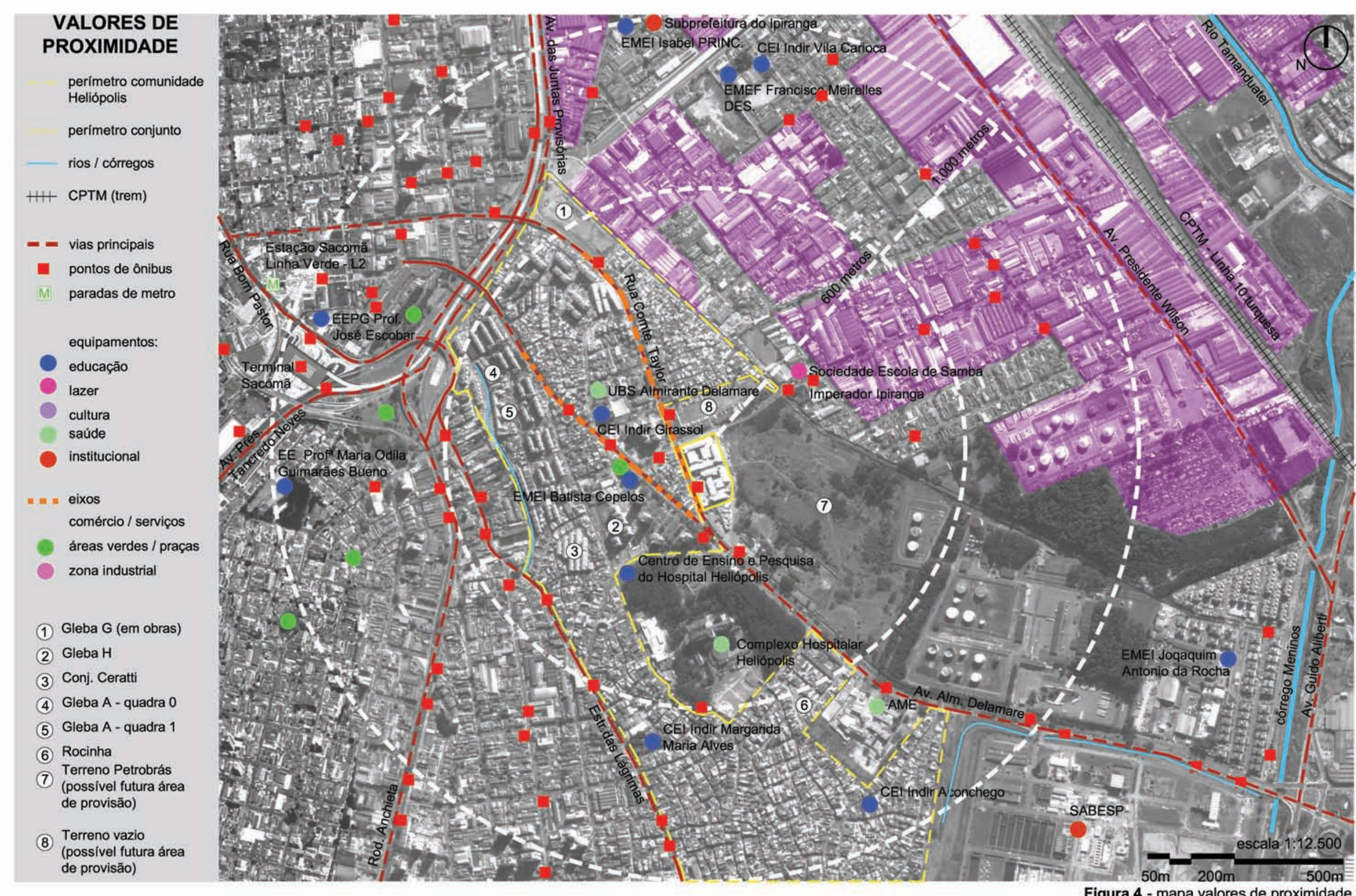


Analisando, portanto, esses valores, a primeira conclusão a que se pode chegar é que Heliópolis está muito bem localizado dentro da cidade, atendido por uma boa rede de ônibus além da estação de metrô do Sacomã (linha verde L2) e do Expresso Tiradentes ${ }^{8}$ (Veículo Leve sobre Pneus - VLP).

Observando o mapa, também é possível identificar o Complexo Hospitalar Heliópolis localizado bem no centro dessa favela, um hospital de referência mantido pelo Governo do Estado. Quanto à saúde, foram identificados também uma AME (Ambulatório Médico de Especialidades) e uma UBS (Unidade Básica de Saúde).

Também é possível identificar a oferta de escolas de diferentes graus, atendendo do ensino infantil ao fundamental. Porém, esse levantamento não teve o aprofundamento necessário para verificar se essa oferta é realmente suficiente à demanda local. Para isso, seria necessário um estudo mais detalhado que extrapolaria a análise do projeto. Além das escolas indicadas no mapa, existe também um Centro Educacional Integrado (CEU) bem próximo a esse entorno, o CEU Meninos localizado no limite com a cidade de São Caetano do Sul.

Pode-se observar também a proximidade com uma importante zona industrial da cidade, caracterizada pelo eixo do córrego Tamanduateí, onde a escala das construções e dos quarteirões é bastante diferente da trama dos bairros residenciais e mais ainda da favela.

As áreas verdes ou espaços de lazer não foram identificados em grande número dentro do perímetro analisado e, portanto, pode-se concluir que faltam espaços com essa característica no entorno do conjunto.

A oferta de comércio é caracterizada por um forte comércio local que atende às necessidades da vida cotidiana da comunidade. A própria Rua Comandante Taylor foi identificada, junto à Avenida Almirante Delamare como importantes eixos comerciais para o bairro.

${ }^{8} \mathrm{O}$ Expresso Tiradentes, inicialmente chamado de Fura-Fila, é um transporte de veículo leve sobre pneus (VLP) de média capacidade que conecta a região do Sacomã a Cidades Tiradentes passando, inclusive pelo Parque Dom Pedro. 


\subsubsection{INSERÇÃO \\ URBANA}

O Conjunto Comandante Taylor foi implantado em um terreno de $13.152 \mathrm{~m}^{2}$, localizado no limite do perímetro da favela Heliópolis que, como foi citado no início do capítulo, pertencia a uma empresa de terraplenagem e foi desapropriado pela prefeitura para a construção desse empreendimento. Além disso, também havia no terreno uma escola que acabou tendo as edificações preservadas e aproveitadas pelo projeto.

Programa

O conjunto organiza-se a partir da implantação de 14 edifícios residenciais, identificados em blocos de $\mathrm{A}$ a $\mathrm{X}^{9}$, como pode ser observado na imagem ao lado, além de um Centro Comunitário (1) para práticas esportivas, atividades culturais e de entretenimento e para a administração do conjunto; um Centro de atividades para Idosos (2) e um playground (3) incorporados ao programa.

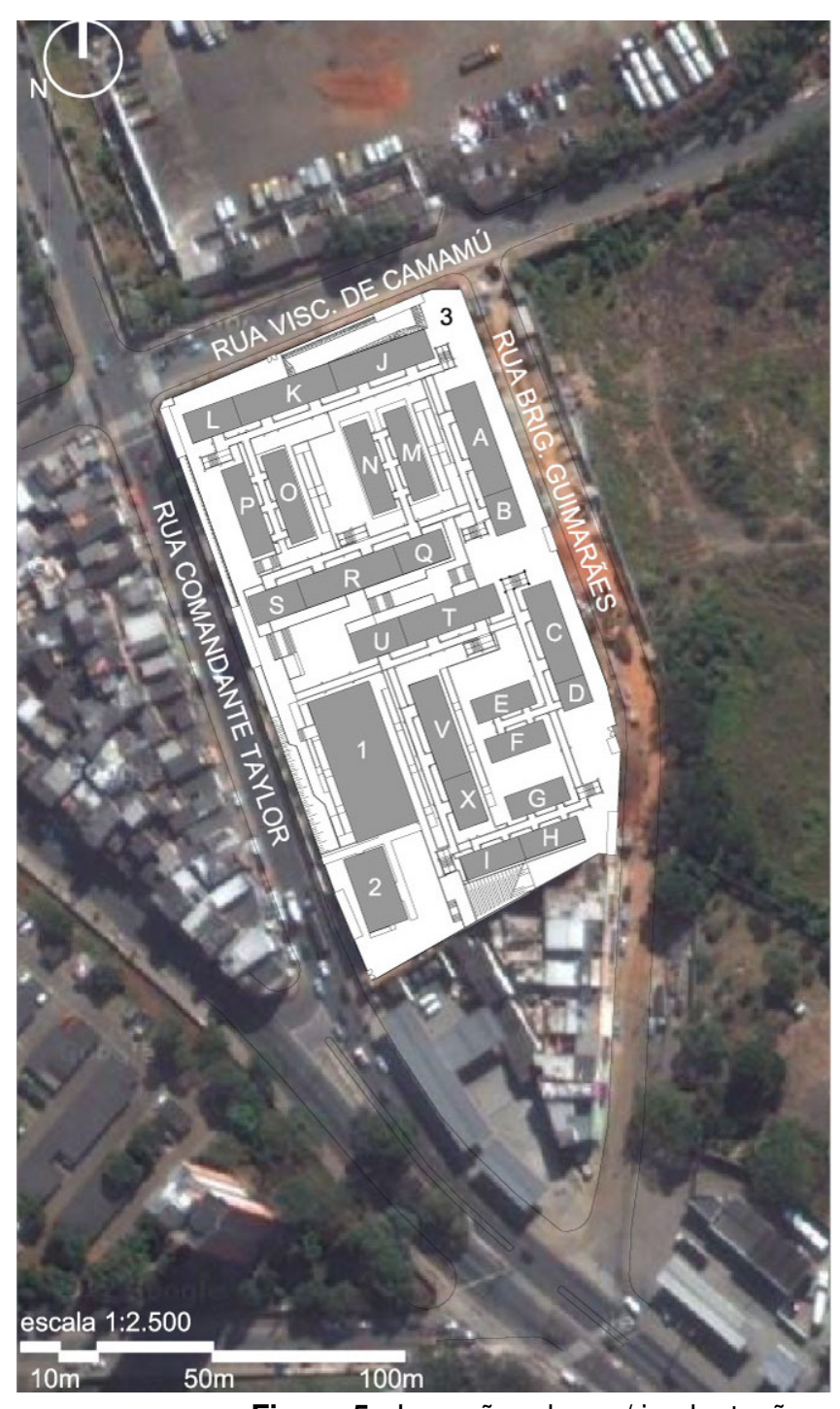

Figura 5 - Inserção urbana / implantação.

${ }^{9}$ A classificação em blocos foi realizada a partir de variações de número de pavimentos em um mesmo edifício devido à adaptação ao terreno e da posição das juntas de dilatação resultantes do sistema construtivo adotado (alvenaria estrutural com blocos de concreto). 
Segundo Renata Semin, desde o início do projeto ficou definido que esses usos não residenciais seriam implantados nas edificações já existentes no terreno, onde antes havia uma escola e que, por terem uma localização, cota e dimensões favoráveis, seriam preservadas e a intervenção se basearia na adaptação desses espaços aos novos usos. Além disso, durante o desenvolvimento da obra, esses edifícios existentes foram aproveitados como canteiro de obras e como espaço para a instalação da administração da construtora e do serviço social (informação verbal) ${ }^{10}$.

Durante o desenvolvimento do projeto foi possível verificar que o galpão apresentava boas condições e que seria possível conservar a estrutura existente sendo necessário apenas a criação de uma estrutura complementar para a construção da cobertura. Segundo a arquiteta, após a saída da equipe da prefeitura e da construtora do local, verificou-se que a estrutura havia sido danificada e que será necessário realizar reforços, porém desde a ocupação das unidades pelos moradores a obra do Centro Comunitário está paralisada.

O programa do Centro Comunitário contemplava um espaço multiuso, um telecentro, uma biblioteca e espaço para a administração do conjunto no pavimento inferior e a quadra de esportes no nível da rua. Uma vez que essa obra não prosseguiu, a comunidade não pode contar com esses equipamentos e a administração do conjunto está instalada na edificação reformada para abrigar as atividades para idosos compartilhando o uso desse edifício. A definição desse equipamento foi solicitada pelo movimento de moradores que contava com uma demanda de idosos e propôs a construção de um espaço para que eles pudessem desenvolver atividades proporcionando uma troca de experiências com a comunidade e os moradores do conjunto.

Pela posição no limite com a rua, esses equipamentos foram projetados para serem utilizados tanto pelos moradores do conjunto como pela comunidade do bairro tendo acessos independentes.

${ }^{10}$ Informação fornecida pela arquiteta Renata Semin em entrevista realizada em setembro de 2013. 


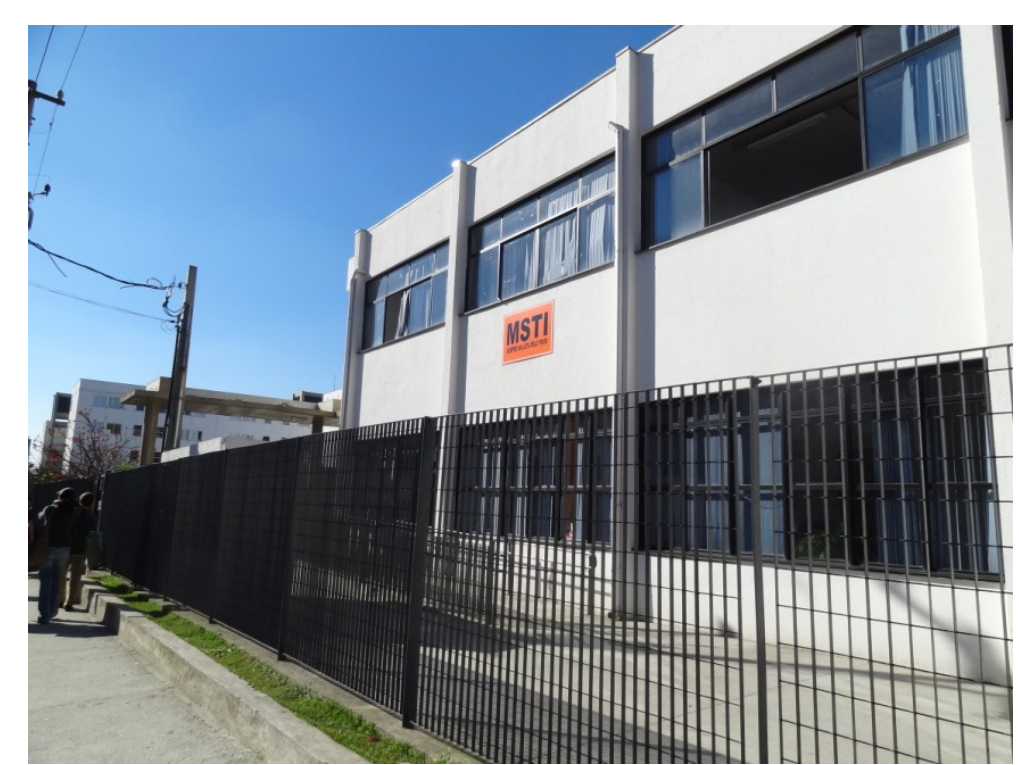

Figura 6 - Centro para Idosos, ocupado também pela administração do conjunto.

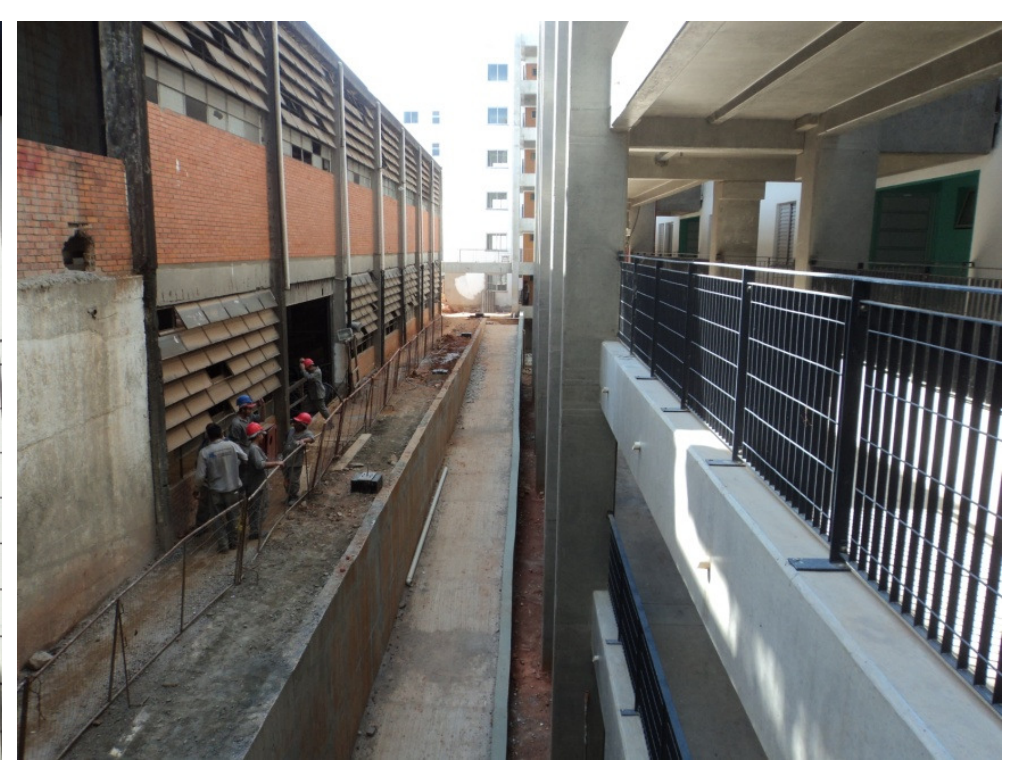

Figura 7 - Galpão onde deverá ser implantado o Centro Comunitário (à esquerda).

\section{Ocupação do terreno}

Analisando-se a implantação, a partir da projeção das áreas construídas e espaços livres podemos obter, em dados gerais, a porcentagem de ocupação do terreno por cada uso, sendo possível verificar a relação entre as áreas construídas e as áreas livres, assim como entre as edificações e as circulações.

Após estudar essas projeções, algumas conclusões são possíveis: como constatar que a porcentagem ocupada pelas circulações (23\%) é quase a mesma que a ocupada pelas edificações de uso habitacional (26\%). 
Essa análise a partir das máscaras geradas pelas projeções, também permite identificar que os espaços livres, apesar de representarem quase $37 \%$ da área do terreno, configuram-se ao redor das edificações e, dessa forma, caracterizam-se como espaços livres espalhados pelo conjunto.
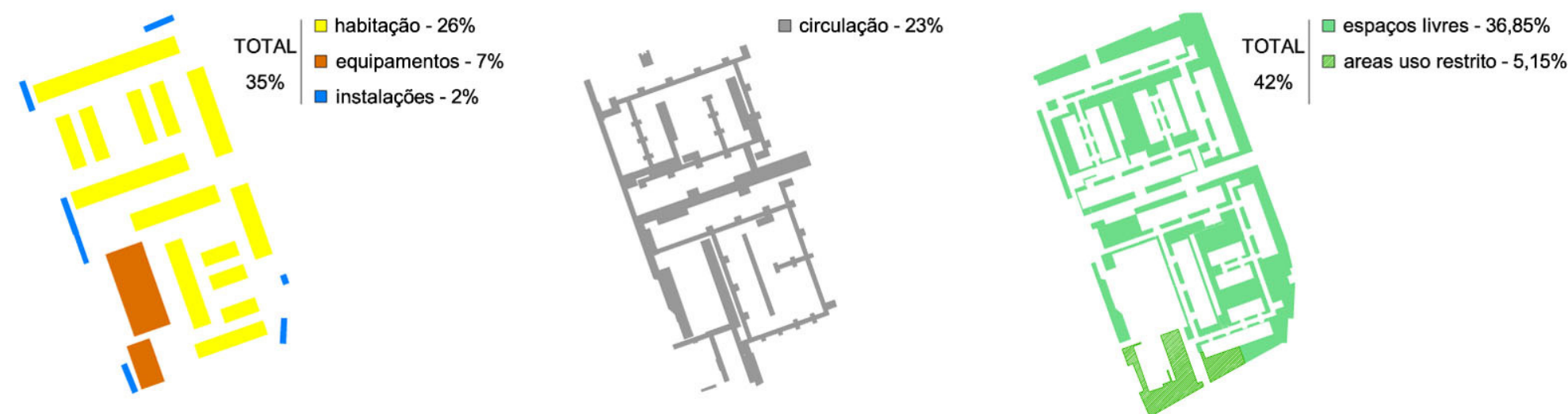

Figura 8 - Ocupação do terreno a partir da projeção das áreas construídas e espaços livres.

Observando-se, porém os primeiros estudos para o projeto (Figura 9 e Figura 10) é possível compreender que essa porcentagem da circulação corresponde à importância desse elemento para a concepção do projeto. Desde os primeiros estudos, as passarelas aparecem com bastante expressão conectando as edificações e, como foi citado pela própria arquiteta, têm referência na valorização das circulações e acessos dos projetos de Paulo Mendes da Rocha, como a Praça dos Museus (em construção na Cidade Universitária) e foram concebidas como calçadas suspensas para propiciar a convivência entre os moradores (informação verbal) ${ }^{11}$.

Ainda observando os estudos, percebe-se que os espaços livres eram maiores e conforme o projeto foi ficando mais denso, foram se diluindo entre as edificações chegando ao resultado representado pelas máscaras acima. 


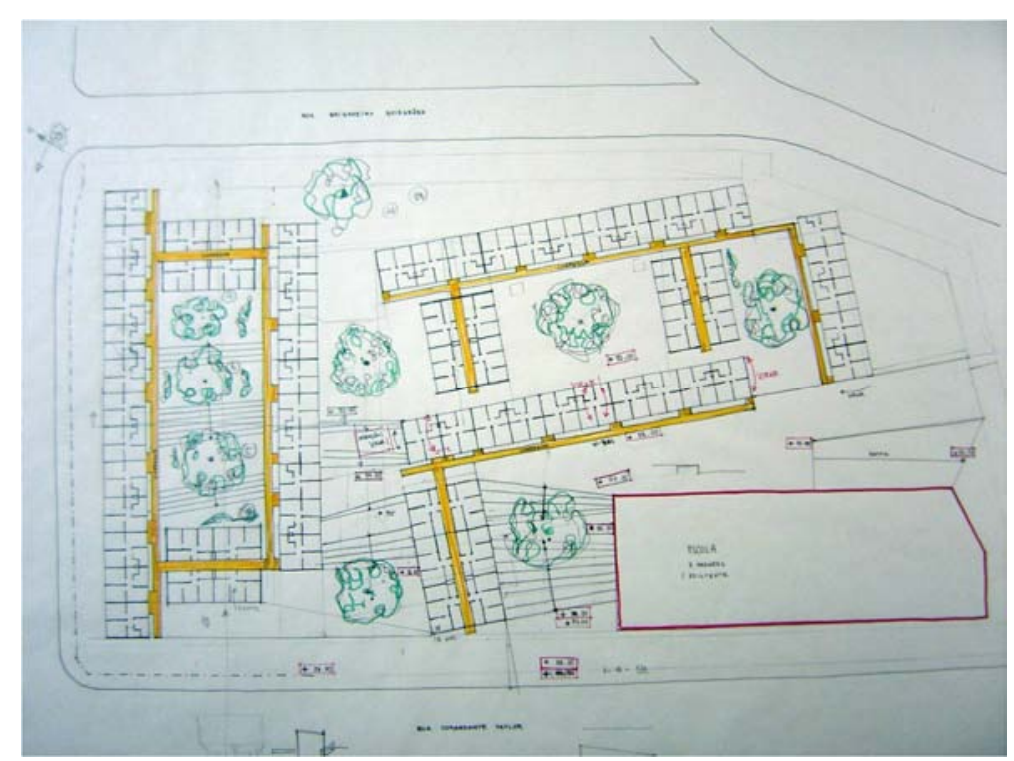

Figura 9 - Primeiros estudos para a implantação do conjunto no terreno.

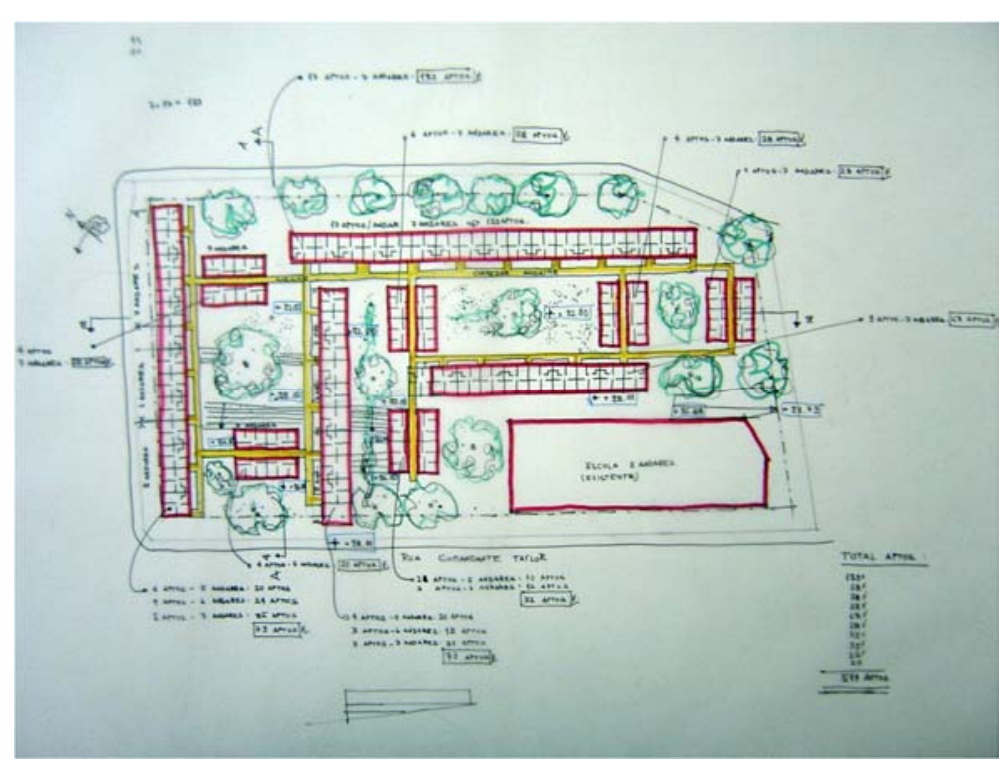

Figura 10 - Primeiros estudos para a implantação do conjunto no terreno.

\section{Definição do limite do conjunto}

A definição do limite do conjunto também é um item importante a ser analisado dentro do tema inserção urbana, pois verifica como o projeto se define com respeito à cidade e como se dá a relação entre interior e exterior do conjunto. Existem diferentes maneiras para definir o limite do conjunto e no caso do Comandante Taylor, os gradis foram o elemento adotado.

A opção pelos gradis proporciona transparência e permeabilidade visual com o exterior, permitindo que, ao menos visualmente, o conjunto se relacione com a cidade. Porém, os espaços entre as edificações e os gradis também fazem parte dessa análise e, no Comandante Taylor, duas situações foram identificadas: em algumas partes, como 
no playground, um uso é proposto e o espaço é aproveitado pelos moradores; em outras situações, esses espaços representam apenas o recuo entre os gradis e o edifício, utilizados para circulação ou como áreas verdes. Nesse momento, nos permitimos ir mais além e tentar imaginar que características poderiam ter, se as entradas das unidades do térreo estivessem voltadas para esses espaços, pois como podemos observar por todo o conjunto, os moradores tendem a apropriar-se das áreas à frente de suas casas como se fossem seus próprios quintais. Isso poderia dar mais vida e maior uso a esses espaços que hoje praticamente representam os recuos.

Está claro que essas alternativas não significam simplesmente inverter as edificações. Uma alteração como essa interfere nos acessos e até mesmo na distribuição dos ambientes no interior das unidades, porém são situações que podem ser consideradas durante a concepção dos projetos e, no caso do Comandante Taylor, ficou definido que os acessos às unidades e, consequentemente, essas extensões das residências ficariam voltados para 0 interior do conjunto.

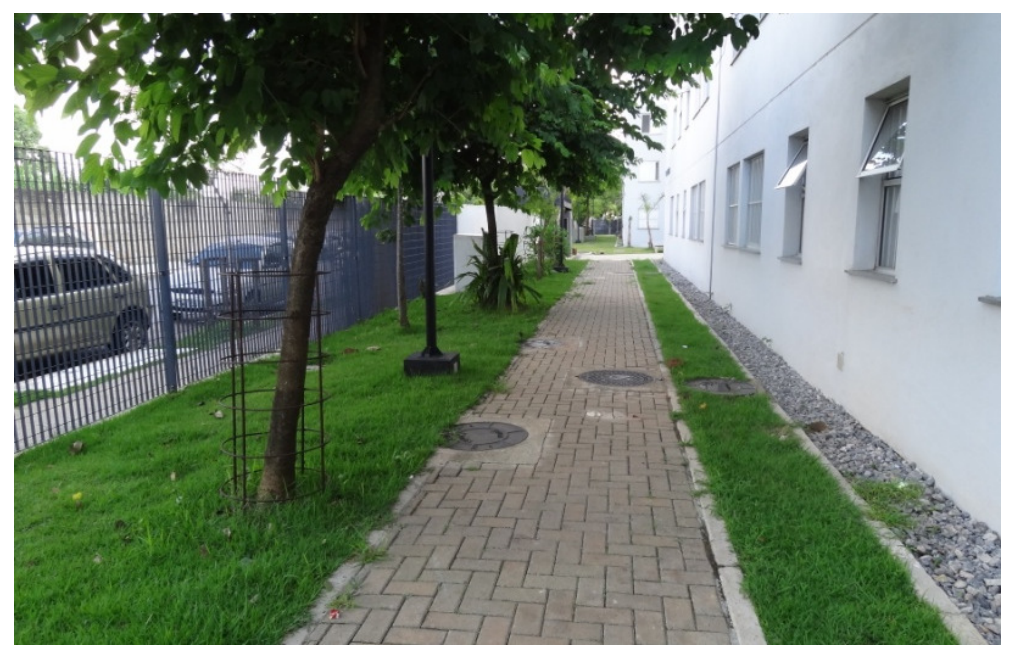

Figura 11 - Circulação entre o gradil e a edificação.

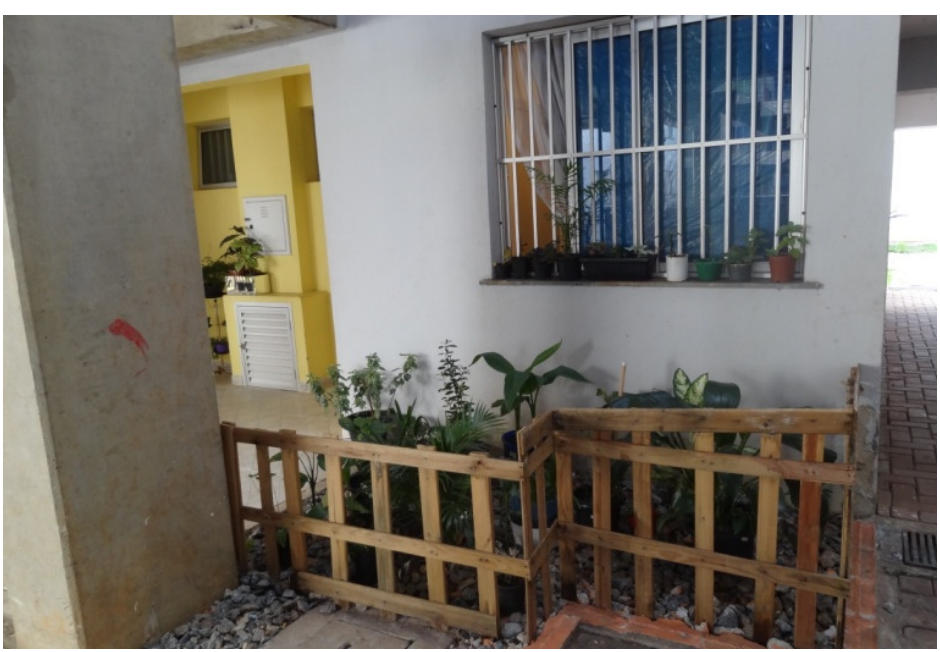

Figura 12 - Apropriação, pelos moradores, dos espaços do térreo. 


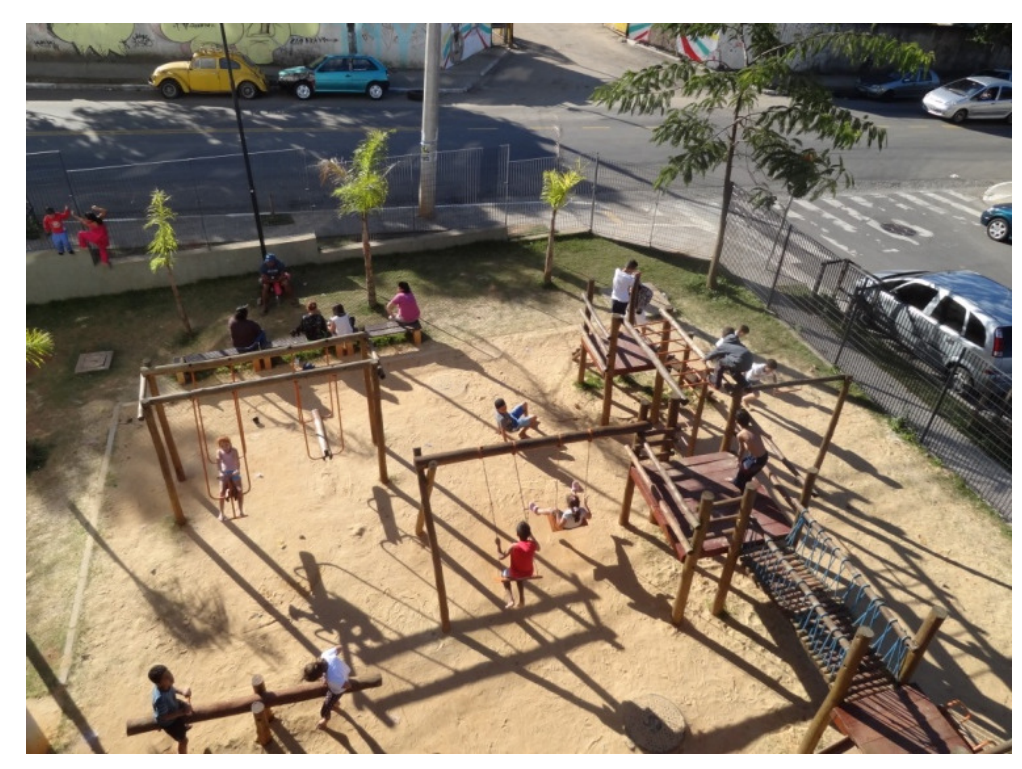

Figura 13 - Playground.

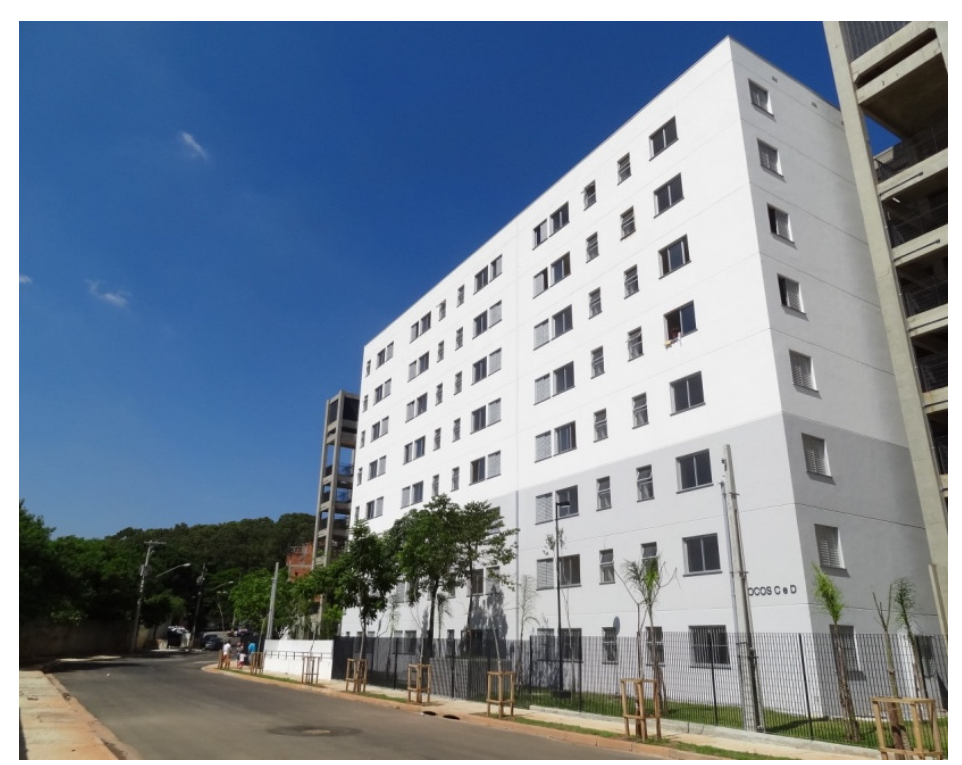

Figura 14 - Rua Brigadeiro Guimarães. Definição do limite do conjunto com gradis - transparência. / Pavimentos inferiores pintados de cinza.

\section{Adaptação ao terreno}

O terreno onde o Conjunto Comandante Taylor foi implantado apresenta um desnível de até 8 metros e a adaptação a esse terreno foi o partido adotado para a implantação do conjunto, buscando estabelecer platôs e adaptar as edificações a esses desníveis para realizar, o mínimo possível, grandes movimentos de terra e diminuir as contenções (Figura 16; Figura 17; Figura 18 e Figura 19).

Como pode ser observado nos cortes transversais, o nível da Rua Comandante Taylor foi definido como o térreo do conjunto e a Rua Brigadeiro Guimarães está três níveis abaixo. Aproveitando-se desses desníveis, os edifícios ganharam mais pavimentos que as edificações de $T+4$ (térreo mais quatro pavimentos) normalmente utilizadas 
para a construção de edifícios para habitação de interesse social, uma vez que atingem o número máximo de pavimentos sem necessidade de instalação de elevadores. No caso desse conjunto, alguns edifícios chegam a ter oito pavimentos beneficiando-se da situação do térreo intermediário e assim, conseguem oferecer um maior número de unidades habitacionais sem a necessidade de implantar elevadores.

Vale destacar aqui que a definição do nível da Rua Comandante Taylor como térreo é reforçada também visualmente pela pintura do conjunto sendo que, os pavimentos inferiores foram pintados de cinza e os acima do nível térreo, de branco, como pode ser observado na Figura 14.

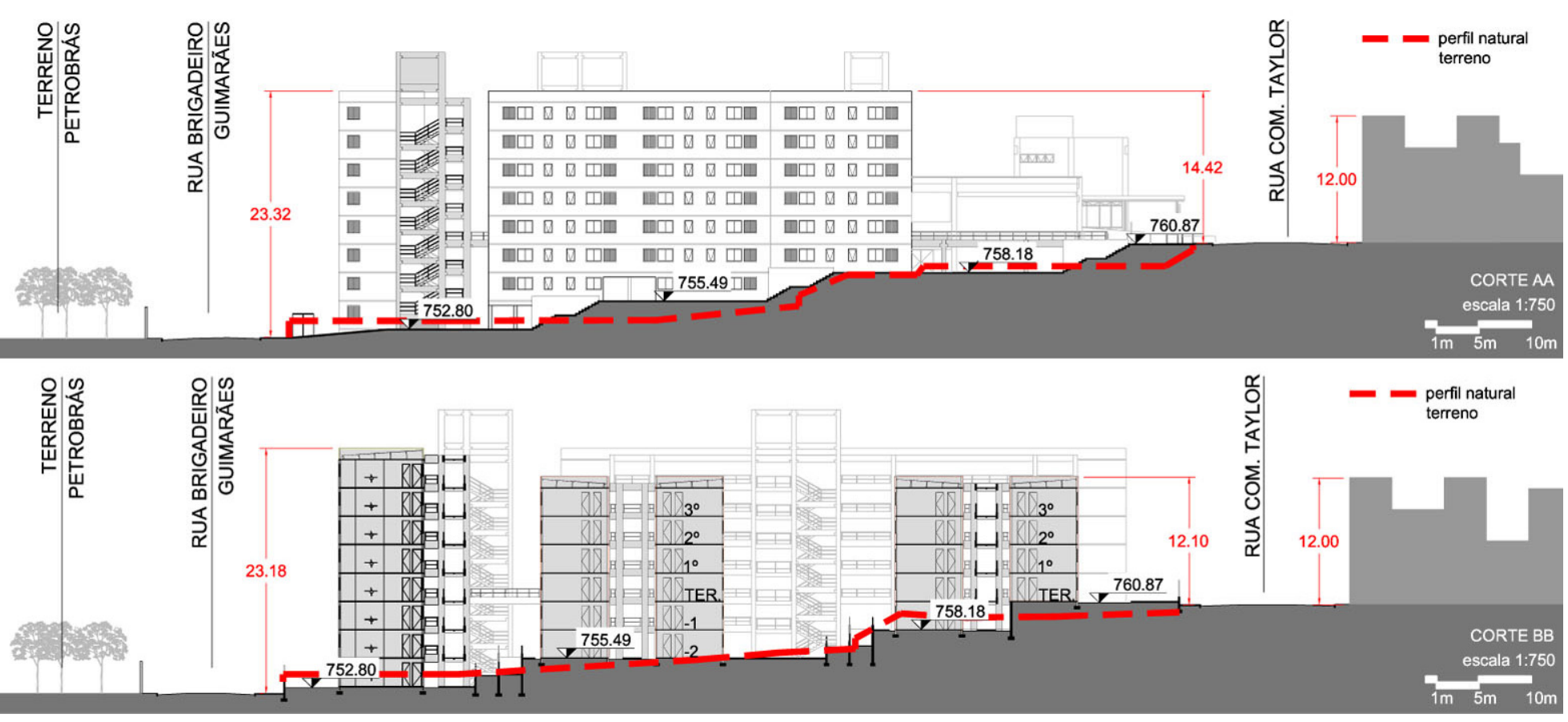

Figura 15 - Cortes Transversais - adaptação aos desníveis do terreno. 


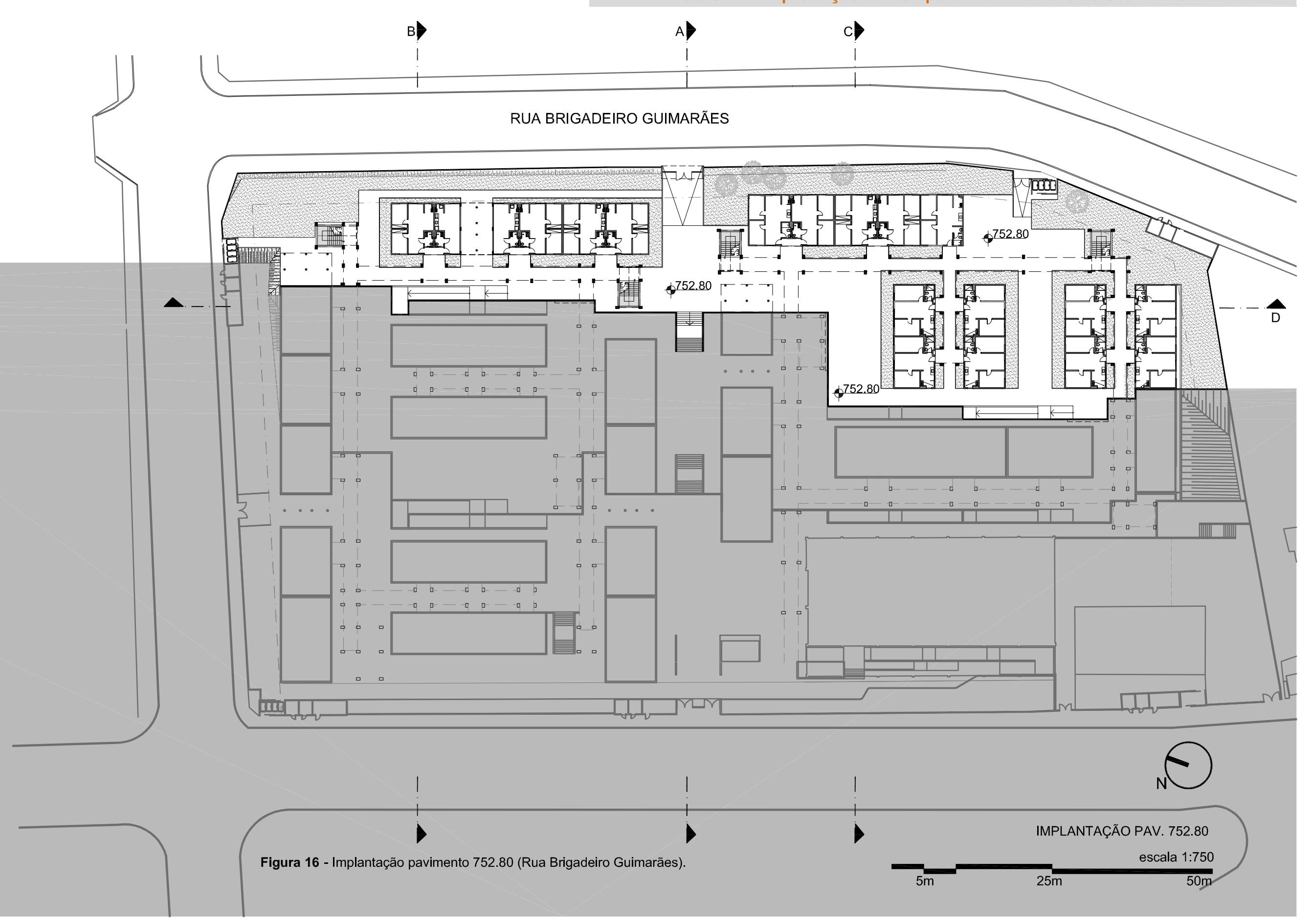




\section{COMANDANTE TAYLOR}

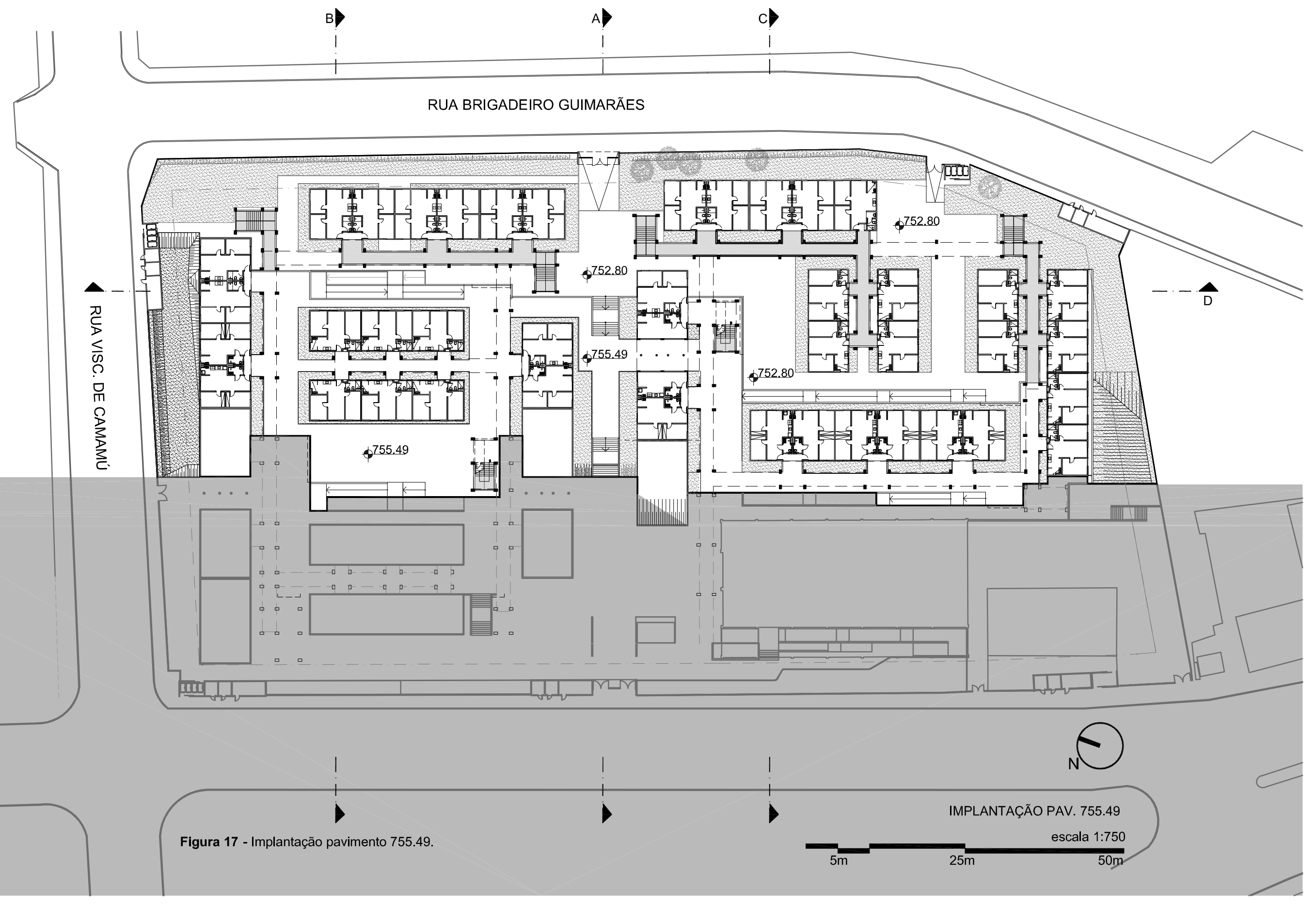




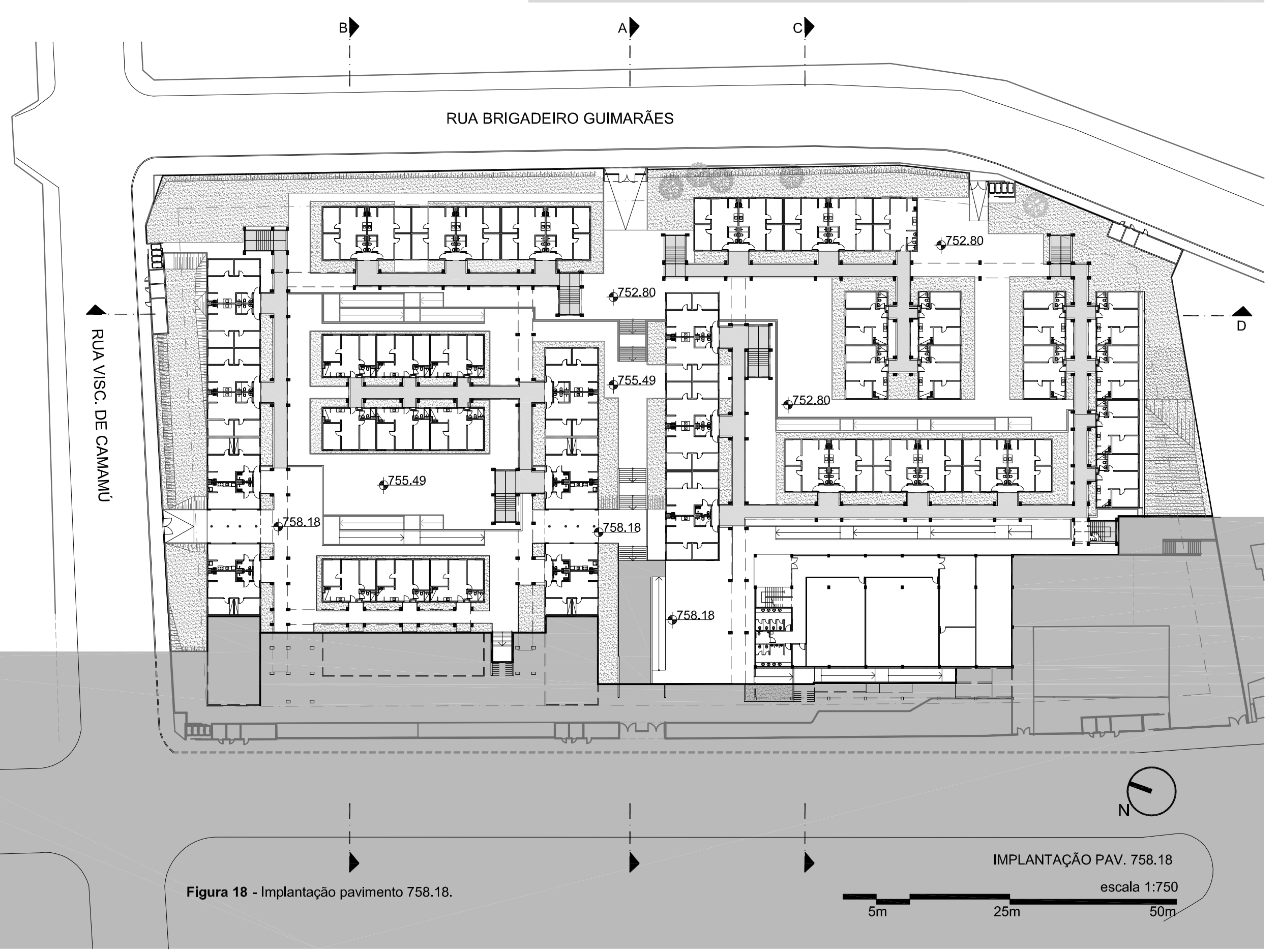




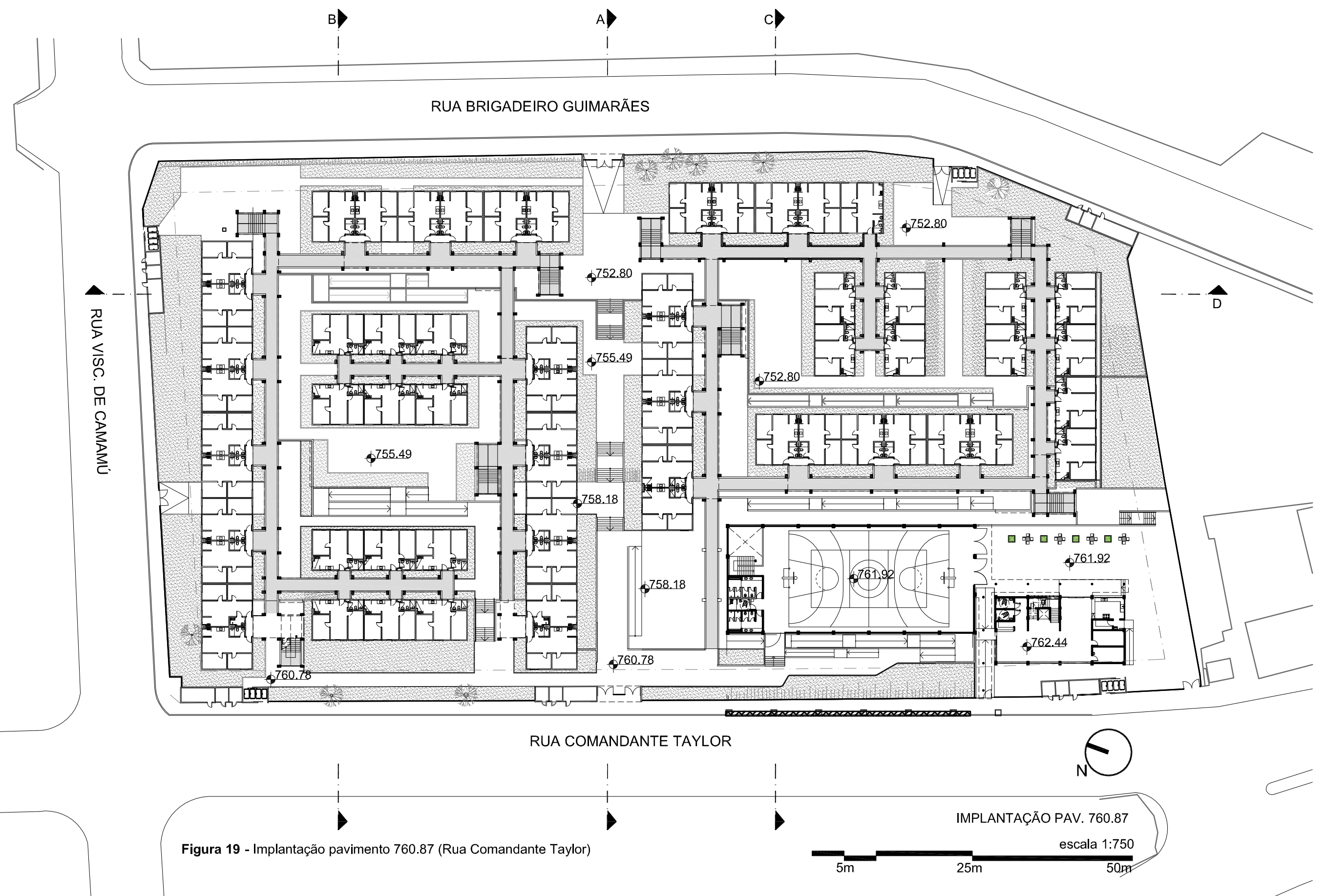




\section{Diálogo volumétrico}

Para completar o tema referente à inserção urbana, será analisado também o diálogo volumétrico que o conjunto estabelece com o entorno em que está inserido. É muito importante que os conjuntos não sejam um "elemento estranho ao entorno", conforme recomendações do trabalho Instrumentos de Avaliação de Projetos (PREFEITURA DE SÃO PAULO, 2012b, p. 278), mas, ao contrário, sejam inserções que façam parte da cidade, comunicando-se com ela.

Ao analisar a implantação do Comandante Taylor (Figura 4 e Figura 5), verificou-se que, em duas laterais, o conjunto faz limite com terrenos vazios que possivelmente configurarão futuros conjuntos de habitação de interesse social, como foi possível observar no mapa de valores de proximidade. Sendo assim, espera-se que esses futuros conjuntos estabeleçam um bom diálogo com o conjunto existente que, de certa forma, impõe sua altura e densidade sobre esses terrenos hoje vazios, como pode ser observado na Figura 20.

Com respeito às outras duas laterais, são ocupadas por construções informais características da favela e, quanto à escala das construções, a diferença é bastante forte, marcadas por proporções bem distintas. Porém, analisando essa relação a partir da perspectiva de um pedestre, no que diz respeito às alturas, o conjunto não se destaca muito sobre essas construções informais que, conforme dados do Projeto de Urbanização de Heliópolis ${ }^{12}$, uma grande porcentagem das construções da favela chega a três e quatro pavimentos, como pode ser observado na própria Rua Comandante Taylor onde as construções de quatro pavimentos têm a mesma altura que os edifícios do conjunto.

12 O Projeto de Urbanização de Heliópolis pode ver encontrado no site Habisp Plus, disponível em: http://www.saopaulocalling.org/project/sao-paulo-heliopolis. Acesso em setembro de 2013. 


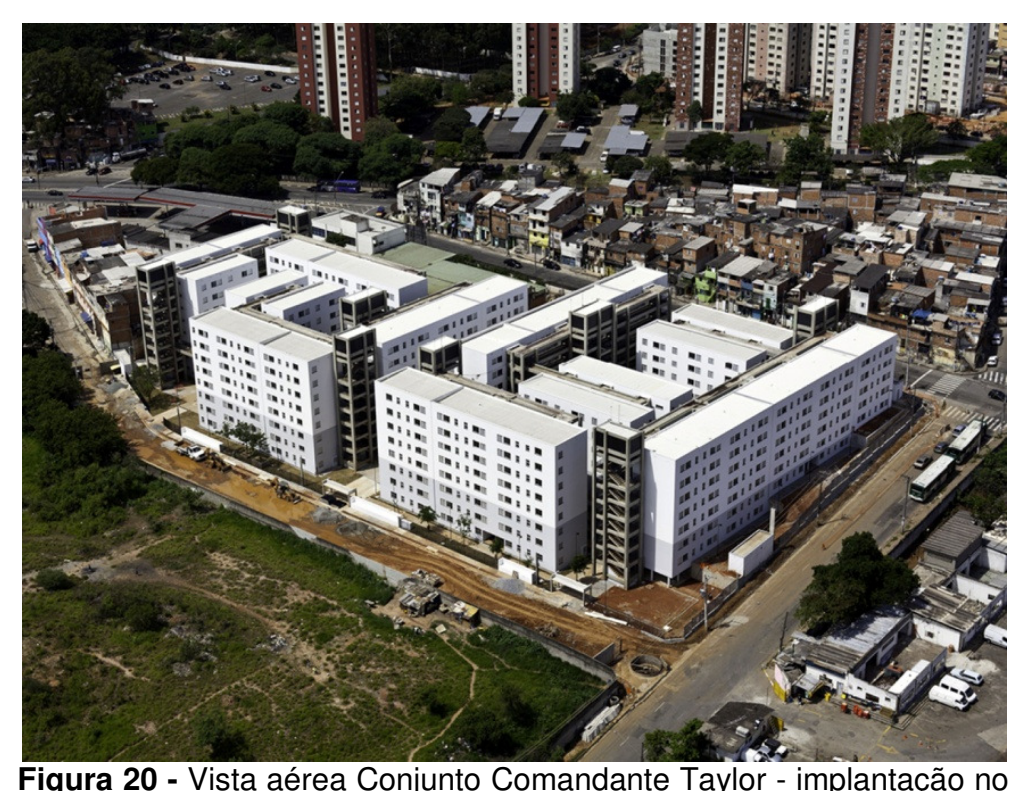

Figura 20 - Vista aérea Conjunto Comandante Taylor - implantação no terreno e relação com o entorno marcada pela forte diferença de escala.

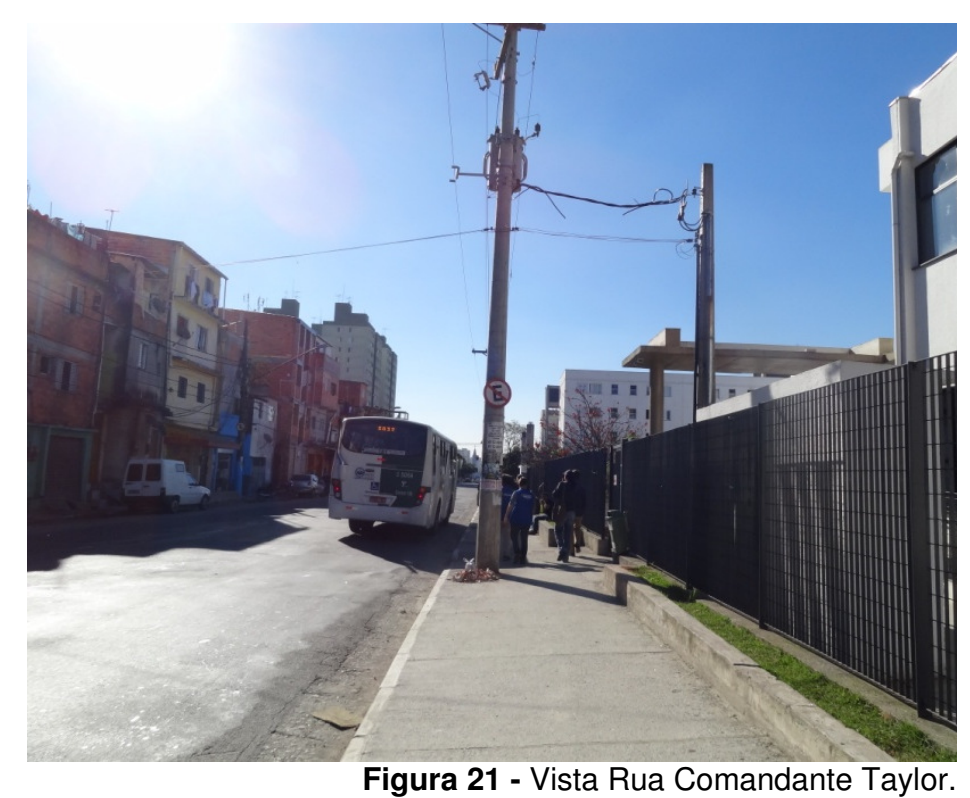

Figura 21 - Vista Rua Comandante Taylor

\subsubsection{ESPAÇOS EXTERIORES}

Como foi observado no item ocupação do terreno, a área construída do conjunto é bastante densa e somada às circulações representam $58 \%$ da área ocupada, porém, os $42 \%$ restantes estão distribuídos ao redor das edificações. Para poder compreender como essas áreas exteriores se relacionam dentro do conjunto e como são utilizadas pelos moradores, será realizada, a seguir, uma análise sobre esses espaços. 


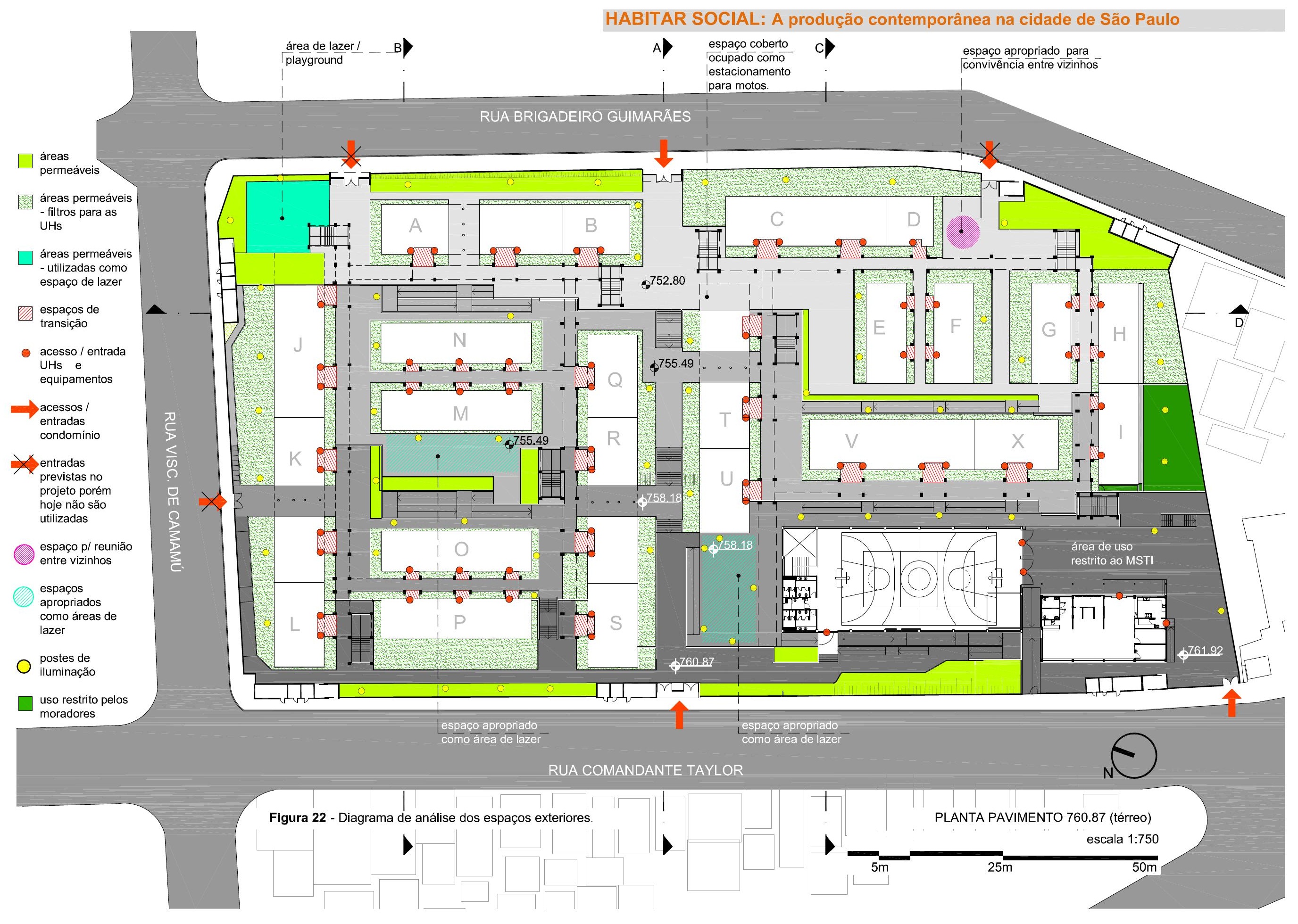


Para realizar essa análise, foi utilizada a planta do pavimento térreo (nível 760.87) a partir da qual é possível visualizar também os pavimentos inferiores e os elementos de circulação que vencem os desníveis definidos pelos platôs.

Observando essa análise, algumas conclusões são possíveis: a maior parte das áreas permeáveis foi definida ao redor das edificações e, devido a essa posição, funcionam como filtros de privacidades às unidades do térreo proporcionando um afastamento das circulações em relação às janelas dos apartamentos (Figura 23).

Como os edifícios estão distribuídos pelo conjunto, uma boa parte dos espaços exteriores acaba sendo utilizada como circulação. Para tornar esse dado mais visível, os acessos às unidades do térreo foram destacados na planta de análise e a partir da identificação desses acessos e das entradas ao conjunto, foi elaborado um diagrama de circulação, como pode ser visto na Figura 24.

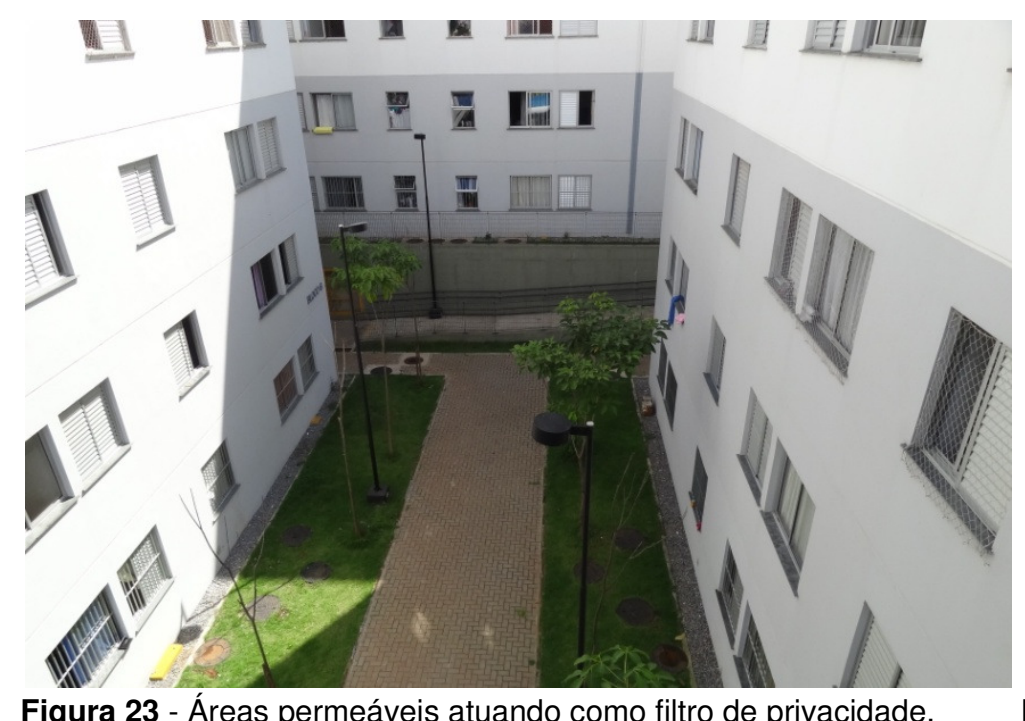

Figura 23 - Áreas permeáveis atuando como filtro de privacidade.

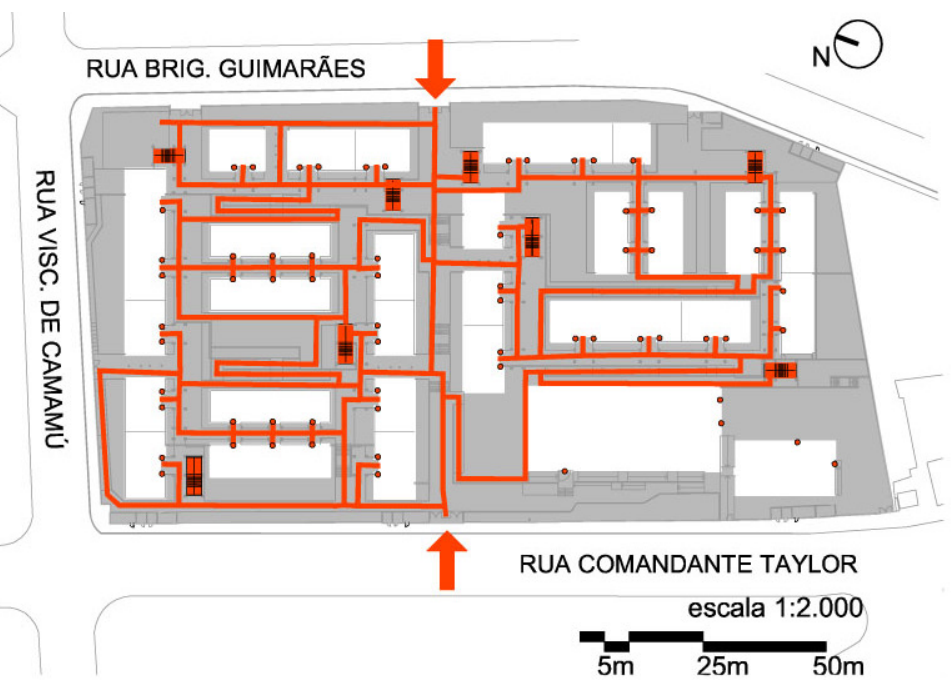

Figura 24 - Diagrama de circulações. 
No que diz respeito aos acessos ao conjunto, verificamos no projeto cinco acessos distribuídos entre a Rua Comandante Taylor, que é o nível mais alto, a Rua Visconde de Camamú, na lateral e a Rua Brigadeiro Guimarães que encontra-se no nível mais baixo do terreno, além do acesso independente ao Centro para Idosos. Porém, dos cinco acessos, apenas dois são utilizados pelos moradores que articularam uma organização interna que controla a entrada e saída do condomínio, sendo utilizadas apenas as duas entradas que dão para o principal eixo que corta o condomínio, como pode ser observado na planta de análise onde as entradas estão indicadas.

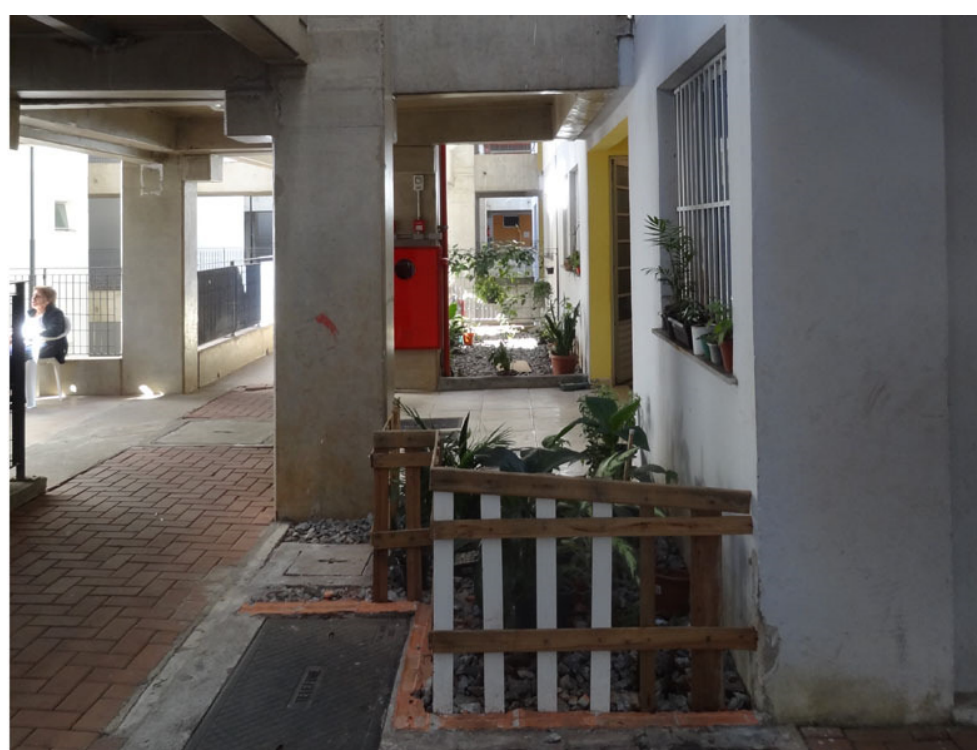

Figura 25 - Espaços de transição apropriados pelos moradores como jardins.

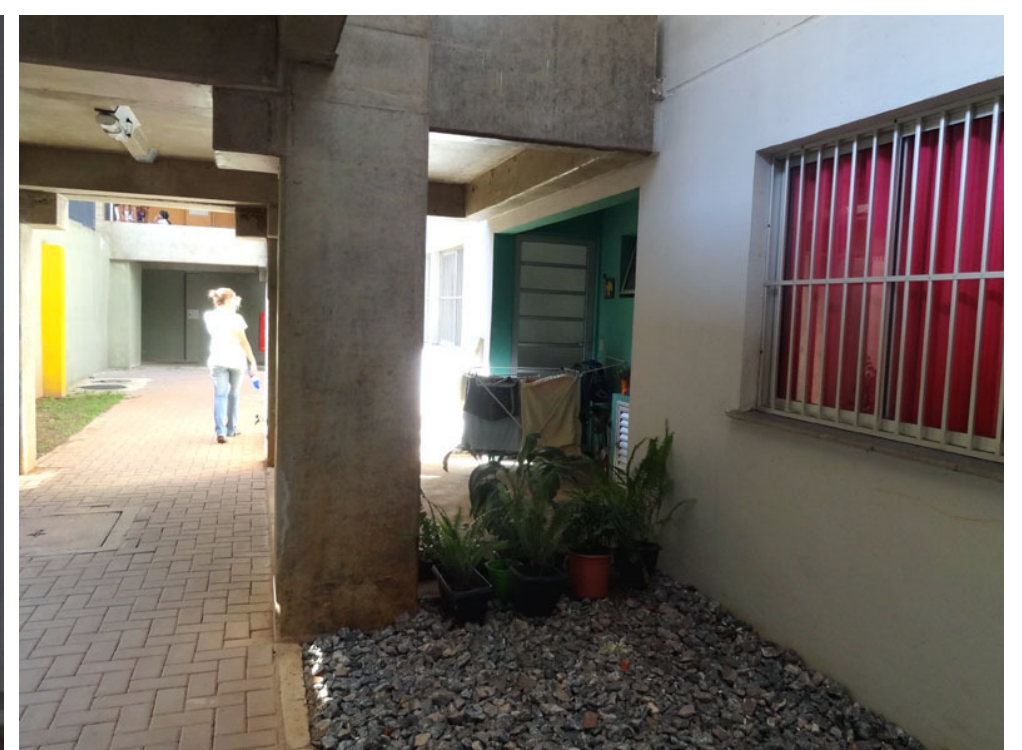

Figura 26 - Espaços de transição apropriados pelos moradores como jardins e área para estender roupas.

Além da análise dos acessos e percursos, vale destacar os espaços identificados junto às portas de entrada dos apartamentos, que atuam na transição entre a circulação comum e o acesso às casas. Esses espaços foram muito bem apropriados pelos moradores como extensões de suas residências. Muitos utilizam essa área como horta ou 
jardim; outros como espaço para o convívio onde podem sentar para conversar com um vizinho ou ver as crianças brincarem; alguns desses espaços também são usados para estender roupa, o que foi observado principalmente nas unidades onde a área de serviço não tem uma boa iluminação e em outros casos, é um espaço onde ficam "guardadas" as bicicletas e outros objetos grandes que não têm um lugar adequado para serem guardados dentro da unidade e também não encontram espaço apropriado dentro do conjunto, uma vez que o espaço projetado para essa função ficaria no Centro Comunitário que teve a reforma paralisada.

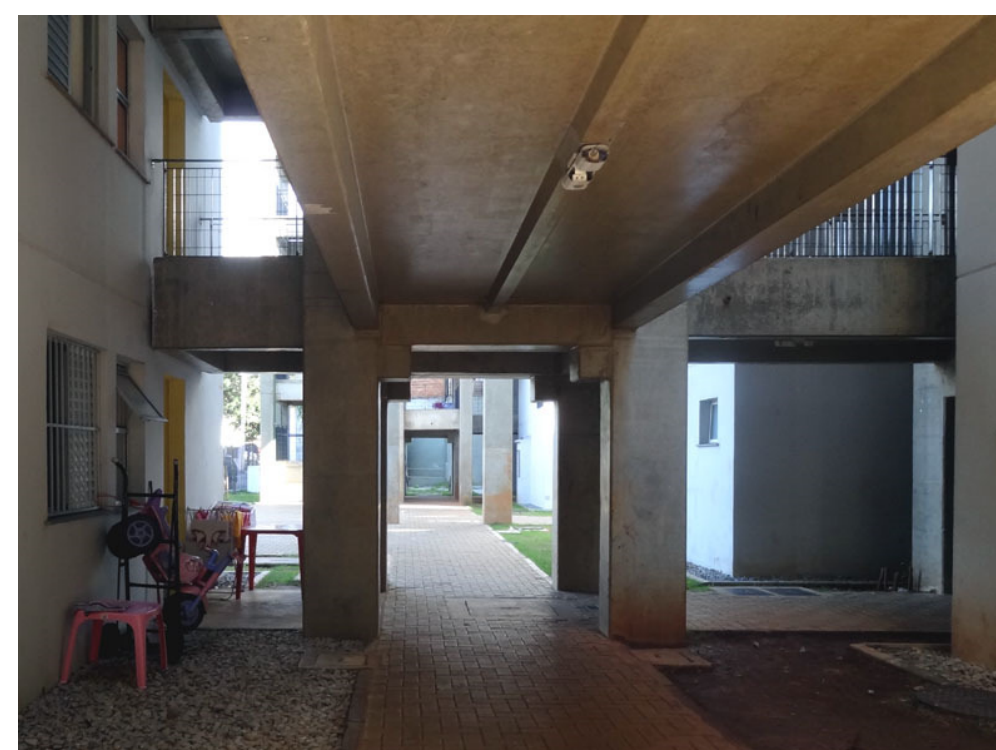

Figura 27 - Espaços de transição apropriados pelos moradores para estender roupa e deixar brinquedos.

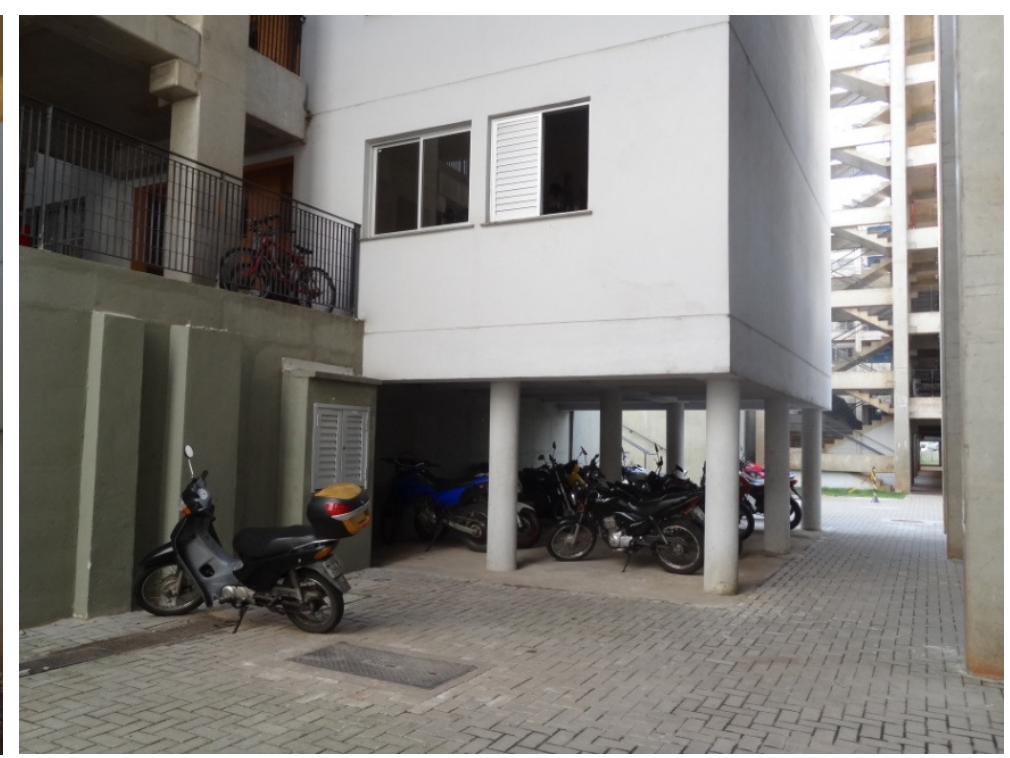

Figura 28 - Espaço exterior coberto utilizado como estacionamento para motos.

No que diz respeito a esses espaços para guardar grandes objetos, também não foram encontrados espaços adequados para estacionar motos, uma situação bastante comum dentro dos conjuntos habitacionais. Porém quando esses espaços não são propostos pelo projeto, os moradores sempre acabam encontrando algum lugar 
para estacionar e, no caso do Comandante Taylor, uma área livre coberta, que poderia ser utilizada para o convívio entre vizinhos ou lazer, foi transformada em estacionamento para motos, como pode ser visto na Figura 28.

Tratando ainda do tema da apropriação dos espaços, podemos ver na planta de análise que o único espaço definido e mobiliado para o lazer é o playground localizado em uma das esquinas do conjunto. Porém, as visitas ao local proporcionaram a oportunidade de identificar outras áreas que, apesar de não terem mobiliário adequado, estão sendo utilizadas, principalmente pelas crianças, como espaços de lazer. São essas áreas hachuradas de verde água na planta que, não coincidentemente, são as áreas mais generosas entre os espaços exteriores do conjunto que, entre outras atividades são utilizadas para jogar bola, como pode ser observado nas imagens abaixo.

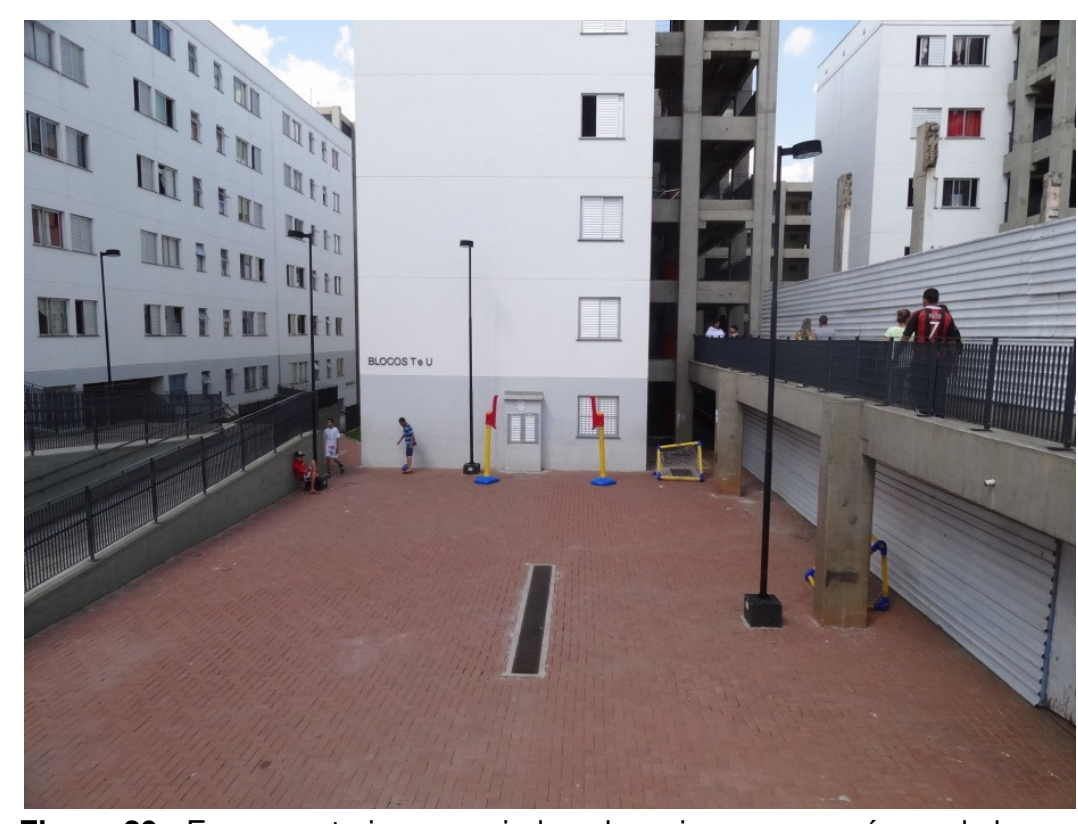

Figura 29 - Espaço exterior apropriado pelas crianças como áreas de lazer.

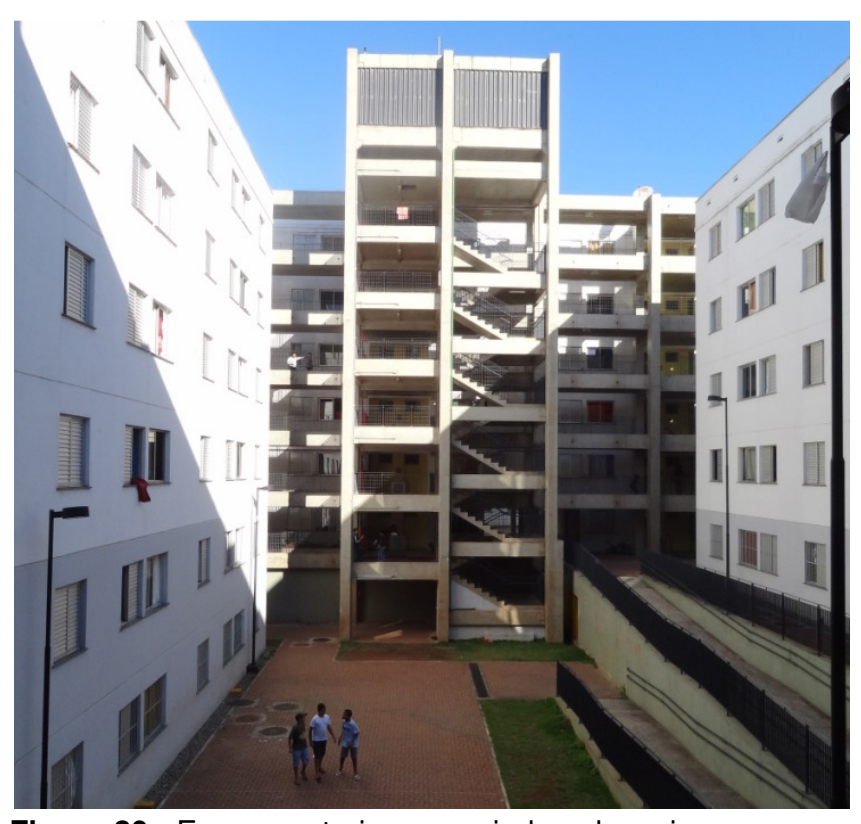

Figura 30 - Espaço exterior apropriado pelas crianças como áreas de lazer. 
Além da apropriação de espaços para o lazer, também foi possível identificar, durante as visitas, uma área utilizada para o encontro e o convívio entre moradores (marcada com hachura pink na planta de análise) que, também não por acaso, foi o único espaço onde foram vistos bancos em todo o conjunto.

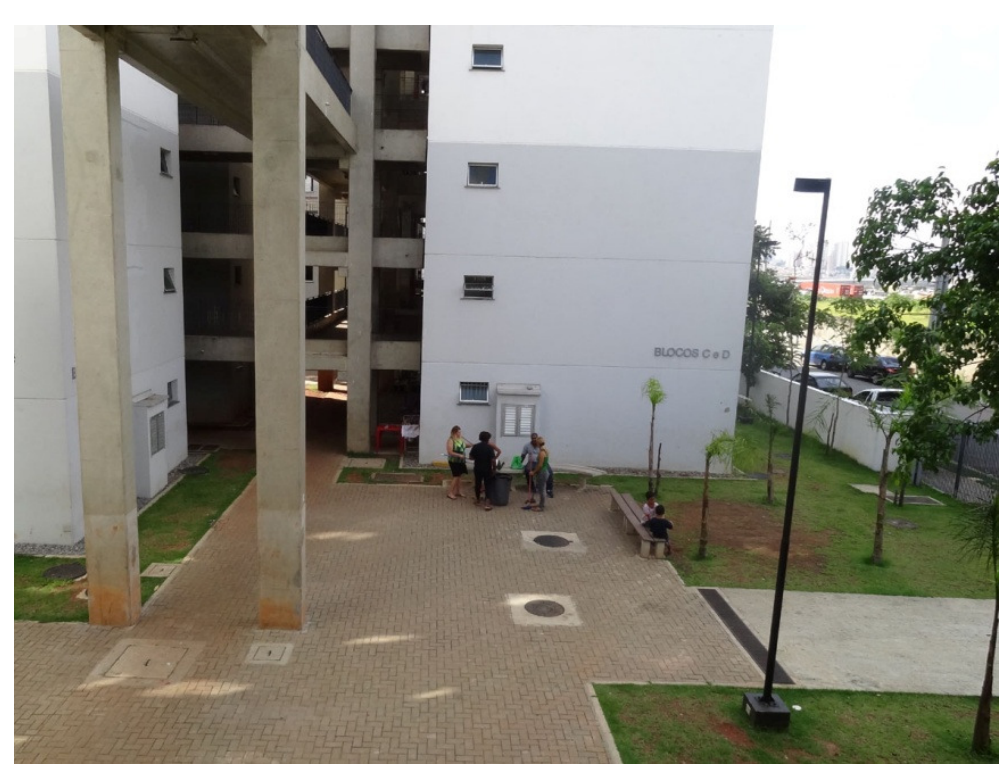

Figura 31 - Espaço de encontro entre vizinhos.

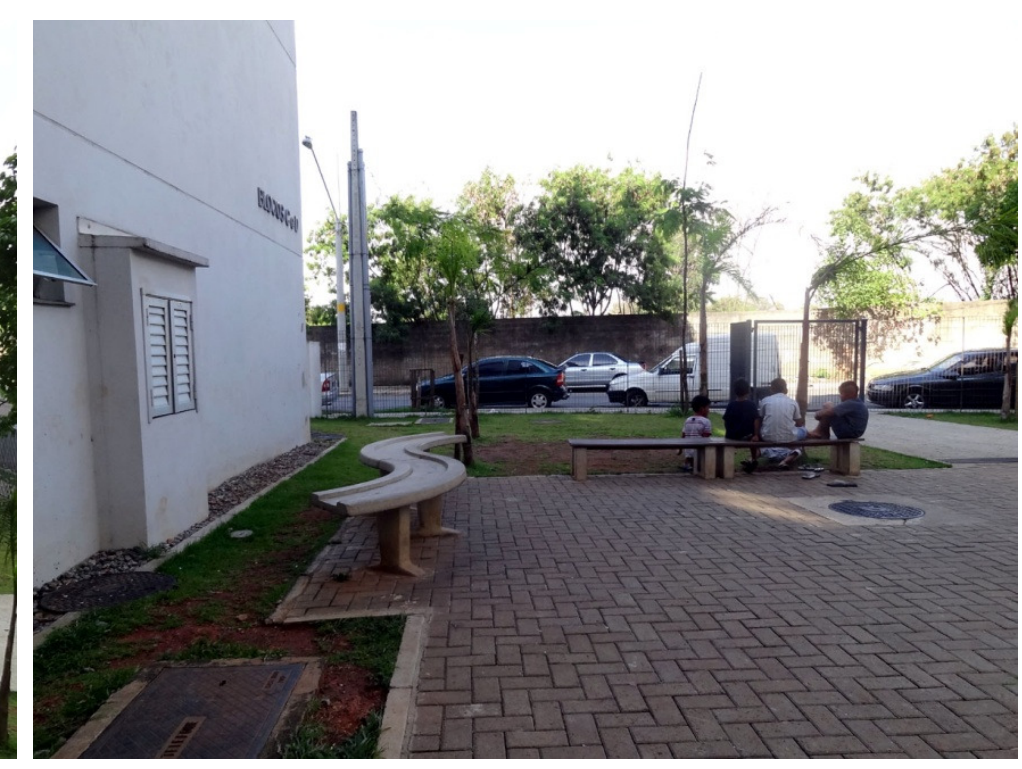

Figura 32 - Espaço de encontro e descanso.

Voltando a analisar o material desenvolvido durante a concepção do projeto, é possível observar que todo um paisagismo foi pensado para o conjunto, proporcionando áreas de sombra e considerando inclusive árvores frutíferas que incentivariam o cuidado pelos moradores. Porém durante a realização da obra, esse paisagismo não chegou a ser executado.

Observando ainda a perspectiva, é possível identificar como é que esses espaços indicados pela apropriação como espaços de lazer (Figura 29 e Figura 30) foram concebidos e almejados durante o desenvolvimento do projeto. Foram pensadas em áreas livres, como hoje, porém com mais vegetação. É possível observar ainda as trepadeiras 
subindo pelas passarelas, um conjunto que intervenções e incorporação do verde que tornaria esses espaços exteriores muito mais agradáveis. Analisando essas propostas, o que se pode concluir é que oxalá, com o tempo, a apropriação dos moradores chegue a valorizar os espaços tanto quanto como foram concebidos.

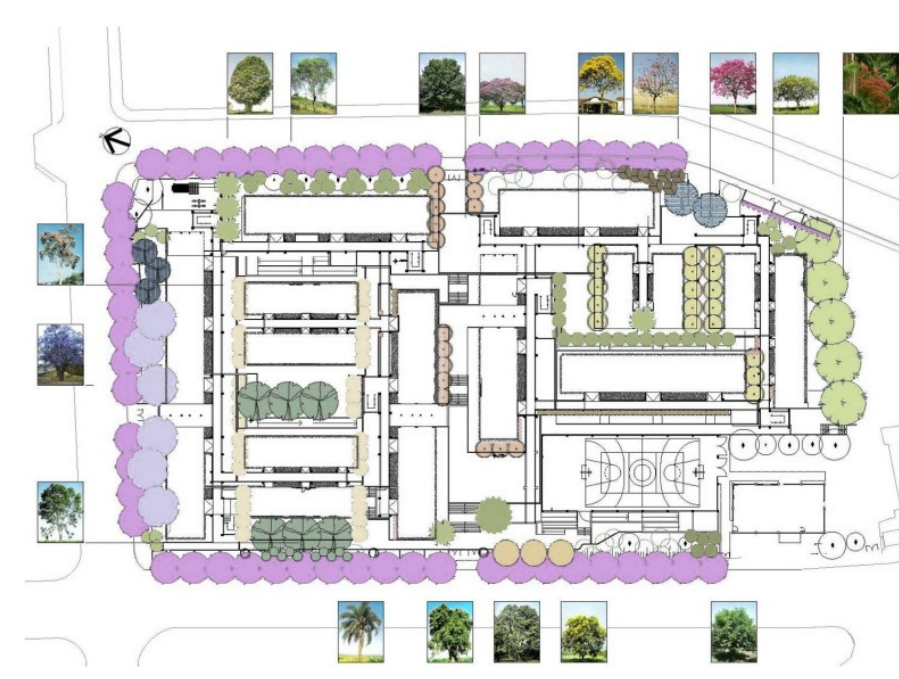

Figura 33 - Implantação proposta de paisagismo realizada durante o desenvolvimento do projeto.

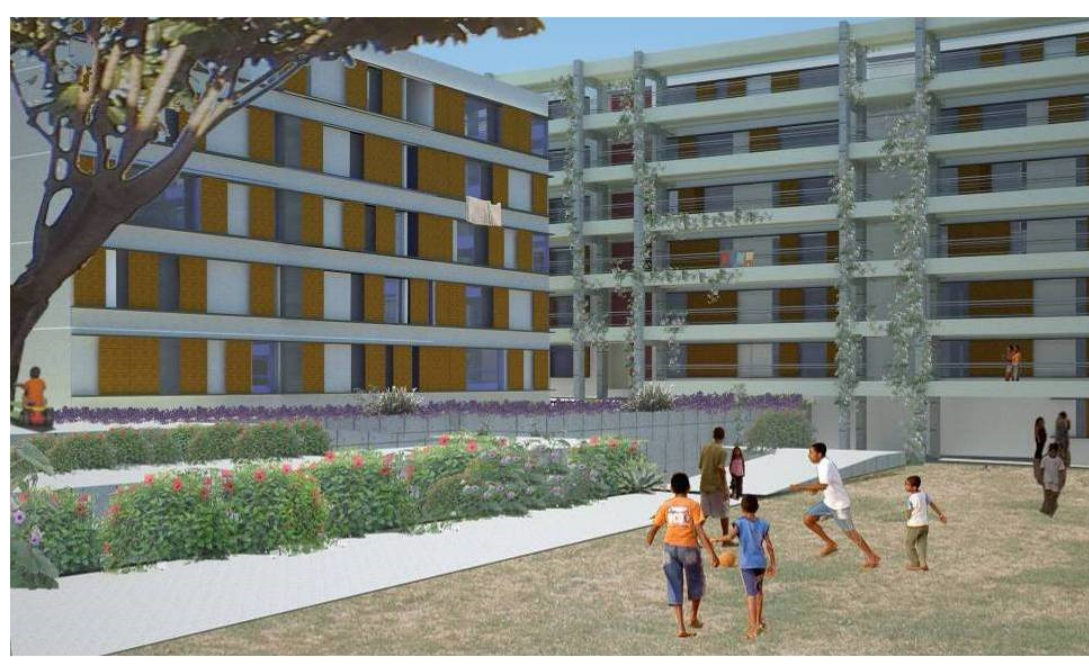

Figura 34 - Perspectiva desenvolvida pelo escritório de arquitetura durante o desenvolvimento do projeto.

Vale ressaltar ainda o uso restrito de um espaço exterior, marcado na planta atrás do edifício "l", que não tem livre acesso e apenas os moradores das unidades do térreo desse edifício controlam ou poder-se-ia dizer cuidam desse espaço. Por um lado, considerando a posição em que se encontra, parece melhor que seja utilizado pelos moradores do que seja apropriado de formas indesejáveis por estar em uma área de pouco acesso e pouca visibilidade, no limite entre o edifício e o muro que divide o conjunto da favela ao lado. Porém não parece que isso tenha sido considerado no projeto e, se tivesse sido previamente definido, talvez poderiam ter sido desenhados quintas para as unidades do térreo, tanto nessa lateral, mais escondida, como nos espaços de recuo que já foram comentados anteriormente quando explorou-se o tema definição dos limites do conjunto. 
No nível mais alto do térreo, o platô onde está implantado o edifício proposto como Centro para ldosos, o uso do espaço exterior também não se comunica com o conjunto. Ao observar o projeto, é possível identificar uma escada que conecta o conjunto a esse espaço, porém essa escada não existe mais e esse espaço é utilizado, apenas pelo Centro para Idosos não havendo mais essa comunicação.

Por último, outro item importante a ser analisado quando estão sendo estudados os espaços exteriores, é a iluminação proposta, pois a utilização adequada e a sensação de segurança são fatores que possuem uma forte relação com a iluminação do local. Para isso, os postes e pontos de iluminação foram destacados na planta de análise, o que nos permitiu identificar que há postes distribuídos por todo o conjunto proporcionando uma boa iluminação aos espaços exteriores. Vale ressaltar também que, além dos postes identificados em planta, também há iluminação embaixo de todas as passarelas.

\subsubsection{RELAÇÃO ENTRE OS EDIFÍCIOS.}

Esse último tema da escala conjunto é uma análise intermediária entre essa escala e a do edifício, é um tema de transição que irá explorar as relações entre os edifícios. Um conjunto habitacional, como o próprio nome diz, é a implantação de mais de uma edificação no mesmo terreno e a relação entre essas edificações também é um tema importante para ser analisado, observando a forma como esses edifícios foram implantados; se estão de acordo com a melhor insolação; a distância entre eles e as sombras que geram uns sobre os outros, assim como sobre as áreas comuns; as relações visuais proporcionadas; os acessos e circulações nos pavimentos superiores; a diversidade tipológica e a forma como as tipologias estão distribuídas, etc. Para isso, foi feita uma análise sobre a planta do pavimento tipo (nível 763.56) do conjunto Comandante Taylor procurando identificar essas relações (Figura 35). 


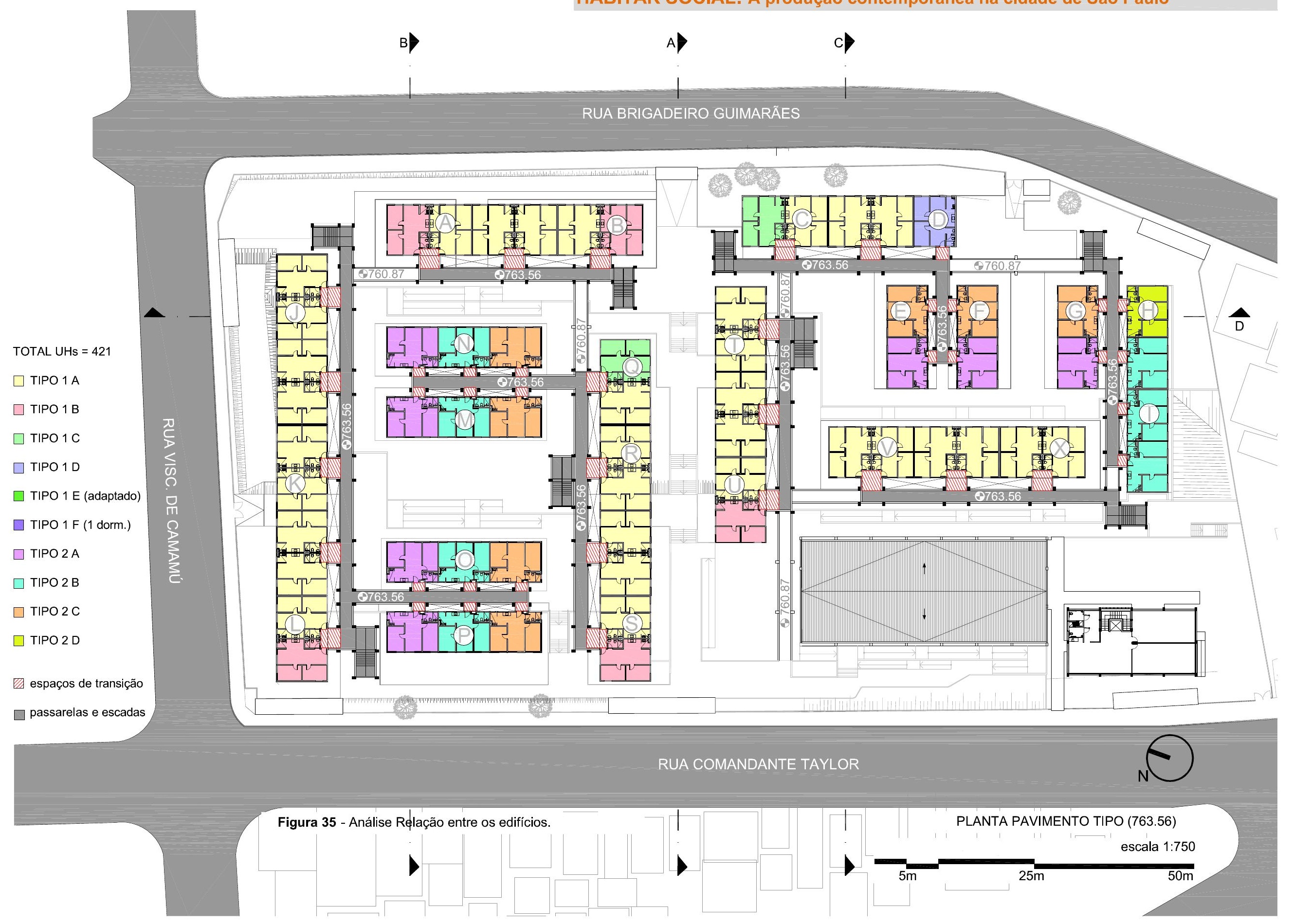




\section{Acessos e circulação}

O acesso aos pavimentos superiores se dá através de oito torres de escada distribuídas pelo conjunto e a conexão entre os edifícios é feita por robustas passarelas de concreto pré-fabricado que praticamente formam dois anéis de circulação, pelo menos no nível do térreo (760.87) no qual, todas as passarelas se comunicam. Observando a planta com detalhe, é possível perceber que não existem escadas vinculadas especificamente a um edifício. As torres de escada estão conectadas às passarelas, ou às "calçadas suspensas" que, por sua vez, comunicam as edificações.

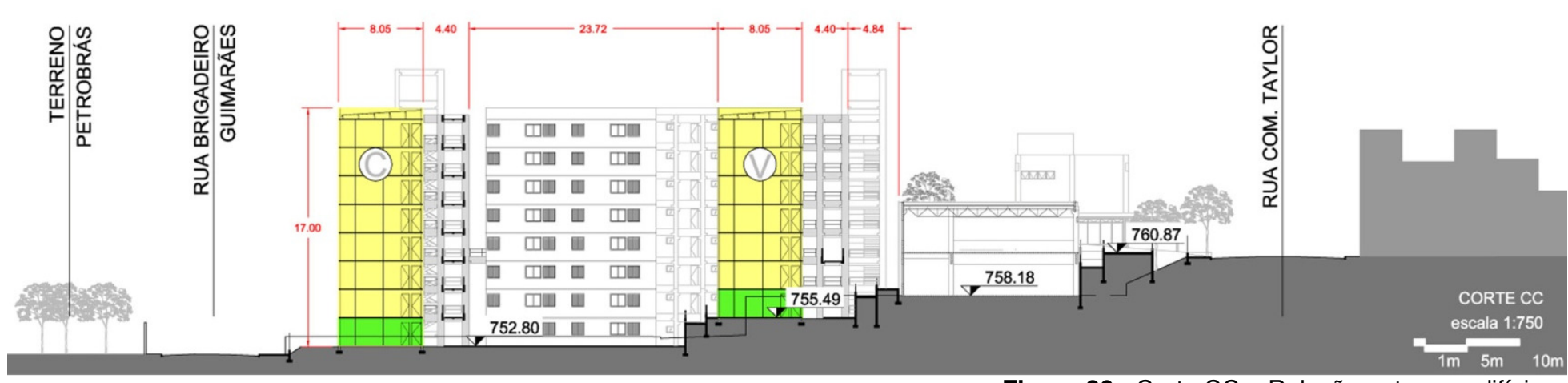

Figura 36 - Corte CC - Relação entre os edifícios.

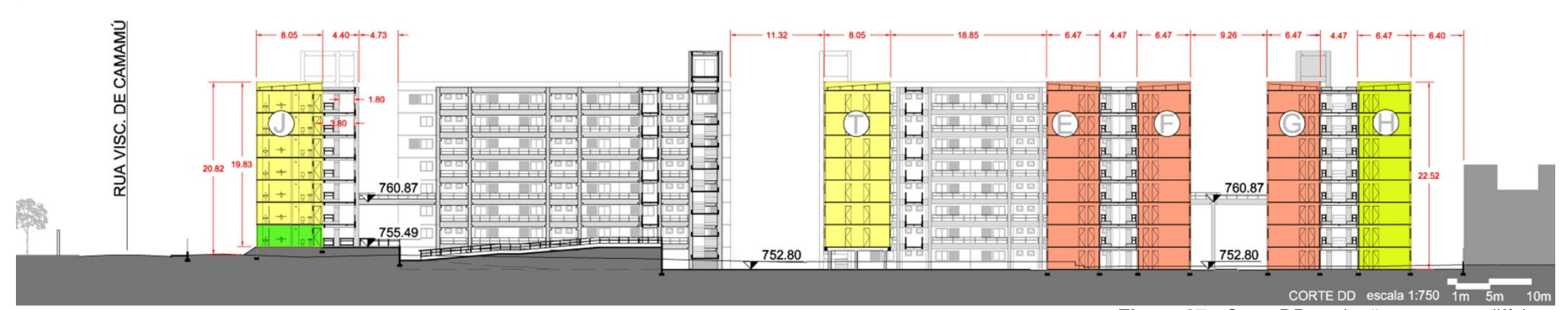

Figura 37 - Corte DD - relação entre os edifícios. 
Esse "sistema de circulação", como foi chamado pela arquiteta, formado pelas torres de escada e pelas passarelas, foram os primeiros elementos a serem construídos e, para facilidade da obra, puderam ser utilizados como estrutura de apoio para a construção das edificações substituindo o uso dos andaimes.

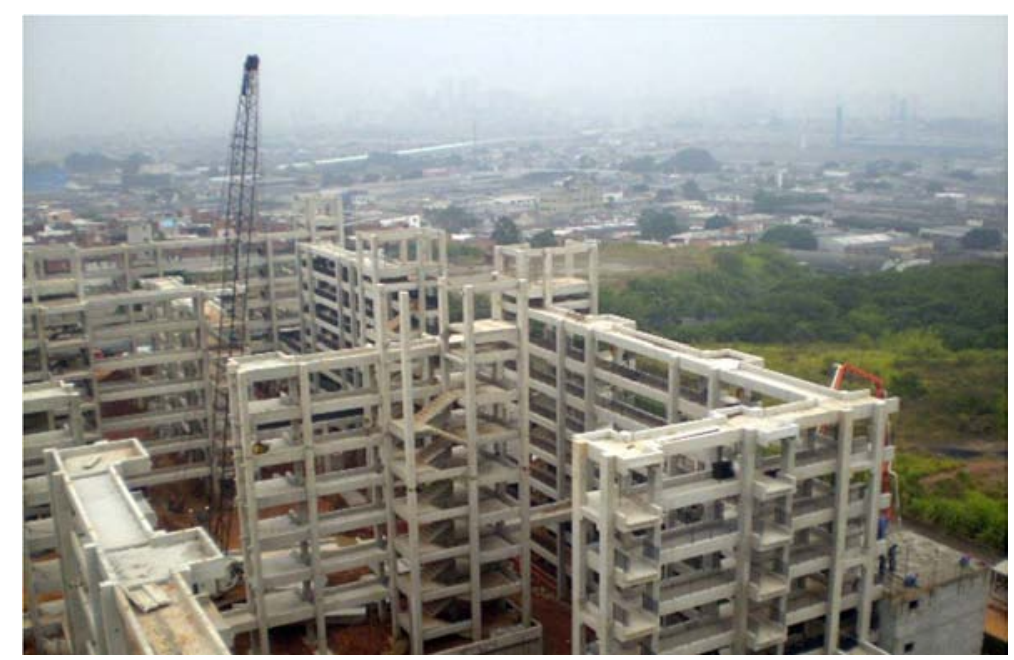

Figura 38 - Foto aérea da construção do "sistema de circulação".

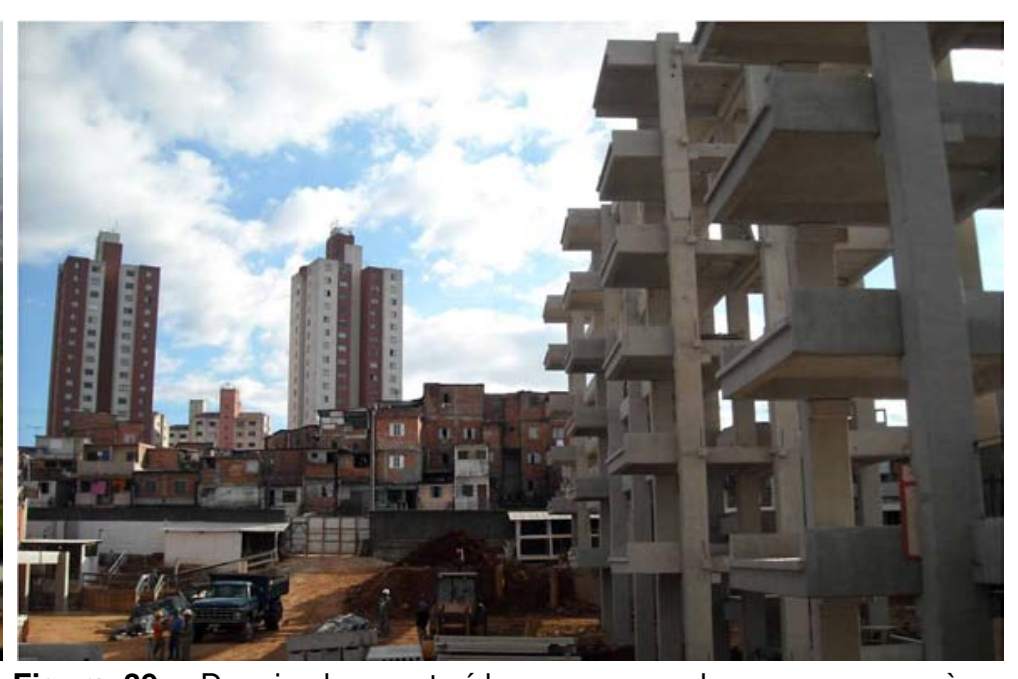

Figura 39 - Depois de construídas as passarelas, os acessos às unidades ficam prontos esperando a construção do edifício.

Como referência, vale citar o sistema construtivo adotado pelo Coletivo Usina que, em seus projetos ${ }^{13}$ de mutirão e autogestão, sempre adotou a construção das torres de escada logo após a execução das fundações permitindo o transporte seguro de pessoas e materiais.

Quanto à definição do material utilizado para a construção desse "sistema de circulação", a arquiteta Renata Semin esclarece que, durante o desenvolvimento do projeto foram levantados orçamentos referentes à três opções: estrutura de concreto moldada in loco; pré-fabricado de concreto e estrutura metálica. Esteticamente e

${ }^{13}$ Entre os projetos desenvolvidos por esse coletivo que adotaram esse sistema, pode-se citar o União da Juta em São Mateus, SP e o Mutirão Paulo Freire em Cidade Tiradentes, SP. 
construtivamente a estrutura metálica apresentava vantagem sobre as outras duas opções, porém ainda assim seu custo superava em até $20 \%$ o da estrutura pré-fabricada de concreto que era a opção intermediária. Sendo assim, ficou decidido de comum acordo entre o escritório de arquitetura e a Sehab que esses elementos seriam executados em peças pré-fabricadas de concreto.

Essa opção, visualmente, deu muito mais peso e massa a esses elementos de circulação, além do que, em alguns momentos, prejudica a chegada de luz natural às unidades. Esse é, portanto um fator a ser considerado na análise, pois apesar da necessidade de cumprir um orçamento adequado, decisões como essas podem prejudicar o projeto e a qualidade dos espaços. Portanto, mais uma vez fica ressaltada a importância de encontrar um equilíbrio entre as exigências da Secretaria, seja com respeito ao orçamento ou ao aproveitamento máximo dos coeficientes, e a qualidade oferecida pelos projetos aos futuros moradores.

A largura total das passarelas é de 4,40 metros sendo, 1,80m livre para circulação e 3,80m nos pontos em que a passarela se alarga na entrada das unidades conformando os espaços de transição indicados na planta de análise. Esses espaços, assim como acontece no térreo, foram apropriados pelos moradores como extensões de suas casas.

As torres de escada não relacionadas com um edifício especificamente e os caminhos elevados configurados pelas passarelas não colaboram para a legibilidade dos espaços e percursos que, muitas vezes, chegam a transmitir a sensação de se estar andando em um labirinto e, em alguns casos, não é tão simples descobrir como se chega ao edifício que se vê do lado oposto. Seguramente, a visualização em planta é muito mais esclarecedora que a perspectiva que se tem caminhando pelo conjunto e, por isso, parece necessário que houvesse algum tipo de comunicação visual que auxiliasse as pessoas a se localizarem dentro do conjunto. 


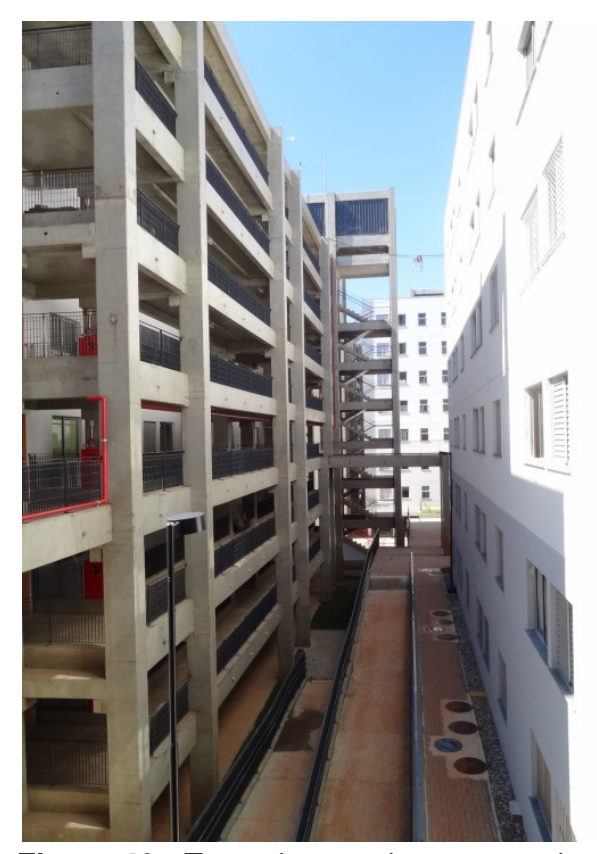

Figura 40 - Torre de escada e passarela.

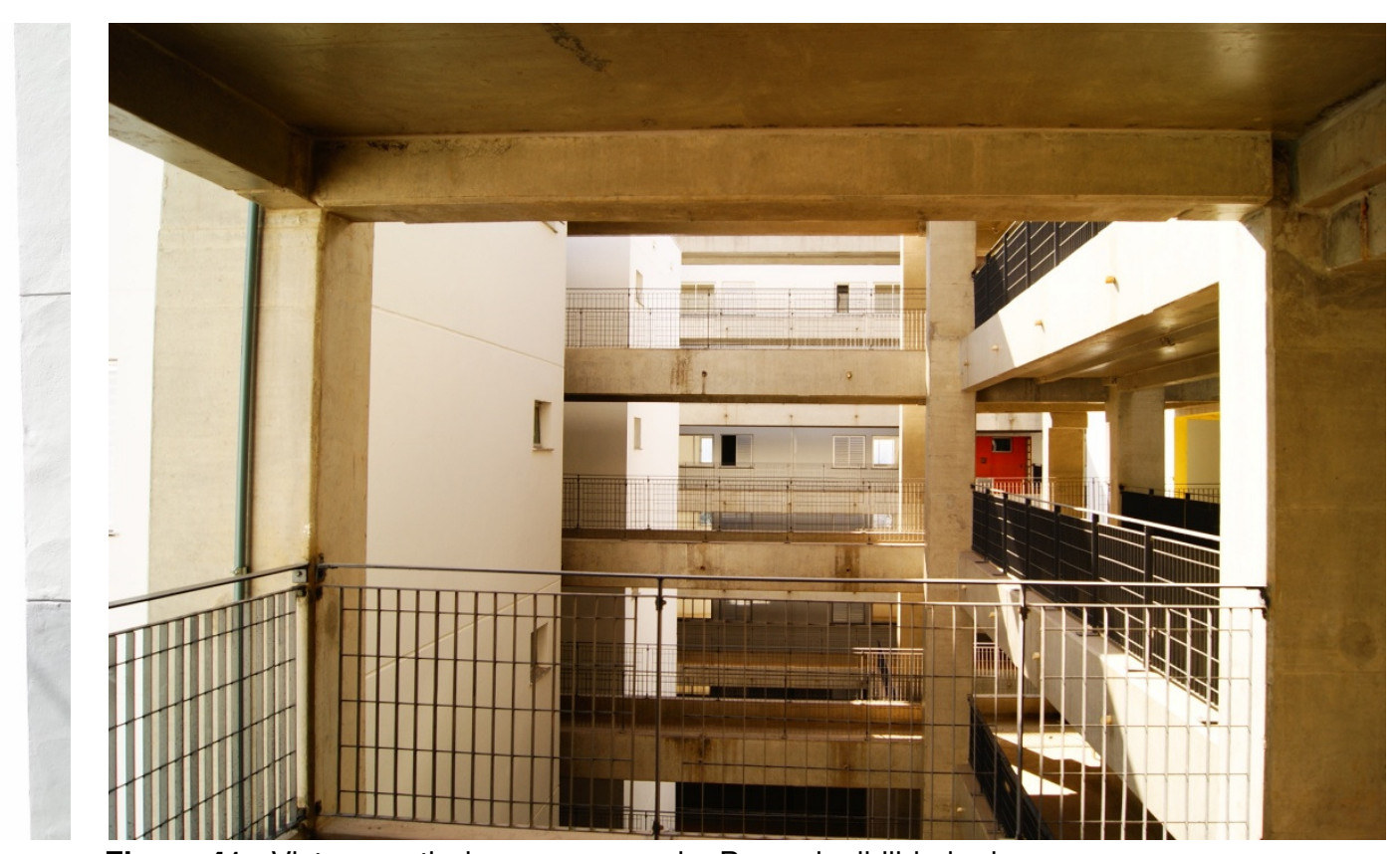

Figura 41 - Vista a partir de uma passarela. Pouca legibilidade dos percursos.

A arquiteta comentou que foram realizados estudos de comunicação visual sugerindo a colocação de números, visualmente grandes, pintados nas caixas d'água localizadas no topo das torres de escada e logo, uma palheta de cores para pintar o hall de acesso às unidades que ajudaria aos moradores a se localizarem e identificarem seus apartamentos. Porém essa comunicação não chegou a ser realizada e a própria Sehab acreditava que ainda era um método confuso. Finalmente, a única ação que pode ser considerada é o fato dos halls terem sido pintados de cores diferentes. Entretanto, as cores se repetem dentro do conjunto, o que não proporciona total clareza no reconhecimento dos percursos e dos edifícios.

Observando a implantação, é possível identificar claramente um eixo central que divide o conjunto em duas partes. Apesar desse eixo sempre ter existido nos níveis do térreo, o mesmo não ocorria nos pavimentos superiores onde 


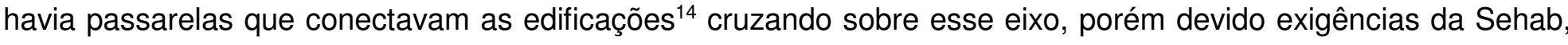
essas passarelas não foram construídas para atender a uma recomendação quando a definição de condomínios dentro do conjunto.

A divisão em condomínios, ainda que imaginária, pois não há limites físicos que a definam, está relacionada com as exigências da Secretaria de Habitação de que não deve haver condomínios com mais de 200 unidades habitacionais devido às dificuldades de gestão condominial.

De acordo com as Diretrizes de Projetos de Edificação,

Aconselha-se a divisão em conjuntos habitacionais de até 100 unidades, podendo chegar a 200 unidades em casos excepcionais aprovados pela Sehab.

As divisões condominiais deverão compreender também a individualização das redes de infraestrutura (água, esgoto, gás, energia elétrica, telefonia), considerando a manutenção e os gastos de cada edifício. Sempre que possível, os medidores também deverão ser distribuídos por edifício, facilitando a gestão do rateio das contas. (PREFEITURA DE SÃO PAULO, 2012b, p.232)

No caso do Comandante Taylor, os condomínios atingem o número máximo de unidades habitacionais (UHs) recomendado por condomínio uma vez que possui, no total, 421 UHs que estão distribuídas em 14 edifícios, valendo ressaltar que essa divisão envolve apenas a aprovação do projeto uma vez que não existem limites dividindo os condomínios e até onde foi possível avaliar, está ocorrendo uma gestão global dos espaços. Porém, será preciso verificar dentro de alguns anos o estado de conservação desse conjunto para poder avaliar se esse é realmente um fator que interfere na manutenção.

É claro que, quanto menos famílias envolvidas, mais fácil é a gestão e mesmo sem a propriedade de um profissional da área social, acredita-se que a gestão depende mesmo da organização e esforço dos moradores, o

${ }^{14}$ Informação fornecida pela arquiteta Renata Semin em entrevista realizada em setembro de 2013. 
que varia muito caso a caso. Pelo que foi possível perceber através da história da concepção do projeto, já existe um grupo organizado há muitos anos que hoje assumiu a gestão do conjunto o que é um ponto favorável para sua conservação.

$\mathrm{Na}$ foto abaixo, é possível perceber o eixo central que divide o conjunto em duas partes comunicando a Rua Brigadeiro Guimarães com a Rua Comandante Taylor no outro extremo do conjunto, três níveis acima.

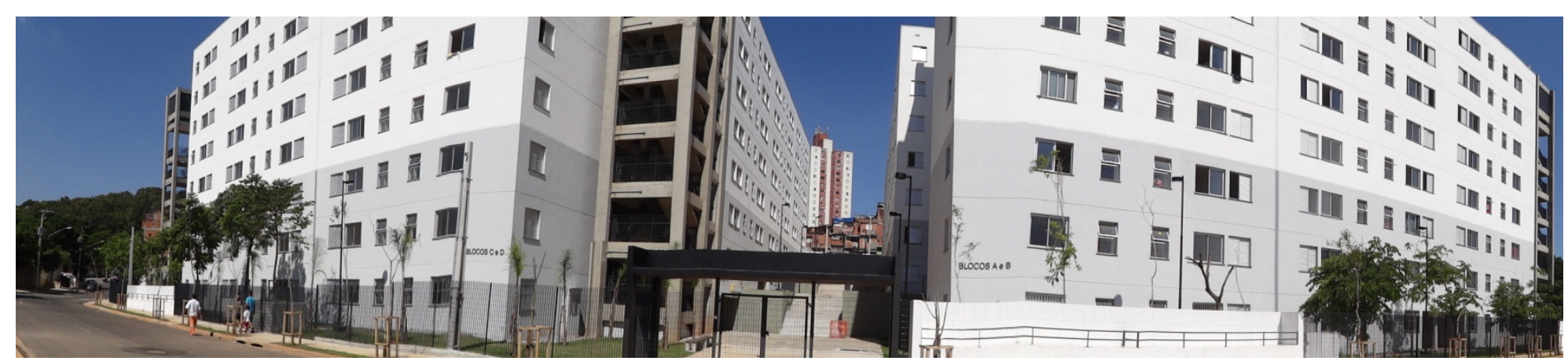

Figura 42 - Acesso Rua Brigadeiro Guimarães.

\section{Variedade tipológica}

Analisando os edifícios, pode-se identificar duas tipologias principais: os edifícios que iremos chamar de independentes, por serem apenas eles conectados à passarela ( $A B$ / CD / JKL / QRS / TU / VX) e os edifícios duplos que se conectam à passarela dois a dois $(\mathrm{EF} / \mathrm{GHI} / \mathrm{MN} / \mathrm{OP})^{15}$.

${ }^{15}$ Como já foi comentada no começo do capítulo, a classificação em blocos foi realizada a partir de variações de número de pavimentos em um mesmo edifício devido à adaptação ao terreno e da posição das juntas de dilatação resultantes do sistema construtivo adotado (alvenaria estrutural com blocos de concreto) e, portanto, não está relacionada à variedade tipológica. 
É possível encontrar dez diferentes tipos de unidades habitacionais indicadas na planta e nos cortes, que representam apenas variações de dois tipos principais: o tipo 1 no edifício independente e o tipo 2 nos edifícios duplos. O restante apresenta diferentes posições de janelas, adequando-se às pontas dos edifícios, além das unidades adaptadas e das que possuem apenas um dormitório como poderá ser visto na escala unidade. Tratandose da escala conjunto, o importante é identificar como essa diversidade de edifícios e tipologias está implantada no conjunto e como se relaciona com o todo.

Essa variedade representa o cuidado com que as tipologias foram estudadas buscando, a partir de pequenas variações, oferecer soluções mais adequadas a cada situação. $O$ fato das unidades das pontas dos edifícios terem as janelas voltadas para a lateral mostra a preocupação com as visuais e em proporcionar essa possibilidade em uma fachada que poderia ser completamente cega.

Com exceção das unidades adaptadas no térreo, verticalmente, não há variedade de tipo, ou seja, os tipos variam lado a lado, mas os que estão dispostos uns sobre os outros, não apresentam nenhuma variação, nem mesmo nas aberturas que, quando definidas em uma posição, ocorrem do mesmo modo em todos os pavimentos. Isso garante a racionalidade da distribuição das instalações e da disposição da estrutura na vertical.

\section{Implantação e \\ orientação}

Quanto à atenção à orientação, pelo que se pode perceber, não foi um tema determinante para a implantação dos edifícios, pois nota-se que a mesma edificação tem os acessos ora voltados para o sul, ora para o norte proporcionando assim que, também os dormitórios estejam, em algumas situações, voltados para a face sul, como acontece nos edifícios QRS, $\mathrm{F}$ e HI. 
A definição das circulações voltadas para o centro dos anéis formados acabou acarretando essas situações que geram diferentes necessidades aos apartamentos. Se por um lado a edificação QRS conta com a passarela como proteção solar voltada para a face norte, enquanto tem o estar e um dormitório voltados para o sul; por outro, o edifício JKL tem a circulação na face sul enquanto as aberturas do estar e do dormitório estão completamente expostas à fachada norte sem contar com nenhum tipo de proteção solar, o que também pode proporcionar uma sensação térmica bastante alta, principalmente nos apartamentos dos pavimentos mais altos.

Quanto aos edifícios duplos, nas faces onde estão conectados à passarela, praticamente não recebem iluminação natural, pois a passarela ocupa toda a distância entre eles e não permite que chegue luz principalmente nas unidades dos pavimentos inferiores. Entre todos os edifícios, identificou-se como os mais prejudicados pela implantação os blocos $\mathrm{F}$ e HI que, além de terem a sala e os dormitórios voltados para a face sul, têm a passarela na fachada norte impedindo a entrada de luz natural. No caso do bloco $\mathrm{HI}$, ainda verifica-se que a tipologia da ponta (tipo 2D) tem uma janela voltada para a face leste, aproveitando, ao menos, o sol da manhã. Por outro lado, o mesmo não acontece com o bloco $\mathrm{F}$ que até poderia ter essas janelas laterais, mas, infelizmente, a única abertura voltada para as laterais é a dos banheiros e não dos dormitórios.

Vale ainda ressaltar as distâncias entre as edificações, principalmente com respeito aos edifícios duplos que possuem apenas 4,47 metros completamente ocupados pela passarela. Por outro lado, há momentos de maior respiro entre os edifícios independentes e entre os blocos de edifícios duplos, proporcionando, em alguns pontos, distâncias entre 15 e 20 metros, como pôde ser observado na Figura 36 e Figura 37. Durante a entrevista com Renata Semin a arquiteta comentou que foram realizados estudos de insolação e ventilação durante 0 desenvolvimento do projeto e, para solucionar problemas de ilhas de calor, chegou-se a diminuir a altura dos edifícios duplos garantindo o fluxo de ventilação necessário a uma boa circulação de ar. Contudo, essa ação não teve o mesmo resultado para a iluminação, que permaneceu prejudicada nos pavimentos inferiores. 


\subsubsection{ESCALA EDIFÍCIO}

Tratando da escala dos edifícios, foram selecionados dois exemplos: um de edifício independente e um do duplo para serem analisados a partir de fatores como a diversidade de tipologias, os acessos, os espaços de circulação e o sistema construtivo utilizado.

\subsubsection{EDIFÍCIO DUPLO}

\section{Acessos e circulação}

Entre os edifícios duplos, foi selecionado como exemplos o bloco MN. Analisando os desenhos pode-se perceber, como já foi citado na escala conjunto, que as torres de escada não estão relacionadas especialmente com um edifício e, dessa forma, a escada que aparece no recorte é a mesma utilizada para acessar o edifício QRS.

Como é possível observar, o acesso às unidades se dá através da passarela que, no caso dessa tipologia, está entre os dois edifícios e, nas entradas dos apartamentos, há uma espécie de hall que, tanto nas unidades do térreo como dos pavimentos superiores funcionam como um espaço de transição entre a circulação comum e as entradas das unidades, assim como foi explorado no item espaços exteriores, os moradores se apropriam desses espaços como extensões de suas casas.

No caso dessa tipologia de edifícios frente a frente, a localização da passarela prejudica a entrada de luz nas faces conectadas a ela. Pode-se notar na planta do pavimento tipo que existe um vazio que proporciona um pouco mais de privacidade às janelas das cozinhas, voltadas para a passarela e que deveria aumentar a iluminação, porém quanto a esse aspecto, com base nas visitas ao local em diferentes horas do dia, o que pôde ser concluído é que esses vazios não cumprem bem essa função como pode ser verificado nas fotos (Figura 44 e Figura 45). 


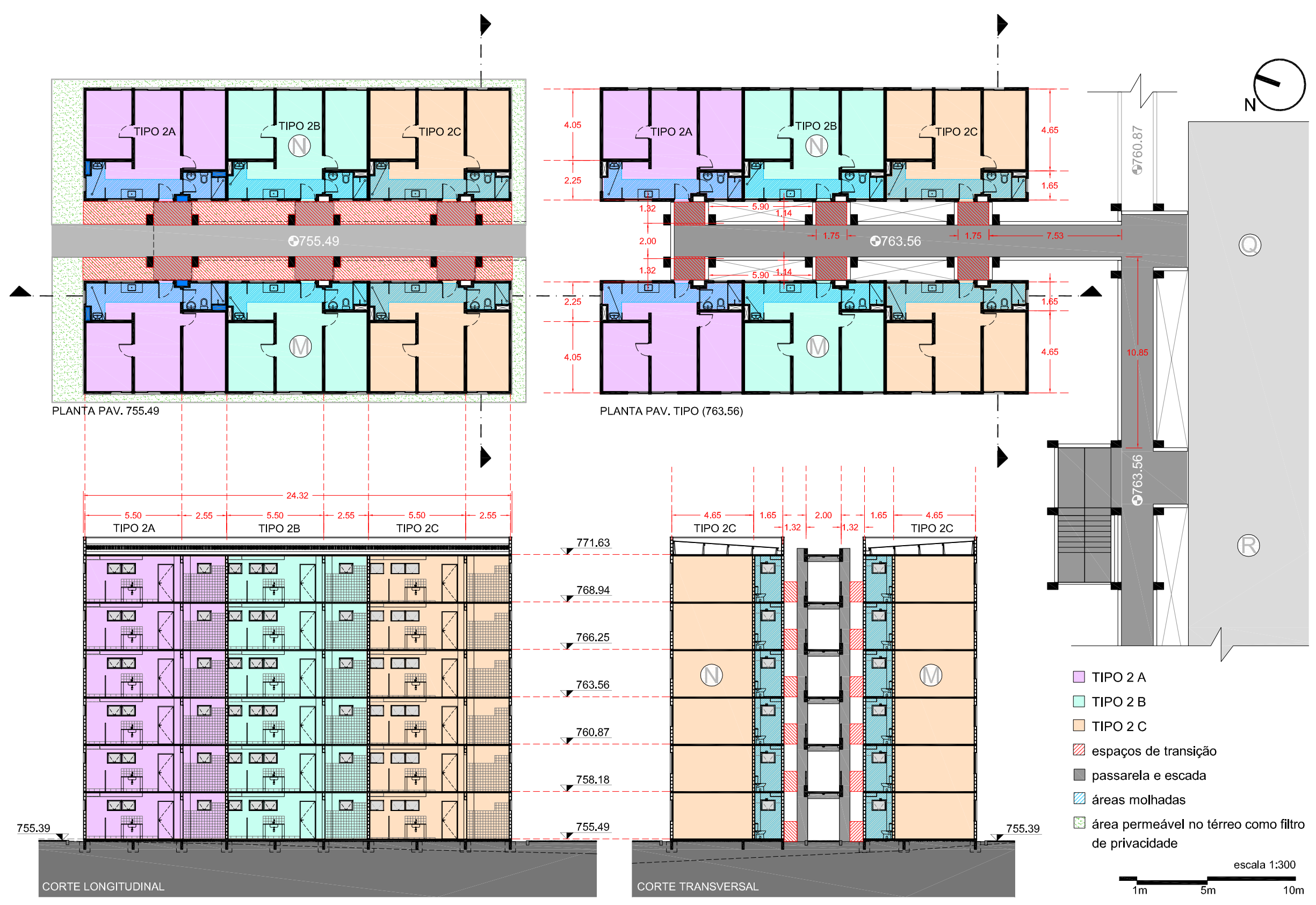

Figura 43 - Análise edifício duplo (MN). 


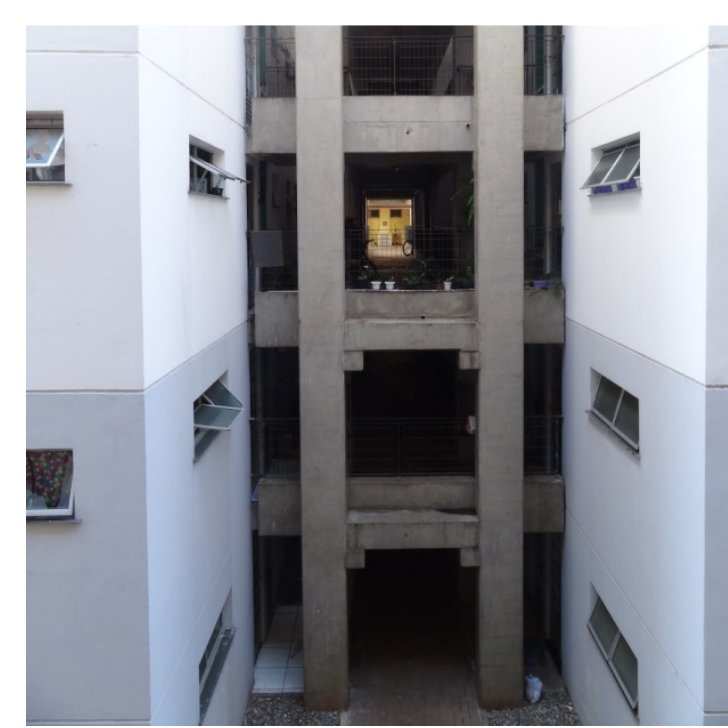

Figura 44 - Passarela pré-fabricada entre os edifícios.

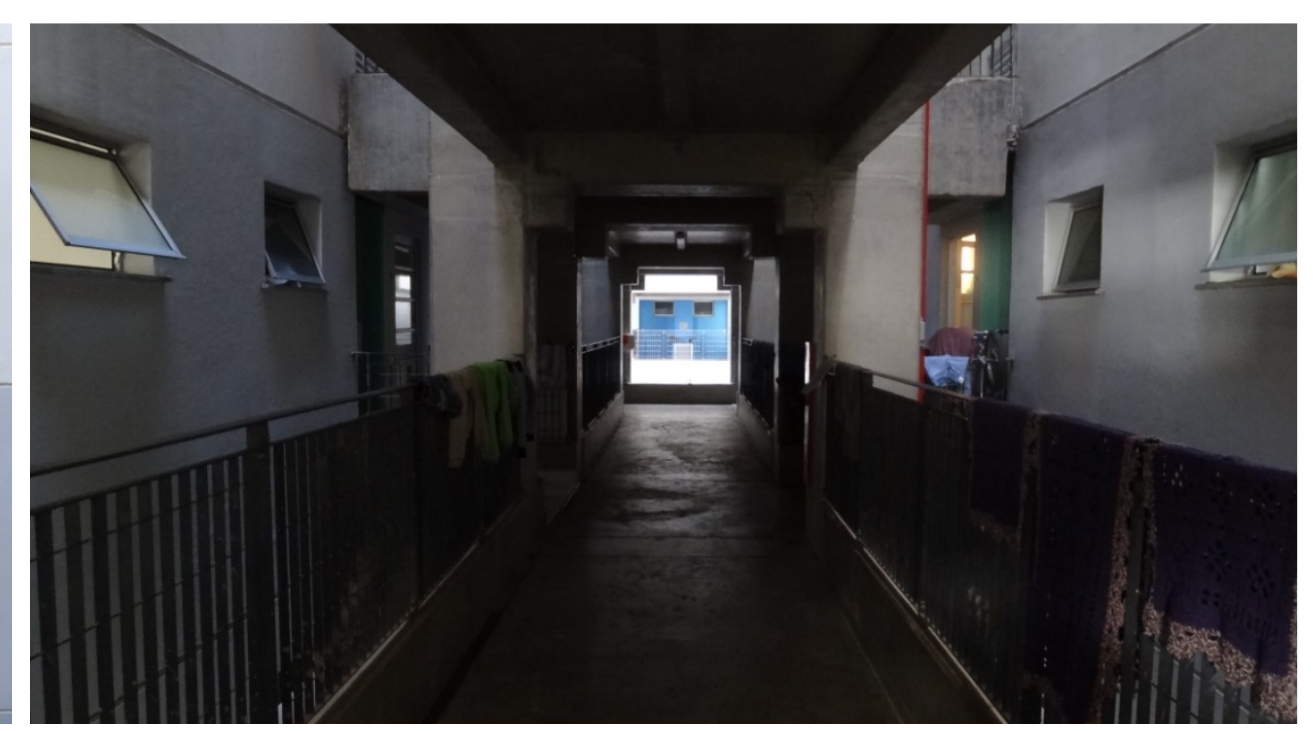

Figura 45 - Falta de iluminação nos espaços entre os edifícios e apropriação dos espaços de transição.

Como pôde ser observado nas fotos, esses espaços da passarela entre os edifícios são lugares pouco iluminados que não transmitem uma sensação agradável aos moradores e às pessoas que circulam por ai, além disso, com exceção do tipo $2 \mathrm{~A}$, as janelas das áreas de serviço estão voltadas para esses espaços o que possivelmente prejudica a secagem da roupa, pois com base nas visitas, mais de uma vez foi possível observar roupas secando para fora da unidade, no hall de entrada dos apartamentos ou na própria passarela.

\section{Diversidade tipológica}

Quanto à variação das tipologias dessa edificação, podemos observar que trata-se apenas da posição das janelas da área de serviços e do banheiro que, nas pontas, abrem para a lateral. Além disso, não há variação de tipo em altura sendo que, nessa edificação não há unidades adaptadas. 


\section{Estrutura e aberturas}
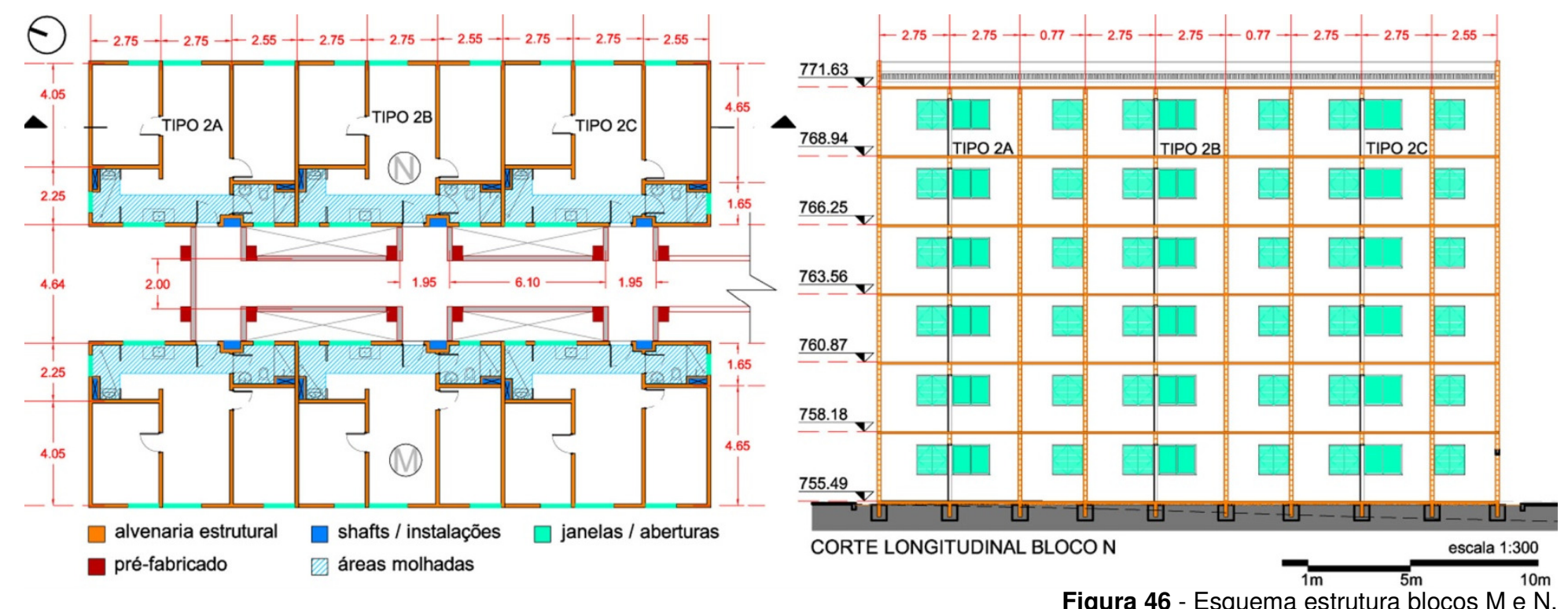

Observando tanto a planta como o corte transversal dessa edificação (Figura 43), é possível verificar que as áreas molhadas (cozinha, banheiro e área de serviço) estão concentradas e, no esquema estrutural (Figura 46) é possível perceber que a tipologia foi desenvolvida a partir de uma faixa de áreas molhadas na face que dá para a passarela deixando os outros ambientes voltados para outra fachada. Os shafts e passagens de instalações também estão destacados no esquema o que permite identificar a proximidade deles com essas áreas molhadas.

Como já foi observado anteriormente, o sistema construtivo adotado para as passarelas foi o sistema pré-fabricado de concreto. Quanto às unidades, o sistema construtivo utilizado foi alvenaria estrutura de bloco de concreto e como pode ser observado, não foi possível identificar divisórias leves, ou seja, não estruturais nessa tipologia, o que nos permite concluir que trata-se de uma planta que não oferece grandes possibilidades de flexibilidade no espaço interno, não sendo possível unir ambientes gerando espaços maiores nos casos em que os dois 
dormitórios não são necessários como quando, por exemplo, os filhos saem de casa e ficam só o marido e a mulher; entre outras situações semelhantes. De acordo com Renata Semin, o sistema estrutural permite apenas pequenas aberturas um pouco maiores que uma porta que proporcionaria uma comunicação entre ambientes, mas nunca a retirada total de uma parede.

No esquema também é possível identificar as aberturas, verificando como foram propostas. Nas faces que não estão voltadas para a passarela, percebe-se que as janelas dos dormitórios foram encostadas em uma das laterais do ambiente para um melhor aproveitamento do espaço interno, como será analisado na escala da unidade e, como foi observado no item diversidade tipológica, as unidades localizadas nas pontas do edifício têm as janelas da área de serviços (tipo 2A) e do banheiro (tipo 2C) abertas para a lateral, sendo que apenas a unidade central tem todas as aberturas da áreas molhadas voltadas para a passarela, sendo, portanto, a unidade menos favorecida desse bloco.

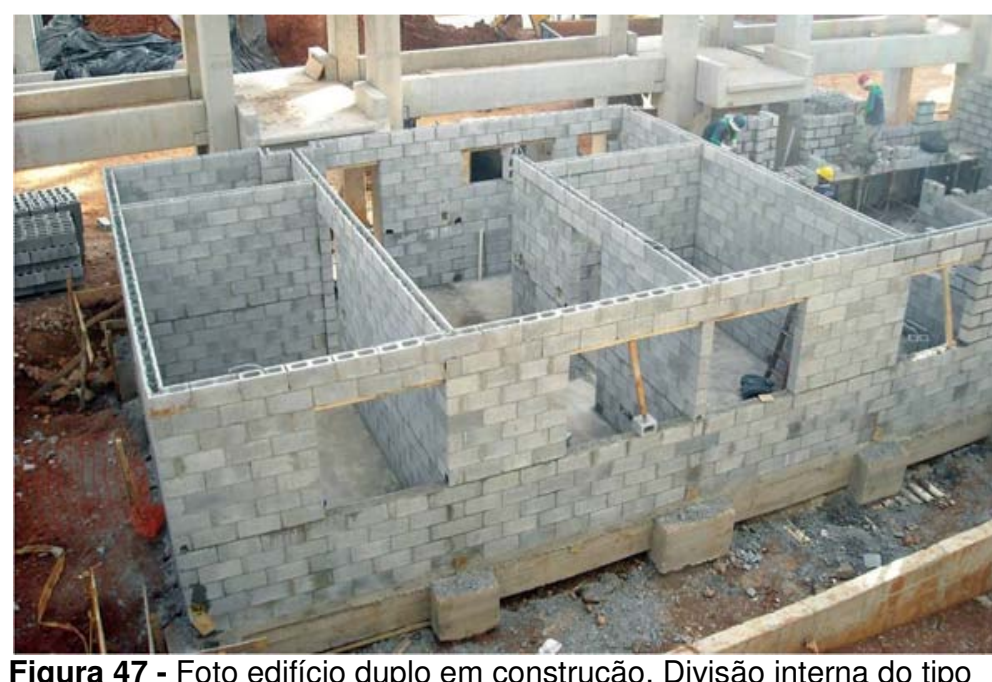

$2 \mathrm{~A}$.

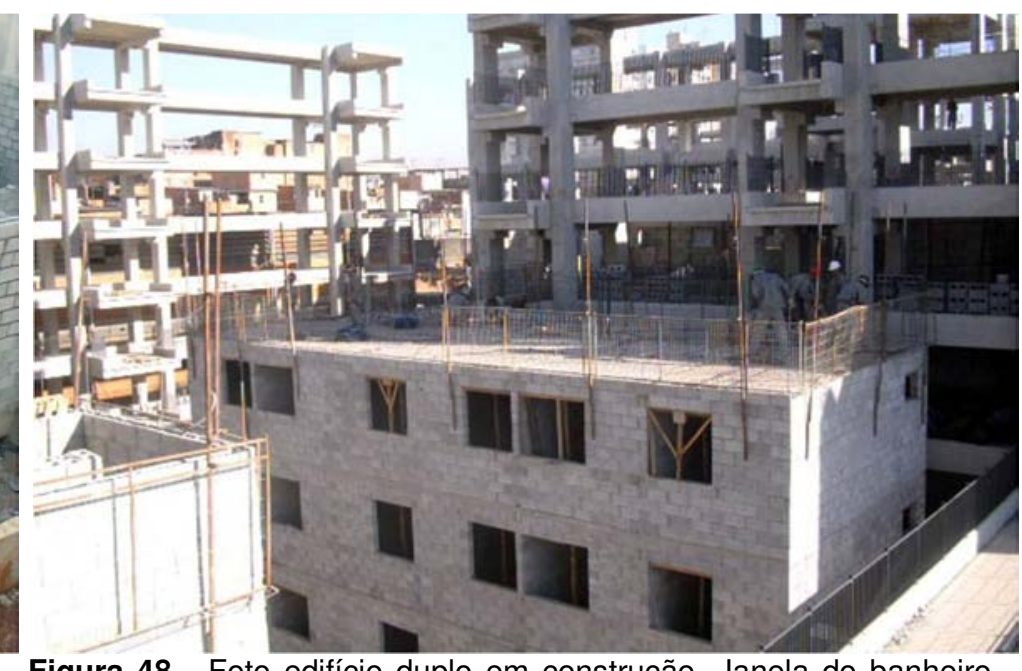

Figura 48 - Foto edifício duplo em construção. Janela do banheiro abrindo para a lateral. 
4.1.2.2. EDIFÍCIO

INDEPENDENTE

\section{Acessos e circulação}

O exemplo selecionado entre os edifícios chamados independentes foi o bloco JKL, implantado paralelo à Rua Visconde de Camamú, transversalmente aos desníveis do terreno. Devido sua extensão de 67 metros, está conectado a duas torres de escada, uma em cada ponta, conectadas pela passarela que, no caso desse bloco, está voltada para a face sul, porém, como foi citado no item relação entre os edifícios, também ocorre na implantação casos em que a passarela está voltada para a face norte e a fachada livre do edifício para o sul o que acaba prejudicando a insolação das unidades.

Porém, diferentemente do que foi apontado na edificação anterior, nesse caso, apesar de toda sua dimensão, a passarela não prejudica a insolação às unidades, é claro que diminui a intensidade com que a luz chega às janelas, entretanto, com base no que foi possível perceber durante as visitas realizadas, não representa uma redução significativa, além disso, assim como as outras, a passarela dessa edificação também apresenta vazios que permitem a entrada de luz e melhoram a privacidade das unidades que, nesse caso, possuem janelas de dormitórios voltadas para ela.

Os espaços de transição, nessa tipologia, são compartilhados entre vizinhos dois a dois e é interessante observar a necessidade apresentada pelos moradores de personalizar esses espaços colocando inclusive um revestimento diferente da passarela para representar que existe ali uma mudança no grau de privacidade daquele espaço, fazendo valer assim o título de espaço de transição como pode ser observado nas fotos (Figura 51 e Figura 52). 


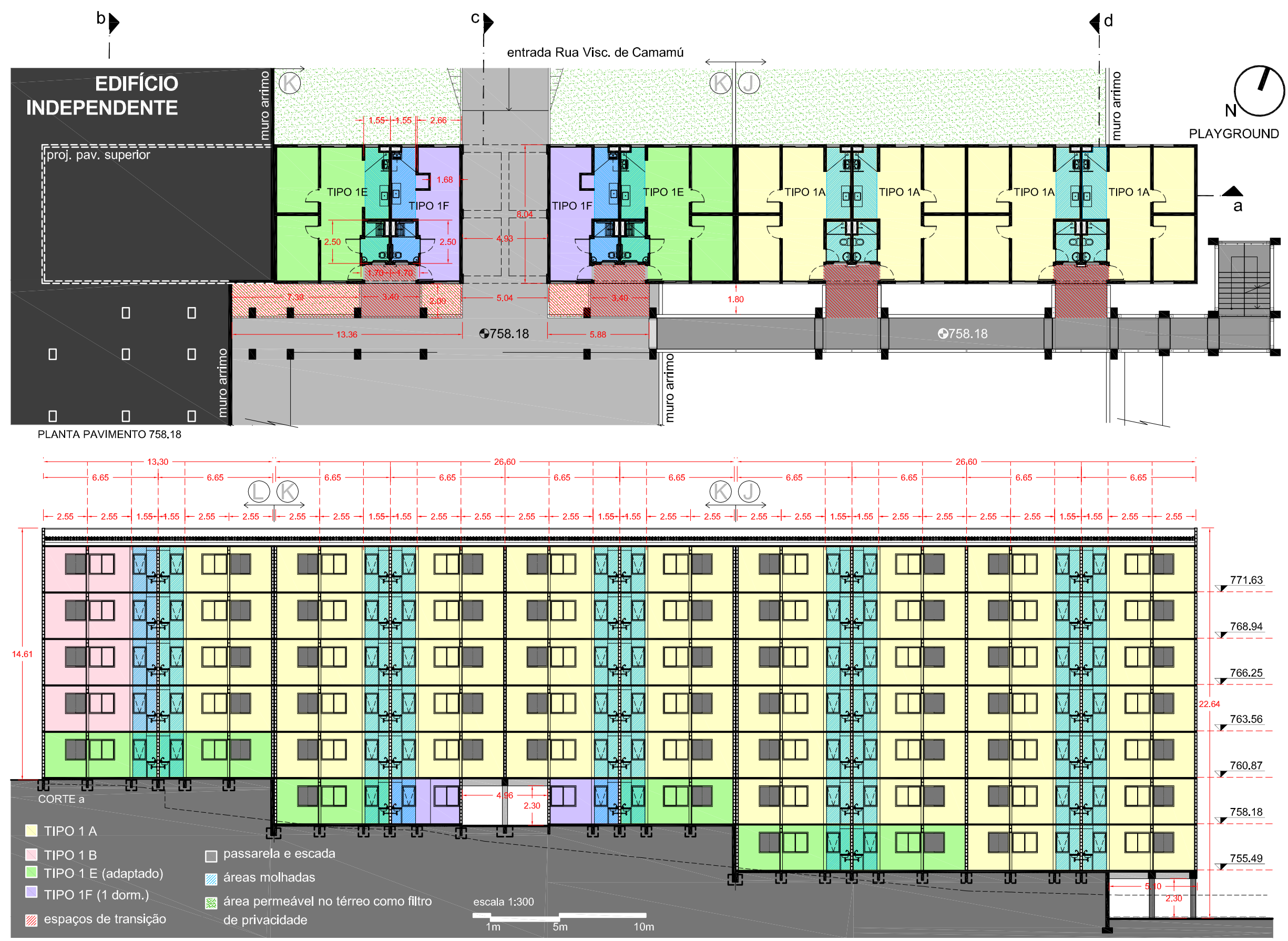

Figura 49 - Análise edifício independente (JKL). 


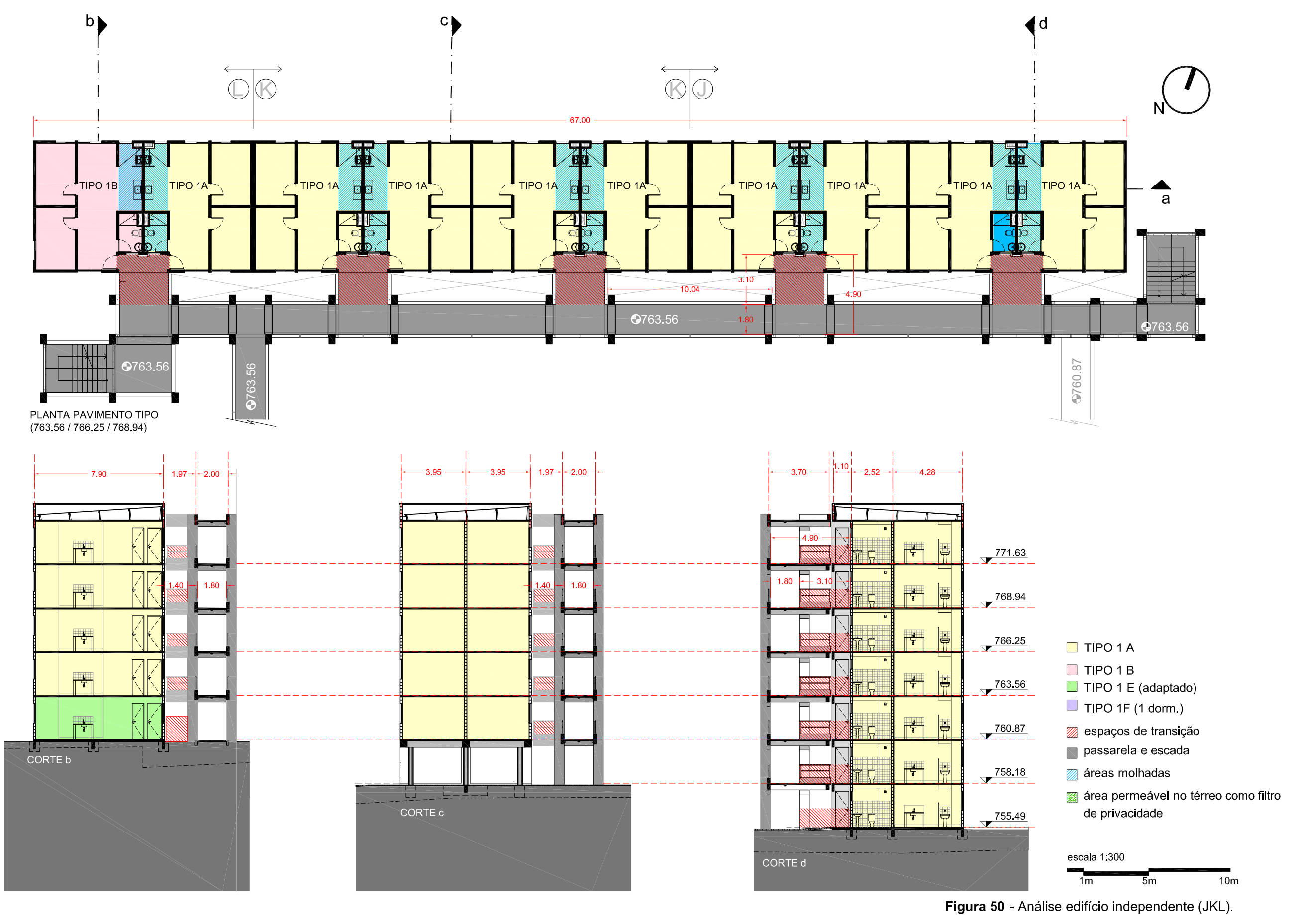




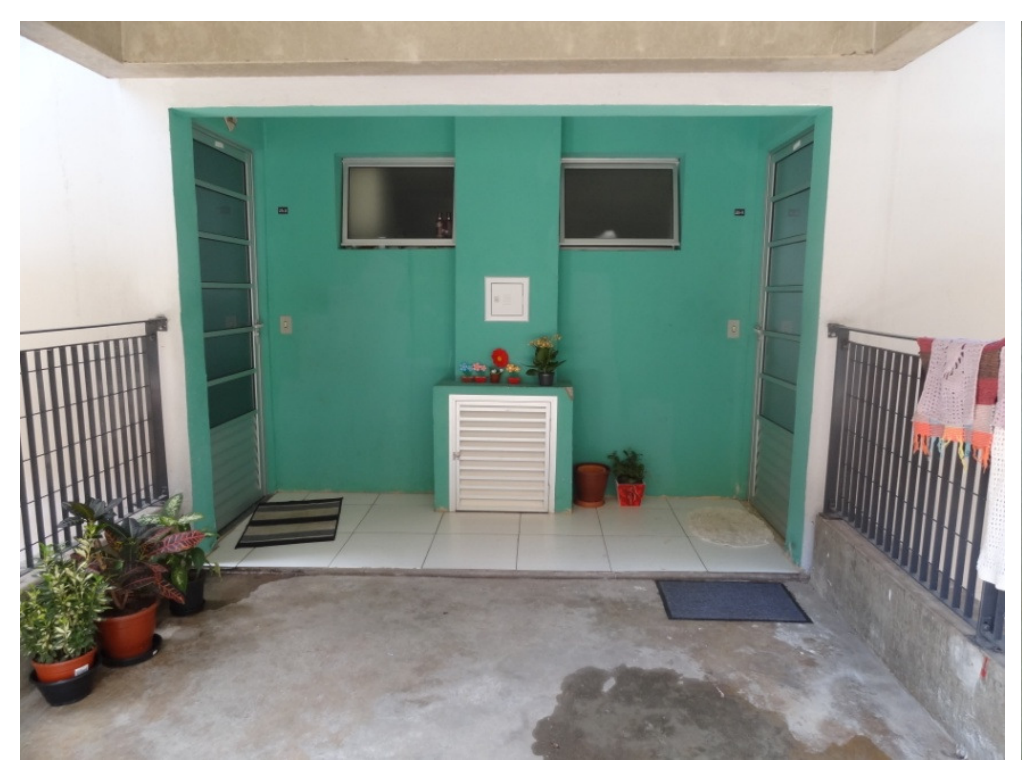

Figura 51 - Espaço de transição compartilhado entre vizinhos.

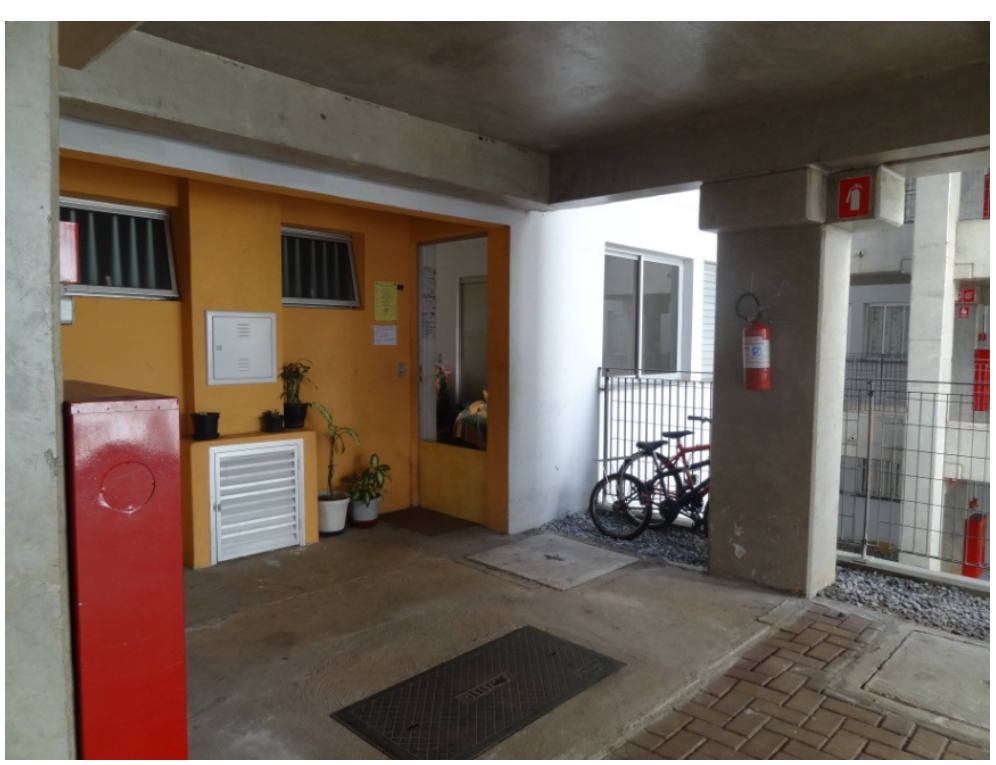

Figura 52 - Hall de entrada dos apartamentos pintados de diferentes cores ajuda a dar identidade para os blocos.

Como já foi comentado no item relação entre os edifícios, na concepção do projeto foi feita uma proposta de cores para pintar esses halls de entrada das unidades buscando dar maior identidade aos blocos dos edifícios, porém não chega a ser uma comunicação visual perfeita, pois as cores se repetem dentro do conjunto e considerando que trata-se de um espaço onde a legibilidade dos percursos não é clara o suficiente, seria mesmo necessário que houvesse algum tipo de comunicação para que as pessoas pudessem se localizar melhor dentro do conjunto que, de modo geral, transmite uma sensação labiríntica a quem circula por ele as primeiras vezes.

Nas fotos também é possível identificar que, além da apropriação desse espaço de transição com vegetação, em muitos casos os moradores utilizam esses halls para deixar amarradas as bicicletas ou outros objetos grandes que não têm lugar adequado para serem guardados dentro da unidade e nem no térreo dos edifícios ou do conjunto. 


\section{Diversidade tipológica}

Esse bloco foi selecionado, pois além de apresentar diferentes exemplos de tipologias, como as variações do tipo $1 \mathrm{~A}$ devido a posição das janelas; o tipo adaptado e a quitinete, também é interessante analisar a adaptação do edifício ao terreno através dos desníveis resultantes dos platôs sobre os quais o conjunto está implantado. Essa adaptação definiu a divisão do edifício nos três blocos: J, $\mathrm{K}$ e $\mathrm{L}$ de acordo com o número de pavimentos, como pode ser observado no corte longitudinal (Figura 49). Além da diferença de pavimentos, também se destaca nesse edifício a passagem no nível 758.18 situada bem em frente ao acesso proposto para a Rua Visc. de Camamú (hoje desativado) que acaba resultando na tipologia da quitinete, pois como é possível observar em planta, esse tipo teve o módulo dos dormitórios subtraído para gerar essa passagem.

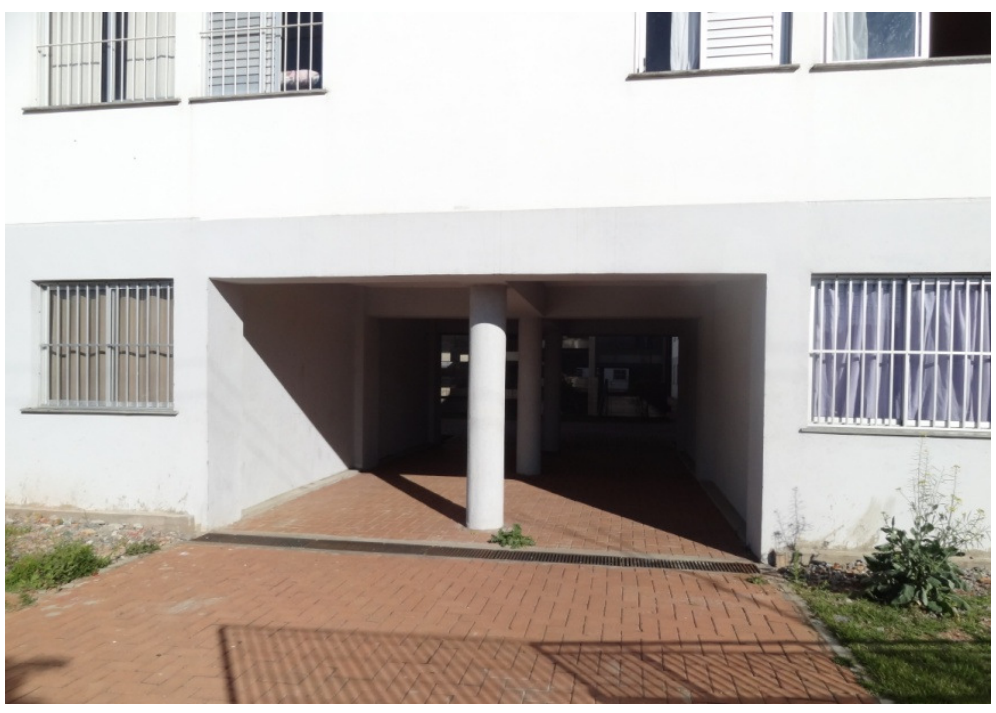

Figura 53 - Passagem através do edifício resultando nas tipologias quitinete.

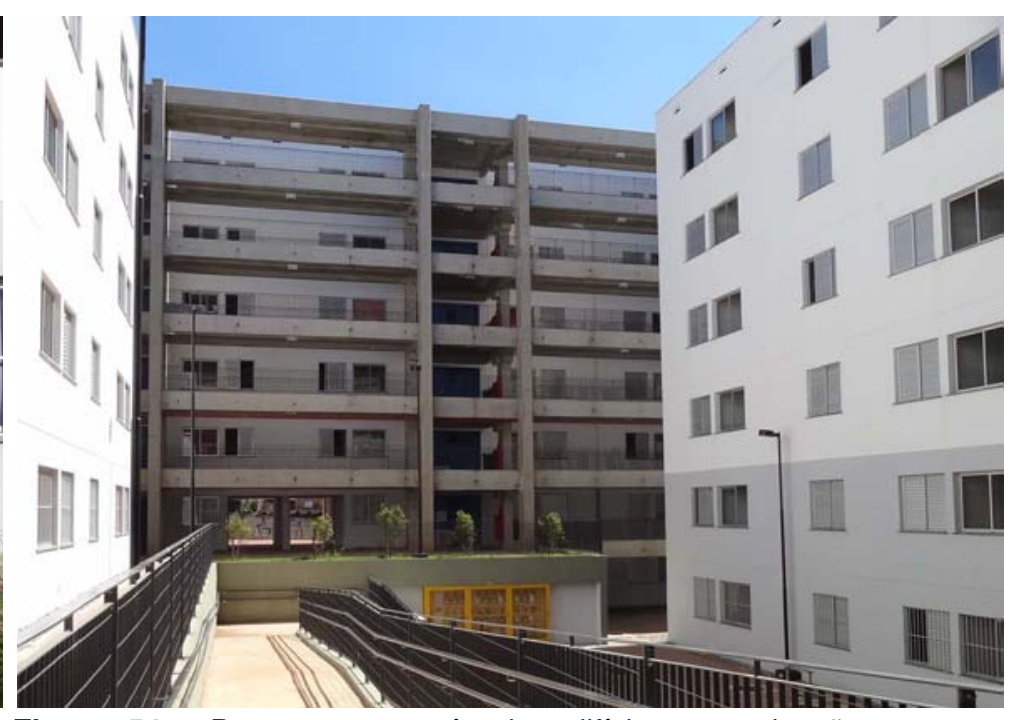

Figura 54 - Passagem através do edifício, comunicação com o acesso da Rua Visc. de Camamú, hoje não utilizado. 
As unidades adaptadas localizam-se apenas nos pavimentos inferiores acessados pelas entradas em diferentes níveis, como vimos a Rua Comandante Taylor está a aproximadamente oito metros acima do nível da Rua Brigadeiro Guimarães, porém, apesar das diferenças de níveis as rampas distribuídas permitem que pessoas com necessidades especiais e cadeirantes circulem pelo nível mais baixo de todo o conjunto.

Vale observar ainda que na ponta do edifício que está voltada para a Rua Comandante Taylor (tipo 1B), existe uma variação na posição da janela proporcionando visibilidade para essa rua o que é positivo, pois aumenta as relações visuais, por outro lado, o mesmo não acontece na ponta que está voltada para a Rua Brigadeiro Guimarães onde encontra-se o playground. Com respeito à visibilidade desse espaço de lazer, seria interessante que fosse mais visível desde as janelas dos edifícios, porém, de acordo com a arquiteta Renata Semin, decidiu-se não colocar aberturas nessa lateral devido a acústica, pois imaginou-se que o barulho do playground poderia ser bastante incômodo principalmente para as unidades dos andares inferiores.

Situação contrária ocorre com o espaço central apropriado como área de lazer (Figura 30) onde pode-se perceber que as janelas estão todas voltadas para esse espaço permitindo que as mães vejam seus filhos brincando a partir das janelas de suas casas. No caso do playground, pode-se verificar em planta e na Figura 55 que apenas o bloco $\mathrm{AB}$ tem janelas na lateral (mesmo tipo 1B que a ponta da Rua Comandante Taylor).

Na Figura 56 é possível observar, na fachada norte do edifício JKL, as aberturas voltadas para a Rua Visconde de Camamú o que proporciona maior visibilidade colaborando para a segurança do entorno uma vez que os próprios moradores podem tomar conta dessa rua a partir das janelas de suas casas, que segundo Jane Jacobs (1961) são os olhos da rua. 


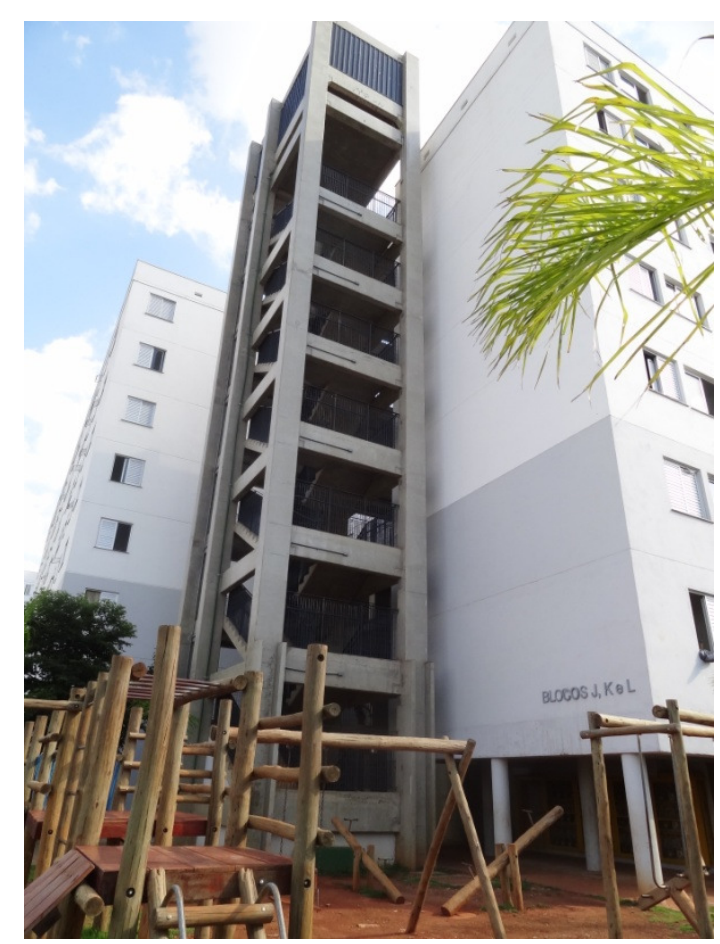

Figura 55 - Vista a partir do playground. Unidade da ponta do bloco $\mathrm{J}$ não tem janelas voltadas para esse espaço de lazer.

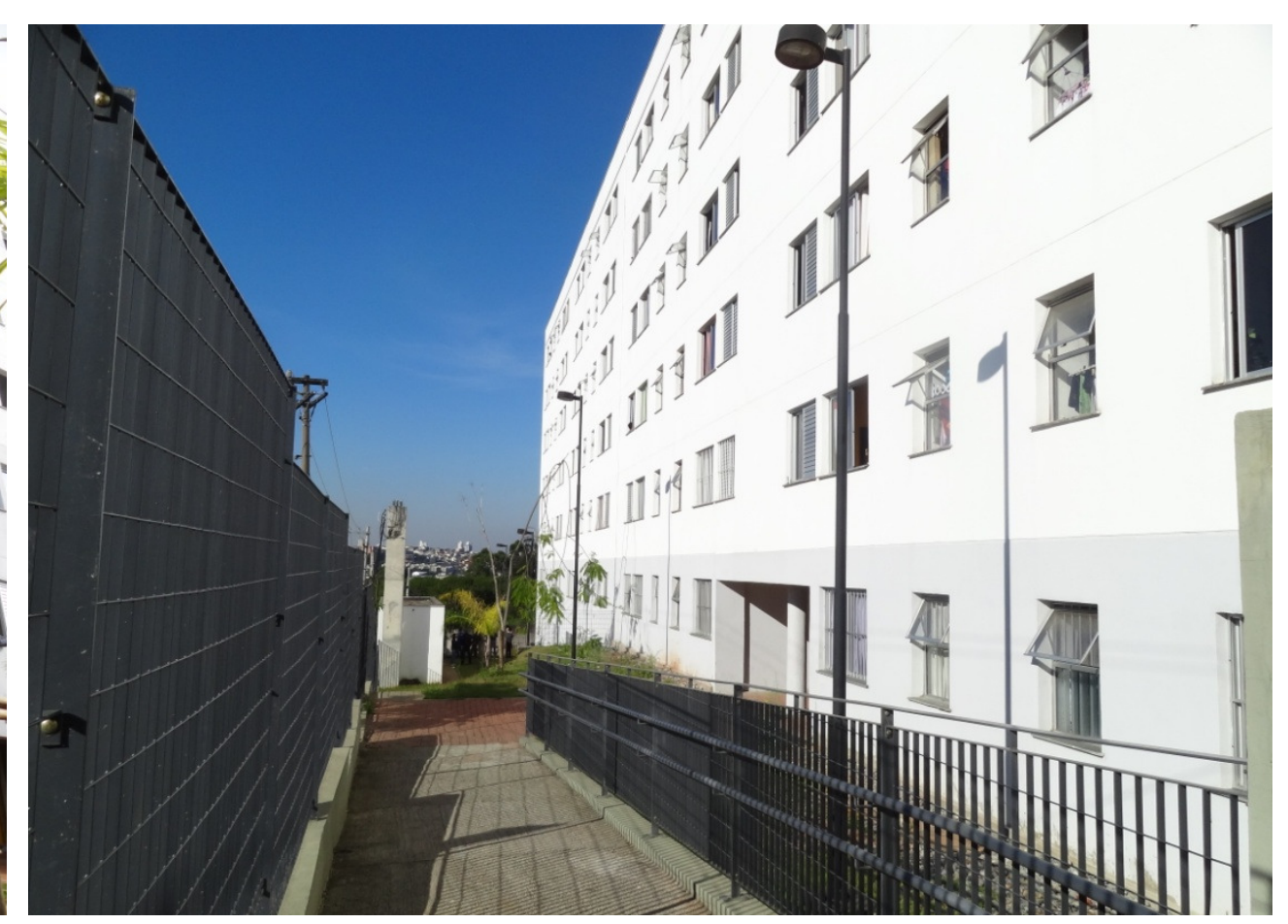

Figura 56 - Fachada do edifício JKL voltada para a Rua Visc. de Camamú.

\section{Estrutura e aberturas}

Quanto ao sistema construtivo, essa edificação também foi construída em alvenaria estrutural com blocos de concreto e, assim como a tipologia de edifícios duplos, não foi possível identificar no projeto paredes não estruturais resultando em uma tipologia sem possibilidade de grandes transformações espaciais no seu interior. 


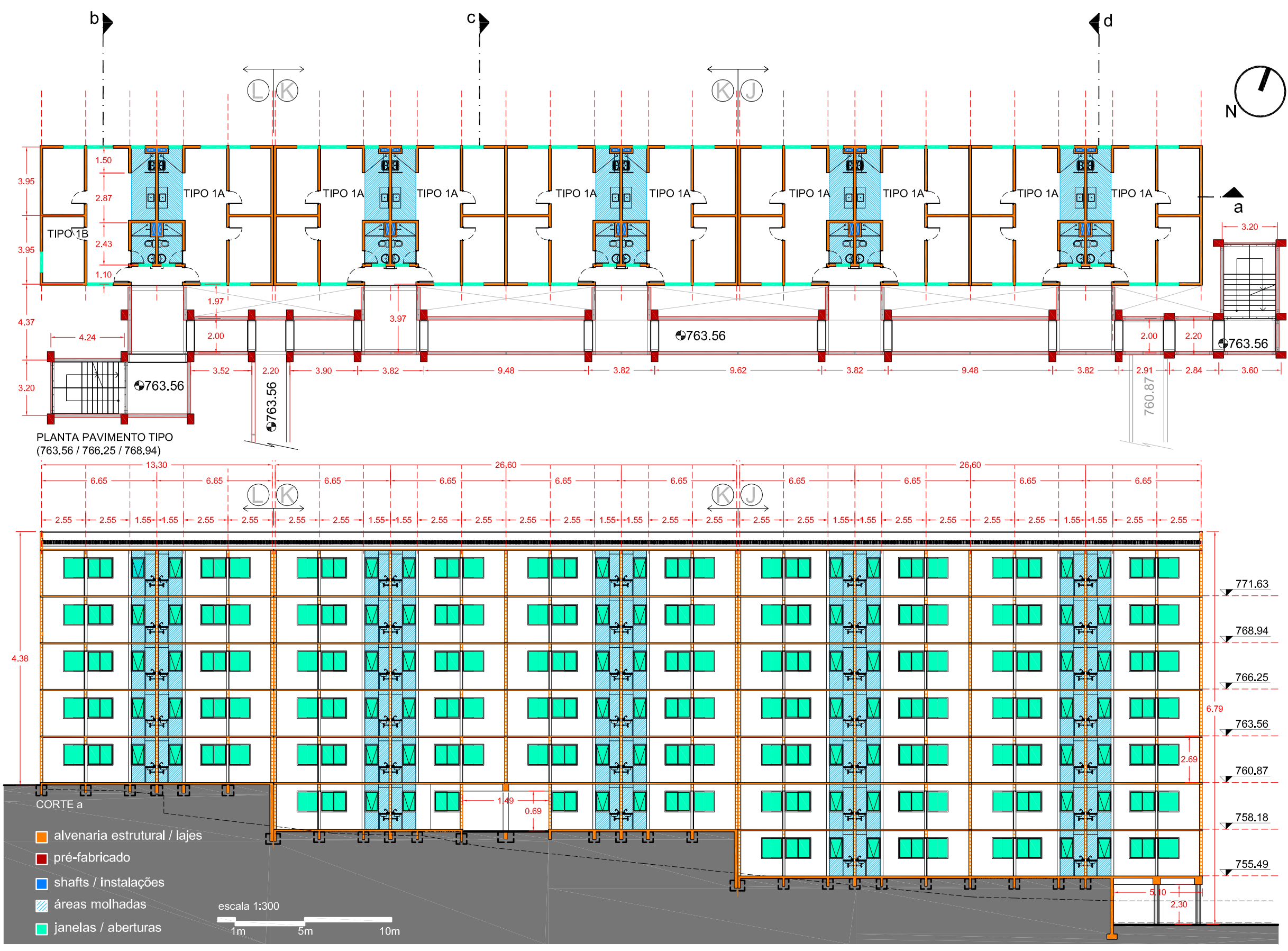


Quanto às áreas molhadas, estão espelhadas a cada duas unidades e concentradas em uma faixa de 1,55 metros que faz parte da modulação da estrutura do edifício $(2,55 m-2,55 m-1,55 m)$. O fato de estarem espelhadas acaba liberando as fachadas para as aberturas que, da forma como estão dispostas, proporcionam ventilação cruzada no interior das unidades. Assim como no edifício duplo, as janelas estão deslocadas para uma das laterais dos ambientes buscando oferecer um melhor aproveitamento dos espaços.

O vazio entre a passarela e o edifício é de 1,80 metros (1,97m entre eixos) o que proporciona certa privacidade às janelas, porém, vale ressaltar que a partir da passarela, visualmente, é possível enxergar a unidade de ponta a ponta devido a essa disposição o que, por outro lado, não acontece na tipologia do edifício duplo que, para a passarela, abre apenas janelas altas e das áreas molhadas.

Também é possível observar no esquema os muros de arrimo de aproximadamente 2,60 metros de altura construídos para fazer a contenção de terra e implantar a edificação transversalmente aos desníveis.

Por último, vale ressaltar que todas as instalações do conjunto têm medição individualizada e remota facilitando a gestão condominial uma vez que cada morador receberá suas contas correspondentes aos próprios gastos sem contar com consumo comum o que propiciava um alto índice de inadimplência.

\subsubsection{ESCALA UNIDADE}

Dentro da escala unidade, serão analisados os temas relacionados aos espaços interiores: as dimensões, suas características, as relações visuais e espaciais que estabelecem entre si, o conforto ambiental e as possibilidades de layout e diversidade de usuários. É certo que, tratando-se de uma unidade que não pode extrapolar $50 \mathrm{~m}^{2}$, muitas possibilidades ficam limitadas, porém é importante considerar esses critérios de análise e buscar identificar, entre os exemplos estudados, os que apresentam melhores soluções espaciais dentro dessa área tão enxuta definida para as unidades de habitação de interesse social. 


\subsubsection{TIPO 1}

Inversamente à escala conjunto, começaremos a análise pelo tipo da edificação independente e, em seguida, veremos quais as características apresentadas pelo tipo 2 e suas variações.

Como pode ser observado, essa tipologia pode ser dividida em três módulos: módulo dormitórios; módulo espaço livre para o estar e módulo serviços, onde estão concentradas as áreas molhadas. É interessante observar que, com esse arranjo, o módulo estar possui abertura para as duas fachadas proporcionando melhor iluminação e ventilação cruzada à unidade, como foi observado na escala do edifício e pode ser verificado no esquema de iluminação e ventilação na análise da unidade.

\section{Ambientes não especializados}

Analisando-se as dimensões internas desses ambientes chamados de não especializados ${ }^{16}$, verifica-se que a largura dos espaços internos é de 2,38m, uma medida bastante justa quando se utiliza como referência as dimensões mínimas de mobiliário recomendadas pelos manuais da Companhia de Desenvolvimento Habitacional e Urbano $(\mathrm{CDHU})^{17}$ ou pela cartilha do programa Minha Casa Minha Vida ${ }^{18}$ em que, uma cama de casal $(1,40 \mathrm{~m})$ mais dois criados-mudos $(0,50 \mathrm{~m})$ exigem a medida mínima de $2,40 \mathrm{~m}$ e no outro sentido, deve-se considerar pelo menos $50 \mathrm{~cm}$ de passagem nos pés da cama, ou seja, 1,90m (comprimento mínimo para camas de casal) somados aos $50 \mathrm{~cm}$ precisariam de pelo menos os mesmo $2,40 \mathrm{~m}$, isso sem contabilizar a medida dos armários.

\footnotetext{
${ }^{16}$ Os ambientes não especializados não possuem ou ao menos não seria necessário que possuíssem uma função específica podendo ser utilizados da maneira que melhor conviesse aos moradores, como estar, dormitório, espaço de trabalho, escritório, sala de jantar, enfim, qualquer uso que não necessitasse de instalações especiais como é o caso dos ambientes especializados

17 Desenho Universal Habitação de Interesse Social, 2010.

${ }^{18}$ Cartilha do Programa Minha Casa Minha Vida. Disponível em: http://www1.caixa.gov.br/gov/gov social/municipal/programas habitacao/pmcmv/documentos download.asp. Acesso em setembro de 2013.
} 


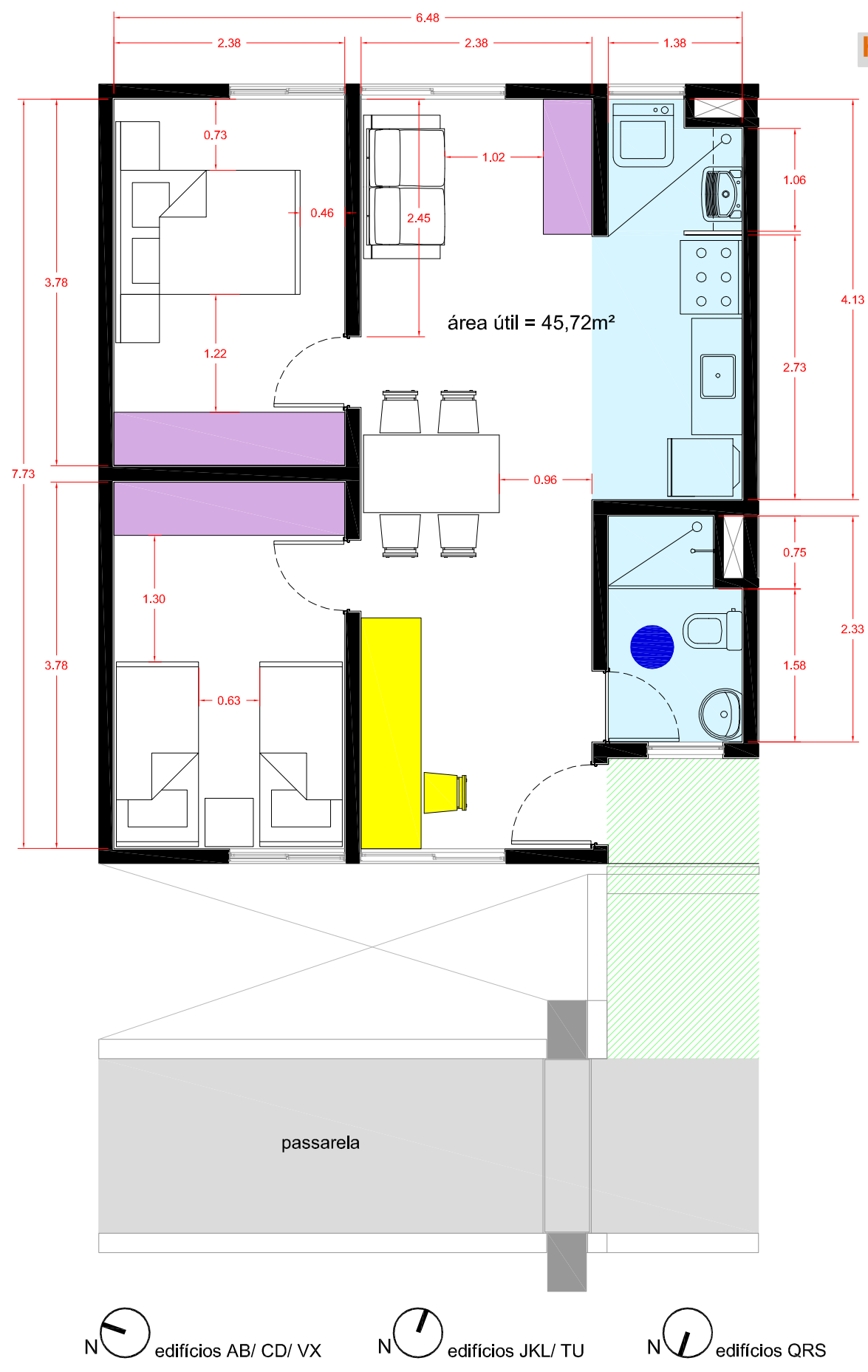

PLANTA TIPO 1A - layout e dimensões. escala 1:75

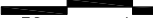

$\square$ concentração das áreas molhadas

$\square$ espaços para guardar

$\square$ espaços de estudo/trabalho

uso do banheiro

1 pessoa

$\square$ espaço exterior próprio

$\square$ apropriação do espaço de transição como espaço exterior

CICLO DA ROUPA:

$$
\text { 1. roupa suja }
$$

2. lavar

3. secar

4. passar

5. roupa limpa

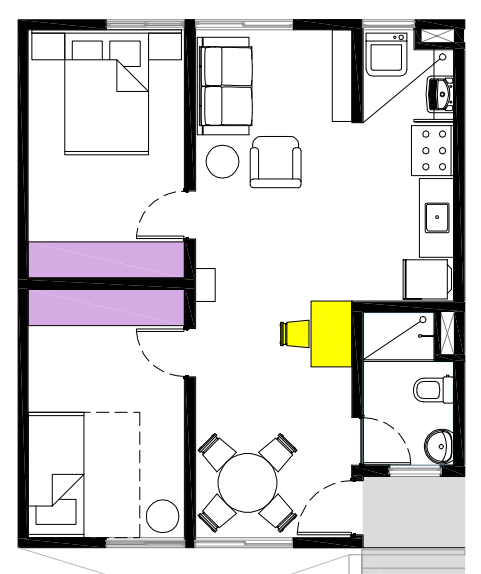

PLANTA TIPO 1A - proposta de layout apartamento decorado escala 1:150

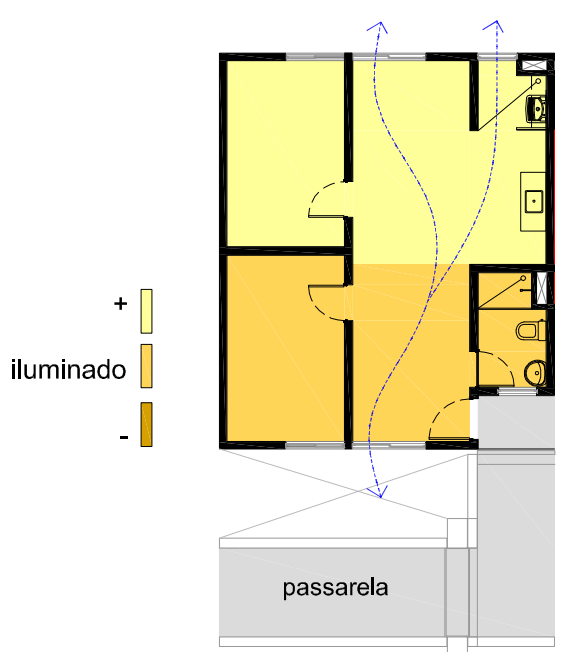

ESQUEMA ILUMINAÇÃO E VENTILAÇÃO (orientação de referência: edifício JKL) escala 1:200

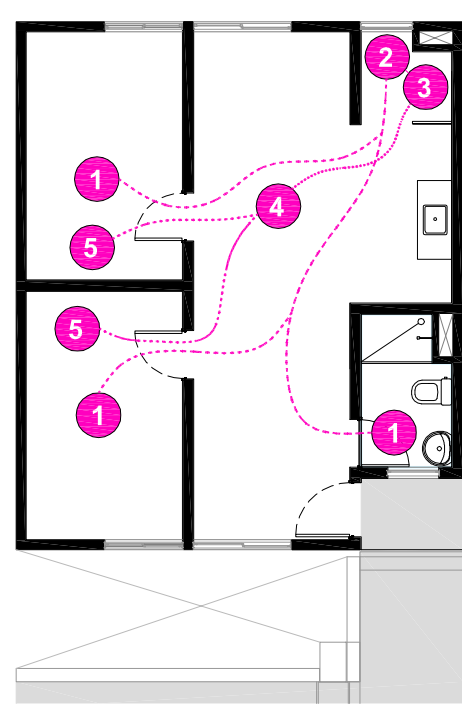

PLANTA TIPO 1A - ciclo da roupa escala 1:150

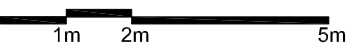

Figura 58 - Análise Tipo 1 
Se, por um lado, a largura desses ambientes está no limite, por outro, o comprimento de 3,78m é bastante confortável. No layout proposto pelo escritório de arquitetura, o mobiliário se encaixa nessas medidas e a posição das portas dos dormitórios proporciona um ganho de espaço para os armários, como pode ser observado na planta e na foto tirada de um apartamento modelo decorado pela construtora (Figura 59).

Outra decisão projetual que facilita a utilização do espaço é o deslocamento da janela para uma das laterais do ambiente, assim o espaço restante é suficiente para encostar um beliche (Figura 60) ou qualquer outro móvel mais alto, isso porque se subtrairmos $1,20 \mathrm{~m}$ (largura da janela) da largura total do dormitório $(2,38 \mathrm{~m})$ restaria apenas $1,18 \mathrm{~m}$ que, divido em duas partes, não seria suficiente para encostar o beliche, por exemplo.

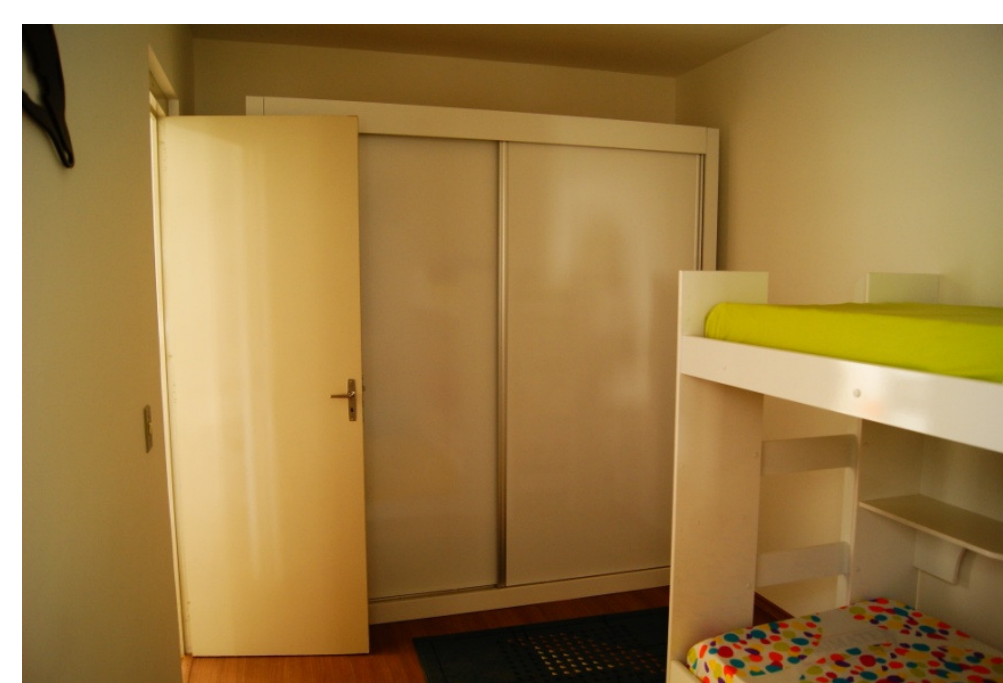

Figura 59 - Apartamento decorado - posição da porta proporciona espaço para o armário.

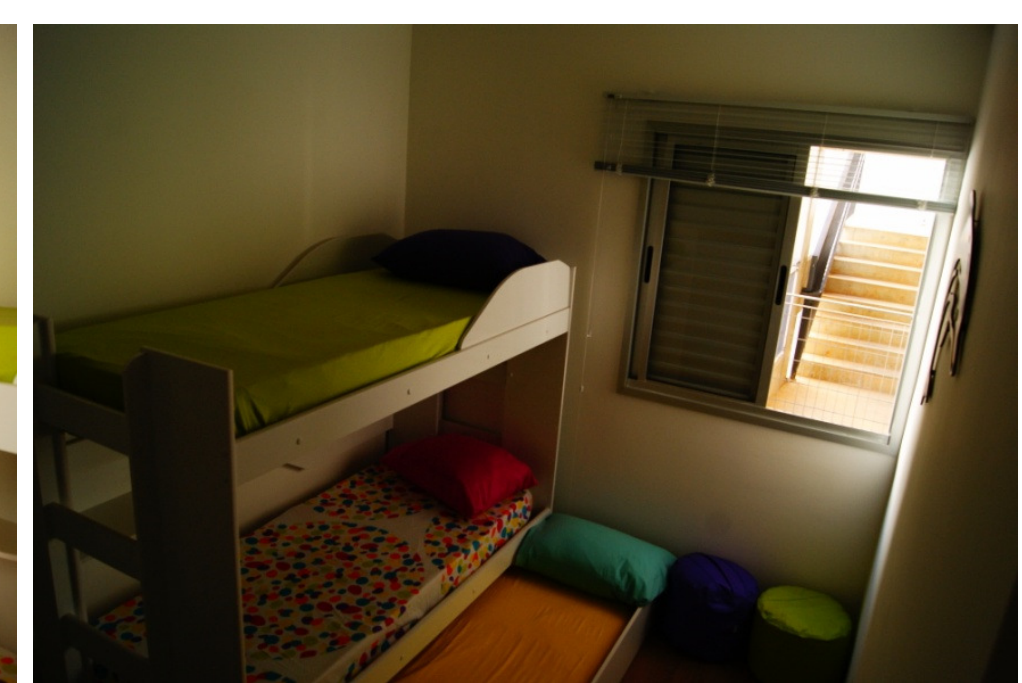

Figura 60 - O deslocamento da janela facilita a disposição de móveis grandes e altos encostados na parede.

Quanto ao layout do espaço de estar, algumas situações podem não ser consideradas muito confortáveis como, por exemplo, a distância de apenas 1 metro entre o sofá e o móvel para TV ou a posição da mesa de jantar com as 
cadeiras na passagem para os dormitórios e um grande espaço sendo utilizado para uma mesa de trabalho. Está claro que essas considerações devem sempre levar em conta os diversos tipos de usuários que poderão viver nesse apartamento, mais uma vez, se considerarmos as recomendações mínimas dos manuais, a sala deveria ter dimensões suficientes para a quantidade de moradores do apartamento, ou seja, pelo menos quatro pessoas deveriam conseguir sentar confortavelmente para assistir TV.

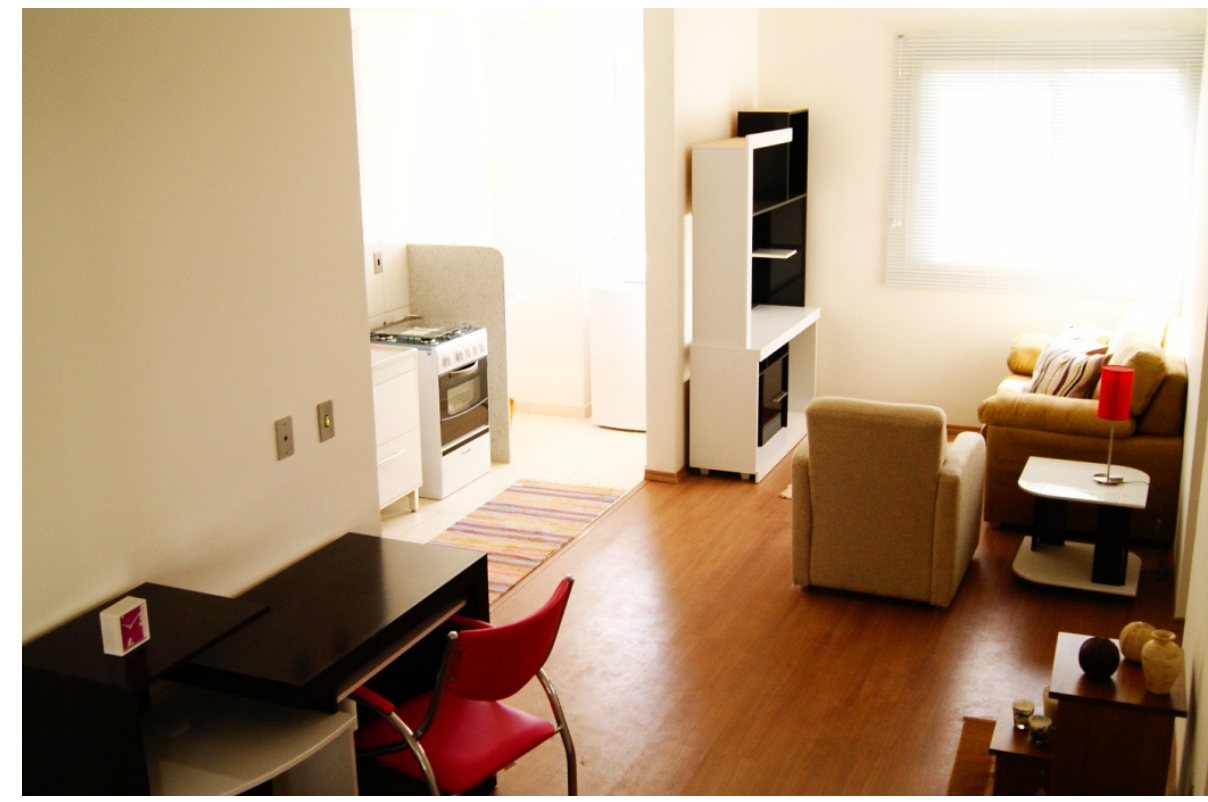

Figura 61 - Proposta de layout do apartamento modelo.

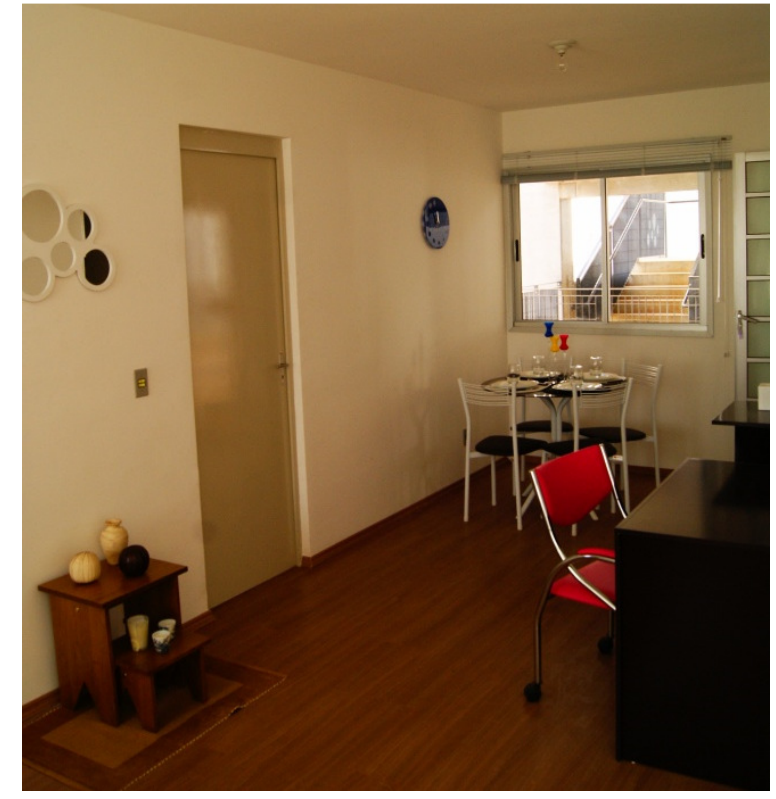

Figura 62 - Proposta de layout do apartamento modelo.

Apenas como referência, se observarmos o layout sugerido no apartamento modelo, vemos que houve uma tentativa de encaixar mais lugares na sala, que a mesa de trabalho ficou na parede menor e que a mesa de jantar foi colocada próximo à porta de entrada (situação que também pode atrapalhar a abertura da porta), porém essa é apenas uma referência de possibilidade de layout para esse espaço e o importante é que o projeto ofereça as 
condições e dimensões mínimas para que sejam apropriados de diversas maneiras atendendo à necessidade dos diferentes tipos de moradores.

\section{Ambientes}

especializados

Os ambientes especializados são os que necessitam de instalações específicas e, no caso das unidades habitacionais que estão sendo estudadas, se resumem nas áreas molhadas: cozinha, área de serviços e banheiro. A concentração das áreas molhadas já foi observada na escala unidade, porém vale ressaltar que, nessa planta, essas áreas estão agrupadas em um mesmo módulo.

A largura da cozinha seria inferior à exigida pelos manuais e catálogos de referência caso não estivesse integrada com a sala, pois de acordo com as Especificações Mínimas do Programa Minha Casa Minha Vida a cozinha deve ter largura mínima de 1,80m. O espaço deixado para fogão de seis bocas vai de encontro com as recomendações das diretrizes de projeto, pois com base na experiência de acompanhar a mudança dos moradores para as novas unidades, a equipe social da Sehab verificou a necessidade de maiores espaços para o fogão permitindo que os moradores pudessem utilizar os eletrodomésticos que já possuíam e que, muitas vezes, eram fogões de seis bocas.

O banheiro é único e não permite o uso simultâneo o que poderia ser uma facilidade quando imagina-se quatro ou cinco pessoas morando juntas e, pela manhã, todas precisando tomar banho, escovar os dentes e usar o banheiro antes de sair de casa. Porém, segundo a arquiteta, no início do projeto o banheiro de uso compartilhado estava sendo cogitado, mas foi descartado após pesquisa com os futuros moradores que se manifestaram contra essa separação de funções. 


\section{Relação entre os}

ambientes

Apesar das dimensões mínimas, pode-se considerar que, espacialmente, a cozinha está totalmente integrada com a sala de estar, uma definição que, com base nas visitas realizadas aos apartamentos, parece não ter agradado muito aos moradores que acabaram fechando um pouco o espaço da cozinha, seja esticando a parede da área de serviços um pouco mais, seja construindo uma mureta que ajuda a definir melhor o espaço. Foi curioso observar, durante as visitas aos apartamentos, situações idealizadas no projeto que são adequadas às necessidades dos moradores após a ocupação das unidades.

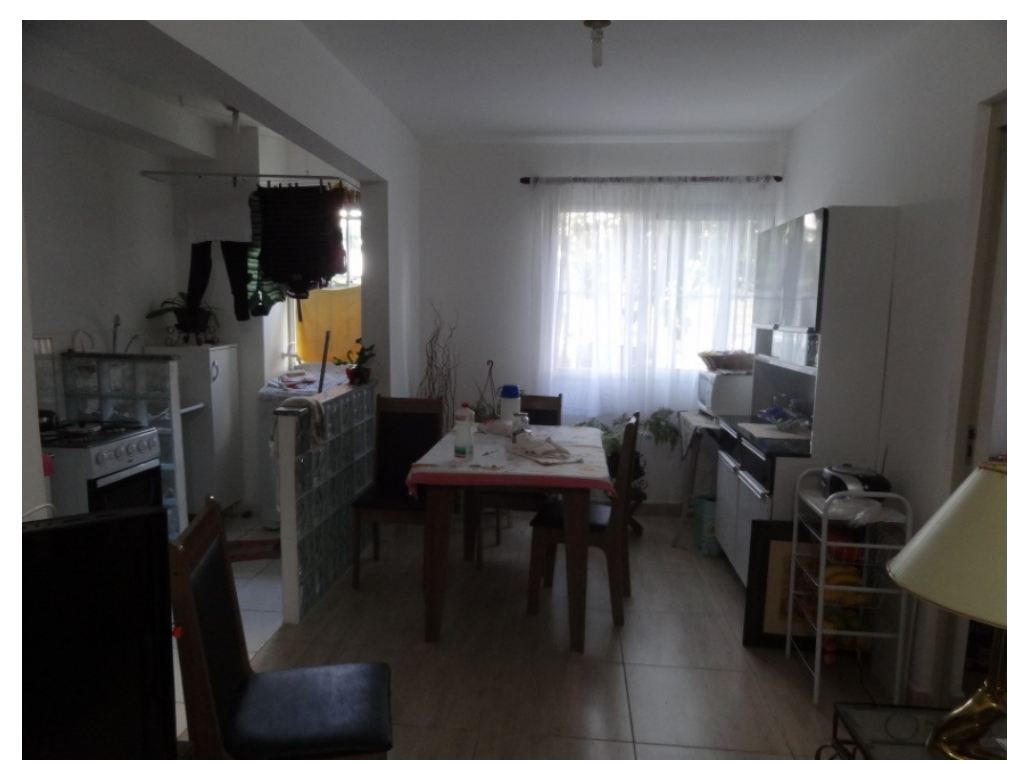

Figura 63 - Unidade visitada onde os moradores construíram mureta com tijolos de vidro.

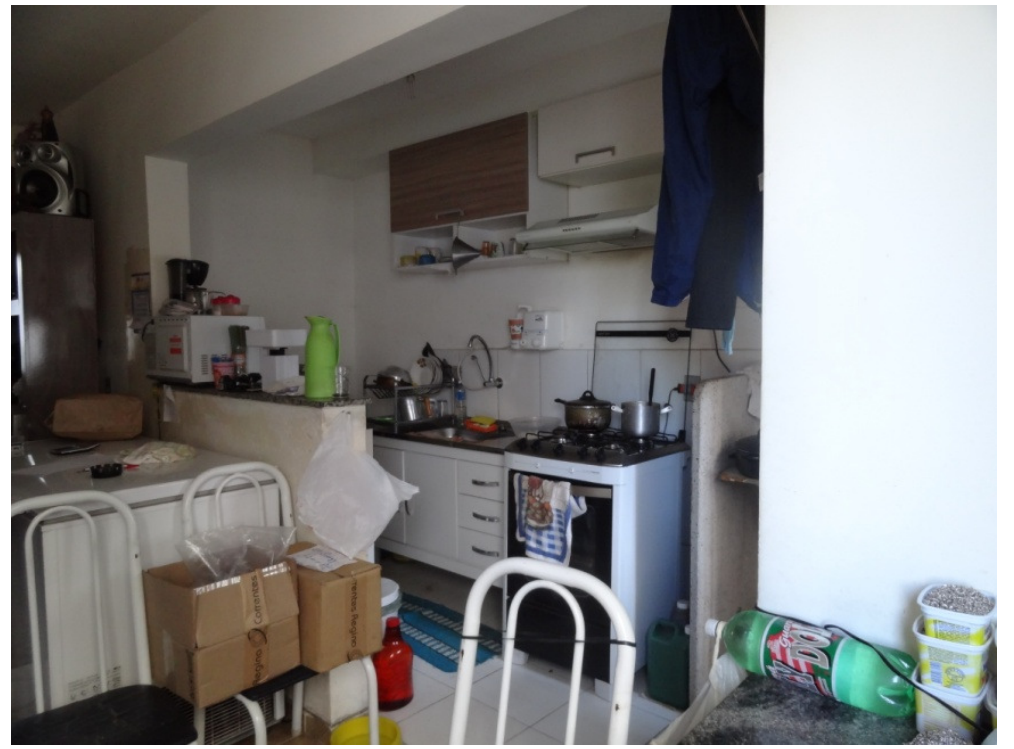

Figura 64 - Mureta construída entre a cozinha e a área de estar. 
A cozinha e a área de serviços estão diretamente integradas e a cozinha é iluminada e ventilada pela janela da área de serviços, porém, diferentemente de muitas tipologias de habitação de interesse social, nesse caso, o banheiro tem ventilação e iluminação própria não precisando ventilar e receber iluminação através da área de serviço, situação que piora ainda mais quando a cozinha também ventila pelo mesmo espaço.

A área de serviço é um espaço muito importante para a manutenção dos lares, porém é um ambiente que sempre apresenta dificuldades para ser bem encaixado dentro dessas unidades compactas, pois na maioria das vezes, fica muito exposto dentro da unidade permitindo que as roupas estendidas sejam vistas quase que de todos os ângulos da casa, porém é um espaço necessário e os projetos devem considerar sua relação com os outros ambientes.

No caso dessa tipologia, existe relação visual com a área de serviço desde o espaço de estar que talvez pudesse ter sido amenizada se a parede que a define fosse estendida um pouco mais, porém essas são soluções que deveriam ter sido resolvidas durante o projeto.

Outro instrumento de metodologia de análise utilizado para avaliar as unidades é o ciclo da roupa. Por esse instrumento, podemos verificar como os ambientes, envolvidos nesse ciclo, estão relacionados. Seria recomendável, por exemplos, a proximidade da área de serviço com o banheiro, evitando que a roupa limpa ou suja passasse pela cozinha, porém, a distribuições dessas funções dentro de apartamentos compactos não é uma tarefa fácil e, portanto, podemos observar pela análise realizada que as dimensões da área de serviço são pequenas quando pensamos nas atividades ai realizadas, pois não há um lugar apropriado para secar a roupa que não seja em varais suspensos sobre o tanque ou a máquina, tampouco há espaço para passar a roupa (entendendo-se que essa atividade deverá ser realizada na sala ou nos dormitórios) e por último, percebe-se que a roupa circula por toda a unidade durante seu ciclo sem evitar, principalmente, a etapa de secagem próxima à cozinha. 


\section{Espaço exterior}

próprio

No caso das tipologias desenvolvidas para esse conjunto, não é possível dizer que possuem espaço exterior próprio, pois, esses espaços devem estar relacionados com o interior da unidade. Porém, vale relembrar aqui a existência dos halls de acesso, classificados como espaços de transição que, em alguns momentos poderiam ser considerados como espaços exteriores onde os moradores podem descansar ou aproveitar do espaço exterior. Foi possível, inclusive identificar moradores que colocam as roupas para secar nesse espaço, portanto, na falta de um espaço exterior próprio, esses espaços de transição acabaram substituindo, pelo menos em parte, sua função.

\section{Variações do TIPO 1}

Como foi visto na escala conjunto, essa tipologia apresenta seis variações: os tipos 1A, 1B e 1C têm a mesma disposição do acesso e dos ambientes e apresentam variação apenas na localização da janela dos dormitórios que, nas situações em que é implantado nas pontas do edifício, abrem a janela para a lateral proporcionando visibilidade a partir de uma fachada que poderia ser cega.

O tipo 1D, é uma tipologia que resultou na ponta de um edifício, porém sem ser espelhado, como acontece com as outras unidades, portanto, tem o hall de acesso único, ou seja, sem compartilhar com a unidade vizinha e sofreu uma pequena adaptação no banheiro para adequar esse acesso. Entre todos os tipos, é o único que apresenta banheiro de uso simultâneo, ou seja, tem a pia para o lado de fora e possibilita o uso por mais de uma pessoa. Segundo a arquiteta, essa tipologia foi desenvolvida para atender a uma demanda, colocada pela associação de moradores, de estudantes que poderiam compartilhar os apartamentos e, devido a isso, essa separação de 
funções foi contemplada no projeto. Além disso, a área de serviço é um pouco maior que as outras e a unidade conta com aproximadamente $1,5 \mathrm{~m}^{2}$ a mais que as outras unidades.

O tipo 1E representa a unidade adaptada e aparece apenas nos níveis mais baixos do terreno, as dimensões do banheiro são maiores e foram realizadas pequenas alterações nas muretas da cozinha para facilitar a circulação de cadeirantes.

Por último, o tipo 1F é a quitinete que, em realidade, segue a modulação das outras unidades não tendo apenas o módulo dos dois dormitórios. A arquiteta também comentou que essas unidades foram desenvolvidas para atender à demanda de idoso que viviam sozinhos, membros da associação de moradores. Com relação às outras unidades, aparece, nessa tipologia, um nicho para a geladeira que, aparentemente, ajuda a definir melhor o espaço destinado ao dormitório e assim como o tipo 1F, possui banheiros adaptados.

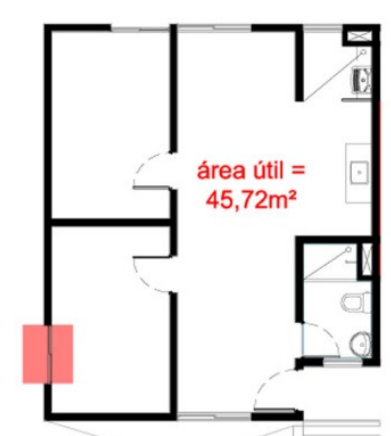

\section{PLANTA TIPO 1B} janela para lateral

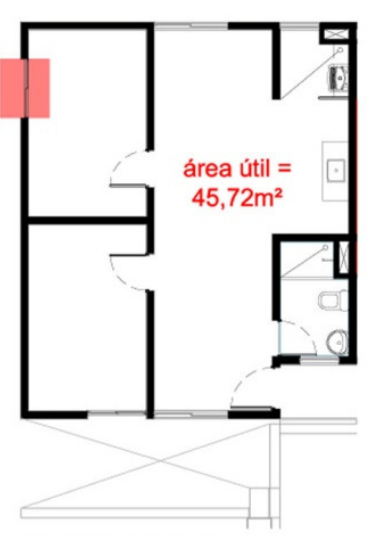

PLANTA TIPO $1 C$ janela para lateral

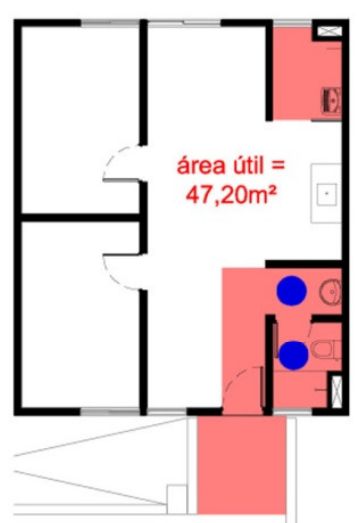

\section{PLANTA TIPO 1D} hall entrada - banheiro e área de serviço

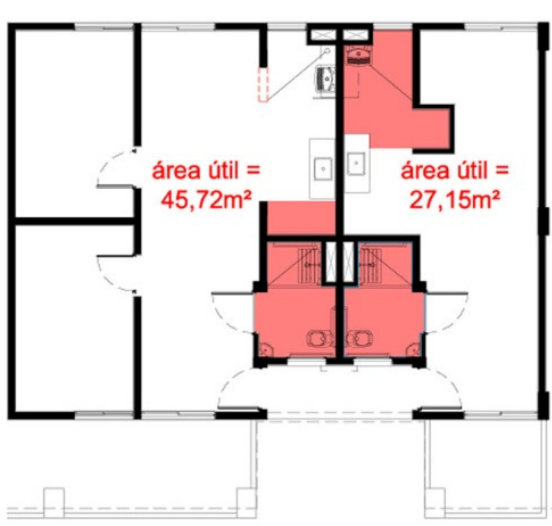

\section{PLANTA TIPO 1E} banheiro e área de serviço
PLANTA TIPO 1F banheiro, cozinha e a. serviço

$\square$ destaque para as variações entre os tipos

uso do banheiro - 1 pessoa

escala 1:200

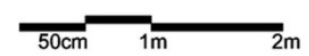

Figura 65 - Variações do tipo 1. 


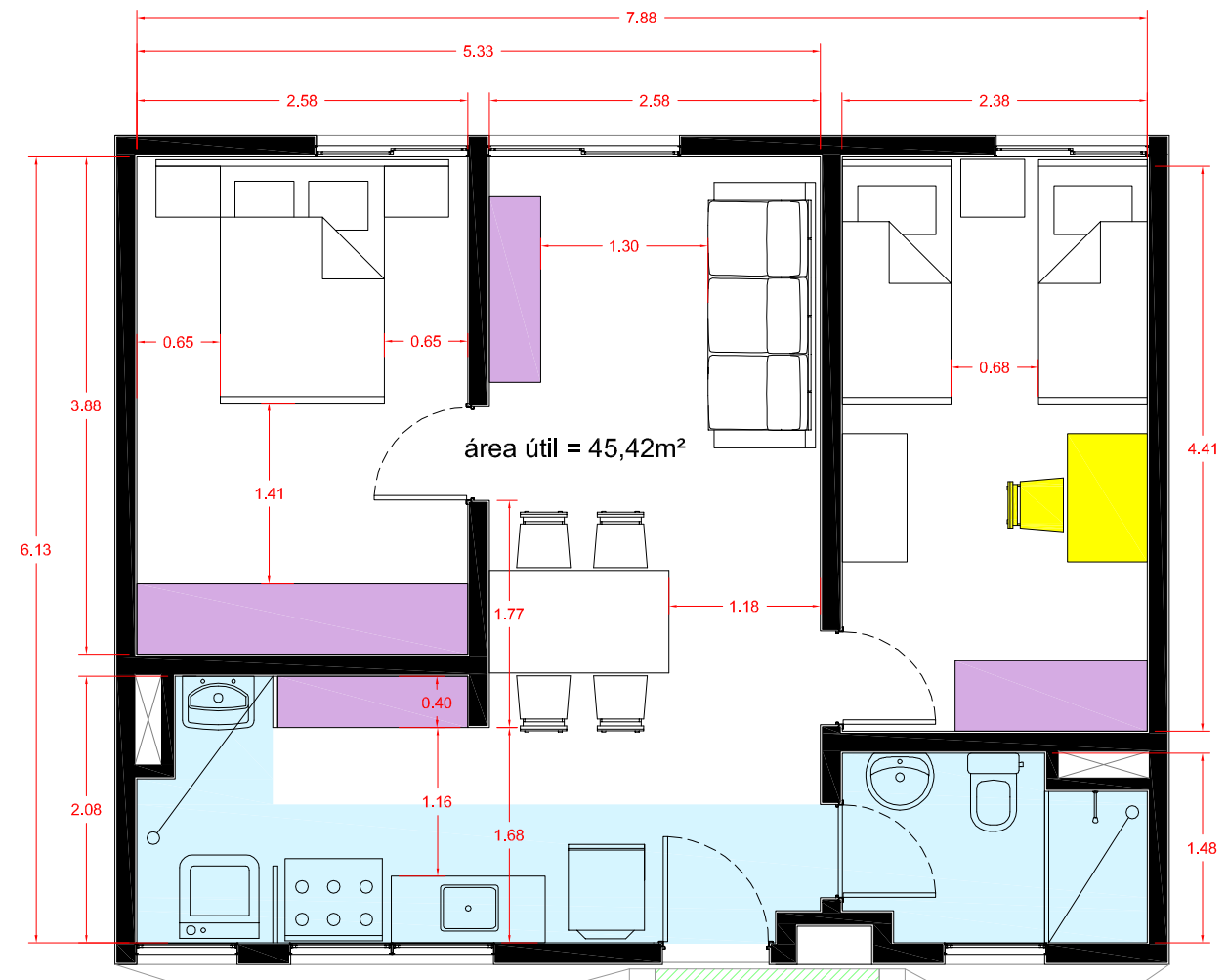

PLANTA TIPO 2B - layout e dimensões. escala 1:75

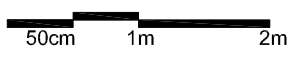

$\square$ concentração das áreas molhada

$\square$ espaços para guardar

$\square$ espaços de estudo/trabalho

uso do banheiro

$\square$ espaço exterior próprio

$\square$ apropriação do espaço de transição como espaço exterior

CICLO DA ROUPA:

$$
\text { 1. roupa suja }
$$

2. lavar

3. secar

4. passar

5. roupa limpa

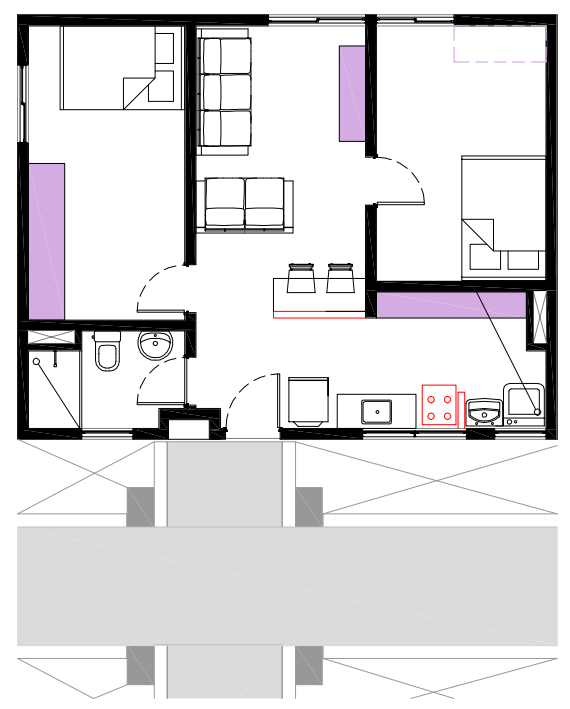

ESQUEMA ILUMINAÇÃO E VENTILAÇÃO (orientação de referência: edifício $\mathrm{N} /$ tipo $2 \mathrm{~B}$ ) escala 1:200

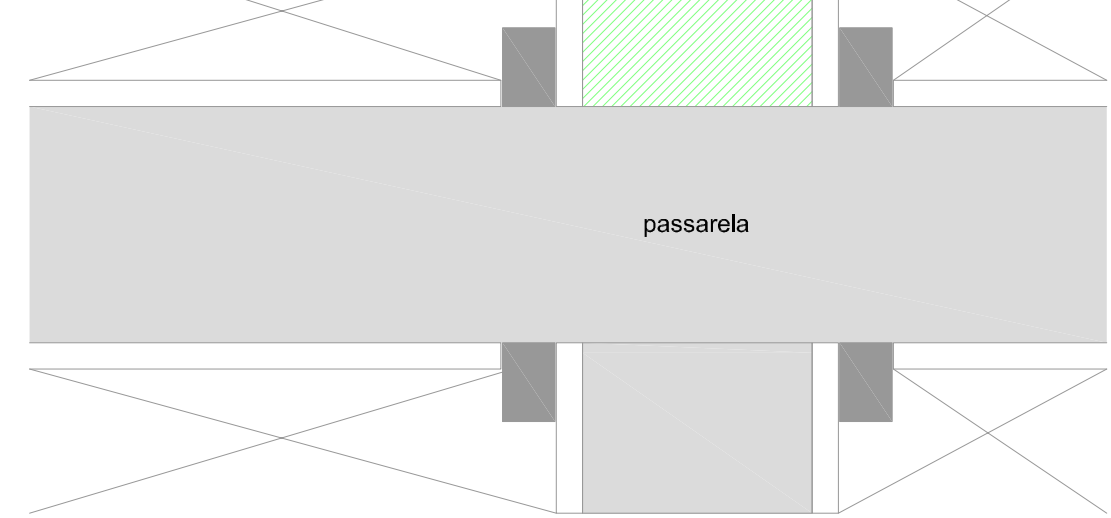

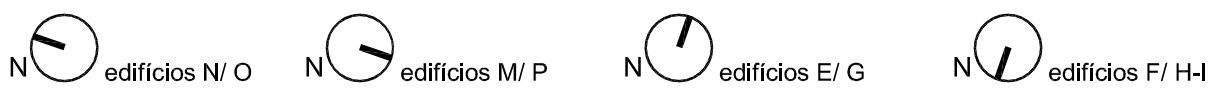

PLANTA TIPO 2D - reprodução de layout de um apartamento visitado já ocupado pelos moradores. escala 1:150
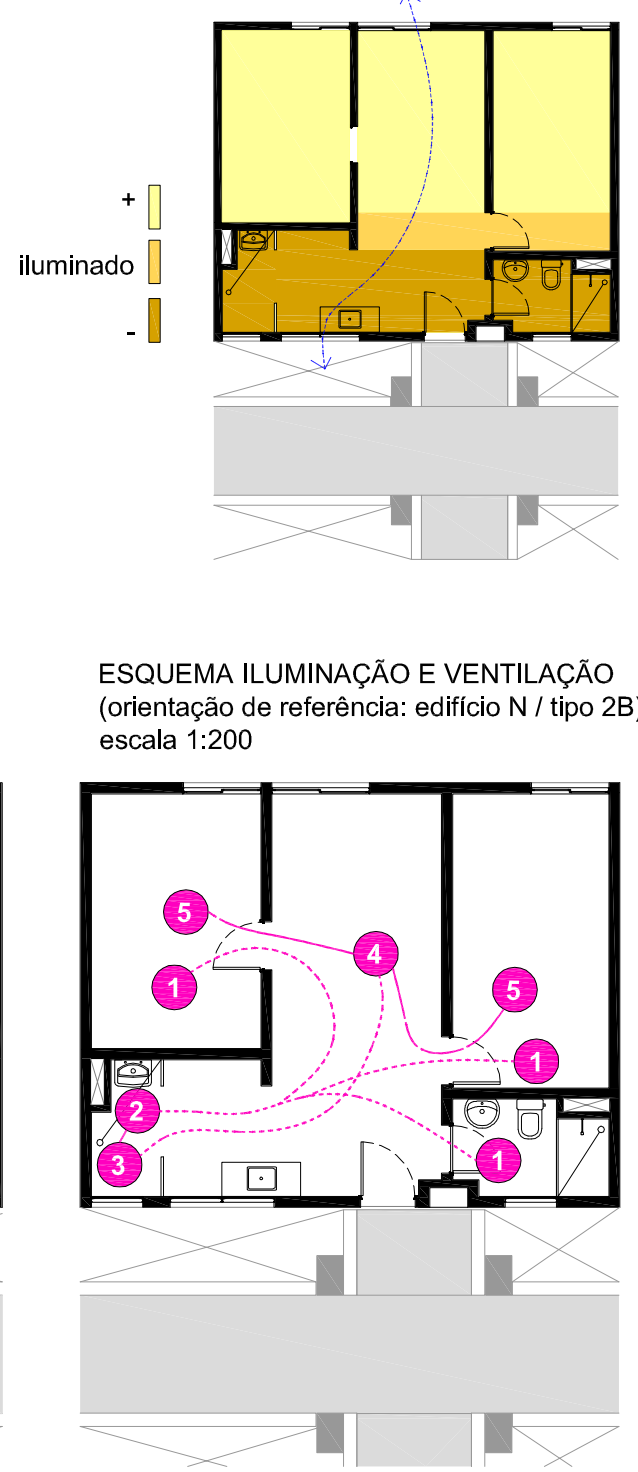

PLANTA TIPO 2B - ciclo da roupa ${ }_{1 \mathrm{~m}}$ escala 1:150

Figura 66 - Análise Tipo 2. 


\subsubsection{TIPO 2}

O tipo 2 corresponde aos apartamentos do edifício duplo que possuem a passarela entre os dois blocos. Como pode ser observado na análise (Figura 66), a concentração das áreas molhadas ocorre ao longo da passarela e os ambientes não especializados estão distribuídos na outra fachada.

\section{Ambientes não especializados}

Em comparação com o tipo 1, essa tipologia apresenta maiores dimensões quanto à largura do estar e de um dos dormitórios. O segundo dormitório possui a mesma largura que os dormitórios do tipo analisado anteriormente, os 2,38m que estão no limite da medida exigida pela cartilha do programa Minha Casa Minha Vida, adotada como referência para a análise uma vez que é, atualmente, o programa financiador da produção de habitação de interesse social da Secretaria Municipal de Habitação.

Nessa tipologia também observamos o deslocamento das janelas para melhor aproveitamento do espaço e, em apenas um dos dormitórios, o deslocamento da porta deixando espaço para o armário. Os dormitórios apresentam dimensões generosas favorecendo a variedade de possibilidades de layouts.

A partir das visitas ao conjunto e da oportunidade de entrar em algumas unidades já habitadas, foi possível analisar a forma como os moradores se apropriaram do apartamento e como foi feita a disposição do mobiliário. Em um dos casos, a moradora colocou um conjunto de sofás de dois e três lugares na sala o que nos leva a concluir a necessidade de mais lugares para assistir TV. Quanto aos quartos, foi possível verificar que nem sempre o espaço idealizado para colocar o armário é visto da mesma forma pelos moradores que, em mais de um exemplo não colocam o armário onde havia sido proposto pelo projeto como pode ser observado nas fotos a seguir. 


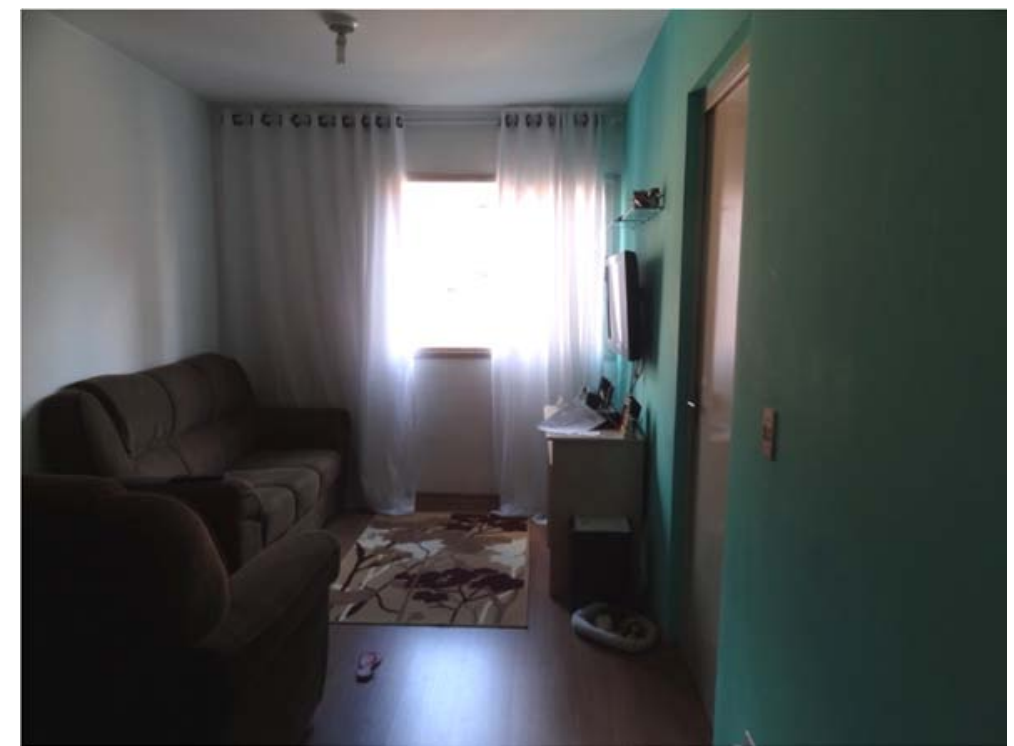

Figura 67 - Foto disposição de layout por moradores. Estar com sofás de dois e três lugares (layout Figura 66).

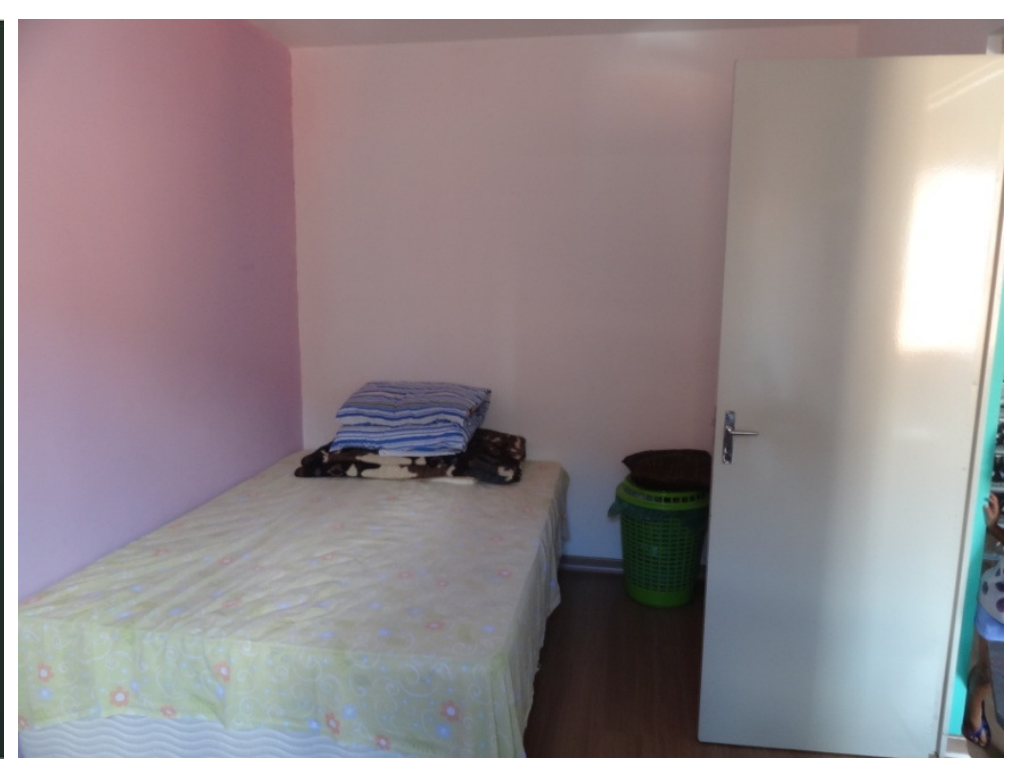

Figura 68 - Foto disposição de layout pelos moradores. Cama encaixada no espaço projetado para o armário.

\section{Ambientes especializados}

Por estar disposta ao longo da passarela a área molhada acaba sendo cortada pela porta de entrada. A cozinha, apesar das dimensões mínimas para o mobiliário e eletrodomésticos necessários, conta com um espaço extra para armário a partir do momento em que o dormitório é recuado e sobra, para a cozinha e área de serviço, um nicho de $40 \mathrm{~cm}$ muito útil como espaço complementar.

O banheiro, assim como na outra tipologia também não proporciona o uso simultâneo, pois como já foi explicado na análise do tipo 1, a associação de moradores foi consultada sobre essa possibilidade e optou pelo banheiro único. 


\section{Relação entre os} ambientes

A cozinha e o estar são um espaço integrado e, na proposta de layout desenvolvida pelo escritório de arquitetura uma mesa configura a divisão espacial entre esses dois ambientes mantendo sua integração visual e organizando as circulações. Porém, com base nas visitas aos apartamentos já ocupados pelos moradores, foi possível identificar, novamente, a necessidade de construir um elemento, geralmente uma mureta, definido melhor essa divisão dos espaços.

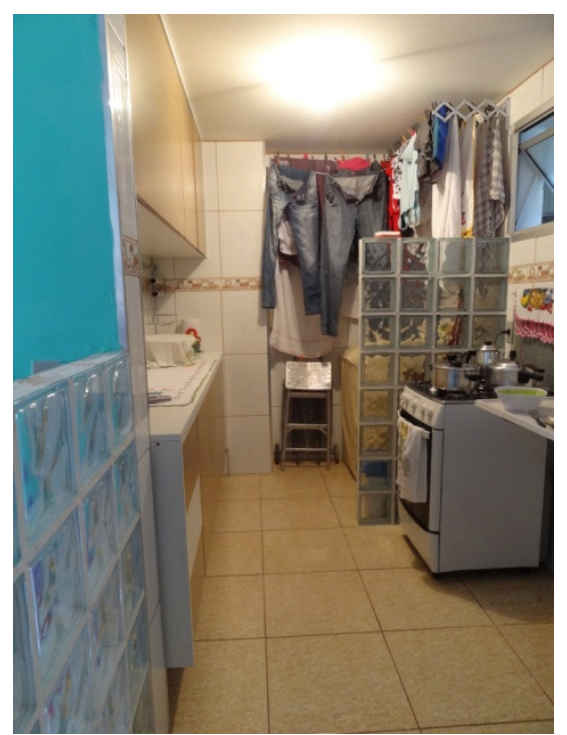

Figura 69 - Mureta de tijolos de vidro definindo o espaço da cozinha e o espaço de $40 \mathrm{~cm}$ deixado para o armário foi ampliado em direção à área de serviço (layout Figura 66)

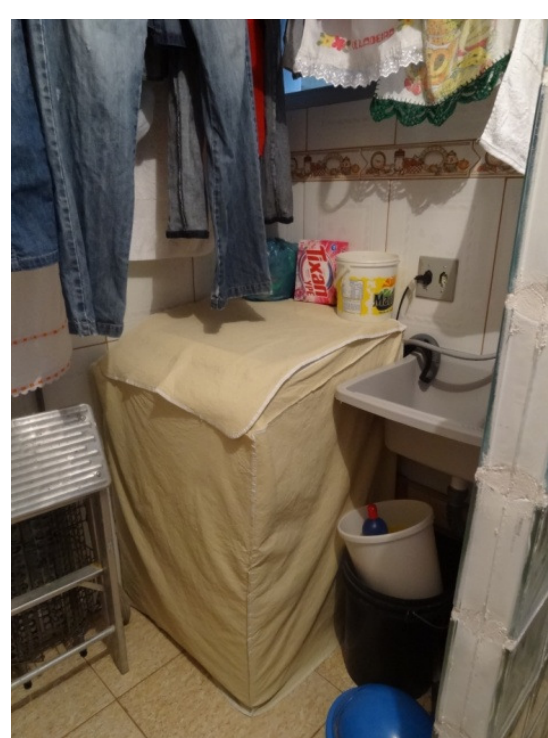

Figura 70 - O morador alterou a posição do tanque colocando-o ao lado da máquina de lavar e liberando espaço para ampliar o armário no nicho de $40 \mathrm{~cm}$ (layout Figura 66).

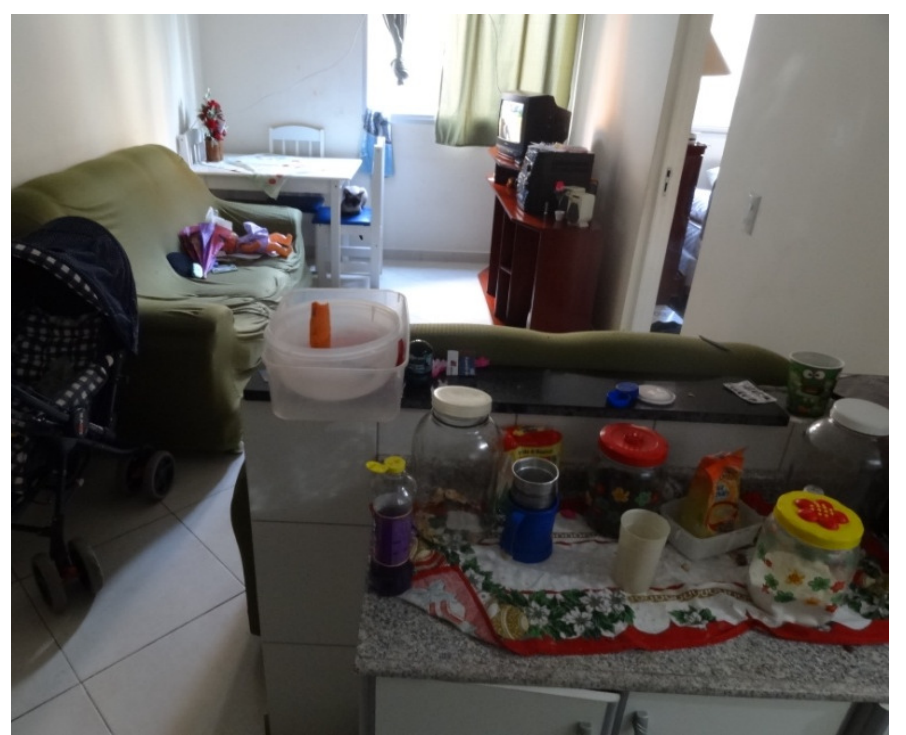

Figura 71 - Nesse caso a mureta foi colocada de modo que oferecesse um espaço para um balcão voltado para a cozinha e foi utilizada para encostar o sofá na sala de estar. 
Quanto á área de serviço, pode-se dizer que, no caso desse tipo, está ainda mais exposta que no tipo 1, pois está na lateral da porta de entrada e não há como não ser vista a não ser que existisse alguma divisória alta isolando esse espaço.

Pela análise do ciclo da roupa, conclui-se, mais uma vez que não há espaço suficiente para realizar as atividades relacionadas ao cuidado na roupa na área de serviço e, no caso dessa tipologia, a etapa da secagem é prejudicada pela pouca quantidade de luz natural que chega até as janelas dos tipos $2 \mathrm{~B}, 2 \mathrm{C}$ e $2 \mathrm{D}$ devido à passarela.

\section{Espaço exterior \\ próprio}

Assim como no tipo 1, essa tipologia não possui espaço exterior próprio, mas acaba buscando compensar a falta desse espaço com a apropriação do espaço de transição no hall de entrada da unidade.

\section{Variações do TIPO 2}

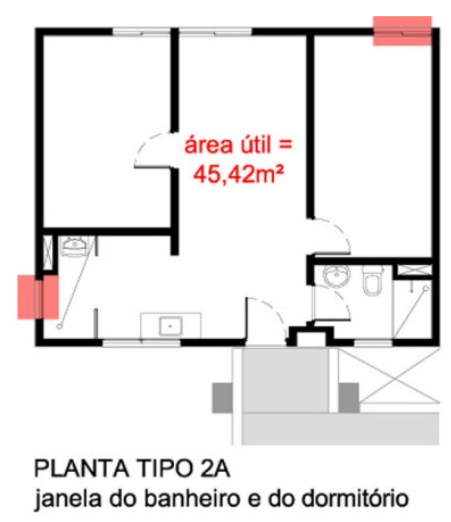

$\square$ destaque para as variações entre os tipos

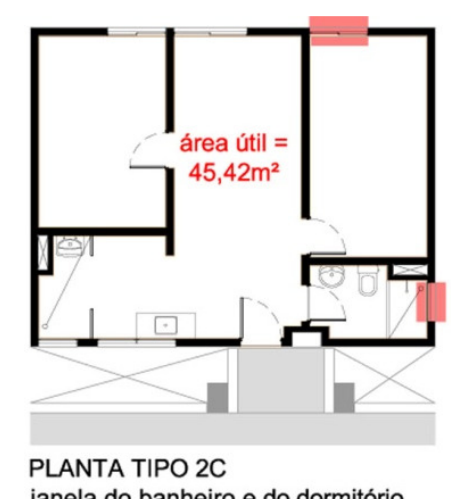

janela do banheiro e do dormitório

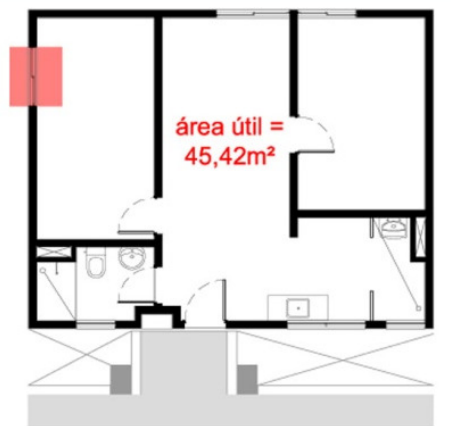

PLANTA TIPO 2D

janela do dormitório para a lateral

escala 1:200

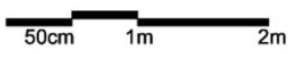

Figura 72 - Variações do tipo 2. 
As variações do tipo 2 concentram-se apenas na alteração da posição das janelas. Os tipos 2A e 2C, localizados nas pontas do edifício, possuem as janelas da área de serviço (2A) e do banheiro (2C) voltadas para a lateral. No caso do tipo 2B, como pode ser observado na Figura 66, todas as janelas das áreas molhadas estão voltadas para a passarela. Esses tipos também apresentam pequena variação no deslocamento das janelas do dormitório deixando-as sempre na fase mais central e menos nas extremidades do edifício.

O tipo 2D é o que apresenta maior variação a partir da alteração da abertura da janela do dormitório para a lateral o que é positivo por proporcionar visuais que poderiam não existir caso essa lateral fosse uma fachada cega.

\subsubsection{CONSIDERAÇÕES}

FINAIS

De modo geral, se fôssemos elencar os pontos positivos e negativos explorados a partir da análise do Conjunto Residencial Comandante Taylor, chegaríamos à conclusão de que existe um equilíbrio entre esses valores nesse projeto.

Como pontos negativos, pode-se citar a pouca iluminação entre os edifícios duplos e a falta de legibilidade dos percursos e acessos como as principais situações a serem apontadas. Quanto ao primeiro item, apesar de ser possível compreender a necessidade de adensar e construir o maior número de unidades habitacionais possível, sem recorrer à implantação de elevadores, não há como não destacar a falta de iluminação nos acessos às unidades desses edifícios, principalmente nos pavimentos inferiores que é tão marcante quando se visita esse conjunto. Entretanto, no que diz respeito à legibilidade, entende-se que a disposição das passarelas que vão circulando entre os edifícios e conectando-os em níveis elevados foi uma decisão projetual que acabou priorizando o conceito das "calçadas suspensas" em detrimento da clareza dos percursos. Porém, voltamos a comentar aqui 
que uma proposta de comunicação visual poderia ser implantada, seja a desenvolvida pelo escritório de arquitetura, seja outra realizada pela prefeitura, desde que alguma ação fosse feita para melhorar a legibilidade dos espaços.

Em segundo lugar, pode-se citar ainda a falta de cuidado com a construção dos espaços de lazer e convivência. Parece ter havido um desencontro de objetivos quando vemos o playground localizado em uma posição tão periférica com relação a um conjunto implantado em $13.152 \mathrm{~m}^{2} \mathrm{e}$, por outro lado, áreas centrais, como as apontadas no diagrama de análise dos espaços exteriores (Figura 22), sem mobiliário adequado para as atividades de lazer e que, ainda assim, são apropriadas pelas crianças como espaço para brincar e jogar bola. Essas áreas centrais são os espaços mais generosos entre as áreas externas e localizadas em uma situação privilegiada por estarem cercadas pelos edifícios, protegidas pelos olhos dos moradores a partir das janelas dos apartamentos, o que não acontece com o playground. É certo que o playground foi apontado como bom exemplo de utilização dos espaços do recuo, porém, ainda que represente esse bom exemplo de utilização dos espaços periféricos, pelo menos ao que se pode analisar explorando o projeto, não justifica a falta de infraestrutura para os espaços que poderiam ser de lazer localizados no interior do conjunto. $O$ fato de não haver mobiliário adequado e do paisagismo concebido não ter sido realizado de acordo com o projeto, prejudicam a qualidade espacial dos espaços exteriores do conjunto que seguramente poderiam ser muito mais agradáveis.

Ainda sobre os espaços exteriores, vale ressaltar a falta de espaços adequados para estacionar motos, pois a ilusão de que essa situação se solucionará após a ocupação pelos moradores ou de que isso é um problema de cada morador é um engano, pois quando esses espaços não são devidamente projetados, os moradores encontram maneiras de solucionar sua falta e, na maioria dos casos, acabam invadindo áreas que poderiam ser utilizadas para o lazer para definir um estacionamento em local seguro para as motos. A falta de espaços para guardar grandes objetos como carrinhos e bicicletas também pode ser apontada aqui como uma deficiência, pois basta caminhar um pouco pelo conjunto que já será possível identificar esses objetos espalhados, presos aos 
guarda-corpos o que não é um problema estético, mas de praticidade da vida cotidiana se pensarmos em subir mais de quatro andares com uma bicicleta, por exemplo.

A análise geral do projeto também fica prejudicada pelo fato do Centro Comunitário não ter sido acabado e, o que é ainda mais grave, ter tido as obras paralisadas sem previsão para serem retomadas. Situações como essas são complicadas, pois levam à consolidação de espaços residuais que colaboram para a degradação dos espaços ao redor ou podem ainda estar sujeitos a serem invadidos. Os usos propostos para o Centro Comunitário complementariam o uso habitacional do conjunto com espaço para atividades culturais e esportivas, além de um espaço adequado para a administração e acima de tudo, representaria mais um equipamento público para a comunidade de Heliópolis.

Por outro lado, a análise desenvolvida também apontou pontos positivos do projeto que devem ser destacados para podermos refletir sobre eles e utilizá-los como referência para outras intervenções. O envolvimento do escritório de arquitetura com a associação de moradores que representava a demanda para a qual o conjunto estava sendo construído, é um fato importante a ser destacado, pois a participação dos moradores no desenvolvimento do projeto é muito positivo para que, futuramente, haja uma melhor apropriação dos espaços propostos. Além do mais, conhecer a demanda, permite que a equipe de arquitetura trabalhe sobre dados reais e possa buscar, a partir do projeto, atender às necessidades desses futuros moradores, como de fato ocorreu no Comandante Taylor com a oferta de unidades quitinete para as pessoas idosas da associação, que viviam sozinhas e também na definição do programa do equipamento implantando junto ao conjunto, um Centro de atividades para Idosos.

Quanto à implantação do conjunto, vale ressaltar a preocupação em adaptar a construção ao terreno evitando grandes movimentos de terra e contenções que muitas vezes não acrescentam qualidade aos projetos e ainda aumentam os custos da intervenção. A adoção de áreas verdes como filtros de privacidade para as unidades do térreo também é uma estratégia que deve ser destacada, pois nos conjuntos habitacionais o tema da privacidade 
dessas unidades é um fator bastante importante para o conforto e segurança dos moradores. É claro que o espaço verde não substitui o uso de grades nas janelas, porém, de forma mais agradável, procura afastar as circulações da proximidade com as janelas.

A concepção do "sistema de circulação" formado pelas torres de escada e passarelas e a utilização desse sistema para o desenvolvimento da obra, dispensando a utilização de andaimes, também é um ponto a ser comentado, pois a racionalização das construções é muito importante para um bom desenvolvimento da obra e economia de tempo e material. Aqui vale ressaltar ainda a oportunidade de utilizar o galpão existente como canteiro de obra para que sirva de referência para outros projetos buscando aproveitar da melhor maneira possível os elementos ou as construções que muitas vezes já existem nos terrenos.

Quanto às tipologias propostas, considera-se importante analisar as variações desenvolvidas durante o projeto em busca de soluções adequadas às diferentes situações. $O$ fato de que alguns tipos sofreram alteração na posição das janelas proporcionando novas visuais ou em busca de melhor ventilação e iluminação, mostra a preocupação com a qualidade dos espaços propostos e com a relação entre interior e espaços exteriores. $O$ dimensionamento dos ambientes não especializados e a integração espacial cozinha - estar [ainda que tenham sofrido alterações por parte dos moradores], são critérios aplicados na concepção da tipologia que devem ser considerados nos projetos habitacionais, principalmente quando trata-se de espaços com dimensões tão enxutas, as relações espaciais são fundamentais.

Apesar de não terem sido propostos espaços exteriores próprios, os alargamentos das passarelas nas entradas dos apartamentos, também representam uma solução que deve ser apontada pela oferta de qualidade espacial. Os chamados espaços de transição atuam como extensões às unidades e promovem a relação e a convivência entre os moradores, além de funcionarem também como filtro de privacidade. 
Por último, vale deixar registrado que durante a entrevista realizada com Renata $\operatorname{Semin}^{19}$, a arquiteta comentou a referência de um arquiteto suíço chamado Walter Fischer ${ }^{20}$. Ficou claro que a referência não está relacionada com a escala do projeto, mas sim com a qualidade dos espaços propostos, a transição a partir dos espaços exteriores até a chegada à unidade e até mesmo a incorporação do paisagismo na arquitetura que, infelizmente, não se vê aplicada no conjunto, mas pode-se perceber ao analisar os projetos de paisagismo propostos e as perspectivas desenvolvidas pelo escritório de arquitetura.

Concluir a análise desse projeto com esse registro significa reforçar a importância de explorar e conhecer referências. Ao desenvolver uma pesquisa que analisa a produção de habitação de interesse social, buscando visibilizar soluções de qualidade e apontar deficiências para que sirvam de exemplos para outros trabalhos, registrar as referências utilizadas e, perceber que existem projetos de qualidade sendo desenvolvidos pelo mundo que podem servir de inspiração para a produção paulista, pareceu uma consideração importante a ser feita.

${ }^{19}$ Entrevista realizada em setembro de 2013, em São Paulo.

${ }^{20}$ FISCHER, Walter. Conjunto de edifícios residenciais na cidade de Meilen, Suíça. 
4.2 ESTUDO DE CASO: CONJUNTO HABITACIONAL JARDIM EDITE 



\subsection{JARDIM EDITE}

\section{Conjunto Habitacional Jardim Edite}

Localização: esquina das Avenidas Engenheiro Luis Carlos Berrini e Jornalista Roberto Marinho

Distrito: Itaim Bibi - Subprefeitura: Pinheiros - Zona: Oeste

Distância até o centro da cidade: $10,9 \mathrm{Km}$.

Conclusão da obra: 2013 - início projeto: 2008

Arquitetura: MMBB + Hereñú \& Ferroni Arquitetos

Autores: Marta Moreira, Milton Braga e Fernando de Mello Franco +

Eduardo Ferroni e Pablo Hereñú

Equipe MMBB: Eduardo Martini, Marina Sabino, Giovanni Meirelles, Cecilia Góes, Gleuson Pinheiro Silva, Adriano Bergemann, André R. Costa, Maria João Figueiredo, Naná Rocha, Tiago Girao, Guilherme Pianca, Gisele Mendonça, Eduardo Pompeo

Equipe H+F: Tammy Almeida, Joel Bages, Natália Tanaka, Diogo Pereira, Gabriel Rocchetti, Thiago Benucci, Mariana Puglisi, Luca Mirandola, Thiago

Moretti, Bruno Nicoliello, Renan Kadomoto

Promoção: Programa de urbanização de favelas da Secretaria Municipal de Habitação de São Paulo (Sehab)

Coordenação Sehab: Luiz Fernando Arias Fachini

Área do terreno: $19.000 \mathrm{~m}^{2}$ / Área Construída: $25.700 \mathrm{~m}^{2}$

Coeficiente de aproveitamento: 1,35

no unidades habitacionais: $252 \mathrm{UHs}$

Densidade: $132 \mathrm{UHs} / \mathrm{ha}-477$ habitantes/ha ${ }^{1}$

Programa: Unidades Habitacionais / Restaurante Escola $\left(850 \mathrm{~m}^{2}\right)$ Unidade Básica de Saúde $\left(1.300 \mathrm{~m}^{2}\right) /$ Creche $\left(1.400 \mathrm{~m}^{2}\right)$

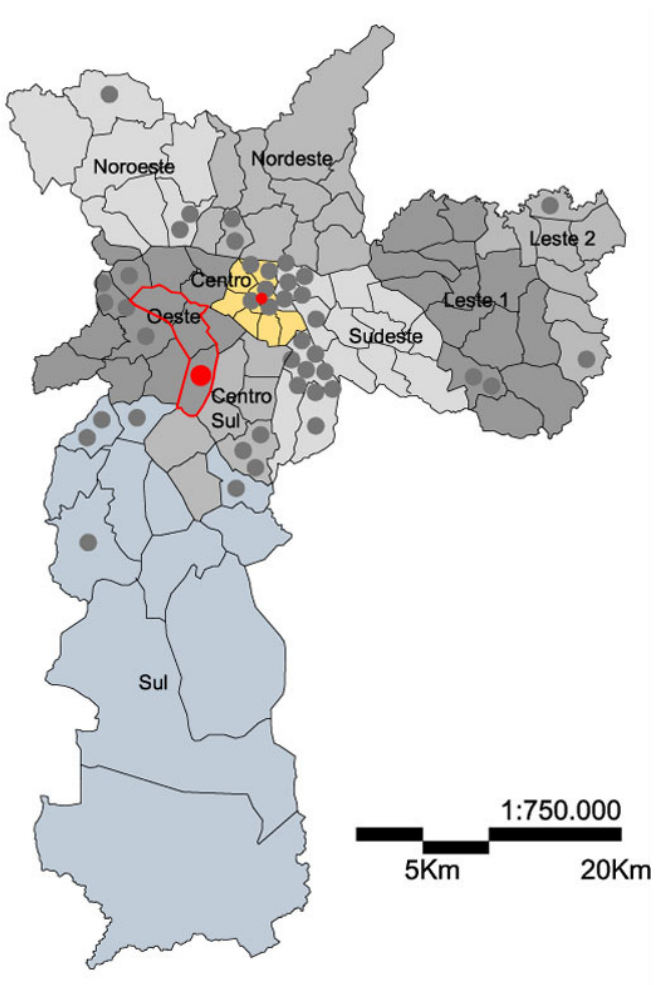

Figura 2 - Localização com relação à cidade.

${ }_{1}^{1}$ Foi adotada a média de 3,6 habitantes por unidade habitacional em aglomerados subnormais - fonte: IBGE, Censo Demográfico 2010, p. 33. 
O Conjunto Habitacional Jardim Edite ${ }^{2}$ localiza-se em um terreno de $19.000 \mathrm{~m}^{2}$ na esquina das avenidas Jornalista Roberto Marinho - antiga Água Espraiada - e Eng. Luis Carlos Berrini, uma importante área da cidade, em uma região bastante valorizada e bem atendida por infraestrutura, transporte, comércio e serviços. Anteriormente à construção do conjunto habitacional, o terreno era ocupado pela favela Jardim Edite onde viviam aproximadamente 845 famílias $^{3}$.

Em Parceiros da Exclusão, Mariana Fix (2001, p.38) comenta que, de acordo com depoimentos de moradores, a formação da favela começou no início dos anos 1970 "quando a Berrini 'era só mato' e aquele terreno era uma 'lagoa do rio Pinheiros'”. Porém, nessa época, a favela não se limitava apenas ao terreno de $19.000 \mathrm{~m}^{2}$. Segundo FIX, em 1995,

Entre a Marginal do rio Pinheiros e a Avenida Luís Carlos Berrini ficava a favela Jardim Edith, formada por aproximadamente 3 mil famílias, num terreno de 68 mil metros quadrados, ao lado da obra do Centro Empresarial Nações Unidas e do recém-inaugurado megaempreendimento World Trade Center, conjugado ao hotel 'cinco estrelas' Meliá e ao Shopping D\&D (FIX, 2001, p.37).

No final da década de 1970, a marginal do rio Pinheiros começou a transformar-se em um grande eixo de negócios e consumo impulsionando o desenvolvimento de um novo polo empresarial na região. FIX (2001, p.29) ressalta que, de meados dos anos 1980 até 2001, ocorreu uma grande valorização do solo na região da Berrini:

[...] o preço do metro quadrado passou de 100 para 2 mil dólares. No período entre 1992 e 1995, o segmento Marginal Pinheiros - Berrini foi um dos que apresentou maior valoração de preço do metro quadrado em

2 Durante a pesquisa percebeu-se que, em alguns momentos, o nome da favela aparecia com "th" (Edith) e em outros com "te" (Edite). Mariana Fix (2001) utiliza o termo "Jardim Edith", assim como aparece no site da associação de moradores. Porém, nas publicações da Secretaria Municipal de Habitação (Sehab) aparece o termo "Jardim Edite", portanto, nesse trabalho será adotado "Jardim Edite".

${ }^{3}$ De acordo com a Prefeitura de São Paulo, havia 845 famílias morando na favela Jardim Edite quando começaram os trabalhos de remoção em 2007. Fonte: BRITO, Luísa. Moradores de favela dizem que prefeitura dificulta liberacão de bolsa-aluguel. Em: G1: $O$ Portal de notícias da Globo, São Paulo, abril de 2009. Disponível em: <http://g1.globo.com/Noticias/SaoPaulo/0,,MUL1068190-5605,00.html>. Acesso em novembro de 2013. 
construções novas para fins comerciais: $57,5 \%$ superando a Paulista e a Faria Lima, que tiveram uma valorização de $24,3 \%$ e $13,1 \%$ (FIX, 2001, p. 30 e 31$)^{4}$.

Frente a toda valorização, foram propostas intervenções urbanas para garantir o acesso à região, porém, os meios de transporte priorizados foram os carros e o transporte aéreo. Segundo FIX (2001, p.32) a Emurb contratou, em 1994, projeto para um aeroporto de helicópteros que "foi proposto para uma área de 20 mil metros quadrados, entre a avenida Berrini e a Marginal Pinheiros, junto à avenida Água Espraiada", onde localizava-se a favela Jardim Edite.

Além do "aeroporto" proposto, estava sendo concluído, no mesmo período, o minianel viário, do qual fazia parte a avenida dos Bandeirantes e o complexo Maria Maluf e, para o fundo de vale por onde passa o córrego Água Espraiada, estava sendo construída uma via expressa que fazia parte de um projeto maior visando interligar a Marginal Pinheiros e a Berrini com o aeroporto de Congonhas e a rodovia dos Imigrantes, uma alternativa à avenida dos Bandeirantes que, até hoje não foi concretizada.

Conforme conta Mariana Fix (2001, p.37), no início dos anos 1970, o Governo do Estado desapropriou muitos imóveis para a construção da avenida Água Espraiada, porém, com a paralisação das obras - devido modificações no traçado do projeto - os imóveis abandonados acabaram sendo invadidos e várias favelas foram se formando ao longo do córrego. "Em 1995, eram 68 núcleos de favelas lineares, com uma população superior a 50 mil pessoas".

Para a construção das "infraestruturas" citadas acima - aeroporto para helicópteros e avenidas interligadas - uma boa parte dessas favelas foram removidas, entre elas a do Jardim Edite que localizava-se em uma região de interesse dos empresários da Berrini.

4 Dados apresentados por Mariana Fix com base no Relatório de Impacto Ambiental da Operação Urbana Água Espraiada (EIA-RIMA), Emurb. 
$\mathrm{Na}$ foto ao lado, retirada do livro Parceiros da Exclusão (2001), é possível identificar o córrego Água Espraiada, o trecho da favela Jardim Edite localizado entre a Marginal Pinheiros e a avenida Berrini que foi removido e também o trecho que permaneceu e que, recentemente, deu lugar ao Conjunto Jardim Edite permitindo que parte dos moradores se fixassem no local.

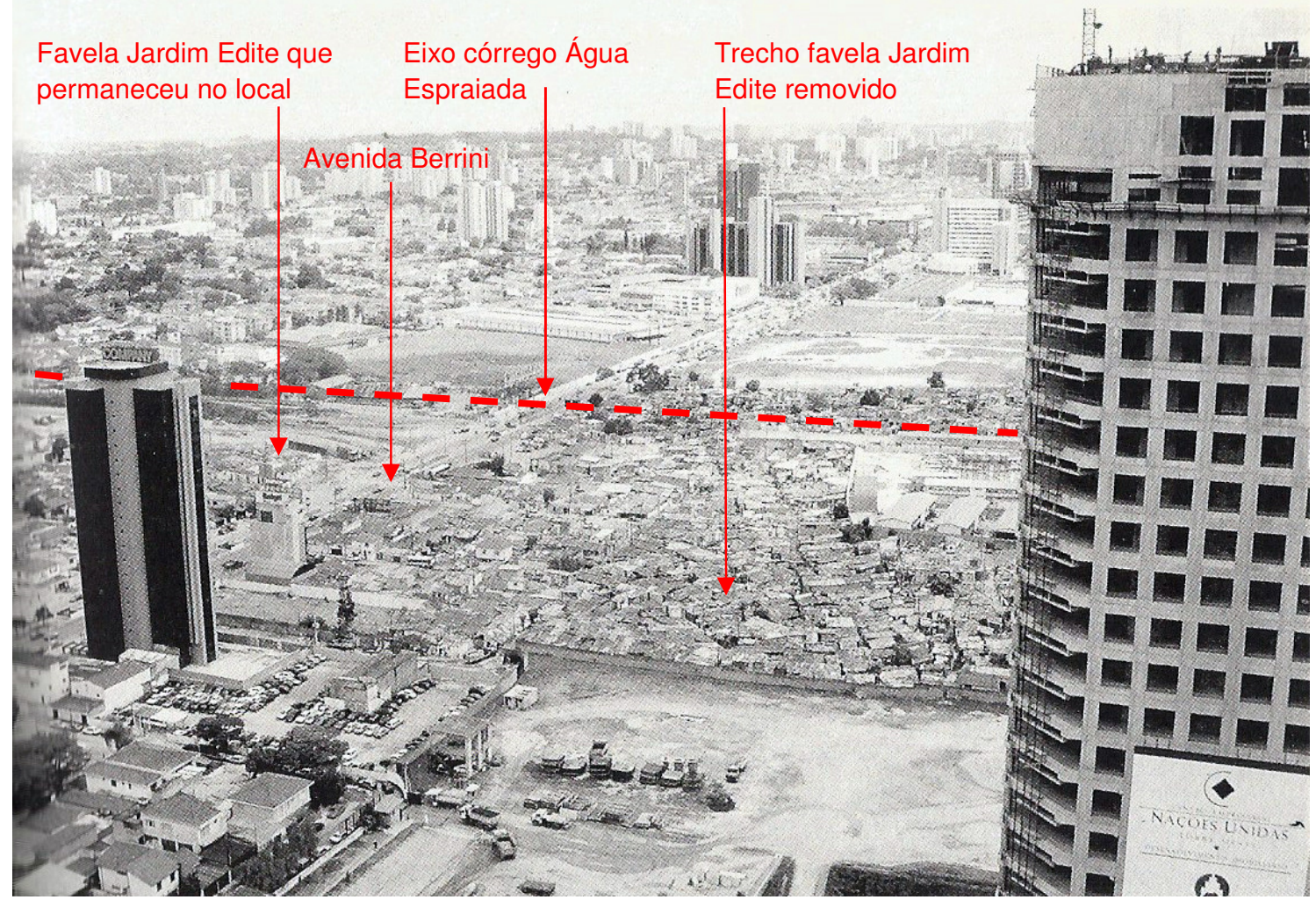

Figura 3 - Foto região da Berrini antes da remoção de parte da favela Jardim Edite.

FIX (2001, p.38) comenta que as famílias removidas tinham a opção de escolher entre comprar uma moradia financiada e construída pela Prefeitura; receber uma verba em dinheiro; ou ganhar uma passagem de volta para a "terra natal". Para as famílias que escolheram ser reassentadas, estavam sendo construídos apartamentos na Cidade Tiradentes, a 50 quilômetros da favela - um exemplo típico da remoção de favelas para a periferia da cidade. Entretanto, a situação das famílias do Jardim Edite era considerada "privilegiada" pelas assistentes sociais e responsáveis pelas remoções, pois contavam com a possibilidade de aguardar pela construção de unidades habitacionais em um terreno no Jardim Educandário - a apenas 15 quilômetros de distância - que havia sido 
comprado graças à "doação" de um grupo de empresários da Berrini ${ }^{5}$ - tamanha era a vontade que tinham de remover a favela daquela região. Posteriormente, verificou-se que parte da população removida migrou para outras favelas como Paraisópolis e Real Parque e até mesmo para as áreas de mananciais.

Na foto ao lado, também retirada do livro Parceiros da Exclusão (2001), é possível identificar terreno vazio entre a avenida Berrini e a Marginal Pinheiros após a remoção de parte da favela Jardim Edite. Está destacado o trecho que permaneceu, onde hoje foi construído o Conjunto Jardim Edite. Na legenda, Mariana Fix identifica os eixos viários e os futuros empreendimentos ao longo da Marginal.

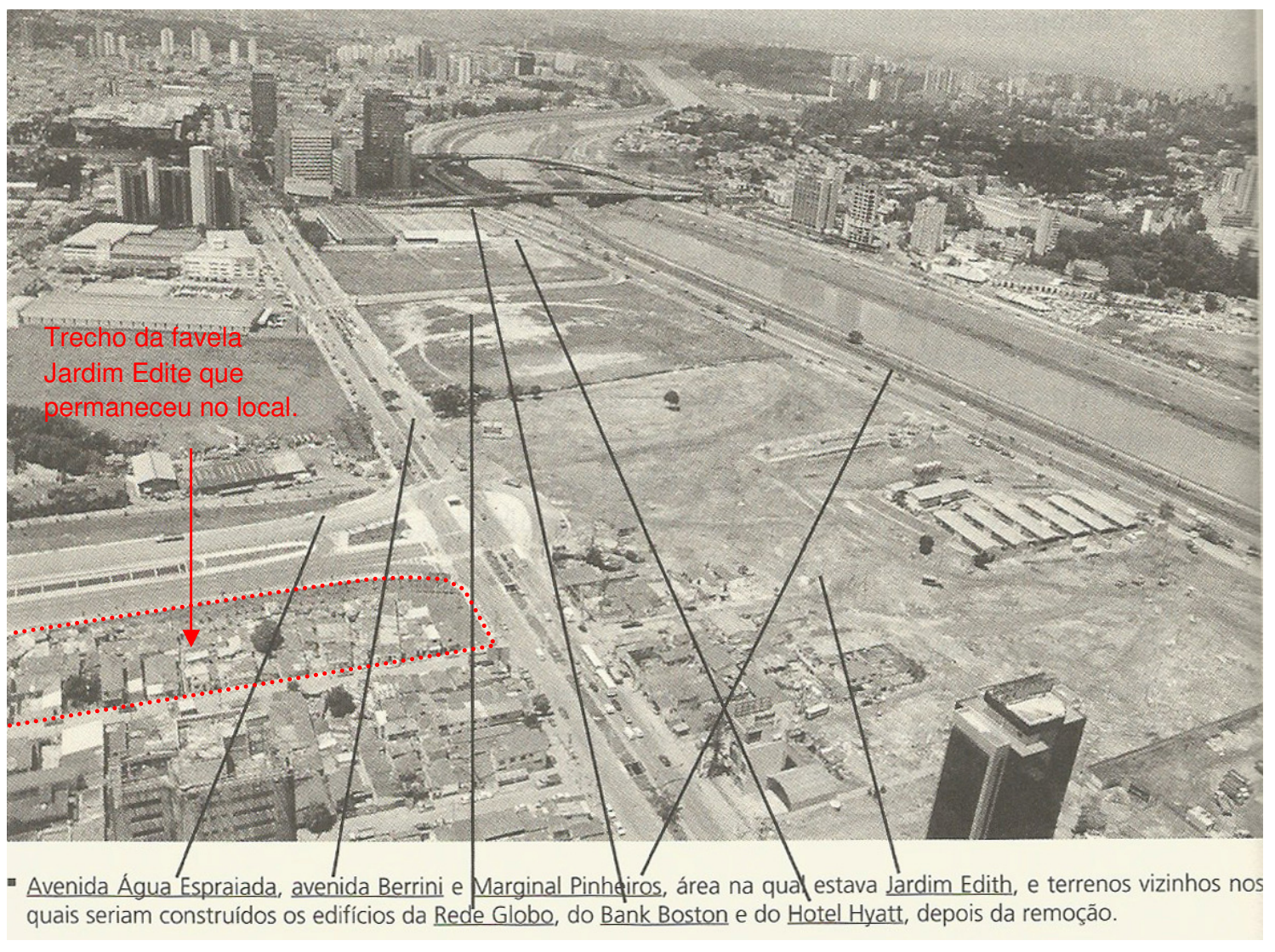

Figura 4 - Foto região da Berrini após a remoção de parte da favela Jardim Edite.

${ }^{5}$ Mariana Fix refere-se a doações de um pool de empresários que verificaram que a retirada dos "favelados" representaria um ganho imobiliário incrível. Dessa forma, entendemos que encontraram uma maneira de dar um "empurrãozinho" nas remoções que, financeiramente, seriam muito compensatórias. 
Maria Cecília Fontes (2011, p. 107) esclarece que, com a aprovação da Lei da Operação Urbana Consorciada Água Espraiada (OUCAE), em 2001, e do novo Plano Diretor Estratégico, em 2002, iniciaram-se novas prerrogativas sobre a área remanescente da favela Jardim Edite. A área foi definida como Zona Especial de Interesse Social (ZEIS 1), certificando-se assim, que apenas fosse permitido o uso de interesse social para esse terreno. "O novo projeto da Operação Urbana previa a construção de uma ponte estaiada ${ }^{6}$ sobre o Rio Pinheiros e a construção de 6 mil unidades habitacionais de interesse social distribuídas por toda a extensão da avenida [Jornalista Roberto Marinho]".

A partir de 2007 a Prefeitura voltou a intervir no terreno da favela Jardim Edite. Segundo artigo publicado no G1, em abril de 2008:

Em outubro de 2007 a prefeitura passou a oferecer às famílias [moradores do Jardim Edite] um cheque-despejo no valor de $\mathrm{R} \$ 5$ mil a $\mathrm{R} \$ 8$ mil ou moradia no conjunto habitacional da CDHU, no Campo Limpo. Cerca de 500 famílias aceitaram a proposta e outras 300 permaneceram na favela.

Na área em que a comunidade está instalada, afetada pelo programa de intervenção urbanística do município, está prevista a construção de um complexo viário ligando a Avenida Jornalista Roberto Marinho à Marginal Pinheiros.

Na determinação, o juiz da 13 $3^{\underline{a}}$ Vara da Fazenda Pública exige "uma efetiva e concreta política habitacional" que "prevê o reassentamento definitivo das famílias atingidas pelas obras, enquanto o Estatuto da Cidade também exige um programa de atendimento econômico e social para a população diretamente afetada pela operação". (G1, 04/04/08).

Em uma matéria publicada na Revista Projeto Design em julho de 2013, podemos identificar os destinos das famílias removidas da favela Jardim Edite:

${ }^{6}$ Com obras iniciadas em 2003, a ponte estaiada Octávio Frias de Oliveira foi inaugurada em maio de 2008. 
Após uma primeira rodada de desapropriações, saíram 199 famílias em 2005 - por causa da obra viária vinculada à construção da ponte estaiada Octávio Frias de Oliveira -, um incêndio de grandes proporções, em 2007, foi o estopim para que a prefeitura anunciasse o fim da favela, com a retirada de mais de 700 famílias residentes.

Um convênio da Secretaria Municipal de Habitação (Sehab) com a Caixa Econômica Federal e a Companhia de Desenvolvimento Habitacional e Urbano do Estado de São Paulo (CDHU) desenhou o mapa de distribuição dessa população pela cidade: 244 famílias optaram pelo recebimento de ajuda de custo (5 mil reais), e partiram; 130 decidiram comprar um imóvel popular; uma família escolheu a obtenção de carta de crédito; 118 se mudaram para empreendimento da CDHU; 54 preferiram morar de aluguel, pago pela prefeitura, até que terminasse a obra do conjunto Estevão Baião (ainda em construção, com projeto de Marcelo Suzuki).

As restantes se beneficiaram da resposta à ação judicial movida pelos moradores, que determinou em 2008 a construção de novas unidades habitacionais na área da extinta favela (GRUNOW, em: Revista Projeto Design, julho de 2013).

O senhor Gerôncio Henrique, presidente da associação de moradores do Jardim Edite desde 2002, comenta que conseguiram entrar em acordo com a Prefeitura de São Paulo, em setembro de 2008, definido a construção de unidades habitacionais no local. O presidente da associação acrescenta que também negociaram a implantação de uma AMA - posto de saúde - creche e escola técnica; e que os moradores saíram pacificamente em 2009, contando com o auxílio bolsa-aluguel durante o período em que o conjunto estava sendo construído (informação verbal $)^{7}$.

7 Depoimento Sr. Gerôncio Henrique (presidente da associação de moradores do Jardim Edith). Museu da Pessoa. Disponível em: <http://www.youtube.com/watch?v=86PIXXZBDfU\#t=226>. Acesso em novembro de 2013. 
Evelise Grunow complementa o texto da Revista Projeto concluindo que "arquitetos e Sehab iniciaram assim a criação de 240 unidades (número que depois subiu para 252) e três equipamentos públicos: uma creche, uma unidade de saúde e um restaurante-escola (demanda dos moradores), para a formação de mão de obra afinada com o entorno, notadamente corporativo" (GRUNOW, em: Revista Projeto Design, julho de 2013).

Cícera, uma moradora do conjunto Jardim Edite que atualmente faz parte do corpo de assistentes sociais que trabalham nas obras do conjunto habitacional Real Parque, comentou que vive no Jardim Edite há aproximadamente trinta anos. Na época em que a primeira parte da favela foi removida, foi, junto com sua mãe e irmã, morar na favela Real Parque - do outro lado do Rio Pinheiros. Voltou a viver no Jardim Edite no início dos anos 2000 e, após a intervenção da Secretaria de Habitação, foi atendida como demanda recebendo um apartamento na torre 2. Cícera contou que, durante a construção do conjunto, alugou um apartamento nos edifícios Cingapura do Real Parque com o auxílio do bolsa-aluguel (informação verbal) ${ }^{8}$.

Assim, o Conjunto Habitacional Jardim Edite foi concluído no início de 2013, reafirmando o direito dos moradores de permanecerem no local onde já habitavam, ainda que estejam em meio a uma zona supervalorizada da cidade, cercados por edifícios empresariais.

O conjunto de 252 unidades habitacionais + creche + Unidade Básica de Saúde (UBS) + restaurante-escola, apresenta uma densidade aproximadamente três vezes menor que a da favela existente no local anteriormente $e$ cinco vezes maior se comparada às densidades do distrito e da subprefeitura.

${ }^{8}$ Entrevista com moradora do conjunto Jardim Edite durante visita à sua residência. São Paulo, 17 de dezembro de 2013. 
Tabela 1- Densidade do Conjunto com relação à comunidade, distrito e subprefeitura.

Por se tratar de uma ZEIS em área de Operação Urbana, o Coeficiente de Aproveitamento (C.A.) permitido para o terreno da favela Jardim Edite seria 4, ou seja, seria possível construir até quatro vezes a área do terreno (19.000 x $4=76.000 \mathrm{~m}^{2}$ ). Questionados sobre o assunto, os arquitetos comentaram que, após vários estudos e diferentes arranjos, decidiram (em comum acordo com os moradores e com a Sehab) pela solução construída que, apesar de atingir um C.A. de apenas 1,35, atendeu à demanda e permitiu desenvolver uma proposta que se relacionasse "de igual para igual" com os edifícios ao redor. Segundo Milton Braga, a definição das torres que, consequentemente exigiram a implantação de elevadores, também está relacionada à relação que buscaram estabelecer com o entorno altamente verticalizado (informação verbal) ${ }^{12}$.

${ }^{9}$ Para obter dado sobre a densidade da comunidade Jardim Edite, multiplicou-se o número de famílias que viviam no local em 2007 (845 famílias), por 3,6 (média de acordo com IBGE 2010). Chegou-se ao resultado de 3.042 famílias vivendo no terreno de $19.000 \mathrm{~m}^{2}$ (1,9ha), sendo assim, concluiu-se que a densidade da comunidade era de aproximadamente 1.601 habitantes por hectare antes do início das remoções.

10 Fonte: Dados Demográficos dos Distritos pertencentes às Subprefeituras, site da prefeitura de São Paulo, disponível em: http://www.prefeitura.sp.gov.br/cidade/secretarias/subprefeituras/subprefeituras/dados demograficos/. Acesso em setembro de 2013.

11 lbid. 3.

12 BRAGA, Milton. Palestra: Programa de Pós Graduação da Faculdade de Arquitetura e Urbanismo da USP - Disciplina: Arquitetura Contemporânea Paulista / Crítica de arquitetura. Professores responsáveis: Mônica Junqueira de Camargo; Hugo Segawa. São Paulo: 17 de julho de 2013 


\subsubsection{ESCALA CONJUNTO}

A partir da análise dos valores de proximidade é possível verificar que o Conjunto habitacional Jardim Edite está localizado em uma região bem estruturada e atendida por transporte público. Considerando-se o raio de 600 metros, verifica-se que há várias linhas de ônibus que passam pela região conectando-a a diferentes partes da cidade. Duas estações de trem da CPTM estão próximas ao raio de 1.000 metros e, está em construção, no terreno em frente ao Jardim Edite, a futura estação Brooklin da Linha 17 - ouro do metrô.

A avenida Berrini e a Jornalista Roberto Marinho foram identificadas como importantes eixos viários para o bairro e são avenidas com um fluxo muito intenso de veículos, assim como a Marginal do Rio Pinheiros / Avenida das Nações Unidas.

As avenidas Padre Antônio José dos Santos, Luís Carlos Berrini e Morumbi foram identificadas como importantes eixos de serviços e comércio.

Apesar dos raios de proximidade atingirem a outra margem do Rio Pinheiros, é importante ressaltar que a comunicação entre os dois lados não acontece com muita facilidade, tanto por transporte público, como caminhando. Os ônibus que cruzam o rio levam aproximadamente vinte minutos para realizar o trajeto. É possível cruzar as pontes caminhando, porém o espaço para pedestres não é muito adequado e seguro. Esse percurso pode inclusive ser bastante perigoso em horas do dia com pouco movimento, portanto, não podemos considerar que os moradores do Jardim Edite tenham acesso fácil aos equipamentos e serviços existentes do outro lado do Rio Pinheiros.

Quanto à oferta de equipamentos, verificou-se que há escolas públicas no entorno do conjunto, porém não foi possível verificar se são suficientes para atender à demanda local. É importante destacar que foi implantada uma creche no térreo do conjunto para atender à demanda dos moradores. 


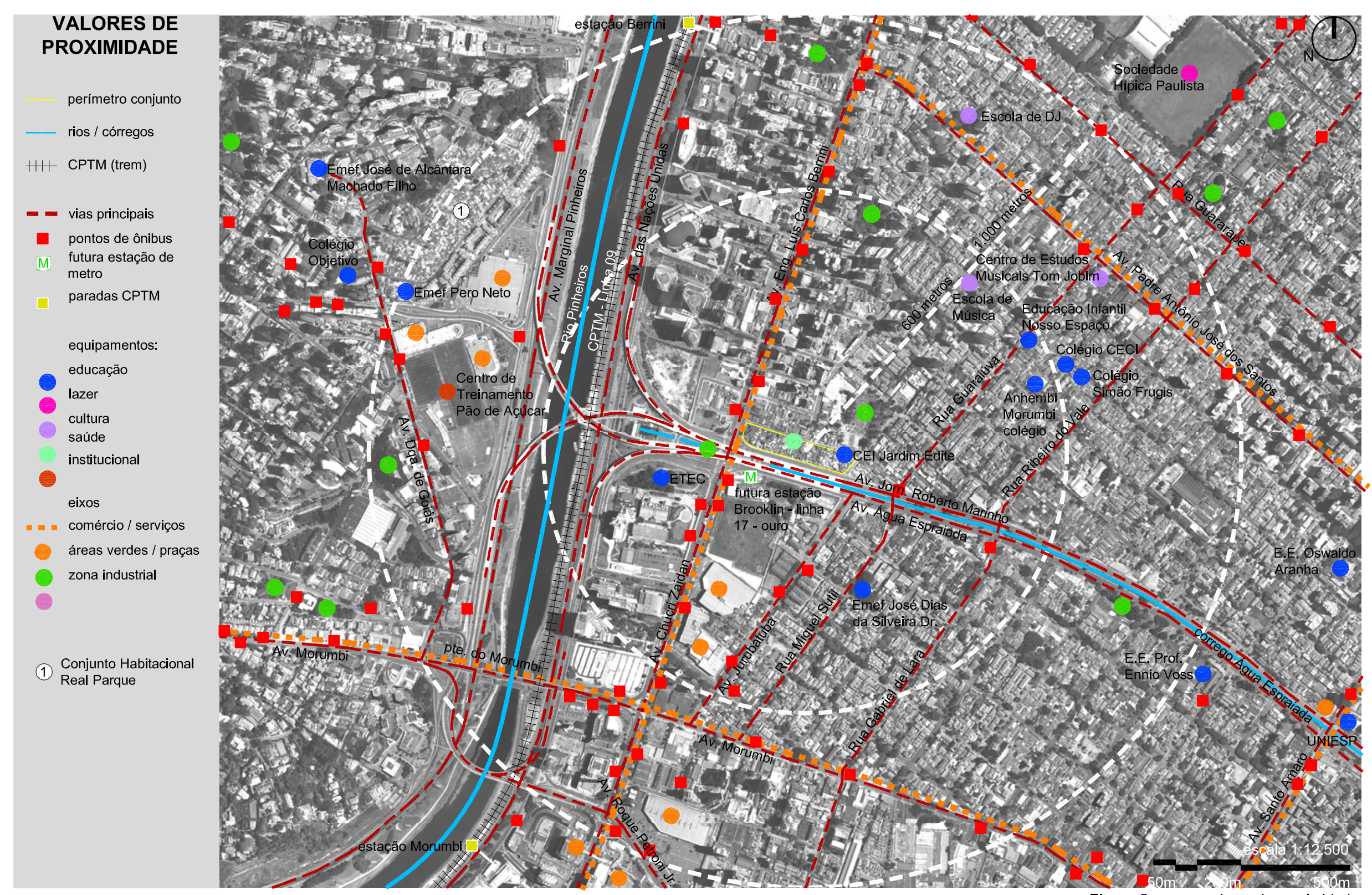


Além da creche, também foi implantada uma UBS (Unidade Básica de Saúde) e, pelo o que foi possível verificar com o desenvolvimento desse mapa de valores de proximidade, é o único posto de atendimento público nas proximidades.

Segundo os moradores, tanto a creche, como o posto de saúde, oferecem bom atendimento. A moradora Ana Paula, vizinha de Cícera - moradora que viveu no conjunto Real Parque durante certo tempo -, conta que conseguiu vaga na creche para seu filho, mas que, para o próximo ano, já há fila de espera para vagas, dependendo da idade.

As moradoras também comentaram que a região é bastante cara, inclusive "o preço do pão" e que, para fazer compras, precisam ir até os supermercados próximos ao aeroporto de Congonhas - o que extrapola o raio de proximidade -. Por outro lado, elogiam muito a rede de transporte público (informação verbal) ${ }^{13}$.

O entorno do conjunto é caracterizado pelos "altos" edifícios empresariais que atraem um grande número de pessoas para a região durante a semana em horário comercial e que, durante a noite e finais de semana apresentam uma forte diminuição do movimento. Afastando-se um pouco do eixo Berrini em direção à Avenida Santo Amaro, identifica-se um bairro predominantemente residencial e de baixa densidade.

Foi possível notar, ainda, a pouca oferta de equipamentos de cultura e lazer. No entorno, não foram identificadas bibliotecas, teatros ou centros culturais e as praças e espaços verdes existentes, parecem poucos para o bairro e nem todas possuem espaços para o lazer. Afortunadamente, a praça Arlindo Rossi, em frente ao Jardim Edite, tem uma área maior e quadras esportivas que pode ser utilizada pelos moradores (Figura 6). Segundo as moradoras Cícera e Ana Paula, essa praça é muito movimentada durante os finais de semana e bastante frequentada pelos moradores do conjunto.

${ }^{13}$ Entrevista com as moradores Cícera e Ana Paula do conjunto Jardim Edite durante visita a suas residências. São Paulo, 17 de dezembro de 2013. 


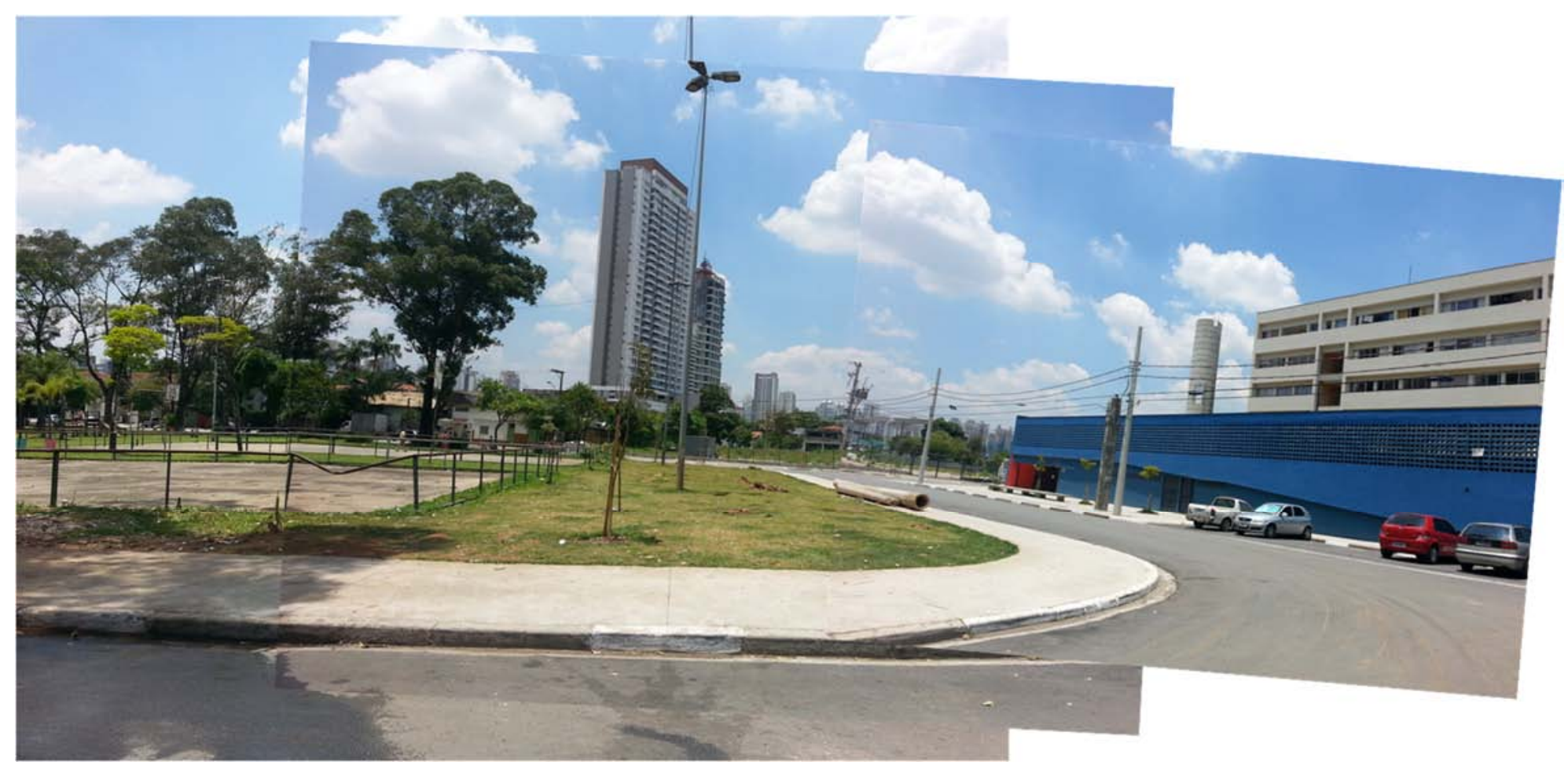

Figura 6 - Montagem Praça Arlindo Rossi + entrada Creche Jardim Edite (direita).

\subsubsection{INSERÇÃO URBANA}

O conjunto configura-se em duas quadras, separadas por um viário que havia sido ocupado pela favela, e que foi recuperado pelo projeto (Rua George Ohm). 
As ruas que contornam o conjunto apresentam características bastante distintas: enquanto a Avenida Berrini possui um caráter de maior fluxo, símbolo de um eixo empresarial e a Avenida Roberto Marinho um importante eixo de conexão para a cidade, dando continuidade à ponte Estaiada (Viaduto José Bonifácio Nogueira), as Ruas Araçaíba e George Ohm já apresentam um caráter mais local, de bairro, como pode ser verificado (Figura 6; Figura 7).

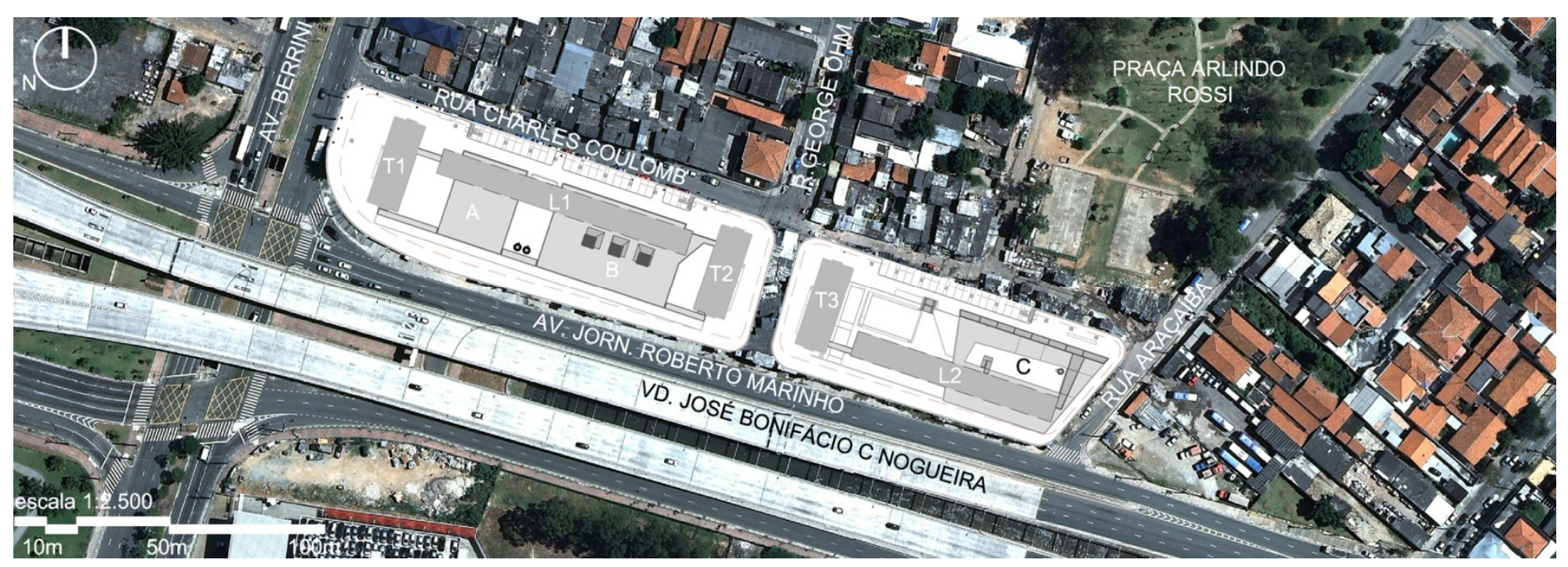

Figura 7 - Inserção urbana / implantação.

\section{Programa}

Os equipamentos públicos foram implantados no térreo do conjunto e o setor residencial encontra-se acima, configurado por três torres (T1; T2; T3) e duas lâminas (L1; L2).

Na quadra 1 foram implantados o restaurante-escola (A) e a UBS (B). O restaurante-escola possui $850 \mathrm{~m}^{2}$ de área construída e, até o momento [novembro de 2013], ainda não está funcionando. Os arquitetos comentaram que a prefeitura ofereceu a gestão do restaurante para o Senac que não mostrou interesse, pois segundo explicaram, já 
tinham uma unidade nas proximidades e, com isso, estavam buscando outros parceiros (informação verbal) ${ }^{14}$. A UBS, com $1.300 \mathrm{~m}^{2}$ complementa o térreo dessa quadra e já está em funcionamento.

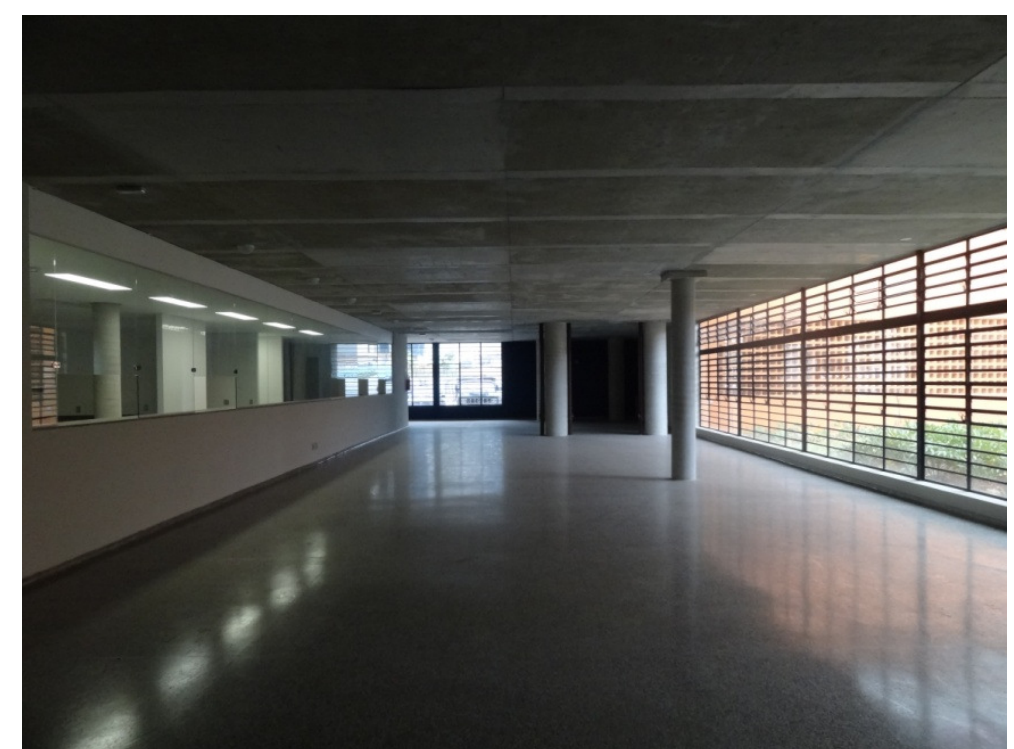

Figura 8 - Interior do restaurante - escola, ainda não ocupado.

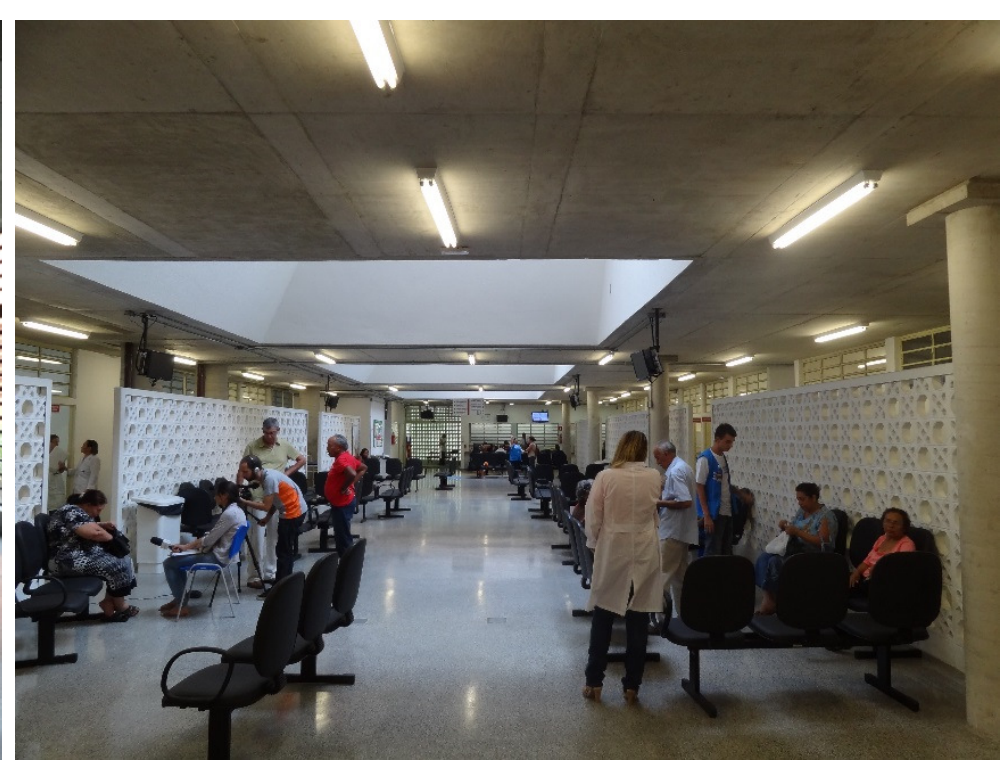

Figura 9 - Interior da UBS antes de começar a ser utilizada.

No térreo da quadra 2 foi implantada a Creche Municipal Jardim Edite (C), com $1.400 \mathrm{~m}^{2}$ que já está em funcionamento. Conforme pode ser observado (Figura 10; Figura 11), a área de uso condominial dos edifícios localiza-se sobre os equipamentos implantados no térreo.

14 MOREIRA, Marta; FERRONI, Eduardo. Visita ao Conjunto Habitacional Jardim Edite acompanhada pelos arquitetos. Visita promovida pela disciplina: Arquitetura Contemporânea Paulista / Crítica de arquitetura. Professores responsáveis: Mônica Junqueira de Camargo; Hugo Segawa. São Paulo, 24 de julho de 2013. 
As 252 unidades habitacionais estão distribuídas nas três torres de 17 andares $(T+16)$ e nas duas lâminas, inseridas entre as torres, de cinco andares sendo que os apartamentos do último pavimento são duplex. As unidades possuem aproximadamente $50 \mathrm{~m}^{2}$ e, segundo publicado na Revista Projeto Design de julho de 2013, "simultaneamente, os moradores, representados em audiências públicas, posicionaram-se contra a criação de quitinetes ou apartamentos de um dormitório, de modo a desenhar-se o quadro qualitativo do complexo: unidades de dois dormitórios, servidos por sala, cozinha e área de serviço" (GRUNOW, em: Revista Projeto Design, julho de 2013).
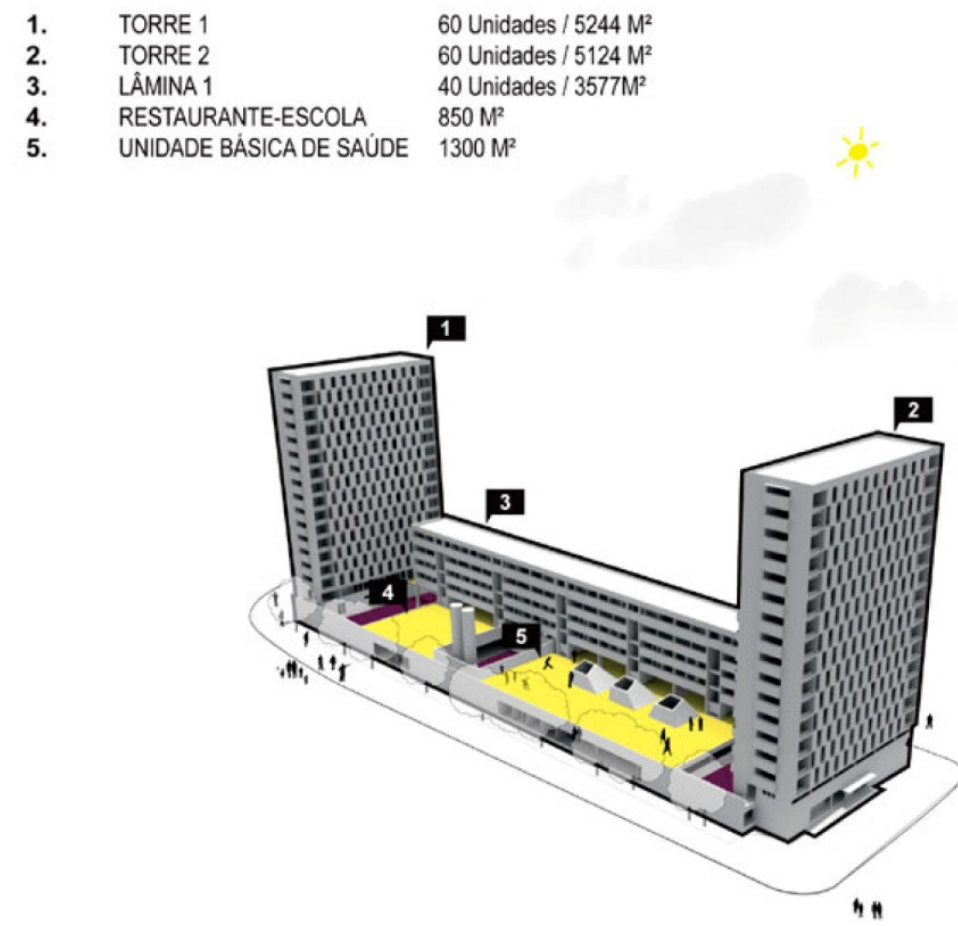

Figura 10 - Setorização do programa - quadra 1. Desenhos elaborados pela equipe de arquitetos.

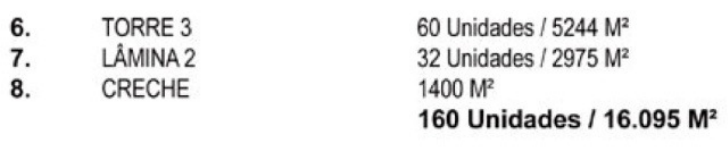

160 Unidades / $16.095 \mathrm{M}^{2}$

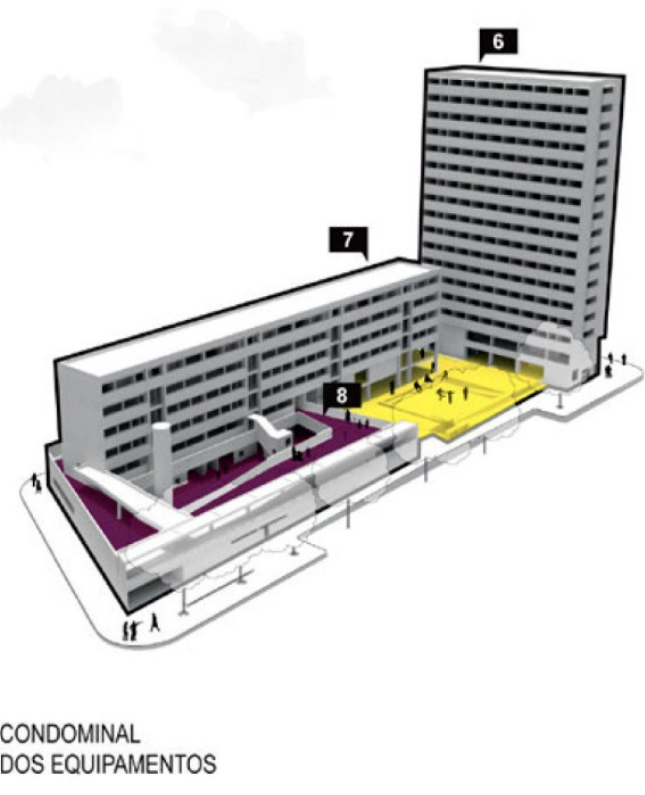

ÁREAS DE USO DOS EQUIPAMENTOS

Figura 11 - Setorização do programa - quadra 2. Desenhos elaborados pela equipe de arquitetos. 


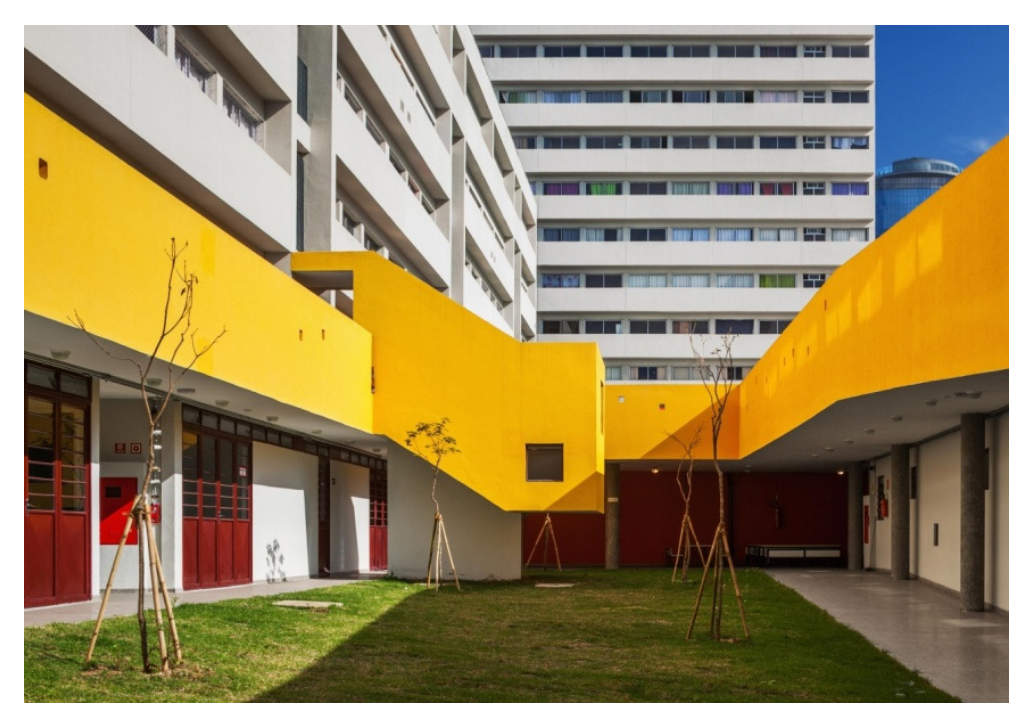

Figura 12 - Pátio da Creche Municipal Jardim Edite com parte da lâmina 2 à esquerda e da torre 3 ao fundo.

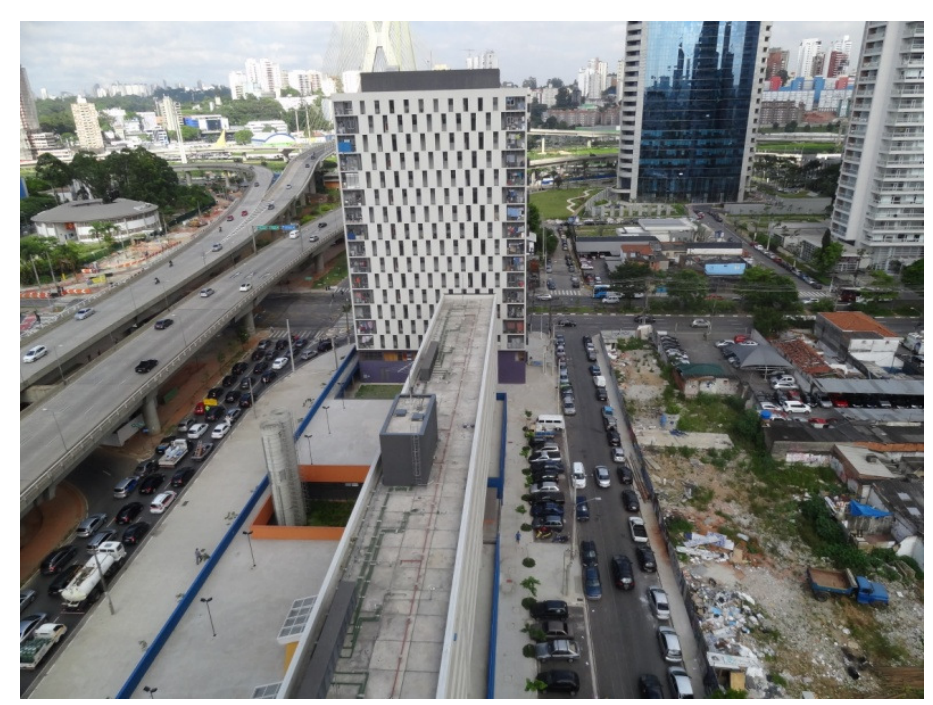

Figura 13 - Espaço condominial sobre a UBS e o restaurante escola. À direita, lâmina $1 \mathrm{e}$ ao fundo, torre 1.

\section{Ocupação do terreno}

A partir da análise das projeções das áreas construídas e espaços livres sobre o terreno, algumas conclusões são possíveis, como verificar que a porcentagem de área de circulação é pequena, enquanto os espaços livres de uso público são praticamente o dobro do espaço livre privado. Isso acontece, pois segundo os arquitetos, foi decidido doar os recuos como parte do passeio público aumentando o tamanho das calçadas que circundam o conjunto.

Ao observar a projeção das áreas construídas, é possível identificar 10,42\% de uso misto que acontece nos momentos em que há sobreposição de usos, quando os edifícios habitacionais encontram-se sobre os equipamentos. Entretanto, também seria possível identificar essa sobreposição quanto aos espaços livres de uso 
privado, pois se considerarmos que os tetos dos equipamentos são utilizados como áreas de lazer condominial, esses "tetos" poderiam ser somados à porcentagem desses espaços.

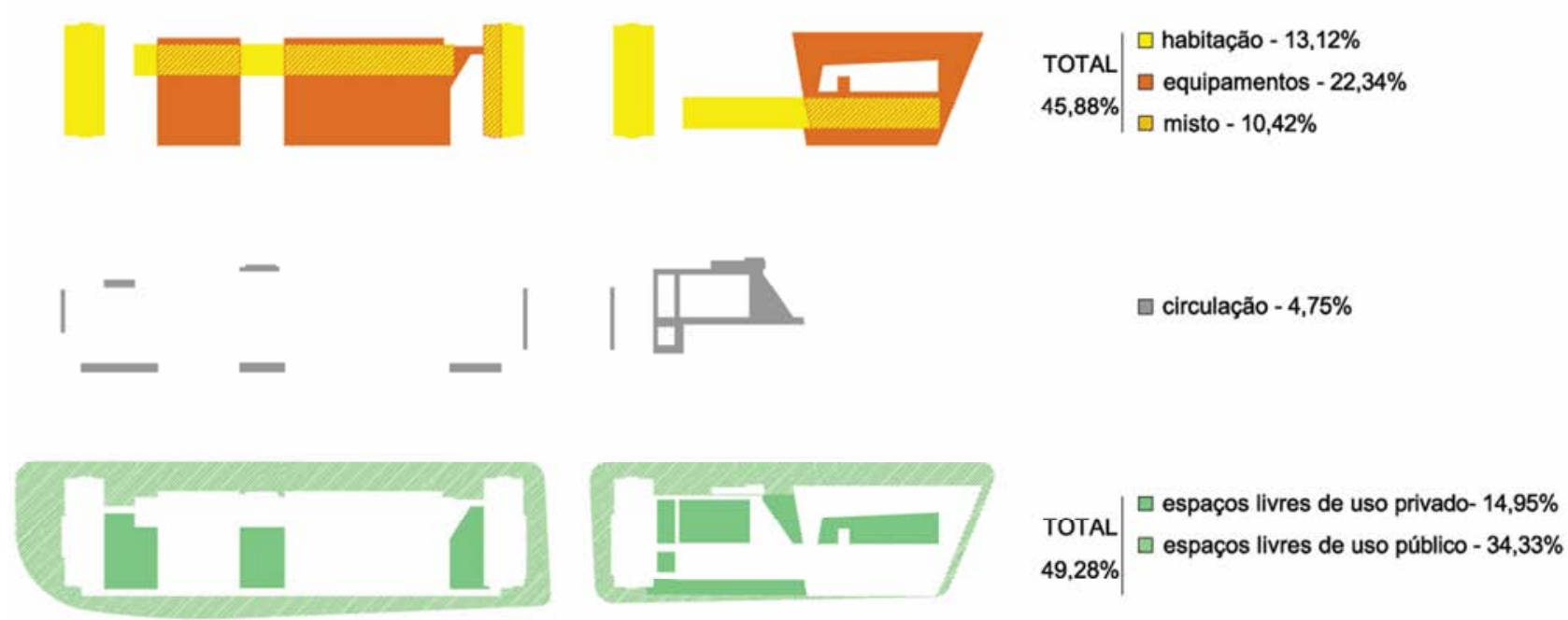

Figura 14 - Ocupação do térreo a partir da projeção das áreas construídas e espaços livres.

\section{Definição do limite \\ do conjunto}

Conforme comentado no item anterior, os recuos foram doados como espaço público, evitando, dessa forma, a delimitação do lote com muros ou gradis e a formação de espaços que poderiam se tornar residuais. Assim, o limite das edificações se relaciona diretamente com a rua e as calçadas ganharam maiores dimensões. 
Ao observarmos a calçada da Avenida Roberto Marinho (Figura 15), notamos um grande alargamento, porém, é importante considerar que, para esse trecho, existe previsão de alargamento da avenida que diminuirá um pouco essa calçada. Quanto à Rua Charles Coulomb, parte do alargamento foi utilizada para demarcar vagas para automóveis ao longo do conjunto (Figura 16).

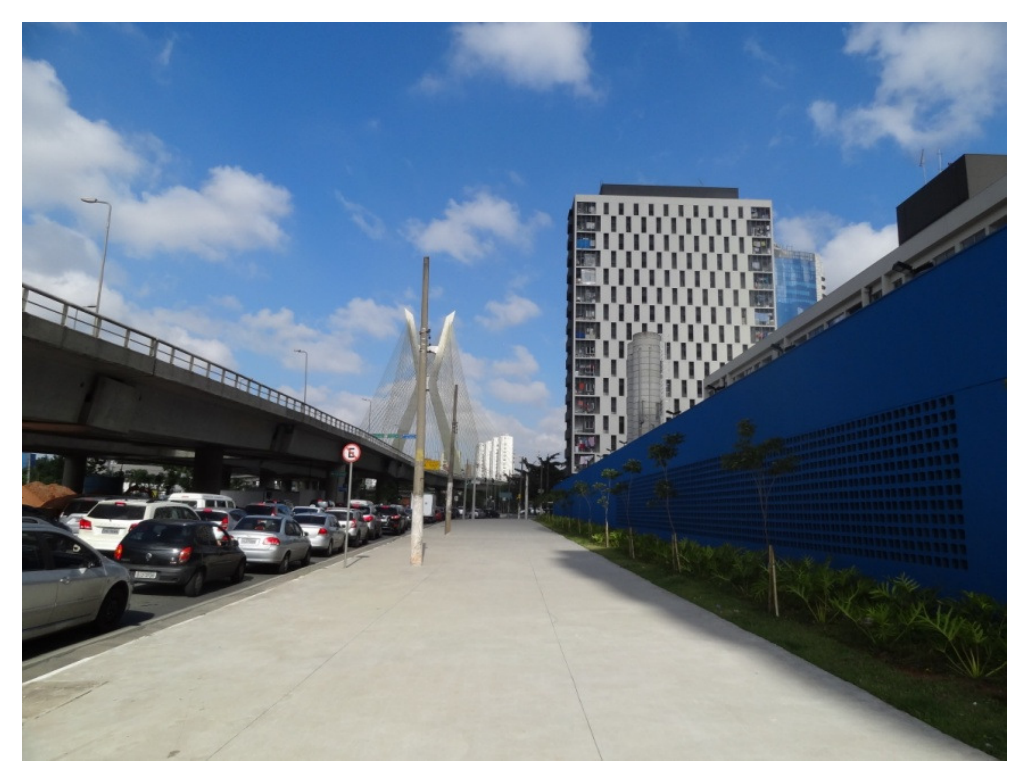

Figura 15 - Calçada Av. Jorn. Roberto Marinho

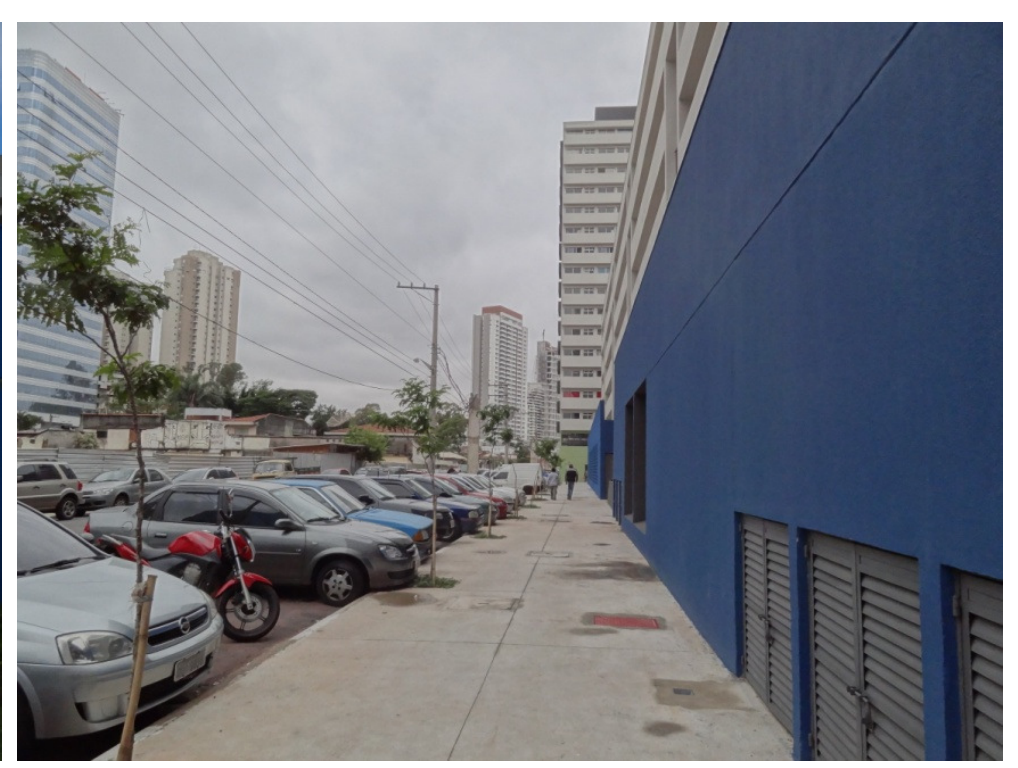

Figura 16 - Calçada Rua Charles Coulomb

Essas vagas são bastante disputadas, pois além dos moradores, há muitas pessoas que trabalham e/ou frequentam a região e buscam vagas públicas. Com isso, os moradores começaram a desenvolver uma maneira de reservar suas vagas demarcando no chão o número dos apartamentos (Figura 17). De forma geral, as vagas foram concebidas como espaço público e não poderiam ter sido apropriadas com exclusividade pelos moradores, porém, a questão das garagens é um tema bastante polêmico dentro da Secretaria de Habitação que, apesar de ter conhecimento sobre a necessidade de assumir que os moradores possuem carros e precisam de um lugar 
apropriado para estacionar, vive o conflito de que isso significaria investir dinheiro, em estacionamento, que poderia estar sendo destinado à construção de outras unidades habitacionais.

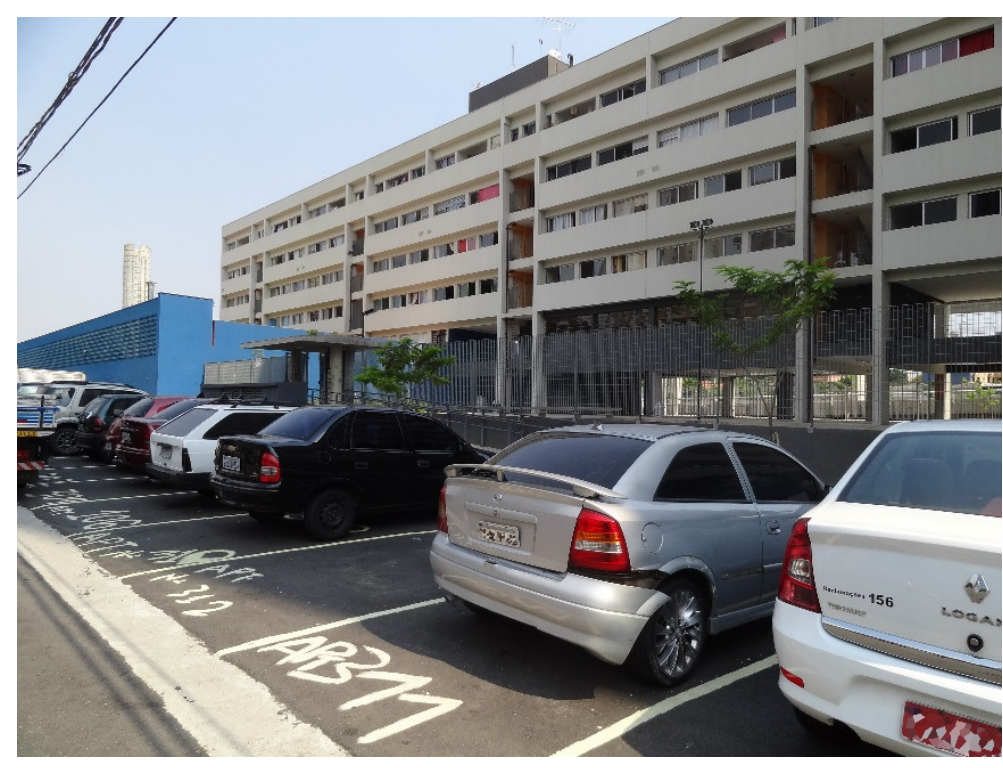

Figura 17 - Vagas demarcadas pelos moradores.

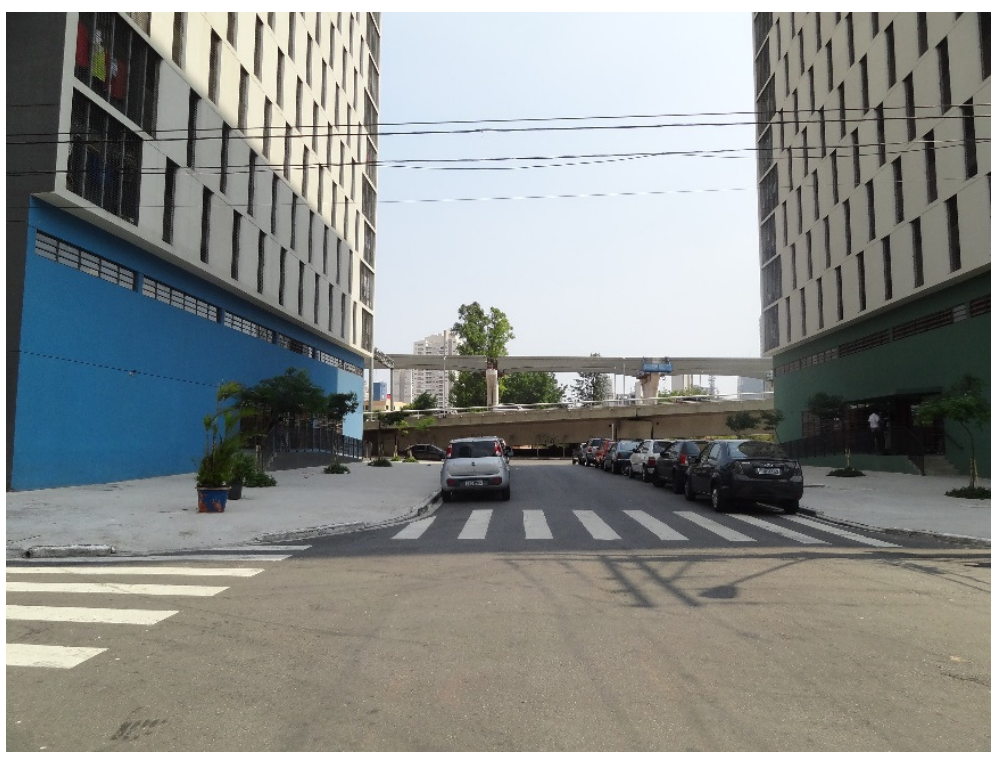

Figura 18 - Rua George Ohm, entradas torres 2 (direita) e 3 (esq.).

Os acessos aos edifícios habitacionais estão diretamente conectados com a rua, como pode ser observado na Figura 18, onde vemos as entradas das torres 2 e 3. Os acessos aos equipamentos (creche, UBS e restauranteescola) dão para a Rua Charles Coulomb e não para a Avenida Jornalista Roberto Marinho. Segundo os arquitetos, essa foi uma maneira que encontraram para garantir maior movimento de pessoas nessa rua mais tranquila e evitar a intensidade da outra avenida (informação verbal) ${ }^{15}$. Porém, para a Avenida Jorn. Roberto Marinho, o limite

${ }^{15}$ MOREIRA, Marta; FERRONI, Eduardo. Visita ao Conjunto Habitacional Jardim Edite acompanhada pelos arquitetos. Visita promovida pela disciplina: Arquitetura Contemporânea Paulista / Crítica de arquitetura. Professores responsáveis: Mônica Junqueira de Camargo; Hugo Segawa. São Paulo, 24 de julho de 2013. 
do conjunto acabou resultando em um longo muro azul que não estabelece relação com a cidade e parece, inclusive, funcionar como filtro a essa avenida de grande fluxo (Figura 15).

Nesse momento, poderíamos nos perguntar: Que relações o conjunto poderia estabelecer com uma avenida com um forte fluxo de veículos e que, além do mais, está em um ponto de conexão com um viaduto? É verdade que a avenida apresenta essas características, porém, seria importante pensar nas pessoas que caminham por essa lateral, ou a melhor opção foi mesmo "proteger" o conjunto dessa avenida?

Os próprios arquitetos comentaram que chegaram a se questionar sobre a falta de permeabilidade dessa lateral, porém, ao desenvolver os projetos, decisões precisam ser tomadas e, nesse caso, definiu-se que esse seria o limite do conjunto com a cidade.

\section{Adaptação ao terreno}

Quanto à adaptação ao terreno, o conjunto foi implantado em terreno praticamente plano. Como pode ser observado nas elevações, a implantação é constante e não há diferenças de nível significativas (Figura 21).

Sendo assim, o conjunto foi implantado em terreno plano e, para solucionar a privacidade dos equipamentos e espaços condominiais, utilizou-se de dois térreos: um no mesmo nível que a rua onde estão os acessos; e o pavimento condominial, que atende aos edifícios habitacionais e foi implantado sobre os equipamentos, como podemos observar nas implantações (Figura 19; Figura 20). 


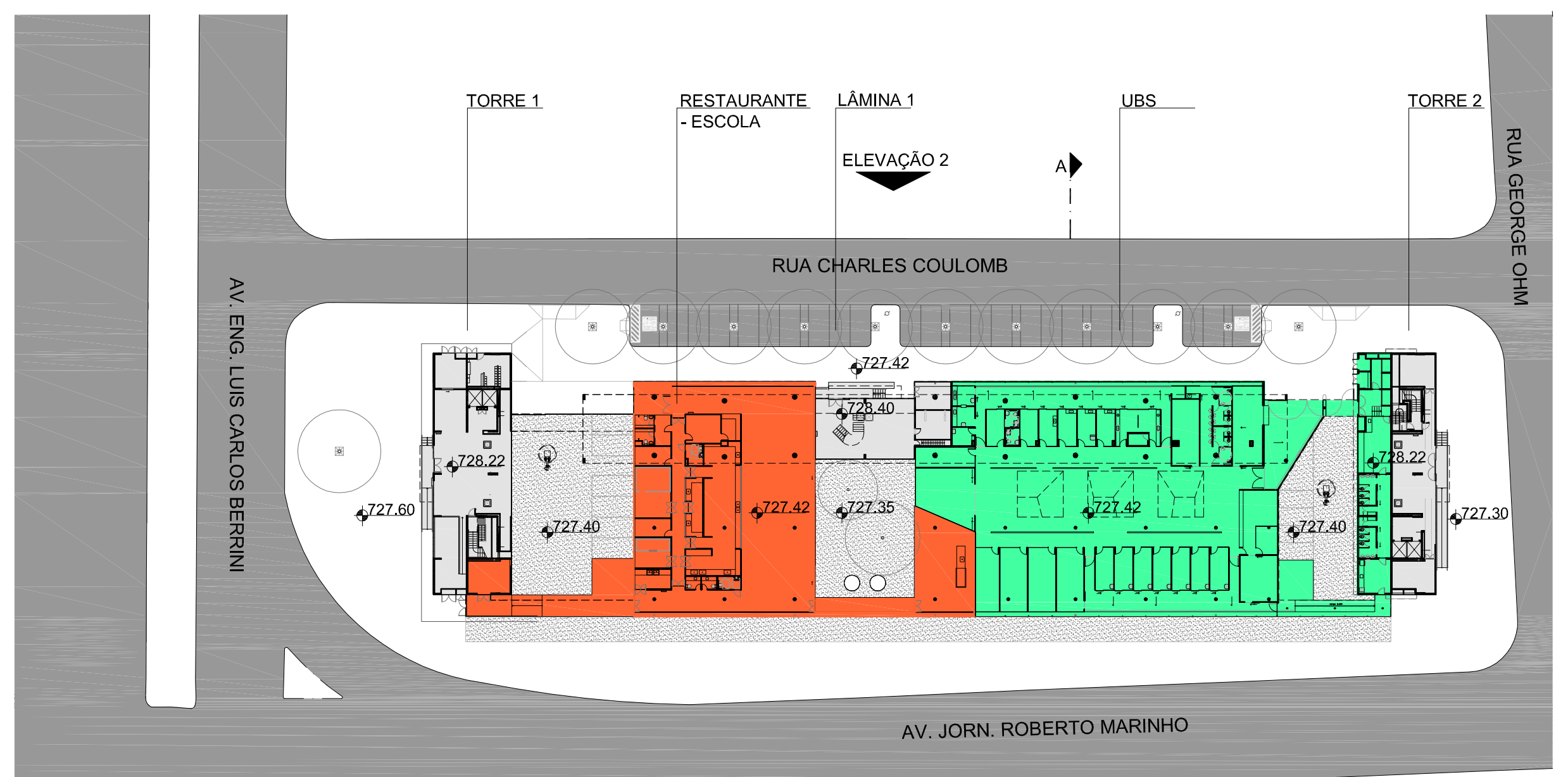




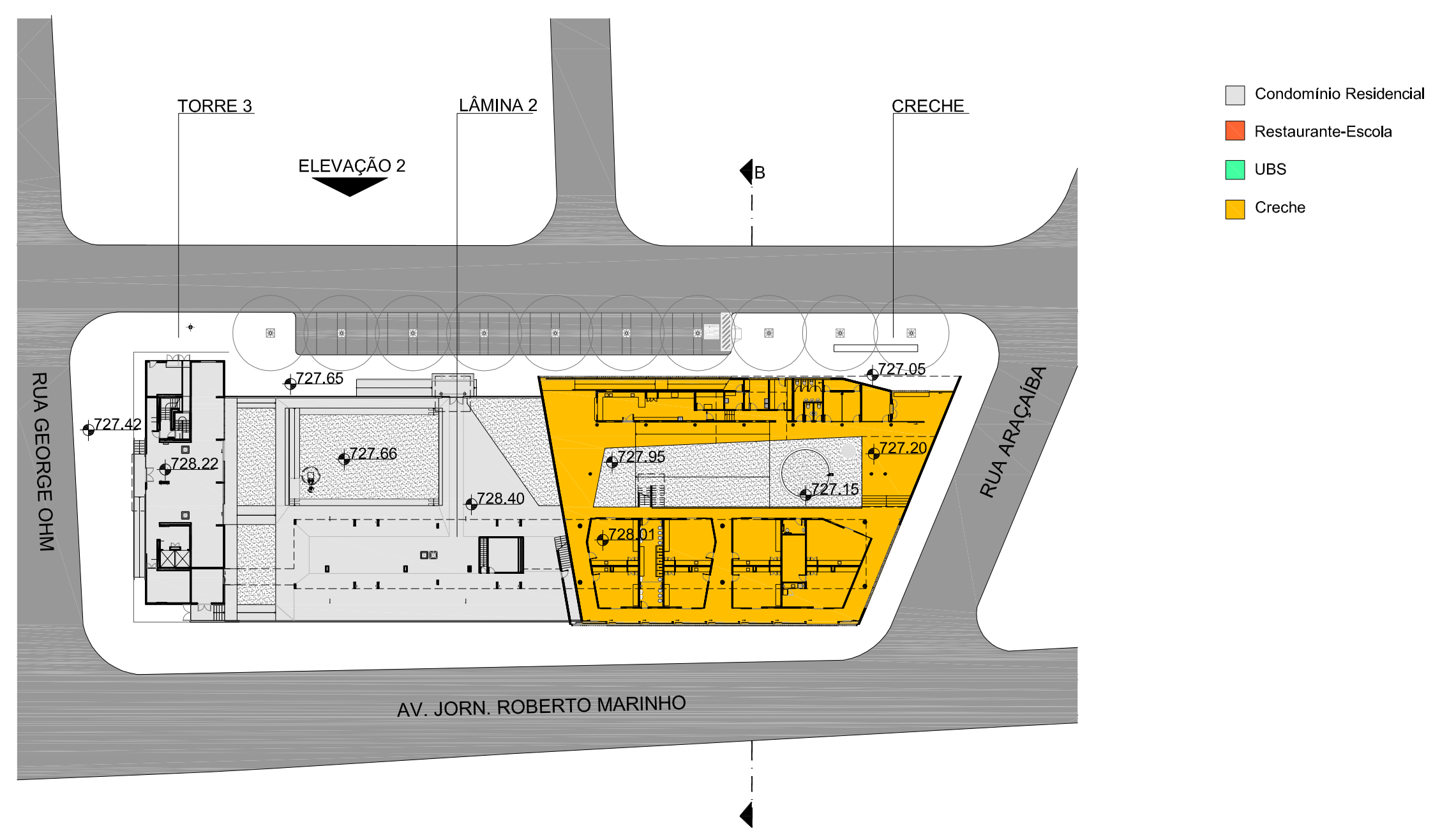




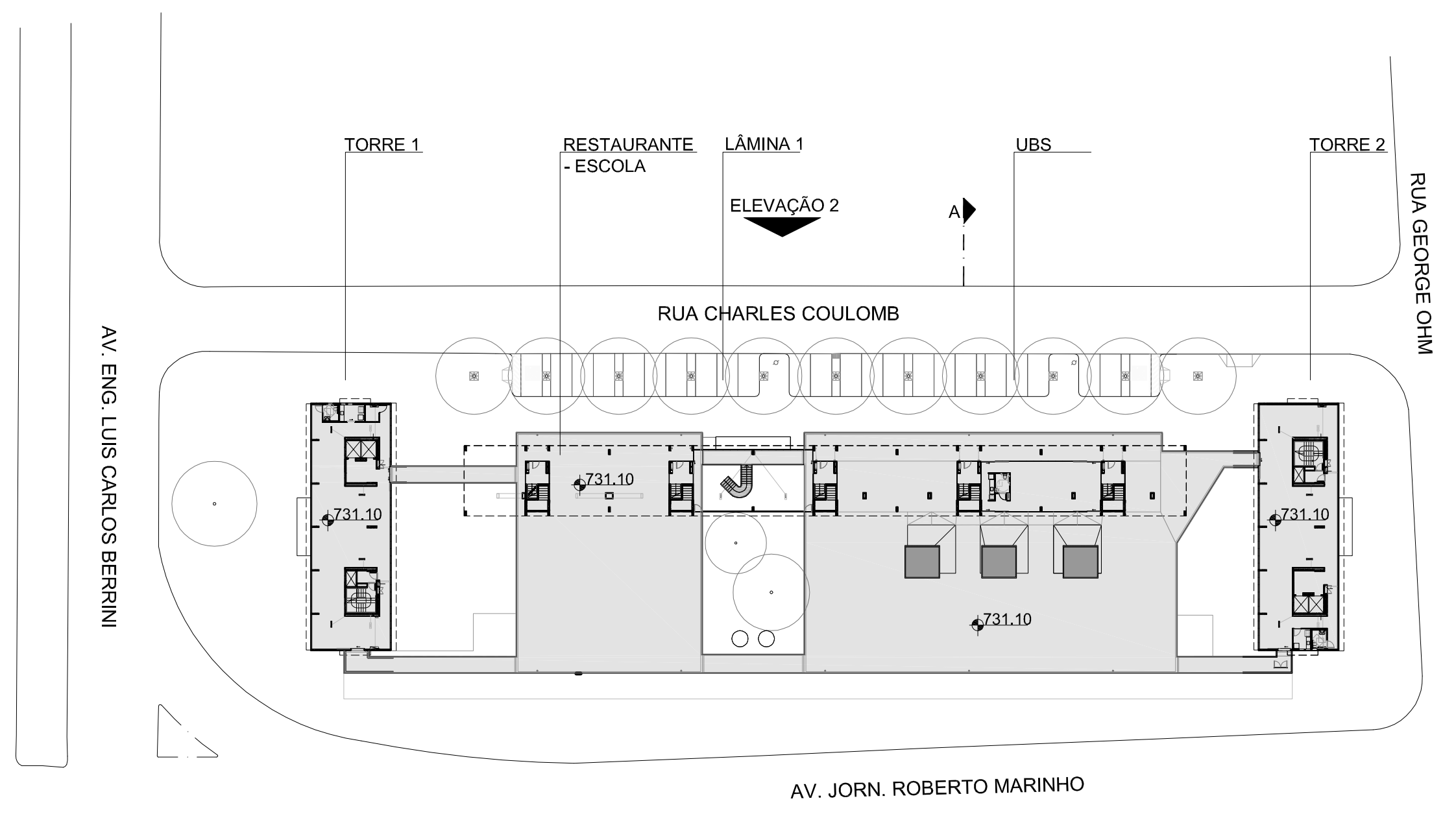




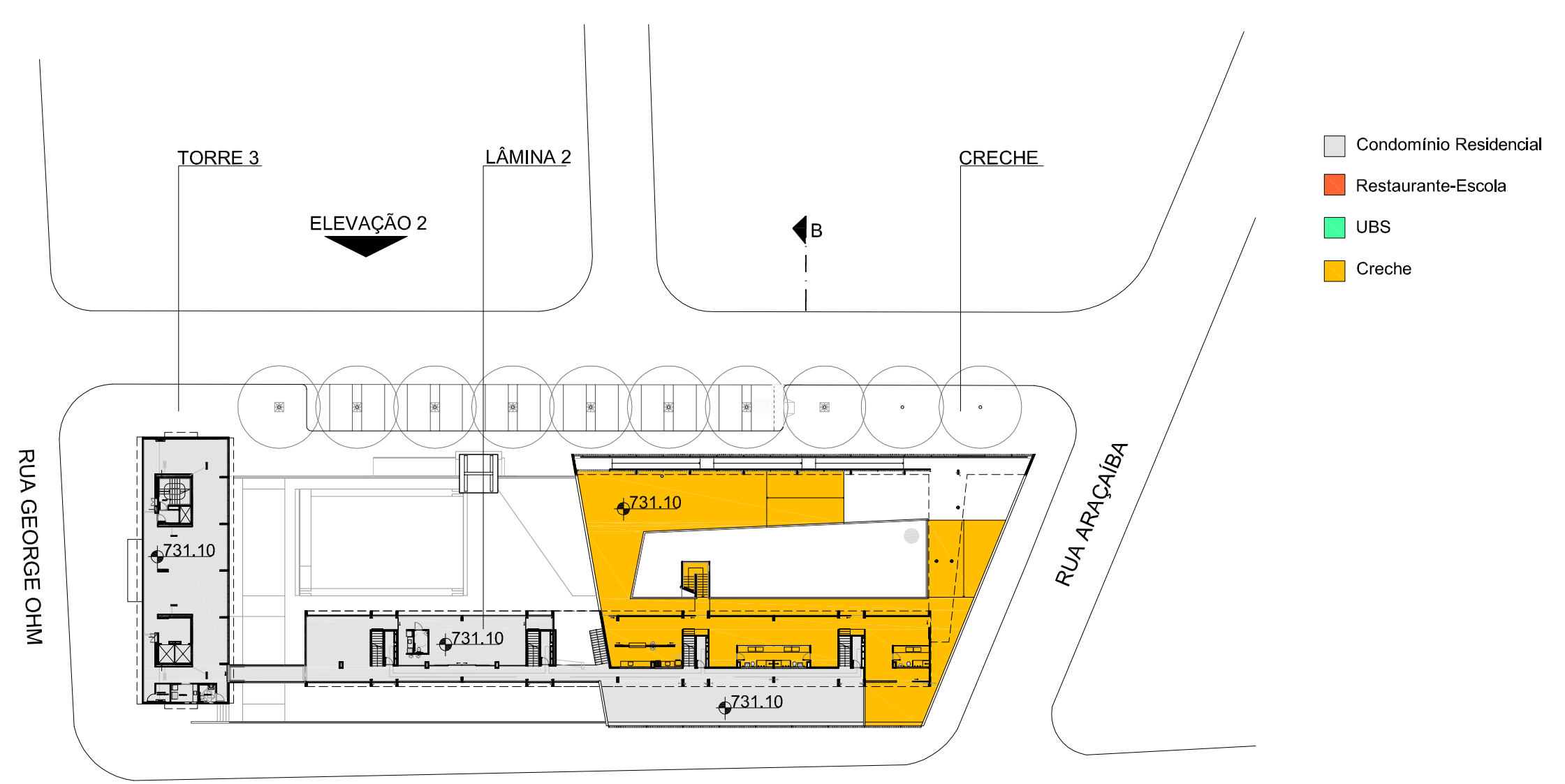

AV. JORN. ROBERTO MARINHO

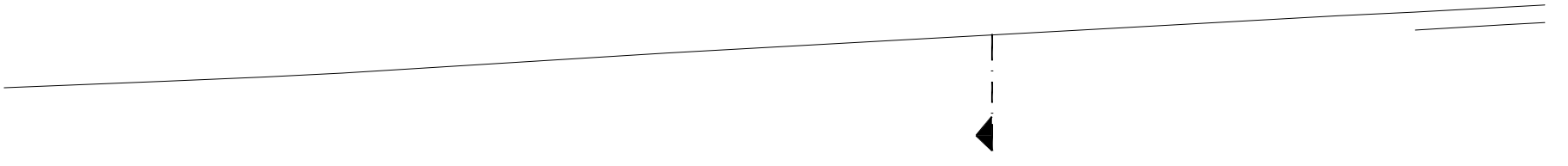

ELEVAÇÃO 1 

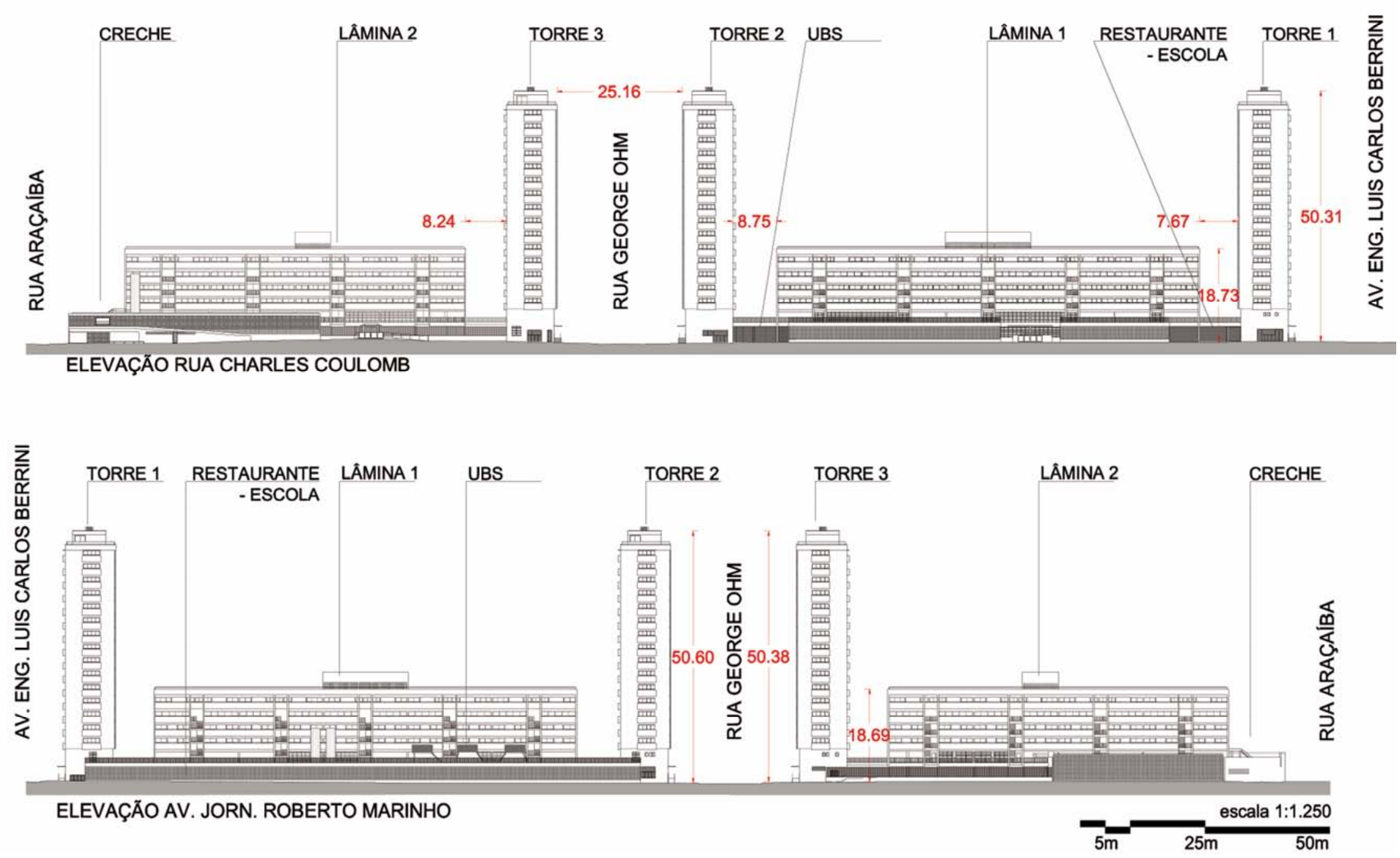

Figura 21- Elevações Conjunto Habitacional Jardim Edite. 


\section{Diálogo volumétrico}

O diálogo volumétrico diz respeito à forma como o projeto relaciona-se com o entorno em escala e altura. No caso do Jardim Edite, foi comentado no início da análise que os próprios arquitetos decidiram adotar o partido de verticalizar para estabelecer relação com o entorno de altos edifícios, característicos dessa região da cidade, ao longo da Avenida Berrini.

Como pode ser observado nas fotos que seguem, a partir desse ponto de vista, pode-se dizer que conjunto estabelece diálogo com o entorno em que encontra-se inserido. Nesse momento, depois de ver o conjunto acabado, seria difícil imaginar que esse mesmo projeto poderia ter sido construído como um conjunto mais denso e de menor altura, características comuns a esse tipo de intervenção, porém, muito provavelmente a escala poderia não relacionar-se tão bem com o entorno como o projeto realizado.

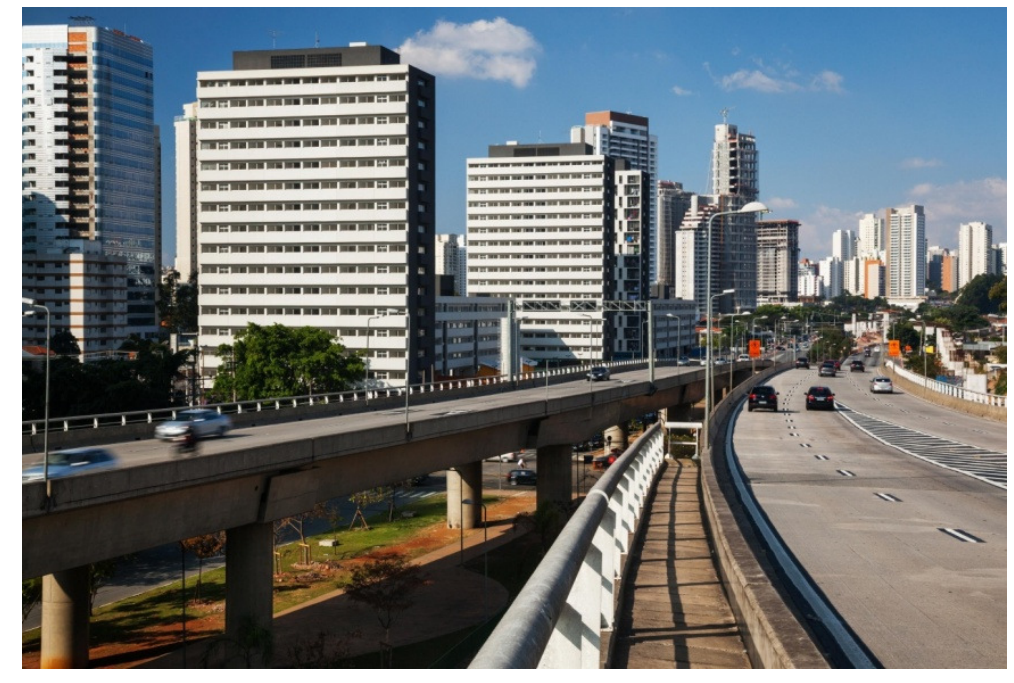

Figura 22 - Vista Edifícios Jardim Edite a partir da ponte Água Espraiada.

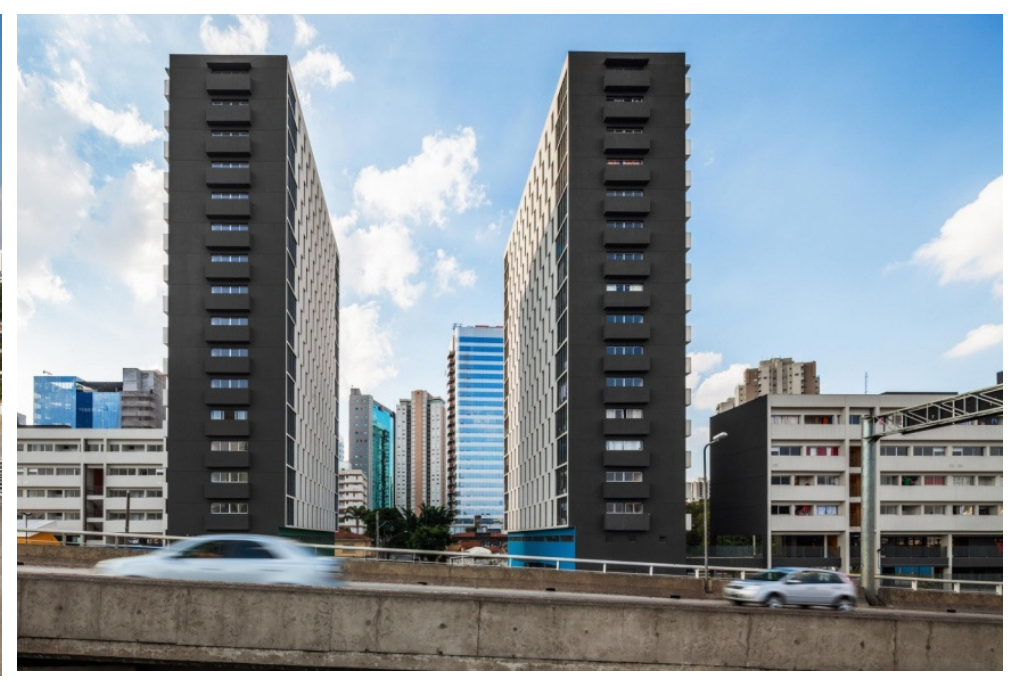

Figura 23 - Edifícios Jardim Edite contrastando com as torres da Berrini ao fundo. 


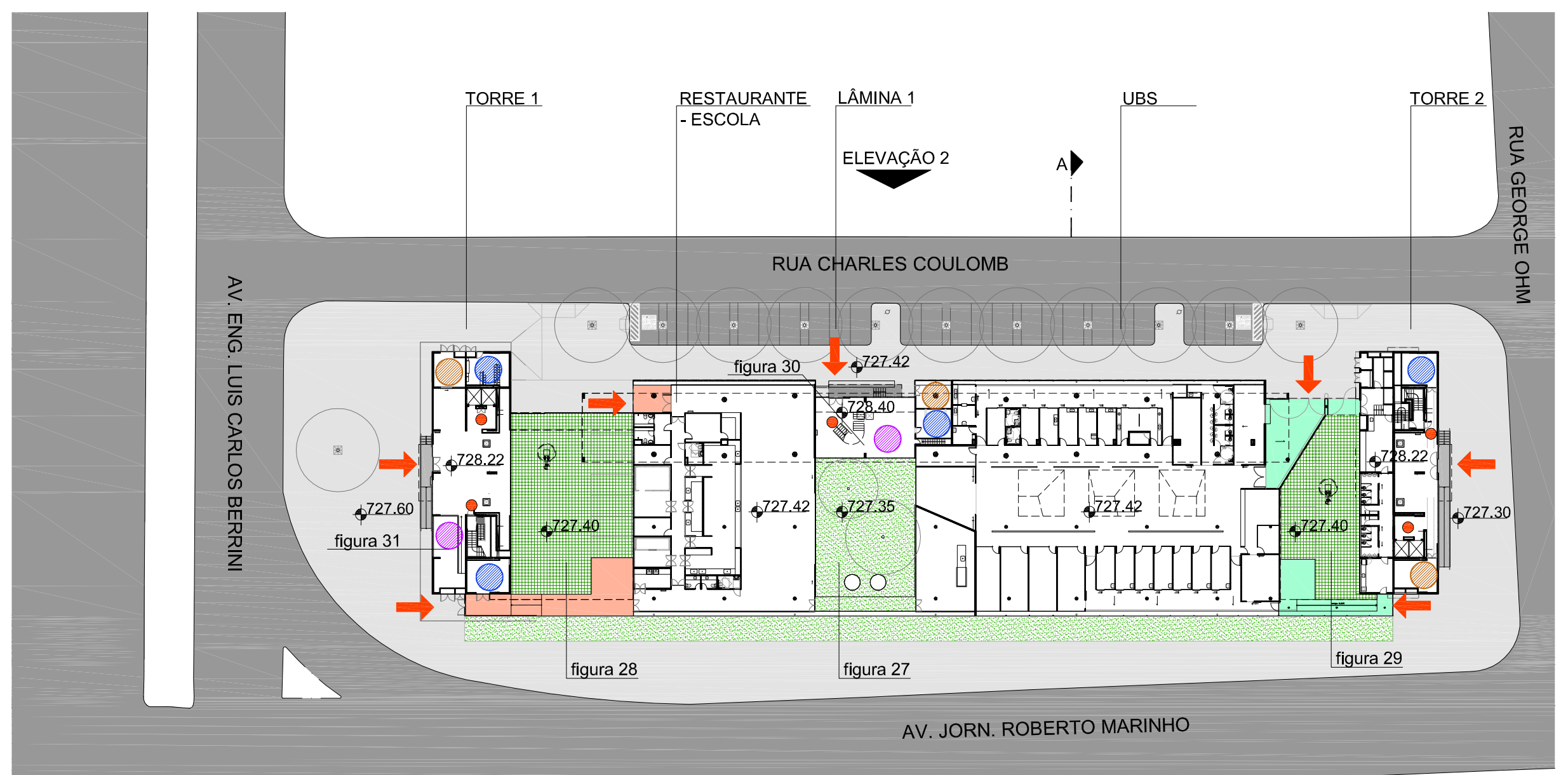




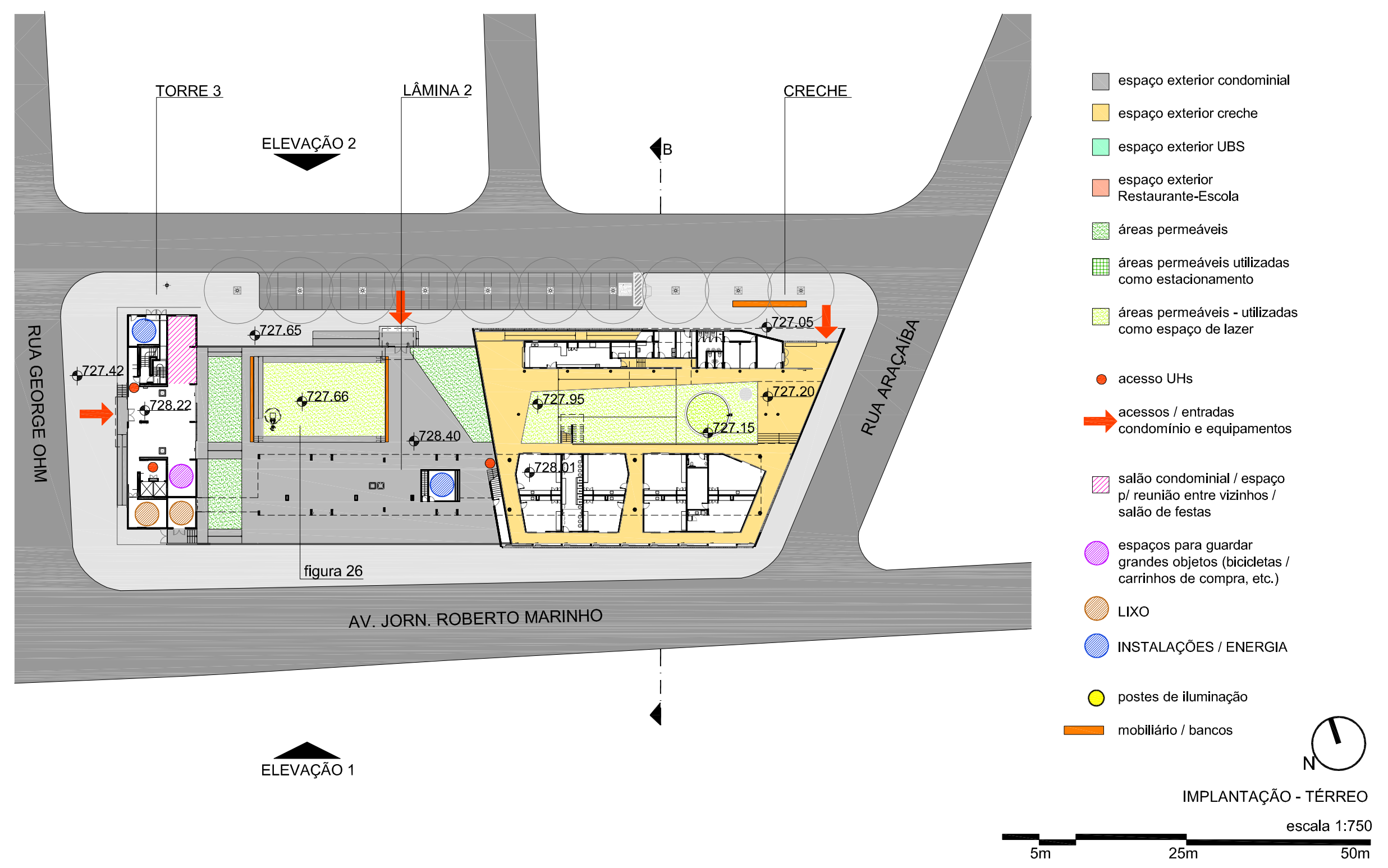

Figura 24 - Diagrama de análise dos espaços exteriores. 

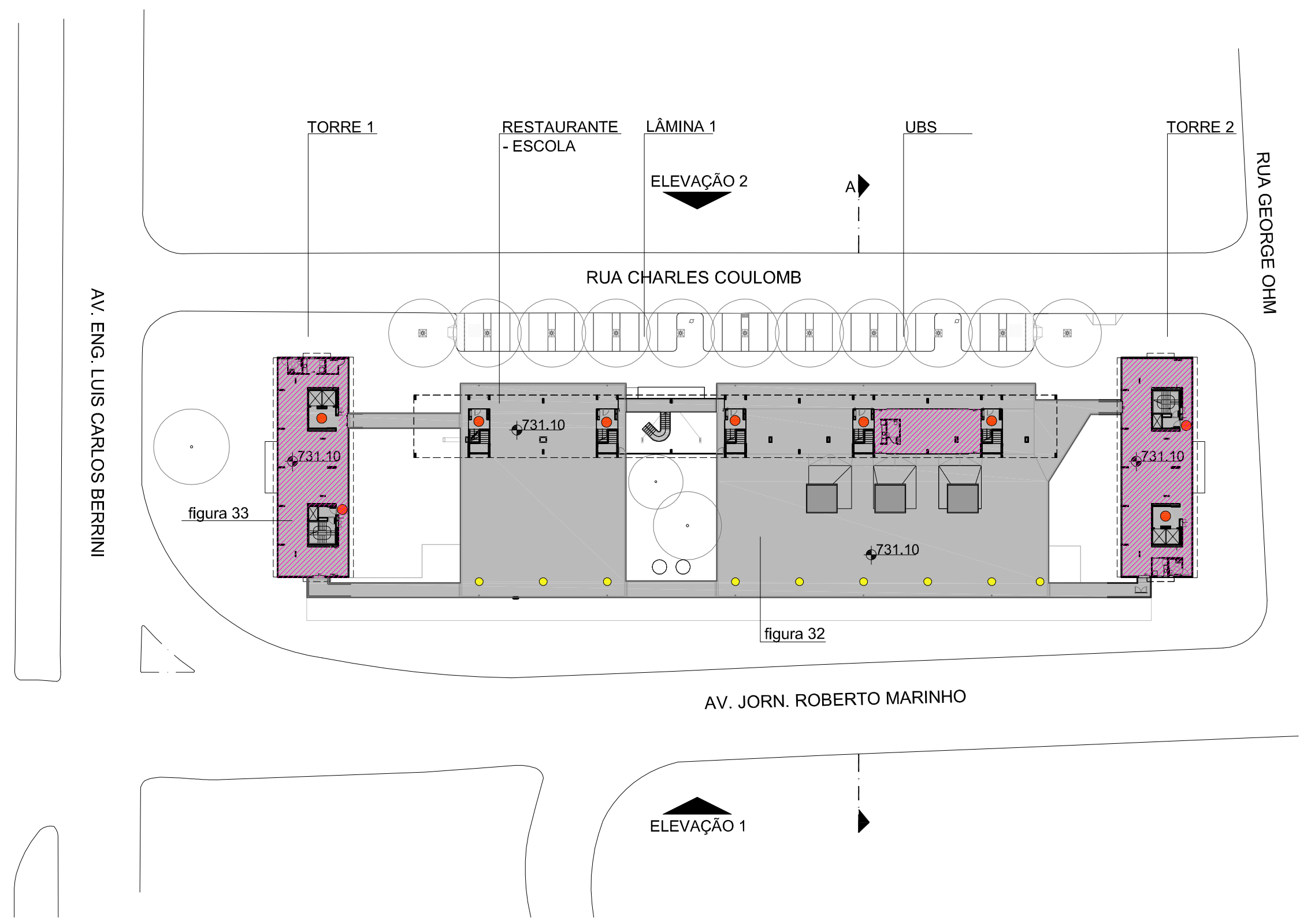


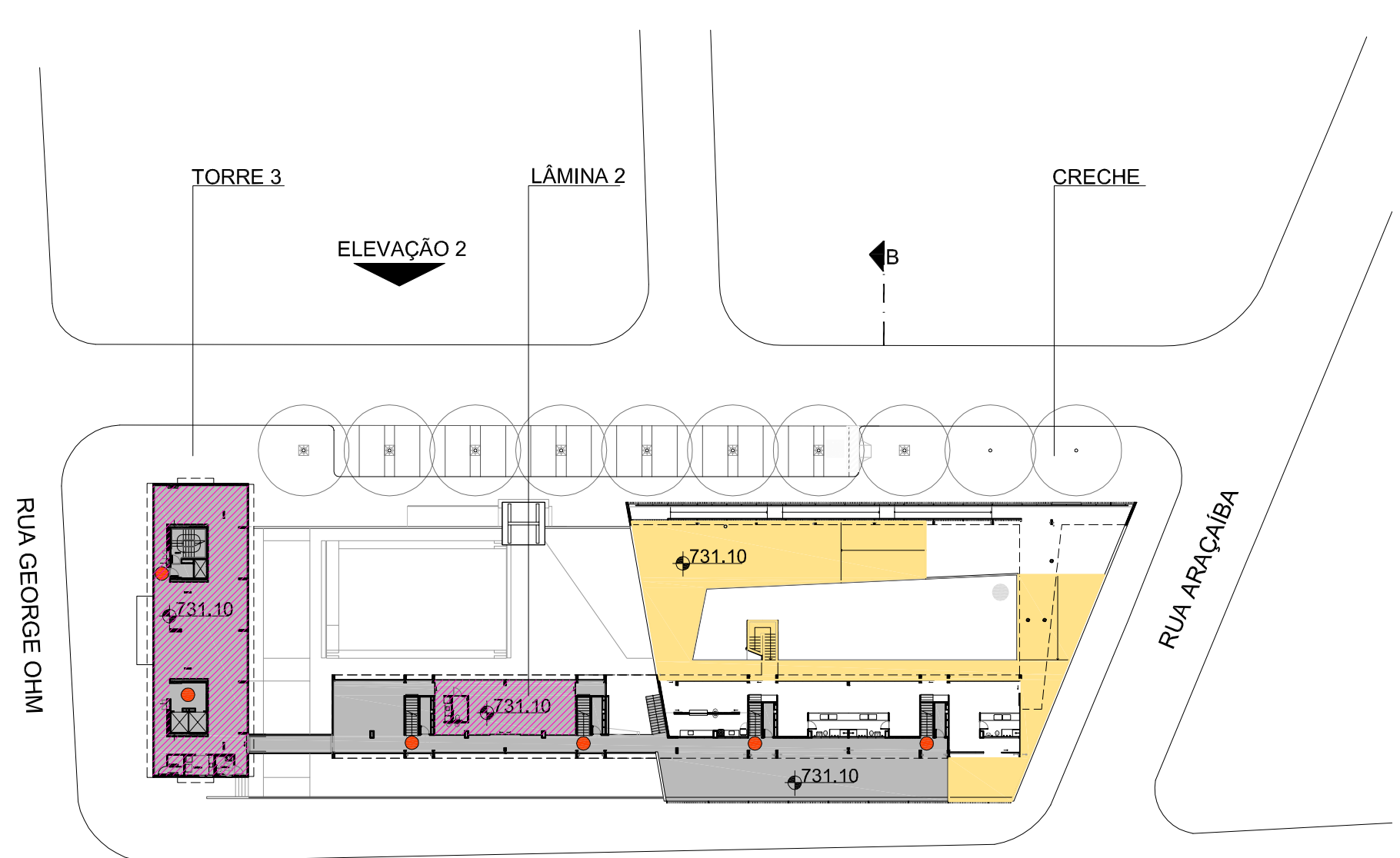

AV. JORN. ROBERTO MARINHO $\square$ espaço exterior condominial

$\square$ espaço exterior creche

$\square$ espaço exterior UBS

$\square$ espaço exterior Restaurante-Escola

áreas permeáveis

áreas permeáveis utilizadas como estacionamento

$\square$ áreas permeáveis - utilizadas como espaço de lazer

\section{- acesso UHs}

acessos / entradas

cequipamentos

salão condominial / espaço p/ reunião entre vizinhos / salão de festas

- espaços para guardar grandes objetos (bicicletas carrinhos de compra, etc.)

(1) $L I X O$

dINSTALAÇÕES / ENERGIA

postes de iluminação 


\subsubsection{ESPAÇOS EXTERIORES}

Para realizar a análise dos espaços exteriores será necessário utilizar a implantação de dois pavimentos: o térreo e o pavimento condominial (nível 731.10). No pavimento térreo, percebe-se que há pouca área externa destinada ao uso condominial, com exceção da área sob a lâmina 2 (Figura 26) e os acessos, o restante é todo dedicado aos equipamentos e, além disso, são organizadamente setorizados definindo claramente os acessos de cada um e os espaços exteriores que pertencem a eles (Figura 24).

O restaurante-escola e a UBS contam com espaço de estacionamento para carga e descarga, independentes (Figura 28; Figura 29). Entre esses dois equipamentos há um pátio que pode ser acessado a partir do restauranteescola, mas não da UBS, estabelecendo com esse último, contato apenas visual (Figura 27).

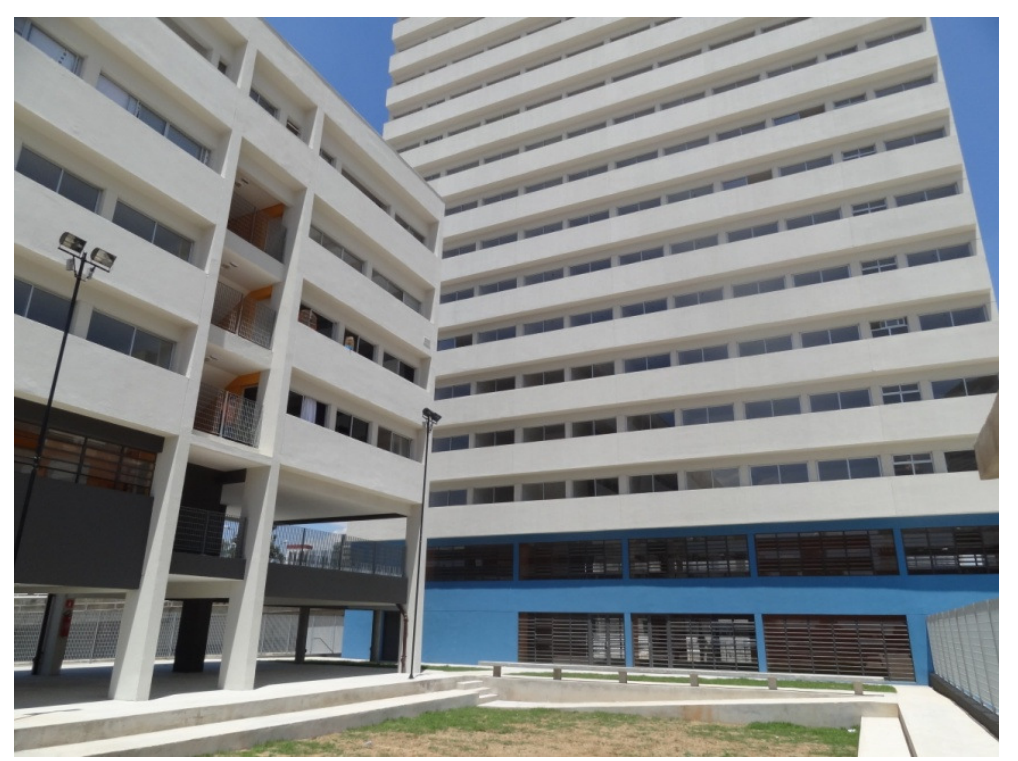

Figura 26 - Espaço exterior condominial sob a lâmina 2.

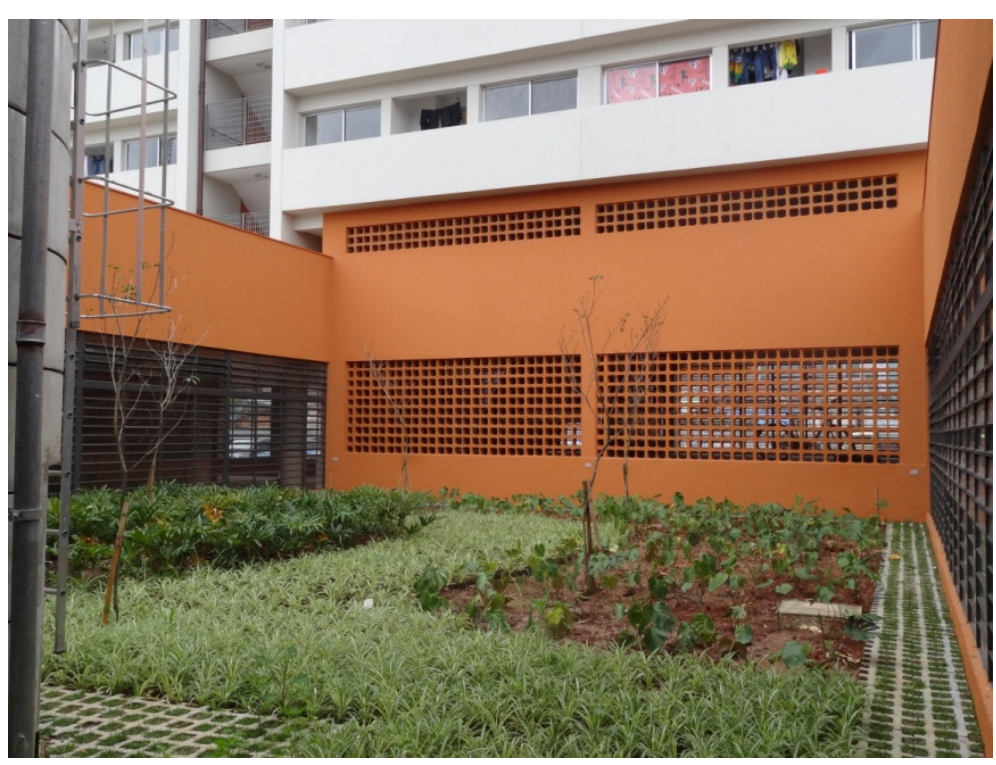

Figura 27 - Pátio entre o restaurante-escola (dir.) e a UBS (esq.). 

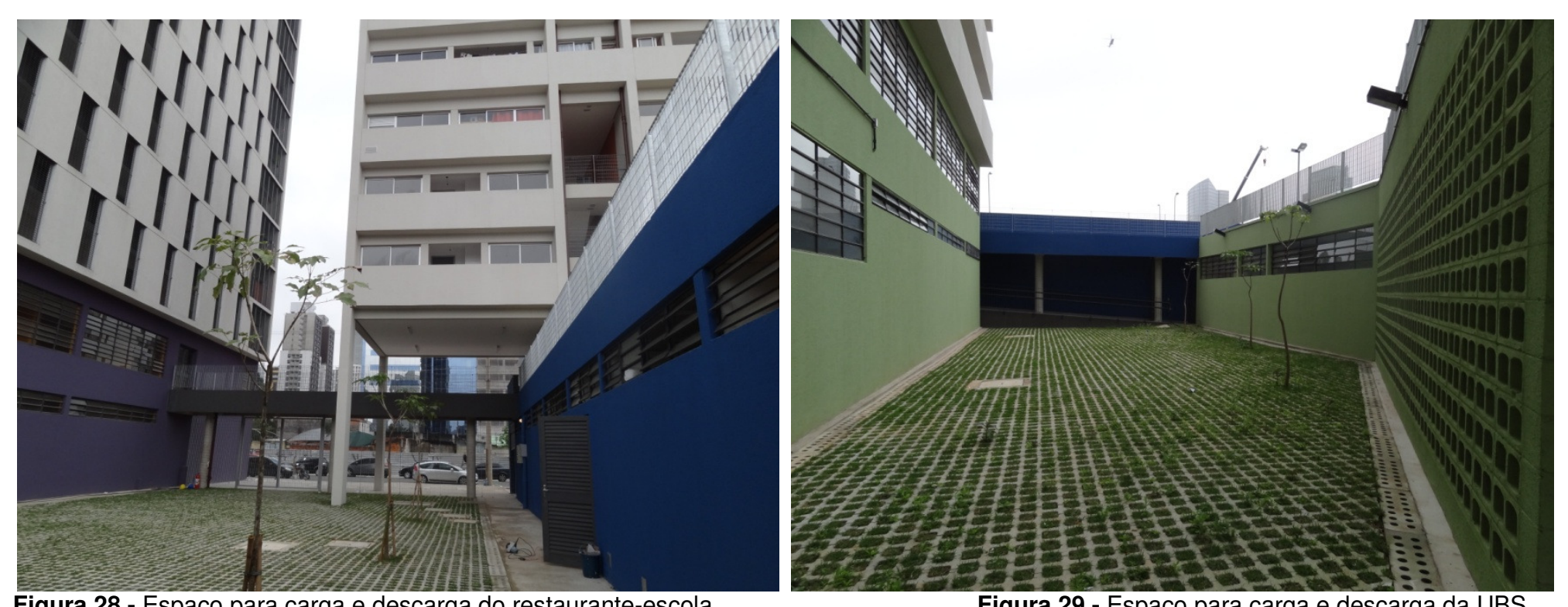

Figura 28 - Espaço para carga e descarga do restaurante-escola.

Figura 29 - Espaço para carga e descarga da UBS.

No térreo das torres, além do acesso às unidades habitacionais, encontram-se espaços destinados a abrigos de lixo, instalações e também espaços para guardar grandes objetos, como bicicletas, carrinhos de compra, carrinhos de bebê e até mesmo carrinhos de pipoca como pode ser observado na Figura 30.

Prever esses espaços no projeto é muito importante, pois os apartamentos têm dimensões reduzidas e não há espaço para guardar grandes objetos. Ao visitar os conjuntos habitacionais, é comum ver muitas bicicletas e motos que não têm um lugar específico para serem guardadas e muitas vezes são colocadas em lugares que atrapalham a circulação ou tomam espaço das áreas de lazer. Portanto, é importante valorizar a inclusão desses espaços no projeto. 


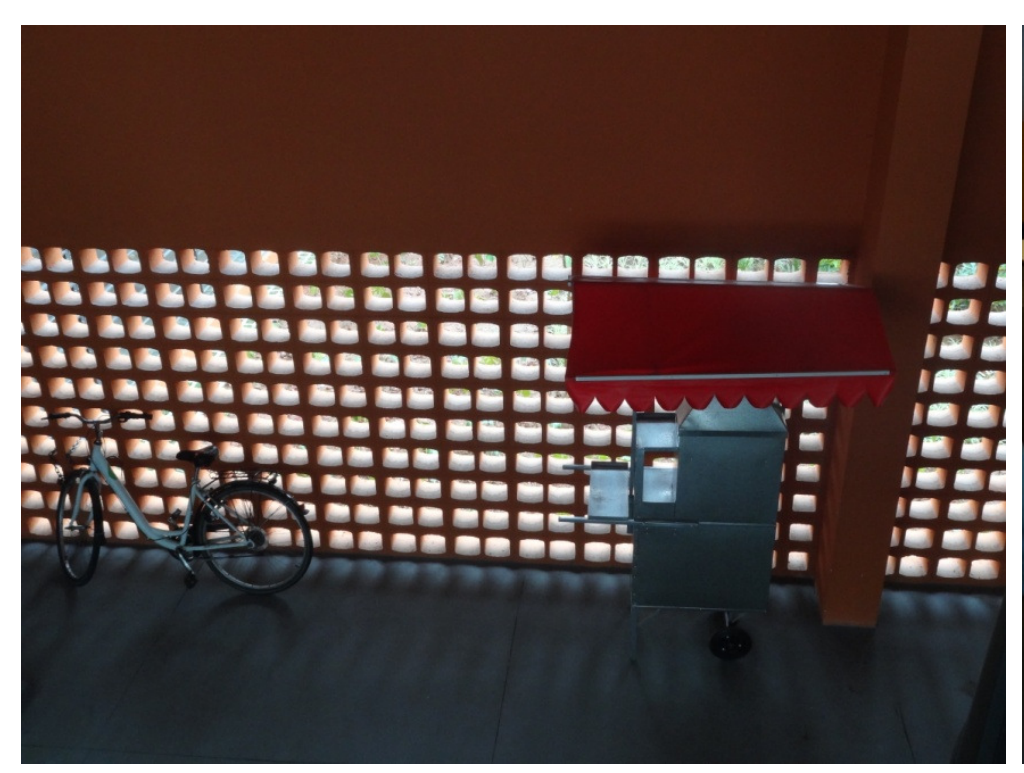

Figura 30 - Espaço para guardar grandes objetos / bicicletário. Lâmina 1.

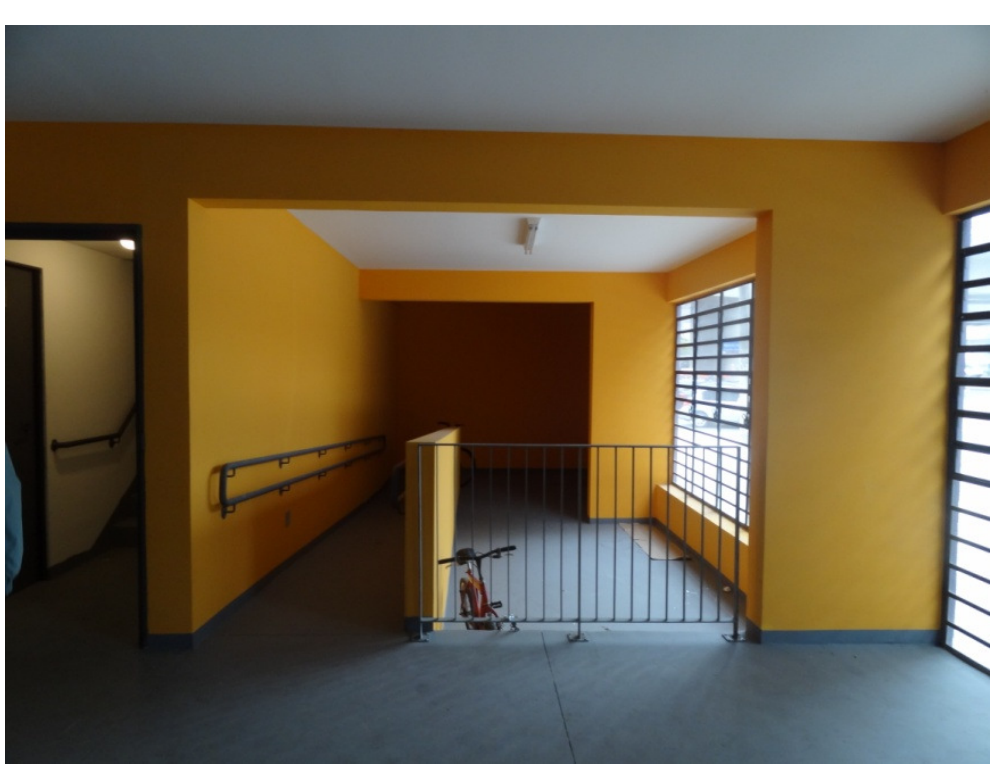

Figura 31 - Espaço para guardar grandes objetos - bicicletário. Torre 1

Subindo para o pavimento condominial, encontra-se o espaço de lazer para os moradores do conjunto. Nesse pavimento, todos os edifícios (torres e lâminas) estão conectados, pelo menos dentro de cada quadra.

Embaixo das torres e de uma parte da lâmina 1, foram propostos os salões condominiais, que são espaços para a reunião entre os moradores, para festas ou para estudo (Figura 33).

O espaço livre é bem grande e é possível notar aí a falta de mobiliários (Figura 32), lugares para sentar, brinquedos para as crianças, enfim, elementos que poderiam tornar esses espaços mais agradáveis e atraentes para os moradores. As moradoras Cícera e Ana Paula comentaram que, mesmo sem mobiliário, essa área de lazer é bastante utilizada pelas crianças do condomínio, porém, elas que moram no $15^{\circ}$ andar da torre 2 , declararam não sentir-se tranquilas quando seus filhos ou sobrinhos vão brincar "lá em baixo". As moradoras comentaram que essa 
área é muito distante de seus olhos e que preferem acompanhar as crianças quando querem brincar. Comentaram ainda que o mesmo não deve ocorrer com as mães que moram na lâmina 1, que podem cuidar de seus filhos a partir das janelas de suas casas mais facilmente (informação verbal) ${ }^{16}$

Na quadra 2 o espaço de lazer já é menor, por estar dividido com a creche. Não há comunicação entre o setor condominial e a creche. Os espaços foram devidamente projetados para serem independentes e incomunicáveis.

Sob as lâminas, estão os acessos às escadas que levam às unidades habitacionais. Entende-se, portanto, que esse pavimento condominial pode ser interpretado como um "pavimento filtro" que separa o espaço público dos equipamentos do espaço privado das unidades através de um percurso que passa por diferentes escalas até chegar às portas das casas dos moradores.

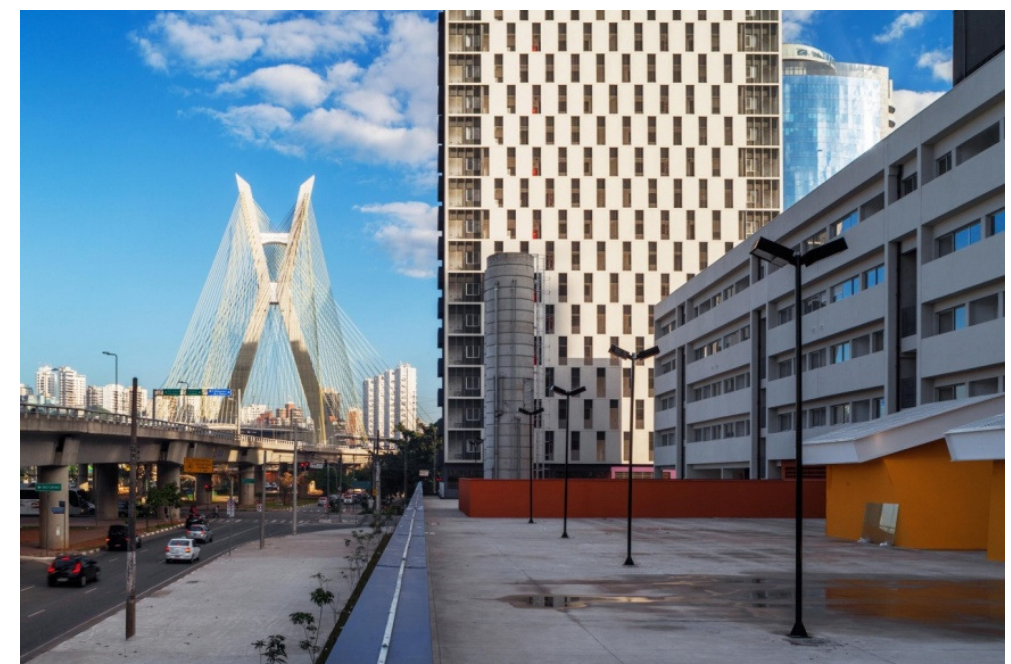

Figura 32 - Espaço de lazer condominial. Quadra 1.

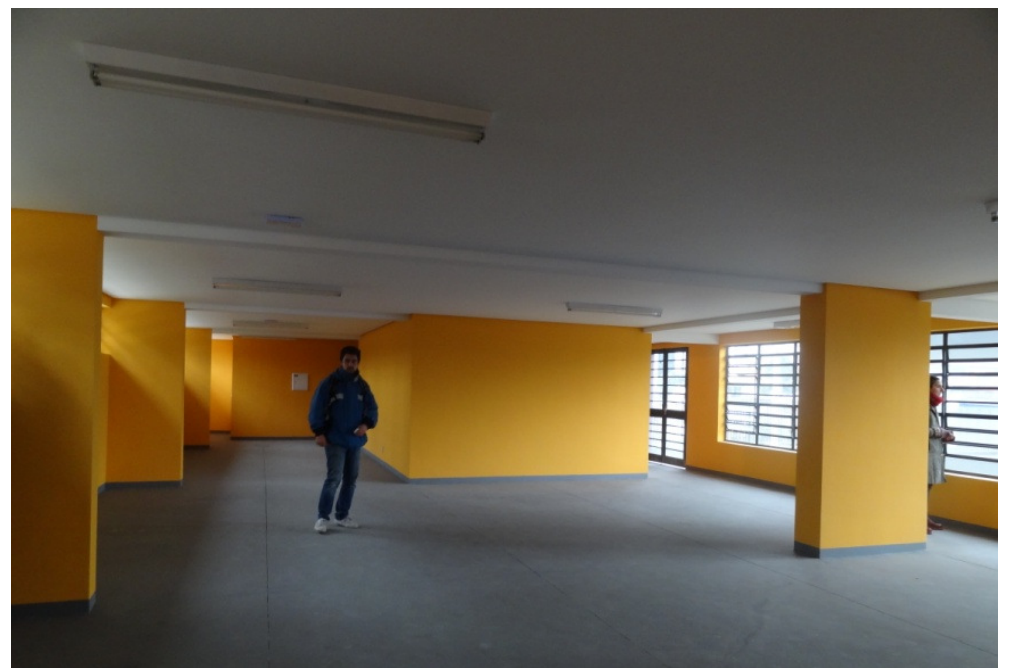

Figura 33 - Salão condominial. Torre 1.

${ }^{16}$ Entrevista com as moradores Cícera e Ana Paula do conjunto Jardim Edite durante visita a suas residências. São Paulo, 17 de dezembro de 2013. 

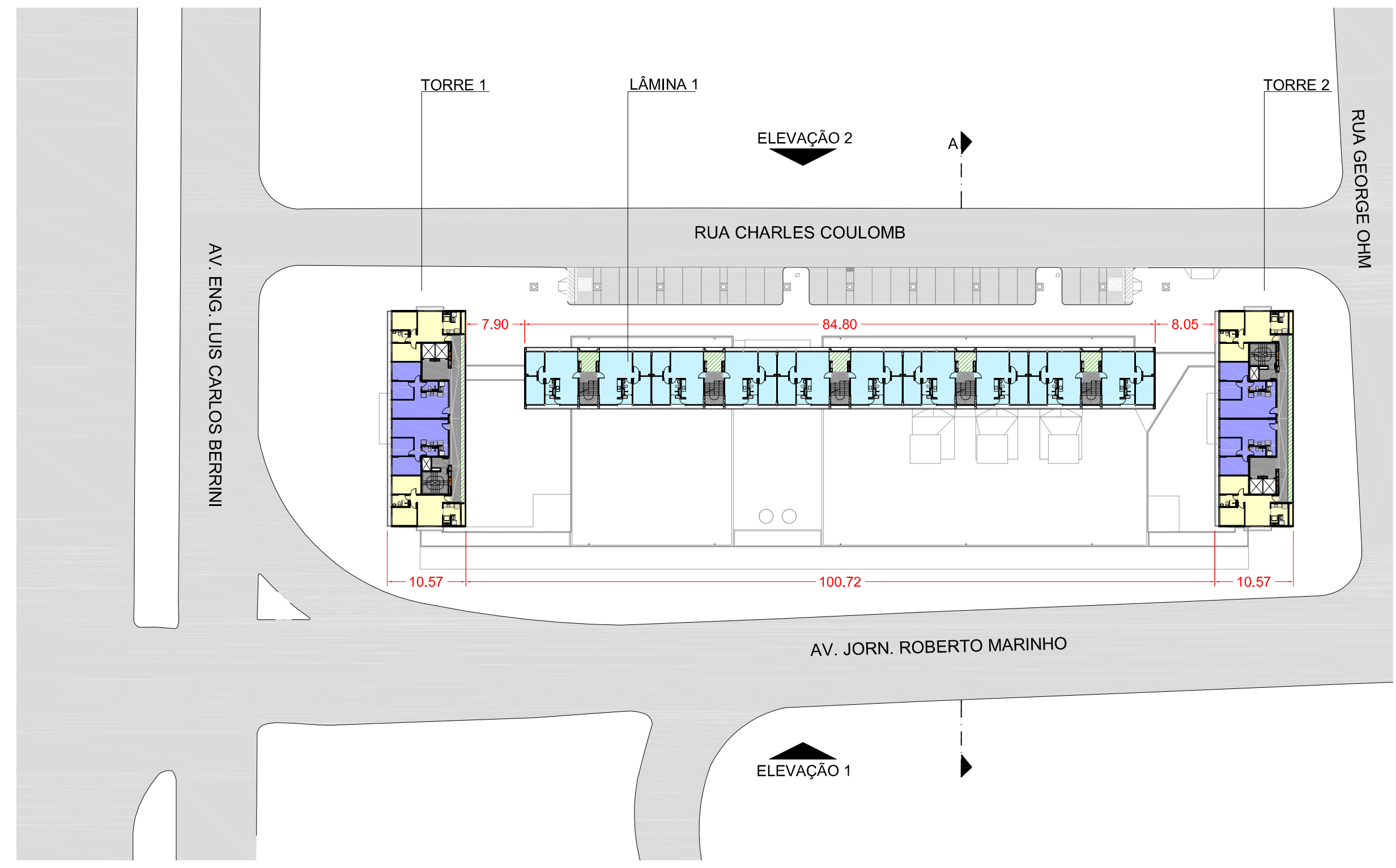


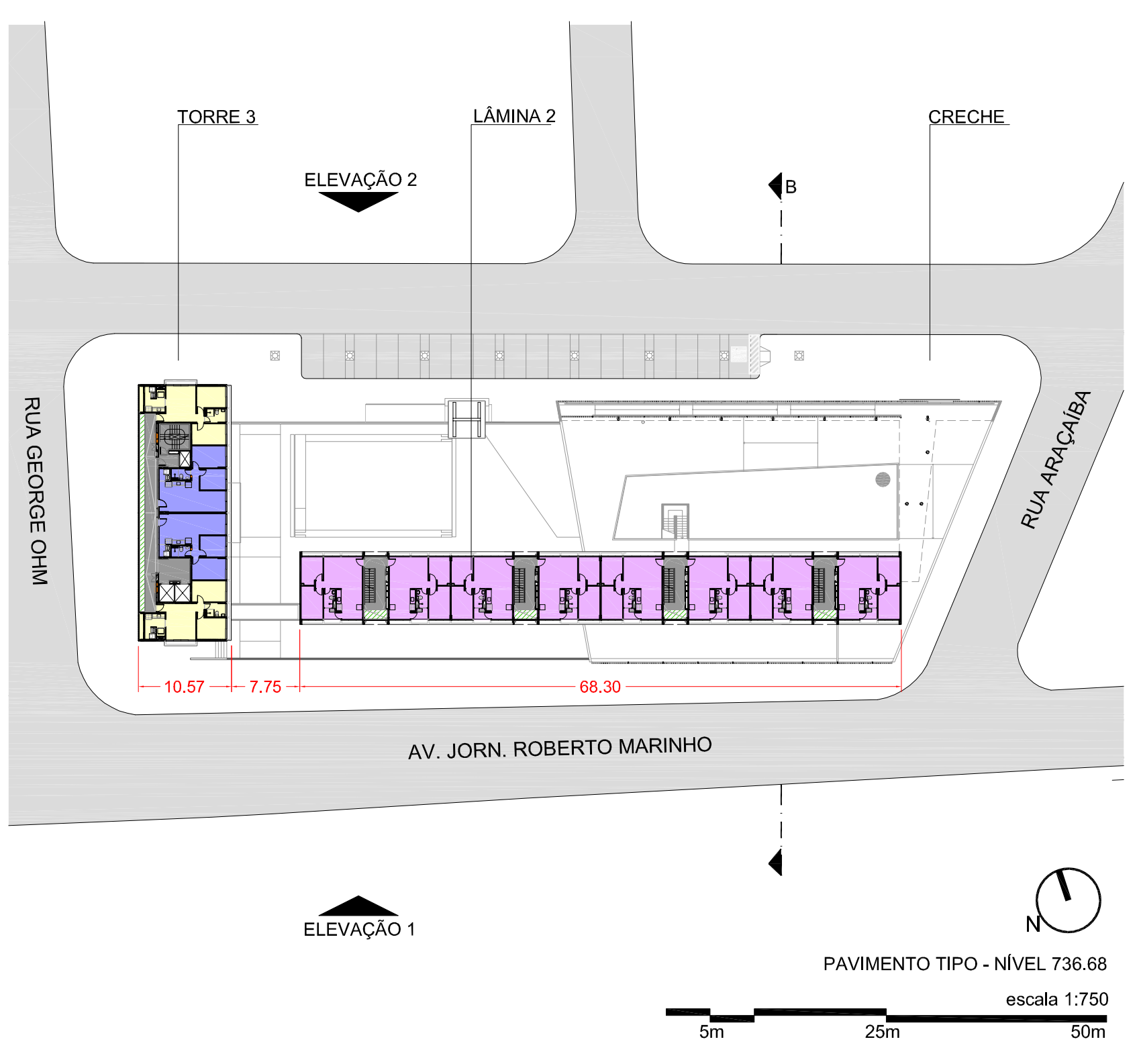

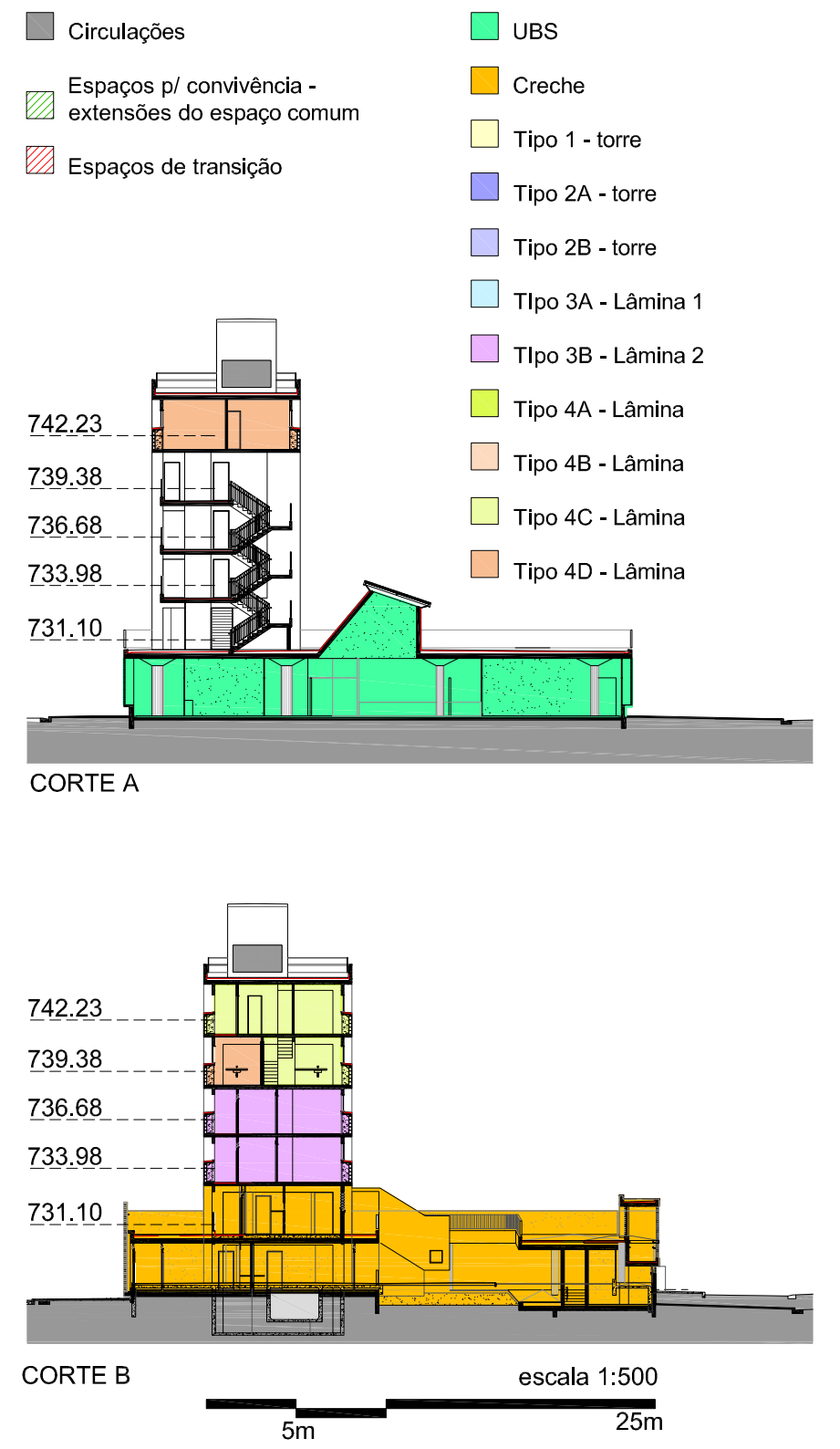

Figura 34 - Análise relação entre os edifícios. 
4.2.1.4. RELAÇÃO

ENTRE OS EDIFÍCIOS

Os edifícios que conformam o conjunto dividem-se em três torres e duas lâminas que se destacam acima de um embasamento maciço no qual foram implantados os equipamentos. As torres, com maior altura, possuem 17 andares e as lâminas são mais horizontais, com apenas 4 andares acima do pavimento condominial. Na quadra 1, a lâmina horizontal garante o afastamento de 100 metros entre as torres. No pavimento condominial é onde se tem a sensação de um maior espaçamento entre as construções. Essa percepção é seguramente garantida pelo fato das lâminas, implantadas entre as torres, estarem alinhadas a uma das faces das quadras, deixando o espaço restante livre. Por outro lado, a sensação, no nível da rua, é de uma base bastante densa.

\section{Acessos e circulação}

Todos os edifícios, tanto os equipamentos quanto os residenciais, têm acessos independentes a partir da rua. Nas torres, os moradores acessam diretamente o térreo dos edifícios utilizando as circulações verticais - escadas e elevadores - para acessarem aos andares. No caso das lâminas, após o acesso pela rua, os moradores ainda precisam acessar o pavimento condominial, a partir do qual têm acesso às várias escadas que levam aos apartamentos. Isso comprova a observação feita no item anterior - Espaços Exteriores - de que o pavimento condominial tem a função de um "filtro" entre o espaço público e o privado. Nas lâminas, cada escada atende a apenas dois apartamentos por andar.

Em cada andar, tanto nas torres, como nas lâminas, os espaços de circulação foram complementados por espaços que serão chamados, nesse trabalho, de "espaços para convivência" que funcionam como extensões dos espaços de circulação e uso comum. A partir das análises, foi possível identificar diferenças entre essas extensões dos espaços de circulação e os espaços de transição, indicados no estudo de caso Comandante Taylor. 
No caso dos espaços de transição do Comandante Taylor, esses "espaços extra" estavam relacionados diretamente com as portas dos apartamentos, funcionando como extensões das próprias casas. No caso do Jardim Edite, verificou-se que esses espaços são extensões do espaço de circulação e não relacionam-se diretamente com as portas de entrada das unidades, sendo assim, foram classificados como extensões do espaço comum tendo a função de ampliar o espaço de convívio entre os moradores.

\section{Variedade tipológica}

Como pôde ser observado nas análises, o conjunto apresenta quatro tipologias principais: nas torres, as tipologias das pontas diferenciam-se das centrais; e, nas lâminas, as tipologias dos dois pavimentos inferiores são diferentes dos duplex que ocupam os dois últimos pavimentos. Entretanto, todas as tipologias apresentam o mesmo programa: dois dormitórios, um banheiro, sala de estar, cozinha e área de serviço.

\section{Implantação e}

orientação

Quanto às orientações, verificou-se que as torres foram implantadas garantindo que as fachadas de maior extensão, onde está a maior parte das aberturas, estivessem na orientação leste-oeste. As lâminas possuem fachadas norte-sul, porém, é possível notar que o espaço da sala de estar e ao menos um dormitório estão voltados para a fachada norte, resultando que as áreas de serviço, cozinhas e um dormitório estejam voltadas para o sul.

\subsubsection{ESCALA EDIFÍCIO}

$\mathrm{Na}$ escala edifício serão analisados, separadamente, os dois tipos de edificações habitacionais propostas: a torre e a lâmina. 
TORRE 1

$\boldsymbol{\nabla}--$

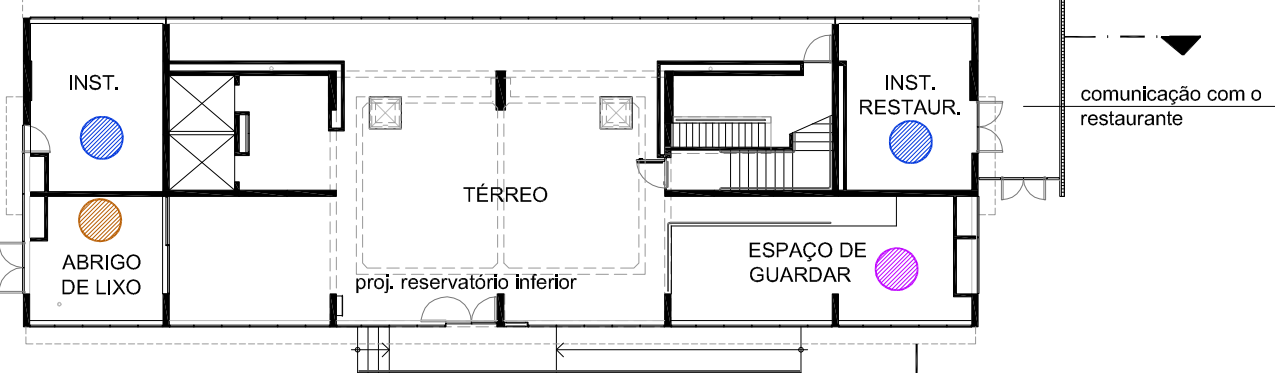

PLANTA TÉRREO (728.22) - escala 1:300
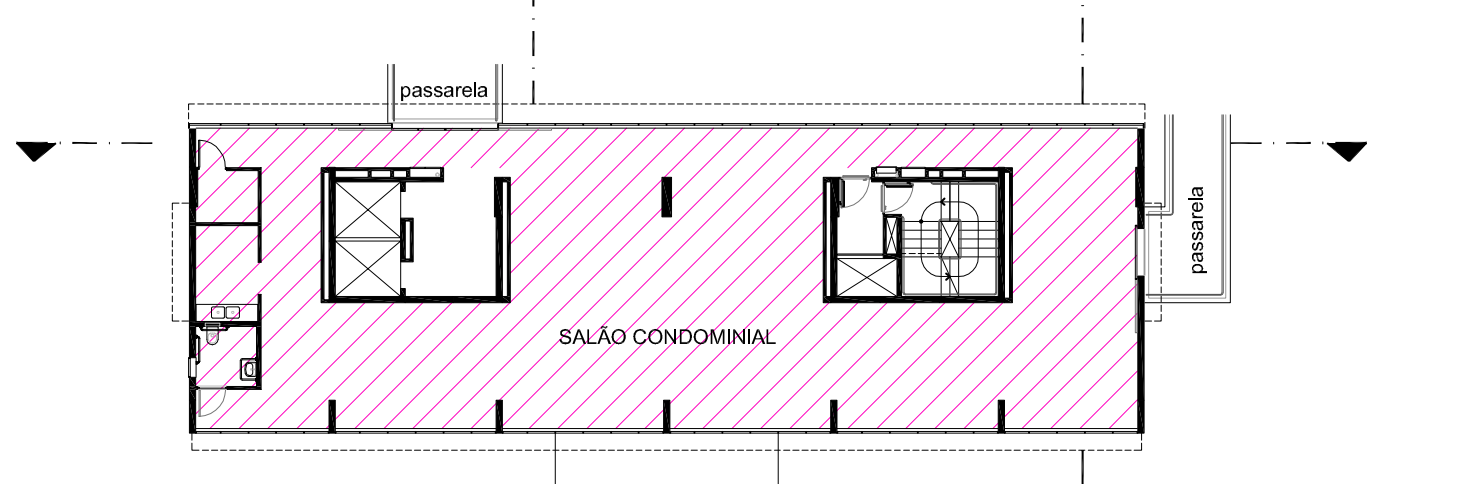

PLANTA PAVIMENTO CONDOMINIAL (731.10) - escala 1:300

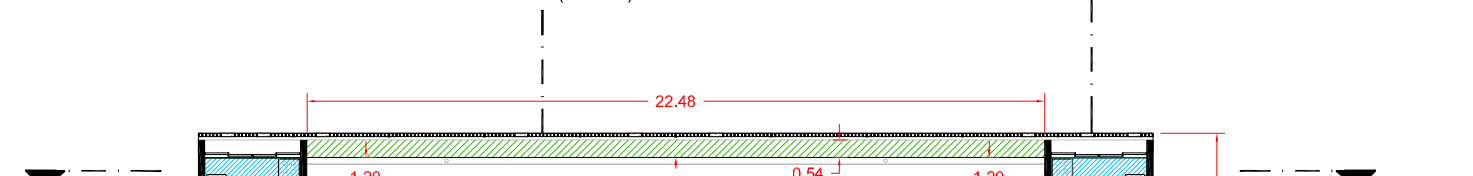

$\nabla--$

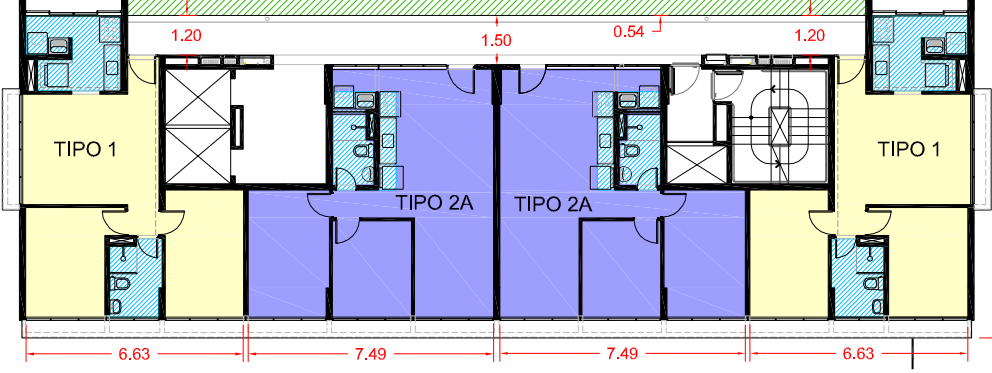

PLANTA PAVIMENTO TIPO (736.68 a 771.78) - escala 1:300

escala 1:300

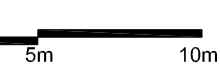




\section{TORRE 1}

$\square$ Tipo 1 - torre

$\square$ Tipo $2 \mathrm{~A}$ - torre

$\square$ Tipo 2B - torre

$\square$ TIpo 3A - Lâmina 1

$\square$ Tlpo 3B - Lâmina 2

$\square$ Tipo 4A - Lâmina

$\square$ Tipo 4B - Lâmina

$\square$ Tipo 4C - Lâmina

$\square$ Tipo 4D - Lâmina

Espaços p/ convivência extensões do espaço comum

$\mathbb{Z}$ áreas molhadas

salão condominial / espaço $\mathrm{p} /$ reunião entre vizinhos / salão de festas

- espaços para guardar grandes objetos (bicicletas / carrinhos de compra, etc.)

LIXO

dINSTALAÇÕES / ENERGIA

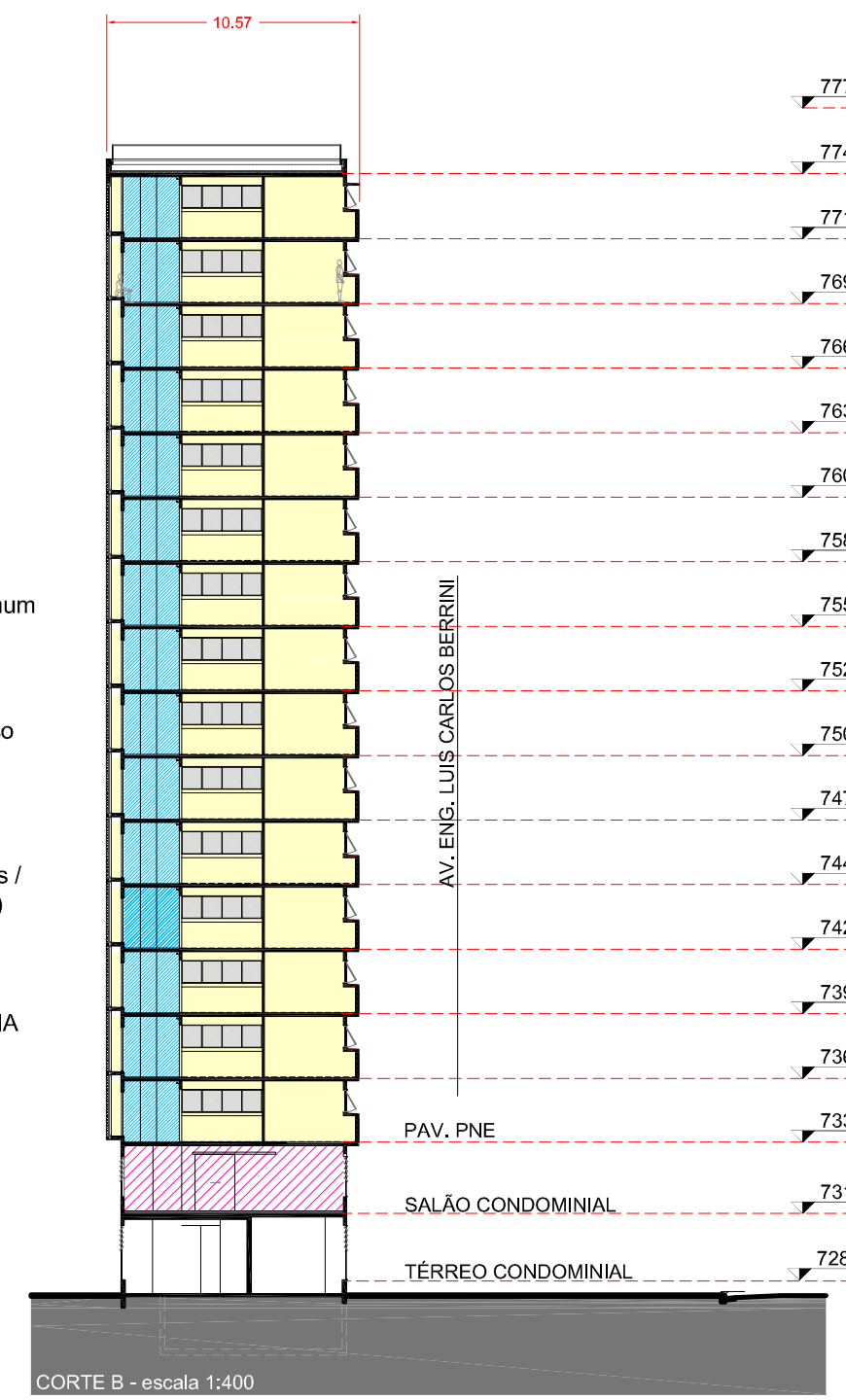

\begin{tabular}{|l|l|l|l|l|}
\hline & 777.32 & \\
\hline
\end{tabular}

escala 1:400

CORTE LONGITUDINAL - escala 1:400

Figura 35 - Análise escala edifício: torre 1.

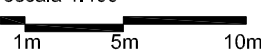




\subsubsection{TORRE}

Entre as três torres, foi selecionada a torre 1 como base para os desenhos de análise, porém, todas apresentam o mesmo programa e mesma disposição dos acessos e unidades. A única diferença significativa é com relação à implantação da torre 3 que possui a circulação voltada para oeste enquanto ao outras duas, têm a circulação na face leste. Os usos no térreo também variam de uma torre para outra, porém essa variação pôde ser observada na implantação (Figura 19).

\section{Acessos e circulação}

As torres são acessadas diretamente pela rua (Figura 36). No térreo há um hall que comunica as duas caixas de circulação verticais - escadas e elevadores - e também o espaço definido como bicicletário, onde os moradores podem guardar grandes objetos, bicicletas, motos, etc. não havendo a necessidade de subir com esses objetos até os andares dos apartamentos.

Ainda no térreo, encontra-se o abrigo de lixo e as salas de instalações elétricas. No caso da torre 1, nota-se que existem duas salas de instalações elétricas: uma para a própria torre residencial; e outra para o restaurante com acesso direto.

O salão condominial está no primeiro pavimento e comunica-se, através de passarelas, com o espaço de lazer implantado sobre os equipamentos. Esse salão pode ser utilizado para festas, encontros entre os vizinhos e até mesmo como salas de estudo. O uso dependerá da organização e gestão dos moradores. 


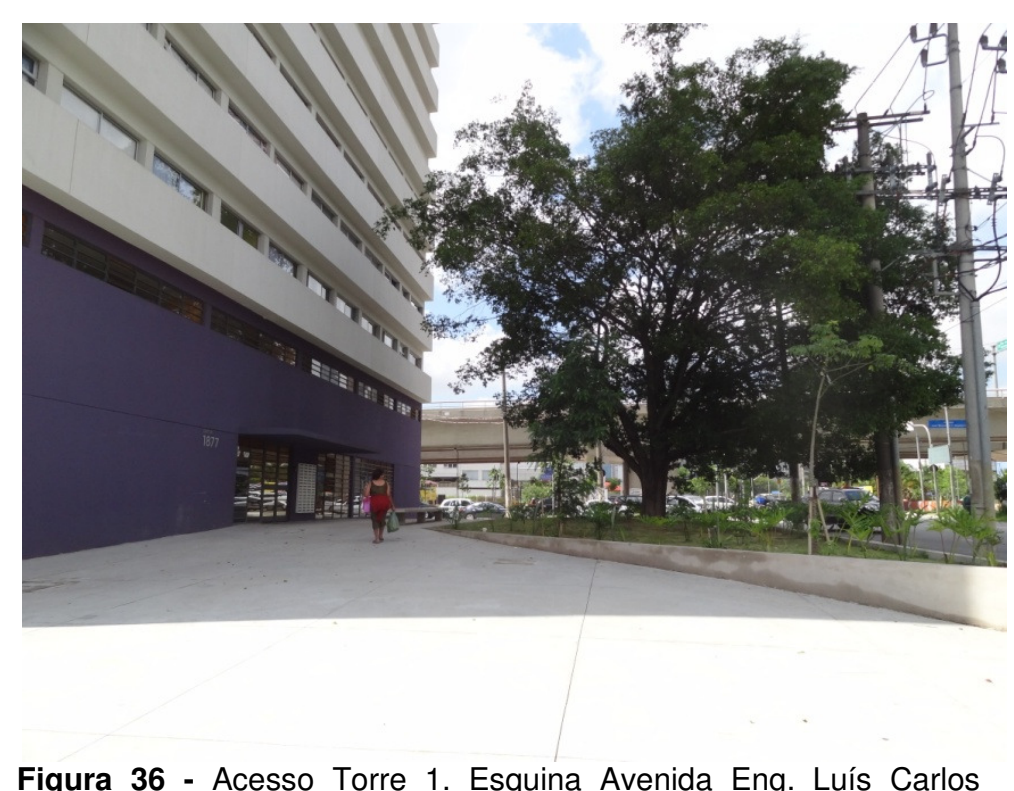

Figura 36 - Acesso Torre 1. Esquina Avenida Eng. Luís Carlos Berrini x Avenida Jorn. Roberto Marinho.

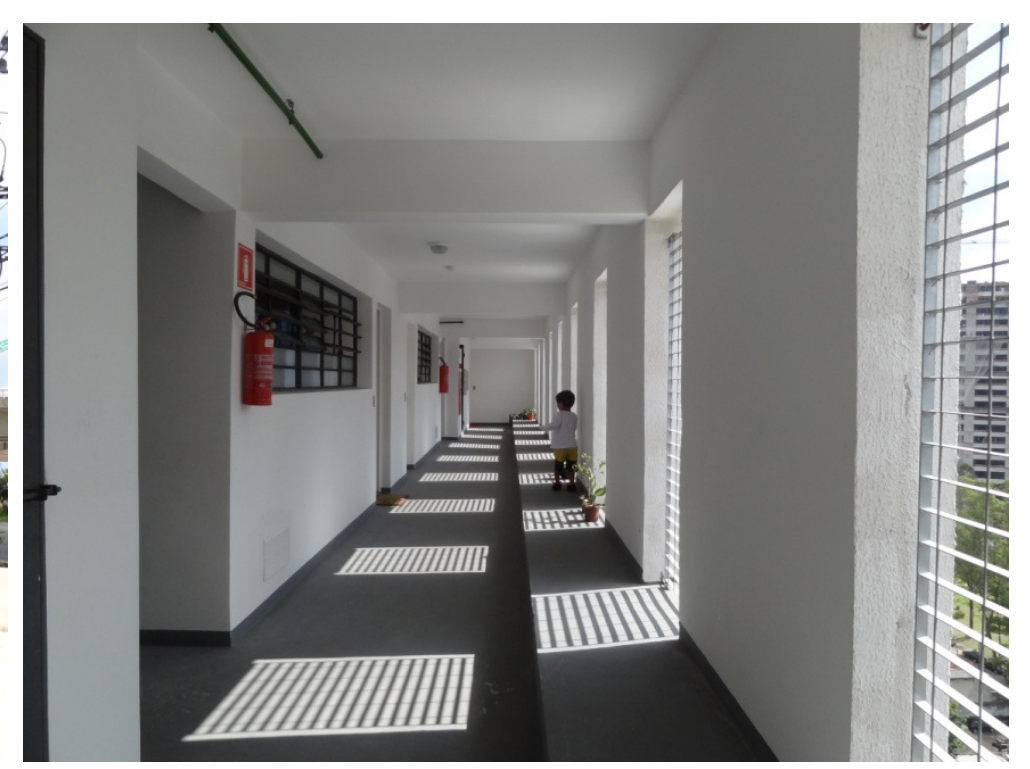

Figura 37 - Corredor de acesso às unidades.

No pavimento tipo as unidades estão distribuídas ao longo de um corredor de acesso (Figura 37). Segundo os arquitetos, o edifício Normandie (1953-57), de Franz Heep, foi referência para a concepção desses corredores. Eduardo Ferroni comentou que chegaram a visitar o edifício para entender como esse espaço funcionava, o que ocorria em dias de chuva, se havia ralos, etc. (informação verbal) ${ }^{17}$.

17 MOREIRA, Marta; FERRONI, Eduardo. Visita ao Conjunto Habitacional Jardim Edite acompanhada pelos arquitetos. Visita promovida pela disciplina: Arquitetura Contemporânea Paulista / Crítica de arquitetura. Professores responsáveis: Mônica Junqueira de Camargo; Hugo Segawa. São Paulo, 24 de julho de 2013. 
Edson Lucchini Jr. (2010, p.55), ao analisar o edifício de Heep em sua dissertação de mestrado ${ }^{18}$, observa que "em todos os andares destinados às habitações $\left(1^{\circ}\right.$ ao $\left.21^{\circ}\right)$, o arranjo espacial dos pavimentos se dá por um corredor linear voltado para a face posterior da lâmina principal, que iluminado e ventilado por cobogós de concreto, distribui os fluxos para os apartamentos, voltados para a face principal".

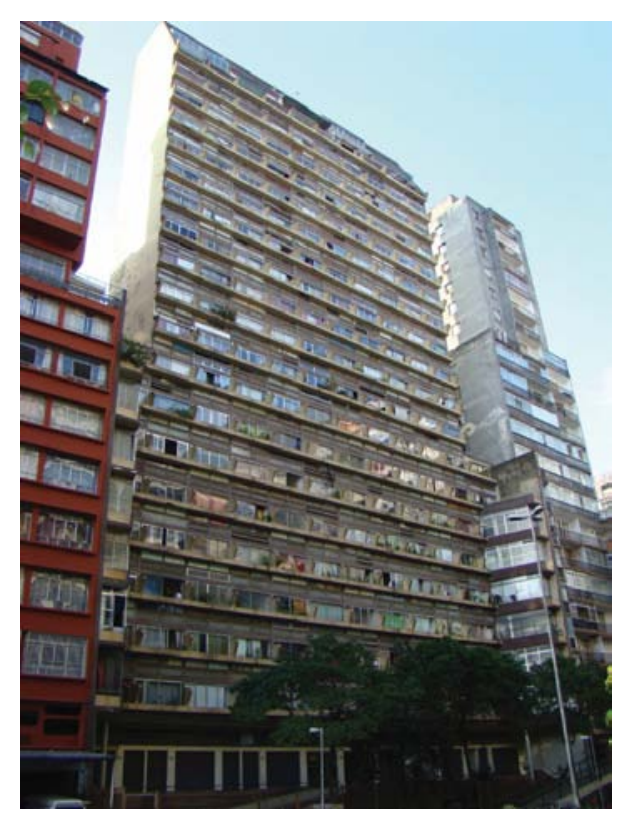

Figura 38 - Ed. Normandie, Av. Nove de Julho, SP.

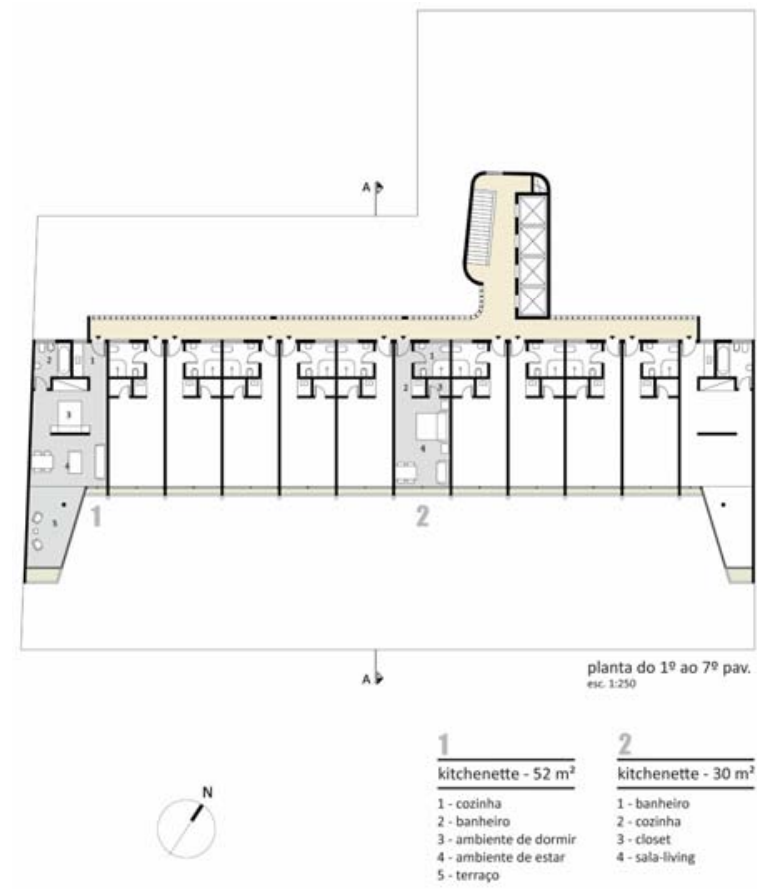

Figura 39 - Planta (1ํa ao $7^{\circ}$ pav.). Desenho de Edson Lucchini Jr.

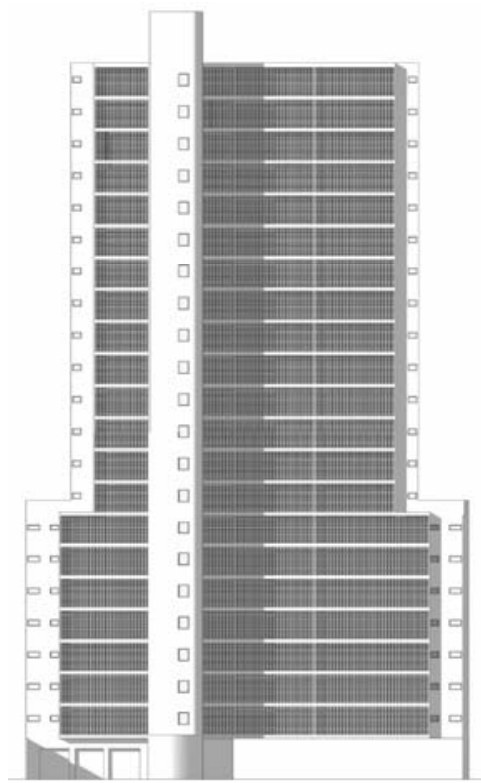

Figura 40 - Fachada Posterior. Desenho de Edson Lucchini Jr.

${ }^{18}$ LUCCHINI, Edson Jr. Adolf Franz Heep: edifícios residenciais. Um estudo da sua contribuição para a habitação coletiva em São Paulo nos anos 1950. 300f. Dissertação (Mestrado em Arquitetura e Urbanismo) - Universidade Presbiteriana Mackenzie. São Paulo, 2010. 
No caso do Jardim Edite, os cobogós foram substituídos por planos intercalados de painéis cegos e permeáveis de gradil metálico. A alternância proposta proporcionou ritmo entre os cheios e vazios nas fachadas das torres (Figura 41).

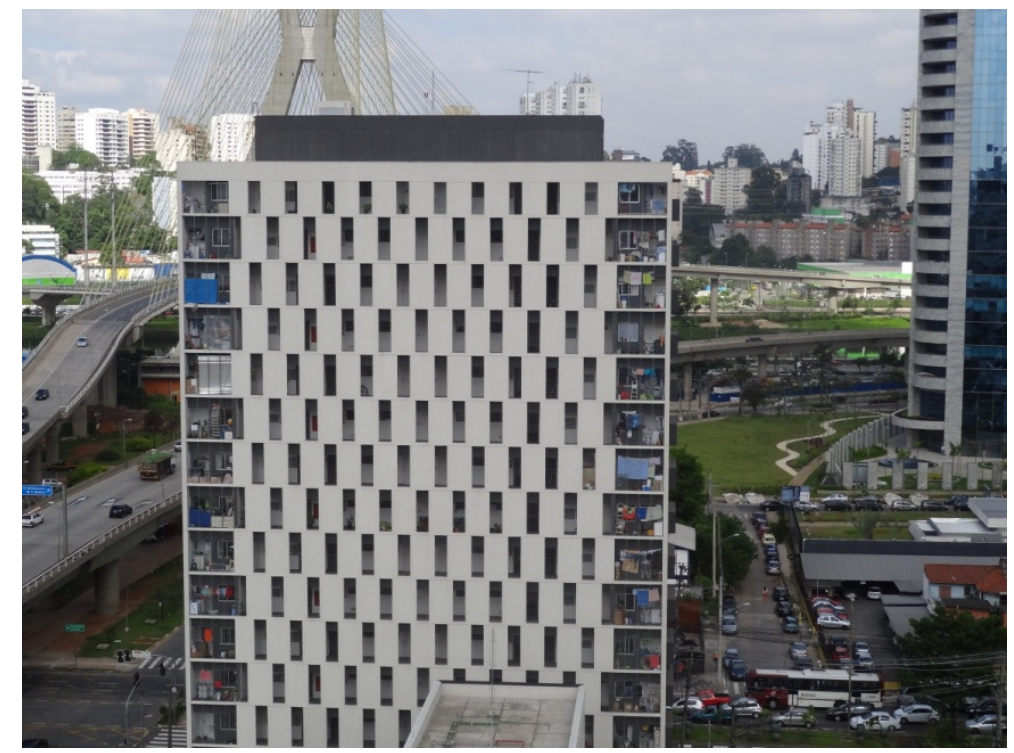

Figura 41 - Fachada Torre 1. Ritmo dado pelos cheios e vazios dos painéis de fechamento do corredor de acesso aos apartamentos.

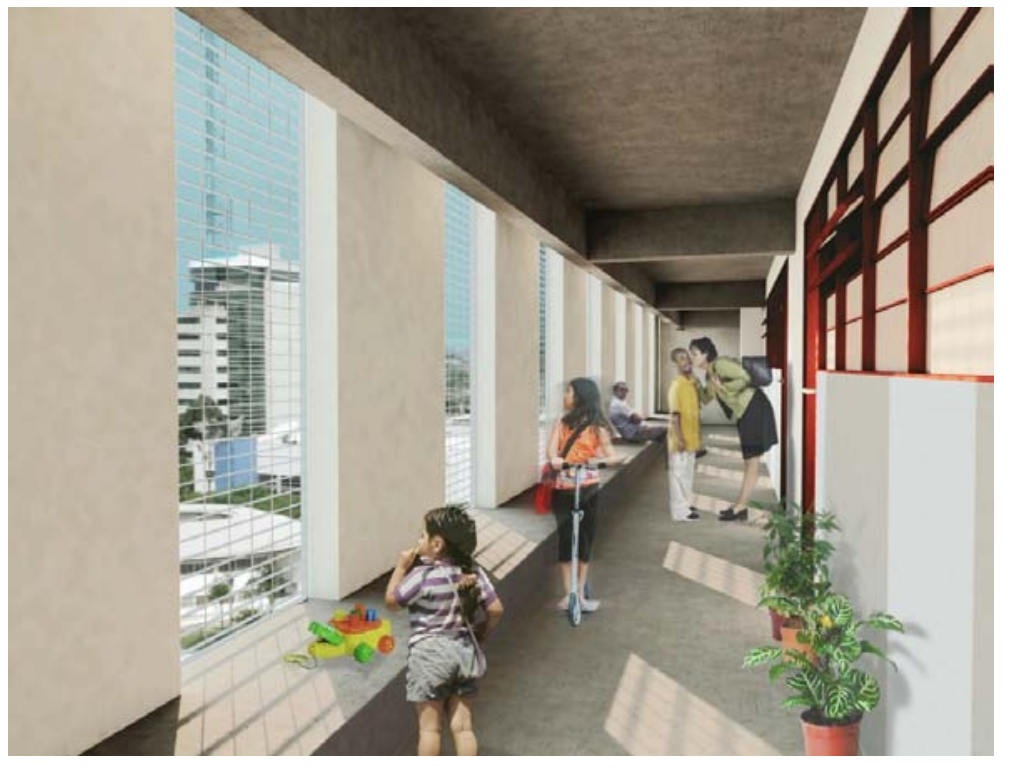

Figura 42 - Perspectiva realizada pelos arquitetos representando os corredores como espaços para convivência.

Internamente, a proposta desses corredores vai mais além de apenas dar acesso ás unidades. Segundo os arquitetos, esse espaço foi concebido para ser apropriado pelos moradores como espaços para convivência, como pode ser observado na Figura 42. À esquerda, no limite do fechamento, foi proposto um degrau, ou um banco onde 
as crianças podem brincar e os vizinhos podem sentar para conversar. Enfim, foi gerado um espaço com elementos que proporcionam o convívio entre os moradores.

Finalizando o tema das circulações, é importante comentar a existência dos elevadores nessa proposta. Segundo as Diretrizes de Projetos de Edificação (Prefeitura de São Paulo, 2012 b, p.232), "caso não seja possível atingir o coeficiente de aproveitamento máximo sem o uso de elevadores, o projeto deverá incorporar o equipamento em sua solução", porém, essa diretriz não se aplicaria ao Jardim Edite uma vez que o projeto não atinge o coeficiente de aproveitamento máximo, ao contrário, fica bem abaixo do que seria permitido, como foi visto no início da análise (C.A. permitido $=4$ / C.A. construído $=1,35$ ).

Alguns dos problemas apontados pela inclusão de elevadores no projeto são a gestão e o custo da manutenção. No caso do Jardim Edite, os arquitetos e técnicos da Sehab explicaram que foi feita uma triagem das condições da demanda e que as famílias com condições financeiras inferiores foram alocadas nas lâminas, onde não há elevadores e, portanto, o valor do condomínio é menor.

O conjunto foi entregue aos moradores há pouco tempo (janeiro de 2013) e, portanto, não houve tempo necessário para que uma avaliação fosse consolidada sobre a manutenção dos elevadores. De qualquer forma, como já foi citado anteriormente, a verticalização foi o partido adotado para o desenvolvimento do projeto e a demanda de moradores, que viviam na favela anteriormente às remoções, foi atendida. Portanto, será necessário acompanhar e analisar dentro de alguns anos, o estado de conservação desses equipamentos para verificar se realmente foi uma ousadia bem sucedida. 


\section{Diversidade tipológica}

Quanto á diversidade de tipologias nas torres, pode-se concluir que foram propostas apenas duas tipologias: o Tipo 1, localizado nas extremidades do edifício; e o Tipo 2, ocupando a posição central.

As unidades dedicadas à pessoas com necessidades especiais (P.N.E.) foram adaptadas a partir do Tipo 2 e localizam-se no segundo andar, acima do salão condominial. Nas torres 1 e 3 , há apenas um pavimento com unidades adaptadas e na torre 2, são dois andares, o segundo e o terceiro, cumprindo assim o número mínimo de $3 \%$ de unidades P.N.E., exigido pela legislação.

Ao analisar os cortes, verifica-se que, verticalmente, as áreas molhadas estão todas sobrepostas. Porém, o mesmo não ocorre no sentido horizontal, em que, como podemos observar nas plantas (Figura 35), estão concentradas dentro de cada unidade, mas não entre uma unidade e outra.

As unidades Tipo 1, por estarem nas extremidades do edifício, puderam avançar sobre o espaço dos corredores e, dessa forma, são as únicas tipologias que têm frente para as duas fachadas.

\section{Estrutura e aberturas}

Os edifícios foram construídos em estrutura moldada in loco e alvenaria convencional. Os pilares vencem vãos de 5,10 metros e foram posicionados perpendicularmente às fachadas, permitindo maiores aberturas. Nesse caso, as aberturas vão de parede a parede, como pode ser observado no corte longitudinal (Figura 43).

Dois detalhes construtivos merecem atenção nesse projeto: os armários construídos abaixo das janelas; e o "banco-degrau" dos corredores de acesso às unidades. No detalhe da Figura 43, pode-se observar que as janelas são recuadas para que se formem, na parte de baixo, esses espaços horizontais que podem ser utilizados como armários ou apenas considerados um espaço a mais dentro da unidade. 

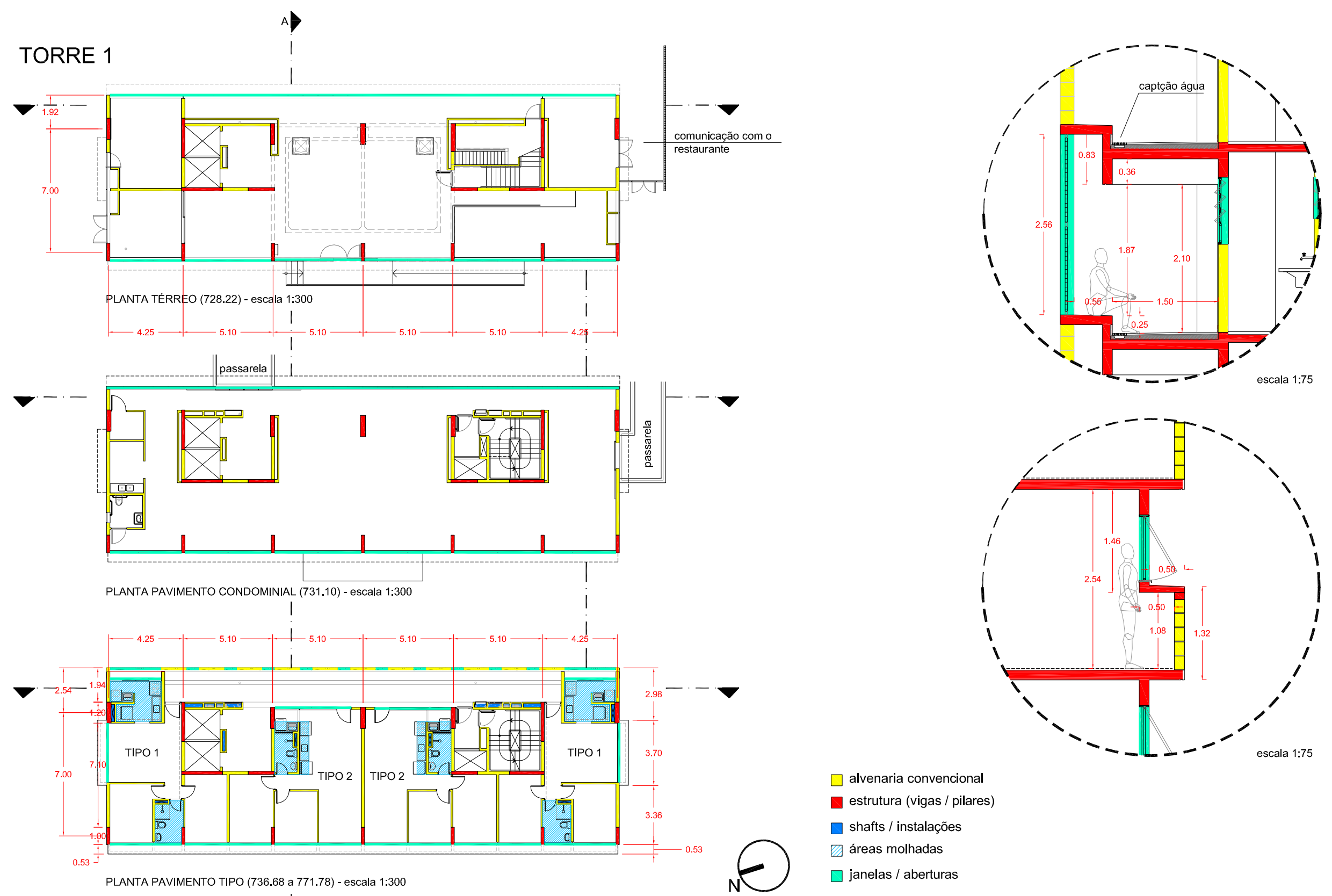

escala 1:300

$\square$ alvenaria convencional

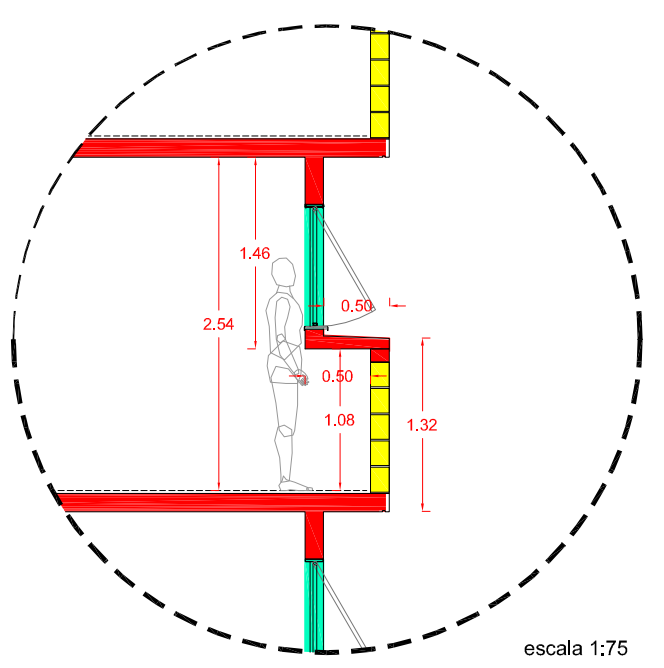

$\square$ estrutura (vigas / pilares)

$\square$ shafts / instalações

$\square$ áreas molhadas

$\square$ janelas / aberturas

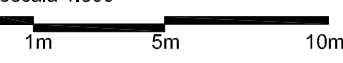




\section{TORRE 1}
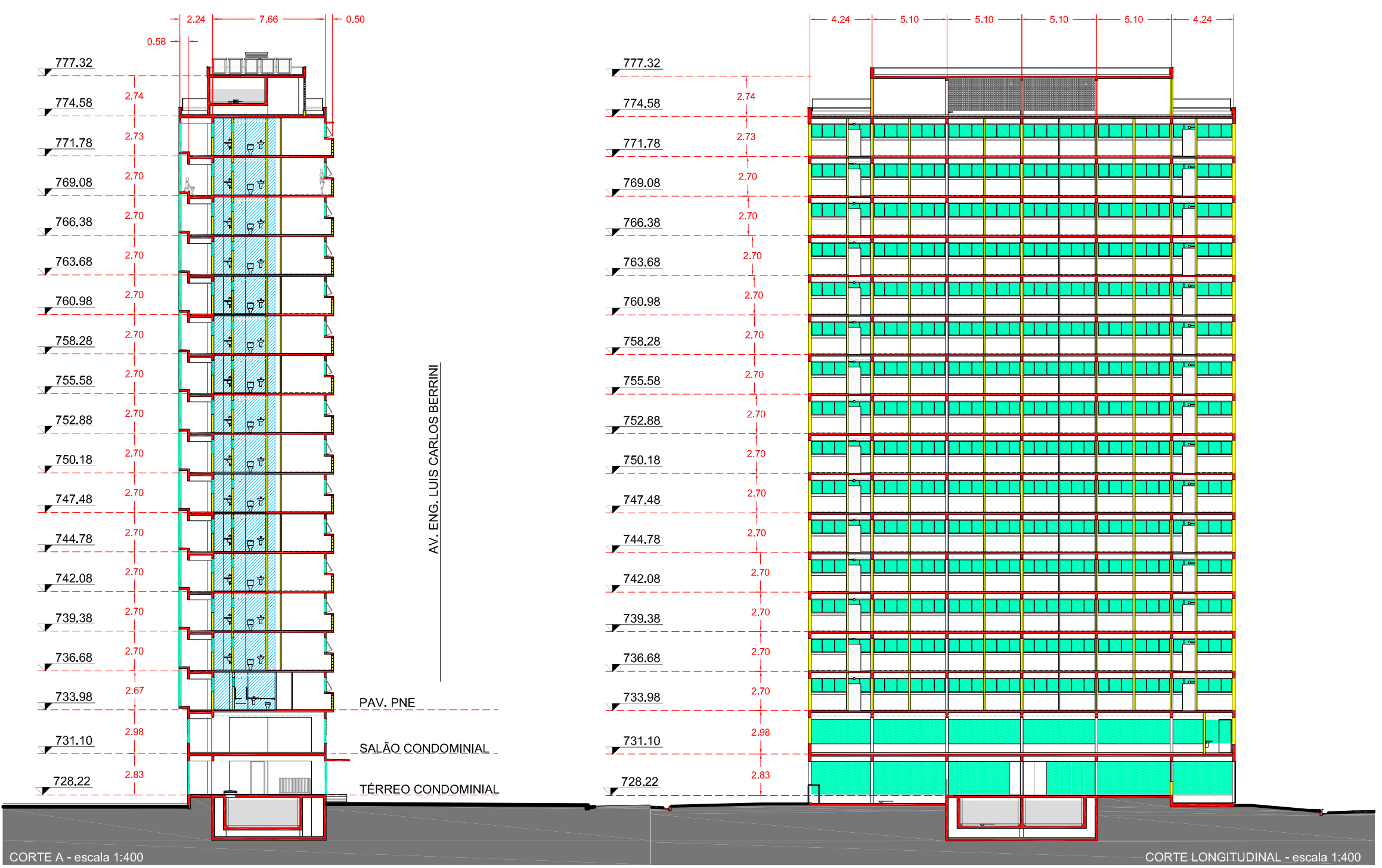

escala 1:400

Figura 43 - Esquema estrutural - Torre 1.

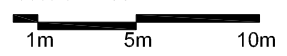


Os armários embaixo das janelas geram volumes que se destacam nas fachadas (Figura 44). Quando não se sabe que são armários internos, esses volumes, nas fachadas, podem ser confundidos com pequenos terraços ou até jardineiras.

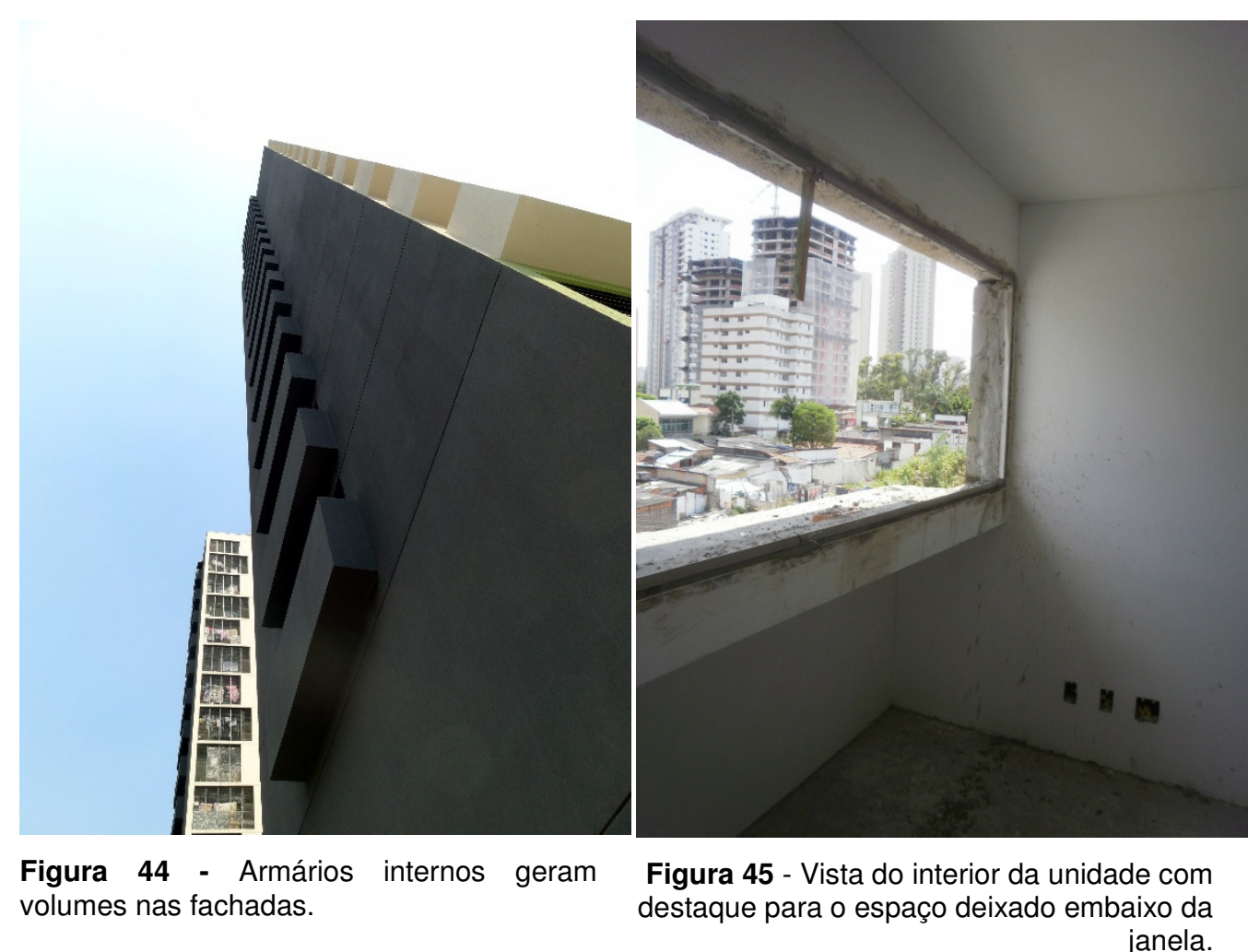

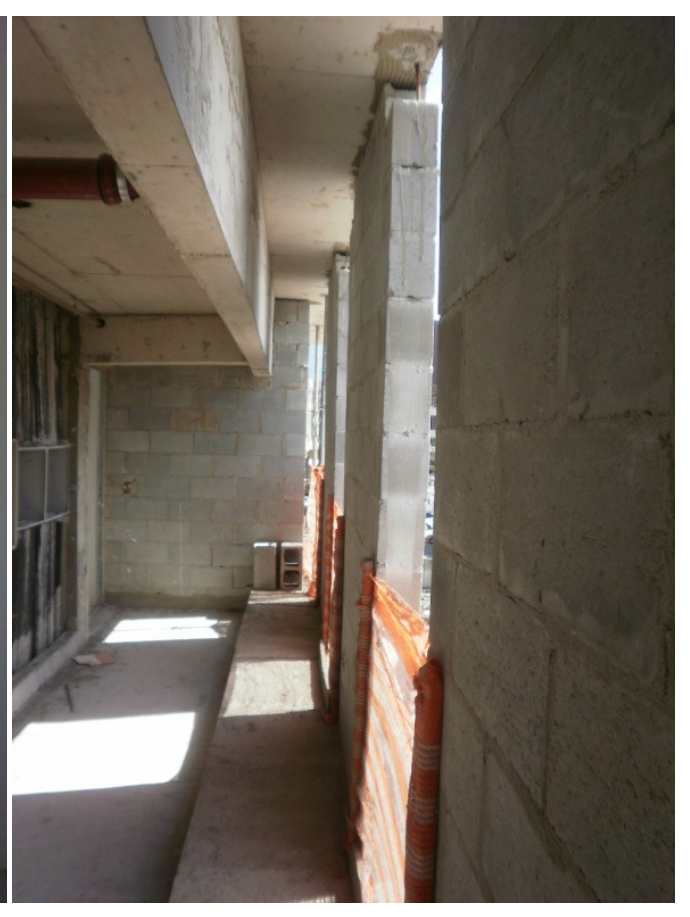

Figura 46 - Detalhe construtivo do "bancodegrau" e do fechamento do corredor.

Quanto ao "banco-degrau", podemos verificar que trata-se de um detalhe construtivo da própria viga que gera esses desníveis ao longo do corredor. No detalhe da Figura 43, também é possível observar o fechamento, com gradis metálicos, do corredor de acesso às unidades, que se alterna com painéis de alvenaria gerando os cheios e vazios da fachada das torres. 


\subsubsection{LÂMINA}

Como exemplo da escala edifício, será analisada a lâmina 2. Porém, não há diferenças significativas entre as duas lâminas. Em alguns momentos, nota-se diferenças na posição dos acessos às unidades e com relação ao desenho da escada que, na lâmina 1 é em formato "U" e, na lâmina 2, a escada é contínua proporcionando um corredor na lateral. Essas diferenças puderam ser observadas nas plantas do pavimento tipo em Relação entre os Edifícios (Figura 34).

\section{Acessos e circulação}

Diferentemente das torres, as lâminas não têm acesso direto desde a rua e, para chegar até às unidades, é necessário realizar um percurso pela parte comum do conjunto. É no pavimento condominial que as escadas de acesso às unidades estão distribuídas.

Cada escada acessa duas unidades por andar nos dois primeiros pavimentos e, no terceiro pavimento, acessa quatro unidades duplex. Como pode ser observado na Figura 47, a caixa de escada para no penúltimo andar e o último é ocupado pelo andar superior das unidades duplex.

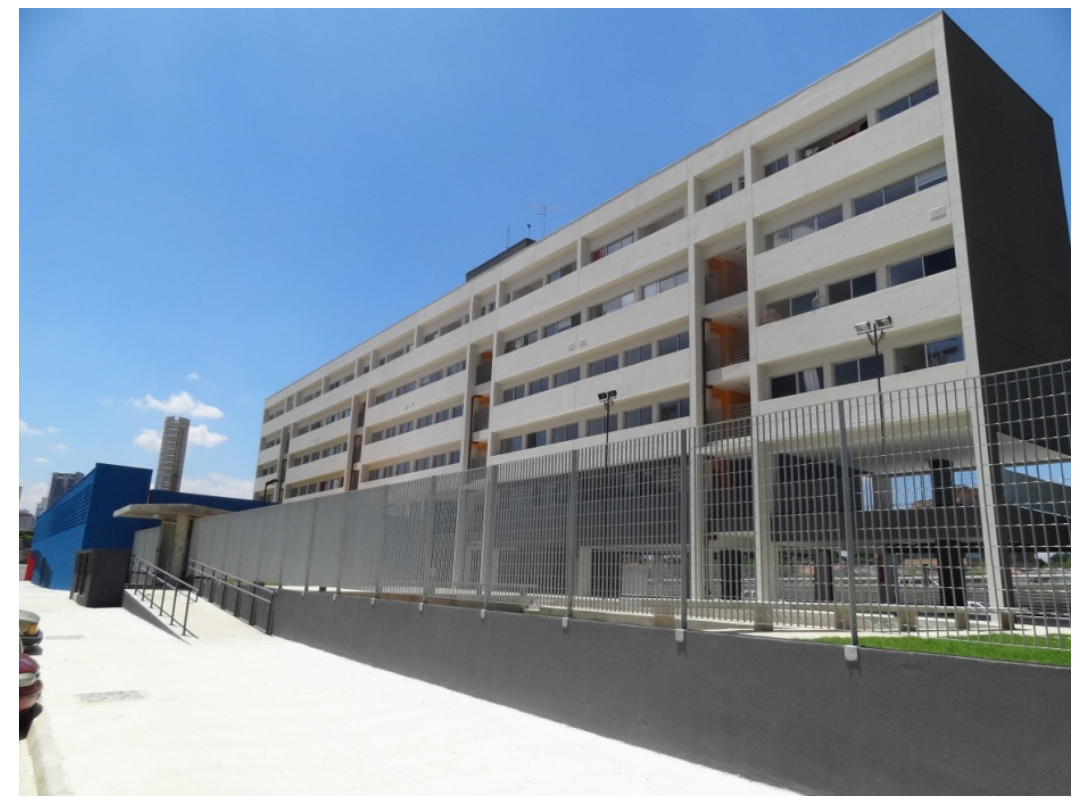

Figura 47 - Lâmina 2 


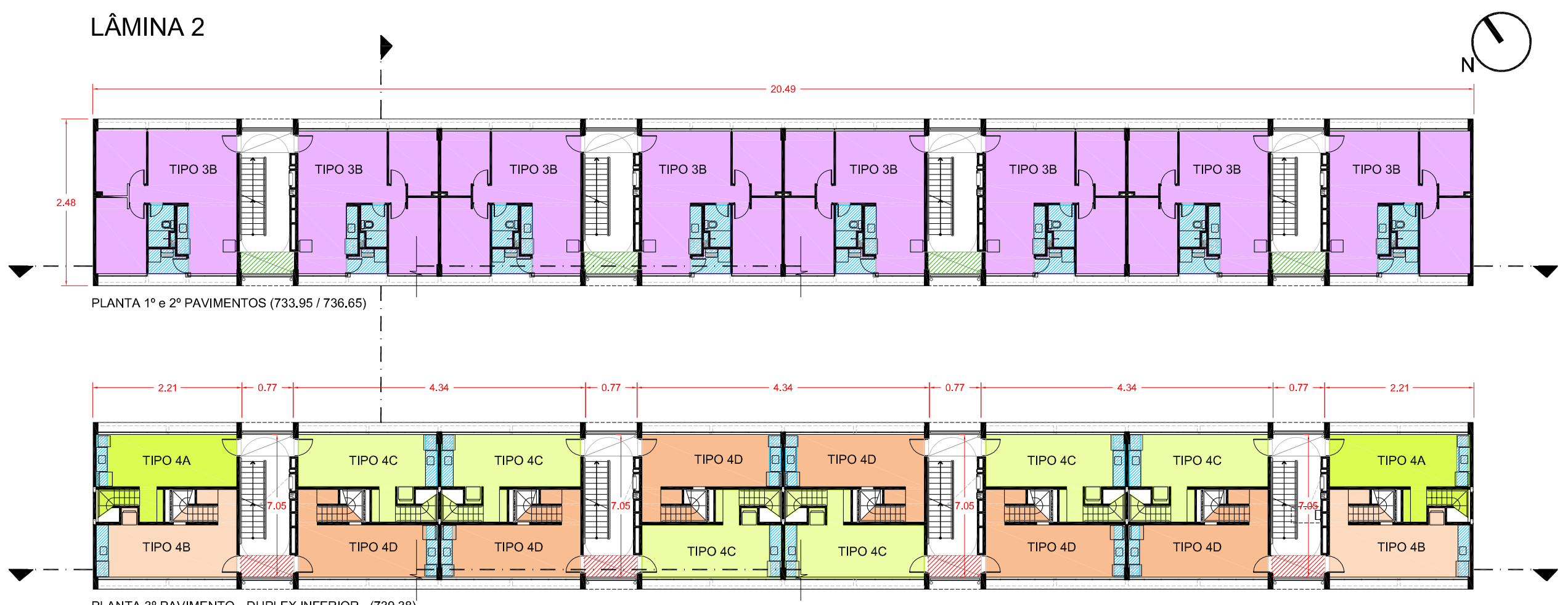

PLANTA $3^{\circ}$ PAVIMENTO - DUPLEX INFERIOR - (739.38)

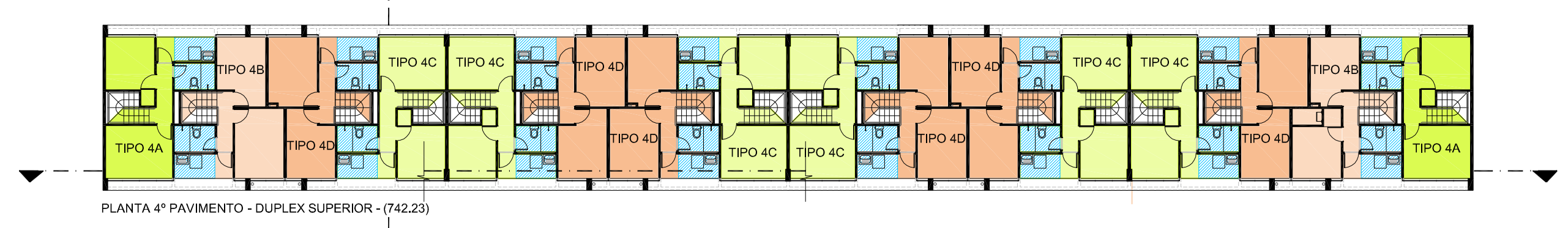
PLANTA $4^{\circ}$ PAVIMENTO - DUPLEX SUPERIOR - (742.23)
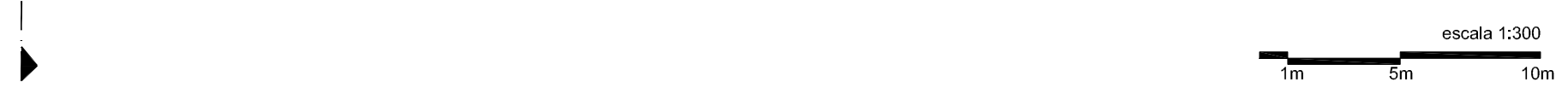


\section{LÂMINA 2}

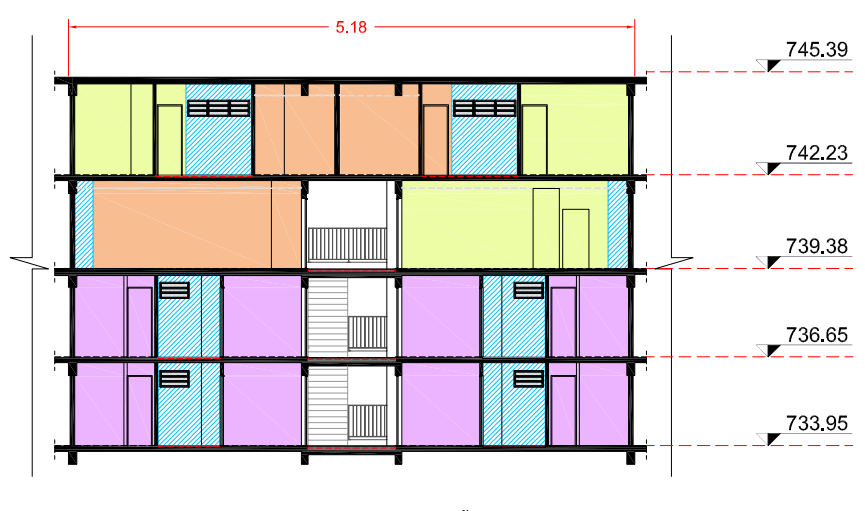

(módulo que se TRECHO SEÇÃO LONGITUDINAL espelhado ao longo da lâmina)
$\square$ Tipo 1 - torre
$\square$ Tipo $2 \mathrm{~A}$ - torre
$\square$ Tipo 2B - torre
$\square$ TIpo 3A - Lâmina 1
$\square$ TIpo 3B - Lâmina 2
$\square$ Tipo 4A - Lâmina
$\square$ Tipo 4B - Lâmina
$\square$ Tipo 4C - Lâmina
$\square$ Tipo 4D - Lâmina
Espaços p/ convivência -
extensões do espaço comum
Espaços de transição
Q áreas molhadas

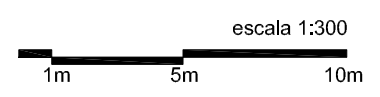

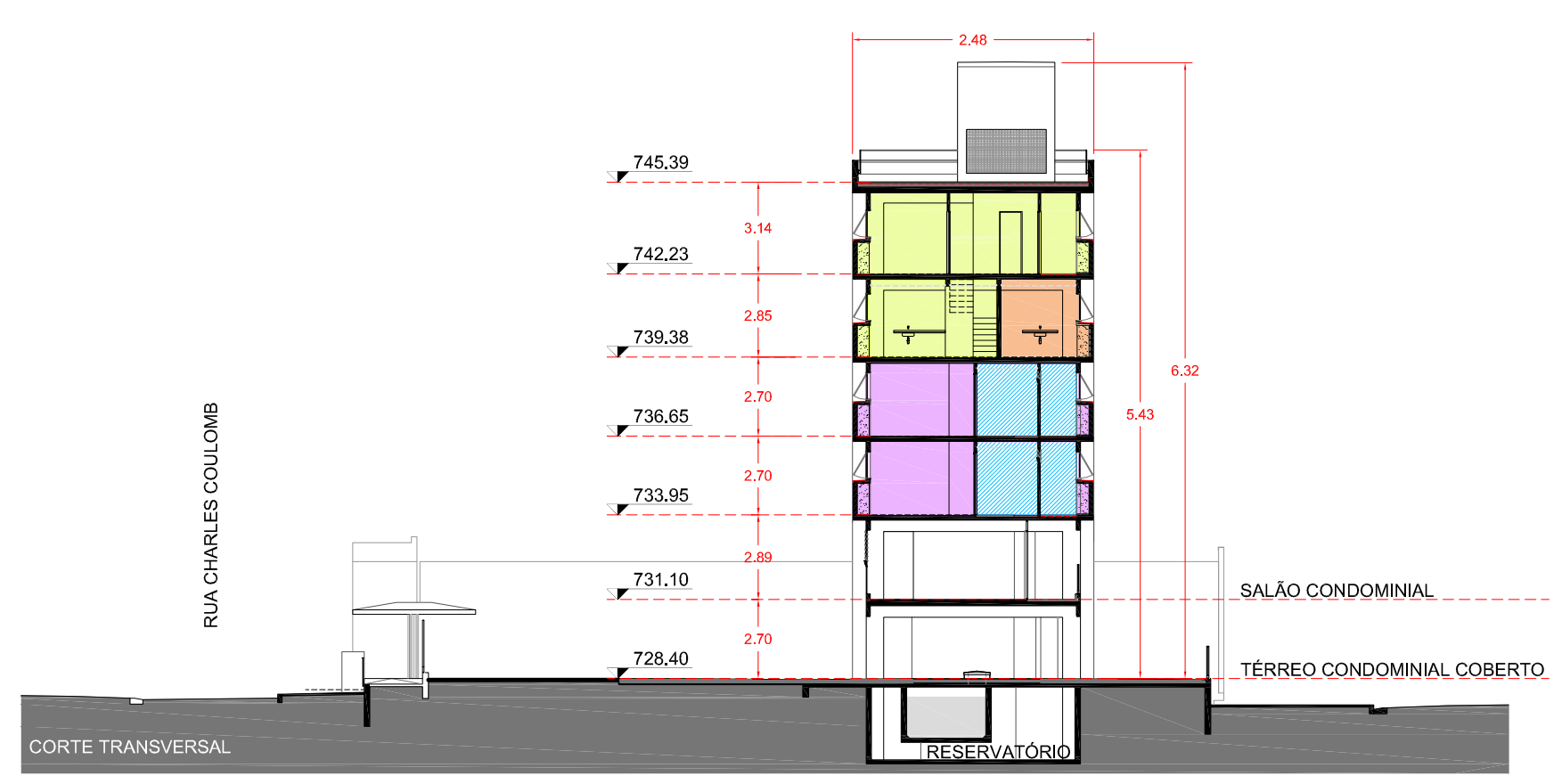

Figura 48 - Análise escala edifício: lâmina 2. 


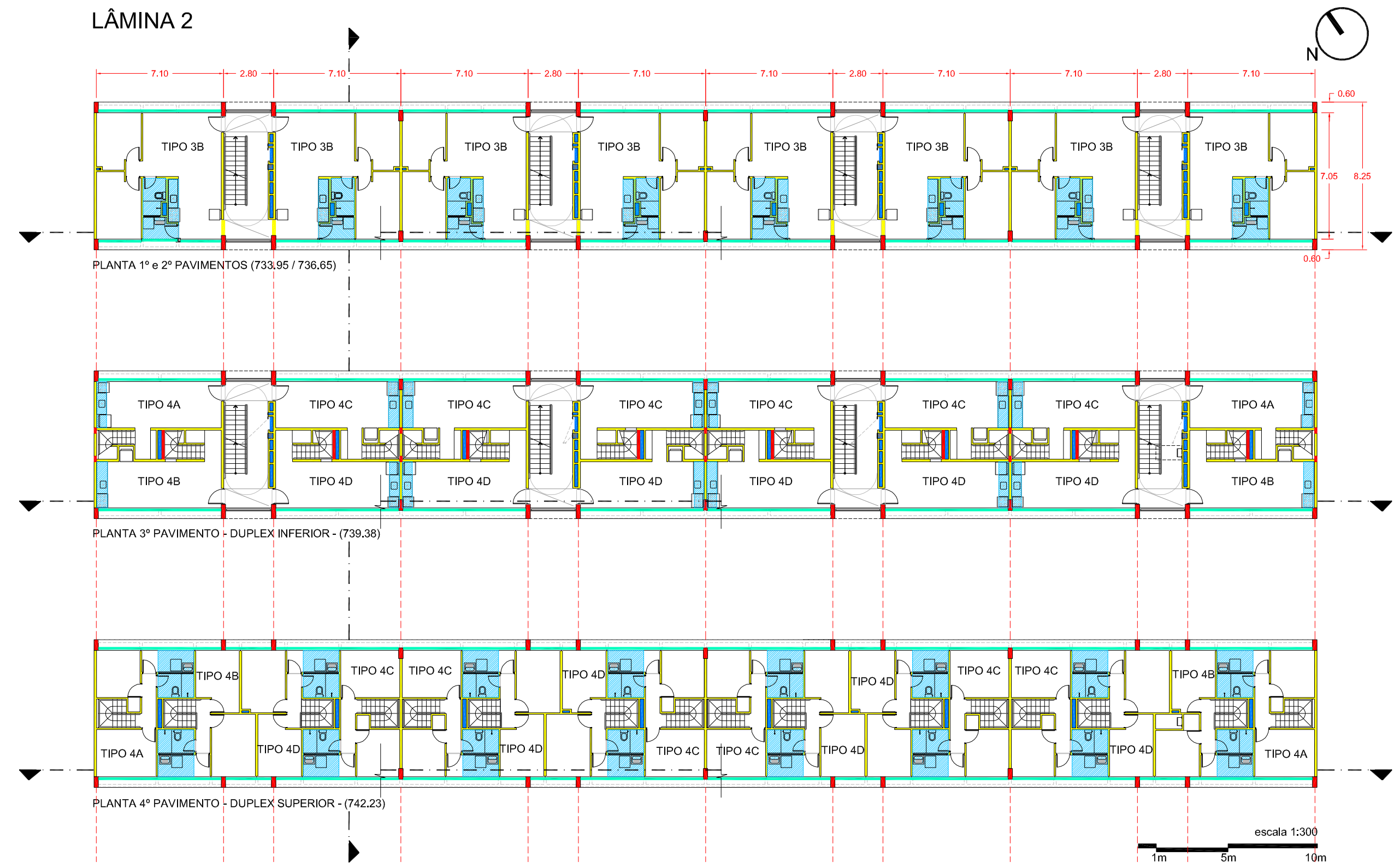




\section{LÂMINA 2}

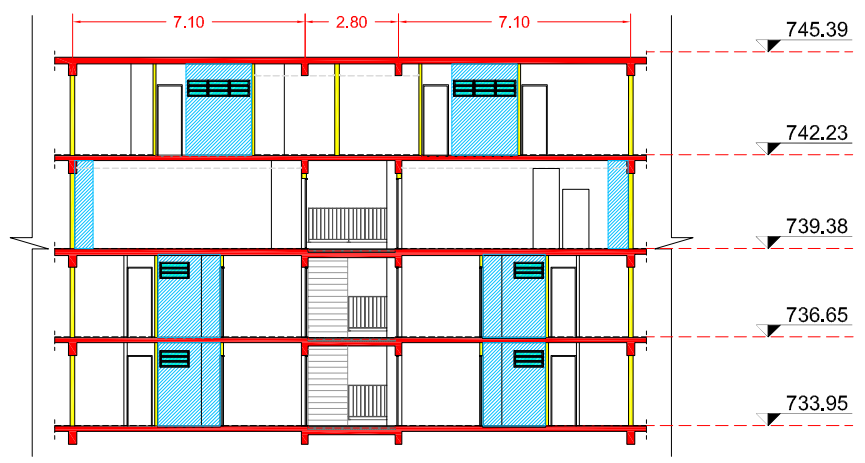

TRECHO SEÇÃO LONGITUDINAL

$\square$ alvenaria convencional $\square$ estrutura (vigas / pilares)

$\square$ shafts / instalações

$\square$ áreas molhadas

$\square$ janelas / aberturas

escala 1:300

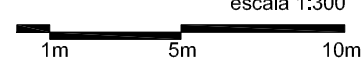

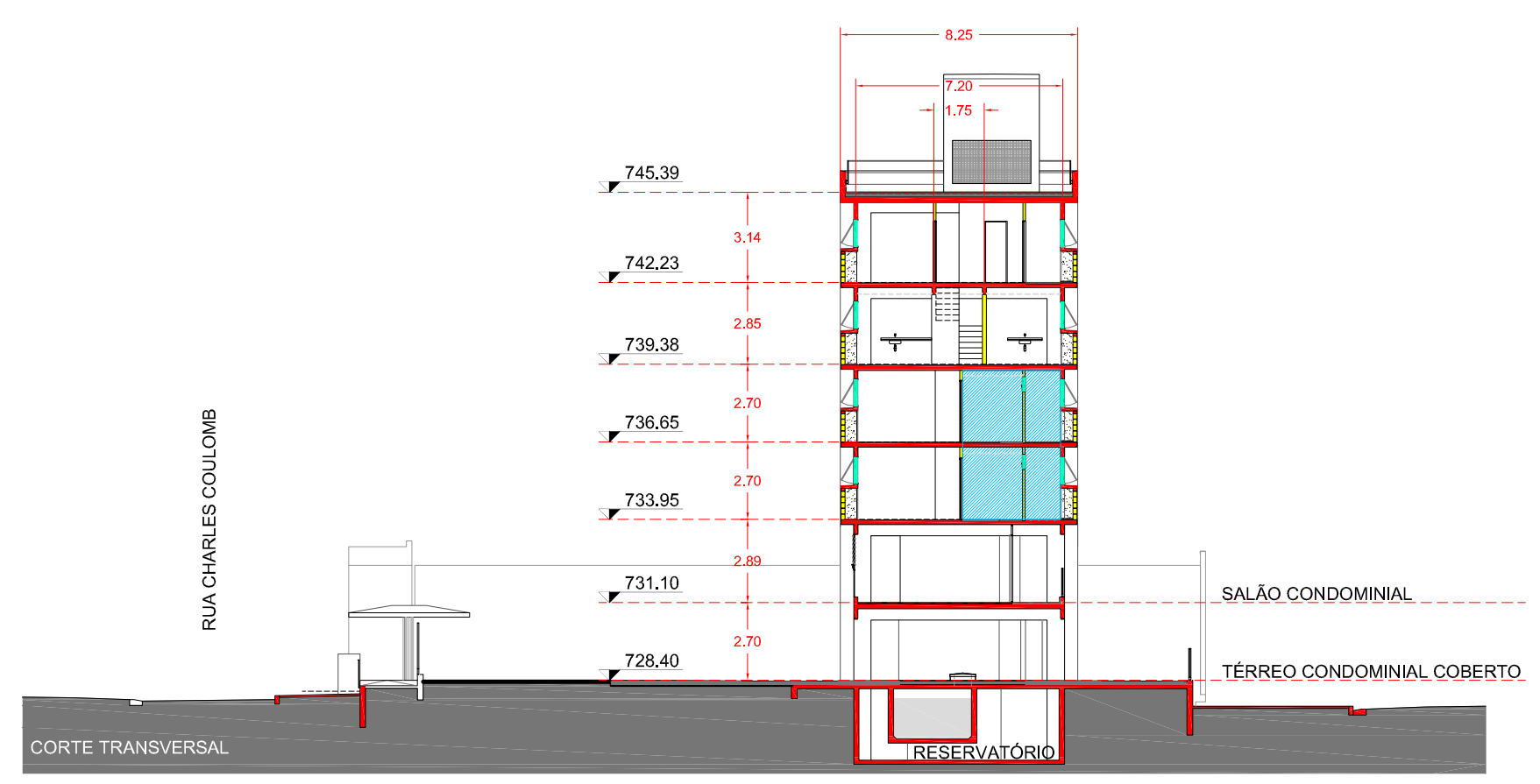

Figura 49 - Esquema estrutural: lâmina 2 
Como os dois primeiros andares (térreo e primeiro pavimento) foram destinado à espaços de uso condominial, as unidades aparecem a partir do segundo pavimento e, de acordo com o Código de Obras de São Paulo ${ }^{19}$, o acesso às unidades, unicamente por escada, é permitido apenas até o quarto pavimento (térreo +4 andares), sendo assim, as unidades duplex permitem que um maior número de UHs sejam construídas aproveitando a dupla altura dos apartamentos.

No caso das unidades "não duplex", o espaço de circulação ao redor da escada proporciona um alargamento da circulação que foi classificado como espaço para a convivência. Esses espaços, que não estão diretamente associados às portas das unidades, podem ser utilizados pelos vizinhos como um espaço para sentar, conversar, descansar, ou até mesmo para as crianças brincarem, mais próximas aos cuidados dos pais. O mesmo não ocorre no andar de acesso às unidades dúplex porque esse espaço foi utilizado como hall de entrada. Porém, por estarem relacionados com a entrada, foram classificados como espaços de transição, funcionando como um estreito filtro de privacidade e espaço de apropriação para os moradores. Esse espaço diferencia-se do deixado em frente às portas das unidades "não dúplex" porque, nesse caso, o espaço deixado é exatamente o necessário para o raio da circulação, não sobrando espaço para "filtrar" o acesso à essas unidades.

\section{Diversidade tipológica}

As lâminas apresentam dois tipos de unidades: os duplex (Tipo 4) e as unidades de um único andar (Tipo 3). Como foi citado anteriormente, os duplex ocupam os dois últimos andares e se acomodam acima da caixa de escada. Os apartamentos são encaixados entre si proporcionando espaço para dois dormitórios, banheiro e área de serviço no andar superior.

${ }^{19}$ Código de Obras e Edificações do Município de São Paulo. Lei Municipal no 11.228 de 25 de junho de 1992. "9.5.1 - Deverão ser servidas por elevadores de passageiros as edificações com mais de cinco andares e/ou que apresentem desnível, entre o pavimento do último andar e o pavimento do andar inferior - incluindo pavimentos destinados a estacionamento - superior a 12,00 m (doze metros)". 
As áreas molhadas estão agrupadas dentro das unidades Tipo 3 e, nos duplex (Tipo 4) estão espelhadas a cada duas unidades, no pavimento inferior. O shaft existente atrás da escada do duplex, comunica as áreas molhadas do pavimento superior com as unidades Tipo 3.

\section{Estrutura e aberturas}

Assim como as torres, as lâminas também foram construídas em estrutura moldada in loco e alvenaria convencional. Os pilares foram locados nas extremidades das unidades vencendo vãos de 7,10m e, a cada duas unidades, encontra-se uma caixa de escadas com largura de 2,80m entre eixos. Essa disposição dos pilares deixa as fachadas livres para as aberturas.

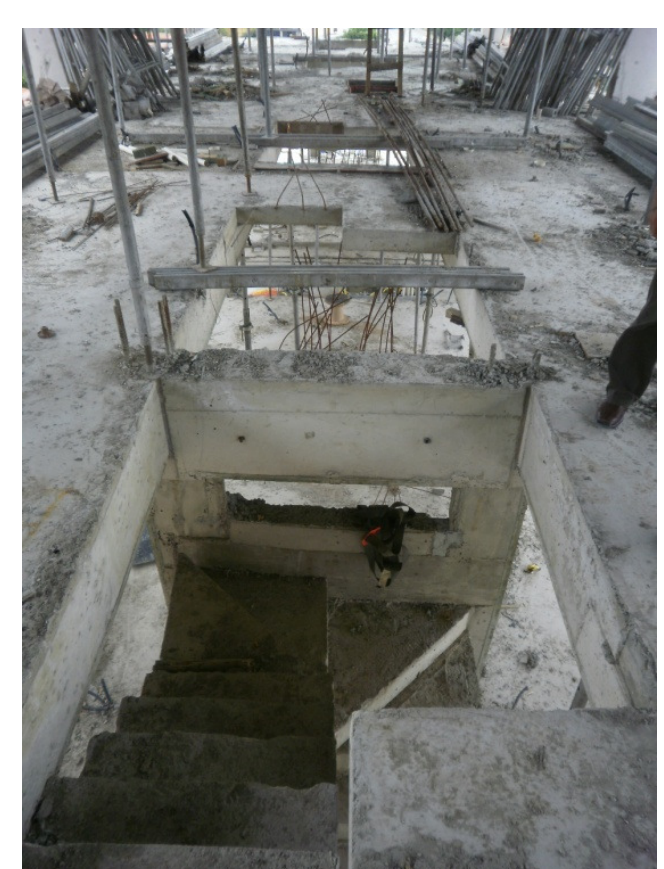

Figura 50 - Escadas dos duplex em construção.

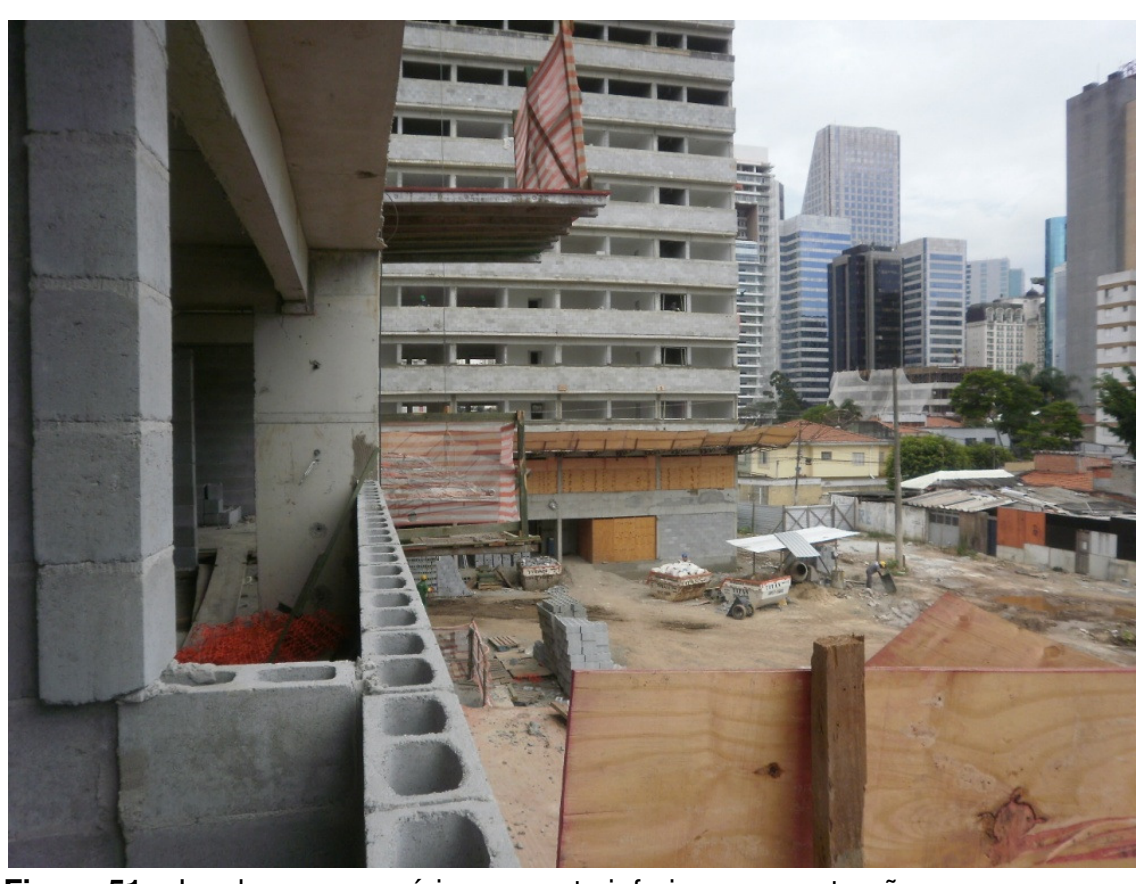

Figura 51 - Janelas com armários na parte inferior em construção. 
As escadas internas dos duplex configuram um alinhamento no meio do edifício que organizam os acessos e separam os andares inferiores dessas unidades voltados metade para cada fachada. $O$ detalhe dos armários abaixo das janelas também ocorre nas lâminas e, nesse caso, ocorre nas duas fachadas de maior dimensão.

\subsubsection{ESCALA \\ UNIDADE}

$\mathrm{Na}$ escala edifício foi possível observar que o conjunto Jardim Edite possui quatro tipologias principais distribuídas entre as torres e os edifícios, porém, todas apresentam o mesmo programa: dois dormitórios; um banheiro; sala de estar; cozinha e área de serviço em aproximadamente $50 \mathrm{~m}^{2}$. Isso nos permite concluir que as variações nas tipologias ocorreram devido a necessidades formais e projetuais durante o desenvolvimento do projeto, não estando relacionadas às diferentes necessidades da demanda uma vez que o programa é o mesmo para todas.

\subsubsection{TIPO 1}

O Tipo 1 localiza-se nas extremidades das torres e, com isso, tem aberturas voltadas para as duas fachadas do edifício o que garante a ventilação cruzada constante, como pode ser observado no esquema de iluminação e ventilação (Figura 52). Apesar dos edifícios apresentarem diferenças na implantação, essa tipologia tem insolação leste - oeste garantida em qualquer posição. Apenas estão mais prejudicados os apartamentos que têm a janela da sala de estar voltada para a face sul, o que acontece em metade dos casos. 


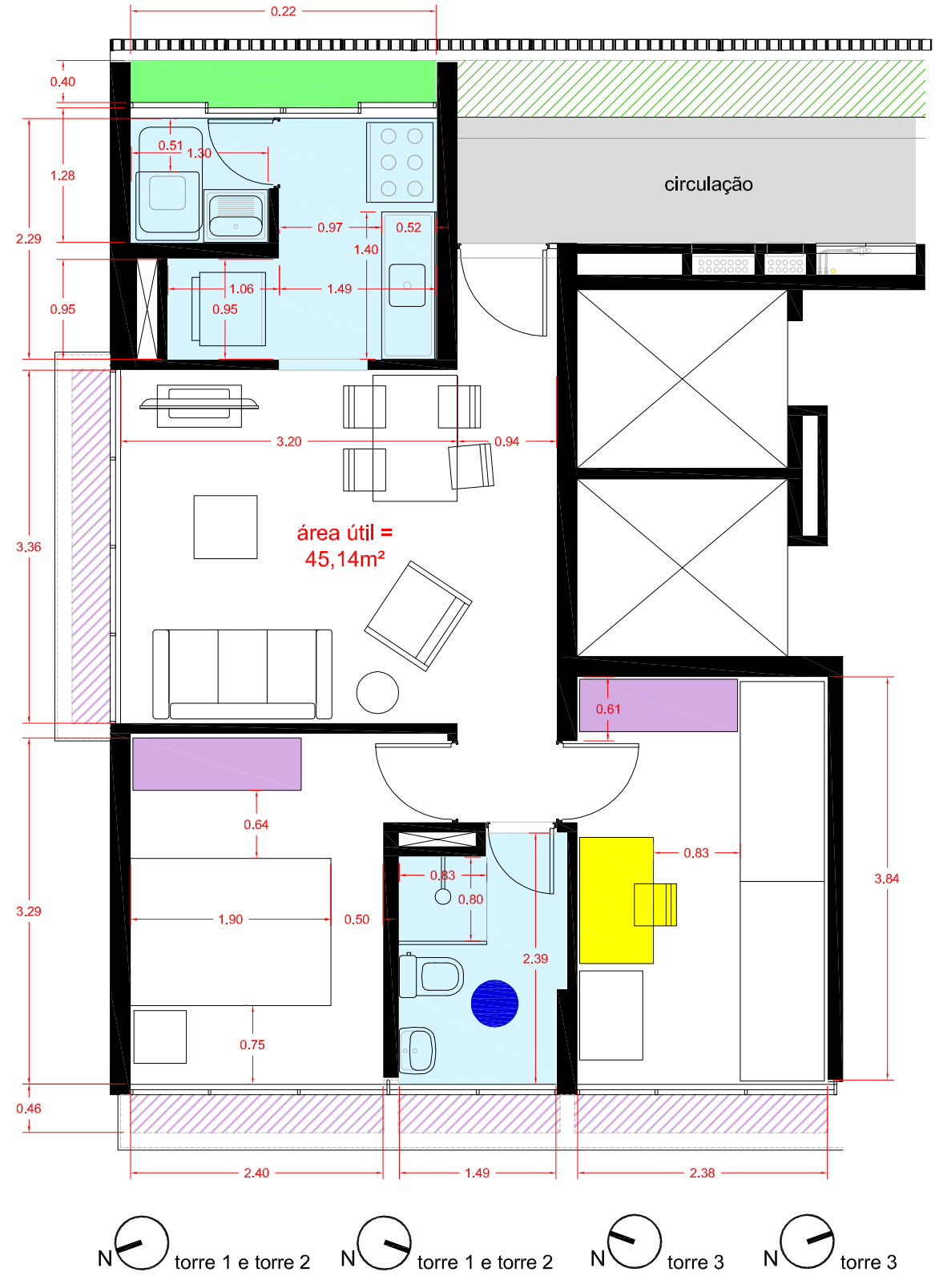

PLANTA TIPO 1 - layout e dimensões. escala 1:75
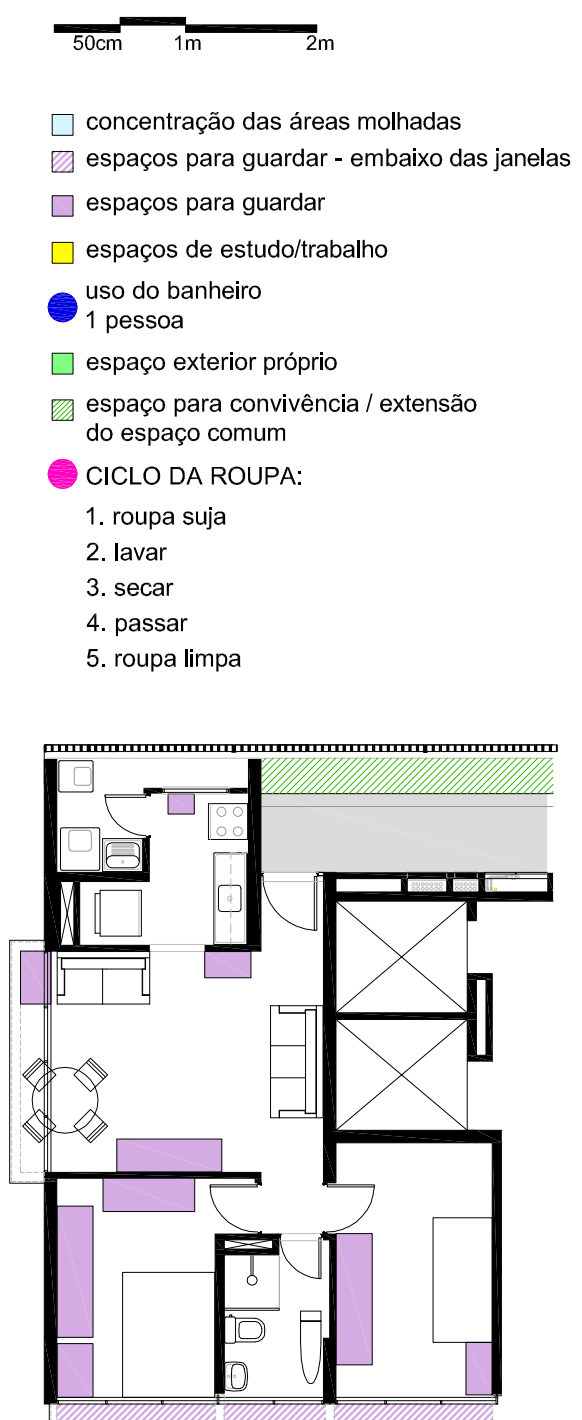

PLANTA TIPO 1 - reprodução de layout de um apartamento visitado já ocupado pelos moradores. escala 1:150

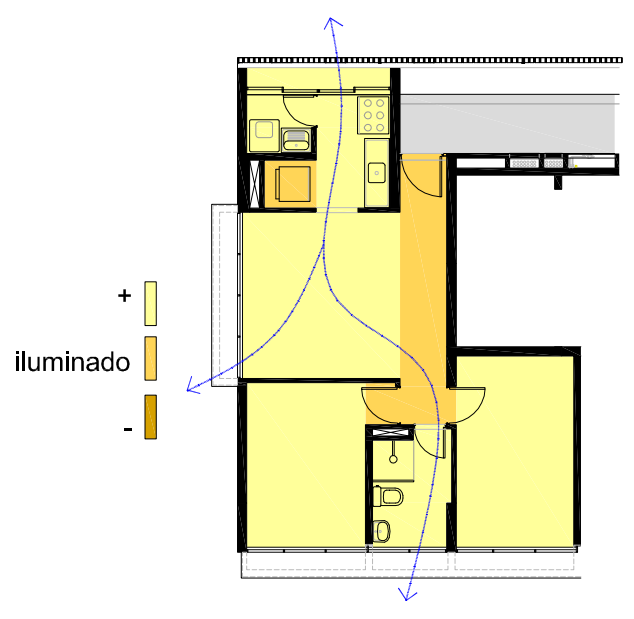

ESQUEMA ILUMINAÇÃO E VENTILAÇÃO (orientação de referência: torre 1 ) escala 1:200

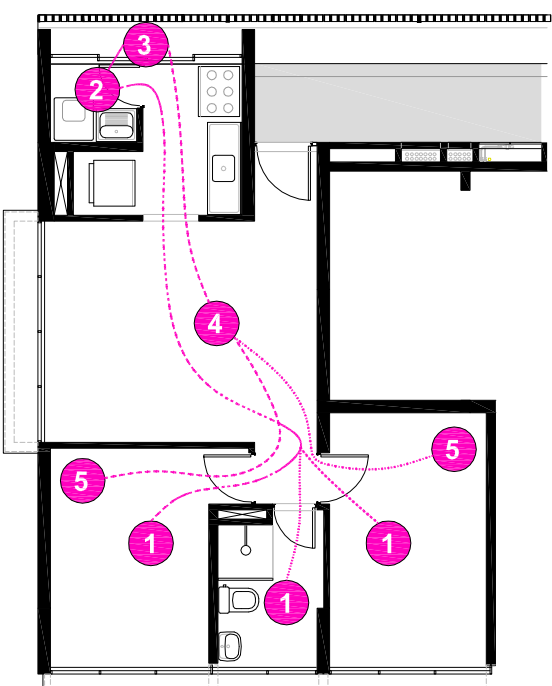

PLANTA TIPO 1 - ciclo da roupa escala 1:150

Figura 52 - Análise Tipo 1. 


\section{Ambientes não} especializados

As medidas dos espaços destinados ao uso de dormitórios e sala de estar permitem variações na disposição do layout dando maior flexibilidade de uso a esses ambientes. Os dormitórios possuem dimensões um pouco diferentes entre eles: um é mais retangular, tem apenas 2,38m de largura, mas ganha espaço no outro sentido com $3,84 \mathrm{~m}$. No layout desenhado pelos escritórios de arquitetura, nota-se que estão dispostas duas camas de solteiro nesse dormitório, aproveitando seu comprimento. Nota-se também que, nesse ambiente, foi possível avançar sobre a caixa dos elevadores garantindo espaço para um armário na parte atrás da porta. O outro dormitório tem a forma mais quadrada, com largura de 2,40m, medida justa para uma cama de casal mais $50 \mathrm{~cm}$ de passagem.

Ao visitar um apartamento já ocupado pelos moradores, é possível perceber que, nem sempre, os espaços são utilizados da forma como foi pensada pelos arquitetos. Por um lado, oferecer espaços com dimensões um pouco mais generosas, favorece a utilização e deixa os moradores mais livres para mobiliarem os ambientes da forma que mais os agradar, contudo, durante as visitas, foi possível perceber que algumas situações ocorrem, também, por falta de orientação. No quarto mais estreito da casa visitada (Figura 53), podemos observar que os moradores não colocaram o armário no espaço reservado atrás da porta e, ao serem indagados sobre o assunto, responderam que "preferiam o armário ao lado da cama mesmo" (informação verbal) ${ }^{20}$.

No outro dormitório (Figura 54) é possível notar que a circulação foi comprometida, pois o armário foi colocado no menor sentido do ambiente. Com isso, foi necessário inverter a posição da cama e encostá-la na parede. Ao conversar com a moradora, ela compreendeu que poderia colocar a cômoda no espaço embaixo da janela e encostar o armário na parede da porta, o que permitirá colocar a cama em uma melhor posição e ganhar mais espaço para circulação.

${ }^{20}$ Entrevista com a moradora Cícera do conjunto Jardim Edite durante visita a suas residências. São Paulo, 17 de dezembro de 2013. 


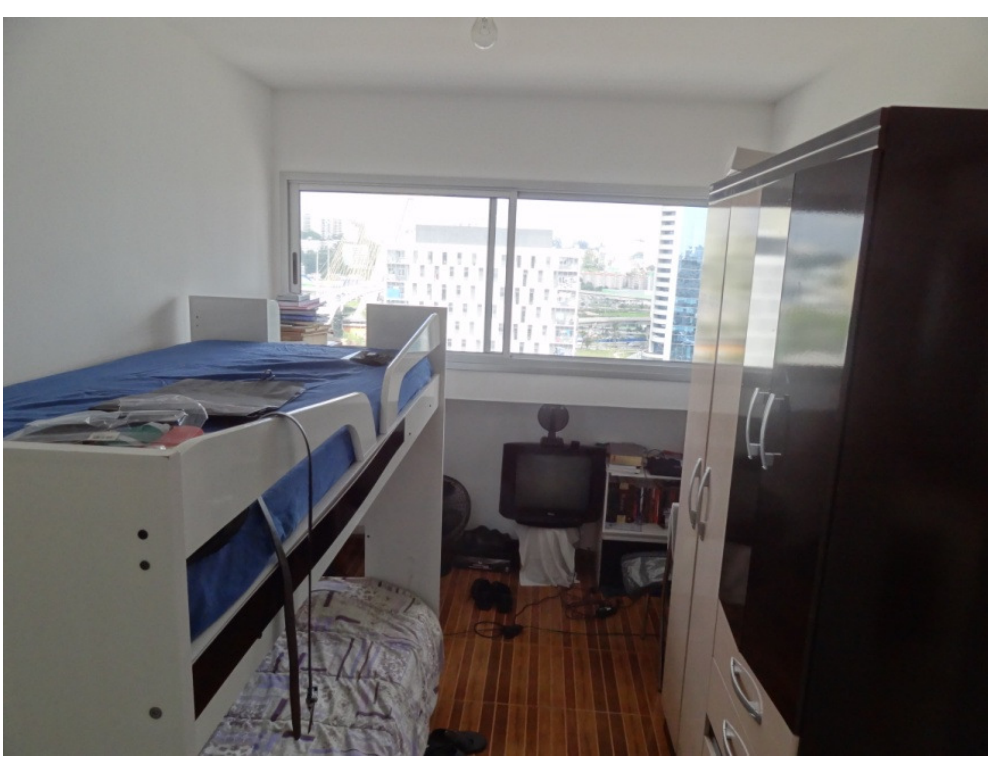

Figura 53 - Dormitório para solteiro do apartamento visitado.

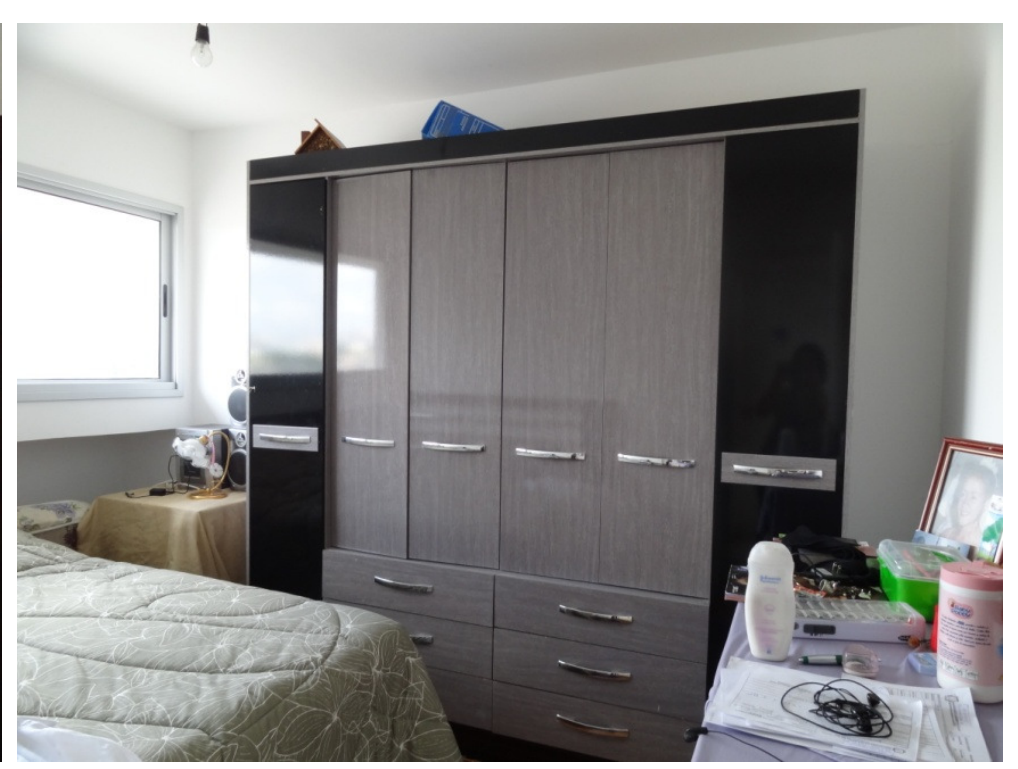

Figura 54 - Dormitório de casal do apartamento visitado.

A janela ocupa toda a largura do quarto, o que é muito positivo para a iluminação dos ambientes, todavia, não é adequado que objetos altos, como armários ou beliches, sejam encostados nessa lateral. Nas figuras acima é possível observar também que as janelas especificadas para os dormitórios não têm veneziana para filtrar a iluminação. Essa situação pode ser solucionada com cortinas mais grossas ou persianas, mas em alguns casos, os moradores acabam improvisando enquanto não têm condições de comprá-las (Figura 55).

Além disso, de acordo com as recomendações indicadas pelos Instrumentos de Avaliação de Projetos (Prefeitura de São Paulo, 2012b, p. 310), é importante que, "nos ambientes mais privados e de descanso (dormitório), o projeto das esquadrias contemple ou permita a instalação de elemento de escurecimento sem impossibilitar a ventilação, especialmente em dias de chuva e vento forte (ex.: venezianas, cortinas, basculantes, etc.)". 
Os espaços para guardar foram identificados nas plantas e é possível observar os armários construídos abaixo das janelas como espaços de armazenamento que podem ser aproveitados pelos moradores de diversas formas: colocando prateleiras; fechando com portas, etc. Esses espaços ampliam um pouco a área utilizável da unidade.

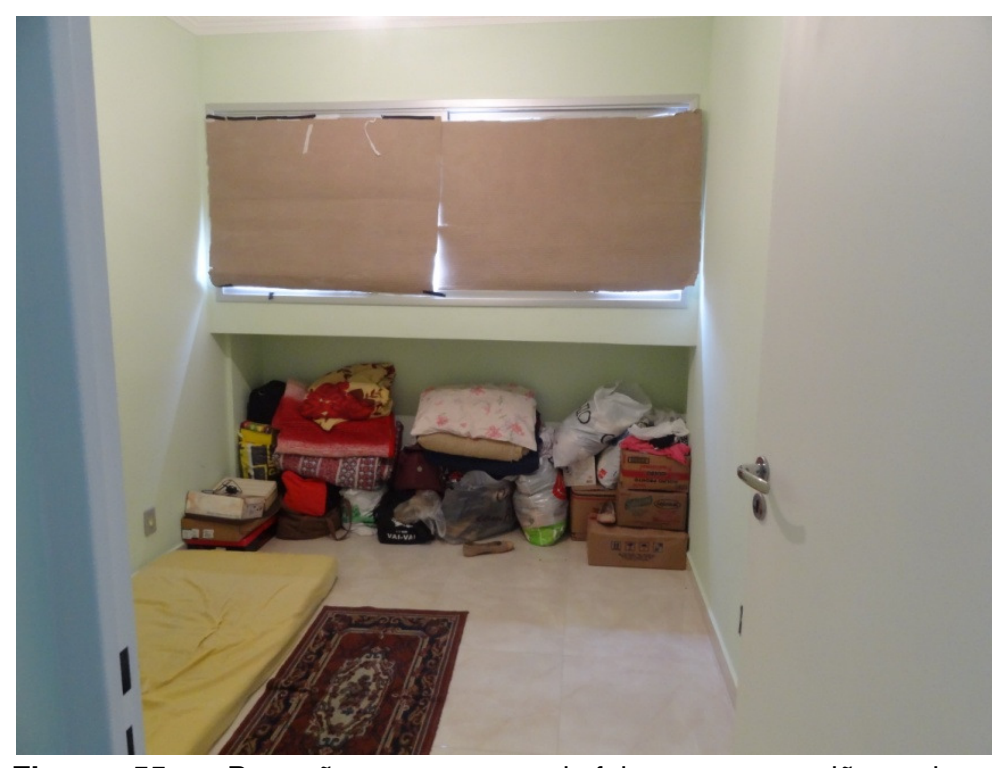

Figura 55 - Proteção contra o sol feita com papelão pelos moradores.

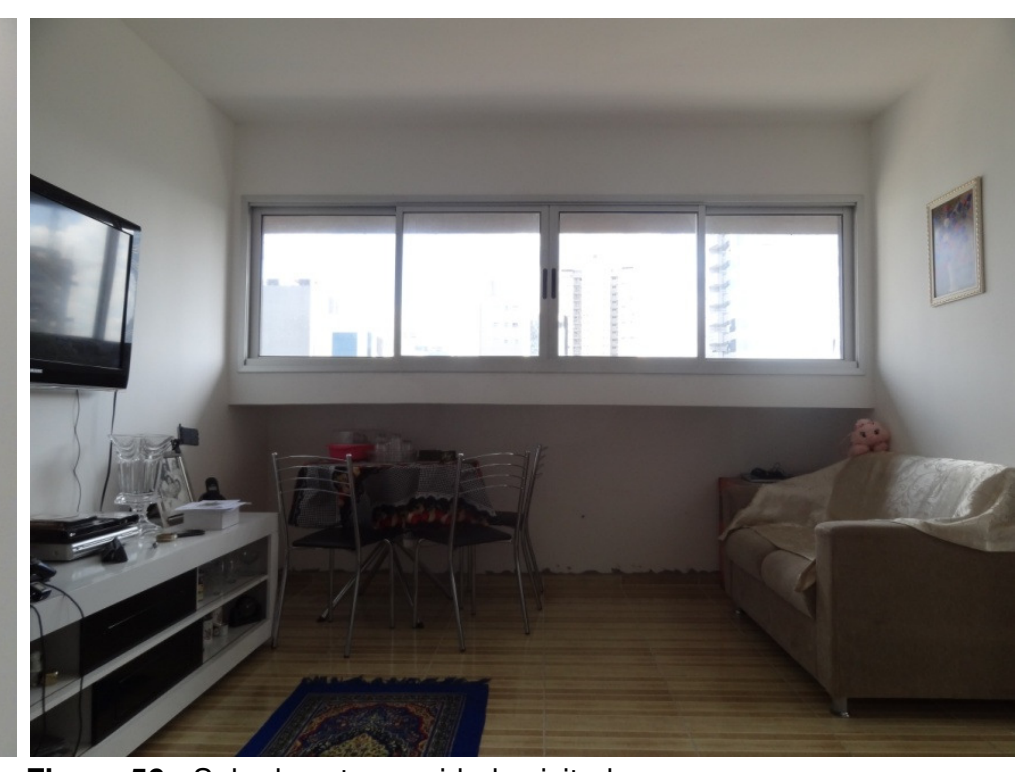

Figura 56 - Sala de estar - unidade visitada.

Esses armários também existem nas salas e são utilizados pelos moradores das mais diferentes maneiras. No caso do apartamento visitado, enquanto não tem dinheiro para mandar fazer um armário, a moradora utiliza esse espaço para colocar a mesa, com isso ganha mais espaço e, quando precisa utilizá-la, "é só puxar para o meio da sala".

As dimensões da sala de estar permitem acomodar bem os jogos de sofás de dois e três lugares, existentes na maioria das casas e que, muitas vezes, não cabem nos apartamentos. 
Ambientes especializados

Cozinha e lavanderia estão agrupadas em uma lateral da unidade e o banheiro está na outra. Enquanto os espaços não especializados têm dimensões mais confortáveis, tanto cozinha, como a área de serviço apresentam dimensões compactas e, ainda assim é possível ter uma pia de 1,40m e fogão de seis bocas. Nota-se, porém, a falta de espaços para armários. Imagina-se, portanto, que acabarão sendo instalados embaixo e sobre a pia, conforme aconteceu na unidade visitada (Figura 57).

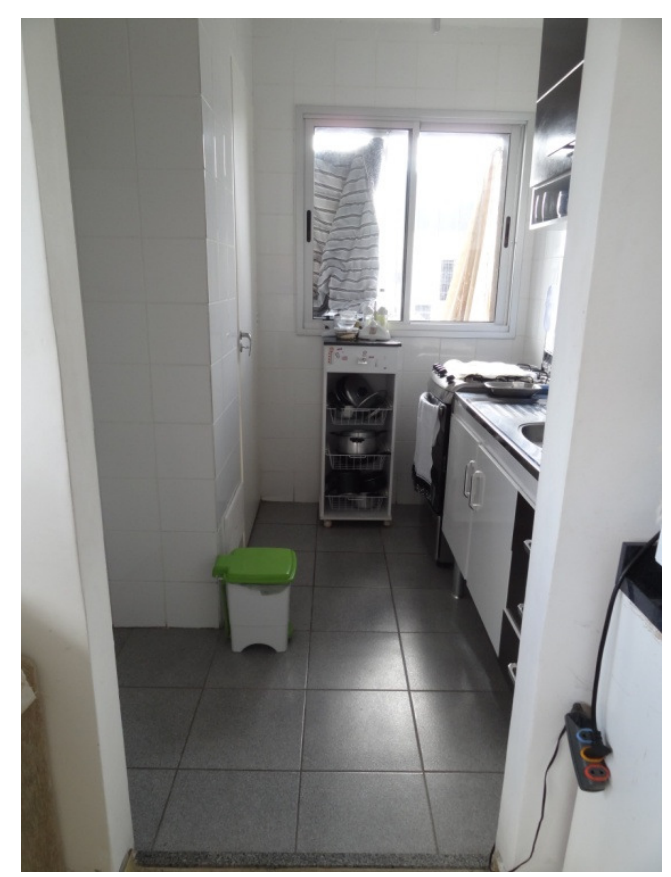

Figura 57 - Cozinha da unidade visitada.

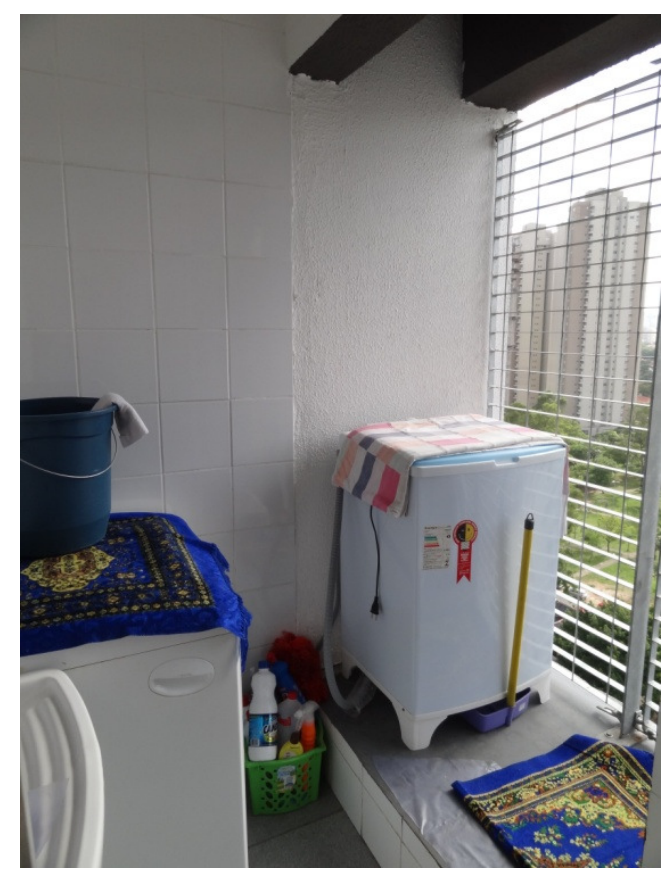

Figura 58 - Área de serviço da unidade visitada.

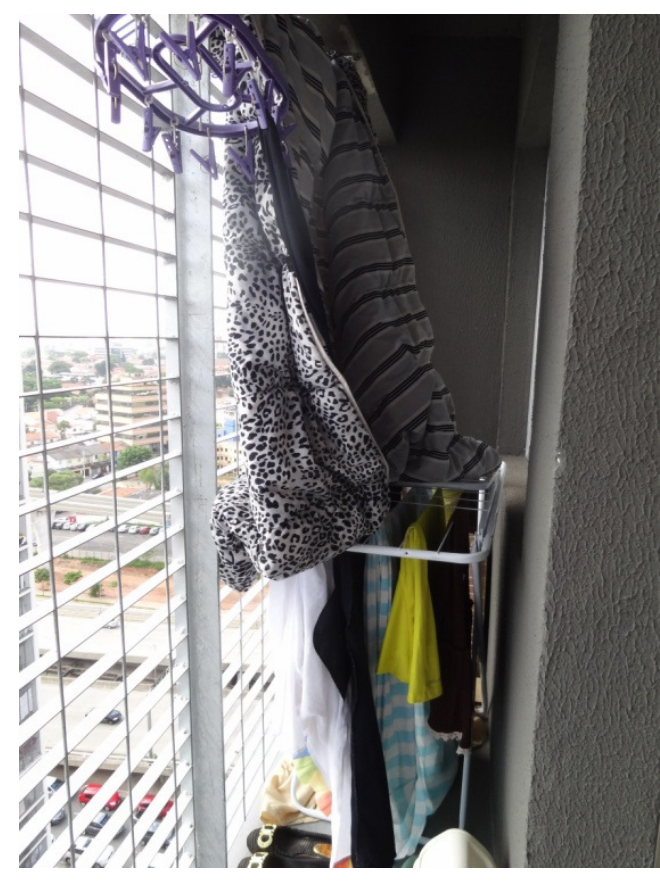

Figura 59 - Área para estender roupa da unidade visitada. 
A área de serviço está protegida da visibilidade de quem entra na unidade e, no caso do Tipo 1, é favorecida com um "espaço extra" para estender a roupa que foi classificado como espaço exterior próprio. Esse espaço é facilmente notado nas fachadas das torres compondo com os painéis de cheios e vazios (Figura 58; Figura 59).

O banheiro localiza-se entre os dois dormitórios e permitem o uso de apenas uma pessoa por vez. Analisando-se a planta, percebe-se que a pia está mais próxima à janela e o chuveiro está próximo à entrada. Entende-se, portanto, que isso acontece devido às janelas dos banheiros estarem na fachada e por manterem a mesma altura de peitoril que as outras janelas da unidade, o que poderia prejudicar a privacidade da área do banho.

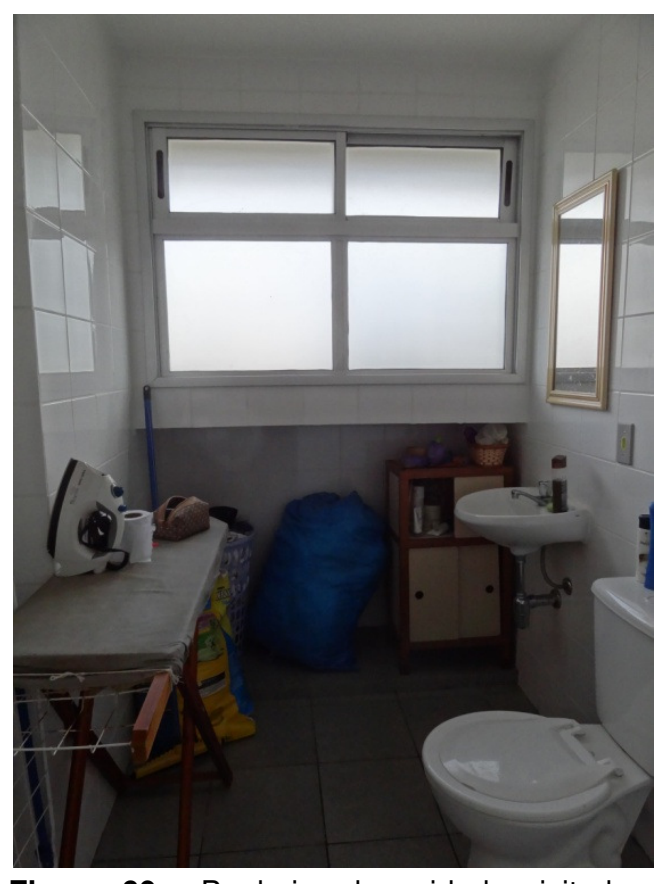

Figura 60 - Banheiro da unidade visitada Janela que compõe com a fachada.

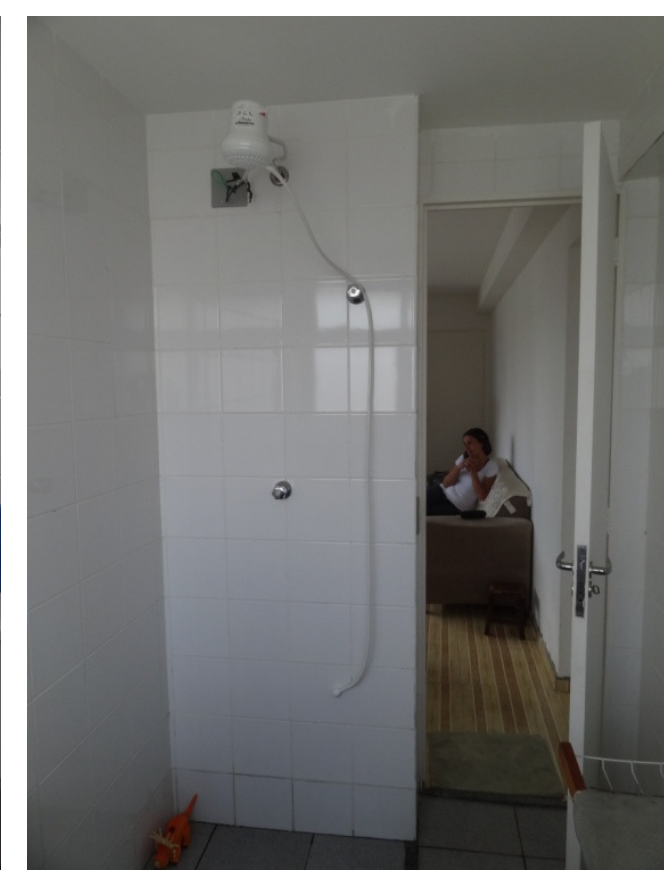

Figura 61 - Banheiro da unidade visitada. Chuveiro próximo à entrada.

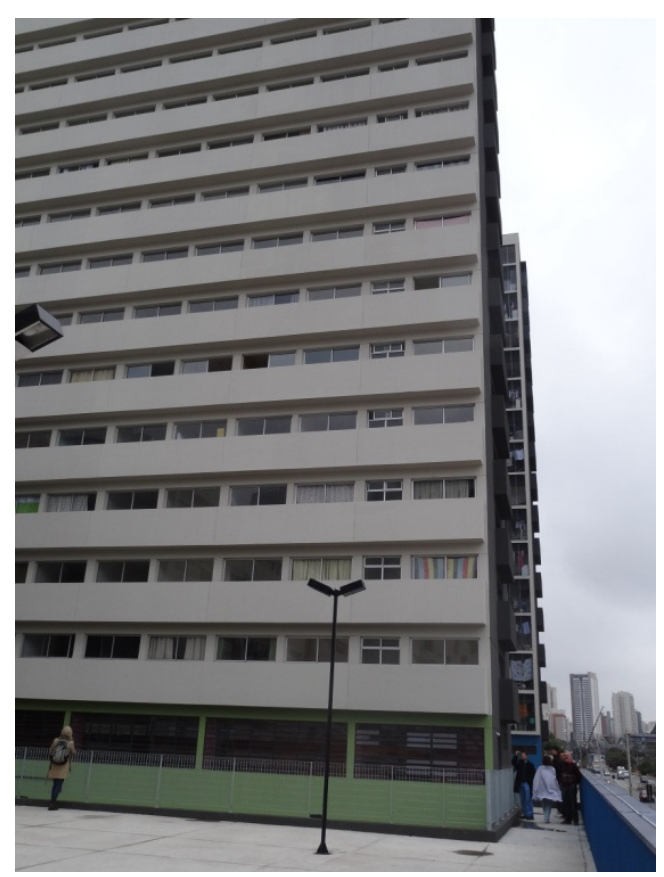

Figura 62 - Fachada Torre 2. Notar composição da janela do banheiro. 
É possível perceber ainda que essa disposição das peças permite que o espaço deixado como armário abaixo da janela seja mais útil do que seria, caso estivesse dentro do box do chuveiro, porém os moradores se queixaram da posição do chuveiro, pois molha a entrada e, enquanto não podem colocar um box, devem ficar sempre puxando a água com rodo para não molhar o banheiro todo.

Mais uma vez, é possível perceber que determinadas soluções estão bastante relacionadas com a forma e estética do edifício. Claro que a estética é muito importante, porém entende-se que a realização das atividades cotidianas também devem ser levadas em consideração durante o desenvolvimento do projeto e, nesse caso, talvez tivesse sido importante considerar que nem todos os moradores têm condições de instalar um box no banheiro. Outra solução, diante da priorização da estética, seria incorporar a instalação de box no orçamento da obra e entregar os apartamentos com esses elementos já instalados, uma vez que a solução proposta interfere no bom uso dos espaços.

\section{Relação entre os}

ambientes

A comunicação entre a cozinha e a sala se dá através da abertura de uma porta, porém os apartamentos não são entregues com porta. Dessa forma, os espaços se comunicam sem deixar a cozinha totalmente exposta. Entre a cozinha e a área de serviço há uma porta e janela, pois a área de serviço tem ventilação constante e, portanto, é necessário esse isolamento.

Os dormitórios, espaços mais privados, possuem um distanciamento da área social, permitindo que a privacidade seja preservada. 
Quanto ao ciclo da roupa, como ocorre na maioria dos casos, a roupa circula por toda a unidade, passando pela sala e pela cozinha para chegar à área de serviço. O espaço exterior é muito útil para a secagem da roupa. Essa tipologia possibilita que a roupa seque sem o contato direto com a cozinha, entretanto, também não foi possível identificar um espaço para passar roupa que não seja na sala ou nos dormitórios.

No caso da unidade visitada, conforme pôde ser observado na Figura 60, a moradora deixa a tábua de passar roupa dentro do banheiro, que tem boas dimensões, diferentemente da área de serviço.

\section{Espaço exterior}

próprio

No caso da unidade Tipo 1, verificamos que há um espaço exterior próprio conjugado à área de serviço, muito útil para as atividades de cuidado da roupa.

$\mathrm{Na}$ circulação comum do edifício, foi identificado o espaço chamado "espaço para convivência", que representa uma extensão do espaço comum. Esse espaço não está diretamente relacionado com a porta de entrada das unidades, mas foi concebido com a intenção de que fosse apropriado pelos moradores.

\subsubsection{TIPO 2}

O Tipo 2 é a segunda tipologia das torres e localiza-se no meio da planta do edifício. Uma das fachadas comunicase diretamente com o exterior e a outra, onde estão a entrada e as janelas da cozinha e da área de serviço, comunica-se com o corredor comum que acessa as unidades. Essa situação proporciona iluminação indireta a esses espaços, pois a luz natural é "filtrada" pelo corredor antes de entrar na unidade (Figura 63). Pode-se considerar que há ventilação cruzada, pois o corredor, para onde abrem as janelas, possui ventilação permanente. 


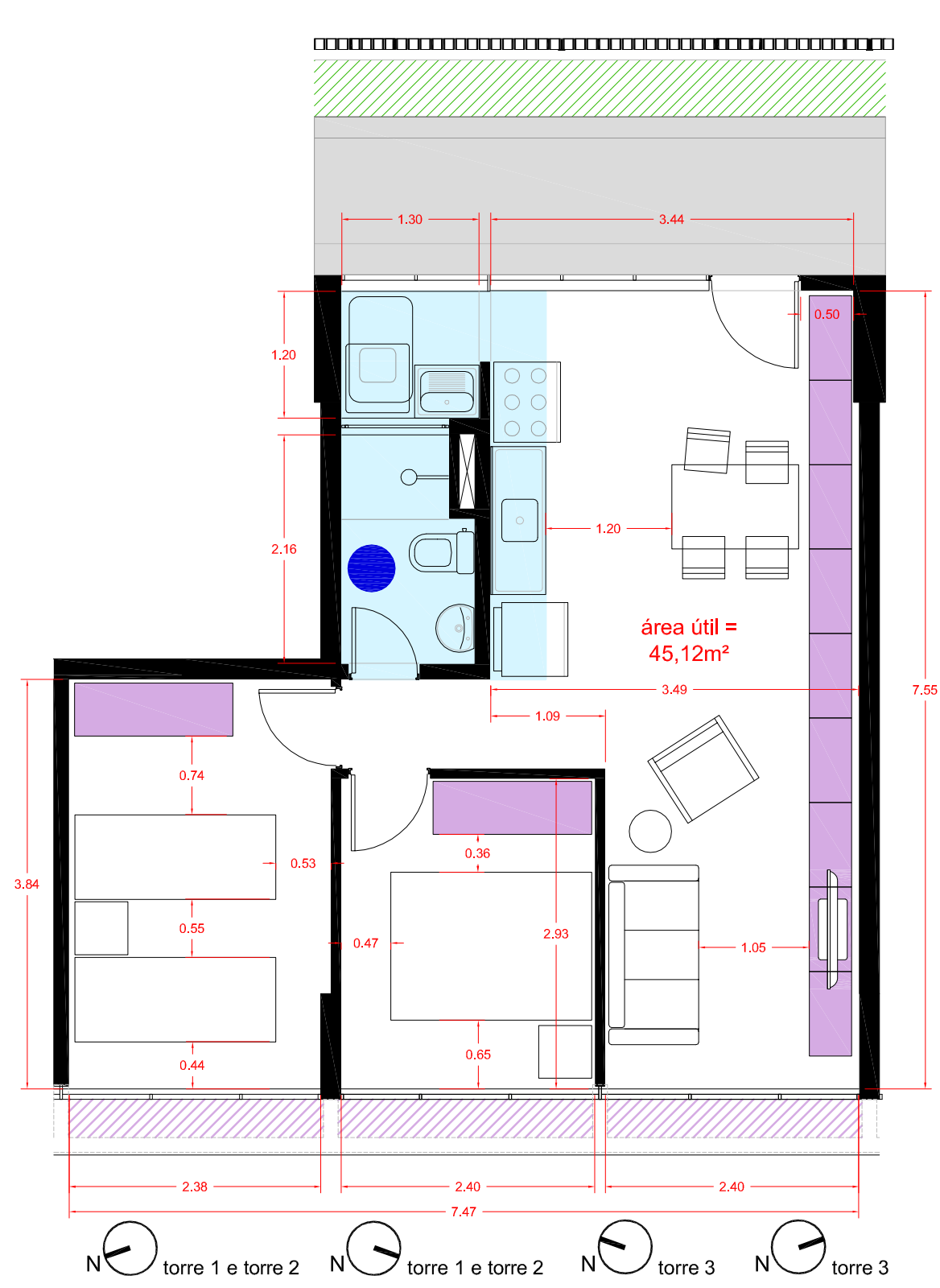

PLANTA TIPO 2A - layout e dimensões. escala $1: 75$

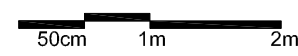

$\square$ concentração das áreas molhadas

$\square$ espaços para guardar

四 espaços para guardar - embaixo das janelas

$\square$ espaços de estudo/trabalho

uso do banheiro

$\square$ espaço exterior próprio

espaço para convivência / extensão

do espaço comum

CICLO DA ROUPA

1. roupa suja

2. lavar

3. secar

4. passar

5. roupa limpa

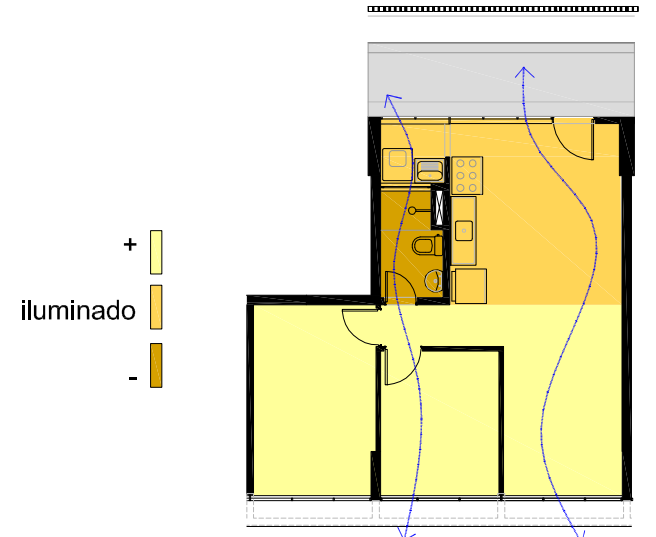

m

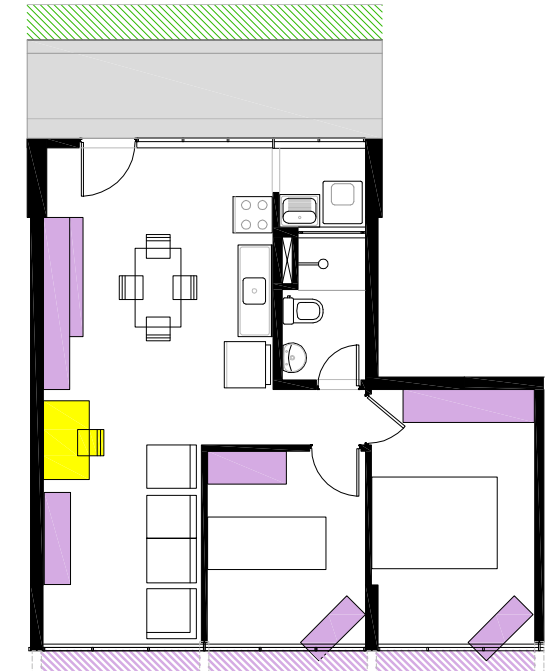

ESQUEMA ILUMINAÇÃO E VENTILAÇÃO (orientação de referência: torre 1 )

$$
\text { escala 1:200 }
$$

PLANTA TIPO 2A - reprodução de layout de um apartamento visitado já ocupado pelos moradores. escala 1:150

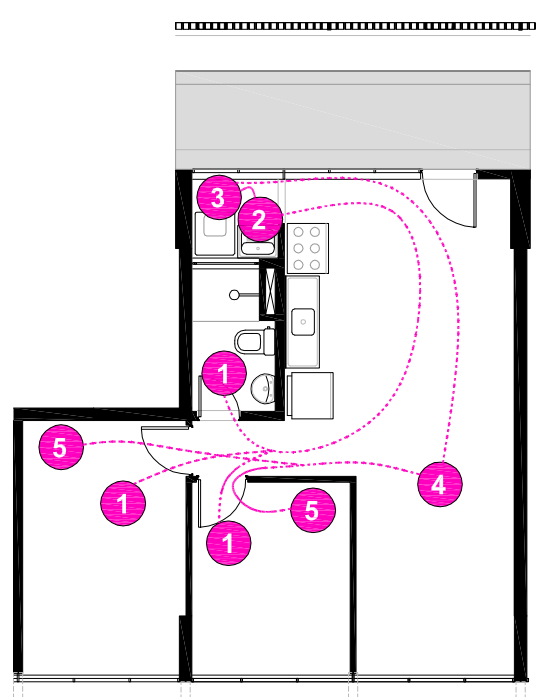

PLANTA TIPO 2A - ciclo da roupa escala 1:150

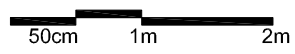

Figura 63 - Análise Tipo 2. 


\section{Ambientes não} especializados

Os dormitórios possuem as mesmas dimensões que o Tipo 1 e o espaço destinado à sala de estar, apresenta uma configuração mais alongada, sendo possível dividi-lo em estar / sala de TV e espaço para colocar a mesa, mais relacionado com a área da cozinha.

Os espaços para guardar, foi um tema bastante trabalhado nesse projeto e, no caso do Tipo 2, além dos espaços deixados embaixo das janelas, nota-se, através do layout desenhado pelos arquitetos, a proposta de uma "paredearmário" que atenderia tanto a cozinha, como o estar.

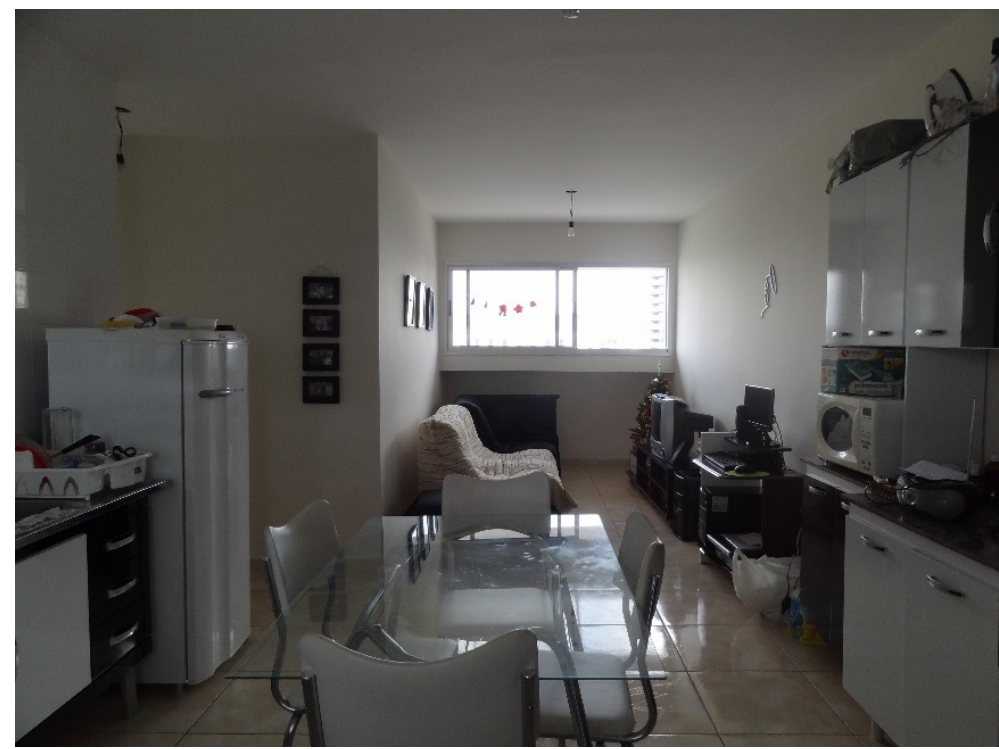

Figura 64 - Cozinha e Sala de Estar - unidade visitada.

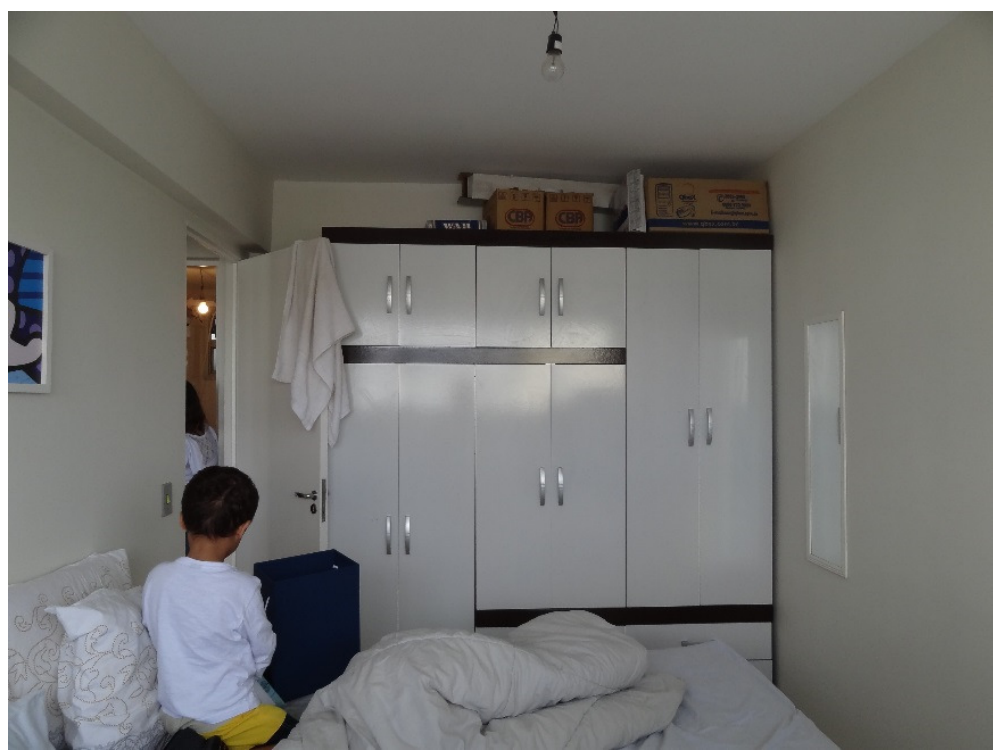

Figura 65 - Dormitório casa - unidade visitada. 
Observando o apartamento visitado, é possível verificar que a "parede-armário" está mesmo sendo utilizada. Na Figura 64, vemos os armários da cozinha, seguidos por uma mesinha para computador e o hack da sala, todos nessa mesma parede.

No dormitório de casal vemos que, quando não foi possível deixar espaço atrás da porta para colocar os armários, muitas vezes a abertura da porta pode ser comprometida pelo tamanho do armário.

Na unidade visitada, moram apenas um casal e o filho pequeno. Na Figura 66 é possível observar o dormitório da criança.

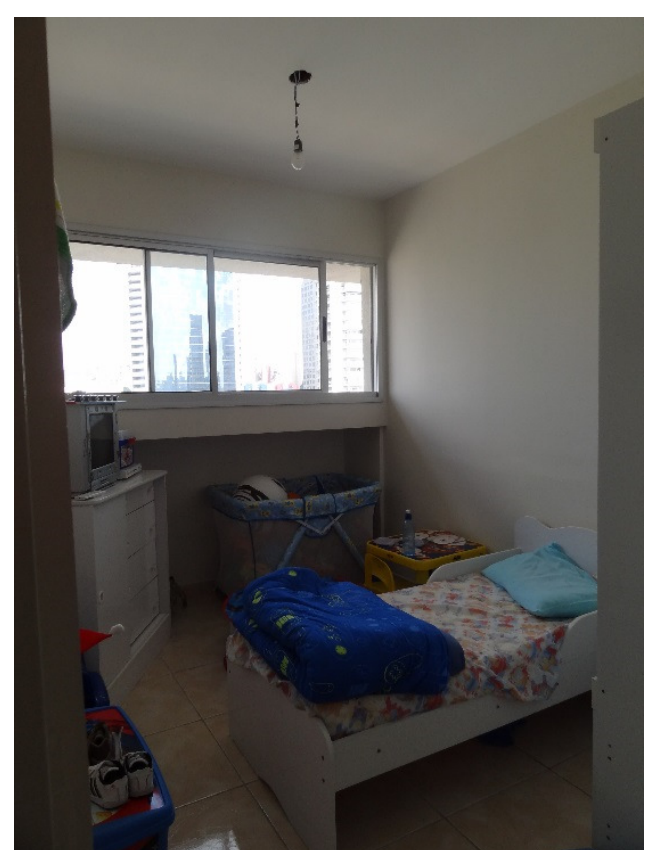

Figura 66 - Dormitório infantil - unidade visitada

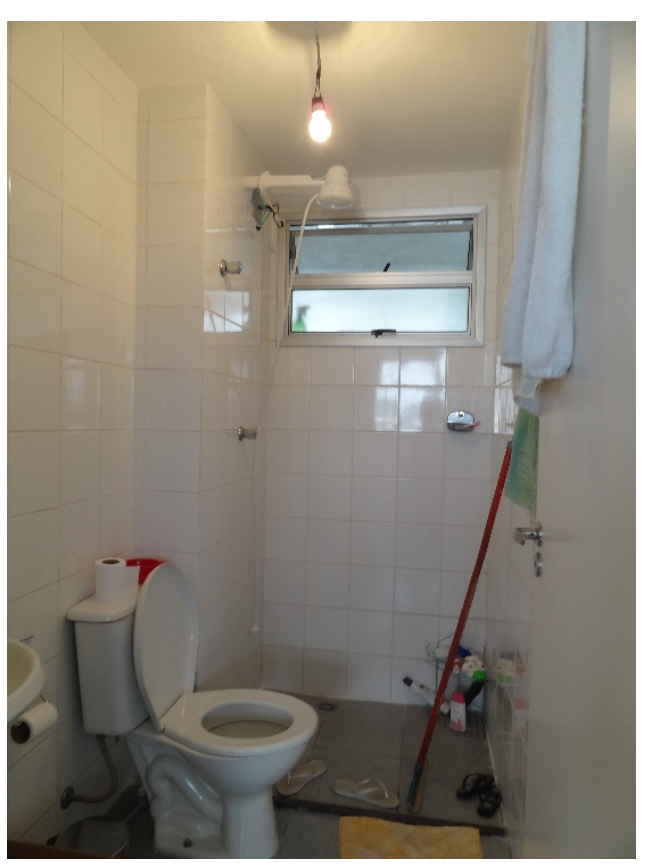

Figura 67 - banheiro - unidade visitada

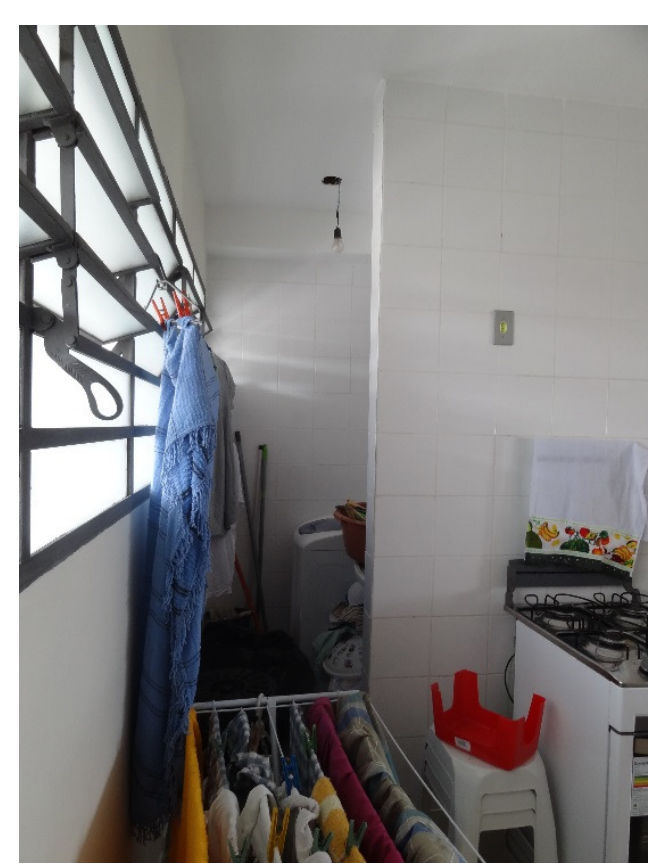

Figura 68 - área de serviço - unidade 


\section{Ambientes}

\section{especializados}

Nessa tipologia as áreas molhadas estão todas concentradas. O banheiro abre para o corredor de acesso aos dormitórios e ventila pela área de serviço (Figura 67) que, por sua vez, ventila pelo corredor. A cozinha está instalada na parede hidráulica e se relaciona diretamente com a sala. Diferentemente do Tipo 1, nesse caso, a cozinha fica bastante exposta.

A disposição do banheiro também não permite que seja utilizado por mais de uma pessoa ao mesmo tempo. Porém, essa seria uma situação possível, caso a porta de entrada fosse recuada.

A área de serviço ocupa um espaço bem compacto onde cabem apenas a máquina de lavar roupa, o tanque e o varal sobre a máquina. Essa tipologia não conta com um "espaço-extra" para secar as roupas e, além disso, devido à posição do corredor, também não recebe luz natural direta (Figura 68).

\section{Relação entre os} ambientes

Como foi citado anteriormente, no Tipo 2, a cozinha fica bastante exposta e relaciona-se completamente com a sala de estar, sem oferecer a possibilidade de isolar ou resguardar esse espaço. Essa situação pode não ser muito adequada, pois como vimos no estudo do Conjunto Comandante Taylor, os moradores sempre buscam uma maneira de tornar o espaço da cozinha mais reservado.

A área de serviço relaciona-se parcialmente com a cozinha e, caso os moradores desejem, é possível instalar uma porta que isole completamente esses espaços. Neste caso, há que se levar em consideração que isso restringiria 
ainda mais o espaço da área de serviço que, como pôde ser observado na Figura 68, muitas vezes se estende para a cozinha.

Ao analisar o ciclo da roupa, percebe-se claramente que o espaço da área de serviço é bastante pequeno e pouco apropriado para secar as roupas devido à falta de iluminação natural.

\section{Espaço exterior próprio}

A unidade Tipo 2 não possui espaço exterior próprio e poderia apropriar-se apenas do espaço para a convivência resultante do alargamento dos corredores.

\section{Variações do Tipo 2}

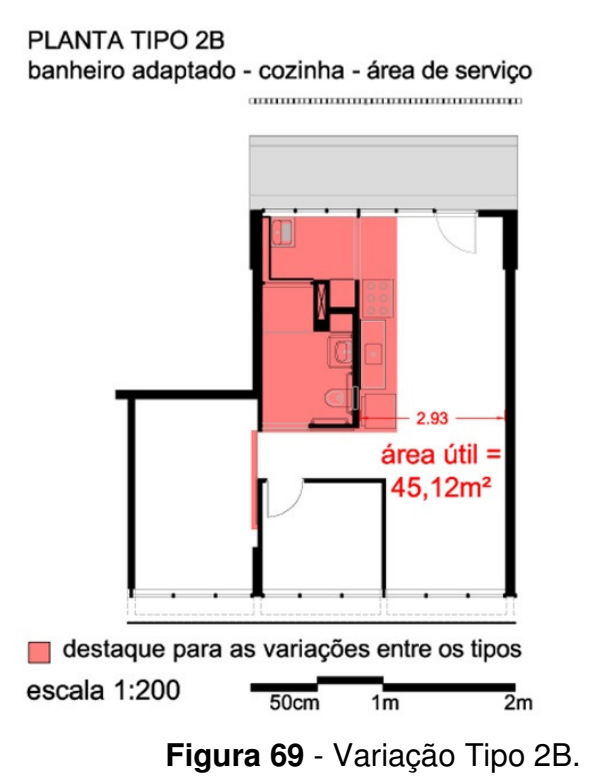

Como variação do Tipo 2, identificou-se apenas o Tipo 2B que é a adaptação dessa unidade para P.N.E. Nesse caso, o banheiro é maior, conta com a instalação de todos os acessórios necessários e, devido a suas dimensões, a cozinha acaba ficando um pouco mais estreita. A posição do tanque também foi alterada com relação ao Tipo $2 \mathrm{~A} \mathrm{e,} \mathrm{tanto}$ no dormitório maior, como no banheiro, as portas foram substituídas por portas de correr, pois não seria possível instalar portas que abrissem para fora nessas situações. 


\subsubsection{TIPO 3}

O Tipo 3 ocorre nos dois pavimentos inferiores das lâminas. Uma escada de acesso atende a duas unidades por andar. Essa tipologia tem aberturas para as duas fachadas de maior dimensão no sentido note-sul o que proporciona ventilação cruzada em todos os ambientes. Em todos os casos, a sala de estar e um dos dormitórios estão voltados para o norte e o outro dormitório, a área de serviço e a cozinha, estão voltados para o sul.

Essa tipologia possui aproximadamente $2 \mathrm{~m}^{2}$ a mais de área útil que as outras duas apresentadas. A distribuição dos ambientes organiza bem a unidade e proporciona, inclusive, boa setorização, resguardando os dormitórios da área social e permitindo que a cozinha possa ser totalmente ou parcialmente isolada sem interferir no uso dos outros ambientes.

\section{Ambientes não \\ especializados}

A sala de estar e os dormitórios apresentam dimensões bastante confortáveis permitindo acomodar bem diferentes usos e distribuições do mobiliário.

A disposição dos dormitórios permitiu criar espaço para armários. Entretanto, nem sempre os moradores utilizam esses espaços da maneira como foram pensados pelos arquitetos. Na Figura 71 pode-se observar a cama encaixada no nicho projetado para armários, porém, no outro dormitório (Figura 73), uma cômoda foi colocada no mesmo espaço. 


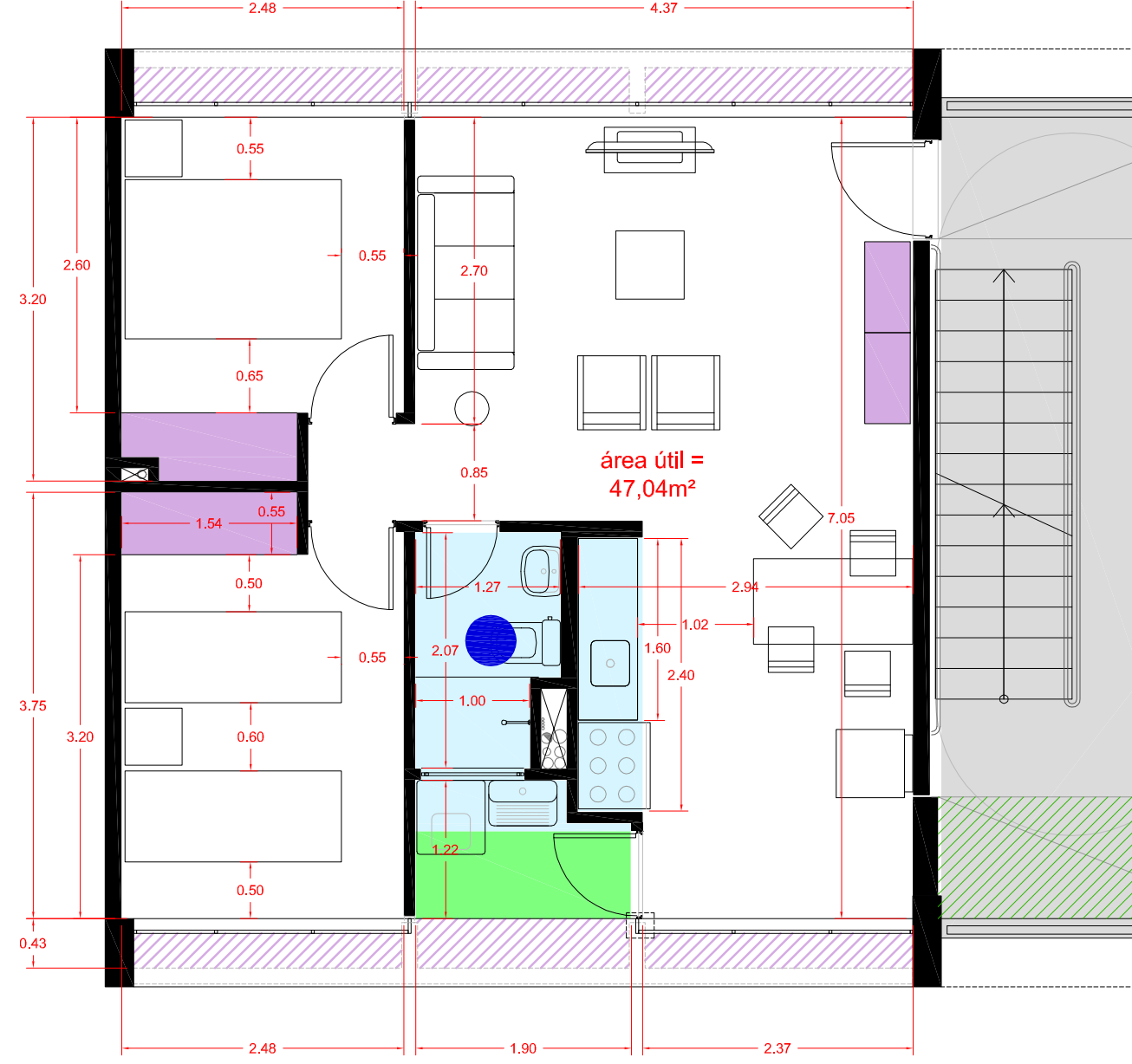

${ }_{N} \bigcirc \bigcup_{\text {lâminas 1 e } 2}$
PLANTA TIPO 3B - layout e dimensões. escala 1:75

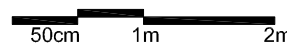

$\square$ concentração das áreas molhadas

espaços para guardar - embaixo das janelas

$\square$ espaços para guardar

$\square$ espaços de estudo/trabalho

uso do banheiro

1 pessoa

$\square$ espaço exterior próprio

V espaço para convivência / extensão

do espaço comum

CICLO DA ROUPA:

1. roupa suja

2. lavar

secar

4. passar

5. roupa limpa

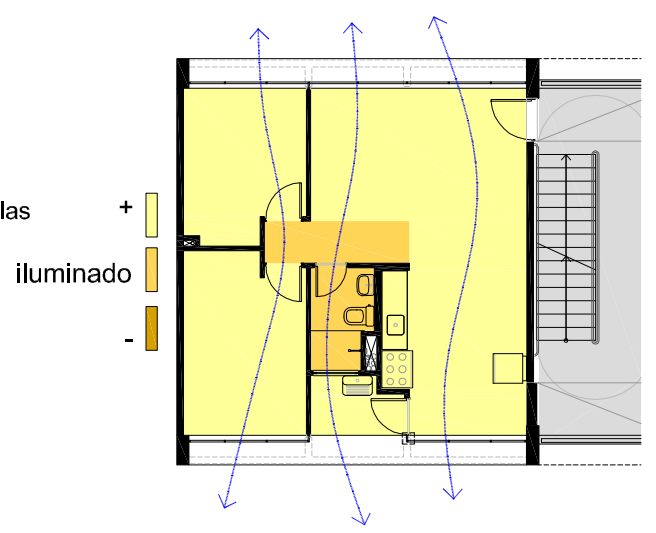

ESQUEMA ILUMINAÇÃO E VENTILAÇÃO (orientação de referência: lâmina 2) escala 1:200

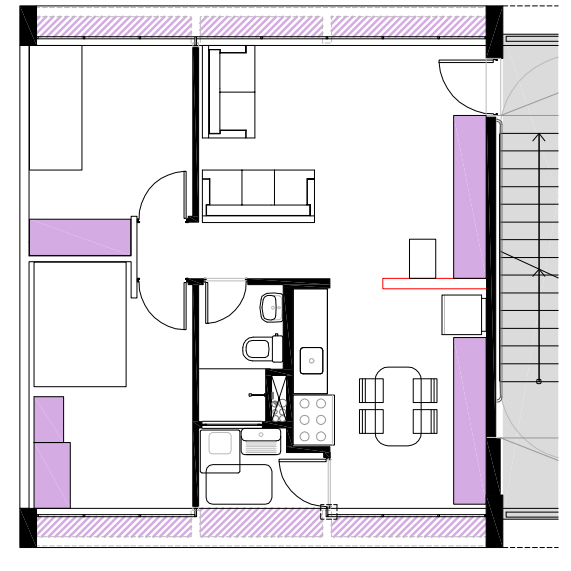

PLANTA TIPO 3B - reprodução de layout de um apartamento visitado já ocupado pelos moradores.

escala 1:150

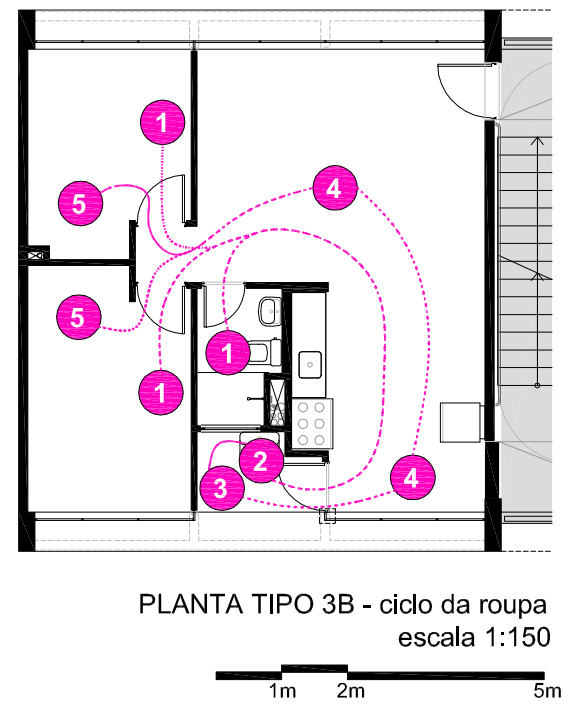

Figura 70 - Análise Tipo 3. 
As fotos foram tiradas em janeiro de 2013 e, portanto, os moradores haviam mudado para o conjunto recentemente, por isso, vemos muitas caixas e malas nos apartamentos, mas é interessante notar que, mesmo nessa fase de mudança, esses objetos e pertences são guardados nos armários embaixo das janelas.

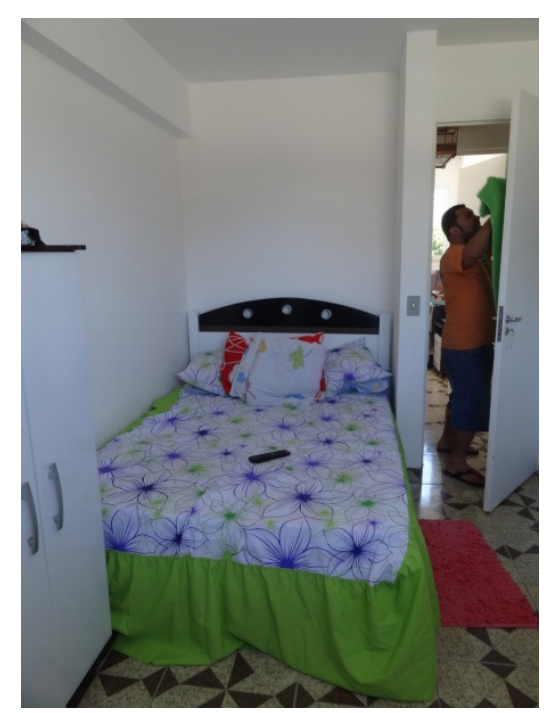

Figura 71 - Dormitório Tipo 3,

Exemplo mobiliário.

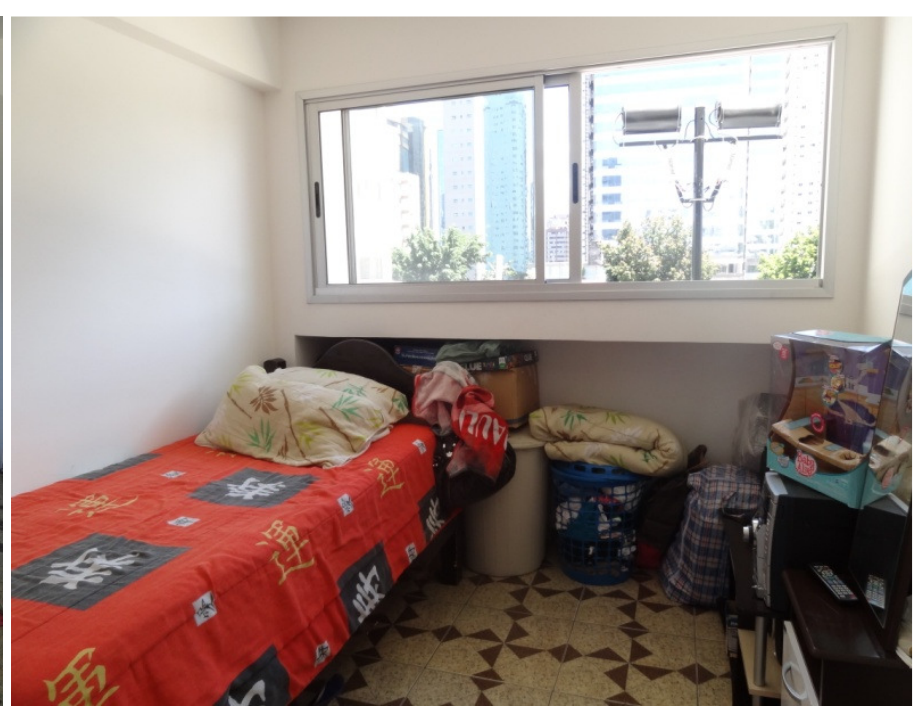

Figura 72 - Dormitório Tipo 3, Exemplo de disposição do mobiliário.

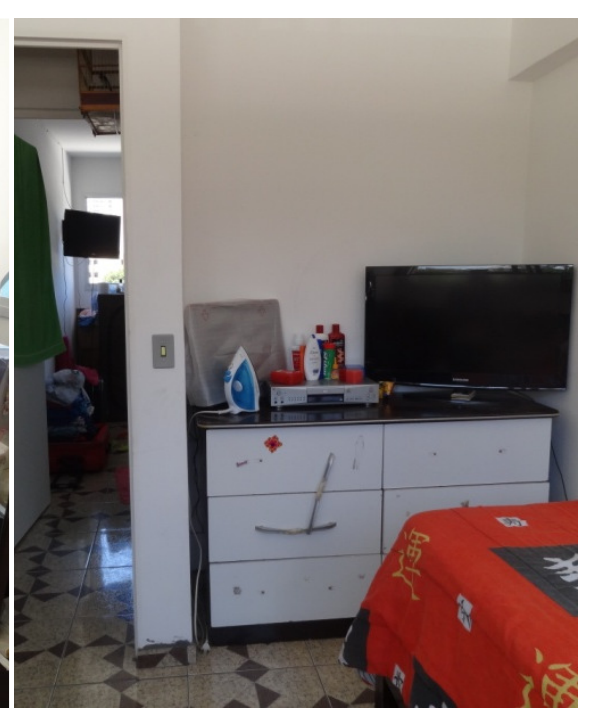

Figura 73 - Dormitório Tipo 3 Exemplo de disposição do mobiliário.

\section{Ambientes}

especializados

Assim como no Tipo 2, as áreas molhadas estão concentradas e o banheiro ventila pela área de serviço. No caso do Tipo 3, essa área não tem janelas, conta apenas com um vão aberto garantindo a ventilação permanente. Por esse motivo, há uma porta que separa essa área da cozinha e, com isso, esse espaço pode ser considerado como um espaço exterior próprio dessa unidade (Figura 76). 
A cozinha possui boas dimensões possibilitando a instalação de fogão de seis bocas e uma pia grande no nicho deixado na parede por onde passam as instalações hidráulicas. Ainda no espaço destinado à cozinha, também é possível colocar uma mesa e armários ao lado da geladeira.

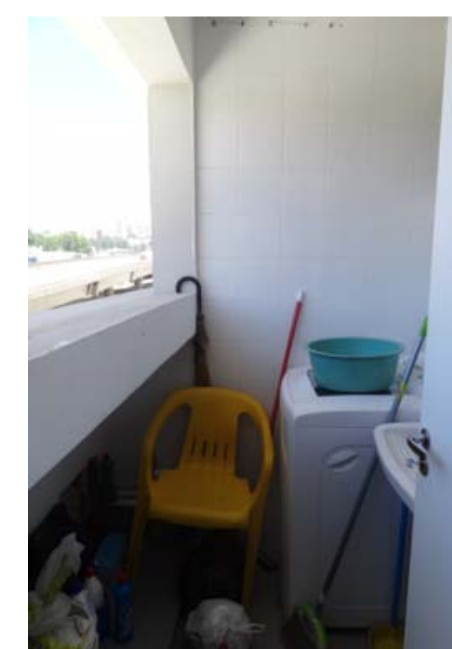

Figura 74 - Área de Serviço unidade visitada. Tipo 3.

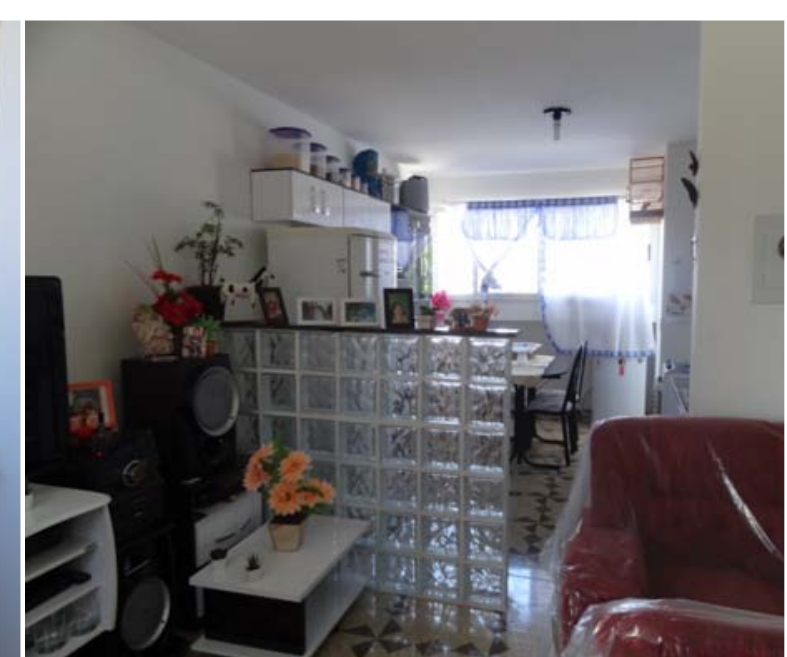

Figura 75 - Sala e cozinha, unidade visitada. Tipo 3.

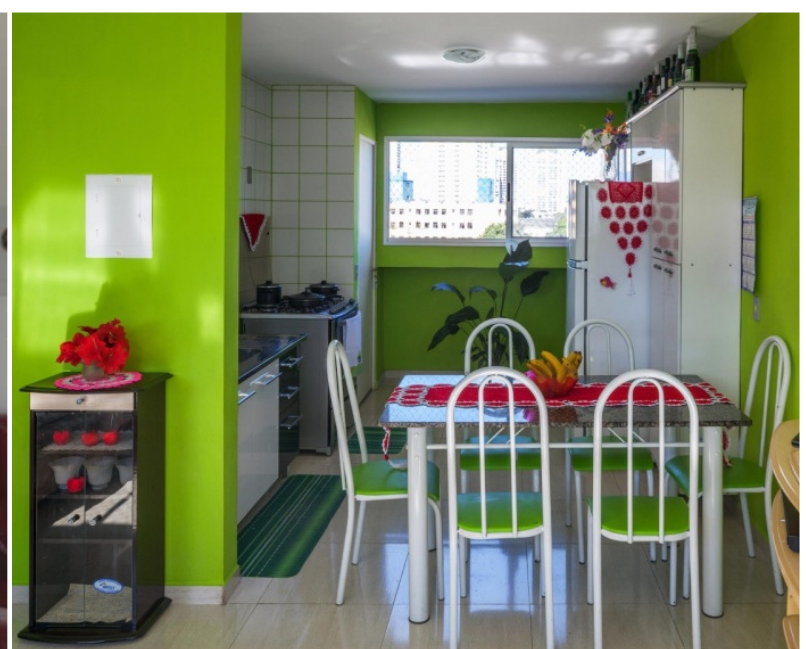

Figura 76 - Exemplo Tipo 3.

\section{Relação entre os ambientes}

Nessa tipologia os arquitetos conseguiram propor uma boa integração entre sala e cozinha com a possibilidade de tornar a cozinha um espaço mais resguardado, caso fosse desejado pelos moradores. Como podemos observar na Figura 75, os moradores acabaram construindo uma parede baixa de tijolos de vidro para definir melhor os espaços. Assim como vimos no Comandante Taylor, é possível concluir que esse é um ponto importante, pois na maioria dos lares visitados, notou-se a necessidade de definir melhor os espaços. 
Devido à porta instalada, a área de serviço está isolada e, nessa unidade não há problema de deixar as roupas estendidas próximo ao fogão. Considerando-se as boas dimensões da cozinha, ao analisar o ciclo da roupa, imaginou-se que o espaço entre a área de serviço e a cozinha poderia ser utilizado para passar roupas, porém essa atividade também pode ser realizada na sala ou nos quartos.

\section{Espaço exterior} próprio

Como já foi citado, podemos considerar que a área de serviço é um espaço exterior próprio, dentro na unidade Tipo 3 , onde os moradores podem secar roupa ao ar livre, ter plantas e até animais de estimação como passarinhos, por exemplo. Além desse espaço, foi identificado, junto à circulação, o espaço para convivência, que pode ser compartilhado entre as duas unidades de cada andar.

\section{Variações do Tipo 3}

Como variação do Tipo 3B, é possível observar que, no Tipo 3A, a posição da porta de entrada é diferente, localiza-se em uma posição mais central, alinhada ao corredor que acessa aos dormitórios e ao banheiro. O Tipo 3A ocorre na lâmina 1 . As escadas de acesso às unidades sofrem pequena variação de uma lâmina para a outra, sendo que, na lâmina 2 a escada é linear e, na lâmina 1, em formato "U”, como pode ser observado na Figura ao lado.
PLANTA TIPO 3A

porta de entrada / circulação escada.

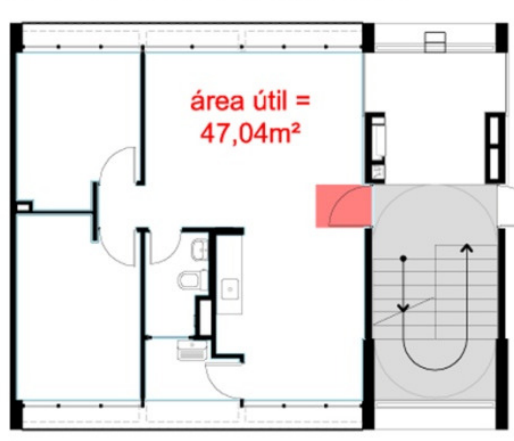

$\square$ destaque para as variações entre os tipos escala 1:200

Figura 77 - Variação Tipo $3 \mathrm{~A}$. 


\subsubsection{TIPO 4}

O Tipo 4 representa as unidades duplex que ocorrem nos dois últimos pavimentos das lâminas. Nesses casos, cada escada atende a quatro unidades. Com área reduzida, no pavimento inferior, os apartamentos ocupam apenas metade da planta o que resulta em aberturas voltadas apenas para a fachada sul ou para norte. Com isso, esse pavimento não tem ventilação cruzada. Já o pavimento superior, ao colocar-se no sentido invertido, alcança as duas fachadas, garantindo assim ventilação cruzada principalmente no tipo 4A, pois a posição das portas dos dormitórios facilita a ventilação.

Sala de estar e cozinha estão no pavimento inferior enquanto o banheiro, os dois dormitórios e a área de serviços encontram-se no pavimento de cima.

\section{Ambientes não especializados}

A sala de estar divide o espaço do pavimento inferior com a cozinha e, por ocuparem um espaço amplo, possibilita variações no layout de acordo com as necessidades dos moradores, permitindo que seja colocado um jogo de sofás de dois e três lugares, ou uma mesa para estudar ou trabalhar, etc.

Os dormitórios apresentam medidas semelhantes com largura mínima de 2,42m. Observando as plantas, é possível perceber que os dormitórios do Tipo 4B são maiores que os do 4A. Isso ocorre devido a posição das escadas que, na tipologia $4 \mathrm{~A}$, encontra-se entre os dormitórios, reduzindo um pouco o espaço destinado a esses ambientes. Podemos identificar como menor dormitório, o do Tipo 4A que aproveita um nicho sobre a escada para sugerir que seja utilizado como armário, porém, não há espaço suficiente nesse ambiente para uma cama de casal e um armário convencional comprado pronto. 


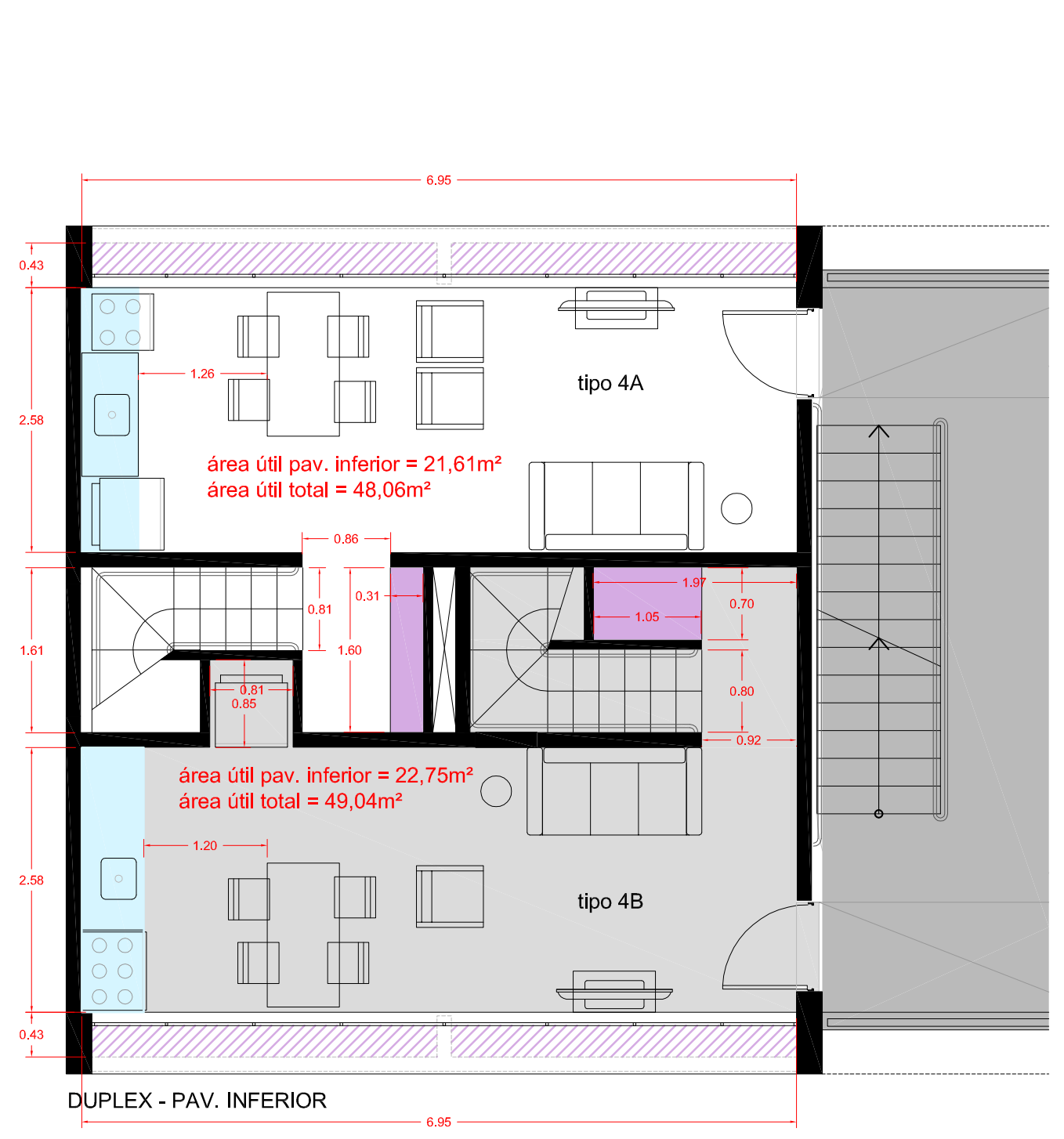

${ }_{N} 000$ (âminas 1e 2
PLANTA TIPO 4A / 4B - layout e dimensões.

escala 1:75

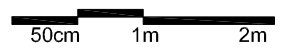

$\square$ concentração das áreas molhadas

尚 espaços para guardar - embaixo das janelas

$\square$ espaços para guardar

$\square$ espaços de estudo/trabalho

uso do banheiro

1 pessoa

$\square$ espaço exterior próprio

匈 espaço para convivência / extensão do espaço comum

CICLO DA ROUPA.

1. roupa suja

2. lavar

3. secar

4. passar

5. roupa limpa
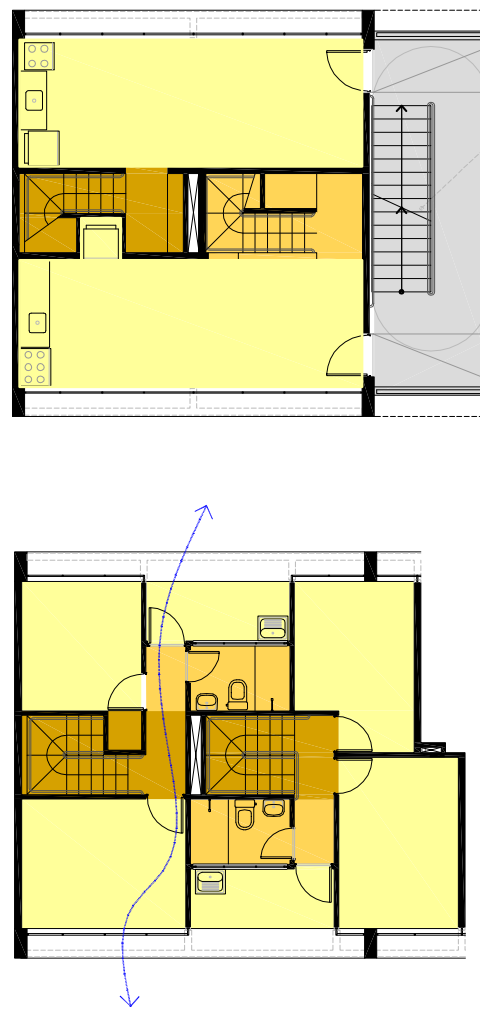

ESQUEMA ILUMINAÇÃO E VENTILAÇÃO (orientação de referência: lâmina 2) escala 1:200 


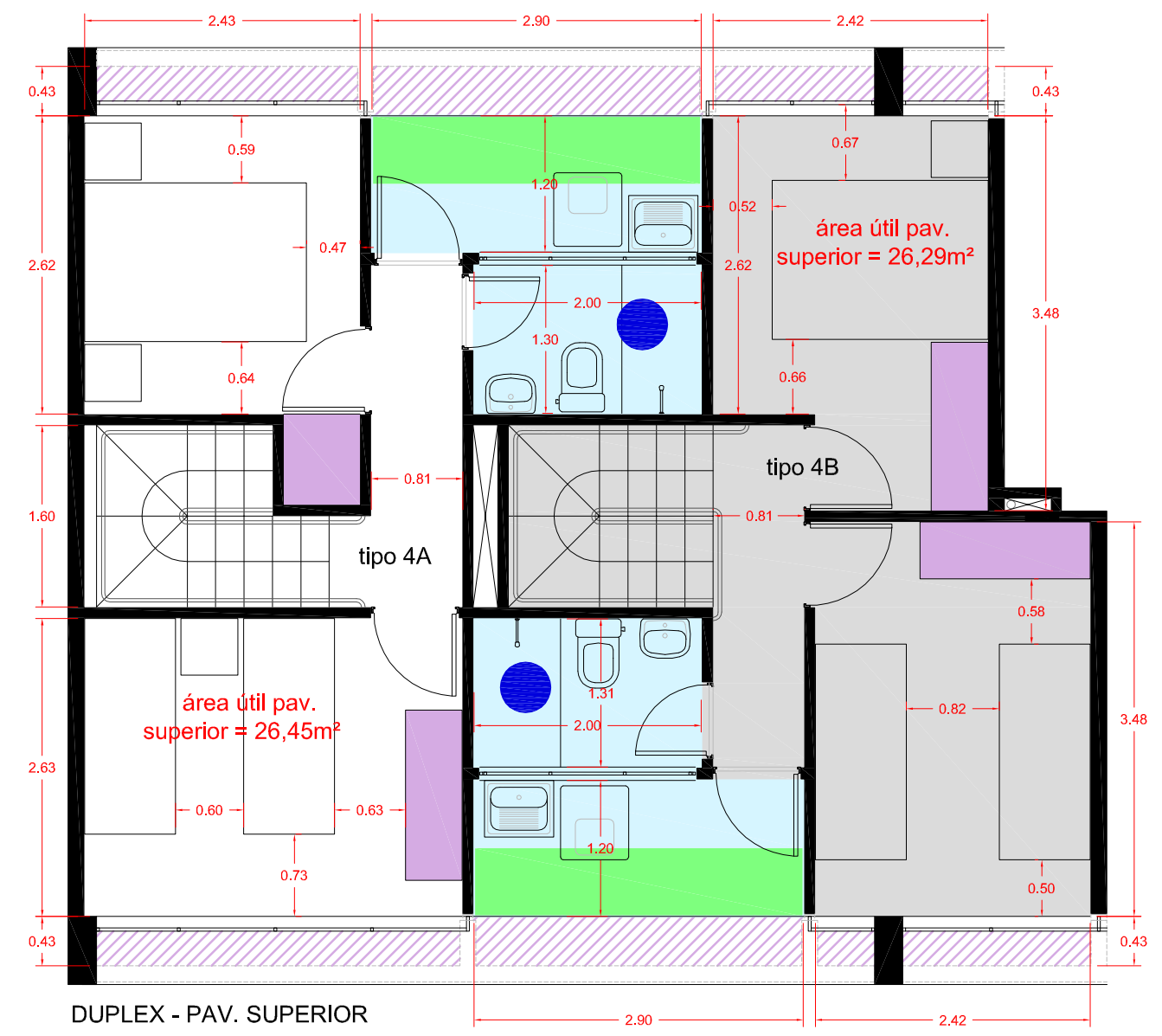
${ }_{N} 000$ (âminas 1e 2

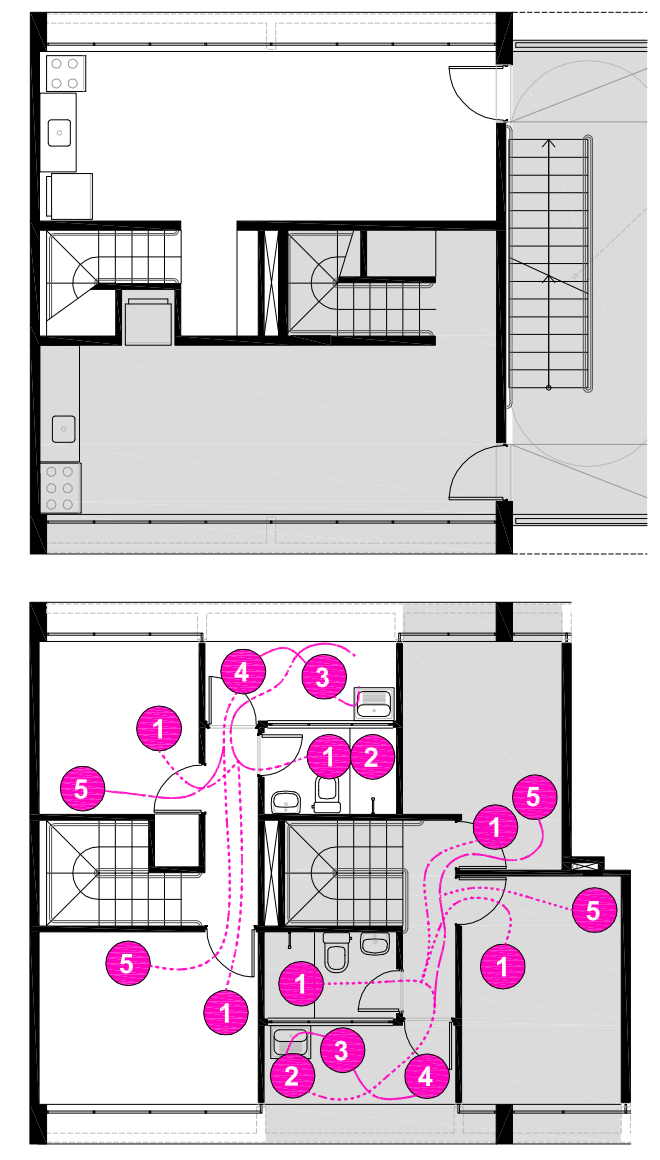

PLANTA TIPO 4A / 4B - ciclo da roupa escala 1:150 Figura 78 - Análise Tipo 4. 


\section{Ambientes}

especializados

No pavimento superior os banheiros ventilam através da área de serviço que possui ventilação permanente, pois assim como o Tipo 3, não possuem fechamento. Como pode ser observado nos desenhos, os banheiros não foram projetados para serem usados simultaneamente por mais de uma pessoa.

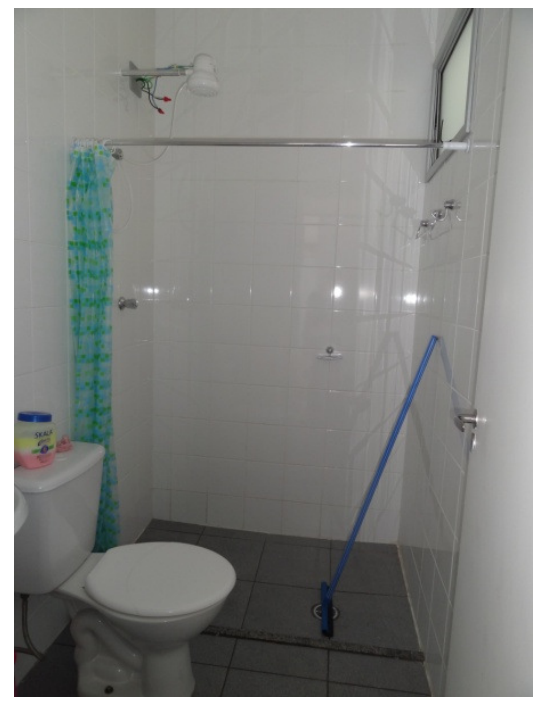

Figura 79 - Banheiro Tipo 4B

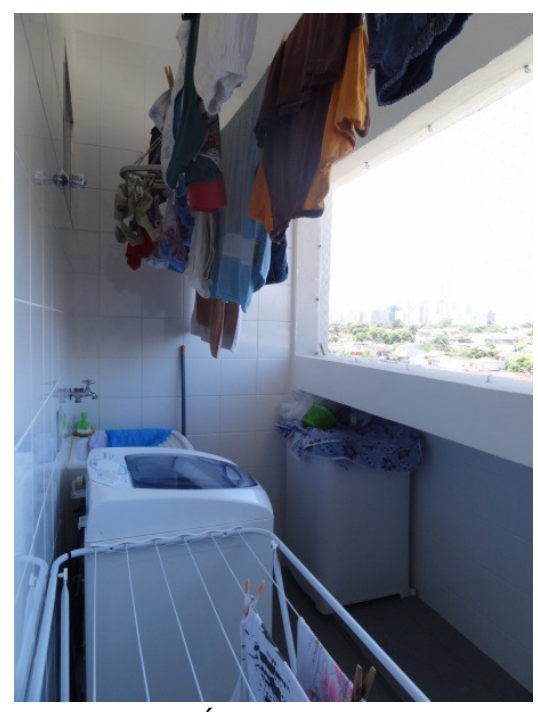

Figura 80 - Área de Serviço Tipo 4B.

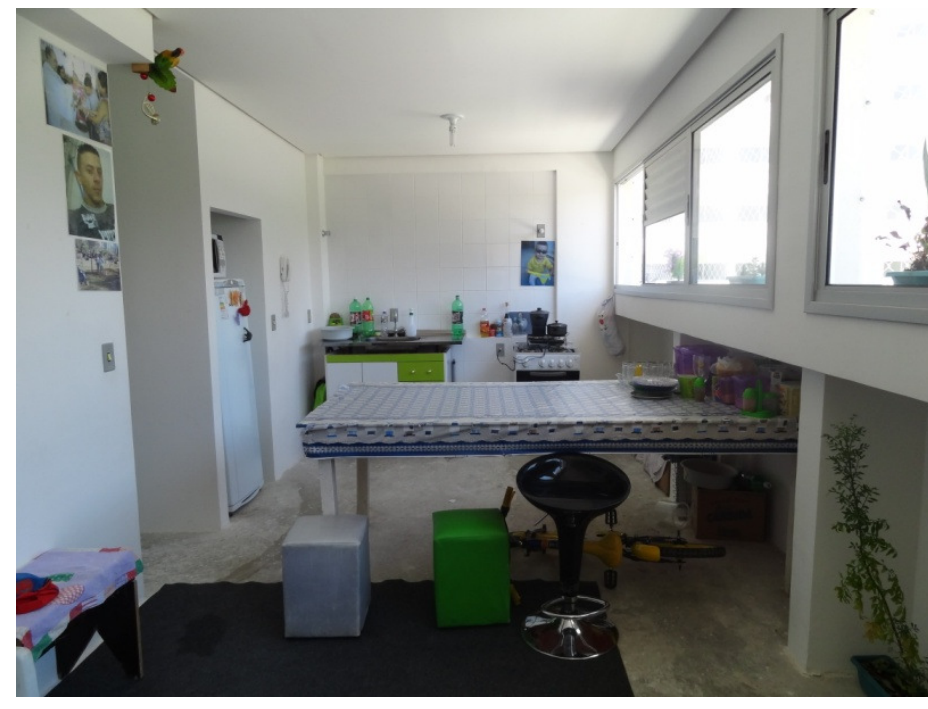

Figura 81 - Pavimento inferior Tipo 4B

De acordo com a distribuição do layout apresentada pelos escritórios de arquitetura, a cozinha do Tipo 4B possui mais espaço para a pia e o fogão, pois foi possível deixar um nicho para a geladeira embaixo da escada (Figura 81). O mesmo não ocorre no Tipo 4A que, ao precisar encaixar a geladeira na mesma parede, onde estão a pia e o fogão, acaba deixando espaço mais reduzido permitindo que seja utilizado apenas um fogão de quatro bocas. 


\section{Relação entre os}

ambientes

Cozinha e sala de estar compartilham o mesmo espaço no pavimento inferior dos duplex, porém caso algum morador deseje separar esses ambientes deixando a cozinha mais resguardada, é possível, principalmente no Tipo 4B que possui o acesso para a escada próximo à entrada da unidade.

Analisando-se o ciclo da roupa é possível notar que a área de serviço, localizada no pavimento superior, proporciona um percurso mais eficiente e curto que se concentra nesse pavimento. Porém, é preciso ressaltar que, normalmente, a mesma pessoa responsável pelo cuidado da roupa, também é responsável por fazer a comida e cuidar da cozinha. Com isso, muitas mulheres - pois são majoritariamente as mulheres responsáveis pelas tarefas domésticas - preferem que cozinha e área de serviço estejam próximas para facilitar o desenvolvimento dessas atividades.

\section{Espaço exterior próprio}

Assim como o Tipo 3, as unidades duplex possuem área de serviço com ventilação permanente que podem ser consideradas como espaços exteriores próprios nessas unidades. 


\section{Variações do Tipo 4}

As variações do Tipo 4 são muito sutis. Acontece que, ao espelhar e inverter as plantas ocorrem algumas alterações com relação à escada e aos nichos para as geladeiras. Considera-se que o Tipo $4 \mathrm{C}$ é uma variação do $4 \mathrm{~A}$, por terem os dormitórios alinhados. Já os tipos 4B e 4D, não têm os dormitórios alinhados e vão se alternando.
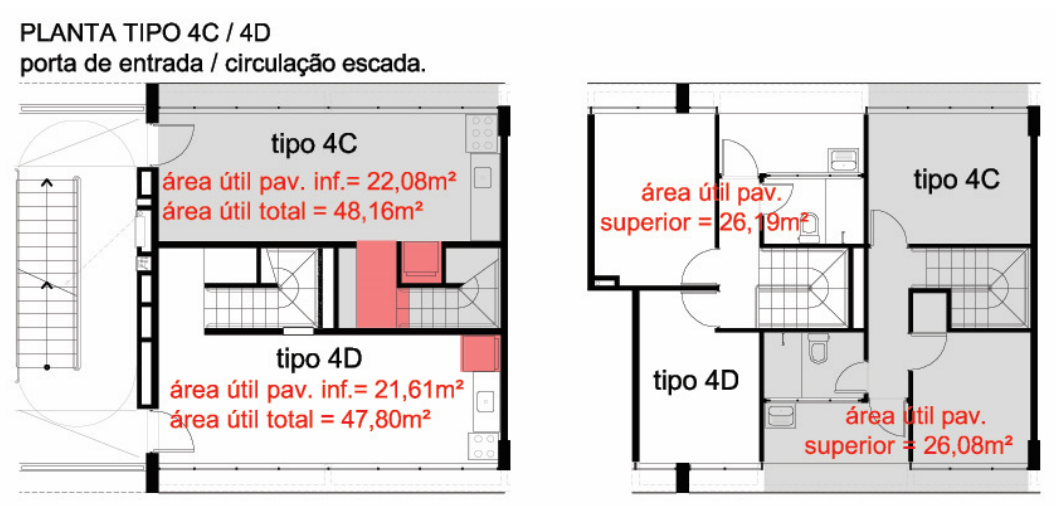

$\square$ destaque para as variações entre os tipos escala 1:200

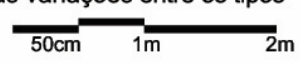

Figura 82 - Variações Tipo 4.

\section{CONSIDERAÇÕES}

FINAIS

Considera-se o Conjunto Habitacional Jardim Edite um exemplo entre as intervenções realizadas pela Secretaria de Habitação, pois permitiu que os moradores da antiga favela permanecessem no mesmo local onde já viviam e possuíam suas redes de relações de trabalho, família e amizade. Porém, essa não foi uma tarefa fácil e devemos atribuir o mérito ao esforço dos moradores, principalmente do Sr. Gerôncio - presidente da associação de moradores - que, desde que tomou conhecimento do Plano Diretor Estratégico e do fato do terreno do Jardim Edite ter sido decretado como uma ZEIS (Zona Especial de Interesse Social), lutaram por seus direitos e pela permanência no local. 
Por tratar-se de uma região muito valorizada, entende-se que a construção de um conjunto habitacional de interesse social nesse terreno, em meio a tantas grandes empresas e edifícios de alto padrão, é realmente uma vitória para os moradores e para a Secretaria de Habitação que, durante a gestão do secretário Ricardo Pereira Leite em que a arquiteta Elisabete França estava à frente da superintendência da Sehab, se dedicaram a tornar esse projeto realidade.

Por outro lado, a remoção total das moradias poderia ser questionada, pois entende-se que as diretrizes da Secretaria quanto às remoções, referiam-se a situação de risco de enchente, desmoronamento ou salubridade. $E$ poderia, portanto, ter ocorrido uma classificação e seleção das casas, permitindo que fossem mantidas as que se encontravam em melhor estado de conservação, sem risco e remover apenas as mais precárias, realizando, portanto um trabalho de consolidação e urbanização. Mas esse não foi o caminho adotado pela Sehab e a intervenção resultou na remoção total das moradias o que, seguramente, foi uma das polêmicas com relação a esse projeto durante sua execução, porém, entende-se que a posição da Secretaria devia estar muito relacionada com a valorização da área.

Outra polêmica que envolve esse projeto é o receio de que os moradores comecem a vender seus apartamentos, mudando-se para outras regiões da cidade e que isso gere uma especulação imobiliária, podendo, futuramente, resultar na expulsão involuntária dos que hoje têm o direito de viver aí. Não há mecanismos efetivos para impedir que isso aconteça. $\mathrm{O}$ acesso às moradias está vinculado a contratos de compra a longo prazo e à promessa da regularização e do título de posse das residências. Porém, segundo os técnicos da Sehab, é necessário acreditar que os moradores do Jardim Edite irão valorizar o bem que possuem, além do mais, se antes já viviam nesse local, significa que possuem vínculos que os mantém nessa região e é portanto, acreditando nesse reconhecimento, que a Secretaria apostou nesse projeto. 
Também é importante ressaltar as vantagens apresentadas pela implantação de equipamentos junto ao conjunto habitacional. Essa mescla de uso valoriza o projeto e beneficia aos moradores que, no caso do Jardim Edite, podem contar com uma creche e uma UBS muito próximas às suas casas.

De forma geral, considera-se o Jardim Edite um projeto ousado, por sua localização, pela verticalização e implantação de elevadores, mesmo que isso não tenha derivado da necessidade de atingir ao coeficiente máximo de aproveitamento.

Também foi importante notar a definição clara dos espaços de uso privado e as áreas destinadas aos equipamentos. A consolidação do pavimento condominial sobre os equipamentos ofereceu um "segundo" térreo para os moradores. Porém, teria sido importante que houvesse maior cuidado com os mobiliários das áreas de lazer. Esse espaço que hoje, tem um caráter impessoal, poderia ser mais agradável e convidativo se tivesse sido providenciada a instalação de mobiliário de lazer e descanso para o uso dos moradores.

Vale ressaltar ainda a qualidade especial apresentada pelas tipologias que buscaram, cada uma a seu modo, atender às necessidades mínimas dos moradores nesses espaços com menos que $50 \mathrm{~m}^{2}$.

Espera-se, portanto, que esse estudo de caso seja uma contribuição para o projeto e construção de conjuntos habitacionais como exemplo da mescla de usos e da luta dos moradores pela permanência nos locais onde vivam, almejando ser uma referência de inserção de habitação de interesse social em áreas consolidadas e valorizadas da cidade. 
4.3 ESTUDO DE CASO: RESIDENCIAL PARQUE NOVO SANTO AMARO V 



\subsection{SANTO AMARO V}

Residencial Parque Novo Santo Amaro V

Localização: Rua Coelho Lousada, 1.000

Distrito: Jardim Ângela - Subprefeitura: M'Boi Mirim - Zona: Sul

Distância até $o$ centro da cidade: $25,8 \mathrm{Km}$.

Conclusão da obra: 2013 - início projeto: 2009

Arquitetura: Vigliecca \& Associados

Equipe: Hector Vigliecca, Luciene Quel, Neli Shimizu, Ronald Werner, Caroline Bertoldi, Kelly Bozzato, Pedro Ichimaru, bianca Riotto, Fábio Pittas, Thaís Fróes, Aline Ollertz, Sérgio Faraulo, Paulo Serra, Luci Maie

Promoção: Programa de urbanização de favelas da Secretaria Municipal de Habitação de São Paulo (Sehab)

Coordenação Sehab: Ligia Miranda de Oliveira

Área total de intervenção: 5,39 ha

Área Projeto Habitacional: $18.190,02 \mathrm{~m}^{2}$

Área Construída projeto habitacional: $14.739,73 \mathrm{~m}^{2}$

Coeficiente de aproveitamento dos lotes: 0,81

no unidades habitacionais: $200 \mathrm{UHs}$ construídas + aproximadamente 137 domicílios mantidos

Densidade da área total de intervenção: $62,5 \mathrm{UHs} / \mathrm{ha}$

225,08 habitantes $/$ ha $^{1}$

Densidade Projeto Habitacional: $109,39 \mathrm{UHs} / \mathrm{ha}$ 393,81 habitantes/ha

Programa: Unidades Habitacionais / Comércios / Parque Linear / Centro de Convivência / Campo de Futebol

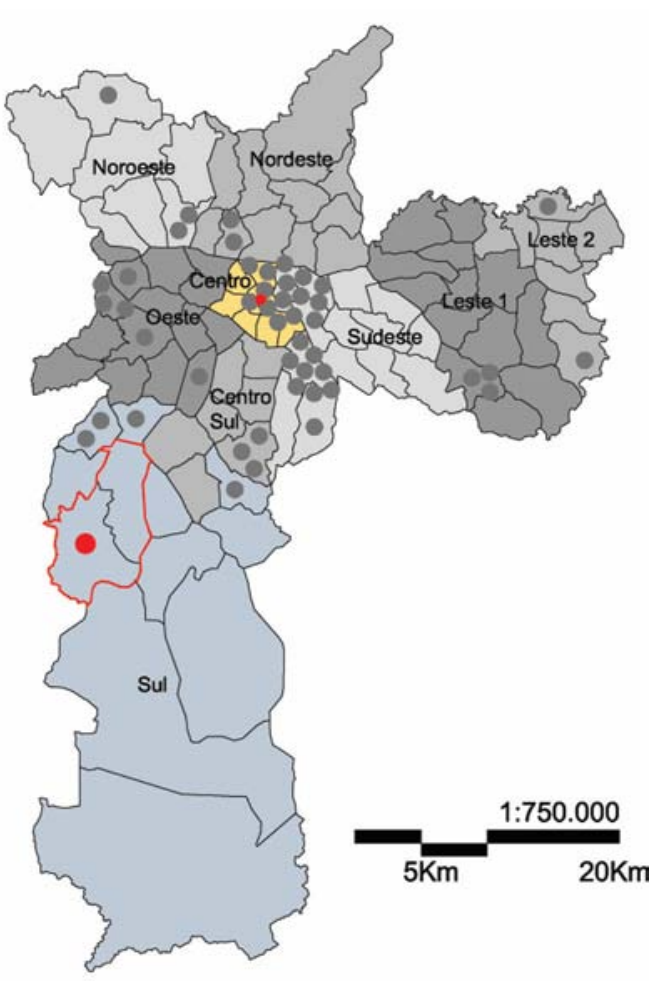

Figura 2 - Localização com relação à cidade.

${ }^{1}$ Foi adotada a média de 3,6 habitantes por unidade habitacional em aglomerados subnormais - fonte: IBGE, Censo Demográfico 2010, p. 
O Residencial Parque Novo Santo Amaro V localiza-se em área de preservação ambiental no entorno da Represa Guarapiranga. Esse projeto foi selecionado como representante das intervenções realizadas em áreas de mananciais e, entre outros ${ }^{2}$, foi realizado através do Programa Mananciais, promovido pela Secretaria Municipal de Habitação.

Antes de entrar diretamente na análise do projeto, julgou-se importante conhecer um pouco sobre a ocupação irregular na região da represa e também sobre o programa, pioneiro no Brasil, de recuperação da Represa Guarapiranga.

De acordo com Elisabete França (2009, p.149), "a Represa do Guarapiranga, desde 1929, passou a responder por boa parte do abastecimento de água da Região Metropolitana de São Paulo (RMSP), no entanto, na época de sua construção, em 1906, seu objetivo era apenas a regulação produtiva da energia elétrica e não o abastecimento hídrico." Durante alguns anos, a região foi explorada por seu potencial turístico e paisagístico e, com isso, localizavam-se nessa região clubes náuticos, restaurantes, etc. Entretanto, na década de 1970, a função principal da Represa Guarapiranga passou a ser a de abastecimento, e segundo a arquiteta,

[...] o governo promulgou a Lei de Proteção aos Mananciais, congelando a utilização do potencial dos terrenos, os proprietários se sentiram desestimulados frente à impossibilidade de realizar os negócios imobiliários previstos. Alguns abandonaram suas áreas, sem interesse na utilização, e outros, entregaram a reponsabilidade da guarda desse patrimônio a pessoas que loteavam as áreas em pequenos lotes e os vendiam irregularmente para pessoas de baixa renda.

Ao mesmo tempo em que essa parte considerável do território paulistano se transformava em zona de proteção aos mananciais, também na década de 1970 era estimulada a construção de indústrias ao longo da Marginal

2 Entre os projetos realizados pela Sehab através do Programa Mananciais, pode-se citar: Cantinho do Céu / Gaivotas; Jardim Iporanga; Mata Virgem; Vila Rubi; Cidade Júlia; Chácara do Conde, etc. Para conhecer mais projetos, consultar a publicação: Plano Municipal de Habitação: a experiência de São Paulo - volume I (2012a). 
Pinheiros, abrindo novos postos de trabalho, que atraíam uma população considerável para a região. (FRANÇA, 2009, p. 150)

Com isso, frente ao desinteresse dos proprietários por suas terras e à nova demanda de trabalhadores que chegava à cidade em busca de lugar barato para morar, a região do Guarapiranga acabou sendo ocupada, irregularmente, por milhares de unidades de lotes mínimos caracterizadas pela precariedade construtiva e ausência de infraestrutura básica. Essa situação acarretou graves problemas com relação à qualidade da água da represa, pois carentes de infraestrutura, "milhares de fontes poluidoras difusas jogavam o esgoto doméstico em canais de drenagem, redes clandestinas, a céu aberto, que chegavam aos córregos contribuintes da represa, concentrando altos níveis de poluição em suas águas" (FRANÇA, 2009, p. 150).

No livro São Paulo Metrópole (2004), os autores comentam sobre o processo de expansão urbana em direção às represas e áreas de mananciais destacando os motivos e as consequências para a cidade:

Nos quadrantes ao sul da metrópole, o processo de expansão urbana e de constituição das periferias foi favorecido pela oferta de empregos, tanto industriais quanto de serviços, concentrados nessa região. Esse fato estimulou a produção de loteamentos populares, com acesso por antigos caminhos ou estradas regionais, transmutados em vias urbanas, em vez da ferrovia. A partir do município de São Paulo, e posteriormente do grande ABCD, o padrão periférico conduziu a urbanização nesses quadrantes, alcançando, na década de 1980, compartimentos ambientais inadequados. E nesse movimento incontido se configurou um dos grandes problemas da urbanização contemporânea: a ocupação urbana precária e ilegal em áreas de proteção aos mananciais metropolitanos, especialmente nos arredores das represas Guarapiranga e Billings, que deveriam estar preservadas de ocupações descontroladas. As estradas de Parelheiros, M' Boi Mirim, do Bororé e do Avarenga são vetores dessa urbanização imprópria. Essas periferias apresentam como denominador comum: a 
distância ao Centro; a função de bairro ou município-dormitório; ser a localização dos pobres (MEYER; GROSTEIN; BIDERMAN, 2004, p. 42).

Zelar pela qualidade das águas da represa e conter o adensamento populacional são os dois principais desafios que vêm sendo enfrentados tanto pelo município, como pelo Estado durante as últimas décadas. ${ }^{3}$ O Programa de Saneamento Ambiental da Bacia do Guarapiranga começou a ser desenvolvido em 1991 por iniciativa do governo do estado e, segundo Elisabete França (2009, p. 174), desde sua estruturação, a Prefeitura de São Paulo participou como organismo executor das futuras ações que viriam a ser implantadas. ${ }^{4}$

Com o início do programa, duas estratégias principais foram definidas:

A primeira tinha como meta desenvolver a capacitação técnica, financeira e institucional para a gestão da bacia, integrando o governo estadual, os governos municipais e a sociedade civil, a qual resultou em um novo estatuto jurídico para a área de mananciais; a segunda tinha como objetivo melhorar a qualidade de vida dos moradores dos assentamentos de baixa renda através da melhoria e expansão da infraestrutura de saneamento básico, da qualificação das áreas urbanas mais densamente ocupadas e em condições de insalubridade, e da proposição de novos espaços públicos para o desenvolvimento de atividades de caráter coletivo (FRANÇA, 2009, p. 178 e 179).

${ }^{3}$ Em 2006 foi instituída a Lei Estadual no 12.233 e, em 2007, o Decreto Estadual no 51.686, que definem a Área de Proteção e Recuperação dos Mananciais da Bacia hidrográfica do Guarapiranga. Esses instrumentos definem também todos os instrumentos de regulação, licenciamento, gestão, urbanização, recuperação, compensação e fiscalização ambiental.

${ }^{4}$ A Primeira fase do Programa Guarapiranga estendeu-se até 2000 e foi coordenado pela arquiteta Elisabete França entre 1993 e 2000. 
Entre os órgão envolvido no Programa, estavam: Companhia de Saneamento Básico do Estado de São Paulo (SABESP); Secretaria do Meio Ambiente do Estado de São Paulo (SMA); Companhia de Desenvolvimento Habitacional e Urbano do Estado de são Paulo (CDHU); Eletricidade de são Paulo S.A (Eletropaulo); Prefeitura do Município de São Paulo (PMSP).

Para Elisabete França (2009, p. 193), o Programa Guarapiranga foi responsável pela implantação de um conjunto de práticas inovadoras na esfera pública, entre elas, a Unidade de Gestão do Programa, a integração de ações entre órgãos públicos de diferentes níveis e a preparação dos fundamentos para a nova legislação ambiental. Dentre as práticas inovadoras, a arquiteta destaca especialmente o programa de urbanização de favelas desenvolvido no âmbito do subprograma de recuperação urbana, coordenado pela Prefeitura de São Paulo.

Após as primeiras intervenções com projetos centrados na implantação de redes de infraestrutura básica, a urbanização de favelas evoluiu para ações bem mais complexas. Os projetos e obras passaram a ter como objetivo maior a integração dos assentamentos precários e informais, à cidade reconhecida como formal, adotando-se, a partir daí, o conceito de "qualificação urbana", ou seja, a transformação de áreas de "urbanização sem cidade" em novos bairros dotados de serviços e que permitiam aos moradores, o seu "pertencimento" à cidade.

[...] Dessa forma, a partir de 1993, sem um projeto metodológico definido, foi dado início à implantação de um ambicioso programa de urbanização de favelas localizadas na Bacia do Guarapiranga, com vistas a diminuir os crescentes níveis de poluição ocasionados pelos poluidores dispersos que viviam nessas áreas precárias. Ao final da primeira fase do Programa Guarapiranga (2000), as ações que visavam à urbanização de favelas eram reconhecidas como uma das práticas de melhor resultado no âmbito dos programas financiados pelo Banco Mundial (FRANÇA, 2009, 193 e 194) 
Após o "aprendizado" adquirido durante a primeira fase do Programa Guarapiranga, a Prefeitura de São Paulo manteve a atuação nas áreas de mananciais. Muitos projetos consistiram em urbanizar as ocupações existentes, recuperando as margens da represa ou dos rios que nela desaguam, como foram os casos do Cantinho do Céu e Jardim Iporanga, por exemplo.

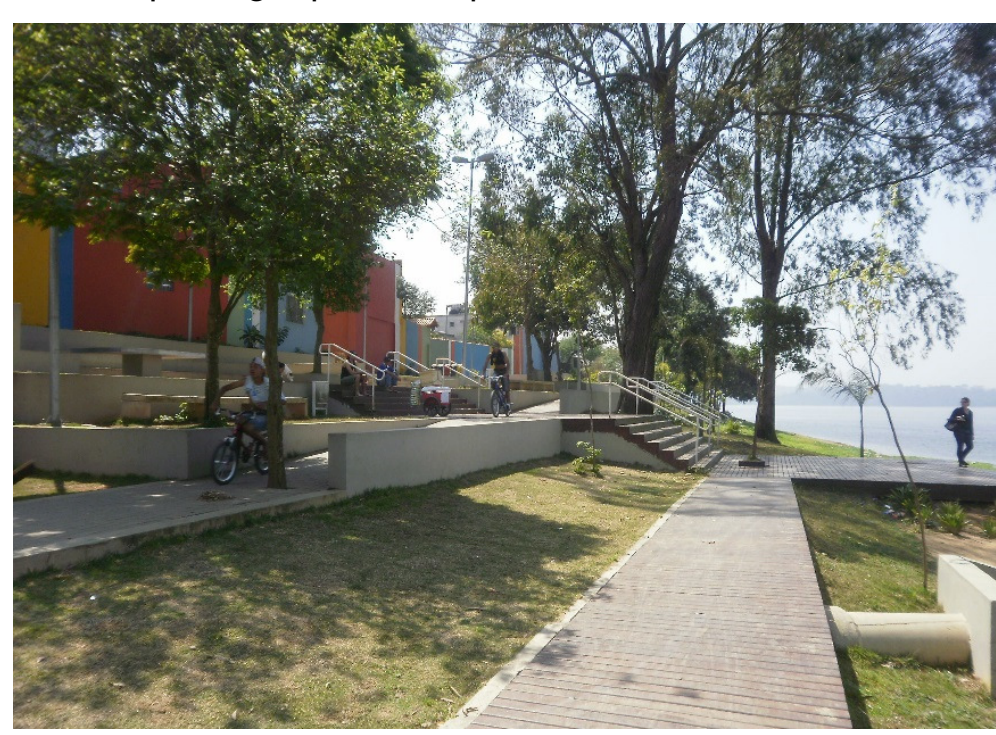

Figura 3 - Cantinho do Céu. Projeto realizado pelos arquitetos Marcos Boldarini, Melissa Matsunaga e equipe. É considerado, atualmente, um importante exemplo de urbanização e oferta de espaço público. Esse projeto foi bastante premiado nos anos de 2010 e 2012, ficando em terceiro lugar no concurso mundial de Habitação Social e Desenvolvimento Urbano na Bienal Panamericana de Arquitetura de Quito, 2010.

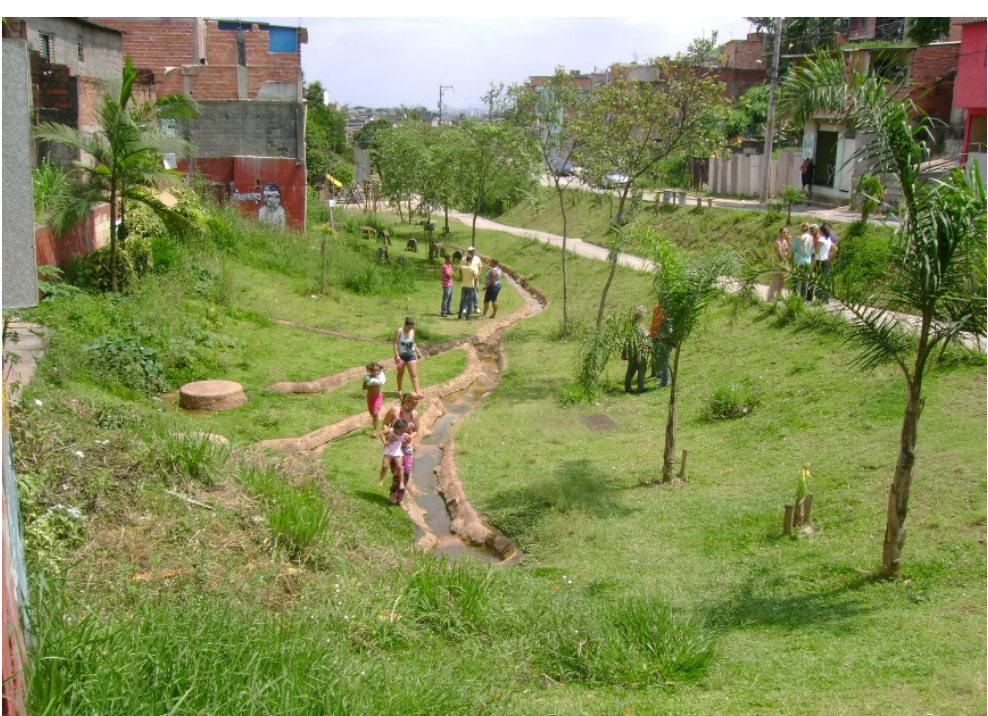

Figura 4 - Jardim Iporanga. Exemplo de incorporação da nascente do córrego à urbanização.

${ }^{5}$ PREFEITURA DE SÃO PAULO. FRANÇA, Elisabete; BARDA, Marisa (Orgs.). Entre o céu e a água. 0 Cantinho do Céu. 1ª edição. São Paulo: HABI - Superintendência de Habitação Popular, $2012 f$ (Série Novos Bairros de São Paulo). 
Nesse contexto, o Residencial Parque Novo Santo Amaro V foi selecionado como exemplo de intervenção mista, contemplando tanto a urbanização, como a construção de novas edificações habitacionais. Conforme memorial descritivo do projeto realizado pelo escritório Vigliecca \& Associados,

Entendemos moradia como sinônimo de cidade. E entendemos que a produção de habitação em grande escala constitui a parte básica na produção da cidade.

Projetos de arquitetura coletiva devem gerar setores visíveis e compreensíveis que organizem a escala enfrentando a cidade real e rejeitando formalismos heroicos.

Acreditamos que a reprodução da habitação deve valorizar a variedade e a identidade, alcançadas através de um relacionamento de respeito à geografia e de solidariedade ao existente (Disponível em: <http://www.vigliecca.com.br/pt-BR/projects/novo-santo-amaro-v\#memorial>. Acesso em dezembro de 2013).

Foi com essa "solidariedade ao existente" que o projeto implantou-se em meio a uma trama com caráter de cidade informal, onde as ruas são estreitas e as casas se sobrepõem dentro de pequenos lotes, buscando levar ao entorno uma intervenção de qualidade que beneficiasse a todos os moradores, tanto os das novas unidades, quanto aos que tiveram suas moradias mantidas e consolidadas.

A área de intervenção está inserida em uma Zona de Interesse Social - ZEIS 1 e é composta por áreas públicas e loteamentos ocupados irregularmente.

De acordo com o conceito apresentado no memorial descritivo,

A diretriz geral do projeto é criar ao longo do curso d'água existente um eixo central verde, caracterizado como um parque linear, que estrutura todo o conjunto das intervenções. Ele é um eixo de animação que qualifica a área, estimulando um sentimento de identificação nos seus moradores. Os equipamentos de educação e 
lazer, são instalados nas extremidades desse eixo, funcionando como pontos de atração, justamente para estimular as pessoas a circularem e, assim, garantir a segurança e animação do local.

Os edifícios de habitação fazem a interface entre a rua oficial do entorno e o parque na área interna. Eles possuem sempre acessos pelas duas faces para garantir a circulação e, com isso, a segurança e manutenção das áreas externas e internas do conjunto (Disponível em: <http://www.vigliecca.com.br/pt-BR/projects/novosanto-amaro-v\#memorial>. Acesso em dezembro de 2013).

No croqui, desenhado por Hector Vigliecca, é possível visualizar toda a "vida" que o arquiteto desejou que a intervenção tivesse ao conceber o projeto. A passarela representa a intenção de proporcionar espaços permeáveis e a comunicação entre os dois lados da intervenção. A imagem transmite a sensação de uma passarela pública, muito utilizada pelas pessoas.

A comunicação com o nível do parque também é enfatizada e esse espaço representa a força das áreas públicas como incentivo à qualificação do entorno. No alto do desenho, vemos duas pipas e isso me leva a relacioná-las a uma imagem, apresentada por Hector Vigliecca em uma palestra ${ }^{6}$, em que um garoto "soltava pipa na laje". O comentário de Vigliecca sobre essa foto foi com relação à falta de espaço público e, portanto, a presença das pipas no desenho estabelece uma relação direta com a forte vontade do arquiteto de proporcionar espaços públicos de qualidade aos moradores da região.

6 VIGLIECCA, Hector. Palestra: Programa de Pós Graduação da Faculdade de Arquitetura e Urbanismo da USP - Disciplina: Arquitetura Contemporânea Paulista / Crítica de arquitetura. Professores responsáveis: Mônica Junqueira de Camargo; Hugo Segawa. São Paulo: 18 de julho de 2013. 


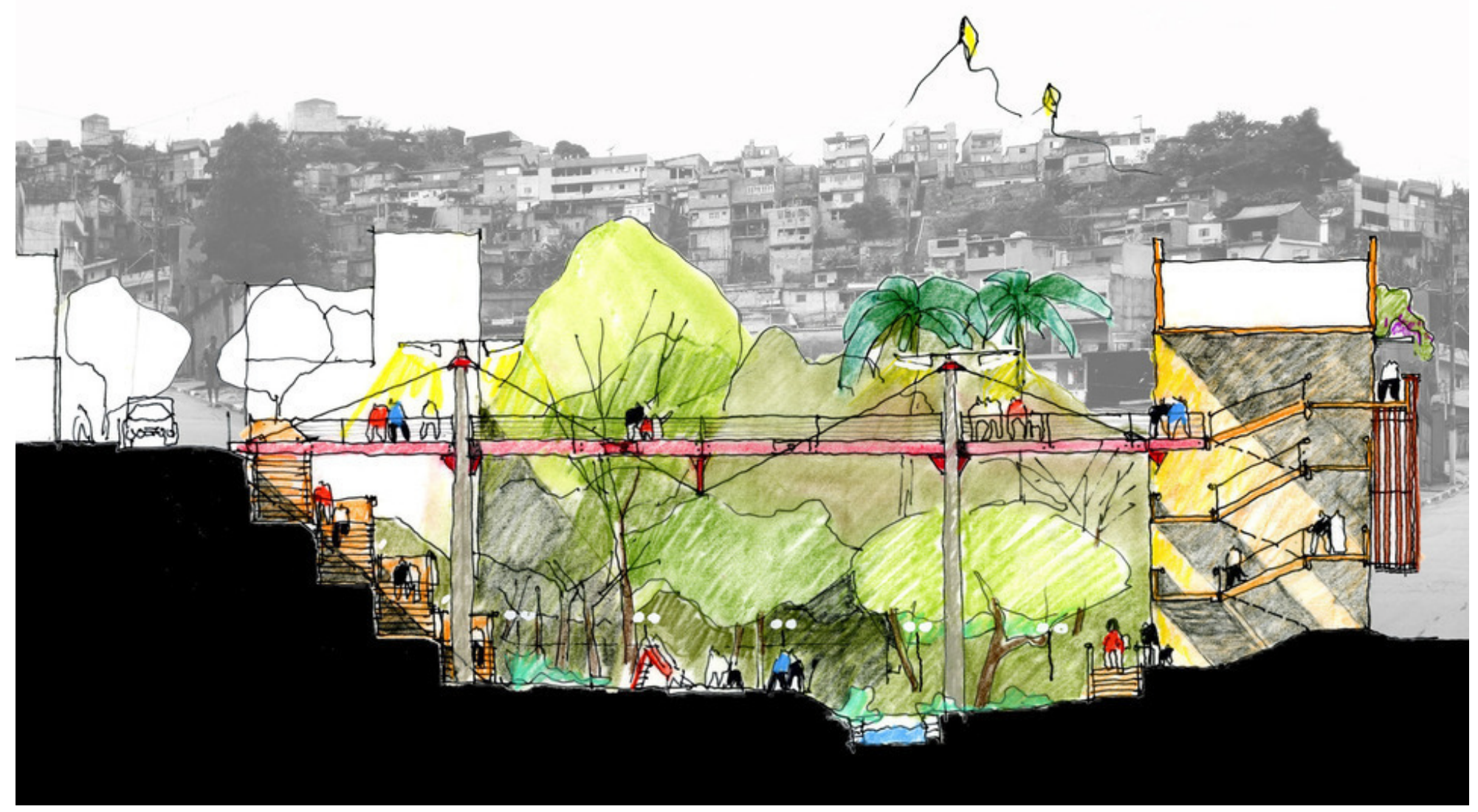

Figura 5 - Croqui conceitual sobre a proposta de intervenção desenhado por Hector Vigliecca. 
Na Figura 6 é possível observar o limite da área de intervenção anteriormente às remoções. Também é possível observar a trama do entorno, com ruas tortuosas e lotes bem pequenos. No lado esquerdo do limite, próximo à Rua Agostinianos, vemos o campo de futebol pré-existente que foi mantido e requalificado no projeto final.

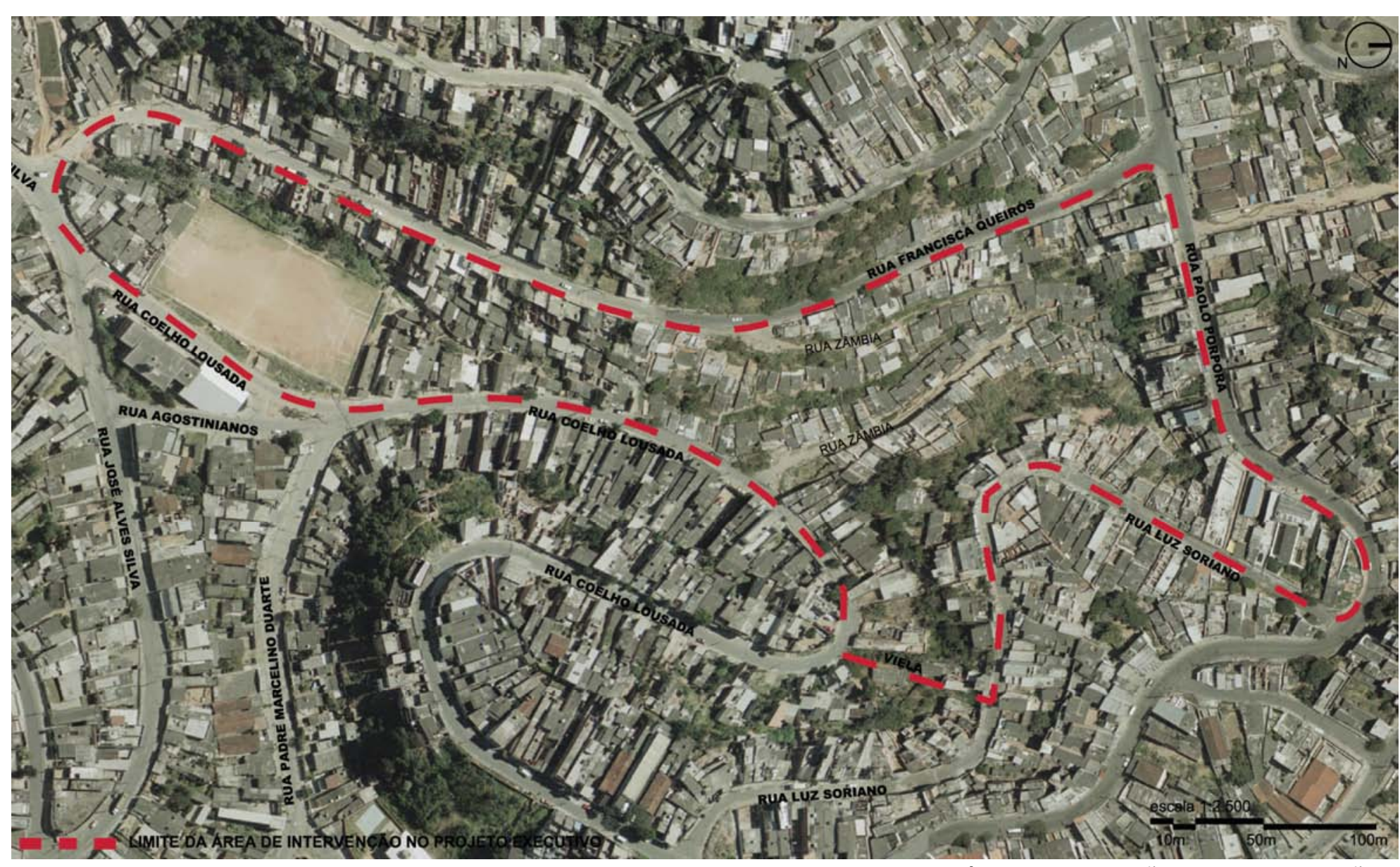

Figura 6 - Limite a área de intervenção antes das remoções. 
Na Figura 7, é possível observar a definição dos domicílios que foram removidos e quais foram consolidados. Também é possível identificar o curso d'água existente ao longo do qual o arquiteto propôs criar um eixo central verde caracterizado como parque linear e elemento estruturador do conjunto.

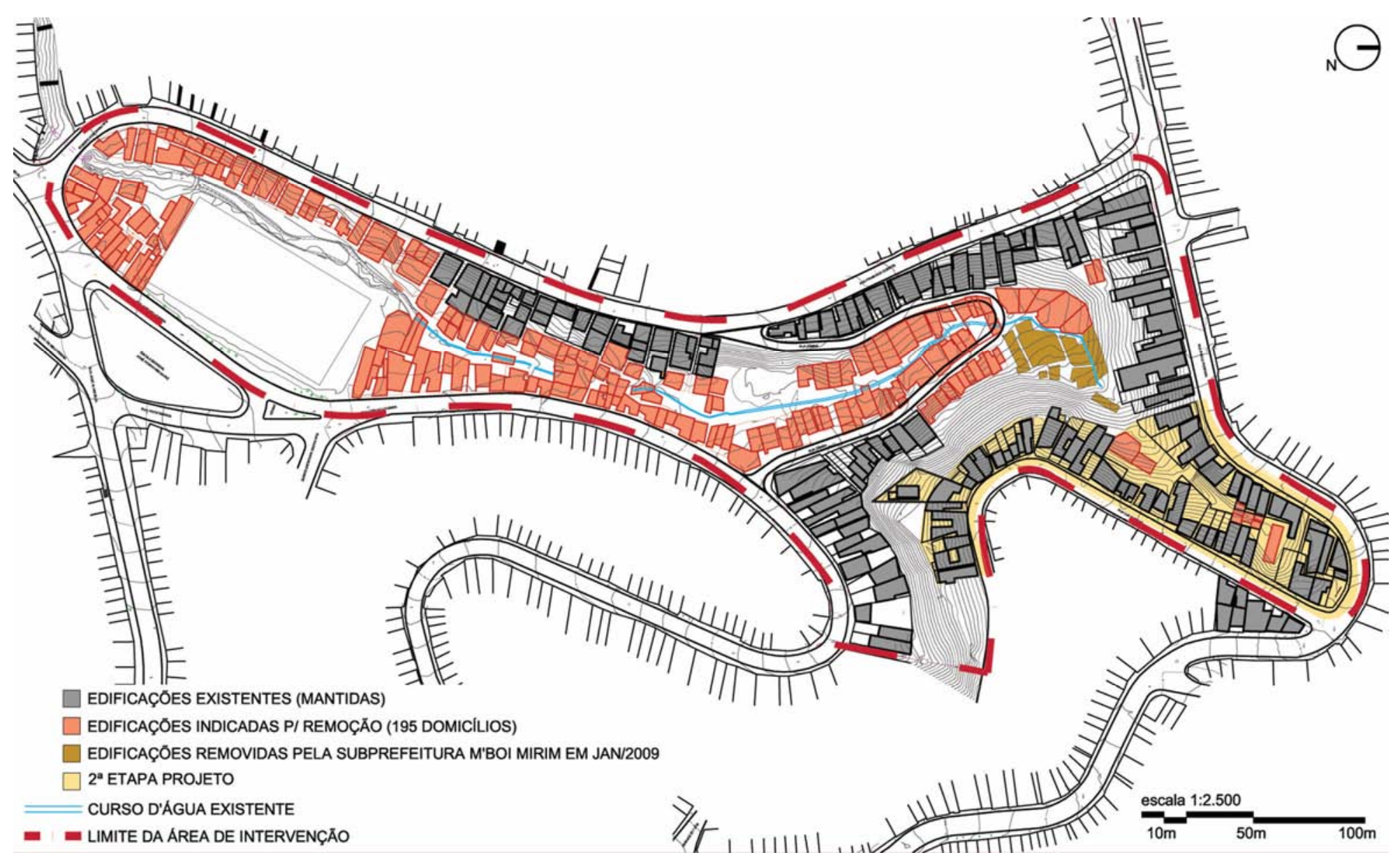

Figura 7 - Planta de Remoções indicando os domicílios mantidos e removidos para a realização da intervenção. 
A partir da análise detalhada que será realizada a seguir, será possível conhecer o projeto mais profundamente, buscando identificar os conceitos citados no memorial descritivo. A análise nos permitirá entender através de quais mecanismos o arquiteto propõe estimular o sentimento de identificação nos moradores e a circulação de pessoas em busca de uma garantia de maior segurança e manutenção dos espaços propostos.

\subsubsection{ESCALA CONJUNTO}

O primeiro item a ser analisado na Escala Conjunto são os valores de proximidade. O levantamento realizado através do Google Maps permitiu identificar a localização do Residencial Parque Novo Santo Amaro V com relação ao Parque Estadual Guarapiranga. Possibilitou também verificar a caraterística das ocupações dessa região, marcada por ruas tortuosas e pequenos lotes, como já foi citado anteriormente.

A identificação das principais vias baseou-se nas conexões existentes e também na oferta de transporte público. Dessa forma, também foram classificadas como vias principais as ruas por onde passam ônibus. A Estrada M' Boi Mirim representa um importante eixo de conexão da zona sul da cidade e está apenas a 600 metros de distância do conjunto.

Quanto à oferta de transporte público, identificou-se apenas o ônibus para atender à população que vive nessa região. Não há por perto nenhuma linha de metrô ou trem.

Com relação aos equipamentos, foi possível identificar algumas escolas públicas nas proximidades, uma delas, inclusive, é bastante próxima ao conjunto estando no limite da área de intervenção, a escola José Porphyrio da Paz. Um pouco mais afastado e fora do raio de 1.000 metros, também foi localizado um Centro de Educação Unificado, o CEU Feitiço (ao norte da Rua Luar do Sertão).

Na avenida M'Boi Mirim encontra-se o Hospital Cidade Tiradentes, o único equipamento de saúde identificado nas proximidades além da UBS Luar do Sertão, ambos localizados no limite do raio de 1.000 metros. 


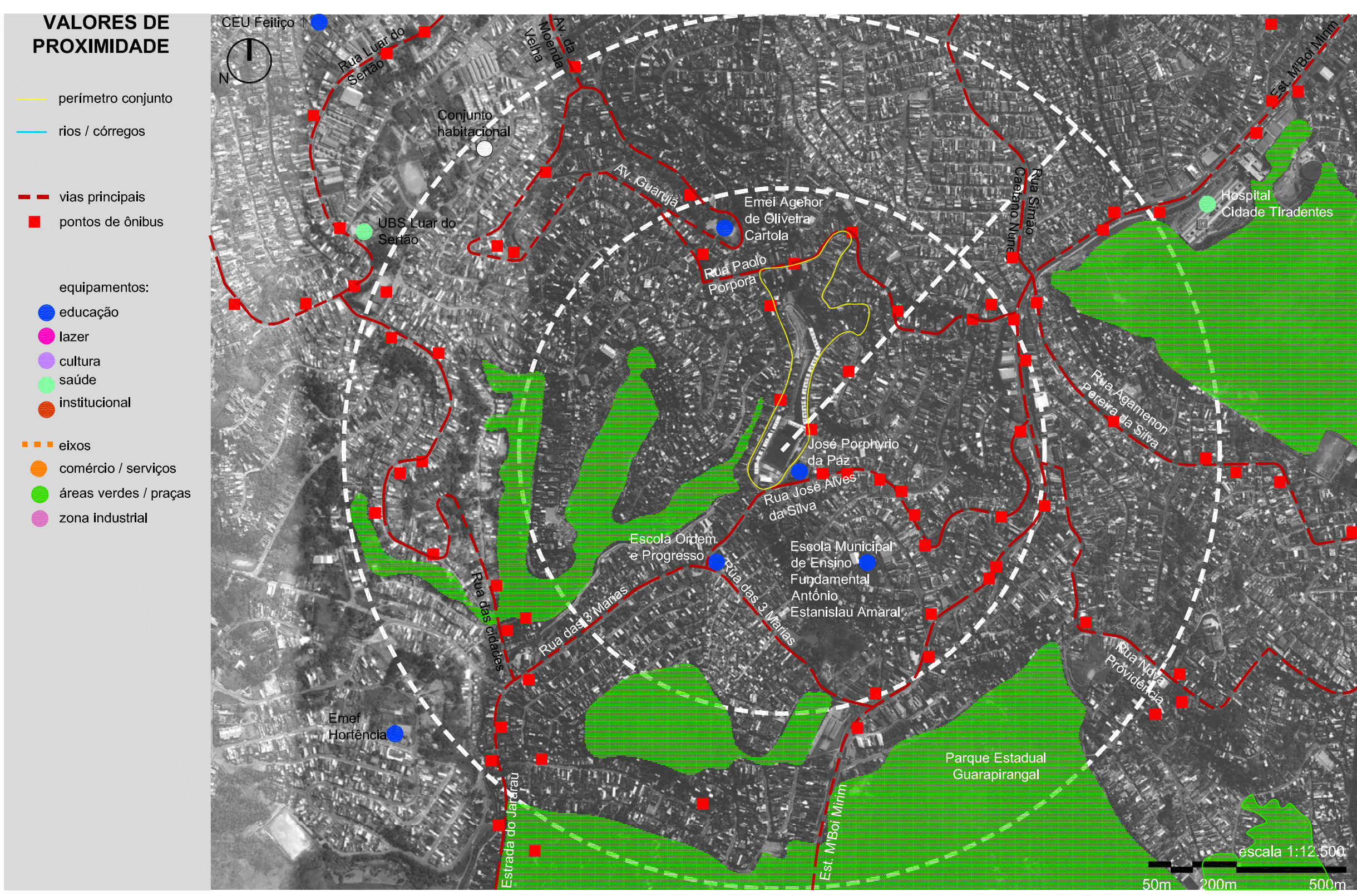


Quanto à oferta de comércio, não foi possível identificar, através da ferramenta utilizada, grandes centros comerciais ou supermercados. Porém, com base nas visitas ao local, foi possível verificar a existência de um grande número de comércio de rua que atende aos moradores da região. Devido ao conhecimento superficial do entorno do projeto, não foi possível identificar essas ruas comerciais no mapa, porém, é possível observar, nas fotos abaixo a caraterística desses comércios.

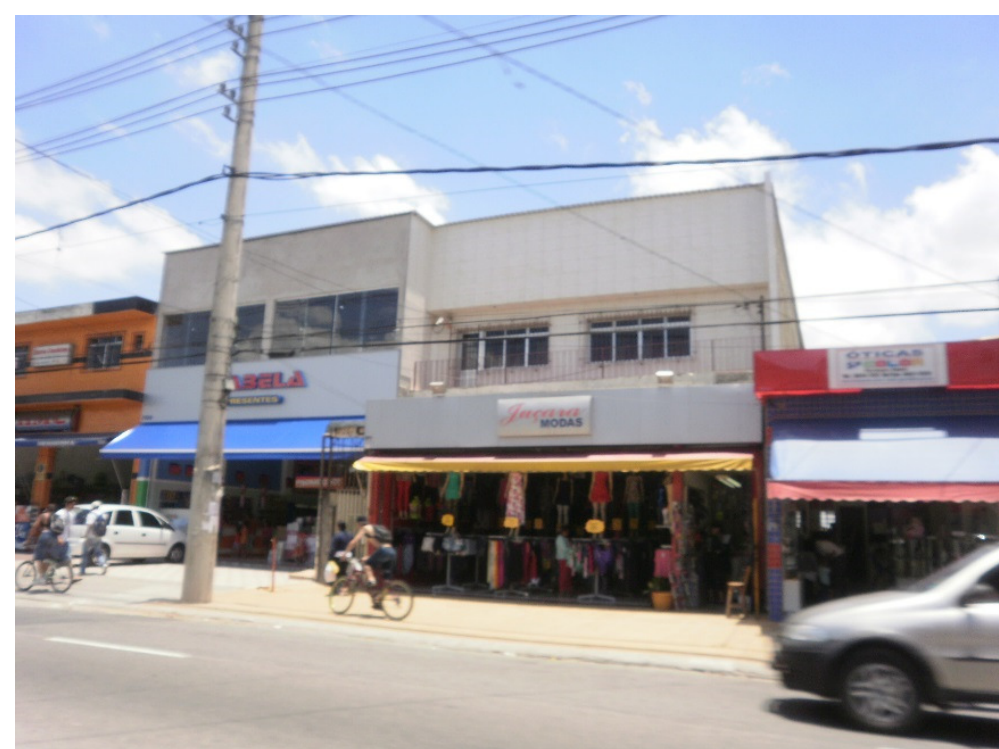

Figura 9 - Comércio local no entorno do conjunto.

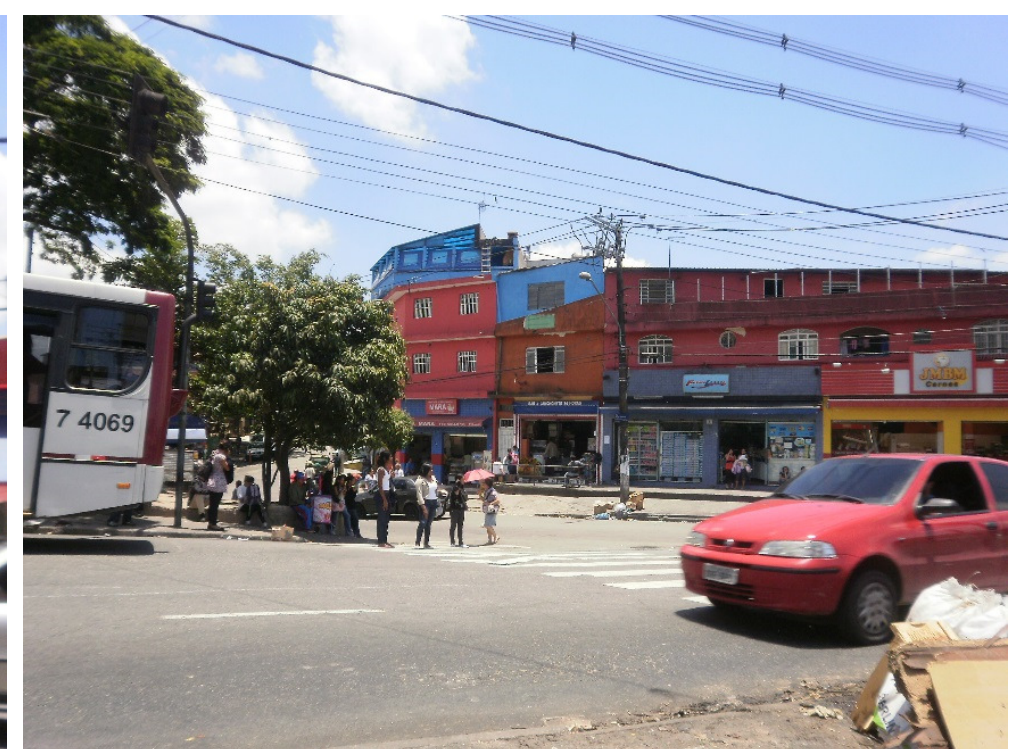

Figura 10 - Comércio local no entorno do conjunto.

As áreas verdes identificadas na Figura 8 são matas mais densas e não praças ou espaços para o lazer. Também não foi possível identificar equipamentos culturais e espaços de lazer para a população. Ao olhar a foto aérea é inevitável a sensação de adensamento e a falta de espaços livres. 


\subsubsection{INSERÇÃO URBANA}

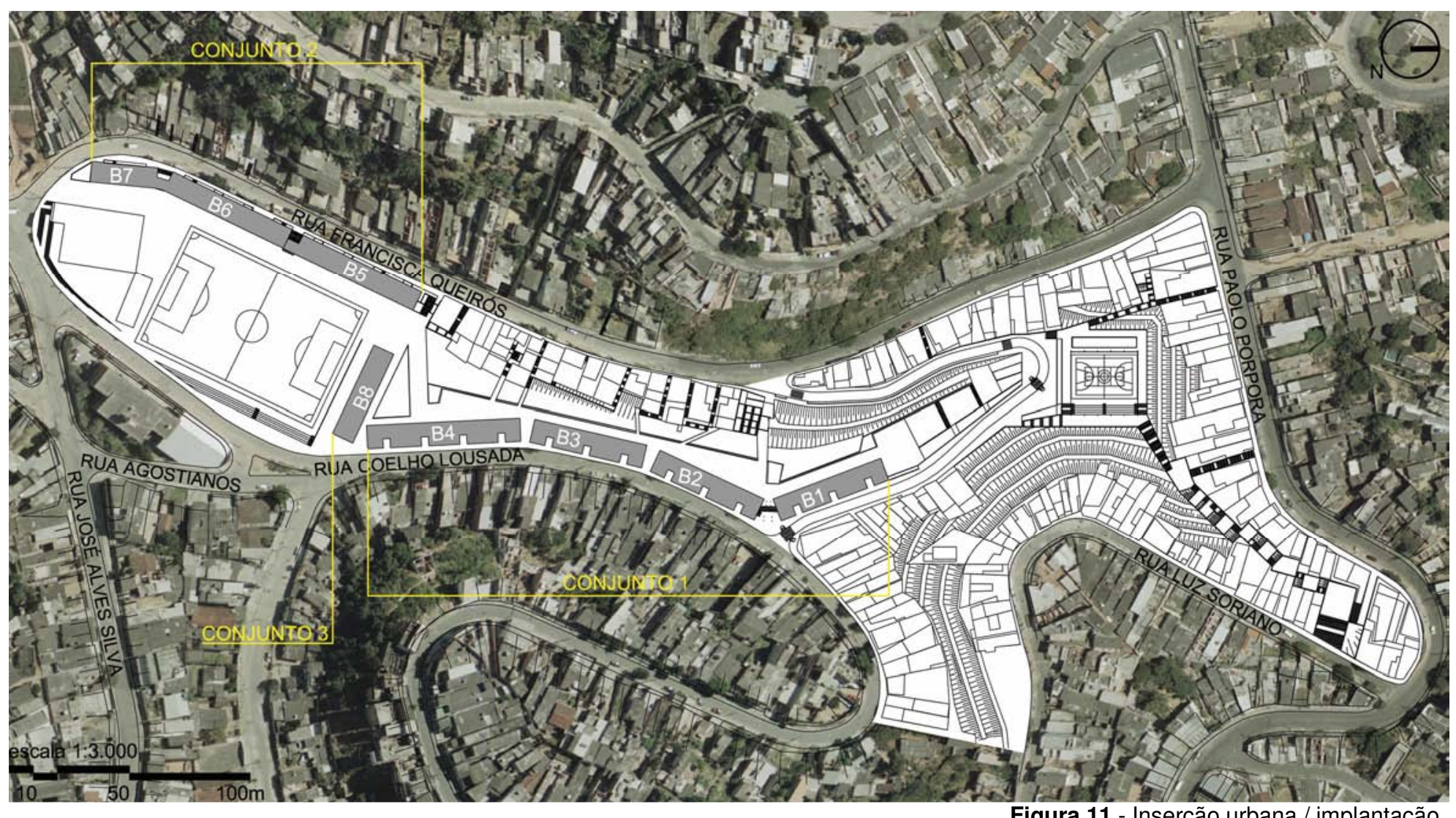

Figura 11 - Inserção urbana / implantação.

A área total da intervenção é de 5,39 hectares, dentro dos quais, os edifícios habitacionais são construídos em meio à consolidação de moradias existentes. O projeto de urbanização contemplava, além da construção dos novos edifícios, a criação de ligações que atravessariam os trechos de domicílios mantidos, buscando oferecer maior permeabilidade à área e estimular a circulação de pessoas através dessas conexões, que podem ser identificadas 
pelas escadarias no meio dos domicílios. Contudo, após a finalização do projeto, essas conexões não foram realizadas, pois esse trecho do terreno era particular e, devido à situação fundiária, a Sehab não pôde atuar. Para isso, seria necessário desapropriar terrenos, o que dificultou a realização dessas conexões.

\section{Programa}

Os edifícios habitacionais estão divididos em três conjuntos: Conjunto 1 (blocos 1, 2, 3 e 4); Conjunto 2 (blocos 5, 6 e 7); e Conjunto 3 (bloco 8). Ao todo, esses edifícios somam 200 unidades habitacionais.

O campo de futebol é um espaço livre de uso privado que funciona sob a gestão de uma associação local e, portanto, os moradores do conjunto não têm livre acesso. Para utilizá-lo é necessário reservar o espaço como qualquer outro campo gerido por algum clube ou associação. Segundo a arquiteta Neli Shimizu, o campo de futebol já existia antes da intervenção e, durante as reuniões com os líderes comunitários para discutir o projeto, foi pedido que o campo fosse mantido no mesmo lugar (informação verbal). ${ }^{7}$

De acordo com o Manual da Moradia do Residencial Parque Novo Santo Amaro V (2012e) - uma cartilha que é entregue aos moradores do conjunto quando se mudam - as áreas de uso comum são: três salões de festa; duas áreas de lazer com churrasqueira; duas áreas de lazer infantil; equipamentos de exercícios para idosos e pista de skate, que também foi solicitada pelos moradores.

Além dessas áreas de uso comum, o conjunto também contará com um Centro Comunitário e dois CRAS (Centro de Referência de Assistência Social) que até o momento da última visita ao conjunto, em novembro de 2013, ainda não haviam sido instalados.

7 VIGLIECCA, Hector; SHIMIZU, Neli. Entrevista: Residencial Parque Novo Santo Amaro V. São Paulo, 23 de janeiro de 2014. 


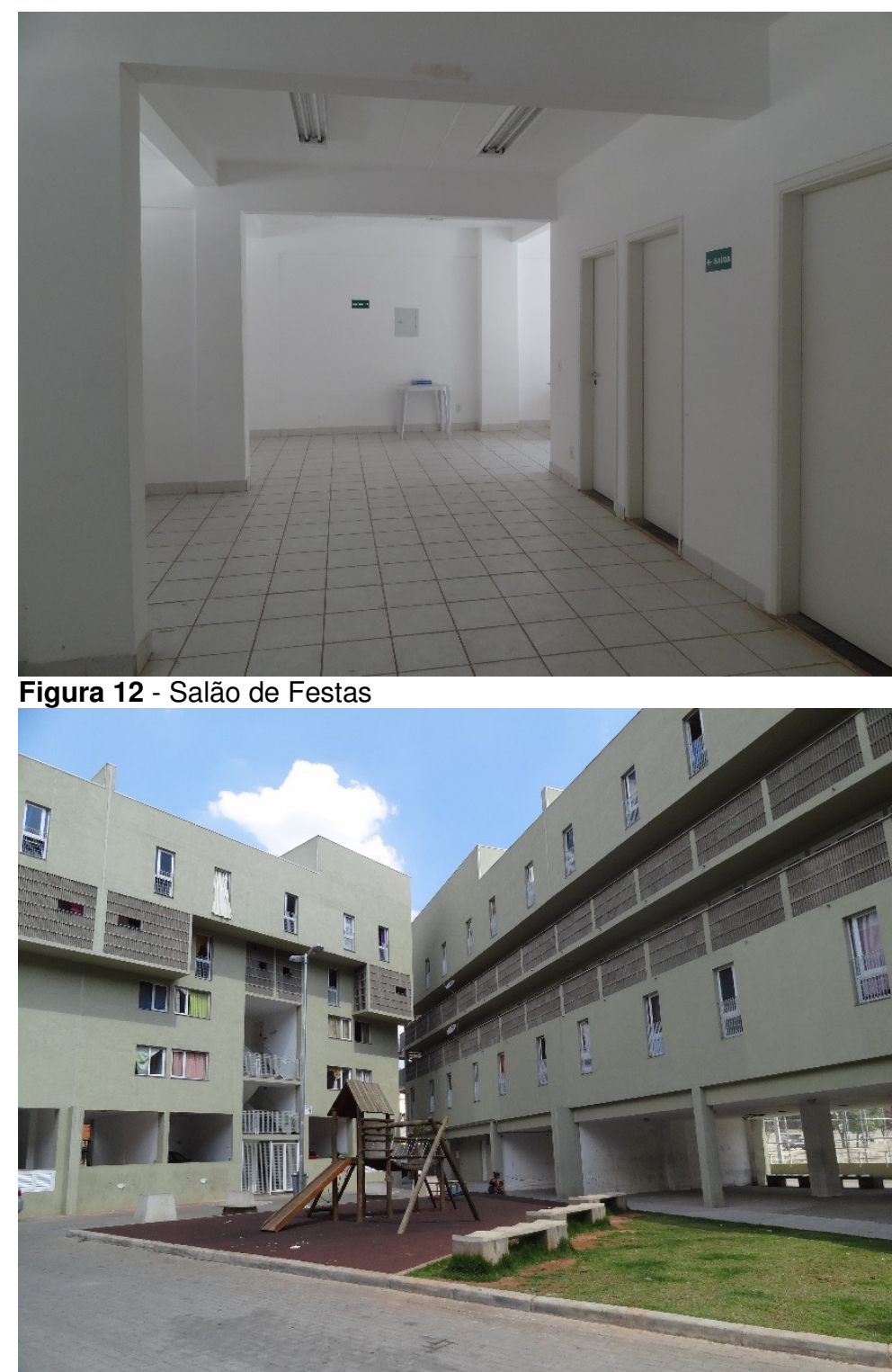

Figura 14 - Espaço de lazer para crianças

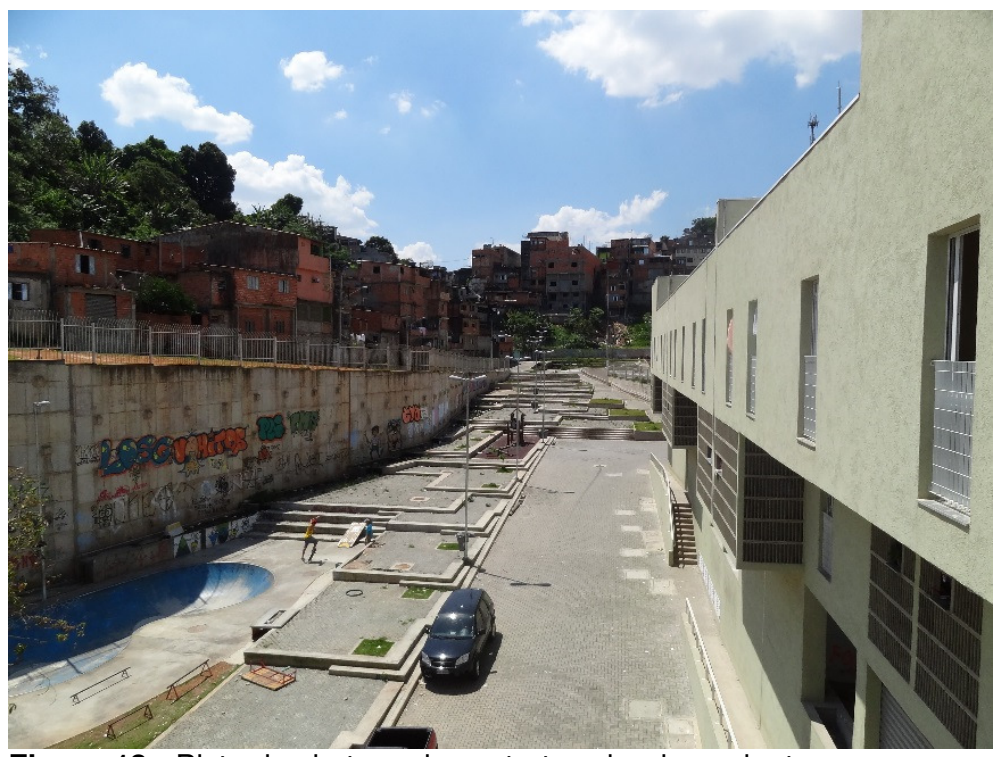

Figura 13 - Pista de skate e eixo estruturador do conjunto

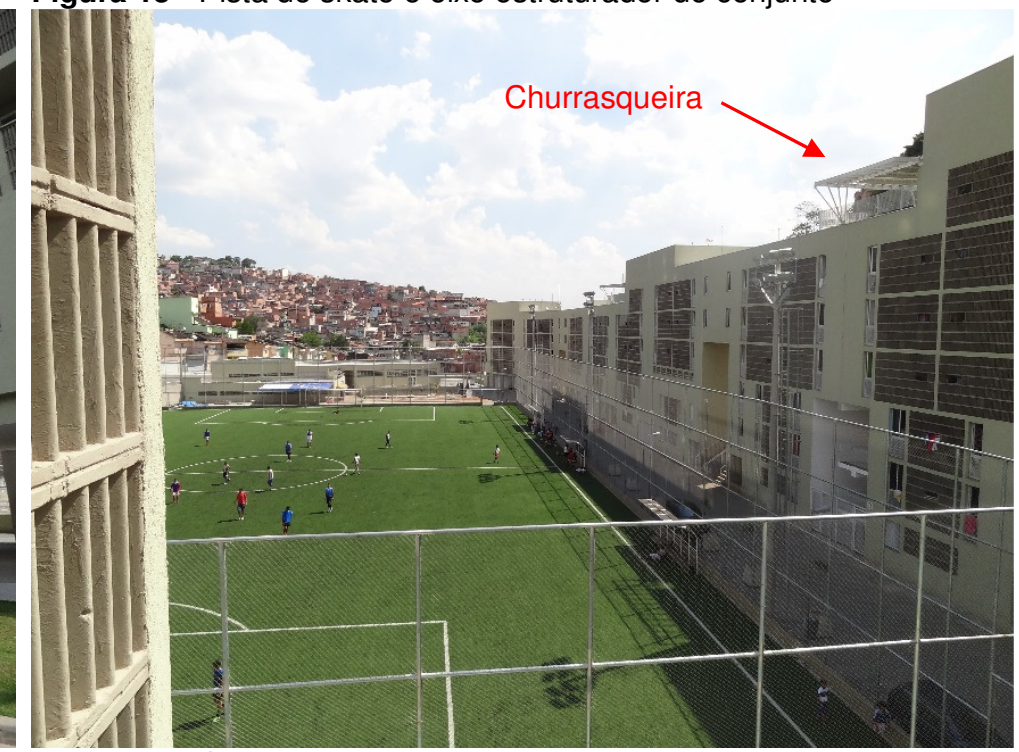

Figura 15 - Campo de Futebol e churrasqueira na cobertura 


\section{Ocupação do terreno}
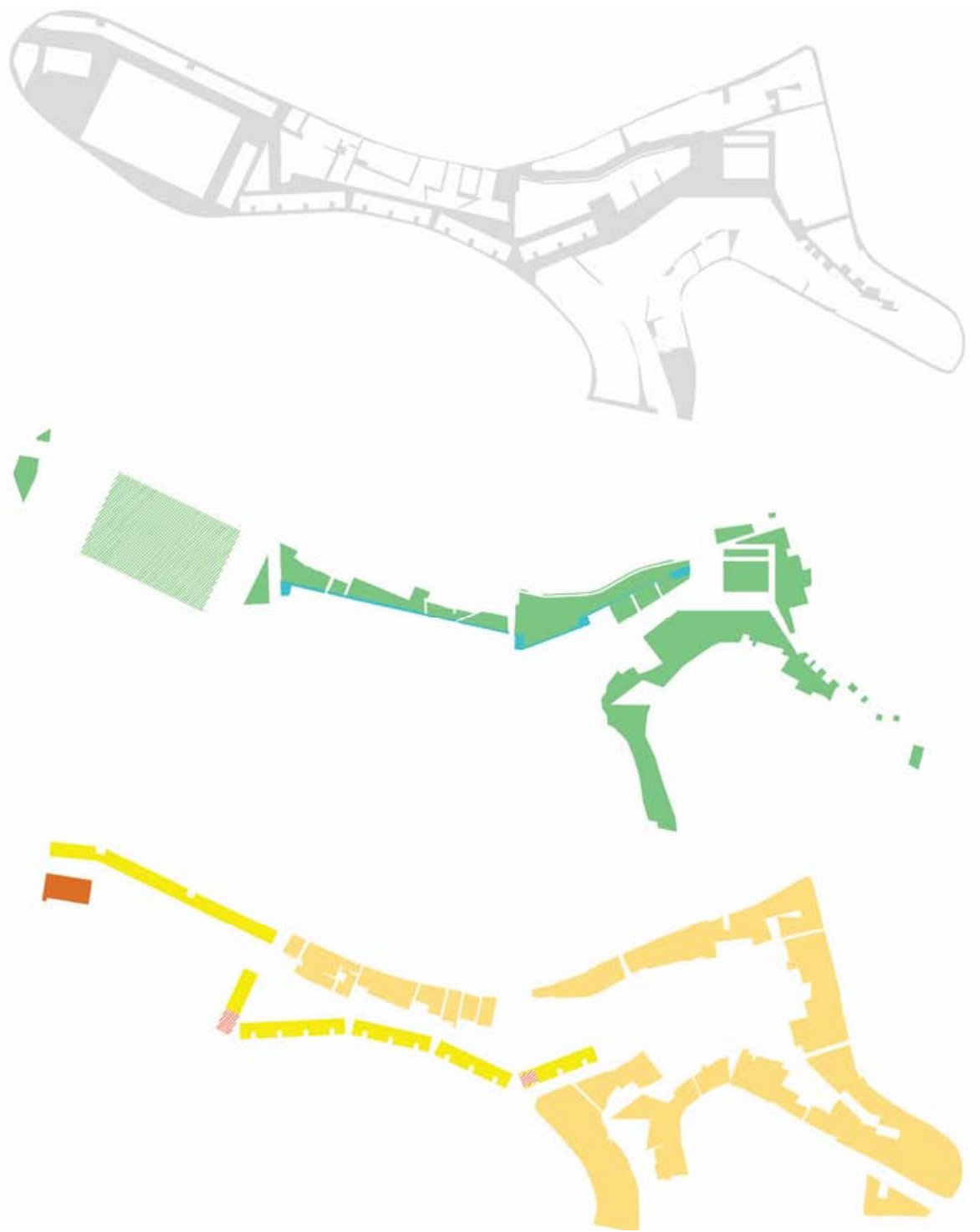

— circulação - $31,29 \%$

$$
\begin{array}{r|l}
\text { TOTAL } & \square \text { espelho d'água- } 0,51 \% \\
28,67 \% & \square \text { espaços livres de uso público - } 19,36 \% \\
& \square \text { espaços livres de uso privado - } 8,80 \%
\end{array}
$$

$\square$ habitação - $6,45 \%$

TOTAL misto (comércio no térreo) - 0,39\%

$40,04 \%$ q equipamento público - 0,82\%

$\square$ lotes de domicilios existentes - $32,38 \%$ 
O estudo da ocupação do terreno foi realizado sobre toda a área de intervenção. A partir das máscaras de ocupação é possível verificar que 40,04\% representa as áreas construídas. Desse percentual, 32,38\% representam os domicílios existentes mantidos e apenas $6,45 \%$ referem-se às novas edificações de unidades habitacionais.

Os espaços identificados como mistos foram concebidos para serem utilizados como comércios e, segundo a arquiteta Neli Shimizu, foram propostos para aproveitar a vocação comercial existente na esquina da Rua Zâmbia com a Rua Coelho Lousada. Porém, após a inauguração do conjunto, o uso comercial não foi aprovado pela Secretaria de Habitação, que não dispõe de instrumentos para fazer a gestão desses espaços que acabaram sendo utilizados para abrigar os Centros de Assistência Social (CRAS).

Quanto aos espaços livres, diferentemente de outros projetos, esse conjunto não é cercado criando espaços livres privados. Com exceção do campo de futebol, todas as outras áreas livres são de uso público podendo ser acessadas e utilizadas por qualquer morador do bairro.

Esse uso público dos espaços é reforçado pelos percursos propostos que, propositadamente, atravessam o conjunto incentivando que as pessoas circulem através dos caminhos, vielas e passarelas criados.

A proposta de áreas livres públicas é exemplar e representa, ao menos a partir do ponto de vista da arquitetura, o auge da inserção urbana e qualificação do entorno, pois, ao intervir na cidade, além das novas construções, proporciona espaços públicos de qualidade com a intenção de atender aos moradores do bairro e não apenas os moradores do novo conjunto habitacional.

Porém, a visita ao conjunto e uma conversa com Janete ${ }^{8}$ - a assistente social que acompanhou a visita - demostrou que, na realidade, esta inserção não funciona tão bem quanto parece. Segundo Janete, ainda que os espaços 
sejam públicos e abertos para o uso de todos, os moradores do entorno não compreendem que esses espaços também foram concebidos para eles e, ao invés de utilizarem e ajudarem na manutenção, acabam degradando essas áreas livres e de lazer. Por outro lado, os moradores do conjunto, ao perceberem que os espaços são públicos, não se responsabilizam pela manutenção, o que amenta o estado de degradação.

Segundo Janete, alguns moradores até chegaram a fazer mutirões de limpeza, mas esse trabalho ainda não é suficiente para conservar e manter limpos os espaços públicos. A assistente social comentou que, pela vontade dos moradores do conjunto, esses espaços seriam cercados. Um limite físico seria definido e ai então eles se responsabilizariam pela limpeza, gestão e manutenção dos espaços. Porém, é importante destacar que, uma vez que os espaços são públicos, a gestão deveria ter ficado a cargo da subprefeitura e não dos moradores.

É curioso perceber a atitude das pessoas com relação às novas intervenções. Nesse caso, perece que os moradores do entorno não acreditam que os espaços tenham sido projetados para eles, para o uso de todos. Acredita-se que seria necessário um trabalho social mais integrado que já tivesse se iniciado durante a construção do conjunto, com a função de incentivar a participação popular dos moradores do bairro. Com isso, talvez ficasse mais fácil incentivar a apropriação com relação aos novos espaços. O que fica claro, é a necessidade de um trabalho social intenso e bem estruturado.

De qualquer forma, entende-se que a administração pública também deve ser responsabilizada pelo estado de conservação dos espaços públicos, pela falta de gestão, organização e falta de comunicação entre os departamentos, o que prejudica muito o resultado das intervenções.

Entretanto, não há uma fórmula pronta que garanta o sucesso das intervenções. O que não pode ocorrer, é que exemplos desse tipo deixem de ser propostos, pois, é a partir de experiências como essa que será adquirido um 


\section{Definição do limite do conjunto}

aprendizado diferente e novas estratégias de intervenção irão surgir em direção a projetos cada vez mais integrados à cidade e aceitos pela sociedade.

Como foi explicado no item anterior, o conjunto não é cercado. Não há grades ou muros que definam a entrada e saída conjunto. Na realidade, esse projeto tem a escala de uma intervenção urbana e os conjuntos habitacionais apenas fazem parte do todo.

A implantação dos edifícios foi uma estratégia utilizada para, de certa forma, definir os limites da área de intervenção. Assim como em outros projetos, Vigliecca utiliza os próprios edifícios, implantando-os diretamente em contado com a rua.

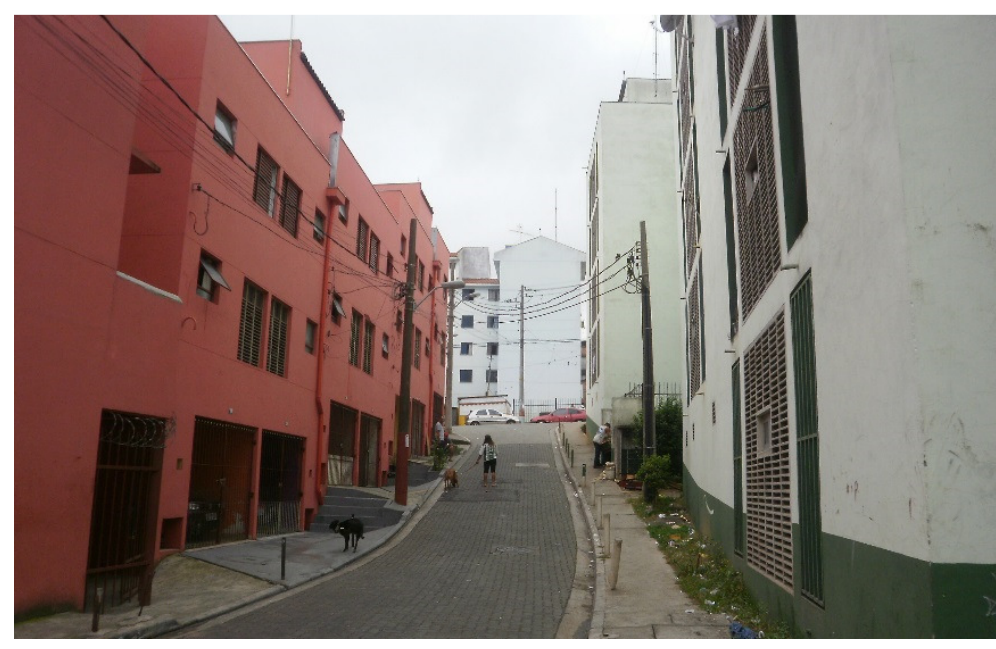

Figura 16 - Projeto gleba A, quadra 0 e quadra 1 - Heliópolis. Nesses projetos notamos as garagens em contato com a rua ou elementos vazados que aumentam a privacidade.

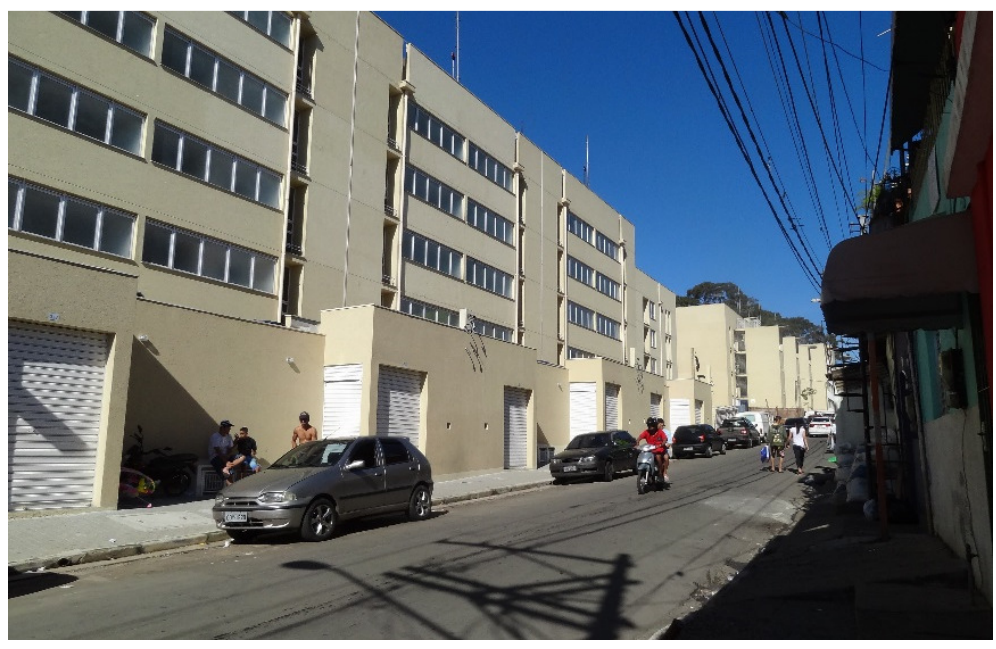

Figura 17 - Projeto Quadra H - Heliópolis. Nesse caso, há uma fila de salas comerciais em contato direto com a rua e os edifícios estão mais recuados. 


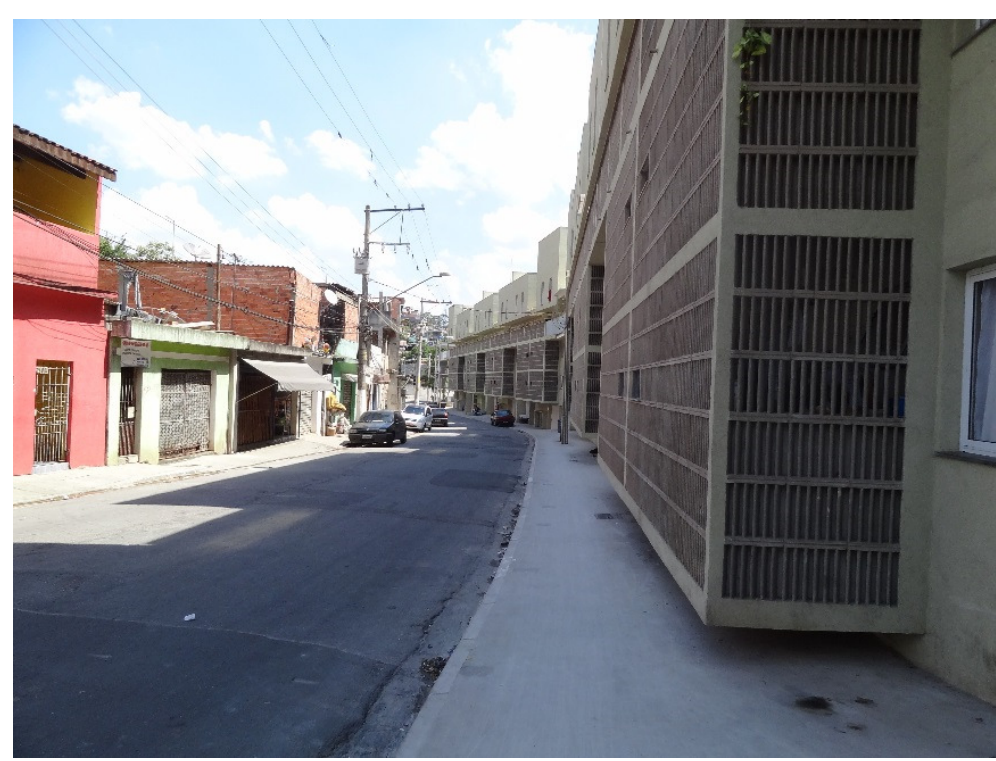

Figura 18 - Residencial Parque Novo Santo Amaro V - Rua Coelho Lousada

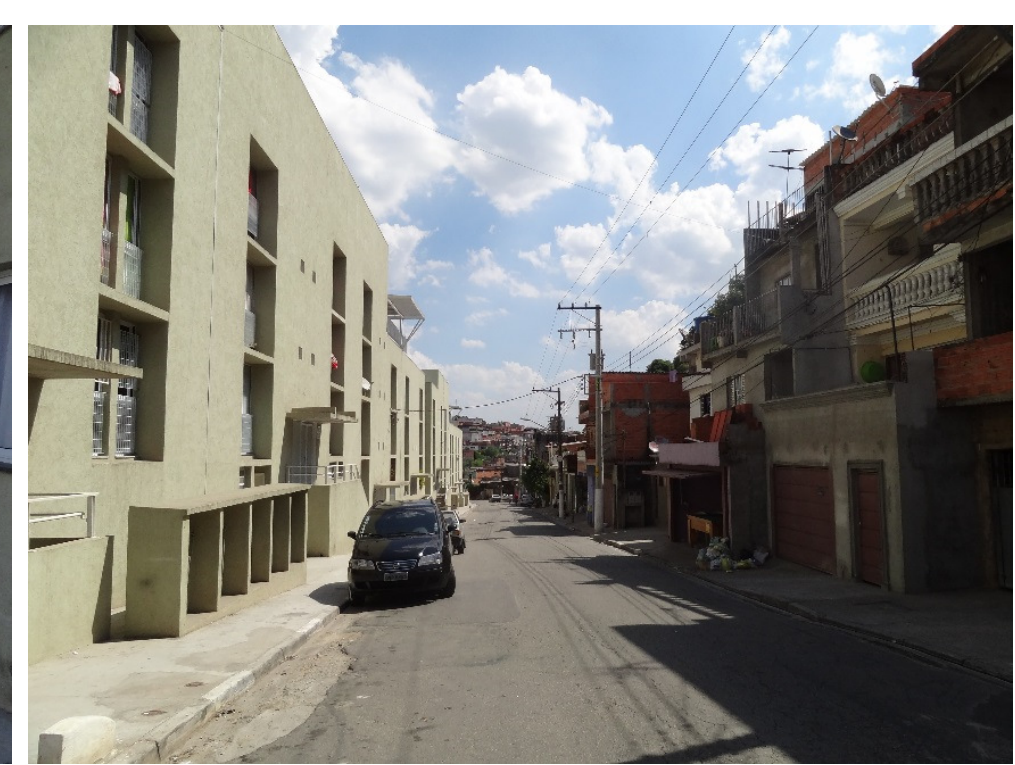

Figura 19- Residencial Parque Novo Santo Amaro V - Rua Francisca Queirós

No caso do Santo Amaro V, ao implantar os edifícios em contato direto com a rua, há diferentes elementos que aumentam a privacidade das unidades. Em alguns casos, são utilizados os fechamentos com elementos vazados (Figura 18), em outros as aberturas encontram-se mais elevadas e um pouco recuadas (Figura 19). Nesse projeto também há momentos em que as garagens encontram-se no térreo em contato com a rua.

Devido à grande declividade do terreno, também foi necessário realizar grandes contenções e, em alguns momentos, os limites definidos por essas contenções não são muito agradáveis, destoando do cuidado com que foram propostos os outros limites.

Como pode ser observado nas imagens que seguem, há um gradil alto sobre o muro de contenção que funciona como proteção, mas também define o limite da intervenção. 


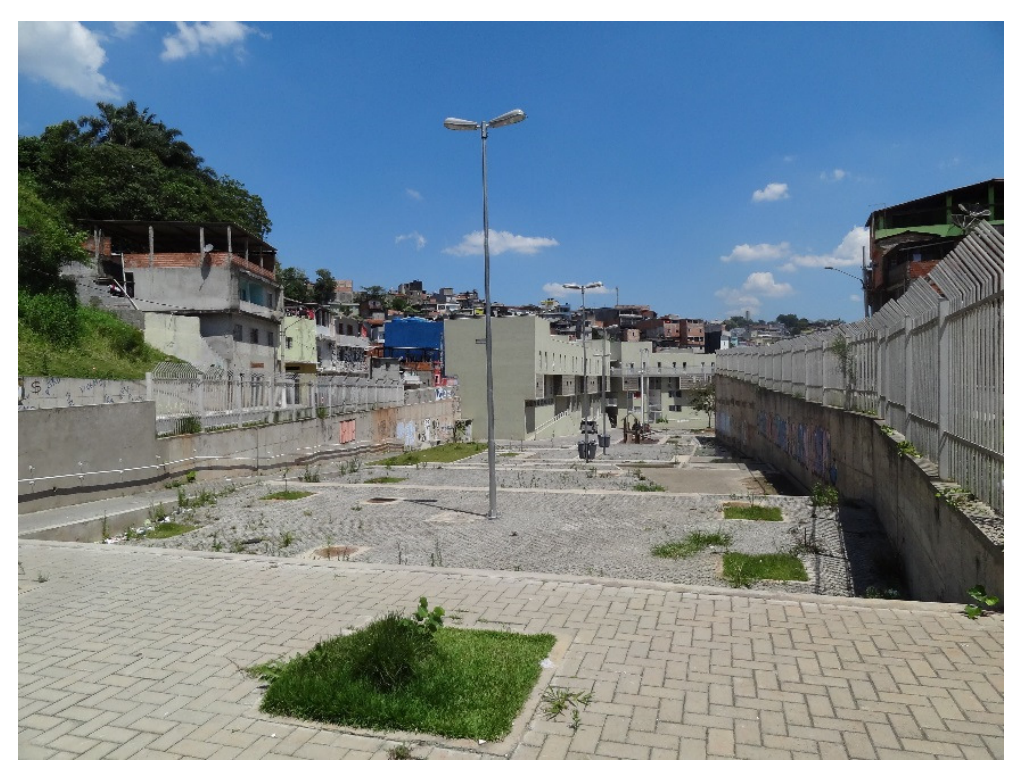

Figura 20 - Após o bloco 1, há altos muros de contenção nas duas laterais do conjunto que acabam definindo limites.

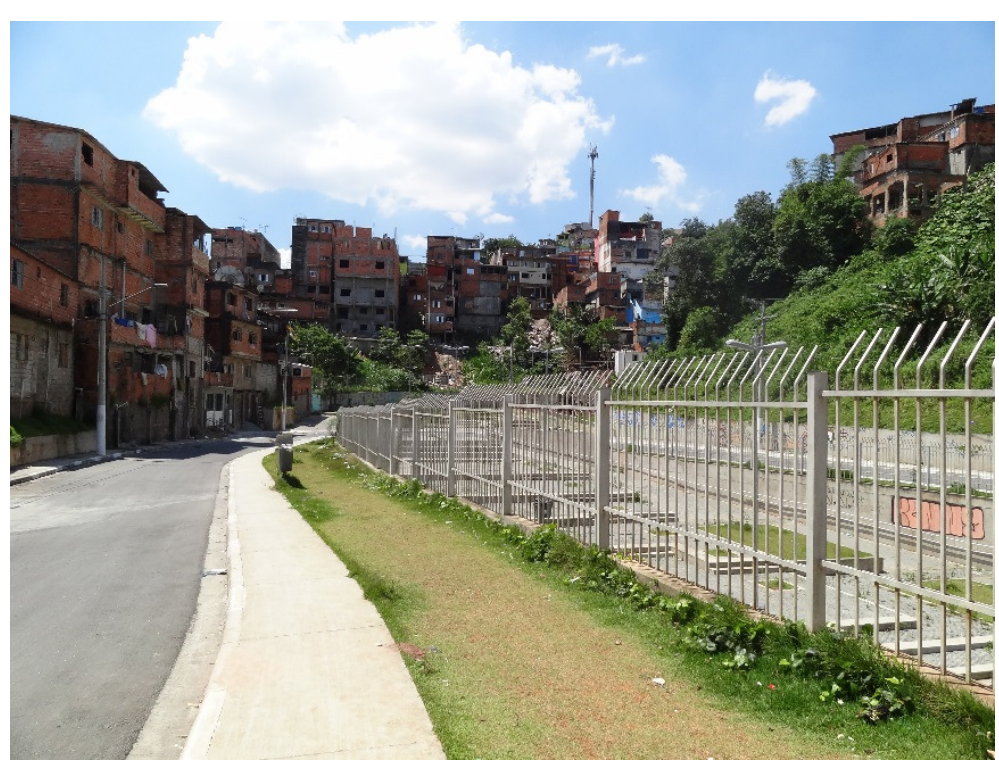

Figura 21 - Vista a partir do "exterior" do conjunto.

Analisando-se essas imagens, podemos questionar se esses limites poderiam também ter intimidado os moradores do entorno a compreenderem que os espaços propostos são de livre acesso para todos. Seria possível pensar em alguma outra maneira de quebrar um pouco essa barreira criada pela contenção? Poderiam existir acessos intermediários? Um gradil mais baixo, mas que garantisse a segurança?

De qualquer forma, é importante ressaltar que os limites propostos variam ao redor de toda a intervenção, proporcionando uma dinâmica de cidade. Também devemos considerar os próprios domicílios mantidos como definição de limites.

Ao analisar a implantação e os cortes, é possível verificar essas constatações com mais detalhe. 


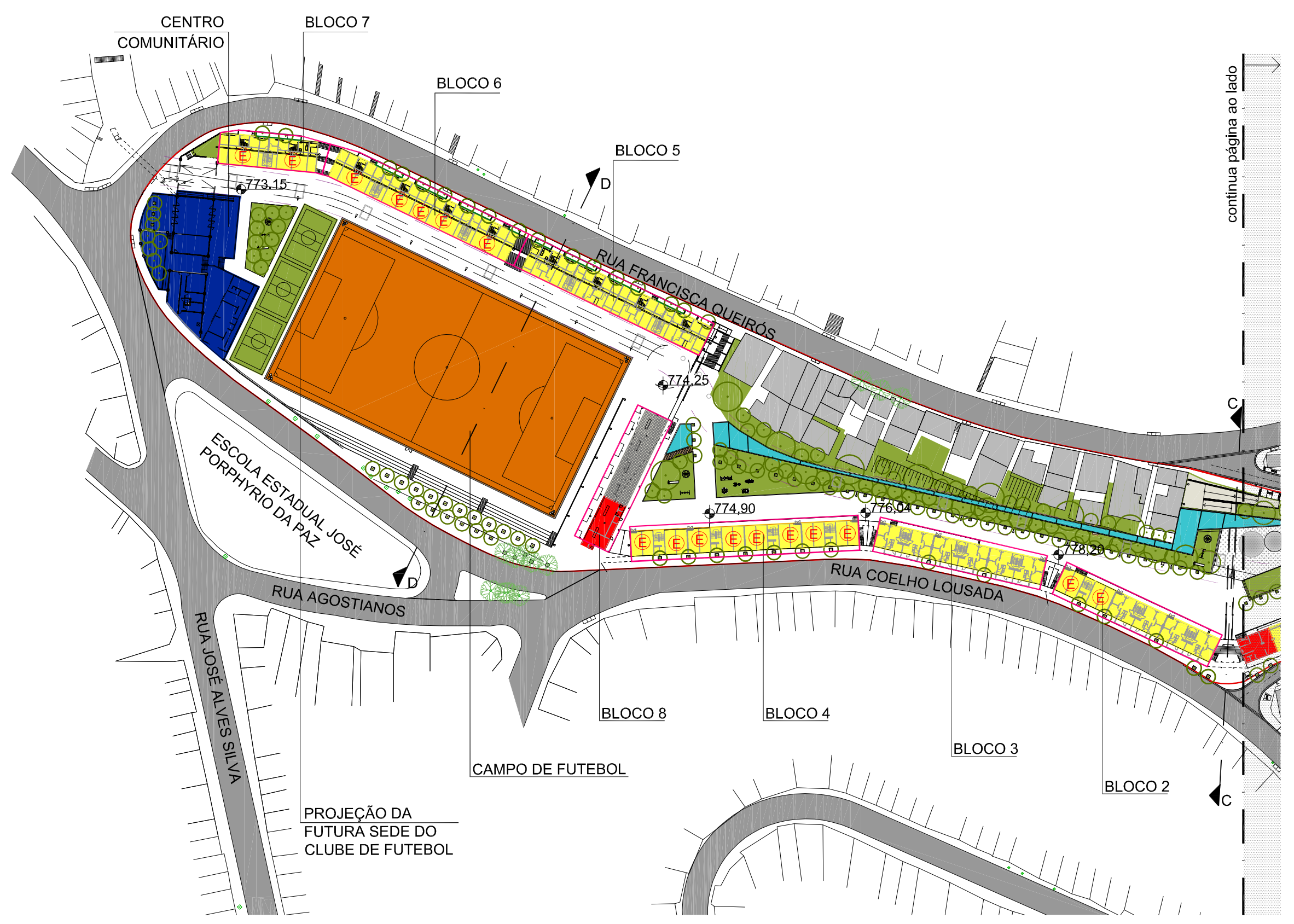




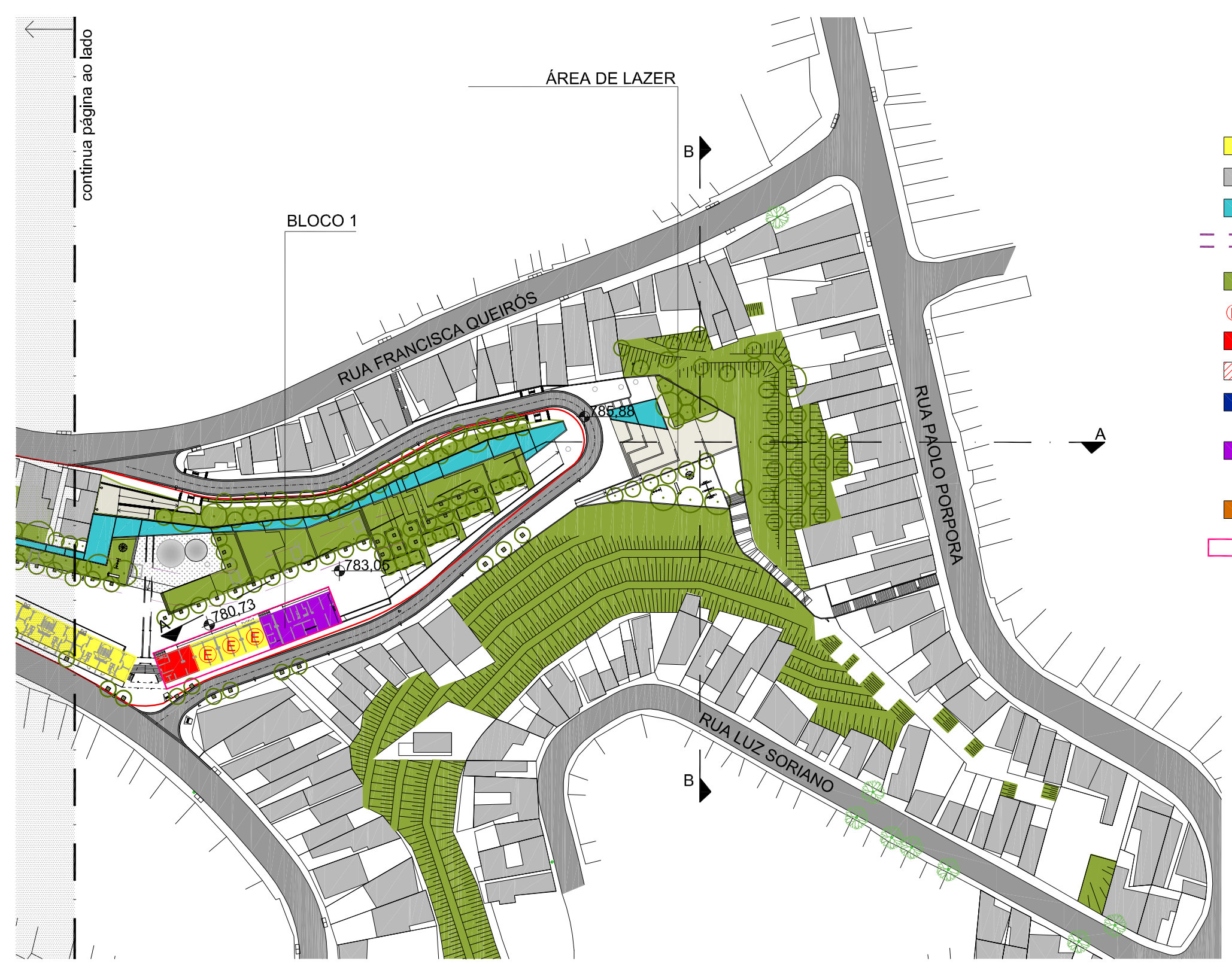

$\square$ Blocos residenciais

$\square$ Domicílios existentes (mantidos) $\square$ Espelho d'água

二 Z Faixa non aedificandi ( $4 \mathrm{~m}$ de cada lado da canalização)

$\square$ Área de vegetação / permeável

(E) Garagens para estacionamento

Espaços comerciais

$\square \triangle$ Áreas comuns

Equipamento de uso público Centro Comunitário

Espaços de uso comunitário do conjunto

\section{Equipamento de uso privado}

Lotes das novas unidades habitacionais 

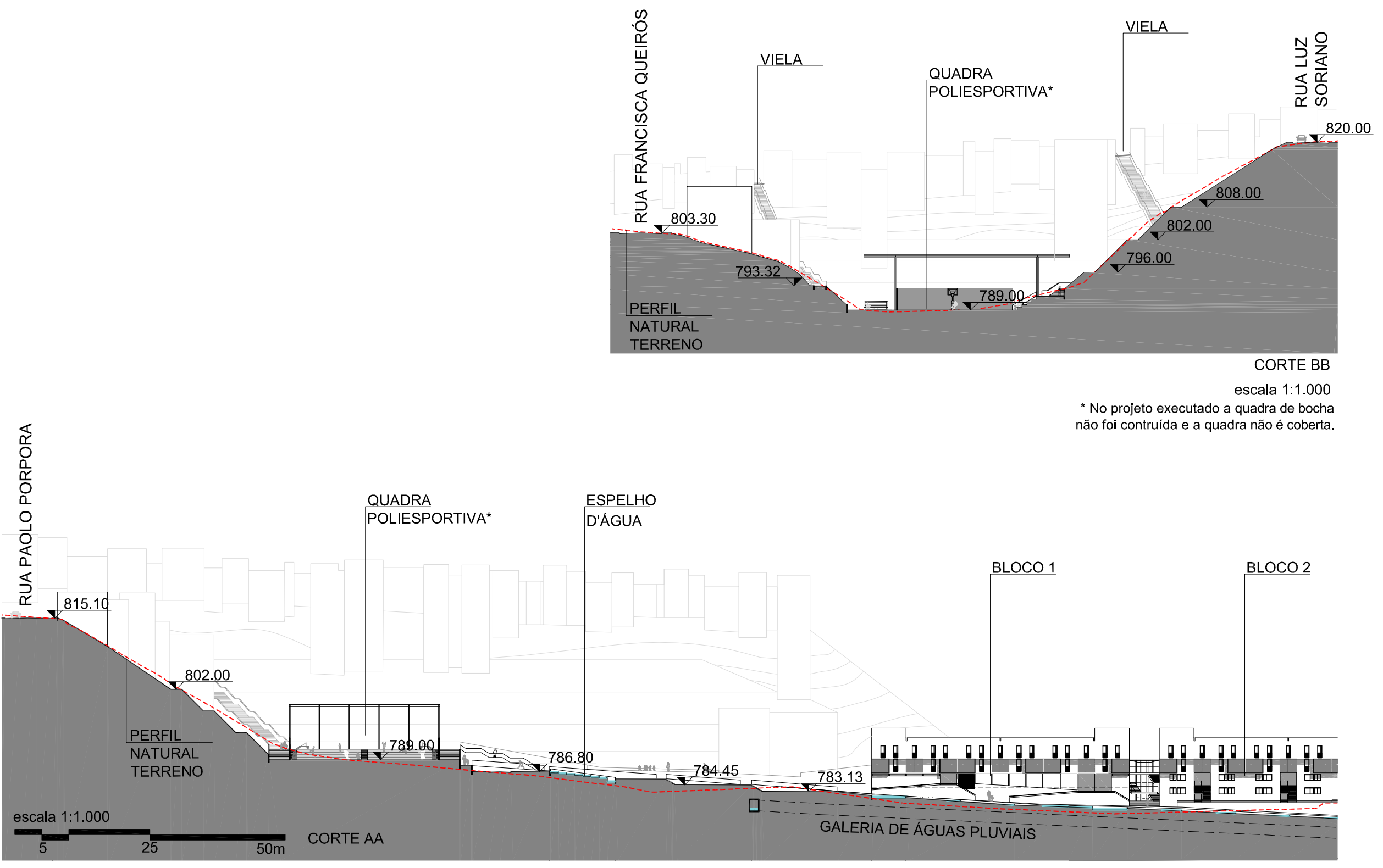


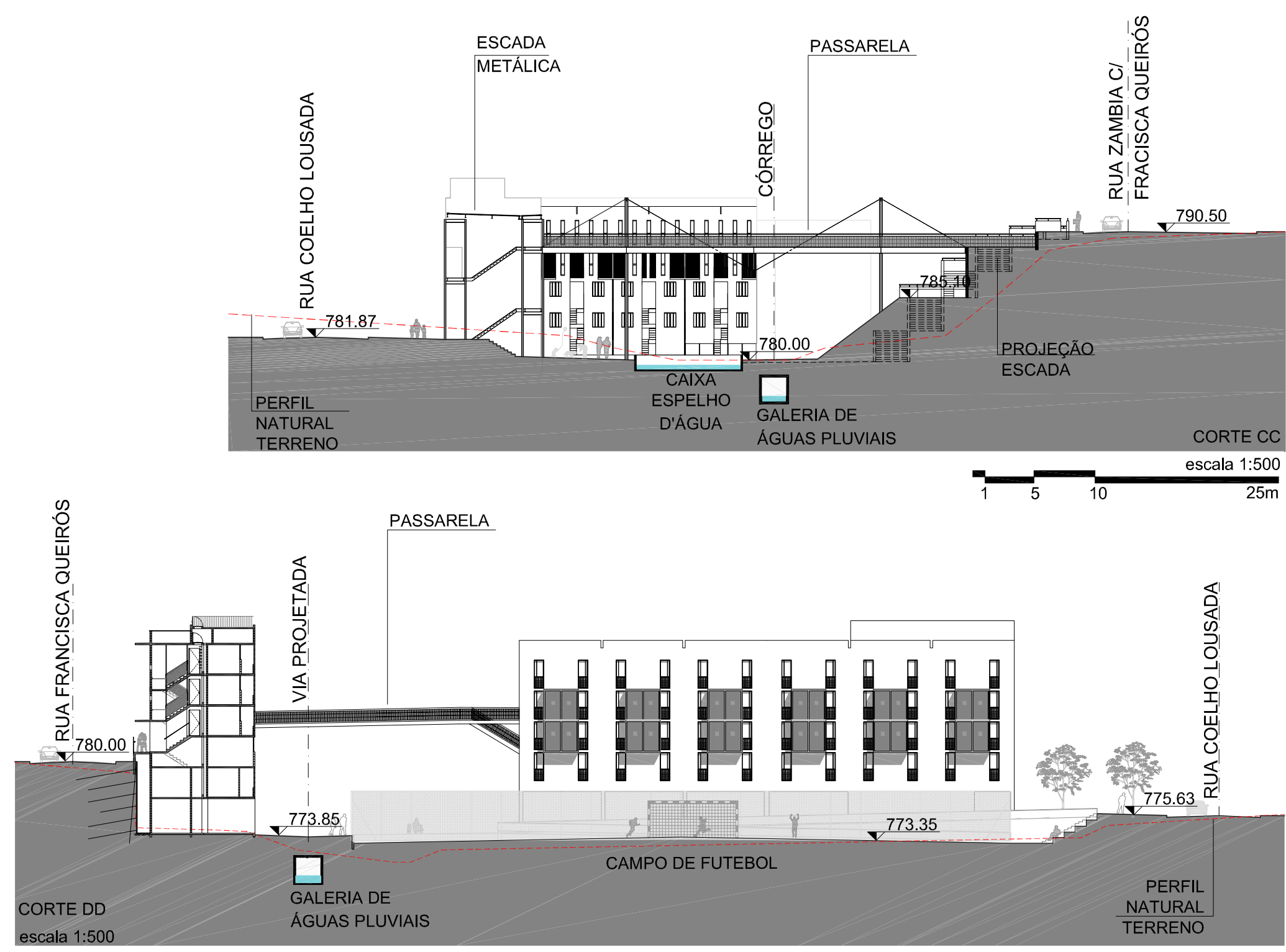

Figura 23 - Cortes implantação 


\section{Adaptação ao terreno}

Como foi possível observar nos cortes, os desníveis do terreno são bastante acentuados e o projeto foi implantado nas cotas mais baixas. Contudo, utilizando-se da altura dos edifícios, o arquiteto encontrou maneiras de vencer esses desníveis e estabelecer conexões através de acessos em diferentes pavimentos, como pôde ser observado nos cortes C e D (Figura 23). A implantação de passarelas e escadas também foi uma estratégia para adaptar a implantação ao terreno.

\section{Diálogo volumétrico}

Ao analisar o Conjunto Jardim Edite, verificou-se a importância de estabelecer relação com o entorno ao implantar um conjunto sem que este seja visto como um "elemento estranho", fora do contexto. No caso do projeto estudado no capítulo anterior, verticalizar foi uma estratégia válida para estabelecer essa relação.

Quanto ao residencial Parque Novo Santo Amaro V, já verificamos, na análise dos valores de proximidade, que o entorno onde o projeto está inserido é caraterizado por pequenos lotes e casas sobrepostas, uma escala de ocupação bastante densa e pouco verticalizada.

\begin{tabular}{lr} 
Conjunto Parque Novo Santo Amaro V & 225,08 habitantes /ha \\
\hline Distrito Jardim Angela ${ }^{9}$ & 78,99 habitantes/ha \\
\hline Subprefeitura M' Boi Mirim ${ }^{10}$ & 90,71 habitantes/ha
\end{tabular}

Tabela 1- Densidade do Conjunto com relação ao distrito e subprefeitura.

9 Fonte: Dados Demográficos dos Distritos pertencentes às Subprefeituras, site da prefeitura de São Paulo, disponível em: http://www.prefeitura.sp.gov.br/cidade/secretarias/subprefeituras/subprefeituras/dados demograficos/. Acesso em dezembro de 2013.

10 Ibid. 3. 
Apenas para efeito de comparação, a densidade do conjunto é quase três vezes maior que a do distrito Jardim Ângela. Para calcular essa densidade, somou-se a quantidade de domicílios mantidos, ao número de UHs propostas e, mesmo considerando os domicílios existentes, verificamos que a densidade do conjunto é muito maior que a do entorno.

Entretanto, mesmo tratando-se da implantação de um conjunto habitacional, podemos considerar que esse projeto estabelece, sim, diálogo volumétrico com o entorno. Ao observar as imagens (Figura 24; Figura 25) é possível notar o esforço presente no projeto para estabelecer relações. Até mesmo as diferenças de altura dos edifícios parecem uma releitura das casas sobrepostas existentes ao redor.

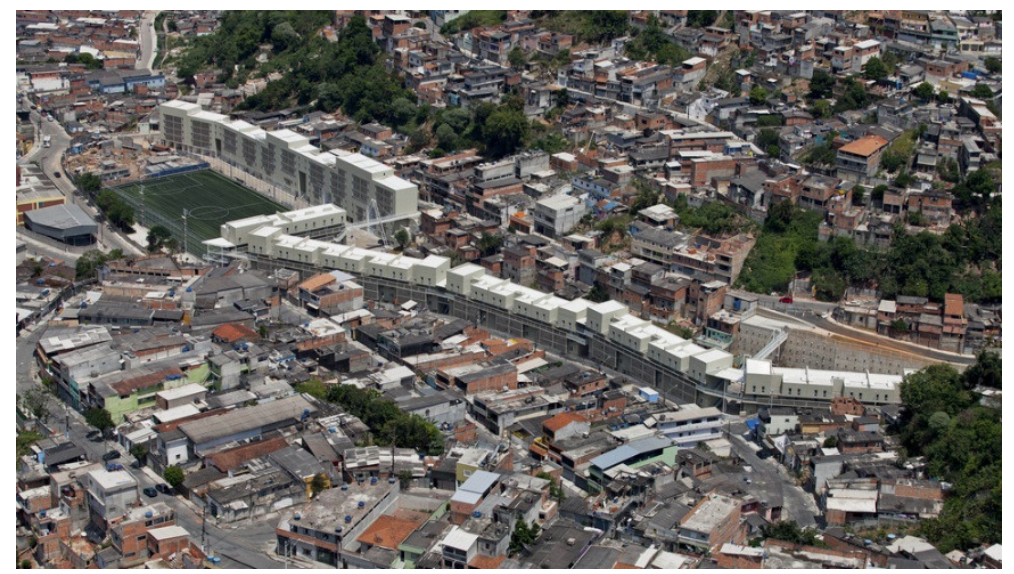

Figura 24 - Implantação do conjunto e relação com o entorno.

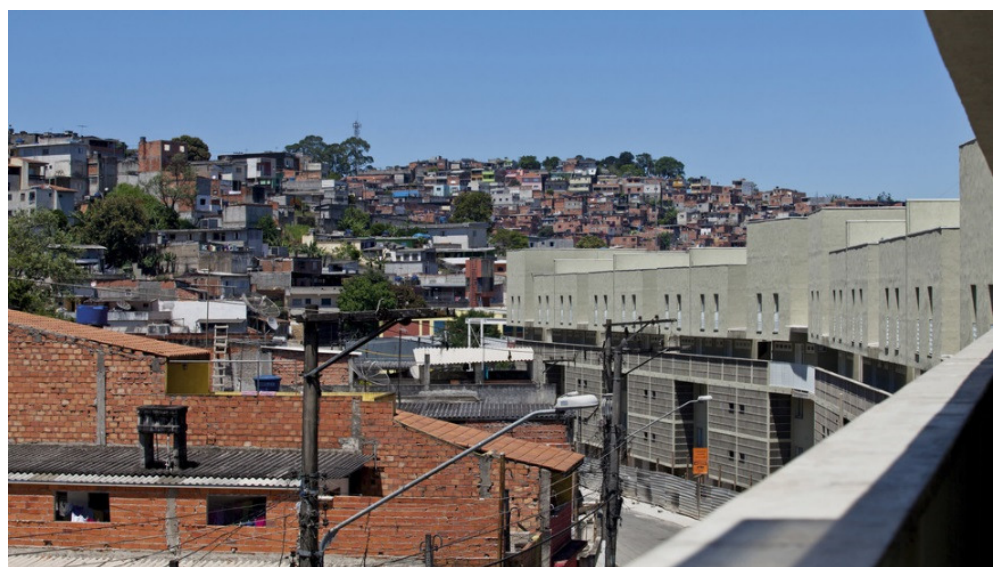

Figura 25 - Relação de altura com as construções do entorno.

\subsubsection{ESPAÇOS EXTERIORES}

A partir da análise dos espaços exteriores, será possível compreender melhor como esses espaços foram concebidos. 


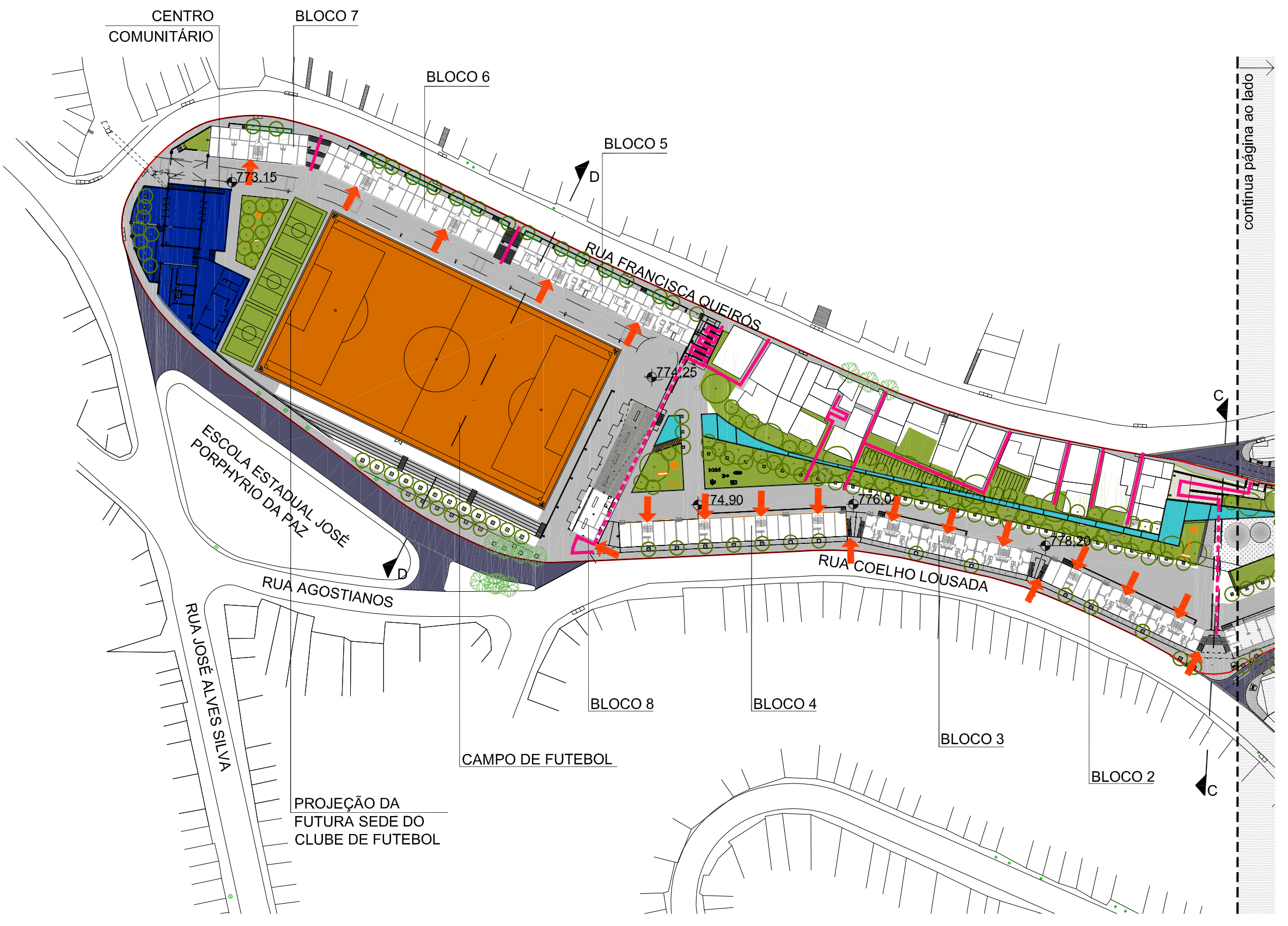




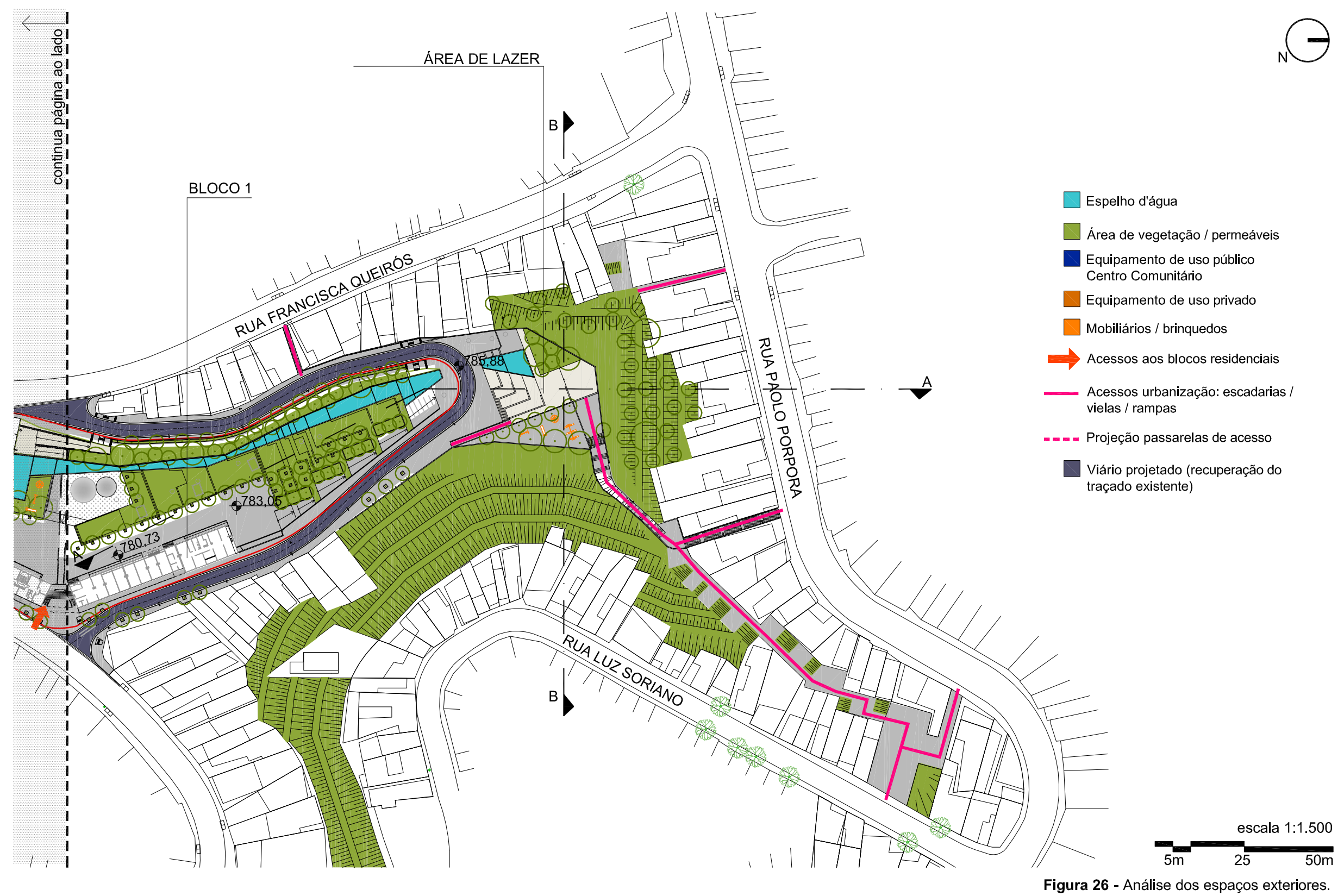


De acordo com o memorial descritivo, a diretriz geral do projeto era criar um eixo central verde, caracterizado como um parque linear estruturador do conjunto das intervenções. Esse parque linear acontece sobre uma galeria de águas pluviais e a água da nascente do curso d'água existente corre pelo espelho d'água proposto ao longo desse eixo.

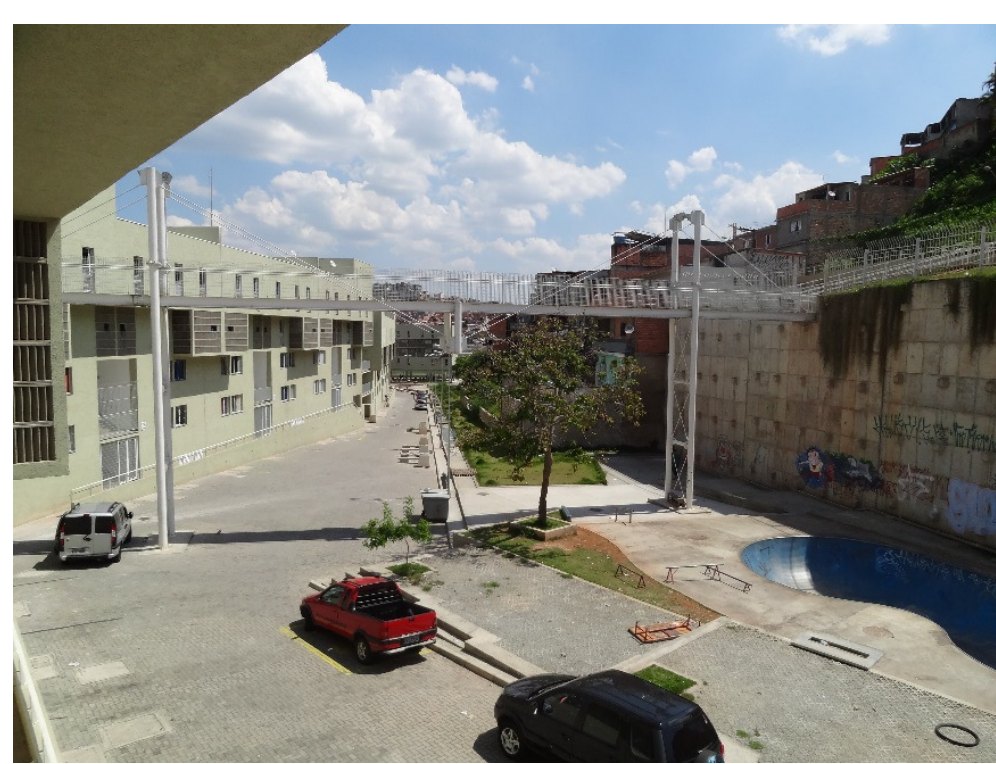

Figura 27 - Espaços exteriores. Pista de skate à direita e eixo verde ao meio.

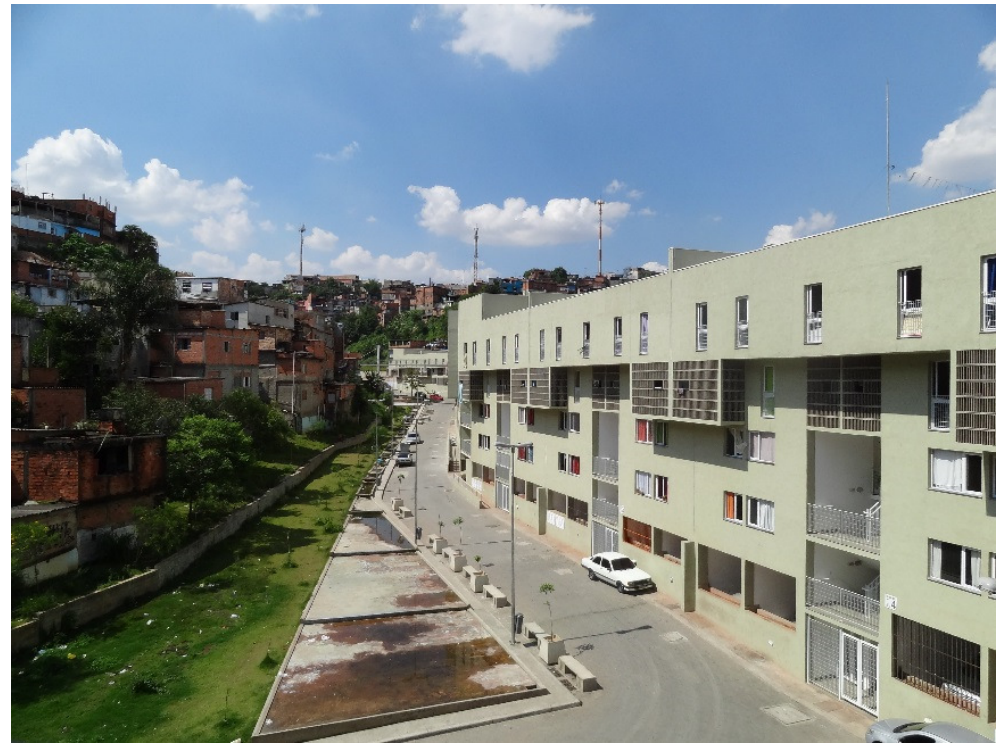

Figura 28 - Eixo verde e espelho d'água. Situação atual.

No memorial, constava, ainda, que a localização dos equipamentos nas extremidades dos eixos foi proposital, para que funcionassem como pontos de atração, estimulando as pessoas a circularem.

O conceito de colocar os equipamentos nas extremidades para estimular a circulação é válido, porém no caso da área de lazer localizada ao norte da intervenção, podemos identificar, como deficiência, a falta de "olhos" sobre 
esse espaço, ou seja, não há edifícios novos por perto e são poucos os domicílios existentes ao redor. Com isso, sabemos que as mães não deixarão seus filhos brincar longe de seus olhos e a apropriação desse espaço pode ser prejudicada. Ao menos no dia da visita, encontrou-se esse espaço bastante degradado, como pode ser observado na Figura 29. Porém, é importante esclarecer que, no projeto inicial, estavam sendo propostas uma quadra poliesportiva coberta e um pista de bocha nesse espaço, entretanto, devido a situação fundiária (trata-se de uma área particular) a prefeitura decidiu implantar apenas a área de lazer.

Por outro lado, foi proposto, na outra extremidade da intervenção, um campo de futebol que, apesar de não ser de uso público, como citado anteriormente, é um espaço livre agradável que pode ser visto a partir das janelas dos edifícios e que estimula a circulação de muitas pessoas (Figura 30).

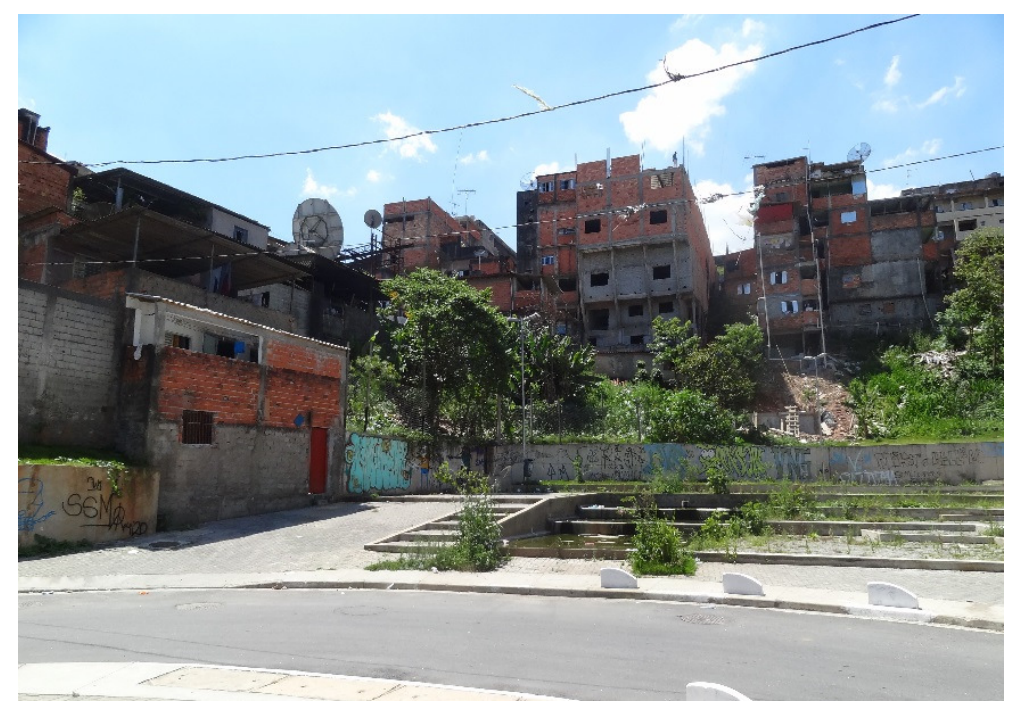

Figura 29 - Espaço onde foi proposta a quadra poliesportiva e de bocha. Situação atual.

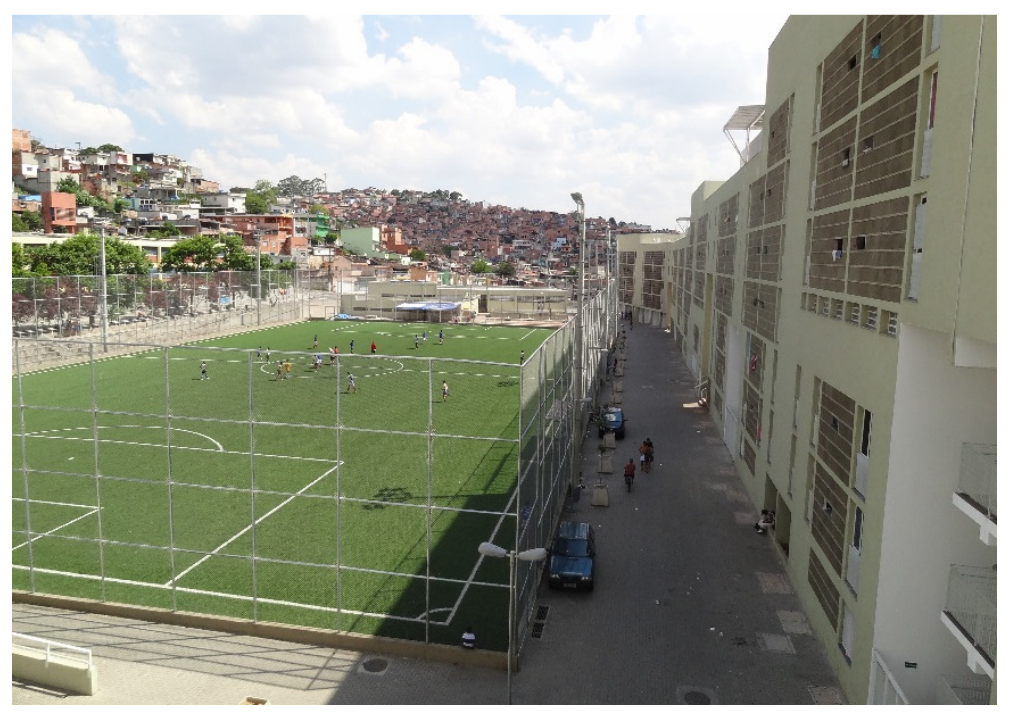

Figura 30 - Campo de futebol - espaço de uso privado. 
Além dos equipamentos, há também espaços de lazer para crianças nas duas extremidades, uma próxima ao bloco 8 e outra próxima ao bloco 1.

No térreo do bloco 8 há um espaço projetado como comércio, que possivelmente se transformará em um CRAS e o restante é uma área livre. Esse espaço foi considerado, portanto, como área comum coberta.

Também é possível observar, no diagrama de análise dos espaços exteriores, os acessos previstos pela urbanização, como escadarias, passagens e vielas através dos domicílios mantidos. Nem todas essas ligações foram executadas, mas é possível compreender o conceito do incentivo à circulação através da proposta apresentada pelo projeto, que oferece mais permeabilidade aos percursos.

Além das passagens para pedestres, a intervenção também considerou uma rua existente reconstruindo-a e incorporando-a ao projeto.

Por último, vale ainda ressaltar a posição dos acessos aos edifícios que ocorrem, tanto a partir do interior da intervenção, como a partir da rua, de acordo com o andar dos apartamentos. Porém o mais importante é que há acessos distribuídos por toda a intervenção, o que reforça a ideia de incentivo à circulação de pessoas.

\subsubsection{RELAÇÃO ENTRE OS EDIFÍCIOS}

Para analisar a relação entre os edifícios, foi necessário selecionar a planta de dois pavimentos diferentes, pois, como veremos, as tipologias são bastante variadas e não existe um pavimentos tipo que represente, por si só, o projeto. Por isso, também é importante analisar esse item com base nos cortes, através dos quais é possível compreender a sobreposição das tipologias. 
Os edifícios, chamados de blocos, estão organizados em três conjuntos e cada um possui um grupo de tipologias que se sobrepõem, conforme tabela abaixo:

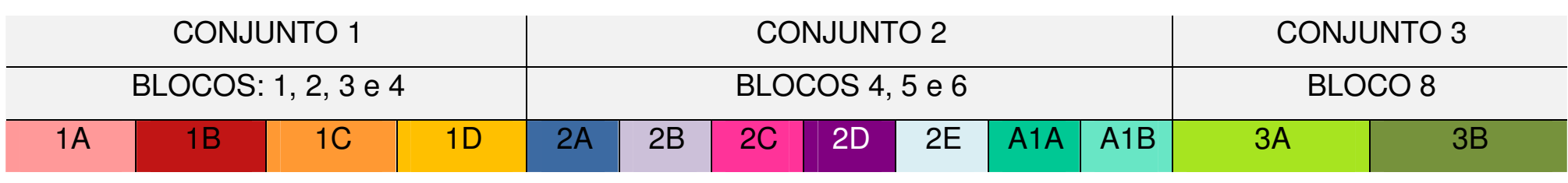

Tabela 2- Conjuntos, blocos e tipologias.

\section{Acessos e circulação}

Como foi visto na análise dos espaços exteriores, os blocos possuem vários acessos distribuídos ao longo dos conjuntos. Como não se trata de um projeto cercado, não há uma entrada ao conjunto e sim, acessos independentes ao longo de cada bloco.

No caso do Conjunto 2, há acessos pelo interior da intervenção às unidades dos primeiros pavimentos e, a partir da Rua Francisca Queirós, para os andares superiores, como pode ser observado nos cortes dos blocos 5, 6 e 7 (Figura 31).

No caso do Conjunto 1, os apartamentos dos dois primeiros andares são acessados por escadas que atendem a duas unidades por andar e que estão voltadas para o interior da intervenção. A partir do terceiro pavimento, as unidades se transformam em duplex e são acessadas através de passarelas, na terceira planta, que estão ligadas e articuladas por torres de escadas metálicas em formato triangular.

O bloco 8 é acessado por duas torres de escada, uma localizada na Rua Coelho Lousada e outra na Rua Francisca Queirós, que estão conectadas pela passarela existente ao longo do edifício. Duas passarelas sobrepostas no segundo e terceiro pavimento do bloco 8 dão acesso à todas as unidades desse edifício. 


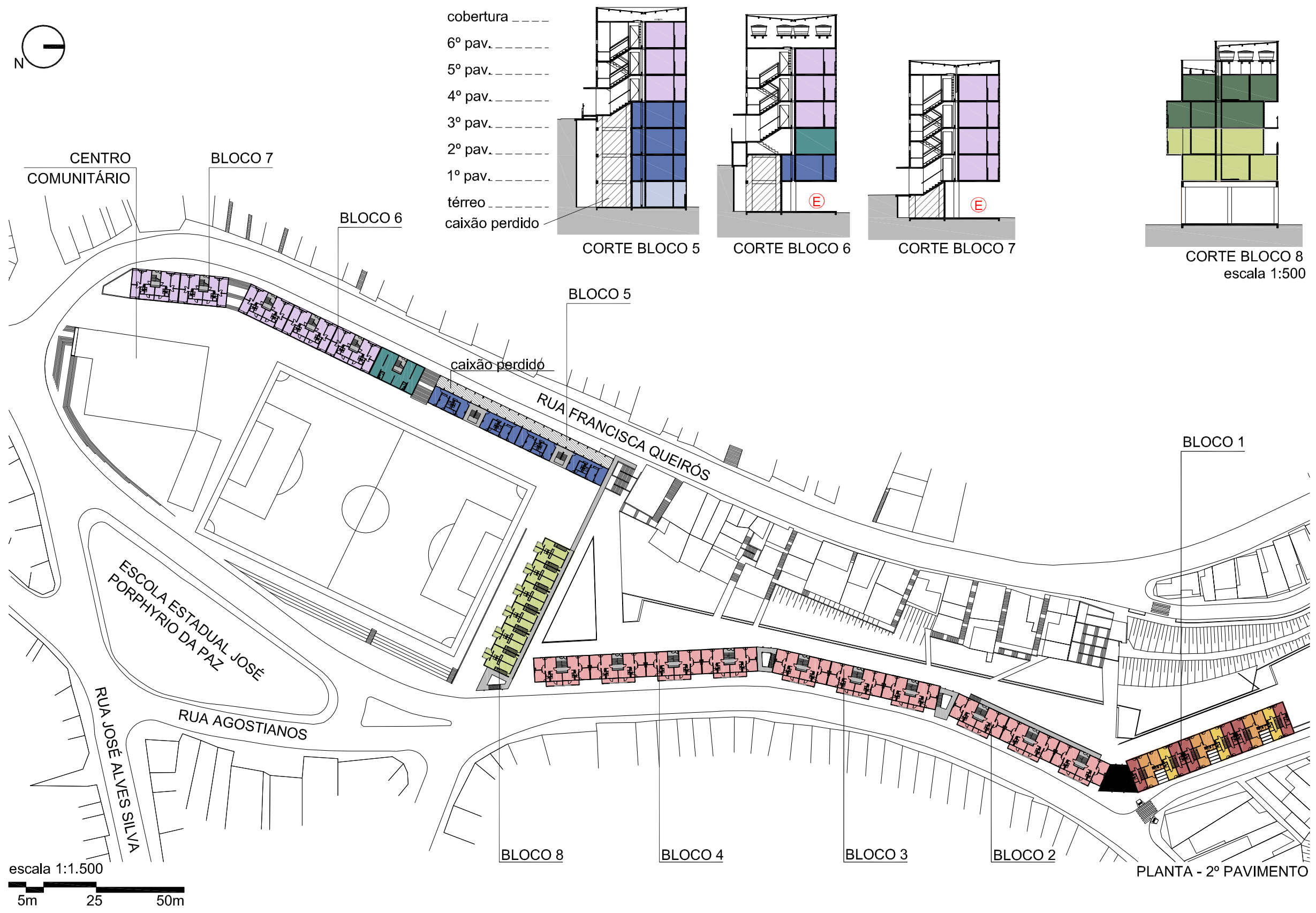




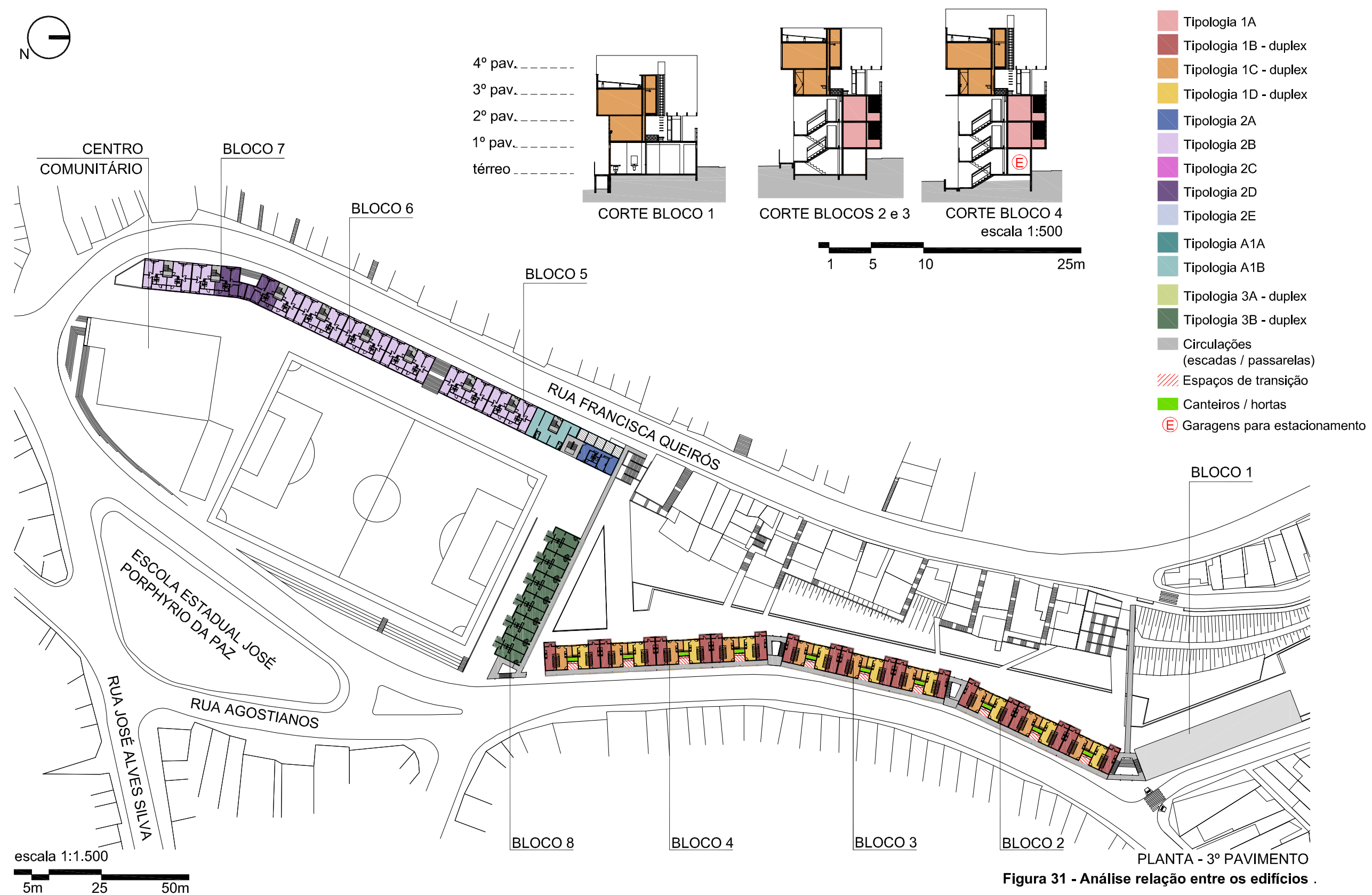


$\mathrm{Na}$ escala da intervenção, notamos duas passarelas que comunicam as ruas Francisca Queirós e Coelho Lousada (Figura 32; Figura 33). Essas passarelas representam o conceito de circulação e permeabilidade contido no projeto.

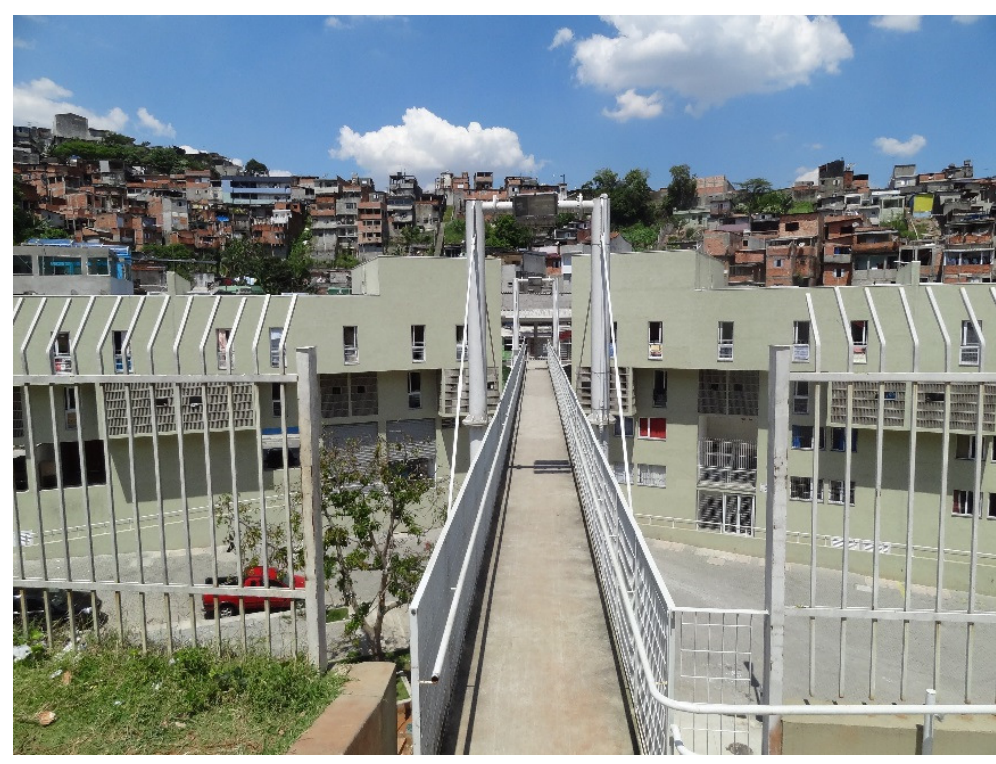

Figura 32 - Passarela entre os blocos 1 e 2

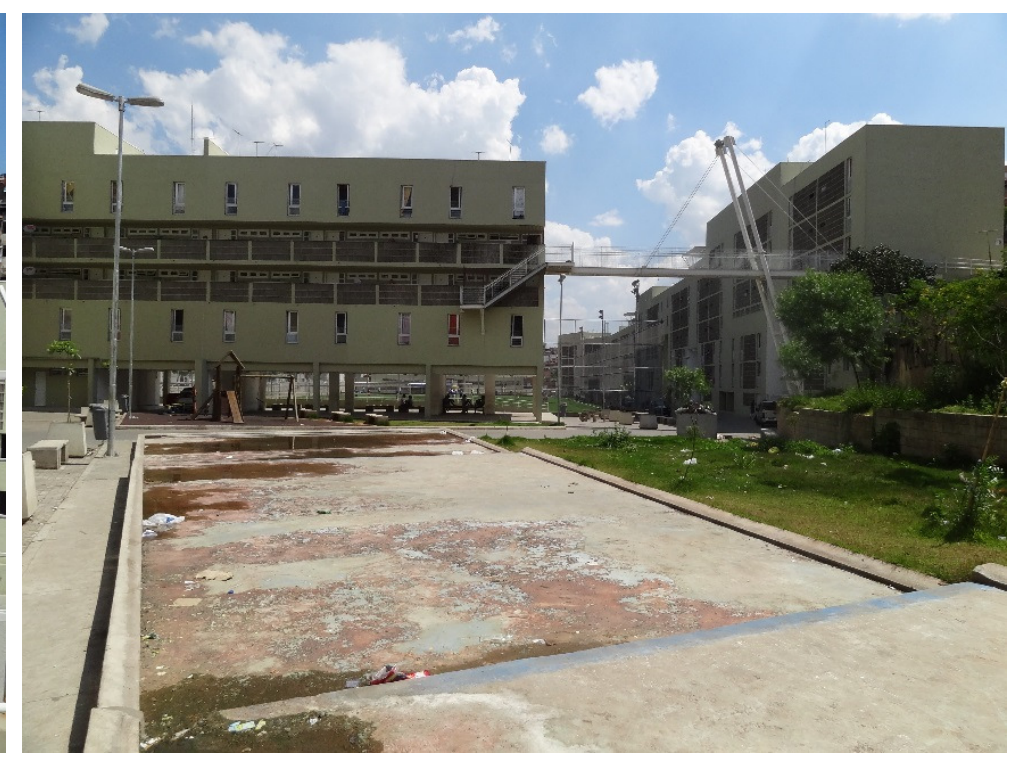

Figura 33 - Passarela ao longo do bloco 8. Observar que existe uma escada saliente que comunica os dois níveis de passarelas existentes nesse bloco.

As duas passarelas transversais comunicam-se através da circulação existente ao longo dos blocos 2 , 3 e 4 e foram projetadas para serem públicas, entretanto, por questões de privacidade, os moradores fecharam com portões a circulação entre os blocos, como pode ser observado na Figura 34.

Na Figura 35 vemos a escada que conecta a Rua Francisca Queirós ao nível mais baixo da intervenção - o térreo dos edifícios. Nessa figura também é possível identificar o início da passarela de acesso ao bloco 8. Portanto, os moradores desse bloco, para acessarem seus apartamentos, devem subir por essa escada e caminhar pela passarela até o edifício ou pela escada na outra extremidade do bloco, próximo da Rua Coelho Lousada. 


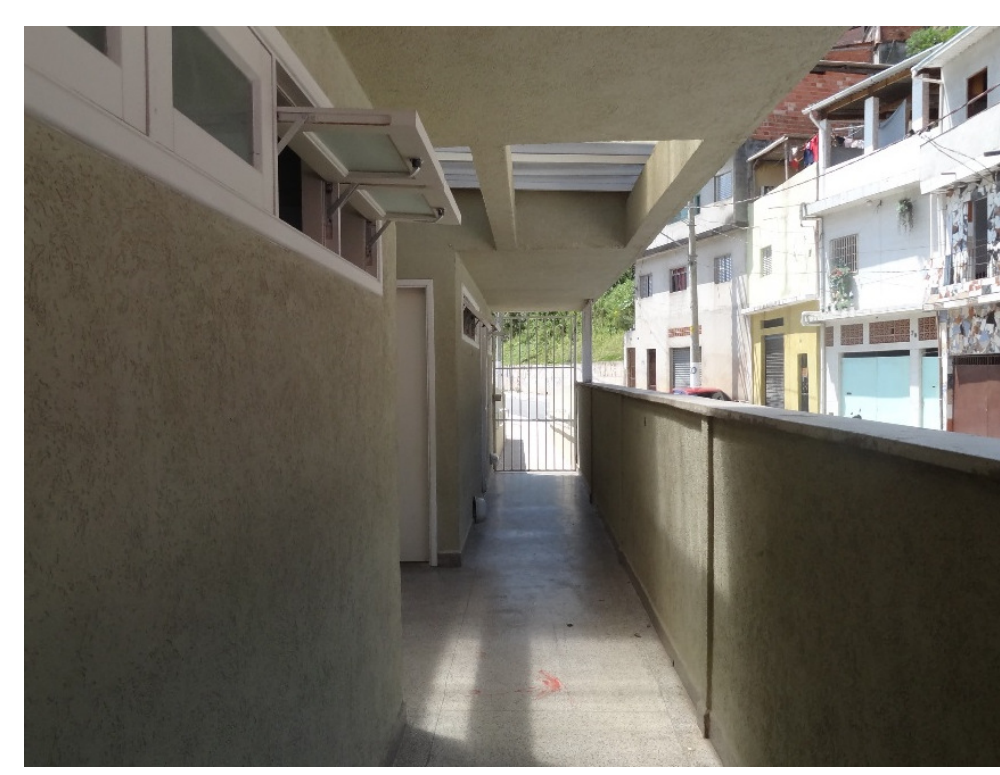

Figura 34 - Ao fundo, portão colocado pelos moradores que garante maior privacidade e segurança.

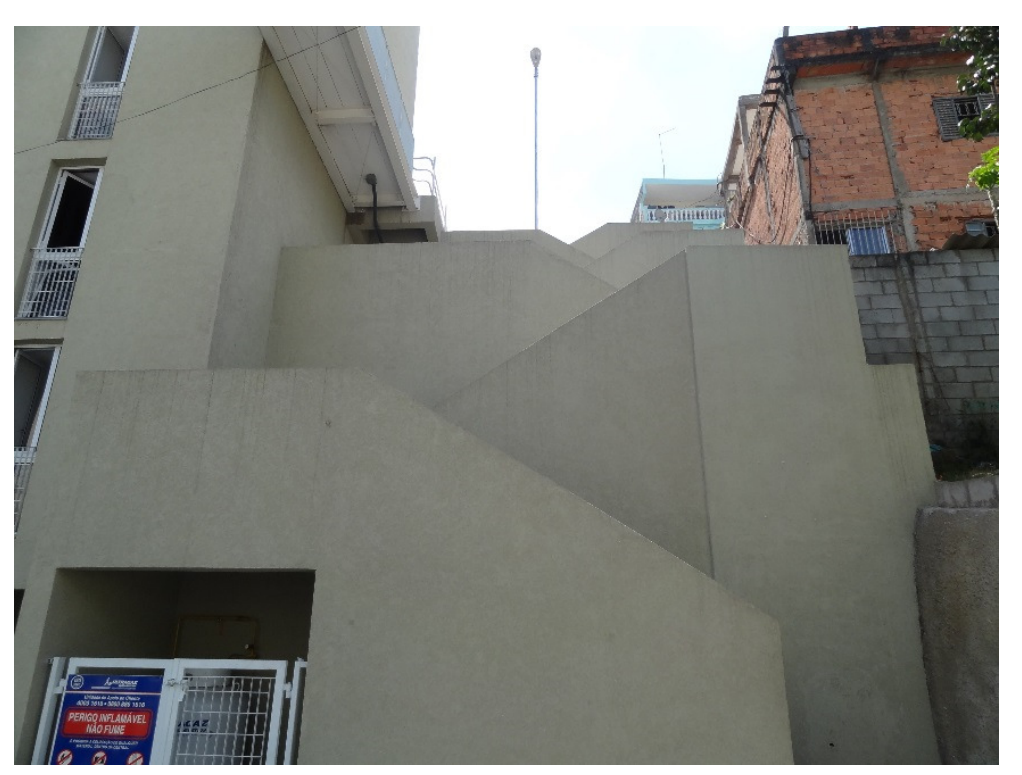

Figura 35 - Escada Rua Francisca de Queirós e acesso à passarela metálica.

\section{Variedade tipológica}

Como pôde ser observado na análise da relação entre os edifícios (Figura 31), esse projeto apresenta uma grande variedade de tipologias que estão organizadas por conjunto. A variação ocorre também em altura, proporcionando diferentes formas de circulação e acesso, de acordo com a situação e implantação de cada bloco.

A sobreposição de tipologias pode ser observada nos cortes apresentados e no esquema de tipologias realizado pelo escritório de arquitetura para explicar os módulos tipo que configuram os edifícios (Figura 36).

As tipologias especiais do Conjunto 2 ( $\mathrm{A} 1 \mathrm{~A}$ e A1B) não são unidades habitacionais, mas sim espaços de uso comum inseridos no edifício entre as unidades que, contudo, respeitam a modulação do conjunto. 


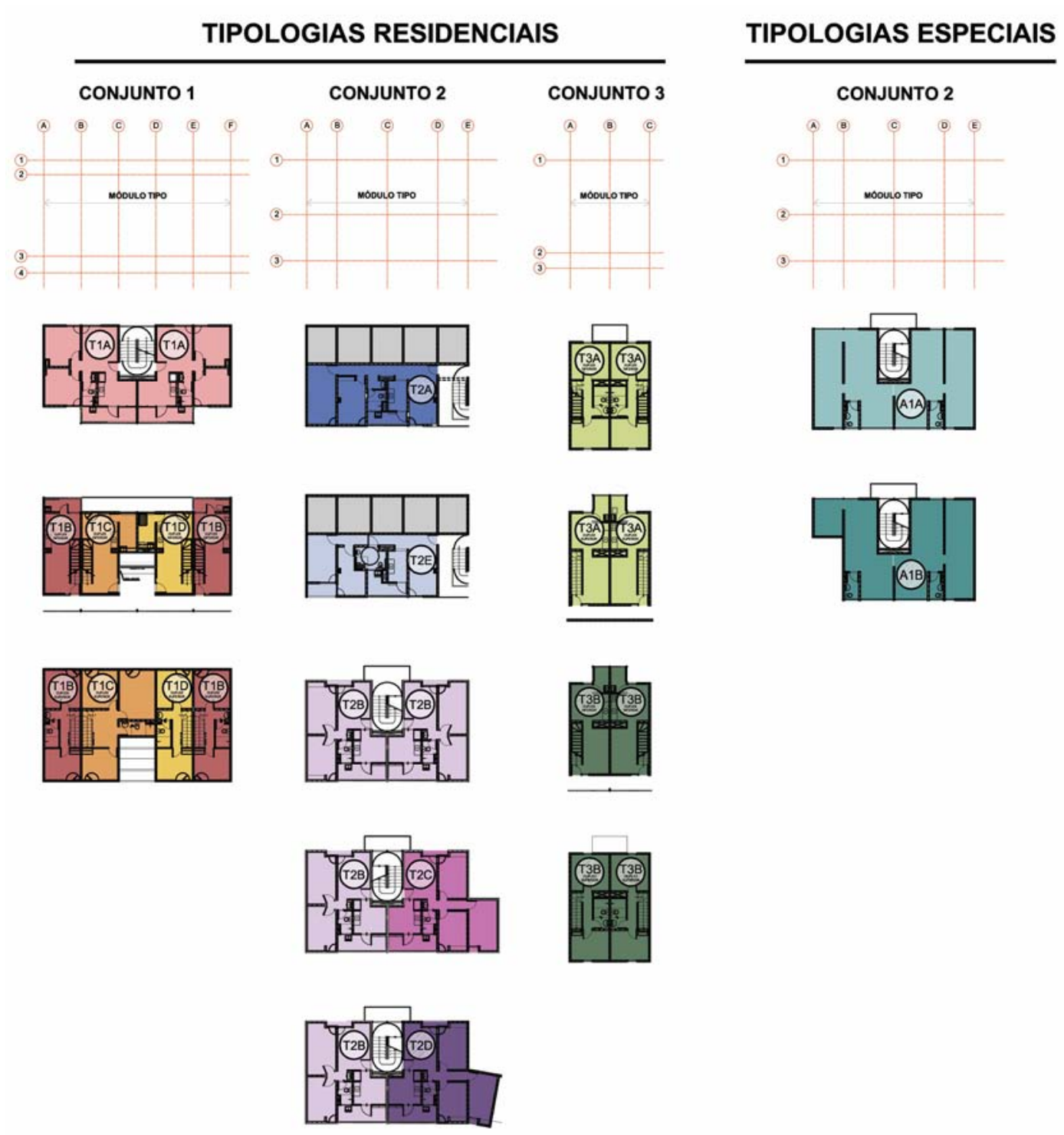

Figura 36 - Módulo tipo das tipologias por conjunto. Sem escala. 


\section{Implantação e}

orientação

Quanto à orientação, com exceção do bloco 8, todos os outros recebem iluminação leste - oeste. 0 bloco 8 é 0 único transversal que possui aberturas para norte e para o sul e, analisando-se a planta das tipologias, vemos que as cozinhas, lavanderias e um dos dormitórios estão voltados para o sul, enquanto a circulação que acessa às unidade e um dos dormitórios têm insolação norte.

A forma linear - como se fossem vagões de trem - como estão implantados os edifícios, garante que os blocos não façam sobra uns sobre os outros, garantindo ventilação e insolação durante todo o período.

\subsubsection{ESCALA EDIFÍCIO}

$\mathrm{Na}$ escala edifício serão analisados um exemplar de cada conjunto. Dessa forma, conheceremos com maior detalhe os blocos 2 (Conjunto 1); 6 (Conjunto 2) e 8 (Conjunto 3).

\subsubsection{BLOCO 2}

O bloco 2 foi selecionado como exemplar do Conjunto 1, pois apresenta todas as tipologias contidas no módulo 1 e permitirá, portanto, compreendermos os acessos propostos e a sobreposição dos quatro tipos que aparecem nesse edifício. 


\section{BLOCO 2 (conjunto 1)}

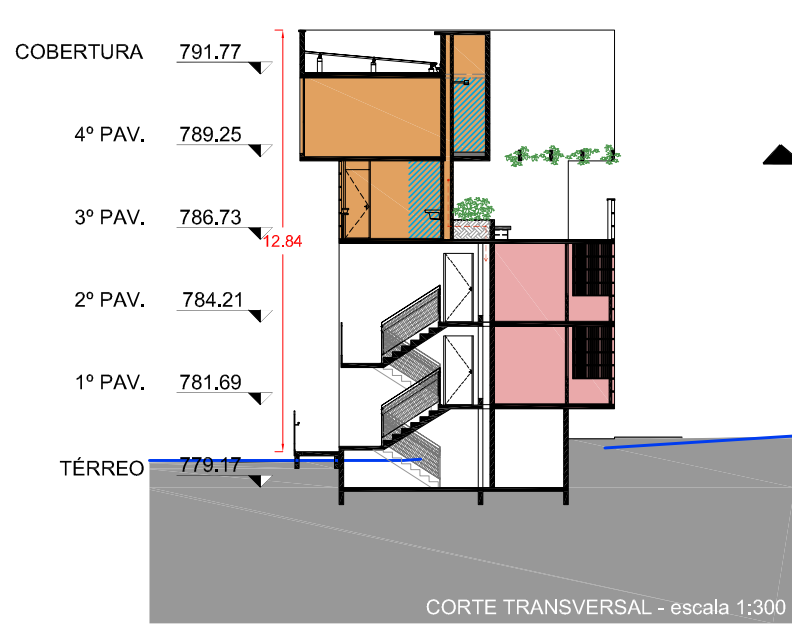

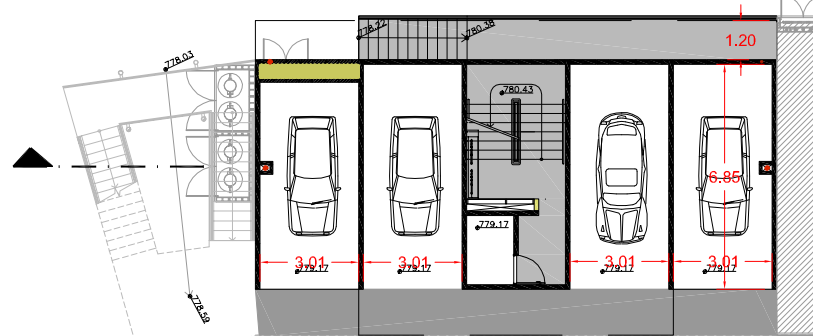

PLANTA TÉRREO (779.17) - escala 1:300

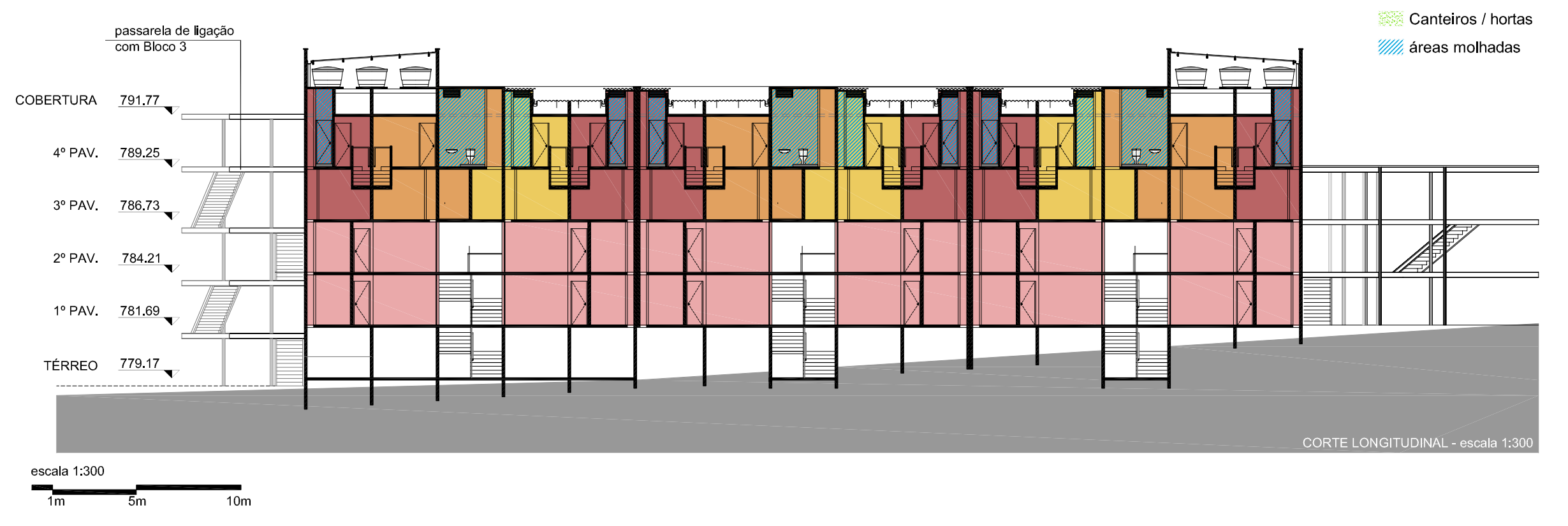




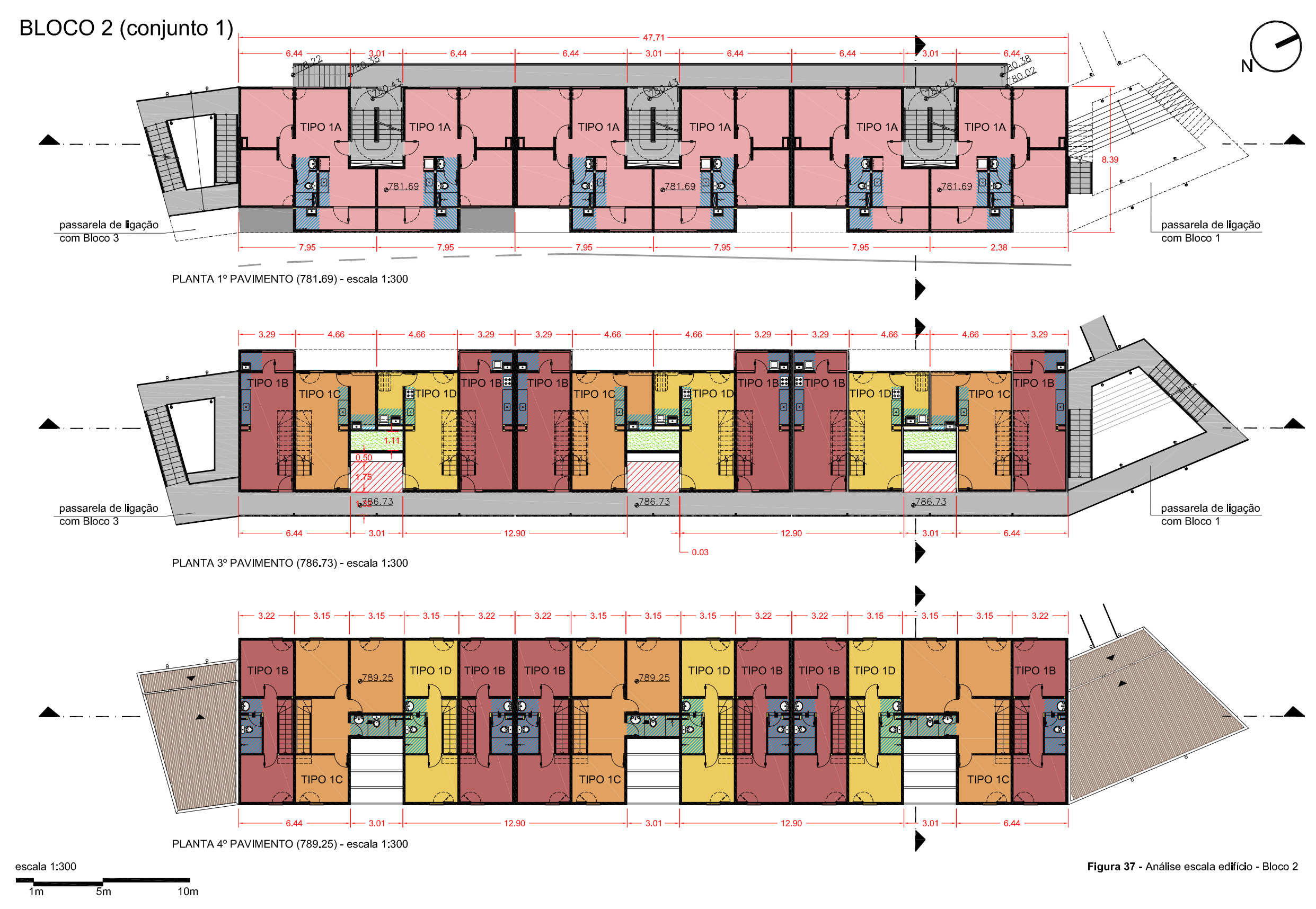




\section{Acessos e circulação}

Conforme pôde ser observado no corte longitudinal, o bloco 2 possui o térreo variável devido à adaptação ao terreno. Com isso, uma parte do térreo está "enterrada" e o restante, já no nível da rua, é dividido em garagens com acessos individuais pela Rua Coelho Lousada.

O primeiro e segundo pavimentos são acessados a partir de escadas voltadas para o interior da intervenção. $\mathrm{Na}$ planta do $1^{\circ}$ pavimento podemos observar que existe uma circulação externa que acessa essas escadas. Isso ocorre devido à inclinação do terreno.

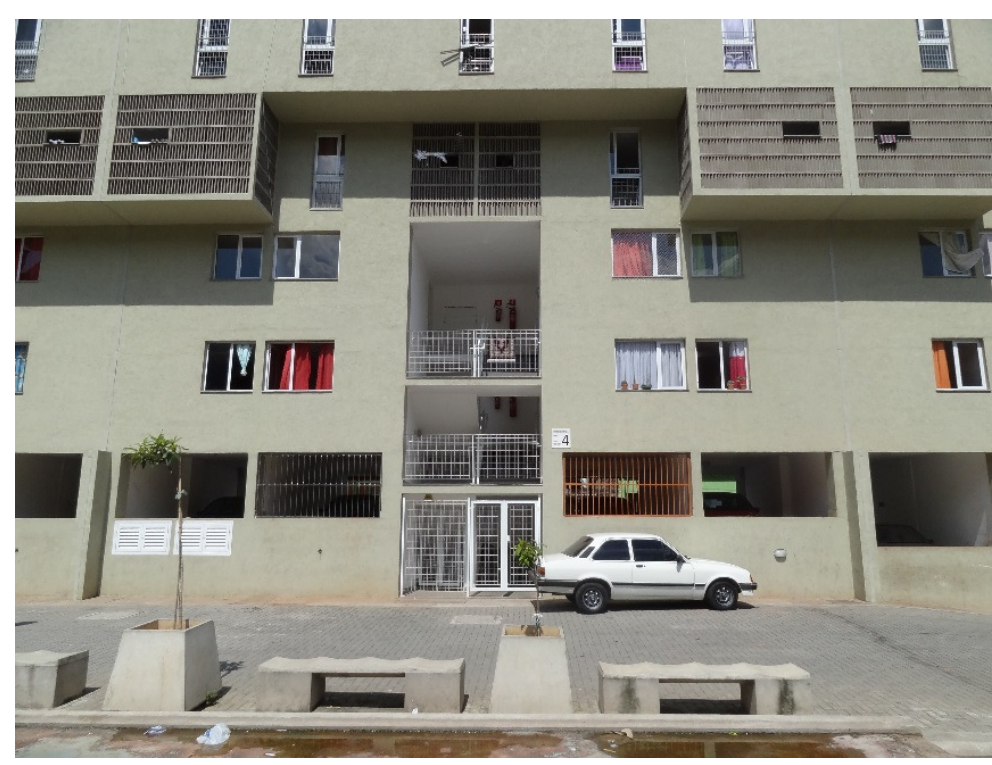

Figura 38 - Escada que acessa às unidades do $1^{\circ}$ e $2^{\circ}$ andar (Tipo 1A) e parte de trás das garagens que têm entradas para a Rua Coelho Lousada.

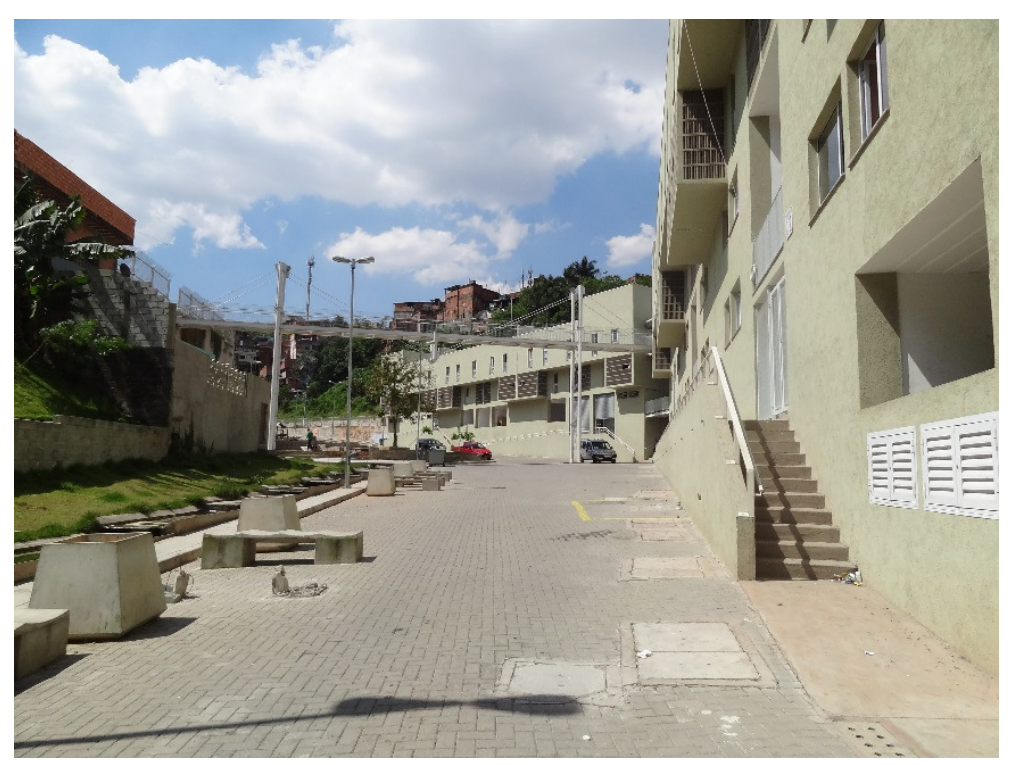

Figura 39 - Circulação externa que adapta o acesso às escadas ao desnível do terreno. 
A partir do terceiro pavimento, o acesso às unidades se dá através de uma passarela que percorre e comunica todos os blocos do Conjunto 1. Essa passarela é acessada a partir das escadas metálicas, com formato triangular, localizadas entre os blocos, atuando como elementos de articulação.

Nas imagens abaixo, podemos ver a passarela ao longo do bloco 1 (Figura 40) e a escada metálica entre os blocos 1 e 2 (Figura 41). Nessas imagens, podemos notar também que os espaços no térreo, com portão de alumínio, são os que foram projetados para serem comerciais e hoje abrigam um dos CRAS que serão instalados na intervenção. Na Figura 40, podemos observar ainda as garagens abertas para a Rua Coelho Lousada.

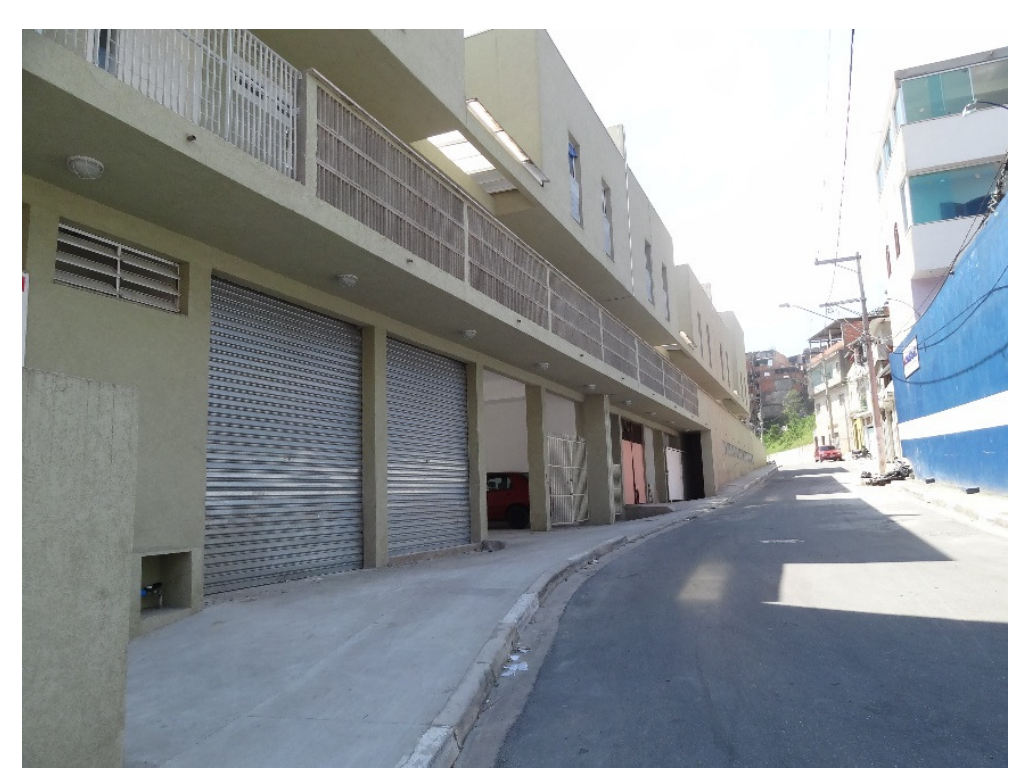

Figura 40 - Rua Coelho Lousada. Passarela de circulação ao longo do bloco 1.

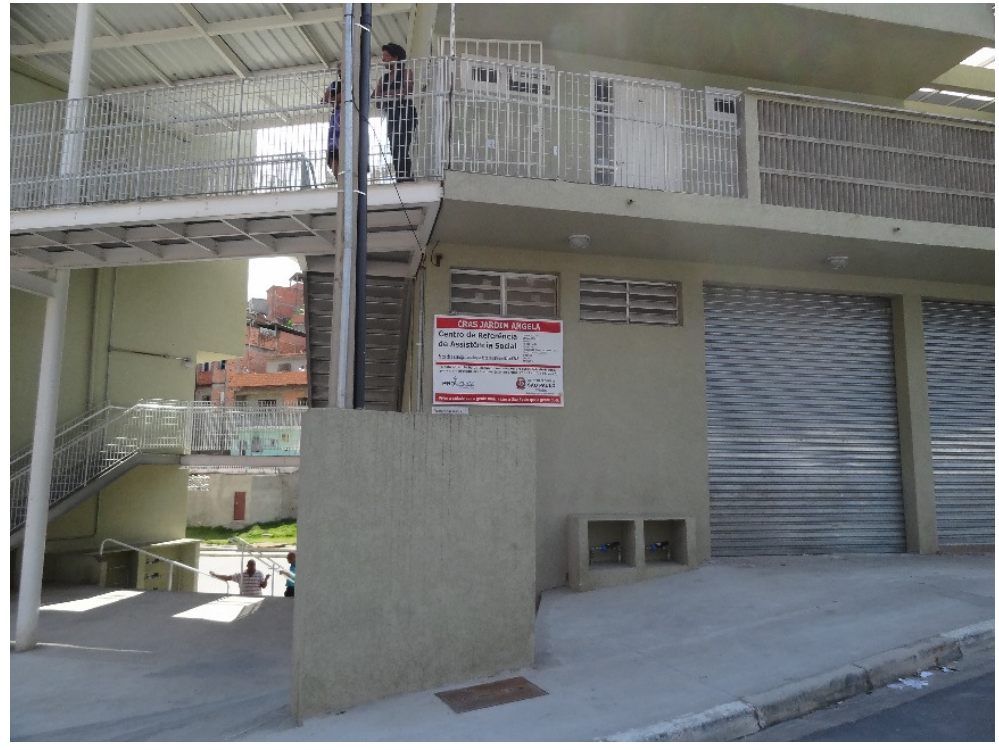

Figura 41 - Escada metálica entre os blocos 1 e 2. Na placa vermelha está escrito: CRAS Jardim Ângela. 
Como foi citado na análise da relação entre os edifícios, as passarelas foram concebidas para terem o acesso livre, ou seja, público - como se fossem ruas elevadas. Porém, por questões de segurança e privacidade, os moradores colocaram portões que bloqueiam a circulação contínua.

$\mathrm{Na}$ planta do terceiro pavimento é possível observar que, em alguns momentos, se formam halls de acesso às unidades que foram classificados como espaços de transição, pois permitem que os moradores se apropriem desses espaços, que funcionam como um filtro de privacidade para a porta de entrada das unidades. Os espaços de transição são enriquecidos com uma horta, que é cuidada pelos moradores, o que aumenta ainda mais a apropriação sobre esses espaços, tornando-os áreas muito agradáveis.

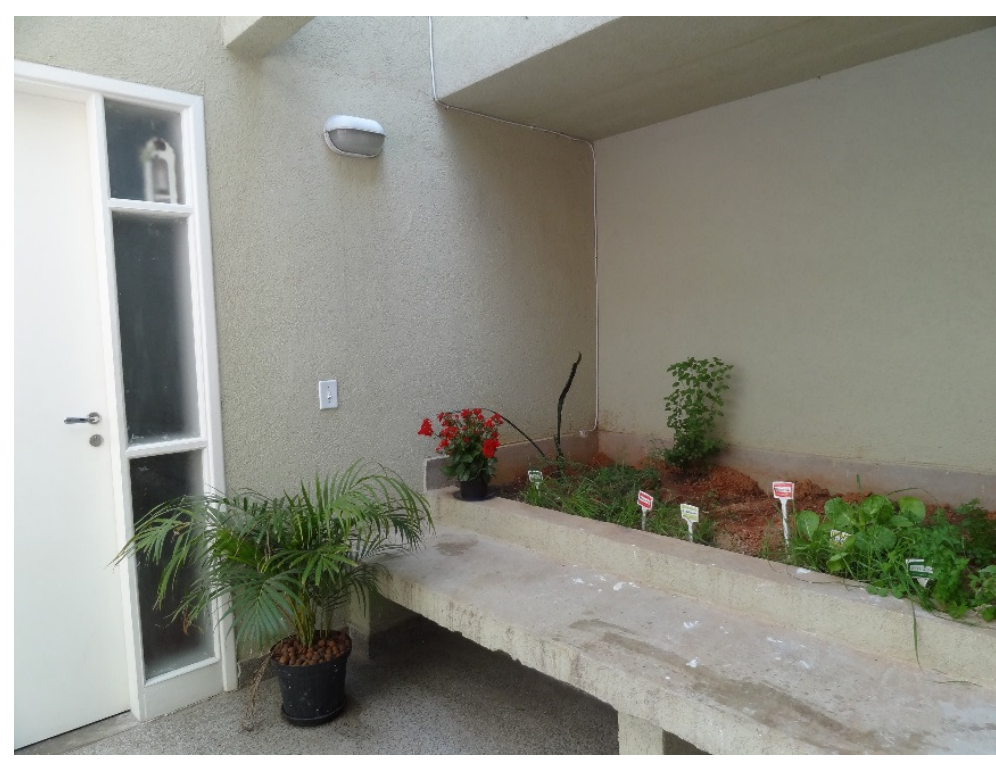

Figura 42 - Horta e espaço de transição.

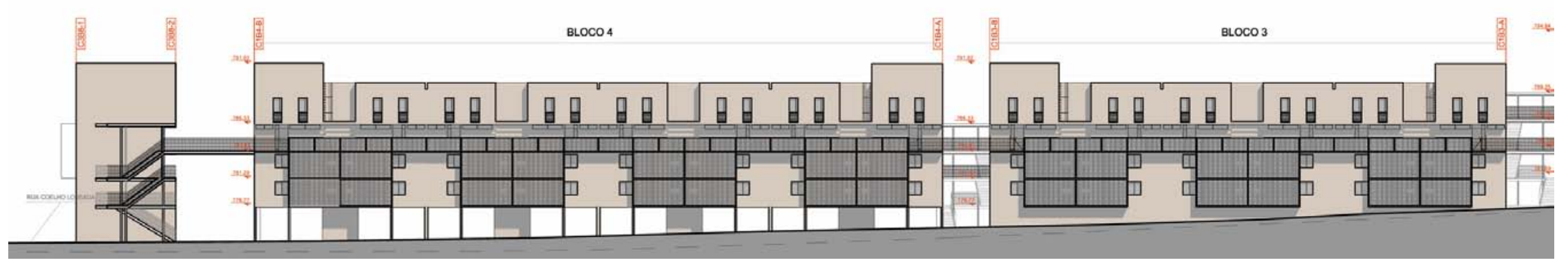




\section{Diversidade tipológica}

Quanto à diversidade de tipologias presente no bloco 2, é possível verificar que existe uma única tipologia de um pavimento $(1 \mathrm{~A})$ e três tipologias duplex (1B; $1 \mathrm{C}$ e 1D). As tipologias duplex localizam-se nos dois últimos pavimentos e se articulam possibilitando, inclusive, que uma delas tenha três dormitórios (1C).

Ao observar o corte transversal (Figura 37), nota-se claramente que a passarela do 3ํㅜ pavimento está sobre as áreas de serviço do tipo 1A. O mesmo também pode ser verificado na Figura 43, que representa todas as fachadas dos blocos do Conjunto 1, onde também pode ser observada a relação com o desnível do terreno e as escadas que conectam os blocos.

O bloco 1 é o único que não possui tipologias do tipo 1A, tendo apenas o pavimentos térreo a as tipologias duplex.

No bloco 2, os duplex estão acima do tipo $1 \mathrm{~A}$ e a sobreposição dessas tipologias criam os cheios e vazios que podem ser observados nas fachadas. No pavimento superior, as tipologias duplex avançam sobre a passarela, proporcionando, com isso, que essa circulação seja coberta (Figura 40).

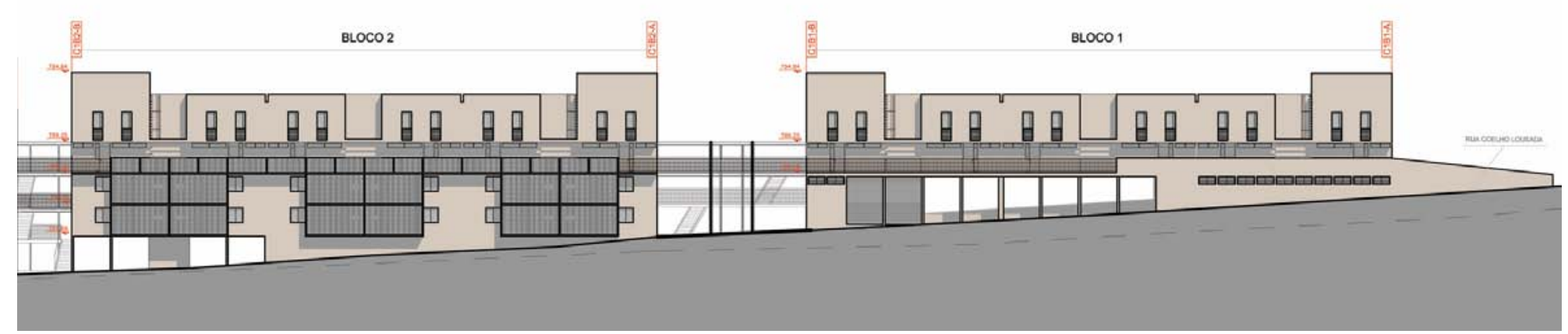

Figura 43 - Fachada Conjunto 1. 


\section{Estrutura e aberturas}

Todos os edifícios foram construídos em alvenaria de bloco estrutural. As escadas e trechos das passarelas, que não estavam inseridos nos edifícios, foram executados em estrutura metálica.

A posição dos eixos estruturais permitiu que as fachadas ficassem livres para as aberturas.

Quanto às áreas molhadas, podemos observar que, sempre que possível, estão espelhadas entre as unidades e, apesar da sobreposição de diferentes tipologias, a posição dos shafts permite uma boa distribuição dessas áreas.

No corte longitudinal é possível verificar que as aberturas dos banheiros localizados no pavimento superior dos duplex, estão acima do nível da cobertura, criando, com isso, os volumes mais altos que vemos na fachada do edifício. Esta solução possibilitou proporcionar luz natural e iluminação aos banheiros inseridos no meio das plantas (Figura 45).

As áreas de serviço têm vedação de elementos vazados. Externamente, vemos os elementos vazados revestirem todo o volume. Porém, a partir do interior, vemos os elementos vazados apenas na parte superior e blocos de vedação fazendo o fechamento da parte inferior (Figura 46). Um dos motivos que justifica essa dupla vedação é a fragilidade dos blocos de elementos vazados que não garantiam a segurança como guarda-corpos. O mesmo ocorre nas passarelas que externamente estão revestidas pelos elementos vazados e os blocos de vedação fazem o revestimento interno.

As aberturas das unidades que estão em contato direto com as passarelas são mais altas, para proporcionar maior privacidade às unidades, como pode ser observado na Figura 47. 
BLOCO 2 (conjunto 1)
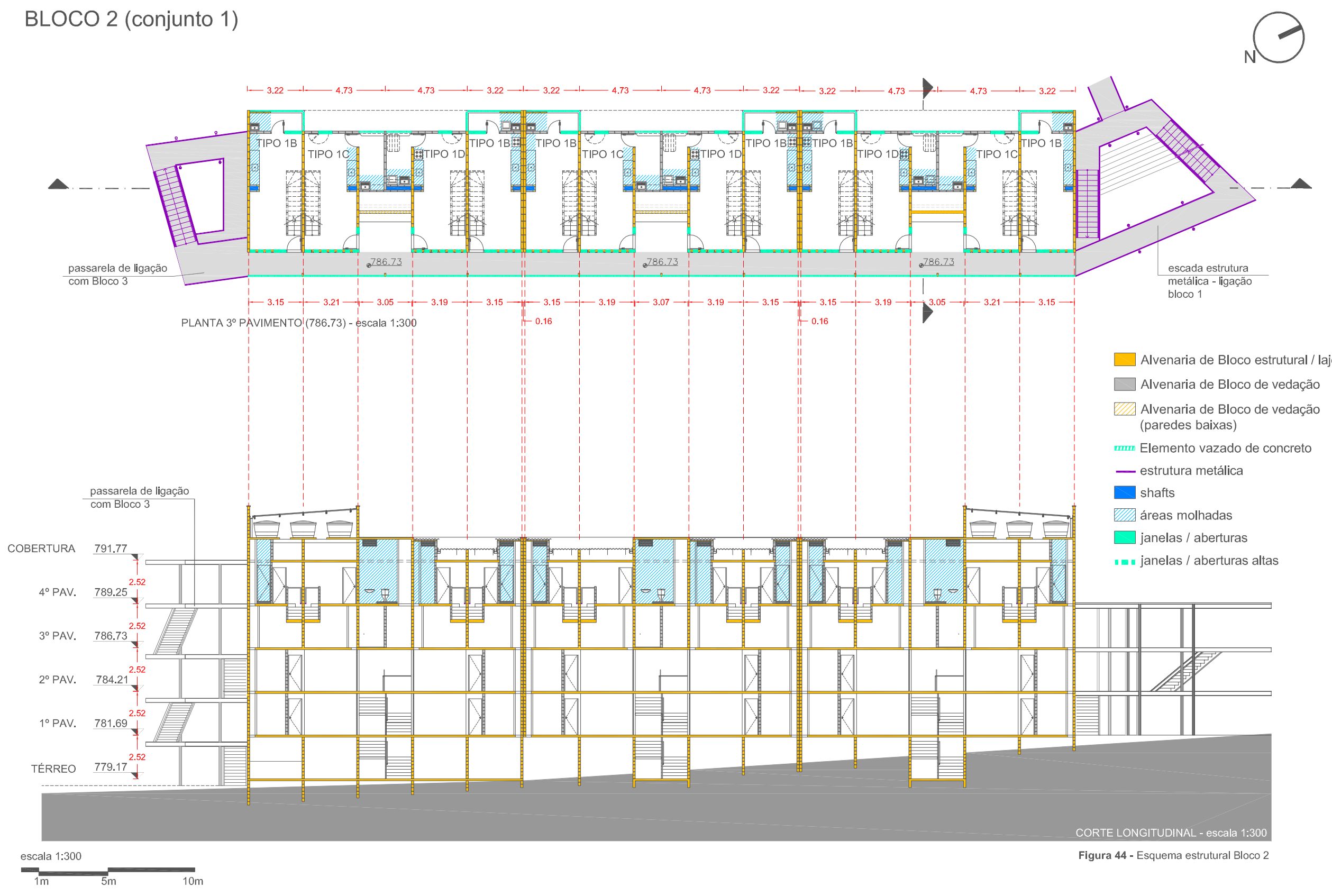


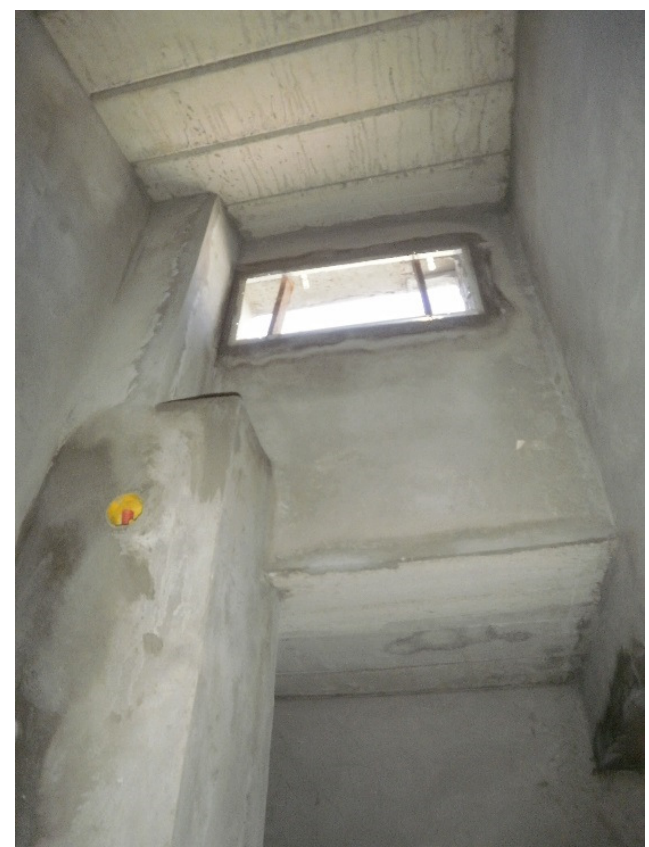

Figura 45 - janelas altas nos banheiros.

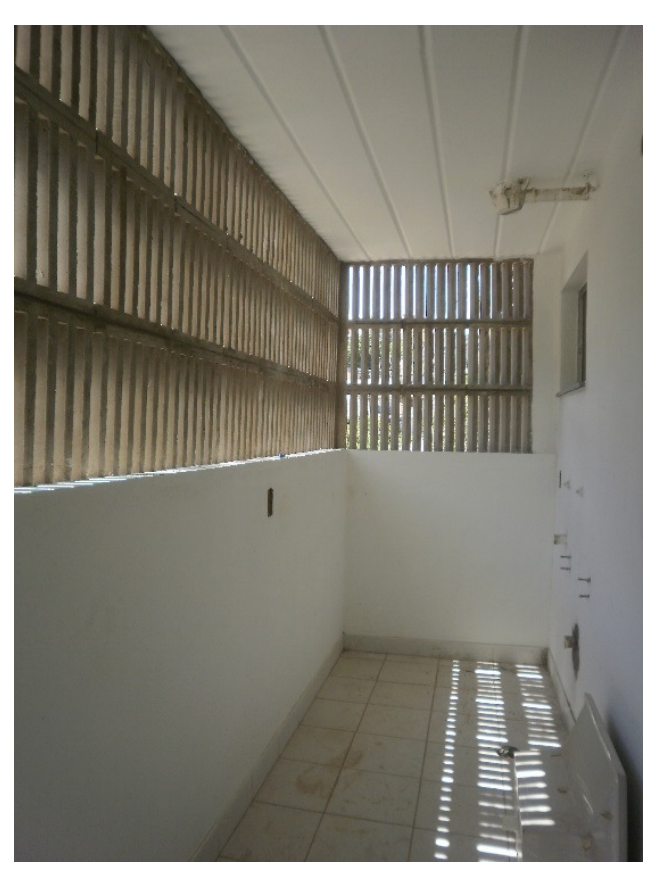

Figura 46 - Fechamentos das áreas de serviço com elementos vazados na parte superior e blocos na parte inferior.

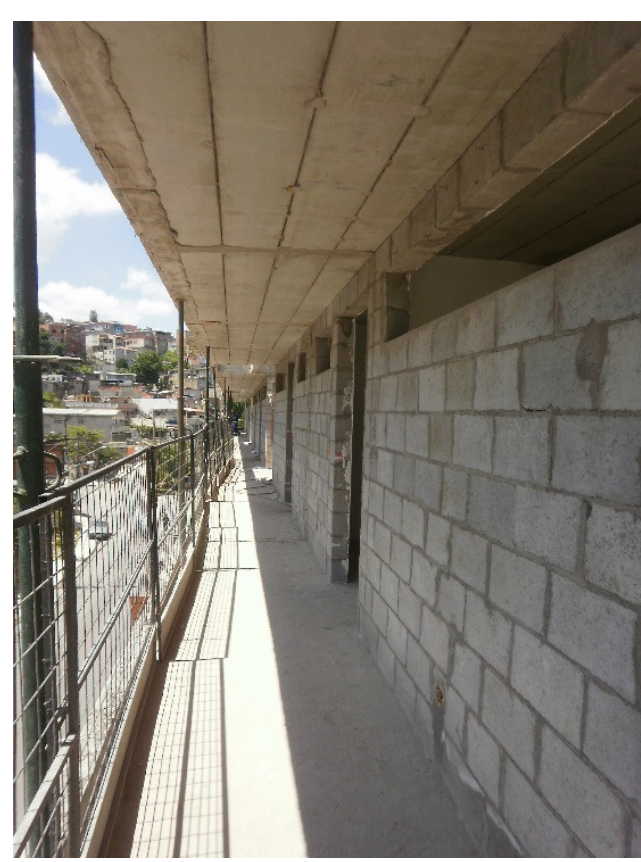

Figura 47 - As aberturas voltadas para a passarela são mais altas para garantir a privacidade.

\subsubsection{BLOCO 6}

O bloco 6 foi o edifício escolhido para representar o conjunto 2, pois, como bloco intermediário, nos permite conhecer também a articulação entre ele e os blocos 5 e 7.

O Conjunto 2 faz limite com a Rua Francisca Queirós e a distribuição das tipologias está diretamente relacionada ao desnível existente entre essa rua e o interior da intervenção. 
Tanto no corte transversal como nas plantas do térreo e 1ำ pavimento, podemos observar um grande espaço indicado como vazio. Esse vazio está diretamente relacionado ao desnível do terreno. Pela análise é possível perceber que as unidades implantadas abaixo do nível da Rua Francisca Queirós possuem aberturas apenas para o interior do conjunto. A forma como essas unidades foram implantadas acabou criando esse espaço que pode ser classificado como um "caixão perdido".

Ao analisar o projeto, é possível compreender a existência desse espaço, principalmente quando se leva em consideração a adaptação ao desnível e à sobreposição de diferentes tipologias. Contudo, é inevitável questionar se não haveria alguma outra maneira de aproveitar esse espaço, mesmo que não fosse como unidade. Talvez tivesse sido possível aproveitá-lo como área comum, desde que houvesse aberturas que proporcionassem boa iluminação e ventilação, ou até mesmo como depósito.

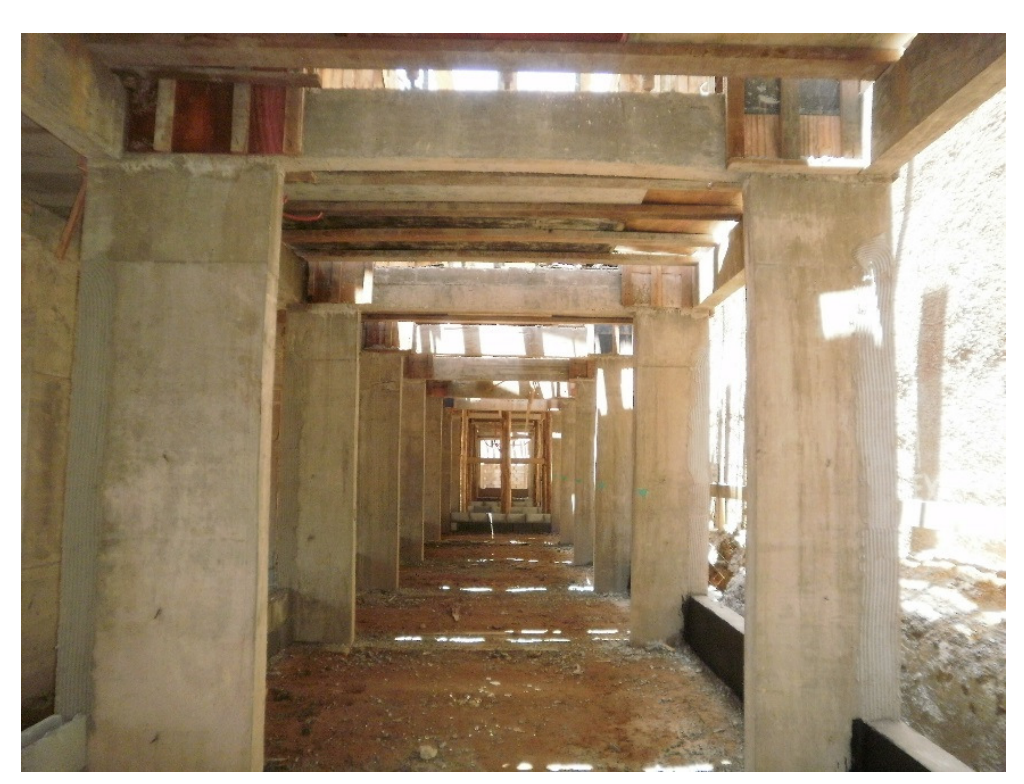

Figura 48 - Caixão perdido atrás das unidade tipo 2A, abaixo do nível da Rua Francisca Queirós.

Ao observar a planta do térreo, nota-se que parte desse espaço, atrás das escadas, foi utilizada como casas de medição, o que já garante um melhor uso a um espaço que ficaria perdido. 


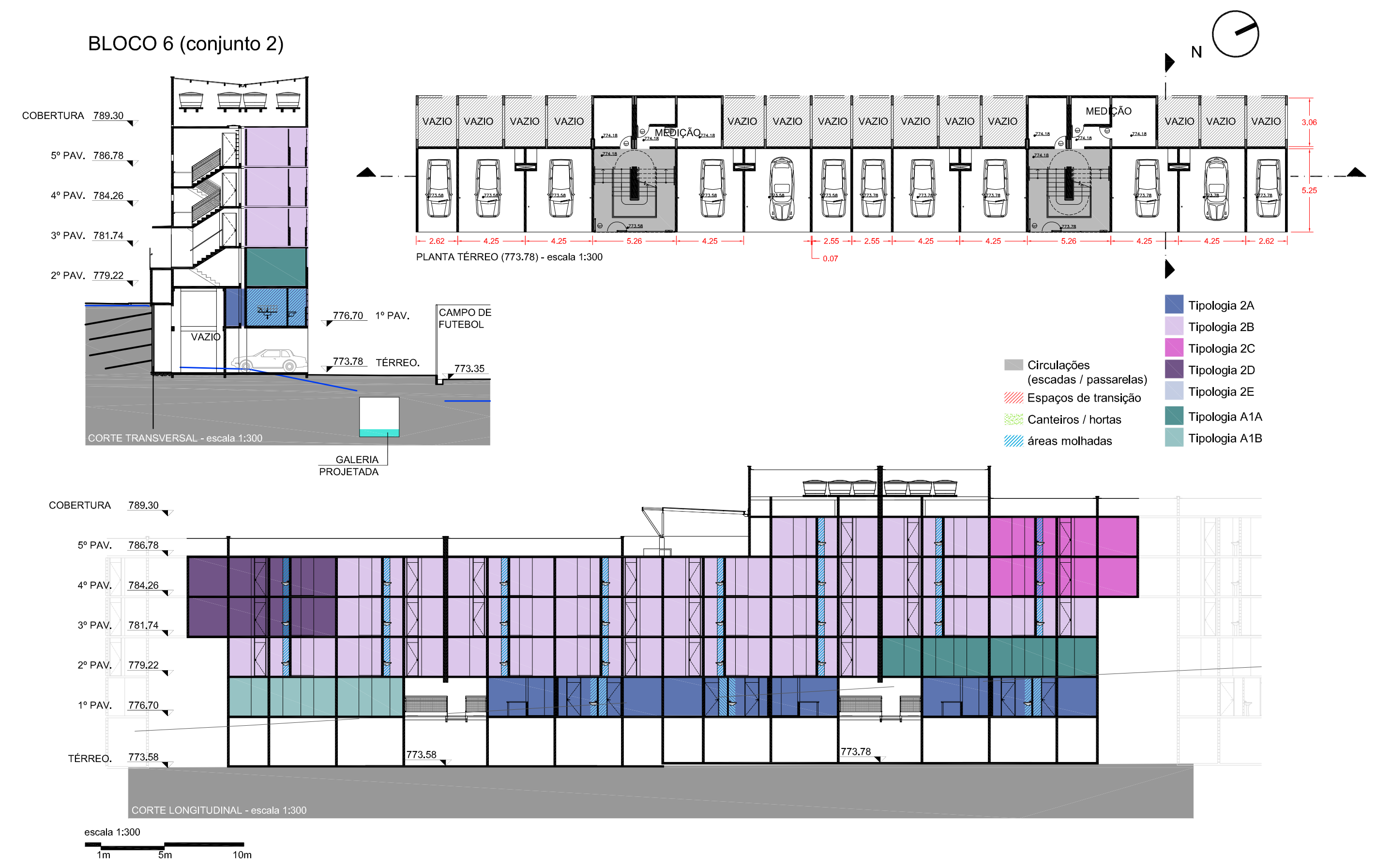




\section{BLOCO 6 (conjunto 2)}
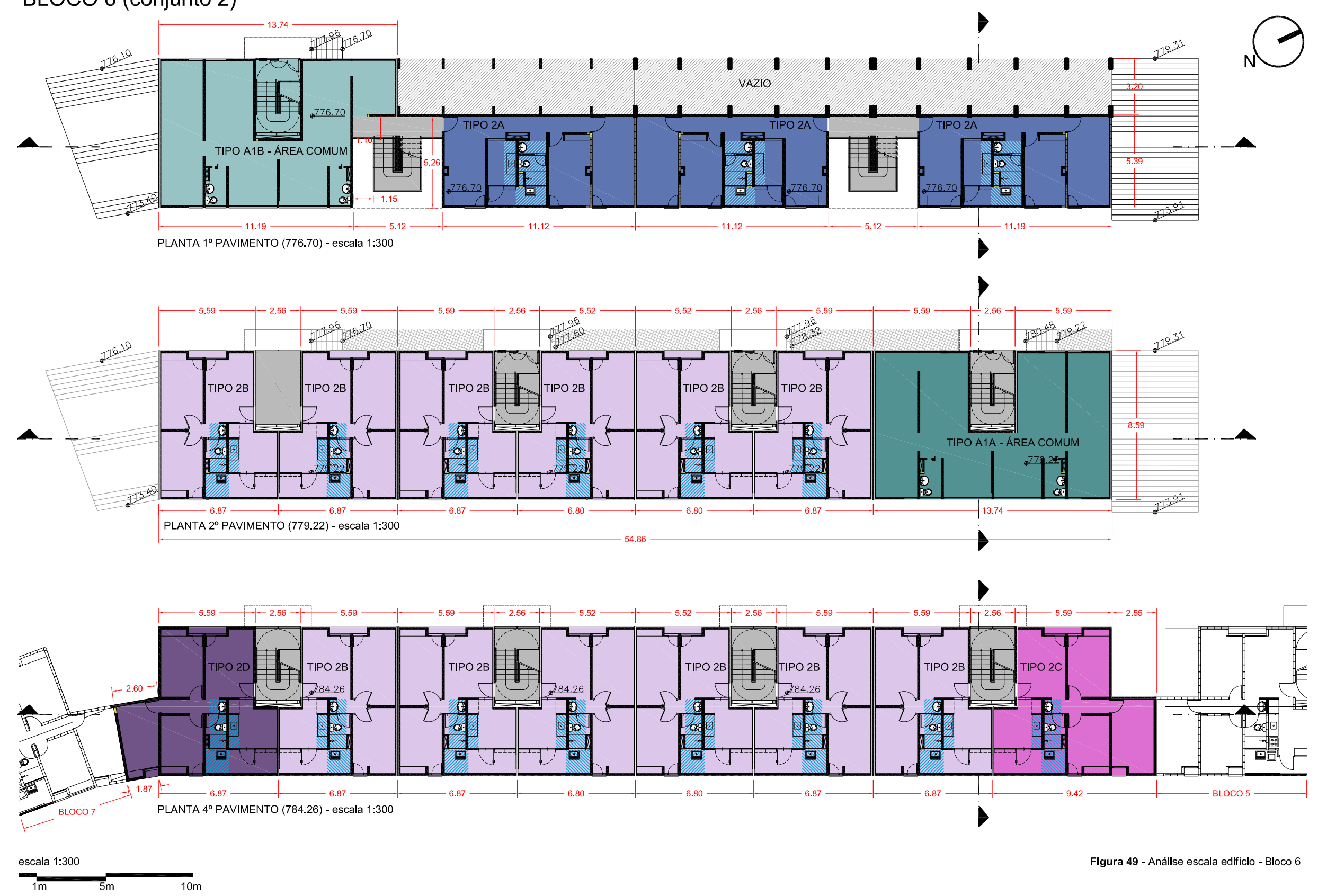


\section{Acessos e circulação}

Ao observar as plantas é possível identificar que o bloco 6 possui duas caixas de escada: uma com acesso a partir do interior do conjunto; e outra acessada pela Rua Francisca Queirós. As unidades localizadas nos pavimentos abaixo do nível da rua, são acessadas pela escada do interior e os apartamentos dos andares superiores são acessados diretamente pela rua. Cada escada acessa duas unidades por andar.

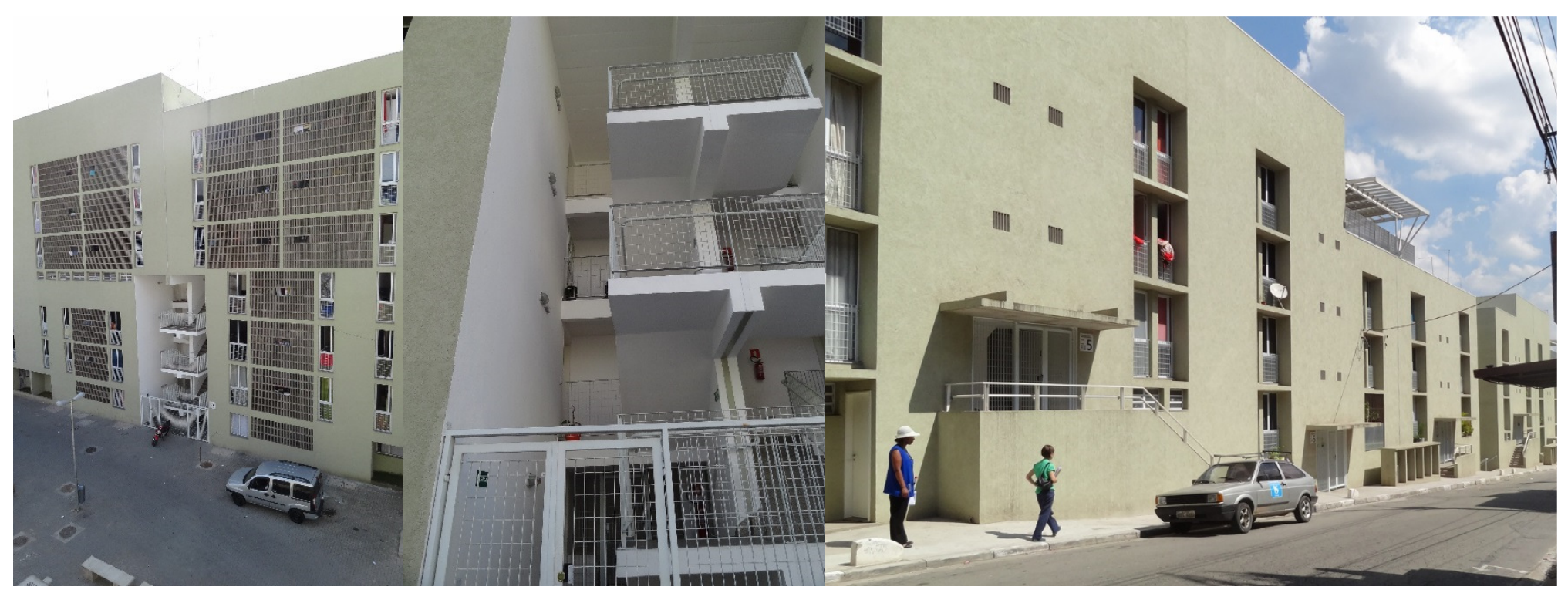

Figura 50 - Escadas voltadas Figura 51 - Detalhe das escadas Figura 52 - Acessos voltados para a Rua Francisca Queirós. para o interior do conjunto. $\quad$ voltadas para o interior do conjunto.

\section{Diversidade tipológica}

As unidades tipo 2A, como já foi enfatizado, são as que possuem aberturas apenas para o interior do conjunto e ocorrem nos pavimentos inferiores. $\mathrm{O}$ tipo $2 \mathrm{E}$ não aparece no bloco 6 , mas representa apenas a adaptação do tipo 
2A para pessoas com necessidade especiais (P.N.E.). As diferenças entre essas duas tipologias, poderão ser vistas com mais detalhe no item que analisa as unidades.

Acima do nível da Rua Francisca Queirós encontram-se os tipos 2B, 2C e 2D. $\mathrm{Na}$ realidade, $2 \mathrm{C}$ e $2 \mathrm{D}$ são variações do tipo $2 \mathrm{~B}$ com três dormitórios. Essa variação é possível, pois, entre os blocos, foram definidos pórticos que comunicam o interior da intervenção com a rua. A parte superior desse pórtico é exatamente o terceiro dormitório dessas tipologias. No caso do tipo 2D, o ângulo entre os blocos 6 e 7 cria uma inclinação no terceiro dormitório, como pode ser verificado na planta do $4^{\circ}$ pavimento.

As tipologias $\mathrm{A} 1 \mathrm{~A}$ e $\mathrm{A} 1 \mathrm{~B}$ não são unidades habitacionais, são espaços destinados ao uso comum que estão inseridos no edifício e respeitam a modulação de estrutura das unidades. Outras áreas comuns existentes nesse conjunto são as churrasqueiras localizadas nas coberturas dos blocos 5 e 6 .

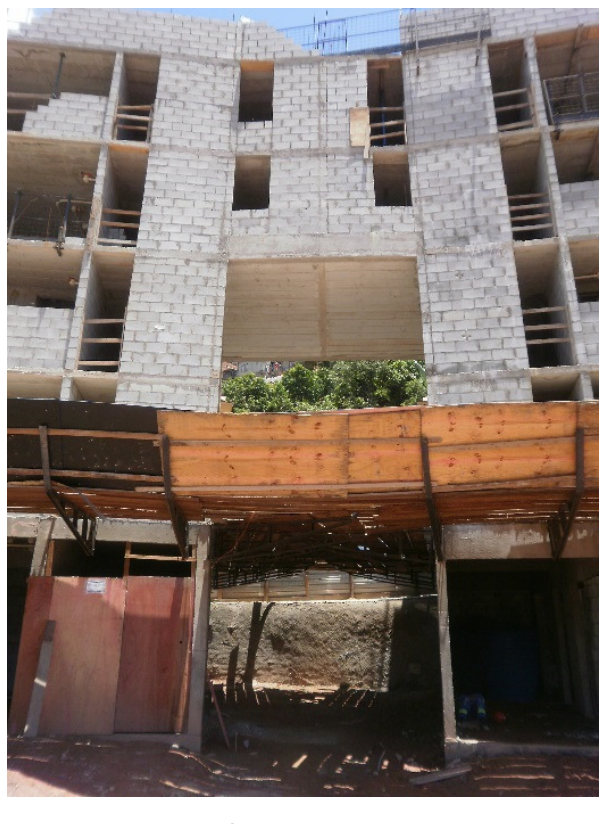

Figura 53 - Conjunto 2 em construção. Pórtico entre os blocos 6 e 7. Bloco

Figura 54 - Fachada Conjunto 2. Notar pórticos entre os blocos. Sem escala. 


\section{Estrutura e aberturas}

O bloco 6, assim como os outros, possui estrutura em alvenaria de bloco estrutural.

No corte longitudinal é possível verificar que as áreas molhadas estão agrupadas verticalmente e a planta do $4^{\circ}$ pavimento permite notar que são agrupadas no interior de cada unidade, mas não se espelham.

As aberturas propostas para essas unidades são recuadas na fachada, criando armários para o interior das unidades, como pode ser observado nas imagens abaixo.

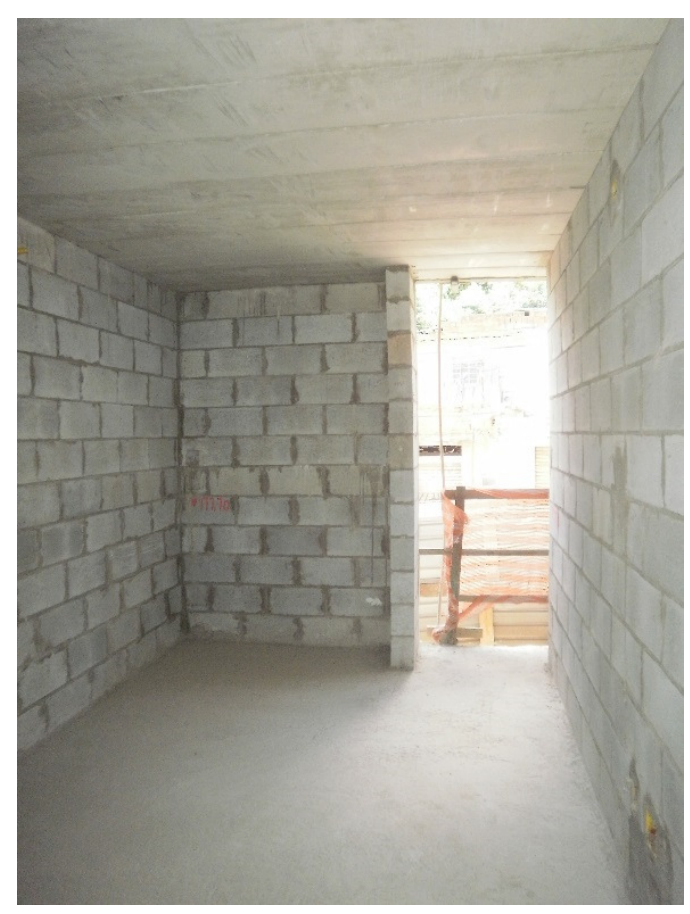

Figura 55 - Abertura vertical das janelas e armário para o interior da unidade.

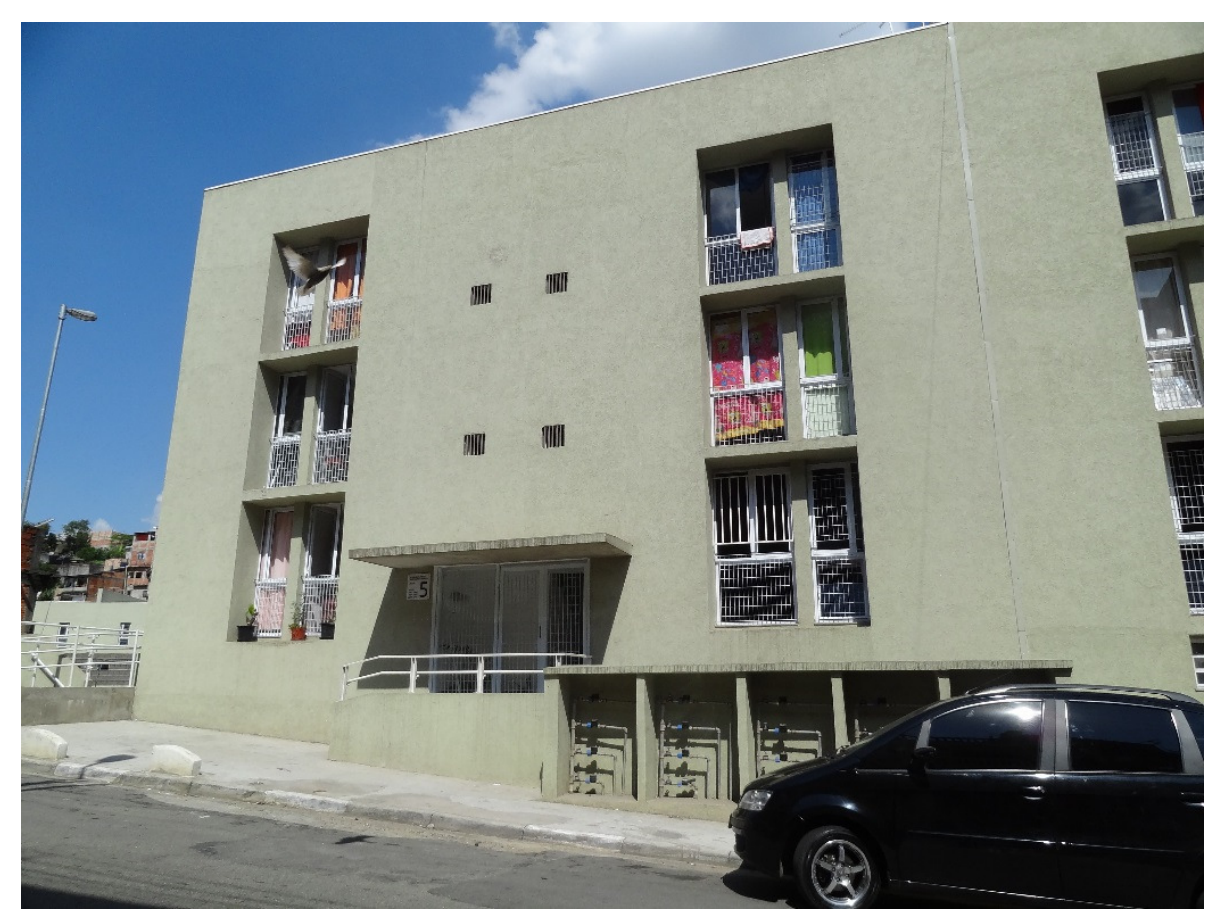

Figura 56 - Fachada do bloco 5, com detalhe para as janelas recuadas. 


\section{BLOCO 6 (conjunto 2)}

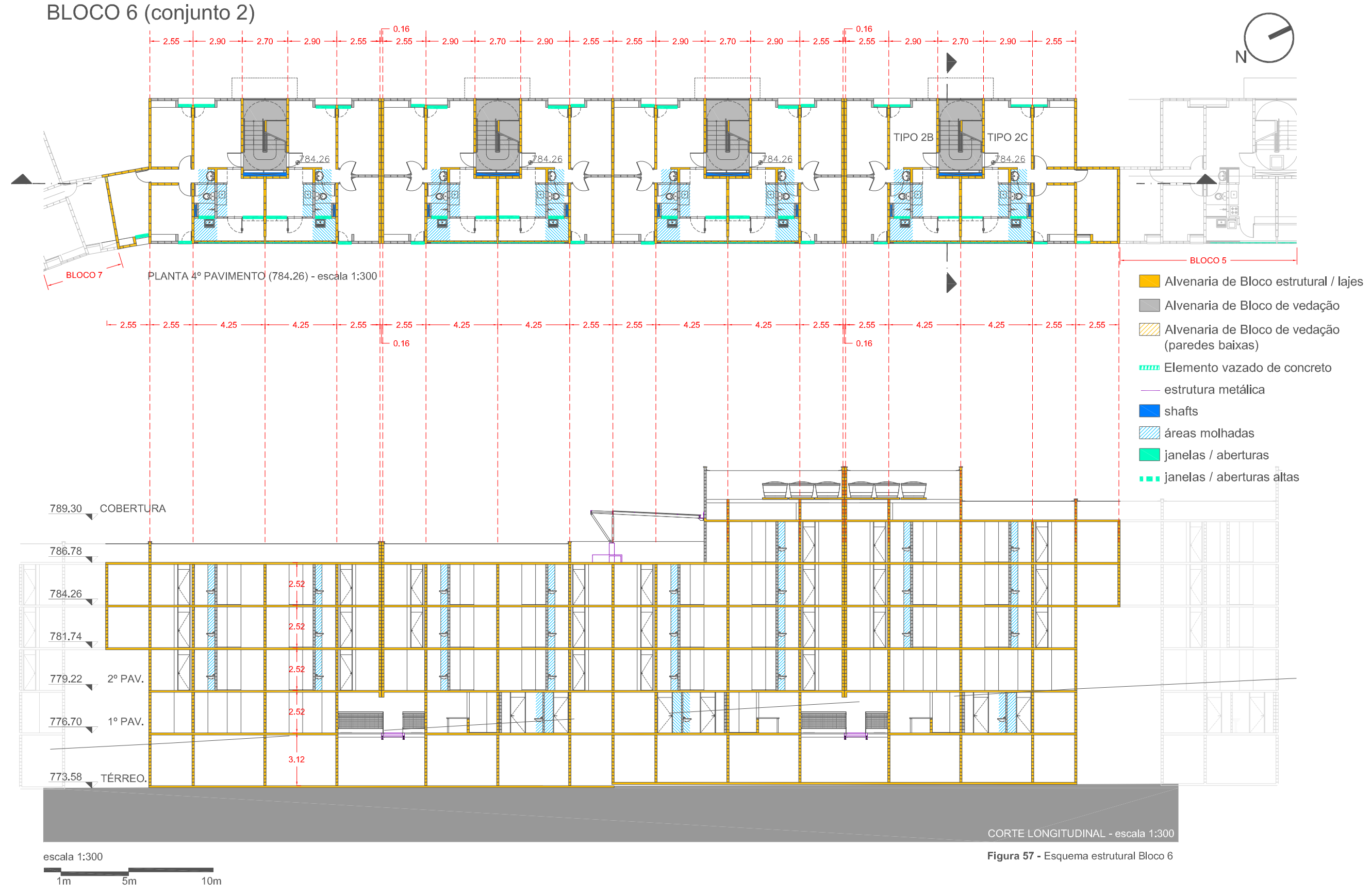




\section{SANTO AMARO V}

\section{BLOCO 8 (conjunto 3)}
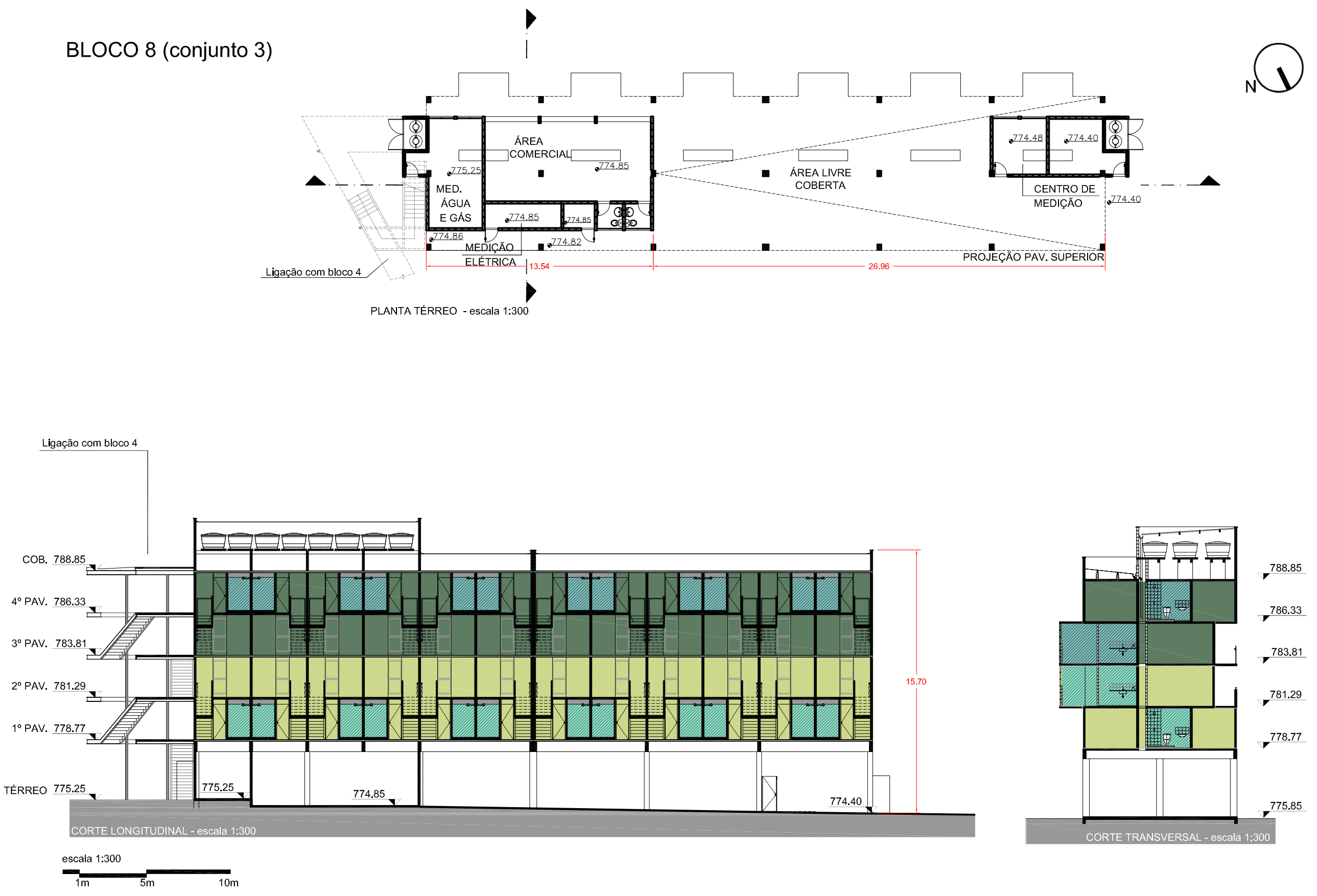
BLOCO 8 (conjunto 3)
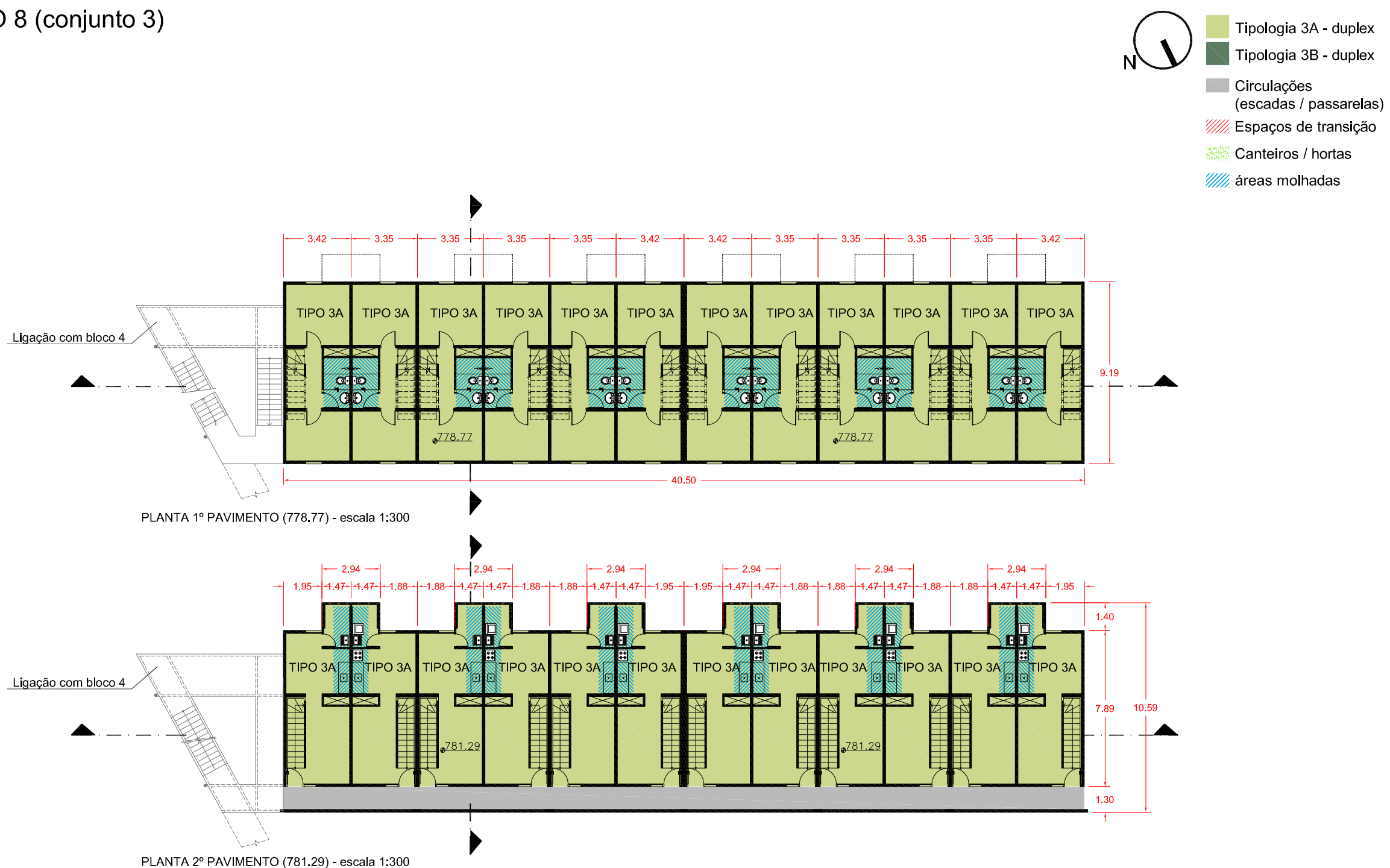


\subsubsection{BLOCO 8}

O Conjunto 3 é o único que possui apenas 1 edifício. O bloco 8 é o edifício implantado perpendicularmente aos outros e que comunica, através da passarela inserida no terceiro pavimento, as Ruas Francisca Queirós e Coelho Lousada.

O térreo desse bloco é ocupado por um espaço que foi projetado para ser comercial, porém, até o momento em que foi realizada a última visita (novembro de 2013), permanece fechado e, possivelmente, será ocupado pelo segundo CRAS proposto para o conjunto. O restante do térreo resultou em uma área livre coberta.

\section{Acessos e circulação}

O acesso a esse bloco se dá através da passarela que comunica as duas ruas e pelas escadas existentes nas extremidades. A escada próximo da Rua Coelho Lousada também atua na ligação com o bloco 4 . Na outra extremidade, o acesso à passarela se dá diretamente no nível da Rua Francisca Queirós. Além disso, há também uma escada que conecta o nível dessa rua ao térreo da intervenção (Figura 35).

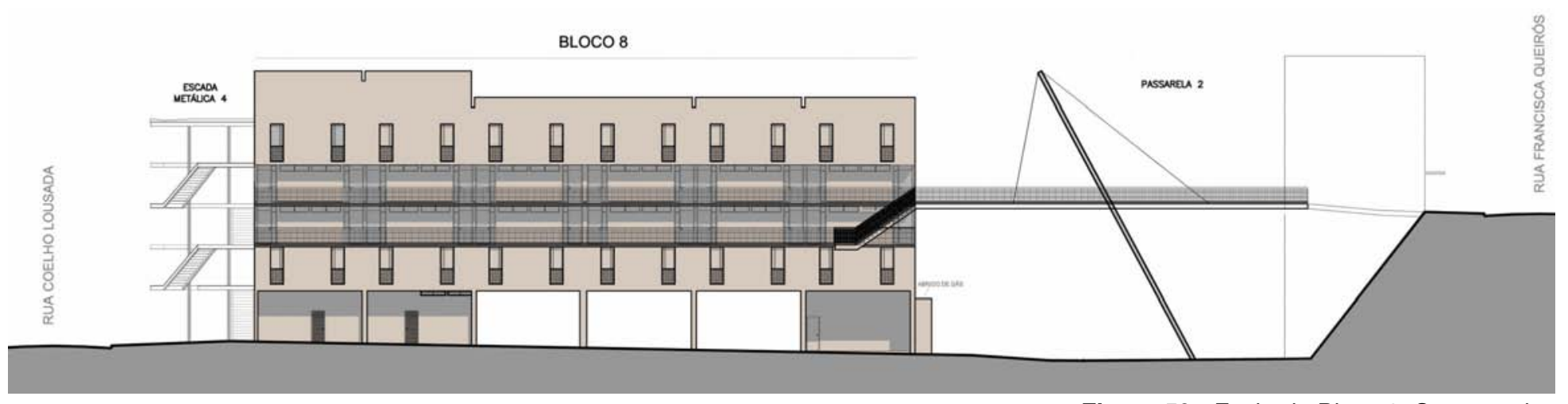

Figura 59 - Fachada Bloco 8. Sem escala. 
As entradas das unidades estão distribuídas ao longo das duas passarelas existentes no segundo e terceiro pavimentos. O Acesso à passarela inferior ocorre através de uma escada metálica que aparece como uma saliência ao longo das passarelas, em uma das extremidades do edifício e, na outra, se dá através da escada da Rua Coelho Lousada.

\section{Diversidade tipológica}

O bloco 8 possui apenas duas tipologias: 3A e 3B. Entretanto, a variação entre elas refere-se apenas ao acesso e à posição dos dormitórios. No tipo 3A, sala de estar, cozinha e área de serviço localizam-se no pavimento superior ( $2^{\circ}$ andar) e o banheiro, junto aos dormitórios, localiza-se no pavimento inferior ( $1^{\circ}$ andar). No caso do tipo 3B, a sobreposição dos andares é inversa: mantendo os dormitórios e o banheiro no andar superior (4ํandar) enquanto os outros ambientes localizam-se no pavimento de baixo.

\section{Estrutura e aberturas}

O bloco 8 também possui estrutura em alvenaria de bloco estrutural. As escadas são um elemento bastante presente na estrutura desse edifício.

As áreas molhadas estão sobrepostas verticalmente e espelhadas a cada duas unidades.

Na Figura 60 é possível observar o bloco 8 posicionado perpendicularmente aos outros e as conexões com as Ruas Francisca Queirós e Coelho Lousada. A escada que conecta a Rua Francisca Queirós ao térreo da intervenção foi construída em concreto, pois ocorre junto ao muro de contenção. Na outra extremidade, é possível identificar a escada metálica em formato triangular que comunica o bloco 8 ao 4 . 
O trecho da passarela inserido no edifício é construído em alvenaria estrutural e possui guarda corpo em elemento vazado, assim como as passarelas do Conjunto 1. Mais uma vez nota-se o conceito de utilizar a metálica para todas as estruturas de conexão que não estão inseridas nos edifícios e manter os edifícios em alvenaria de bloco estrutural.

As áreas de serviço são um volume em balanço na fachada posterior revestidos com elemento vazado. Como pode ser observado na Figura 61, esses volumes dão ritmo aos cheios e vazios dessa fachada com vista para o campo de futebol.

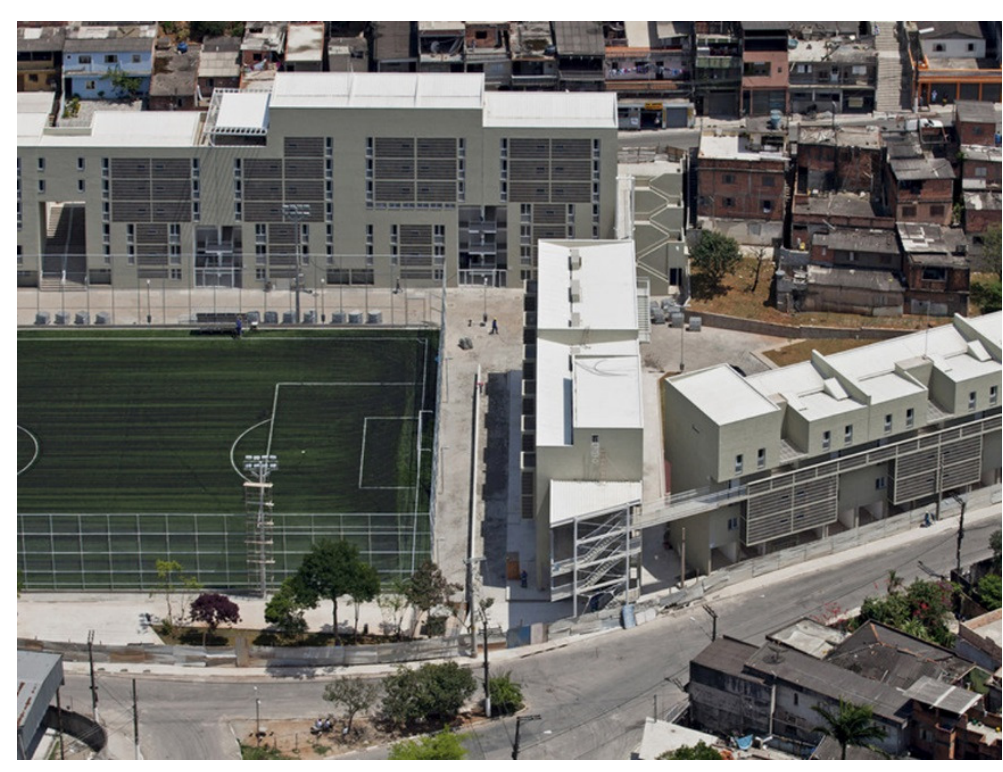

Figura 60 -Bloco 8 e conexões com as Ruas Francisca Queirós e Coelho Lousada.

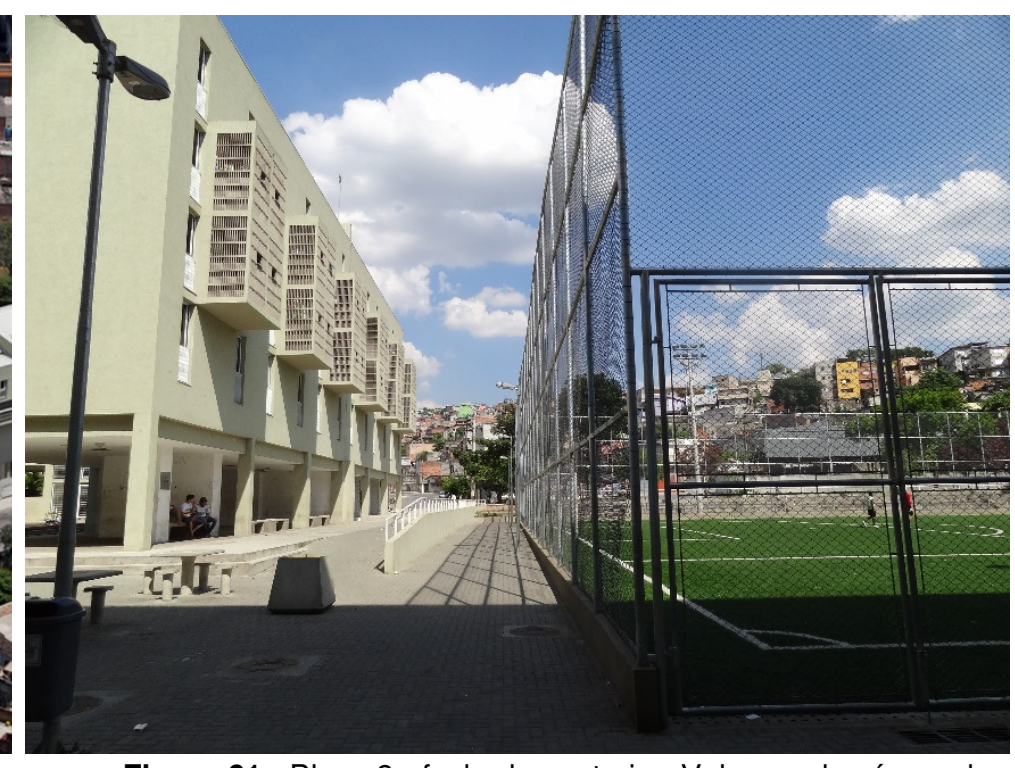

Figura 61 - Bloco 8 - fachada posterior. Volumes das áreas de serviço em balanço. 
BLOCO 8 (conjunto 3)

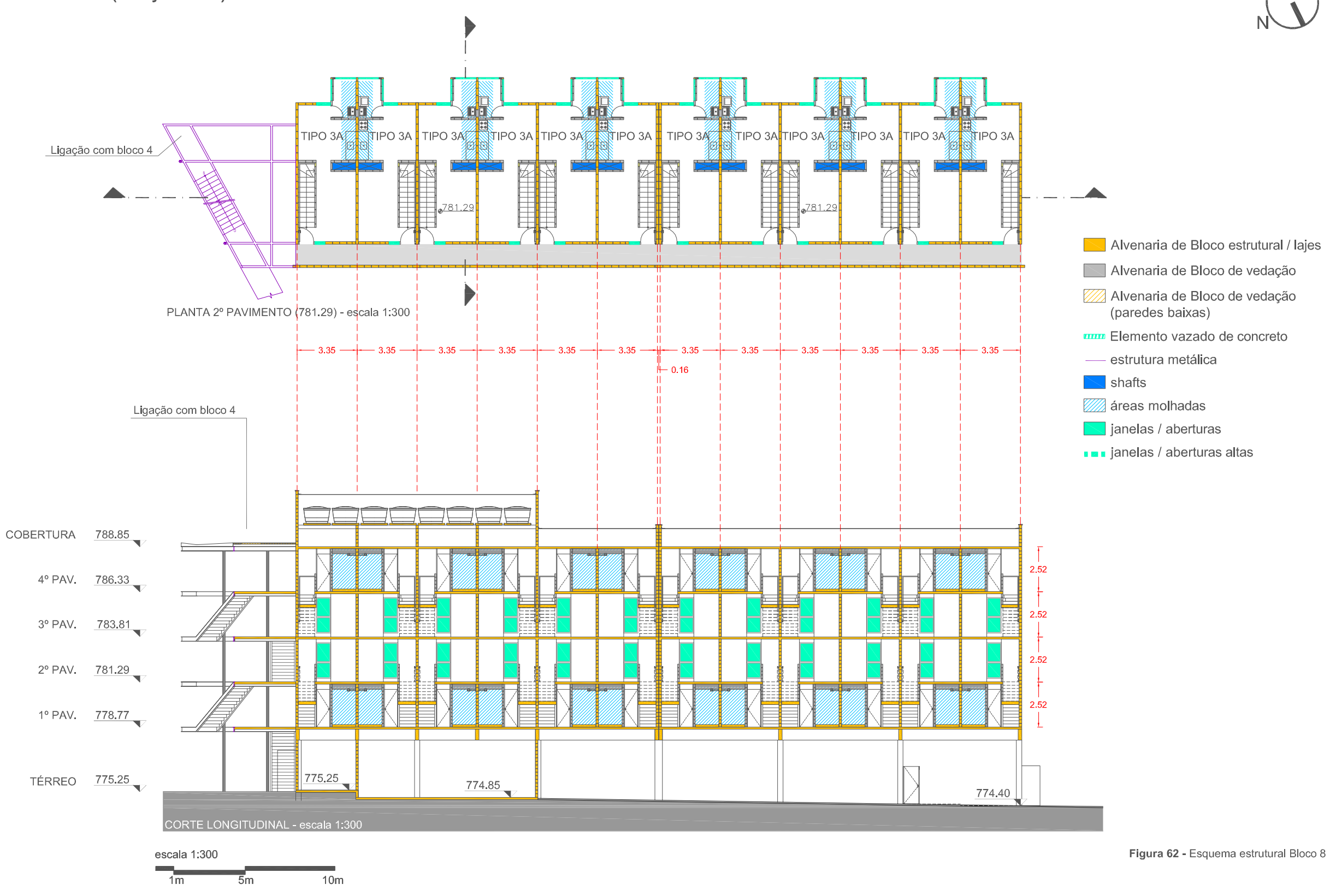


4.3.3. ESCALA UNIDADE

Como já foi comentado, o projeto Parque Novo Santo Amaro V apresenta uma grande variedade de tipologias que estão organizadas e moduladas dentro de cada conjunto. Na escala unidade, será possível analisar com maior detalhe cada uma das tipologias existentes no projeto e suas variações.

Do Conjunto 1 serão analisados os quatro tipos, pois cada um apresenta uma especificidade. No entanto, os tipos 1B, 1C e 1D serão analisados juntos por serem bastante articulados entre si.

Do Conjunto 2 serão analisados os tipos 2A, 2B e suas variações e, por último, analisaremos o tipo 3A.

\subsubsection{TIPO 1A}

O tipo $1 \mathrm{~A}$ ocorre nos pavimentos inferiores dos blocos do Conjunto 1. Em todas as posições recebem insolação no sentido leste - oeste. Ao ocuparem toda a largura do edifício, possuem aberturas nas duas fachadas, o que proporciona a ventilação cruzada. A posição das portas dos dormitórios alinhadas com as janelas favorece ainda mais a ventilação através dos ambientes.

\section{Ambientes não \\ especializados}

Sala e dormitórios apresentam dimensões confortáveis e praticamente não apresentam variação de tamanho entre eles, o que favorece a desierarquização ${ }^{11}$ dos espaços.

${ }^{11}$ Consta no glossário de Instrumentos de Avaliação de Projetos (2012b, p. 188) que o termo desierarquização significa: prática projetual que evita a criação de hierarquias entre os ambientes. Este conceito significa a "não" determinação de usos específicos nem hierarquias espaciais, pelo contrário, favorece a utilização mais flexível, não exclusiva e não predeterminada dos espaços. 


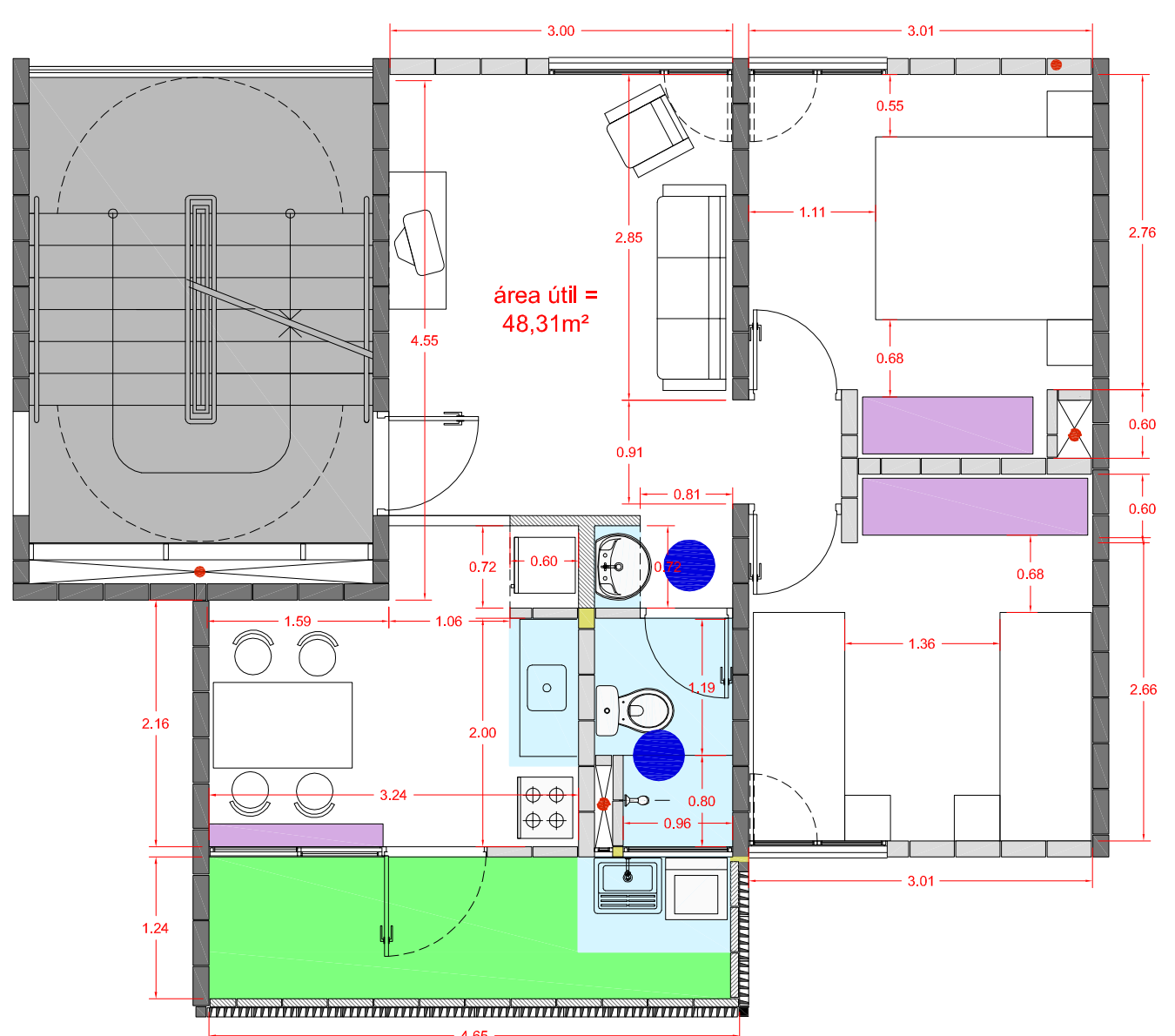

PLANTA TIPO 1A - layout e dimensões.

escala 1:75

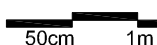

$\square$ concentração das áreas molhadas

$\square$ espaço exterior próprio

$\square$ espaços para guardar

$\square$ espaços de estudo/trabalho

uso do banheiro
1 pessoa $\square$ Alvenaria de Bloco estrutural / lajes

$\square$ Alvenaria de Bloco de vedação

Alvenaria de Bloco de vedação (paredes baixas)

IIII) Elemento vazado de concreto

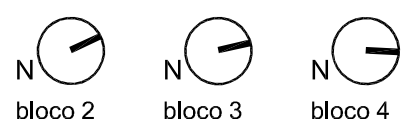

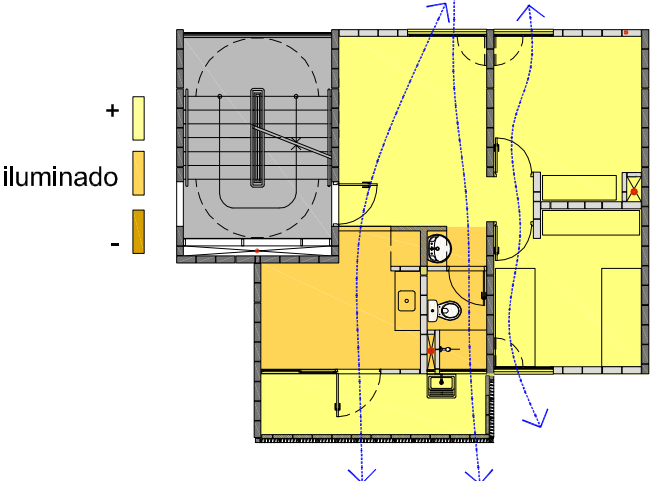

ESQUEMA ILUMINAÇÃO E VENTILAÇÃO

(orientação de referência: bloco

escala 1:200

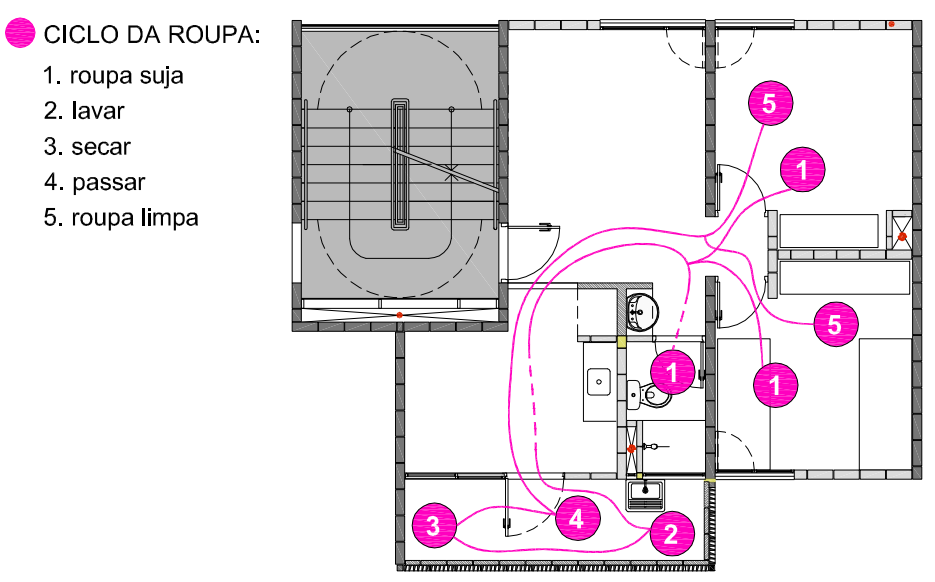

PLANTA TIPO 1A - ciclo da roupa escala 1:150

Figura 63 - Análise Tipo 1A. 
De acordo com Instrumentos de Avaliação de Projetos (2012b, p. 300), "os ambientes não especializados que sejam utilizados como espaço de dormir, ou de descanso individual, devem permitir a máxima variedade de layouts e não devem hierarquizar nenhum ambiente com relação a outro, sendo, portanto, equivalentes em suas características".

Observando a planta, podemos notar que os três ambientes (sala e dormitórios) possuem largura interna de 3 metros em um sentido e, no outro, as dimensões variam entre $2,66 \mathrm{~m}$ e 2,85m. Medidas que permitem a variedade de layouts recomendada pelos Instrumentos de Avaliação de Projetos, melhorando a qualidade espacial desses ambientes. Os dormitórios contam ainda com um "espaço para guardar" de $60 \mathrm{~cm}$ de profundidade criado a partir do posicionamento das portas.

O alinhamento da porta de entrada com o corredor que leva até os dormitórios, de certa forma, setoriza a área social, privada e de serviço, organizando e distribuindo os ambientes no interior da unidade.

\section{Ambientes \\ especializados}

As áreas molhadas encontram-se agrupadas dentro da unidade.

O banheiro oferece a vantagem de permitir o uso de mais de uma pessoa ao mesmo tempo, pois possui a pia separada do vaso sanitário e chuveiro. Com isso, um morador pode, tranquilamente, escovar os dentes enquanto outro toma banho, sem sobrepor funções no mesmo espaço. O banheiro ventila através da área de serviço que possui ventilação permanente devido ao fechamento em blocos de elemento vazado, o que favorece a ventilação. 
As áreas de serviço são volumes em balanço na fachada. Nota-se na Figura 64 que há uma abertura no fechamento de elementos vazados. Segundo o arquiteto, essa abertura chama-se "janela do grito" e serve para as mães poderem chamar seus filhos através dela (informação verbal). ${ }^{12}$

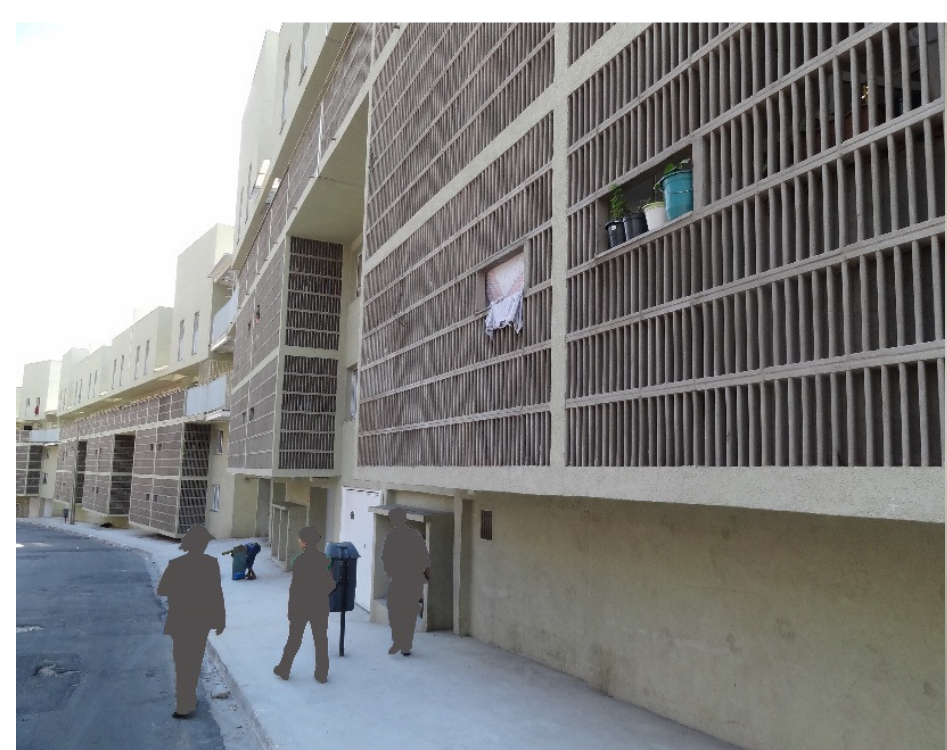

Figura 64 - Volumes das áreas de serviço e "janelas do grito".

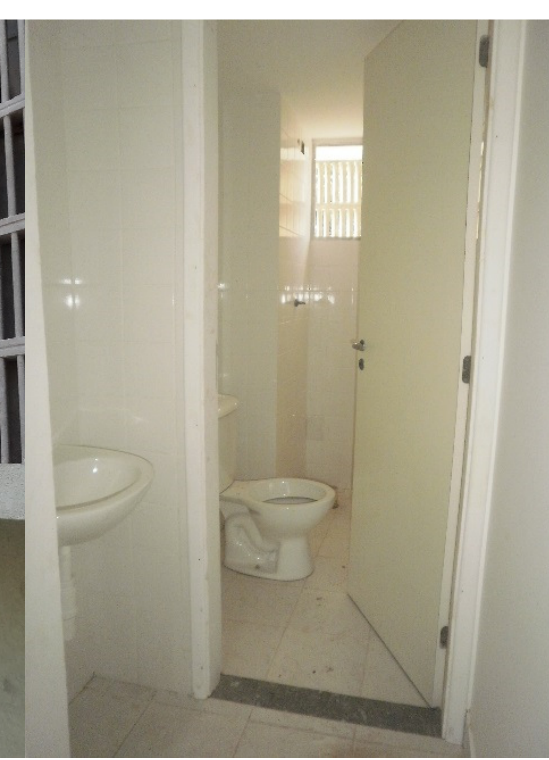

Figura 65 - Banheiro com funções separadas.

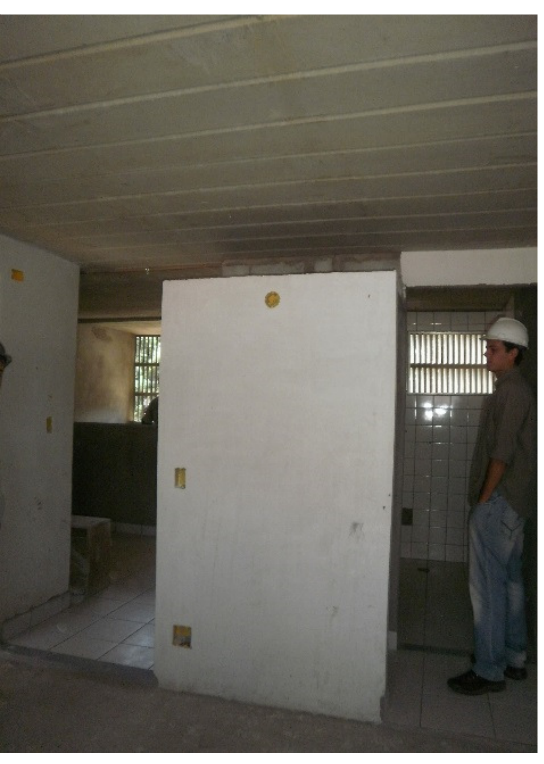

Figura 66 - Nicho para geladeira e pia do banheiro - parede mais baixa.

O nicho criado para a geladeira e para a pia do banheiro tem a parede mais baixa e, de acordo com os conceitos de utilização de espaço do arquiteto, essa parede mais baixa serve para os moradores poderem colocar plantas (samambaias), deixando os ambientes mais agradáveis, como podemos ver no croqui que segue (Figura 67).

12 VIGLIECCA, Hector. Construir Cidadania. Conferência: Museu da Casa Brasileira, São Paulo, 28 de novembro de 2012. 


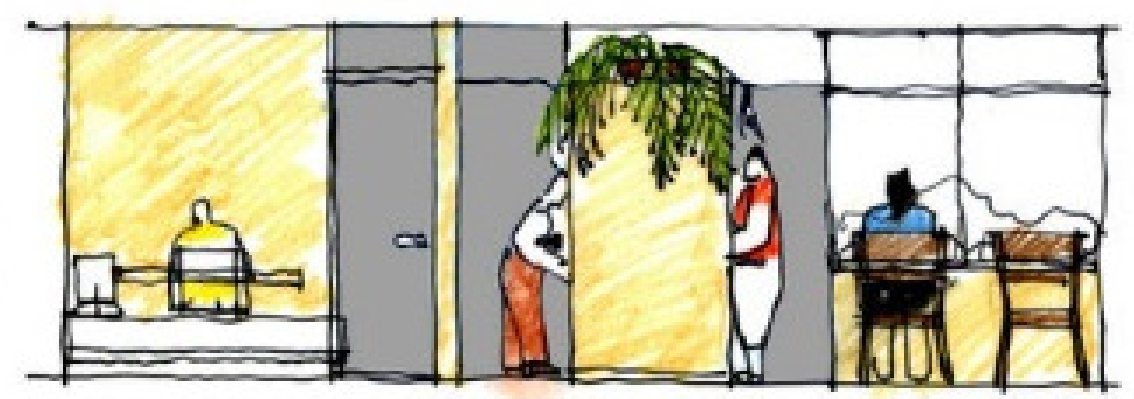

Figura 67 - Croqui Hector Vigliecca sobre o conceito da parede mais baixa.

\section{Relação entre os}

ambientes

Essa tipologia proporciona boa setorização dos espaços, porém mantém relação entre a sala de estar e a cozinha. Não se trata de sala e cozinha integradas. Caso o morador deseje, é possível, inclusive, isolar a cozinha, entretanto, a forma como esses espaços estão propostos não deixa a cozinha muito exposta e ainda assim garante certa integração.

A área de serviço está bastante protegida dos olhos de quem entra na unidade e apresenta boas dimensões possibilitando que as tarefas relacionadas ao cuidado da roupa sejam realizadas nesse ambiente, sem prejuízo de espaço.

\section{Espaço exterior próprio}

Por ter ventilação permanente e contato com o exterior, mesmo que seja através da "janela do grito", a área de serviço foi identificada como o espaço exterior próprio dessa unidade. 


\subsubsection{TIPOS 1B 1C 1D}

Os tipos 1B, 1C e 1D são as tipologias duplex, que ocorrem sobre as unidades Tipo 1A, do Conjunto 1. Esses tipos serão analisados em conjunto, pois são semelhantes e estão bastante relacionados entre si. Ao observar o pavimento superior, é possível verificar que o banheiro e o terceiro dormitório do Tipo C localizam-se acima das áreas de serviço dos Tipos C e D. Além disso, os dormitórios da face leste avançam sobre a passarela proporcionando uma circulação coberta.

Em todas as situações as aberturas estão voltadas para as faces leste e oeste. Com exceção do pavimento superior do tipo 1C, a posição das aberturas - mantendo portas e janelas alinhadas - proporciona ventilação cruzada através da unidade. Vale a pena ressaltar que, ao realizar as visitas aos apartamentos, foi possível verificar a boa circulação de ar nos ambientes. A visita foi realizada em um dia bastante quente e, ainda assim, o interior da unidade permanecia fresco e ventilado. ${ }^{13}$

\section{Ambientes não especializados}

Os espaços dedicados ao estar apresentam uma área mais retangular devido à posição da escada, restando apenas $2,11 \mathrm{~m}$ livres. Além do mais, esse ambiente também é utilizado como passagem para a cozinha e, apesar de estreito, permite a disposição do mobiliário adequadamente.

Nas tipologias visitadas foi possível verificar que as moradoras conseguiram colocar, até mesmo, um jogo de sofás na sala, junto ao hack para a TV, sem obstruir a passagem (Figura 70; Figura 71).

13 Visita realizada em novembro de 2013. 


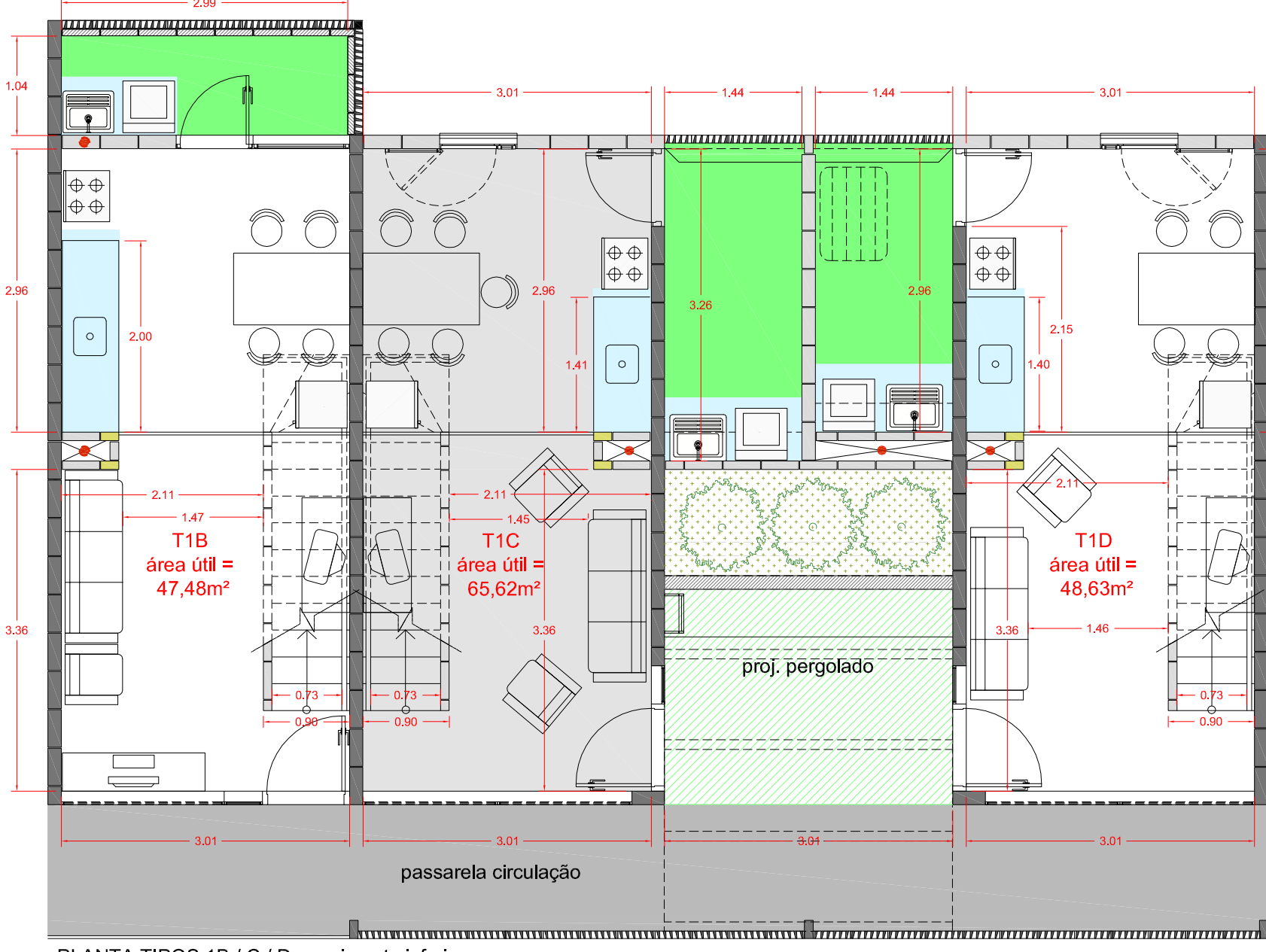
PLANTA TIPOS 1B / C / D - pavimento inferior
PLANTA TIPOS 1B / C / D - layout e dimensões. escala 1:75

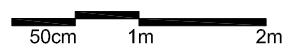

$\square$ concentração das áreas molhadas

$\square$ espaço exterior próprio

$\square$ apropriação do espaç̧o de transição como espaço exterior próprio

$\square$ espaços para guardar

$\square$ espaços de estudo/trabalho

uso do banheiro

1 pessoa

$\square$ Alvenaria de Bloco estrutural / lajes

$\square$ Alvenaria de Bloco de vedação

Alvenaria de Bloco de vedação (paredes baixas)

[IIII) Elemento vazado de concreto
No
N
$N$
$\mathrm{N}$
bloco 1
bloco 2
bloco 3
bloco 4 


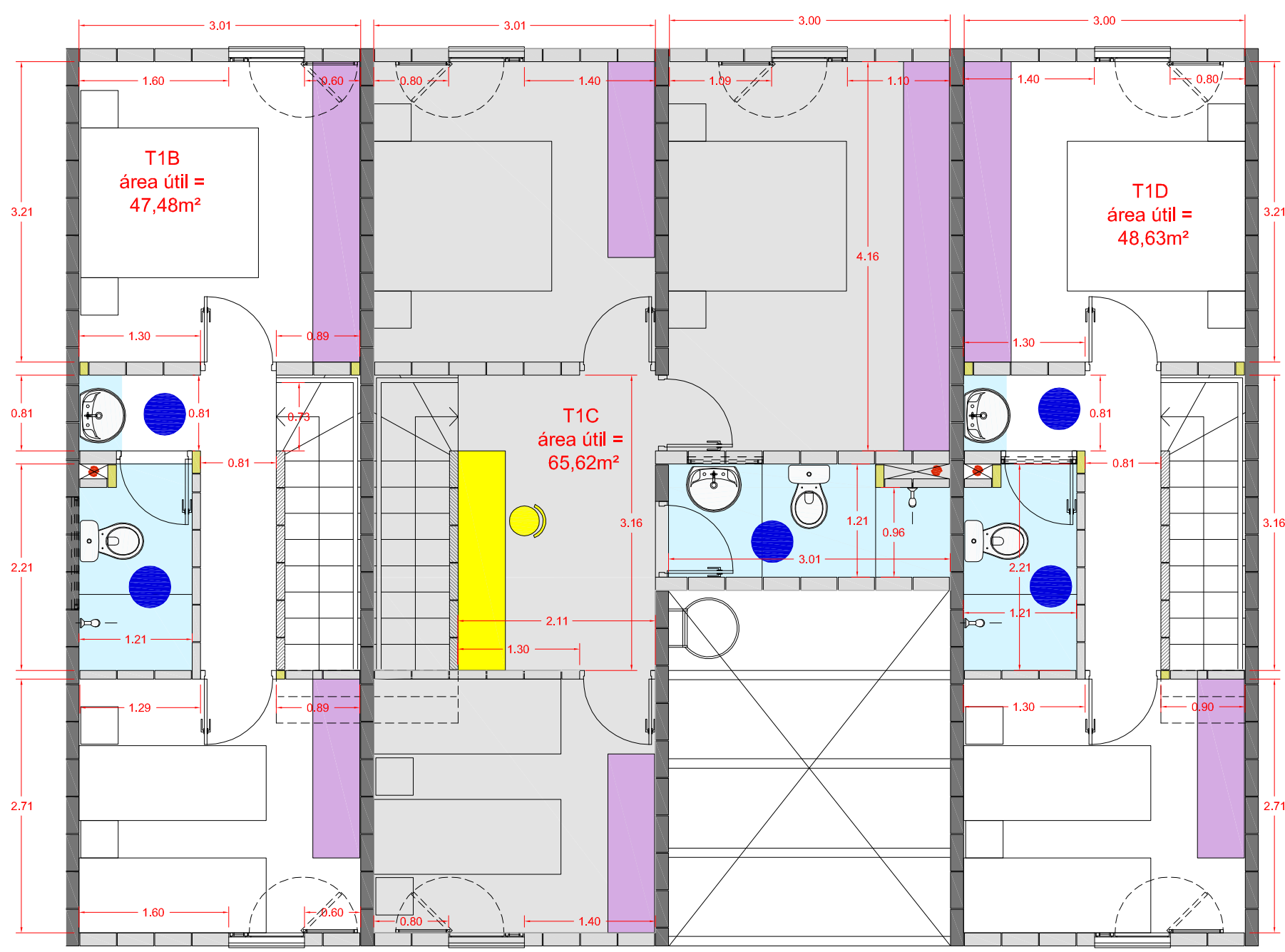

PLANTA TIPOS 1B / C / D - pavimento superior
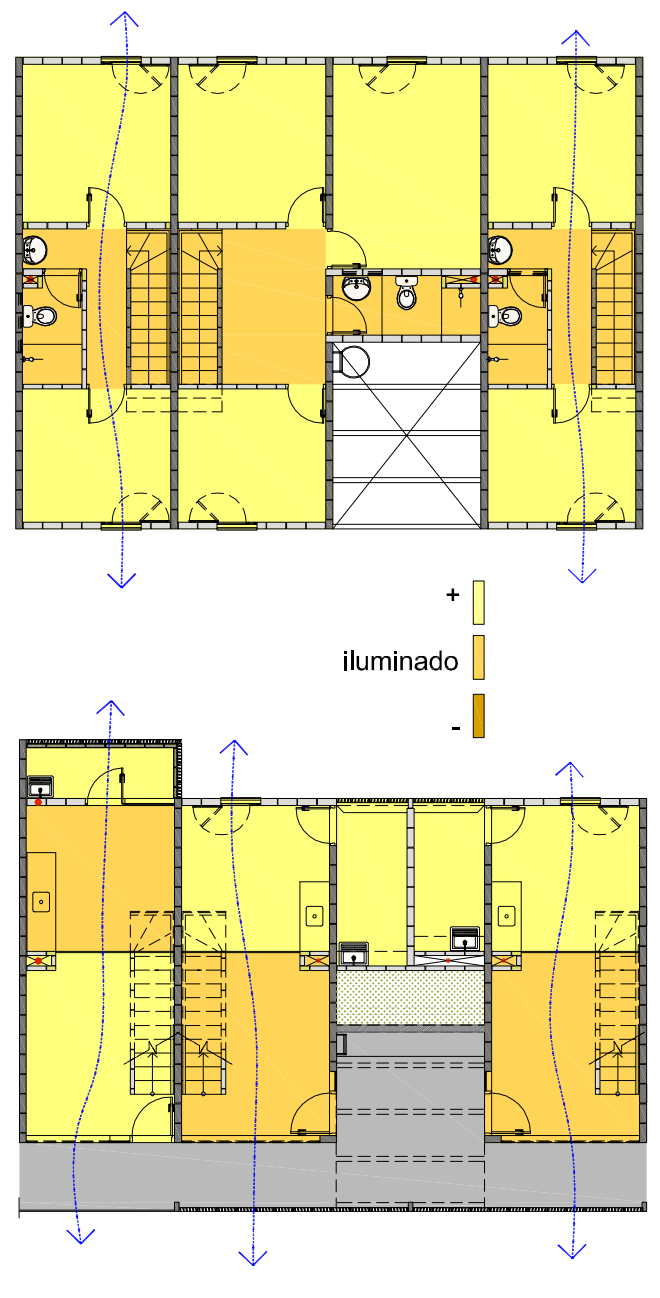

ESQUEMA ILUMINAÇÃO E VENTILAÇÃO (orientação de referência: bloco 2) escala 1:200

Figura 68 - Análise Tipos 1B, 1C e 1D 


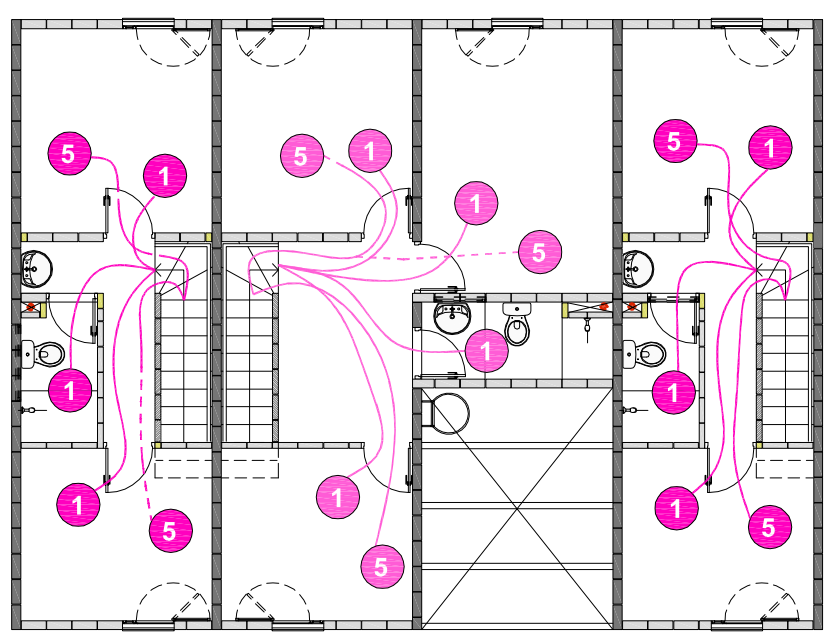

CICLO DA ROUPA

1. roupa suja

2. lavar

3. secar

4. passar

5. roupa limpa

PLANTA TIPO 1B - reprodução de layout de um apartamento visitado já
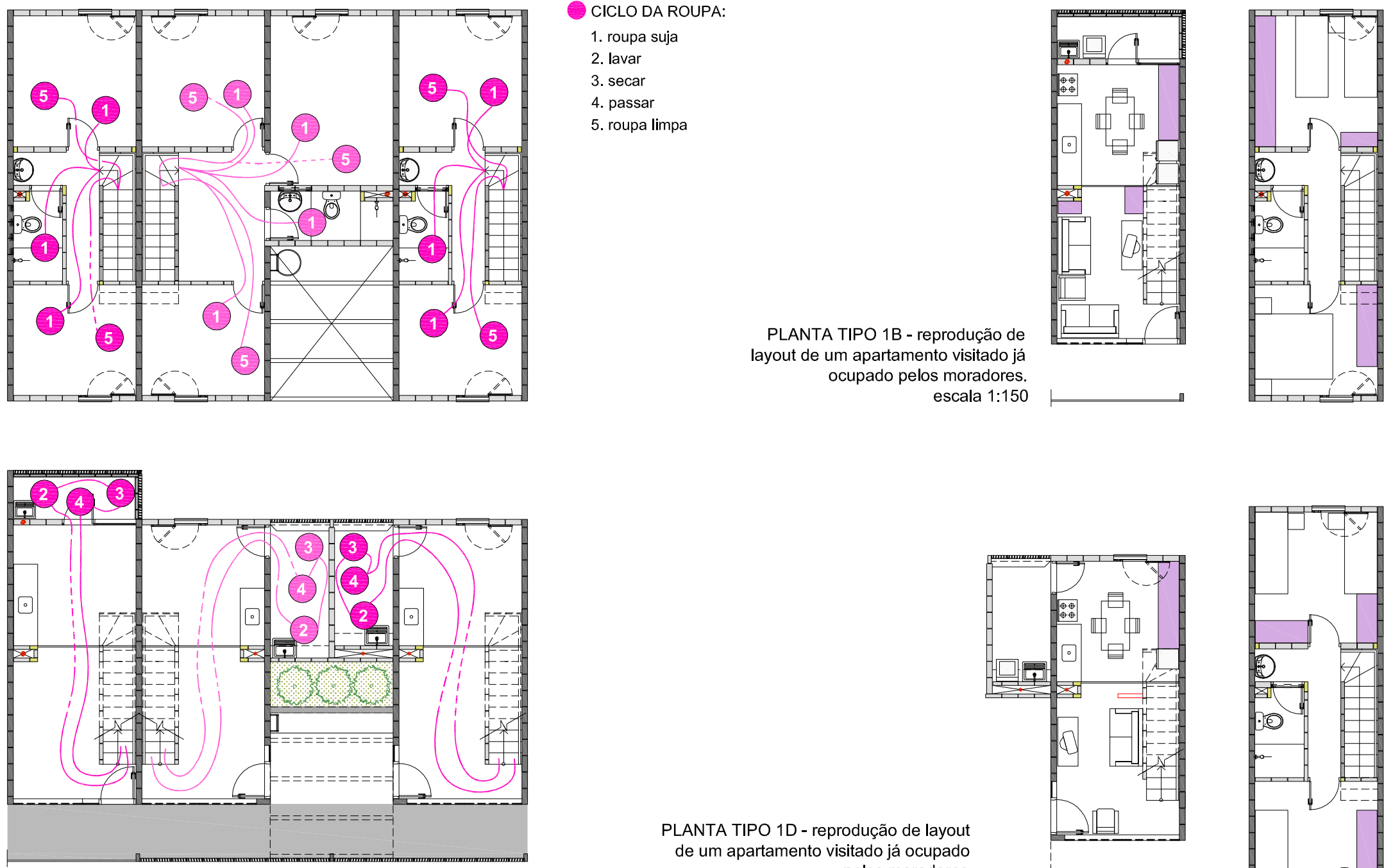

PLANTA TIPO 1B / C / D - ciclo da roupa

PLANTA TIPO 1D - reprodução de layout de um apartamento visitado já ocupado pelos moradores.
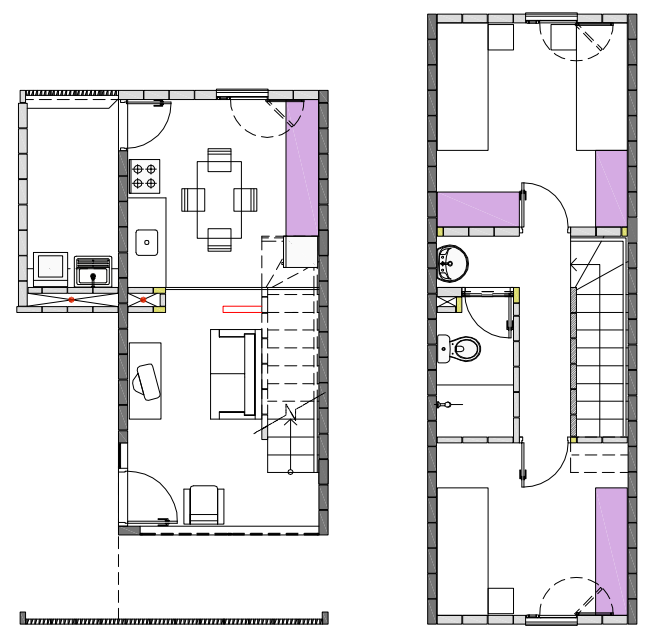
escala 1:150 


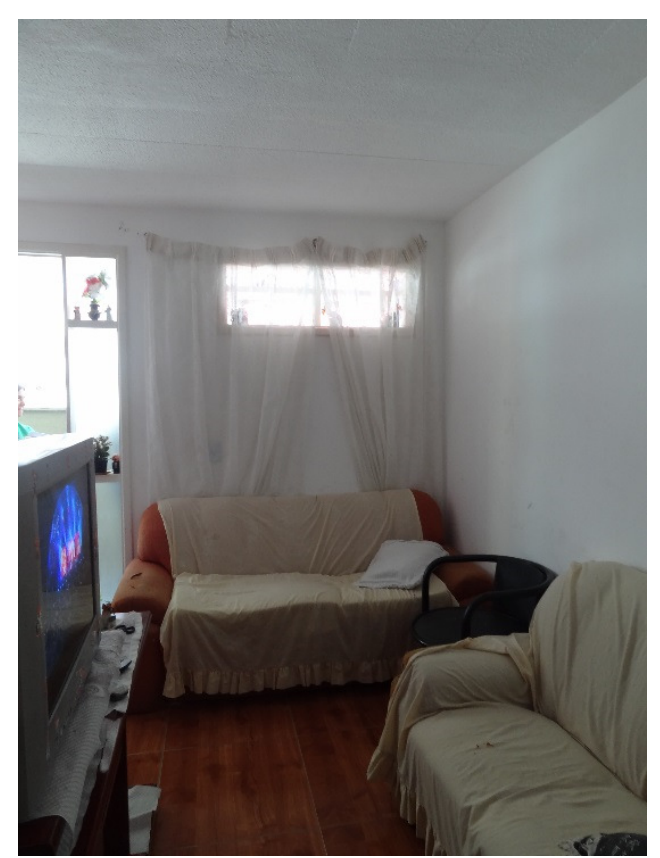

Figura 70 - Sala de estar unidade visitada Tipo 1B

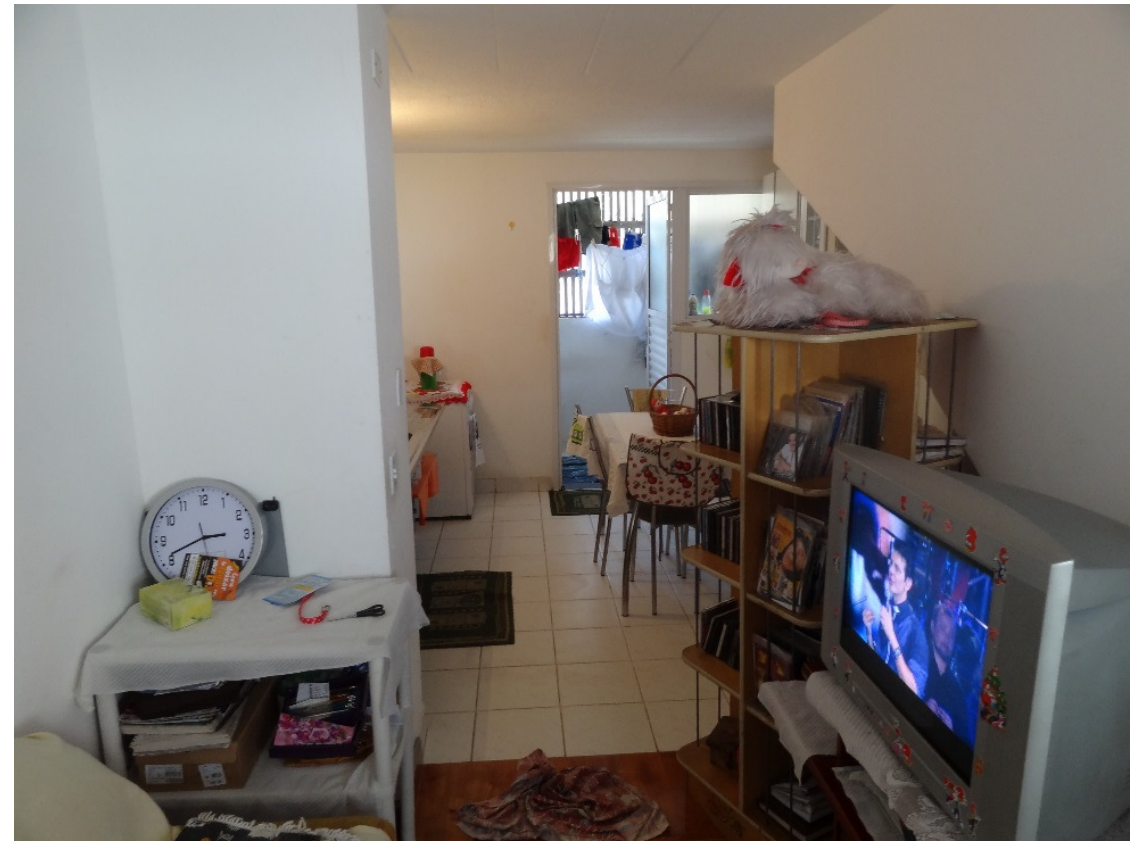

Figura 71 - Sala de estar unidade visitada Tipo 1B. Passagem para a cozinha.

No pavimento inferior, as janelas das salas de estar estão em contato direto com a passarela de circulação. Em função disso, foram especificadas janelas altas que preservassem a privacidades dos moradores.

Entre as três tipologias analisadas, duas delas têm as portas de acesso voltadas para o hall criado para ser utilizado como espaço de transição. Apenas o Tipo 1B possui a porta voltada para a passarela. As portas são um elemento que também merece atenção, pois há, na lateral, uma abertura vertical vedada com vidro translucido que aumenta a iluminação no interior da unidade e permite que os moradores vejam, ainda que de forma distorcida, as pessoas que passam pela passarela ou que batem na porta de suas casas. 
Durante as visitas realizadas, foi possível perceber que muitos moradores se apropriaram dessa abertura colocando enfeites, imagens de santos, etc. Essa apropriação agrega identidade às portas das casas.

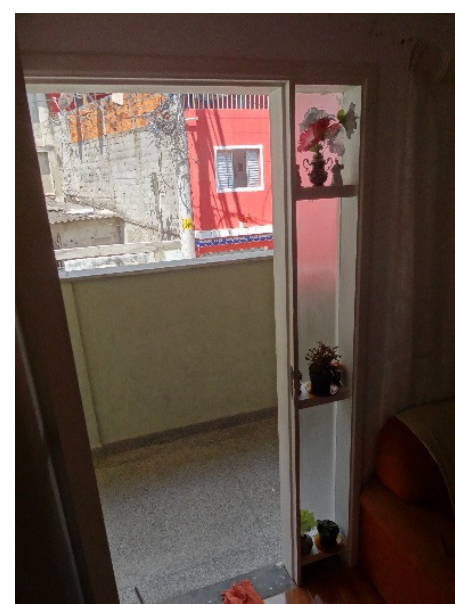

Figura 72 - Tipo 1B.

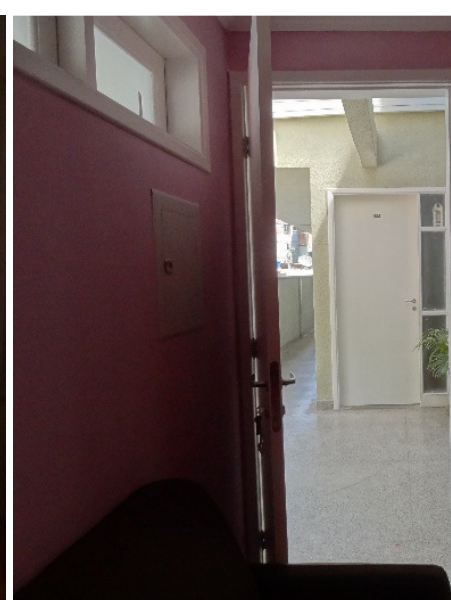

Figura 73 - Tipo 1D

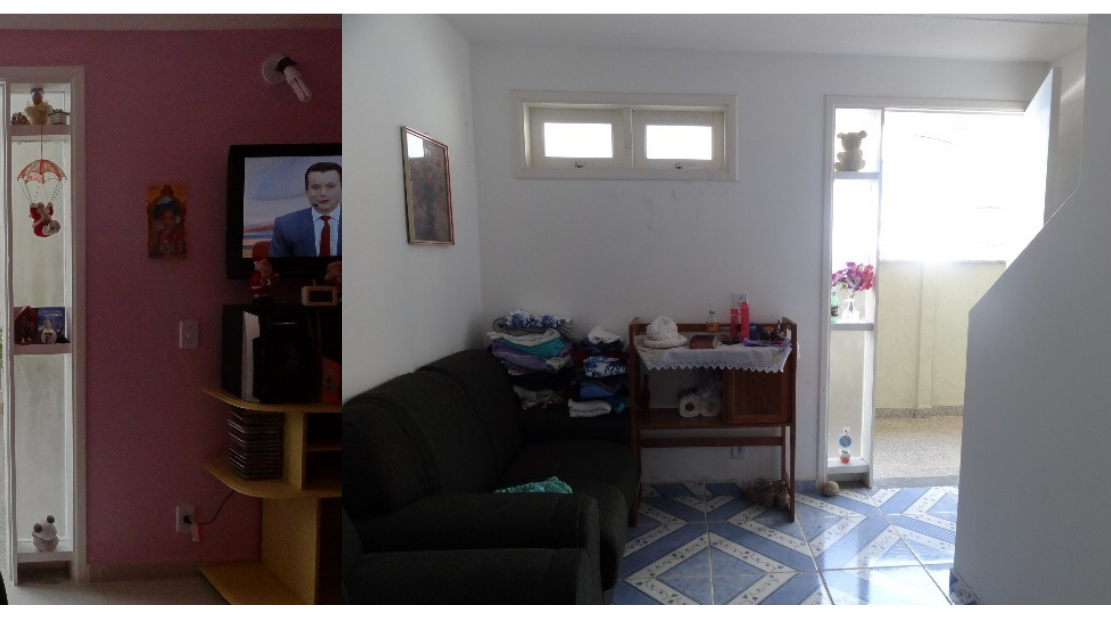

Figura 74 - Tipo 1B

Tratando-se do tema da identidade, também é curioso observar, com base nas visitas realizadas, as cores que os moradores utilizam para pintar suas casas. Em muitos casos foi possível verificar cores bastante fortes que reafirmam a identidade dos apartamentos. Essa situação foi observada nesse capítulo, mas como já foi possível notar, acontece também nos outros projetos.

No pavimento superior os dormitórios apresentam dimensões confortáveis permitindo flexibilidade de uso, pois possibilitam várias disposições de mobiliário.

É valido destacar ainda a posição das janelas que, por estarem no meio do ambiente, permitem que os armários sejam colocados encostados nas paredes. Podemos considerar, ainda, situações em que duas camas de solteiro são colocadas no dormitório deixando a janela no centro, como foi observado durante as visitas (Figura 75). 
As janelas especificadas para os dormitórios são retangulares e altas, possuindo a parte de baixo também em vidro. Entretanto, durante a visita foi possível perceber que muitos moradores colocam panos na parte inferior das janelas tentando bloquear a visão. Questionada sobre a situação, uma moradora comentou que a visibilidade da parte de baixo das janelas tirava a privacidade e por isso havia decidido tampar.

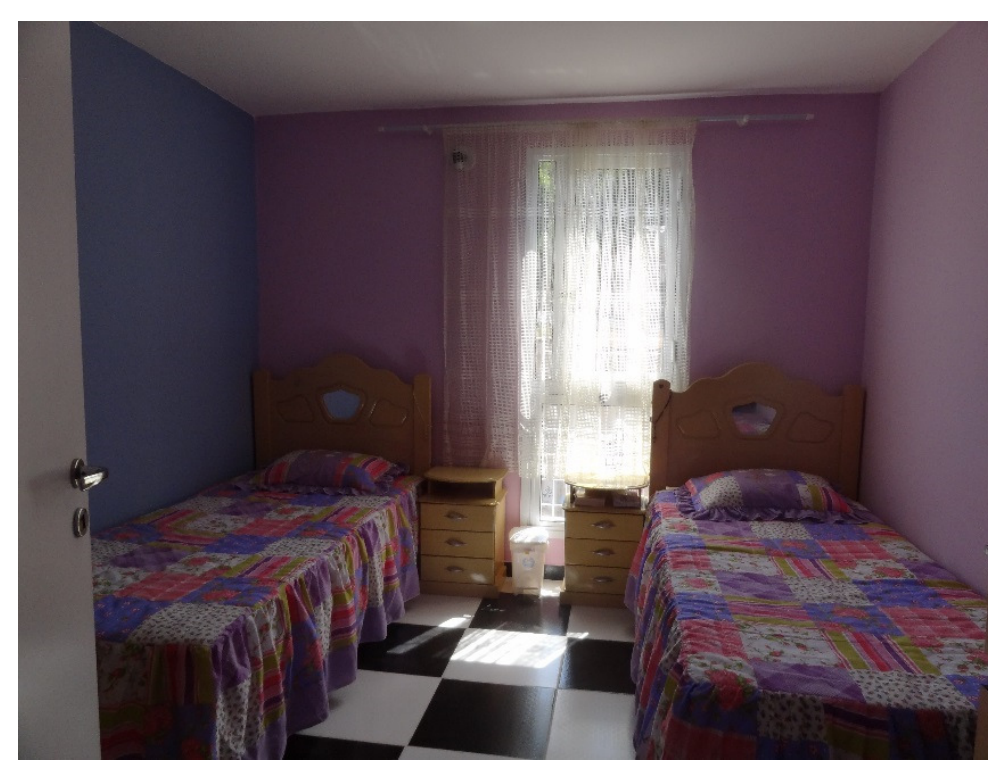

Figura 75 - Dormitório com duas camas de solteiro. Unidade visitada. Tipo 1D.

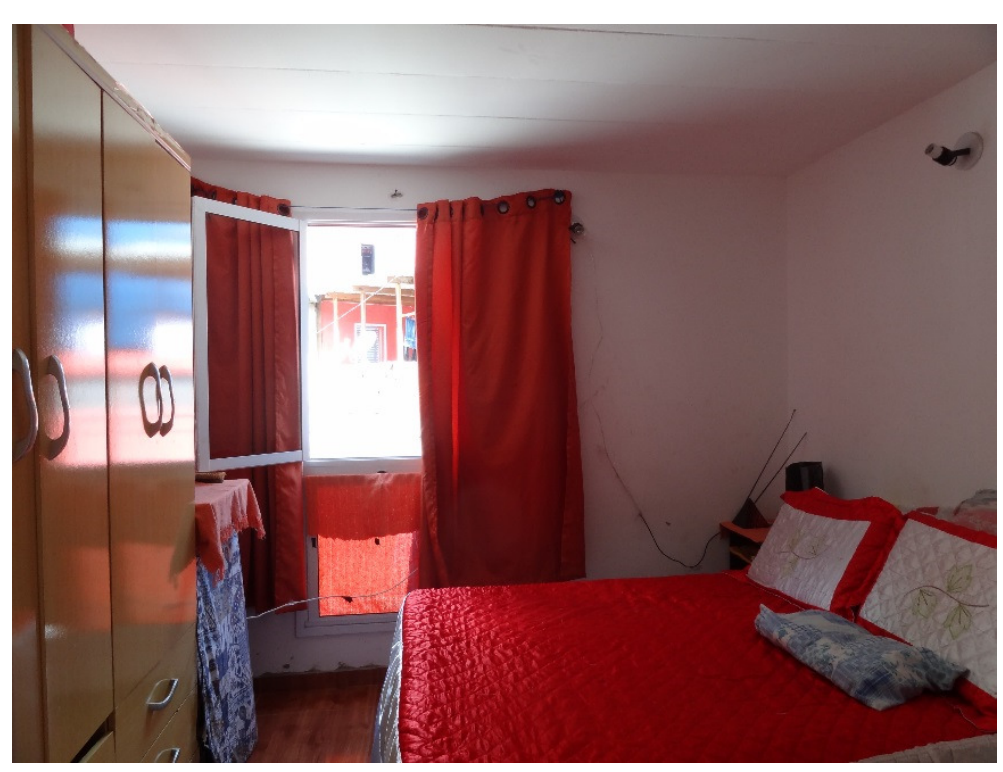

Figura 76 - Dormitório com cama de casal. Unidade visitada. Tipo $1 \mathrm{~B}$.

Das três tipologias, o Tipo C é o único que possui três dormitórios. Ao observar a planta do pavimento, nota-se que esse terceiro dormitório apresenta dimensões bastante generosas. O Tipo $C$ também conta com um espaço, ao lado da escada, que pode ser utilizado para estudo ou área de trabalho, porém esse espaço não possui iluminação natural direta e depende dos outros ambientes para ventilar. 


\section{Ambientes} especializados

Cozinhas e áreas de serviço localizam-se no pavimento inferior enquanto que os banheiros encontram-se no superior. A concentração e distribuição das tubulações para as áreas molhadas se dá através dos shafts localizados em posições estratégicas nas plantas.

Em todas as unidades visitadas as moradoras utilizaram a parede da escada para colocar os armários e a mesa ficou no meio da cozinha. Na maioria dos casos, o espaço embaixo da escada foi utilizado para colocar geladeira, armários para a cozinha, um pequeno depósito ou até mesmo espaço para a casinha de gato, como foi visto em um dos apartamentos visitados. Isso comprova a máxima utilização dos espaços.
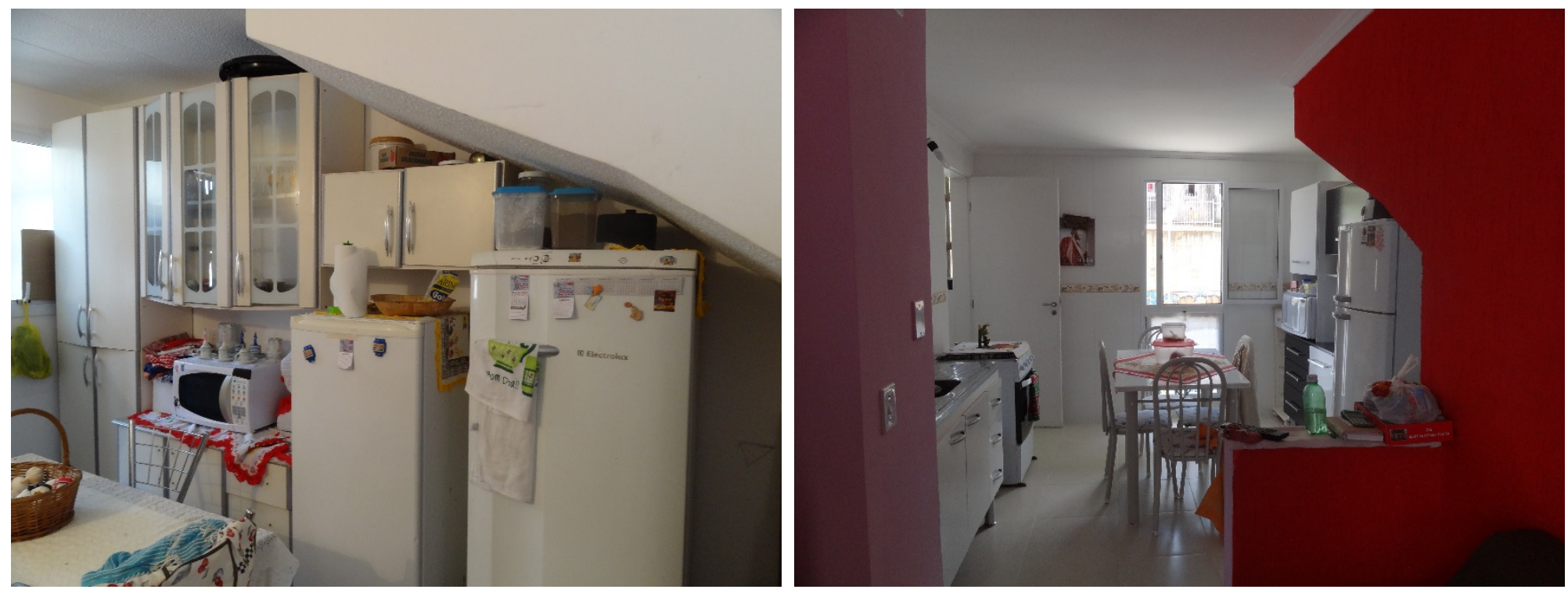

Figura 77 - Cozinha Tipo 1B. A moradora possui 2 geladeiras e armários ao longo da parede da escada.

Figura 78 - Geladeira e armários na parede e mesa ao centro. Tipo $1 \mathrm{D}$. 
As áreas de serviço são acessadas através das cozinhas, mas há fechamento com portas (tipo 1C e tipo 1D) ou portas e janelas (1B) que preservam esse espaço do campo de visão de quem entra na unidade. Esses ambientes são vedados com elementos vazados e, portanto, possuem ventilação permanente sendo considerados assim como um espaço exterior da unidade.

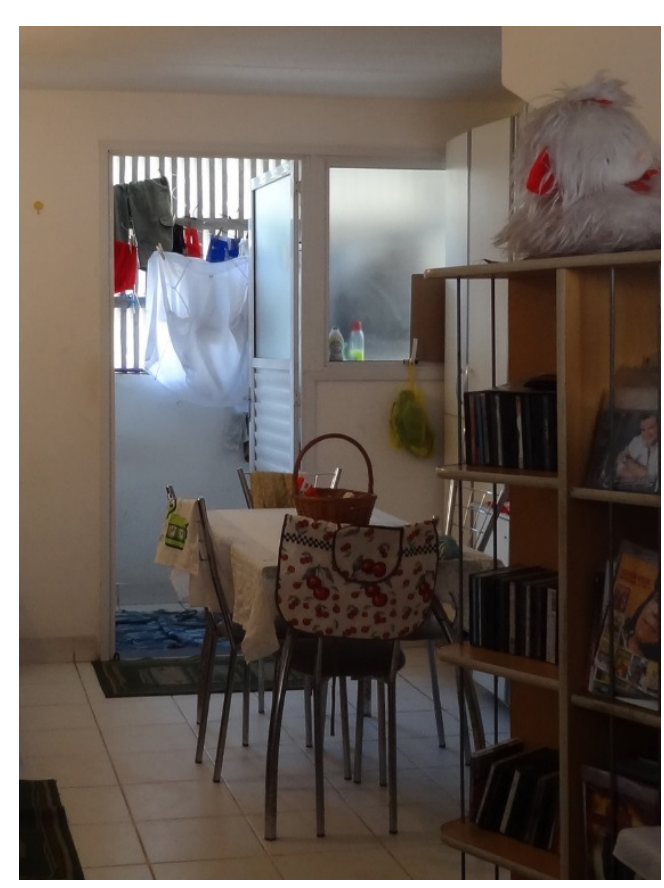

Figura 79 - Porta e janela separando cozinha da área de serviço. Tipo $1 \mathrm{~B}$.

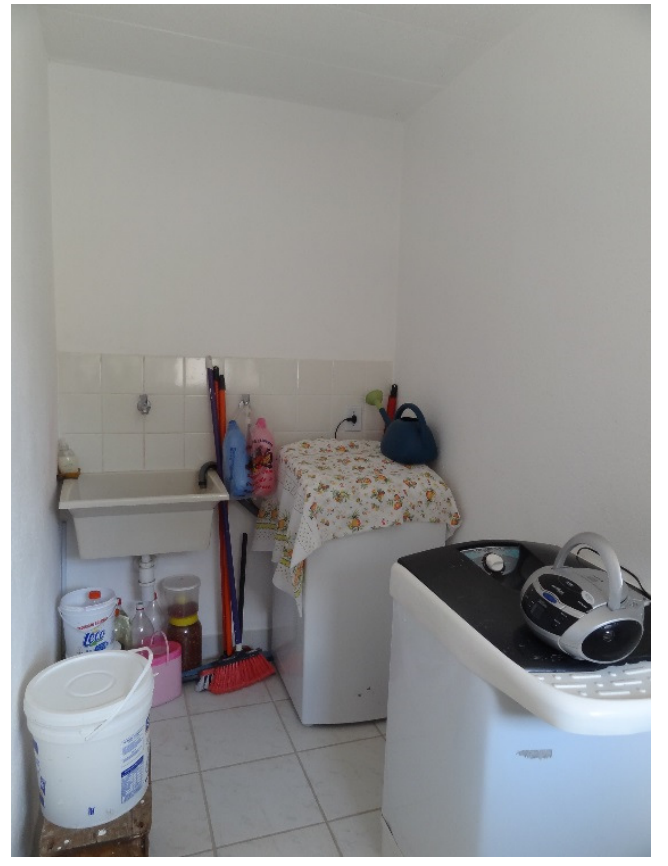

Figura 80 - Área de serviço Tipo 1D.

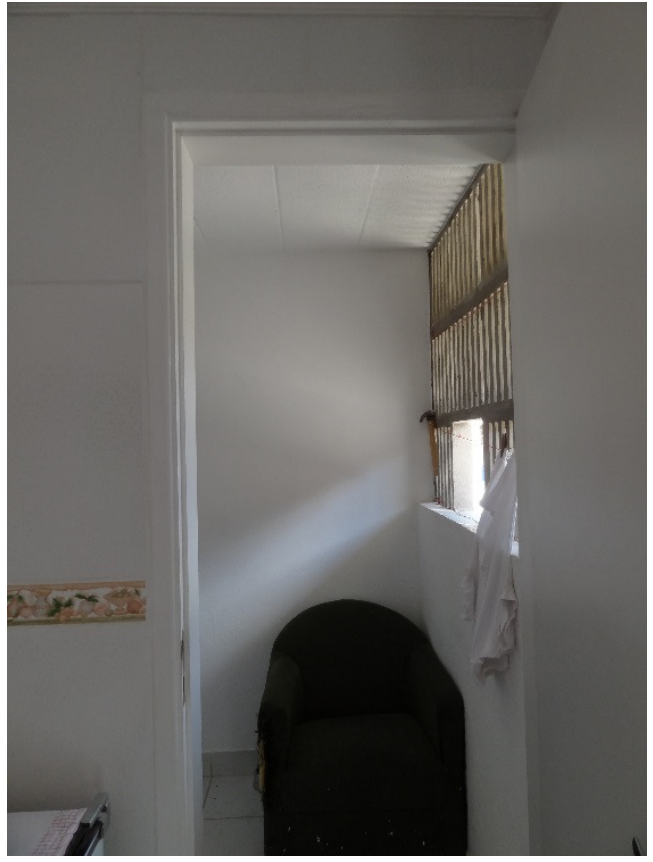

Figura 81 - Porta que separa a cozinha da área de serviço. Tipo 1D. Notar "janela do grito".

Os banheiros estão localizados no meio das plantas do pavimento superior e, por isso, foi necessário encontrar uma forma de garantir a ventilação e iluminação desses ambientes. Para isso, a solução projetual adotada foi 
aumentar a altura interna dos banheiros até que ultrapassassem a laje da cobertura permitindo que janelas de veneziana fossem colocadas na parte superior.

Nos cortes abaixo é possível verificar a solução de ventilação de cada um dos banheiros das três tipologias estudadas.

Com exceção do Tipo C, os outros dois possuem banheiros que permitem o uso simultâneo devido à separação das funções.

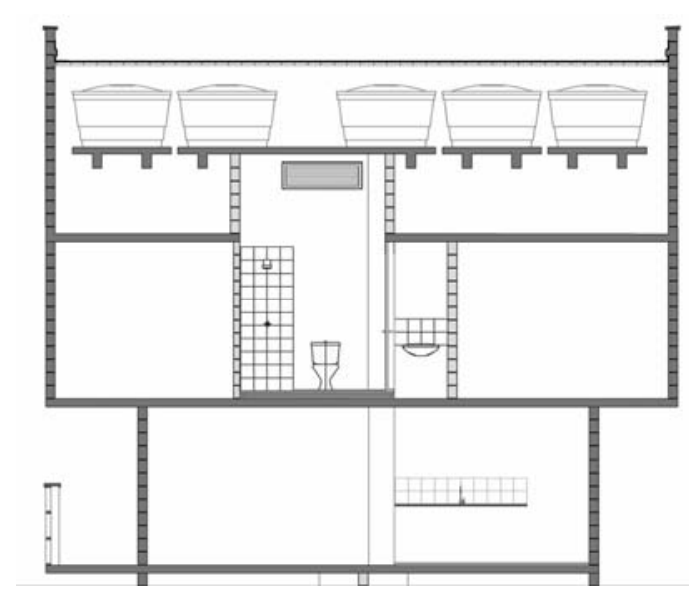

Figura 82 - Corte Tipo 1B

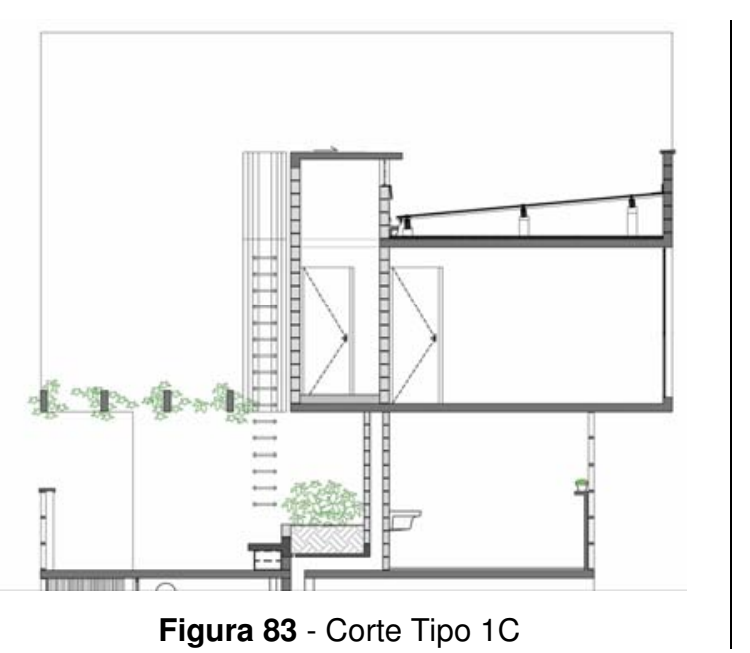

Figura 83 - Corte Tipo 1C

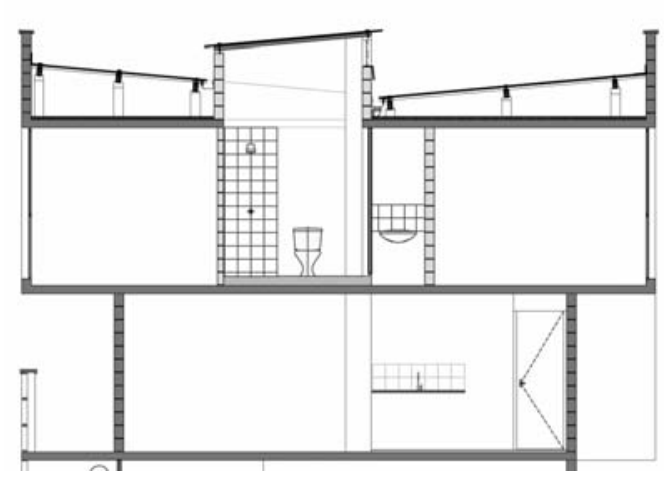

Figura 84 - Corte tipo 1D 


\section{Relação entre os}

ambientes

Cozinhas e salas são ambientes integrados espacialmente, mas essas tipologias oferecem a possibilidade de isolamento da cozinha, caso os moradores assim o desejem.

Em uma das unidades visitadas, a moradora construiu apenas uma mureta baixa que, segundo ela, ajudou a organizar melhor os espaços (Figura 78).

Analisando-se o ciclo da roupa percebe-se que as áreas de serviço apresentam dimensões adequadas às atividades realizadas em seu interior e que, por estarem no pavimento inferior, faz-se necessário que o percurso da roupa sejam maior, circulando por toda a unidade.

\section{Espaço exterior \\ próprio}

Assim como no Tipo 1A, as áreas de serviço foram consideradas como espaço exterior próprio das unidades.

Além disso, também podemos considerar que o espaço de transição - o hall entre as unidades tipo 1C e 1D - é um espaço exterior que pode ser apropriado pelos moradores como extensões de suas casas, aproveitando esse espaço para cultivar uma horta ou sentar para conversar com os vizinhos. 


\subsubsection{TIPO 2A}

O Tipo 2A ocorre apenas nos primeiros pavimentos dos blocos 5 e 6 . Por localizarem-se nos andares do edifício abaixo do nível da Rua Francisca Queirós, possuem aberturas apenas para a face leste. Por isso, são tipologias mais retangulares com uma área maior em contato com o exterior. A disposição dessas unidades não permite ventilação cruzada.

O acesso aos ambientes se dá através de um corredor que é o trecho que menos recebe iluminação em toda a unidade.

\section{Ambientes não \\ especializados}

Os dormitórios são ambientes grandes, sendo que um deles chega a medir, em seu comprimento, 5,11m. Ao analisar a variação desse tipo, o Tipo 2E, que é uma unidade adaptada para pessoas com necessidades especiais, vemos que um trecho do maior dormitório é ocupado por um canteiro. Isso ocorre nas unidades do térreo, pois dessa forma, foi possível oferecer um pouco de privacidade às janelas dos dormitórios através da utilização do canteiro como um filtro.

\section{Ambientes}

especializados

As áreas molhadas estão concentradas no centro da unidade. Banheiro e cozinha ventilam através da área de serviço que possui ventilação permanente devido ao fechamento em elementos vazados. 


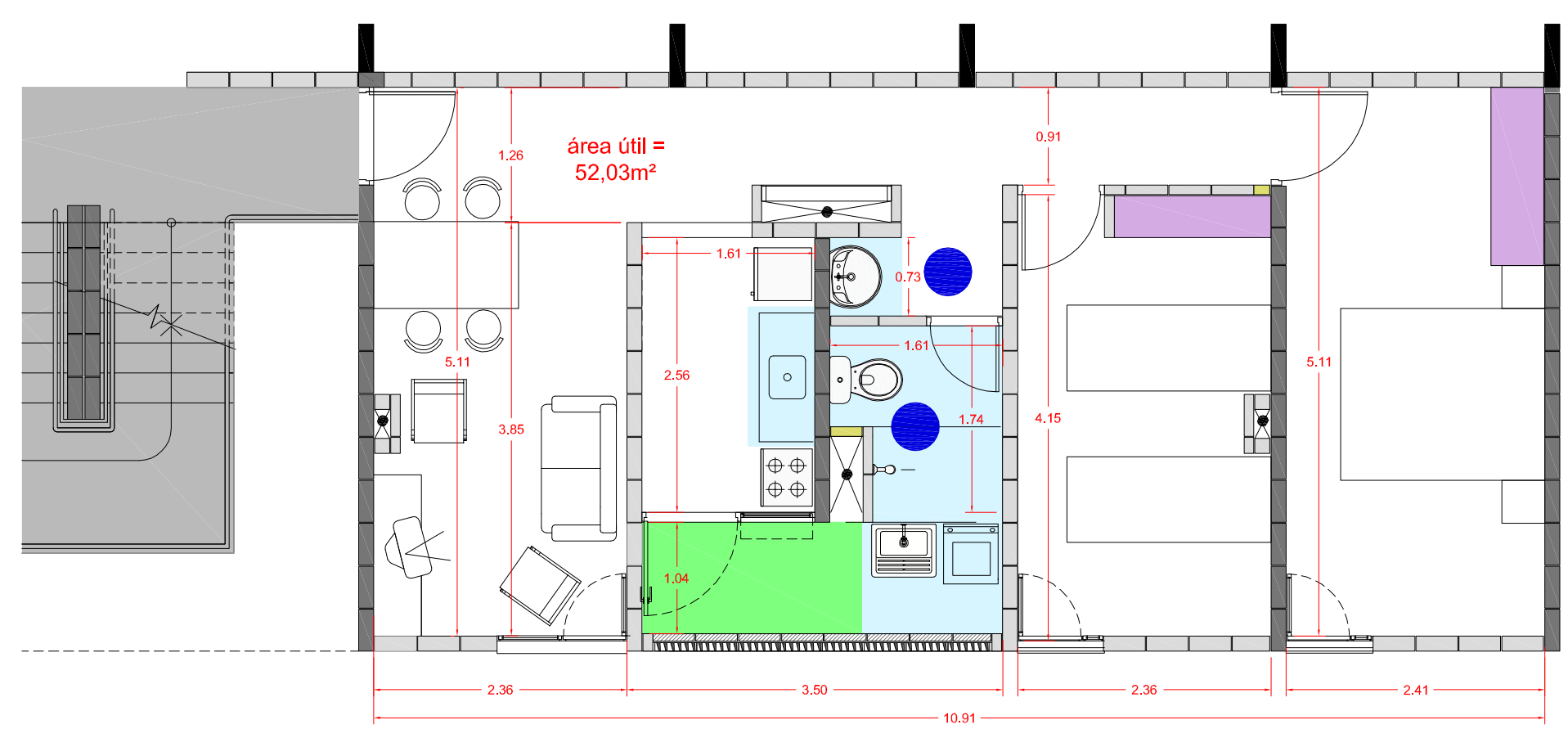

PLANTA TIPO 2A - layout e dimensões. escala 1:75

\section{0cm $1 \mathrm{~m} \quad 2 \mathrm{~m}$}

$\square$ concentração das áreas molhadas

$\square$ espaço exterior próprio

apropriação do espaço de transição como espaço exterior próprio

$\square$ espaços para guardar

$\square$ espaços de estudo/trabalho

uso do banheiro

1 pessoa

$\square$ Alvenaria de Bloco estrutural / lajes

$\square$ Alvenaria de Bloco de vedação

Alvenaria de Bloco de vedação (paredes baixas)

IIII) Elemento vazado de concreto

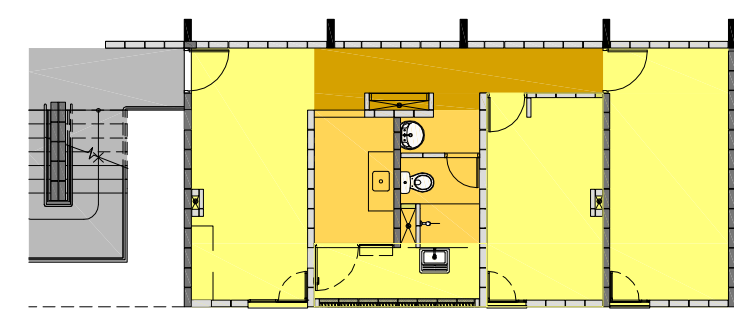

ESQUEMA ILUMINAÇÃO E VENTILAÇÃO

(orientação de referência: conjunto 6 )

\section{${ }_{N} \bigcirc_{\text {blocos } 5 \text { e } 6 \text { bloco } 7}$}

escala 1:200

$$
\Pi+
$$

iluminado

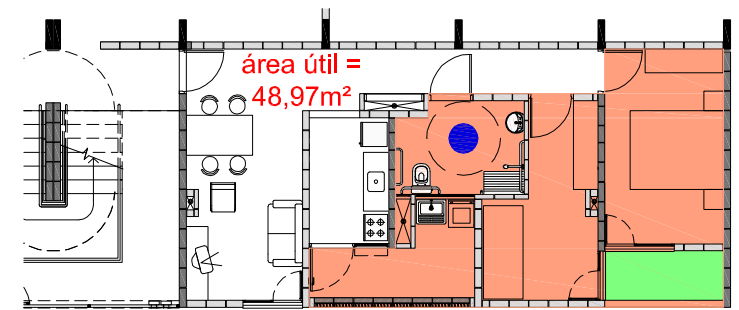

PLANTA TIPO 2E (conjunto 5) adaptado P.N.E.:

- banheiro

área de serviço

- dormitórios

canteiro como filtro de privacidade das

unidades do térreo

$\square$ destaque para as variações entre os tipos

escala 1:200

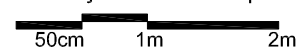

PLANTA TIPO 2A - ciclo da roupa escala 1:150

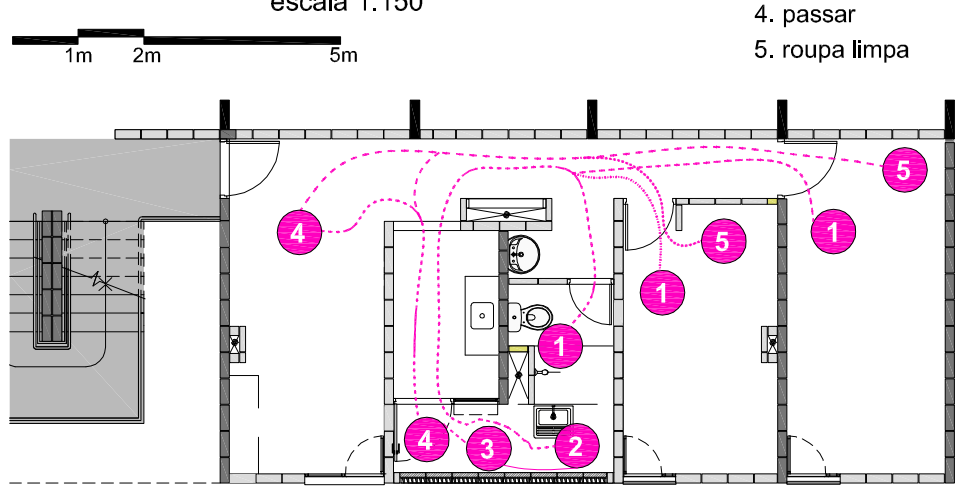

Figura 85 - Análise Tipo 2A. 
Entre todas as tipologias estudadas desse projeto, essa é a que apresenta cozinha de menor dimensão. Nos outros casos, os layouts desenhados pelo escritório de arquitetura propunham uma mesa dentro da cozinha. Essa é a única tipologia do Santo Amaro $V$ que tem a mesa desenhada na sala devido às dimensões enxutas da cozinha.

\section{Relação entre os}

ambientes

No tipo 2A, sala e cozinha não estão diretamente relacionadas e, como foi dito, a cozinha tem dimensões reduzidas contando com a extensão da sala para complementar seu espaço.

A área de serviço também não tem dimensões tão generosas quanto as outras tipologias analisadas, mas ainda assim oferece espaço mínimo para a realização das atividades ai desenvolvidas.

\section{Espaço exterior}

próprio

Nessa tipologia também consideraremos a área de serviço como espaço exterior próprio. Vale ainda ressaltar o canteiro proposto no Tipo $2 \mathrm{E}$ que funciona como filtro de privacidade e espaço exterior próprio protegendo um pouco as janelas das unidades do térreo (Figura 86).

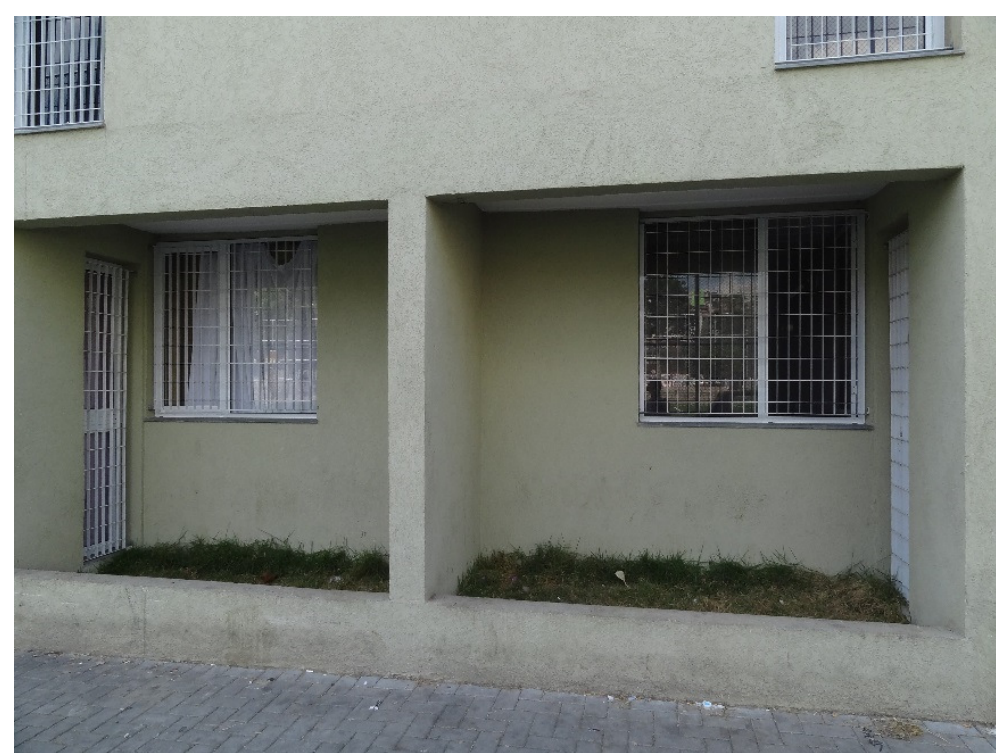

Figura 86 - Canteiros atuando como filtro de privacidade no térreo dos 


\section{Variações do Tipo 2A}

O Tipo 2E foi classificado como variação do Tipo 2A, pois se trata da mesma tipologia que, neste caso, foi adaptada para pessoas com necessidades especiais (P.N.E.). Essa tipologia ocorre apenas no térreo do Conjunto 5.

Como pôde ser observado na Figura 85, o banheiro foi ampliado, diminuindo, com isso, as dimensões de um dos dormitórios. Com a alteração do tamanho do banheiro, a área de serviço ficou maior, possibilitando que um cadeirante entre e utilize adequadamente esse espaço.

\subsubsection{TIPO 2B}

O tipo 2B ocorre nos andares superiores dos edifícios do Conjunto 2 e são acessados a partir da Rua Francisca Queirós. Cada caixa de escada acessa a dois apartamentos por andar.

Por estarem nos andares superiores, essas unidades possuem ventilação cruzada e, como já foi ressaltado em outras tipologias analisadas, o alinhamento das portas e janelas proporciona uma ventilação ainda melhor. Cozinha e banheiro são ambientes um pouco menos iluminados, pois têm as janelas voltadas para a área de serviço que, devido ao fechamento em elementos vazados, acaba filtrando a luz natural.

Essas unidades têm aberturas voltadas para as faces leste e oeste.

Através do croqui, desenhado por Hector Vigliecca, é possível visualizar os conceitos contidos nessa unidade. Nota-se claramente que os espaços foram concebidos a partir de um estudo cuidadoso sobre os percursos realizados dentro das casas e sobre as atividades cotidianas (Figura 87).

Analisando-se o croqui é possível identificar seis pessoas, distribuídas nos ambientes, realizando diferentes atividades. Nota-se o espaço para secar e passar as roupas dentro da área de serviços; é possível notar a 
importância da mesa que, quando não está sendo utilizada durante as refeições, serve como espaço para estudar ou trabalhar; o espaço para estudo dentro do dormitório; a divisão de funções do banheiro a partir da separação da pia e das outras peças, etc.

Devemos observar, ainda, a vegetação colocada nas janelas graças ao recuo adotado que, por um lado, cria espaço para um armário no interior e, por outro, proporciona esse "espaço exterior próprio" para ser apropriado pelos moradores (Figura 88).

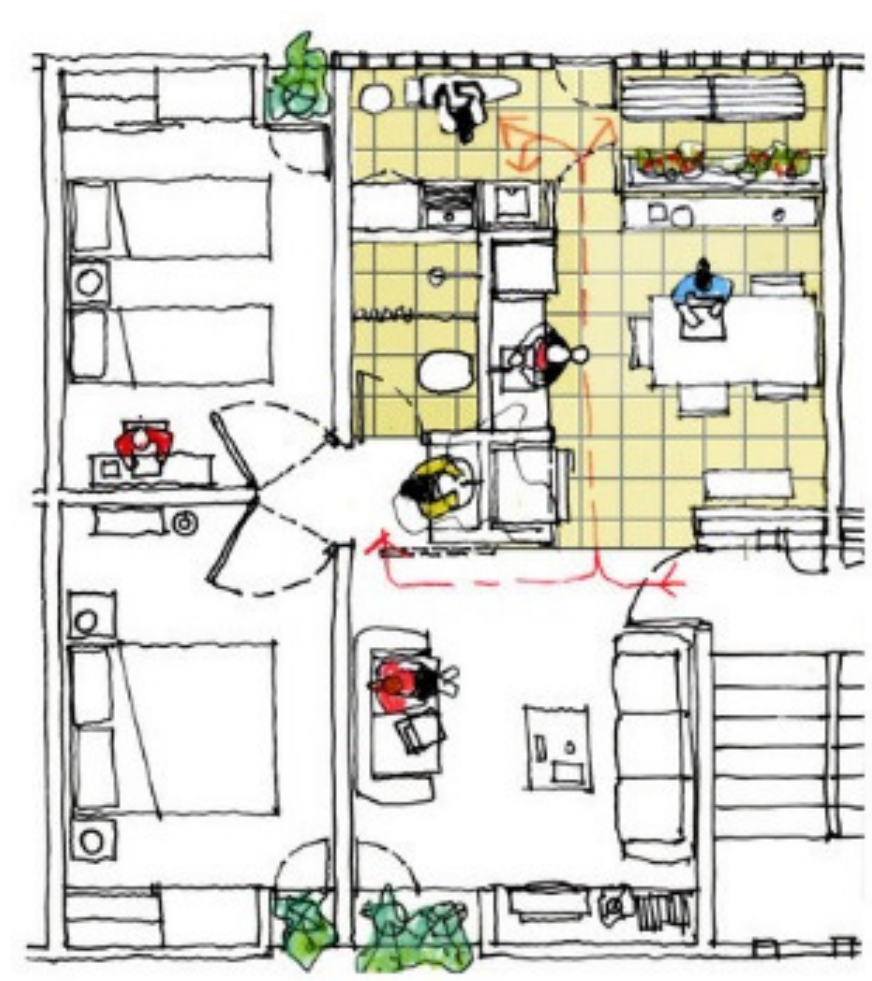

Figura 87 -- Croqui de Hector Vigliecca. Tipo 2B.

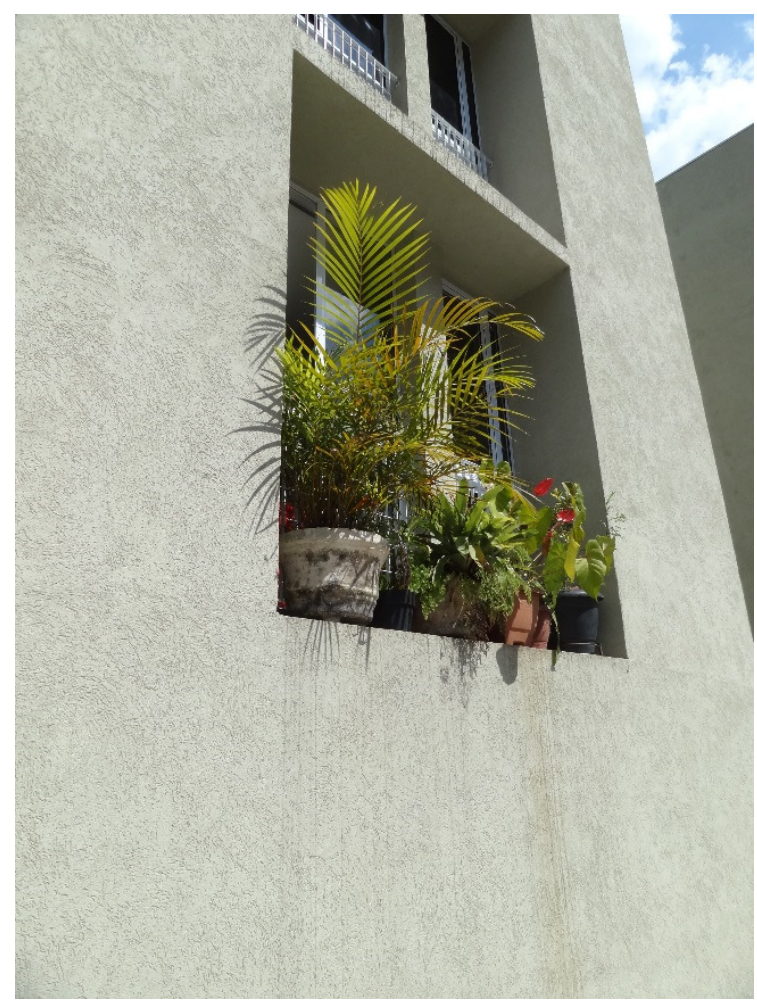

Figura 88 - Apropriação dos recuos das janelas. 


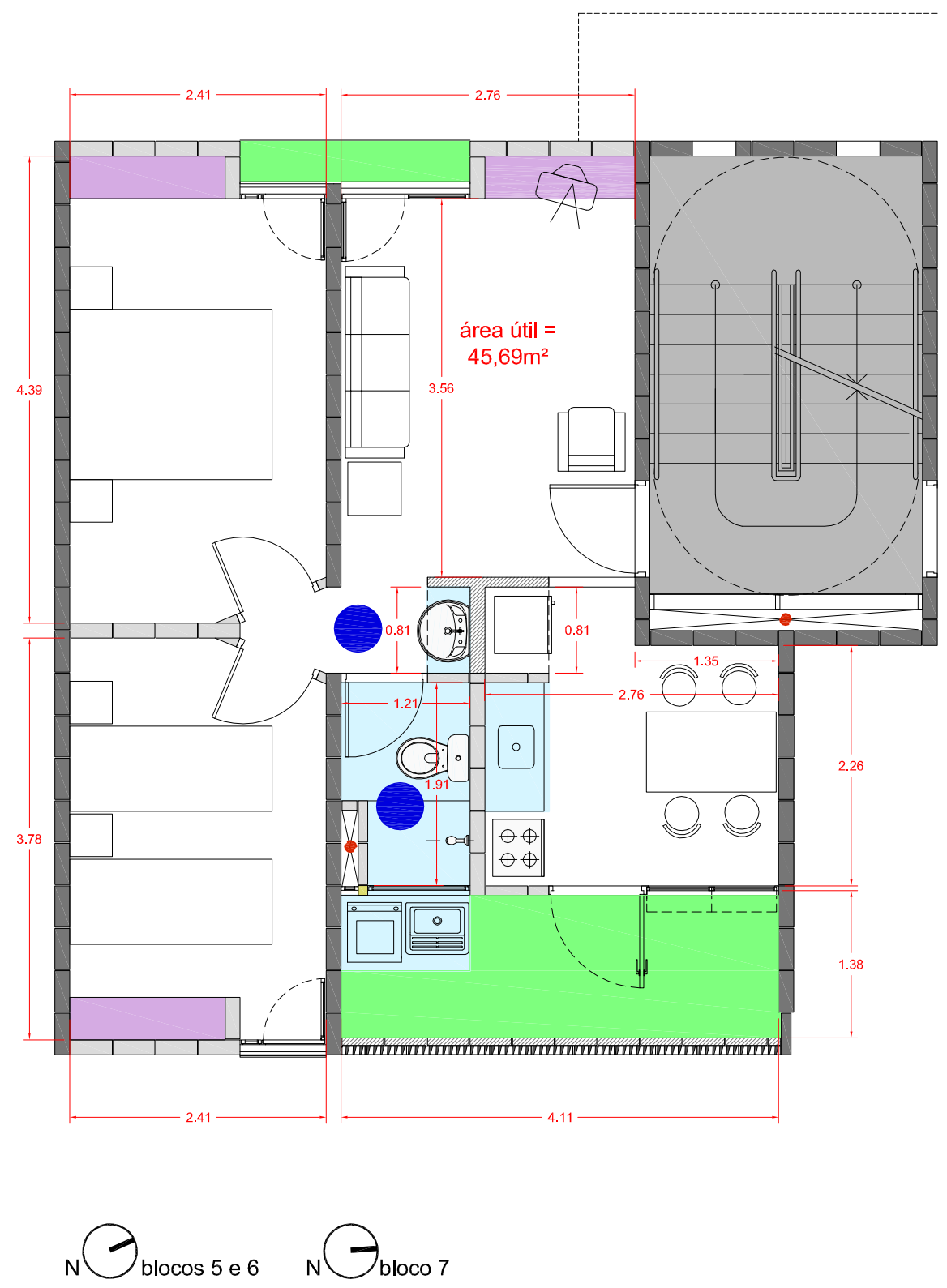

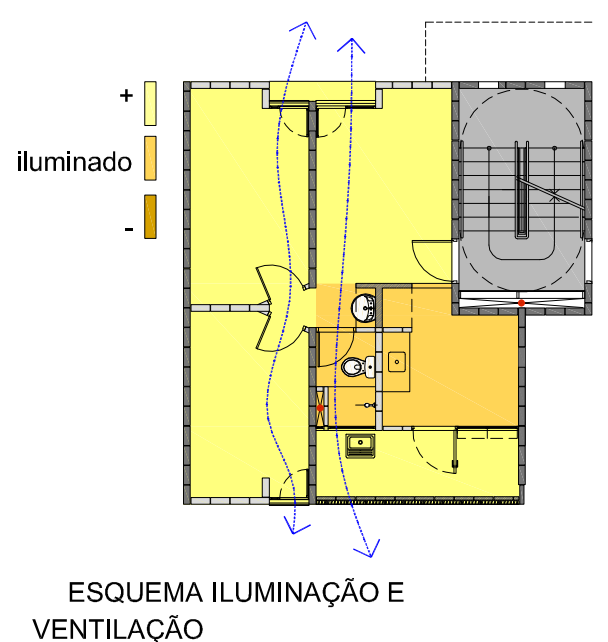
VENTILAÇÃO

6)

(orientação de referência: conjunto

$\square$ Alvenaria de Bloco estrutural / lajes

$\square$ Alvenaria de Bloco de vedação

Alvenaria de Bloco de vedação

(paredes baixas)

IIIm Elemento vazado de concreto

CICLO DA ROUPA:

1. roupa suja

2. lavar

3. secar

4. passar

5. roupa limpa

escala 1:200

PLANTA TIPO 2B - ciclo da roupa escala 1:150
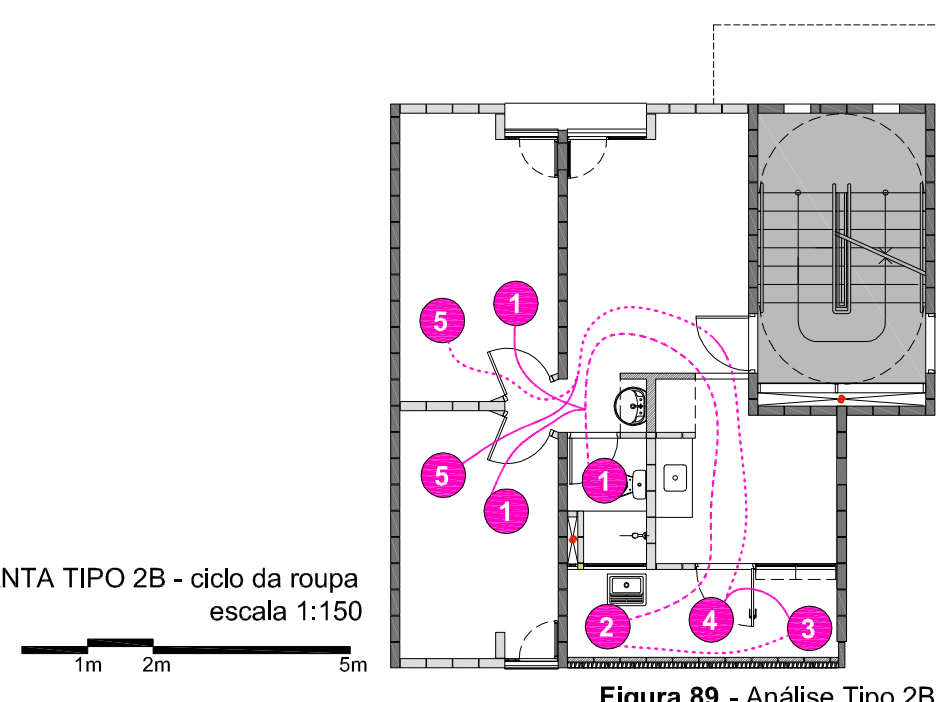


\section{Ambientes não}

especializados

Sala de estar e dormitório são ambientes com espaços generosos e todos possuem espaços para os armários já concebidos pelo projeto.

\section{Ambientes}

especializados

As áreas molhadas estão concentradas na unidade; o banheiro possui funções separadas, possibilitando que mais de uma pessoa o utilize ao mesmo tempo; e a área de serviço possui dimensões adequadas ao desenvolvimento das atividades de cuidado da roupa.

Essa tipologia apresenta-se bastante semelhante ao Tipo $1 \mathrm{~A}$ e, como nesse outro, tem o nicho para a geladeira e para a pia do banheiro. As paredes desse nicho são mais baixas incentivando que os moradores coloquem plantas sobre ele.

\section{Relação entre os}

ambientes

Cozinha e sala não são integradas, mas possuem relação entre elas.

É interessante notar que, nessa tipologia, praticamente não há corredor ou hall de acesso aos dormitórios. A disposição dos ambientes e a relação entre eles permite aproveitar ao máximo os 45,69m² dessa unidade. 
O ciclo da roupa ocorre da mesma maneira que nos outros tipos analisados e, nesse caso, como vimos no croqui realizado pelo arquiteto, há espaço suficiente para que a roupa seja lavada, secada e passada dentro da área de serviço, sem interferir nas atividades realizadas na cozinha e vice-versa.

Observando os projetos de habitação de interesse social, há muitos casos em que cozinha e área de serviço são espaço integrados, isto é, muitas vezes parece que a área de serviço é apenas uma extensão da cozinha. Essa situação apresenta pontos negativos. Na maioria dos casos, não há um espaço adequado para que a roupa seque e os varais são propostos em cima das máquinas de lavar ou de tanques e, muitas vezes, a proximidade com os fogões prejudica muito essa função. Analisando-se as tipologias do Parque Novo Santo Amaro V, fica provado que é possível encontrar soluções de qualidade para o espaço da área de serviço. A utilização dos elementos vazados, além de proporcionar uma variedade nas fachadas, agregando maior qualidade visual e estética ao projeto, proporciona ventilação permanente a esse espaço onde colocamos roupa para secar, ou objetos guardados para "tomar ar", etc.

\section{Espaço exterior \\ próprio}

O Tipo 2B conta com dois diferentes espaços exteriores próprios na unidade: as áreas de serviço, muito importantes para o desenvolvimento das atividades de cuidado da roupa; e os recuos das janelas onde os moradores podem colocar vasos de plantas dando maior identidade a suas casas.

\section{Variações do Tipo 2B}

Os Tipos 2C e 2D são variações do Tipo 2B que possuem três dormitórios. Essas unidades são apenas oito em todo o conjunto - quatro de cada - e ocorrem na junção entre os blocos $5 \mathrm{com} 6$ e $6 \mathrm{com} 7$. Na análise dos edifícios foi possível entender que esses tipos aparecem acima dos pórticos projetados, no encontro entre os blocos. 
Ao incluir o terceiro dormitório, os outros dois existentes ficam um pouco menores para dar espaço para o corredor que aparece na unidade.

O Tipo 2D possui o dormitório em ângulo, exatamente devido ao ângulo formado entre os blocos 6 e 7 .

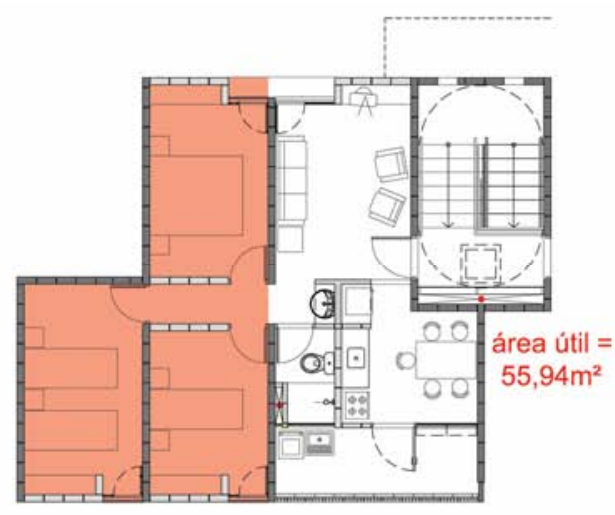

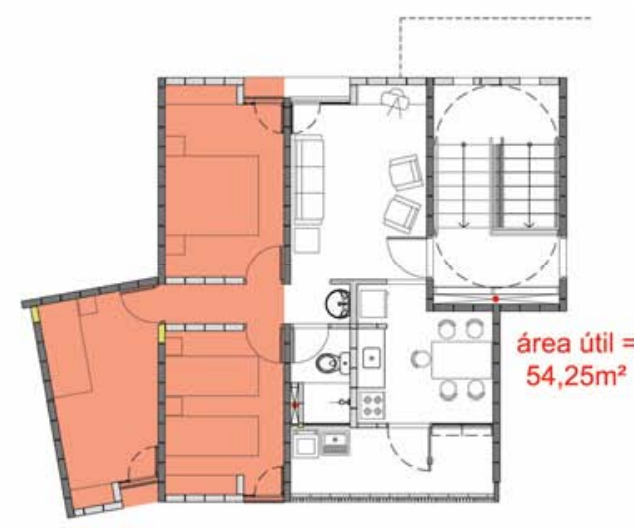

Figura 90 - Variações do Tipo 2B: Tipos 2C (esquerda) e 2D (direita).

\subsubsection{TIPO 3A}

Por fim, analisaremos o Tipo 3A que ocorre no bloco 8, o único edifício do Conjunto 3. Essa tipologia é um duplex e, como foi visto na análise dos edifícios, esse bloco configurar-se pela sobreposição de dois duplex acessados a partir de duas passarelas localizadas nos pavimentos intermediários. 


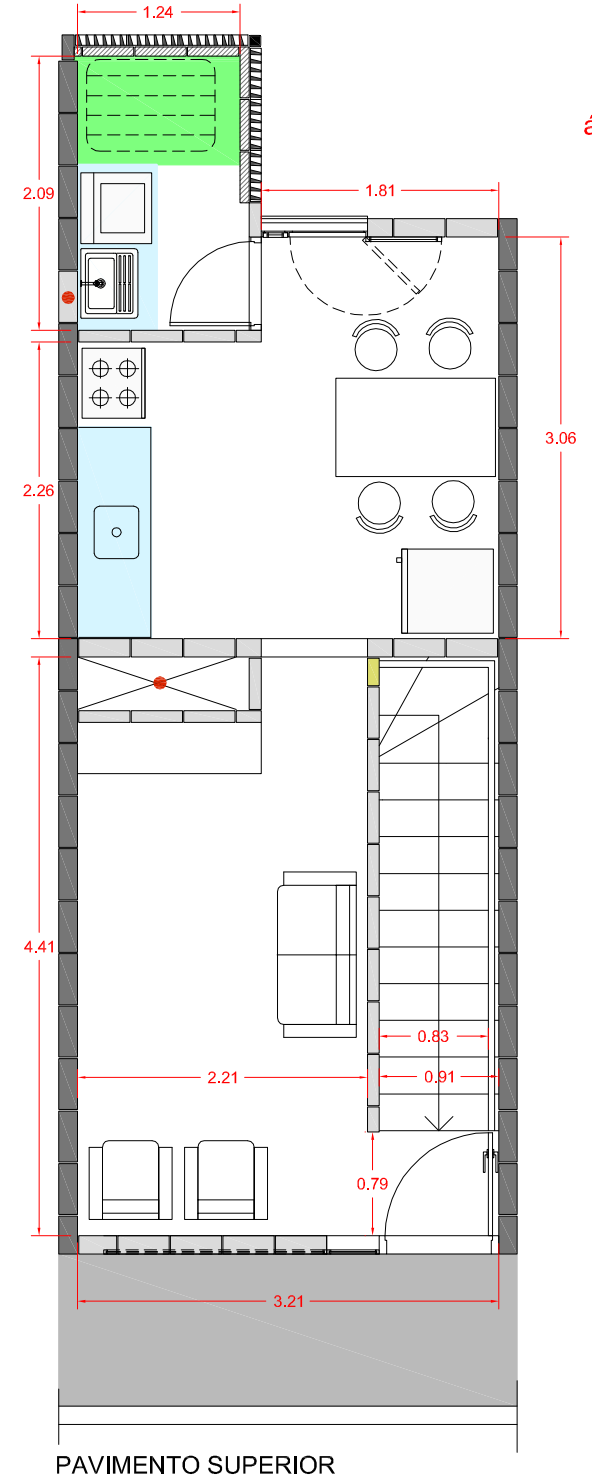

PAVIMENTO SUPERIOR

Q área útil =

$49,14 \mathrm{~m}^{2}$

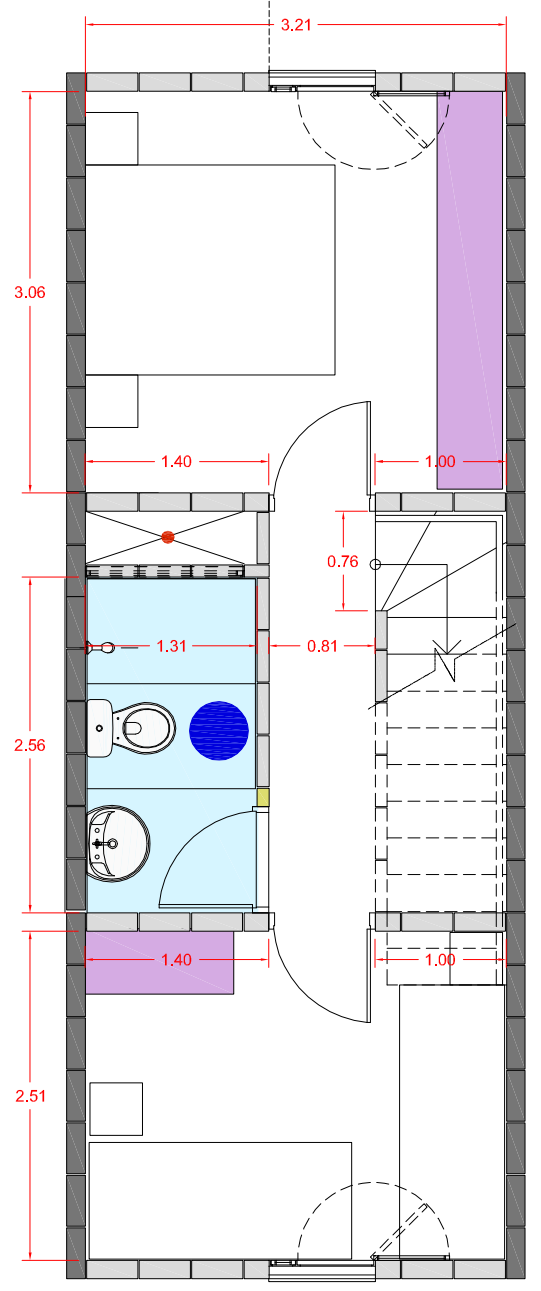

PAVIMENTO INFERIOR
PLANTA TIPO 3A - layout e dimensões. escala 1:75

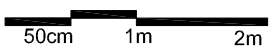

$\square$ concentração das áreas molhadas

$\square$ espaço exterior próprio

$\square$ apropriação do espaço de transição

como espaço exterior próprio

$\square$ espaços para guardar

$\square$ espaços de estudo/trabalho

$$
\begin{aligned}
& \text { uso do banheiro } \\
& 1 \text { pessoa }
\end{aligned}
$$

$\square$ Alvenaria de Bloco estrutural / lajes

$\square$ Alvenaria de Bloco de vedação

Alvenaria de Bloco de vedação (paredes baixas)

mimm Elemento vazado de concreto

\section{CICLO DA ROUPA}

1. roupa suja

2. lavar

3. secar

4. passar

5. roupa limpa

PLANTA TIPO 3A - ciclo da roupa
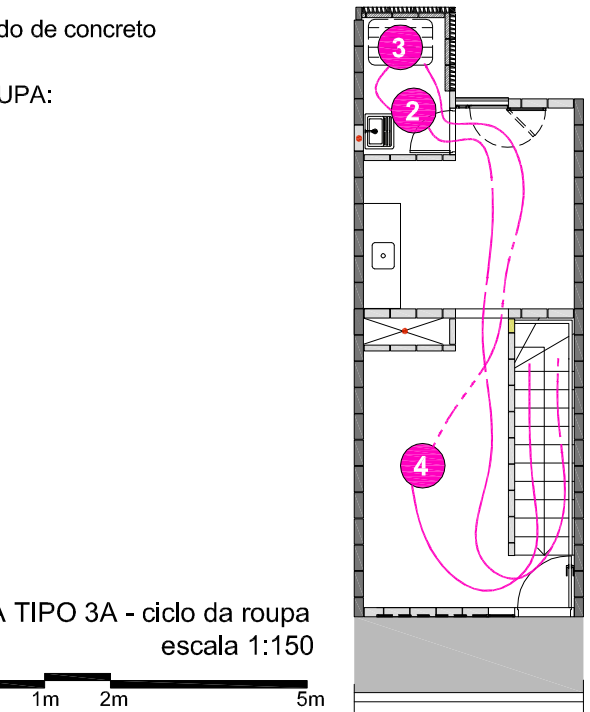

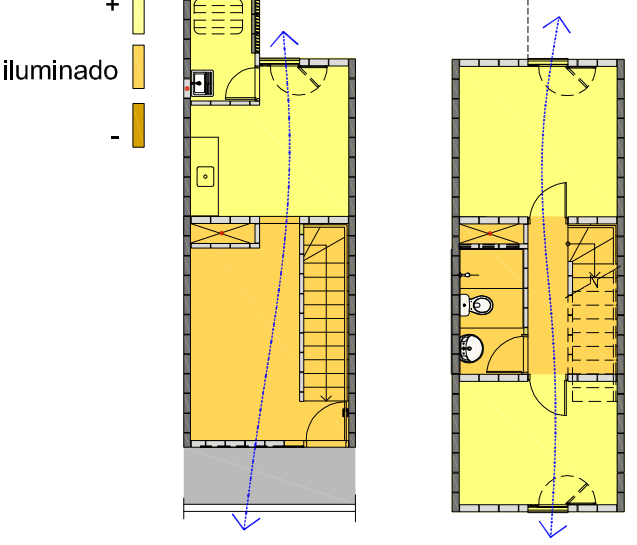

ESQUEMA ILUMINAÇÃO E VENTILAÇÃO (orientação de referência: bloco 8 )

$$
\text { escala 1:200 }
$$

Figura 91 - Análise Tipo 3A. 
Esse edifício, implantado perpendicularmente aos outros, tem fachadas voltadas para norte e sul. No pavimento superior do Tipo 3A, área de serviço e cozinha estão voltados para o sul, enquanto a sala de estar está voltada para o norte situação em que as passarela de acesso filtram um pouco a insolação norte desses ambientes. No pavimento inferior é possível verificar-se que um dormitório localiza-se na face sul e o outro na norte.

\section{Ambientes não especializados}

Os dormitórios possuem a mesma largura, porém apresentam diferença de $55 \mathrm{~cm}$ no comprimento. Ao visitar um apartamento já habitado, foi possível observar a ocupação dos ambientes conforme Figura 92.

É possível notar que a cama de casal está no quarto menor. Além disso, verifica-se também que as dimensões desse espaço estão no limite para abrigar esse mobiliário (notar aberturas da porta e da janela).

Assim como nos outros duplex estudados (1B, 1C e 1D), a sala de estar é um ambiente mais estreito e também é utilizada como espaço de passagem para acessar a cozinha.

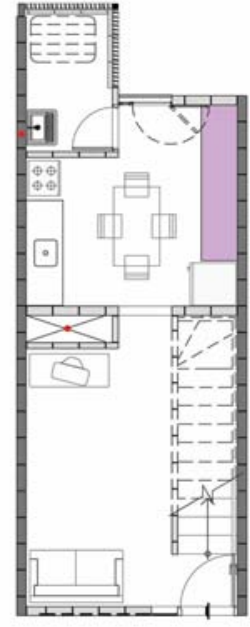

PLANTA TIPO 3B - reprodução de layout de um apartamento visitado já ocupado de um apartamento visitado já ocupado
escala 1:150

Figura 92 - Reprodução de layout de apartamento visitado. 
Outra situação que merece destaque é a posição das portas e janelas que, assim como já foi comentado em outras tipologias, proporcionam ventilação cruzada bastante eficiente para a unidade, principalmente no pavimento dos dormitórios. Quanto ao outro pavimento, a ventilação cruzada também ocorre graças à janela da cozinha e à janela alta existente na sala de estar.

As portas localizadas no meio dos ambientes permitem que armários ou outros móveis, como camas ou cômodas, sejam encostados nas paredes deixando a circulação central livre.

\section{Ambientes}

especializados

Cozinha e área de serviço localizam-se em um pavimento e o banheiro no outro. No caso dessa tipologia, a cozinha tem sua própria janela e não ventila através da área de serviço que, assim como todas as outras analisadas, é vedada com elementos vazados e possui ventilação permanente.

Os banheiros ventilam através de um duto para ventilação que atravessa todo o edifício, mas não recebem luz natural. Nessa tipologia, o banheiro não apresenta a possibilidade de uso simultâneo.

\section{Relação entre os}

ambientes

O duto de ventilação dos banheiros é um elemento que, em planta, define os espaços de sala de estar e cozinha. A relação entre esses dois ambientes ocorre através da comunicação existente entre a escada e o shaft de ventilação. 


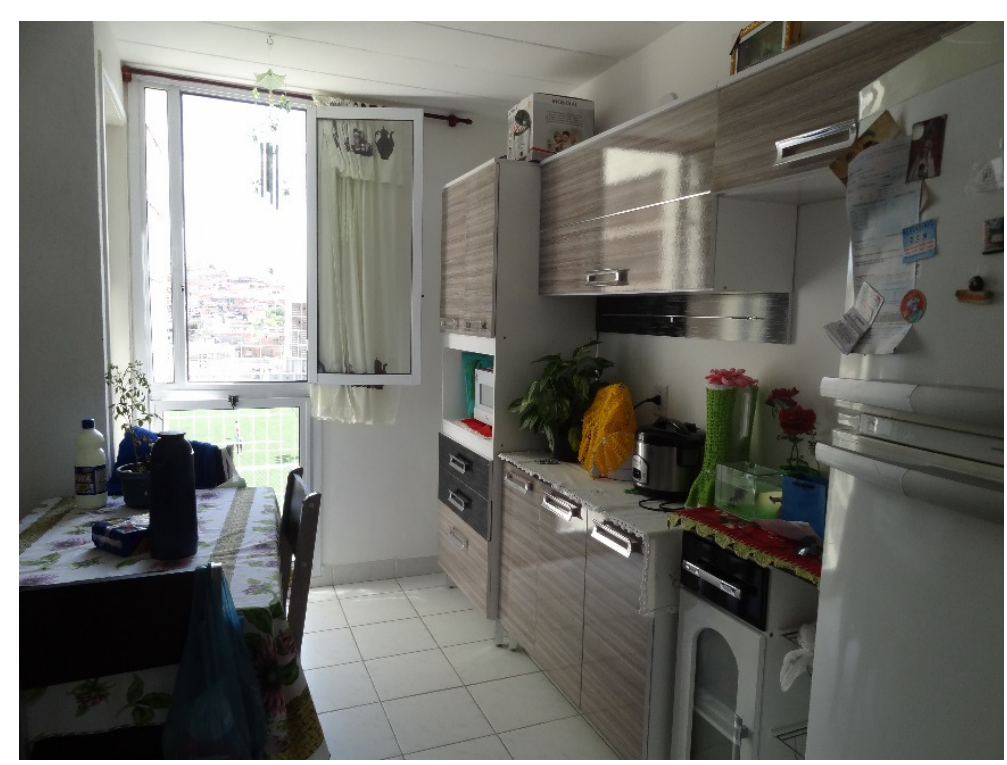

Figura 93 - Cozinha do apartamento visitado. Tipo 3B.

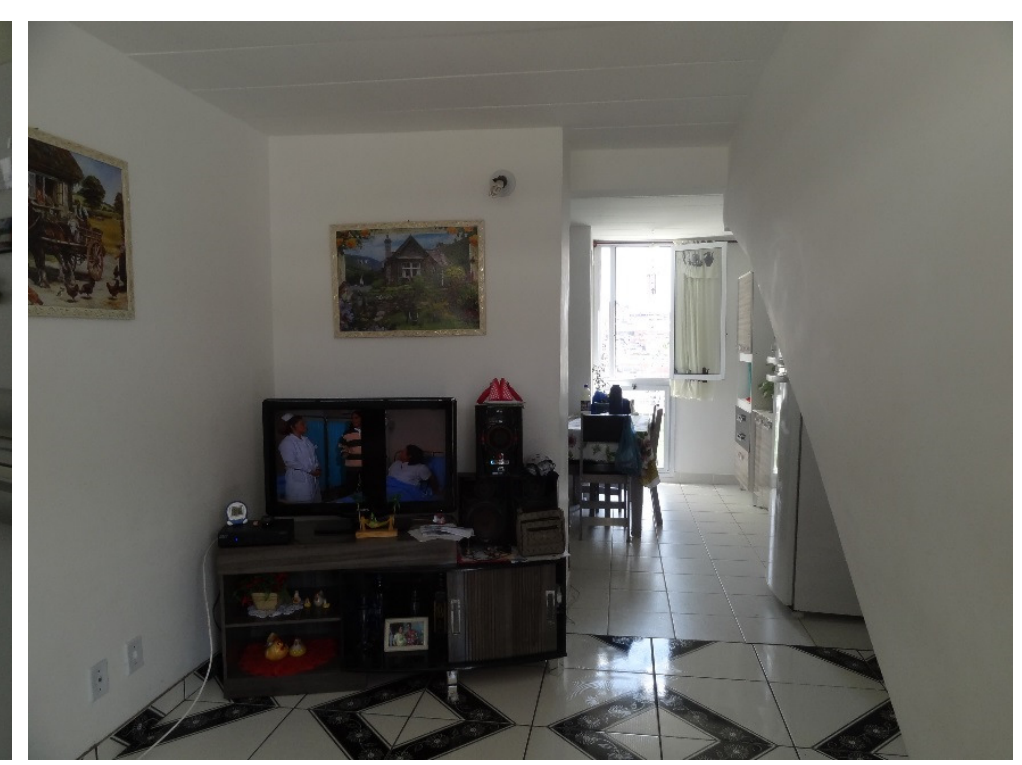

Figura 94 - Sala de estar e relação com a cozinha do apartamento visitado. Tipo 3B.

\section{Espaço exterior \\ próprio}

A área de serviço, que avança além da planta e configura volumes na fachada, é considerada como espaço exterior próprio dessa unidade. 


\section{Variações do Tipo 3A}

Os tipos 3A e 3B apresentam a mesma configuração de espaços $e$, inclusive, mesma área útil. $A$ única diferença entre os dois é o sentido das escadas: ao entrar no tipo $3 \mathrm{~A}$, é necessário descer para chegar aos dormitórios - pode-se dizer que essa tipologia seja um duplex invertido. Já o 3B, pode ser classificado como um duplex convencional que possui os dormitórios no pavimento superior.

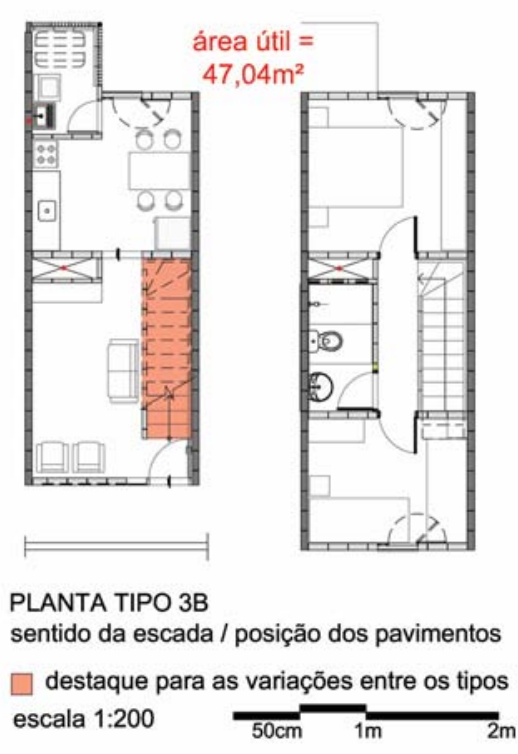

Figura 95 - Tipo 3B. Variação do Tipo 3A.

\subsubsection{CONSIDERAÇÕES}

FINAIS

O projeto do Residencial Parque Novo Santo Amaro V é, provavelmente, o mais complexo entre os quatro projetos analisados. Ao estudar esse projeto, muitos conceitos de espaço público, circulação e atividades cotidianas ficam claros e percebe-se a importância deles para a concepção do projeto.

Como consta no memorial descritivo, para o arquiteto, moradia é entendida como sinônimo de cidade e é a partir desse princípio que Hector Vigliecca e sua equipe desenvolvem grandes projetos de qualidade. Santo Amaro V não é único, apenas faz parte de uma relação de projetos de habitação de interesse social realizados pelo arquiteto. 
Entre os projetos realizados na cidade de São Paulo, pode-se citar: Rincão (1990); Vila Mara e Rio das Pedras (1991-2003); Vila dos Idosos (2003-2007); Casarão do Carmo (2003 - paralisado); Heliópolis Gleba A (2004); Heliópolis Gleba H (2013); Concurso Renova SP: perímetro de ação integrada Ribeirão dos Perus (2011).

Em uma palestra, dada no curso de pós-graduação da Universidade de São Paulo, Vigliecca declarou que os projetos de Alison e Peter Smithson são importantes referências para seus trabalhos e apresentou, como exemplo, o projeto The Economist, em Londres. ${ }^{14}$ De acordo com os conceitos dos Smithson, a cidade ideal deveria combinar atividades diferentes dentro das mesmas áreas; as "modernas" habitações deveriam ser ligadas entre si por ruas elevadas, separando a circulação de pedestres do tráfego de veículos; de acordo com os princípios defendidos pelos arquitetos, os projetos deveriam incentivar, nos moradores, um sentimento de "pertencimento" e "vizinhança".

As passarelas inseridas nos edifícios do Santo Amaro $\mathrm{V}$ podem ser relacionadas às ruas elevadas do projeto Robin Hood Gardens (1962 - 1972), de Alison e Peter Smithson, por exemplo. Segundo Josep Maria Montaner,

Robin Hood Garden está configurado por dois blocos de forma irregular, orientados ao espaço livre interno. Cada bloco é como um muro para o entorno urbano, com uma fachada mais fechada com relação à rua e outra mais aberta com relação ao interior. Os tipos das unidades são tríplex, aos que se acessa pelo corredor. A forma singular e sinuosa dos blocos surge como aplicação da ideia de cluster ${ }^{15}$ e como consequência do novo repertório formal do expressionismo abstrato (MONTANER, 1993, p.76). ${ }^{16}$

14 VIGLIECCA, Hector. Palestra: Programa de Pós Graduação da Faculdade de Arquitetura e Urbanismo da USP - Disciplina: Arquitetura Contemporânea Paulista / Crítica de arquitetura. Professores responsáveis: Mônica Junqueira de Camargo; Hugo Segawa. São Paulo: 18 de julho de 2013.

15 Segundo Josep Maria Montaner, cluster é um dos conceitos mais representativos defendido pelos Smithson. "A palavra cluster que serve para indicar um modelo específico de associação, foi introduzida para substituir grupos de conceitos como 'casa, rua, distrito, cidade' 
Como foi possível observar no projeto analisado, há muita semelhança com os conceitos defendidos pelos Smithson. Esses conceitos são muito presentes nos trabalhos realizados por Hector Vigliecca que acredita no "projeto como instrumento específico de intervenção de uma proposta" (informação verbal). ${ }^{17}$

\section{Segundo a arquiteta Lizete Rubano,}

A experiência do Parque Novo Santo Amaro revela tradição e invenção: estão presentes ali as discussões acerca de outras formas de agenciamento espacial das unidades e, portanto, da conformação do bloco habitacional (opção de Berlage para o enfrentamento da "degeneração da forma" dada pelo fracionamento imposto pelo lote); os debates acerca de novas maneiras de sociabilidade e de suporte material (formaconteúdo) que poderia abriga-las (os clusters das associações humanas dos Smithson); as vias elevadas, que constroem espacialidades intermediárias entre o público e o espaço doméstico da casa (Bakema, novamente os Smithson, Reidy); e ao mesmo tempo, está presente ali o valor da rua, das articulações urbanas, das centralidades já existentes, da linha d’água como linha de privilégio de um lugar.

Mas também há invenção, no sentido da oferta de possibilidades: dada a ausência de urbanidade reconhecível e de qualidade, as arquiteturas apresentam-se como "estruturas urbanas" para além de seu sentido e solução (espacial e técnica) na dimensão tipológica.

Ali, o que temos é mais que um bloco habitacional: é uma articulação urbana de cotas, uma possibilidade de se ancorar, pelo térreo, na cidade, e oferecer-Ihe animação (as áreas comerciais), é uma construção de paisagem urbana e a realização da água - ainda que recuperada artificialmente - como suporte de um espaço público, de caráter metropolitano (comporia com a proposta de parques lineares, idealizados pelos planos regionais para toda a acidade). (RUBANO, Lizete. Em: MONOLITO - no 16, 2013, p.72 e 73).

(subdivisões da comunidade) ou 'quadra, povoado, cidade' (entidades de grupo), que atualmente estão já carregadas de implicações históricas. Qualquer agrupamento é um cluster; cluster é um espécie de termo coringa que se usa durante o período de criação de novas tipologias. (MONTANER, 1993, p.75)

${ }^{16}$ Tradução feita pela autora.

17 Ibid. 14. 
$\mathrm{Na}$ citação anterior, Lizete ressalta as qualidades do projeto e classifica a arquitetura como uma "estrutura urbana". A arquiteta destaca a importância das circulações e a articulação das cotas urbanas; a vida proporcionada pelo comércio e a importância da memória da água.

Como pôde ser visto ao longo desse capítulo, o projeto Santo Amaro V deixa claro a importância dos espaços públicos de qualidade, mas comprova que, talvez, a população e também a administração pública não estejam prontos para assumir essa importância a ponto de preservá-los adequadamente. Nesse projeto, definir todos os espaços livres como públicos deve ser considerado uma ousadia, porém, uma ousadia saudável que deverá servir de exemplo e estimular outros projetos a atuarem da mesma maneira.

Se formos seguir as diretrizes e recomendações da Secretaria de Habitação à risca, projetos como esse jamais seriam viabilizados, pois é mais fácil delimitar os espaços e entregá-los aos cuidados dos novos moradores. Com isso, a administração pública está isenta da responsabilidade da gestão e manutenção. Porém, projetos encerrados em si mesmos não oferecem qualidade à cidade e é exatamente esse o diferencial apresentado pelo projeto aqui analisado que, acredita-se, apenas tenha sido viabilizado porque se encontrou em um momento em que havia vontade política de inovar e realizar projetos de qualidade. Infelizmente, não sabemos se esse momento irá permanecer. ${ }^{18}$

18 No momento em que esse projeto foi viabilizado, a Secretaria de Habitação de São Paulo mostrou-se dedicada a investir em uma produção de habitação de interesse social de qualidade, com isso, envolveu muitos escritórios de arquitetura no desenvolvimento dos projetos incentivando novas ideias e novas formas de intervenção, porém, para isso, também foi necessário organizar as finanças e investir na habitação. Recentemente, com a mudança de gestão da prefeitura municipal de São Paulo, no início de 2013, ocorreram também mudanças nas diretrizes de atuação da Sehab e a principal definição desse governo é aproveitar o programa nacional de financiamento para habitação de interesse social - Minha Casa Minha Vida - como principal agente financiador das intervenções realizadas. Entretanto, esse programa apresenta uma cartilha de diretrizes e definições para o desenvolvimento de projetos que, muitas vezes, são bastante restritivas e que, caso não sejam bem articuladas, podem prejudicar a qualidade dos projetos. Questões como o uso misto e a incorporação de espaços comerciais nos projetos são temas muito discutidos atualmente, pois se por um lado exigem um investimento maior, por outro, podem agregar muita qualidade aos projetos incentivando a relação entre as pessoas e proporcionando, aos moradores dos novos conjuntos, a 
Santo Amaro $V$ é um exemplo de intervenção que foi muito além de apenas construir um novo conjunto habitacional de interesse social. Nesse projeto, as pré-existências foram consideradas, analisadas e, quando possível, mantidas. O projeto buscou compreender e requalificar os percursos e caminhos inseridos entre os domicílios mantidos. Pena que essa parte da intervenção não tenha sido executada até o momento.

O projeto foi implantado buscando estabelecer diálogo e relação com o entorno, mesmo que este tivesse características de cidade informal. O incentivo à circulação, através da proposta das passarelas para a comunicação entre os dois lados da intervenção, também representa a importância dada aos caminhos realizados pelos moradores no seu dia a dia.

A incorporação do espelho d'água ao projeto demostrou a preocupação com a memória e identidade local com base no curso d'água existente anteriormente à intervenção. Entretanto, ao visitar o projeto em novembro de 2013, o espelho d'água foi encontrado com bastante lixo e, segundo a assistente social, havia a possibilidade de que a água estivesse sendo poluída com o lançamento de esgoto clandestinamente. Situação lamentável que exige uma intervenção da prefeitura ou da subprefeitura, que não deveriam permitir que uma obra recentemente inaugurada sofresse esse tipo de problema de conservação.

A implantação dos edifícios é apenas uma parte dentro da intervenção geral. Contudo, a distribuição dos acessos ao longo do conjunto e a variedade tipológica são critérios que merecem destaque.

Todas as tipologias analisadas apresentam grande qualidade espacial e de conforto térmico. Até mesmo temas mais complexos, quando se trata de habitação de interesse social, como as áreas de serviço, foram solucionados adequadamente dentro das unidades sem gerar conflitos com outros usos.

um bom censo entre os programas de financiamento e as reais necessidades dos projetos, para que intervenções de qualidade possam continuar sendo realizadas. 
Após o estudo, algumas situações valem ser discutidas para que sirvam de referência para outros projetos. Foi demostrado na análise a preocupação com algumas áreas públicas que pareceram bem degradas e pouco apropriadas pelos moradores como a área de lazer ao norte do projeto. Será que ela apresentaria as mesmas condições se estivesse mais próxima aos edifícios e aos "olhares" dos moradores? Será que estar localizada na extremidade realmente incentivou a circulação ou acarretou o isolamento desse espaço?

Quanto ao conflito dos moradores com a manutenção dos espaços públicos, será que a apropriação seria maior se os moradores das casas mantidas tivessem sido incorporados aos processos participativos, envolvendo-os no processo de transformação a partir da intervenção? Será que um bom trabalho social pós-ocupação conseguiria reverter essa situação? Oxalá a administração pública trabalhe em direção a uma solução e não ceda ao pedido dos moradores para cercar os conjuntos, caso contrário, esse será mais um conjunto habitacional cercado que agrega pouca qualidade espacial à cidade.

O Residencial Parque Novo Santo Amaro V fica aqui como mais uma contribuição à "cultura de projeto" no âmbito da habitação de interesse social e, nesse caso, fica também como referência de intervenção urbana e relação com a cidade. 
4.4 ESTUDO DE CASO: CONJUNTO HABITACIONAL REAL PARQUE 


\subsection{REAL PARQUE}

\section{Conjunto Habitacional Real Parque}

Localização: Rua Barão de Castro Lima, 20 - Real Parque

Distrito: Morumbi - Subprefeitura: Butantã - Zona: Oeste

Distância até o centro da cidade: $12,1 \mathrm{Km}$.

Conclusão da obra: 2012 / parte da intervenção ainda está em obra Início projeto: 2009

Arquitetura:

Projeto Básico: Geni Sugai e Jeferson Diniz (SEHAB)

Projeto Executivo: Escritório Paulistano de Arquitetura

Equipe Escritório Paulistano: Eduardo Colonelli (arq. responsável); Eduardo Gurian e Fernando Botton (coordenadores); Bruno Nicoliello, Juliana Blanaru, Lourenço rebelo de Andrade, Mayra Rodriguez, Marina Colonelli, Michelle Waisblut, Renan Kadomoto (arquitetos); Marcelo Anaf (estagiário)

Promoção: Programa de urbanização de favelas da Secretaria Municipal de Habitação de São Paulo (Sehab)

Coordenação Sehab: Geni Sugai

Área total (soma dos terrenos): 3,55 ha $\left(35.589,29 \mathrm{~m}^{2}\right)$

Área Construção: $87.977,45 \mathrm{~m}^{2}$

Coeficiente de aproveitamento: 2,47

no unidades habitacionais: 1.251

Densidade da área total de intervenção: $352,39 \mathrm{UHs} / \mathrm{ha}$ $1.268,61$ habitantes/ha ${ }^{1}$

Programa: Unidades Habitacionais / Comércios / Praça de Equipamentos

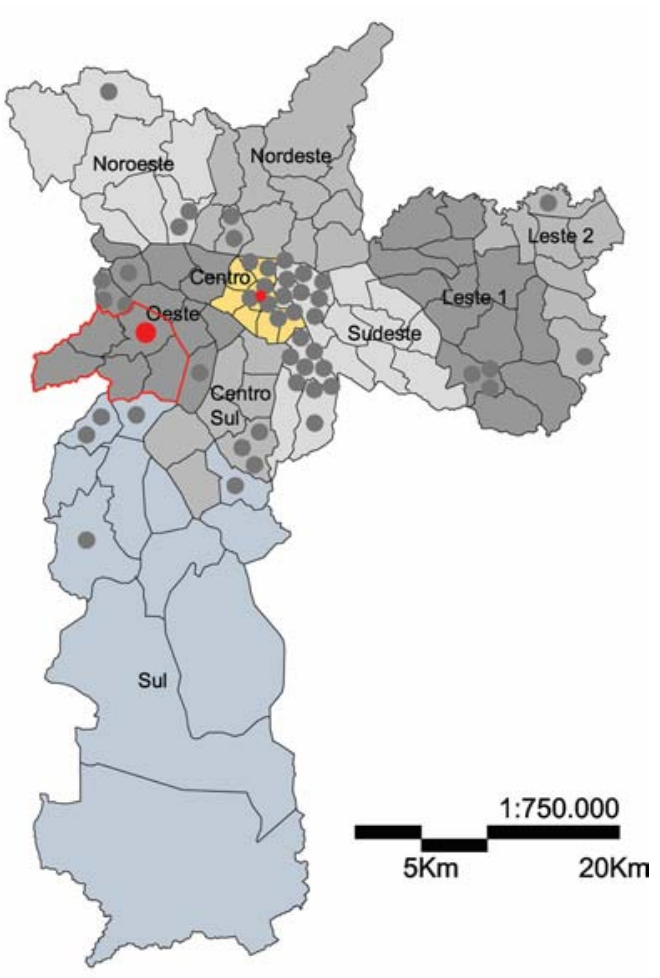

Figura 2 - Localização com relação à cidade.

${ }^{1}$ Foi adotada a média de 3,6 habitantes por unidade habitacional em aglomerados subnormais - fonte: IBGE, Censo Demográfico 2010, p. 
De acordo com a publicação da Revista AU, de março de 2013, sobre o Conjunto Habitacional Real Parque, a favela, de mesmo nome, existe desde os anos 1950 e ocupava uma área de pouco mais de $44.500 \mathrm{mil} \mathrm{m}^{2}$ (FLORESTA, 2013, p. 26)

Cícera, a moradora do Jardim Edite que nos deixou visitar sua casa, também contou que, nos anos 1990, quando ocorreram as remoções na favela Jardim Edite, ela e sua família se mudaram para a favela Real Parque - assim como muitos outros moradores - e segundo ela, "o Real Parque parecia uma pequena fazenda, com hortas, plantações, etc." (informação verbal)²

Mais ou menos na mesma época, em meados de 1990, foram implantados os conjuntos residenciais do Cingapura. Como pode ser observado na imagem ao lado, esses conjuntos foram implantados ao longo da favela, em uma faixa que, de certa forma, ocultava a favela de quem passava pela Marginal do Rio Pinheiros. Atuação muito comum nas intervenções realizadas pelo Programa Cingapura, que na maioria dos casos escondiam as favelas atrás das novas construções para dar a falsa ideia de ter solucionado o problema.

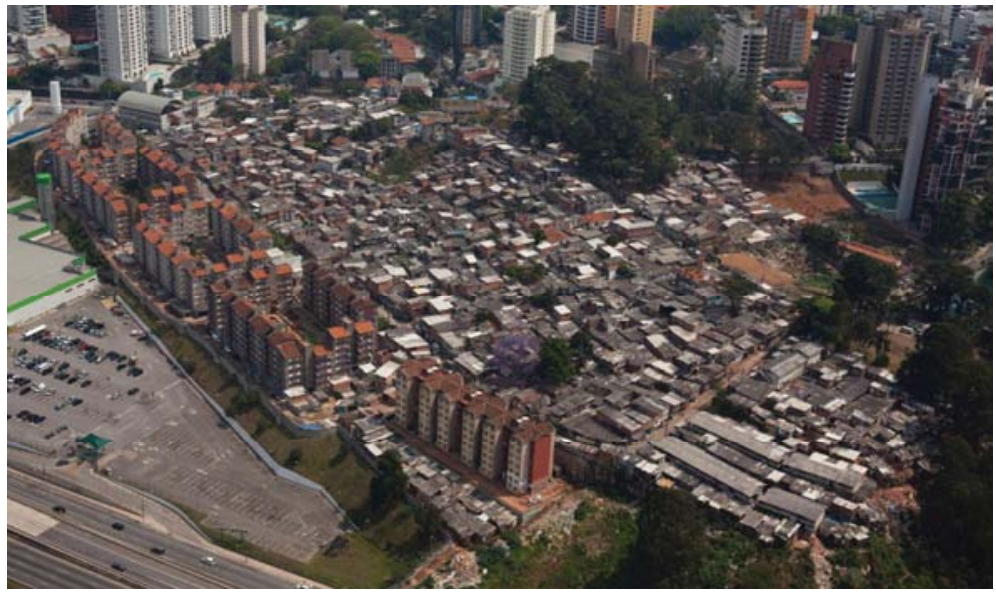

Figura 3 - Foto aérea favela Real Parque anterior à construção do Conjunto Residencial.

${ }^{2}$ Entrevista com moradora do Conjunto Jardim Edite durante visita a sua residência. São Paulo, 17 de dezembro de 2013. 
Posteriormente, a favela Real Parque continuou crescendo atrás dos edifícios e o processo de urbanização promovido pelo Programa de Urbanização de Favelas da Prefeitura de São Paulo - teve início em 2008 com o cadastramento de 1.250 famílias.

Após o cadastramento das famílias, as reuniões para apresentar o projeto à população ocorreram no ano seguinte. Também em 2009 foram promovidas reuniões com a liderança para formar o Conselho Gestor e em 2010 ocorreram as eleições para esse Conselho. Sobre o processo participativo, a arquiteta Geni Sugai, autora do projeto e técnica da Secretaria de Habitação, comentou que foram realizadas diversas reuniões com a população para discutir e aprovar o projeto em desenvolvimento. Geni comentou inclusive que, a princípio, estavam sendo desenvolvidas tipologias duplex, mas após as reuniões, acabaram alterando a proposta, pois os moradores não estavam satisfeitos com essa tipologia. (informação verbal) ${ }^{3}$

Atualmente (janeiro de 2014), parte da intervenção ainda está em obras, mas aproximadamente $60 \%$ do projeto já foi concluído e entregue aos moradores.

${ }^{3}$ Informações obtidas através de conversa com a arquiteta Geni Sugai durante visita ao conjunto em dezembro de 2013. 


\subsubsection{ESCALA CONJUNTO}

Com relação ao estudo do Conjunto Habitacional Real Parque, a escala conjunto acabará sendo ampliada para escala da intervenção em alguns momentos, pois o projeto envolve, ao todo, onze condomínios implantados na área anteriormente ocupada pela favela e também dois terrenos adjacentes, como poderemos ver com maior detalhe no item inserção urbana.

O projeto localiza-se em uma região bastante valorizada da cidade de São Paulo. A partir da análise dos valores de proximidade, pode-se observar a proximidade ao bairro Morumbi, uma região caracterizada por condomínios e residências de alto padrão. É importante observar que muitos moradores do Real Parque trabalham nas residências e escritórios da região.

O entorno do Conjunto Habitacional Real Parque é bastante residencial. No trecho mais próximo à Marginal Pinheiros, encontram-se os grandes centros comerciais como a Leroy Merlin, o Pão de Açúcar e a Decathlon.

A oferta de transporte é maior na Marginal do rio Pinheiros, na Avenida Duquesa de Goiás e na Avenida Morumbi, sendo que a última já encontra-se fora do raio de 1.000 metros de proximidade. Cruzando o rio Pinheiros, há acesso ao trem e a conexão com o centro da cidade é melhor, inclusive a oferta de transporte público. Para cruzar o rio os moradores contam com ônibus e o trajeto demora em torno de vinte minutos.

Próximo à intervenção há dois colégios públicos e uma UBS. 


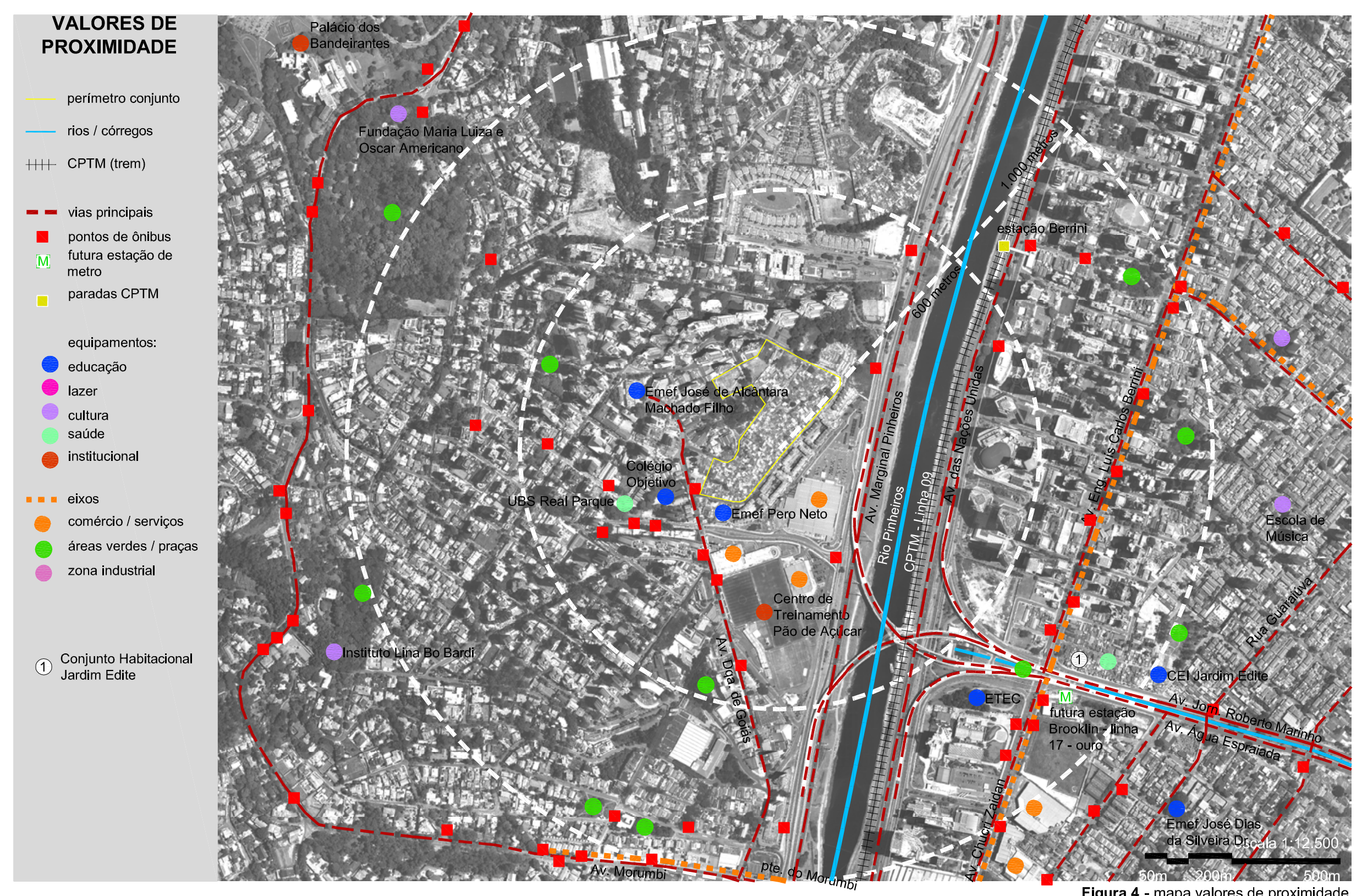




\subsubsection{INSERÇÃO URBANA}

Os estudos para a proposta de intervenção iniciaram-se em 2008 e, segundo Geni Sugai, decidiu-se pela remoção e reconstrução total da favela com base nos seguinte motivos:

- havia presença de alto risco devido às encostas íngremes voltadas para sul e sudeste;

- tratava-se de uma área servida por infraestrutura urbana;

- tratava-se de uma área valorizada dentro da cidade;

Além disso, o terreno onde localizava-se a favela Real Parque, era uma Zona Especial de Interesse Social (ZEIS

1). Com isso, as diretrizes para o desenvolvimento da proposta foram:

- remoção total das construções existentes e atendimento a todas as famílias;

- construção de edifícios verticais de até nove pavimentos sem elevador (utilizando-se como estratégia o acesso por pavimento intermediário);

- construção de equipamentos de uso comunitário;

- manutenção da atividade comercial existente.

Com base nessas diretrizes, a proposta desenvolvida buscou reestruturar toda a área ocupada pela favela a partir da implantação dos conjuntos residenciais divididos em quatro quadras principais: quadra $\mathrm{H}$; quadra I; quadra $\mathrm{A}$ Leste; e quadra A Oeste. Os viários existentes foram mantidos e melhorados para permitir o acesso adequado aos novos conjuntos residenciais. 
Eduardo Colonelli, ao falar sobre a intervenção, comenta que, "O conjunto está inserido em uma região consolidada e próximo a áreas de infraestrutura. É uma situação favorável e por isso se fez tanto esforço para viabilizar a transformação da favela no bairro Real Parque" (em: FLORESTA, 2013, p. 27)

Elisabete França também comentou, em uma palestra no Museu da Casa Brasileira, que o projeto do Conjunto Habitacional Real Parque era uma grande conquista, pois estavam intervindo em uma região consolidada e, inclusive, tiveram muitos conflitos com os moradores do entorno, que não desejavam que as pessoas da favela fossem, finalmente, fixadas ali a partir da construção dos conjuntos habitacionais. Fato que representa uma grande contradição, uma vez que muitos dos trabalhadores (empregadas domésticas, babás, motorista, etc.), dos condomínios residenciais ao redor, vivem na favela Real Parque. (informação verbal) ${ }^{4}$

A urbanização do Real Parque recebeu verba proveniente da Operação Urbana Faria Lima ${ }^{5}$ e os primeiros conjuntos a serem construídos foram os da quadra $\mathrm{H}$ e quadra I, implantados em dois terrenos vizinhos que foram desapropriados pela Prefeitura com verba da Operação Urbana.

Com base na implantação geral é possível observar a transformação da área, anteriormente ocupada pela favela onde viviam aproximadamente 1.250 famílias, em bairro - conforme comentário do arquiteto Colonelli - configurado pelos conjuntos habitacionais.

${ }^{4}$ FRANÇA, Elisabete. Habitação Social em São Paulo: Perspectivas. Conferência: Museu da Casa Brasileira, São Paulo, 15 de junho de 2011.

${ }^{5}$ Operação Urbana Faria Lima, Lei oํ 13.769/04. 

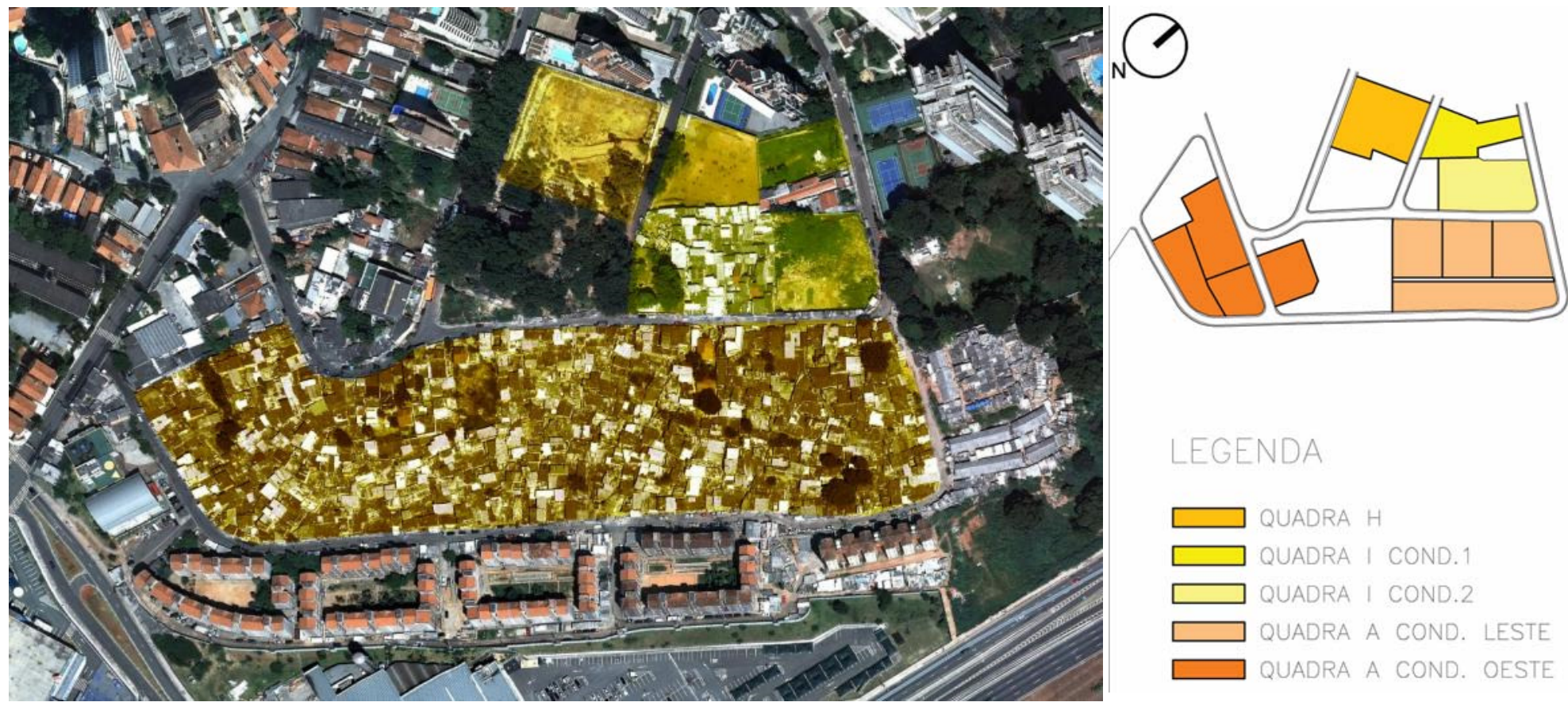

Figura 5 - Foto aérea com destaque para a área de intervenção.

\begin{tabular}{llllll} 
& QUADRA H & QUADRA I & QUADRA A LESTE & QUADRA A OESTE \\
\hline Finalização da obra & Dezembro 2011 & Agosto $/ \mathrm{Set}$. 2012 & Dez 2012/ Agosto 2013 & Em obras \\
\hline Área do terreno & $5.284,03 \mathrm{~m}^{2}(0,52 \mathrm{ha})$ & $7.464,86 \mathrm{~m}^{2}(0,74 \mathrm{ha})$ & $12.906,15 \mathrm{~m}^{2}(1,29 \mathrm{ha})$ & $9.934,25 \mathrm{~m}^{2}(0,99 \mathrm{ha})$ \\
\hline Área construída & $9.735,15 \mathrm{~m}^{2}$ & $16.573,23 \mathrm{~m}^{2}$ & $34.846,60 \mathrm{~m}^{2}$ & $26.822,47 \mathrm{~m}^{2}$ \\
\hline C.A. & 1,84 & 2,22 & 2,69 & 2,69 \\
\hline No de unidades & $140 \mathrm{UHs}$ & $237 \mathrm{UHs}$ & $480 \mathrm{UHs}$ & $394 \mathrm{UHs}$ \\
\hline Densidade (UHs/ha) & $269,23 \mathrm{UHs} / \mathrm{ha}$ & $320,27 \mathrm{UHs} / \mathrm{ha}$ & $372,09 \mathrm{UHs} / \mathrm{ha}$ & $397,97 \mathrm{UHs} / \mathrm{ha}$ \\
\hline Densidade (hab./ha) & $969,23 \mathrm{hab} / \mathrm{ha}$ & $1.152,97 \mathrm{hab} / \mathrm{ha}$ & $1.339,53 \mathrm{hab} / \mathrm{ha}$ & $1.432,72 \mathrm{hab} / \mathrm{ha}$ \\
\hline
\end{tabular}

LEGENDA

$\square$ QUADRA

$\square$ QUADRA I COND.1

$\square$ QUADRA I COND.2

$\square$ QUADRA A COND. LESTE

$\square$ QUADRA A COND. OESTE

Tabela 1 - Dados por quadra. 


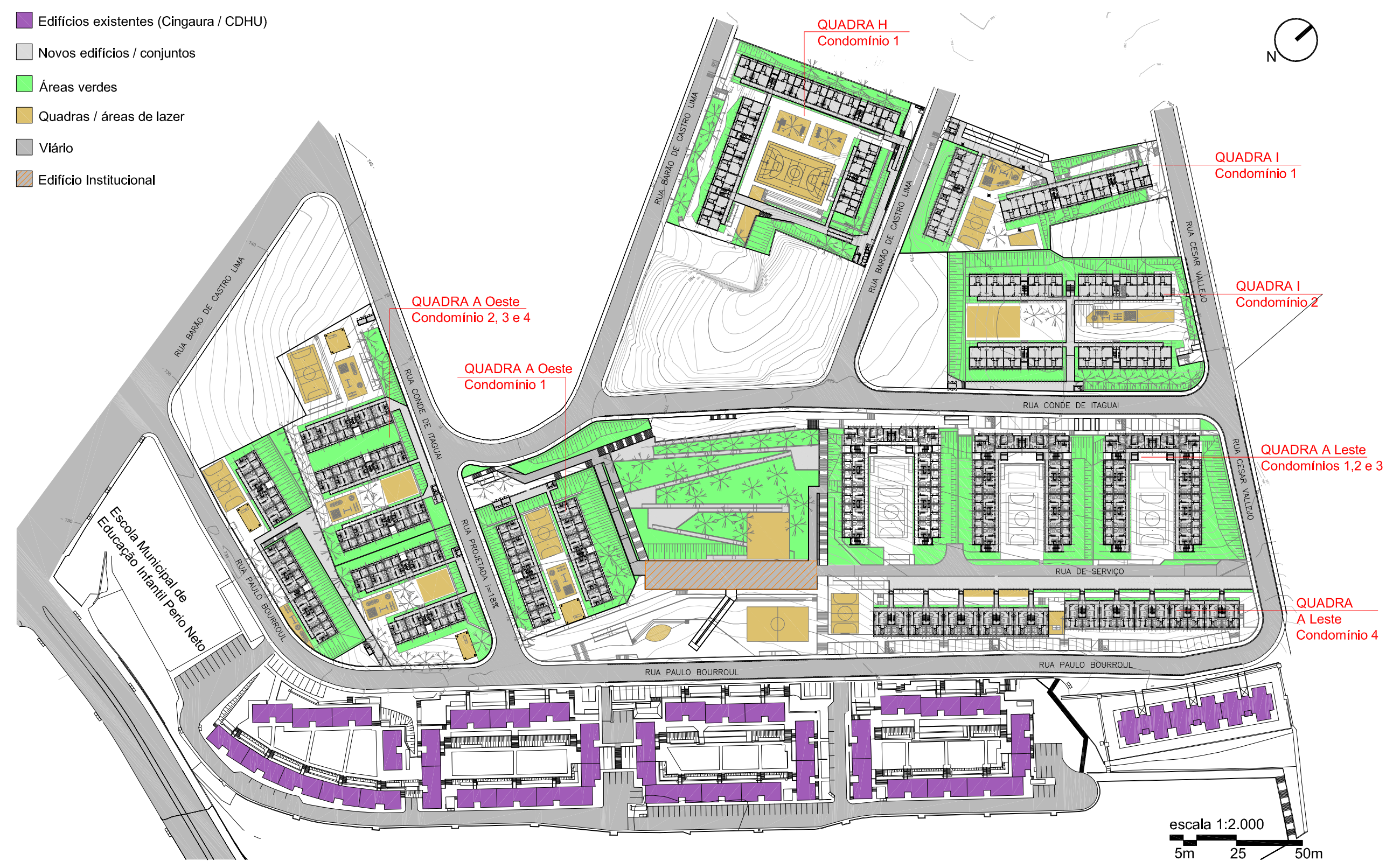

Figura 06 - Implantação Geral. 
Como foi possível verificar, a partir do quadro resumo apresentado para cada quadra, a quadra A oeste é o único trecho da intervenção que ainda está em obras. Os demais condomínios já foram finalizados ou estão em fase de finalização e já estão ocupados pelos moradores, alguns deles há mais de um ano, como é o caso das quadras $\mathrm{H}$ e I.

Nas imagens abaixo é possível conhecer melhor os terrenos que foram desapropriados pela Prefeitura para a construção dos condomínios da quadra $\mathrm{H}$ e I:

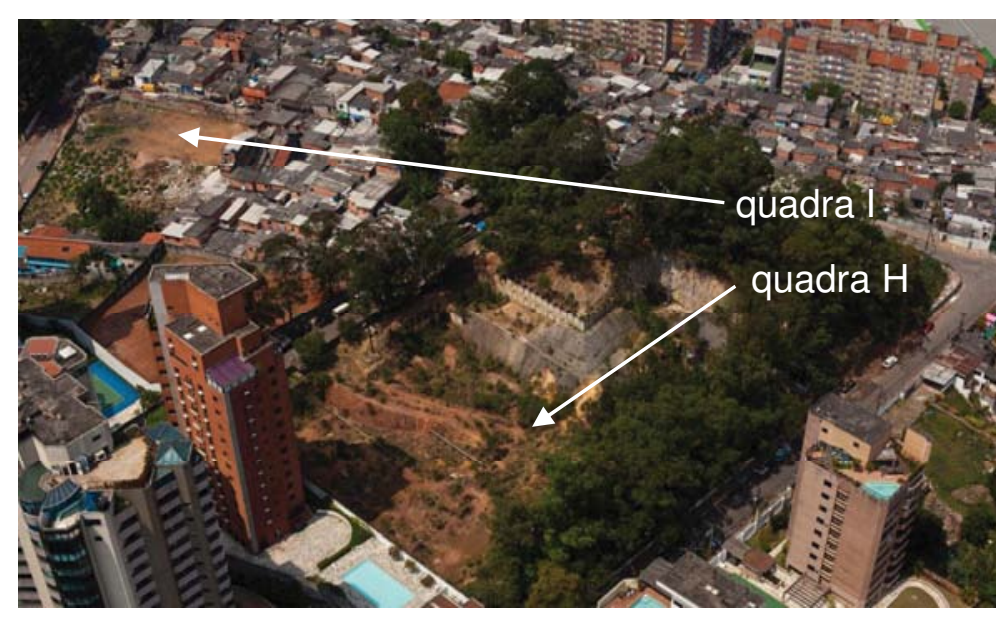

Figura 7 - Terreno desapropriado pela Prefeitura para a construção da quadra $\mathrm{H}$. Ao fundo, terrenos quadra $\mathrm{I}$.

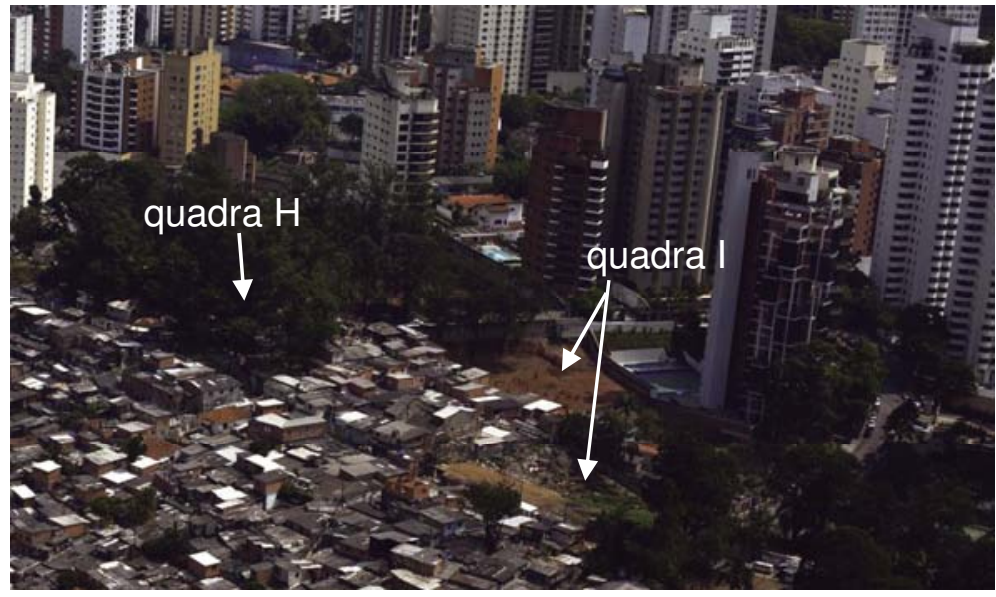

Figura 8 - Favela Real Parque à frente e terrenos quadra I e quadra $\mathrm{H}$ ao fundo.

Durante os processos de urbanização nas favelas é comum que parte dos moradores seja removida para liberar espaço para o início das obras. Nesses casos, as famílias removidas são obrigadas a procurar uma casa para alugar e, durante o período de obras, recebem o auxílio aluguel financiado, na maioria dos casos, pela Prefeitura. No Real Parque o processo foi diferente. As famílias não precisaram ser removidas, pois a Prefeitura conseguiu 
desapropriar dois terrenos vizinhos à favela que permitiram que as obras fossem iniciadas sem intervir na situação dos moradores. Com isso, após a finalização das obras, as famílias cadastradas para os conjuntos construídos se mudaram, liberando, a partir de então, área para as intervenções seguirem, dessa vez dentro do terreno da favela.

Nas imagens abaixo é possível observar o processo de construção dos conjuntos e a remoção gradativa da favela.

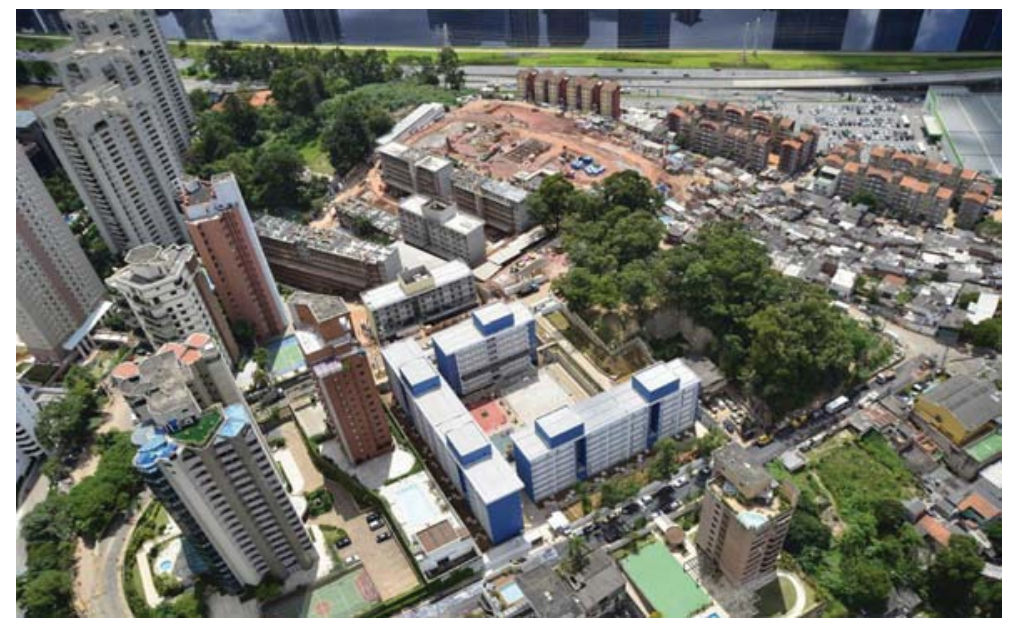

Figura 9 - Conjunto quadra $\mathrm{H}$ finalizado e quadra I em obra.

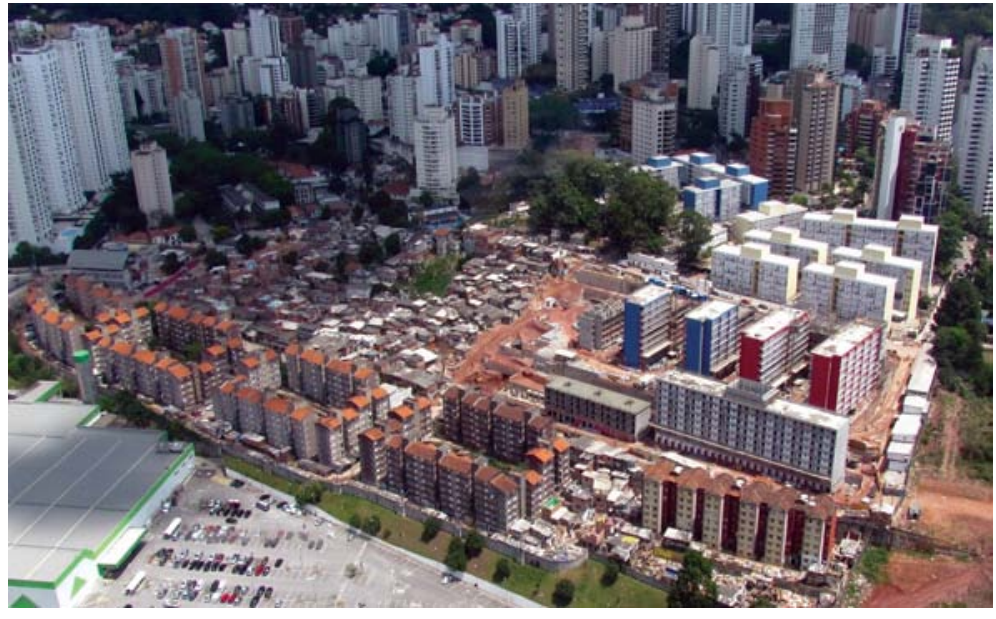

Figura 10 - Quadras H e I finalizadas e quadra A Leste em obras. Trecho da quadra A Oeste ainda está ocupado por parte da favela.

Como foi possível observar na tabela de dados por quadra (Tabela 1), a densidade proposta pela intervenção é bastante alta. A quadra A Leste chega a uma média de 1.339 habitantes por hectare, porém é equivalente à densidade da comunidade uma vez que todas as famílias estão sendo reassentadas no mesmo local (Tabela 2). A comparação fica bastante discrepante ao relacionar a densidade da intervenção com a do distrito ou da Subprefeitura, porém, como já foi citado, esse conjunto está inserido em um entorno de alto padrão com 
características completamente diferentes das existentes dentro do limite da intervenção. Esse é, portanto, mais um exemplo de favelas inseridas em trechos da cidade, bastante consolidados e bem estruturados, como Paraisópolis, Jardim Edite, etc. Situação bastante comum na cidade de São Paulo, pois as favelas acabaram se formando próximas aos locais com oferta de trabalho. Pode-se dizer que as favelas que cresceram nesses meios consolidados, foram formações espontâneas e as localizadas na periferia são consequência da intervenção do poder público. Várias foram as tentativas de erradicar as favelas, acreditando-se que afastar essa população das regiões centrais e levá-las para a periferia, onde não havia infraestrutura nem oferta de transporte, seria uma solução.

\begin{tabular}{lr} 
Conjunto Habitacional Real Parque & $1.268,61$ habitantes /ha \\
\hline Comunidade Real Parque (anteriormente às intervenções) & $1.285,71$ habitantes /ha \\
\hline Distrito Morumbi & 41,19 habitantes/ha \\
\hline Subprefeitura Butantã & 76,33 habitantes/ha
\end{tabular}

Tabela 2 - densidade do Conjunto com relação à Comunidade, Distrito e Subprefeitura.

6 Para calcular a densidade da Comunidade Real Parque, considerou-se a área ocupada pela favela (aproximadamente $35.786 \mathrm{~m}^{2}$ ) e o número de famílias cadastradas (1.250 famílias). Multiplicando-se o número de famílias por 3,6 (média de habitantes por unidade habitacional em aglomerados subnormais de acordo com IBGE 2010) chegou-se ao valor de 4.500 habitante em 3,5 ha.

7 Fonte: Dados Demográficos dos Distritos pertencentes às Subprefeituras, site da prefeitura de São Paulo, disponível em: http://www.prefeitura.sp.gov.br/cidade/secretarias/subprefeituras/subprefeituras/dados demograficos/. Acesso em dezembro de 2013.

8 Ibid. 3. 


\section{Programa}

O conjunto habitacional Real Parque contará com a construção de 1.251 unidades habitacionais distribuídas entre os onze condomínios.

A Rua Paulo Bourroul delimita o perímetro da intervenção com relação aos conjuntos construídos pelo programa Cingapura, entretanto, a nova intervenção deverá favorecer a todos. Entre as quadras A Leste e A Oeste há uma área bastante íngreme onde será construída uma praça com equipamentos de lazer, que deverá ser utilizada por todos os moradores da região.

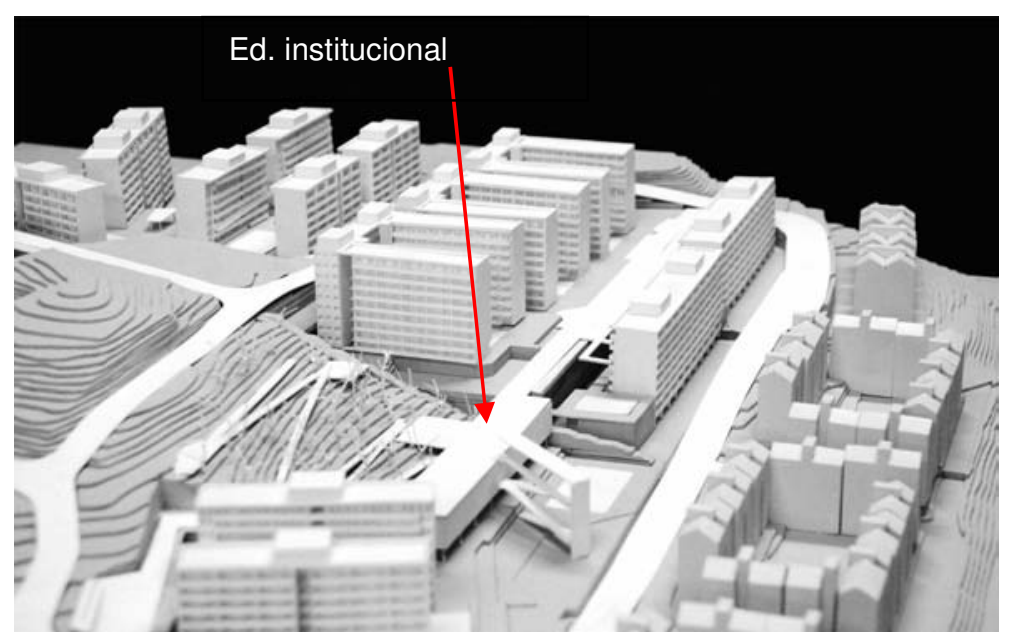

Figura 11 - Foto maquete física. Destaque para inserção do edifício institucional.

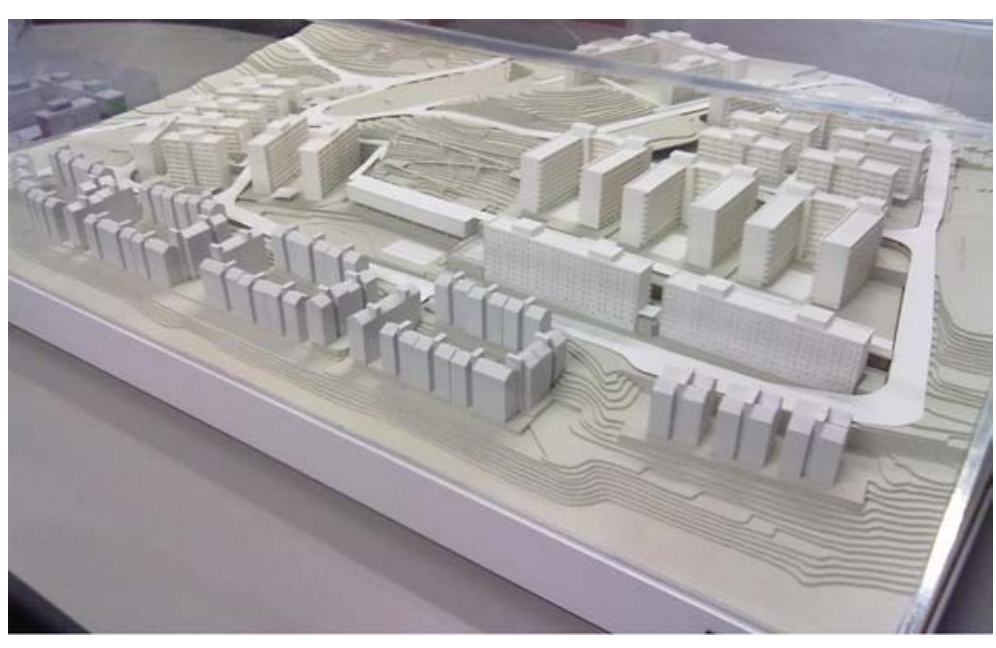

Figura 12 - foto maquete física.

Junto a essa praça será construído um edifício institucional, onde deverá haver também uma creche. De acordo com o projeto, esse edifício será encaixado no terreno tendo a parte superior nivelada à Rua de Serviço criada 
entre os condomínios da quadra A Leste. Como esse trecho do projeto ainda não foi executado, podemos observar na maquete física a forma como esse edifício institucional será inserido no terreno (Figura 11).

Além dos edifícios habitacionais, da praça e do edifício institucional, também foram incluídas, no projeto, áreas comerciais, pois de acordo com as diretrizes para a intervenção, a atividade comercial local deveria ser conservada.

No esquema ao lado (Figura 14) é possível verificar os usos distribuídos pelos espaços comerciais propostos no térreo dos edifícios da quadra A Leste que estão em contato com o nível da rua.

A proposta de usos considerou os comércios locais já existentes na favela Real Parque. Até o momento os espaços comercias ainda não estão em funcionamento e isso será, portanto, uma pendência deixada por esse trabalho, pois será muito interessante poder voltar a visitar esse conjunto dentro de algum tempo e verificar como estarão funcionando esses espaços comerciais.

$\mathrm{Na}$ foto ao lado é possível observar as lojas comerciais, ainda fechadas, no térreo do condomínio 2 da quadra $A$ Leste e também as vagas de estacionamento demarcadas à frente.

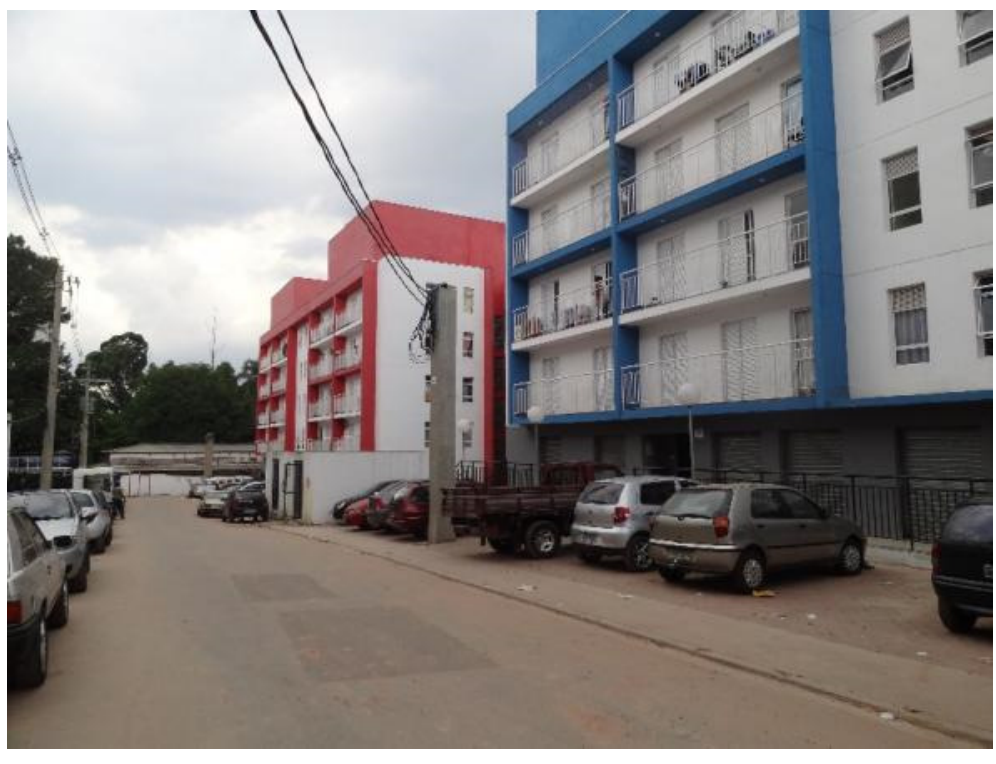

Figura 13 - Lojas comerciais no térreo do edifício condomínio 2, quadra A Leste. 


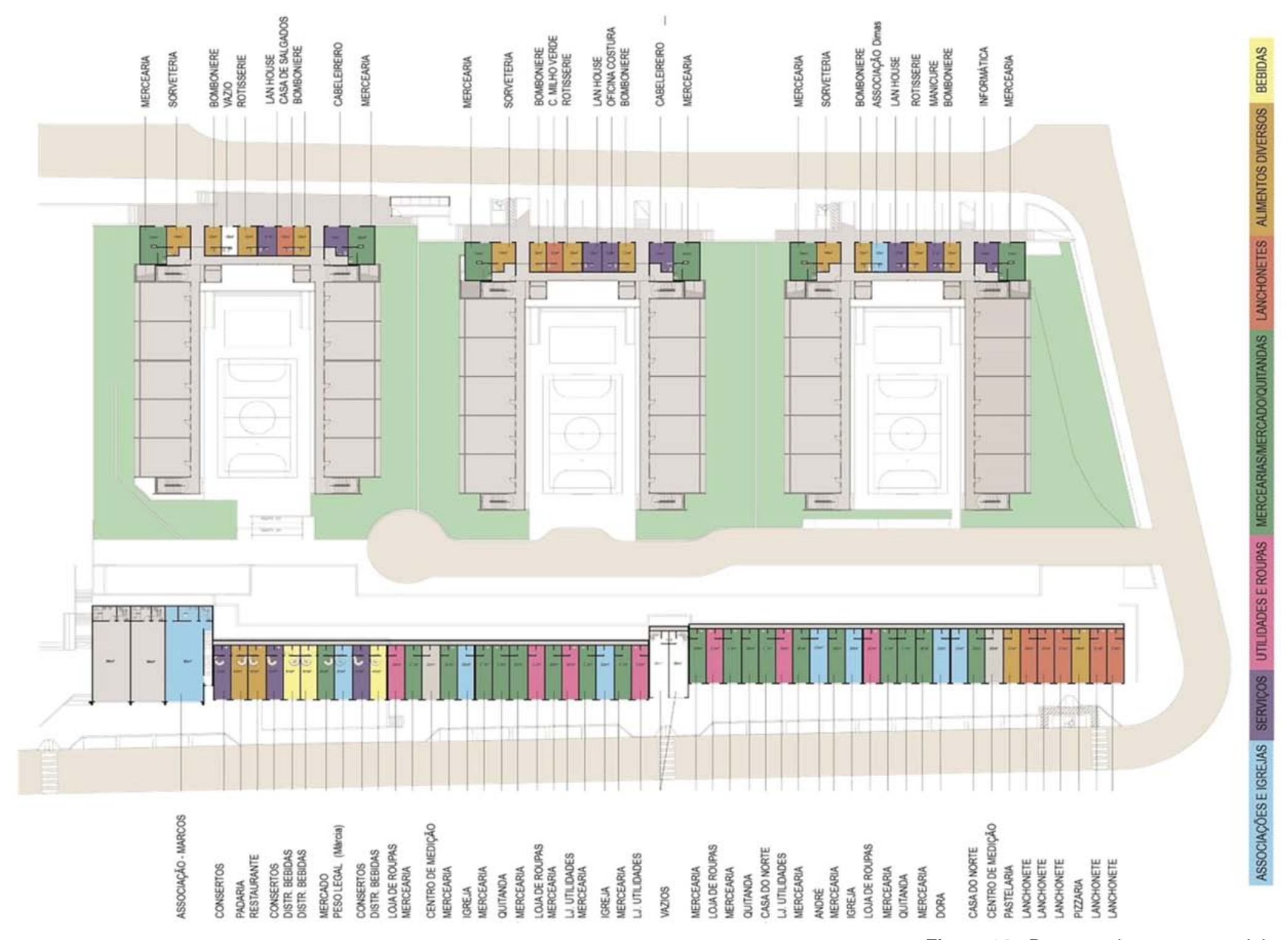

Figura 14 - Proposta de usos comerciais. 


\section{Ocupação do terreno}

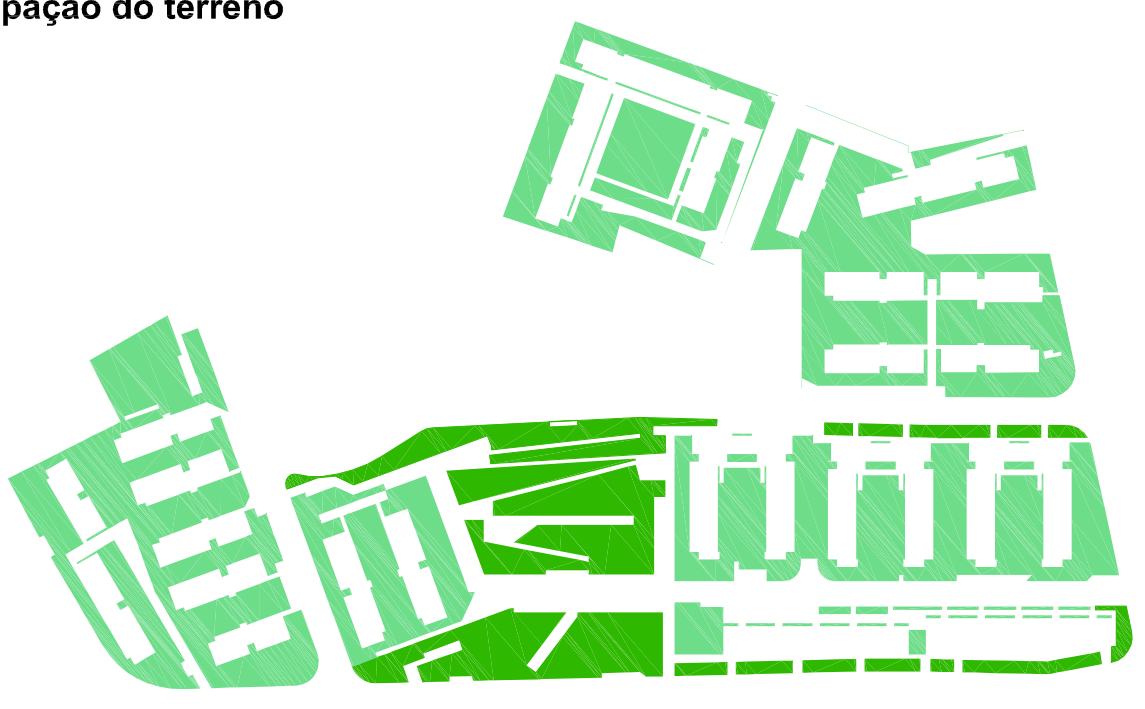

-

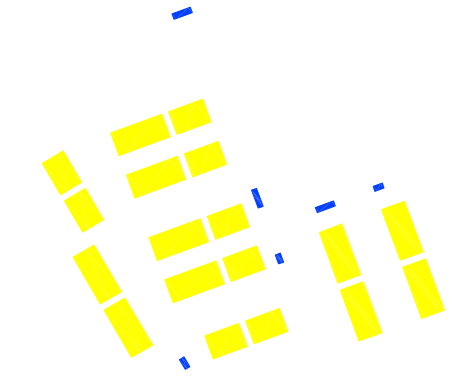

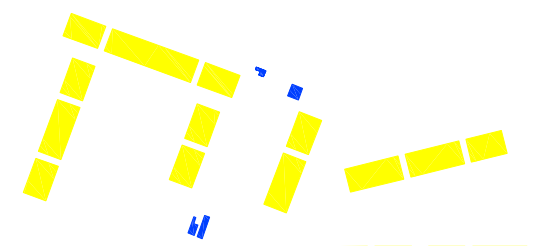

u

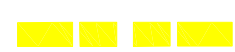

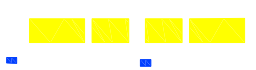

IIIIIIII, IIIIIIII, IIIIIIIII

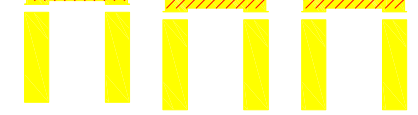

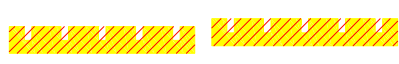

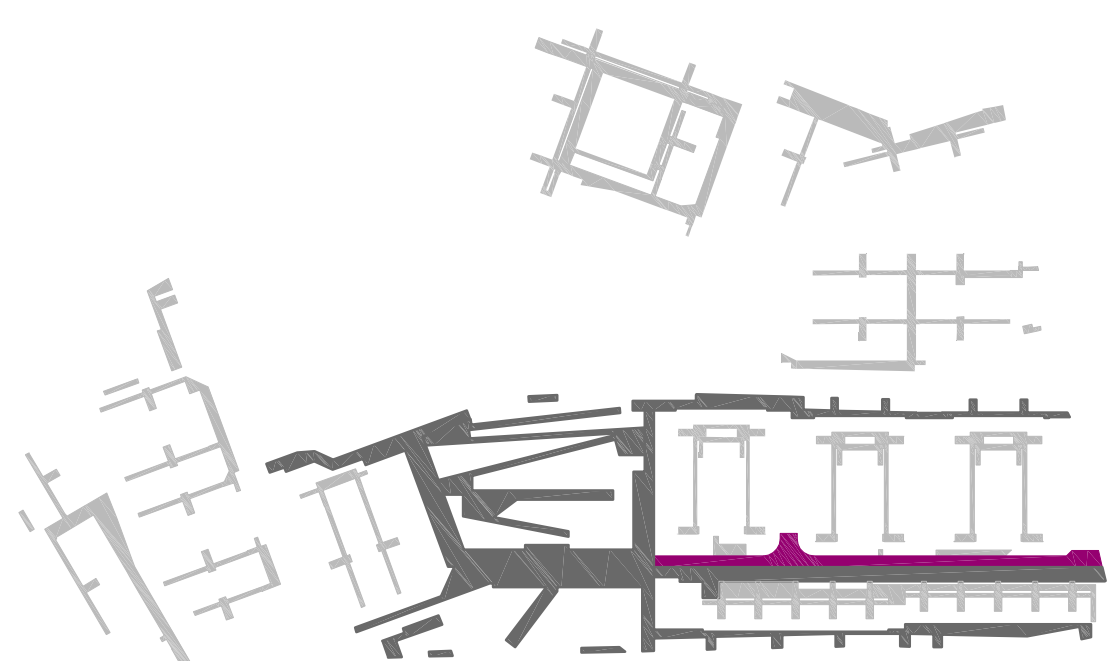

\begin{tabular}{l|l} 
TOTAL & $\square$ circulação interna conjuntos - $12,36 \%$ \\
$24,39 \%$ & $\square$ circulação - pública - $10,48 \%$ \\
$\square$ viário projetado - $1,55 \%$
\end{tabular}

TOTAL $\square$ espaços livres de uso público - 13,55\%

$56,05 \% \square$ espaços livres de uso privado - $42,50 \%$

TOTAL $\square$ habitação - 15,66\%

19,56\% $\square$ misto (comércio no térreo) - 3,60\%

- intalações - 0,30\% 
A partir das máscaras resultantes da projeção das áreas construídas, áreas livres e áreas destinadas à circulação, podemos observar que mais de $50 \%$ da área da intervenção são espaços livres, tanto condominiais, como públicos. A praça que será implantada entre as quadras A Leste e Oeste representa quase $14 \%$ dos espaços livres e o restantes está distribuído nos condomínios. Vale a pena observar que todos os condomínios contam com espaços livres, entre os edifícios, onde foram propostos espaços de lazer.

A área construída ocupada pelos edifícios representa apenas 19,56\% da ocupação do terreno, sendo, no entanto, bastante verticalizada (chegando a até nove pavimentos), o que proporciona a alta densidade observada.

Como circulação, foram identificadas tanto as internas aos conjuntos - que dão acesso aos edifícios - quanto as públicas e também o viário proposto. O total da área ocupada do terreno referente às circulações é de aproximadamente $25 \%$.

\section{Definição do limite do conjunto}

Todos os condomínios têm seu limite claramente definido e são cercados com grades. Devido aos desníveis do terreno, na maioria dos casos, os edifícios estão implantados abaixo do nível da rua. Essa situação cria espaços entre o limite do lote e os edifícios - que precisaram de tratamento adequado para não se tornarem espaços residuais dentro dos condomínios.

Na Figura 16, podemos observar que, no caso do condomínio 1 da quadra I, esse limite foi tratado com paisagismo. É possível identificar - ao lado esquerdo da foto - o muro de contenção e o nível da rua acima. Considerando-se que esse condomínio foi entregue há aproximadamente um ano e quatro meses, podemos constatar que o paisagismo está sendo conservado pelos moradores. De qualquer forma, vale destacar que as entradas das casas 
não estão voltadas para esse lado e, portanto, esse espaço é um trecho mais reservado do conjunto, com pouca circulação de pessoas.

Cabe aqui questionar como seria esse espaço se as entradas das unidades estivessem voltadas para ele. Por um lado, teriam mais movimento, mas será que estariam tão bem conservados? Ou pode ser que estariam mais apropriados pelos moradores? Quando observamos os trechos de jardim que estão próximos às entradas das casas, identificamos uma apropriação maior, como pode ser observado na Figura 17. Outra solução possível, seria tê-los concebido como quintais privados das unidades do térreo, conectando-os diretamente aos apartamentos.

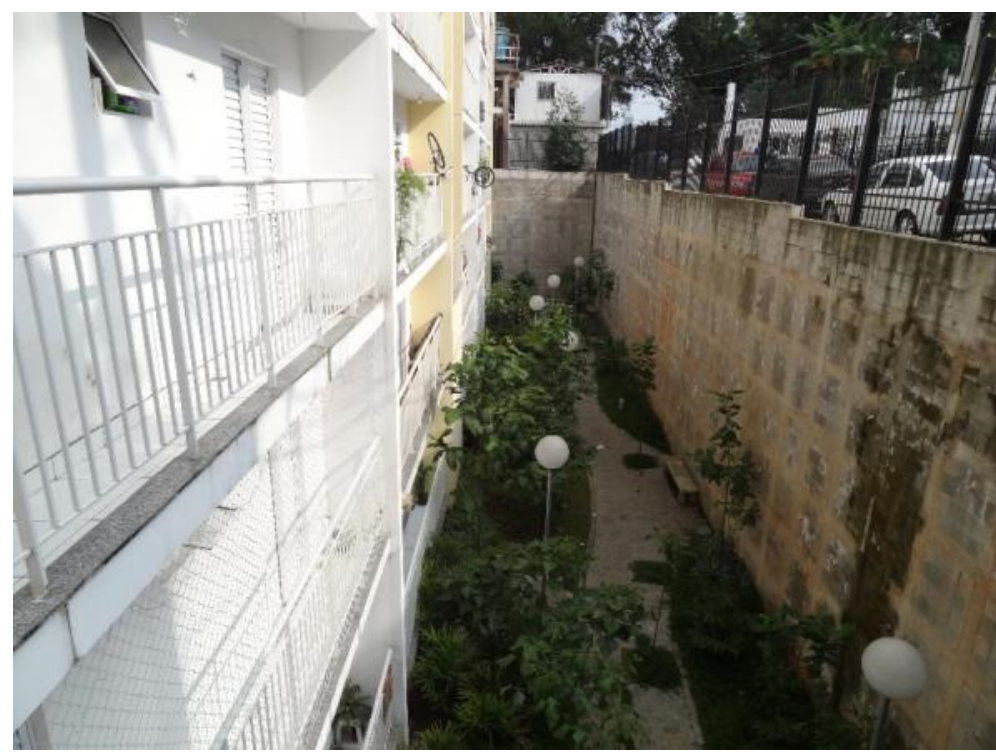

Figura 16 - Quadra I, condomínio 1 - bloco 1. Espaço entre o edifício e o limite do conjunto tratado com paisagismo.

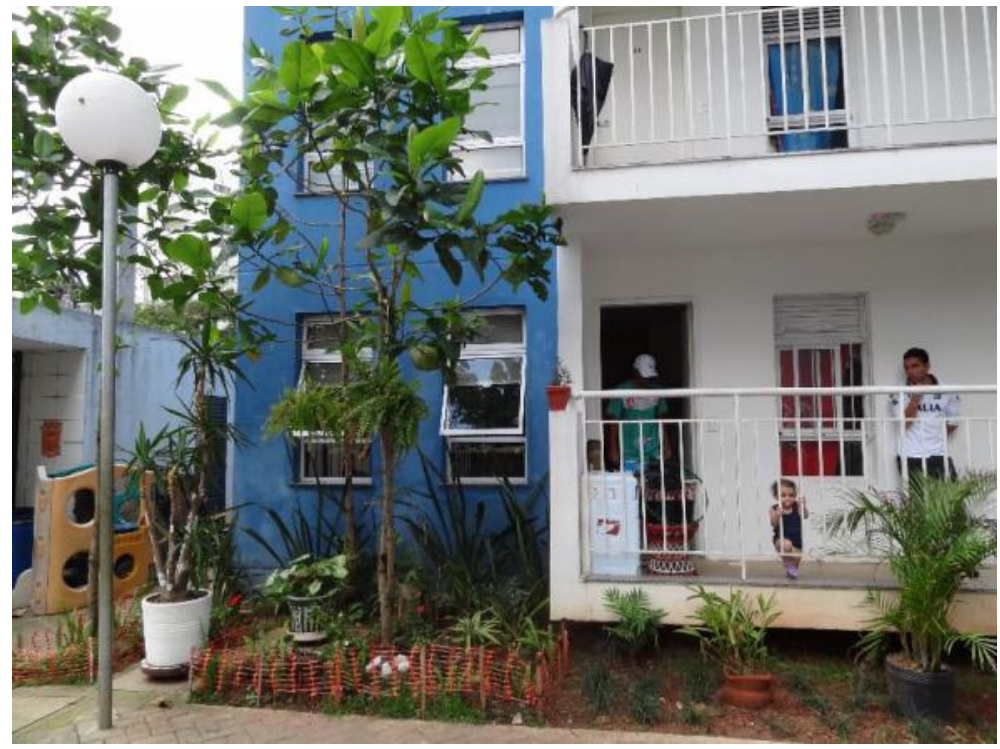

Figura 17 - Jardim cuidado e apropriado pelos moradores. Condomínio - quadra $\mathrm{H}$ 
A arquiteta Geni Sugai comentou que o projeto do conjunto Residencial Alexandre Mackenzie, desenvolvido pelo arquiteto Marcos Boldarini, foi uma importante referência para o desenvolvimento do Conjunto Habitacional Real Parque e, ao observarmos esses espaços entre o limite do conjunto e os edifícios, podemos identificar semelhanças em seu tratamento, assim como nos jardins em frente às entradas das unidades.

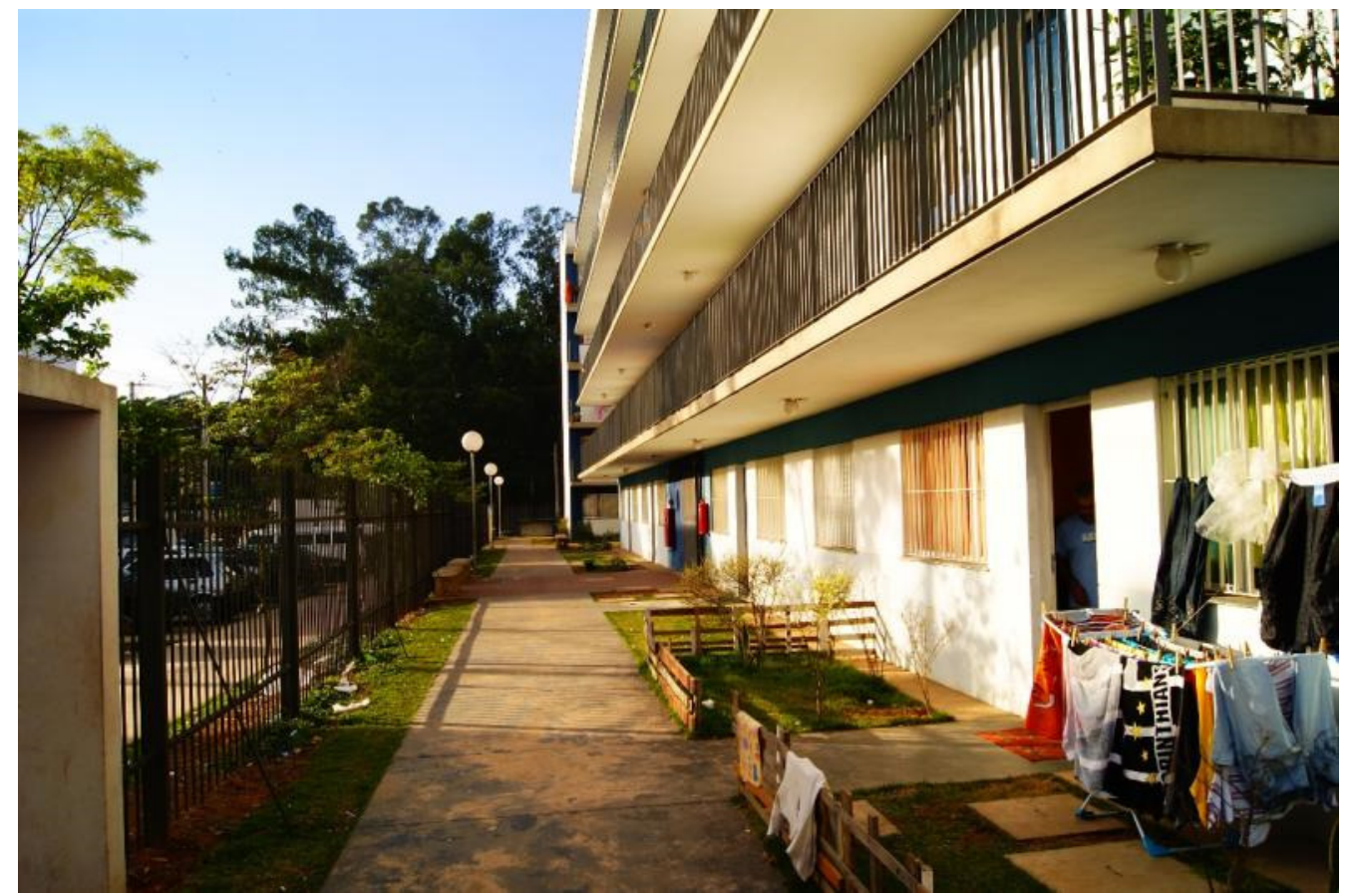

Figura 18 - Residencial Alexandre Mackenzie. Limite do conjunto e espaço na entrada das unidades.

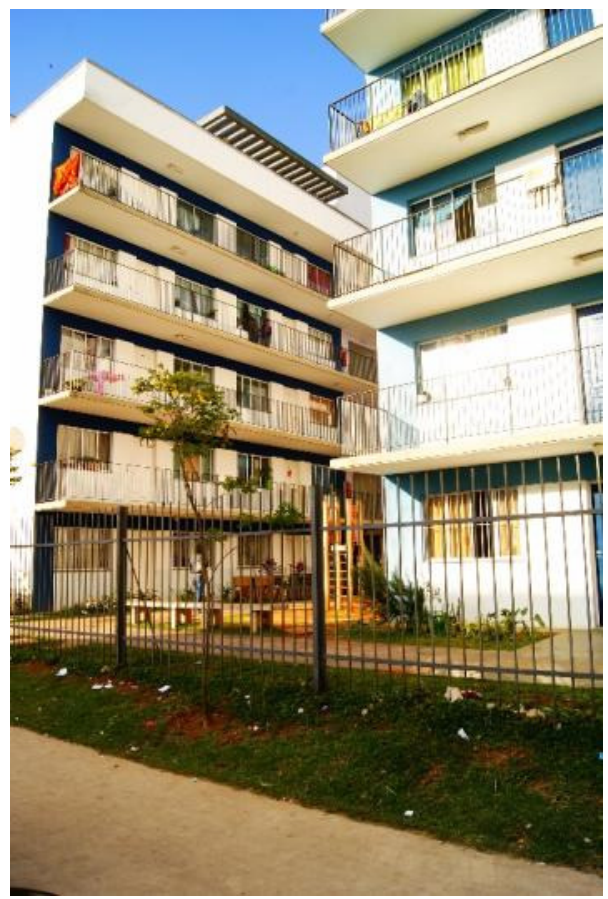

Figura 19 - Residencial Alexandre Mackenzie.

Entretanto, no caso do Residencial Alexandre Mackenzie, as entradas das unidades estão voltadas para o limite do conjunto que, nesse caso, estão diretamente relacionados com a rua - não há desníveis. 
$\mathrm{Na}$ quadra A Leste, mesmo tratando-se da implantação dos três condomínios (1, 2 e 3) lado a lado, há um gradil delimitando a divisão entre eles, como podemos observar na Figura 20. O espaço entre os dois condomínios acaba aparecendo como um espaço de divisa. Mais uma vez, vale enfatizar que as entradas das unidades não estão voltadas para esses limites o que poderia gerar outro tipo de situação e relação entre os espaços.

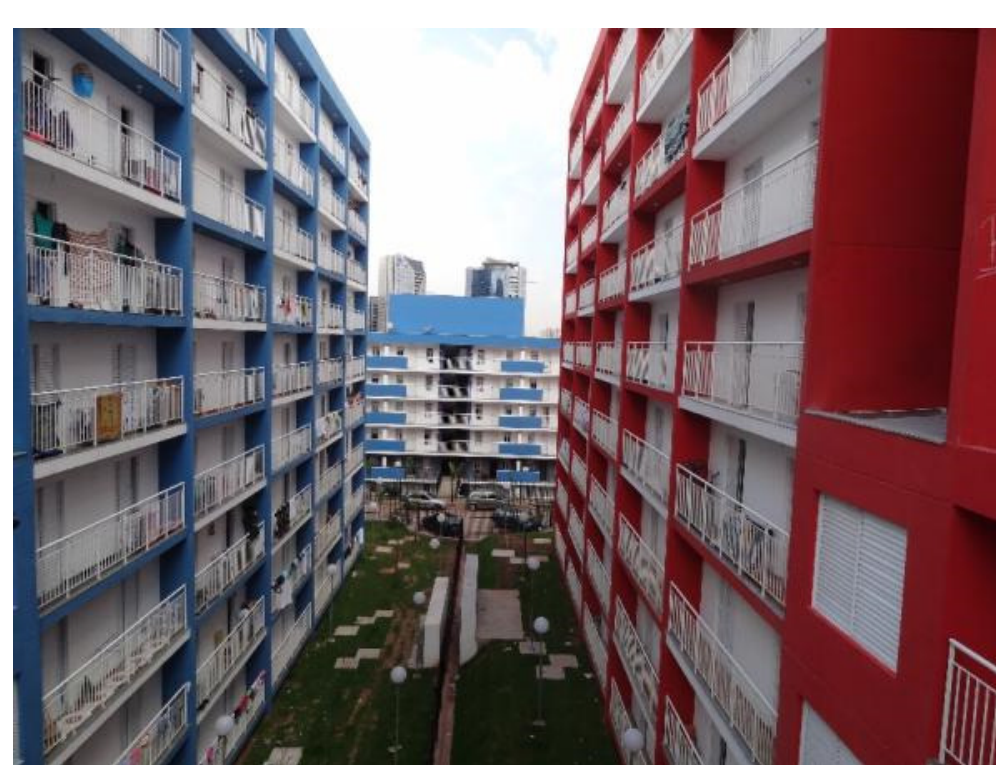

Figura 20 - Limite entre condomínio 2 e 3 - Quadra A Leste.

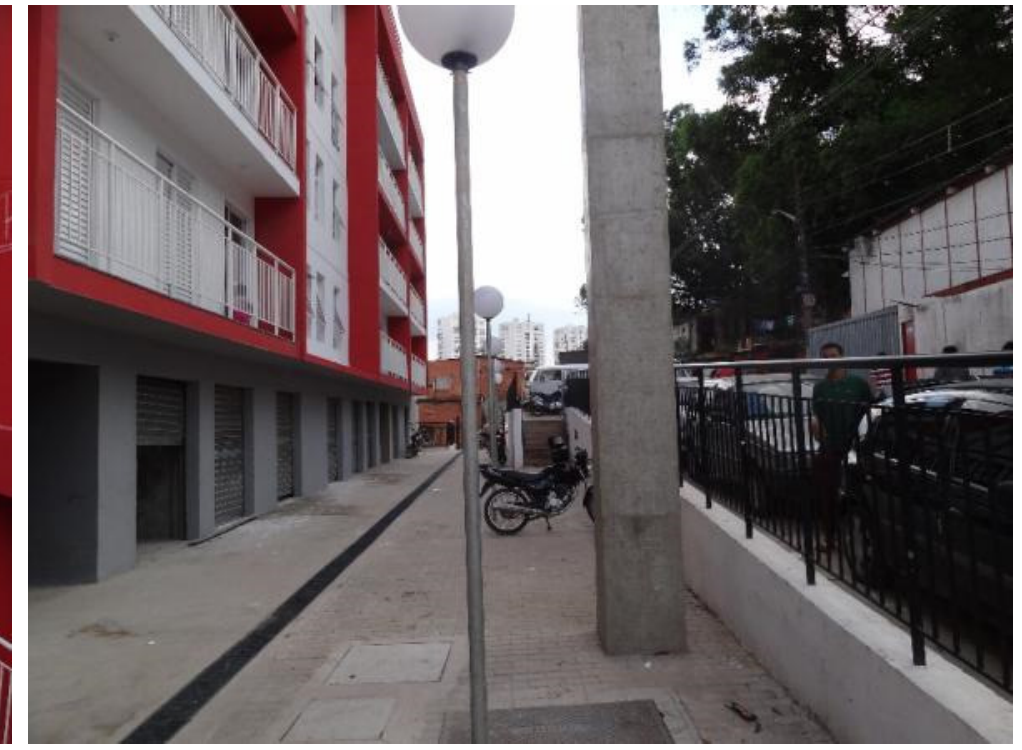

Figura 21 - Acesso às lojas comerciais. Térreo do Condomínio 3 Quadra A Leste.

No trecho onde há lojas comerciais no térreo, o acesso às lojas é livre e há portões que bloqueiam o acesso ao interior do condomínio. Entre a rua oficial - Rua Conde de Itaguaí - e as lojas, foi criada uma rua de acesso que soluciona o desnível existente. 
No condomínio 4 da quadra A Leste o desnível é bem alto e, assim como nos outros casos, foi tratado com paisagismo e uma circulação. Porém, é importante destacar que, nesse condomínio, as entradas das unidades estão voltadas para esse limite, como pode ser observado na Figura 22.

$\mathrm{Na}$ foto podemos observar a rua (à esquerda), o muro de contenção e as passarelas que conectam o edifício à rua. Três níveis abaixo localiza-se o térreo inferior do condomínio.

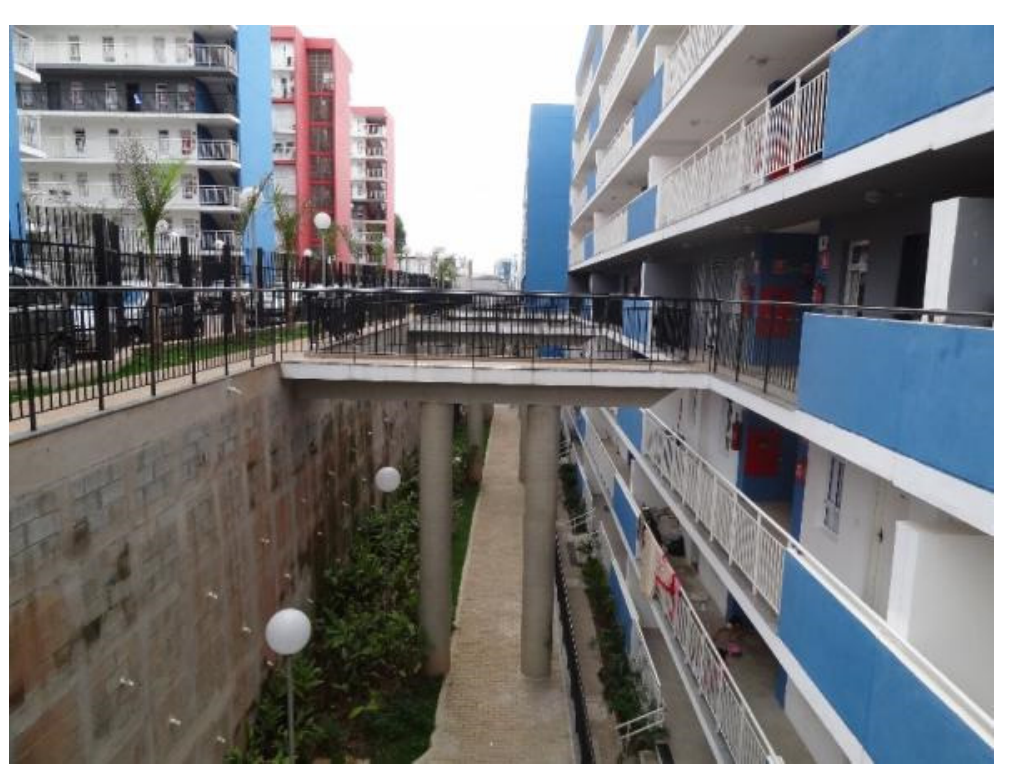

Figura 22 - Limite entre a rua e o edifício no condomínio 4 - quadra A Leste.

\section{Adaptação ao terreno}

Como já foi citado anteriormente, o terreno onde está sendo implantado o Conjunto Habitacional Real Parque é bastante íngreme. De acordo com o arquiteto Eduardo Colonelli,

[...] os grandes desafios do projeto e de sua implantação foram a topografia acidentada e o fato de já existirem arruamentos, que impuseram alguns limites à configuração desses 11 condomínios. 'Por outro lado, essa limitação fez com que se criassem tipologias diferentes nos blocos. Não dava para repetir um mesmo padrão'. Os desníveis também viabilizaram a construção de edifícios de até nove pavimentos, mesmo sendo os prédios desprovidos de elevadores. Isso foi possível porque o acesso a partir da rua é feito sempre em um andar intermediário, localizado no quarto pavimento, com quatro andares superiores e, de acordo com a condição topográfica, entre dois e quatro inferiores. (em: Revista AU - FLORESTA, 2013, p. 29) 
O arquiteto comentou ainda que, "além da legislação desobrigar as habitações de interesse social da instalação de elevadores, era um desejo dos próprios moradores que o acesso aos prédios fosse apenas por rampas e escadas uma forma de diminuir os custos de manutenção." (FLORESTA, 2013, p. 29).

No item definição do limite do conjunto, foi possível observar a topografia existentes e as soluções projetuais para implantar os edifícios, que em muitos casos, resultou em acessos a partir de pavimentos intermediário e muros de contenção de até três pavimentos.

Nos cortes ao lado é possível identificar os desníveis e a forma como os edifícios foram implantados, adaptando-se à situação. $\mathrm{O}$ corte $\mathrm{A}$, atravessa transversalmente a futura praça de equipamentos representando a inclinação do terreno. O edifício institucional será implantado tirando partido do desnível e realizando a conexão entre dois níveis.

O corte B ilustra como os níveis vão diminuindo a partir do condomínio da quadra I até o condomínio 4 da quadra A Leste e o conjunto Cingapura.

Por último o corte $\mathrm{C}$ representa, mais uma vez, o futuro edifício de equipamentos e o desnível existente entre as quadras A Leste e Oeste.

Com relação à quantidade de muros de contenção que aparece no projeto, formando, em muitos casos, grandes paredões, fica aqui uma reflexão: Será que esse muros não poderiam ser objeto de um trabalho social que envolvesse os moradores para pintar e fazer grafite nesses espaços? Entende-se, esses trabalhos com a comunidade, como sendo uma estratégia de atuação para incentivar a apropriação e identificação dos moradores com os espaços. 

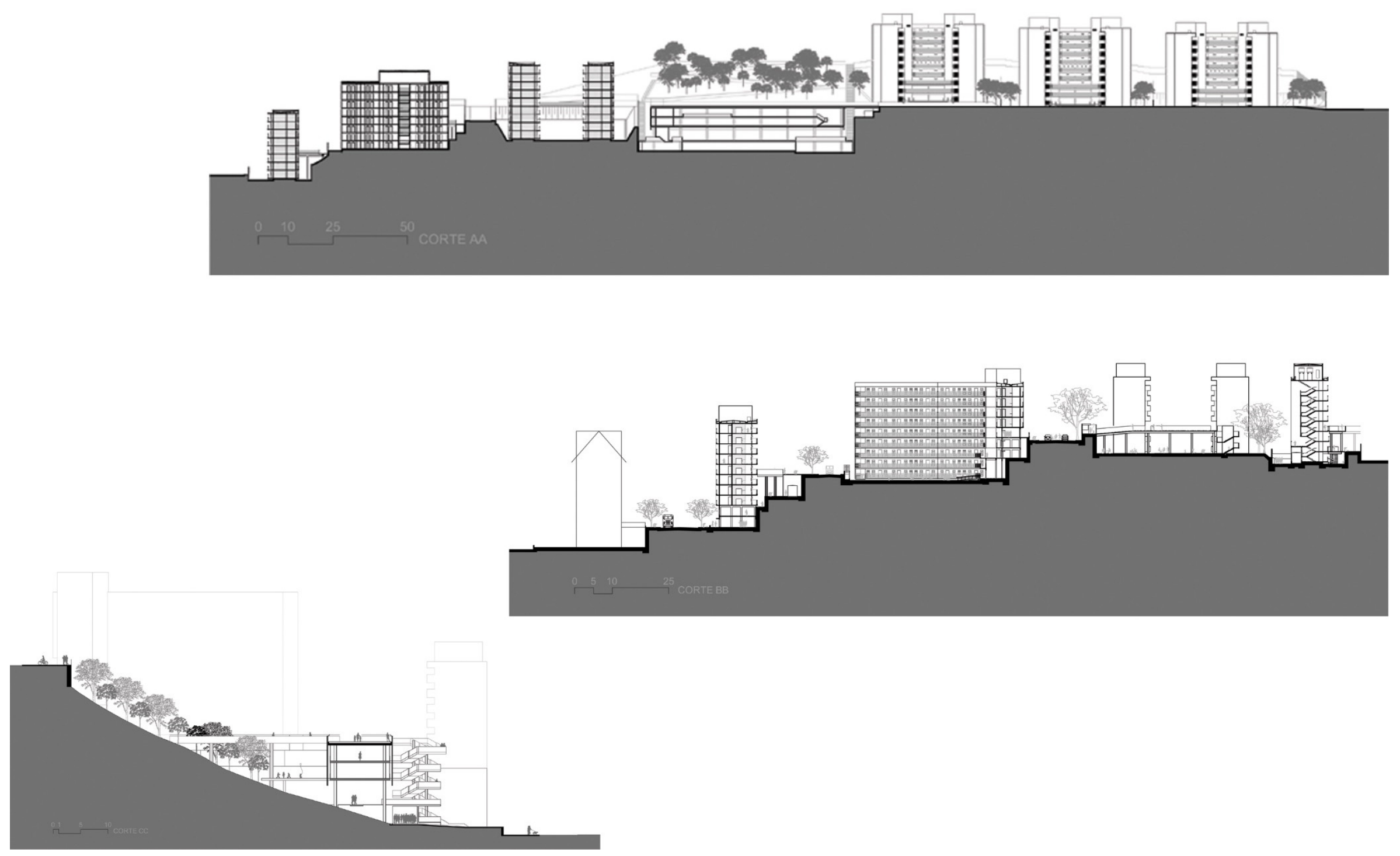

Figura 23 - cortes gerais da implantação. 


\section{Diálogo volumétrico}

O Conjunto Habitacional Real Parque está inserido em um bairro consolidado da zona sul da cidade. Ao redor do projeto há muitos edifícios residenciais de alto padrão. Entretanto, sua localização é bastante particular, pois está próximo da Marginal do Rio Pinheiro onde há grandes centros comerciais como a Leroy Merlin, a Decathlon, o Pão de Açúcar e o centro de treinamento do Pão de Açúcar, construções de grande porte e baixa altura.

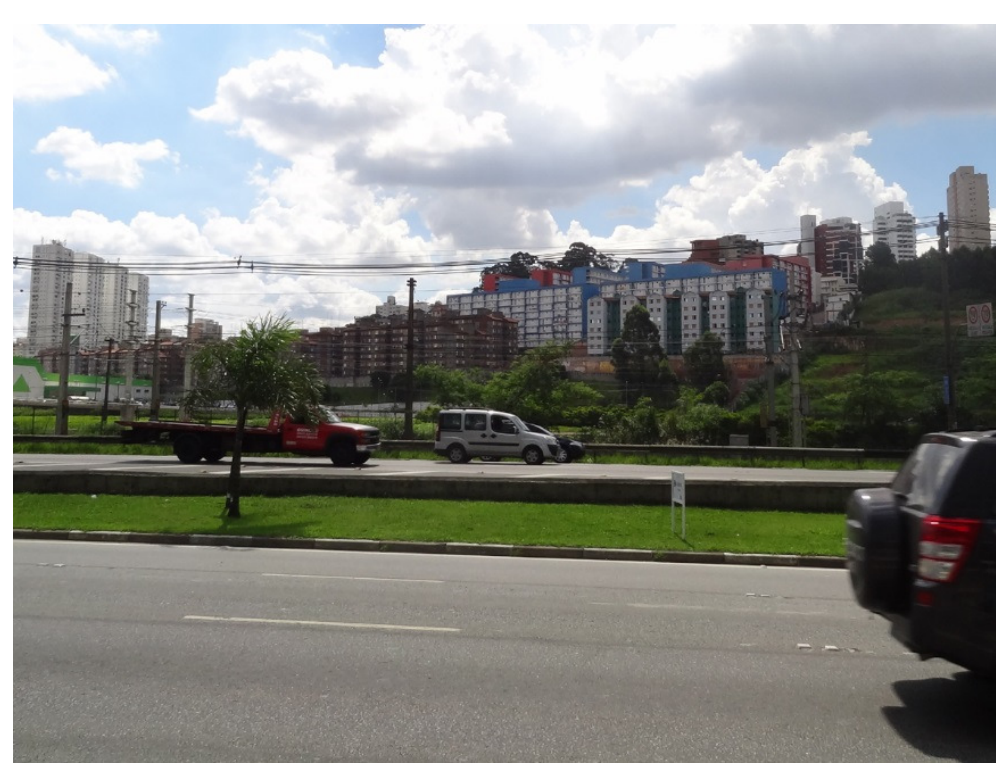

Figura 24 - Vista do Conjunto Habitacional Real Parque a partir da Marginal do Rio Pinheiros.

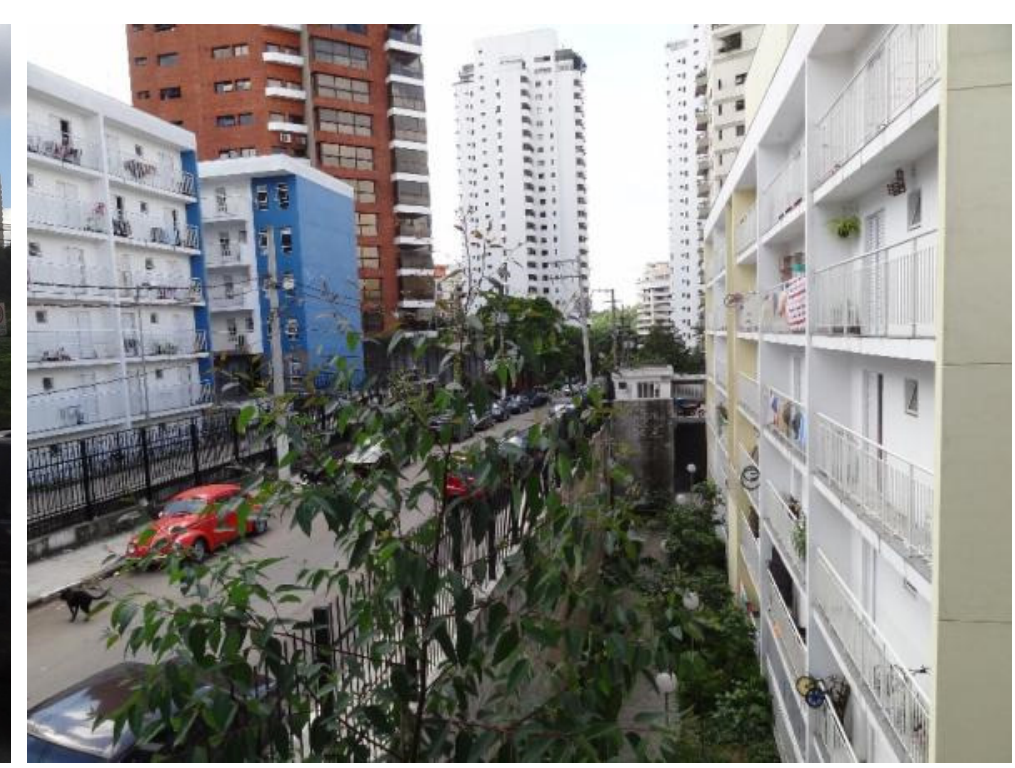

Figura 25 - Conjunto Habitacional Real Parque e edifícios vizinhos ao fundo.

Ao observar o conjunto a partir do outro lado da Marginal Pinheiros, podemos ver claramente que ele se destaca dos edifícios vizinhos. Por um lado, as cores primárias são responsáveis por um destaque maior, mas por outro, a 
configuração do conjunto faz com que os edifícios do Real Parque se destaquem dos edifícios ao redor. Além do mais, o conjunto é bastante grande, com a implantação de seus onze condomínios.

Quanto ao diálogo que estabelece com o entorno, podemos considerar que há relação a partir de alguns aspectos como a proposta de edifícios residenciais e a verticalização, bem como a dimensão dos edifícios. Porém, talvez pela proporção da intervenção, ao observar-se esse conjunto com relação ao entorno, tem-se a sensação de que ele sempre será visto como um conjunto habitacional de interesse social implantado no bairro. Algumas características são muito marcantes e fazem com que ele se diferencie do entorno.

\subsubsection{ESPAÇOS EXTERIORES}

A partir do item espaços exteriores a análise será focada nas três quadras que já estão construídas: quadra H; quadra I e quadra A Leste.

Para a análise desse item foi necessário estudar separadamente as quadras, pois essa separação permitiu apresentar os desenhos em escala adequada para compreensão.

Todos os condomínios contam com área de lazer localizada entre os edifícios. Essa situação de implantação permite que sempre haja "olhos" cuidando desses espaços, pois os moradores que circulam pelas passarelas de acesso aos apartamentos estarão sempre assistindo ao que acontece nas áreas de lazer.

Se por um lado essa situação é vantajosa a partir da perspectiva da segurança, por outro devemos considerar também o incômodo do ruído. Os moradores comentaram que o barulho na quadra é constante e que, muitas vezes, sentem-se incomodados, ainda mais à noite. Um morador que acompanhou a visita realizada ao conjunto contou que a iluminação da quadra é desligada à noite, justamente para que esse espaço não seja utilizado. 
QUADRA H
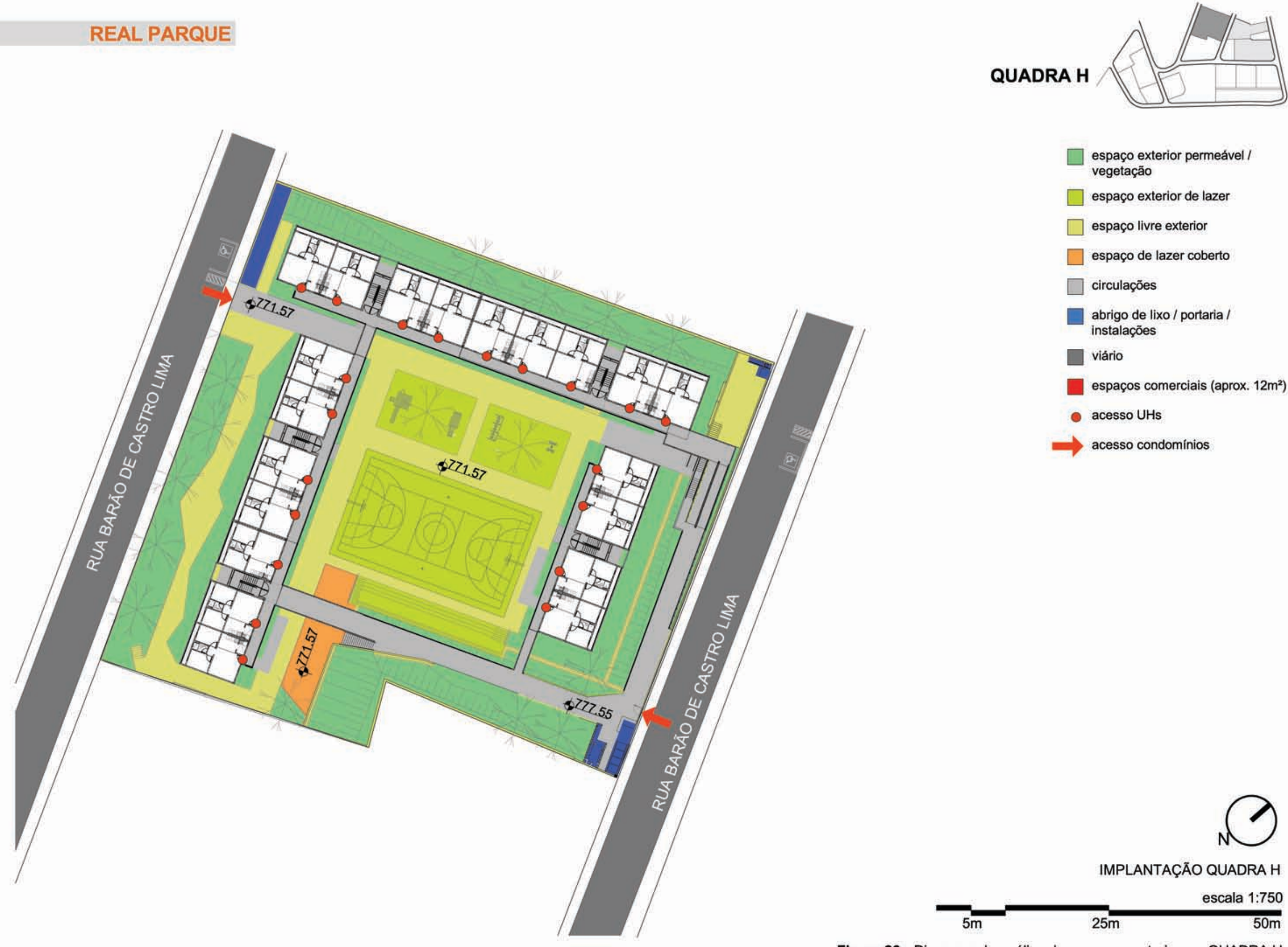

espaço exterior permeável / vegetaçăo

$\square$ espaço exterior de lazer

espaço livre exterior

$\square$ espaço de lazer coberto

$\square$ circulaçōes

abrigo de lixo / portaria / instalações

$\square$ viário

espaços comerciais (aprox. $12 \mathrm{~m}^{2}$ )

- acesso UHs

$\Rightarrow$ acesso condomínios

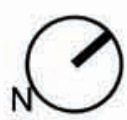

IMPLANTAÇÃO QUADRA H

escala 1:750

Figura 26 - Diagrama de análise dos espaços exteriores - QUADRA H. 


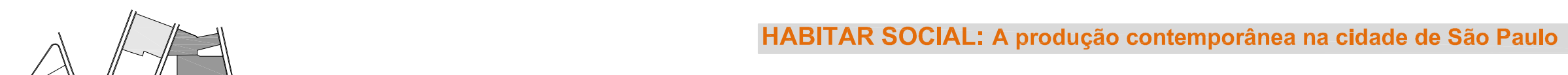

\section{QUADRA I}

condomínios 1 e 2

$\square$ espaço exterior permeável/ vegetação

$\square$ espaço exterior de lazer

$\square$ espaço livre exterior

$\square$ espaço de lazer coberto

$\square$ circulações

abrigo de lixo / portaria instalações

$\square$ viário

espaços comerciais (aprox. 12m²)

- acesso UHs

$\Rightarrow$ acesso condomínios

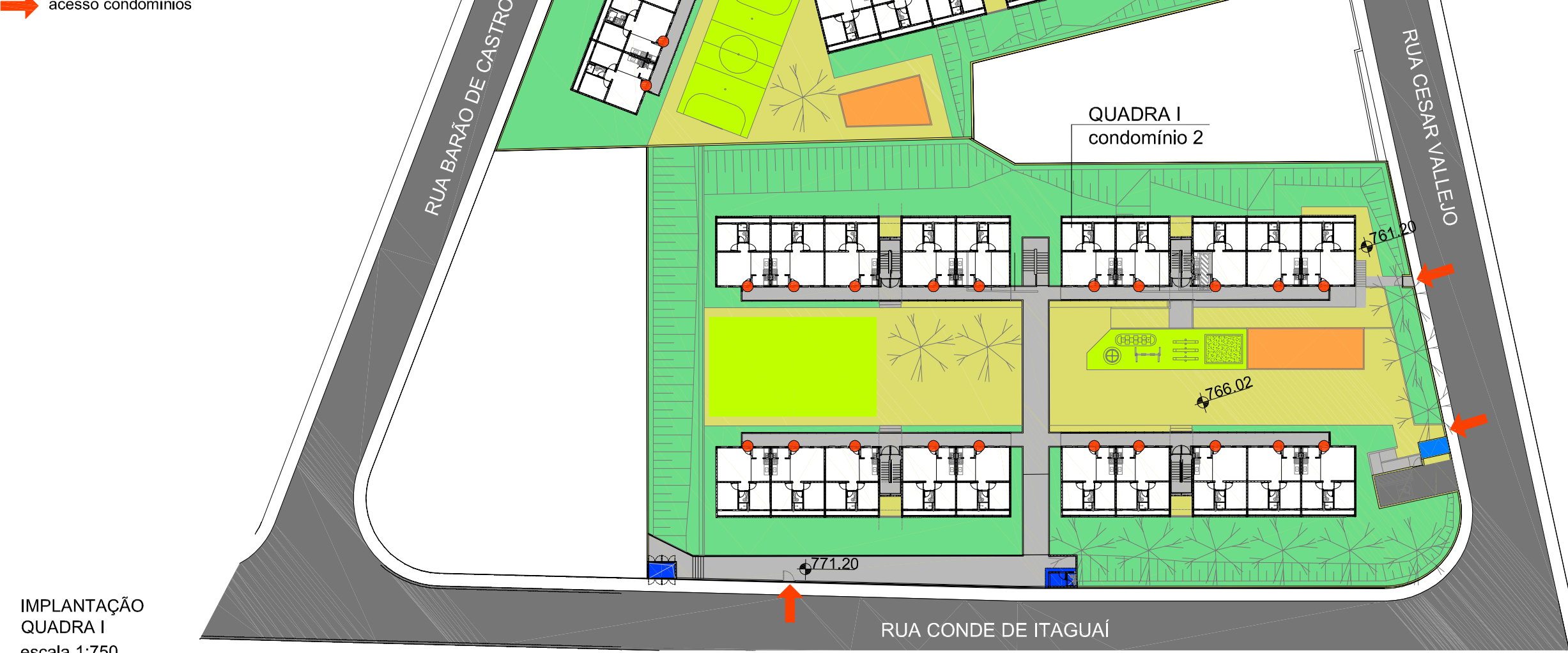




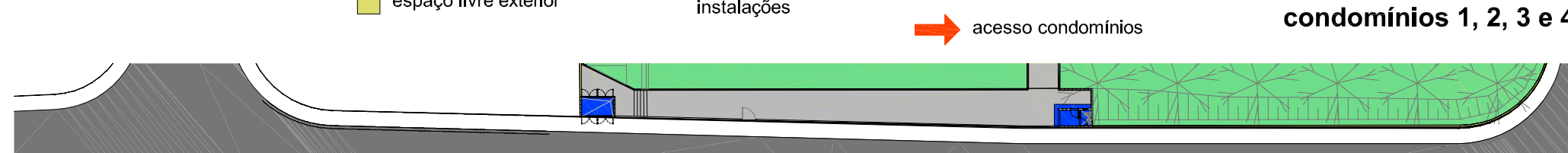

RUA CONDE DE ITAGUAÍ

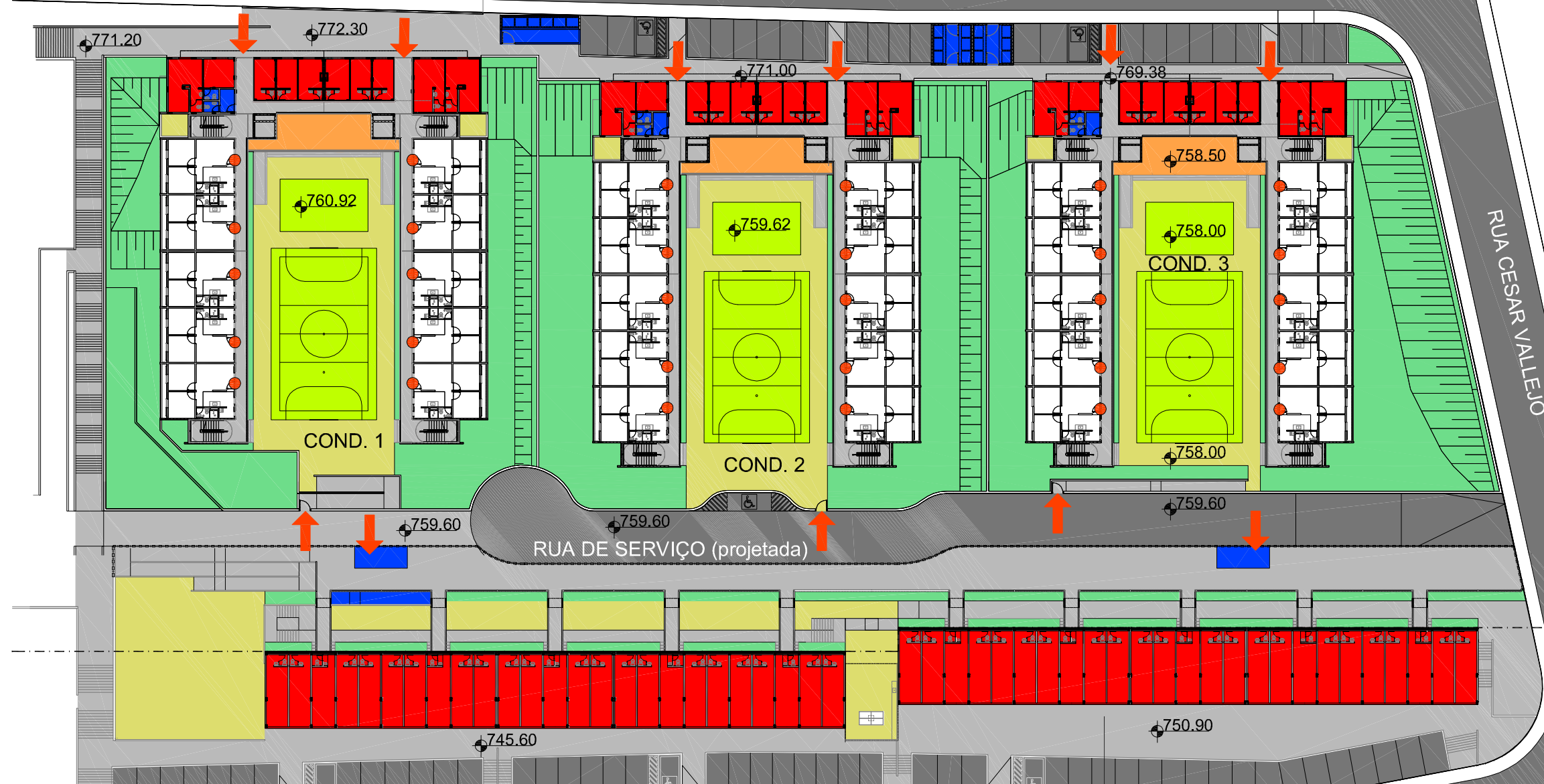


Segundo o morador, os adolescentes que querem continuar jogando durante a noite, se organizam para que alguns fiquem correndo pelos corredores, pois nos corredores há sensores de luz que ajudam a aumentar a iluminação da quadra. Essa situação refere-se, particularmente, ao caso dos condomínios da quadra A Leste, onde a proximidade das quadras com os edifícios é maior que nos outros casos devido ao "u" formado pelos edifícios ao redor das áreas de lazer.
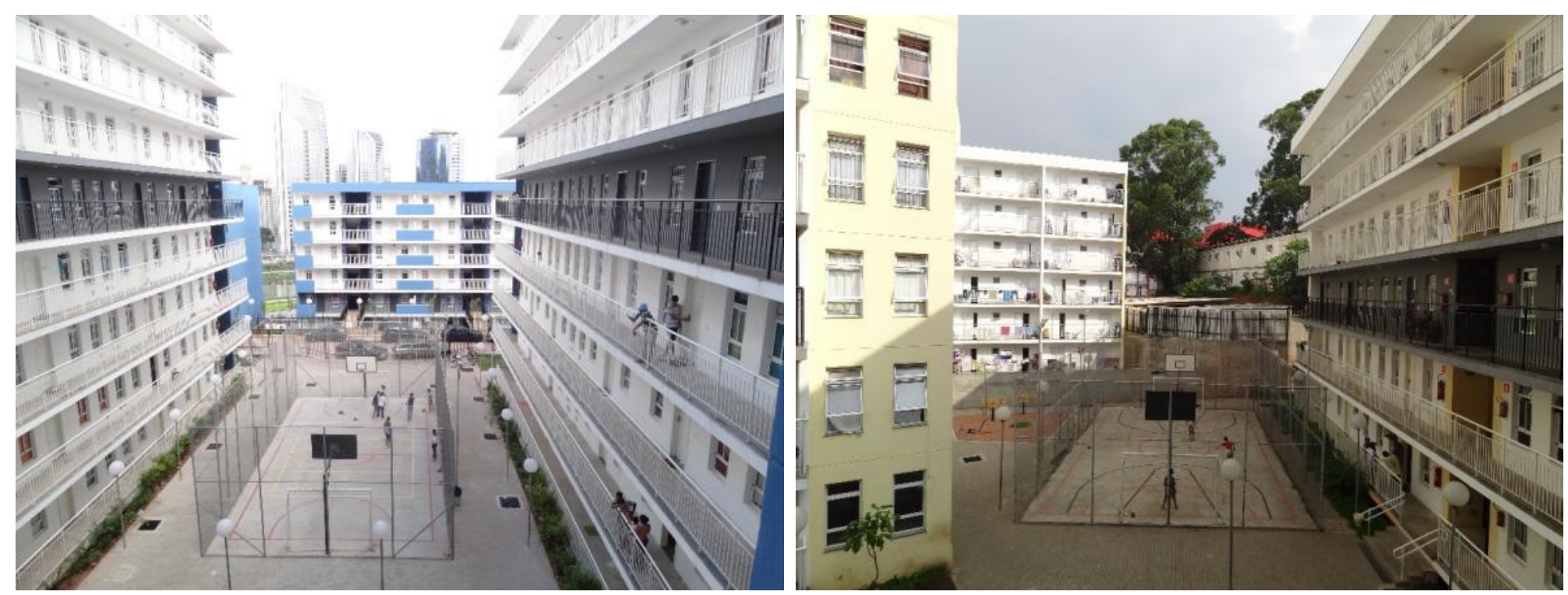

Figura 29 - quadra no térreo inferior do condomínio 2 - quadra A Figura 30 - Quadra no interior do condomínio da quadra H. Leste.

No diagrama de análise dos espaços exteriores é possível observar também que as áreas com vegetação (áreas permeáveis) localizam-se no perímetro dos condomínios entre os edifícios e o limite dos conjuntos. São as áreas observadas no item definição do limite do conjunto. 
Em todos os condomínios é possível identificar os espaços de lazer cobertos. São áreas conjugadas aos espaços exteriores, porém cobertas. De acordo com a legislação de HIS ${ }^{9}$ e com as Diretrizes de Projetos de Edificação, "no caso de condomínio horizontal de até 20 unidades habitacionais, não é obrigatório prever áreas de lazer. Acima de 20 unidades, deve-se destinar $10 \%$ da área do lote, com formato que permita a inserção de círculo com $\mathrm{R}=3 \mathrm{~m}$ " (Prefeitura de São Paulo, 2012b, p. 237).

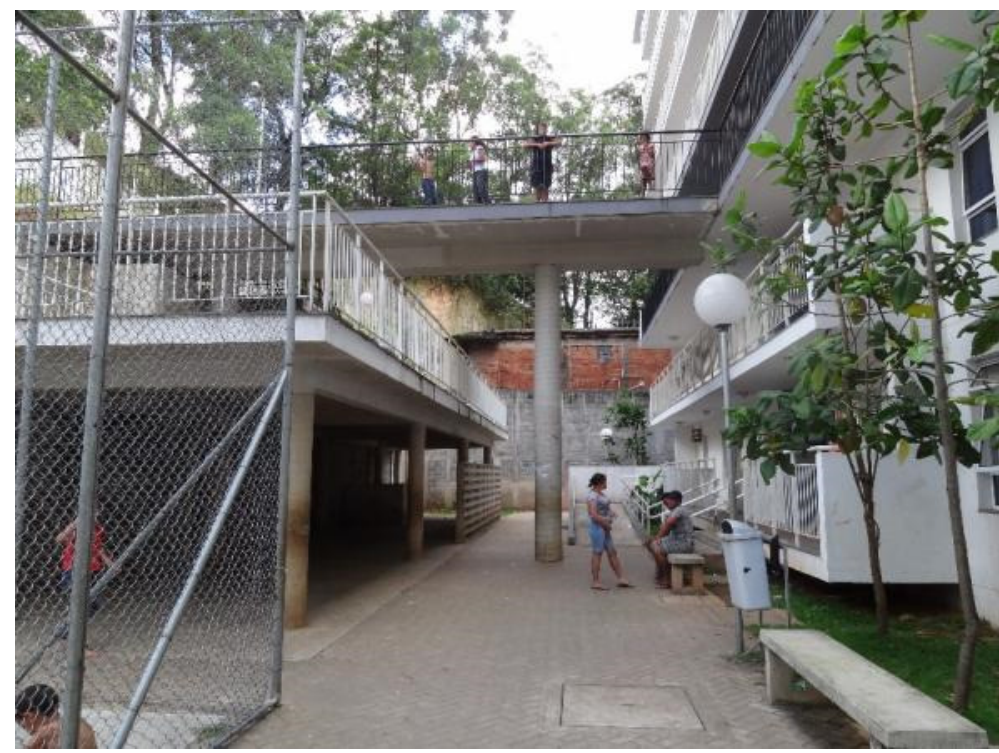

Figura 31 - Área de lazer coberta ao fundo - quadra $\mathrm{H}$.

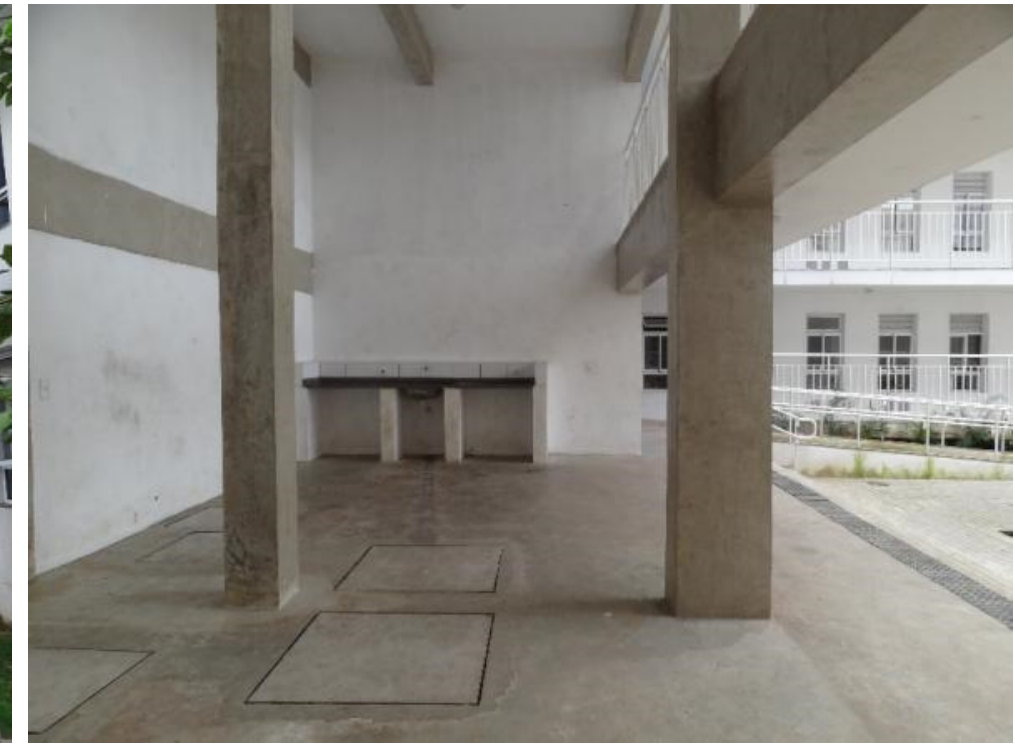

Figura 32 - Áreas de lazer coberta - condomínio 2 - quadra A Leste.

A área destinada a espaço de lazer coberto da quadra $\mathrm{H}$ localiza-se abaixo de uma das passarelas de acesso, porém de acordo com o que foi possível observar durante a visita, e também com base nos comentários da arquiteta Geni Sugai, esse espaço não é muito utilizado. Segundo Geni, os moradores solicitaram que seja fechado

${ }^{9}$ Decreto Municipal № 44.667/04 (ZEIS, Empreendimentos Habitacionais de Interesse social, Parcelamento do Solo de Interesse Social, Habitações de Mercado Popular). 
para poderem utilizar como sala de reuniões ou salão e festas. O fato é que, como está hoje, não é útil para os moradores e resulta, inclusive, em um espaço residual.

Quanto ao lazer coberto dos condomínios 1, 2 e 3 da quadra A Leste, são áreas mais amplas, com pé-direito mais alto e bem relacionados com o espaço de lazer exterior, mas ainda assim, foi solicitado pelos moradores que o espaço seja fechado. A arquiteta entende que esse pedido está relacionado com a privacidade, pois no caso do espaço ser fechado, os moradores poderão reservá-lo para festas particulares e, da forma como está hoje, isso não seria possível, pois é muito exposto.

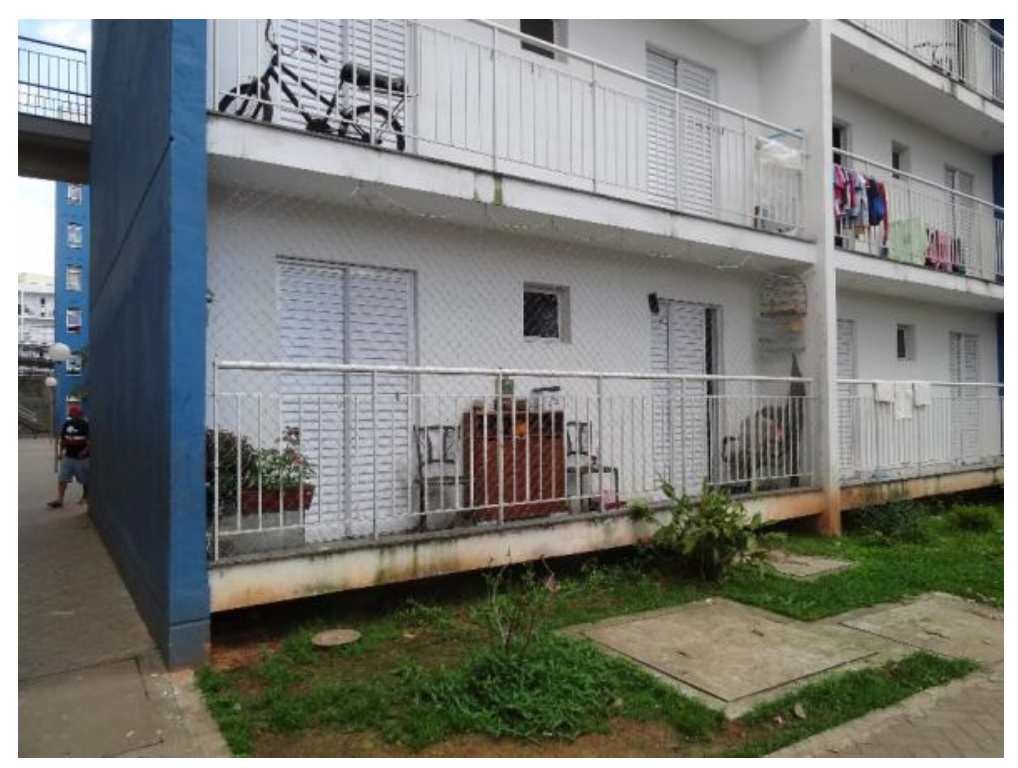

Figura 33 - Varandas das unidades do pavimento inferior. Quadra $\mathrm{H}$.

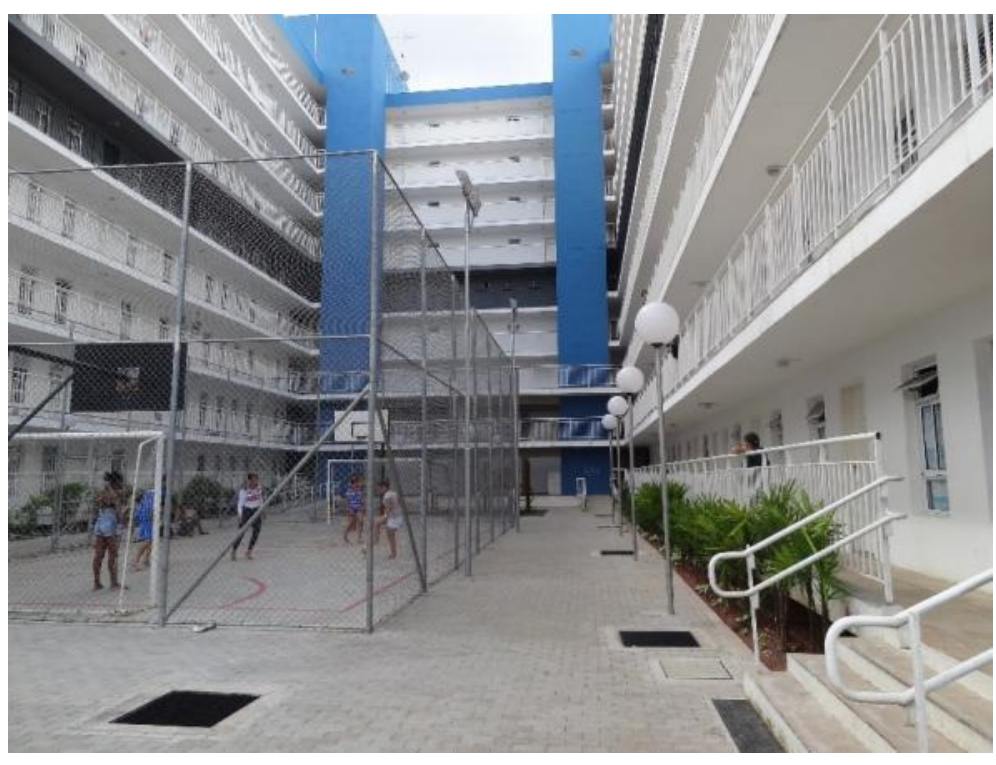

Figura 34 - canteiro, desnível e passarela como filtros de privacidade para a unidade do pavimento inferior. Quadra A Leste - condomínio

Observando a relação que os edifícios têm com o térreo inferior, ou seja, o pavimento mais baixo onde encontramse as áreas de lazer, é possível verificar que foram implantados elevados do solo a aproximadamente $50 \mathrm{~cm}$ de 
altura. Geni Sugai explica que essa solução foi dada para garantir a privacidade das unidades do pavimento inferior e, com isso, conseguiram garantir que essas unidades também tenham varandas, assim como as unidades dos pavimentos superiores.

A estratégia de "soltar" do solo os edifícios e também a implantação de áreas verdes ao longo das passarelas, funcionam como filtros de privacidade que, de certa forma, protegem as portas e janelas dos apartamentos que estão em contato direto com o térreo inferior do conjunto.

Nos condomínios da quadra A Leste, há lojas comerciais no nível que tem acesso direto pela Rua Conde de Itaguaí e pela Rua Paulo Bourroul. No trecho em frente às lojas ocorre um alargamento da calçada onde encontram-se as vagas de estacionamento e também uma "segunda" calçada que funciona como extensão das lojas para a circulação de pessoas. Essas "duas" calçadas permitem que as diferenças de níveis entre rua e o pavimento em que as lojas estão implantadas seja solucionada adequadamente e, quando necessário, existem rampas ou escadas para transpor o desnível.

Como foi visto no item definição do limite do conjunto, os condomínios são cercados com gradis e cada condomínio possui mais de um acesso, de acordo com os níveis das ruas adjacentes. Nos desenhos realizados para analisar os espaços exteriores, é possível identificar esses acessos.

A quadra H possui um acesso no nível inferior pela Rua Barão de Castro Lima (nível 771,57) e outro através do pavimento intermediário (nível 777,55), por outra rua com o mesmo nome.

O condomínio 1 da quadra I possui um dos acessos também pela Rua Barão de Castro Lima (nível 774.60) e outro mais abaixo pela Rua Cesar Vallejo (nível 761.10). O condomínio 2, dessa mesma quadra, possui três acessos: dois pela Rua Cesar Vallejo e um, através do pavimento intermediário, pela Rua Conde de Itaguaí (nível 771.20). 
No caso dos condomínios 1, 2 e 3 os acessos localizam-se na Rua Conde de Itaguaí e na Rua de Serviço - criada pelo projeto - que acessa aos pavimentos inferiores desses condomínios.

O condomínio 4 da quadra A Leste possui duas entradas principais através da Rua de Serviço (indicadas nas fotos abaixo). Internamente ao condomínio, existe um circulação principal que distribui os acessos a partir das passarelas existentes ao longo dos edifícios, como é possível verificar nas figuras abaixo.

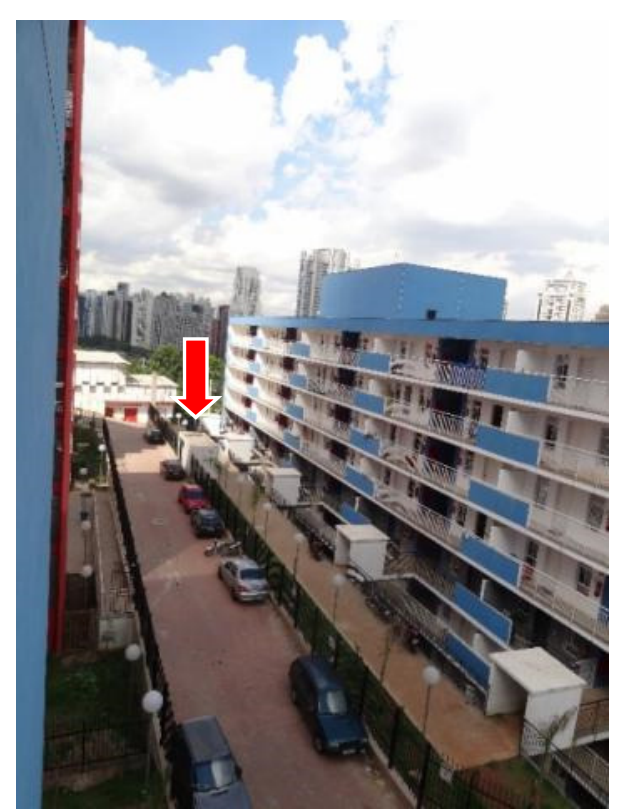

Figura 35 - Acessos ao condomínio 4 . quadra A Leste.

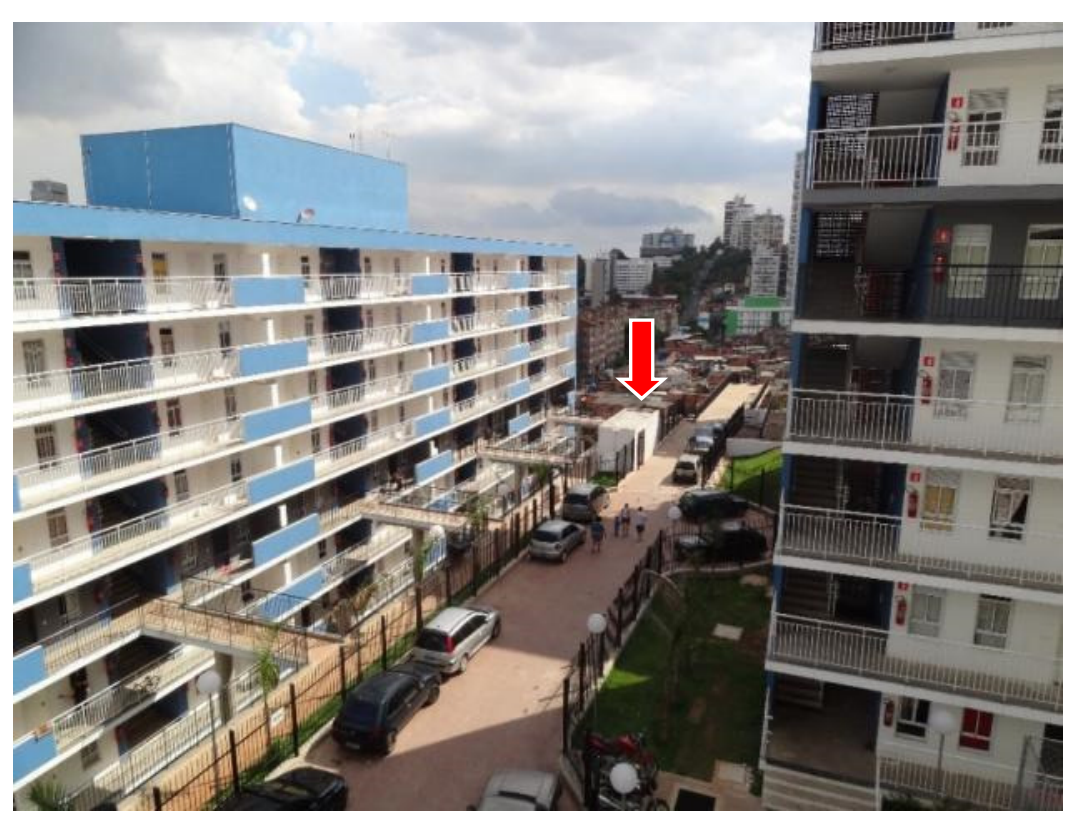

Figura 36 - Figura 35 - Acessos ao condomínio 4 - quadra A Leste. 
4.4.1.4. RELAÇÃO ENTRE OS EDIFÍCIOS

As quadras $\mathrm{H}$ e I são configuradas a partir de diferentes composições utilizando o mesmo bloco de edifício. Ocorrem variações com relação à quantidade de unidades habitacionais em cada bloco e à posição no terreno.

Com relação à quadra $A$ Leste, trata-se de uma outra tipologia de edifício. Nos condomínios 1, 2 e 3 dessa quadra a composição de edifícios cria um "U" que envolve o espaço de lazer. No caso do condomínio 4, trata-se de duas lâminas de 66 metros de comprimento que foram implantadas paralelamente às curvas de nível do terreno, tirando partido do desnível para definir as circulações e acessos.

\section{Acessos e circulação}

Devido à declividade do terreno, os blocos de edifício possuem alturas variadas. Alguns edifícios chegam a ter nove pavimentos, pois conseguem definir acessos a partir de andares intermediários. A vantagem oferecida por esse tipo de implantação é poder alcançar um maior número de pavimentos sem a necessidade de implantar elevadores.

Apesar da não-obrigação dos elevadores, os condomínios 1, 2 e 3 da quadra $A$ Leste possuem, cada um, duas torres de previsão para elevadores. Caso futuramente sejam implantados, as torres já estão construídas e conectadas à circulação (Figura 40).

As passarelas são elementos muito significativos nesse projeto. Nos acessos através dos andares intermediários dos edifícios, a circulação é organizada pela utilização das passarelas e, dentro de cada condomínio, os edifícios estão conectados entre si. 


\section{QUADRA H}

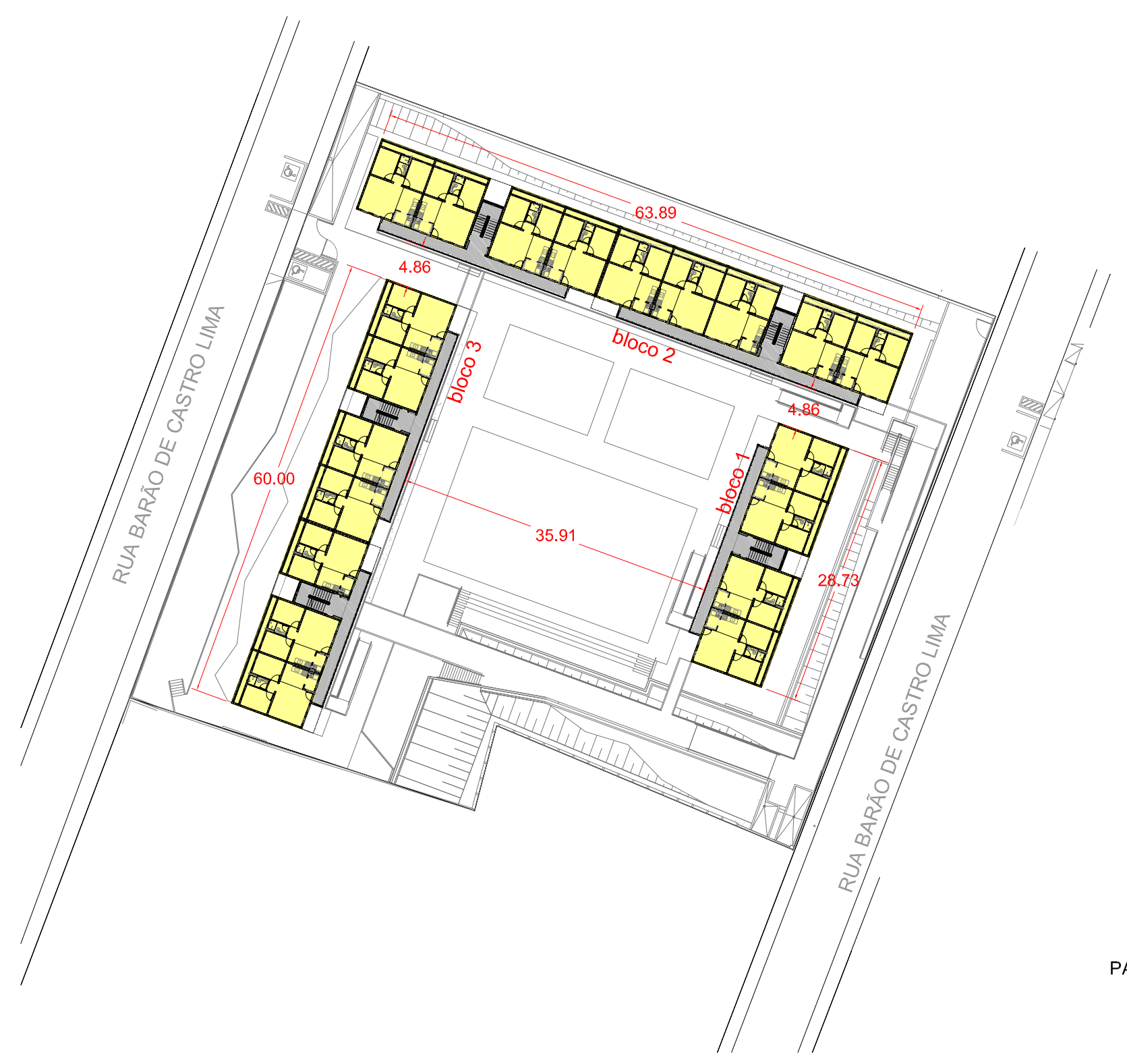

Tipo 1 (quadras $\mathrm{Hel}$ )

Tipo $1 \mathrm{~A}$ - P.N.E. (quadras $\mathrm{He} \mathrm{I}$ )

Tipo 2 - (quadra A Leste cond. 1, 2 e 3)

Tipo 3 - (quadra A Leste cond. 1, 2 e 3)

Tipo $3 A$ - (quadra A Leste cond. 1, 2 e 3)

$\square$ Tipo 4 - (quadra A Leste cond. 1, 2 e 3)

$\square$ Tipo 4A - P.N.E.(quadra A Leste cond. 1, 2 e 3 )

Tipo 5 - (quadra A Leste cond. 4)

Tipo 5A - P.N.E. (quadra A Leste cond. 4)

CIRCULAÇÕES (escadas e passarelas)

espaços de transição

PAVIMENTO TIPO QUADRA H NÍVEIS: 780,25 / 782,95 / 785,65

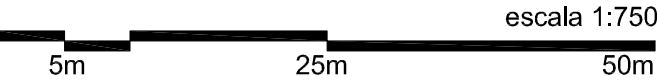

Figura 37 - Análise Relação entre os edifícios - QUADRA H. 
QUADRA I condomínios 1 e 2

$\square$ Tipo 1 (quadras $\mathrm{He}$ )

$\square$ Tipo $1 \mathrm{~A}$ - P.N.E. (quadras $\mathrm{He}$ )

Tipo 2 - (quadra A Leste cond. 1, 2 e 3)

$\square$ Tipo 3 - (quadra A Leste cond. 1, 2 e 3 )

$\square$ Tipo 3A - (quadra A Leste cond. 1, 2 e 3)

$\square$ Tipo 4 - (quadra A Leste cond. 1, 2 e 3 )

$\square$ Tipo 4A - P.N.E.(quadra A Leste cond. 1, 2 e 3)

Tipo 5 - (quadra A Leste cond. 4)

$\square$ Tipo 5 A - P.N.E. (quadra A Leste cond. 4)

$\square$ CIRCULAÇÕES (escadas e passarelas)

espaços de transição 


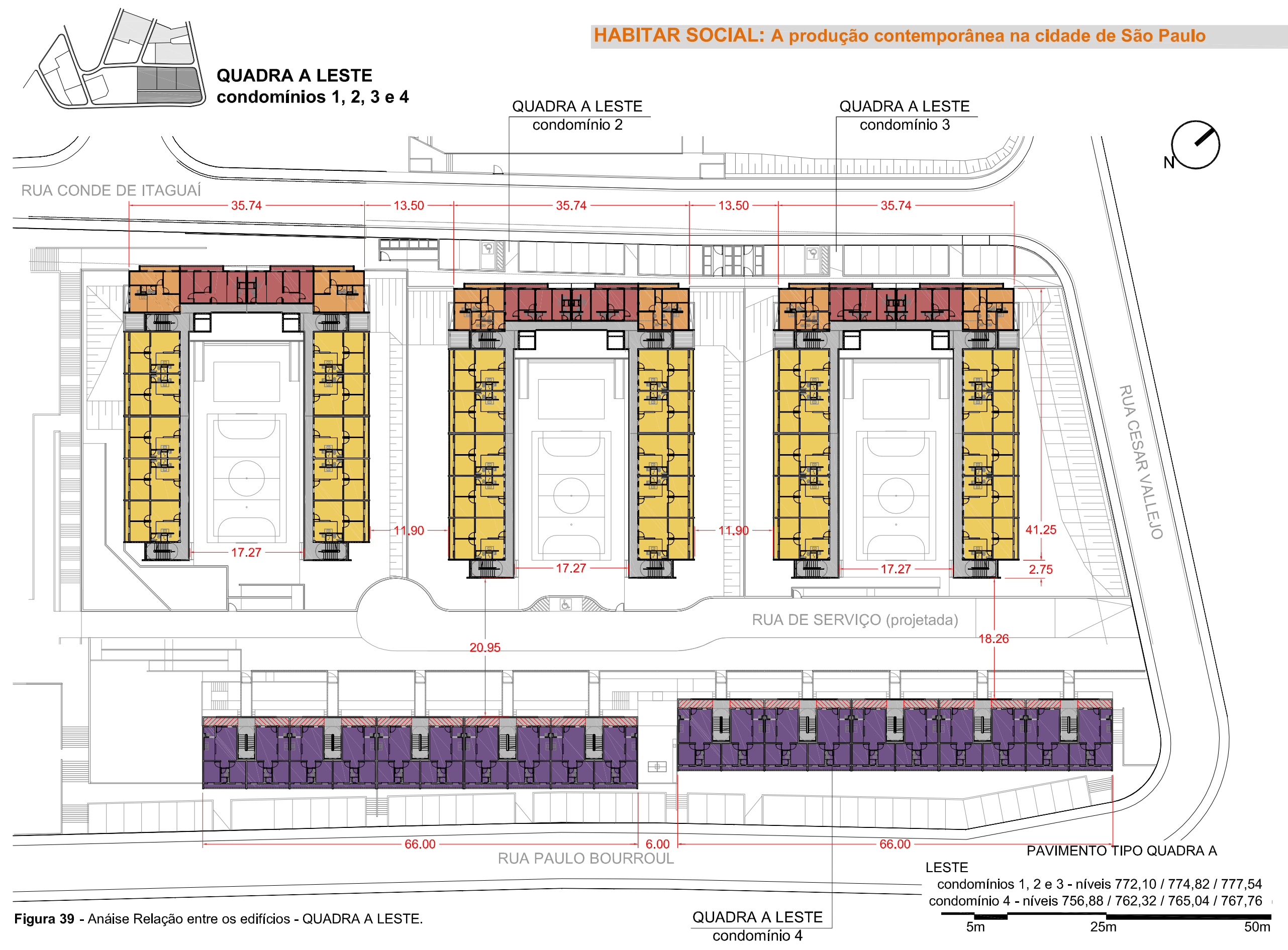


Como pode ser observado na Figura 41, esse andar intermediário é destacado do restante através da diferenciação da cor, com o intuito de identificar o pavimento que acessa a rua. Nesse pavimento todos os blocos de edifícios estão conectados através das passarelas.

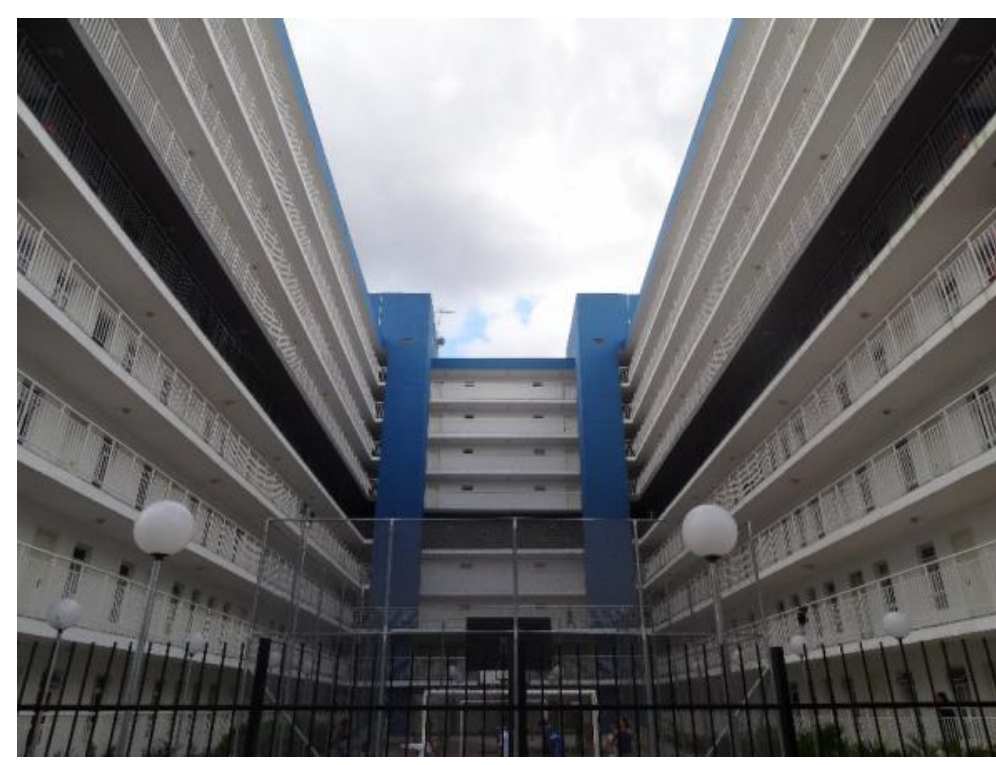

Figura 40 - torres de previsão para elevadores. Quadra A Leste Condomínio 2.

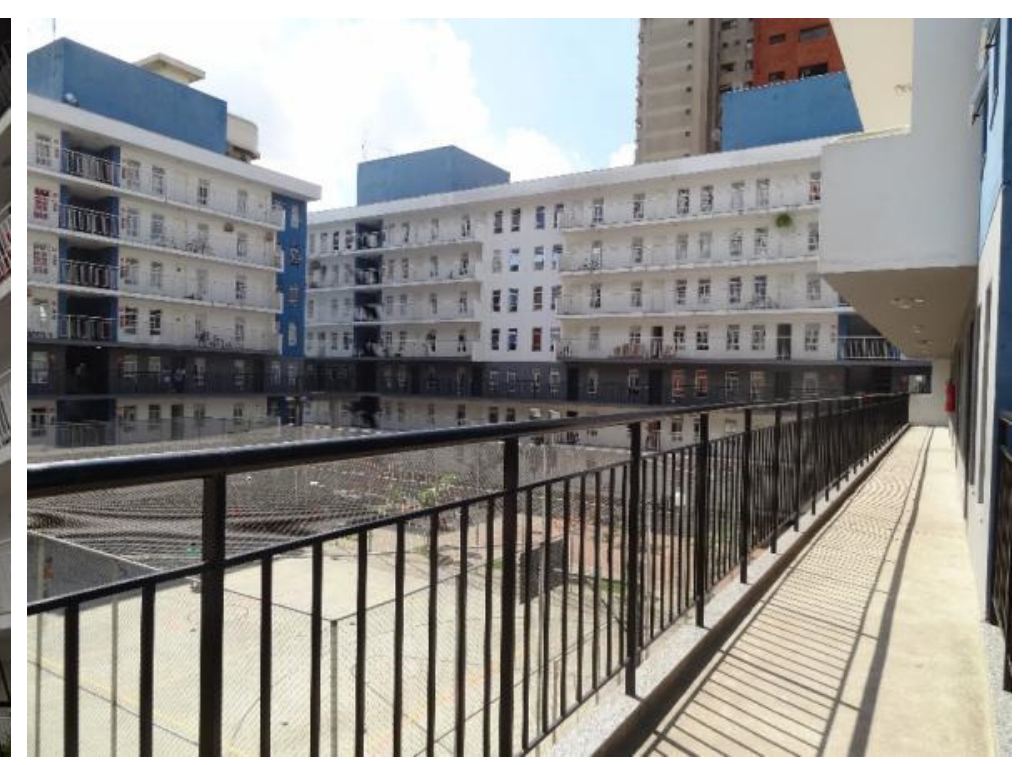

Figura 41 - Andar intermediário de acesso ao condomínio. Diferenciação pela cor.

Nas quadras $\mathrm{H}$ e I é possível observar, a partir dos desenhos de análise, que as passarelas que acessam as unidades - nos andares superiores ou inferiores ao andar intermediário - são bastante compactas. Cada torre de escada leva à uma passarela que atende de três a cinco unidades por andar. Nesses pavimentos as passarelas não se encontram.

Na quadra A Leste a proposta de circulação é um pouco distinta: nos condomínios 1, 2 e 3 há quatro torres de escadas conectadas entre si em todos os andares; já no condomínio 4 cada torre de escada atende a apenas dois 
apartamentos por andar e a passarela não é contínua. Há uma divisão a cada duas unidades, o que proporciona uma situação diferente com relação a esse elemento de circulação que, nesse caso, acaba funcionando como um espaço de transição no acesso a essas unidades.

\section{Variedade tipológica}

Nas três quadras que estão sendo analisadas há cinco tipologias diferentes. Nas quadras $\mathrm{H}$ e I ocorre apenas $\mathrm{O}$ Tipo 1 e sua variação nas unidades para pessoas com necessidades espaciais (P.N.E.). Os condomínios 1, 2 e 3 da quadra A Leste contam com três tipologias diferentes: o Tipo 4 ocorre nos blocos paralelos entre si (pernas do U); o Tipo 3 ocorre nas esquinas e o Tipo 2 aparece nos blocos paralelos à Rua Conde de Itaguaí.

No condomínio 4 da quadra A Leste, assim como nas duas primeiras quadras, há apenas uma tipologia, o Tipo 5 e sua variação para P.N.E. (Tipo 5A).

\section{Implantação e}

orientação

A implantação dos edifícios está bastante relacionada com a forma dos lotes. No caso da quadra $\mathrm{H}$, é possível observar que os edifícios foram implantados na periferia do lote, criando um espaço central onde foram implantadas as áreas de lazer. Dois blocos de edifícios têm orientação leste - oeste e apenas um está implantado com fachada norte - sul. Nesse caso, a passarela localiza-se na fachada sul. Entretanto, ao analisar o partido do projeto, podemos considerar que a passarela, como elemento de circulação voltado para o interior do lote, foi um dos critérios adotados. Entende-se portanto, que a posição da passarelas está mais relacionada ao partido da circulação que pela orientação, pois caso a insolação fosse um dos critérios considerados prioritários, a passarela não seria implantada na fachada que recebe menos luz e que poderia estar completamente exposta. Por outro lado, a passarela na face norte poderia ajudar a controlar um pouco a insolação. 
$\mathrm{Na}$ quadra I também fica claro que a posição dos edifícios é resultado do formato do terreno. Essa implantação proporciona insolação sudeste - noroeste para a maior parte dos edifícios. As passarelas estão voltadas sempre para o interior do condomínio e, portanto, ora para a face sudeste, ora para noroeste.

O condomínio 4 da quadra A Leste possui a mesma orientação que os edifícios da quadra I (condomínio 2), mas nesse caso as passarelas estão voltadas para noroeste e a fachada livre para sudeste. Quanto aos condomínios 1, 2 e 3, pode-se dizer que todas as unidades recebem insolação norte, pois as tipologias ocupam a largura total dos blocos e, com isso, têm aberturas nas duas fachadas. Porém, devido à implantação dos edifícios, em alguns momentos os dormitórios estão voltados para a face predominantemente norte e, em outros, para sul - sudoeste.

Com isso, fica claro que a insolação foi considera, mas não foi o critério que definiu a implantação dos edifícios. Pode-se dizer que a circulação teve maior prioridade o que não foi prejudicial ao conjunto, pois ainda assim, todas as unidades foram consideradas bem iluminadas e com insolação adequada.

\subsubsection{ESCALA EDIFÍCIO}

Nessa escala foram selecionados três edifícios para serem analisados. Como foi citado no item relação entre os edifícios, as quadras $\mathrm{H}$ e I são configuradas pela mesma tipologia edilícia e, portanto, para representar essas quadras foi selecionado o bloco 2 da quadra $\mathrm{H}$. Também serão analisados o condomínio 1 da quadra A Leste e o bloco 1 do condomínio 4 da mesma quadra. 


\subsubsection{Bloco 2 (quadra $H$ )}

O bloco 2 da quadra $\mathrm{H}$ é formado pela junção de dois módulos de edifício: cada um com uma caixa de escada. No primeiro módulo há quatro unidades habitacionais por andar (duas para cada lado da escada) e, no segundo, cinco unidades em cada pavimento, sendo três para um lado e duas para o outro lado da escada. No caso dos outros edifícios da quadra $\mathrm{H}$ e I, ocorrem variações a partir desses módulos.

\section{Acessos e circulação}

O térreo dos edifícios localiza-se $50 \mathrm{~cm}$ acima do térreo inferior do condomínio. Essa elevação permitiu que as varandas fossem mantidas nas unidades do térreo, além de funcionar como um filtro de privacidades atuando na transição entre o térreo condominial e o acesso às unidades desse pavimento. Para acessar a passarela do térreo inferior do edifício há uma pequena escada vencendo os $50 \mathrm{~cm}$ de altura e, no acesso às unidades $P$. N. E., há rampas (Figura 43).

Para chegar aos pavimentos superiores, há duas caixas de escada que, em cada andar, acessam às passarelas que levam às unidades. O fechamento dessas caixas de escada é com elementos vazados, o que garante a ventilação permanente e também acrescenta uma textura interessante aos edifícios, esteticamente falando (Figura 44).

Na parte de trás das caixas de escada localiza-se o reservatório inferior dos edifícios, como é possível observar no corte C (Figura 42). Na cobertura localizam-se as caixas d'água que abastecem as unidades. A medição é individualizada. 
REAL PARQUE

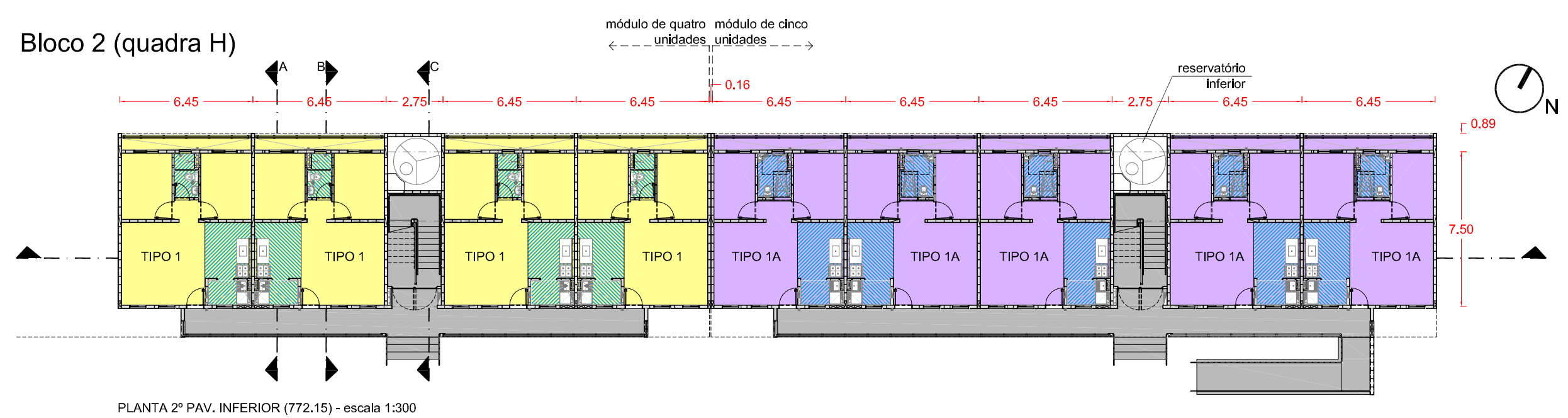

PLANTA $2^{\circ}$ PAV. INFERIOR (772.15) - escala 1:300

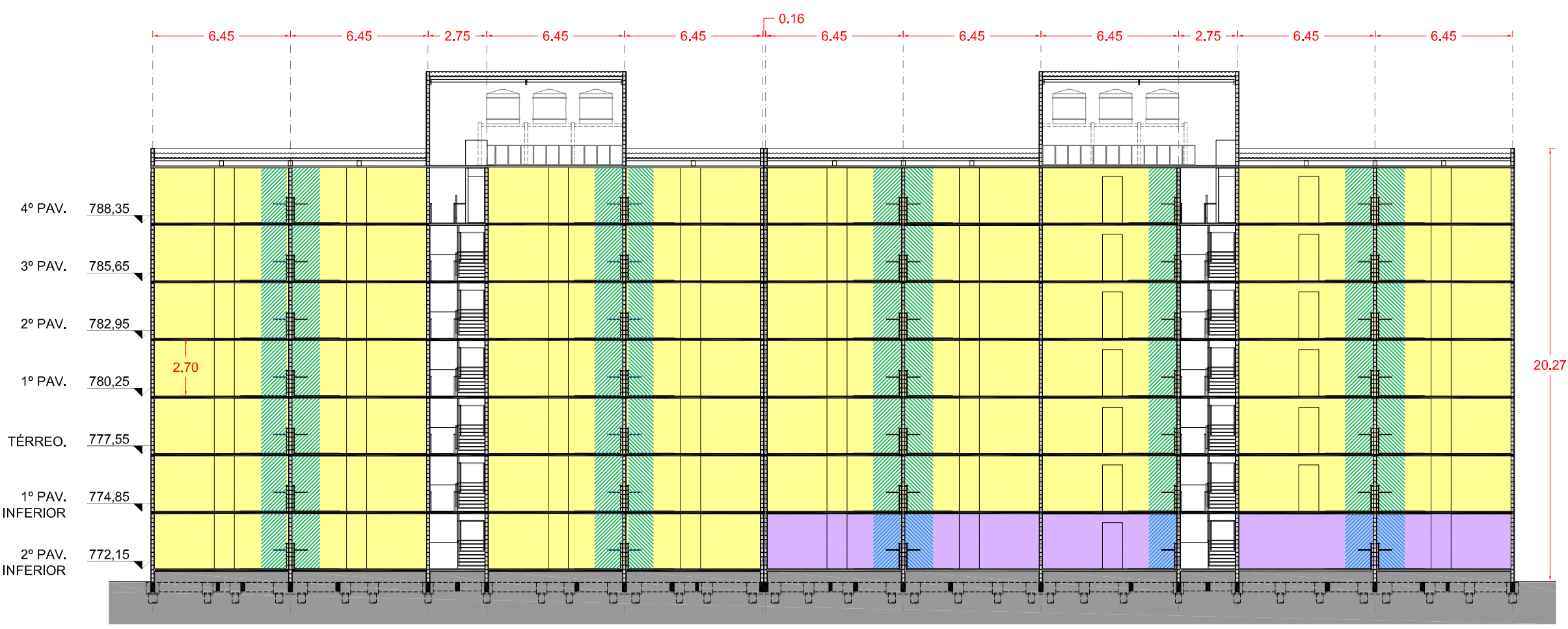

CORTE LONGITUDINAL - escala 1:300

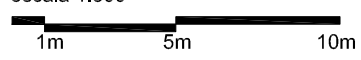



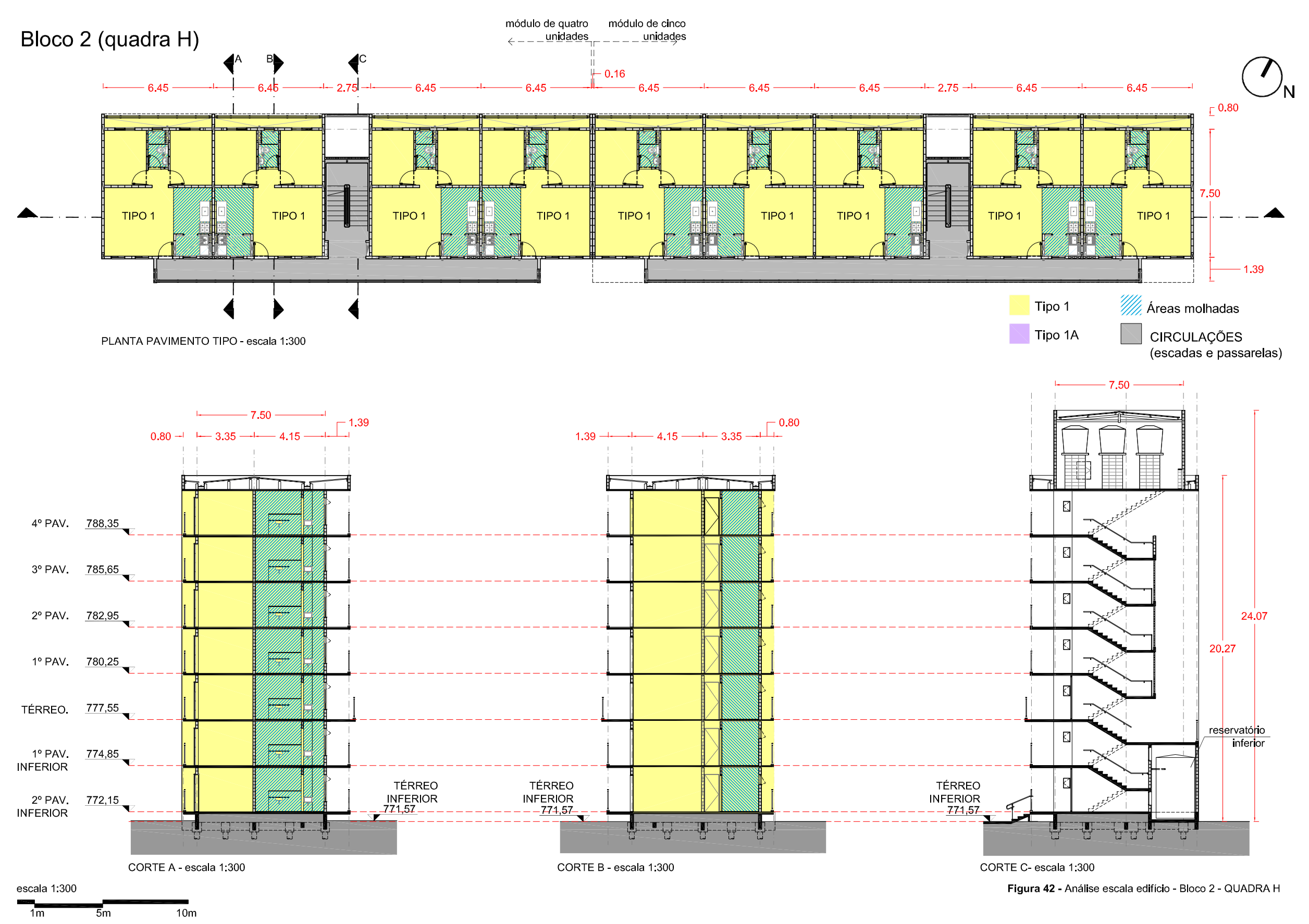


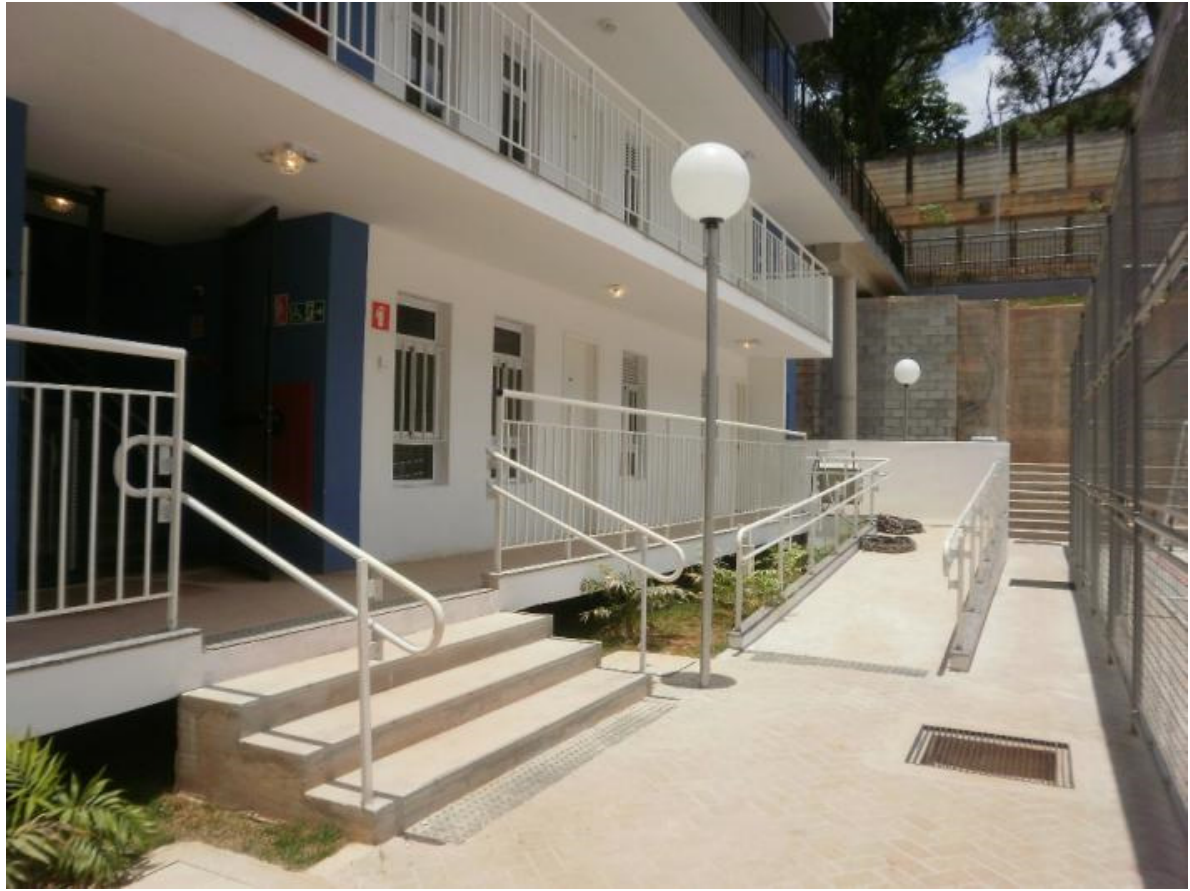

Figura 43 - Acesso à passarela do térreo inferior do edifício através da escada e da rampa.

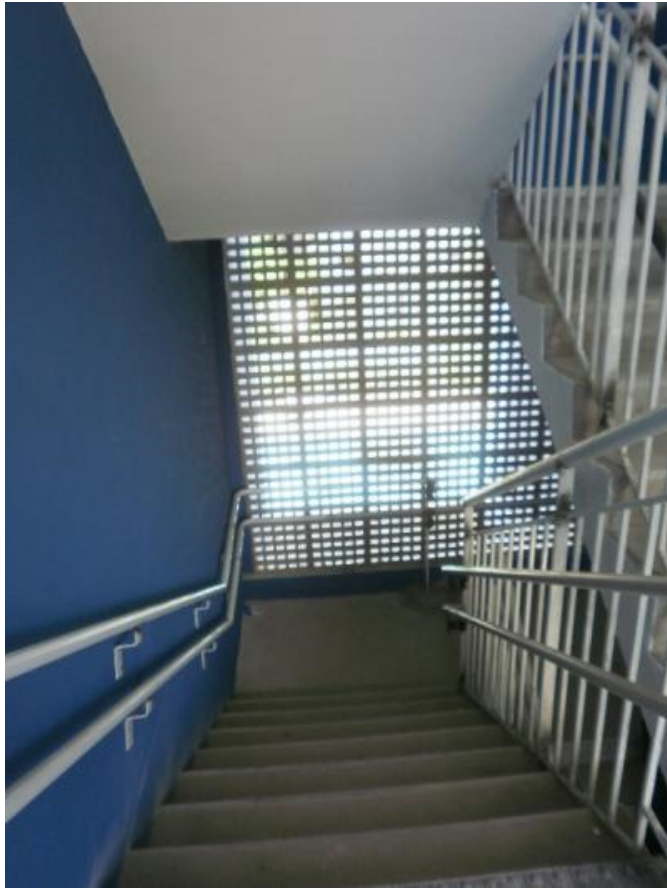

Figura 44 - Caixa de escada com fechamento em elementos vazados.

O pavimento térreo-intermediário (nível 777,50) é o único em que a passarela é contínua e conectada diretamente com a rua. Nos outros andares elas são interrompidas junto às portas das unidades. Isso ocorre devido aos módulos de edifícios. Como foi possível verificar, o bloco 2 é configurado pela junção de dois módulos de edifício, um com quatro unidade por andar e outro com cinco.

Duas questões podem ser levantadas com respeito à interrupção das passarelas: a primeira, é uma medida com relação à economia no valor final do projeto; em segundo lugar, podemos entender que, se a passarela fosse mais extensa, alguns trechos, nas pontas dos edifícios, poderiam ser fechados pelos moradores criando exclusividade de 
uso, o que não seria favorável para o condomínio. Da forma como foram concebidas, as passarelas definem bem as circulações e determinam quais caixas de escada atendem a quais unidades, organizando os acessos e a circulação dentro do condomínio.

O espaço agregado pelas passarelas também funciona como extensões das unidades. Na Figura 46 é possível observar objetos, cadeiras, plantas, etc. colocados pelos moradores nas passarelas, o que comprova a apropriação desses espaços de circulação.

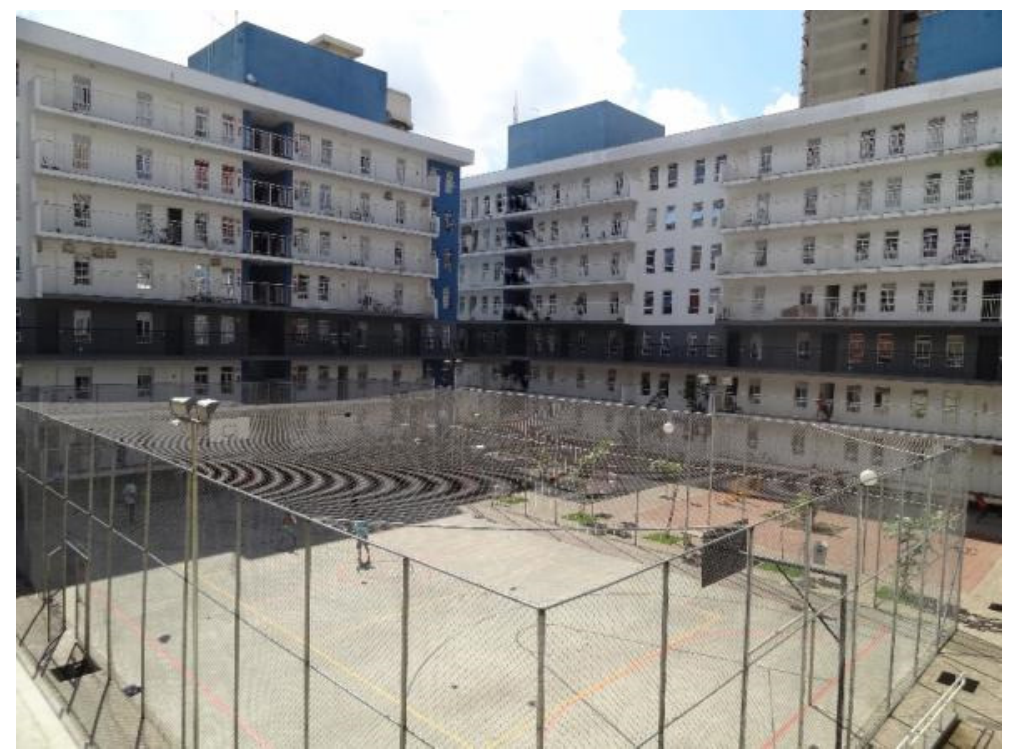

Figura 45 - Passarelas interrompida entre os módulos e contínuas no pavimento térreo-intermediário.

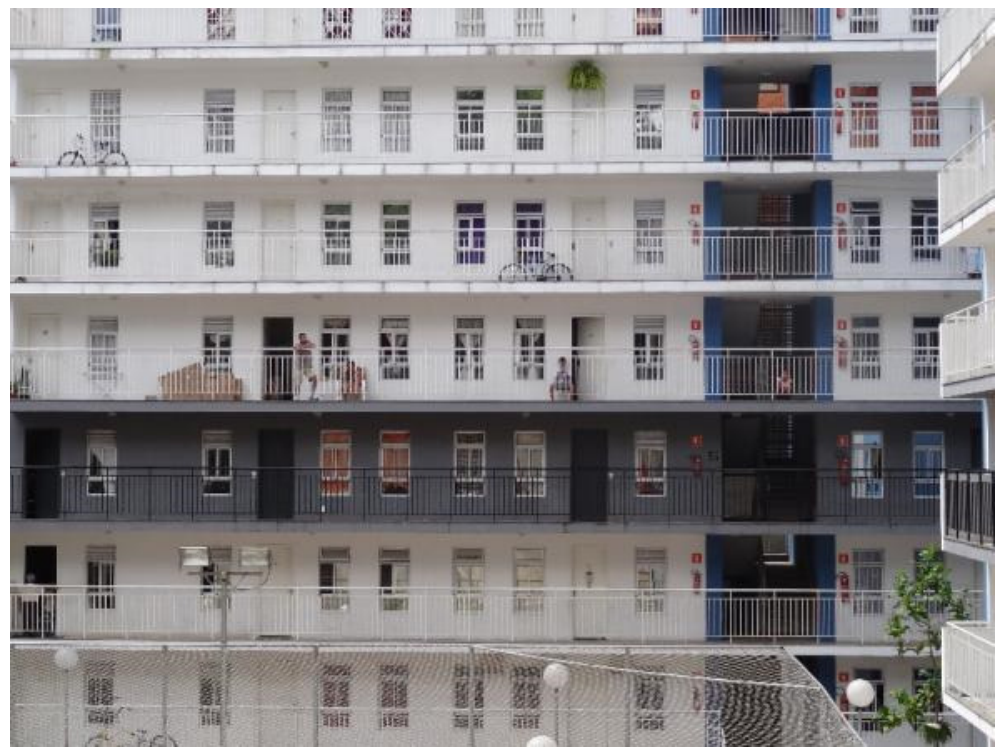

Figura 46 - Passarelas como extensões das unidades. 


\section{Diversidade tipológica}

No edifício analisado não há diversidade tipológica, há apenas uma tipologia em todo o edifício e sua variação que é a adaptação à unidade para pessoas com necessidades especiais. As unidades P.N.E. ocorrem no térreo inferior do edifício e o restante são todas unidades Tipo 1.

De acordo com os desenhos de análise, pode-se observar que as tipologias estão espelhadas e que as áreas molhadas das cozinha estão concentradas a cada duas unidades.

\section{Estrutura e aberturas}

Os edifícios foram construídos em alvenaria de bloco estrutural com modulação de 6,45m entre eixos. Segundo o arquiteto Eduardo Colonelli, essa solução, apesar de ser muito usual, pois em muitos momentos se considerou mais econômica, "hoje se discute muito porque ela limita a versatilidade e a flexibilidade do apartamento" (FLORESTA, 2013, p. 29)

Podemos observar, na Figura 47, que apenas as paredes do banheiro e da área de serviço são de blocos de vedação, o restante das paredes é estrutural e, conforme depoimento do arquiteto, não oferece versatilidade aos apartamentos.

As áreas molhadas estão concentradas verticalmente e, nos pavimentos, a cada duas unidades, pois são espelhadas entre si. Os banheiros localizam-se no centro das tipologias e, portanto, estão concentrados apenas verticalmente através dos shafts localizados atrás dos chuveiros.

Há aberturas nas duas fachadas principais, pois os eixos estruturais ocorrem no outro sentido, deixando essas laterais mais livres. 


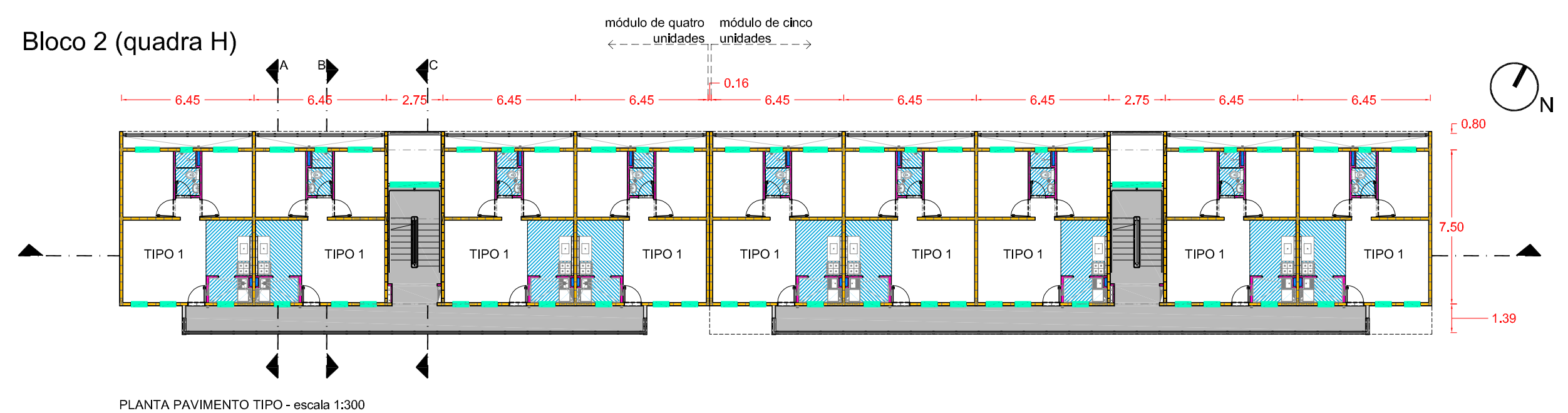

\section{$\square$ Alvenaria de Bloco estrutural}

$\square$ Alvenaria de Bloco de vedação

$\square$ Lajes / pilares (estrutura convencional) $\square$ shafts

TIA áreas molhadas

$\square$ janelas / aberturas

$\square$ circulações (escadas / passarelas)
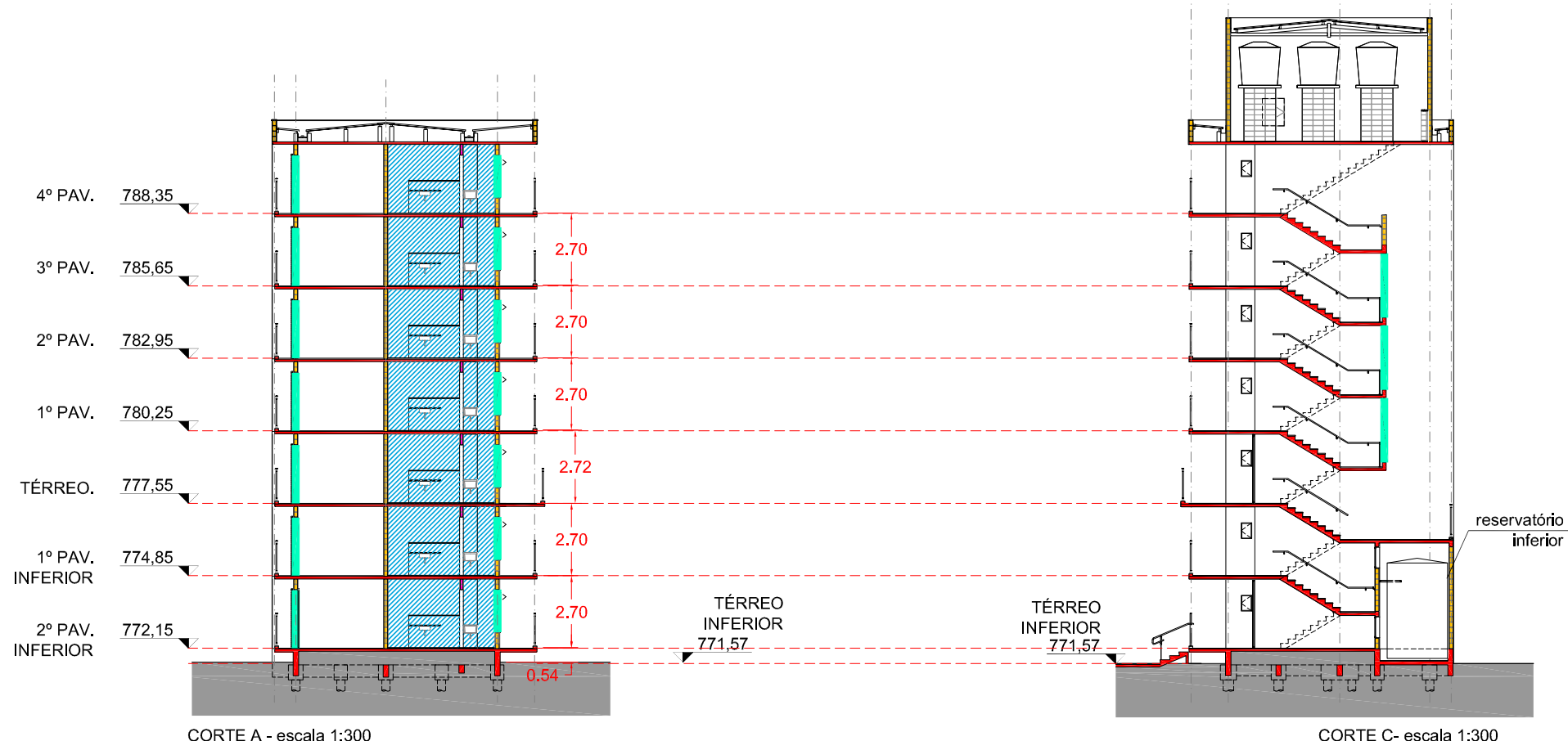

escala 1:300 


\section{Condomínio 1 (QUADRA A LESTE)}

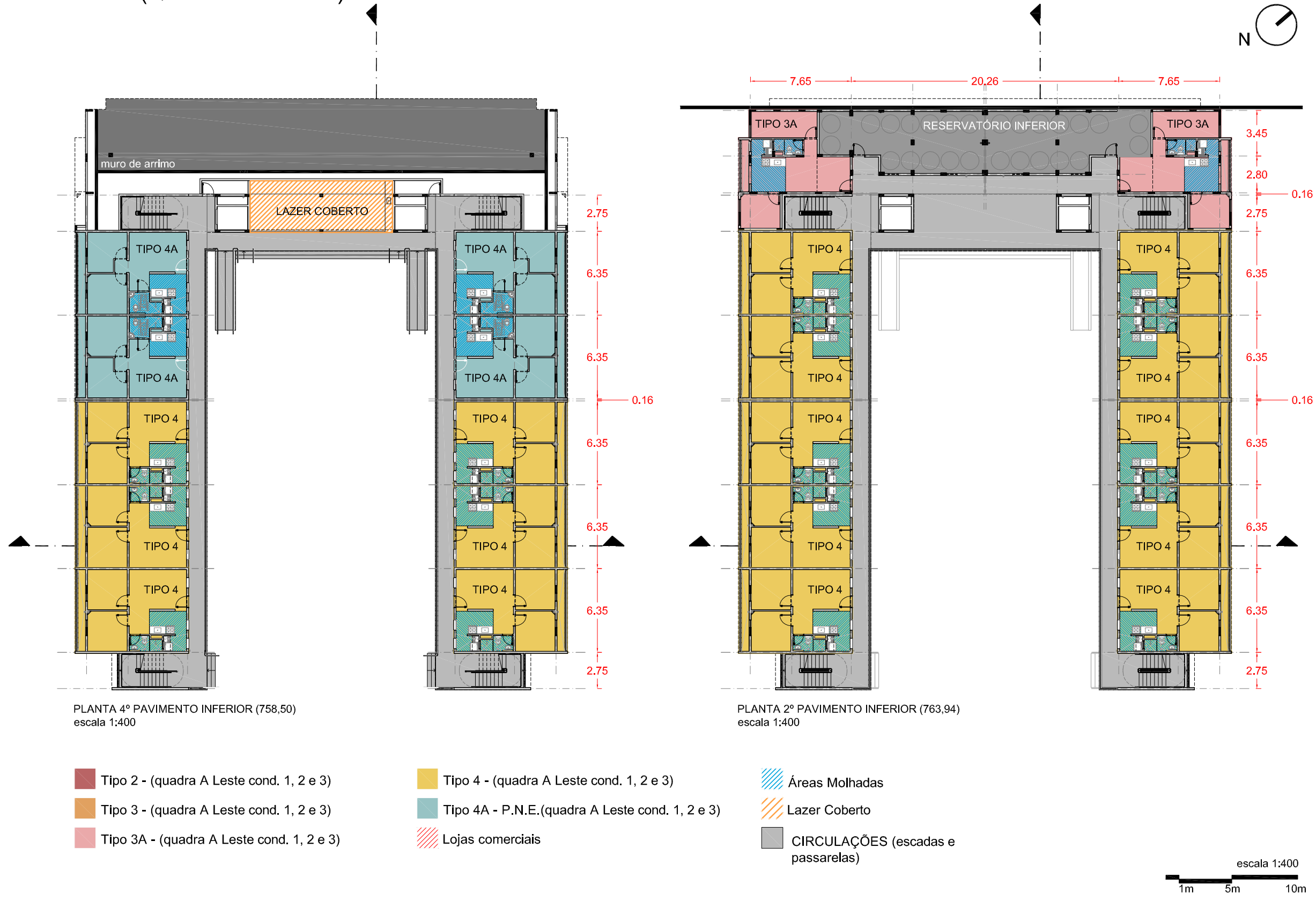




\section{Condomínio 1 (QUADRA A LESTE)}
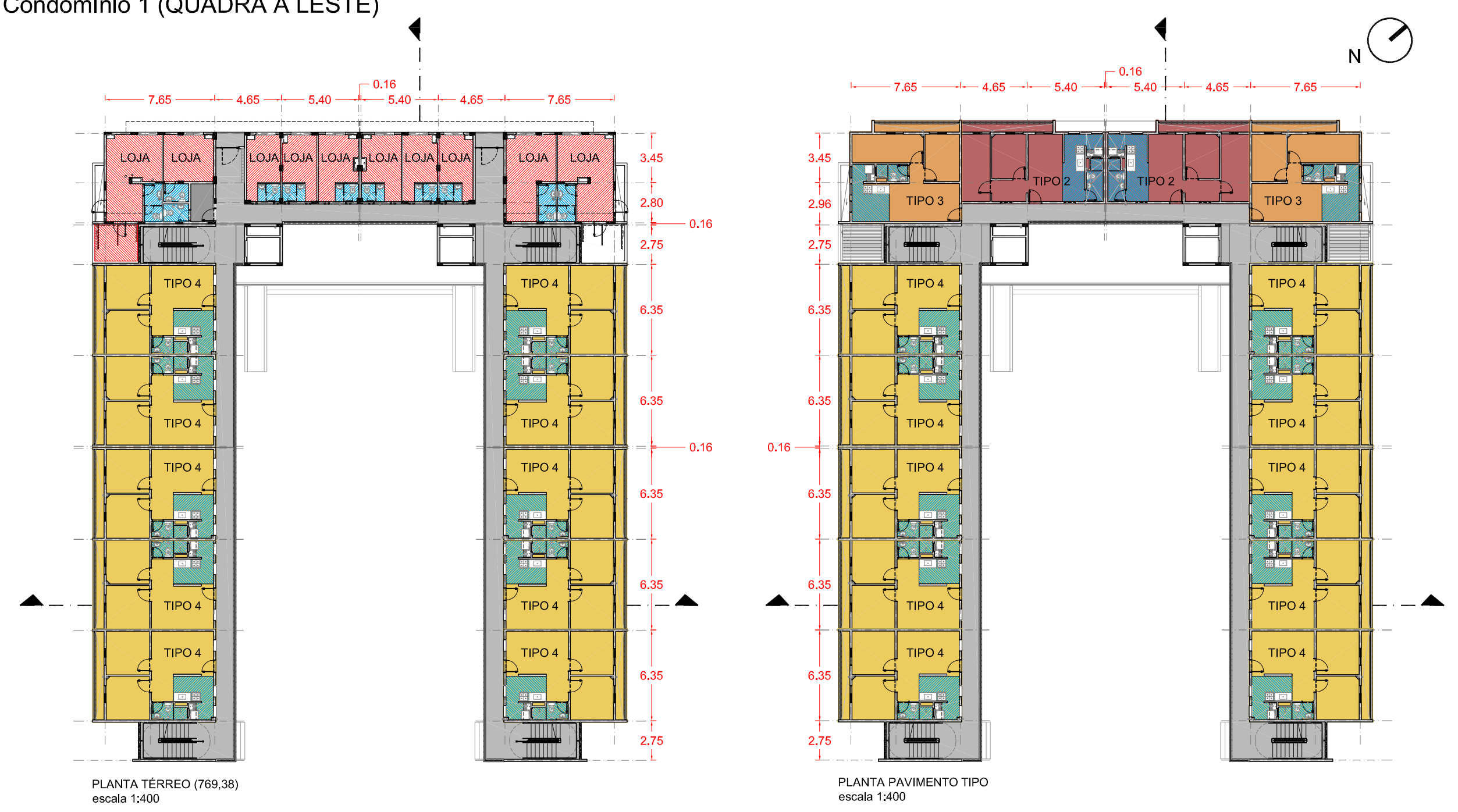

escala 1:400 


\section{Condomínio 1 (QUADRA A LESTE)}

Tipo 2 - (quadra A Leste cond. 1, 2 e 3)

Tipo 3 - (quadra A Leste cond. 1, 2 e 3 )

Tipo 3A - (quadra A Leste cond. 1, 2 e 3)

Tipo 4 - (quadra A Leste cond. 1, 2 e 3)

Tipo 4A - P.N.E.(quadra A Leste cond. 1, 2 e 3)

UI/, Lojas comerciais

W/I/, Áreas Molhadas

U/, Lazer Coberto

$\square$ CIRCULAÇÕES (escadas e passarelas)
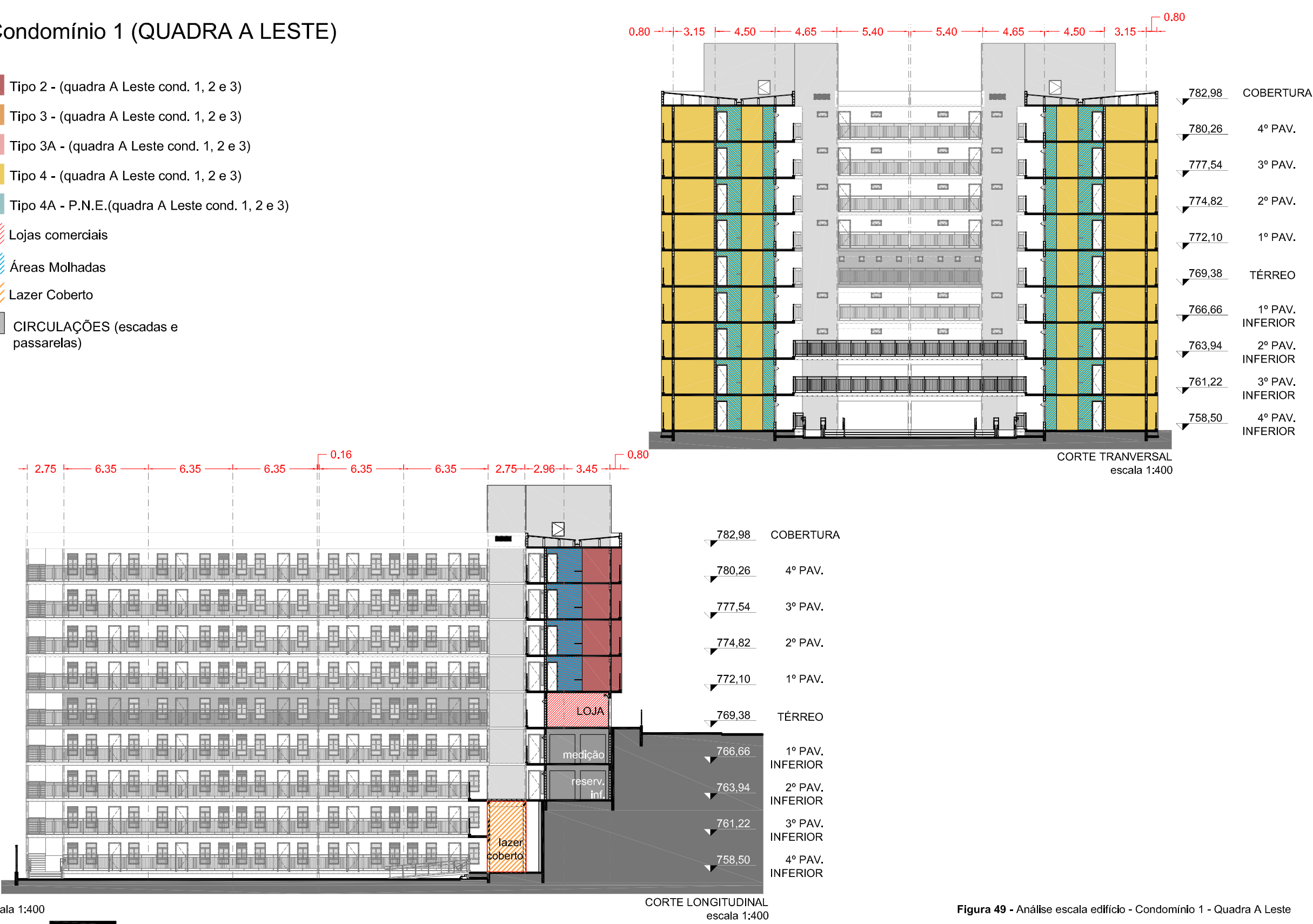

Figura 49 - Análise escala edifício - Condomínio 1 - Quadra A Leste 


\subsubsection{Condomínio 1}

(quadra A Leste)

Esse edifício configura-se como um "U" criando um espaço central onde está localizada a área de lazer. A partir dessa configuração, o lazer torna-se um espaço mais controlado pelos moradores que estão constantemente vigiando-o a partir das passarelas e janelas das casas. Essa situação aumenta a sensação de segurança com relação ao uso dos espaços e também com relação às mães que se sentem mais à vontade para deixar seus filhos brincarem nesses espaços comuns.

Apenas como comparação, na análise do projeto Jardim Edite, verificamos que a distância das áreas de lazer com relação aos apartamentos das torres não proporcionava seguranças às mães que declararam não deixar seus filhos brincarem desacompanhados.

\section{Acessos e circulação}

Esses edifícios possuem dois pavimentos de acesso a partir da rua, um no 4ํㅜ pavimento inferior (nível 758,50) acessado através da Rua de Serviço; e outro no pavimento denominado térreo (nível 769,38 ) acessado pela Rua Conde de Itaguaí. No pavimento térreo, as entradas do edifício localizam-se entre as lojas comerciais.

No 4ํㅜ pavimento inferior, há rampas e escadas que vencem o desnível de aproximadamente $50 \mathrm{~cm}$ entre o nível do solo e o nível das passarelas, assim como ocorre no bloco 2 da quadra $\mathrm{H}$, os edifícios são elevados do solo.

As passarelas contornam todo o edifício na face interior e conectam as quatro torres de escada existentes. Essa trama de escadas e passarelas forma o sistema de circulação do edifício. Assim como no outro edifício estudado, essas passarelas funcionam como extensões das casas dos moradores e também espaço de convivência entre os vizinhos. 


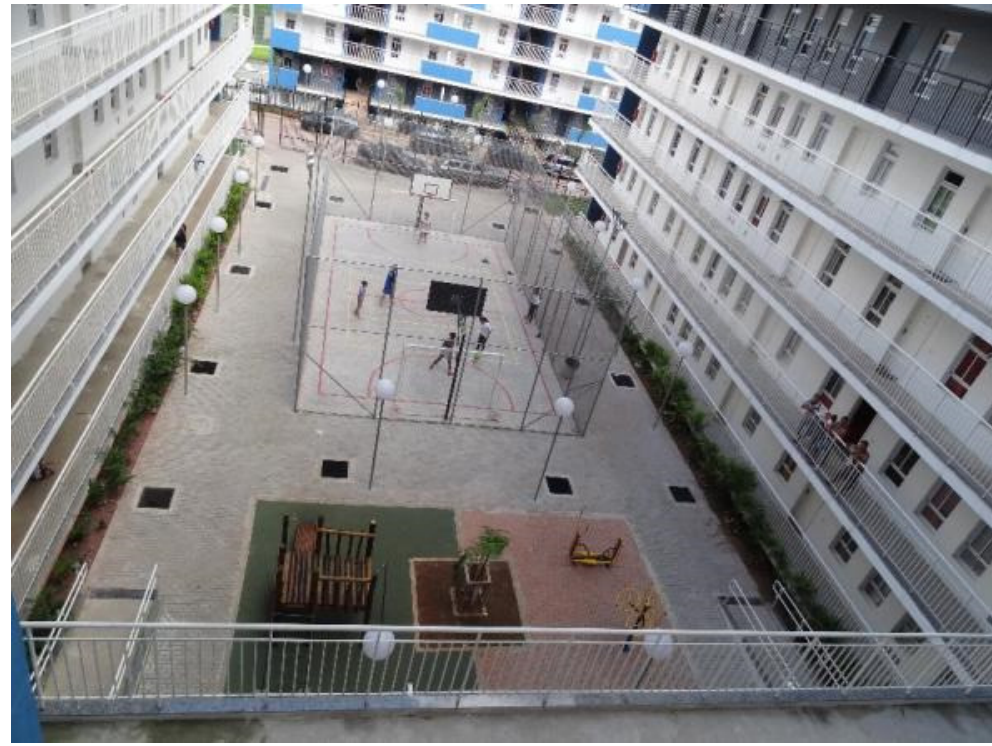

Figura 50 - Passarelas na face interior; lazer condominial; vizinhos na passarela assistindo os outros jogarem na quadra.

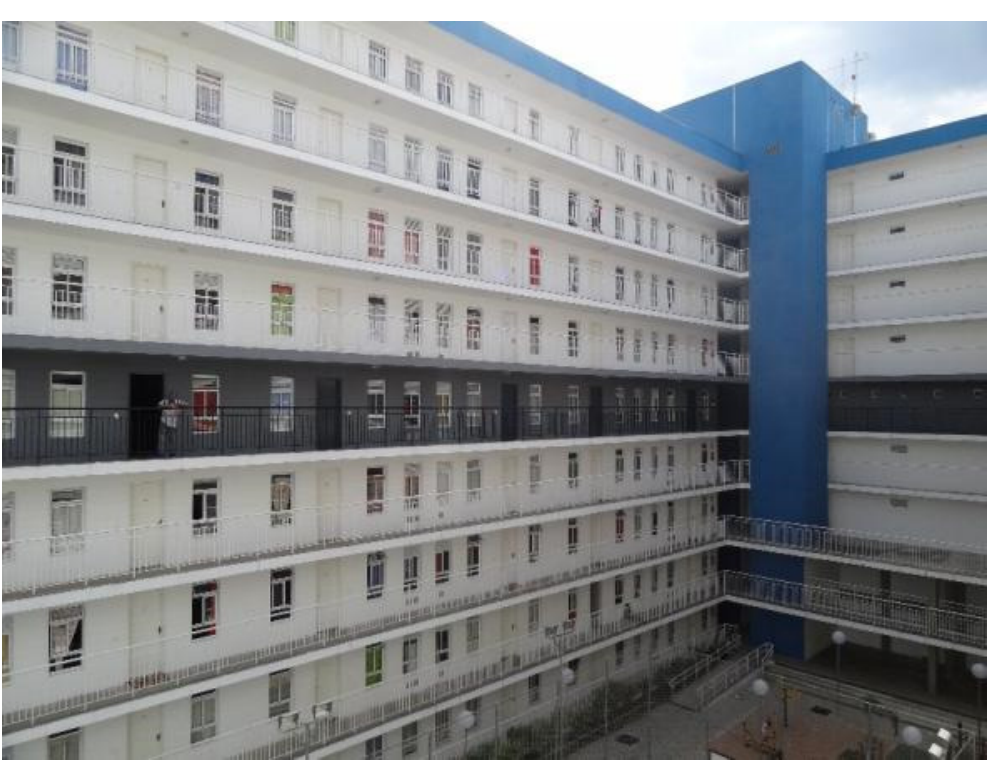

Figura 51 - Passarelas e torre para instalação de elevadores na esquina ao fundo.

Atualmente as escadas são o único elemento de circulação vertical do condomínio, porém, foram construídas duas torres de previsão para instalação de elevadores. Caso, futuramente, os moradores decidam instalá-los, as torres já estão construídas e conectadas às passarelas como é possível observar na Figura 51 (o volume azul ao fundo é a torre construída como provisão para instalação de elevadores).

Na Figura 53 é possível observar as caixas de escada nas extremidades dos edifícios. Os blocos de elemento vazado, utilizados no fechamento desses volumes, além de garantirem ventilação permanente, proporcionam transparecia aos volumes deixando-os menos densos (Figura 52; Figura 53). 


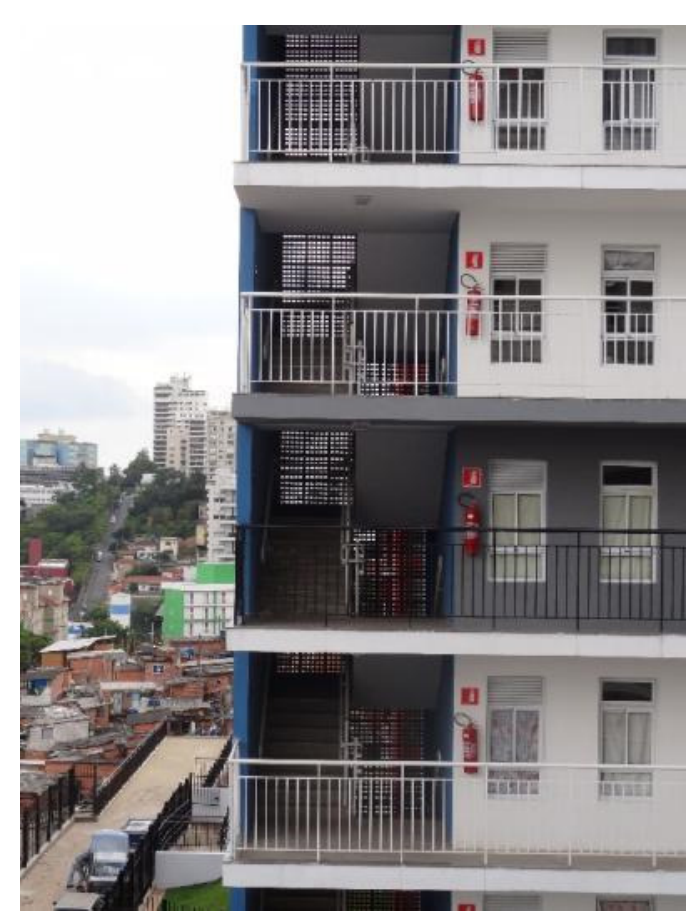

Figura 52 - escadas nas extremidades do edifício. Elemento vazado agrega textura e transparência aos volumes das escadas.

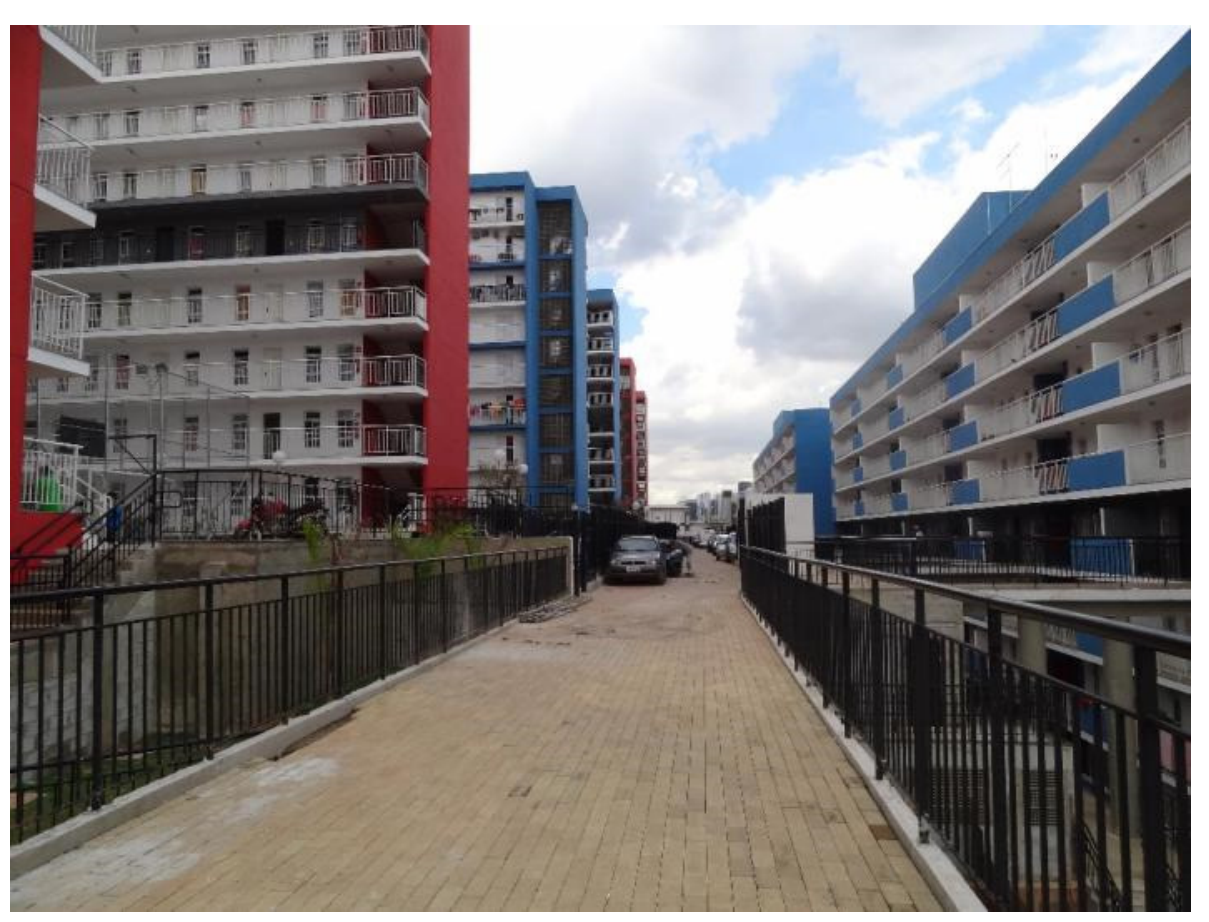

Figura 53 - Rua de Serviço. Caixas de escada nas extremidades dos edifícios dos condomínios 1, 2 e 3 (à esquerda).

\section{Diversidade tipológica}

Nesse edifício aparecem três tipologias habitacionais diferentes, mas a diversidade não ocorre no programa, que permanece igual para todas (dois dormitórios, sala de estar, cozinha, áreas de serviço e um banheiro). A diferença entre as tipologias está relacionada com a posição da unidade no edifício e, de acordo com as condições existentes, ocorreram diferenciações entre elas. 
O Tipo 2 ocorre na parte superior do "U". Trata-se de uma unidade mais estreita onde os ambientes estão dispostos lado a lado. Desse tipo há apenas duas unidades por pavimento.

O Tipo 3 foi a tipologia desenvolvida para as esquinas do conjunto e também só existem duas unidades desse tipo por andar. Nos dois pavimentos abaixo do térreo ( $1^{\circ}$ e $2^{\circ}$ pavimento inferior), a unidade classificada como Tipo 3 sofre algumas alterações devido à existência do espaço para os reservatórios inferiores. Com isso, essas unidades alteradas foram classificadas como Tipo 3A. As variações entre essas duas tipologias serão estudadas com maior detalhe no item escala unidade.

O Tipo 4 ocorre nos dois blocos paralelos do edifício ("pernas do U") e aparece em maior quantidade por pavimento. No 4ํㅜ pavimento inferior aparece o tipo 4A resultante da adaptação do Tipo 4 para unidades P.N.E.

\section{Estrutura e aberturas}

Esse edifício também foi construído em alvenaria de bloco estrutural e a modulação varia de acordo com as tipologias das unidades. Em alguns momentos os vãos são de $6,35 \mathrm{~m}$ e chegam a até 7,65m nas tipologias das esquinas (Tipo 3).

Com exceção do Tipo 3, o restante possui aberturas nas duas faces. As áreas molhadas estão concentradas a cada duas unidades sempre que possível e, verticalmente, seguem o mesmo eixo de instalações. 


\section{Condomínio 1 (QUADRA A LESTE)}
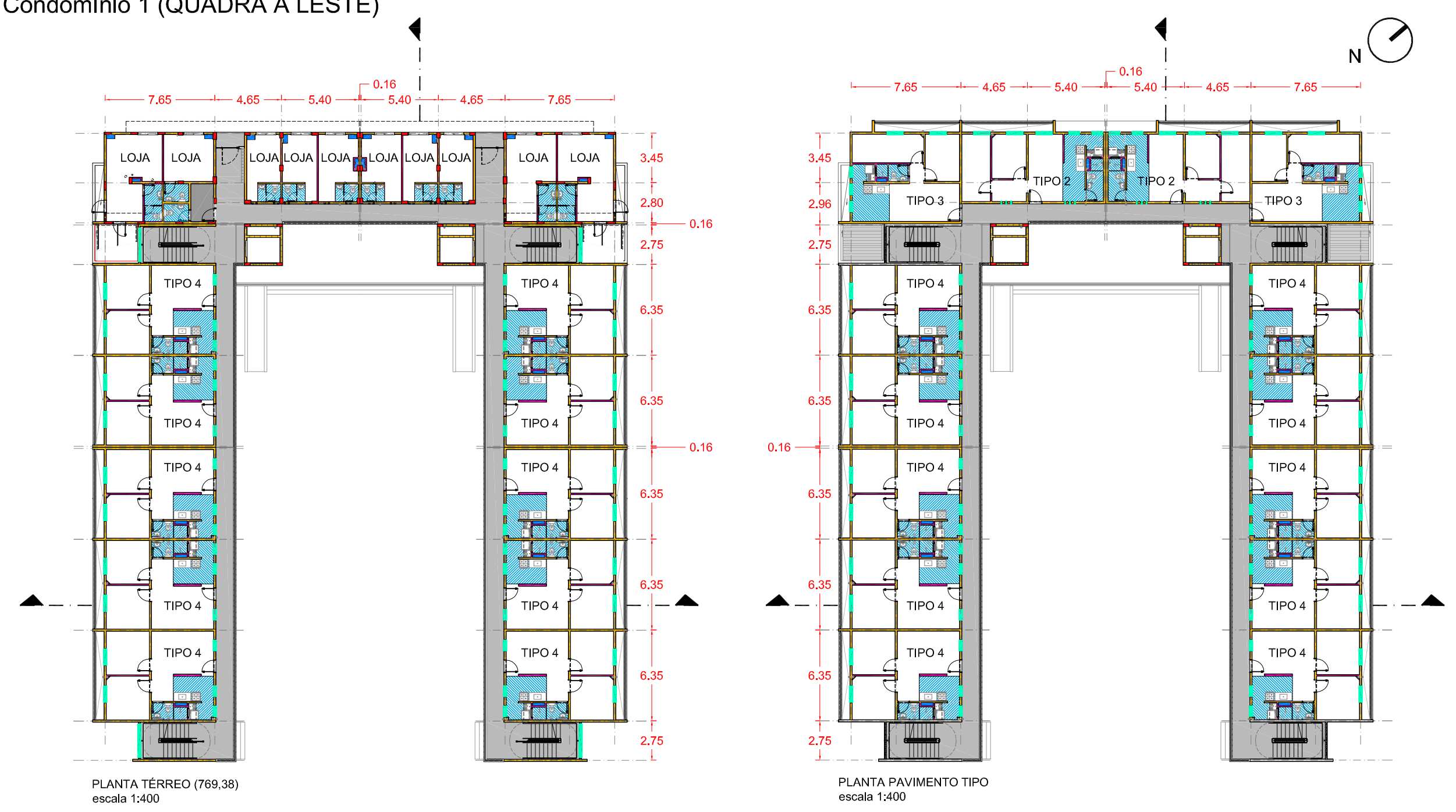

$\square$ Alvenaria de Bloco estrutural

$\square$ Alvenaria de Bloco de vedação

Lajes / pilares (estrutura convencional)

$\square$ shafts

escala 1:400

$\sqrt{1 \mathrm{~m} \quad 5 \mathrm{~m} \quad 10 \mathrm{~m}}$
TIA áreas molhadas

$\square$ janelas / aberturas

|1 | | | janelas / aberturas - altas

$\square$ circulações (escadas / passarelas) 
$\square$ Alvenaria de Bloco estrutural

$\square$ Alvenaria de Bloco de vedação

Lajes / pilares (estrutura convencional)

\section{$\square$ shafts}

VITa áreas molhadas

$\square$ janelas / aberturas

| I| || janelas / aberturas - altas

$\square$ circulaçōes (escadas / passarelas)

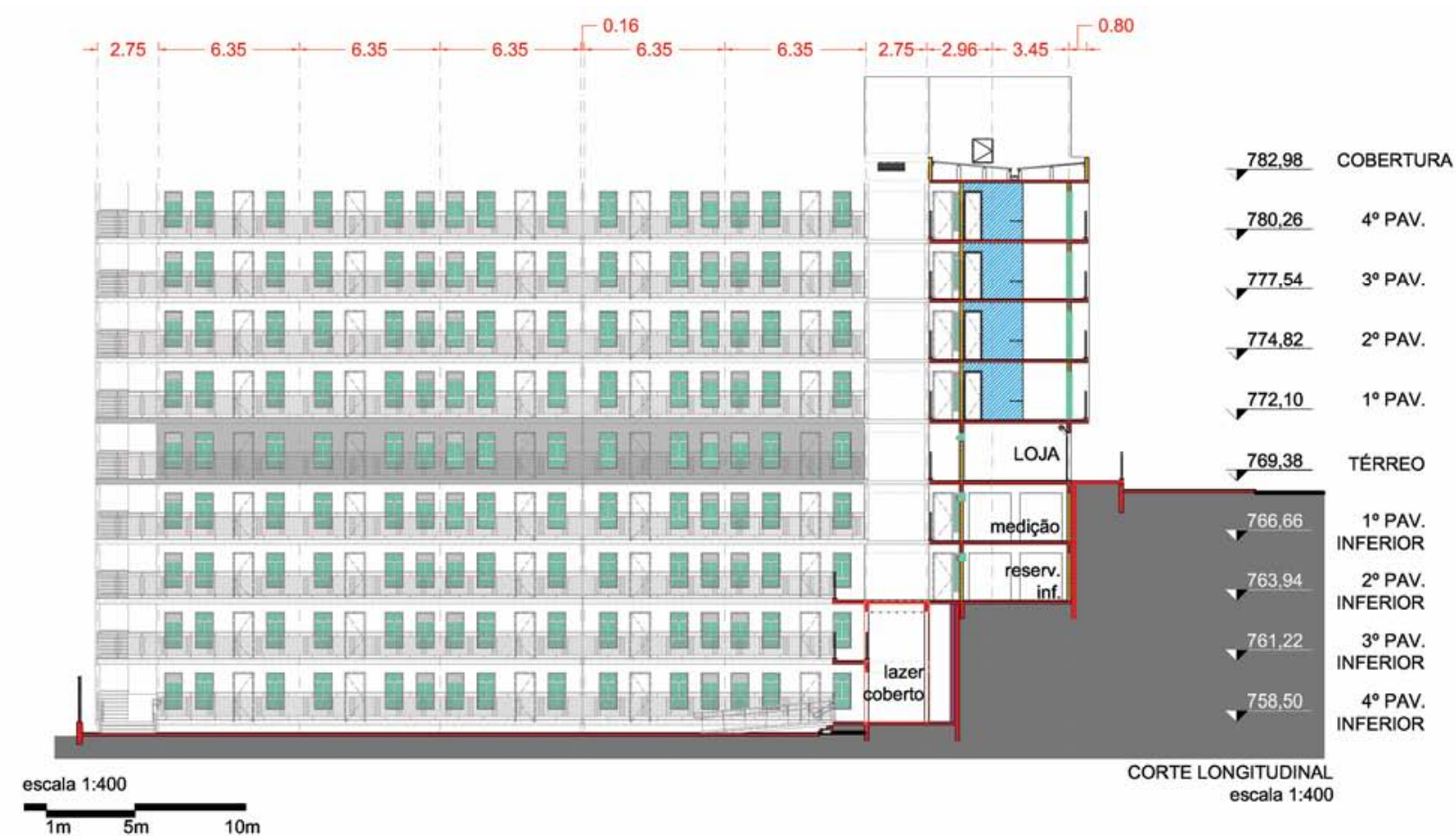

Figura 55 - Análise escala edifício - Estrutura - Condomínio 1 - Quadra A Leste.

No corte acima é possível observar a fachada de parte do edifício e as aberturas ao longo dessa lateral. O corte também representa o desnível existente entre as duas ruas de acesso e a forma como o edifício é implantado para vencer esse desnível. Vemos que os dois pavimentos inferiores ( $1^{\circ}$ e $\left.2^{\circ}\right)$ têm essa parte do edifício ocupada pela sala de medição e pelo espaço para os reservatórios inferiores.

No térreo intermediário podemos observar a implantação das lojas e as unidades Tipo 2 aparecem nos pavimentos acima. 


\subsubsection{Bloco 1 - Condomínio}

4 (quadra A Leste)

Esse edifício possui formato de lâmina e está implantado na mesma direção que as curvas de nível do terreno. Assim como os outros, também existe um desnível significativo entre os dois térreos: térreo intermediário e térreo inferior. O edifício possui oito pavimentos, quatro acima e três abaixo do nível intermediário.

\section{Acessos e circulação}

O pavimento considerado com térreo intermediário (nível 759,60) tem acesso pela Rua de Serviço. O térreo inferior (nível 750,85) é acessado a partir da Rua Paulo Bourroul, porém apenas as lojas comerciais são acessadas a partir dessa rua; o acesso às unidades habitacionais se dá através da Rua de Serviço, proposta pelo projeto (Figura 57).

Esse edifício possui cinco caixas de escada e cada uma acessa apenas duas unidades por andar. $O$ acesso às unidades ocorre através das passarelas que são interrompidas a cada duas unidades gerando um espaço mais reservado em frente às portas das casas. A privacidade proporcionada pela interrupção das passarelas criou espaços que foram classificados como espaços de transição. Esses espaços funcionam como extensões das casas e, ao mesmo tempo, atuam como um filtro de privacidade (Figura 58).

Os espaços de transição indicados nesse edifício se diferenciam dos espaços criados nos outros edifícios, pois aqui as passarelas são interrompidas não permitindo um fluxo de circulação de pessoas. Apenas transitam por esses espaços de transição as pessoas que desejam entrar nas casas. 
REAL PARQUE

Bloco 1 - Condomínio 4 (QUADRA A LESTE)

(1)
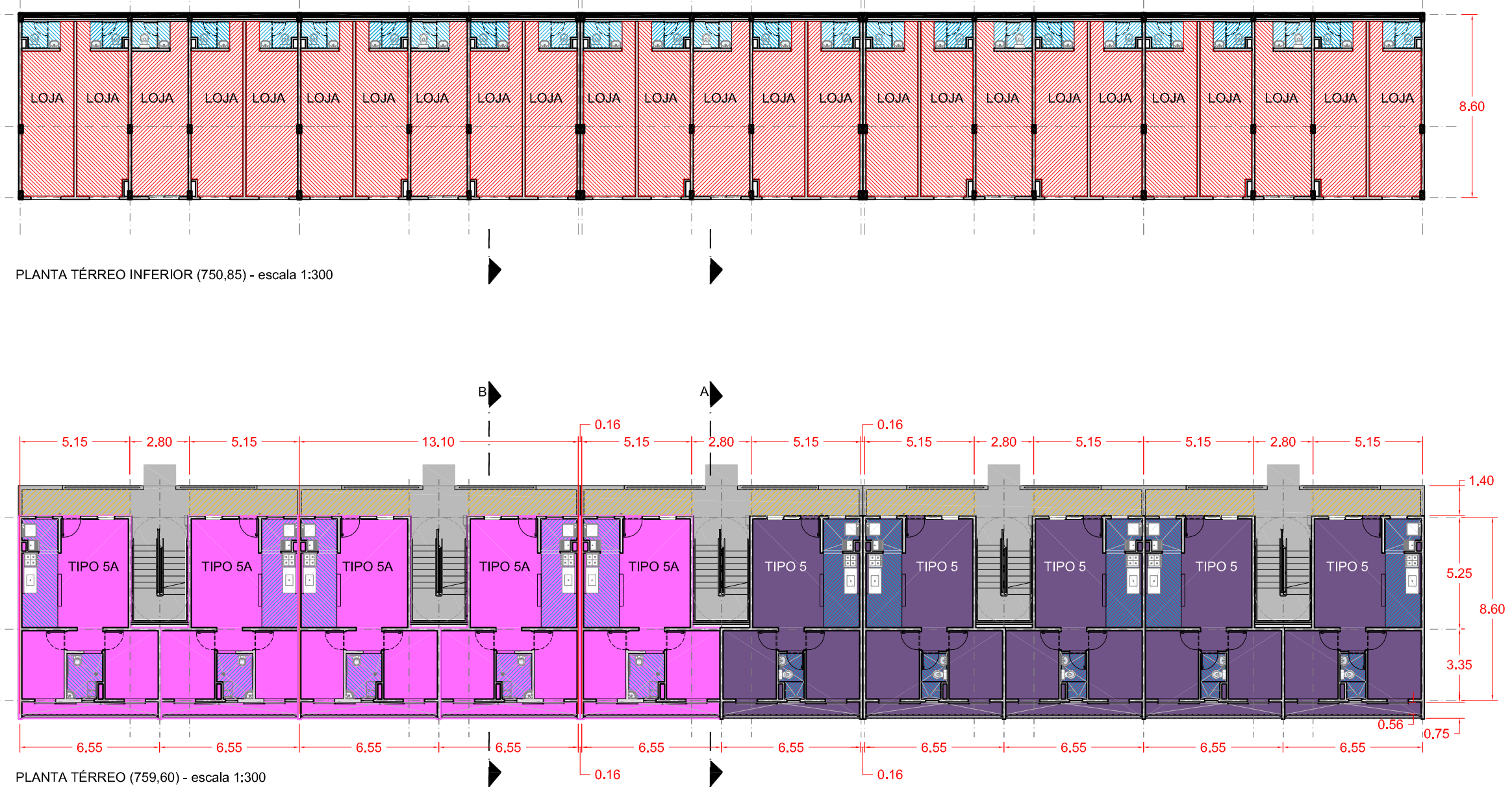

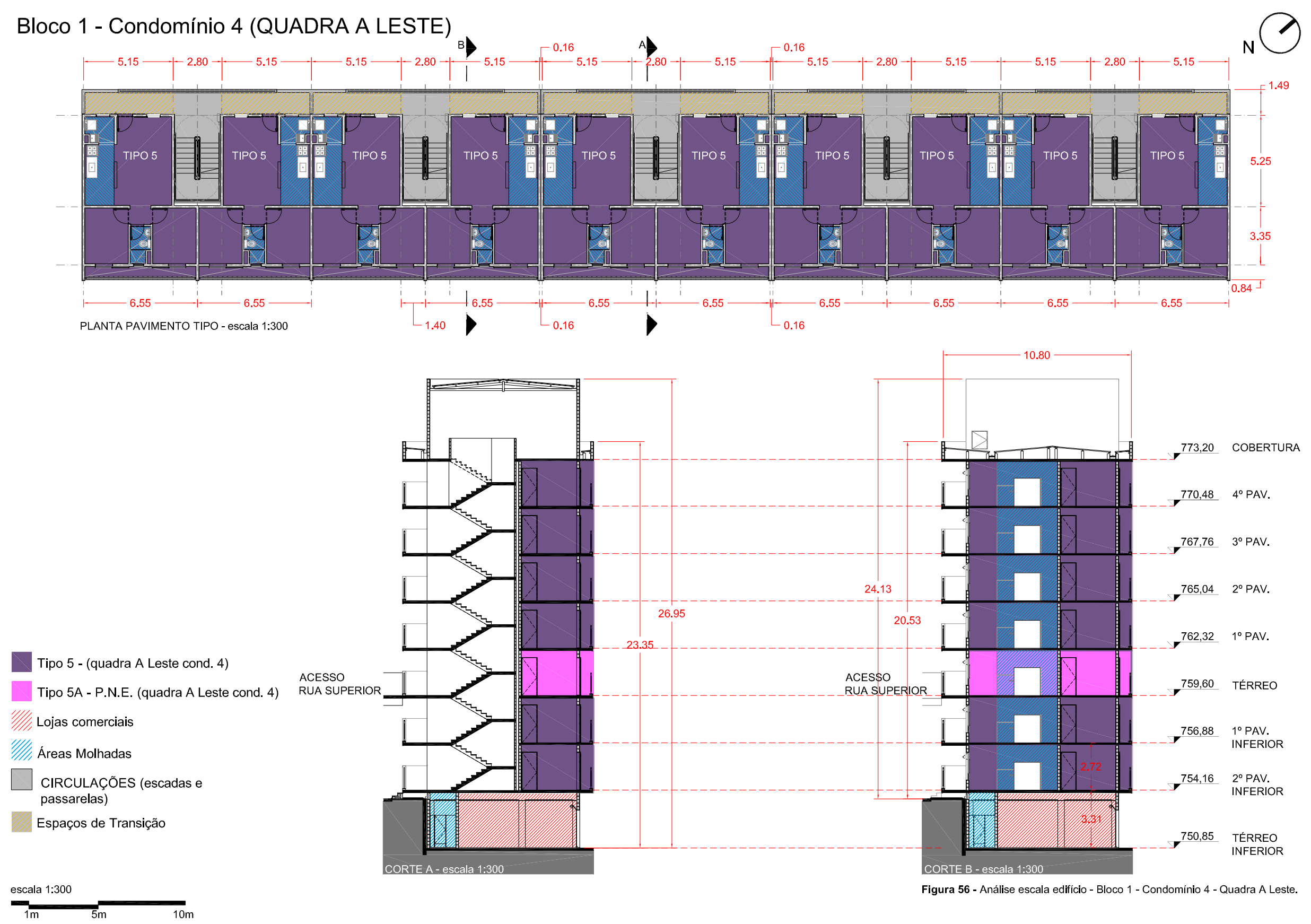


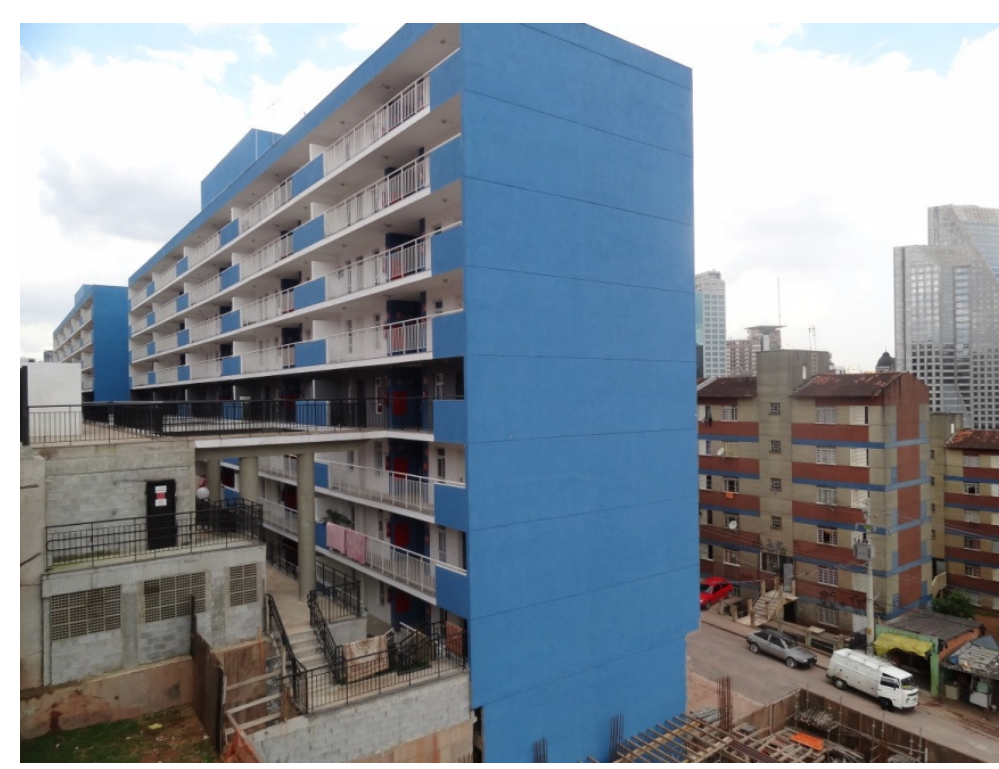

Figura 57 - desnível entre os dois térreos. As lojas localizam-se no térreo inferior.

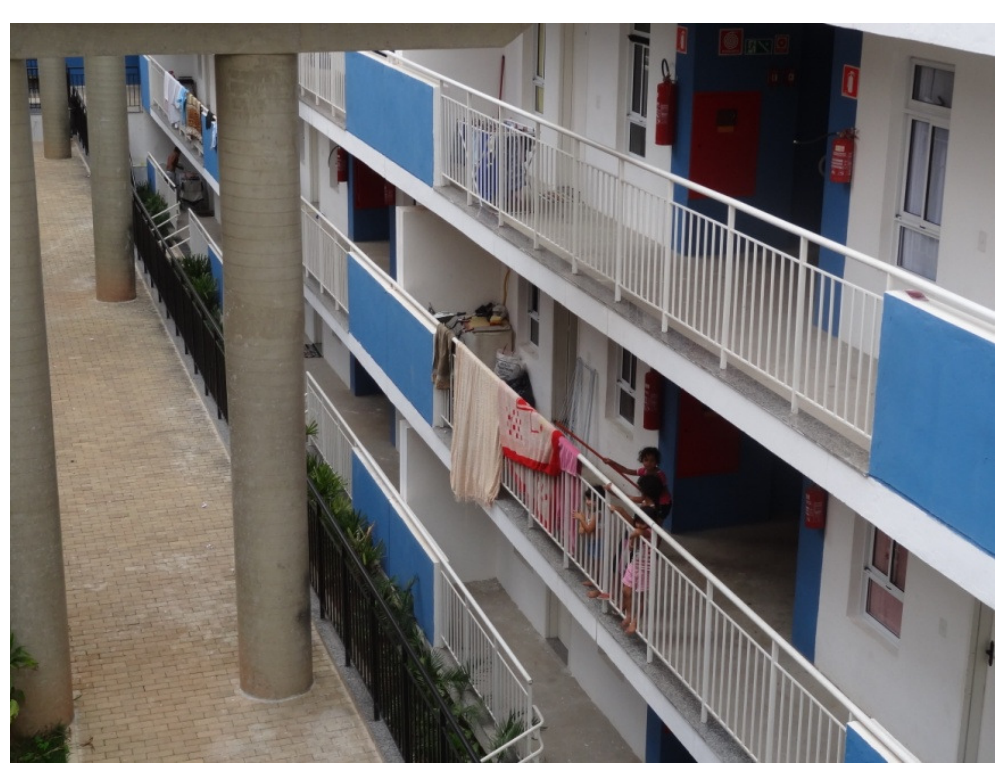

Figura 58 - Espaços de transição apropriados pelos moradores.

\section{Diversidade tipológica}

Nesse edifício há apenas uma tipologia e sua adaptação para unidades P.N.E. - Tipo 5 e Tipo 5A. As unidades adaptadas localizam-se no pavimento térreo que tem acesso direto pela rua.

\section{Estrutura e aberturas}

Esse edifício também foi concebido em alvenaria estrutural e o vão entre eixos é de 6,50m. em uma das faces e $5,15 \mathrm{~m}$ na face onde está o acesso às escadas. As áreas molhadas da cozinha e área de serviço estão concentradas e espelhadas a cada duas unidades. 
Bloco 1 - Condomínio 4 (QUADRA A LESTE)

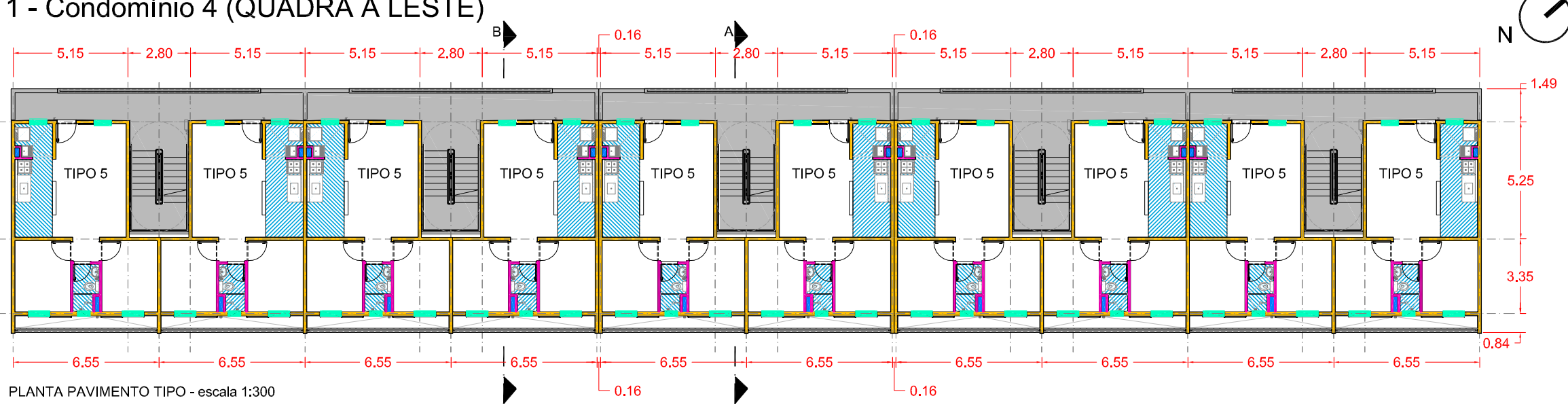

$\square$ Alvenaria de Bloco estrutural

\section{Alvenaria de Bloco de vedação}

$\square$ Lajes / pilares (estrutura convencional)

$\square$ shafts

W17 áreas molhadas

$\square$ janelas / aberturas

$\square$ circulações (escadas / passarelas)

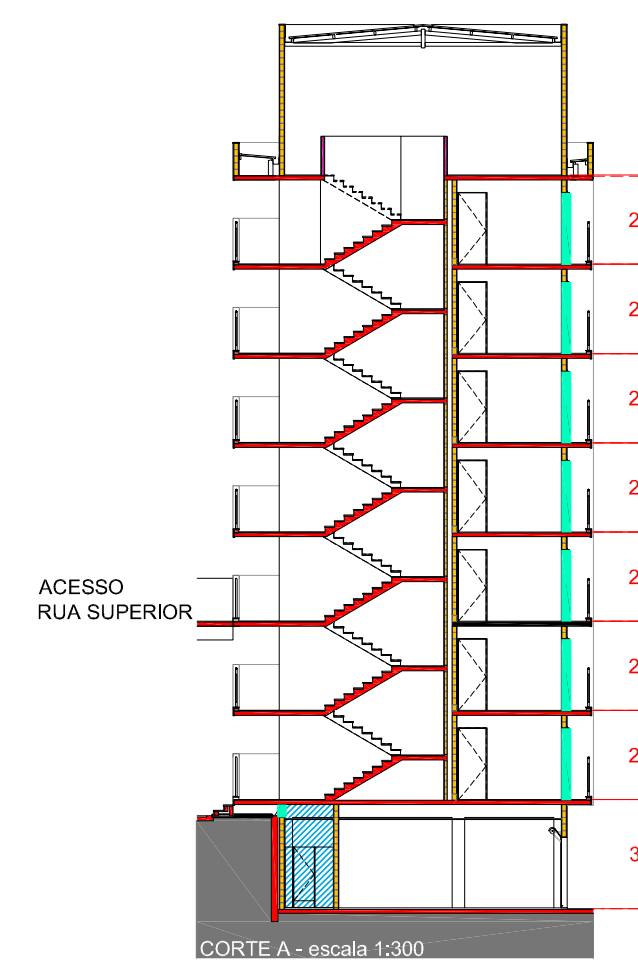

ACESSO

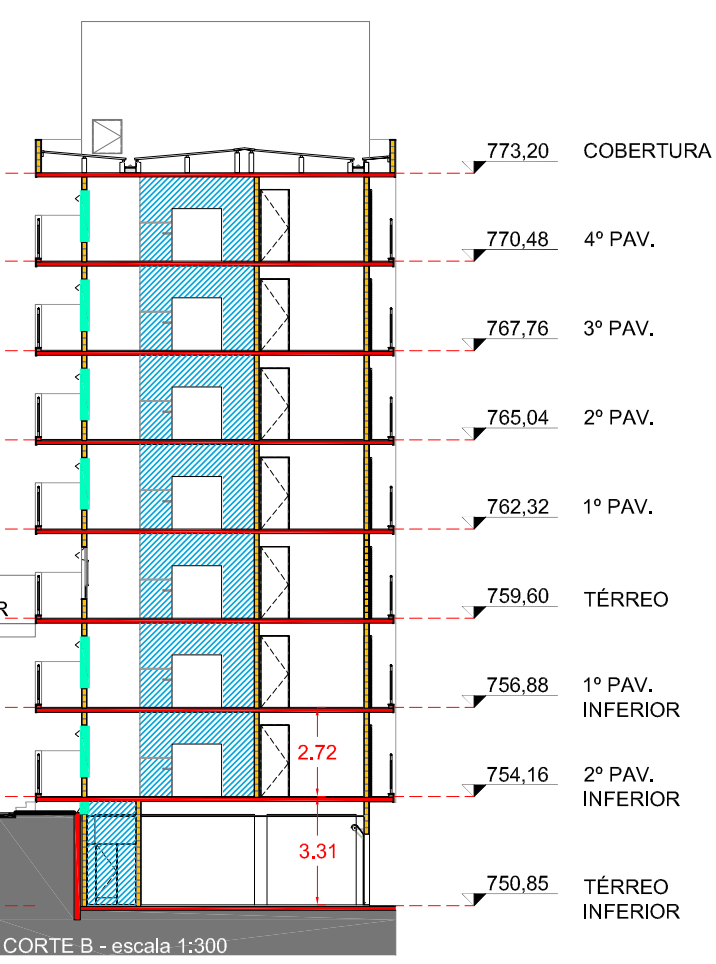

escala 1:300

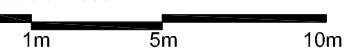

Figura 59 - Análise escala edifício - Bloco 1 - Condomínio 4 - Quadra A Leste. 


\subsubsection{ESCALA UNIDADE}

Nas três quadras analisadas foi possível identificar cinco diferentes tipologias de unidades habitacionais. Os tipos 1 e $1 \mathrm{~A}$ ocorrem nas quadras $\mathrm{H}$ e I; os tipos 2, 3, 3A, 4 e 4A ocorrem nos condomínios 1, 2 e 3 da quadra A Leste; e os tipos 5 e $5 \mathrm{~A}$ aparecem apenas no condomínio 4 desta última quadra.

Apesar da variedade, todas as tipologias apresentam o mesmo programa. Entende-se, portanto, que a variação está relacionada com as decisões projetuais e espaciais dos edifícios e não com a variedade e opções de programas.

\subsubsection{TIPO 1}

Essa tipologia, ao ser replicada em vários edifícios, possui diferentes orientações. Contudo, há aberturas nas duas fachadas principais o que garante a insolação das unidades. A posição das aberturas também proporciona ventilação cruzada no interior dos apartamentos que só não é mais eficaz devido à posição das portas dos dormitórios, pois caso tivessem as aberturas na direção das janelas, proporcionariam maior ventilação, como foi possível observar nas tipologias do projeto Santo Amaro V, onde portas e janelas estavam alinhadas.

Os ambientes são bem iluminados e apenas a cozinha recebe menos luz natural pois não têm janelas diretamente para o exterior. As cozinhas dessas unidades são ventiladas e iluminadas através das janelas da área de serviço e também há contribuição das janelas da sala de estar. 

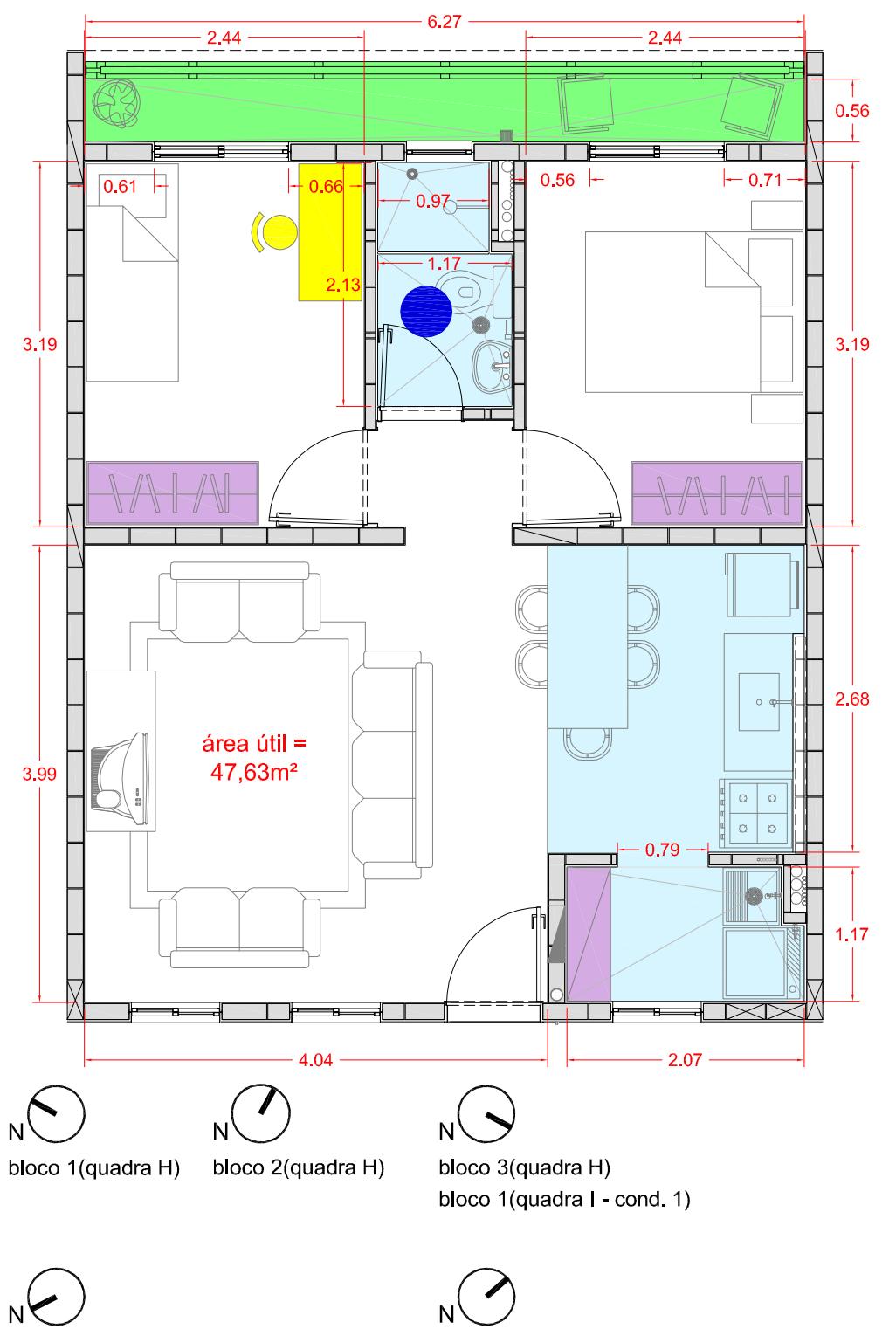

bloco 2(quadra I - cond. 1)
PLANTA TIPO 1 - layout e dimensões. escala $1: 75$

\section{$50 \mathrm{~cm} \quad 1 \mathrm{~m}$}

$\square$ concentração das áreas molhadas

$\square$ espaço exterior próprio

apropriação do espaço de transição

como espaço exterior próprio

$\square$ espaços para guardar

$\square$ espaços de estudo/trabalho

uso do banheiro

CICLO DA ROUPA:

\section{1. roupa suja}

2. lavar

3. secar

4. passar

5. roupa limpa

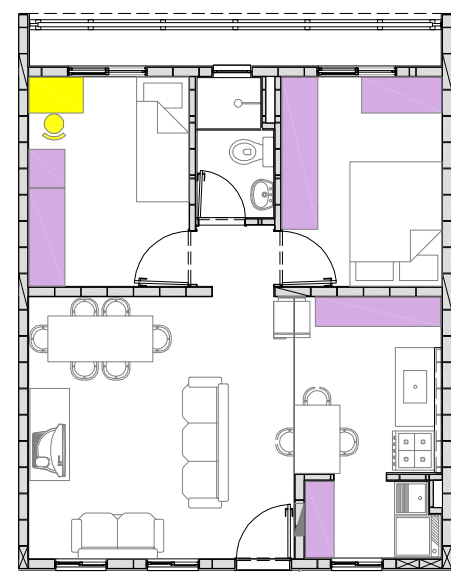

PLANTA TIPO 1 - reprodução de

layout de um apartamento visitado já ocupado pelos moradores.

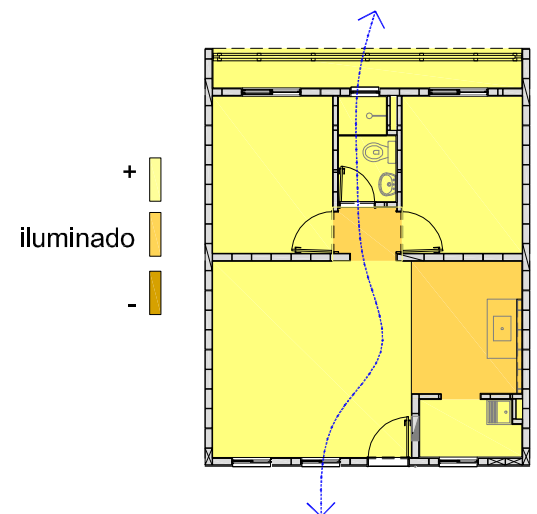

ESQUEMA ILUMINAÇÃO E VENTILAÇÃO (orientação de referência: bloco 2 - quadra $\mathrm{H}$ ) escala 1:200

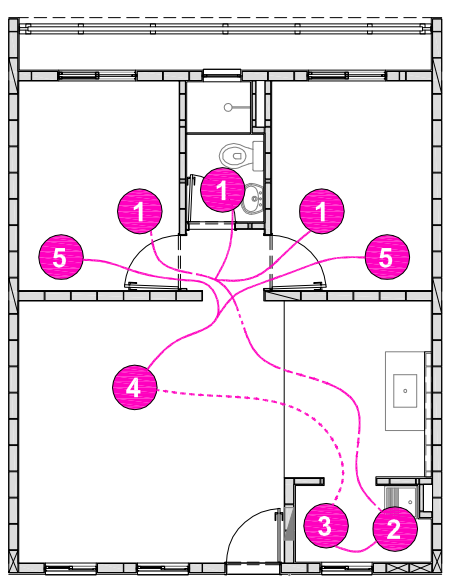

PLANTA TIPO 1 - ciclo da roupa escala 1:150

Figura 60 - Análise Tipo 1. 


\section{Ambientes não} especializados

É possível perceber que, nesse tipo, não há hierarquia quanto ao tamanho dos dormitórios. Ambos apresentam as mesmas medidas, o que favorece a diversidade de uso desses ambientes. A sala de estar apresenta maiores dimensões o que é favorável nas situações de famílias numerosas e, dessa forma, o espaço permite acomodar confortavelmente um maior número de pessoas. Ao observar o layout proposto pelos arquitetos, verifica-se que é possível acomodar até três sofás (1 de três lugares e 2 de dois lugares) nesse espaço.

No apartamento visitado, havia dois sofás e uma mesa de jantar nesse ambiente, como pode ser observado na Figura 61.

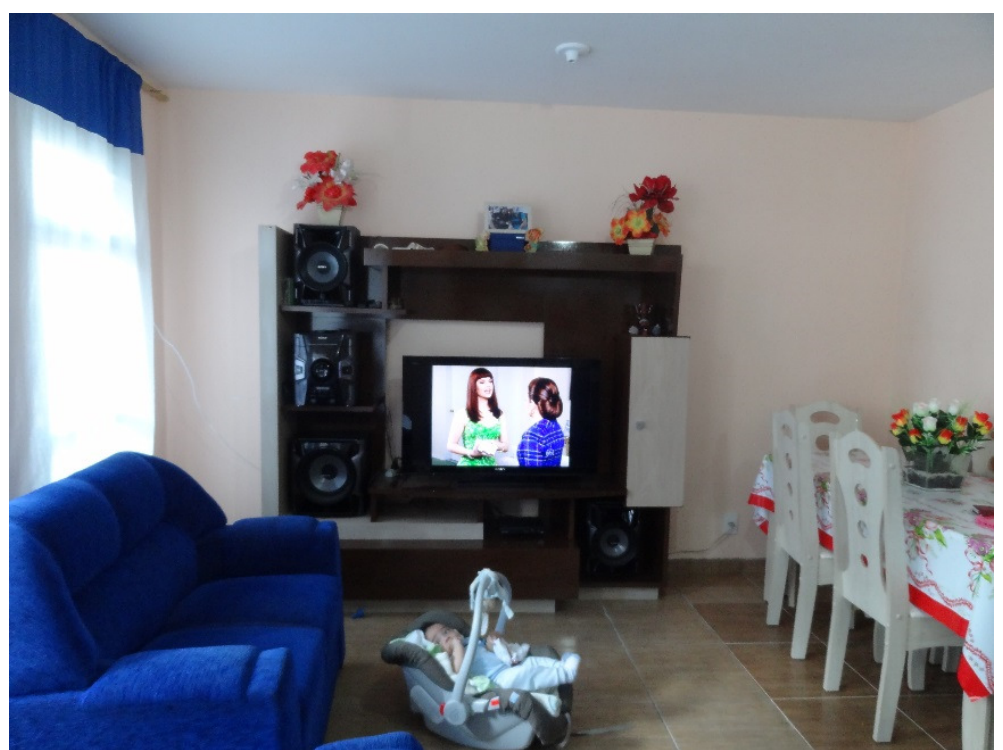

Figura 61 - Sala de estar - apartamento visitado.

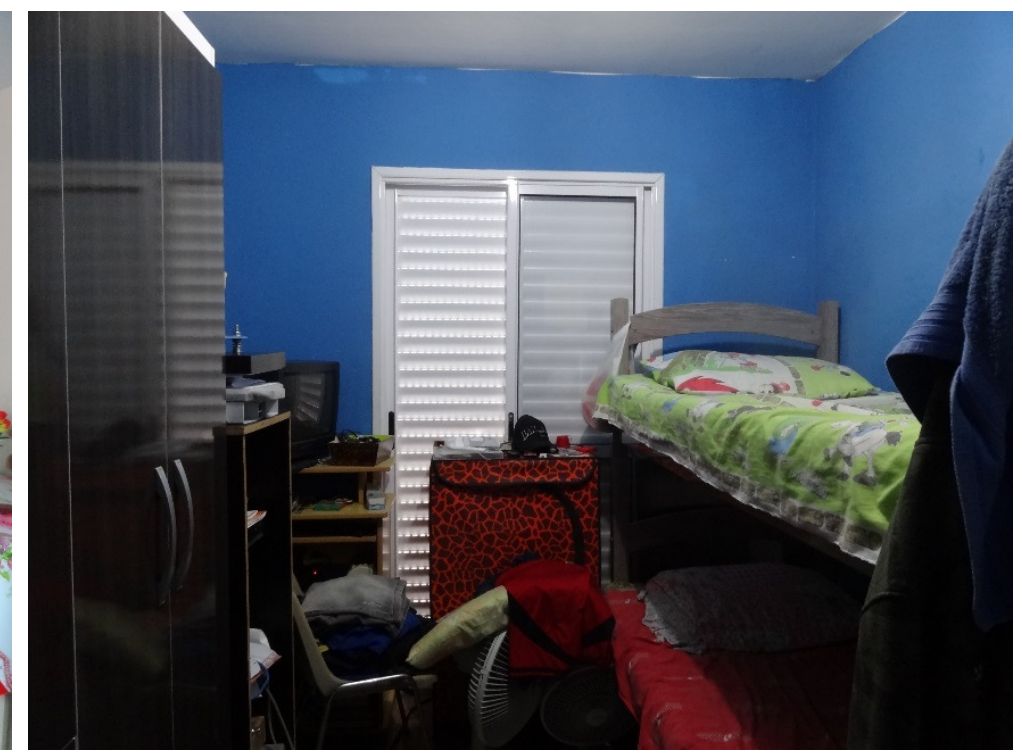

Figura 62 - Dormitório - apartamento visitado. 
As aberturas dos dormitórios são portas-balcão e estão praticamente centralizadas nos ambientes. A centralização das aberturas é favorável em muitos momentos e, ao desenvolver os projetos, parece até uma tendência natural colocar as janelas no centro das paredes. Porém, valeria a pena avaliar as possibilidades de disposição de layout antes de definir a posição das aberturas, pois em alguns casos, seria mais útil deixar uma lateral mais larga, com aproximadamente $80 \mathrm{~cm}$, onde se pudesse encostar um beliche.

No apartamento visitado, havia um beliche no dormitório que, como pode ser observado na Figura 62, avança aproximadamente $15 \mathrm{~cm}$ sobre a porta-balcão. Essa é apenas uma situação observada, mas que fica aqui como registro para que a posição das aberturas seja avaliada durante o projeto de acordo com as possibilidades de uso dos espaços.

No apartamento decorado (visitado um pouco antes da inauguração da quadra $\mathrm{H}$ ), nota-se que a proposta para 0 dormitório de casal considerava que o armário ficasse na parede lateral, ao lado da abertura da porta (Figura 63; Figura 64). Porém, ao visitar um apartamento já ocupado pelos moradores, foi possível observar que o armário da família era bem maior que o espaço deixado e, então, acabaram colocando-o na parede com maior dimensão. Com isso, foi necessário encostar a cama de casal na parede e a passagem entre a cama e o armário ficou bastante estreita (Figura 65).

A observação mencionada acima nos leva a concluir que a largura de 2,44m para os dormitórios é o limite para uma cama e a passagem, mas quando aparecem situações como a que foi vista no apartamento visitado, a circulação acaba sendo comprometida. 


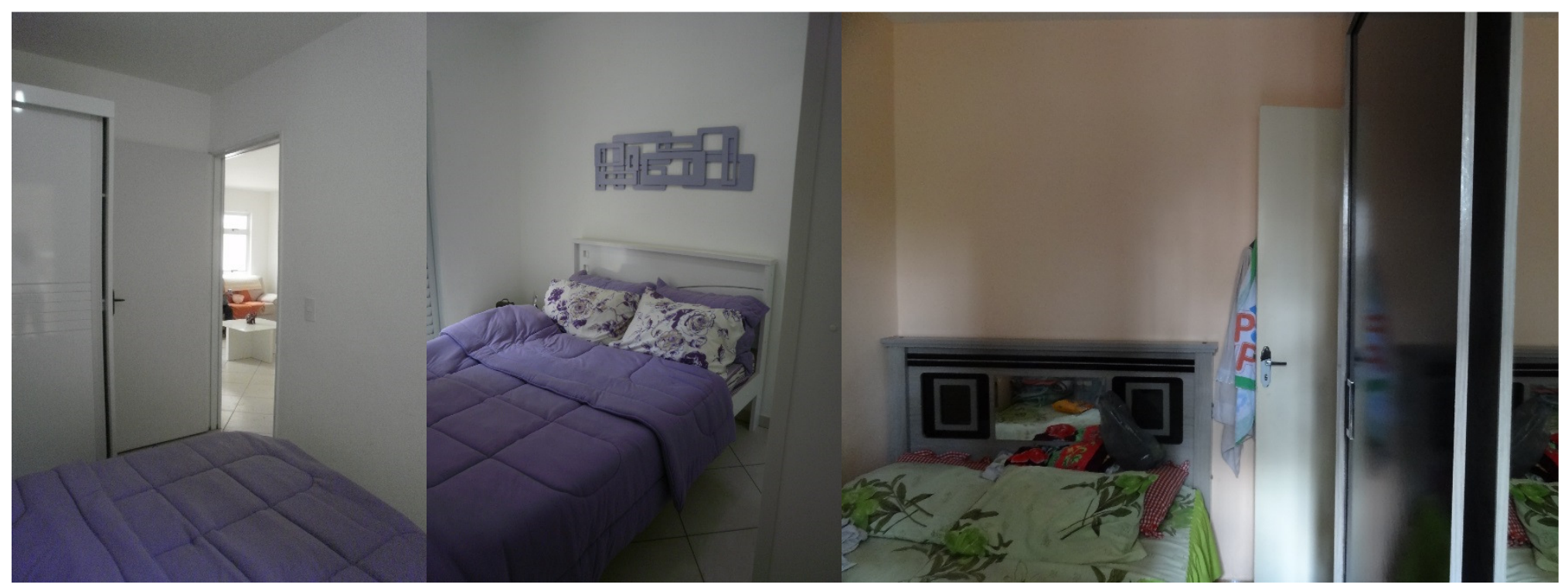

Figura 63 - Apartamento decorado. Figura 64 - apartamento decorado. Figura 65 - Apartamento visitado já ocupado pelos moradores.

\section{Ambientes especializados}

Cozinha e área de serviço estão concentradas e o banheiro localiza-se entre os dormitórios. Os banheiros dessa tipologia não permitem o uso simultâneo, pois todas as peças estão dentro do mesmo ambiente.

A cozinha possui as dimensões mínimas para acomodar em uma mesma parede a bancada da pia (1,20m), fogão e geladeira. Apesar de não possuir grandes dimensões, o espaço destinado à cozinha é aberto e bem relacionado com a sala de estar, não apresentando a sensação de espaço pequeno. 
Nas fotos a seguir é possível observar a proposta da cozinha decorada e a cozinha de um dos apartamentos visitados.

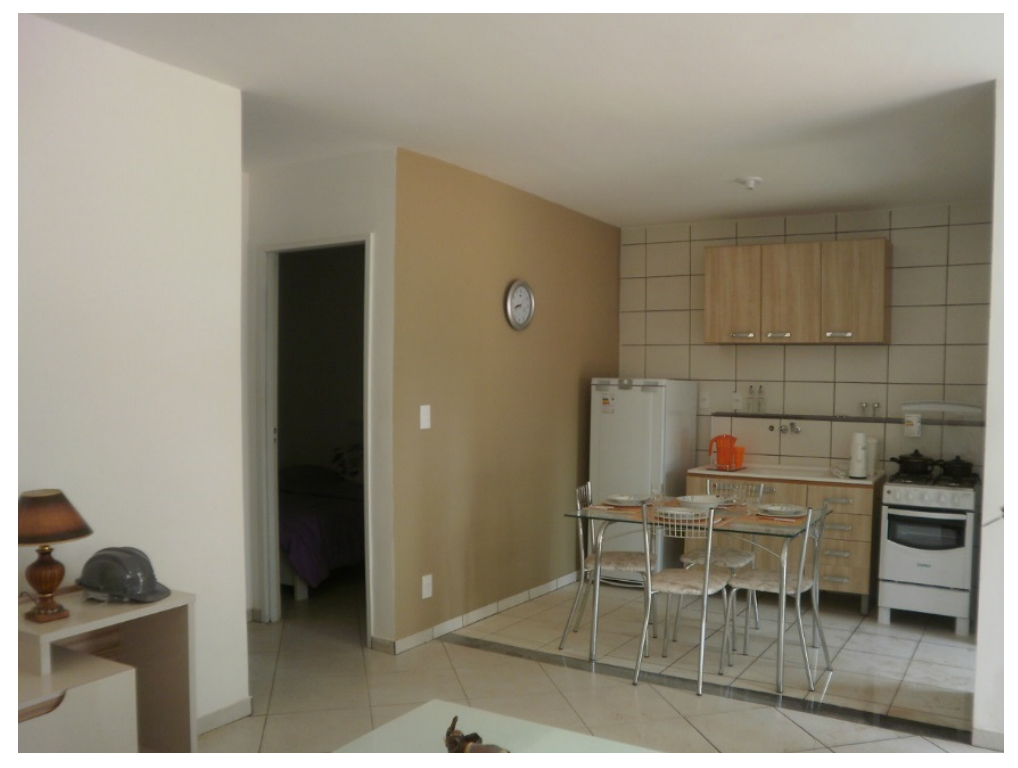

Figura 66 - Cozinha - apartamento decorado.

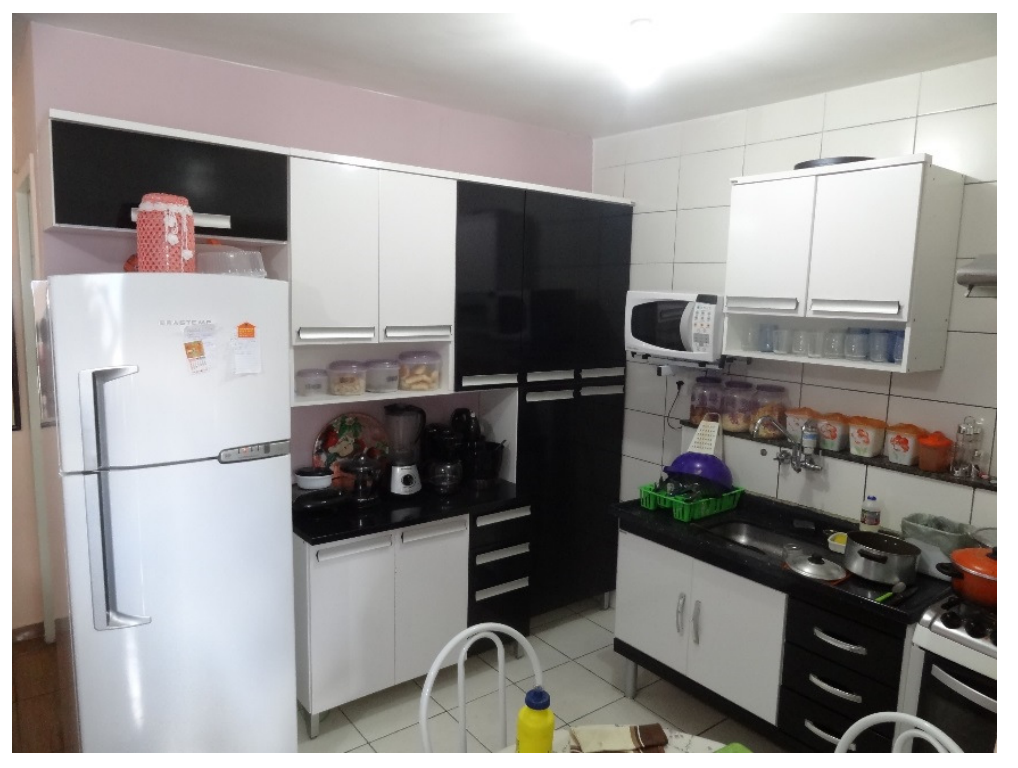

Figura 67 - Cozinha - apartamento visitado.

Ao comparar as duas cozinhas, o que fica mais claro é a necessidade de colocação de armários que, muitas vezes não é considerada nos projetos de arquitetura.

A área de serviço possui dimensões mínimas para um tanque e uma máquina de lavar. No esquema de análise do ciclo da roupa, é possível observar que a etapa de passar as roupas não pode ser realizada dentro desse ambiente devido às pequenas dimensões. Porém, vale destacar que foi deixado, pelo projeto, um espaço onde pode ser colocado um armário. Esse espaço para armário é bastante útil pois pode servir tanto para guardar produtos de 
limpeza, vassouras, tábua de passar roupa, como também uma parte da despensa, ampliando a área de armazenamento da cozinha.

No apartamento visitado (Figura 69) foi possível perceber que os moradores preferem cobrir as janelas das áreas de serviço, que dão para as passarelas, como maneira de aumentar a privacidade. A mesma situação foi observada no projeto Santo Amaro V. Portanto, fica aqui registrada a importância de tratar adequadamente as aberturas, voltadas para áreas comuns do conjunto, para não comprometer a privacidades dos moradores.

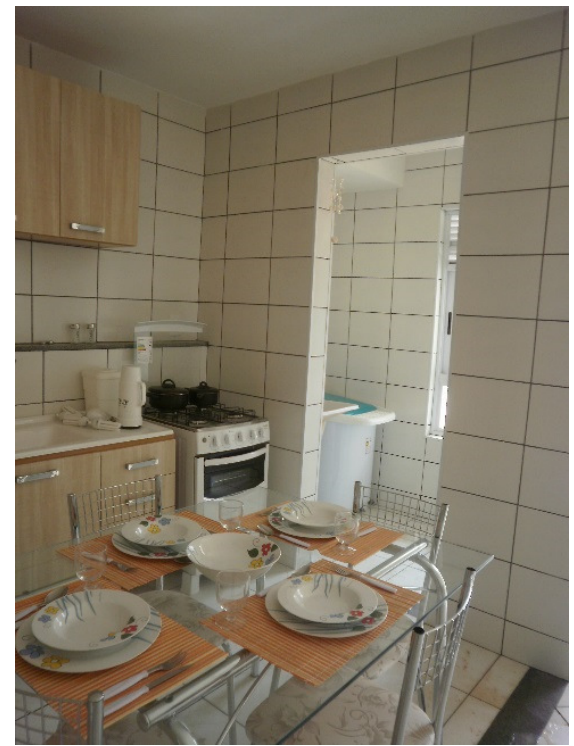

Figura 68 - Área de serviço e cozinha - apartamento decorado.

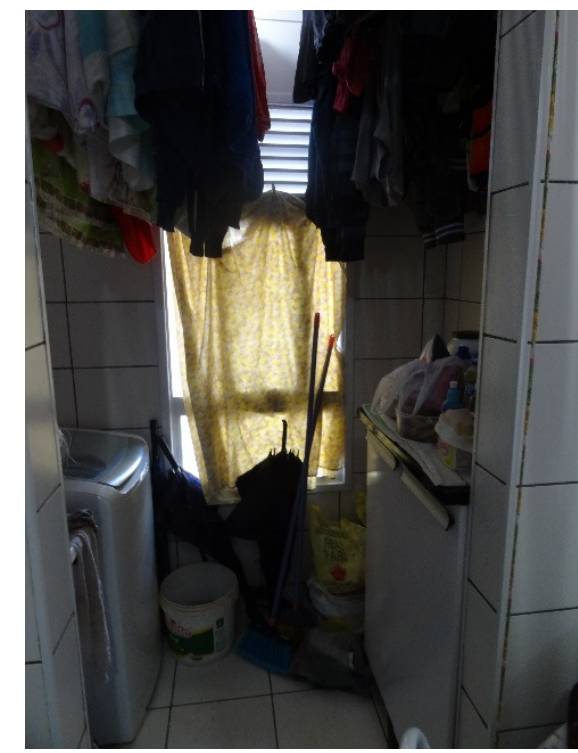

Figura 69 - Área de serviço apartamento visitado.

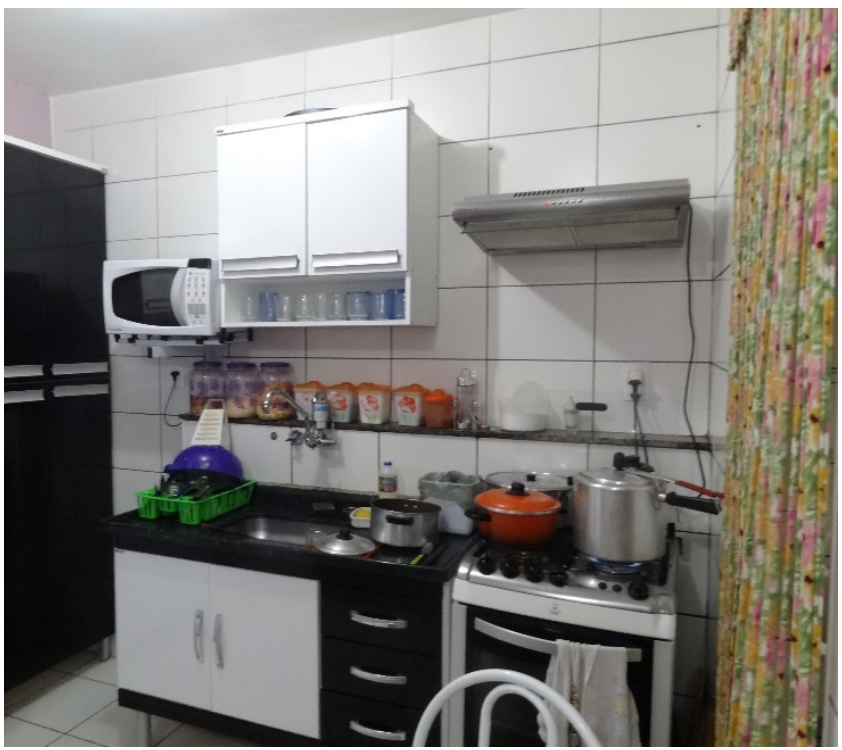

Figura 70 - Cortina (à direita) separando a cozinha da áreas de serviço - Apartamento visitado. 


\section{Relação entre os}

ambientes

Nessa tipologia cozinha e área de serviço estão diretamente relacionadas e, inclusive, a cozinha não possui iluminação e ventilação própria, dependendo das janelas da área de serviço e da sala de estar para receber iluminação e ventilação.

A área de serviço está localizada, dentro da unidade, de uma forma que não fique muito exposta aos olhos de quem entra no apartamento. A entrada desse ambiente está relacionada com a cozinha. Ainda assim, foi possível perceber, durante as visitas realizadas, que também existe uma preocupação, por parte dos moradores, em proteger, visualmente, a áreas de serviço. É o que pode ser observado na Figura 70, na qual vemos a cortina que a moradora colocou entre a cozinha e a áreas de serviço.

A cozinha está diretamente relacionada com a sala de estar, proporcionando a sensação de espaço mais amplo. Contudo, caso algum morador sinta a necessidade de isolar a cozinha da sala de estar, a disposição dos ambientes permitiria essa situação sem prejuízo para os espaços.

No item relação entre os ambientes, vale destacar ainda que a posição das portas dos dormitórios proporciona maior privacidade a esses ambientes.

\section{Espaço exterior próprio}

Todas as tipologias, que serão analisadas, desse projeto apresentam espaço exterior próprio. Em todos os casos há um varanda de apenas $56 \mathrm{~cm}$ de largura, relacionada com os dormitórios, que cumpre a função de espaço exterior próprio para os apartamentos. 
Ao visitar o conjunto, fica muito claro a importância desses espaços para os moradores que se apropriam das mais variadas formas dessas varandas proporcionando, inclusive, variedade de usos nas fachadas. Em muitos casos, esse espaço é utilizado para guardar as bicicletas - uma vez que não existe dentro do condomínio um bicicletário coletivo - em outros, os varais para secar as roupas são colocados ai, pois há mais ventilação e sol direto que dentro das áreas de serviço; alguns moradores colocam vasos de plantas; outros gaiolas de passarinhos. Enfim, durante as visitas, foi possível verificar que esse espaço foi muito bem aceito pelos moradores e que ele representa uma parte muito importante dentro das unidades habitacionais.

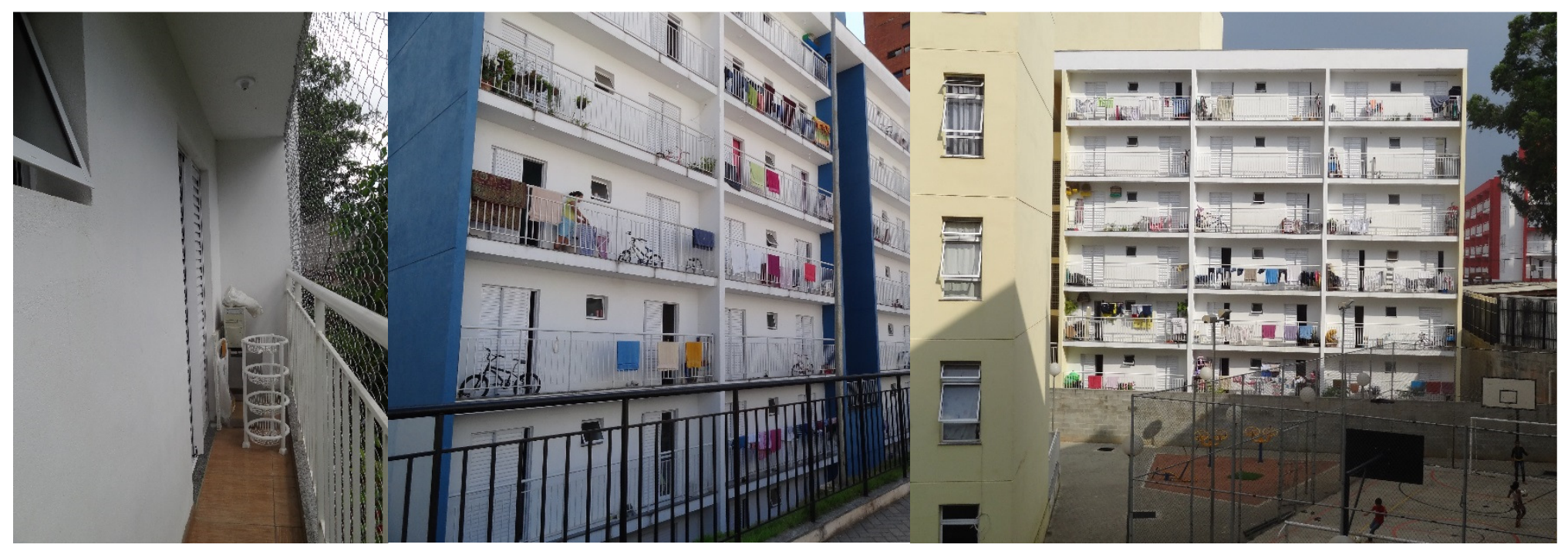

Figura 71 - espaço exterior Figura 72 - vista das varandas do bloco 1 - Figura 73 - vista das varandas de um dos edifícios da próprio. quadra $\mathrm{H}$ quadra I. 


\section{Variações do Tipo 1}

O Tipo $1 \mathrm{~A}$ representa a variação do Tipo 1 devido às adaptações necessárias para uma unidade para pessoas com necessidades especiais (P.N.E.).

Nesse caso, o banheiro é maior, reduzindo as dimensões de um dos dormitórios. Para garantir que um cadeirante entre nas áreas de serviço, a parede que criava um espaço para armário no Tipo 1 foi retirada para ampliar a área de passagem.

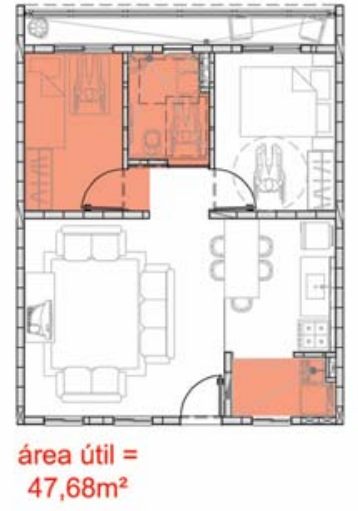

PLANTA TIPO 1A variaçöes:

- unidade P.N.E. - banheiro adaptado - dormitório foi reduzido par adequar o banheiro - alteração no acesso à área de serviço

$\square$ destaque para as variações entre os tipos escala 1:200

Figura 74 - Tipo $1 \mathrm{~A}$

\subsubsection{TIPO 2}

Essa tipologia aparece na parte mais estreita dos edifícios "U" dos condomínios 1, 2 e 3. Por esse motivo os apartamentos são mais retangulares e os ambientes estão dispostos um ao lado do outro.

Uma das faces da unidade está voltada para o interior do edifício, em contato direto com a passarela de circulação. Nessa face as janelas da cozinha e da área que foi classificada como espaço de estudo, são altas, garantindo a privacidade dos moradores. Contudo, garantem também a ventilação cruzada no interior do apartamento.

De qualquer forma, as janelas mais altas e o filtro criado pela passarela acabam comprometendo um pouco a iluminação da parte dos ambientes mais próxima a essa face. Por outro lado, a outra fachada possui insolação noroeste, garantindo boa iluminação. 


\section{Ambientes não} especializados

\section{Ambientes} especializados

Os dormitórios dessa tipologia apresentam formato e dimensões bastante distintas: um é retangular com 4,70m de comprimento e 2,00m de largura; o outro é quadrado com 2,40 x 3,09. A menor dimensão do primeiro dormitório compromete seu uso, pois os $2,00 \mathrm{~m}$ de largura não permitem que uma cama de casal seja colocada adequadamente dentro desse ambiente. Isso restringe a flexibilidade de uso dos ambientes.

No dormitório de forma quadrada, as medidas são mínimas para uma cama e um guarda-roupa pequeno. Um armário grande, seguramente encontrará problemas para ser encaixado dentro desse ambiente, conforme vimos acontecer no Tipo 1.

A sala de estar é o ambiente central do apartamento comunicando-se com a cozinha e com o corredor que leva aos dormitórios. Esse corredor é alargado e proporciona um "espaço-extra" na unidade para colocar uma mesa para estudo - como proposto pelo layout realizado pelos arquitetos - ou um armário, por exemplo.

No Tipo 2 todas as áreas molhadas estão concentradas. O banheiro ventila através da áreas de serviço e a cozinha possui sua própria janela.

A cozinha possui largura de 1,56 e todos os equipamentos, como pia, fogão, geladeira e até mesmo um armário estreito estão acomodados em uma mesma parede. Com base nas visitas realizadas, foi possível verificar que, normalmente, os moradores possuem armários maiores e provavelmente terão que utilizar a parede onde a mesa está encostada. Aqui, há que se cuidar para não obstruir a janela alta existente nessa parede.

A área de serviço possui dimensões mínimas e o banheiro não permite o uso simultâneo. 

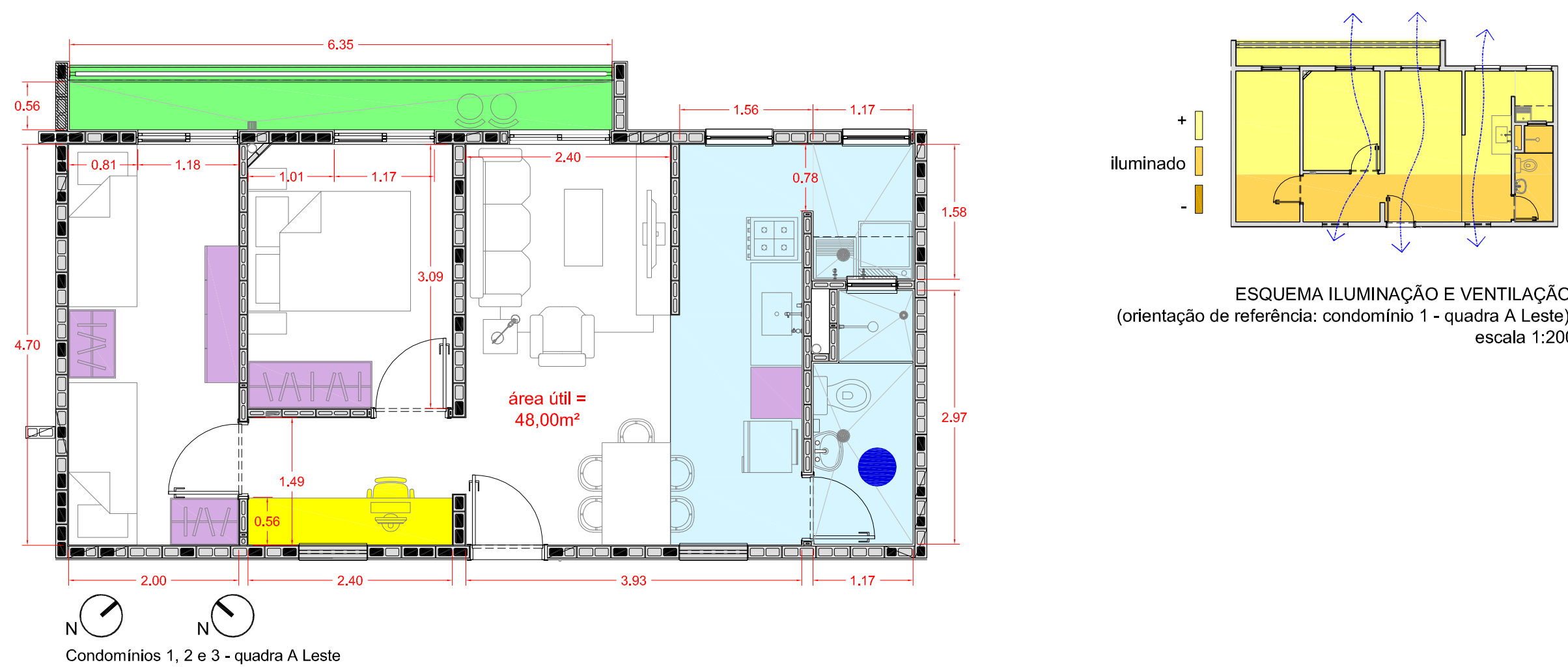

ESQUEMA ILUMINAÇ̃̃O E VENTILAÇÃO (orientação de referência: condomínio 1 - quadra A Leste) escala 1:200

PLANTA TIPO 2 - layout e dimensões.

escala $1: 75$

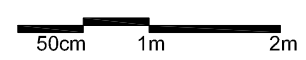

$\begin{array}{ll}\square \text { concentração das áreas molhadas } & \text { CICLO DA ROUPA: } \\ \square \text { espaço exterior próprio } & \text { 1. roupa suja } \\ \square \text { apropriação do espaço de transição } & \text { 2. lavar } \\ \text { como espaço exterior próprio } & \text { 3. secar } \\ \square \text { espaços para guardar } & \text { 4. passar } \\ \square \text { espaços de estudo/trabalho } & \text { 5. roupa limpa } \\ \begin{array}{l}\text { uso do banheiro } \\ \text { 1 pessoa }\end{array}\end{array}$

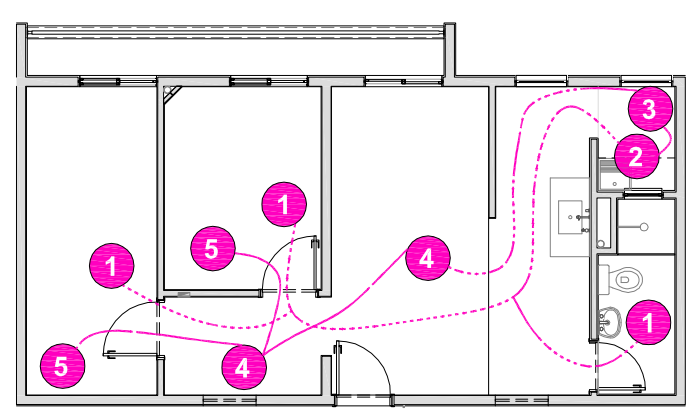

PLANTA TIPO 2 - ciclo da roupa escala 1:150

Figura 75 - Análise Tipo 2. 


\section{Relação entre os}

ambientes

Essa tipologia possui uma parte do espaço dedicada à circulação: o corredor de acesso aos dormitórios, bem como a entrada e a comunicação com a cozinha. A sala, apesar de estar mais contida em parte do ambiente, relaciona-se diretamente com a cozinha e atua como espaço articulador da unidade que comunica os ambientes.

Assim como ocorreu no Tipo 1, caso os moradores desejem tornar a cozinha um ambiente mais reservado, é possível colocar uma porta ou parede sem prejudicar as funções, iluminação e ventilação dos ambiente.

A área de serviço é um espaço bastante reservado e, como é possível observar no esquema do ciclo da roupa, tem espaço suficiente para lavar e secar. Contudo, a atividade de passar as roupas deverá ser realizada na sala de estar ou também poder-se-ia tirar partido do "espaço-extra" existente nessa unidade.

\section{Espaço exterior \\ próprio}

No Tipo 2 a varanda estende-se pelos dormitórios e também pela sala de estar.

$\mathrm{Na}$ foto ao lado, podemos observar as três portasbalcão desses ambientes.

Entre as varandas também podemos observar, na foto, as janelas da cozinha e da área de serviço espelhadas a cada duas unidades.

Figura 76 - Fachada Condomínio 3 - quadra A Leste. Unidades Tipo 2.

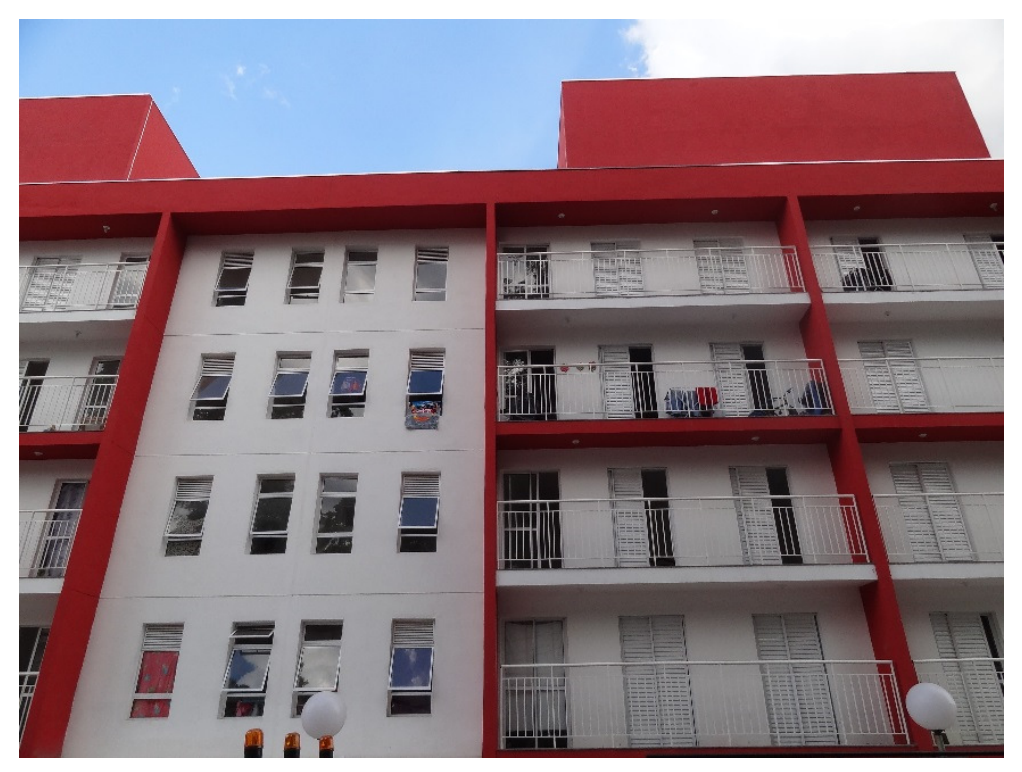


4.4.3.3. TIPO 3

O Tipo 3 ocorre nas esquinas do edifício "U" e portanto, teve que adaptar o interior da unidade para se encaixar no espaço disponível. Assim como no Tipo 2, percebe-se que trata-se de uma adaptação da tipologia para ser encaixada no espaço existente e resultante da configuração do edifício.

Por estar localizado na esquina, a única ventilação cruzada ocorre apenas através da porta de entrada. Essa posição favorece a boa iluminação dos ambientes sendo que, apenas a sala de estar é menos iluminada, pois não possui janelas próprias, sendo iluminada e ventilada através da janela da cozinha. Para ajudar na iluminação, as portas dessa unidade possuem uma abertura lateral.

\section{Ambientes não especializados}

Os dormitórios do Tipo 3 apresentam a mesma configuração que os dormitórios do Tipo 2: um com formato retangular e 5,00m de comprimento por 2,00m de largura; e outro mais quadrado, porém esse é um pouco mais alargado em um dos sentido com 3,30 de comprimento e 2,40 de largura. No Tipo 3, podemos concluir que ocorre o mesmo problema apontado no Tipo 2: o dormitório de formato retangular restringe o uso desse ambiente devido aos $2,00 \mathrm{~m}$ de largura.

A sala de estar apresenta dimensões mínimas, porém adequadas e mostra-se como um espaço mais amplo devido à relação com a cozinha e o espaço onde foi proposta uma mesa de jantar. No layout proposto pelo escritório de arquitetura há também uma mesa de estudo inserida na área comum do apartamento. 


\section{Ambientes}

especializados

As áreas molhadas estão concentradas na unidade e, assim como no Tipo 2, o banheiro ventila através da área de serviço. Como também acontece nas outras unidades estudadas, o banheiro não foi concebido para proporcionar o uso simultâneo, pois todas as peças estão dentro do mesmo ambiente; e a área de serviço apresenta dimensões mínimas para instalar um tanque e uma máquina de lavar. Nessa tipologia a cozinha está completamente relacionada com a sala de estar e ocupa um espaço mais amplo dentro da unidade.

\section{Relação entre os}

ambientes

Nessa tipologia, mesmo que os moradores desejassem, não seria indicado isolar sala de estar e cozinha, pois a sala não possui iluminação e ventilação próprias. É recomendado, portanto, que estes espaços estejam totalmente integrados.

Ao analisar o ciclo da roupa, vemos que a roupa pode secar sem a interferência da cozinha, ou seja, como a cozinha não ventila pela área de serviço, não há o risco de que as roupas "peguem cheiro" de comida por estarem penduradas no varal, mesmo não havendo porta que isole esses dois ambientes. Também é possível observar que não há um espaço adequado para passar a roupa e que, saindo do banheiro ou dos quartos, a roupa circula por toda a casa para cumprir seu ciclo de limpeza.

Nesse tipo também nota-se que os dormitórios estão mais reservados com relação aos espaços comuns do apartamento, garantindo maior privacidade. 


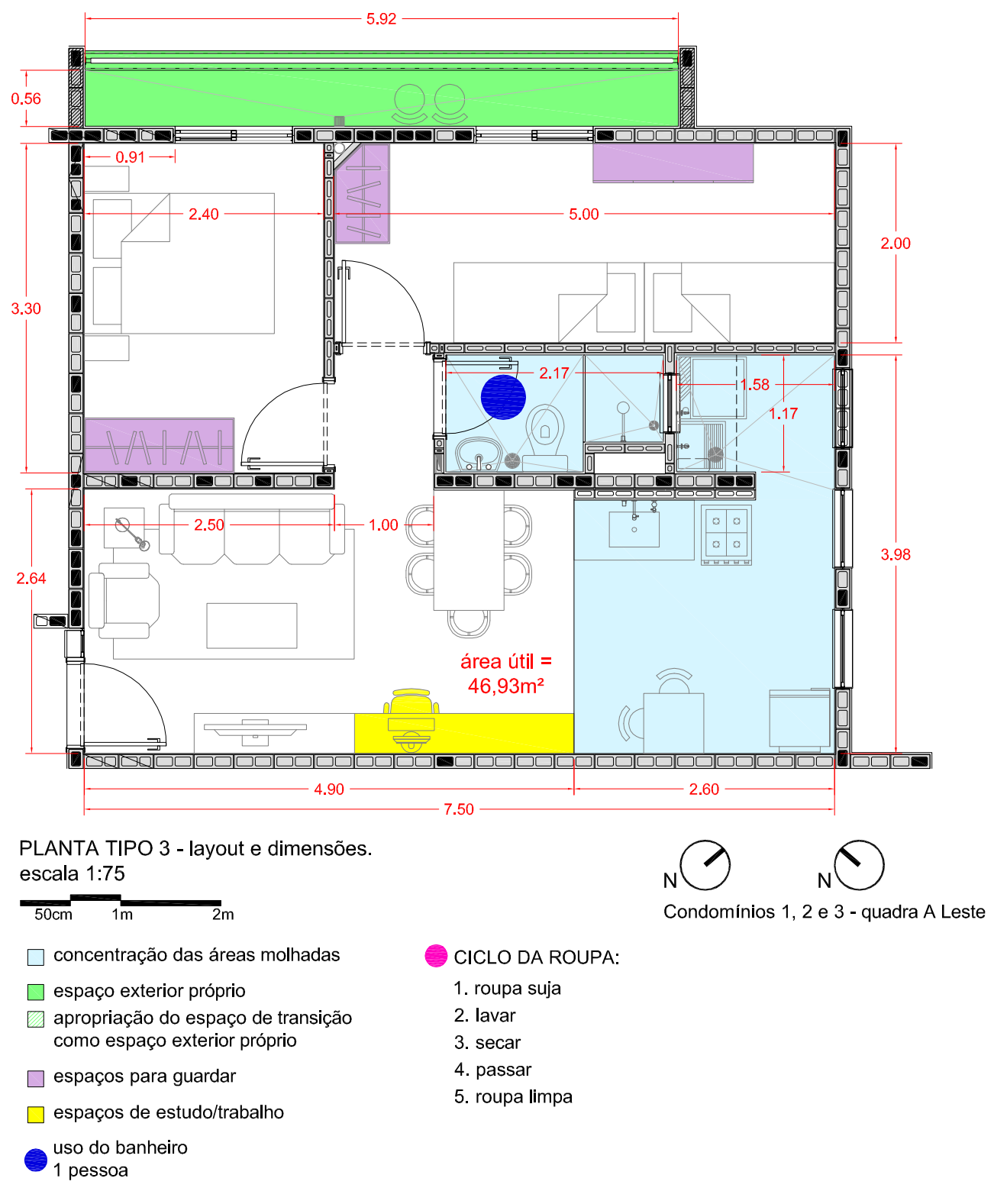

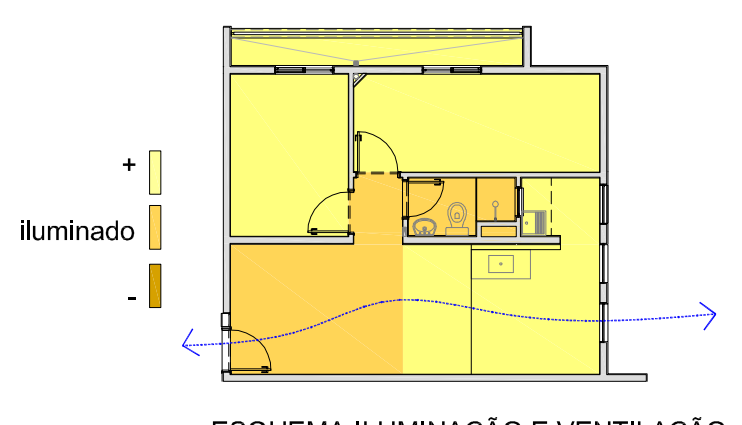

ESQUEMA ILUMINAÇÃO E VENTILAÇÃO (orientação de referência: condomínio 1 - quadra A Leste) escala 1:200

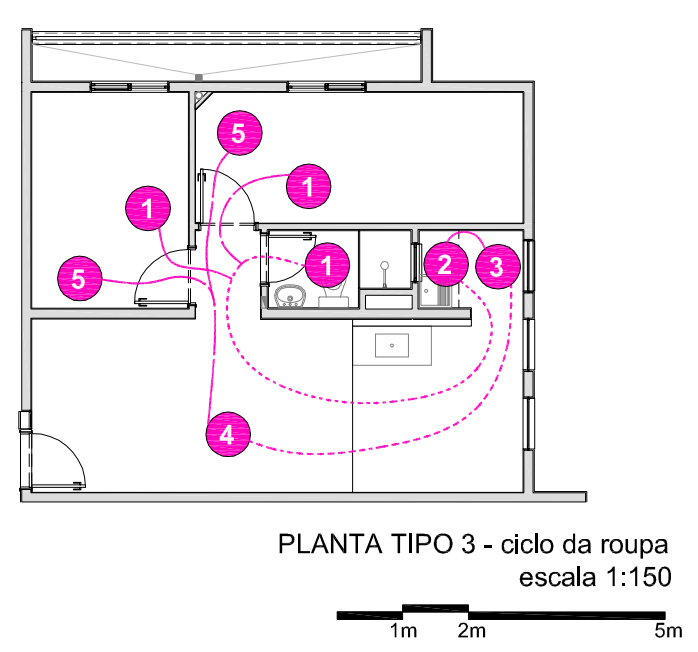

Figura 77 - Análise Tipo 3. 


\section{Espaço exterior}

próprio

No Tipo 3 a varanda representa o espaço exterior próprio da unidade e está conectada apenas aos dois dormitórios.

\section{Variações do Tipo 3}

Nos dois pavimentos do edifício abaixo do térreo

- 1ํ e $2^{\circ}$ inferiores - há um espaço destinado aos reservatórios inferiores ( $2^{\circ}$ pavimento inferior) e à sala de medição ( $1^{\circ}$ pavimento inferior). Nesses andares, devido à existência dessas áreas técnicas, o Tipo 3 precisou sofrer alterações para se encaixar no espaço disponível.

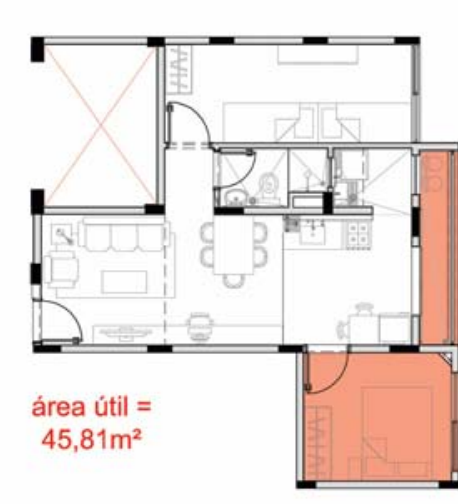

PLANTA TIPO 3A variaçöes:

- posição do segundo dormitório - posiçăo da varanda escala 1:200

destaque para as variaçōes entre os tipos

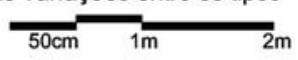

Figura 78 - Variação Tipo 3A.

Com isso, o Tipo 3A teve um dos dormitórios remanejados para a outra lateral, próximo à cozinha e, a partir dessa alteração, a varanda também foi reposicionada, sendo que, no Tipo 3A, está conectada à cozinha e à área de serviço, o que pode ser considerado uma vantagem com relação ao ciclo da roupa, pois a área de serviço tem acesso direto à varanda. 
4.4.3.4. TIPO 4

O Tipo 4 é a terceira e última tipologia dos edifícios em "U". Essa unidade é a que aparece em maior quantidade no edifício pois está localizada nos dois blocos paralelos que configuram as "pernas do U". Essa tipologia é bastante semelhante ao Tipo 1, considerando-se, como maior alteração, a posição do banheiro.

Há aberturas nas duas faces, o que garante a ventilação cruzada no interior das unidades e também boa iluminação em todos os ambientes. Quanto à iluminação, o único ambiente menos iluminado é o banheiro que ventila através da área de serviço.

\section{Ambientes não especializados}

Os dois dormitórios apresentam as mesmas dimensões não interferindo no uso desses ambientes, uma vez garantida a não hierarquia dos espaços. Com aproximadamente 3,00 x 3,00 metros, esses dormitórios permitem uma boa disposição do mobiliário.

A sala de estar também apresenta boas dimensões e está integrada à cozinha, separada apenas por uma parede baixa que define o limite dos espaços sem bloquear a integração.

Ambientes especializados

Os ambientes especializados, ou seja, os que necessitam de instalações próprias estão concentrados dentro da unidade. O banheiro ventila através da área de serviço e a cozinha possui iluminação e ventilação próprias. 


\section{Relação entre os}

ambientes

\section{Espaço exterior \\ próprio}

A cozinha está integrada tanto à sala de estar como à área de serviço. Porém, caso os moradores desejem, é possível isolar esses ambientes sem interferir nos usos, pois todos possuem ventilação e iluminação independentes. De qualquer forma, a parede baixa proposta entre sala e cozinha já é uma forma de proteger um pouco a cozinha sem romper a integração, proporcionando assim, a sensação de um espaço mais amplo.

Analisando-se o ciclo da roupa, conclui-se o mesmo que nos outros casos analisados desse projeto. A área de serviço é um espaço mais protegido e que permite lavar e secar as roupas adequadamente, não havendo, entretanto, espaço para passar as roupas. Portanto, subentende-se que esta atividade será realizada na sala ou nos dormitórios.

No Tipo 4 a varanda está conectada apenas aos dois dormitórios e representa o espaço exterior próprio dessas unidades. Nos condomínios 1, 2 e 3 da quadra A Leste as fachadas com varandas estão frente a frente e, como podemos ver nas fotos que seguem (Figura 80; Figura 81), os moradores utilizam muito esses espaços. Entre os usos, guardar as bicicletas e colocar as roupas para secar são os mais frequentes. Vale a pena ressaltar que, mesmo tendo espaço dentro das áreas de serviço para pendurar um varal de teto, os moradores preferem colocar as roupas para secar nas varandas, com sol direto. Fica aqui a observação da importância desse espaço e, portanto, nós arquitetos devemos pelo menos tentar, sempre que possível, proporcionar esses espaços nas unidades que projetamos, pois agregam muita qualidade aos apartamentos. 


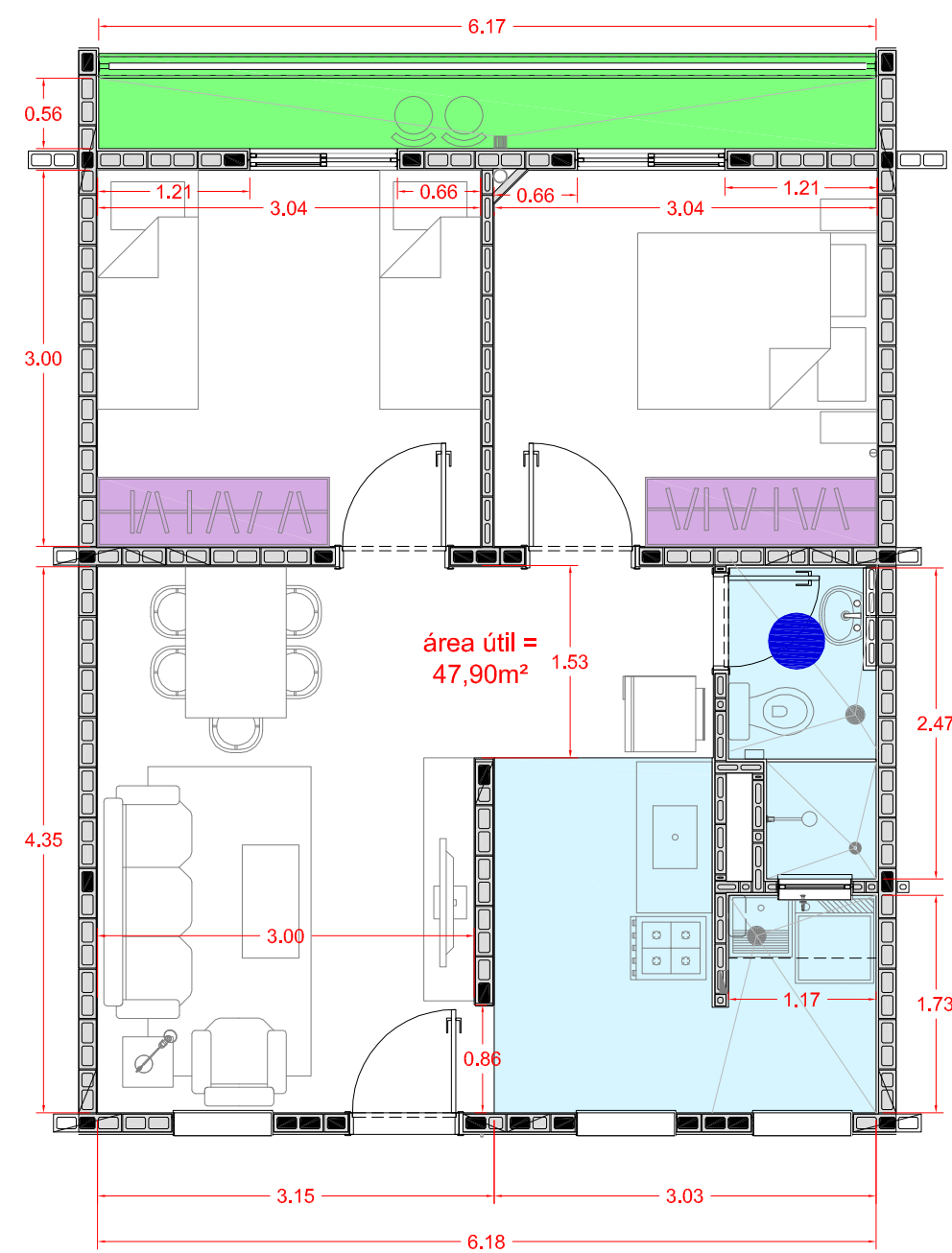

${ }_{n} \bigcirc{ }_{n} O{ }_{n} O$

Condomínios 1,2 e 3 - quadra A Leste
PLANTA TIPO 4 - layout e dimensões. escala 1:75

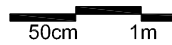

$\square$ concentração das áreas molhadas

$\square$ espaço exterior próprio

apropriação do espaço de transição como espaço exterior próprio

$\square$ espaços para guardar

$\square$ espaços de estudo/trabalho

uso do banheiro

CICLO DA ROUPA

1. roupa suja

2. lavar

3. secar

4. passar

5. roupa limpa

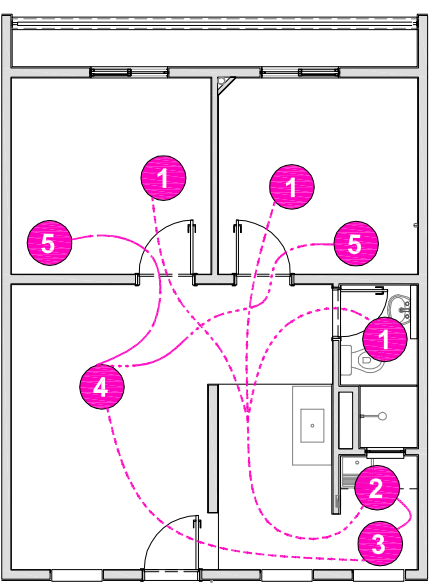

PLANTA TIPO 4 - ciclo da roup escala 1:150

Figura 79 - Análise Tipo 4. 


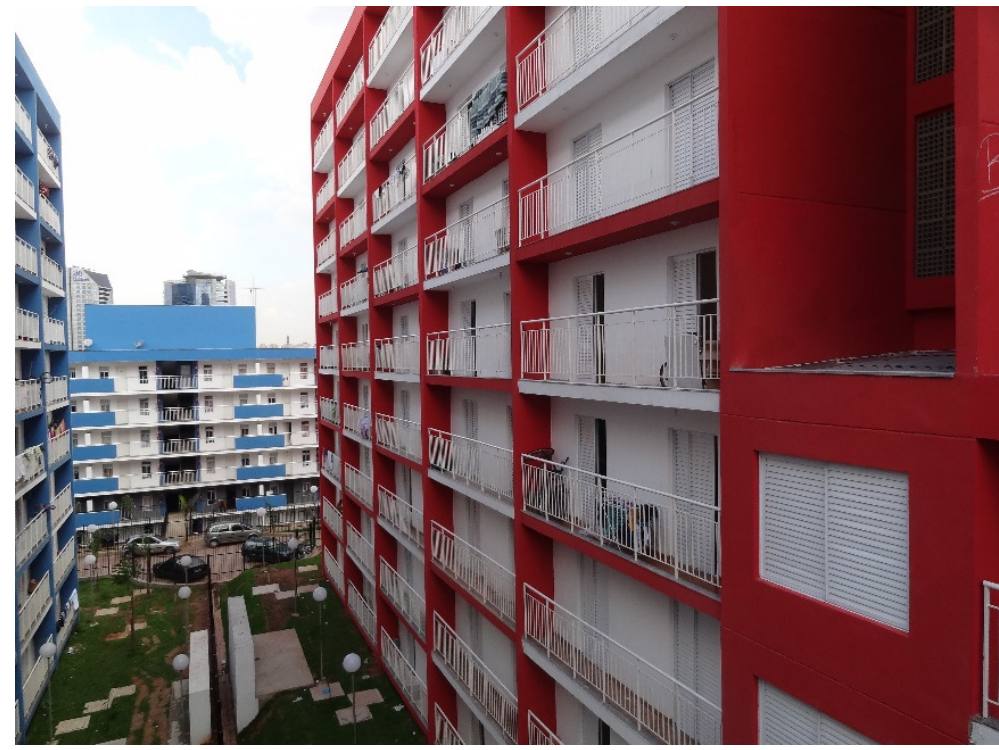

Figura 80 - Fachada com varandas - condomínio 3 - quadra A Leste.

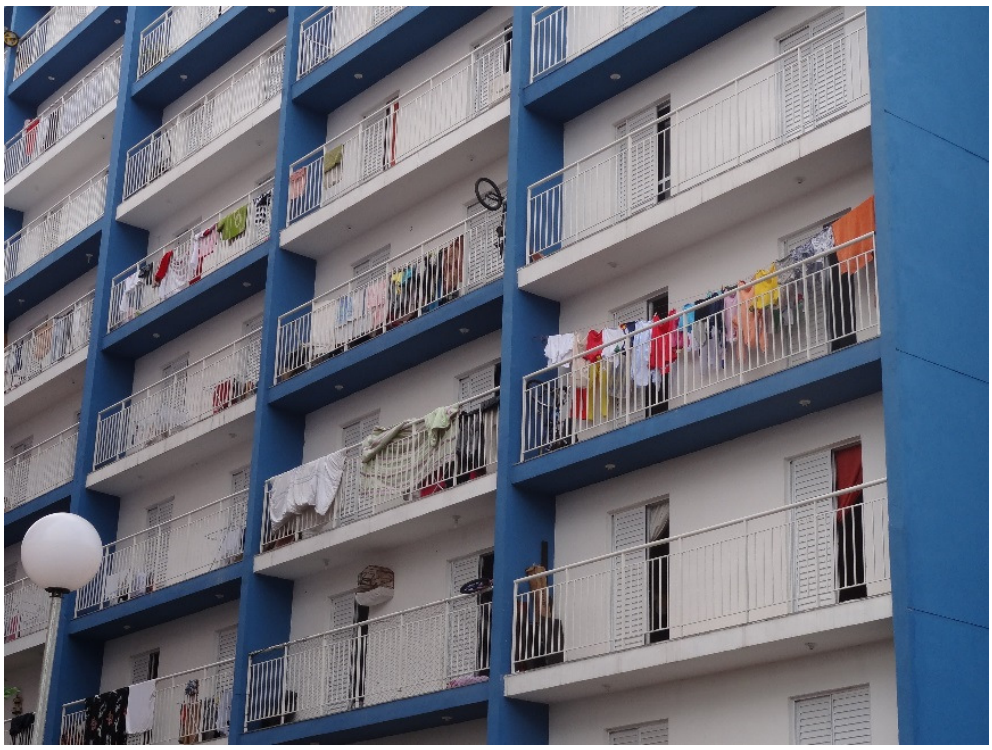

Figura 81 - Varandas condomínio 2 - quadra A Leste.

\section{Variações do Tipo 4}

As unidades tipo 4A são as adaptações do tipo 4 para unidades para pessoas com necessidades especiais (P.N.E.) e ocorrem no térreo inferior dos edifícios.

As alterações identificadas estão relacionadas ao tamanho do banheiro; ao hall de acesso ao banheiro; e às entradas dos dormitórios.

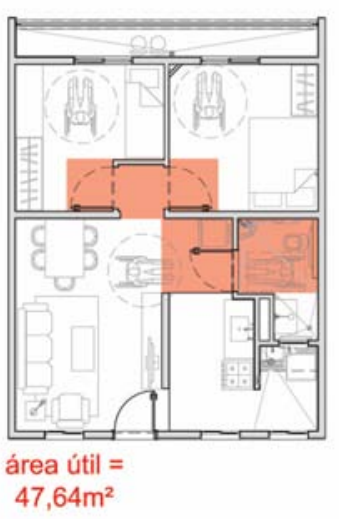

PLANTA TIPO 4A

variaçöes:

- unidade P.N.E.

- banheiro adaptado

- alteração na posição das portas dos

dormitórios

- alteração no acesso ao banheiro

$\square$ destaque para as variaçöes entre os tipos

escala 1:200

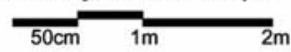

Figura 82 - Variação Tipo 4A. 


\subsubsection{TIPO 5}

O Tipo 5 aparece nos edifícios lâmina do condomínio 4 - quadra A Leste. O edifício todo apresenta a mesma tipologia considerando apenas a adaptação para unidades P.N.E. (Tipo 5A) que ocorrem no pavimento de acesso, o térreo intermediário.

Durante a visita ao conjunto, a tipologia visitada foi uma unidade tipo 5A, conforme será possível observar nas fotos a seguir.

Essa unidade possui boa iluminação em praticamente todos os ambientes. Apenas a cozinha é um pouco menos iluminada por estar relacionada com a área de serviço.

\section{Ambientes não especializados}

A configuração do banheiro entre os dormitórios e a dimensão destes ambientes são semelhanças que podem ser apontadas entre essa tipologia e a do Tipo 1. Nos dois casos não há hierarquia entre os dormitórios. Ambos apresentam as mesmas dimensões.

A sala de estar é um espaço bastante amplo com 5,09 metros de comprimento e permite acomodar confortavelmente de quatro a cinco pessoas, tanto para assistir TV como sentadas à mesa. 


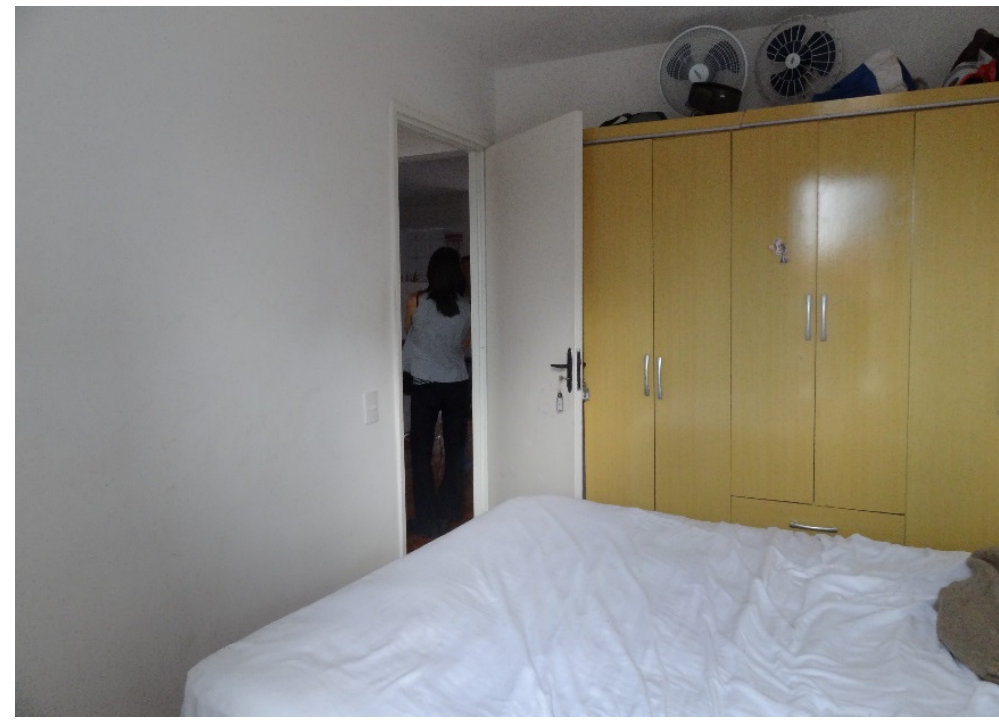

Figura 83 - Dormitório do apartamento visitado.

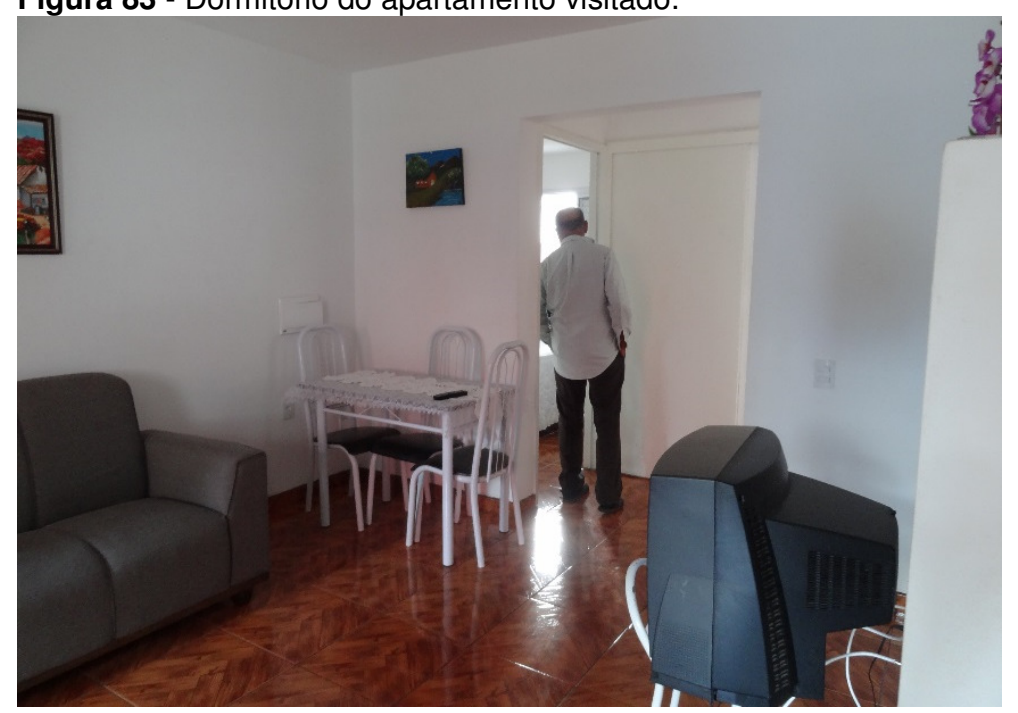

Figura 85 - Sala de estar e hall de acesso aos dormitórios e banheiro - unidade visitada.

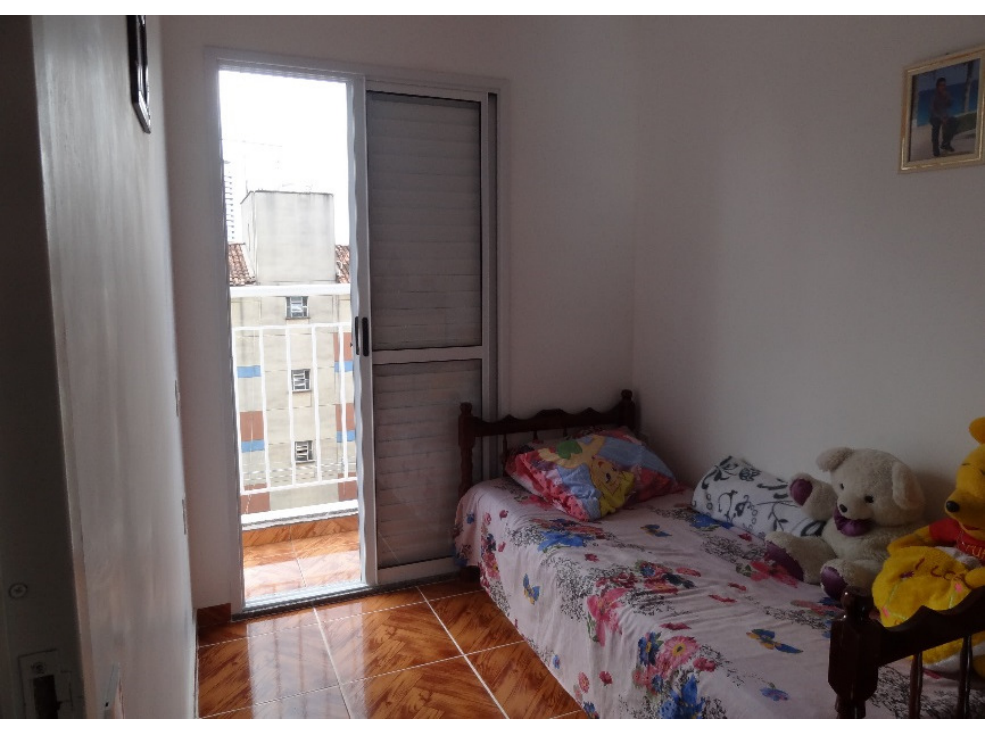

Figura 84 - Segundo dormitório do apartamento visitado.

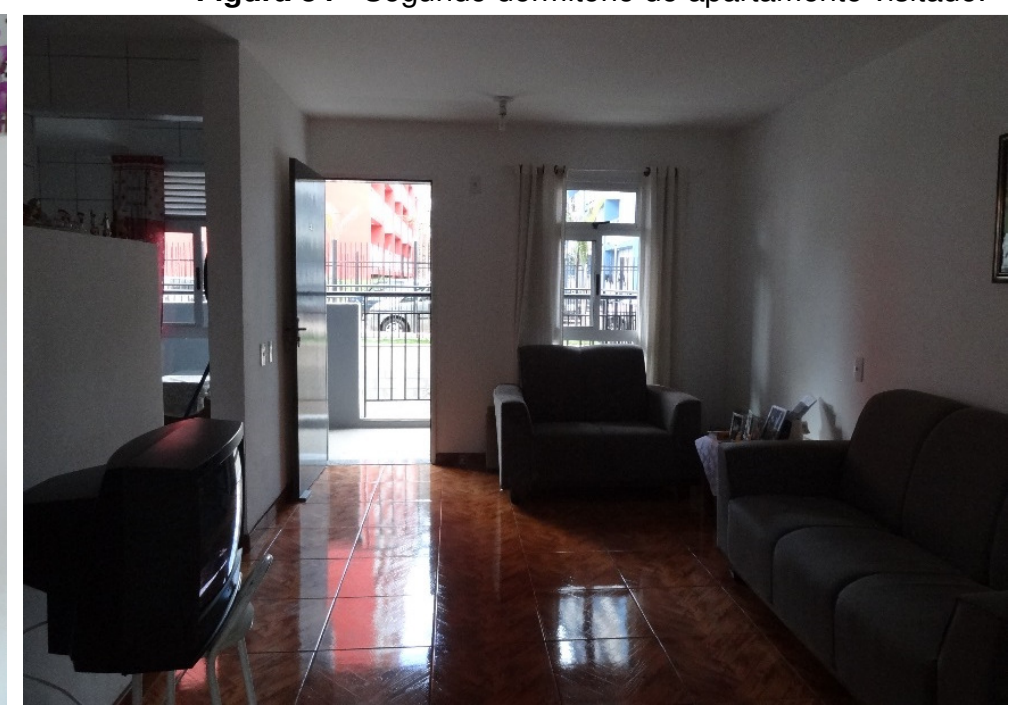

Figura 86 - Sala de estar unidade visitada. 


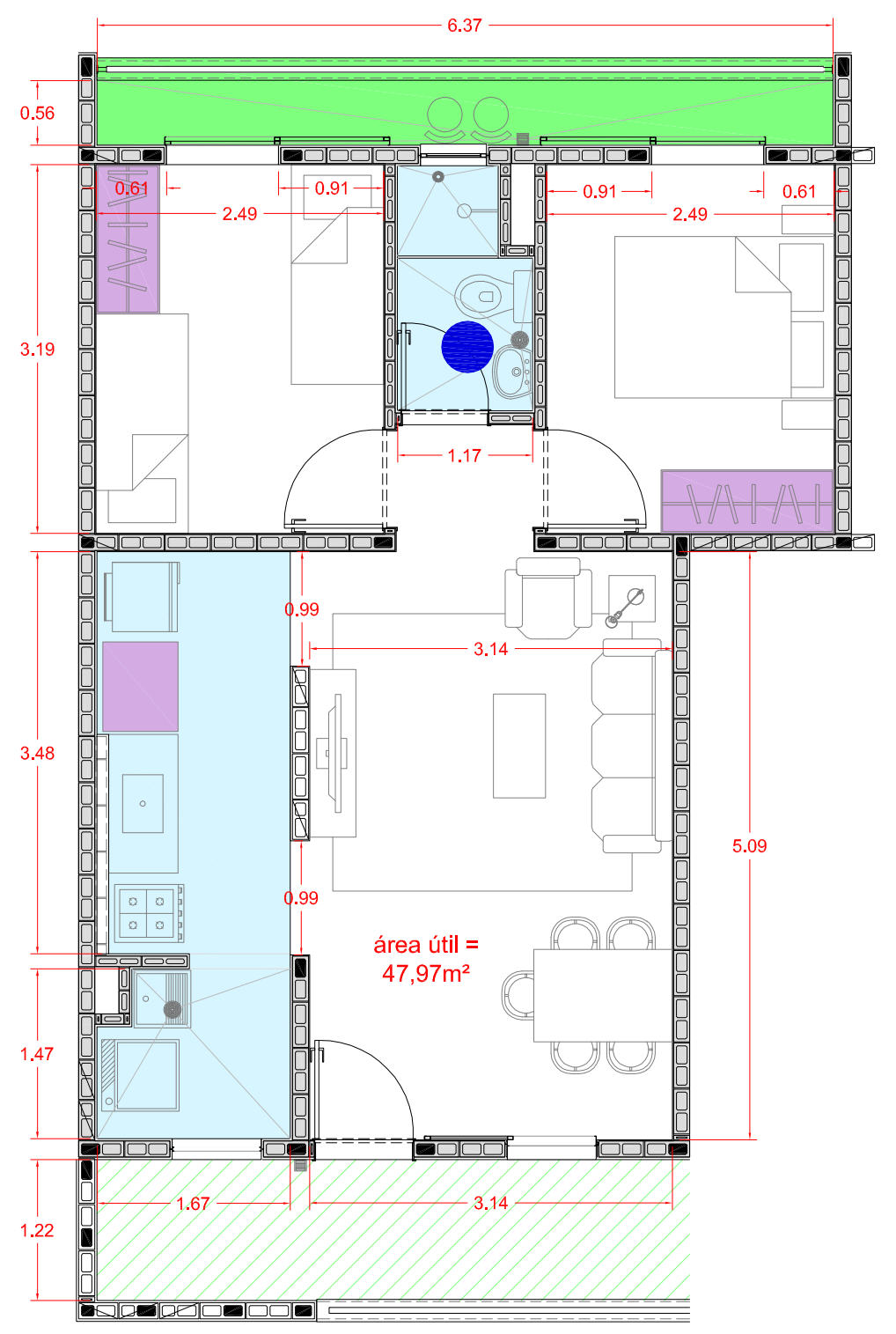

${ }_{n} \bigcirc$

Blocos 1 e 2 - Condominio 4 - quadra A Leste
PLANTA TIPO 5 - layout e dimensões. escala 1:75

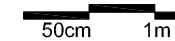

$\square$ concentração das áreas molhadas

$\square$ espaço exterior próprio

apropriação do espaço de transição

como espaço exterior próprio

$\square$ espaços para guardar

$\square$ espaços de estudo/trabalho

uso do banheiro

CICLO DA ROUPA:

1. roupa suja

2. lavar

3. secar

4. passar

5. roupa limpa

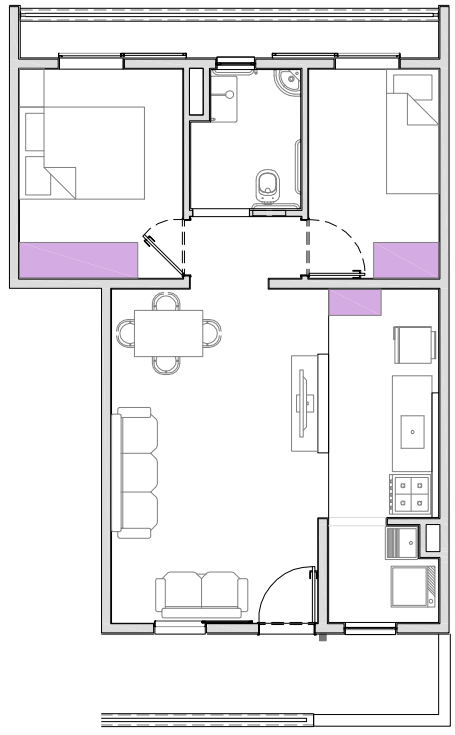

PLANTA TIPO 5A - reprodução de layout de um apartamento visitado já ocupado pelos moradores.

escala 1:150

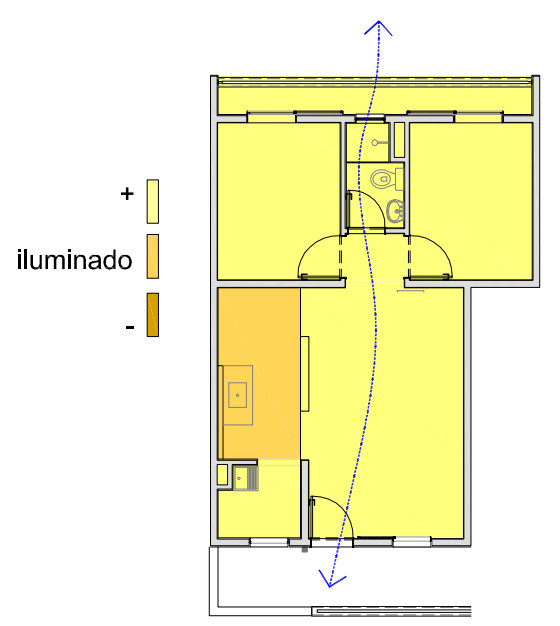

ESQUEMA ILUMINAÇÃO E VENTILAÇÃO (orientação de referência: condomínio 4 - quadra A Leste) escala 1:200

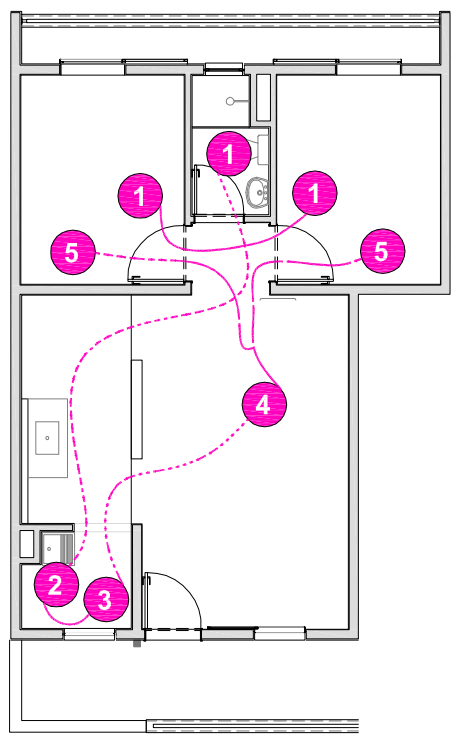

PLANTA TIPO 5 - ciclo da roupa escala 1:150 $1 \mathrm{~m} \mathrm{2m} 5 \mathrm{~m}$ Figura 87 - Análise Tipo 5. 


\section{Ambientes}

especializados

Apenas cozinha e área de serviço estão concentradas nessa unidade, o banheiro, como foi dito, localiza-se entre os dormitórios. Em nenhuma das tipologias analisadas desse conjunto o banheiro permite o uso simultâneo. Todas configuram os banheiros como um único ambiente.

Cozinha e área de serviço ocupam um espaço mais estreito dentro da unidade ao longo dos 5 metros da sala de estar. Assim como no Tipo 4, a cozinha está separada da sala por uma parede baixa que define o limite desses ambientes.

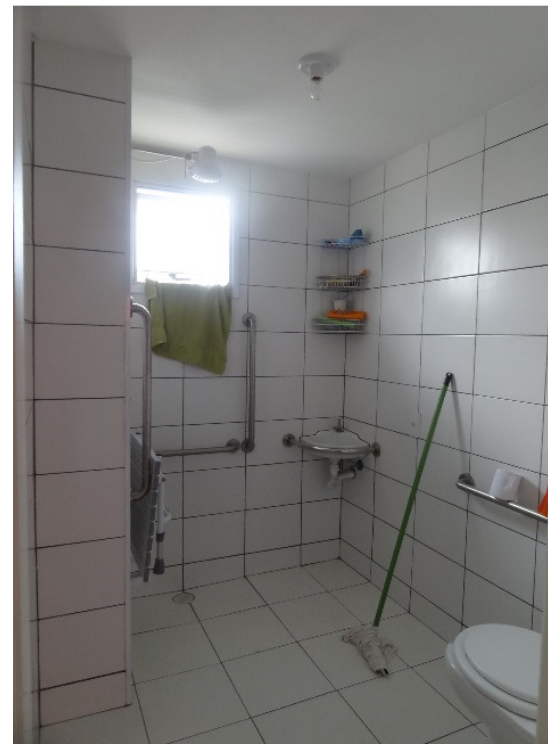

Figura 88 - Banheiro adaptado para P.N.E. - unidade visitada.

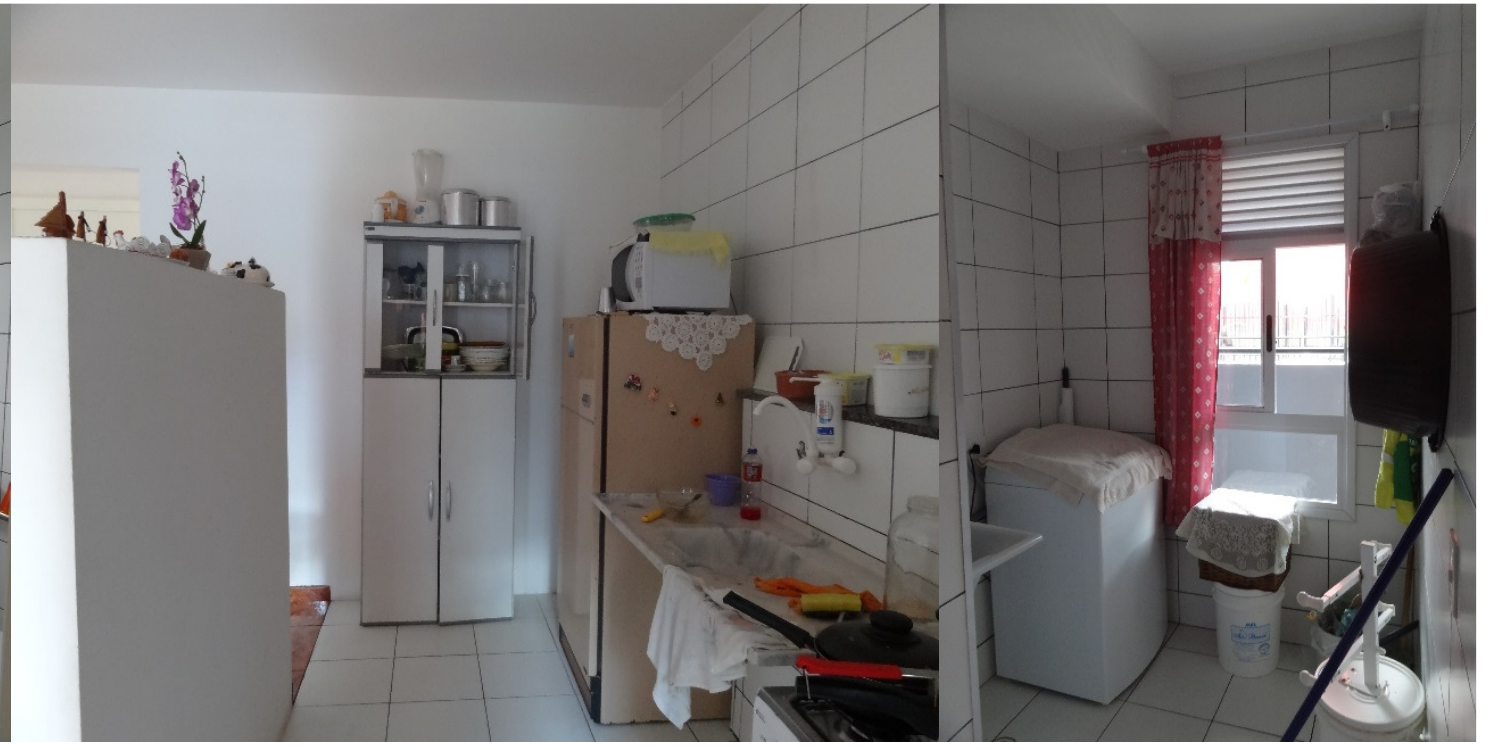

Figura 89 - Cozinha unidade visitada.

Figura 90 - área de serviço unidade visitada. 


\section{Relação entre os}

ambientes

Assim como no tipo 4, é possível isolar a cozinha da sala de estar. Porém, o espaço é bem amplo e a parede existente entre os ambientes, apesar de baixa, já garante um pouco de privacidade à cozinha.

No caso dessa tipologia, devido ao fato da cozinha ventilar através da janela da área de serviço, identificou-se o problema das roupas estendidas que podem ficar cheirando a comida devido à essa proximidade. Entretanto, como nos outros casos, os moradores desse conjunto podem contar com o espaço exterior próprio da unidade para colocar as roupas para secar.

\section{Espaço exterior próprio}

Quanto ao espaço exterior próprio, o Tipo 5 apresenta uma vantagem com relação às outras tipologias analisadas: quem mora nesses apartamentos pode contar com mais um espaço exterior além da varanda dos dormitórios. Devido à configuração do edifício, as passarelas são interrompidas a cada duas unidades e essa situação cria um espaço em frente às portas de entrada que, apesar de ser uma área comum do edifício, pode ser apropriada pelos moradores como extensões de suas casas. Essas áreas são os espaços de transição apropriados como espaços exteriores dessas unidades (Figura 91; Figura 92). 


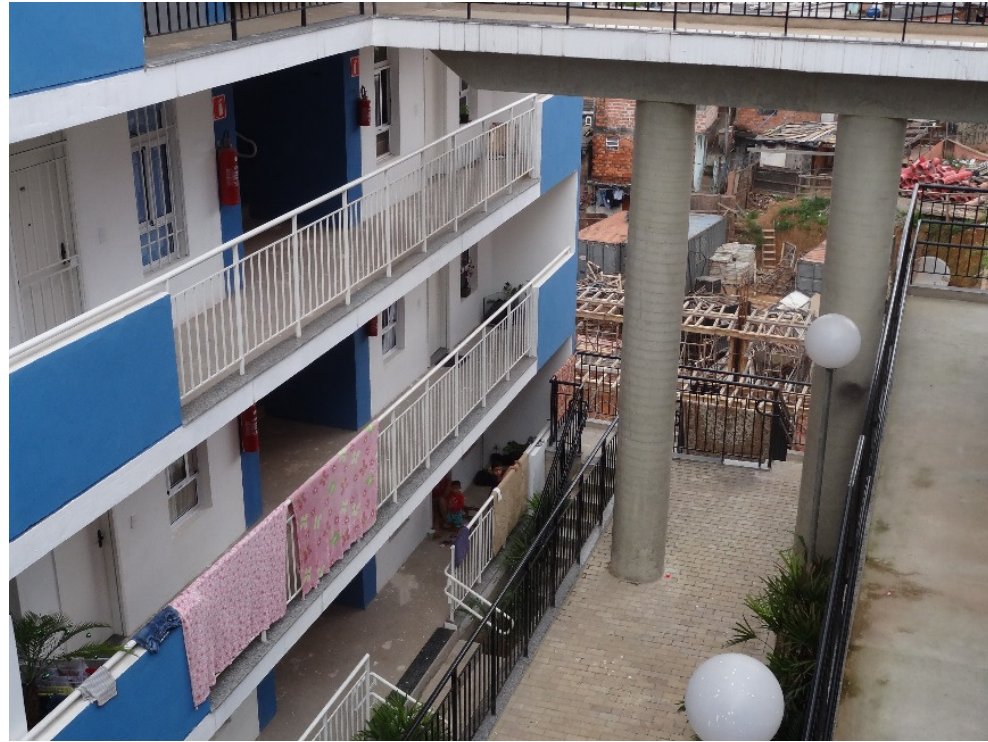

Figura 91 - Espaços de transição apropriados como espaços exteriores próprios das unidades.

\section{Variações do Tipo 5}

O Tipo 5 também sofre variação para se adaptar como uma unidade P.N.E. Nesse caso apenas o banheiro e um dos dormitórios são alterados. O banheiro fica maior e o dormitório, menor, permitindo as adaptações dentro do banheiro.

Essa tipologia ocorre no pavimentos que estão no mesmo nível que a rua.

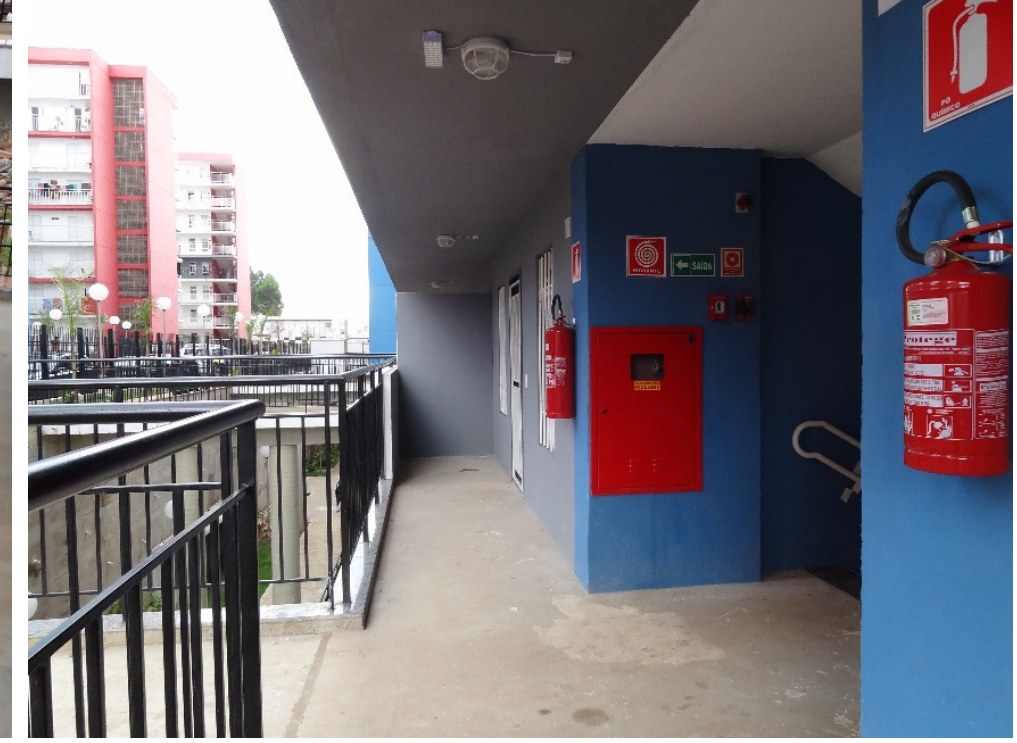

Figura 92 - Trecho da passarela interrompido criando espaço para apropriação em frente às portas dos apartamentos.

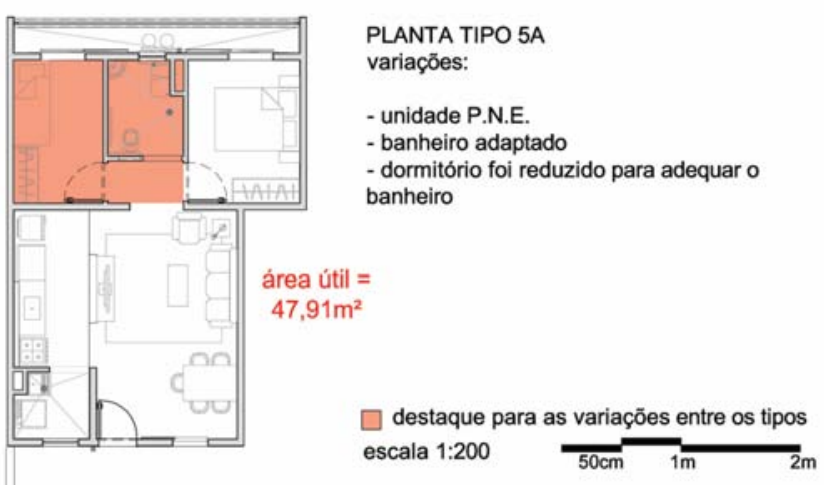

Figura 93 - Variação Tipo 3A. 


\subsubsection{CONSIDERAÇÕES}

FINAIS

O Conjunto Habitacional Real Parque é uma intervenção de grande porte que apresentou como proposta a transformação de um favela em bairro a partir da construção de conjuntos habitacionais. Os autores e técnicos da prefeitura sempre defenderam a remoção total da favela. Como vimos, os motivos principais são a valorização da área e a situação de risco devido à forte declividade do terreno. Contudo, é preciso ter consciência de que, talvez, outra proposta menos agressiva fosse possível. É provável que existissem casas em bom estado de conservação e que não se encontravam em situação de risco em meio à todas as moradias demolidas.

Os processos de urbanização não são simples e sempre existem dois caminhos a seguir: o primeiro, menos agressivo, seria considerar as preexistências, analisar as situações de risco e, a partir de um trabalho minucioso, se definir o que deveria ser conservado e a maneira como o novo - as novas construções e espaços - iriam se inserir naquele meio existente; o outro caminho é menos detalhista, mas tem maior impacto ao decidir eliminar totalmente as favelas e construir um novo projeto, apagando a memória da situação anterior.

Entre os quatro projetos analisados, o único que escolheu o primeiro caminho foi o Santo Amaro V. Entre os outros três, o Comandante Taylor tratava-se de uma área de provisão e o Jardim Edite e o Real Parque foram realizados sobre o terreno onde anteriormente havia a favela.

Esses projetos têm como objetivo construir um novo trecho de cidade e os conjuntos habitacionais são o objeto dessa reconstrução. Porém, fica aqui uma reflexão quanto às preexistências e à memória dos lugares. Será que as intervenções não seriam mais originais se permitissem consolidar as moradias em bom estado de conservação e, nessa situação, as novas construções seriam apenas um instrumento para complementar o projeto de urbanização com oferta de mais moradias ou proporcionando moradia às famílias que precisassem ser removidas por estarem 
vivendo em situação de risco? Será que a remoção total é mesmo a opção mais indicada, ou simplesmente é a mais fácil? E a mais cara também, pois exige a reconstrução total do local e, em muitos casos, envolve o custo adicional do auxílio moradia para as famílias durante o período da construção.

No caso do Real Parque, existiu a vantagem de não precisar investir nos auxílios moradia, pois a intervenção pôde contar com a desapropriação de dois terrenos que permitiram iniciar a construção dos conjuntos antes de realizar as remoções. Outro ponto positivo da intervenção, foi ter podido atender a $100 \%$ dos moradores, permitindo que todos fossem, definitivamente, fixados no local.

Segundo a arquiteta Geni Sugai, os moradores tiveram a oportunidade de participar de todo o processo de desenvolvimento e puderam opinar, colaborando na concepção do projeto.

Além da remoção total da favela para a construção dos novos conjuntos, outra situação questionável nesse projeto é o fato dos condomínios serem completamente cercados. É sabido que cercar os conjuntos faz parte das recomendações da Secretaria Municipal de Habitação e que, em muitos casos, os próprios moradores preferem que os limites dos condomínios sejam definidos fisicamente. Entretanto, é preciso considerar que, ao cercar os conjuntos, a oferta para o bairro e para a cidade é muito menor. Antes da intervenção, todas as famílias conviviam em um mesmo espaço. Essa situação não poderia ter continuado após a construção dos edifícios habitacionais? Ao invés de 11 condomínios, não poderiam ser edifícios construídos dentro do bairro Real Parque?

Essa é uma discussão bastante complexa que ainda precisa ser amadurecida a partir das novas experiências de intervenção em favelas. Utilizando, mais uma vez, do projeto Residencial Parque Novo Santo Amaro $V$ como exemplo, do ponto de vista da arquitetura, foi um avanço terem conseguido propor os espaços comuns como espaços públicos. Há apenas que se levar em conta, como foi possível verificar ao estudá-lo, que a gestão é complicada e os próprios moradores chegaram a pedir que o conjunto fosse cercado. Nessas situações vemos a 
importância da atuação do Estado, pois enquanto o poder público não assumir e atuar na gestão dos espaços públicos, continuará sendo mais fácil cercar os conjuntos e deixar a gestão nas mãos dos moradores. Por outro lado, as intervenções seguirão favorecendo a um grupo específico de moradores sem oferecer nada, ou oferecendo muito pouco aos vizinhos e ao bairro.

Nesse projeto foi possível observar algumas estratégias de construção muito válidas quanto ao aproveitamento do terreno, como a construção de um maior número de pavimentos utilizando-se como acesso principal o andar intermediário do edifício - estratégia já utilizada em um dos maiores ícones da produção de habitação social no Brasil: o Pedregulho.

A partir da análise do projeto, foi possível identificar também a preocupação com a privacidade das unidades do térreo. Ao elevar os edifícios, o projeto conseguiu criar filtros de privacidade à esses apartamentos através do desnível, da passarelas e até mesmo das varandas que protegem um pouco as janelas dos dormitórios.

A circulação também é um elemento muito importante para esse projeto. Os percursos criados e também os interrompidos proporcionaram diferentes situações de privacidade e relações entre moradores dentro dos conjuntos. As áreas de lazer foram implantadas no centro dos condomínios, cercadas pelos edifícios, o que garante maior sensação de segurança com relação a esses espaços que estão constantemente sendo vigiados pelos olhares dos moradores a partir das janelas e das próprias passarelas.

Por último, vale ainda ressaltar a importância das varandas - os espaços exteriores próprios das unidades espaços que agregaram qualidade aos apartamentos e que são muito valorizados pelos moradores.

O Conjunto Habitacional Real Parque é mais um exemplo de atuação e revitalização de favelas na cidade de São Paulo que ficará como contribuição devido aos conceitos utilizados em sua concepção. É mais um exemplo de intervenção que permitiu a fixação dos moradores no local a partir da oferta de moradias com qualidade. 

5. RELAÇÕES REFLEXÕES E CONCLUSÕES 



\subsection{RELAÇÕES}

A análise dos quatro projetos proporcionou um conhecimento detalhado sobre eles e também realçou muitos conceitos presentes em cada um. Conceitos que agregaram qualidade aos projetos, mas também algumas soluções projetuais que, como pudemos observar, não foram bem sucedidas.

O conhecimento dos conceitos aplicados nesses projetos nos permitiu formar um repertório de soluções que, como anseia essa dissertação de mestrado, tem a intenção de colaborar com a "cultura de projeto"1 de habitação de interesse social e para isso, durante o desenvolvimento do trabalho, buscou-se apresentar as possibilidades de soluções projetuais contidas nos projetos.

Entretanto, para desenvolver as análises, foi necessário definir critérios comuns a partir dos quais os projetos foram observados. A definição desses critérios baseou-se na organização a partir de três escalas principais: o Conjunto; o Edifício; e a Unidade. Como foi exposto no capítulo de metodologia para a análise de projetos, esses critérios foram definidos tomando, como referência, outros trabalhos, entre eles, o Instrumentos de Avaliação de Projetos (2012b).

\section{Referências}

Lizete Rubano (2001, p. 113) destaca a importância da permanência das referências para o desenvolvimento de projetos com maior qualidade. Ao desenvolver a reflexão "pensando acerca da cultura de projeto no Brasil",

1 O termo "cultura de projeto" é utilizado pela arquiteta Lizete Rubano em sua tese de doutorado: RUBANO, Lizete Maria. Cultura de Projeto: Um estudo das ideias e propostas para habitação coletiva. 2001. Volume 1: As Ideias, 265f. Volume 2: Caderno de Projetos, 120f. Tese (Doutorado em arquitetura) - Faculdade de Arquitetura e Urbanismo, Universidade de São Paulo, São Paulo, 2001. 
referindo-se aos grandes exemplos de conjuntos habitacionais dos anos 40 e 50 e também aos promovidos pelos Institutos de Aposentadoria e Pensões (IAPs), comenta que

[...] muito pouco permaneceu como continuidade de um pensamento projetual, ora por 'abandono' do projeto voltado à qualidade de vida urbana e ao homem (BNH - COHAB), ora pelas condições tão diversas - e adversas - do Brasil contemporâneo, muito distantes das perspectivas democráticas imaginadas e desejadas pelos arquitetos nos anos 40 e 50! (RUBANO, 2001, p. 113)

A arquiteta relaciona algumas questões quanto à permanência ou continuidade do pensamento projetual:

[...] mas, se as condições mudaram tão significativamente como poderiam perdurar temas e resoluções de projeto de períodos anteriores? Ou ainda, se a própria resolução de espaços habitacionais muito se transformou a partir da crítica década de 60 , por que no Brasil haveríamos de continuar repetindo, ou reproduzindo, as megaestruturas, como as de Pedregulho, da Gávea, da Vila Isabel; ou as unidades de vizinhança dos IAPs, do projeto da Mannesman; ou, ainda, a cidade fragmentada e funcional da Carta de Atenas, como o que se dá com as superquadras de Brasília ou com o Conjunto Zezinho Magalhães Prado? (RUBANO, 2001, p. 113)

Por fim, RUBANO explica que a intenção não é a repetição e sim a permanência de referências:

A questão que se pretende colocar não é a da repetição e sim da permanência de referências, de um acúmulo de formulações e proposições dadas no tempo e que, constituindo o que se está chamando de cultura de projeto, dariam densidade e suporte às novas proposições, pela retomada, reinvenção e/ou adaptação de soluções estéticas funcionais, de arranjo urbano, construtivas, simbólicas já experimentadas e propostas no tempo. (RUBANO, 2001, p. 113)

Lizete Rubano conclui sua reflexão defendendo que "tais proposições poderiam dar suporte e densidade (entendida como atribuição de valor) às intervenções contemporâneas, além de manter constante a responsabilidade da temática da habitação social como item fundamental na constituição das cidades". 
O desenvolvimento do raciocínio da arquiteta, é muito válido e necessário. Para que ocorra uma evolução das soluções projetuais é preciso conhecer as referências anteriores, analisá-las, para então poder apropriar-se, realizando alterações e adaptações às novas condições, sem deixar para trás os avanços já realizados e os conceitos aprendidos.

O trabalho de Lizete Rubano tinha como foco a produção realizada no início dos anos 90 (1989 - 1992). Segundo Nabil Bonduki, sobre esse período, pode-se dizer que vinha se desenvolvendo no país "uma nova postura para enfrentar a questão urbana":

Essa nova postura, baseada, entre outras características, na descentralização, na participação popular, parceria com organizações não governamentais (ONGs), respeito ao meio ambiente e busca do direito à cidade, representa um novo caminho - ainda a ser mais bem formulado - que poderá significar a construção de cidades menos desiguais e mais humanas (BONDUKI, 2000b, p. 17 e 18).

De fato esse período foi muito importante para a produção de habitação de interesse social. Durante o mandato de Luiza Erundina, muitas atitudes foram tomadas com respeito a essa produção: o $1^{\circ}$ Concurso Nacional de Projetos de Habitação Popular proporcionou a retomada das discussões sobre projetos e propostas; o Programa de Produção de Habitação por Mutirão e Autogestão foi implantado pela prefeitura; importantes projetos foram desenvolvidos durante esse período, como: Conjunto Paranapiacaba (arquiteto Décio Tozzi); Conjunto Rincão e Rio das Pedras (arquitetos Hector Vigliecca e Bruno Padovano); Conjunto Minas Gás (arquiteto Ubyrajara Gilioli); e Conjunto Heliópolis I (arquitetos Angelo Cecco Jr. e Luís Espalhargas).

$\mathrm{Na}$ gestão seguinte, todo o avanço representado pela retomada das discussões e pelo desenvolvimento de programas para a produção por mutirões foi paralisado. Durante os mandatos de Paulo Maluf (1993 - 1996) e Celso Pitta (1997 - 2000) a produção de habitação social da cidade de São Paulo foi marcada pelo Programa 
Cingapura, caraterizado pela implantação repetitiva do mesmo modelo de edifício habitacional sem considerar as preexistências ou a relação com a cidade.

Posteriormente a esse "período de escuridão", nas palavras de Hector Vigliecca², inicia-se o período estudado por essa dissertação de mestrado. Contudo, identificou-se, durante o desenvolvimento do capítulo produção contemporânea, que a ênfase dada pelo mandato de Marta Suplicy (2001 - 2004) estava relacionada aos programas de Reabilitação do Centro da Cidade, pelos quais foram viabilizados:

- Reciclagem de edifícios em área central: Edifícios Fernão Sales e Rizkallah Jorge (arquiteta Helena Saia); Edifício Senador Feijó (Barbosa \& Corbucci Arquitetos Associados); Edifício Riachuelo (Paulo Bruna Arquitetos Associados), entre outros.

- Programa de locação social: Conjunto Olarias (Fábrica Urbana); Conjunto Parque do Gato (Teresa Herling + Peabiru); Conjunto Vila dos Idosos (Vigliecca \& Associados).

- Reabilitação de cortiços: Casarão Celso Garcia (Claudio Manetti); Edifício Pedro Fachini (Barbosa \& Corbucci Arquitetos Associados); Casarão do Carmo (Vigliecca \& Associados); Edifício Imoroti (Peabiru); etc.

- Retomada do programa dos mutirões autogeridos: Conjunto Paulo Freire (USINA), entre outros.

Quanto ao Plano de Ação em favelas, foi implantado o Programa Bairro Legal que focava a realização de obras de urbanização; regularização urbanística e fundiária; reassentamento para eliminação de risco e a recuperação e preservação socioambiental. Contudo, não foi possível identificar, dentro dos primeiros quatro anos estudados, uma produção significativa de conjuntos habitacionais, foco desse trabalho.

Nas duas gestões seguintes (2005 - 2012) - tendo como prefeitos José Serra, inicialmente, e Gilberto Kassab como vice da primeira gestão e reeleito prefeito na segunda - identificou-se o Programa de Urbanização de Favelas e a construção de conjuntos habitacionais como "carro chefe" das intervenções realizadas no âmbito da habitação.

2 VIGLIECCA, Hector; SHIMIZU, Neli. Entrevista: Residencial Parque Novo Santo Amaro V. São Paulo, 23 de janeiro de 2014. 
Durante esse período, é possível identificar maior dedicação à produção de conjuntos de habitação de interesse social por parte do poder público e a inclusão de arquitetos no desenvolvimento dos projetos, incentivando maior variedade de atuações e proporcionando a retomada das discussões quanto a esse campo de atuação da arquitetura, como vimos no capítulo produção contemporânea.

Como foi explicado no capítulo metodologia para análise de projetos, entre toda a produção contemporânea de conjuntos habitacionais, foram selecionados quatro projetos para serem analisados com maior detalhe. Ao desenvolver essas análises, o objetivo esperado é poder identificar conceitos que possam ser incorporados ou comparados às referências projetuais citadas por Lizete Rubano.

\section{Considerações sobre os conjuntos não analisados}

Durante a etapa de pesquisa de campo - que coincidiu com o desenvolvimento do trabalho Instrumentos de Avaliação de Projetos - muitos conjuntos de habitação de interesse social foram visitados. Contudo, não seria possível, nessa dissertação de mestrado, realizar a análise detalhada de todos.

Propõe-se, portanto, durante o desenvolvimento desse último capítulo, estabelecer comparações e relações entre os projetos analisados e esses outros que foram visitados e que também fazem parte do repertório de projetos contemporâneos de conjuntos de habitação social promovidos pela Secretaria Municipal de Habitação (Sehab).

Nas páginas a seguir, será possível conhecer brevemente cada um dos vinte e três projetos selecionados como referências complementares desse trabalho. 

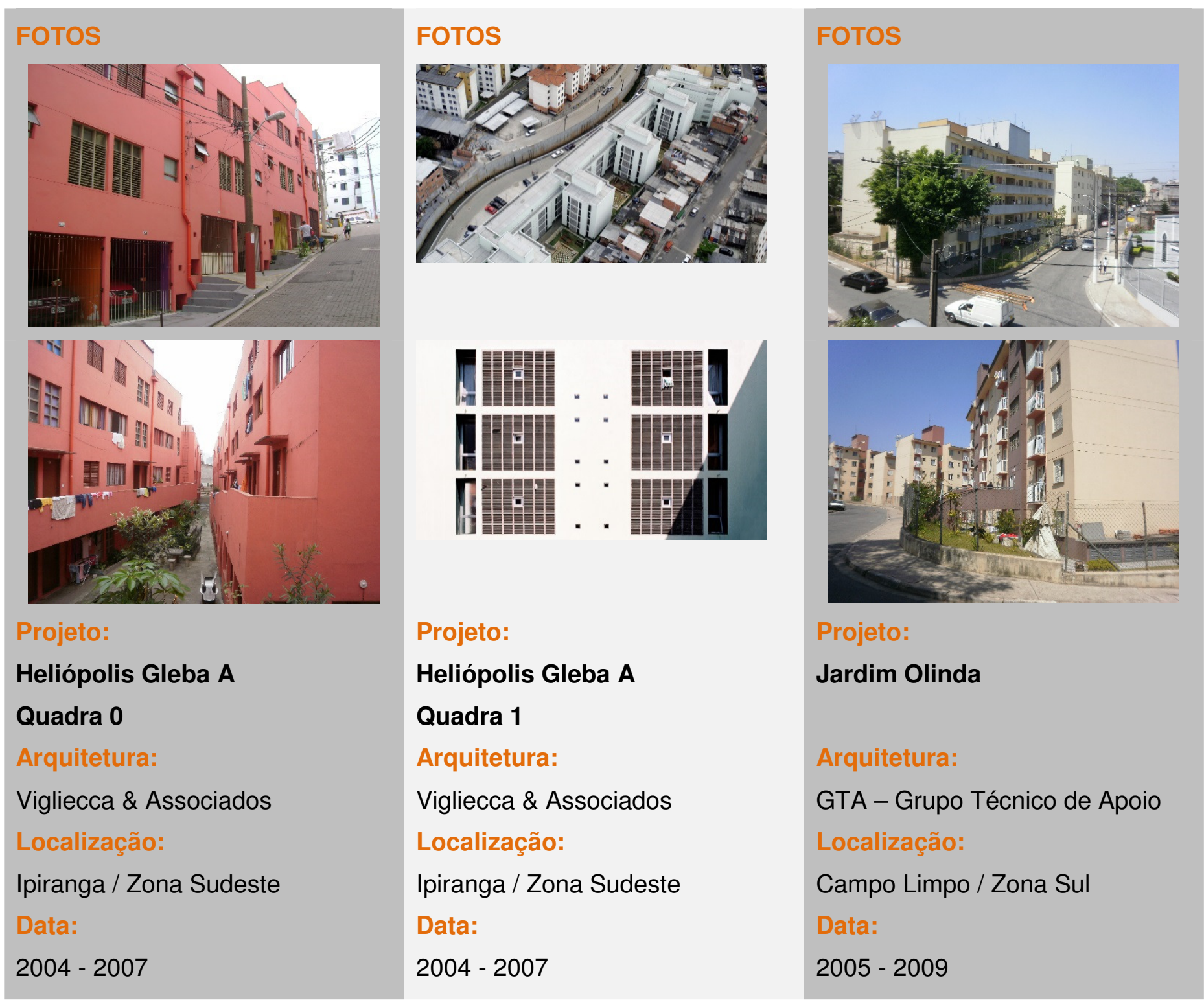

FOTOS
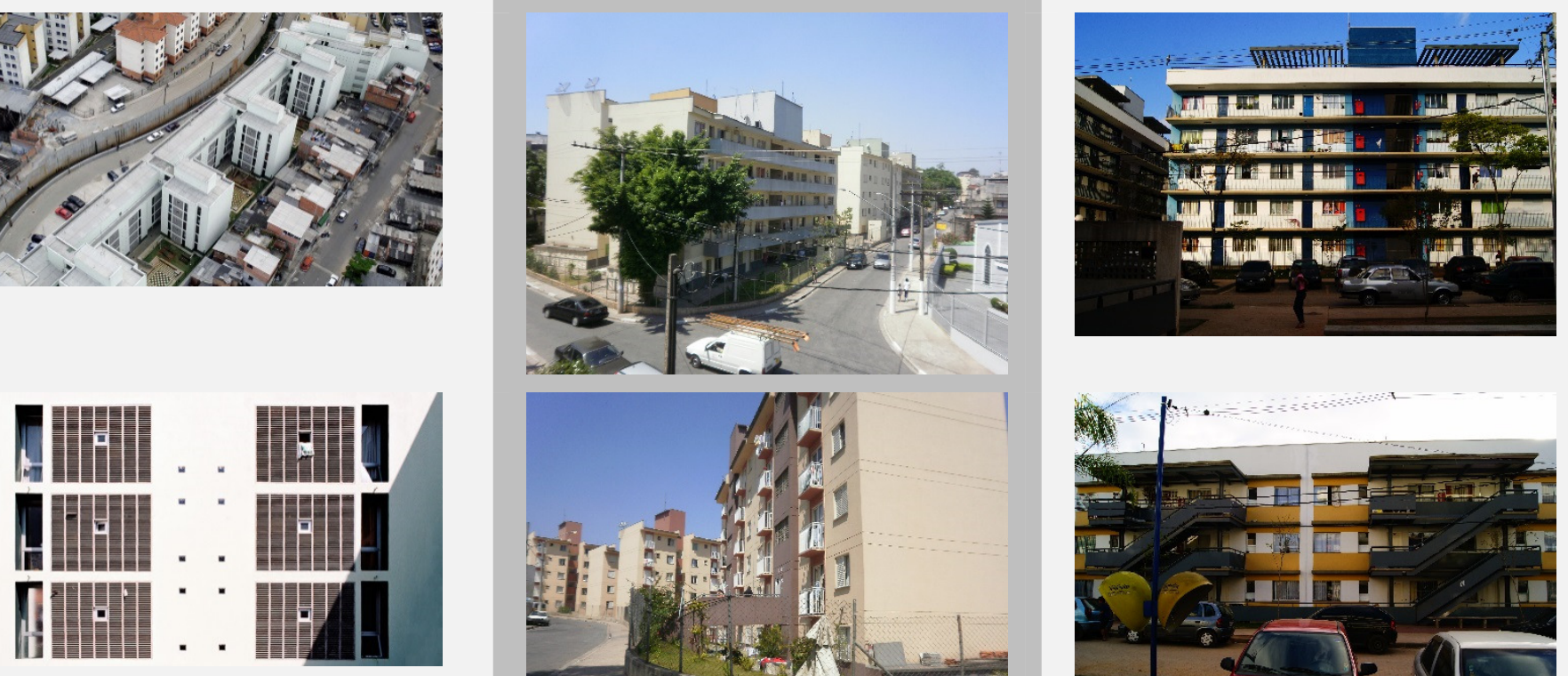

Projeto:

Heliópolis Gleba A

\section{Quadra 1}

Arquitetura:

Vigliecca \& Associados

Localização:

Ipiranga / Zona Sudeste

Data:

$2004-2007$

Projeto:

Jardim Olinda

Arquitetura:

GTA - Grupo Técnico de Apoio

Localização:

Campo Limpo / Zona Sul Data:

$2005-2009$

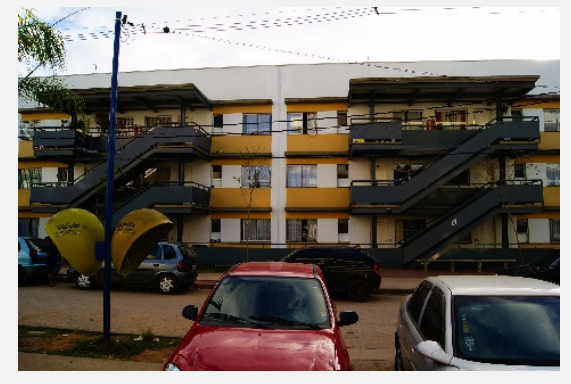

Projeto:

\section{Alexandre Mackenzie}

Arquitetura:

Boldarini Arquitetura e Urbanismo Localização:

Jaguaré / Zona Oeste Data:

$2008-2009$ 

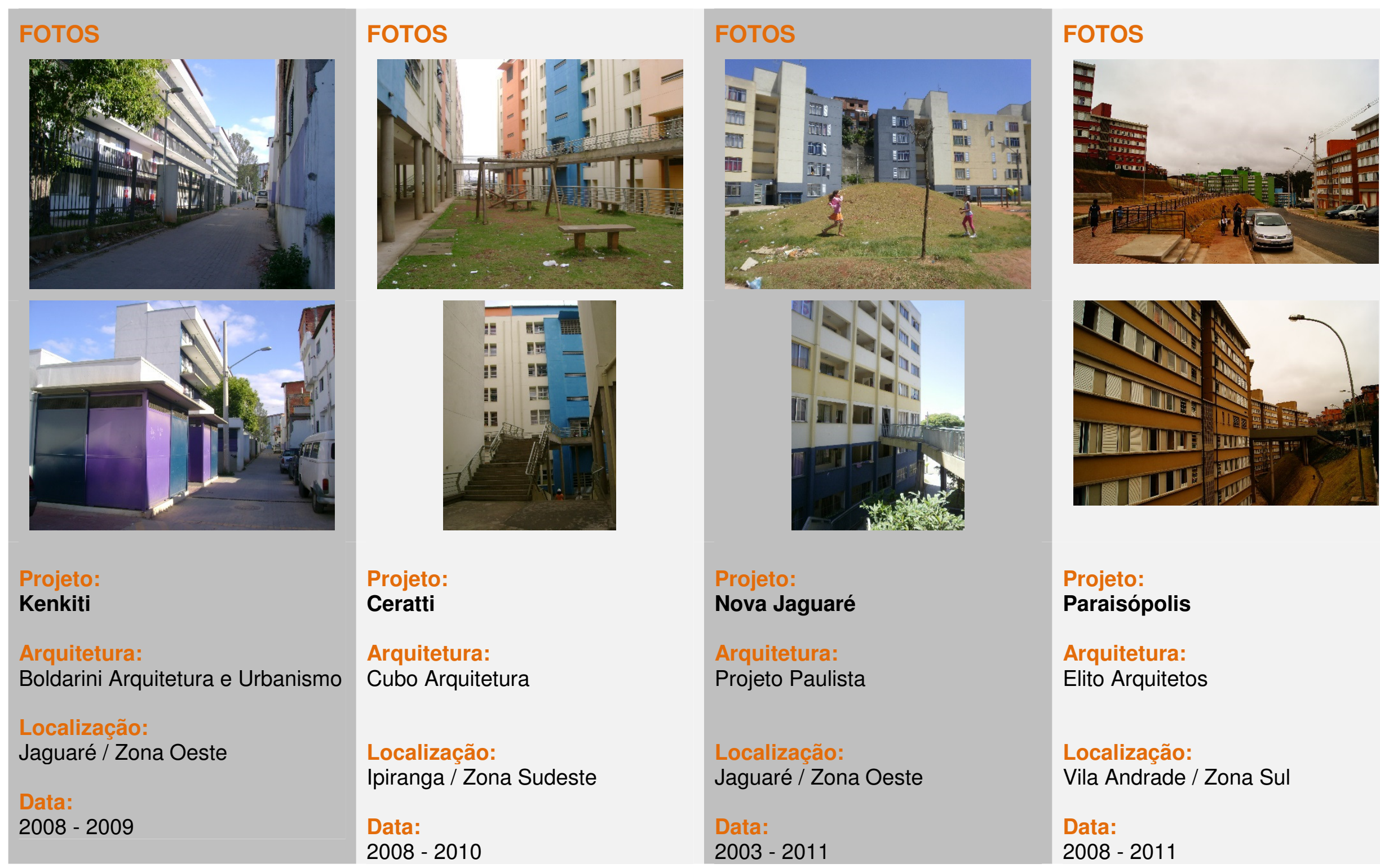

Projeto:
Ceratti

Arquitetura:

Cubo Arquitetura

Localização:

Ipiranga / Zona Sudeste

Data:

$2008-2010$

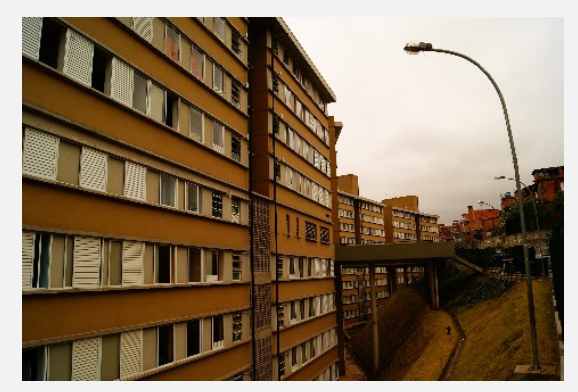

Projeto:

Paraisópolis

Arquitetura:

Elito Arquitetos

Localização:

Vila Andrade / Zona Sul

Data:

$2008-2011$ 


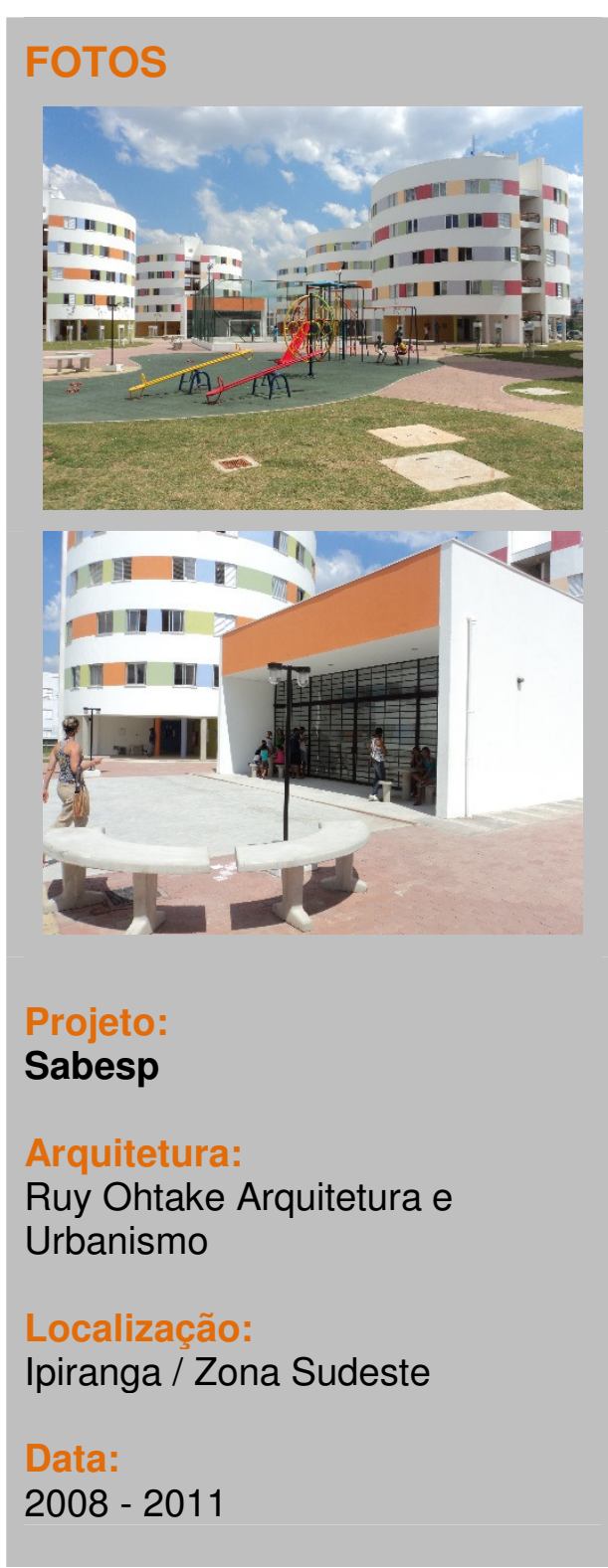

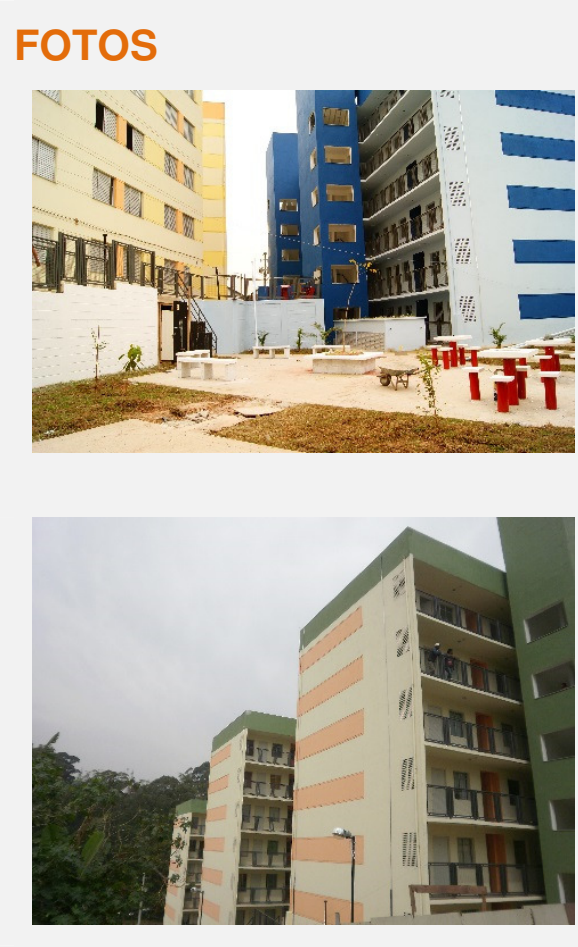

Projeto:

Jardim Celeste

Arquitetura:

Arquitetos Urbanistas

Localização:

Jabaquara / Zona Sudeste

Data:

$2008-2011$
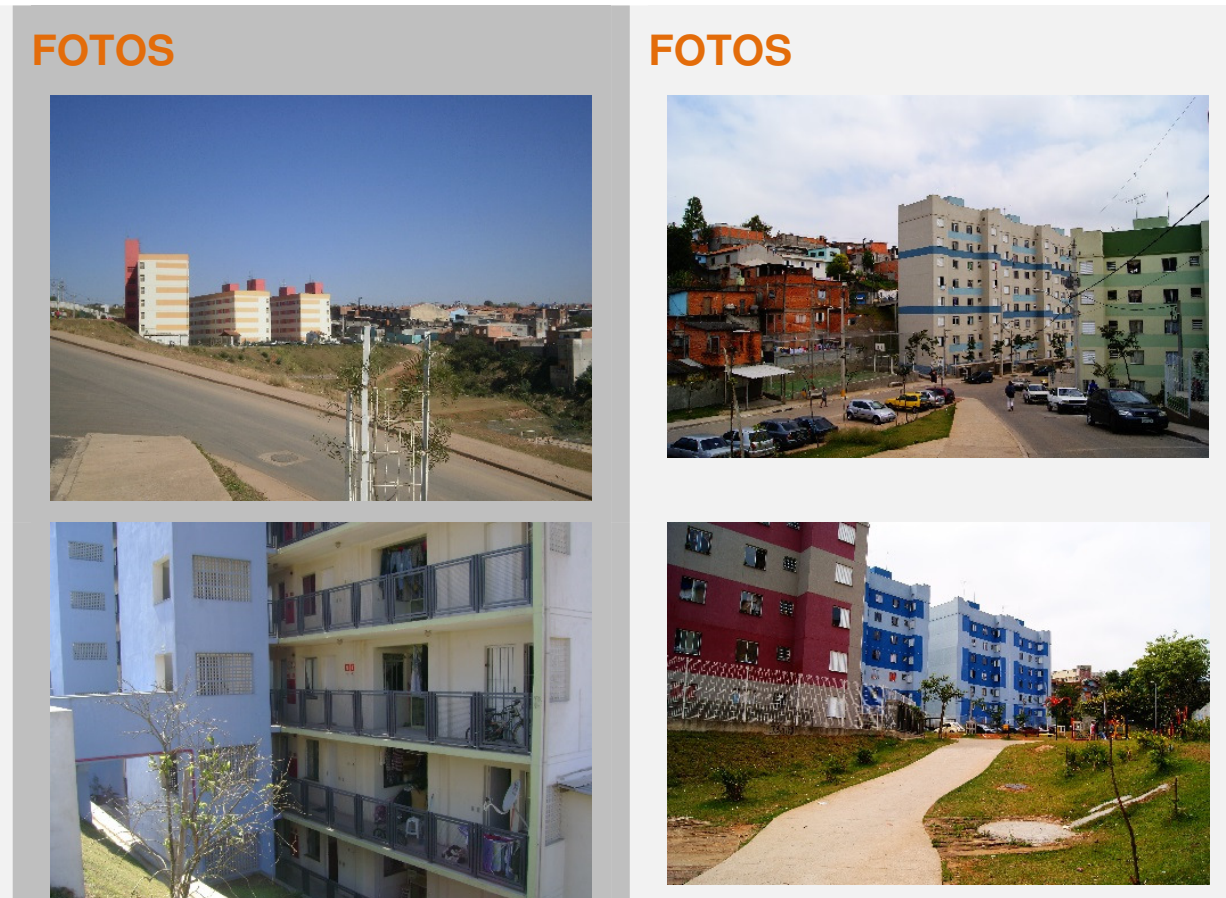

Projeto:

Jardim das Rosas; Jardim Irene I; Parque Fernanda II

Arquitetura:

Arquitetos Urbanistas

Localização:

São Mateus / Zona Leste

Data:

$2008-2011$
Arquitetura:

GTA - Grupo Técnico de Apoio

Localização:

Campo Limpo / Zona Sul

Data:

$2009-2011$ 

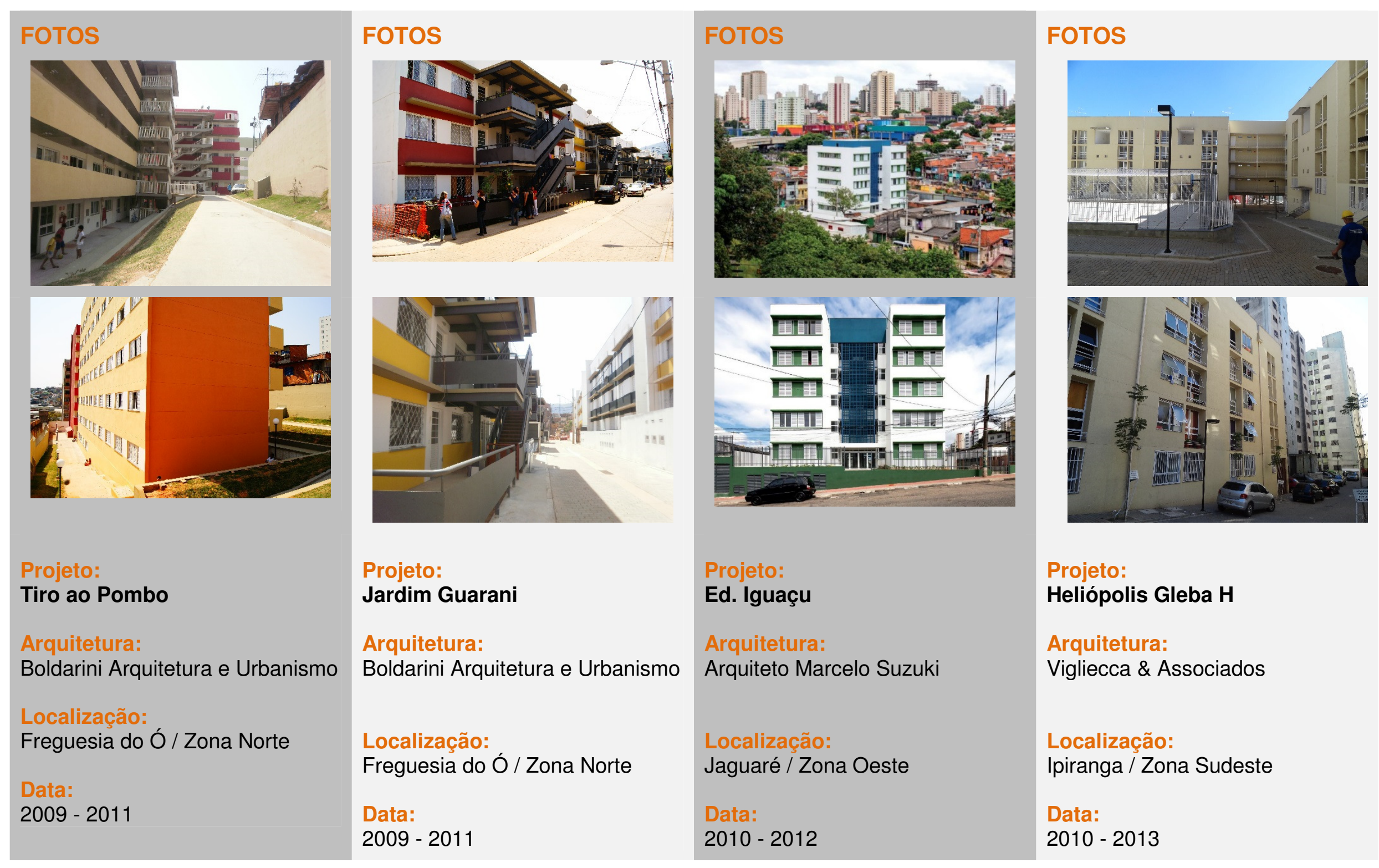

Projeto:

Heliópolis Gleba H

Arquitetura:

Vigliecca \& Associados

Localização:

Ipiranga / Zona Sudeste

Data:

$2010-2013$ 


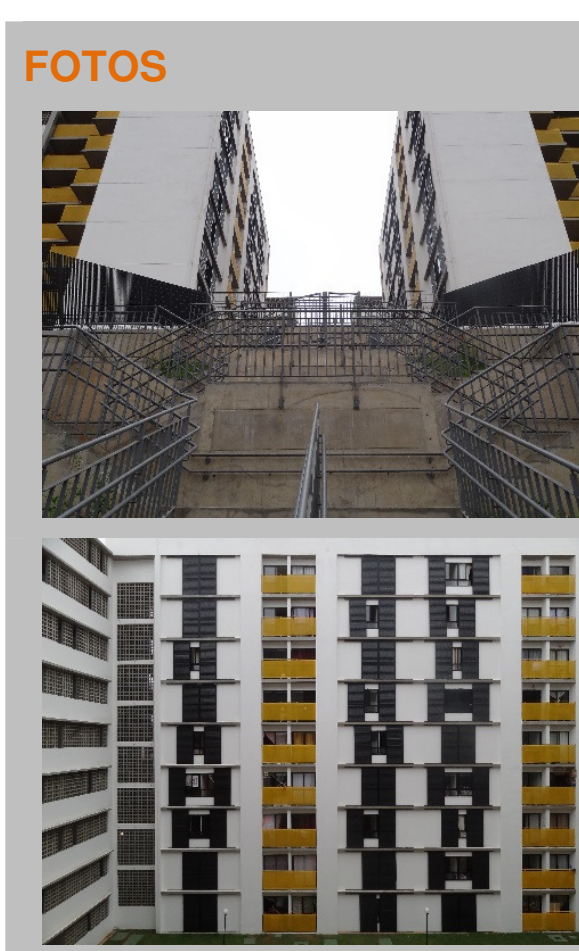

Projeto:

Corruíras

Arquitetura:

Boldarini Arquitetura e Urbanismo Localização:

Jabaquara / Zona Sudeste

Data:

$2010-2013$

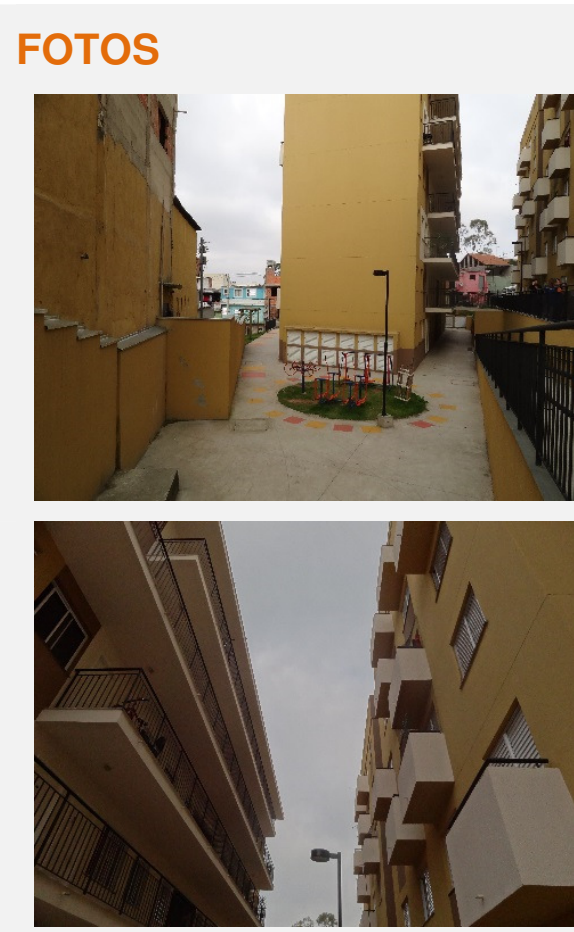

Projeto:

\section{Rocinha}

Arquitetura:

Arquitetos Urbanistas

Localização: Ipiranga / Zona Sudeste

Data:

2013

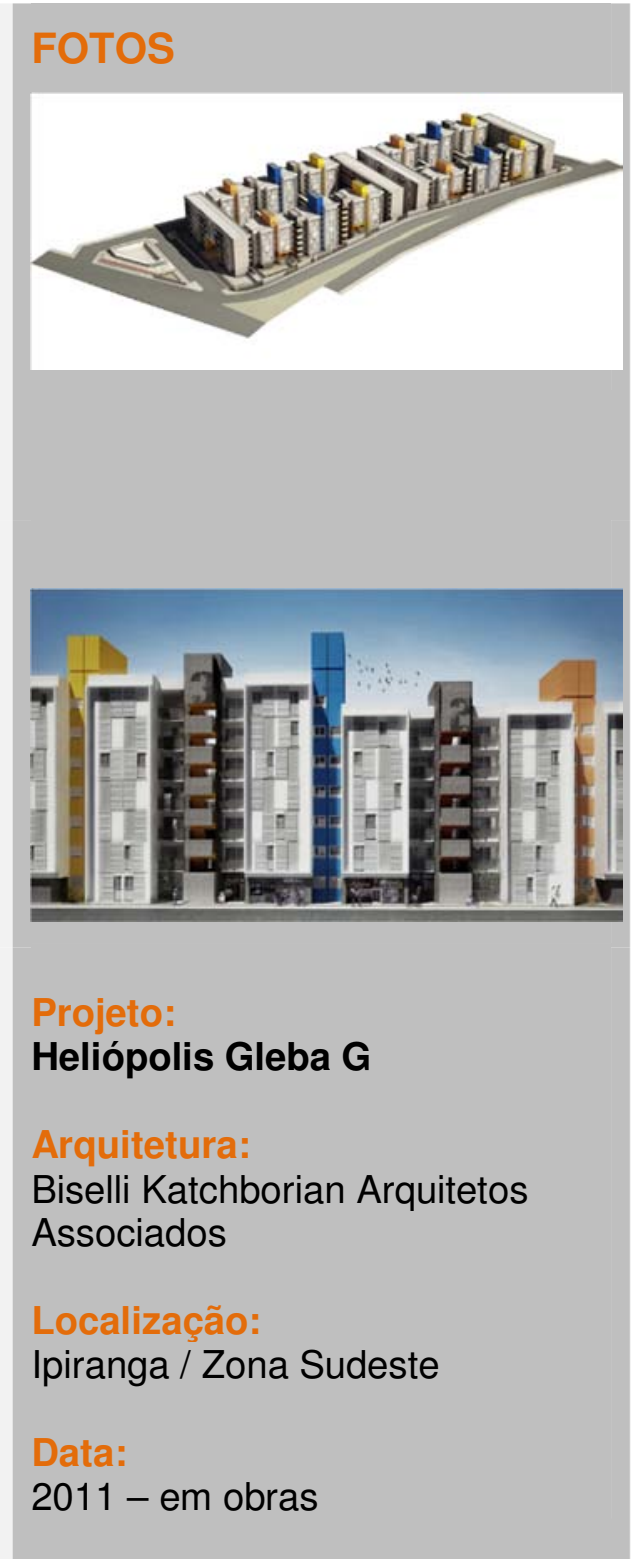

FOTOS

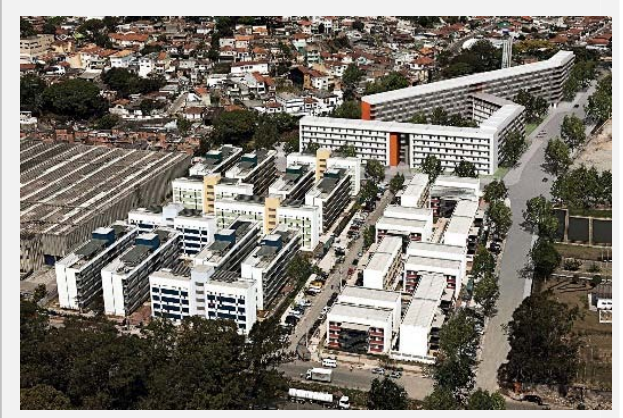

Projeto:

Diogo Pires

Arquitetura:

Boldarini Arquitetura e Urbanismo

Localização:

Jaguaré / Zona Oeste

Data:

2011 - em obras 


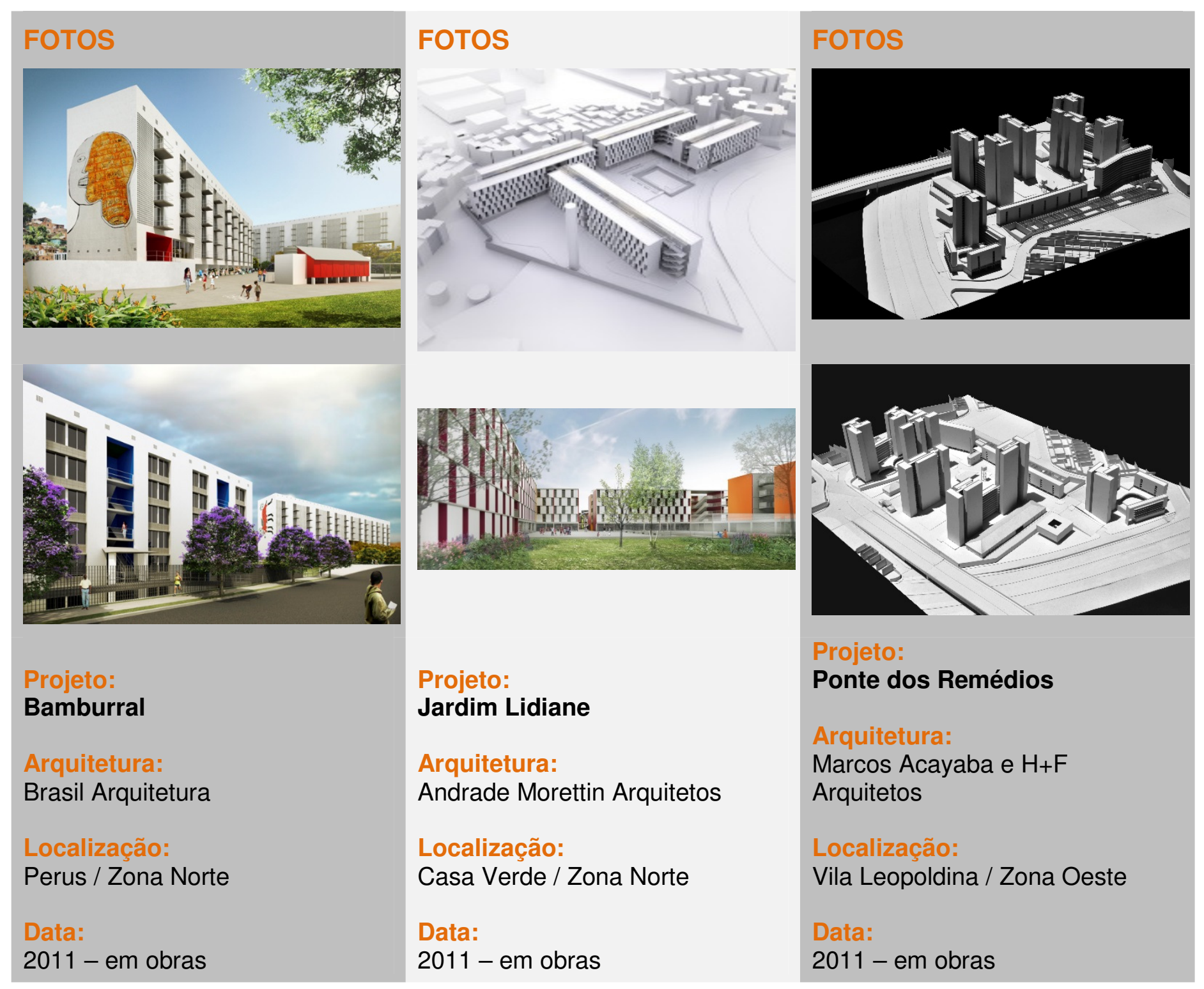




\section{ESCALA CONJUNTO}

Valores de

proximidade
No início da arquitetura do movimento moderno, as propostas de habitação coletiva estavam projetadas em uma estreita relação com a morfologia urbana. Essa relação tende a perder-se quando se prioriza - a partir da promoção e da gestão - que o edifício de habitação seja um objeto isolado.

Por tanto, o problema da habitação apenas é solucionável em estreita relação com uma política urbana que configure as infraestruturas necessárias para viver, trabalhar e mover-se com dignidade; com uma gestão da urbanização (usos e parcelamentos) que permita a variedade funcional e urbana (MONTANER; MUXí, 2006, p.34) $)^{3}$

Na citação acima, Josep Maria Montaner, Zaida Muxí e a equipe envolvida na produção do catálogo Habitar el Presente, ressaltam a importância da mescla de usos no tecido urbano, o que chamam de infraestruturas necessárias para levar uma vida digna.

De acordo com os autores, "os valores que devem ser levados em consideração prioritariamente são os de proximidade: ao transporte público, às compras cotidianas, à educação, ao trabalho, à saúde, ao lazer e ao esporte, e às bibliotecas de bairro". Para eles, "a proximidade aos equipamentos básicos e à diversidade funcional são valores essenciais dos quais as habitações devem disfrutar e que elas mesmas devem enriquecer". 
Os valores de proximidade foram observados durante as análises realizadas tomando-se como referência os raios de 600 e 1.000 metros ao redor dos conjuntos habitacionais em estudo. Com isso, foi possível identificar a oferta de transporte, equipamentos, comércios e serviços existentes no entorno ${ }^{4}$.

No caso do Jardim Edite, por exemplo, identificou-se que não havia postos de saúde nas proximidades. Em contato com a administração da Unidade Básica de Saúde (UBS) incorporada ao projeto ${ }^{5}$, verificou-se que a Secretaria de Saúde já havia identificado essa debilidade na região e, após a implantação da UBS Jardim Edite, muitos moradores foram beneficiados. Segundo a administração, a demanda atendida corresponde a aproximadamente $75 \%$ de moradores do conjunto, $15 \%$ de pessoas que trabalham na região e, pelo menos $10 \%$ de moradores do entorno. Como citado em Habitar el Presente, a oferta desse equipamento proporcionou "enriquecimento" à região.

Quanto ao projeto Real Parque, a análise dos valores de proximidade permitiu identificar a existência de um comércio local dentro da favela que não poderia ser substituído pelo comércio existente no entorno do projeto, uma vez que se caracterizam como grandes centros comerciais. Além disso, o bairro em que esse projeto está inserido apresenta caráter residencial de alto padrão. Com base nessas informações, os arquitetos puderam identificar a necessidade de inserir lojas comerciais no projeto, para manter o comércio local existente anteriormente à

${ }^{4}$ Segundo as estratégias urbanísticas, a distância de 1.000 metros equivale a 15 minutos de caminhada em terrenos praticamente planos (máximo de $8 \%$ de inclinação) (PREFEITURA DE SÃO PAULO, 2012b, p.64). Além disso, recomenda-se que a distância máxima entre os pontos de ônibus seja de 600 metros, considerando um raio de 150 metros para terrenos íngremes e 300 metros como regra geral (PREFEITURA DE SÃO PAULO, 2012b, p.100). Para as análises desenvolvidas, além do raio de 1.000 metros, foi considerado também um raio de 600 metros que dá a referência de um entorno mais próximo e da distância considerada ideal para os pontos de parada do transporte público.

${ }^{5}$ Visita realizada à UBS Jardim Edite em 06 de janeiro de 2014. Com autorização da assessoria de imprensa da UBS foi possível conhecer todas as dependências do equipamentos e conversar com a administração local. 
intervenção. Situações semelhantes também podem ser observadas nos projetos de Paraisópolis (Figura 1) e Heliópolis Gleba H (Figura 2).

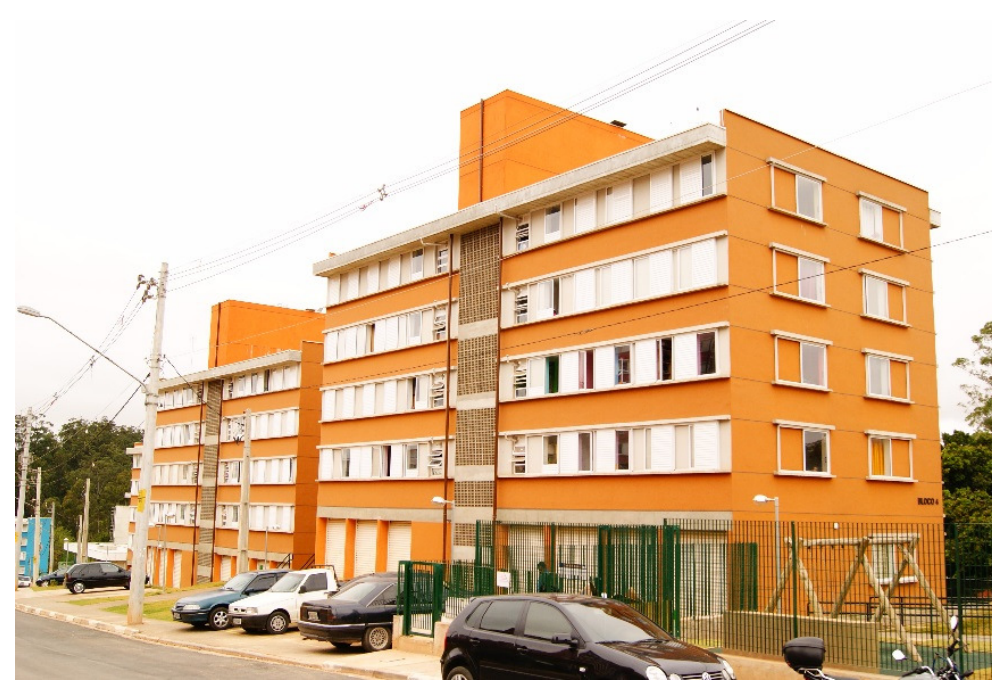

Figura 1 - Lojas comerciais no térreo dos edifícios de Paraisópolis. Projeto: Elito Arquitetos.

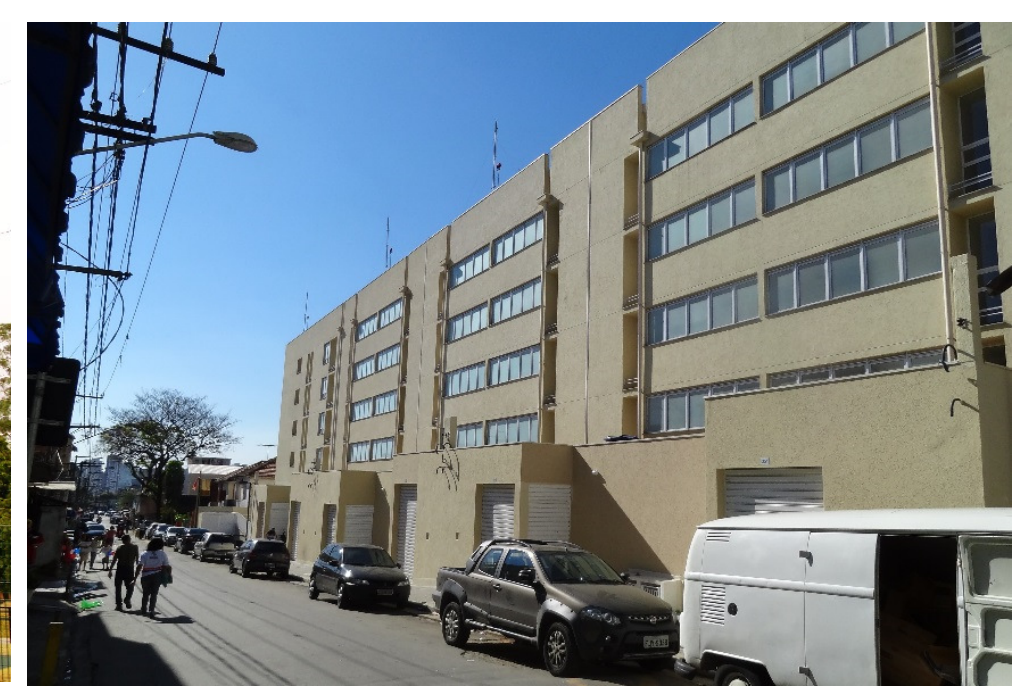

Figura 2 - Blocos de lojas comerciais à frente dos edifícios do Conjunto Heliópolis Gleba H. Projeto: Vigliecca \& Associados.

\section{Programa}

A análise dos valores de proximidade colabora para a definição do programa dos conjuntos habitacionais, pois se entende que, ao identificar as deficiências do entorno, é possível propor a incorporação de outros usos aos projetos de habitação, que complementariam a oferta existente e supririam as necessidades identificadas.

A diversidade comercial nos bairros e a incorporação de lojas comerciais aos edifícios é um tema defendido por muitos autores (MONTANER; MUXÍ; BOFFIL; CAMPOS FILHO; LEITE; SANTOS; MELHADO et al, etc.) com relação à formação de uma cidade mais sustentável e, portanto, não poderia deixar de ser aplicado aos conjuntos de habitação social. 
Candido Malta Campos Filho (2003, p. 17) atrela a oferta de comércio e serviços à mobilidade urbana e divide essa oferta em três níveis:

- o comércio e serviço de apoio imediato à moradia, classificado como "local" - de frequência diária - como açougue; quitanda; bar ou boteco; pequeno mercado; etc.

- o comércio e serviço ainda de apoio à moradia, mas de menor frequência, como supermercados; lojas de roupas e sapatos; lojas de eletrodomésticos; etc.

- o comércio de apoio a outras atividades urbanas, com frequência muito menor e esporádica, como relojoarias; artigos de cama, mesa e banho; lojas de automóveis; etc.

Dentro desses três níveis, CAMPOS FILHO identifica a necessidade de que o comércio "local" esteja o mais próximo possível das residências: "para o morador interessa que, quanto maior a frequência da demanda, mais fácil deve ser o acesso a esse comércio ou serviço" e, gradativamente, os outros níveis podem estar mais afastados (CAMPOS FILHO, 2003, p. 18).

Ana Rocha Melhado esclarece que "a coesão social e a diversidade econômica são elementos essenciais de um bairro sustentável, uma vez que se torna possível a criação de empregos, reduzindo consequentemente o deslocamento." Entre as diretrizes recomendadas pela autora, pode-se citar:

Proporcionar uso misto, incluindo espaços que favoreçam o convívio social; adaptar a oferta de negócios no bairro, em função da necessidade do local; proporcionar uma diversidade de tipologias e comércio; oferecer serviços e equipamentos a todas as gerações; promover diversão no bairro, por meio da atividades culturais e de lazer; evitar a segregação espacial, a partir da diversidade social e da qualificação dos espaços urbanos. (MELHADO, et al. 2013, p. 222 e 223) 
Quanto à diversidade comercial, a autora deixa claro que "assegurar a manutenção do comércio local e ainda por cima valorizar a sua diversidade é a ação-chave desta diretriz. Uma solução comum na França é a instalação de áreas de comércio e serviços no pavimento térreo dos edifícios, tais como cafeterias, livrarias, floriculturas, etc." (MELHADO, et al. 2013, p. 223).

Tratando-se dos edifícios de habitação social estudados nesse trabalho, provavelmente livrarias e floriculturas não estariam na lista de comércios mais necessários para o dia-a-dia, porém, poderiam ser considerados usos comerciais como padarias; minimercados; papelarias; bancas de jornal; açougues; etc. no térreo dos edifícios.

Com relação à diversidade de programas, merecem destaque os projetos que consideraram a implantação de equipamentos públicos ou comércio, incentivando o movimento de pessoas e proporcionando espaços de qualidade para o bairro. Entre os vinte e sete projetos de conjuntos habitacionais citados nesse trabalho, treze possuem um programa mais amplo, indo além da oferta única de unidades habitacionais. Os projetos que oferecem, como parte do programa, equipamentos e/ou lojas comerciais são: Nova Jaguaré (telecentro + equipamentos de lazer); Paraisópolis (comércio); Comandante Taylor (Centro de Comunitário + Centro para Idoso); Jardim Edite (UBS + restaurante-escola + creche); Real Parque (comércio + creche + áreas livre de lazer); Heliópolis Gleba H (comércio); Parque Novo Santo Amaro V (comércio + Centro Comunitário + Áreas de Lazer); Heliópolis Gleba G (comércio); Diogo Pires (comércio); Kenkiti (comércio); Bamburral (comércio); Jardim Lidiane (comércio) e Ponte dos Remédios (comércio + UBS + creche + telecentro). ${ }^{6}$

Eduardo Ferroni ( $\mathrm{H}+\mathrm{F}$ Arquitetos), autor dos projetos Jardim Edite e Ponte dos Remédios, ao falar sobre a oferta de comércio e equipamentos no projeto Ponte dos Remédios, comentou que

${ }^{6}$ Os projetos: Heliópolis gleba G; Diogo Pires; Bamburral; Jardim Lidiane e Ponte dos Remédios ainda não foram finalizados. As informações quanto aos usos proposto foram retiradas dos projetos. Portanto, não se pode afirmar que esses usos serão construídos. Será necessário verificar após a finalização das obras. São citados aqui apenas como exemplo da tentativa dos escritórios de arquitetura em propor uso misto junto aos conjuntos habitacionais. 
[...] por ser um local que possui o entorno isolado (não tem comércio, padaria, entre outros estabelecimentos), eles [os arquitetos] tiveram que buscar incorporar ao projeto o máximo de instalações urbanas que fosse possível, para, novamente, evitar que o local virasse um bolsão residencial.

"Brigar por esse tipo de coisa é o que leva mais tempo, e não a criação do projeto em si", falou Ferroni, expondo as dificuldades que eram impostas ao plano de tornar a área o mais urbana possível, com bastante uso comercial. Apesar disso, no fim das contas eles conseguiram incorporar ao projeto uma unidade básica de saúde, duas creches, um clube-escola, um telecentro, uma padaria escola e um lugar que poderá ser uma lanchonete ou um bar. (AMORIN, 2013, disponível em: http://www.usp.br/aun/exibir.php?id=5200).

A dificuldade em conseguir o aval da Secretaria de Habitação para a implantação desses outros usos explica-se por dois motivos: primeiramente, a prefeitura ainda não possui instrumentos adequados para realizar a gestão das áreas comerciais e os equipamentos apenas funcionam bem quando alguma Secretaria ou entidade assume a gestão e manutenção; em segundo lugar, se pode citar as exigências do programa de financiamento para habitação de interesse social, o Minha Casa Minha Vida. De acordo com as normas desse programa, a Caixa Econômica Federal (CEF) não financia unidades comerciais e, portanto, caso esse uso seja incorporado ao projeto, sua execução deve ser financiada pela municipalidade, sem contar com o financiamento federal, o que nem sempre é possível.

Isso significa que, mais uma vez, a qualidade de vida dos moradores está atrelada à dificuldades de organização, gestão e financiamento. Entretanto, é importante continuar "lutando" para que esses usos possam ser incorporados aos projetos, pois são muito importantes para a manutenção da vida cotidiana e, conforme depoimento do arquiteto Hector Vigliecca, não aceitar o comércio é "ir contra a realidade". (informação verbal) ${ }^{7}$

${ }^{7}$ VIGLIECCA, Hector; SHIMIZU, Neli. Entrevista: Residencial Parque Novo Santo Amaro V. São Paulo, 23 de janeiro de 2014. 


\section{Definição do limite}

do conjunto

Como pôde ser observado durante as análises realizadas, há diversas formas de definir o limite da área de intervenção. Alguns projetos utilizam a própria edificação como elemento delimitador (Jardim Edite, Santo Amaro V, Heliópolis Gleba A - quadras 0 e 1). Dessa forma, evitam, ou ao menos diminuem o uso de gradis ou muros. Não é aceitável, porém, soluções que proporcionam espaços residuais entre os edifícios e os limites do conjunto.

De acordo com as Diretrizes de Projeto de Edificações, "o lote deverá ser cercado com gradil, acessado por portões exclusivos, com clara definição entre público e privado. Em caso de supressão de recuos lateral ou frontal - quando permitido -, o projeto poderá dispensar ou minimizar o uso de gradil, mantendo apenas o portão de acesso" (PREFEITURA DE SÃO PAULO, 2012b, p. 232).

Com base nas diretrizes, fica claro a necessidade de definição do limite da intervenção ou do conjunto, pois dessa forma, também fica definida a responsabilidade pela gestão e, uma vez cercados, a gestão e manutenção dos espaços internos ficam à cargo dos moradores e não da administração pública - representada pela Subprefeitura na esfera do bairro. Essa é, definitivamente, a solução mais "fácil" e que exige menos do poder público. Contudo, agindo dessa forma, deixamos de lado a construção dos "espaços coletivos" interpretados por SOLÀ -MORALES como os espaços da urbanidade contemporânea.

A urbanidade intensiva tem sempre a ver com a simultaneidade entre os domínios do privado e do público. Muitas vezes insisti nisso. A cidade, tradicionalmente, foi um mecanismo de adequação entre ambos, com vantagem oscilante entre uma e outra parte nos distintos tempos e lugares. Porém, se os espaços públicos são a imagem social da cidade e as casas privadas o privilégio do cidadão individual, onde aparece a urbanidade 
contemporânea em seu grau máximo é no que definimos como "espaços coletivos", espaços híbridos, ao mesmo tempo públicos e privados, onde a força do urbano como mecanismo mediador, no espacial das diferenças do social se faz concreta, material, conflitiva às vezes (SOLÀ-MORALES, 2003, p. 149) ${ }^{8}$.

O projeto Parque Novo Santo Amaro $\mathbf{V}$ é exemplo de implantação aberta, onde os espaços livres no interior do conjunto são "espaços coletivos" que podem ser utilizados por todos os moradores do bairro. Contudo, os conflitos são inevitáveis, principalmente com relação à manutenção e gestão dos espaços. Conclui-se, portanto, que a incorporação desses espaços coletivos às intervenções realizadas é muito importante para a qualidade dos espaços urbanos. Porém, só será verdadeiramente viável, quando o poder público assumir sua função com relação aos espaços coletivos, principalmente nas áreas de urbanização.

Outro exemplo semelhante, é o conjunto Nova Jaguaré. Nesse projeto os edifícios foram implantados ao longo da rua, configurando espaços coletivos entre eles (Figura 3). Os dois projetos citados têm como semelhança o fato de estarem inseridos dentro de favelas urbanizadas ou em processo de urbanização.

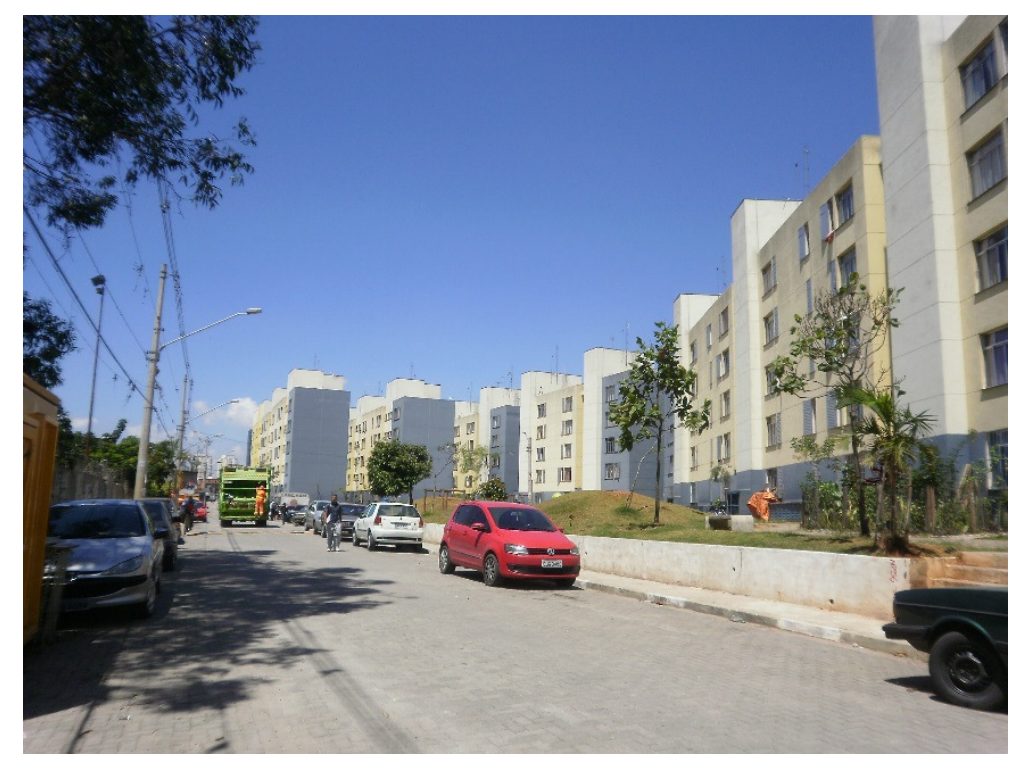

Figura 3 - Nova Jaguaré. Projeto: Escritório de arquitetura Projeto 
O projeto Jardim Guarani e parte do conjunto Alexandre Mackenzie (os edifícios mais baixos, de apenas três pavimentos, que apresentam mesma tipologia que o Jardim Guarani) também não são cercados. Os edifícios estão em contado direto com a rua e representam uma relação de maior proximidade e relação com a cidade, a partir do momento que não estão escondidos atrás de gradis (Figura 4).

Na foto ao lado é possível notar um alargamento da calçada que proporciona a possibilidade de uso desses espaços para a convivência entre vizinhos e para o descanso, tornando o limite do conjunto uma divisão física mais agradável.

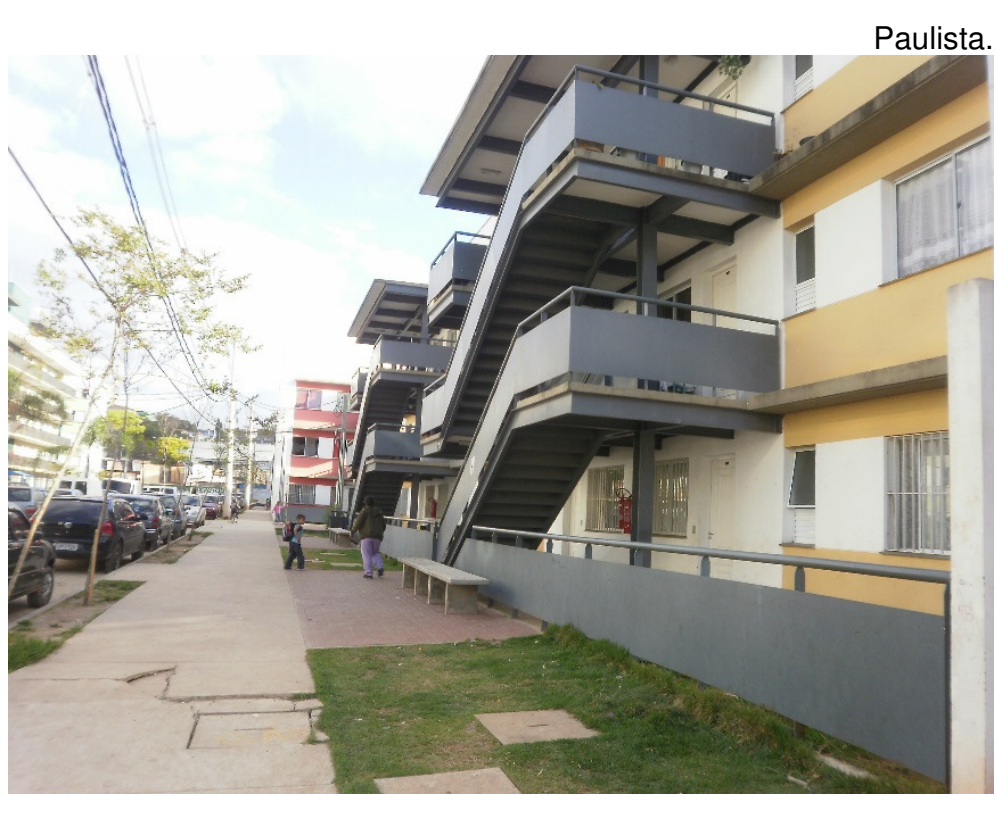

Figura 4 - Conjunto Alexandre Mackenzie. À direita edifícios de três pavimentos em contato direto com a rua. Projeto: Boldarini Arquitetura e Urbanismo.

Como exemplos de conjuntos cercados por gradis, que estabelecem má relação com os espaços coletivos, pode-se citar Jardim das Rosas, Jardim Irene I e Parque Fernanda II, onde a relação com os espaços exteriores é interrompida pela existência dos gradis. Nesses casos, a forma como os conjuntos foram cercados, cria espaços residuais que não se comunicam com os espaços ao redor.

$\mathrm{Na}$ foto do Jardim das Rosas (Figura 5), é possível identificar o isolamento do conjunto e a sensação residual proporcionada ao espaço público criado ao longo do edifício. Na Figura 6 percebe-se o longo corredor criado entre os edifícios, configurando um espaço de segregação ao invés de transmitir a ideia de conjunto. Um espaço que geralmente torna-se "espaço de ninguém". 


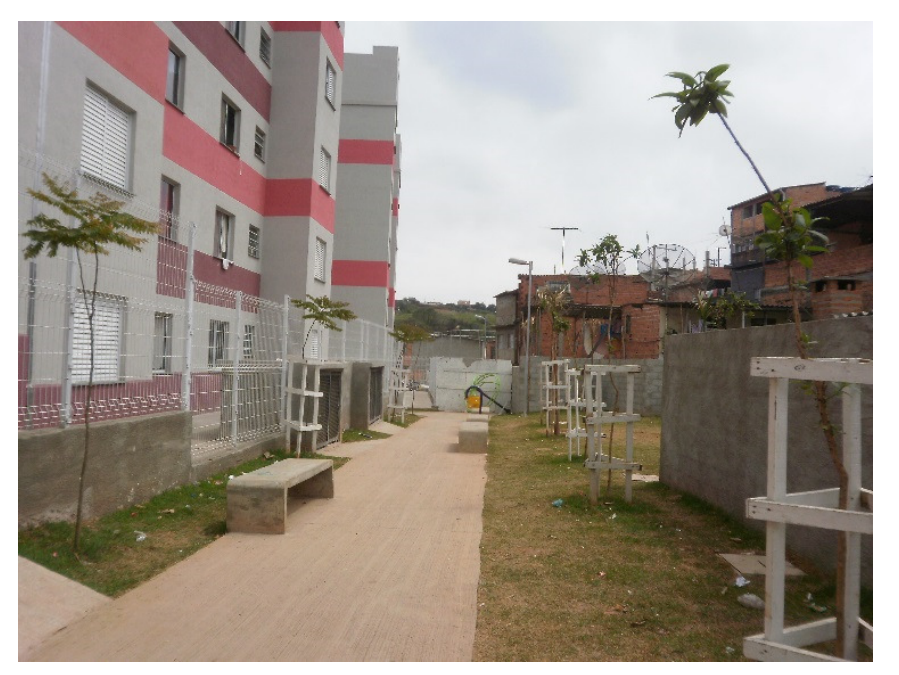

Figura 5 - Jardim das Rosas: segregação entre o conjunto, o espaço livre e os domicílios existentes da favela "escondidos atrás do muro.

No caso do Alexandre Mackenzie, pode-se observar na foto ao lado que o espaço compreendido entre os edifícios e os gradis foi apropriado pelos moradores com jardins, hortas e espaços para o convívio entre vizinhos. Ao analisar o projeto com mais cuidado, é possível identificar que as unidades do térreo têm o acesso direto por esse pavimento o que torna esses espaços extensões de suas casas além de garantir que os moradores circulem por aí. Dessa forma esses espaços passam a ser mais cuidados pelos próprios moradores, pois não são mais simples recuos ou áreas comuns aos conjunto. A partir dessa configuração, esses espaços tornam-

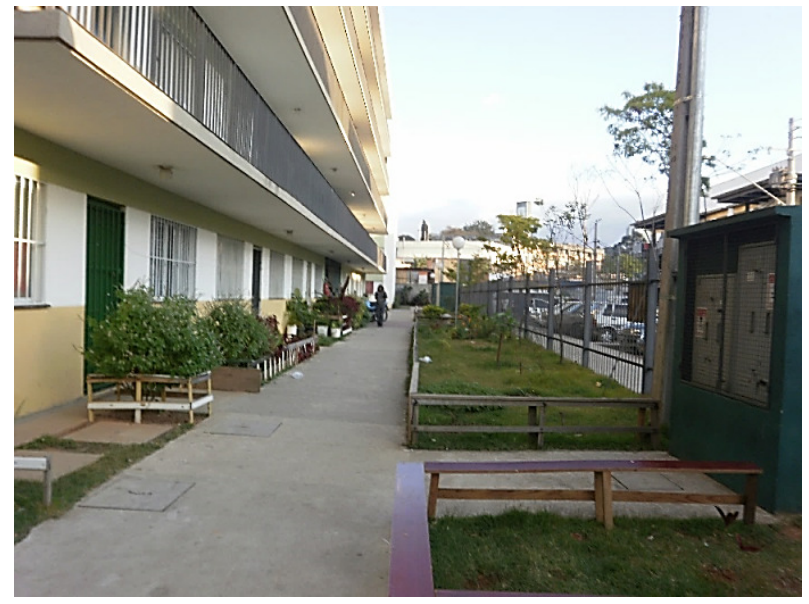

Figura 7 - Alexandre Mackenzie (edifícios mais altos). Projeto: Boldarini Arquitetura e Urbanismo. 
se a frente dessas casas ou até mesmo os próprios quintais.

Essas soluções de jardins ou hortas em frente às casas, não são novidade. Situações semelhantes já eram realizadas na Europa dos anos 1930. Paulo Bruna (2010, p. 35) comenta que conjuntos habitacionais, como o Römerstadt, tinham a preocupação de criar filtros entre a passagem pública e a porta das casas. Esses jardins também funcionavam como filtro de privacidade. Entretanto, a manutenção desses espaços era destinada a cada morador. Segundo BRUNA, os moradores eram cobrados pelos vizinhos caso essas áreas ajardinadas não se encontrassem bem cuidadas (informação verbal) ${ }^{9}$.

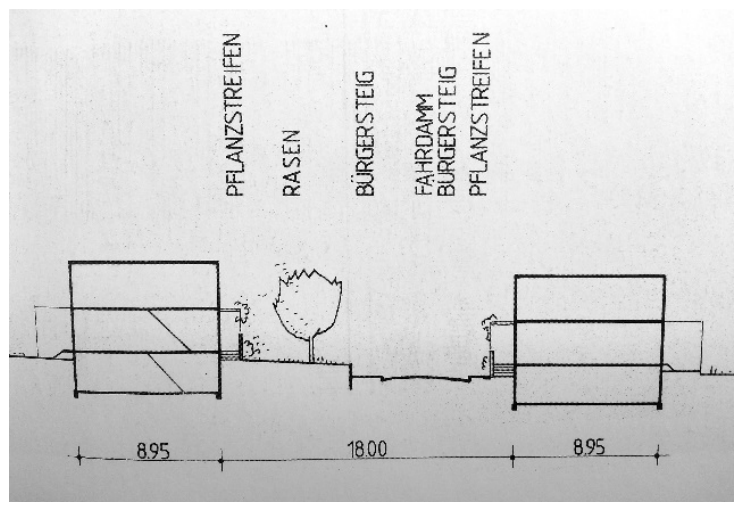

Figura 8 - Corte esquemático projeto Römerstad. Fonte: BRUNA, 2010, p. 35

Na Figura 8 é possível identificar a área ajardinada entre a circulação comum e o edifício e também o desnível deixado, contribuindo assim, para aumentar a privacidade.

\section{Adaptação ao terreno}

A adaptação do projeto à topografia do terreno é um fator que contribui consideravelmente com o custo do projeto, além de interferir na relação do conjunto com a rua. O ideal é que o projeto seja desenvolvido levando em consideração o perfil natural do terreno e buscando, da melhor maneira possível, adaptar-se a ele, evitando grandes movimentos de terra, cortes e contenções. De acordo com as Diretrizes de Projeto de Edificações, é importante: 
Minimizar os impactos negativos causados pela implantação do empreendimento, considerando as características naturais do terreno: geologia, topografia, vegetação, cursos de água. Promover medidas que propiciem condições adequadas de insolação, luminosidade, ventilação e vistas panorâmicas. Também deverão ser observadas as características do entorno, respeitando-se o preexistente.

Otimizar cortes e aterros, minimizando as contenções e volume de transporte de terra. Para tanto, as informações obtidas por meio de sondagens são essenciais para verificar a adequação do tipo de solo para esse fim (PREFEITURA DE SÃO PAULO, 2012b, p. 231).

A partir da análise realizada, foi possível identificar as diferentes soluções adotadas pelos projetos. Os blocos do Comandante Taylor foram implantados sobre platôs. Com isso os acessos ao conjunto foram definidos através dos dois níveis de rua existentes, um mais abaixo e outro mais acima, definindo assim um acesso através de pavimento intermediário (página 95). No caso do Real Parque, o acesso pelo pavimento intermediário também foi a solução adotada, mas mesmo assim, em alguns momentos foi necessário utilizar muros de contenções (página 361). No Parque Novo Santo Amaro V, pudemos observar que as próprias edificações foram utilizadas para vencer as diferenças de nível do terreno, o que resultou, inclusive, no desenvolvimento de tipologias específicas para os andares que possuíam abertura apenas para uma das laterais do edifício, pois na outra estavam abaixo do nível da rua (página 268 e 291).

Ainda como exemplo de adaptação ao terreno, pode-se citar os Condomínios de Paraisópolis (Figura 9). As imagens a seguir são dos condomínios A e B e mostram como os edifícios foram implantados em platôs vencendo, pouco a pouco, o desnível inicial do terreno com pequenos taludes sem configurar barreiras dentro do conjunto ou em relação à rua. Como pode ser observado no corte (Figura 10), há uma passarela que conecta o nível mais alto do terreno aos edifícios, interligando-os e gerando um novo térreo. 


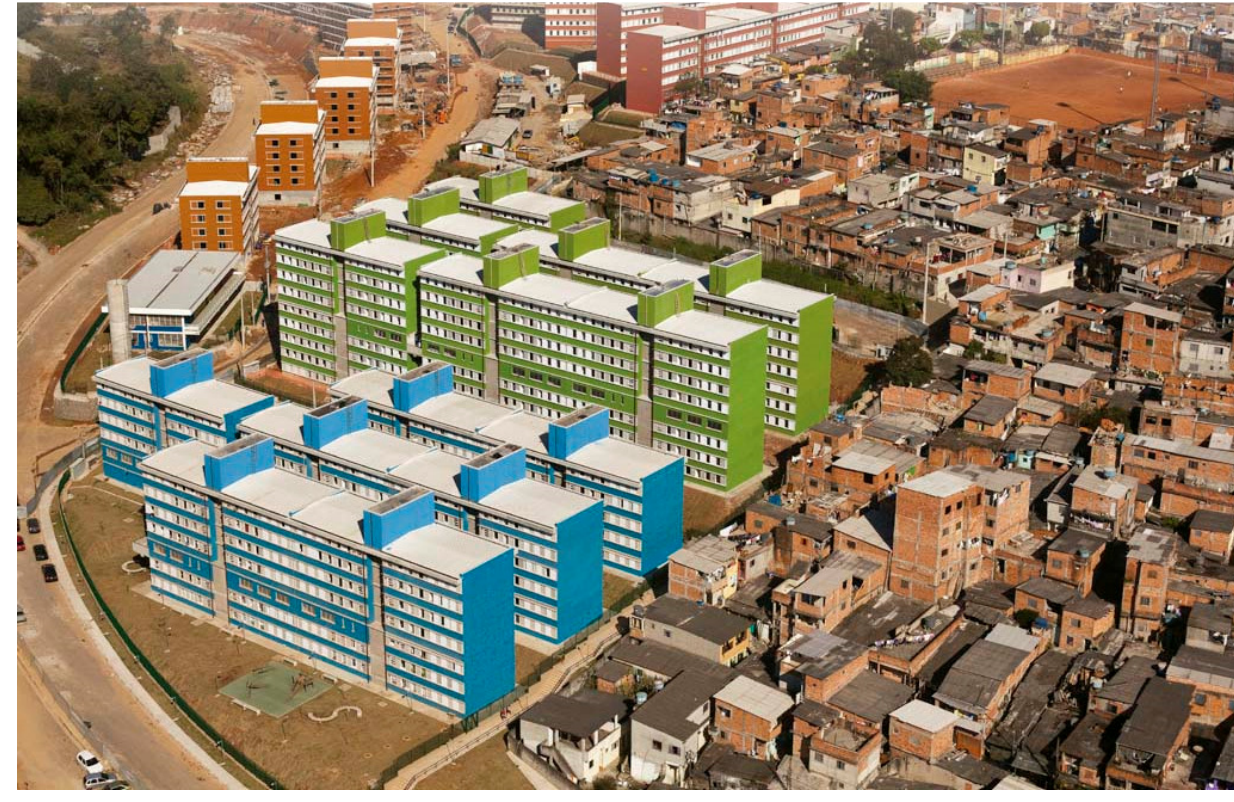

Figura 9 - Paraisópolis - Vista aérea dos condomínios A (azul); B (verde). Os edifícios foram implantados sobre platôs.

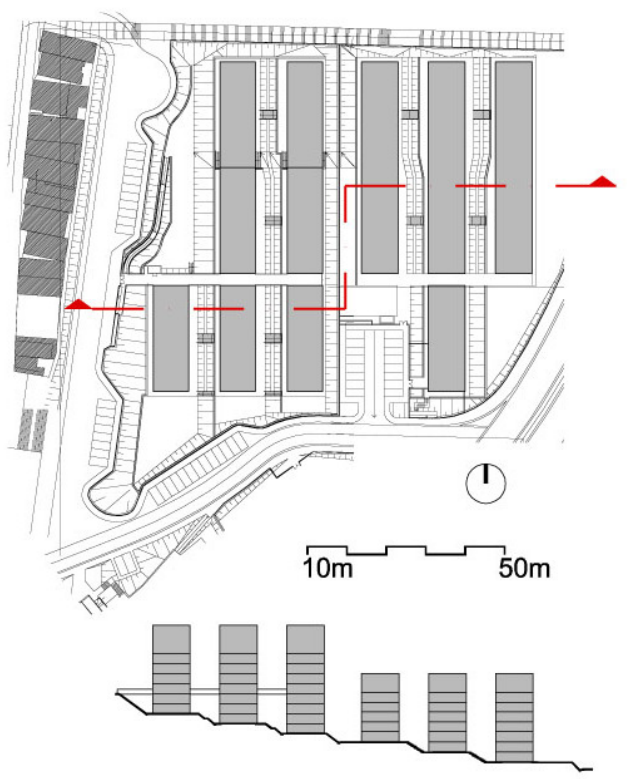

Figura 10 - Paraisópolis - Condomínios A+B: implantação e corte esquemático.

A solução do pavimento intermediário, adotada nos exemplos citados, colabora para a construção de um maior número de andares sem extrapolar o número máximo de quatro pavimentos para cima ou para baixo, dispensando o uso de elevadores.

Mais uma vez, nota-se a utilização de conceitos já conhecidos e utilizados em projetos anteriores como soluções para os conjuntos contemporâneos. O pavimento intermediário foi proposto pelo arquiteto Affonso Eduardo Reidy, no Pedregulho, no final dos anos 1940 e utilizado posteriormente no Conjunto da Gávea em 1952, também de autoria de Reidy. 
[...] Duas pontes dão acesso a um pavimento parcialmente livre, através do qual se tem uma belíssima vista panorâmica. Este pavimento proporcionará uma imensa área plana, bem ventilada e protegida, onde as crianças poderão abrigar-se nas horas mais quentes e nos dias de chuvosos. Será parcialmente ocupada pela instalação do Serviço Social e da Administração, assim como pela escola maternal, o jardim de infância e o teatro infantil. Distante de 50 em 50 metros, aproximadamente, acham-se localizadas as escadas coletivas de acesso aos diversos pavimentos. Os dois pavimentos inferiores contêm apartamentos de uma só peça e os superiores duas ordens de apartamentos duplex de um a quatro dormitórios. A solução duplex foi adotada para a maioria dos apartamentos por ser aquela que oferece maior rendimento, pela possibilidade de atingir, sem elevador, a quatro pavimentos, e permitir, mediante maior profundidade do bloco, o mínimo de testada, aumentando desta forma o número de unidades do bloco (BONDUKI (Org.), 2000a, p. 82).

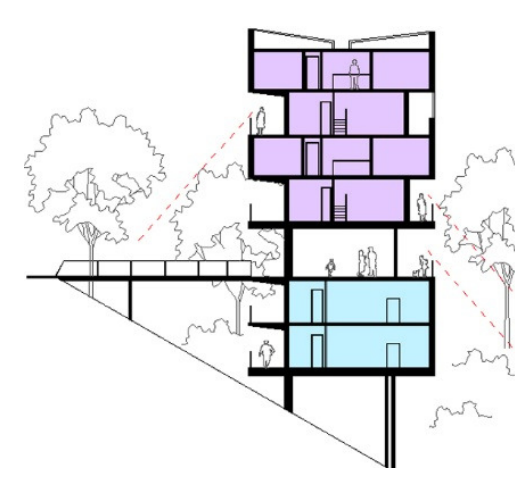

Figura 11 - Pedregulho. Corte Conceitual.

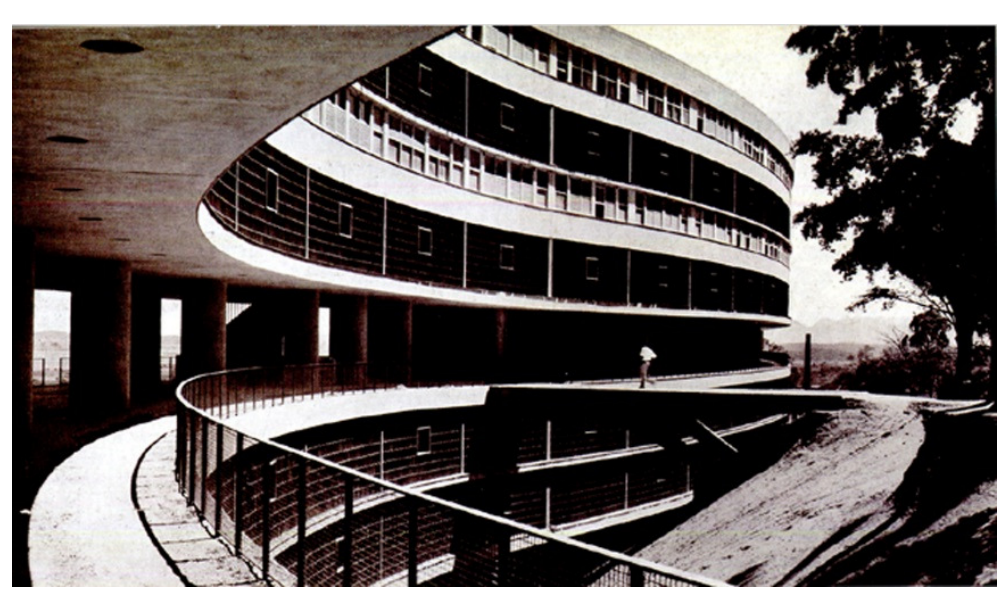

Figura 12 - Pedregulho. Foto do pavimento intermediário. 
Após o exemplo do Pedregulho, chega a ser desanimador observar os exemplos de implantações que criaram espaços sem uma utilização adequada dentro do conjunto e sem relação com a rua. São casos onde o terreno é, geralmente, aterrado a partir do nível mais baixo o que, se por um lado, facilita a implantação dos edifícios, por outro, cria espaços residuais que comprometem a qualidade espacial do conjunto, além da construção de muros de contenção que encarecem o projeto.

Essas situações foram identificadas nos projetos: São Francisco e Ceratti. Ao observar o Conjunto Ceratti (Figura 13; Figura 14) é possível identificar o alto muro de contenção e o espaço residual abaixo do nível da rua entre os edifícios e esse muro.

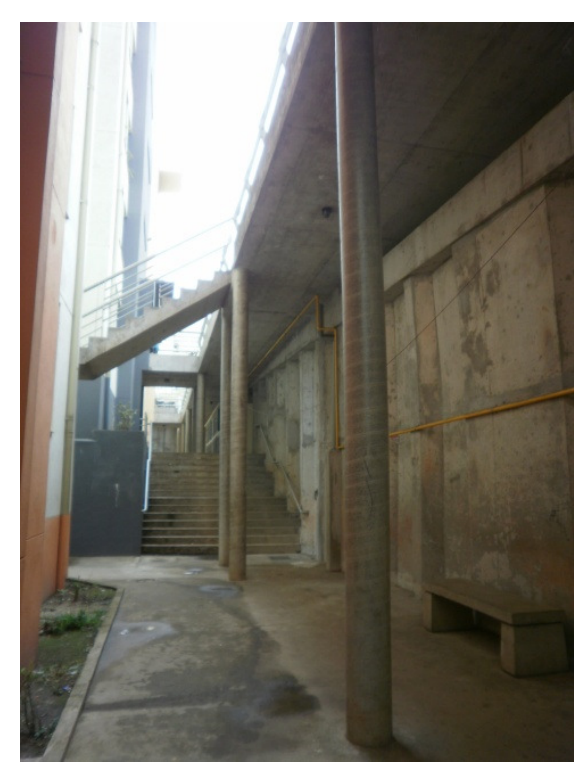

Figura 13 - Conjunto Ceratti - muro de contenção sob o nível da rua.

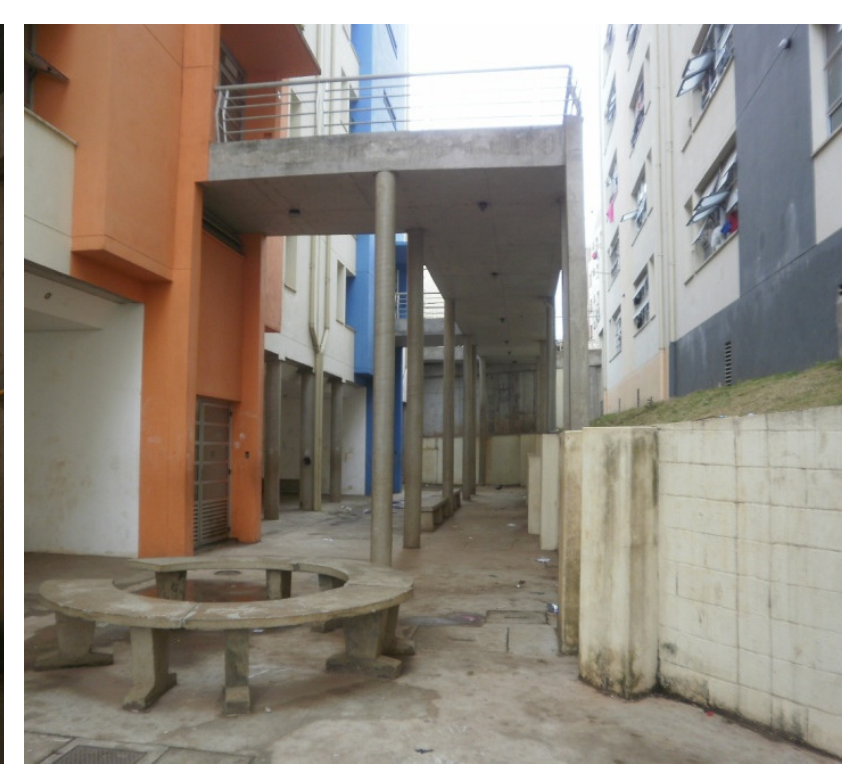

Figura 14 - Conjunto Ceratti - espaços de lazer e convivência.

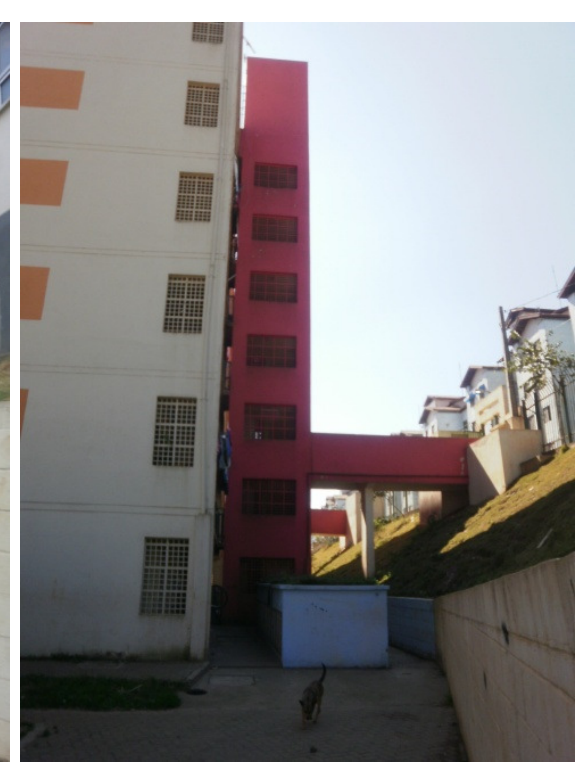

Figura 15 - São Francisco (Provisão 3) - térreo abaixo do nível da rua sem iluminação direta. 
No caso do São Francisco (Figura 15), o desnível é vencido por um talude com cobertura permeável, porém, a distância entre esse talude e a edificação somados ao volume da escada acabaram criando um espaço residual no térreo, agravado pela falta de luz natural direta. Apesar da solução do talude parecer mais agradável que o muro de contenção, a implantação deveria ter considerado as distâncias adequadas e a insolação, para não proporcionar espaços sem qualidade dentro dos conjuntos.

\section{Diálogo volumétrico}

Para uma boa relação com o entorno, de acordo com as recomendações do trabalho Instrumentos de Avaliação de Projetos, deve-se "procurar uma transição volumétrica de modo que o novo conjunto não signifique um corte ou elemento estranho ao entorno. As novas edificações não devem causar impactos negativos em relação à escala $\mathrm{e}$ ao volume do tecido existente" (PREFEITURA DE SÃO PAULO, 2012b, p. 278).

O Conjunto Habitacional Santo Amaro $\mathbf{V}$ é um exemplo de como intervir, com qualidade, dentro do perímetro da favela sem deixar de estabelecer um diálogo volumétrico. Ao observar a vista aérea da implantação do conjunto (figura 24 - página 269), fica claro que não se trata de um "elemento estranho ao entorno". Pode-se dizer que esse projeto faz uma releitura da favela ao propor o bloco linear onde as unidades habitacionais expressam a mesma escala e volumetria irregular que as moradias construídas espontaneamente na favela.

Porém, nem sempre as intervenções têm esse cuidado com o entorno existente e o Jardim São Francisco é um exemplo disso.

No processo de ocupação do território, especialmente entre 1979 e 2004, dois aspectos se destacam na formação e na consolidação do Jardim São Francisco como um dos novos bairros mais emblemáticos da cidade de São Paulo: a participação ativa dos moradores e dos movimentos populares no desenvolvimento e no acompanhamento dos programas realizados na área; e a implantação de projetos habitacionais por parte do 
poder público que foram sendo implantados de forma isolada, desprovidos de uma preocupação de criar conexões internas.

O primeiro programa habitacional público implantado na gleba em 1982 tinha inspiração e financiamento do BNH - através da Cohab SP - quando foram implantados os embriões que integravam o programa Promorar. Quase uma década depois, no início dos anos 1990, a Sehab deu início ao Programa de Mutirões - carro chefe da política habitacional no período 1989-1992 -, e vários projetos foram implantados no bairro. Nos anos seguintes, a política habitacional desenvolvida na cidade adotou o conceito de verticalização, através do Programa Cingapura e, novamente, o Jardim São Francisco foi palco da nova experiência habitacional (PREFEITURA DE SÃO PAULO, 2012c, p. 37).

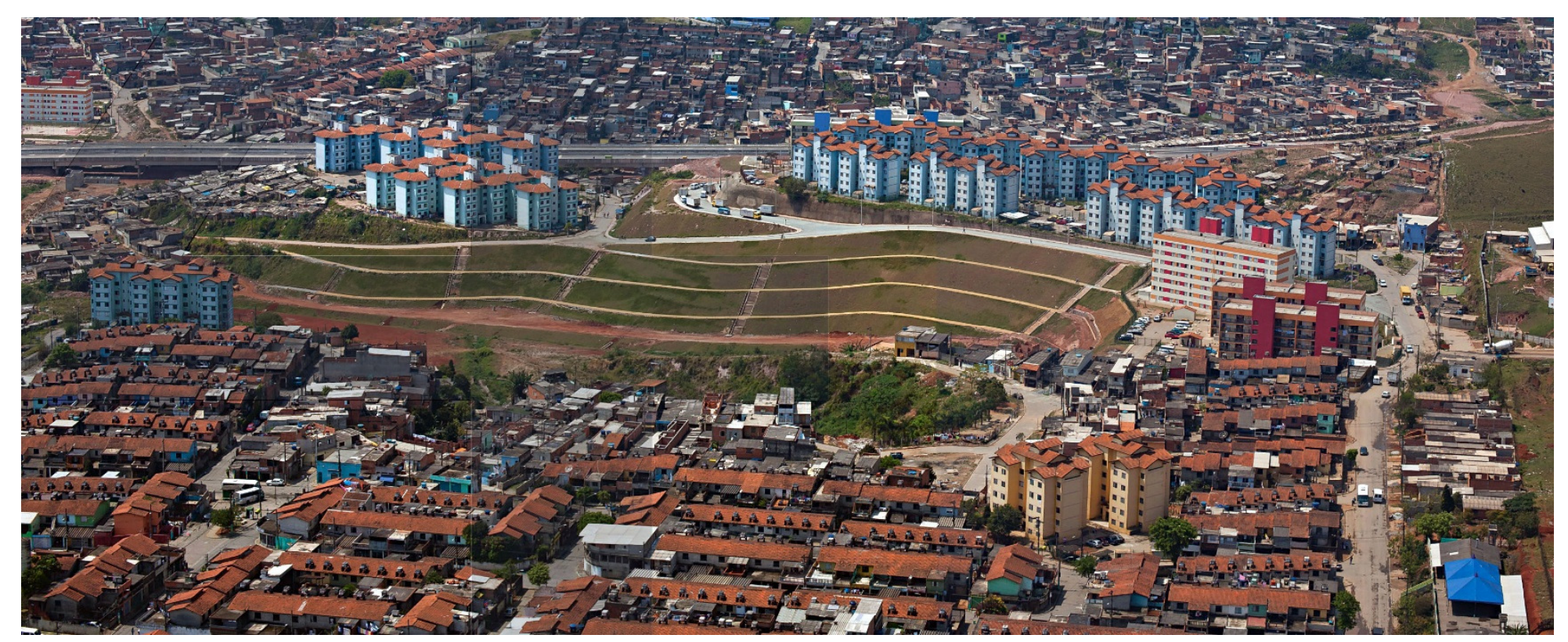

Figura 16 - Jardim São Francisco. Sucessão de intervenções desarticuladas e falta de diálogo volumétrico com o entorno existente. Foto retirar do livro Jardim São Francisco, Projeto Global de Urbanização (2012c). 
Essa despreocupação em criar conexões internas, é claramente identificada ao olhar-se a imagem aérea do bairro, sendo possível identificar as "ilhas" geradas pelas intervenções completamente desarticuladas com o entorno. Os projetos mais recentes podem ser identificados, na foto, pelos edifícios com listras laranja e os volumes das caixas de escada em vermelho. Com base na publicação sobre o bairro Jardim São Francisco, Projeto Global de Urbanização (2012c), sabe-se que atualmente existe um plano de urbanização para toda a região que busca "costurar" essa desarticulação.

Ao analisar os conjuntos mais recentes, nota-se que se configuram, a partir de diferentes arranjos, utilizando-se da repetição de uma mesma edificação, o que pode ser apontado como um dos fatores responsáveis pela falta de diálogo. No caso do Parque Novo Santo Amaro V, fica claro que o projeto foi desenvolvido especificamente para aquele local e que cada abertura foi pensada em relação ao entorno, o que não acontece no São Francisco.

Para finalizar esses exemplos, pode-se analisar o conjunto habitacional Sabesp, em Heliópolis, desenvolvido pelo arquiteto Ruy Ohtake e equipe, no qual fica claro que o partido adotado é o de destaque na paisagem, não cabendo, nesse caso, exigir do projeto qualquer relação com o existente, uma vez que se propõe exatamente como um elemento diferente, para não dizer, "estranho" ao entorno.

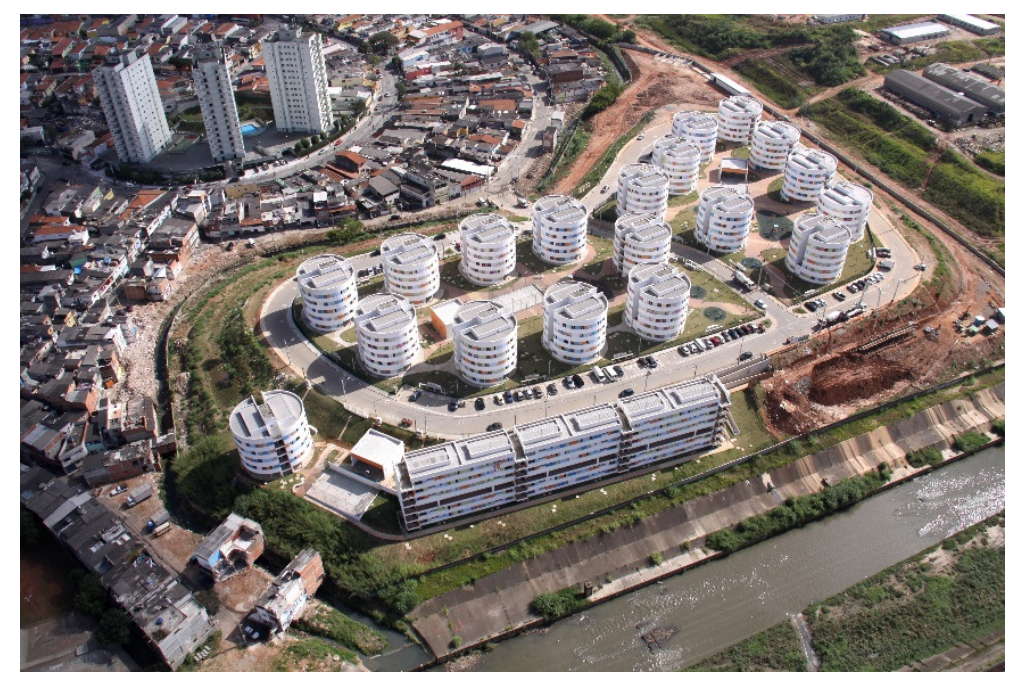

Figura 17 - Conjunto Habitacional Sabesp, Heliópolis. Implantação de destaque na paisagem. 
Por outro lado, o Jardim Edite é um exemplo de conjunto habitacional inserido na cidade, que estabelece diálogo volumétrico com o entorno. Como vimos, esse projeto foi implantado em uma região caracterizada pelos grandes edifícios empresariais - a Avenida Berrini. A proposta consolidou-se em altas torres que conseguiram estabelecer diálogo com os edifícios ao redor. Questionados sobre a decisão projetual de construir torres altas, contando com uso de elevadores (um tema ainda polêmico ao se tratar de habitação de interesse social na cidade de São Paulo $)^{10}$, os arquitetos comentaram que, tratando-se da localização do terreno e da forte característica do entorno, não tiveram dúvidas sobre a implantação das torres (informação verbal) ${ }^{11}$. Desta forma, o projeto dialoga de igual para igual com os outros edifícios da região (figuras 22 e 23, página 281).

\section{ESPAÇOS EXTERIORES}

Durante o desenvolvimento das análises, considerou-se como espaços exteriores os espaços coletivos que configuram os conjuntos habitacionais, os espaços de circulação e acesso aos edifícios e também espaços de convivência entre os vizinhos, onde podem ser encontrados equipamentos de lazer ou áreas para reunião e descanso, por exemplo. Esses espaços podem ser de uso privado do conjunto, como visto nos projetos Comandante Taylor, Jardim Edite e Real Parque, ou de uso público, como foi o caso do Parque Novo Santo Amaro V.

\footnotetext{
${ }^{10}$ A utilização de elevadores nos conjuntos de habitação de interesse social ainda é um tema que gera discussões, pois a degradação desses equipamentos ao longo do tempo devido à falta de manutenção é um fator importante para que se tome a posição contrária a seu uso, porém isso é uma questão relacionada à gestão condominial e outras prioridades, como aproveitar o coeficiente máximo do terreno para oferecer um maior número de unidades habitacionais, está do outro lado da balança.

11 Informação fornecida pelo arquiteto Milton Braga durante conferência ministrada na FAU-Maranhão em julho de 2013, parte do programa da disciplina Arquitetura Contemporânea Paulista / Crítica de Arquitetura.
} 
Quanto aos espaços exteriores concebidos como espaços públicos, foi possível verificar, ao longo da análise do projeto Santo Amaro $\mathbf{V}$, que apesar de representarem uma grande contribuição ao bairro, essa atuação também proporcionou conflitos com relação à gestão e à manutenção dos espaços, uma vez que, nem os moradores, nem a Subprefeitura assumem essas responsabilidades. Conflitos que poderiam ser solucionados ou amenizados se a presença do poder público fosse mais atuante.

Vale ressaltar aqui a importância dos processos participativos, pois se os moradores, tanto do conjunto, como do entorno, estivessem envolvidos no desenvolvimento do projeto, durante todo o processo, acredita-se que estariam cientes da condição pública dos espaços e, uma vez que estivessem de acordo, entende-se que se mobilizariam os dois grupos - para cuidar e gerir as áreas públicas oferecidas pelo projeto. Ressalte-se que, infelizmente, os moradores não podem contar com a manutenção e gestão da administração pública completamente.

Em uma análise mais profunda, não podemos dizer que não houve participação. Os arquitetos Hector Vigliecca e Neli Shimizu comentaram que houve processo participativo e que a associação de moradores esteve envolvida durante o desenvolvimento do projeto ${ }^{12}$. Durante a visita realizada, foi possível conversar com a assistente social que atua na região e verificar que estão sendo feitos trabalhos para envolver a população. Contudo, será que a participação foi realmente efetiva? Será que os moradores do entorno não deveriam ter sido envolvidos também no processo participativo desde o início para compreenderem que aqueles espaços também foram criados para o bairro?

12 VIGLIECCA, Hector; SHIMIZU, Neli. Entrevista: Residencial Parque Novo Santo Amaro V. São Paulo, 23 de janeiro de 2014. 
Definitivamente, não temos uma cultura de participação e essa falta de comunicação com os futuros moradores e usuários dos espaços, acaba prejudicando a qualidade espacial oferecida por projetos como o Santo Amaro V, que tão acertadamente desenvolveu espaços coletivos públicos visando favorece-los aos moradores de todo o bairro.

Como vimos, para a prefeitura, é mais fácil definir os limites dos conjuntos e determinar que, dos portões para dentro, a responsabilidade seja dos moradores. Contudo, os espaços comuns e áreas de lazer do interior dos conjuntos cercados nunca serão em benefício do bairro e os conjuntos continuarão sendo implantados isoladamente, como ilhas, numa situação completamente oposta à situação das favelas, por exemplo, onde os moradores viviam em contato direto com o espaço público.

Entende-se, portanto, a importância da dedicação aos espaços exteriores e fica clara a necessidade de uma revisão da postura da administração pública, tanto com relação à gestão dos espaços, como quanto a realização dos processos participativos.

Tratando-se dos espaços exteriores privados, no Real Parque, ficou clara a intensão de inserir as áreas de lazer junto aos edifícios, garantindo que esses espaços estejam constantemente sob o cuidado dos "olhares" dos moradores, de acordo com os conceitos de visibilidade e segurança difundidos por Jane Jacobs (1961).

Outro projeto que trata as áreas de lazer como espaço central é o Sabesp. Nesses projetos as áreas de lazer são constantemente vigiadas pelos moradores dos edifícios (Figura 18).

Situações como essas oferecem mais segurança aos moradores que temem que os espaços de lazer sejam apropriados indevidamente. Como vimos no Jardim Edite, muitas mães que moravam nas torres não se sentiam seguras para deixar seus filhos brincarem no pavimento condominial, pois estariam "longe de seus olhos" (páginas 188 e 189). 
Não são considerados como bons exemplos os casos em que as áreas de lazer localizam-se em espaços do conjunto sem visibilidade. No caso do Condomínio F de Paraisópolis é possível observar, na Figura 19, que o playground localiza-se na lateral do edifício em um espaço para o qual não há janelas voltadas. Utilizar áreas residuais como áreas de lazer, prejudica a sensação de segurança e interfere na qualidade espacial dos projetos.

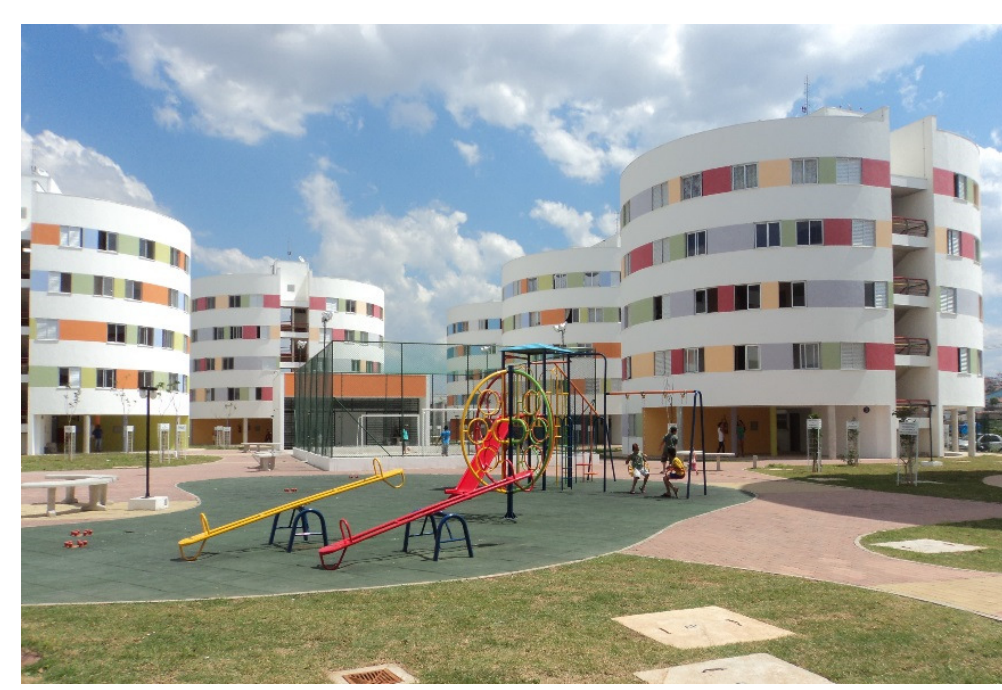

Figura 18 - Conjunto Habitacional Sabesp. Espaços exteriores privados.

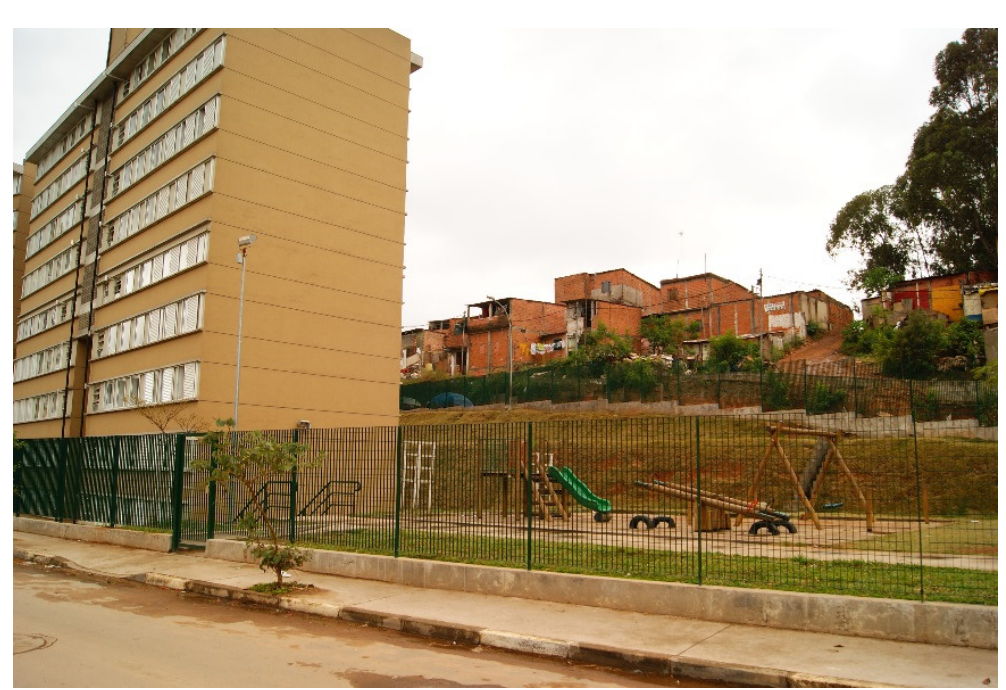

Figura 19 - Condomínio F - Paraisópolis - áreas de lazer.

No livro Defensible Space: crime prevention through urban design, Oscar Newman (1973) estuda e apresenta situações que, através do desenho e da concepção dos projetos, permitem que os moradores tenham controle sobre os espaços ao redor de suas casas. NEWMAN analisa situações como a posição das janelas; a posição das entradas dos edifícios e a visibilidade desses espaços; a justaposição dos edifícios na implantação, garantindo que os moradores dos edifícios vizinhos possam monitorar os corredores de circulação dos edifícios ao lado ou em frente; analisa também os materiais utilizados nos interiores dos edifícios e a degradação que sofrem pelos moradores; etc. 
Para NEWMAN (1973, p.9), "o posicionamento das janelas dos apartamentos permite que os moradores realizem um controle natural com relação aos espaços externos e áreas públicas do entorno de onde vivem”¹3.

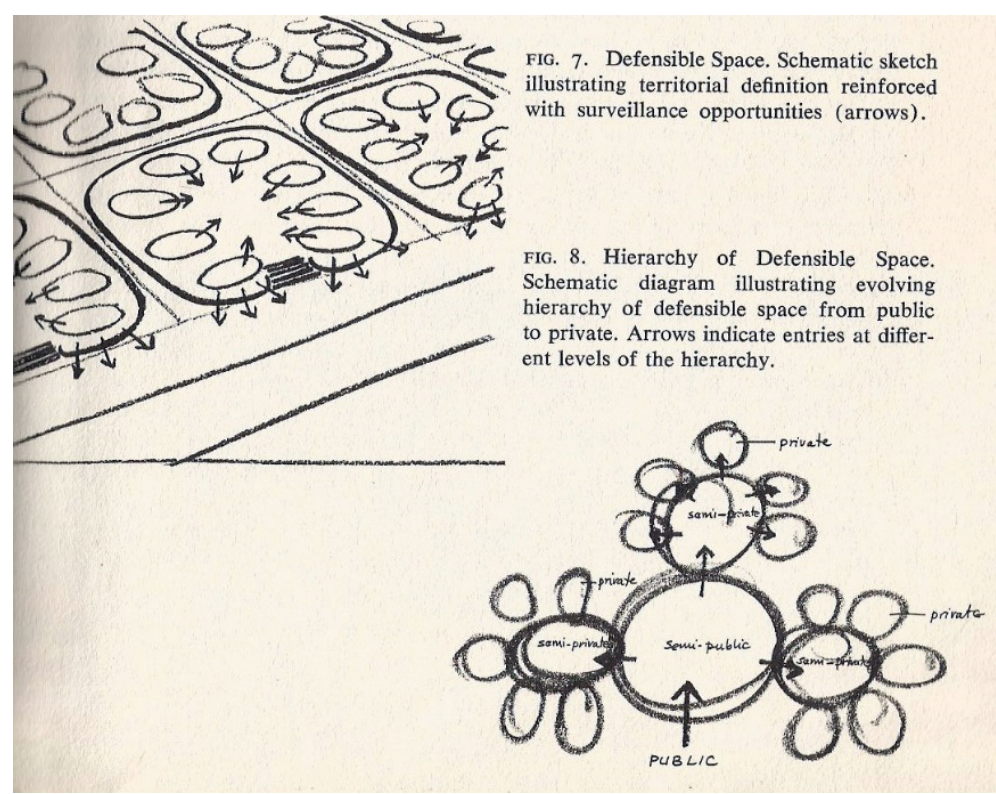

Figura 20 - diagrama da hierarquia do "espaços defensáveis" entre o público e o privado.

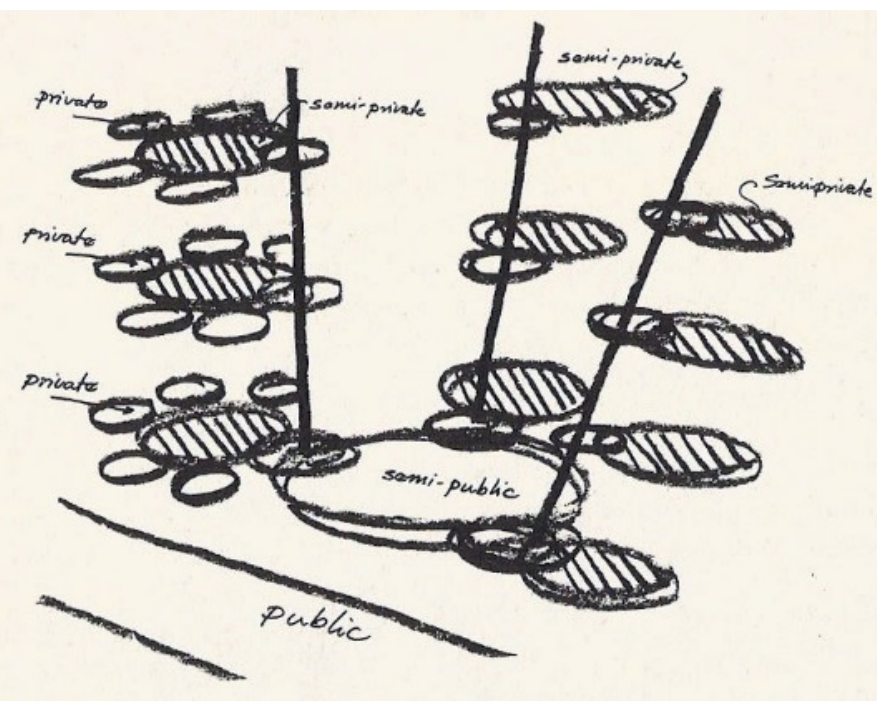

FIG. 9. Defensible space hierarchy in multi-level dwelling.

Figura 21 - hierarquia dos espaços defensáveis nos vários andares de um edifício habitacional.

Os diagramas acima (Figura 20; Figura 21), retirados do livro de Oscar Newman, representam as relações propostas de visibilidade entre os espaços, que o autor chama de semi-privados e semi-públicos ${ }^{14}$ que atuam na

\section{Tradução realizada pela autora.}

14 Os espaços exteriores, existentes em um conjunto habitacional, compreendidos entre a rua e a porta das unidades, possuem diferentes caráteres de privacidade, variando, como colocado por NEWMAN, entre sem-públicos e semi-privados. O professor Paulo Bruna, durante as 
gradação dos espaços para obtenção de um controle mais eficiente. Na Figura 21 é possível visualizar a hierarquia desses espaços nos andares de um edifício habitacional.

O espaço defensável pode ser realizado a partir de uma hierarquia de evolução de níveis no habitat humano coletivo - estendendo-se do apartamento até a rua [espaços semi-públicos e semi-privados]. É uma técnica aplicável à baixa densidade de casas agrupadas, bem como em empreendimentos compostos por prédios de apartamentos. O pequeno aglomerado de apartamentos em cada andar de um edifício de vários andares é o primeiro nível, além das unidades habitacionais, onde os moradores podem estender suas responsabilidades. $O$ segundo nível abrange a circulação comum dentro dos edifícios. O terceiro nível é representado pelo agrupamento de edifícios que definem um projeto e sua entrada. O último nível na hierarquia ocorre em relação às ruas urbanas. ${ }^{15}$ (NEWMAN, 1973, p. 9 e 10).

Considera-se fundamental os conceitos colocados por NEWMAN. É importante que todos esses espaços intermediários - entre a rua e a porta das unidades - sejam devidamente tratados para não proporcionar sensações de insegurança. Legibilidade e visibilidade são dois critérios-chave para a concepção de espaços mais seguros ou defensáveis.

Tratando-se dos espaços exteriores no térreo dos conjuntos, vale a pena ressaltar a importância dos filtros de privacidade. Na maioria dos projetos há unidades residenciais no térreo. Como esse pavimento é uma área de circulação, essas unidades acabam sofrendo com a falta de privacidade.

e semi-privado, a escada de um condomínio" (informação verbal - disciplina AUH 5819 - História Social da Arquitetura e do Urbanismo Modernos - março de 2011).

15 Tradução realizada pela autora. Texto original: Defensible space can be made to operate in an evolving hierarchy from level to level in the collective human habitat - to extend from apartment to street. It is a technique applicable to low-density row-house groupings as well as to developments composed of high-rise apartment buildings. the small cluster of apartments at each floor of a multi-story building is the first level beyond the apartment unit where occupants can made to extend the realm of their homes and responsibilities. The second level is the common entry and circulation paths within their buildings. The third level is the clustering of buildings which define a project's grounds and its entry. The final level in the hierarchy occurs when the housing development stakes its claim on surrounding urban streets. 
No caso do Comandante Taylor vimos que a maior parte das áreas permeáveis está localizada junto aos edifícios atuando como filtros para as janelas que estão em contato direto com o térreo (página 104). As entradas das casas também são protegidas pelos canteiros e as portas não estão voltadas diretamente para a circulação. Os halls criados em frente às portas e, ainda que timidamente, protegidos pelos canteiros, foram classificados como espaços de transição. No Conjunto Habitacional Real Parque pudemos observar a estratégia utilizada a partir da elevação do térreo dos edifícios $50 \mathrm{~cm}$ acima do nível do solo. A partir desse desnível e das áreas verdes, as entradas das unidades ficaram um pouco mais protegidas (páginas 365 e 384).

No projeto Frauen Werk Stadt I, em Viena, um projeto promovido pelo departamento de gênero da cidade e desenvolvido pela arquiteta Franziska Ullman, os filtros de privacidade também são utilizados para proteger as unidades do térreo. Uma das estratégias utilizadas é a criação de uma circulação dupla, onde a passarela que acessa as unidades é mais protegida que a circulação comum do conjunto. Assim como no Real Parque, os edifícios do projeto de Viena também encontram-se levemente elevados do térreo (Figura 22).

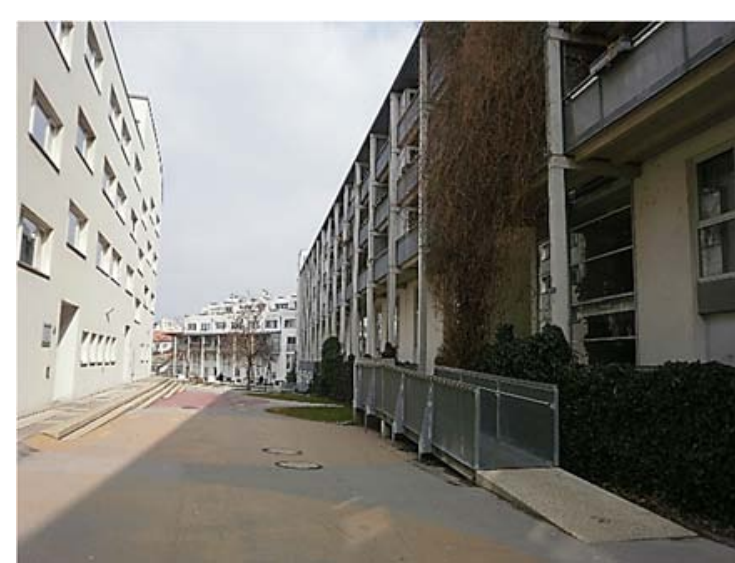

Figura 22 - Circulação central. Projeto Frauen Werk Stadt, Viena.

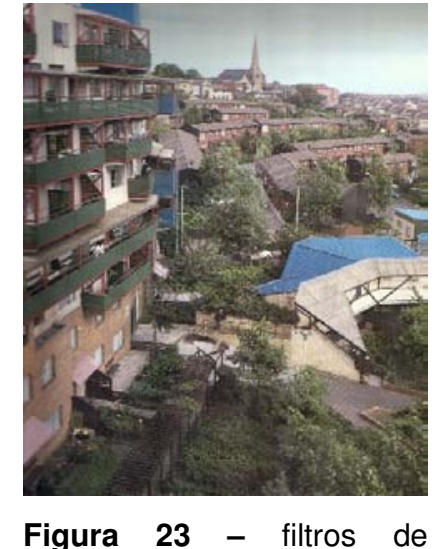

Figura 23 - filtros de privacidade. The Byker Wall, Newcastle.

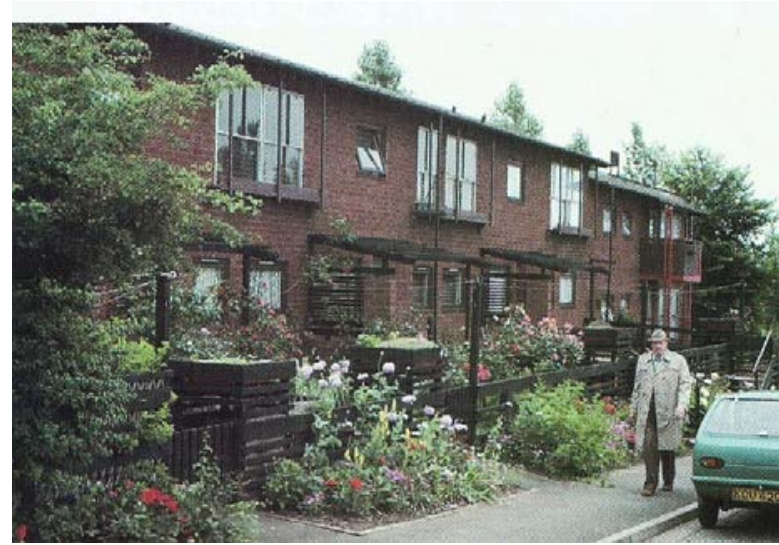

Figura 24 - filtros de privacidade para as entradas no térreo. The Byker Wall, Newcastle. 
Também, como exemplo de projeto que proporciona maior privacidade para as entradas dos apartamentos no térreo, pode-se citar The Byker Wall (1969 - 81) em Newcastle, desenvolvido por Ralph Erskine. Nas figuras 23 e 24 é possível observar as áreas ajardinadas inseridas entre a circulação e os edifícios e as diferenças de níveis que proporcionam maior privacidade às casas e ao térreo dos edifícios (ENGELIUS, 1990, p.153).

No Santo Amaro V as situações são variáveis. Em alguns momentos as janelas são mais altas, em outros foram propostos canteiros em frente às janelas ou espaço para floreira. As fachadas voltadas para a rua possuem suas entradas elevadas do nível da calçada. Situação que proporciona maior proteção às entradas dos apartamentos (páginas 269; 294; 322).

O Jardim Edite não apresentou esse tipo de situação, pois não possui unidades em contato direto com o térreo (páginas 182 a 189). Como vimos, o térreo desse conjunto é ocupado pelos equipamentos implantados Restaurante-Escola, UBS e Creche. Nas torres, o térreo é ocupado pelo hall de entrada do edifício e pelas salas de instalações, lixeira e espaço de guardar para grandes objetos.

Foi abordado, junto ao tema espaços exteriores, a importância de haver, no térreo dos conjuntos, espaços para guardar grandes objetos, como bicicletas, carrinhos de compras, etc. Esses espaços poupariam os moradores de subirem até suas residências com esses objetos que, também por suas dimensões, não possuem lugar adequado para serem guardados dentro das casas. Entretanto, o único projeto, no qual esses espaços foram identificados, foi o Jardim Edite. Fica aqui, portanto, a recomendação de que esses espaços sejam incorporados aos projetos, pois facilitam em muito as atividades da vida cotidiana. 


\title{
RELAÇÃO ENTRE
}

OS EDIFÍCIOS

O item relação entre os edifícios buscou identificar conceitos com relação aos acessos e circulações dentro do conjunto, à variedade de tipologias presentes nos edifícios e também analisar as implantações para verificar as distâncias entre os edifícios, as situações de insolação e orientação.

\section{Acessos e circulação}

no conjunto

\begin{abstract}
Os espaços de circulação são espaços compartilhados e necessários para todos(as) os(as) moradores(as) do edifício. Estes espaços devem ser facilmente legíveis (claridade nos percursos e diferenciação dos edifícios para facilitar a orientação), sem cantos escuros, sendo portanto, bem iluminados. Com dimensões um pouco maiores, estes espaços podem ser convertidos em espaços intermediários que potencializem as relações entre as pessoas, além de representarem extensões do público para o privado e do privado para o público. Os espaços de circulação utilizados como espaços intermediários, são espaços de proximidade que podem potencializar a sociabilização. Entretanto, o arquiteto deverá verificar, quando do desenvolvimento do projetos, o equilíbrio alcançado entra áreas privativas e áreas comuns a fim de evitar o desperdício de grandes áreas construídas computáveis ou um grande impacto no custo da construção da edificação (PREFEITURA DE SÃO PAULO, 2012b, p.292)
\end{abstract}

De acordo com Instrumentos de Análise de Projetos, os espaços de circulação são importantes espaços que incentivam a convivência e a socialização. Porém, deve-se tomar cuidado para que não sejam espaços escuros, ou labirínticos, prejudicando a legibilidade das circulações. 
Oscar Newman (1973, p. 71) defende que "a redução do número de apartamentos agrupados que compartilham um território definido coletivamente e limitar o número de edifícios que compõem um projeto habitacional, são fatores extremamente importantes para o êxito na criação de espaços defensáveis" ${ }^{\prime 16}$. Newman também recomenda que os espaços de circulação e os halls de acesso às escadas e elevadores devem ter uma leitura clara e ser facilmente identificados pelos moradores (p. 75).

Nos esquemas ao lado é possível identificar o que Oscar Newman quer dizer sobre a legibilidade e visibilidade dos espaços de circulação.

Ao dividir o edifício em três, cada segmento teria sua própria entrada e dois elevadores, que serviriam a um número entre 160 e 180 famílias. Dessa forma, o comprimento dos corredores é reduzido e os moradores podem ter maior controle sobre a circulação.

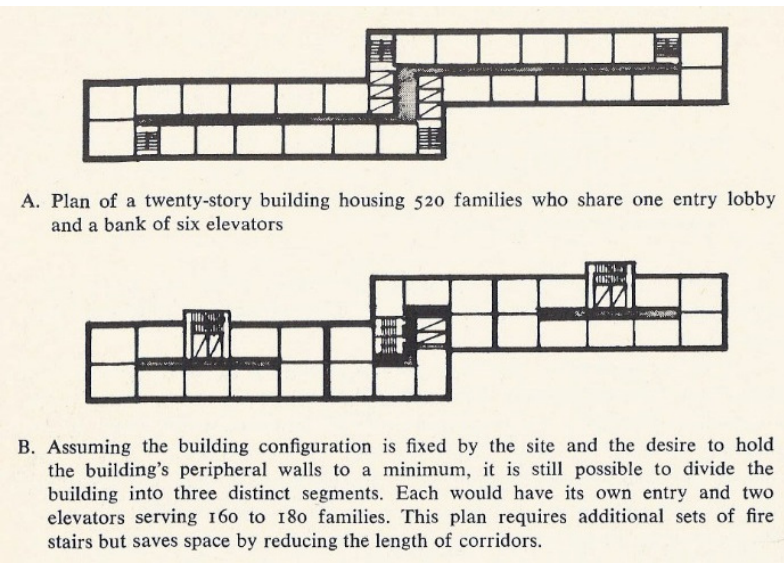

Figura 25 - Esquemas de alternativas para circulação.

$\mathrm{Na}$ análise do projeto Comandante Taylor, identificamos uma circulação labiríntica que prejudica a legibilidade dos espaços. Além do mais, a recomendação de NEWMAN é contrária a esse conjunto onde todos os edifícios estão conectados às contínuas passarelas de circulação.

16 Tradução realizada pela autora. 
Outro exemplo semelhante é o projeto Corruíras ${ }^{17}$, no qual as escadas localizam-se nas extremidades dos blocos conectadas por longos corredores, a partir dos quais as unidades são acessadas (Figura 26).

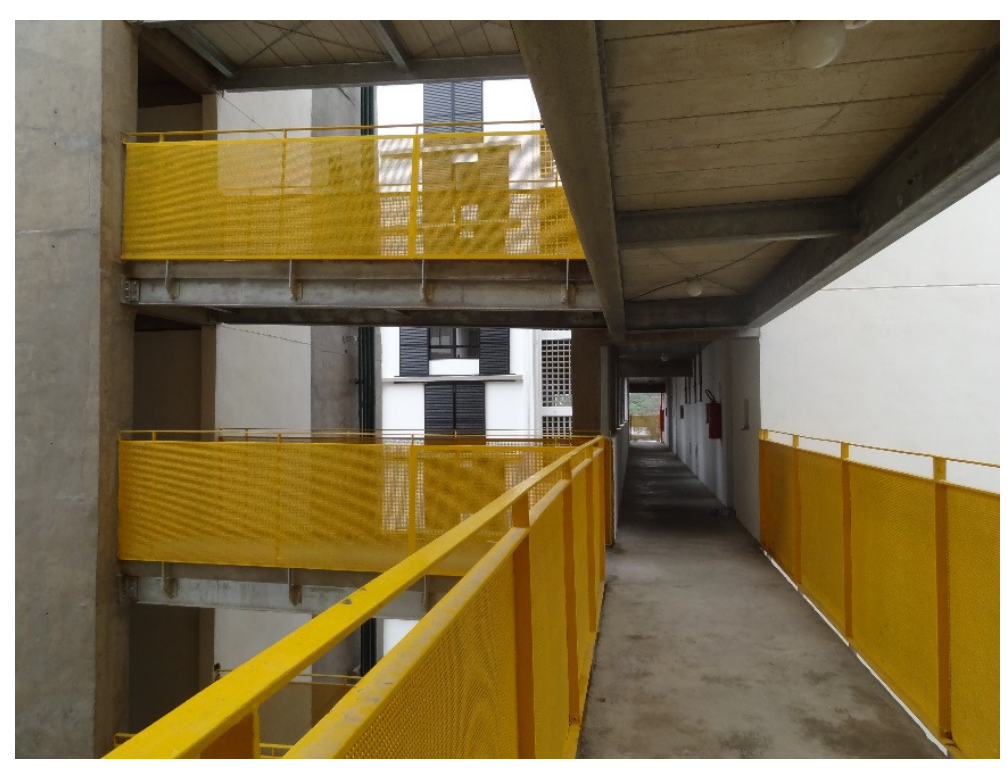

Figura 26 - Projeto: Corruíras. Arquitetura: Boldarini Arquitetura e Urbanismo.

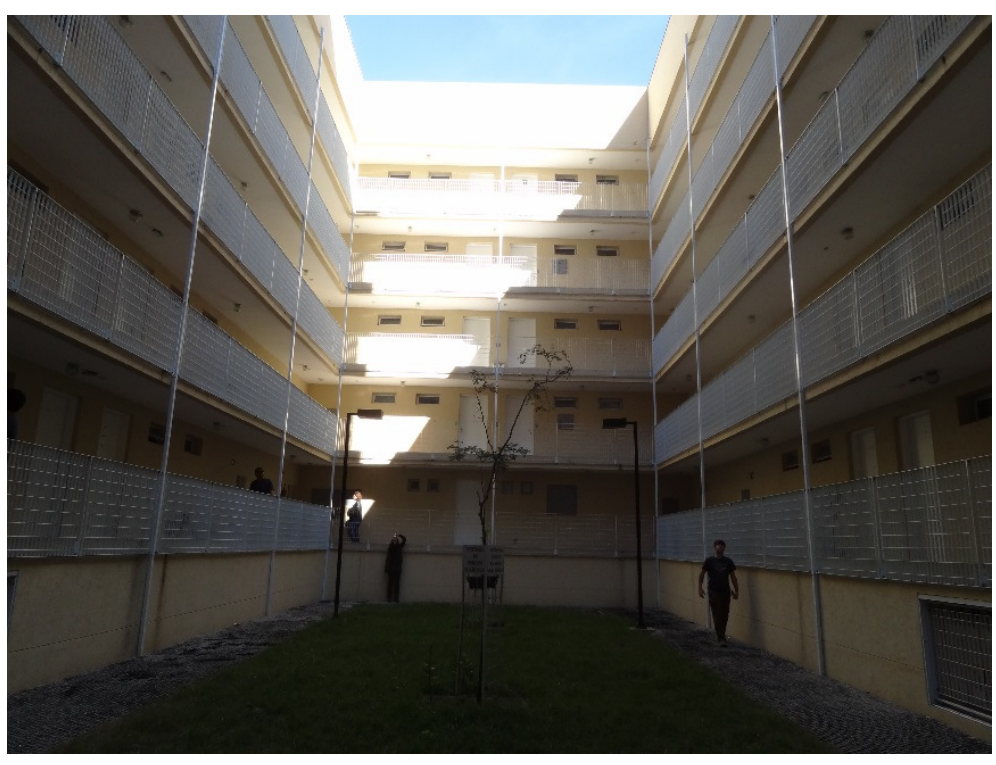

Figura 27 - Projeto: Heliópolis Gleba H. Arquitetura: Vigliecca \& Associados.

Nos projetos Real Parque e Heliópolis gleba H (Figura 27), os edifícios configurados em formato de U possuem a circulação voltada para o interior. Nesses casos, a legibilidade desses corredores de acesso é maior e permite o "controle natural", nas palavras de Oscar Newman, dos espaços exteriores e de circulação.

${ }_{17}$ Para mais informações sobre o Residencial Corruíras, consultar: Revista AU - ARQUITETURA E URBANISMO Ano 28 - no 236. São Paulo: ed. Pini, novembro de 2013. 


\section{Variedade tipológica}

Quanto à variedade tipológica, foi importante observar se existia e como essa variedade ocorria nos projetos.

No caso do Comandante Taylor vimos que as tipologias estavam relacionadas às diferentes configurações de edifícios. Para os edifícios independentes havia sido desenvolvida uma tipologia habitacional e, para os edifícios chamados de duplos, outra. Nessa segunda situação, vimos que as tipologias concentram as áreas molhadas na face que recebe menos iluminação deixando os ambientes não especializados (dormitórios e sala de estar) voltados para a outra fachada, mais iluminada (páginas 111 e 121).

No Jardim Edite pudemos observar que as tipologias habitacionais desenvolvidas para as torres não eram as mesmas que as existentes nos edifícios lâmina, devido as condições de cada edifício (páginas 190 e 191) e, tanto no Real Parque como no Santo Amaro V, vimos que as tipologias habitacionais variavam de acordo com os pavimentos e em relação à topografia do terreno.

As análises realizadas nos mostraram a importância de desenvolver tipologias específicas para cada situação. Contudo, de acordo com as diretrizes definidas recentemente (início de 2013 com a mudança de gestão) pela Secretaria de Habitação, é recomendado que seja desenvolvida apenas uma tipologia edilícia por projeto ${ }^{18}$. Entende-se, porém, que essa determinação obriga uma padronização e a definição de um modelo de edifício que, ao ser implantado em diferentes condições, pode proporcionar grandes prejuízos ao projeto, criando espaços residuais, deixando de estabelecer relação com o entorno ou ainda, onerando a execução do projeto, uma vez que o terreno deverá ser preparado para receber um projeto modelo.

${ }^{18}$ Essa definição está de acordo com as normas do Programa Federal de financiamento Minha Casa Minha Vida. 
Entre os conjuntos habitacionais estudados, são exemplos da implantação de um edifício modelo os conjuntos São Francisco, Jardim Celeste e Rocinha.

No conjunto São Francisco (Figura 28), vemos que foi necessário aterrar o terreno a partir o nível mais baixo para a implantação do edifício, situação que, além de aumentar o custo da implantação com o movimento de terra, prejudica a relação com a rua ${ }^{19}$.

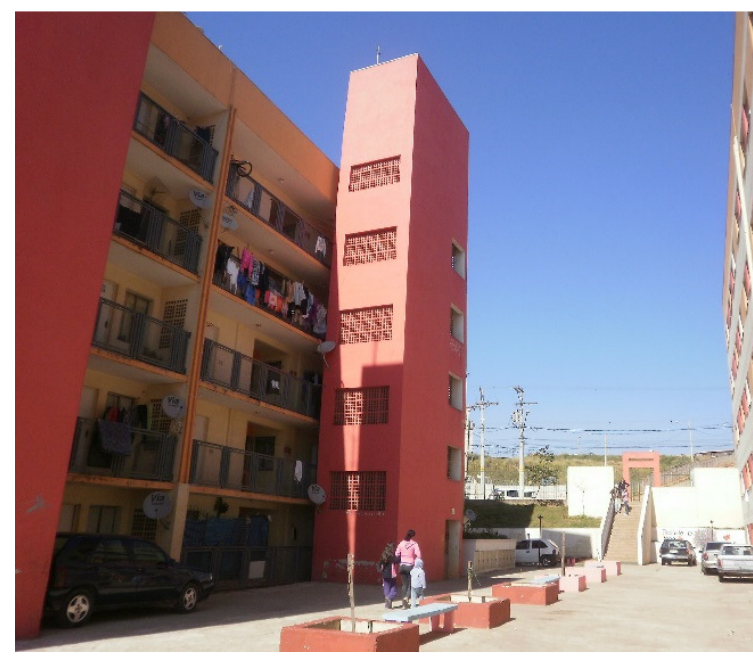

Figura 28 - Projeto: São Francisco. Arquitetura: Arquitetos Urbanistas.

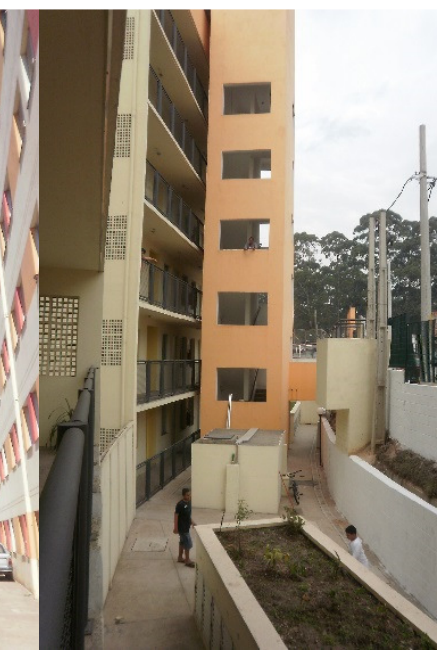

Figura 29 - Projeto: Jardim Celeste. Arquitetura: Arquitetos Urbanistas.
Figura 30 - Projeto: Rocinha. Arquitetura: Arquitetos Urbanistas.

${ }^{19}$ No projeto São Francisco, existe uma rua lateral, secundária, que permite o acesso de pessoas com necessidades especiais e também de carros ao térreo do conjunto, porém não deixa de ser um acesso secundário e a relação com a rua principal se vê bastante prejudicado. 
No Jardim Celeste (Figura 29), nota-se a implantação do mesmo edifício modelo, também no nível mais baixo do terreno. Nesse caso, a caixa de escala está bastante próxima ao limite do conjunto, funcionando como barreira para a visibilidade a partir das passarelas. Quando os edifícios não estabelecem diálogo com as condições do terreno, é inevitável a criação de espaços residuais.

Na Figura 30, a implantação do conjunto Rocinha também não estabelece relação com a rua e, como podemos observar, fachadas sem aberturas estão voltadas para a rua, prejudicando o conceito de visibilidade e segurança defendidos por Jane Jacobs (1961) e Oscar Newman (1973). Ainda de acordo com as recomendações de Instrumentos de avaliação de projetos,

\begin{abstract}
A disposição de uma nova volumetria arquitetônica deve atender, de modo prioritário, à construção do traçado urbano e à continuidade dos espaços públicos dotados da máxima visibilidade, legibilidade e acessibilidade, que permitam a percepção segura do bairro por parte de todos os seus habitantes. A morfologia do agrupamento evitará a criação de lugares que possam abrigar usos não desejados. A base fundiária deverá ser definida no início dos trabalhos, estabelecendo os limites entre o lote e seus confrontantes (PREFEITURA DE SÃO PAULO, 2012b, p. 182).
\end{abstract}

A partir do conceito de visibilidade, entende-se, que as fachadas cegas são um elemento ruim para os projetos. De fato, com base nas recomendações de MONTANER e MUXÍ, JACOBS e NEWMAN, não são a solução mais apropriada. Contudo, como alternativa a essa situação, o projeto Alexandre Mackenzie propõe a justaposição dos edifícios, permitindo que todos os espaços do interior do conjunto sejam "controlados" pelos moradores. 

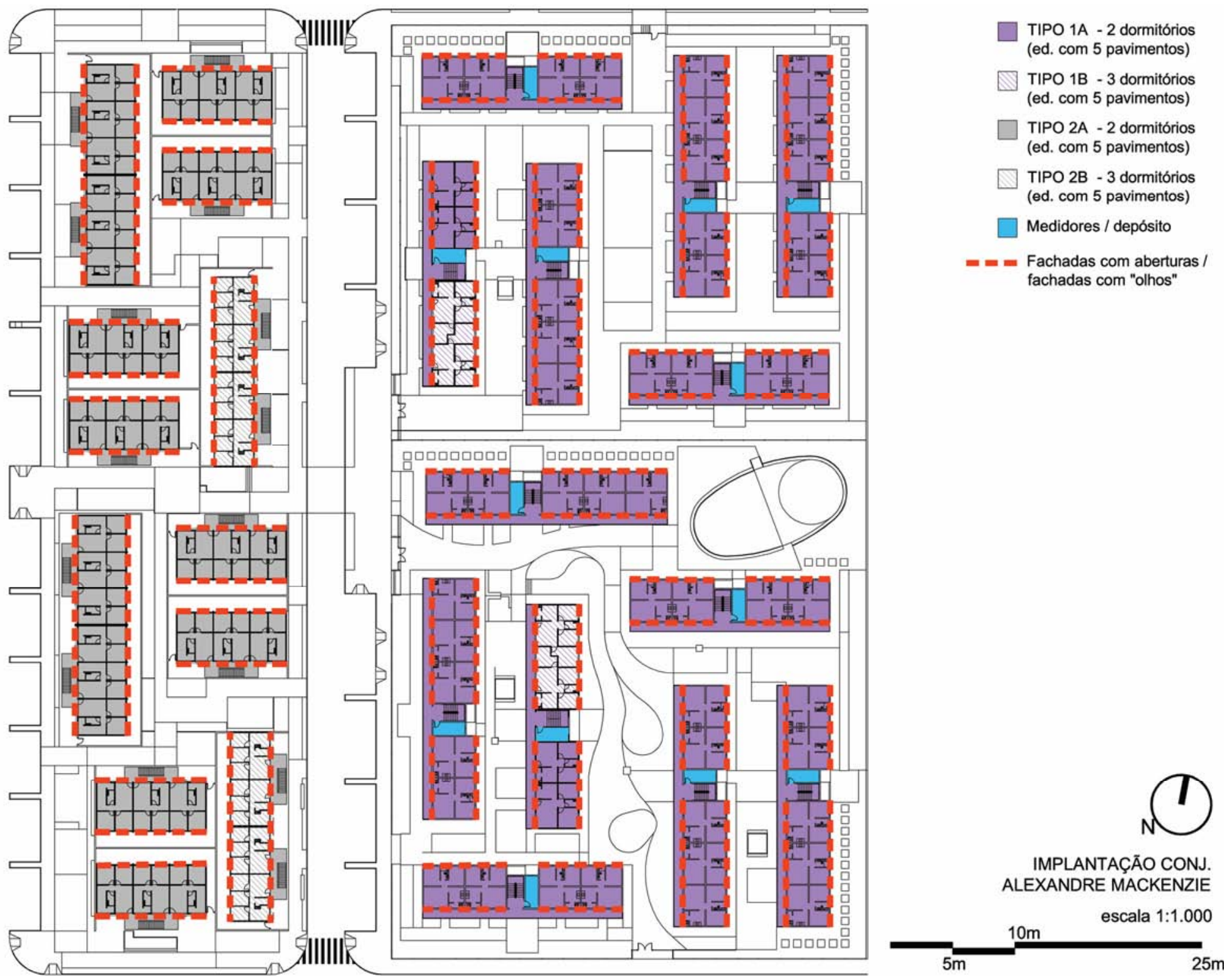

TIPO $1 \mathrm{~A}$ - 2 dormitórios
(ed. com 5 pavimentos)

TIPO 1B - 3 dormitórios (ed. com 5 pavimentos)

$\square$ TIPO 2A - 2 dormitórios (ed. com 5 pavimentos)

$\square$ TIPO 2B - 3 dormitórios (ed. com 5 pavimentos)

$\square$ Medidores / depósito

$=\mathbf{m}=$ Fachadas com aberturas / fachadas com "olhos"

Figura 31 - Implantação Alexandre Mackenzie. 
No conjunto Alexandre Mackenzie não há aberturas em todas as fachadas. As fachadas laterais são grandes empenas cegas (Figura 32). Entretanto, ao observar a implantação do conjunto (Figura 31), podemos perceber uma estratégia de localização dos edifícios, que busca, da melhor maneira possível, colocar fachadas com aberturas em frente às fachadas cegas, tentando não deixar espaços do conjunto que não sejam vistos, ou "vigiados".

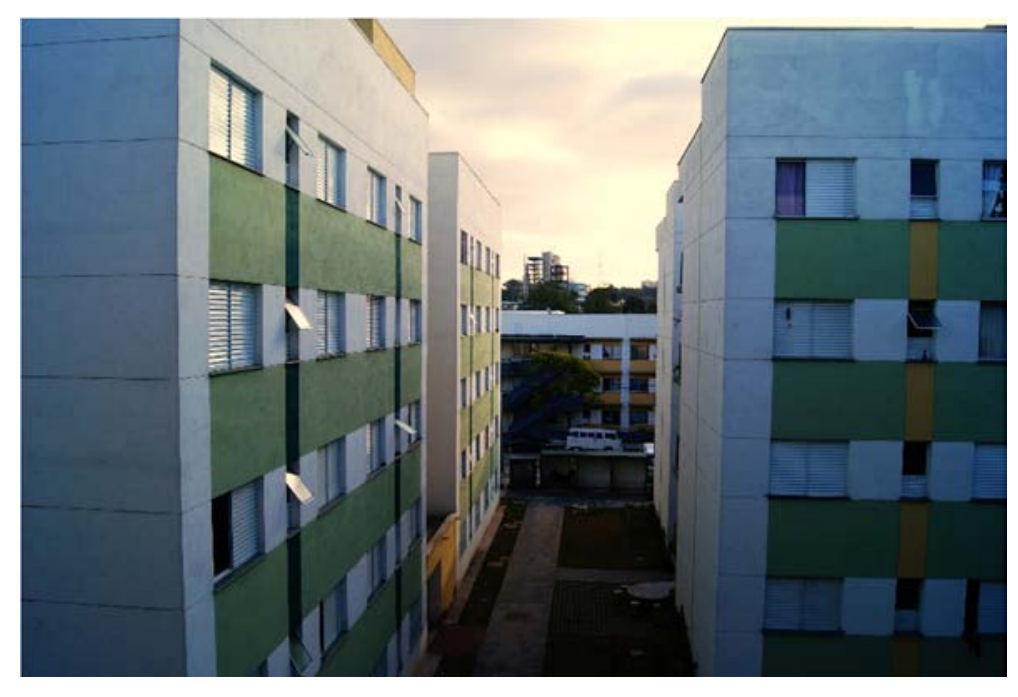

Figura 32 - Conjunto Alexandre Mackenzie. Projeto: Boldarini Arquitetura e Urbanismo

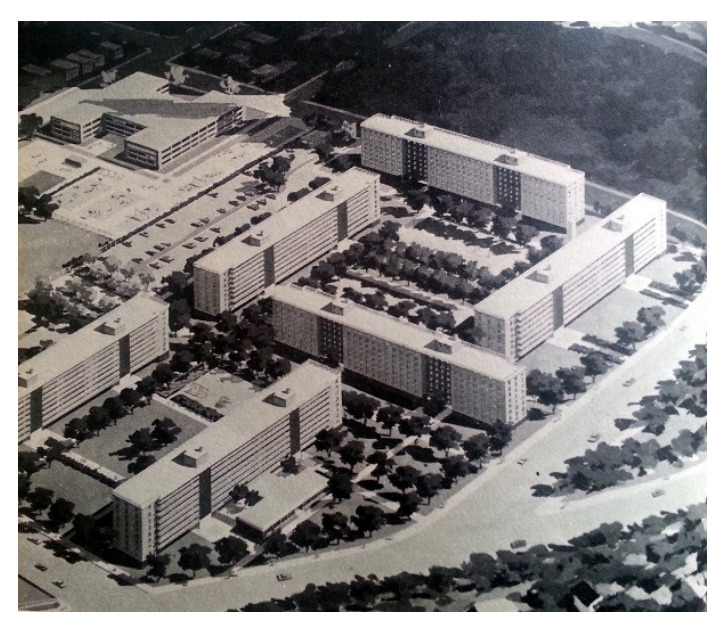

Em Defensible space, Oscar Newman (1973, p. 94) já havia demostrado situação semelhante, indicando que "a justaposição de blocos de edifícios permite o monitoramento dos corredores de um edifício pelos moradores dos apartamentos do outro edifício". Como exemplo, NEWMAN utilizou-se do projeto Stapleton Houses, em Staten Island Nova York.

Figura 33 - Stapleton Houses, em Staten Island - Nova York. Exemplo de justaposição de edifícios. Fonte: Defensible Spaces (1973, p.94). 


\section{ESCALA EDIFÍCIO}

Os temas analisados na escala edifício foram: a circulação nos edifícios e os acessos às unidades; a diversidade de tipologias presentes em cada tipo de edifício e questões relacionadas à estrutura e às aberturas.

\section{Acessos e circulação \\ no edifício}

A grande discussão que gira em torno da circulação nos edifícios é a instalação ou não de elevadores. De acordo com as Diretrizes de Projetos de Edificação,

Devido à escassez de terrenos para promoção de Empreendimentos de Habitação de Interesse Social (EHIS) na cidade de São Paulo, o projeto deverá buscar atingir o coeficiente de aproveitamento máximo definido pela legislação vigente, viabilizando a implantação do maior número de unidades habitacionais permitido.

Caso não seja possível atingir o coeficiente de aproveitamento máximo sem o uso de elevadores, o projeto deverá incorporar o equipamento em sua solução.

Caso o projeto atenda ao coeficiente máximo de aproveitamento sem o uso de elevador, reservar espaço para o poço de elevador, para futura instalação do equipamento (PREFEITURA DE SÃO PAULO, 2012b, p. 243).

Considerando-se os quatro projetos analisados e os outros vinte e três visitados e estudados, apenas o Jardim Edite possui elevador. Como foi possível verificar na análise desse conjunto, essa decisão esteve totalmente relacionada à solução projetual e à proposta das torres e não ao coeficiente de aproveitamento, que mesmo com o uso de elevadores, não atingiu o máximo permitido. 
Seguindo as diretrizes da Secretaria de Habitação, os conjuntos Real Parque e Corruíras já incorporaram ao projeto torres de previsão para os elevadores, como a que pode ser observada na Figura 34.

As visitas aos dois conjuntos permitiram observar que os volumes dessas torres, "ocas" atualmente, representam interferência nos projetos. A sensação que se tem é que são volumes que foram anexados ao projeto depois de pronto. Tanto no Real Parque, como no Corruíras, notou-se que as torres criam espaços mais escuros nas passarelas e interferem na visibilidade de parte da circulação.

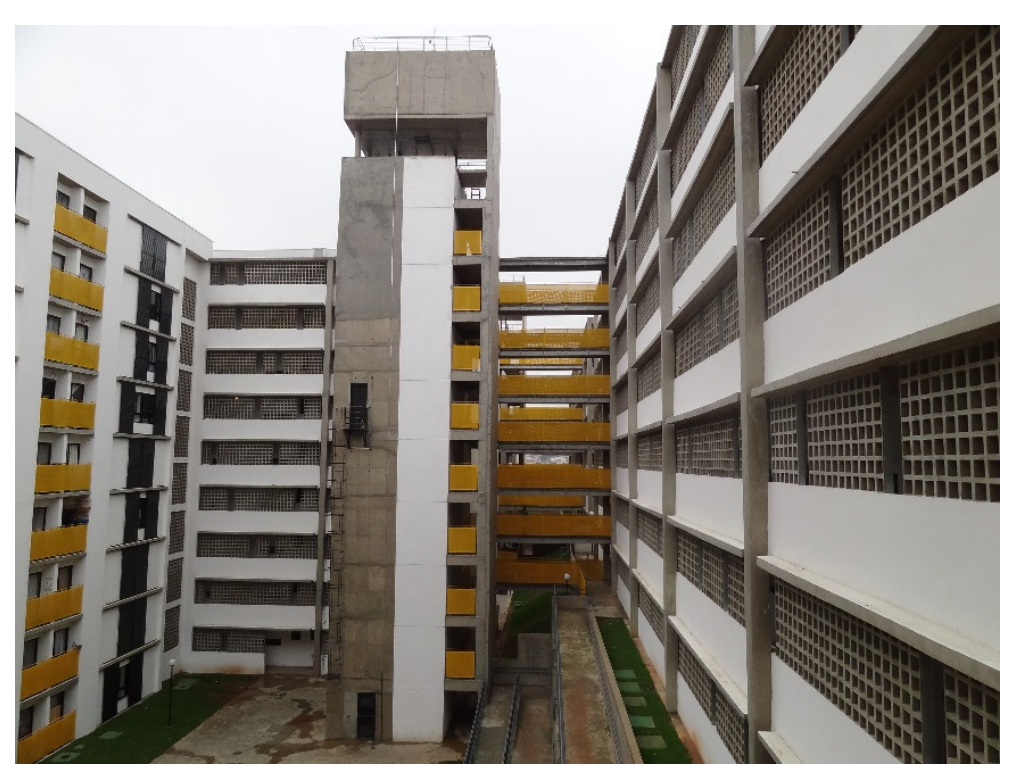

Figura 34 - Projeto: Corruíras. Arquitetura: Boldarini Arquitetura e Urbanismo.

Além disso, podemos nos perguntar: se a própria prefeitura não foi capaz de custear a instalação dos elevadores, será que os moradores serão? Talvez tenhamos a resposta dentro de alguns anos. No momento, apenas podemos afirmar que existe um elemento "sobrando" nos conjuntos, que não possui nenhuma função.

Em todos os projetos analisados a circulação interna e o acesso às unidades ocorrem através de passarelas. Essa situação, apesar de proporcionar os espaços de convivência e socialização, conforme estudado no item acessos e circulação no conjunto, exige que estratégias projetuais sejam implantadas para garantir a privacidade das unidades que estão em contato direto com essas circulações. 
No projeto Comandante Taylor as passarelas foram afastadas das fachadas dos edifícios criando um vazio entre eles que protege as janelas do acesso direto de quem circula pelas passarelas (páginas 126 e 135). A solução adotada também proporcionou um hall de acesso às unidades, classificado como espaço de transição.

Nas torres do Jardim Edite, no projeto Santo Amaro V e também no Heliópolis Gleba H (Figura 27), a solução adotada foi elevar as janelas voltadas para as passarelas, garantindo a privacidade, mas mantendo a ventilação e iluminação, mesmo que indireta.

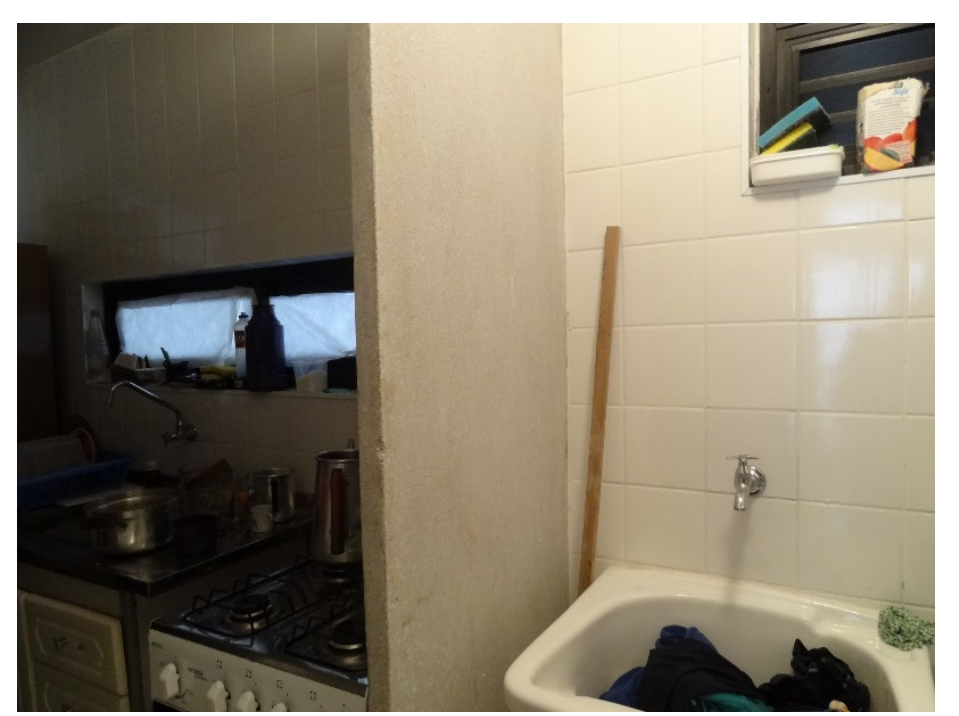

Figura 35 - Projeto: Corruíras. Arquitetura: Boldarini Arquitetura e Urbanismo.

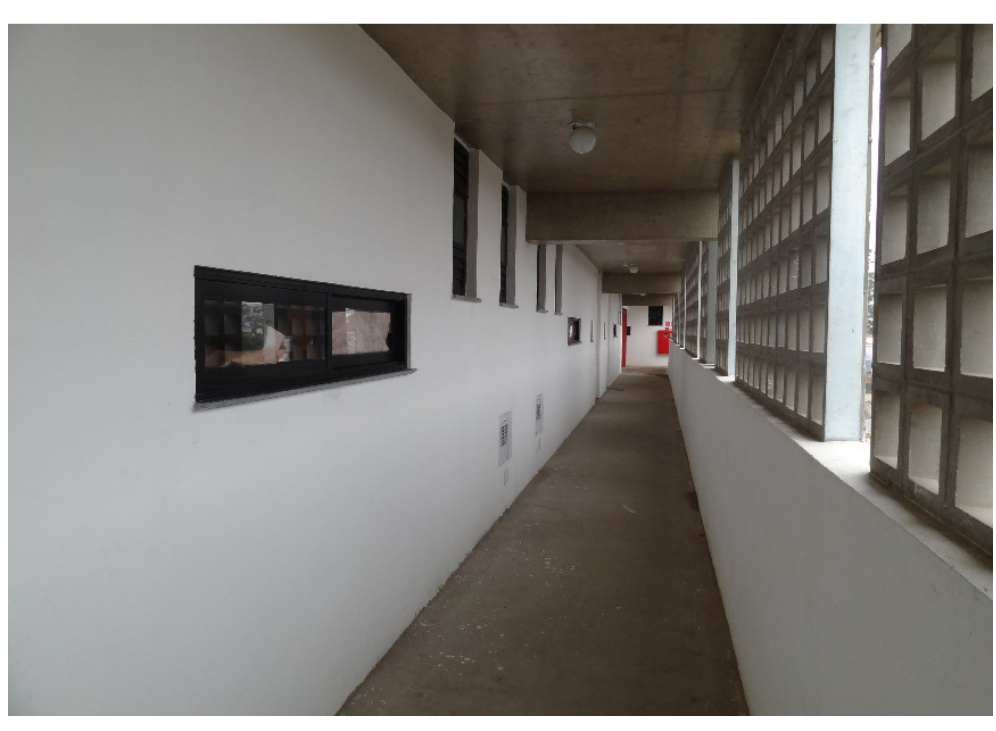

Figura 36 - Projeto: Corruíras. Arquitetura: Boldarini Arquitetura e

No projeto Corruíras (Figura 35; Figura 36) foram propostas janelas com altura intermediária na cozinha e na sala de estar. Baseado na visita realizada ao conjunto, verificou-se que essa solução não agradou às moradoras. Em várias situações, foi possível identificar papeis ou cortinas tampando essas aberturas. Conversando com algumas moradoras foi possível reconhecer que se sentiam incomodadas com a altura dessas janelas. Segundo depoimento 
de uma moradora "eu tampei porque qualquer pessoa que passa pelo corredor, fica olhando para dentro da minha casa"20.

Ao percorrer o conjunto Corruíras, comprovou-se que de fato, a solução adotada interfere na privacidade dos moradores. Contudo, consultando projetos de casas emblemáticas construídas entre os anos 1940 e 1960, verificamos soluções para a iluminação e ventilação das cozinhas que apresentam certa semelhança, sendo, porém, muito mais engenhosas, por separar as funções da iluminação e da ventilação.

$\mathrm{Na}$ imagem ao lado (Figura 37), vemos a cozinha da residência do arquiteto Rino Levi e o sistema de iluminação e ventilação proposto. As venezianas localizam-se na parte superior, para a saída do ar e, na altura do plano de trabalho, conta-se apenas com a

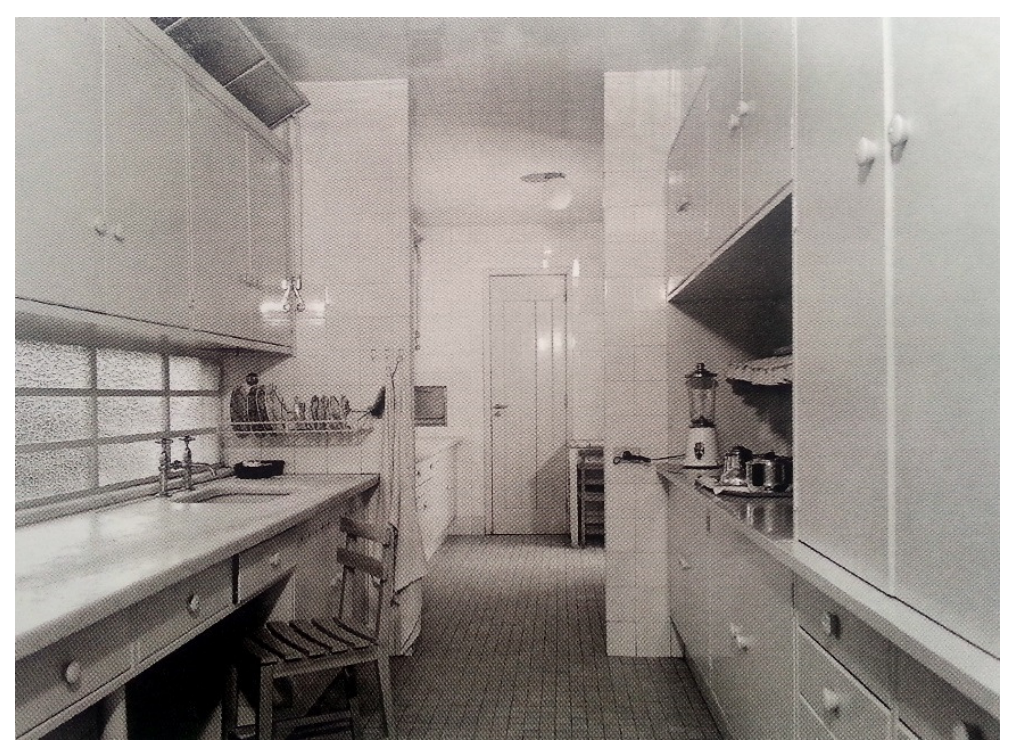

Figura 37 - Residência Rino Levi - Rua Bélgica, 1944. iluminação.

Mônica Junqueira de Camargo ensinou, durante as aulas da pós-graduação ${ }^{21}$, que o arquiteto Carlos Milan dedicou-se ao entendimento da função da janela e também utilizava-se da estratégia da dupla faixa de iluminação. Entre outros exemplos, essa solução foi adotada na Residência Roberto Milan (1960).

${ }^{20}$ Conversa com moradoras do Residencial Corruíras. Visita realizada em setembro de 2013.

${ }^{21}$ Programa de Pós Graduação da Faculdade de Arquitetura e Urbanismo da USP - Disciplina: Arquitetura Contemporânea Paulista / Crítica de arquitetura. Professores responsáveis: Mônica Junqueira de Camargo; Hugo Segawa. São Paulo: julho de 2013. 
Outro tema que envolve as circulações dos edifícios é a apropriação desses espaços como extensões dos espaços privados das unidades. Ao realizar as visitas, foi possível registrar muitas situações em que os moradores se apropriaram dos espaços oferecidos pelas passarelas colocando vegetação; utilizando-os para a convivência, colocando cadeiras para fora de casa (Figura 38), etc.

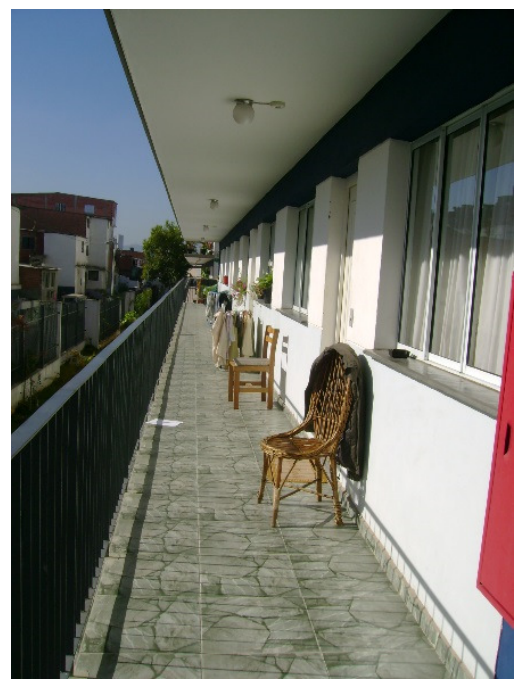

Figura 38 - Projeto: Kenkiti. Arquitetura: Boldarini Arquitetura e Urbanismo.

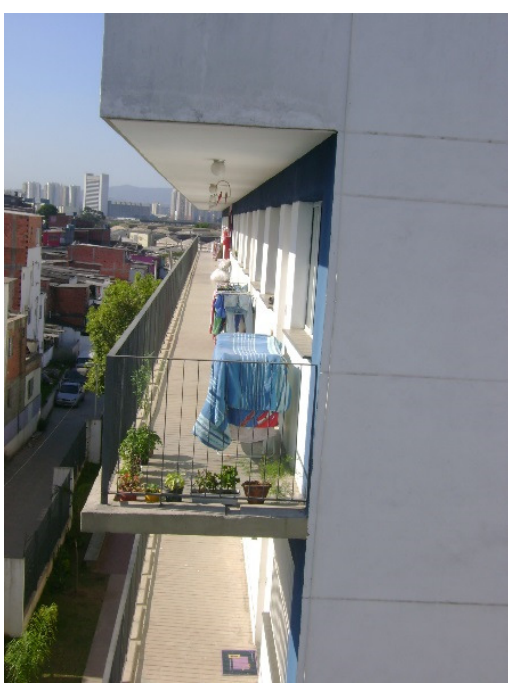

Figura 39 - Projeto: Kenkiti. Arquitetura: Boldarini Arquitetura e

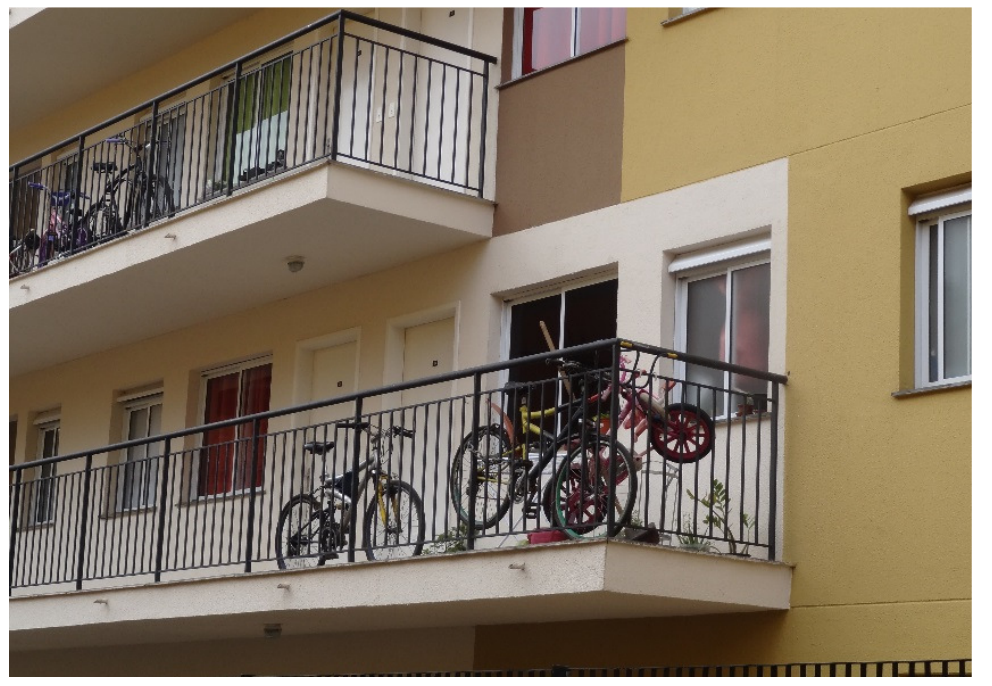

Figura 40 - Projeto: Rocinha. Arquitetura: Arquitetos Urbanistas.

Também é muito comum ver roupas estendidas em varais colocados nas passarelas (Figura 39; Figura 41). Observou-se, porém que, em muitos casos, essa situação ocorre porque as áreas de serviço são espaços pequenos e não possuem iluminação e ventilação adequada.

Outra situação observada foi a das bicicletas penduradas nas passarelas (Figura 40). Identificou-se, porém, que essa situação ocorre porque, conforme foi alertado no item espaços exteriores, os edifícios não contam com 
espaços comuns para guardar esses grandes objetos e, com isso, os moradores se vêm obrigados a levar suas bicicletas para a frente de suas casas.

Com relação à falta de espaço para secar roupas, vale ressaltar que, nos projetos Alexandre Mackenzie (edifícios mais altos) e Kenkiti (Figura 42) foi proposto, na cobertura, uma área de uso comum onde os moradores podem secar suas roupas. Esses espaços são muito úteis e deveriam ser considerados também nos outros projetos, uma vez que as áreas de serviço são, na maioria dos casos, espaços mínimos.

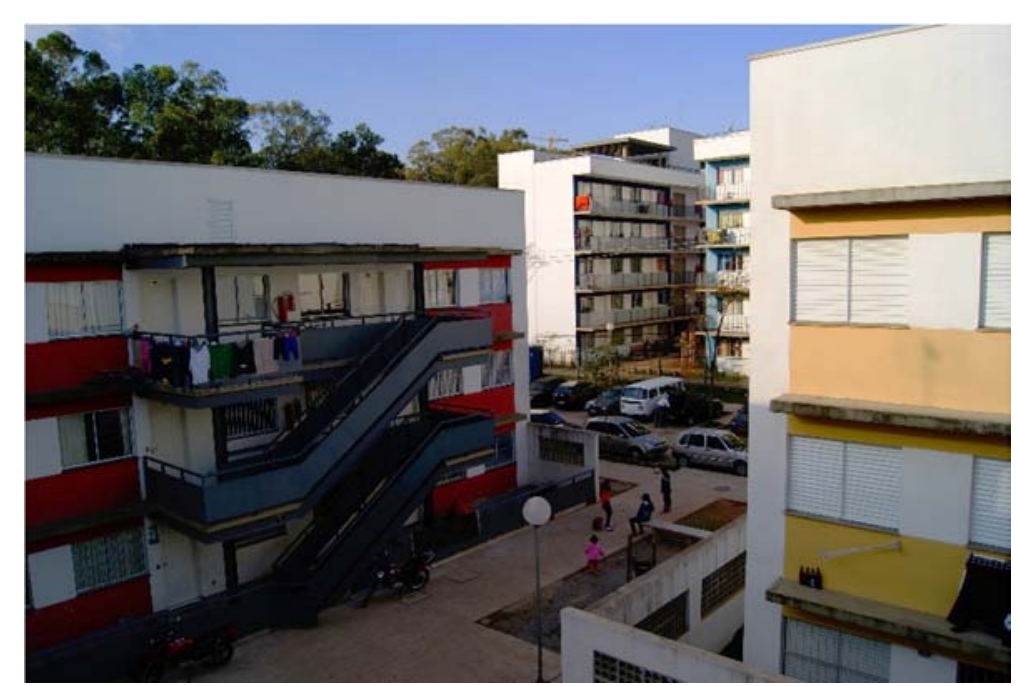

Figura 41 - Projeto: Alexandre Mackenzie. Arquitetura: Boldarini Arquitetura e Urbanismo

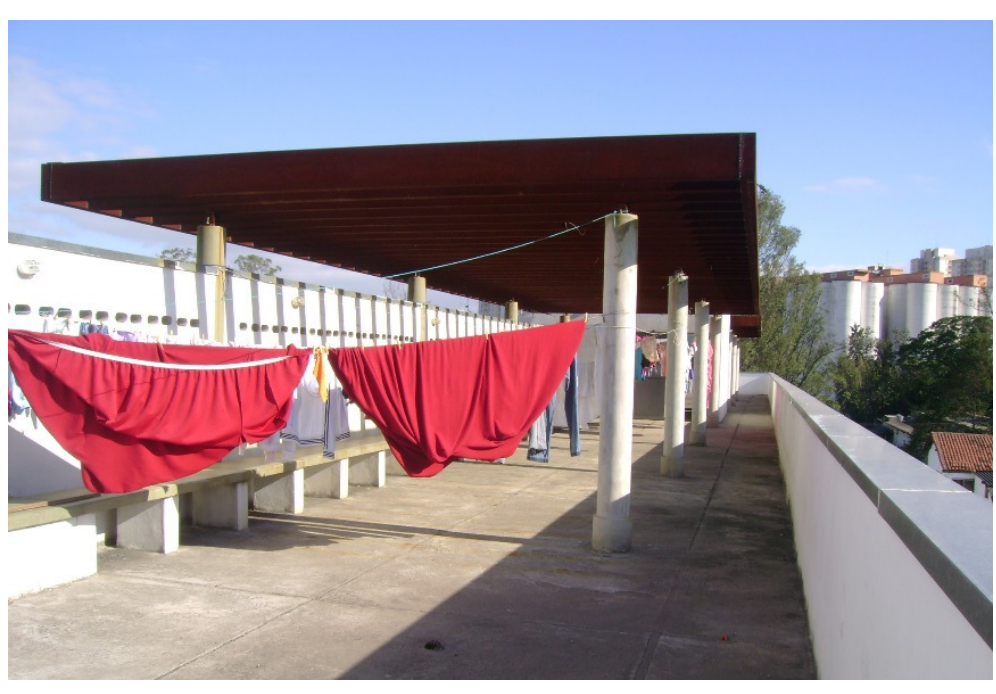

Figura 42 - Projeto: Kenkiti. Arquitetura: Boldarini Arquitetura e Urbanismo

Fica claro, portanto, a deficiência de oferta de espaços de uso comum nos projetos de conjuntos habitacionais. As situações identificadas, como falta de espaços para estender as roupas ou falta de espaços adequados para guardar bicicletas e outros objetos que não cabem dentro de casa, poderiam ser solucionadas com a implantação 
de espaços comuns para esses usos. Os problemas identificados são recorrentes na maior parte dos projetos visitados e, se não houver uma mudança de atitude, permanecerão comprometendo a qualidade desses edifícios.

A proposta de lavanderias coletivas e outros espaços de uso comum, não são simples de serem implantadas nos edifícios de habitação social, principalmente devido à dificuldade da gestão. Reidy já havia proposto lavanderias comuns nos conjuntos Pedregulho e da Gávea durante os anos 1950. Porém, de acordo com Flavia Brito do Nascimento (2008, p.153) "a lavanderia foi, também, grande questão para os moradores do Pedregulho. Segundo relatório do serviço social, houve resistência a seu uso, tendo sido preciso criar um sistema invisível de marcação de roupas para evitar constrangimentos". Por dificuldade de gestão ou por constrangimento, o fato é que a incorporação de lavanderias coletivas ou apenas espaços coletivos para secar as roupas, são, ainda hoje, um tema polêmico e de difícil aceitação para os edifícios de habitação de interesse social.

É preciso compreender que as unidades habitacionais são apartamentos de áreas mínimas que poderiam ser melhoradas se pudessem contar com o uso de espaços coletivos. Entende-se, porém, que essa situação envolveria mudanças no modo de habitar, assim como as discutidas na Europa dos anos 1920.

Guilherme Wisnik resgata o tema dos apartamentos mínimos:

O advento da arquitetura moderna na Europa, no início do século 20, representou a invenção de um "novo morar", em que a ociosidade espacial da mansão burguesa, dependente do trabalho abundante de serviçais, é substituída pela compactação dos ambientes (Existenzminimum), pela redução ou eliminação dos espaços exclusivos de circulação (corredores), e pela racionalização de cômodos vitais para o trabalho diário, como a cozinha, equipados por artefatos industriais e integrados às áreas de estar (WISNIK, 2009, p. 15). 
Ainda, com relação à arquitetura moderna da Europa do início do século 20, se deseja relembrar que nos conjuntos de habitação social construídos na época, os apartamentos de dimensões mínimas eram complementados por áreas coletivas como cozinhas e áreas de serviço, como ocorreu no projeto Karl-Marx-Hof, por exemplo.

Sobre o Existenzminimum e a nova cultura da habitação, Paulo Bruna (2010, p. 62), comenta que "os grandes equipamentos coletivos do bairro - as lavanderias, as creches, as salas de reunião - permitiram levar para fora de casa as tarefas domésticas, contribuindo para a evolução do conceito de família". Quase um século mais tarde, os projetos de habitação de interesse social continuam "espremendo" suas áreas de serviço dentro dos apartamentos de $50 \mathrm{~m}^{2}$.

\section{Diversidade tipológica}

\section{De acordo com Instrumentos de Avaliação de Projetos:}

Os edifícios de habitação coletiva devem ter a capacidade de adequar-se aos diferentes grupos de convivência existentes na sociedade contemporânea. Com o objetivo de favorecer a integração social e evitar qualquer discriminação, os edifícios residenciais devem oferecer a seus habitantes uma adequada diversidade de tipologias, podendo prever inclusive os possíveis mecanismos de associação/junção ou dissociação das unidades. Além disso, deve-se evitar a exclusão daqueles que possuem outras capacidades motoras ou sensoriais, motivo pelo qual deve-se tentar alcançar a plena acessibilidade nas das unidades e dos espaços comuns. Sempre que possível, o edifício de habitação deve corresponder ao perfil dos habitantes para os quais estão sendo construídos (PREFEITURA DE SÃO PAULO, 2012b, p.209).

Nos projetos analisados, foi possível observar o desenvolvimento de tipologias que correspondessem ao perfil dos habitantes, principalmente nos casos em que houve maior contato com a população. No Real Parque a arquiteta Geni Sugai comentou que os moradores não aceitaram as unidades duplex que estavam sendo desenvolvidas e, 
com isso, o projeto foi alterado para atendê-los. ${ }^{22}$ No Santo Amaro V, unidades com três dormitórios foram projetadas para atender a demanda de famílias numerosas e no Comandante Taylor, o contato com os futuros moradores definiu a proposta de apartamentos tipo quitinetes para idosos.

Contudo, os arquitetos vivem um conflito entre desejar desenvolver tipologias específicas para os diferentes perfis e atender às normas que envolvem a produção de habitação de interesse social.

De acordo com o Decreto de HIS, as unidades de interesse social não podem apresentar área útil interna maior que $50 \mathrm{~m}^{2}{ }^{23}$. Essa é uma normativa municipal que rege a produção realizada pela Prefeitura de São Paulo. Entretanto, há também as regras específicas do Programa Minha Casa Minha Vida (MCMV), ${ }^{24}$ gerido pela Caixa Econômica Federal (CEF) - financiador federal da produção de habitação social. De acordo com as especificações para empreendimentos (apartamentos) de até 3 salários mínimos, a área útil mínima recomendada é de 37,00m² e

22 SUGAI, Geni. Entrevista: Conjunto Habitacional Real Parque. São Paulo, 27 de novembro de 2013.

${ }^{23}$ Revisão do Decreto Habitacional de Interesse Social (versão 26-abril-11). Revisão do Decreto Municipal 44.667/04 - ZEIS, Empreendimentos Habitacionais de Interesse Social, parcelamento do solo de interesse social, Habitação de Mercado Popular.

Art. 22- A unidade de HIS deverá seguir os seguintes padrões construtivos:

I. área útil máxima igual a $50,00 \mathrm{~m}^{2}$ (cinquenta metros quadrados);

II. apenas 1 (um) sanitário, podendo ser previstas peças sanitárias em espaços separados;

III. pé direito mínimo de 2,30m (dois metros e trinta centímetros) para as cozinhas, banheiros e áreas de serviço;

IV. pé direito mínimo de $2,40 \mathrm{~m}$ (dois metros e quarenta centímetros) para os demais compartimentos;

V. no máximo 1 (uma) vaga de estacionamento.

$\S 2^{\circ}$. Não são consideradas, no cálculo da metragem de área útil fixada como limite máximo de metragem de unidade habitacional, as áreas: (Decreto 49.130/08)

I. da vaga de estacionamento coberta, quando houver; (Decreto 49.130/08)

II. de terraços de no máximo 10\% (dez por cento) da área útil da unidade de HIS; (Decreto 49.130/08)

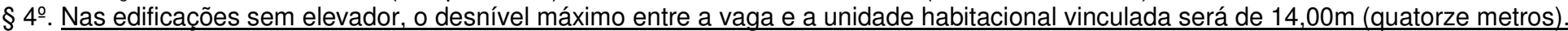

${ }^{24}$ CAIXA ECONÔMICA FEDERAL (CEF). Cartilha Programa Minha Casa Minha Vida. Disponível em:

$<$ http://www1.caixa.gov.br/gov/gov_social/municipal/programas habitacao/pmcmv/documentos download.asp >. Acesso em setembro de 2013. 
o programa exigido é: "Apartamento com sala / 1 dormitório para casal e 1 dormitório para duas pessoas / cozinha / área de serviço / banheiro".

Respeitando ainda o programa de financiamento estadual, o Programa Casa Paulista, ${ }^{25}$ a área útil máxima é de $43,00 \mathrm{~m}^{2}$ e o programa exigido é igual ao do Minha Casa Minha Vida.

Frente a todas as restrições impostas pelos programas - que vão além da área útil dos apartamentos -, os arquitetos se vêm "engessados" durante a criação e o desenvolvimento dos projetos. Fazer unidades habitacionais de qualidade, que correspondam ao perfil dos moradores e que, acima de tudo respeitem as normas impostas, é atualmente, o grande desafio a ser enfrentado.

Segundo Pablo Benetti (2012, p.90) "o diálogo surdo entre a oferta do Estado e a demanda dos moradores que, em muitos momentos caracteriza a oferta de habitação, somente poderá ser superado no momento em que os moradores sejam sujeitos efetivos desta demanda". Para o autor,

Os erros que são cometidos nesta oferta de habitação somente serão sentidos muito tempo depois numa perda evidente de qualidade urbana. No rastro da implosão do Pruit Iggoe, nos EEUU, a maior parte dos recursos do Departamento de Habitação e Desenvolvimento Urbano da década de 90, foram destinados a essa finalidade.

[...] Apresentar essas questões na agenda de discussão é um desafio para a classe de arquitetos, e um desafio direto para a formação de nossos estudantes (BENETTI, 2012, p. 90).

O arquiteto Hector Vigliecca declarou que, para ele, o que está acontecendo atualmente é uma "grande confusão histórica e conceitual por parte do poder burocrático da Caixa Econômica Federal, por acreditar que, ao

25 PROGRAMA CASA PAULISTA - Secretaria da Habitação do Estado de São Paulo. Disponível em:

<http://www.habitacao.sp.gov.br/casapaulista/casa-paulista-form/Index.html>. Acesso em janeiro de 2014. 
estabelecer normas mensuráveis, sairá um bom projeto". Para o arquiteto, isso não é verdade, porque "a arquitetura e o urbanismo, fazer uma cidade, fazer um bairro, não é uma equação matemática". Vigliecca comenta que está de acordo com a definição de dimensionamentos básicos e mínimos. Para ele, "estabelecer conceitos que têm que ser respeitados, é bom." Contudo, "uma coisa é estabelecer um conceito e permitir, dar a liberdade de propor e acrescentar". O que não pode ocorrer é que o arquiteto se veja condicionado a aplicar um modelo fechado, pré-concebido. Para Vigliecca, isso representa um erro histórico e conceitual. Para finalizar, o arquiteto comenta que realizar projetos que atendam às normas impostas é como "tirar leite das pedras". (informação verbal) ${ }^{26}$

Fica aqui registrado, portanto, a importância de propor uma variedade de tipologias que atendam às necessidades dos moradores. Contudo essa missão não é simples e exige muito dos arquitetos que, se for preciso, deverão "tirar leite das pedras" para realizar um projeto de qualidade. Conhecer os projetos realizados e poder analisar os conceitos aplicados em cada um, contribui para aumentar as referências relacionadas ao tema, ou seja, aumentar o repertório de projetos de habitação social poderá ajudar no desenvolvimento de novos projetos.

\section{Estrutura e aberturas}

A maior parte dos projetos adotou a alvenaria de bloco estrutural. Essa escolha está relacionada, na maioria dos casos, ao custo. Os únicos projetos que foram construídos com estrutura convencional foram o Jardim Edite e o Sabesp, o primeiro devido aos equipamentos no térreo e ao grande número de andares das torres. Aliás, as soluções apresentadas de armários nas fachadas e do banco no corredor de acesso às unidades, não poderiam ser executadas se o projeto não fosse construído com estrutura convencional de concreto moldado in loco (página 
202). Quanto ao segundo projeto, a forma curva dos edifícios e as soluções adotadas conduziram ao uso da estrutura convencional.

As decisões construtivas afetam diretamente a habitabilidade das unidades em três aspectos fundamentais: em primeiro lugar, um sistema estrutural adequado pode permitir a disposição de uma unidade livre de elementos estruturais fixos, permitindo possíveis reorganizações. O sistema construtivo mais utilizado é o da alvenaria estrutural, que poderá ser substituído por outro, desde que seja economicamente viável. Além disso, a definição do sistema construtivo deverá considerar a adequação ao partido adotado, tempo e custo de execução, mão de obra disponível, acesso ao terreno e logística. Em segundo lugar, a distribuição das aberturas nas fachadas pode ampliar as possibilidades de compartimentação. Por último, é recomendável que a distribuição das instalações facilite seu acesso sem comprometer a compartimentação no interior da unidade (PREFEITURA DE SÃO PAULO, 2012b, p.296).

Entende-se, portanto, que a concepção de uma estrutura "limpa" e racional contribui para o bom aproveitamento dos espaços interiores e posicionamento das aberturas. As concentração das áreas molhadas e o posicionamento das instalações, para que ofereçam condições adequadas de acesso e manutenção, também são itens importantes para a economia e flexibilidade dos edifícios.

Entre os projetos construídos com bloco estrutural, merece destaque o projeto de Paraisópolis (Figura 43), pois apresenta flexibilidade espacial, uma vez que as paredes internas não são estruturais e permitem que o interior dos apartamentos seja alterado sem interferir na estrutura. 


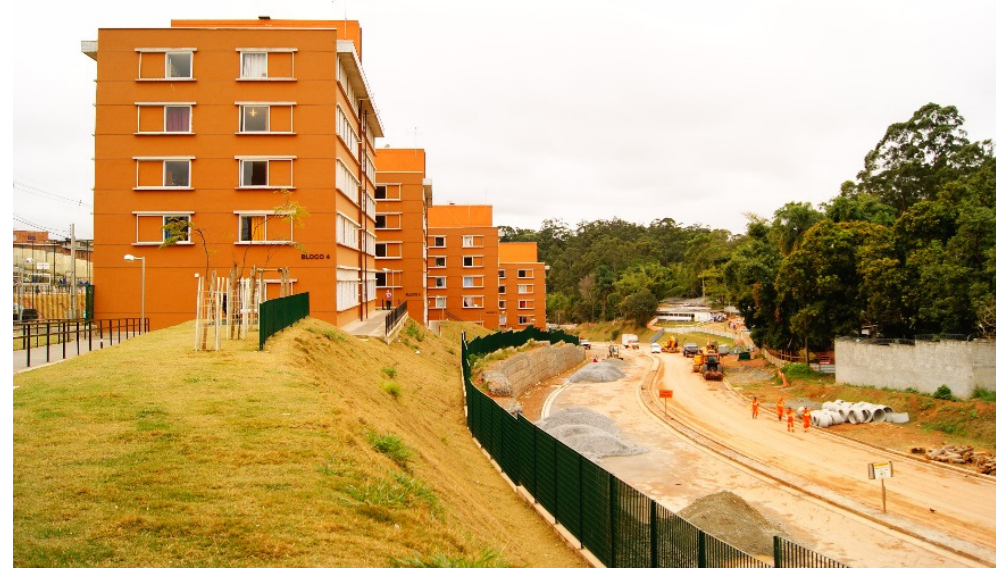

Figura 43 - Projeto: Paraisópolis - condomínio F. Arquitetura: Elito Arquitetos.

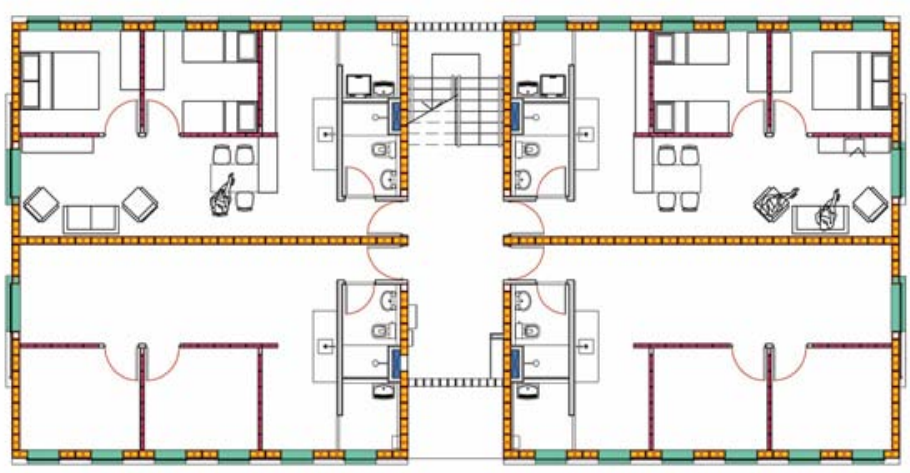

$\square$ Alvenaria de Bloco estrutural

$\square$ Alvenaria de Bloco de vedação

$\square$ shafts

$\square$ dry wall

$\square$ janelas / aberturas

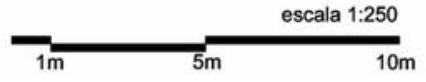

Para isso, o engenheiro responsável pelo projeto, Jorge Zaven Kurkdjian, explicou que, a estrutura foi concebida como uma espinha dorsal liberando assim o interior das unidades. A forma como a estrutura foi concebida também permitiu definir essa série de aberturas nas fachadas que, por serem todas iguais, não comprometem a flexibilidade de uso dos espaços internos. A existência de aberturas nas laterais dos edifícios é muito positiva para a sensação de segurança e para a visibilidade dos espaços públicos a partir das janelas dos apartamentos, conforme os conceitos de Jane Jacobs (1961) e Oscar Newman (1973) discutidos no item espaços exteriores. 


\section{ESCALA UNIDADE}

Mais além da mera denominação funcional dos espaços, a unidade habitacional deve permitir a realização de uma inumerável quantidade de tarefas, deve conjugar o individual e o coletivo: viver juntos e independentemente ao mesmo tempo, descansar, trabalhar, movimentar-se comodamente e poder armazenar. Pensar a unidade habitacional do início do século XXI significa repensar as premissas que lhe deram forma (MONTANER; MUXÍ, 2006, p. 26) 27 .

Josep Maria Montaner e Zaida Muxí realizam uma reflexão sobre a relação dos interiores domésticos com a estrutura hierárquica da família burguesa patriarcal e verificam que os modos de vida mudaram muito nos últimos cinquenta anos. Um dos maiores exemplos dessa mudança foi a inserção da mulher no mercado de trabalho, deixando de ser exclusivamente responsável pelo interior doméstico. Segundo os autores, "Hoje, as premissas de modos de vida muito estáveis já não existem, contudo a distribuição espacial e o conceito de habitação variaram muito pouco em relação às grandes transformações sociais" (MONTANER; MUXí, 2006, p. 26).

A citação de MONTANER e MUXÍ se refere à sociedade de forma geral, mas se formos analisar a situação particular das famílias de classe baixa - população a ser atendida pelos conjuntos habitacionais em estudo veremos que a estrutura familiar é bastante distinta da família burguesa que embasou a concepção dos espaços interiores de nossas casas. Na grande maioria dos casos, as mulheres são as responsáveis pela manutenção do lar e são poucas as situações em que podem contar com seus companheiros homens. Muitas mulheres vivem com os filhos, ou com as mães e os filhos, representando uma formação familiar distinta, que não é considerada no padrão de habitação de $50 \mathrm{~m}^{2}$ com dois dormitórios, sendo um para casal e outro para duas camas de solteiro, conforme manual Minha Casa Minha Vida.

27 Tradução realizada pela autora. 
Guilherme Wisnik, ao falar sobre a organização dos edifícios de São Paulo - de forma geral, sem referir-se à habitação popular - baseado em autores como Roger Bastide e Gilberto Freyre, compara os edifícios com "empilhamentos de casarões-senzalas coloniais miniaturizados":

Hoje em São Paulo, mais de meio século depois das observações de Bastide, apartamentos cada vez menores continuam compartimentando ad infinitum os seus ambientes a ponto de manter, religiosamente, uma senzala inabitável junto à cozinha - quarto, banheiro e área de serviço -, devidamente isolada da área social, no entanto, por uma copa. Não me refiro, aqui, à habitação popular, mas a um padrão de classe média que privilegia lavabos, playgrounds e vagas para automóvel em detrimento de melhores espaços para moradia (WISNIK, 2009, p. 16)

Está claro que o programa descrito por WISNIK não se aplica diretamente às unidades de habitação social. Contudo, ao analisar os projetos, foi possível perceber que a mínima setorização ainda permanece dentro dessas unidades de dimensões reduzidas, como poderemos observar na unidade do projeto Corruíras que analisaremos mais adiante (Figura 44, página 498).

Ciente dessas considerações, a análise da escala unidade buscou identificar, nos projetos, alguns critérios que proporcionassem espaços mais flexíveis e menos hierárquicos.

De acordo com o catálogo Habitar el Presente (2006, p. 25) as recomendações para uma casa sem hierarquias são:

Favorecer a vida comunitária ao mesmo tempo que a individualidade de cada componente do grupo.

Levando-se em consideração que a casa é um lugar onde se trabalha, considerar os espaços necessários para realizar as atividades e para guardar os elementos utilizados.

A distribuição dos banheiros: utilizar bem o espaço favorecendo a máxima possibilidade de uso simultâneo [...]

Favorece a visibilidade e o compartilhamento do trabalho na cozinha, com isso recomenda-se fugir dos espaços mínimos estabelecidos que a consideram um lugar de trabalho solitário e individual. 
A integração da cozinha com a sala de jantar separadas da sala de estar oferece a possibilidade de ter dois espaços comunitários para o grupo. [...] Permitir que haja um obstáculo visual da cozinha, quando desejado.

Espaços não hierárquicos. Os diferentes dormitórios todos do mesmo tamanho (quando possível um mínimo de $\left.10 \mathrm{~m}^{2}\right)$ que permitam diferentes atividades de acordo com os grupos [formações familiares]

Espaços para guardar suficientes, considerando as características dos elementos a serem guardados e oferecendo soluções diferenciadas. [...] (MONTANER; MUXí, 2006, p. 25) 28.

Com bases nessas recomendações e em critérios que proporcionam melhores qualidades espaciais, a análise da escala unidade definiu-se a partir de quatro itens principais: o estudo dos ambientes não especializados; dos ambientes especializados; das relações entre os ambientes; e dos espaços exteriores próprios.

Entre todos os critérios observados, merecem destaque, neste capítulo de relações, o estudo do ciclo da roupa e a oferta de espaços exteriores próprios.

\section{Ciclo da Roupa}

As áreas de serviço são um ambiente muito importante dentro das unidades. Como vimos na escala edifício, a oferta de lavanderias de uso coletivo ou mesmo espaços coletivos para secar as roupas ainda são polêmicos e não são bem aceitos pelos moradores.

Como referência quanto aos espaços dedicados às áreas de serviço, podemos citar os projetos Jardim Edite, Corruíras e Santo Amaro V. Nas tipologias duplex do Jardim Edite (página 231) pudemos verificar que as áreas de serviço estavam localizadas nos pavimentos superiores, junto aos banheiros e dormitórios. Ao analisar o ciclo da roupa, nota-se que essa é uma situação ideal, pois a roupa suja sai dos dormitórios e do banheiro em direção à área de serviço e, depois que estão limpas, secas e passadas, voltam para os dormitórios. Com base nesse

28 Tradução realizada pela autora. 
percurso, vemos que não há necessidade que a roupa atravesse a cozinha ou a sala de estar. Entretanto, mesmo compreendendo esse percurso, é válido deixar aqui uma observação: na maioria das situações, a mesma pessoa é responsável pela roupa e pela cozinha e, avaliando-se o desenvolvimento das atividades cotidianas, essas responsáveis (mulheres na grande maioria dos casos) preferem que cozinha e área de serviço estejam próximas.

No projeto Santo Amaro $\mathbf{V}$ as áreas de serviço possuem dimensões adequadas para as atividades aí realizadas (lavar, secar e passar). Além disso, estão relacionadas com as cozinhas, indo de encontro com a necessidade de que essas áreas estejam próximas para facilitar o desenvolvimento das atividades cotidianas.

O projeto Corruíras propõe uma solução a essa necessidade de que a área de serviço esteja próxima à cozinha e, ainda assim, comunicada com banheiro e dormitórios sem que seja preciso atravessar a cozinha. Com relação ao ciclo da roupa, foi proposta uma porta de correr que permite a comunicação direta entre o corredor de acesso aos dormitórios e ao banheiro e à área de serviço. Dessa forma, se a porta está fechada, a área de serviço é acessada apenas através da cozinha, porém, quando a porta está aberta, há um acesso direto ao "corredor íntimo" da unidade, encurtando os percursos realizados pela roupa durante o ciclo de limpeza (Figura 44; Figura 45).

Quanto ao ciclo da roupa, não há dúvidas de que a proposta atende aos critérios de diminuição dos percursos e proximidade dos ambientes envolvidos. Entretanto, analisando-se a planta dessa unidade é inevitável verificar a máxima setorização dos espaços, assim como foi comentado no início do item escala unidade.

Segundo Paulo Bruna as unidades habitacionais continuam sendo reproduzidas como miniaturas da casa burguesa sem compreender os conceitos básicos de unidade mínima (informação verbal) ${ }^{29}$. 
A parede proposta entre a cozinha e o corredor "intimo", analisando-se friamente, é apenas um capricho formal, pois se esses espaços fossem integrados, ganhar-se-ia mais área útil e aproveitável dentro da unidade em detrimento da perda de um corredor que setoriza essa unidade de apenas $50 \mathrm{~m}^{2}$.

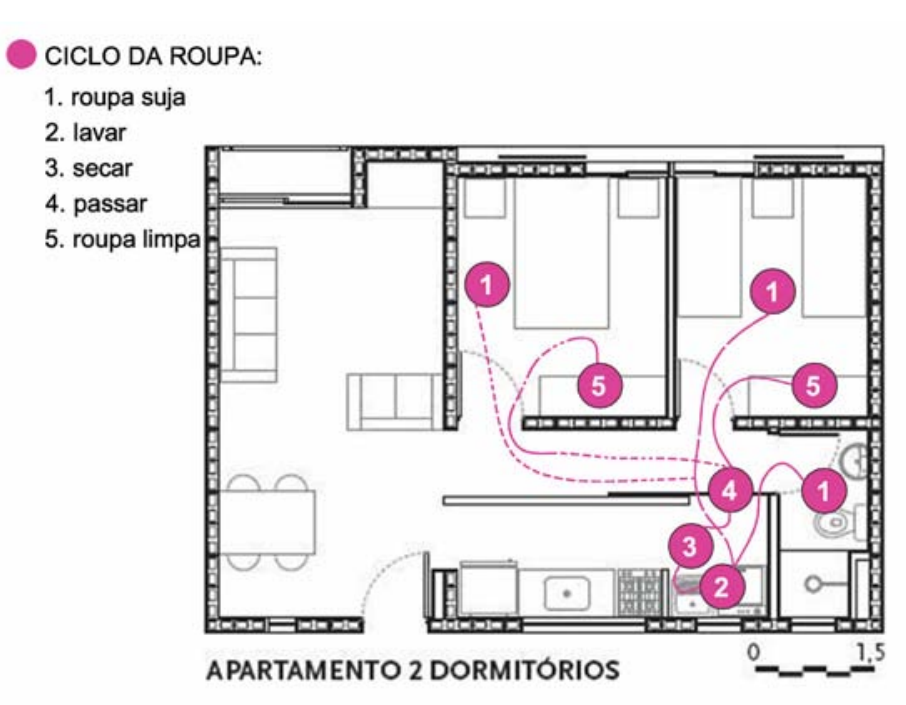

Figura 44 - Planta unidade habitacional. Projeto: Corruíras. Arquitetura: Boldarini Arquitetura e Urbanismo.

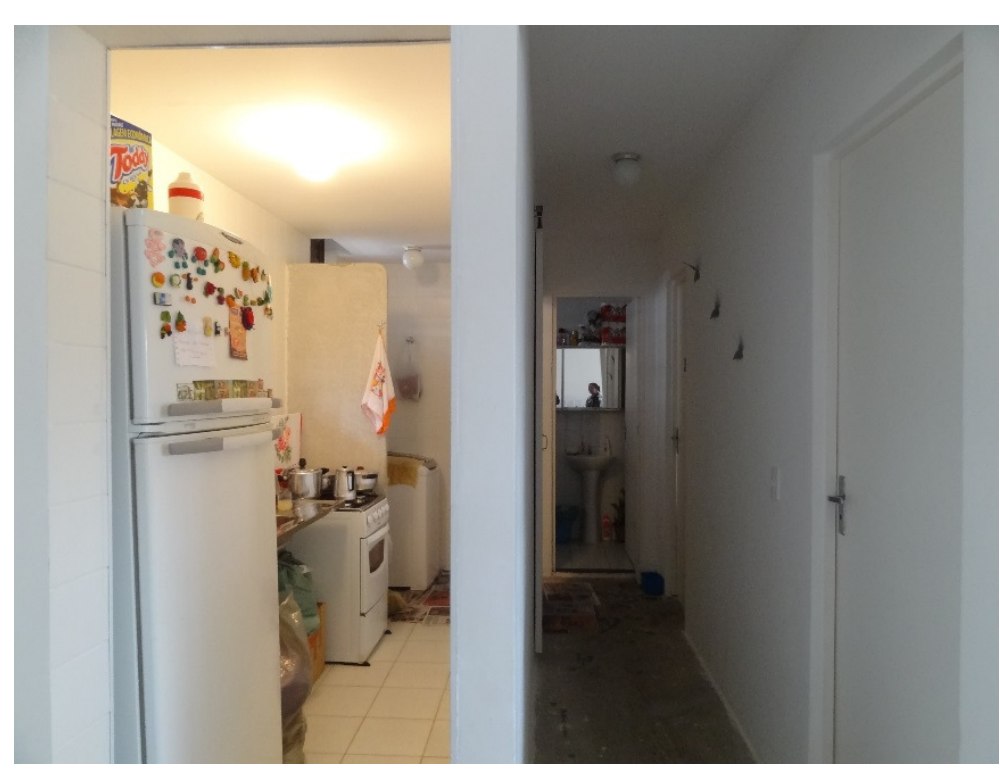

Figura 45 - Cozinha e área de serviço (à esquerda) e corredor de acesso aos dormitórios (à direita) com banheiro ao fundo. Parede mais porta de correr dividindo os espaços.

Entre os projetos estudados, a unidade do Edifício Iguaçu ${ }^{30}$ merece destaque pela proposta de relação entre os espaços. Nota-se, na planta do pavimento tipo (Figura 46), que não há corredor na unidade. A sala de estar é um

${ }^{30}$ Para mais informações sobre o Edifício lguaçu consultar: Revista AU - ARQUITETURA E URBANISMO. Ano 28 - ํo 228. Habitação Social. São Paulo: ed. Pini, março de 2013. 
amplo espaço que acessa a todos os outros ambientes (Figura 47). As janelas altas proporcionam maior privacidade e boa iluminação (Figura 48).

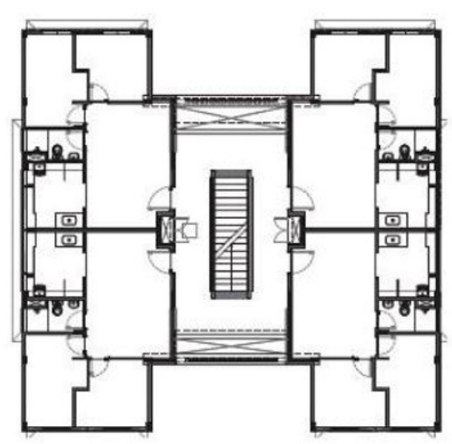

PAVIMENTO-TIPO

Figura 46 - Pavimento tipo Edifício Iguaçu. Arquiteto Marcelo Suzuki.

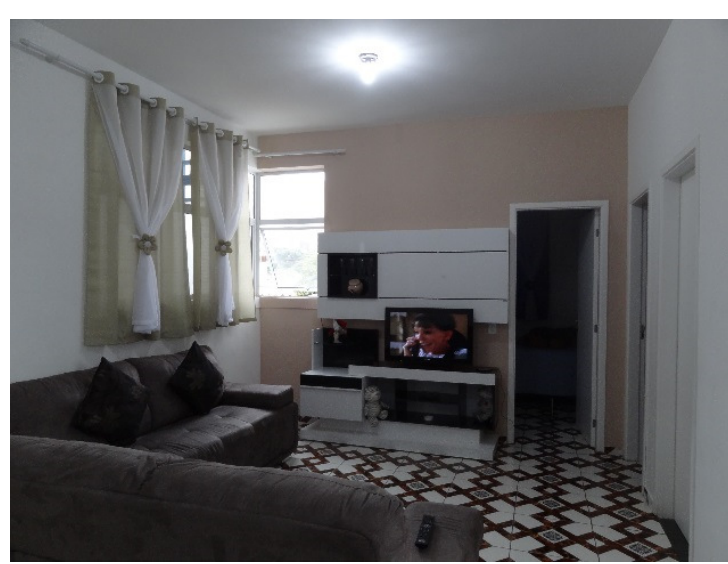

Figura 47 - Sala de estar Ed. Iguaçu.

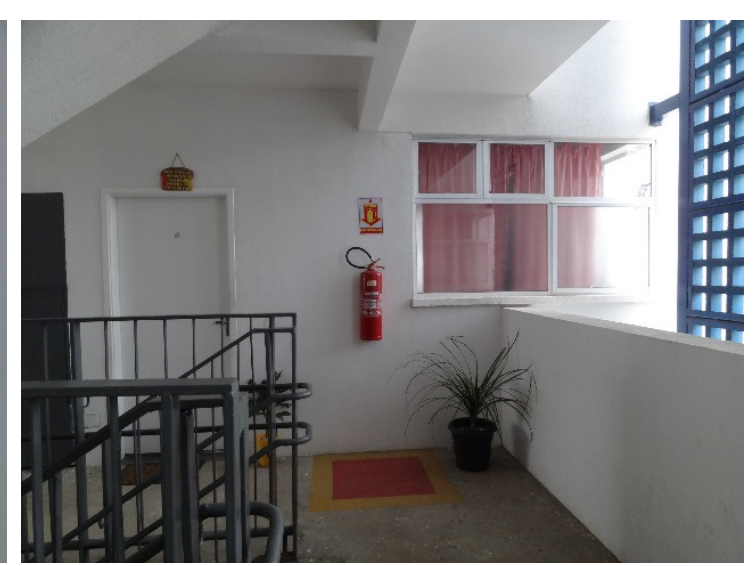

Figura 48 - Janelas altas e em quina. Captam luz e favorecem a privacidade.

\section{Espaço exterior próprio}

Os ambientes privados que dispõem de uma relação mais direta e próxima com a cidade são os espaços exteriores das unidades. São os lugares intermediários que relacionam a atividade pública com o retiro privativo e potenciam a socialização do habitante. Tanto varandas, coberturas e galerias, como pátio - comuns ou privativos - incidem favoravelmente na identificação espacial do ser humano com a cidade, ao mesmo tempo que podem propor perspectivas agradáveis e melhoras do controle climático (PREFEITURA DE SÃO PAULO, 2012b, p. 306). 

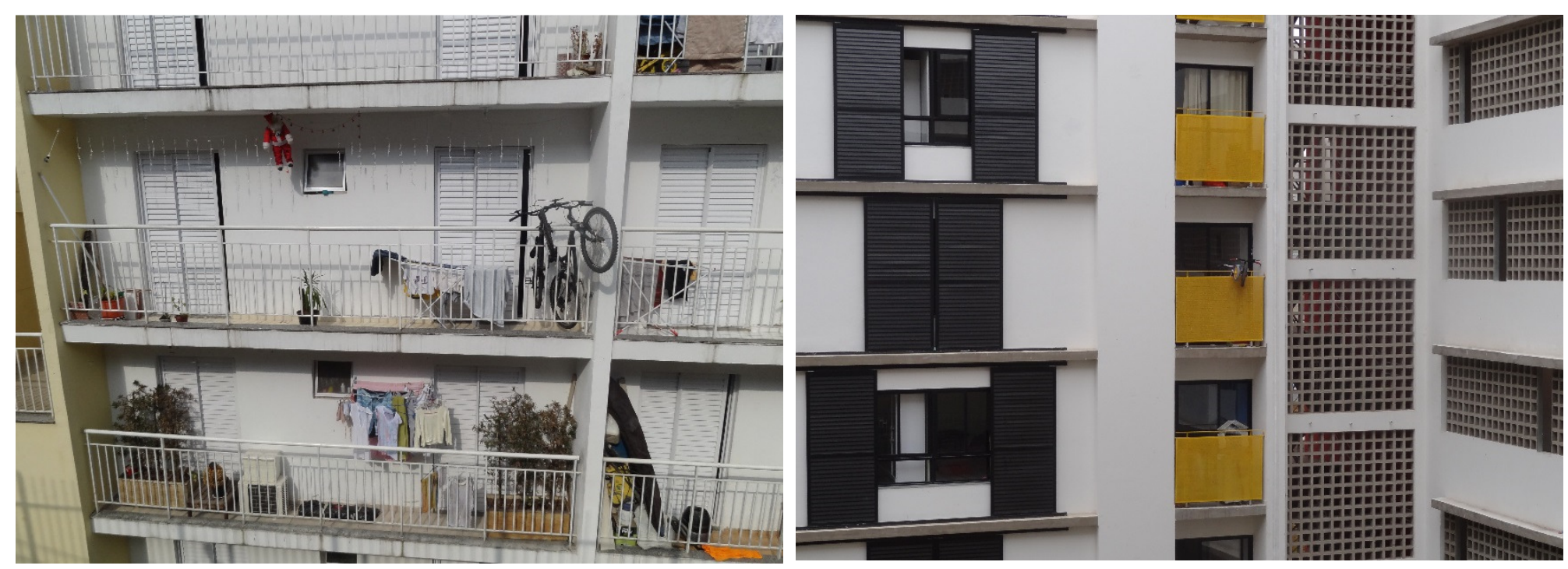

Figura 49 - Projeto: Real Parque. Arquitetura: Geni Sugai, Jeferson Diniz e Escritório Paulistano.

Figura 50 - Projeto: Corruíras. Arquitetura: Boldarini Arquitetura e

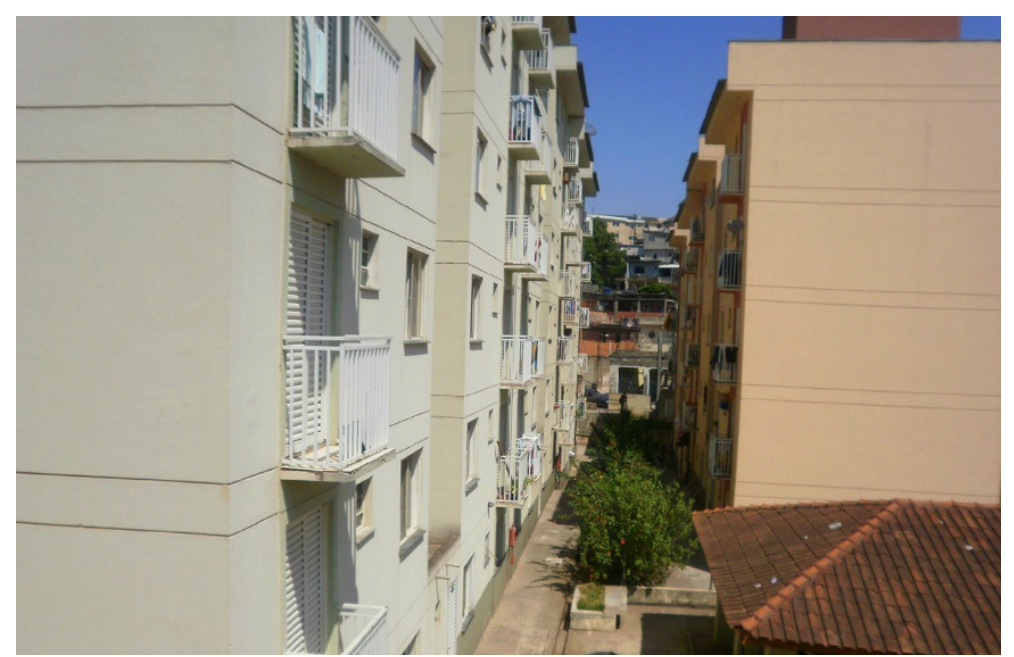
Urbanismo.

Figura 51 - Projeto: Jardim Olinda. Projeto: GTA.

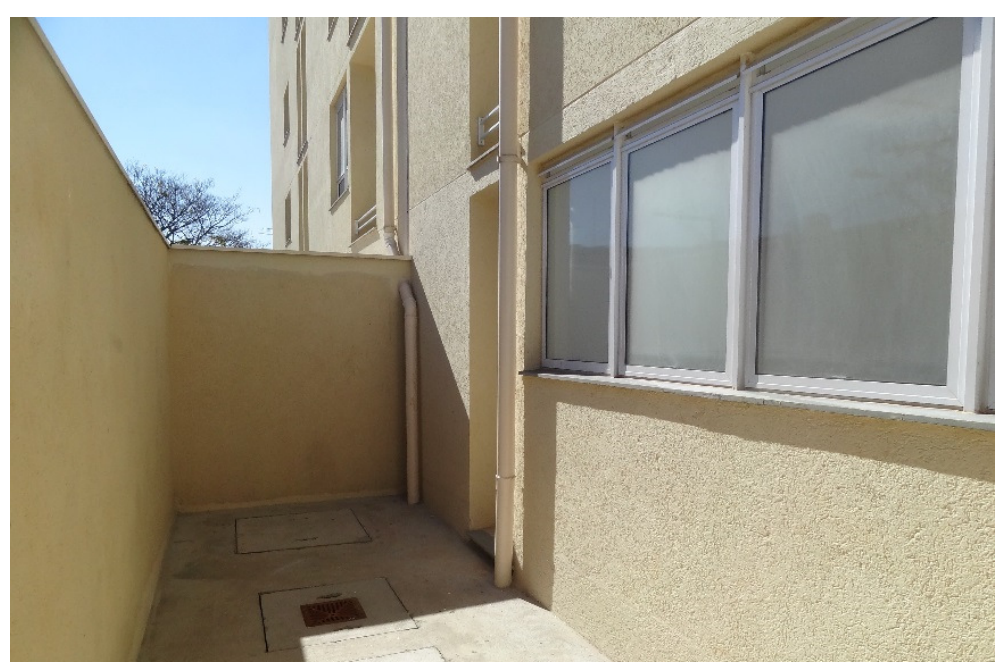

Figura 52 - Quintal privado. Projeto: Heliópolis Gleba H. Arquitetura: Vigliecca \& Associados. 
Ao visitar e analisar os projetos, foi inevitável perceber a importância dos espaços exteriores próprios para as unidades. Nos apartamentos do Real Parque (Figura 49), é nítida a riqueza que as varandas proporcionaram aos apartamentos. Outros projetos que incorporaram esses espaços exteriores às unidades foram: Corruíras (Figura 50); Jardim Olinda (Figura 51) e Rocinha.

No conjunto habitacional Heliópolis Gleba $\mathbf{H}$ (Figura 52), as unidades do térreo poderão contar com um quintal privado. Quando a visita foi realizada, os moradores ainda não estavam vivendo no conjunto, mas foi possível visitar uma das unidades que terá o privilégio de ter um quintal próprio. Essa é uma boa solução quando "sobram" espaços entre o limite do conjunto e os edifícios que podem não ser bem apropriados. Ao invés de permitir que se tornem espaços residuais, definir quintais privativos é uma solução desejável que, inclusive proporciona um espaço exterior de qualidade para essas unidades do térreo que, normalmente, sofrem pela falta de privacidade.

A solução de proporcionar quintais às unidades do térreo já havia sido utilizada por Hector Vigliecca e Bruno Padovano no projeto Vila Mara e Rio das Pedras (1991-1997).

Utilizando-se novamente do projeto Frauen Werk Stadt I como referência, podemos observar as unidades do térreo dos edifícios que foram beneficiadas com quintais privados (Figura 53; Figura 54).

A qualidade espacial oferecida pelas varandas e também pelos quintais - espaços exteriores próprios - é inquestionável. Portanto, considera-se que esses espaços deveriam ser, cada vez mais, incorporados aos projetos, mesmo que isso provoque mais uma confusão conceitual com as normas específicas e órgãos financiadores que, em nenhum momento, consideram as varandas como áreas importantes para as unidades habitacionais. 


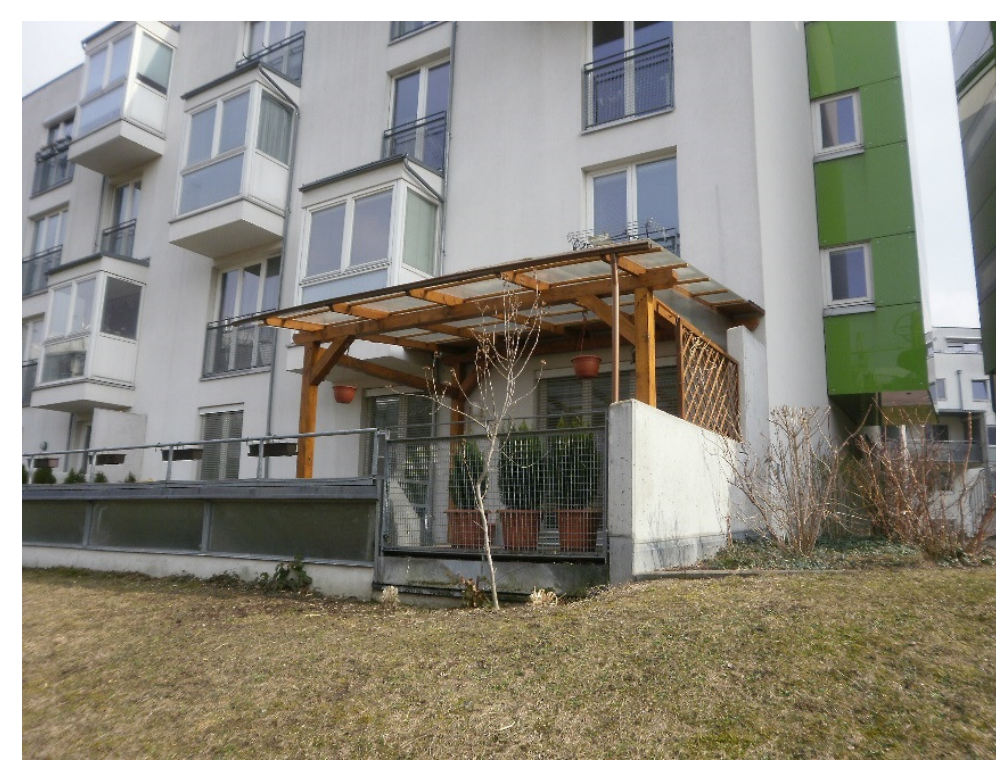

Figura 53 - quintal privado para unidade do térreo. Frauen Werk Stadt I, Viena.

Com isso, conclui-se esse capítulo de relações. O principal objetivo era refletir sobre os projetos analisados, buscando ressaltar os conceitos importantes para a construção de conjuntos habitacionais de qualidade e, para aumentar as referências, demostrar como esses conceitos aparecem nos outros projetos não analisados detalhadamente, mas que também foram visitados e fazem parte do repertório conceitual dessa dissertação de mestrado.

Não se espera que esse trabalho se transforme em uma "cartilha" de especificações, de certo e errado, ou permitido e não permitido. O que se deseja com esse trabalho é ter podido tornar visíveis os conceitos utilizados na concepção dos projetos de habitação de interesse social contemporâneos, que proporcionaram maior qualidade espacial, conceitual e de relações aos projetos. 



\subsection{REFLEXÕES}

\section{Arquitetura}

Enquanto satisfaz apenas as exigências técnicas e funcionais - não é ainda arquitetura; quando se perde em intenções meramente decorativas - tudo não passa de cenografia; mas quando - fruto instantâneo de inspiração, ou de procura paciente - aquele que a ideou para e hesita ante a simples escolha de um espaçamento de pilares ou da relação entre a altura e largura de um vão, e se detém na procura da justa medida entre "cheios" e "vazios", na fixação dos volumes e subordinação deles a uma lei, e se demora atento ao jogo dos materiais e seu valor expressivo, - quando tudo isso se vai pouco a pouco somando, obedecendo aos mais severos preceitos técnicos e funcionais, mas, também, àquela intenção superior que seleciona, coordena e orienta em determinado sentido toda essa massa confusa e contraditória de pormenores, transmitindo assim ao conjunto, ritmo, expressão, unidade e clareza - o que confere à obra o seu caráter de permanência: isto sim é arquitetura (COSTA, 1995, p. 257).

Pareceu importante iniciar esse capítulo de reflexões, com uma citação de Lúcio Costa que representa a importância da qualidade projetual para a arquitetura. A importância do envolvimento do arquiteto com o projeto; das escolhas e decisões; do entendimento de cada projeto como único.

Durante o desenvolvimento desse trabalho, a partir da realização das análises, permaneceu, como objetivo, a identificação dos conceitos empregados nos projetos, que agregassem maior qualidade espacial e de habitabilidade aos conjuntos construídos. 


\section{Agentes}

Apesar da análise focar os conjuntos habitacionais, é importante deixar claro a importância de compreender as relações estabelecidas com o entorno, o bairro e a cidade. Ana Rocha Melhado, ao desenvolver um trabalho sobre bairros sustentáveis, esclarece que:

O edifício deve ser pensado em relação a seu entorno com uma metodologia de gestão de projeto integrada e circular. De fato, cada edifício não deve ser mais pensado de maneira única, isolada e linear; ele faz parte de um projeto de cidade, incorporado em um processo no qual vários agentes participam e devem participar para o melhoramento dos projetos (MELHADO et al, 2013, p.18)

No caso dos edifícios de habitação de interesse social, podemos identificar o poder público como um dos principais agentes envolvidos na promoção dos projetos que irão integrar nossa cidade. Nós, arquitetos, podemos ser identificados como agentes intermediários, atuando no meio do processo e responsáveis pela concepção e proposição dos projetos. Na outra ponta, estão os moradores que devem ser incorporados ao processo, a partir da participação.

\section{Participação}

Os processos de participação não são nenhuma novidade nas sociedades democráticas. Constituem um dos mais importantes indicadores de que cada cidade se esforça para ser mais sustentável, mas humana e mais atenta a sua realidade, diversidade e memória; demostra que trabalha com o objetivo de alcançar benefícios comuns e expressar o desejo da maior parte da cidadania, de formar explicitamente parte da cidade, de reconhecer-se em suas transformações. A participação implica em uma transparência e clareza de interesses e objetivos (MONTANER; MUXÍ, 2011, p. 218)ํ․ 
Ao falar da importância da participação, fica aqui uma questão: Até que ponto a participação ocorre verdadeiramente no desenvolvimento dos projetos de habitação social? Nos casos estudados, os arquitetos declararam que houve processos participativos, que os projetos foram apresentados para os futuros moradores e que esses puderam opinar. No Comandante Taylor, vimos que o escritório de arquitetura já mantinha contato com a associação de moradores, que foi demanda do projeto. Quanto ao Real Parque, a arquiteta Geni Sugai comentou que os moradores recusaram as propostas de duplex e que o projeto foi revisto após as reuniões. No projeto Santo Amaro V, segundo a arquiteta Neli Shimizu², a permanência do campo de futebol foi uma das exigências dos moradores. Porém, será que a administração pública está realmente preparada para desenvolver processos de participação eficientes, que colaborem para a realização de intervenções de qualidade?

No capítulo metodologia para a análise de projetos, há uma citação de Lizete Rubano questionando "qual o real espaço da participação?" (página 76). Nessa citação, RUBANO analisa que os moradores realizam alterações nos projetos originais para adaptá-los às suas necessidades. Será que nesses casos não houve processo participativo? Será que os processos de participação realizados não foram muito eficientes? Ou será que a administração, os assistentes sociais e arquitetos ainda não dominam bem os instrumentos da participação?

MONTANER e MUXÍ complementam o raciocínio comentando que muitos municípios contam com a participação, mas em poucos casos as levam adiante com rigor.

[...] Se fala muito nela, porém, no fundo, a maior parte dos políticos e técnicos a temem e preferiam tomar decisões sem a intervenção dos implicados. Poucos deles estão dispostos a assumir o esforço do trabalho em equipe e da mudança de mentalidade nos processos de projeto e gestão. Os próprios arquitetos estão muito treinados para escutar o que seus clientes privados pedem para suas casas, mas não acontece o mesmo com a

2 VIGLIECCA, Hector; SHIMIZU, Neli. Entrevista: Residencial Parque Novo Santo Amaro V. São Paulo, 23 de janeiro de 2014. 
diversidade de desejos dos vizinhos de uma praça, um novo equipamento ou futuras habitações coletivas. (MONTANER; MUXÍ, 2011, p. 218)

Os arquitetos citam, como exemplo emblemático de participação, o Programa Favela-Bairro, realizado no Rio de Janeiro na década de 1990, durante as gestões de Cesar Maia e Luiz Paulo Conde ${ }^{4}$.

Quanto às intervenções realizadas em São Paulo entre 2005 e 2012 (período em que foi possível conhecer melhor o desenvolvimento dos projetos) sabe-se que houve participação por parte dos futuros moradores e que os assistentes sociais da prefeitura estiveram envolvidos durante todo o processo, permanecendo nos conjuntos habitacionais até seis meses após a conclusão das obras. Recentemente, durante o desenvolvimento das primeiras etapas do concurso Renova SP, sabe-se que também houve o envolvimento da equipe de assistentes sociais da prefeitura atuando no processo de participação da população envolvida e na comunicação com os escritórios de arquitetura contratados. Porém, como as atuações da prefeitura estão diretamente relacionadas aos mandatos políticos, não é possível afirmar que os processos participativos permanecerão, ou como serão realizados daqui por diante.

\section{Arquitetura e Política}

Zaida Muxí e Josep Maria Montaner, no livro Arquitectura y Política: ensayos para mundos alternativos, ressaltam a importância da relação que a arquitetura tem com a vida humana, com o poder político e com a construção das cidades.

A arquitetura tem uma estreita relação com a vida humana; por tanto, tem muito a ver com o poder político e econômico, com a vontade coletiva do social e do comum, do público e da permanência no futuro. São as

\footnotetext{
3 Tradução realizada pela autora.
}

${ }^{4}$ Sergio Magalhães e Verena Andreatta foram os urbanistas coordenadores do Programa Favela-Bairro. 
relações que, por obvias, e inclusive redundantes, não são fáceis de tratar e atualizar de maneira sistemática e crítica. Obvias pelo que diz respeito aos edifícios públicos, mas também vitais por como se legislam e gerem, projetam e constroem as habitações e os bairros como espaços para os novos modos de vida e para a felicidade das pessoas (MOTANER; MUXí, 2011, p.15)

Ao desenvolver um estudo sobre habitação de interesse social promovida pela Secretaria de Habitação de São Paulo, é indispensável compreender a relação entre arquitetura e política. Como foi possível observar no capítulo produção contemporânea, a produção habitacional está diretamente relacionada às ações de cada governo, de cada mandato, cada momento político. Segundo Milton Santos,

Como a divisão social do trabalho e a divisão territorial do trabalho dependem, em proporção crescente, de decisões políticas, o presente e a evolução futura das cidades dependem, em proporções semelhantes, do papel que, na economia, cabe aos autores do jogo político, segundo diferentes níveis, e da forma como, respondendo às determinações, o espaço urbano é, a cada momento, reorganizado (SANTOS, 2009, p.121).

Com relação ao futuro das cidades, Elisabete França comenta que:

Poucos são os temas que têm despertado tanto a atenção nos debates atuais como o futuro das cidades. Parte considerável das publicações dedicadas à questão urbana apresentam aos leitores prognósticos alarmantes sobre um futuro próximo. As cidades - agora megalópoles - crescem de forma desordenada como consequência das migrações para os centros urbanos. Os novos moradores, sem alternativas de moradias acessíveis, passam a ocupar as áreas precárias, desprovidas de infraestrutura.

[...] Na realidade, o entendimento do futuro das cidades, como um não futuro, colabora mais para o sucesso da venda de livros do que para a busca de soluções criativas e possíveis para a transformação das cidades, através da ação da arquitetura e do urbanismo produzindo espaços referenciais para a convivência social (FRANÇA, em: LEITE; AWAD. 2012, p. 180). 
Portanto, com base nos comentários de FRANÇA e SANTOS, depreende-se que é fundamental procurar entender a organização, a reorganização, ou ainda a transformação dos espaços urbanos estudados. Se construir habitação é construir cidades, é importante observar os princípios a partir dos quais as habitações e conjuntos habitacionais são construídos, buscando identificar soluções criativas e espaços referenciais para a convivência. Porém, será que os projetos contemporâneos de habitação de interesse social estão cumprindo essa tarefa? Será que estamos realmente construindo cidades?

Como foram concebidos esses projetos? Que tipo de relações estabelecem com o entorno, com o bairro onde foram inseridos? Que vantagens oferecem aos moradores e à população ao redor? Possuem qualidade projetual? Que tipo de conceitos foi utilizado no desenvolvimento desses projetos? Essas e muitas outras questões foram incorporadas às análises realizadas, buscando compreender que relações os conjuntos habitacionais contemporâneos estabelecem com a cidade de São Paulo e com sua "permanência no futuro", conforme comentam Zaida Muxí e Josep Maria Montener.

\section{$\mathrm{O}$ direito à cidade}

Em uma conversa, muito agradável, com a arquiteta e professora Lizete Rubano, uma questão foi levantada: em um momento onde se fala muito sobre o direito à cidade, qual a contribuição desse trabalho com relação à esse tema?

Ao desenvolver o tema habitação de interesse social na cidade de São Paulo, é inevitável reforçar que um terço da população que vive nessa cidade, vive em favelas e em loteamentos irregulares. Morar nas condições proporcionadas pelas favelas, definitivamente não é ter direito à cidade. 
Entende-se, porém, que atuar na urbanização de favelas e na promoção de habitação social é uma maneira de colaborar para a grande meta de proporcionar direito à cidade.

Como foi observado no capítulo produção contemporânea, a urbanização de favelas abrange várias formas de intervenção. Um grande passo já foi dado na década de 80 quando se assumiu que as favelas deveriam ser aceitas, urbanizadas e incorporadas à cidade. Nesse momento, foi compreendido que a fixação das pessoas, nos locais onde viviam, era importante para a manutenção das relações pessoais, profissionais e de realização das atividades da vida cotidiana. Proporcionar acesso à infraestrutura básica (água, esgoto, energia elétrica, sistema viário adequado, etc.) é fundamental, mas representa apenas parte desse trabalho.

Uma grande parte das favelas encontra-se em situação de risco (desmoronamento, enchentes, salubridade, etc.), ou ainda, implantada em áreas não permitidas, como áreas de proteção ambiental ou terrenos contaminados. Ao intervir nesses trechos das favelas, ou das cidades, é necessário avaliar as condições das moradias e, muitas vezes, é necessário remover os moradores que vivem nessa situação e reassentá-los em outros locais. Para solucionar a necessidade de reassentar essa população removida é que aparecem os conjuntos habitacionais dos quais tratamos nesse trabalho.

Construir conjuntos de habitação de interesse social é a oportunidade de proporcionar moradia digna àqueles habitantes que, anteriormente, viviam em condições precárias. Contudo, tão importante quanto proporcionar moradia digna, construir conjuntos também representa intervir na cidade e, para termos a esperança de realizar "a cidade que queremos", é importante intervir com qualidade.

Lizete Rubano, ao escrever sobre o trabalho do arquiteto Héctor Vigliecca e sua equipe, comenta que um dos principais raciocínios desenvolvidos pelo arquiteto é "como pensar - e propor para - o território urbano". 
Tema de constante atualização na bibliografia de outros campos do conhecimento, a cidade tem sido focalizada como o grande locus onde se realizam transformações técnicas, informacionais, do consumo, nos diferentes momentos da produção da vida material.

[...] Ao mesmo tempo tem sido assunto constante, ao longo da história urbana da civilização, compreender seu vínculo com a história humana, ou seja, o potencial da dimensão urbana para a vida pública, para a experiência pública, para além de seu competente papel nas lógicas da acumulação.

[...] Por mais que se vivencie uma situação de precariedade (e sabemos que em São Paulo cerca de $1 / 3$ da população vive nessas condições), é possível reconhecer o grau de urbanidade presente nos diversos territórios. Ou seja, por mais que o cotidiano das pessoas seja o de enfrentar vias de terra, alagamentos, ausência de infraestruturas e de creches, paradas de ônibus indecifráveis ou sucateadas, fragilidade das calçadas e espaços públicos cercados e controlados, há uma percepção, respaldada por uma vivência para além dessas mazelas urbanas, que permite a essas pessoas também reconhecer os ingredientes de uma cidade conformada. Os elementos públicos da cidade, diz Vigliecca, são legíveis e, por isso, legitimados pela apropriação (RUBANO em: MONOLITO, no 16, 2013, p. 70).

Portanto, de acordo com RUBANO e VIGLIECCA, para intervir na cidade, com qualidade, é importante reconhecer o território urbano e os elementos e/ou situações que proporcionam a apropriação da população. Segundo Milton Santos,

O território não é apenas o resultado da superposição de um conjunto de sistemas naturais e um conjunto de sistemas de coisas criadas pelo homem, O território é o chão e mais a população, isto é, uma identidade, o fato e o sentimento de pertencer àquilo que nos pertence. O território é a base do trabalho, da residência, das trocas materiais e espirituais e da vida, sobre os quais ele influi Quando se fala em território deve-se, pois, de logo, entender que se está falando, em um território usado utilizado por uma dada população (SANTOS, 2013, p. 96). 
Dessa forma, entende-se que, ao construir um conjunto habitacional é importante considerar todas as questões relacionadas às preexistências dos locais, valorizar os elementos de identidade e, acima de tudo, permitir que os futuros moradores participem do processo para que seus desejos e necessidades sejam conhecidos e considerados, aumentando assim as possibilidades de que se identifiquem e se apropriem de suas novas casas e novos espaços de convivência.

\subsection{CONCLUSÕES}

Foi definido como território a ser estudado, a cidade de São Paulo. O período estudado foram os últimos doze anos (2001 - 2013) e a produção escolhida para ser conhecida e analisada, foram os conjuntos habitacionais de interesse social, promovidos pela Secretaria Municipal de Habitação de São Paulo (Sehab).

Com base em outros trabalhos de pesquisa, análise e avaliação de projetos de habitação coletiva, foi possível definir critérios, a partir dos quais foram realizadas as análises aqui apresentadas.

Após o desenvolvimento das quatro análises, se propôs um momento de reflexão sobre o que havia sido estudado e analisado, e também de relação, onde foi possível incluir mais referências de projetos de habitação de interesse social, aumentando assim o repertório de conceitos estudados. Esse capítulo foi realizado como um arremate final das análises, em que os elementos e situações de maior relevância puderam ser ressaltados e novos projetos puderam ser estudados e observados.

As análises aqui realizadas desenvolveram-se, não como repetição no sentido de "mais do mesmo", mas como construção de um raciocínio e um repertório de elementos e situações para que os conceitos presentes em cada projeto pudessem ser visibilizados e compreendidos como estratégias de atuação. 
Reiterando o que foi comentado nas conclusões de cada capítulo, esse trabalho pretende ser uma contribuição à "cultura de projeto"1 de habitação de interesse social, deixando aqui registrado conceitos que possam servir para a construção de novos projetos. Conhecer e poder analisar criticamente o que foi e o que está sendo feito, é uma forma de adquirir experiência para o desenvolvimento de novos projetos, que possam complementar e melhorar os conceitos já observados e não repetir atuações que não foram bem sucedidas.

Contudo, após entrar em contato e conhecer mais profundamente a parte da produção contemporânea que se propôs estudar nesse trabalho, será que podemos considerar que estamos construindo cidade? Josep Maria Montaner e Zaida Muxí alertam para o projeto urbano, que é tão importante quanto os projetos por em si:

Muitos projetos, ainda que proponham uma boa solução para a unidade tipo, não podem ser considerados exemplares. A qualidade das habitações é inseparável do tecido urbano em que se inserem e, por isso, o projeto urbano é imprescindível (MONTANER; MUXÍ, 2006, p. 40).

Muitas questões estão relacionadas ao desenvolvimento dos projetos de conjuntos de habitação social: o reconhecimento do existente e sua relação com o novo; as relações entre as pessoas e a relação do novo com a cidade, que deve ser, da melhor maneira possível, de respeito, incorporação, complementação e diálogo. É importante que os conjuntos habitacionais sejam idealizados e realizados como parte do bairro e da cidade e sempre que possível, possam proporcionar espaços públicos que qualifiquem os entornos em que são implantados.

Assim portanto, cabe reivindicar aquelas experiências onde o projeto residencial forma parte de um projeto urbano equilibrado. É importante entender que as habitações não são, nem podem ser, peças autônomas sobre um tabuleiro de jogo. Quando funcionam, isto é, quando são capazes de favorecer a criação de redes sociais e

1 Termo utilizado pela arquiteta Lizete Rubano em sua tese de doutorado: Cultura de Projeto: Um estudo das ideias e propostas para habitação coletiva. 2001. Volume 1: As Ideias, 265f. Volume 2: Caderno de Projetos, 120f. Tese (Doutorado em arquitetura) - Faculdade de Arquitetura e Urbanismo, Universidade de São Paulo, São Paulo, 2001. 
comunitárias, criam cidade real e o fazem sobre as bases de um bom projeto urbano (MONTANER; MUXí, 2006, p. 40).

De acordo com MONTANER e MUXÍ, para a criação de uma "cidade real" é fundamental a elaboração e/ou colocação em prática de um projeto urbano de qualidade. Com isso reafirma-se a necessidade de que os projetos urbanos sejam considerados e realizados, superando as continuidades ou descontinuidades políticas. Tratando-se de São Paulo, projetos como o Plano Municipal de Habitação (PMH 2009-2024), a Operação Urbana Água Espraiada, o Programa Mananciais, ou ainda os projetos de urbanização de grandes favelas como Heliópolis, Paraisópolis e São Francisco, precisam ser realizados do começo ao fim, senão continuaremos vivendo dentro de um quebra-cabeça com peças que não se encaixam no entorno onde são implantadas, ou seja, em um território fragmentado, como estudado por Milton Santos ${ }^{2}$. Enquanto os projetos urbanos não forem realizados efetivamente, os projetos analisados representam, a partir desse raciocínio, as peças autônomas do grande tabuleiro que é a cidade de São Paulo.

Ainda assim, ousamos entender que esses projetos - e consequentemente as análises realizadas sobre eles também possuem sua função direcionada para a construção de uma cidade melhor. A partir da reflexão proposta por Manuel de Solà-Morales, referindo-se à "modernidade e urbanidade", "a grande metrópole foi desdobrada e os territórios se apresentam como cenários de interesse de todas as escalas e tamanhos." Para o autor,

O projeto urbano agora pode estar mais no estratégico e no material, em intenções acupunturais sobre a pele urbana para afetar ao organismo inteiro. Projeto urbano que para ser efetivo é concentrado e pontual, limitado em seu tempo e espaço de intervenção, mas também aberto e extenso em sua influência mais além de si

2 Para Milton Santos, os territórios tendem a uma compartimentação generalizada, onde se associam e se chocam o movimento geral da sociedade planetária e o movimento particular de cada fração, regional ou local da sociedade nacional. Esses movimentos são paralelo a um processo de fragmentação que rouba às coletividades o comando do seu destino, enquanto os novos autores também não dispõem de instrumentos de regulação que interessem à sociedade em seu conjunto. [...] O espaço geográfico não apenas revela o transcurso da história como indica a seus atores o modo de nela intervir de maneira consciente. (SANTOS, 2013, p.80). 
mesmo. Com a exigência técnica, orçamentária, de infraestrutura e arquitetônica do projeto construtivo. Com a sobreposição de funções e a mescla de usos, privados e públicos e a validade de um programa executivo (SOLÀ-MORALES, 2003, p. 153).

Espera-se, portanto, que os projetos aqui apresentados, representem as intenções acupunturais descritas por SolàMorales. Na falta de um projeto urbano integrado, identificam-se essas intervenções como atuações pontuais que podem e devem proporcionar melhorias para o entorno onde estão implantadas, favorecendo a criação das redes sociais e comunitárias citadas por MONTANER e MUXÍ.

Por fim, se os projetos aqui apresentados puderem efetivamente representar as ações pontuais citadas por SolàMorales, vindo a aumentar o número de referências de atuações projetuais, contribuindo para a "cultura de projeto" cultivada por Lizete Rubano, tem-se a esperança de que representaram, pelo menos, alguns passos em direção à construção de uma cidade melhor, entendendo-se que ainda há um largo caminho pela frente.

Espera-se, portanto, que esse trabalho contribua para comprovar a importância da habitação social para a cidade e que os arquitetos, estudantes de arquitetura ou profissionais de outras áreas interessados pelo tema, que tomem contato com essa dissertação de mestrado, possam retirar lições e aprendizado sobre os projetos analisados para poder seguir observando, analisando outros projetos de habitação social e que cheguem também a contribuir para uma produção com cada vez mais qualidade. 
CRÉDITOS FIGURAS

POR CAPÍTULO

Capa

As fotos da capa são da autora e de Rodrigo Inácio Cenzi tiradas durantes as visitas aos projetos.

\section{Metodologia para análise de projetos}

Figuras 01 - Fonte: elaborado pela autora.

\subsection{Comandante \\ Taylor}

Figura: 01 - Fonte: foto fornecida pela equipe de técnicos da Sehab. Autor: Fabio Knoll.

Figuras 02; 24 - Fonte: elaborado pela autora.

Figura 03 - Fonte: material utilizado pela arquiteta Elisabete França na conferência "Habitação social. A experiência de São Paulo 2005 - 2012. Os Projetos" ministrada na FAU-Maranhão em 16 de agosto de 2013.

Figuras: 04; 05 - Fonte: base Google Maps e análise elaborada pela autora.

Figuras: 06; 07; 08; 11; 12; 13; 14; 21; 23; 25; 26; 27; 28; 29; 30; 31; 32; 40; 42; 44; 45; 51; 52; 53; 54; 55; 56; $63 ; 64 ; 67 ; 68 ; 69 ; 70 ; 71$ - Fonte: foto autora.

Figuras: 09; 10; 33; 34; 38; 39; 47; 48 - Fonte: acervo Piratininga Arquitetos Associados.

Figuras: 15; 16; 17; 18; 19; 22; 35; 36; 37; 43; 46; 49; 50; 57; 58; 65; 66; 72 - base DWG fornecida pela Sehab e autorizada pela arquiteta Renata Semin. Elaboração: autora.

Figura 20: Fonte: Plano de Urbanização para Heliópolis. Disponível em:

http://www.saopaulocalling.org/project/sao-paulo-heliopolis . Acesso em setembro de 2013.

Figuras: 41; 59; 60; 61; 62 - Fonte: foto Rodrigo Inácio Cenzi. 


\subsection{Jardim Edite}

Figuras: 01; 12; 22; 23; 32 - Fonte: Acervo MMBB - Autor: Nelson Kon.

Figuras: 10; 11; 42 - Fonte: Acervo MMBB.

Figura: 02 - Fonte: elaborado pela autora.

Figuras: 03; 04 - Fonte: FIX, Mariana. Parceiros da exclusão: duas histórias da construção de uma "nova cidade" em São Paulo: Faria Lima e Água Espraiada. São Paulo: Boitempo, 2001.

Figuras: 05; 07 - Fonte: base Google Maps e análise elaborada pela autora.

Figuras $14 ; 19 ; 20 ; 21 ; 24 ; 25 ; 34 ; 43 ; 48 ; 49 ; 52 ; 63 ; 69 ; 70 ; 77 ; 78 ; 82$ - base DWG fornecida pela Sehab.

$$
\text { Elaboração: autora. }
$$

Figuras: 06; 08; 13; 15; 16; 18; 26; 27; 28; 29; 30; 31; 33; 36; 37; 41; 45; 46; 47; 50; 51; 53; 54; 55; 56; 57; 58; $59 ; 60 ; 61 ; 62 ; 64 ; 65 ; 66 ; 67 ; 68 ; 71 ; 72 ; 73 ; 74 ; 75 ; 76 ; 79 ; 80 ; 81$ - Fonte: foto autora.

Figura 09; 17; 44: Fonte: fotos Rodrigo Inácio Cenzi

Figuras: 38; 39; 40 - LUCCHINI, Edson Jr. Adolf Franz Heep: edifícios residenciais. Um estudo da sua contribuição para a habitação coletiva em São Paulo nos anos 1950. 300f. Dissertação (Mestrado em Arquitetura e Urbanismo) - Universidade Presbiteriana Mackenzie. São Paulo, 2010.

\subsection{Parque Novo} Santo Amaro V

Figuras $01 ; 03 ; 09 ; 10 ; 12 ; 13 ; 14 ; 15 ; 16 ; 17 ; 18 ; 19 ; 20 ; 21 ; 27 ; 28 ; 29 ; 30 ; 32 ; 33 ; 34 ; 35 ; 38 ; 39 ; 40 ; 41 ; 42$; $45 ; 46 ; 47 ; 48 ; 50 ; 51 ; 52 ; 53 ; 55 ; 56 ; 61 ; 64 ; 65 ; 66 ; 70 ; 71 ; 72 ; 73 ; 74 ; 75 ; 76 ; 77 ; 78 ; 79 ; 80 ; 81 ; 86 ; 88 ; 93 ; 94$ - Fonte: foto autora.

Figura 02 - Fonte: elaborado pela autora.

Figura 04 - Fonte: arquiteta Fabricia Zulin

Figuras 05; 24; 25; 60; 67 - Acervo Vigliecca \& Associados. Disponível em: <http://www.vigliecca.com.br/?locale=pt-BR>. Acesso em dezembro de 2013.

Figura 06 - Base DWG fornecida pela Sehab / Foto acervo MC Engenharia.

Figura $07 ; 22 ; 23 ; 26 ; 31 ; 37 ; 44 ; 49 ; 57 ; 58 ; 62 ; 63 ; 68 ; 69 ; 85 ; 87 ; 89 ; 90 ; 91 ; 92 ; 95$ - fonte: DWG fornecido pela Sehab / Edição autora. 
4.4 Real Parque

Figuras 08; 11 - Fonte: base Google Maps e análise elaborada pela autora.

Figuras $36 ; 43 ; 54 ; 59 ; 82 ; 83 ; 84$ - fonte: DWG fornecido pela Sehab.

Figuras $01 ; 13 ; 16 ; 17 ; 20 ; 21 ; 22 ; 25 ; 29 ; 30 ; 31 ; 32 ; 33 ; 34 ; 35 ; 36 ; 40 ; 41 ; 43 ; 44 ; 45 ; 46 ; 50 ; 51 ; 52 ; 53 ; 57$; $58 ; 61 ; 62 ; 63 ; 64 ; 65 ; 66 ; 67 ; 68 ; 69 ; 70 ; 71 ; 72 ; 73 ; 76 ; 80 ; 81 ; 83 ; 84 ; 86 ; 87 ; 88 ; 89 ; 90 ; 91 ; 92$ - Fonte: foto autora.

Figuras 02; 15 - Fonte: elaborado pela autora.

Figura 18; 19; 24 - Fonte: fotos Rodrigo Inácio Cenzi

Figuras 03; 07; 08; 09; 10; 11; 12; 14 - Acervo Prefeitura Municipal de São Paulo / Fabio Knoll / arquiteta Geni Sugai.

Figura $06 ; 26 ; 27 ; 28 ; 37 ; 38 ; 39 ; 42 ; 47 ; 48 ; 49 ; 54 ; 55 ; 56 ; 59 ; 60 ; 74 ; 75 ; 77 ; 78 ; 79 ; 82 ; 85 ; 93$ - fonte: DWG fornecido pela Sehab / Edição autora.

Figuras 04; 05 - Fonte: base Google Maps e análise elaborada pela autora.

Figuras 23 - fonte: Acervo Escritório Paulistano

\subsection{Relações}

\section{Considerações sobre os} conjuntos não analisados

Obs: todas as fotografias fora tiradas pela autora com exceção das seguintes imagens:

Heliópolis Gleba A / quadra 0 (fotos 01 e 02); Kenkite (fotos 01 e 02) - Fonte: Fabricia Zulin.

Heliópolis Gleba A / quadra 1 (fotos 01 e 02) - Fonte: Acervo Vigliecca \& Associados. Disponível em: $<$ http://www.vigliecca.com.br/pt-BR/projects/heliopolis-sector-a>. Acesso em fevereiro de 2014.

Alexandre Mackenzie (foto 01); Paraisópolis (fotos 01 e 02); Jardim Celeste (foto 01); Jardim das Rosas Jardim Irene - Parque Fernanda II (fotos 01 e 02); Tiro ao Pombo (foto 02); Jardim Guarani (fotos 01 e 02) Fonte: fotos Rodrigo Inácio Cenzi.

Ed. Iguaçu (fotos 01 e 02) - Fonte: Revista AU - ARQUITETURA E URBANISMO Ano 28 - no 228. São Paulo: ed. Pini, novembro de 2013. 
Heliópolis Gleba G (imagens 01 e 02) - Fonte: acervo Biselli Katchborian Arquitetos Associados. Disponível em: http://www.bkweb.com.br/projects/institutional/conjunto-habitacional-heliopolis/. Acesso em fevereiro de 2014.

Diogo Pires (imagens 01 e 02) - Fonte: Revista Projeto Design. № 396. São Paulo, ed. Arco, fevereiro de 2013.

Bamburral (imagens 01 e 02) - Fonte: acervo Brasil Arquitetura. Disponível em:

$<$ http://www.brasilarquitetura.com/projetos.php?mn=8\&img=001\&bg=img\&mn2=157>. Acesso em fevereiro de 2014.

Jardim Lidiane (imagens 01 e 02) - Fonte: acervo Andrade Morettin Arquitetos. Disponível em: http://www.andrademorettin.com.br/projetos/conjunto-habitacional-jd-lidiane/. Acesso em fevereiro de 2014.

Ponte dos Remédios (imagens 01 e 02) - Fonte: acervo H+F Arquitetos. Disponível em

http://www.hf.arq.br/projeto/conjunto-ponte-dos-remedios/. Acesso em fevereiro de 2014.

Figuras

Figuras 01; 32; 41; 43 - Fonte: fotos Rodrigo Inácio Cenzi

Figuras $02 ; 03 ; 04 ; 05 ; 06 ; 0713 ; 14 ; 15 ; 18 ; 19 ; 22 ; 26 ; 27 ; 28 ; 29 ; 30 ; 34 ; 35 ; 36 ; 40 ; 45 ; 47 ; 48 ; 49 ; 50 ; 51$; 52; 53; 54 - Fonte: foto autora.

Figura 08 - Fonte: BRUNA, 2010, p. 35

Figuras 09; 17 - Fonte: acervo Sehab.

Figuras 10; 31; 43 - Fonte: DWG fornecido pela Sehab / Edição autora.

Figura 11 - Fonte: elaborado pela autora.

Figura 12 - Fonte: BONDUKI, 2000a, p. 91.

Figura 16 - Fonte: PREFEITURA DE SÃO PAULO, 2012c

Figuras 20; 21; 25; 33 - Fonte: NEWMAN, 1973, p. 9; 94; 74.

Figuras 23; 24 - Fonte: EGELIUS, 1990, p. 153.

Figura 37 - Fonte: ANELLI; GUERRA; KON, 2001, p. 153.

Figuras 38; 39; 42 - Fonte: Fabricia Zulin.

Figura 44 - Fonte: Revista AU - ARQUITETURA E URBANISMO. Ano 28 - no 236.

Figura 46 - Fonte: Revista AU - ARQUITETURA E URBANISMO. Ano 28 - no 228. 
VISITAS AOS

CONJUNTOS:

Paraisópolis: Julho de 2011

Comandante Taylor: Julho de 2011 / Outubro de 2011 / Março de 2012 / Fevereiro de 2013 / Julho de 2013 Sabesp: Julho de 2011 / Outubro de 2011 / Agosto de 2013

São Francisco: Agosto de 2011

Jardim Celeste: Agosto de 2011

Heliópolis Gleba A: Agosto de 2011

Ceratti: Agosto de 2011

Alexandre Mackenzie e Kenkiti: Setembro de 2011

Tiro ao Pombo: Setembro de 2011

Jardim Guarani: Setembro de 2011

Fernanda - Rosas - Irene: Setembro de 2011

Jardim Olinda: Outubro de 2011

Nova Jaguaré: Outubro de 2011

Jardim Edite: Setembro de 2012 / Janeiro de 2013 / Julho de 2013 / Dezembro de 2013 / Fevereiro de 2014.

Real Parque: Novembro de 2011 / Novembro de 2013

Heliópolis Gleba H: Novembro de 2011

Santo Amaro V: Novembro de 2011 / Novembro de 2013

Ed. Iguaçu: Setembro de 2013

Corruíras: Setembro de 2013

Rocinha: Agosto de 2013. 

REFERÊNCIAS

BIBLIOGRÁFICAS

AMARAL, Ângela de Arruda Camargo. Habitação na cidade de São Paulo. 2ª edição revisada. São Paulo, Pólis / PUC-SP, 2002. (Observatório das Direitos do Cidadão: acompanhamento e análise das políticas públicas da cidade de São Paulo, 4).

AMORIM, Anália; OTERO, Ruben (Orgs.). Habitação e cidade: curso pós-graduação lato sensu Escola da Cidade 2009 - Volume 1. São Paulo: Editora da Cidade, 2010.

ANELLI, Renato (pesquisa e texto); GUERRA, Abilio (coordenação editorial); KON, Nelson (ensaios fotográficos). Rino Levi: Arquitetura e Cidade. São Paulo: Romano Guerra Editora, 2001.

AZEVEDO, Sérgio de; ANDRADE, Luis Aureliano Gama de. Habitação e Poder: da fundação da Casa Popular ao Banco Nacional da Habitação. Rio de Janeiro: Zahar Editores, 1982.

BARROS, Raquel R. M. Paula. Habitação Coletiva: A inclusão de conceitos humanizadores no processo de projeto. São Paulo: Annablume, 2011.

BASTOS, Maria Alice Junqueira; ZEIN, Ruth Verde. Brasil: Arquiteturas após 1950. São Paulo: Perspectiva, 2010.

BENETTI. Pablo. Habitação social e cidade: desafios para o ensino de projeto. Rio de Janeiro: Rio Book's. 1aㅗ edição, 2012.

BESSE, Susan. Modernizando a Desigualdade: reestruturação da ideologia de gênero no Brasil, 1914-1960. São Paulo: Editora da Universidade de São Paulo, 1999. 
BOFILL, Anna. Planejament urbanístic, espais urbans i espais interiors des de la perspectiva de les dones Quaderns de I'Institut. Barcelona: Institut Català de les Dones, 2005.

BOFILL, Anna. Guia per al planejament urbanístic i l’ordenació urbanística amb la incorporació de criteris de gènere. Barcelona: Institut Català de les Dones/Departament de Política Territorial i Obres Públiques, 2008.

BONDUKI, Nabil. Affonso Eduardo Reidy: arquitetos brasileiros. São Paulo: Editorial Blau, Instituto Lina Bo e PM Bardi, 2000a.

Habitar São Paulo: reflexões sobre a gestão urbana. São Paulo: Estação Liberdade, 2000b.

Origens da habitação social no Brasil: arquitetura moderna, lei do inquilinato e difusão da casa própria. 4aㅡ edição. São Paulo: Estação Liberdade, 2004.

BOTELHO, Manoel Henrique Campos; FREITAS, Sylvio Alves de. Código de Obras e edificações do município de São Paulo: comentado e criticado: Lei no 11.228 e decreto no 32.329 com modificações e acréscimos. $2^{\mathrm{a}}$ ed ampl. e atual. - São Paulo: Pini, 2008.

BRUNA, Paulo Júlio Valentino. Os primeiros arquitetos modernos: Habitação social no Brasil 1930-1950. São Paulo: Edusp, 2010.

CAIXA ECONÔMICA FEDERAL (CEF). Cartilha Programa Minha Casa Minha Vida. Disponível em: http://www1.caixa.gov.br/gov/gov social/municipal/programas habitacao/pmcmv/documentos download.a sp. Acesso em setembro de 2013.

CAMINOS, Horacio; GOETHERT, Reinhard. Urbanization Primer: Project assessment, site analysis, design criteria for site and services or similar dwelling environments in developing areas, with a 
documentary collection of photographs on urbanization. Cambridge, Massachusetts, and London, England: The MIT Press, 1978.

CAMPOS FILHO, Cândido Malta. Reinvente seu bairro: caminhos ara você participar do planejamento de sua cidade. São Paulo: Ed.34, 2003.

CARDOSO, Adauto Lucio (Org.). Habitação social nas metrópoles brasileiras: uma avaliação das políticas habitacionais em Belém, Belo Horizonte, Porto alegre, Recife, Rio de Janeiro e São Paulo no final do século XX. Porto Alegre: Associação Nacional de Tecnologia do ambiente Construído (ANTAC), 2007. - (Coleção Habitare).

COLOMINA, Beatriz. La Domesticidad en guerra. Barcelona: Actar, 2006.

COLOMINA, Beatriz. Sexualitat i espai. El disseny de la intimitat. Barcelona: UPC, 1997.

COMPANHIA DE DESENVOLVIMENTO HABITACIONAL E URBANO (CDHU). Desenho Universal. Habitação de Interesse Social. 2010.

CONSTANTINO, Carlos Adriano Santos. A COHAB-SP e uma nova política habitacional: o período 2001-2004. 245f. Dissertação (Mestrado - área de concentração: Habitat) - FAUUSP. São Paulo, 2007.

CORADIN, Renata. CASA - CIUDAD: una perspectiva de género. 200f. Trabalho final de curso (tesina) - Máster Laboratorio de la Vivienda del Siglo XXI, 5a edição - Fundação UPC - Universidad Politécnica de Cataluña. Barcelona, 2010. 
COSTA, Débora Cristina Beraldes. Gestão pós-ocupação em edifícios reabilitados para habitação de interesse social no centro de São Paulo. 164f. Dissertação (Mestrado) - Escola Politécnica da Universidade de São Paulo. Departamento de engenharia de Construção Civil. São Paulo, 2009.

COSTA, Lúcio. Lúcio Costa: registro de uma vivência. São Paulo: Empresa das Artes, 1995.

DIOGO, Érica Cristina Castilho. Habitação social no contexto da reabilitação urbana da Área Central de São Paulo. 171f. Dissertação (Mestrado) - FAUUSP, São Paulo, 2004.

DUARTE, Cristiane Rose; SILVA, Osvaldo Luiz; BRASILEIRO Alice (Orgs.). Favela, um bairro: propostas metodológicas para intervenção pública em favelas do Rio de Janeiro. São Paulo, Pro-Editores, 1996.

EGELIUS. Mats. Ralph Erskine, architect. Stockholm: Byggförlaget junto ao Swedish Museum of Architecture, 1990.

FERREIRA, João Sette Whitaker (Coord.). Produzir casas ou construir cidades? Desafios para um novo Brasil urbano. Parâmetros de qualidade para a implementação de projetos habitacionais e urbanos. São Paulo: LABHAB, FUPAM, 2012.

FIX, Mariana. Parceiros da exclusão: duas histórias da construção de uma "nova cidade" em São Paulo: Faria Lima e Água Espraiada. São Paulo: Boitempo, 2001.

FOLZ. Rosana Rita. Habitações Econômicas Paulistas: análises dos projetos das unidades dos atuais programas habitacionais. 2004. 32f. Monografia (Programa de Pós Graduação - Doutorado - Disciplina SAP-5846: Habitação metrópoles modos de vida) - Escola de Engenharia de São Carlos, Universidade de São Paulo, São Carlos, 2004. 
FONTES. Maria Cecília Levy Piza. Produção habitacional de interesse social no Município de São Paulo: estudo de caso: Gleba N de Heliópolis. 141f. Dissertação (Mestrado em Arquitetura e Urbanismo) Universidade Presbiteriana Mackenzie, São Paulo, 2005.

Operações Urbanas e Habitação Social. 173f. Tese (Doutorado em Arquitetura e Urbanismo) Universidade Presbiteriana Mackenzie, São Paulo, 2011.

FRANÇA, Elisabete. Favelas em São Paulo (1980-2008): Das propostas de desfavelamento aos projetos de urbanização. A experiência do Programa Guarapiranga. 331f. Tese (Doutorado) - Universidade Presbiteriana Mackenzie. São Paulo, 2009.

FRENCH, Hilary. Os mais importantes conjuntos habitacionais do século XX. Porto Alegre: Bookman, 2009.

GUERRA, Abilio (Org.). Textos fundamentais sobre história da arquitetura moderna brasileira: v.1. São Paulo: Romano Guerra, 2010. - (Coleção RG bolso;1).

Textos fundamentais sobre história da arquitetura moderna brasileira: v.2. São Paulo: Romano Guerra, 2010. - (Coleção RG bolso;2).

HABRAKEN, N. John; MIGNUCCI, Andrés. Soportes: Vivienda y ciudad. Barcelona: Máster Laboratorio de la Vivienda del Siglo XXI, 2009. - (Experiencias 1).

HAYDEN, Dolores. Redesigning the American Dream. Gender, Housing and Family Life. New York: W.W. Norton and Co, 1984.

HAYDEN, Dolores. The Grand Domestic Revolution. Cambridge: MIT Press, 1995.

INSTITUTO BRASILEIRO DE GEOGRAFIA E ESTATÍSTICA (IBGE). Censo Demográfico 2010. Aglomerados subnormais, primeiros resultados. Rio de Janeiro, p. 1 - 259, 2010. 


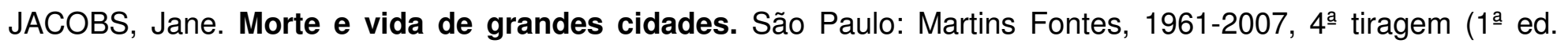
2000).

KAIL, Eva; BAUER, Ursula; ZWINGL, Christine. Model Project “Frauen-Werk-Stadt”. Viena: Women's Affairs Division, 1996.

KAIL, Eva. Frauen-Werk-Stadt. Viena: Stadt Wien, 2001.

KELLY, Burnham. Housin adn economic development. Massachusetts: Arquitectura and Planning, Massachusetts Institute of Technology, 1955.

KOPP, Anatole. Quando o moderno não era um estilo e sim uma causa. São Paulo: Nobel, 1990.

KRÄHENBÜHL, Lair. Cingapura, o encontro de São Paulo com a cidadania. São Paulo, Bix Design Corporativo, 1996.

LEITE, Carlos; AWAD, Juliana di Cesare Marques. Cidades sustentáveis, cidades inteligentes: desenvolvimento sustentável num planeta urbano. Porto Alegre: Bookman, 2012.

LLEÓ, Blanca. Sueño de habitar. Barcelona: Gustavo Gili, 2005.

LUCCHINI, Edson Jr. Adolf Franz Heep: edifícios residenciais. Um estudo da sua contribuição para a habitação coletiva em São Paulo nos anos 1950. 300f. Dissertação (Mestrado em Arquitetura e Urbanismo) - Universidade Presbiteriana Mackenzie. São Paulo, 2010. 
MELHADO, Ana Rocha (coord.); SANTOS, Aurélie dos; MELHADO, Silvio; GURGEL, Adriana. Projetar e construir bairros sustentáveis. São Paulo: Pini, 2013.

MENDES, Izabel Cristina Reis. Programa Favela-Bairro: uma inovação estratégica? Estudo do Programa Favela-Bairro no contexto do Plano Estratégico da Cidade do Rio de Janeiro. 191f. Dissertação (Mestrado - área de Concentração: Projeto, Espaço e Cultura) - FAUUSP. São Paulo, 2006.

MEYER, Regina Maria Prosperi; GROSTEIN, Marta Dora; BIDERMAN, Ciro. São Paulo Metrópole. São Paulo: EDUSP, 2004.

MIRALLES-GUASCH, Carme. Usos del temps i mobilitat. Barcelona: Regidoria Nous Usos Socials del Temps a la Ciutat. Ajuntament de Barcelona, 2006.

MONTANER, Josep Maria. Después del movimiento moderno: arquitectura de la segunda mitad del siglo XX. Barcelona, Gustavo Gili, 1993.

Arquitectura y Crítica. Barcelona: Gustavo Gili, 1999, 2007.

Sistemas arquitectónicos contemporáneos. Barcelona: Gustavo Gili, 2008.

MONTANER, Josep Maria; MUXÍ, Zaida (Dir.). Habitar el Presente: Vivienda en España: sociedad, ciudad, tecnología y recursos. Barcelona: Ministerio de Vivienda, Madrid, 2006.

. (Coord.). Definición, condiciones y criterios de diseño para la vivienda del siglo XXI en Andalucía. Barcelona, 2008. 
(Coord.). Criterios para la ordenación y evaluación urbana de nuevos barrios y genealogía de barrios de las ciudades contemporáneas. Barcelona, 2008.

Arquitectura y Política: ensayos para mundos alternativos. Barcelona: Gustavo Gili, 2011.

MONTANER, Josep Maria; MUXÍ, Zaida; FALAGÁN, David H. Herramientas para habitar el presente: la vivienda del siglo XXI. Barcelona: Máster Laboratorio de la Vivienda del Siglo XXI, 2011.

MUXÍ, Zaida. La arquitectura de la ciudad global. Barcelona: Gustavo Gili, 2004.

Recomanacions per a um habitatge no jerarquic ni androcéntric. Barcelona: Institut Català de les Dones / Departament de Medi Ambient i Habitatge - Secretaria d'Habitatge, 2009.

NAKASHIGUE, Katia Luli. Mutirões verticalizados em São Paulo: avaliação de qualidade dos projetos e satisfação dos moradores. 192f. Dissertação (Mestrado - áreas de concentração: Habitat). Faculdade de Arquitetura e Urbanismo da Universidade de São Paulo. São Paulo, 2008.

NASCIMENTO, Flávia Brito do. Entre a estética e o hábito: o Departamento de Habitação Popular (Rio de Janeiro, 1946-1960). Rio de Janeiro: Secretaria Municipal das Culturas, Coordenadoria de documentação e Informação Cultural, Gerência de Informação, 2008.

NESBITT, Kate (Org.). Uma nova agenda para a arquitetura: antologia teórica (1965-1955). São Paulo: Cosac Naify, 2a ed.rev., 2008. 
NETO, Gustavo Pires de Andrade. Pensando a Cidade no Século XXI: O Concurso Bairro Novo em São Paulo, 2004. 90f. Trabalho final de Graduação (TFG) - Faculdade de Arquitetura e Urbanismo da Universidade de São Paulo (FAUUSP), 2006.

NEWMAN, Oscar. Defensible Space: crime prevention through urban design. Nova York: Collier Books, 1973.

OLIVEIRA, Maria Claudia. A valorização da arquitetura: projetos de habitação: a experiência da Prefeitura de São Paulo (1989-1992). 188f. Dissertação (Mestrado) - Escola de Engenharia de São Carlos Universidade de São Paulo, 1999.

PERLMAN, Janice E. O Mito da Marginalidade: favelas e política no Rio de Janeiro. Rio de Janeiro: Paz e Terra, 1977.

Favela: Four decades of living on the edge in Rio de Janeiro. Nova York: Oxford University Press, 2010.

POPKO, Edward S. Squatter settlements and housing policy. Massachusettss: Department of Urban Studies and Planning - Massachusetts Institute of Technology, 1980.

PORTINHO, Carmen. Por toda a minha vida: depoimento a Geraldo Edson de Andrade. Rio de Janeiro: EdUERJ, 1999.

PREFEITURA DE SÃO PAULO. LOPES, Ana Carolina Louback; FERREIRA, João Sette Whitaker (Orgs.). Balanço qualitativo de gestão 2001-2004: Secretaria da Habitação e Desenvolvimento Urbano do Município de São Paulo - SEHAB, Companhia Metropolitana de Habitação de São Paulo - COHAB. São Paulo, 2004a.

MORAIS, Helen Ferreira Mouço (edição). Cohab SP: Relatório de Gestão 2001/2004. São Paulo, 2004b. 
SILVA, Helena Menna Barreto Silva; CAMPOS, Valéria Nagy de Oliveira. Programa Morar no Centro. São Paulo, 2004c.

SILVA, Helena Menna Barreto Silva; BERNARDINI, Sidney Piochi; HERLING, Tereza Ribeiro. Concurso Habita Sampa: Para projetos de habitação de interesse social na região central da cidade de São Paulo. São Paulo, 2004d.

HERLING, Tereza; FRANÇA, Elisabete (coord.). Habitação de Interesse Social em São Paulo: desafios e novos instrumentos de gestão. Prefeitura do Município de São Paulo, Cities Alliance - São Paulo, Janeiro Projetos Urbanos, 2008a.

BOLDARINI, Marcos (publicação); SANTOS, Maria Teresa Diniz; FRANÇA, Elisabete (coord.). Urbanização de Favelas: A experiência de São Paulo. São Paulo: Boldarini Arquitetura e Urbanismo, 2008b.

BARDA, Marisa; FRANÇA, Elisabete (Coord.). Catálogo: A Cidade Informal no Século 21. 1ª edição. São Paulo, 2010.

BARDA, Marisa; FRANÇA, Elisabete (Orgs.). Renova SP: Concurso de Projetos de Arquitetura e Urbanismo. $1^{\text {a }}$ edição. São Paulo: HABI - Superintendência de Habitação Popular, 2011 (Série Novos Bairros de São Paulo).

FRANÇA, Elisabete; COSTA, Keila Prado (Orgs.). Plano Municipal de Habitação: A experiência de São

Paulo. Volume 1 - 1a edição - São Paulo: HABI Superintendência de Habitação Popular, 2012a (Série Novos Bairros de São Paulo). 
FRANÇA, Elisabete; COSTA, Keila Prado (Orgs.). Do Plano ao Projeto: novos bairros e habitação social em São Paulo. Volume 2 - 1a edição - São Paulo: HABI Superintendência de Habitação Popular, 2012b (Série Novos Bairros de São Paulo).

FRANÇA, Elisabete; COSTA, Keila Prado; DAYER, Marcelle (Orgs.). Jardim São Francisco: Projeto Global de Urbanização. 1ª edição - São Paulo: HABI Superintendência de Habitação Popular, 2012c (Série Novos Bairros de São Paulo).

FRANÇA, Elisabete; COSTA, Keila Prado (Orgs.). O urbanismo nas Preexistências Territoriais e o Compartilhamento de Ideias: Sehab \& ETH Zürich, UCLA, Berlage Institute. $1^{\text {a }}$ edição. São Paulo: HABI - Superintendência de Habitação Popular, 2012d (Série Novos Bairros de São Paulo).

Manual da Moradia: Residencial Parque Novo Santo Amaro V. Conhecendo o imóvel. São Paulo: HABI - Superintendência de Habitação Popular, 2012e.

FRANÇA, Elisabete; BARDA, Marisa (Orgs.). Entre o céu e a água. O Cantinho do Céu. 1a edição. São Paulo: HABI - Superintendência de Habitação Popular, $2012 f$ (Série Novos Bairros de São Paulo).

ROLNIK, Raquel. A cidade e a lei: legislação, política urbana e territórios na cidade de São Paulo. São Paulo: Studio Nobel: Fapesp, 1997. - (Coleção cidade aberta).

São Paulo. São Paulo: Publifolha, 2001 - (Folha explica).

ROSSI, Aldo. A Arquitetura da Cidade. Lisboa: Edições Cosmos, 2001.

RUBANO, Lizete Maria. Cultura de Projeto: Um estudo das ideias e propostas para habitação coletiva. 2001. Volume 1: As Ideias, 265f. Volume 2: Caderno de Projetos, 120f. Tese (Doutorado em arquitetura) Faculdade de Arquitetura e Urbanismo, Universidade de São Paulo, São Paulo, 2001. 
Hipóteses do real: concursos de arquitetura e urbanismo 1973-2011. Vigliecca \& Associados. São Paulo: Vigliecca e Associados, 2012.

RUBANO, Lizete Maria; BONDUKI, Nabil; MARICATO, Ermínia; WISSENBACH, Vicente; (Orgs.). Habitação de interesse social: o direito à arquitetura. São Paulo: Prolivros, 2006. No prelo.

RYBCZYNSKI, Witold. Casa: pequena história de uma ideia. Rio de Janeiro: Record, 1996.

SAMORA, Patricia Rodrigues. Projeto de habitação em favelas: especificidades e parâmetros de qualidade. 348f. Tese (Doutorado - área de concentração: Habitat) - FAUUSP. São Paulo, 2009.

SAMPAIO, Maria Ruth Amaral (coord.). Habitação e cidade. São Paulo, Fauusp, junho de 1998

SANCHES, Débora. Gestão condominial de habitação de interesse social: Estudo na Área Central de São Paulo. 217f. Dissertação (Mestrado em Habitação: Planejamento e Tecnologia) - Instituto de Pesquisas Tecnológicas do Estado de São Paulo (IPT). Área de concentração: Planejamento, Gestão e Projeto. São Paulo, 2008.

SANTOS, Milton. Por uma economia política da cidade: 0 caso de São Paulo. $2^{a}$ edição (2009) - São Paulo: Editora da Universidade de São Paulo, 1994. (Coleção Milton Santos).

A natureza do espaço: técnica e tempo, razão e emoção. 4a edição 7.reimpr. (2012) - São Paulo: Editora da Universidade de São Paulo, 1996. (Coleção Milton Santos).

Por uma outra globalização: do pensamento único à consciência universal. $23^{a}$ ed. Rio de Janeiro: Record, 2013.

SANTOS, Milton; SILVEIRA, María Laura. O Brasil: território e sociedade no início do século XXI. 17ª edição. Rio de Janeiro: Record, 2013. 
SASSEN, Saskia. Sociologia da globalização. Porto Alegre: Artmed, 2010.

SEGAWA, Hugo; GUERRERO, Ingrid Quintana; SILVA, Aline de Figueirôa. Crítica de arquitetura: ensaios latinoamericanos. Cotia, SP: Ateliê Editorial, 2013.

SILVA, Luis Octavio de Faria e; OTERO, Ruben (Orgs.). Habitação e cidade: curso pós-graduação lato sensu Escola da Cidade 2010 - Volume 2. São Paulo: Editora da Cidade, 2011.

SILVA, Luis Octavio de Faria e; OTERO, Ruben (Orgs.). Habitação e cidade: curso pós-graduação lato sensu Escola da Cidade 2011 - Volume 3. São Paulo: Editora da Cidade, 2012.

SOLÀ-MORALES. Manuel de. De cosas urbanas. Barcelona: Gustavo Gili, 2008.

SOMEKH, Nadia e CAMPOS NETO, Candido Malta. A Cidade que não pode parar: Planos urbanísticos de São Paulo no século XX. São Paulo: Ed. Mackpesquisa, 2002.

VILA, Simone Barbosa; ORNSTEIN, Sheila Walbe (Orgs.). Qualidade ambiental na habitação: avaliação pósocupação. São Paulo: Oficina de Textos, 2013.

VILLAÇA, Flávio. Reflexões sobre as cidades brasileiras. São Paulo: Studio Nobel, 2012.

WAISMAN, Marina. El interior de la historia: historiografía arquitectónica para uso de latinoamericanos. Bogotá: Escala, 1990.

La arquitectura descentrada. Bogotá: Escala, 1995. 
WISNIK, Guilherme. Estado Crítico: à deriva nas cidades. São Paulo: Publifolha, 2009.

ZULIN, Fabricia. Habitar coletivo: obras diferenciadas contemporâneas em São Paulo. 521f. Dissertação (Mestrado - Área de Concentração: Projeto de Arquitetura) - FAUUSP. São Paulo, 2013.

\section{ARTIGOS}

AMORIM, Victoria. Projeto da Ponte dos Remédios é apresentado na FAU. Agência Universitário de Notícias (AUN), junho de 2013. Disponível em: <http://www.usp.br/aun/exibir.php?id=5200>. Acesso em janeiro de 2014.

BAUER, Úrsula. Un barrio de Viena desde la perspectiva de género. 1995.

BONDUKI, Nabil; KOURY, Ana Paula. Das reformas de base ao BNH as propostas do Seminário de Habitação e Reforma Urbana. Vitruvius: arquitextos 120.02, maio 2010.

BRITO, Luísa. Moradores de favela dizem que prefeitura dificulta liberação de bolsa-aluguel. Em: G1: O Portal de notícias da Globo, São Paulo, abril de 2009. Disponível em: <http://g1.globo.com/Noticias/SaoPaulo/0,,MUL1068190-5605,00.html>. Acesso em novembro de 2013.

COMAS, Carlos Eduardo Dias. 0 espaço da arbitrariedade. Considerações sobre o conjunto habitacional BNH e o projeto da cidade brasileira. Revista Projeto, no 91. São Paulo, setembro de 1986.

FERREIRA, João Sette Whitaker. Perspectivas e desafios para o jovem arquiteto no Brasil. Qual o papel da profissão? Vitruvius, arquitextos 133.07, julho de 2011. 
FLORESTA, Cleide. Conjunto Habitacional Real Parque. Em: AU - ARQUITETURA E URBANISMO. Ano 28 - no 228. São Paulo: ed. Pini, março de 2013, p. 26.

FRAJNDLICH, Rafael Urano. Jardim Edite. Em: AU - ARQUITETURA E URBANISMO. Ano 28 - № 231. São Paulo: ed. Pini, junho de 2013, p. 26.

G1: O Portal de Notícias da Globo. Justiça manda suspender remoção de moradores de favela. São Paulo, 04/04/08. Disponível em: < http://g1.globo.com/Noticias/SaoPaulo/0,,MRP388488-5605,00.html>. Acesso em novembro de 2013.

GRUNOW, Evelise. Josep Maria Montaner. Em: PROJETO DESIGN. № 394. São Paulo, ed. Arco, dezembro de 2012, p.10.

Cidade Negociada. Em: PROJETO DESIGN № 401. A invenção do programa. São Paulo, ed. Arcoweb, julho de 2013, p. 56.

HARVEY. David. 0 direito à cidade. Em: Revista Piauí, no 82 - julho de 2013. Disponível em: http://revistapiaui.estadao.com.br/edicao-82/tribuna-livre-da-luta-de-classes/o-direito-a-cidade. Acesso fevereiro de 2014.

MARICATO, Erminia. Conhecer para resolver a cidade ilegal. Em: CASTRIOTA, L.B. (Org.). Urbanização Brasileira: redescobertas. Belo Horizonte: editora Arte, 2003. p. 78-96.

MARTINS, Maria Lucia Refinetti. Descentralização e subprefeituras em São Paulo: experiência da gestão 1989-1992: Prefeita Luiza Erundina de Sousa. Novembro de 1997. Disponível em: <http://www.fau.usp.br/depprojeto/labhab/biblioteca/textos/martins_descentralizaerundina.pdf>. Acesso junho de 2013. 
MELENDEZ, Adilson. Concurso HabitaSampa: Soluções para o problema da habitação de interesse social em São Paulo. Em PROJETO DESIGN. № 291. São Paulo, ed. Arco, maio de 2004.

Espaços Coletivos estimulam convivência. Em: PROJETO DESIGN. № 396. São Paulo, ed. Arco, fevereiro de 2013, p. 62.

Comunidade se prepara para a cidade formal. Em: PROJETO DESIGN. № 396. São Paulo, ed. Arco, fevereiro de 2013, p. 66.

PORTAL VITRUVIUS. Concurso HabitaSampa - Projetos para locação social. Vitruvius: Concurso 040.02, abril de 2004.

Concurso Bairro Novo. Vitruvius: Concurso 044.02, agosto de 2004.

Premio Caixa / IAB 2004: Concurso Nacional de Ideias para Habitação Social no Brasil. Brasília, DF. Vitruvius: Concurso 051.03, março de 2005.

Concurso Público Nacional de Ideias e soluções para Habitação Social no Brasil - Premio Caixa / IAB 2006. Rio de Janeiro, 29 de novembro de 2006. Vitruvius: Concurso 077.01, maio de 2007.

Concurso Público Nacional de Arquitetura para Novas Tipologias de Habitação de Interesse Social Sustentáveis. Vitruvius: Concurso 126.02, junho de 2011.

PORTELLA, José Luiz. Direito à cidade - Plano Diretor. Em: Folha de São Paulo, 22 de agosto de 2013. Disponível em: < http://www1.folha.uol.com.br/colunas/joseluizportella/2013/08/1329968-direito-a-cidade--plano-diretor.shtml>. Acesso em fevereiro de 2014.

REVISTA AU. Espaço e Crítica: Projeto Urbanização. Em: AU - ARQUITETURA E URBANISMO. Edição 78. São Paulo: ed. Pini, junho de 1998. 
RUBANO, Lizete Maria. Habitação social: temas da produção contemporânea. Vitruvius: arquitextos 095.07, abril 2008.

Quando a metrópole eclipsou a arquitetura... Em: MONOLITO. № 16. Héctor Vigliecca. São Paulo, ed. Monolito, agosto/setembro de 2013, p. 70 - 73.

SERAPIÃO, Fernando. Quando a favela vira cidade: Urbanização de favelas, concursos, intercâmbios e verbas milionárias incitam debate sobre projetos de interesse social em curso na capital paulista. Em: PROJETO DESIGN. № 369. São Paulo, ed. Arco, novembro de 2010, p. 82.

TRONCOSO, Úrsula. Área de lazer na favela Nova Jaguaré. Em: AU - ARQUITETURA E URBANISMO. Ano 26 - no 217. Renovação. São Paulo: ed. Pini, abril de 2011, p. 56.

Parque Novo Santo Amaro V. Em: AU - ARQUITETURA E URBANISMO. Ano 27 - № 225. Habitação + Espaço Público. São Paulo: ed. Pini, dezembro de 2012, p. 48.

Reurbanização da Favela do Sapé. Em: AU - ARQUITETURA E URBANISMO. Ano 28 - no 234. A cidade e as Águas. São Paulo: ed. Pini, setembro de 2013, p. 46.

Residencial Corruíras. Em: AU - ARQUITEURA E URBANISMO. Ano 28 - no 236. São Paulo: ed. Pini, novembro de 2013, p.36.

\section{REVISTAS}

AU - ARQUITETURA E URBANISMO. Ano 24 - no 186. Habitação. São Paulo: ed. Pini, setembro de 2009. Ano 26 - no 217. Renovação. São Paulo: ed. Pini, abril de 2011. Ano 27 - no 225. Habitação + Espaço Público. São Paulo: ed. Pini, dezembro de 2012. 
Ano 28 - no 228. Habitação Social. São Paulo: ed. Pini, março de 2013. Ano 28 - no 231. São Paulo: ed. Pini, junho de 2013.

Ano 28 - no 234. A cidade e as Águas. São Paulo: ed. Pini, setembro de 2013. Ano 28 - no 236. São Paulo: ed. Pini, novembro de 2013.

DOMUS. № 963. São Paulo Calling. Milão: Editoriale Domus, novembro de 2012.

MONOLITO. № 07. Habitação Social em São Paulo. São Paulo, ed. Monolito, fevereiro/março de 2012. № 16. Héctor Vigliecca. São Paulo, ed. Monolito, agosto/setembro de 2013.

PROJETO DESIGN. № 291. São Paulo, ed. Arco, maio de 2004. . № 358. São Paulo, ed. Arco, dezembro de 2009. № 364. São Paulo, ed. Arco, junho de 2010. № 369. São Paulo, ed. Arco, novembro de 2010. № 384. São Paulo, ed. Arco, fevereiro de 2012. № 394. São Paulo, ed. Arco, dezembro de 2012. № 396. São Paulo, ed. Arco, fevereiro de 2013. . № 401. A invenção do programa. São Paulo, ed. Arco, julho de 2013.

RENOVA SP. Edições 1 a 12. São Paulo, Secretaria Municipal de Habitação, julho de 2011 a julho de 2012. SUMA+ N.127. Habitação Coletiva. Buenos Aires, março 2013. 
WEBSITES

Associação de moradores do Jardim Edith. Disponível em: < http://jardimedith.blogspot.com.br/>. Acesso em novembro de 2013.

Agência Universitária de Notícias (AUN). Disponível em: <http://www.usp.br/aun/exibir.php?id=5200>. Acesso em janeiro de 2014.

Andrade Morettin Arquitetos. Disponível em: < http://www.andrademorettin.com.br/>. Acesso em fevereiro de 2014.

Biselli Katchborian Arquitetos Associados. Disponível em: < http://www.bkweb.com.br/>. Acesso em fevereiro de 2014.

Brasil Arquitetura. Disponível em: < http://www.brasilarquitetura.com/index2.php>. Acesso em fevereiro de 2014.

Caixa Econômica federal. Disponível em: http://www.caixa.gov.br/. Acesso em setembro de 2013.

Depoimento Sr. Gerôncio Henrique (presidente da associação de moradores do Jardim Edith). Museu da Pessoa. Disponível em: <http://www.youtube.com/watch?v=86PIXXZBDfU\#t=226>. Acesso em novembro de 2013.

Extensão Av. Roberto Marinho Águas Espraiadas. Disponível em: <http://www.youtube.com/watch?v=sSxcKGr1L-A>. Acesso em novembro de 2013.

Habisp Plus: Sistema de informações para habitação social na cidade de São Paulo. Disponível em: <http://www.habisp.inf.br/>. Acesso em setembro de 2013.

Hereñú + Ferroni Arquitetos. Disponível em: < http://www.hf.arq.br/>. Acesso em dezembro de 2013. 
Jorge Mario Jáuregui Ateliê Metropolitano. Disponível em: <http://www.jauregui.arq.br/favelas_alemao.html.> Acesso em setembro de 2013.

Máster Laboratorio de la Vivienda Sostenible del Siglo XXI. Disponível em: <http://laboratoriovivienda21.com/blog/>. Acesso em junho de 2013.

MMBB. Disponível em: < http://www.mmbb.com.br/>. Acesso em dezembro de 2013.

Premio Caixa - IAB 2008/2009. Disponível em: <http://www.iabdf.org.br/premiocaixaiab/>. Acesso em outubro de 2013.

Projeto de Urbanização de Heliópolis. Superintendência de habitação popular (HABI) - Secretaria Municipal de Habitação de São Paulo (Sehab). Coordenação: Vanessa Padiá de Souza. Disponível em: <http://www.saopaulocalling.org/project/sao-paulo-heliopolis>. Acesso em setembro de 2013.

PROGRAMA CASA PAULISTA - Secretaria da Habitação do Estado de São Paulo. Disponível em: <http://www.habitacao.sp.gov.br/casapaulista/casa-paulista-form/Index.html>. Acesso em janeiro de 2014.

Usina: Centro de Trabalhos para o Ambiente Habitado. Disponível em: <http://www.usinactah.org.br/index.php?/projetos/uniao-da-juta/>. Acesso em junho de 2013.

Vigliecca \& Associados. Disponível em: <http://www.vigliecca.com.br/?locale=pt-BR>. Acesso em dezembro de 2013. 


\section{OUTROS}

BRAGA, Milton. Palestra: Programa de Pós Graduação da Faculdade de Arquitetura e Urbanismo da USP Disciplina: Arquitetura Contemporânea Paulista / Crítica de arquitetura. Professores responsáveis: Mônica Junqueira de Camargo; Hugo Segawa. São Paulo: 17 de julho de 2013.

Entrevista com moradores do Conjunto Jardim Edite. Moradoras: Cícera e Ana Paula. São Paulo, 17 de dezembro de 2013.

FRANÇA, Elisabete. Habitação Social em São Paulo: Perspectivas. Conferência: Museu da Casa Brasileira, São Paulo, 15 de junho de 2011.

Habitação social: A experiência de São Paulo 2005-2012. O Plano Municipal de Habitação / Os Projetos / Os desafios - projetos de grande escala. Palestra: Programa de Pós Graduação da Faculdade de Arquitetura e Urbanismo da USP - Disciplina: Seminários de Pesquisa em Projeto de Arquitetura II. Professores responsáveis: Rafael Perrone; Helena Ayoub. São Paulo, 06 de agosto de 2013.

MOREIRA, Marta; FERRONI, Eduardo. Visita ao Conjunto Habitacional Jardim Edite acompanhada pelos arquitetos. Visita promovida pela disciplina: Arquitetura Contemporânea Paulista / Crítica de arquitetura. Professores responsáveis: Mônica Junqueira de Camargo; Hugo Segawa. São Paulo, 24 de julho de 2013.

SEMIN, Renata. Entrevista:Conjunto Residencial Comandante Taylor. São Paulo, 13 de setembro de 2013.

SEMINARIO VIVIENDA Y CIUDAD. Barcelona, 2008, Máster Laboratorio de la vivienda del Siglo XXI - Universidad Politécnica de Cataluña (UPC). Professora responsável: Christine Van Sluys.

SEMINÁRIO VIVIENDA Y CIUDAD CONTEMPORÁNEA. SÃO PAULO Y MADRID. São Paulo, maio de 2013, FAUUSP. Organização: Leandro Medrano (FEC-Unicamp) e Luiz Recaman (FAUUSP). 
SUGAI, Geni. Entrevista: Conjunto Habitacional Real Parque. São Paulo, 27 de novembro de 2013.

VIGLIECCA, Hector. Construir Cidadania. Conferência: Museu da Casa Brasileira, São Paulo, 28 de novembro de 2012.

Palestra: Programa de Pós Graduação da Faculdade de Arquitetura e Urbanismo da USP - Disciplina: Arquitetura Contemporânea Paulista / Crítica de arquitetura. Professores responsáveis: Mônica Junqueira de Camargo; Hugo Segawa. São Paulo: 18 de julho de 2013.

VIGLIECCA, Hector; SHIMIZU, Neli. Entrevista: Residencial Parque Novo Santo Amaro V. São Paulo, 23 de janeiro de 2014. 


\section{HABITAR SOCIAL \\ A produção contemporânea na cidade de São Paulo}

RENATA FRAGOSO CORADIN
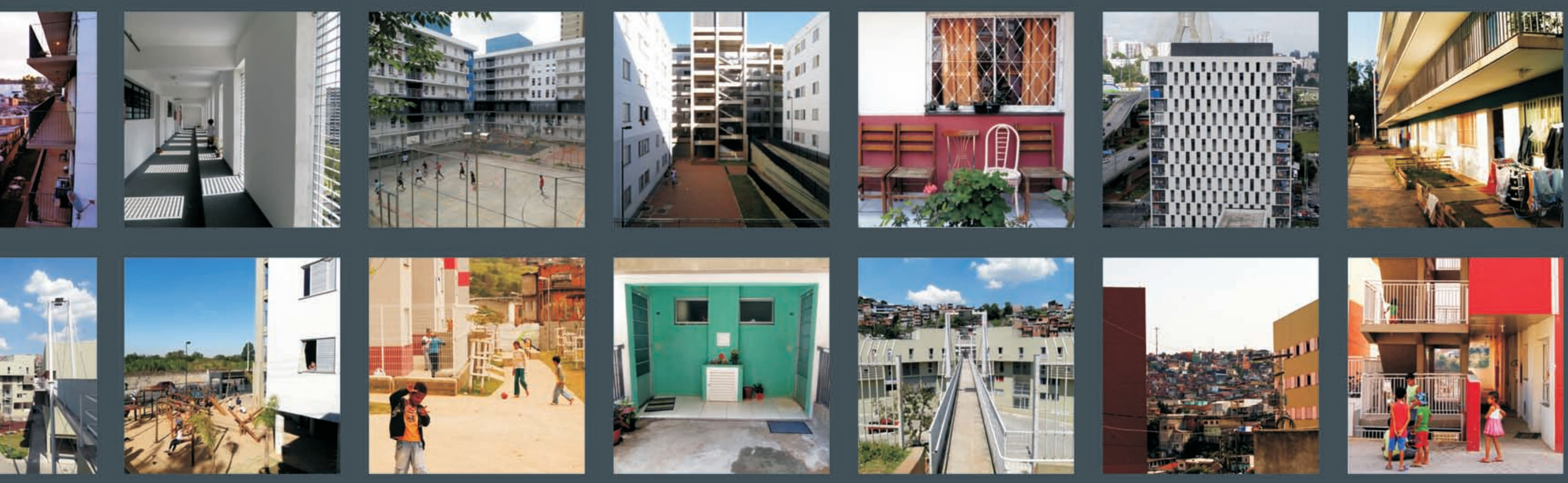

DISSERTAÇÃO DE MESTRADO

Universidade de São Paulo - Faculdade de Arquitetura e Urbanismo História e Fundamentos da Arquitetura e do Urbanismo

Orientador: Prof. Dr. Paulo Bruna 

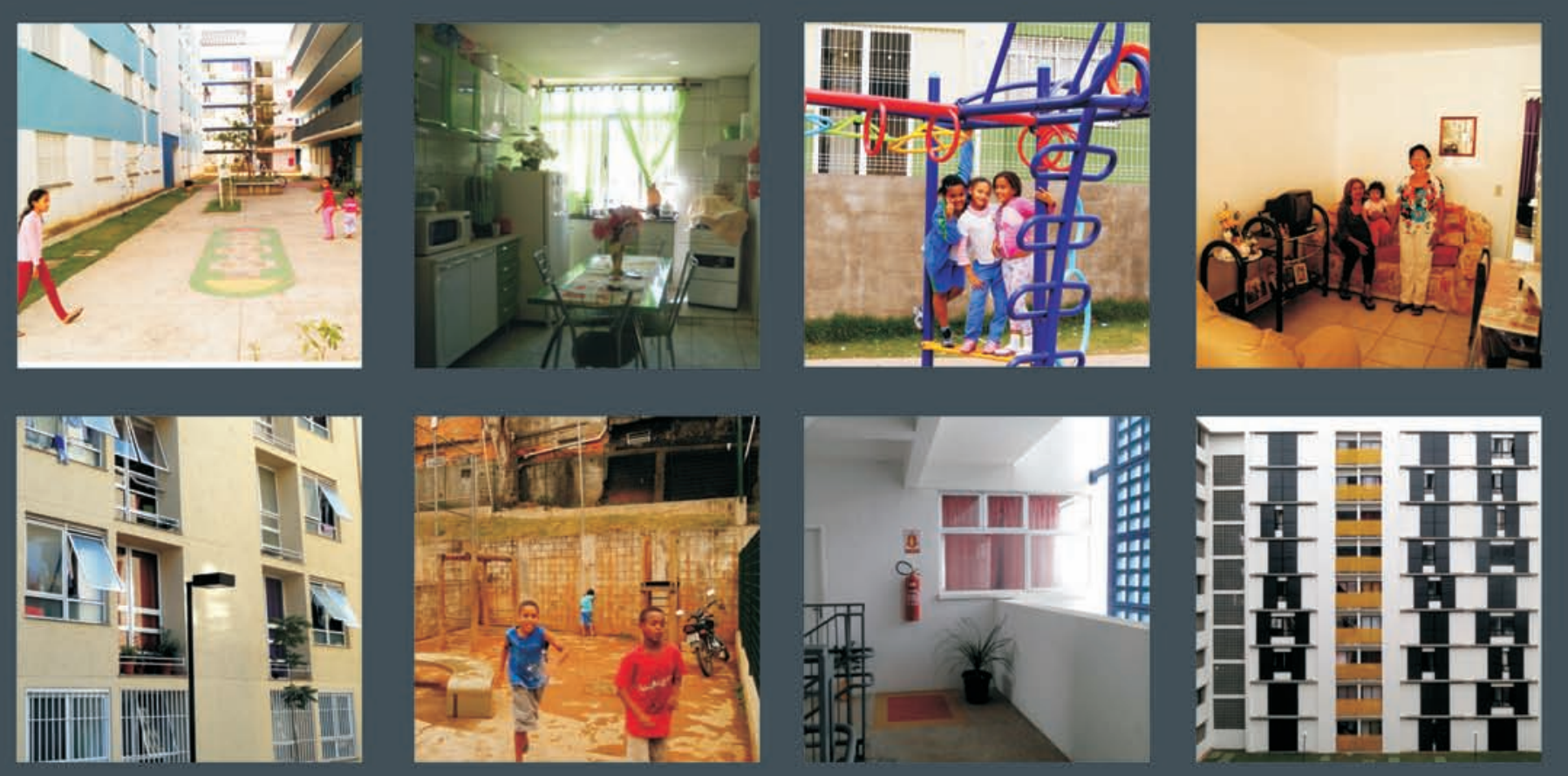
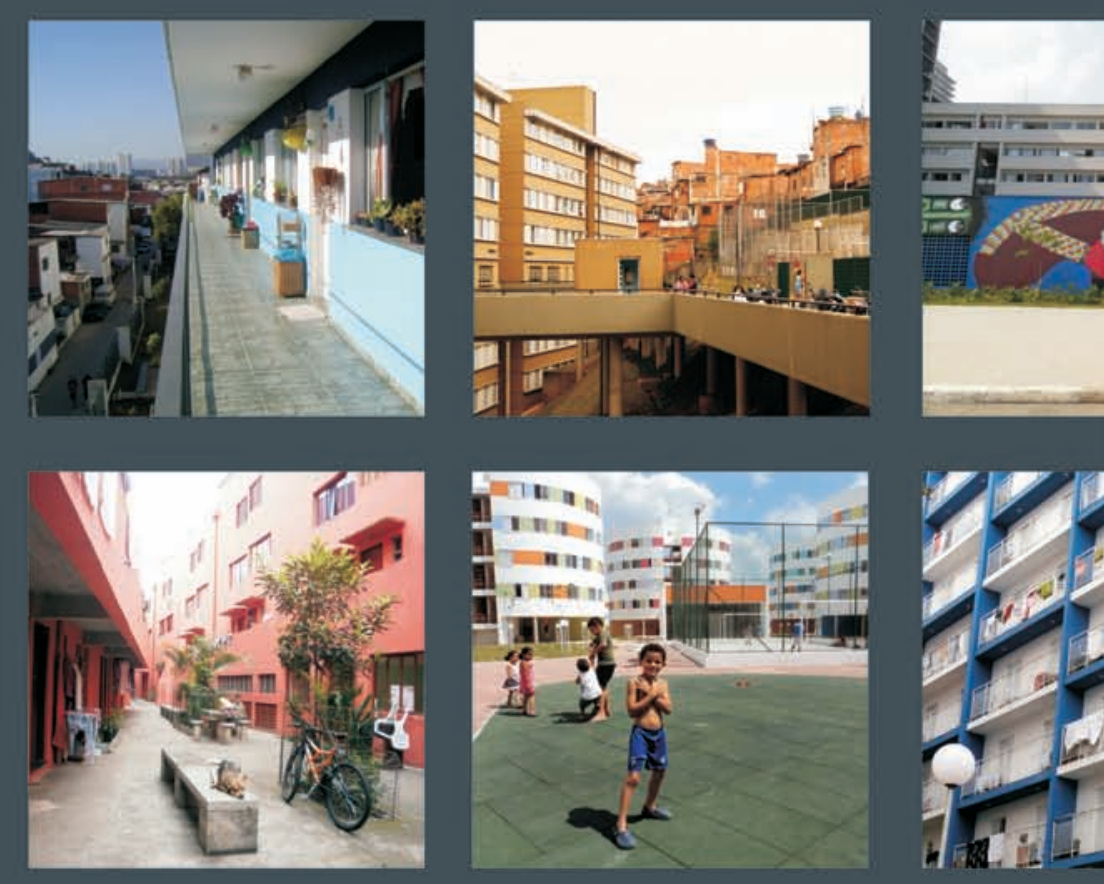